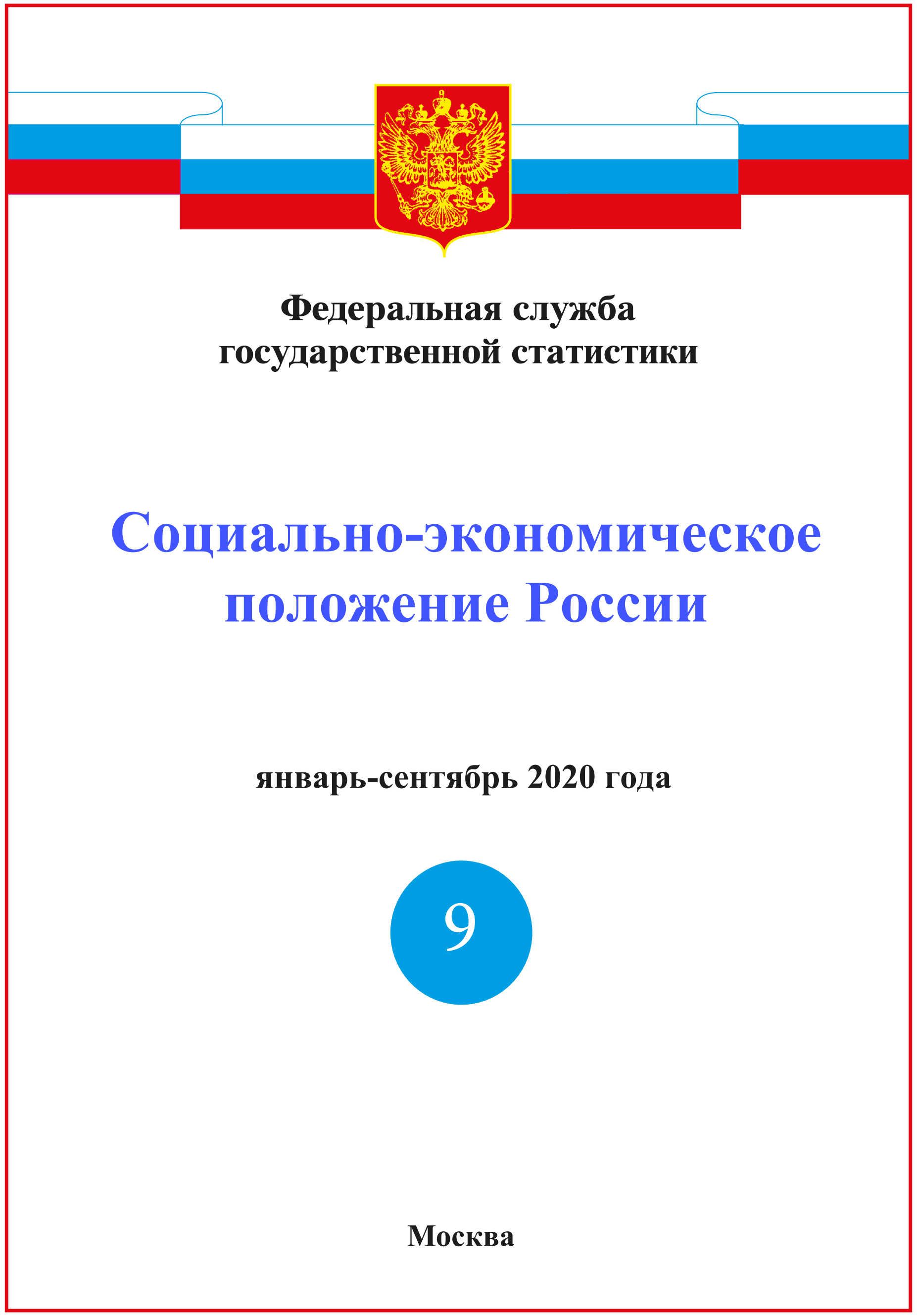




\section{МИНЭКОНОМРАЗВИТИЯ РОССИИ}

ФЕДЕРАЛЬНАЯ СЛУЖБА ГОСУДАРСТВЕННОЙ СТАТИСТИКИ (POCCTAT)

\section{СОЦИАЛЬНО-ЭКОНОМИЧЕСКОЕ ПОЛОЖЕНИЕ РОССИИ}

январь-сентябрь 2020 года 


\section{СОДЕРЖАНИЕ}

Стр.

І. ОСНОВНЫЕ ЭКОНОМИЧЕСКИЕ И СОЦИАЛЬНЫЕ ПОКАЗАТЕЛИ......... 6

II. ЭКОНОМИЧЕСКАЯ СИТУАЦИЯ В РОССИЙСКОЙ ФЕДЕРАЦИИ........... 7

1. Производство товаров и услуг ............................................ 7

1.1. Валовой внутренний продукт.......................................... 7

1.1.1. Объем ВВП.................................................. 7

1.1.2. Индекс выпуска товаров и услуг по базовым видам экономической деятельности............................. 14

1.2. Индексы производительности труда................................

1.3. Оборот организаций................................................ 16

1.4. Промышленное производство...................................... 19

1.4.1. Добыча полезных ископаемых.................................... 20

1.4.2. Обрабатывающие производства................................ 24

1.4.3. Обеспечение электрической энергией, газом и паром; кондиционирование воздуха................................... 68

1.4.4. Водоснабжение; водоотведение, организация сбора и утилизации отходов, деятельность по ликвидации загрязнений....................... 70

1.5. Сельское и лесное хозяйство....................................... 72

1.5.1. Сельское хозяйство......................................... 72

1.5.2. Лесозаготовки........................................................... 78

1.6. Рыболовство и рыбоводство.......................................... 78

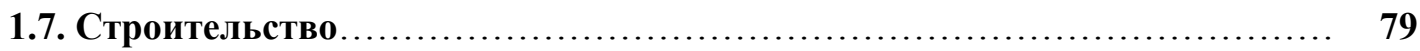

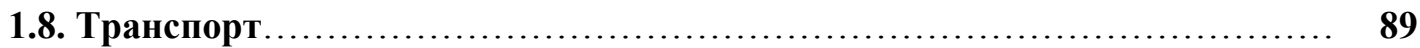

2. Рынки товаров и услуг.............................................. 94

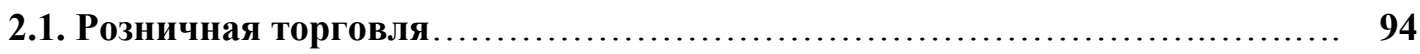

2.2. Рестораны, кафе и бары............................................. 99

2.3. Рынок платных услуг населению..................................... 100

2.4. Оптовая торговля.................................................. 106

2.5. Внешняя торговля.................................................. 112

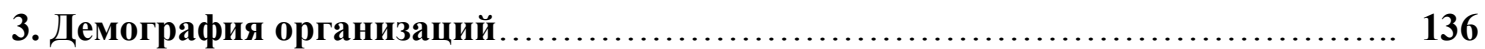




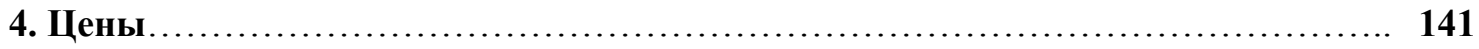

4.1. Потребительские цены........................................... 142

4.2. Цены производителей............................................ 150

4.2.1. Индексы и уровни цен производителей промышленных товаров....................................... 150

4.2.2. Индексы цен производителей сельскохозяйственной продукции............................... 154

4.2.3. Индексы цен на продукцию инвестиционного назначения.................................. 156

4.2.4. Индексы тарифов на грузовые перевозки.......................... 159

4.2.5. Индексы тарифов на услуги связи для юридических лиц............................................. 160

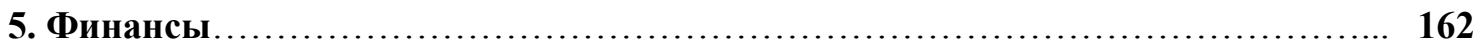

5.1. Государственные финансы......................................... 162

5.1.1. Исполнение бюджета............................................. 162

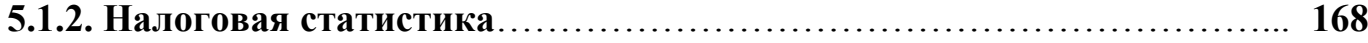

5.2. Финансовая деятельность организаций.............................. 170

5.2.1. Финансовые результаты деятельности организаций................ 170

5.2.2. Состояние платежей и расчетов в организациях................... 174

5.3. Денежно-кредитная система............................................... 186

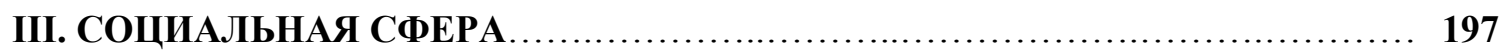

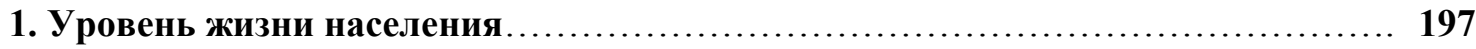

1.1. Денежные доходы................................................... 198

1.2. Социально-экономическая дифференциация.......................... 211

1.3. Использование денежных доходов .................................... 212

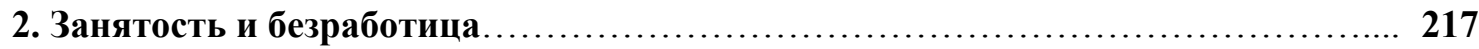

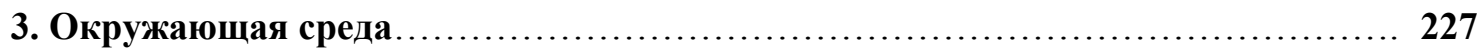

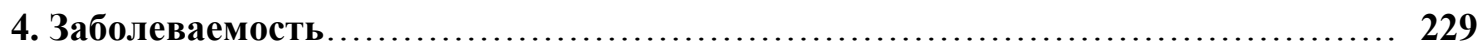

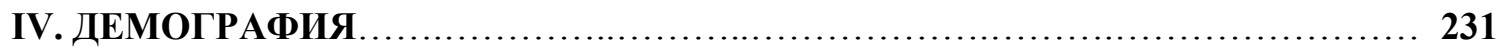

МЕТОДОЛОГИЧЕСКИЕ ПОЯСНЕНИЯ...................................... 236 


\section{Приложение}

\section{НЕКОТОРЫЕ СТАТИСТИЧЕСКИЕ ПОКАЗАТЕЛИ \\ СОЦИАЛЬНО-ЭКОНОМИЧЕСКОГО ПОЛОЖЕНИЯ СУБЪЕКТОВ РОССИЙСКОЙ ФЕДЕРАЦИИ.}

І. Производство товаров и услуг.

Промышленное производство

Сельское хозяйство.

Строительство.

ІІ. Рынки товаров и услуг........................................................ 297

Розничная торговля.

Рестораны, кафе и бары.

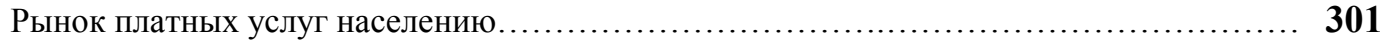

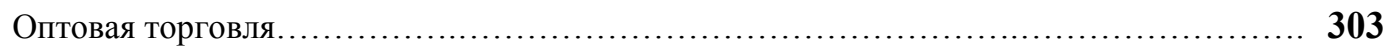

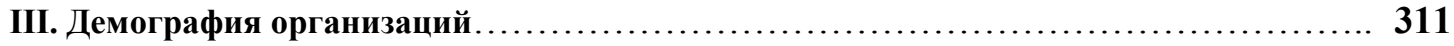

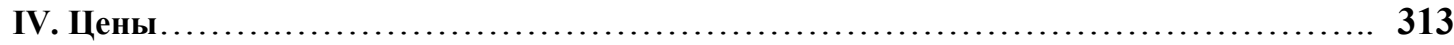

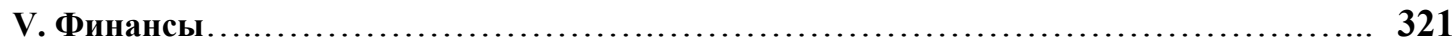

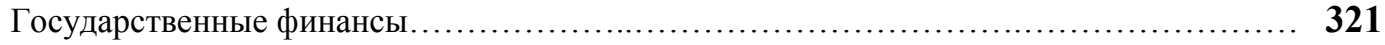

Финансовая деятельность организаций................................................. 325

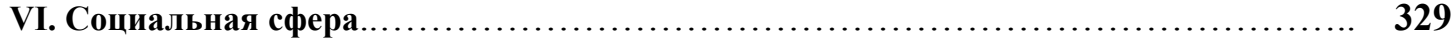

Величина прожиточного минимума и заработная плата.................................... 329

Занятость и безработица.............................................................. 333

VII. Демография................................................................. 341

\footnotetext{
Условные обозначения:

- явление отсутствует;

... данных не имеется;

0,0 небольшая величина
}

В отдельных случаях незначительные расхождения между итогом и суммой слагаемых объясняются округлением данных. 


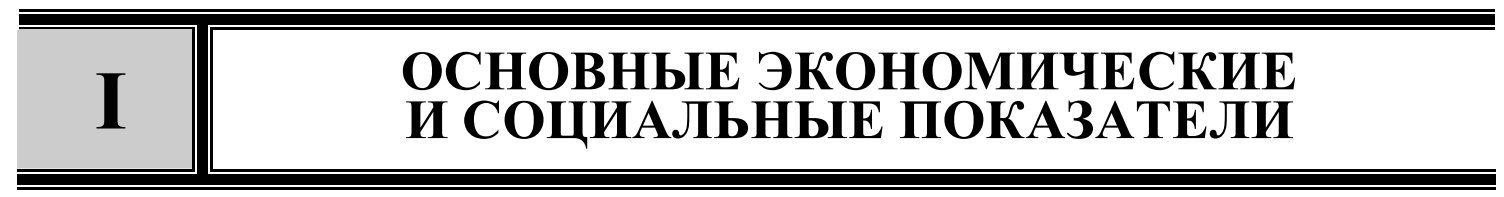

\begin{tabular}{|c|c|c|c|}
\hline & $\begin{array}{l}\text { Іполугодие } \\
20202 .\end{array}$ & $\begin{array}{c}\text { B\% } \\
\text { I полугодию } \\
2019 \text { 2. }\end{array}$ & $\begin{array}{c}\text { Справочно } \\
\text { I полугодие } 2019 \text { г. } \\
\text { в\% } 2018 \text { г } \\
\text { I полугоию } 2018 \text { г }\end{array}$ \\
\hline $\begin{array}{l}\text { Валовой внутренний продукт, } \\
\text { млрд рублей }\end{array}$ & $48605,8^{1)}$ & 96,6 & 100,8 \\
\hline $\begin{array}{l}\text { Инвестиции в основной капитал, } \\
\text { млрд рублей }\end{array}$ & 6916,6 & 96,0 & 101,1 \\
\hline
\end{tabular}

\begin{tabular}{|c|c|c|c|}
\hline & $\begin{array}{c}\text { Январь-сентябрь } \\
2020 \text { г. }\end{array}$ & $\begin{array}{c}\text { В\%к } \\
\text { январю-сентябрю } \\
20192 .\end{array}$ & $\begin{array}{c}\text { Справочно } \\
\text { январь-сентябрь } 2019 \text { г. } \\
\text { в\% к K } \\
\text { январю-сентябрю } 2018 \text { г. }\end{array}$ \\
\hline $\begin{array}{l}\text { Реальные располагаемые } \\
\text { денежные доходы }\end{array}$ & & $95,7^{2)}$ & 100,9 \\
\hline
\end{tabular}

\begin{tabular}{|c|c|c|c|c|c|c|c|}
\hline & \multirow{2}{*}{$\begin{array}{l}\text { Сентяббрь } \\
20202 .\end{array}$} & \multicolumn{2}{|c|}{$\overline{B \% \kappa}$} & \multirow[b]{2}{*}{$\begin{array}{c}\text { Январь- } \\
\text { сентябрь- } \\
2020 \text { г. } \\
6 \% \kappa \\
\text { январю- } \\
\text { сентябрю } \\
2019 \text { г. } \\
\end{array}$} & \multicolumn{3}{|c|}{ Справочно } \\
\hline & & $\begin{array}{l}\text { сентяярю } \\
20192 .\end{array}$ & $\begin{array}{l}\text { ввгусту } \\
2020 \text { ट. }\end{array}$ & & \begin{tabular}{|l|} 
сентябрь 20 \\
сентяборю \\
2018 2.
\end{tabular} & $\begin{array}{l}\frac{19 \text { г. } 6 \% \kappa}{\text { abzcmy }} \\
2019 \text { z. }\end{array}$ & $\begin{array}{c}\text { январь- } \\
\text { сентябрь } \\
2019 \text { 2. } \\
\text { в\% \% } \\
\text { январю- } \\
\text { сентябрю } \\
2018 \text { г. }\end{array}$ \\
\hline $\begin{array}{l}\text { Индекс выпуска товаров и } \\
\text { услуг по базовым видам } \\
\text { экономической деятельности }\end{array}$ & & 97,0 & 107,5 & 96,9 & 103,9 & 107,6 & 101,7 \\
\hline $\begin{array}{l}\text { Индекс промышленного } \\
\text { производства }\end{array}$ & & 95,0 & 100,0 & 97,1 & 104,9 & 100,8 & 103,5 \\
\hline $\begin{array}{l}\text { Продукция сельского хозяйства, } \\
\text { млрд рублей }\end{array}$ & 1327,4 & 101,4 & 182,0 & 103,3 & 105,8 & 186,8 & 103,8 \\
\hline Грузооборот транспорта, млрд т-км & 449,1 & 96,6 & 100,3 & 94,1 & 100,6 & 98,7 & 101,2 \\
\hline $\begin{array}{l}\text { в том числе } \\
\text { железнодорожного транспорта }\end{array}$ & 211,8 & 99,5 & 97,6 & 96,4 & 101,4 & 99,5 & 100,9 \\
\hline $\begin{array}{l}\text { Оборот розничной торговли, } \\
\text { млрд рублей }\end{array}$ & 2897,3 & 97,0 & 98,3 & 95,2 & 100,9 & 98,7 & 101,8 \\
\hline $\begin{array}{l}\text { Объем платных услуг населению, } \\
\text { млрд рублей }\end{array}$ & 778,6 & 87,8 & 104,3 & 81,3 & 101,2 & 99,1 & 100,2 \\
\hline Индекс потребительских цен & & 103,7 & 99,9 & 103,0 & 104,0 & 99,8 & 104,8 \\
\hline $\begin{array}{l}\text { Индекс цен производителей } \\
\text { промышленных товаров }\end{array}$ & & 100,0 & 100,6 & 95,4 & 98,8 & 99,7 & 105,8 \\
\hline $\begin{array}{l}\text { Общая численность безработных } \\
\text { (в возрасте } 15 \text { лет и старше), } \\
\text { млн человек }\end{array}$ & 4,8 & 141,7 & 99,3 & 122,5 & 98,2 & 103,5 & 94,5 \\
\hline \multirow[t]{3}{*}{$\begin{array}{l}\text { Численность официально } \\
\text { зарегистрированных безработных } \\
\text { (по данным Роструда), млн человек } \\
\end{array}$} & 3,7 & в 5,5p. & 101,2 & в 2,8p. & 102,5 & 93,5 & 103,3 \\
\hline & \multirow{2}{*}{$\begin{array}{l}\text { Aвгycm } \\
2020 \text {. }\end{array}$} & \multicolumn{2}{|c|}{ 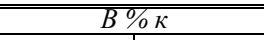 } & \multirow[b]{2}{*}{$\begin{array}{c}\text { Январь- } \\
\text { август- } \\
2020 \text { 2. } \\
\text { в\% \% } \\
\text { январю- } \\
\text { августу } \\
2019 \text { г. }\end{array}$} & \multicolumn{2}{|c|}{$\begin{array}{r}\text { Справочно } \\
\text { август } 2019 \text { 2. . \% К }\end{array}$} & \\
\hline & & $\begin{array}{l}\text { aвгусmy } \\
20192 .\end{array}$ & $\begin{array}{l}\text { июлю } \\
2020 \text {. }\end{array}$ & & $\begin{array}{l}\text { aвгуcm 201 } \\
\text { aвzycmy } \\
2018 \text { 2. }\end{array}$ & 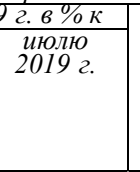 & $\begin{array}{l}\text { январь- } \\
\text { август } \\
2019 \text { г. } \\
\text { в\% K } \\
\text { январю- } \\
\text { августу } \\
2018 \text { z. }\end{array}$ \\
\hline $\begin{array}{l}\text { Внешнеторговый оборот, } \\
\text { млрд долларов США }\end{array}$ & 42,8 & 76,0 & 98,0 & 81,8 & 95,2 & 101,0 & 97,2 \\
\hline $\begin{array}{l}\text { в том числе: } \\
\text { экспорт товаров }\end{array}$ & 23,3 & 67,7 & 96,0 & 75,6 & 91,5 & 102,8 & 96,3 \\
\hline импорт товаров & 19,5 & 88,9 & 100,5 & 92,1 & 101,5 & 98,3 & 98,9 \\
\hline $\begin{array}{l}\text { Среднемесячная начисленная } \\
\text { заработная плата работников } \\
\text { организаций: }\end{array}$ & & & & & & & \\
\hline номинальная, рублей & 47649 & 103,7 & 95,1 & 105,6 & 106,8 & 96,5 & 107,2 \\
\hline реальная & & 100,1 & 95,1 & 102,6 & 102,4 & 96,7 & 102,2 \\
\hline
\end{tabular}




\section{II \\ ЭКОНОМИЧЕСКАЯ СИТУАЦИЯ \\ В РОССИЙСКОЙ ФЕДЕРАЦИИ}

\section{1. ПРОИЗВОДСТВО ТОВАРОВ И УСЛУГ}

\section{1. ВАЛОВОЙ ВНУТРЕННИЙ ПРОДУКТ}

\subsection{1. Объем ВВП}

Производство ВВП. Объем ВВП России за II квартал 2020 г. составил в текущих ценах 23288,2 млрд рублей. Индекс его физического объема относительно II квартала 2019 г. составил 92,0\%. Индекс-дефлятор ВВП за ІІ квартал 2020 г. по отношению к ценам II квартала 2019 г. составил $95,9 \%$.

Объем ВВП России за І полугодие 2020 г. составил в текущих ценах 48605,8 млрд рублей. Индекс его физического объема относительно I полугодия 2019 г. составил 96,6\%. Индексдефлятор ВВП за І полугодие 2020 г. по отношению к ценам I полугодия 2019 г. составил 98,0\%.

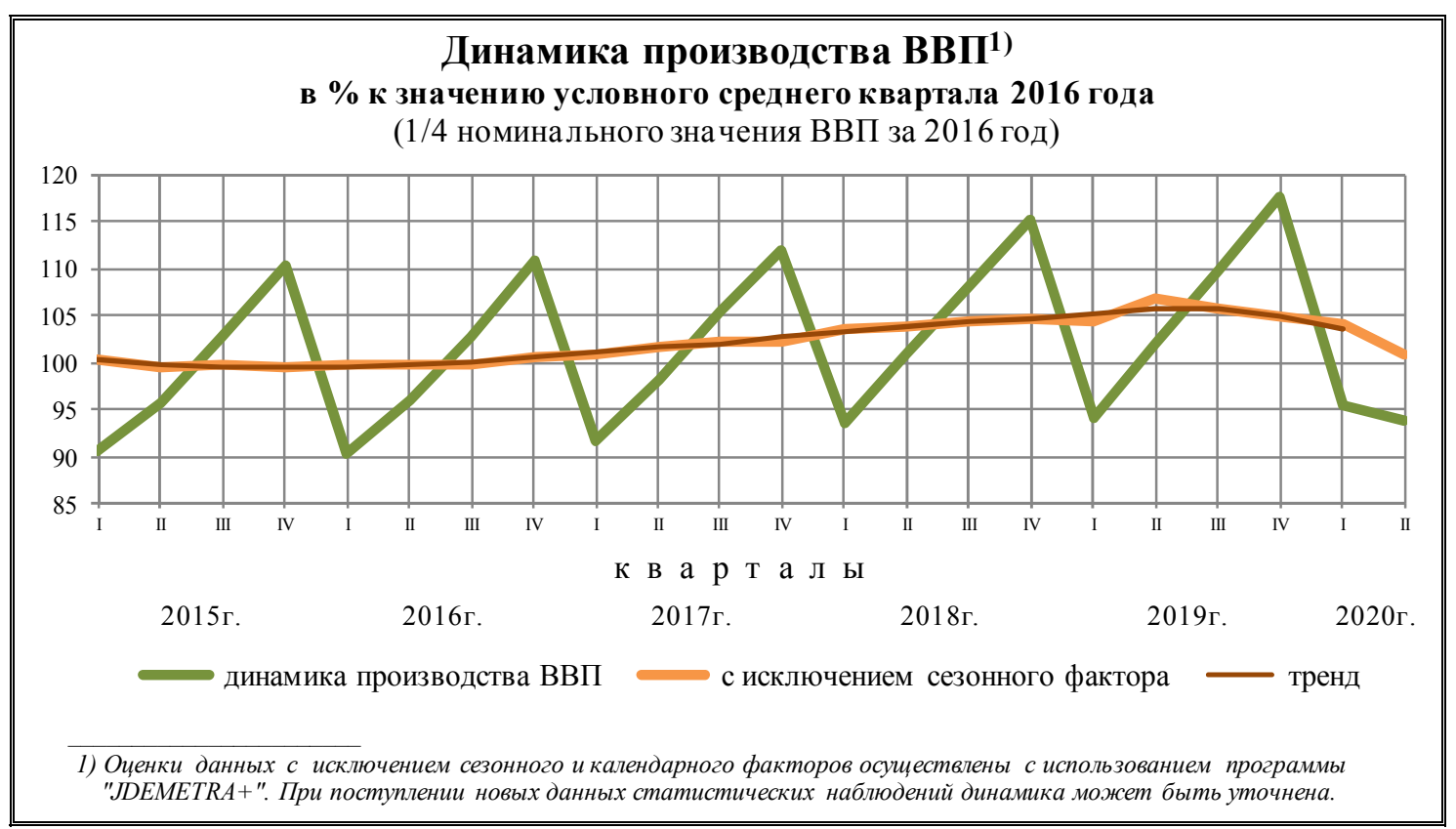


ИНДЕКСЫ ФИЗИЧЕСКОГО ОБЪЕМА ПРОИЗВЕДЕННОГО ВВП

в постоянных ценах

\begin{tabular}{|c|c|c|}
\hline & \multicolumn{2}{|c|}{ 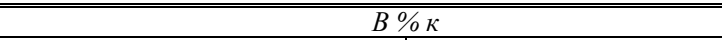 } \\
\hline & $\begin{array}{c}\text { соответствующему } \\
\text { периоду предыдущчего года }\end{array}$ & $\begin{array}{c}\text { предылущему } \\
\text { периоду }\end{array}$ \\
\hline \multicolumn{3}{|c|}{2019 г. } \\
\hline I квартал & 100,4 & 81,7 \\
\hline II квартал & 101,1 & 108,4 \\
\hline I полугодие & 100,8 & \\
\hline III квартал & 101,5 & 107,6 \\
\hline Январь-сентябрь & 101,0 & \\
\hline IV квартал & 102,1 & 107,1 \\
\hline Год & 101,3 & \\
\hline \multicolumn{3}{|c|}{2020 г. } \\
\hline I квартал & 101,6 & 81,3 \\
\hline II квартал & 92,0 & 98,1 \\
\hline I полугодие & 96,6 & \\
\hline
\end{tabular}

Таблица 2

ПРОИЗВОДСТВО ВВП И ВАЛОВОЙ ДОБАВЛЕННОЙ СТОИМОСТИ ПО ОТРАСЛЯМ ЭКОНОМИКИ

в текущих ценах

\begin{tabular}{|c|c|c|c|c|c|c|}
\hline & \multicolumn{2}{|c|}{ І квартал } & \multicolumn{2}{|c|}{ ІІ квартал } & \multicolumn{2}{|c|}{ I полугодие } \\
\hline & $\begin{array}{c}\text { млрд } \\
\text { рублей }\end{array}$ & $\begin{array}{l}\% \% \\
\text { umozy }\end{array}$ & $\begin{array}{c}\text { млрд } \\
\text { рублей }\end{array}$ & $\begin{array}{l}\% \% \kappa \\
\text { uтогу }\end{array}$ & $\begin{array}{c}\text { млрд } \\
\text { рублей }\end{array}$ & $\begin{array}{l}\% \% \\
\text { umozy }\end{array}$ \\
\hline \multicolumn{7}{|c|}{2019 г. } \\
\hline $\begin{array}{l}\text { Валовой внутренний продукт } \\
\text { в рыночных ценах }\end{array}$ & 24944,8 & & 26410,2 & & 51355,0 & \\
\hline $\begin{array}{l}\text { Валовая добавленная стоимость } \\
\text { в основных ценах }\end{array}$ & 22169,7 & 100 & 23720,9 & 100 & 45890,6 & 100 \\
\hline $\begin{array}{l}\text { в том числе: } \\
\text { сельское, лесное хозяйство, охота, } \\
\text { рыболовство и рыбоводство }\end{array}$ & 494,8 & 2,2 & 683,9 & 2,9 & 1178,6 & 2,6 \\
\hline добыча полезных ископаемых & 2987,1 & 13,4 & 3064,6 & 12,9 & 6051,7 & 13,2 \\
\hline обрабатывающие производства & 3317,0 & 15,0 & 3508,9 & 14,8 & 6825,9 & 14,8 \\
\hline $\begin{array}{l}\text { обеспечение электрической энергией, } \\
\text { газом и паром; кондиционирование воздуха }\end{array}$ & 707,7 & 3,2 & 574,8 & 2,4 & 1282,4 & 2,8 \\
\hline $\begin{array}{l}\text { водоснабжение; водоотведение, } \\
\text { организация сбора и утилизации отходов, } \\
\text { деятельность по ликвидации загрязнений }\end{array}$ & 105,3 & 0,5 & 123,4 & 0,5 & 228,6 & 0,5 \\
\hline строительство & 761,3 & 3,4 & 1173,5 & 4,9 & 1934,8 & 4,2 \\
\hline $\begin{array}{l}\text { торговля оптовая и розничная; ремонт } \\
\text { автотранспортных средств и мотоциклов }\end{array}$ & 3033,2 & 13,6 & 3313,8 & 14,0 & 6347,0 & 13,7 \\
\hline транспортировка и хранение & 1517,8 & 6,8 & 1650,5 & 7,0 & 3168,4 & 6,9 \\
\hline
\end{tabular}




\begin{tabular}{|c|c|c|c|c|c|c|}
\hline & \multicolumn{2}{|c|}{ І квартал } & \multicolumn{2}{|c|}{ ІІ квартал } & \multicolumn{2}{|c|}{ І І полугодие } \\
\hline & $\begin{array}{c}\text { млрд } \\
\text { рублей }\end{array}$ & $\begin{array}{l}8 \% \kappa \\
\text { umozy }\end{array}$ & $\begin{array}{c}\text { млрд } \\
\text { рублей }\end{array}$ & $\begin{array}{l}8 \% \kappa \\
\text { umozy }\end{array}$ & $\begin{array}{c}\text { млрд } \\
\text { рублей }\end{array}$ & $\begin{array}{l}6 \% \kappa \\
\text { umozy }\end{array}$ \\
\hline $\begin{array}{l}\text { деятельность гостиниц и предприятий } \\
\text { общественного питания }\end{array}$ & 177,4 & 0,8 & 206,5 & 0,9 & 383,9 & 0,8 \\
\hline деятельность в области информации и связи & 487,0 & 2,2 & 617,1 & 2,6 & 1104,1 & 2,4 \\
\hline деятельность финансовая и страховая & 1048,3 & 4,7 & 984,9 & 4,2 & 2033,2 & 4,4 \\
\hline $\begin{array}{l}\text { деятельность по операциям } \\
\text { с недвижимым имуществом }\end{array}$ & 2274,6 & 10,3 & 2305,2 & 9,7 & 4579,8 & 10,0 \\
\hline $\begin{array}{l}\text { деятельность профессиональная, } \\
\text { научная и техническая }\end{array}$ & 877,2 & 4,0 & 1012,9 & 4,3 & 1890,1 & 4,1 \\
\hline $\begin{array}{l}\text { деятельность административная } \\
\text { и сопутствующие дополнительные услуги }\end{array}$ & 480,1 & 2,2 & 508,7 & 2,1 & 988,8 & 2,2 \\
\hline $\begin{array}{l}\text { государственное управление и обеспечение } \\
\text { военной безопасности; социальное обеспечение }\end{array}$ & 1820,4 & 8,2 & 1843,0 & 7,8 & 3663,4 & 8,0 \\
\hline образование & 774,9 & 3,5 & 776,4 & 3,3 & 1551,3 & 3,4 \\
\hline $\begin{array}{l}\text { деятельность в области здравоохранения } \\
\text { и социальных услуг }\end{array}$ & 790,7 & 3,6 & 839,9 & 3,5 & 1630,6 & 3,6 \\
\hline $\begin{array}{l}\text { деятельность в области культуры, спорта, } \\
\text { организации досуга и развлечений }\end{array}$ & 241,8 & 1,1 & 246,2 & 1,0 & 488,0 & 1,1 \\
\hline предоставление прочих видов услуг & 122,3 & 0,6 & 134,6 & 0,6 & 256,9 & 0,6 \\
\hline $\begin{array}{l}\text { деятельность домашних хозяйств как } \\
\text { работодателей; недифференцированная } \\
\text { деятельность частных домашних хозяйств } \\
\text { по производству товаров и оказанию услуг } \\
\text { для собственного потребления }\end{array}$ & 150,9 & 0,7 & 152,1 & 0,6 & 303,0 & 0,7 \\
\hline Чистые налоги на продукты & 2775,1 & & 2689,3 & & 5464,4 & \\
\hline \multicolumn{7}{|c|}{2020 г. } \\
\hline $\begin{array}{l}\text { Валовой внутренний продукт } \\
\text { в рыночных ценах }\end{array}$ & 25317,7 & & 23288,2 & & 48605,8 & \\
\hline $\begin{array}{l}\text { Валовая добавленная стоимость } \\
\text { в основных ценах }\end{array}$ & 22704,4 & 100 & 20869,1 & 100 & 43573,4 & 100 \\
\hline $\begin{array}{l}\text { в том числе: } \\
\text { сельское, лесное хозяйство, охота, } \\
\text { рыболовство и рыбоводство }\end{array}$ & 492,5 & 2,2 & 678,9 & 3,3 & 1171,4 & 2,7 \\
\hline добыча полезных ископаемых & 2641,0 & 11,6 & 1519,7 & 7,3 & 4160,7 & 9,5 \\
\hline обрабатывающие производства & 3403,6 & 14,9 & 3032,7 & 14,5 & 6436,3 & 14,9 \\
\hline $\begin{array}{l}\text { обеспечение электрической энергией, } \\
\text { газом и паром; кондиционирование воздуха }\end{array}$ & 706,0 & 3,1 & 559,5 & 2,7 & 1265,4 & 2,9 \\
\hline $\begin{array}{l}\text { водоснабжение; водоотведение, } \\
\text { организация сбора и утилизации отходов, } \\
\text { деятельность по ликвидации загрязнений }\end{array}$ & 104,1 & 0,5 & 117,3 & 0,6 & 221,4 & 0,5 \\
\hline строительство & 813,0 & 3,6 & 1198,2 & 5,7 & 2011,2 & 4,6 \\
\hline $\begin{array}{l}\text { торговля оптовая и розничная; ремонт } \\
\text { автотранспортных средств и мотоциклов }\end{array}$ & 3148,4 & 13,8 & 2816,1 & 13,5 & 5964,4 & 13,7 \\
\hline транспортировка и хранение & 1498,5 & 6,6 & 1345,2 & 6,4 & 2843,7 & 6,5 \\
\hline $\begin{array}{l}\text { деятельность гостиниц и предприятий } \\
\text { общественного питания }\end{array}$ & 185,6 & 0,8 & 90,5 & 0,4 & 276,1 & 0,6 \\
\hline деятельность в области информации и связи & 511,4 & 2,3 & 628,2 & 3,0 & 1139,6 & 2,6 \\
\hline деятельность финансовая и страховая & 1105,4 & 4,9 & 1102,8 & 5,3 & 2208,2 & 5,1 \\
\hline $\begin{array}{l}\text { деятельность по операциям } \\
\text { с недвижимым имуществом }\end{array}$ & 2402,7 & 10,6 & 2360,9 & 11,3 & 4763,6 & 10,9 \\
\hline $\begin{array}{l}\text { деятельность профессиональная, } \\
\text { научная и техническая }\end{array}$ & 906,6 & 4,0 & 968,1 & 4,6 & 1874,7 & 4,3 \\
\hline
\end{tabular}




\begin{tabular}{|c|c|c|c|c|c|c|}
\hline & \multicolumn{2}{|c|}{ ІІ квартал } & \multicolumn{2}{|c|}{ ІІІ квартал } & \multicolumn{2}{|c|}{ ІІ полугодие } \\
\hline & $\begin{array}{c}\text { млрд } \\
\text { рублей }\end{array}$ & $\begin{array}{l}6 \% \kappa \\
\text { umozy }\end{array}$ & $\begin{array}{c}\text { млрд } \\
\text { рублей }\end{array}$ & $\begin{array}{l}8 \% \kappa \\
\text { umozy }\end{array}$ & $\begin{array}{c}\text { млрд } \\
\text { рублей }\end{array}$ & $\begin{array}{l}6 \% \kappa \\
\text { umozy }\end{array}$ \\
\hline $\begin{array}{l}\text { деятельность административная } \\
\text { и сопутствующие дополнительные услуги }\end{array}$ & 498,4 & 2,2 & 441,2 & 2,1 & 939,6 & 2,2 \\
\hline $\begin{array}{l}\text { государственное управление и обеспечение } \\
\text { военной безопасности; социальное обеспечение }\end{array}$ & 2060,4 & 9,1 & 2017,6 & 9,7 & 4078,0 & 9,4 \\
\hline образование & 837,7 & 3,7 & 773,5 & 3,7 & 1611,2 & 3,7 \\
\hline $\begin{array}{l}\text { деятельность в области здравоохранения } \\
\text { и социальных услуг }\end{array}$ & 856,7 & 3,8 & 858,5 & 4,1 & 1715,2 & 3,9 \\
\hline $\begin{array}{l}\text { деятельность в области культуры, спорта, } \\
\text { организации досуга и развлечений }\end{array}$ & 258,6 & 1,1 & 177,2 & 0,8 & 435,8 & 1,0 \\
\hline предоставление прочих видов услуг & 121,7 & 0,5 & 98,6 & 0,5 & 220,2 & 0,5 \\
\hline $\begin{array}{l}\text { деятельность домашних хозяйств как } \\
\text { работодателей; недифференцированная } \\
\text { деятельность частных домашних хозяйств } \\
\text { по производству товаров и оказанию услуг } \\
\text { для собственного потребления }\end{array}$ & 152,2 & 0,7 & 84,4 & 0,4 & 236,6 & 0,5 \\
\hline Чистые налоги на продукты & 2613,3 & & 2419,1 & & 5032,4 & \\
\hline
\end{tabular}

Таблица 3

\section{ИНДЕКСЫ ФИЗИЧЕСКОГО ОБЪЕМА ПРОИЗВЕДЕННОГО ВВП И ВАЛОВОЙ ДОБАВЛЕННОЙ СТОИМОСТИ ПО ОТРАСЛЯМ ЭКОНОМИКИ}

в постоянных ценах, в \% к соответствующему периоду предыдущего года

\begin{tabular}{|c|c|c|c|}
\hline & I квартал & ІІ квартал & I полугодие \\
\hline \multicolumn{4}{|l|}{2019 г. } \\
\hline Валовой внутренний продукт в рыночных ценах & 100,4 & 101,1 & 100,8 \\
\hline $\begin{array}{l}\text { в том числе: } \\
\text { сельское, лесное хозяйство, охота, рыболовство и рыбоводство }\end{array}$ & 97,4 & 98,4 & 98,0 \\
\hline добыча полезных ископаемых & 103,3 & 101,8 & 102,5 \\
\hline обрабатывающие производства & 98,6 & 101,1 & 99,9 \\
\hline $\begin{array}{l}\text { обеспечение электрической энергией, газом и паром; } \\
\text { кондиционирование воздуха }\end{array}$ & 97,7 & 99,9 & 98,6 \\
\hline $\begin{array}{l}\text { водоснабжение; водоотведение, организация сбора и } \\
\text { утилизации отходов, деятельность по ликвидации загрязнений }\end{array}$ & 98,0 & 100,2 & 99,2 \\
\hline строительство & 101,0 & 100,0 & 100,4 \\
\hline $\begin{array}{l}\text { торговля оптовая и розничная; } \\
\text { ремонт автотранспортных средств и мотоциклов }\end{array}$ & 96,7 & 99,5 & 98,1 \\
\hline транспортировка и хранение & 102,7 & 102,8 & 102,7 \\
\hline деятельность гостиниц и предприятий общественного питания & 103,2 & 101,4 & 102,2 \\
\hline деятельность в области информации и связи & 103,5 & 105,2 & 104,4 \\
\hline деятельность финансовая и страховая & 107,8 & 107,7 & 107,8 \\
\hline деятельность по операциям с недвижимым имуществом & 99,4 & 99,5 & 99,4 \\
\hline деятельность профессиональная, научная и техническая & 103,9 & 104,7 & 104,3 \\
\hline $\begin{array}{l}\text { деятельность административная } \\
\text { и сопутствующие дополнительные услуги }\end{array}$ & 88,4 & 94,6 & 91,6 \\
\hline
\end{tabular}




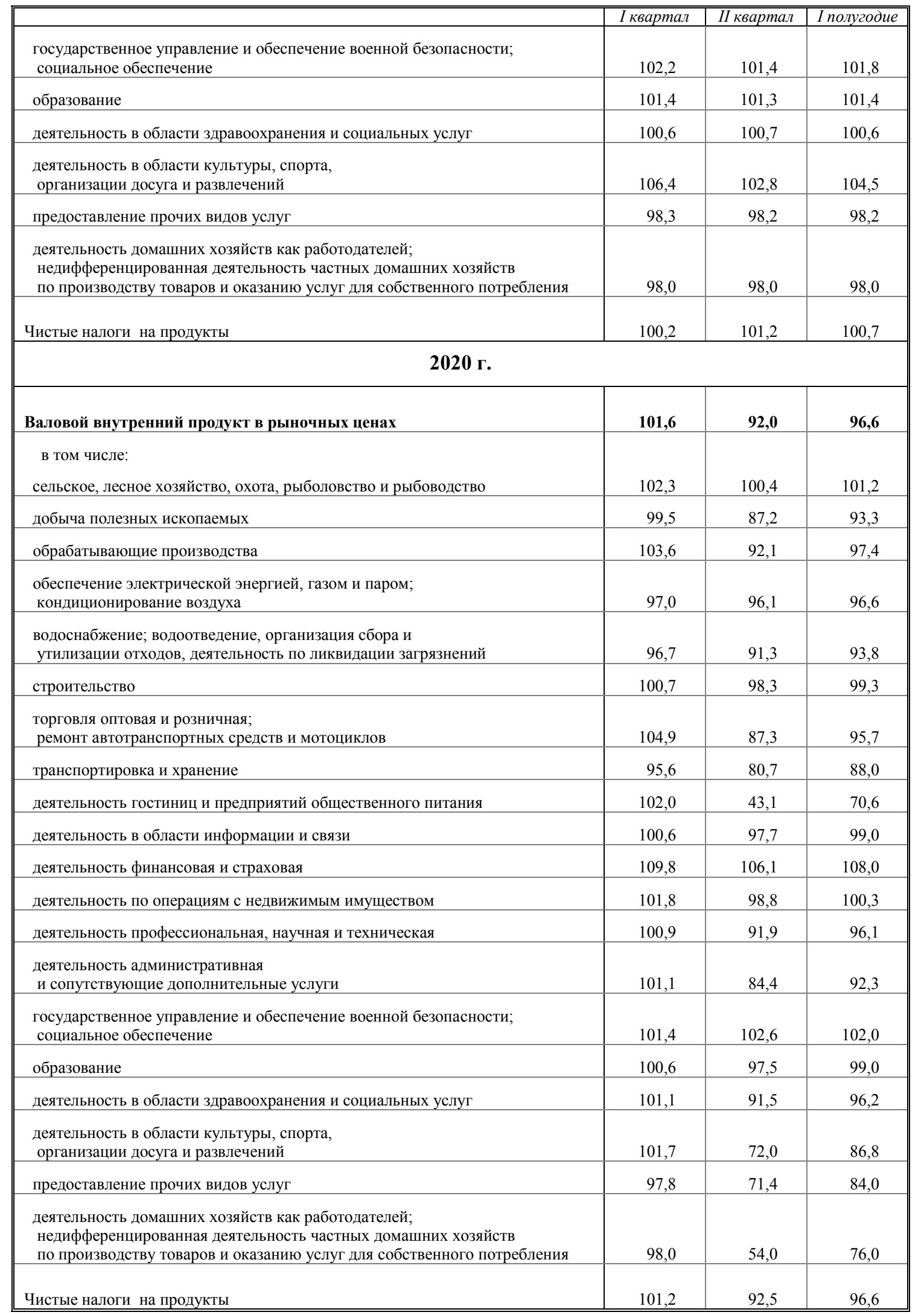




\section{Использование ВВП.}

ВВП, РАССЧИТАННЫЙ МЕТОДОМ ИСПОЛЬЗОВАНИЯ ДОХОДОВ

в текущих рыночных ценах

\begin{tabular}{|c|c|c|c|c|c|c|}
\hline & \multicolumn{2}{|c|}{ І Іквартал } & \multicolumn{2}{|c|}{ II квартал } & \multicolumn{2}{|c|}{ І І полугодие } \\
\hline & $\begin{array}{c}\text { млрд } \\
\text { рублей }\end{array}$ & $\begin{array}{c}\% \% \\
\text { umoгy }\end{array}$ & $\begin{array}{c}\text { млрд } \\
\text { рублей }\end{array}$ & $\begin{array}{c}6 \% \kappa^{\prime} \\
\text { umoгy }\end{array}$ & $\begin{array}{c}\text { млрд } \\
\text { рублей }\end{array}$ & $\begin{array}{c}6 \% \kappa \\
\text { umozy }{ }^{l)}\end{array}$ \\
\hline \multicolumn{7}{|c|}{2019 г. } \\
\hline Валовой внутренний продукт & 24944,8 & 100 & 26410,2 & 100 & $\mathbf{5 1 3 5 5 , 0}$ & 100 \\
\hline в том числе: & & & & & & \\
\hline расходы на конечное потребление & 17862,3 & 72,6 & 18493,4 & 70,3 & 36355,7 & 71,4 \\
\hline домашних хозяйств & 12787,2 & 52,0 & 13357,0 & 50,8 & 26144,2 & 51,4 \\
\hline государственного управления & 4971,9 & 20,3 & 5032,3 & 19,1 & 10004,2 & 19,6 \\
\hline $\begin{array}{l}\text { некоммерческих организаций, } \\
\text { обслуживающих домашние хозяйства }\end{array}$ & 103,2 & 0,3 & 104,1 & 0,4 & 207,3 & 0,4 \\
\hline валовое накопление & 4025,6 & 16,4 & 5830,6 & 22,2 & 9856,2 & 19,4 \\
\hline валовое накопление основного капитала ${ }^{2)}$ & 3589,1 & 14,7 & 4961,9 & 18,9 & 8551,0 & 16,8 \\
\hline $\begin{array}{l}\text { изменение запасов материальных } \\
\text { оборотных средств }\end{array}$ & 436,5 & 1,7 & 868,7 & 3,3 & 1305,2 & 2,6 \\
\hline чистый экспорт & 2710,7 & 11,0 & 1969,4 & 7,5 & 4680,1 & 9,2 \\
\hline статистическое расхождение & 346,2 & & 116,8 & & 463,0 & \\
\hline \multicolumn{7}{|c|}{2020 г. } \\
\hline Валовой внутренний продукт & 25317,7 & 100 & 23288,2 & 100 & 48605,8 & 100 \\
\hline $\begin{array}{l}\text { в том числе: } \\
\text { расходы на конечное потребление }\end{array}$ & 18978,9 & 76,0 & 16257,9 & 70,8 & 35236,8 & 73,6 \\
\hline домашних хозяйств & 13491,1 & 54,1 & 10756,4 & 46,9 & 24247,5 & 50,6 \\
\hline государственного управления & 5371,0 & 21,5 & 5391,4 & 23,5 & 10762,4 & 22,5 \\
\hline $\begin{array}{l}\text { некоммерческих организаций, } \\
\text { обслуживающих домашние хозяйства }\end{array}$ & 116,8 & 0,4 & 110,1 & 0,4 & 226,9 & 0,5 \\
\hline валовое накопление & 4323,0 & 17,3 & 5742,9 & 25,0 & 10065,9 & 21,0 \\
\hline валовое накопление основного капитала ${ }^{2)}$ & 3886,8 & 15,6 & 4629,9 & 20,2 & 8516,7 & 17,8 \\
\hline $\begin{array}{l}\text { изменение запасов материальных } \\
\text { оборотных средств }\end{array}$ & 436,2 & 1,7 & 1113,0 & 4,8 & 1549,2 & 3,2 \\
\hline чистый экспорт & 1667,4 & 6,7 & 941,6 & 4,2 & 2609,0 & 5,4 \\
\hline статистическое расхождение & 348,4 & & 345,8 & & 694,1 & \\
\hline
\end{tabular}


ДИНАМИКА ЭЛЕМЕНТОВ ИСПОЛЬЗОВАНИЯ ВВП

в постоянных ценах, в \% к соответствующему периоду предыдущего года

\begin{tabular}{|c|c|c|c|}
\hline & \multicolumn{3}{|c|}{20202.} \\
\hline & І квартал & ІІ квартал & I полугодие \\
\hline Валовой внутренний продукт & 101,6 & 92,0 & 96,6 \\
\hline в том числе: & & & \\
\hline расходы на конечное потребление & 102,8 & 84,4 & 93,4 \\
\hline домашних хозяйств & 103,3 & 77,8 & 90,2 \\
\hline государственного управления & 101,4 & 101,6 & 101,5 \\
\hline $\begin{array}{l}\text { некоммерческих организаций, } \\
\text { обслуживающих домашние хозяйства }\end{array}$ & 104,6 & 101,5 & 103,0 \\
\hline валовое накопление & 102,6 & 93,9 & 97,1 \\
\hline экспорт & 96,6 & 100,3 & 98,5 \\
\hline импорт & 101,1 & 77,8 & 88,7 \\
\hline
\end{tabular}

Формирование ВВП по источникам доходов.

Таблица 6 ВВП, РАССЧИТАННЫЙ МЕТОДОМ ФОРМИРОВАНИЯ
ПО ИСТОЧНИКАМ ДОХОДОВ

в текущих рыночных ценах

\begin{tabular}{|c|c|c|c|c|c|c|}
\hline & \multicolumn{2}{|c|}{ І квартал } & \multicolumn{2}{|c|}{ ІІ квартал } & \multicolumn{2}{|c|}{ І І полугодие } \\
\hline & $\begin{array}{c}\text { млрд } \\
\text { рублей }\end{array}$ & $\begin{array}{l}8 \% \kappa \\
\text { umozy }\end{array}$ & $\begin{array}{c}\text { млрд } \\
\text { рублей }\end{array}$ & $\begin{array}{l}6 \% \kappa \\
\text { uтогу }\end{array}$ & $\begin{array}{c}\text { млрд } \\
\text { рублей }\end{array}$ & $\begin{array}{l}8 \% \kappa \\
\text { umozy }\end{array}$ \\
\hline \multicolumn{7}{|c|}{2019 г. } \\
\hline Валовой внутренний продукт & 24944,8 & 100 & 26410,2 & 100 & $\mathbf{5 1 3 5 5 , 0}$ & 100 \\
\hline $\begin{array}{l}\text { в том числе: } \\
\text { оплата труда наемных работников } \\
\text { (включая оплату труда и смешанные } \\
\text { доходы, не наблюдаемые прямыми } \\
\text { статистическими методами) }\end{array}$ & 11729,4 & 47,0 & 12512,0 & 47,4 & 24241,4 & 47,2 \\
\hline чистые налоги на производство и импорт & 2936,2 & 11,8 & 3043,2 & 11,5 & 5979,4 & 11,7 \\
\hline $\begin{array}{l}\text { валовая прибыль экономики } \\
\text { и валовые смешанные доходы }\end{array}$ & 10279,2 & 41,2 & 10855,1 & 41,1 & 21134,2 & 41,1 \\
\hline \multicolumn{7}{|c|}{2020 г. } \\
\hline Валовой внутренний продукт & 25317,7 & 100 & 23288,2 & 100 & 48605,8 & 100 \\
\hline $\begin{array}{l}\text { в том числе: } \\
\text { оплата труда наемных работников } \\
\text { (включая оплату труда и смешанные } \\
\text { доходы, не наблюдаемые прямыми } \\
\text { статистическими методами) }\end{array}$ & 13138,4 & 51,9 & 12713,0 & 54,6 & 25851,4 & 53,2 \\
\hline чистые налоги на производство и импорт & 2840,4 & 11,3 & 2551,9 & 11,0 & 5392,3 & 11,1 \\
\hline $\begin{array}{l}\text { валовая прибыль экономики } \\
\text { и валовые смешанные доходы }\end{array}$ & 9338,9 & 36,8 & 8023,3 & 34,4 & 17362,1 & 35,7 \\
\hline
\end{tabular}




\subsection{2. Индекс выпуска товаров и услуг по базовым видам экономической деятельности}

Индекс выпуска товаров и услуг по базовым видам экономической деятельности в сентябре 2020 г. по сравнению с соответствующим периодом предыдущего года составил 97,0\%, в январе-сентябре 2020 г. - 96,9\%.

Таблица 7

ДИНАМИКА ФИЗИЧЕСКОГО ОБЪЕМА ВЫПУСКА

ПО БАЗОВЫМ ВИДАМ ЭКОНОМИЧЕСКОЙ ДЕЯТЕЛЬНОСТИ

в постоянных ценах

\begin{tabular}{|c|c|c|}
\hline & \multicolumn{2}{|c|}{ 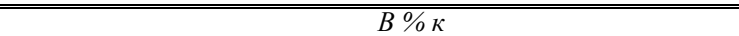 } \\
\hline & $\begin{array}{c}\text { соответствующему } \\
\text { периоду предыдущего года }\end{array}$ & $\begin{array}{c}\text { предылушему } \\
\text { периоду }\end{array}$ \\
\hline \multicolumn{3}{|c|}{2019 г. } \\
\hline Январь & 100,3 & 73,5 \\
\hline Февраль & 101,8 & 99,2 \\
\hline Март & 100,5 & 112,5 \\
\hline І квартал & 100,8 & 79,6 \\
\hline Апрель & 102,6 & 99,3 \\
\hline Май & 99,2 & 98,3 \\
\hline Июнь & 101,3 & 105,2 \\
\hline ІІ квартал & 101,0 & 107,5 \\
\hline I полугодие & 100,9 & \\
\hline Июль & 102,9 & 104,8 \\
\hline Август & 102,5 & 103,5 \\
\hline Сентябрь & 103,9 & 107,6 \\
\hline ІІІ квартал & 103,1 & 113,1 \\
\hline Январь-сентябрь & 101,7 & \\
\hline Октябрь & 104,0 & 101,0 \\
\hline Ноябрь & 101,8 & 94,0 \\
\hline Декабрь & 102,1 & 109,5 \\
\hline IV квартал & 102,7 & 106,1 \\
\hline Год & 102,0 & \\
\hline \multicolumn{3}{|c|}{2020 г. ${ }^{1)}$} \\
\hline Январь & 101,9 & 73,4 \\
\hline Февраль & 104,6 & 101,9 \\
\hline Март & 102,1 & 109,7 \\
\hline І квартал & 102,8 & 79,7 \\
\hline Апрель & 91,4 & 88,9 \\
\hline Май & 90,6 & 97,5 \\
\hline Июнь & 93,5 & 108,5 \\
\hline ІІ квартал & 91,8 & 96,0 \\
\hline I полугодие & 97,1 & \\
\hline
\end{tabular}




\begin{tabular}{|c|c|c|}
\hline & \multicolumn{2}{|c|}{ 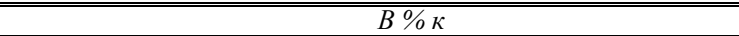 } \\
\hline & $\begin{array}{c}\text { соответствующему } \\
\text { периоду прдыьдущего года }\end{array}$ & $\begin{array}{c}\text { предылущему } \\
\text { периоду }\end{array}$ \\
\hline Июль & 95,8 & 107,3 \\
\hline Август & 97,0 & 104,9 \\
\hline Сентябрь & 97,0 & 107,5 \\
\hline ІІІ квартал & 96,6 & 118,9 \\
\hline Январь-сентябрь & 96,9 & \\
\hline
\end{tabular}

\section{2. ИНДЕКСЫ ПРОИЗВОДИТЕЛЬНОСТИ ТРУДА}

Федеральная служба государственной статистики, в соответствии с утвержденным Регламентом разработки и представления данных, осуществила оценку индексов производительности труда за 2019 год.

Таблица 1

\section{ИНДЕКСЫ ПРОИЗВОДИТЕЛЬНОСТИ ТРУДА}

в \% к предыдущему году

\begin{tabular}{|c|c|}
\hline & 20192. \\
\hline В целом по экономике & 102,0 \\
\hline $\begin{array}{l}\text { по видам экономической деятельности: } \\
\text { сельское, лесное хозяйство, охота, рыболовство и рыбоводство }\end{array}$ & 103,7 \\
\hline $\begin{array}{l}\text { в том числе: } \\
\text { сельское, лесное хозяйство, охота }\end{array}$ & 103,8 \\
\hline рыболовство, рыбоводство & 99,8 \\
\hline добыча полезных ископаемых & 100,8 \\
\hline обрабатывающие производства & 101,6 \\
\hline $\begin{array}{l}\text { обеспечение электрической энергией, газом и паром; } \\
\text { кондиционирование воздуха }\end{array}$ & 99,8 \\
\hline $\begin{array}{l}\text { водоснабжение; водоотведение, } \\
\text { организация сбора и утилизации отходов, } \\
\text { деятельность по ликвидации загрязнений }\end{array}$ & 98,2 \\
\hline строительство & 98,7 \\
\hline $\begin{array}{l}\text { торговля оптовая и розничная; } \\
\text { ремонт автотранспортных средств и мотоциклов }\end{array}$ & 102,9 \\
\hline транспортировка и хранение & 100,8 \\
\hline деятельность гостиниц и предприятий общественного питания & 99,8 \\
\hline деятельность в области информации и связи & 102,6 \\
\hline деятельность по операциям с недвижимым имуществом & 96,7 \\
\hline деятельность профессиональная, научная и техническая & 104,2 \\
\hline $\begin{array}{l}\text { деятельность административная } \\
\text { и сопутствующие дополнительные услуги }\end{array}$ & 96,5 \\
\hline
\end{tabular}




\section{3. ОБОРОТ ОРГАНИЗАЦИЙ}

Таблица 1

\section{ОБОРОТ ОРГАНИЗАЦИЙ \\ ПО ВИДАМ ЭКОНОМИЧЕСКОЙ ДЕЯТЕЛЬНОСТИ}

в действующих ценах

\begin{tabular}{|c|c|c|c|c|}
\hline & \multirow{2}{*}{$\begin{array}{l}\text { Сентябрь } \\
2020 \text { г., } \\
\text { млрд } \\
\text { рублей }\end{array}$} & \multicolumn{2}{|c|}{$B \% \kappa$} & \multirow[b]{2}{*}{$\begin{array}{c}\text { Январь- } \\
\text { сентябрь } \\
2020 \text { г. } \\
\text { в\% к } \\
\text { январю- } \\
\text { сентябрю } \\
2019 \text { г. }\end{array}$} \\
\hline & & $\begin{array}{c}\text { сентябрю } \\
20192 .\end{array}$ & $\begin{array}{c}\text { aвzycmy } \\
2020 \text { 2. }\end{array}$ & \\
\hline Всего & 17676,0 & 102,0 & 103,1 & 100,4 \\
\hline $\begin{array}{l}\text { из них: } \\
\text { сельское, лесное хозяйство, охота, } \\
\text { рыболовство и рыбоводство }\end{array}$ & 379,8 & 119,9 & 119,3 & 109,8 \\
\hline $\begin{array}{l}\text { в том числе: } \\
\text { растениеводство и животноводство, охота и } \\
\text { предоставление соответствующих услуг в этих областях }\end{array}$ & 326,7 & 120,9 & 123,5 & 110,1 \\
\hline лесоводство и лесозаготовки & 21,0 & 109,5 & 96,4 & 107,4 \\
\hline рыболовство и рыбоводство & 32,1 & 117,7 & 100,2 & 109,0 \\
\hline добыча полезных ископаемых & 1337,9 & 88,7 & 100,1 & 80,4 \\
\hline $\begin{array}{l}\text { из нее: } \\
\text { добыча угля }\end{array}$ & 100,2 & 90,6 & 102,0 & 79,8 \\
\hline добыча нефти и природного газа & 780,9 & 77,9 & 94,3 & 72,1 \\
\hline добыча металлических руд & 204,3 & 135,6 & 106,7 & 111,2 \\
\hline добыча прочих полезных ископаемых & 65,6 & 125,9 & 168,8 & 82,7 \\
\hline обрабатывающие производства & 4277,8 & 100,6 & 104,8 & 95,4 \\
\hline $\begin{array}{l}\text { из них: } \\
\text { производство пищевых продуктов }\end{array}$ & 536,0 & 108,6 & 104,3 & 109,7 \\
\hline производство напитков & 76,9 & 102,7 & 95,9 & 93,5 \\
\hline производство табачных изделий & 26,3 & 128,7 & 85,5 & 124,8 \\
\hline производство текстильных изделий & 25,5 & 105,7 & 107,7 & 111,1 \\
\hline производство одежды & 25,2 & 110,1 & 91,0 & 108,9 \\
\hline производство кожи и изделий из кожи & 7,0 & 93,2 & 107,3 & 84,5 \\
\hline $\begin{array}{l}\text { обработка древесины и производство изделий } \\
\text { из дерева и пробки, кроме мебели, производство } \\
\text { изделий из соломки и материалов для плетения }\end{array}$ & 66,5 & 117,6 & 102,2 & 104,6 \\
\hline производство бумаги и бумажных изделий & 101,7 & 115,3 & 106,2 & 98,9 \\
\hline $\begin{array}{l}\text { деятельность полиграфическая } \\
\text { и копирование носителей информации }\end{array}$ & 24,8 & 85,3 & 108,5 & 93,0 \\
\hline производство кокса и нефтепродуктов & 834,9 & 78,2 & 93,1 & 72,9 \\
\hline $\begin{array}{l}\text { производство химических веществ } \\
\text { и химических продуктов }\end{array}$ & 259,3 & 107,2 & 100,0 & 99,3 \\
\hline $\begin{array}{l}\text { производство лекарственных средств и материалов, } \\
\text { применяемых в медицинских целях }\end{array}$ & 89,0 & 139,8 & 123,6 & 145,5 \\
\hline
\end{tabular}




\begin{tabular}{|c|c|c|c|c|}
\hline & \multirow{2}{*}{$\begin{array}{l}\text { Сентябрь } \\
2020 \text { г., } \\
\text { млрд } \\
\text { рублей }\end{array}$} & \multicolumn{2}{|c|}{$\bar{B} \% \mathrm{~K}$} & \multirow[b]{2}{*}{$\begin{array}{c}\text { Январь- } \\
\text { сентябрь } \\
2020 \text { г. } \\
\text { в\% к } \\
\text { январю- } \\
\text { сентябрю } \\
2019 \text { г. } \\
\end{array}$} \\
\hline & & $\begin{array}{c}\text { сентябрю } \\
20192 .\end{array}$ & $\begin{array}{l}\text { aвzycmy } \\
20202 .\end{array}$ & \\
\hline производство резиновых и пластмассовых изделий & 122,5 & 122,9 & 102,4 & 111,5 \\
\hline $\begin{array}{l}\text { производство прочей неметаллической } \\
\text { минеральной продукции }\end{array}$ & 174,8 & 112,4 & 104,3 & 104,7 \\
\hline производство металлургическое & 693,4 & 116,4 & 105,6 & 111,4 \\
\hline $\begin{array}{l}\text { производство готовых металлических изделий, } \\
\text { кроме машин и оборудования }\end{array}$ & 247,2 & 101,7 & 113,0 & 104,3 \\
\hline $\begin{array}{l}\text { производство компьютеров, } \\
\text { электронных и оптических изделий }\end{array}$ & 125,8 & 86,7 & 91,8 & 94,7 \\
\hline производство электрического оборудования & 119,6 & 115,9 & 120,7 & 106,2 \\
\hline $\begin{array}{l}\text { производство машин и оборудования, } \\
\text { не включенных в другие группировки }\end{array}$ & 122,9 & 101,6 & 101,1 & 103,3 \\
\hline $\begin{array}{l}\text { производство автотранспортных средств, } \\
\text { прицепов и полуприцепов }\end{array}$ & 283,2 & 108,1 & 139,7 & 87,1 \\
\hline $\begin{array}{l}\text { производство прочих транспортных } \\
\text { средств и оборудования }\end{array}$ & 176,4 & 92,1 & 129,2 & 96,0 \\
\hline производство мебели & 26,3 & 113,2 & 111,7 & 96,3 \\
\hline производство прочих готовых изделий & 22,0 & 107,0 & 99,3 & 97,7 \\
\hline $\begin{array}{l}\text { обеспечение электрической энергией, } \\
\text { газом и паром; кондиционирование воздуха }\end{array}$ & 709,0 & 101,9 & 105,0 & 100,2 \\
\hline $\begin{array}{l}\text { в том числе: } \\
\text { производство, передача и } \\
\text { распределение электроэнергии }\end{array}$ & 562,8 & 101,2 & 102,5 & 99,5 \\
\hline производство и распределение газообразного топлива & 74,7 & 95,9 & 113,1 & 93,3 \\
\hline $\begin{array}{l}\text { производство, передача и распределение пара и } \\
\text { горячей воды; кондиционирование воздуха }\end{array}$ & 71,5 & 115,8 & 119,5 & 112,0 \\
\hline $\begin{array}{l}\text { водоснабжение; водоотведение, } \\
\text { организация сбора и утилизации отходов, } \\
\text { деятельность по ликвидации загрязнений }\end{array}$ & 117,9 & 111,9 & 103,7 & 108,3 \\
\hline строительство & 743,4 & 95,0 & 99,7 & 110,9 \\
\hline $\begin{array}{l}\text { торговля оптовая и розничная; ремонт } \\
\text { автотранспортных средств и мотоциклов }\end{array}$ & 7215,3 & 108,9 & 102,2 & 108,0 \\
\hline $\begin{array}{l}\text { в том числе: } \\
\text { торговля оптовая и розничная автотранспортными } \\
\text { средствами и мотоциклами и их ремонт }\end{array}$ & 661,6 & 105,6 & 105,1 & 100,1 \\
\hline $\begin{array}{l}\text { торговля оптовая, кроме оптовой торговли } \\
\text { автотранспортными средствами и мотоциклами }\end{array}$ & 4978,2 & 110,5 & 103,9 & 110,7 \\
\hline $\begin{array}{l}\text { торговля розничная, кроме торговли } \\
\text { автотранспортными средствами и мотоциклами }\end{array}$ & 1575,5 & 105,3 & 95,9 & 103,4 \\
\hline транспортировка и хранение & 1058,5 & 88,6 & 95,3 & 92,9 \\
\hline $\begin{array}{l}\text { в том числе: } \\
\text { деятельность сухопутного и трубопроводного транспорта }\end{array}$ & 558,8 & 91,5 & 96,9 & 94,0 \\
\hline $\begin{array}{l}\text { в том числе: } \\
\text { деятельность железнодорожного транспорта: } \\
\text { междугородные и международные } \\
\text { пассажирские перевозки }\end{array}$ & 12,9 & 51,5 & 83,2 & 39,4 \\
\hline
\end{tabular}




\begin{tabular}{|c|c|c|c|c|}
\hline & \multirow{2}{*}{$\begin{array}{l}\text { Сентябрь } \\
2020 \text { г., } \\
\text { млрд } \\
\text { рублей }\end{array}$} & \multicolumn{2}{|c|}{ 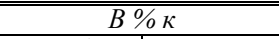 } & \multirow[b]{2}{*}{$\begin{array}{c}\text { Январь- } \\
\text { сентябрь } \\
2020 \text { г. } \\
\text { в\% к } \\
\text { январю- } \\
\text { сентябрю } \\
2019 \text { г. } \\
\end{array}$} \\
\hline & & $\begin{array}{l}\text { сентябрю } \\
2019 \text { г. }\end{array}$ & $\begin{array}{l}\text { aвгусmy } \\
2020 \text { г. }\end{array}$ & \\
\hline $\begin{array}{l}\text { деятельность железнодорожного транспорта: } \\
\text { грузовые перевозки }\end{array}$ & 192,8 & 105,7 & 100,5 & 100,8 \\
\hline $\begin{array}{l}\text { деятельность прочего сухопутного } \\
\text { пассажирского транспорта }\end{array}$ & 38,9 & 93,7 & 103,2 & 84,7 \\
\hline $\begin{array}{l}\text { деятельность автомобильного грузового } \\
\text { транспорта и услуги по перевозкам }\end{array}$ & 108,0 & 81,7 & 102,0 & 95,7 \\
\hline деятельность трубопроводного транспорта & 206,2 & 89,9 & 91,3 & 96,0 \\
\hline деятельность водного транспорта & 28,4 & 91,8 & 97,3 & 105,9 \\
\hline $\begin{array}{l}\text { деятельность воздушного } \\
\text { и космического транспорта }\end{array}$ & 96,8 & 61,8 & 79,4 & 62,6 \\
\hline $\begin{array}{l}\text { складское хозяйство и вспомогательная } \\
\text { транспортная деятельность }\end{array}$ & 351,9 & 93,8 & 97,4 & 100,9 \\
\hline $\begin{array}{l}\text { деятельность почтовой связи } \\
\text { и курьерская деятельность }\end{array}$ & 22,8 & 103,7 & 102,6 & 117,4 \\
\hline $\begin{array}{l}\text { деятельность гостиниц и } \\
\text { предприятий общественного питания }\end{array}$ & 103,2 & 84,9 & 105,2 & 77,2 \\
\hline $\begin{array}{l}\text { в том числе: } \\
\text { деятельность по предоставлению мест } \\
\text { для временного проживания }\end{array}$ & 19,5 & 73,5 & 92,3 & 64,8 \\
\hline $\begin{array}{l}\text { деятельность по предоставлению } \\
\text { продуктов питания и напитков }\end{array}$ & 83,7 & 88,0 & 108,7 & 80,5 \\
\hline деятельность в области информации и связи & 412,9 & 110,2 & 104,5 & 108,6 \\
\hline $\begin{array}{l}\text { из нее: } \\
\text { деятельность издательская }\end{array}$ & 9,3 & 67,6 & 90,1 & 86,7 \\
\hline деятельность в сфере телекоммуникаций & 184,1 & 108,3 & 102,0 & 104,7 \\
\hline $\begin{array}{l}\text { разработка компьютерного программного обеспечения } \\
\text { консультационные услуги в данной области } \\
\text { и другие сопутствующие услуги }\end{array}$ & 138,4 & 124,2 & 134,2 & 101,2 \\
\hline деятельность в области информационных технологий & 50,3 & 107,4 & 102,0 & 139,0 \\
\hline $\begin{array}{l}\text { деятельность по операциям } \\
\text { с недвижимым имуществом }\end{array}$ & 267,7 & 76,3 & 103,3 & 100,5 \\
\hline $\begin{array}{l}\text { деятельность профессиональная, } \\
\text { научная и техническая }\end{array}$ & 505,5 & 103,0 & 120,1 & 102,4 \\
\hline из нее научные исследования и разработки & 115,0 & 76,4 & 134,5 & 82,1 \\
\hline $\begin{array}{l}\text { деятельность административная } \\
\text { и сопутствующие дополнительные услуги }\end{array}$ & 143,4 & 106,3 & 93,8 & 113,2 \\
\hline образование & 60,4 & 104,4 & 153,4 & 86,8 \\
\hline $\begin{array}{l}\text { деятельность в области здравоохранения } \\
\text { и социальных услуг }\end{array}$ & 271,8 & 111,8 & 101,7 & 103,4 \\
\hline из нее деятельность в области здравоохранения & 269,1 & 111,9 & 101,7 & 103,6 \\
\hline $\begin{array}{l}\text { деятельность в области культуры, спорта, } \\
\text { организации досуга и развлечений }\end{array}$ & 38,0 & 134,3 & 120,1 & 106,1 \\
\hline
\end{tabular}




\section{4. ПРОМЫШЛЕННОЕ ПРОИЗВОДСТВО}

Индекс промышленного производства ${ }^{1)}$ в сентябре 2020 г. по сравнению с соответствующим периодом предыдущего года составил 95,0\%, в январе-сентябре 2020 г. - 97,1\%.

Таблица 1

ИНДЕКСЫ ПРОМЫШЛЕННОГО ПРОИЗВОДСТВА

\begin{tabular}{|c|c|c|c|c|c|}
\hline & \multicolumn{5}{|c|}{$B \% \kappa$} \\
\hline & \multirow{2}{*}{$\begin{array}{c}\text { соответствую- } \\
\text { щему периоду } \\
\text { предыдущего года }\end{array}$} & \multicolumn{2}{|c|}{ предыцущему периоду } & \multicolumn{2}{|c|}{ среднемесячному значению 2017 г. } \\
\hline & & фактически & $\begin{array}{c}\text { с исключением } \\
\text { сезонного и } \\
\text { календарного } \\
\text { факторов }^{2}\end{array}$ & фактически & $\begin{array}{c}\text { с исключением } \\
\text { сезонного и } \\
\text { календарного } \\
\text { факторов }^{2)}\end{array}$ \\
\hline \multicolumn{6}{|c|}{2019 г. } \\
\hline Январь & 102,6 & 83,7 & 99,6 & 99,6 & 105,4 \\
\hline Февраль & 104,1 & 97,2 & 100,4 & 96,8 & 105,8 \\
\hline Март & 102,7 & 109,9 & 100,3 & 106,4 & 106,1 \\
\hline І квартал & 103,1 & 89,0 & & & \\
\hline Апрель & 105,1 & 97,7 & 100,3 & 103,9 & 106,5 \\
\hline Май & 100,9 & 97,6 & 100,1 & 101,3 & 106,5 \\
\hline Июнь & 103,1 & 102,3 & 100,8 & 103,6 & 107,3 \\
\hline ІІ квартал & 103,0 & 102,0 & & & \\
\hline I полугодие & 103,1 & & & & \\
\hline Июль & 104,3 & 102,2 & 99,8 & 105,9 & 107,1 \\
\hline Август & 103,8 & 101,7 & 100,0 & 107,7 & 107,1 \\
\hline Сентябрь & 104,9 & 100,8 & 100,5 & 108,6 & 107,6 \\
\hline ІІІ квартал & 104,3 & 104,3 & & & \\
\hline Январь-сентябрь & 103,5 & & & & \\
\hline Октябрь & 104,3 & 106,4 & 100,1 & 115,6 & 107,8 \\
\hline Ноябрь & 101,4 & 96,8 & 99,8 & 111,9 & 107,6 \\
\hline Декабрь & 102,7 & 109,1 & 100,2 & 122,1 & 107,8 \\
\hline IV квартал & 102,8 & 108,5 & & & \\
\hline Год & 103,3 & & & & \\
\hline
\end{tabular}

1) Индекс промышленного производства исчисляется по видам деятельности: "Добыча полезных ископаемых", "Обрабатывающие производства", "Обеспечение электрической энергией, газом и паром; кондииионирование воздуха", "Водоснабжение; водоотведение, организачия сбора и утилизаиии отходов, деятельность по ликвидачии загрязнений" в соответствии с Офичиальной статистической методологией исчисления индекса промылиленного производства (приказ Росстата от 16.01.2020 2. № 7) на основе данных о динамике производства важнейших товаровпредставителей в физическом измерении, очененных в иенах базисного 2018 года. В качестве весов используется структура валовой добавленной стоимости по видам экономической деятельности 2018 базисного года.

Данные за 2019 г. и с января по август 2020 г. уточнены в соответствии с Регламентом разработки и публикаиии данных по производству и отгрузке продукции и динамике промышленного производства (приказ Росстата om 18.08.2020 2. № 470).

2) Оценки данных с исключением сезонного и календарного факторов осуществлены с использованием программы "JDeтеtra+". При поступлении новых данных статистических наблюдений динамика может быть уточнена. 


\begin{tabular}{|c|c|c|c|c|c|}
\hline & \multicolumn{5}{|c|}{$B \% \kappa$} \\
\hline & \multirow{2}{*}{\begin{tabular}{|c|} 
соответствую- \\
щему периоду \\
педьдущегго года
\end{tabular}} & \multicolumn{2}{|c|}{ предыцдущему периоду } & \multicolumn{2}{|c|}{ среднемесячному значению 2017 г. } \\
\hline & & фактически & $\begin{array}{c}\text { с исключением } \\
\text { сезонного и } \\
\text { календарного } \\
\text { факторов }^{21} \\
\end{array}$ & фактически & $\begin{array}{c}\text { с исключением } \\
\text { сезонного и } \\
\text { календарного } \\
\text { факторов }^{21} \\
\end{array}$ \\
\hline \multicolumn{6}{|c|}{2020 г. } \\
\hline Январь & 101,5 & 82,8 & 100,0 & 101,1 & 107,8 \\
\hline Февраль & 104,8 & 100,3 & 100,4 & 101,4 & 108,2 \\
\hline Март & 102,4 & 107,4 & 99,9 & 108,9 & 108,1 \\
\hline І квартал & 102,9 & 89,1 & & & \\
\hline Апрель & 95,5 & 91,0 & 93,6 & 99,2 & 101,1 \\
\hline Май & 92,1 & 94,2 & 99,6 & 93,4 & 100,8 \\
\hline Июнь & 92,9 & 103,1 & 100,1 & 96,3 & 100,9 \\
\hline ІІ квартал & 93,5 & 92,7 & & & \\
\hline I полугодие & 98,1 & & & & \\
\hline Июль & 94,1 & 103,5 & 100,5 & 99,7 & 101,3 \\
\hline Август & 95,8 & 103,5 & 100,5 & 103,2 & 101,8 \\
\hline Сентябрь & 95,0 & 100,0 & 99,8 & 103,2 & 101,6 \\
\hline ІІІ квартал & 95,0 & 106,0 & & & \\
\hline Январь-сентябрь & 97,1 & & & & \\
\hline
\end{tabular}

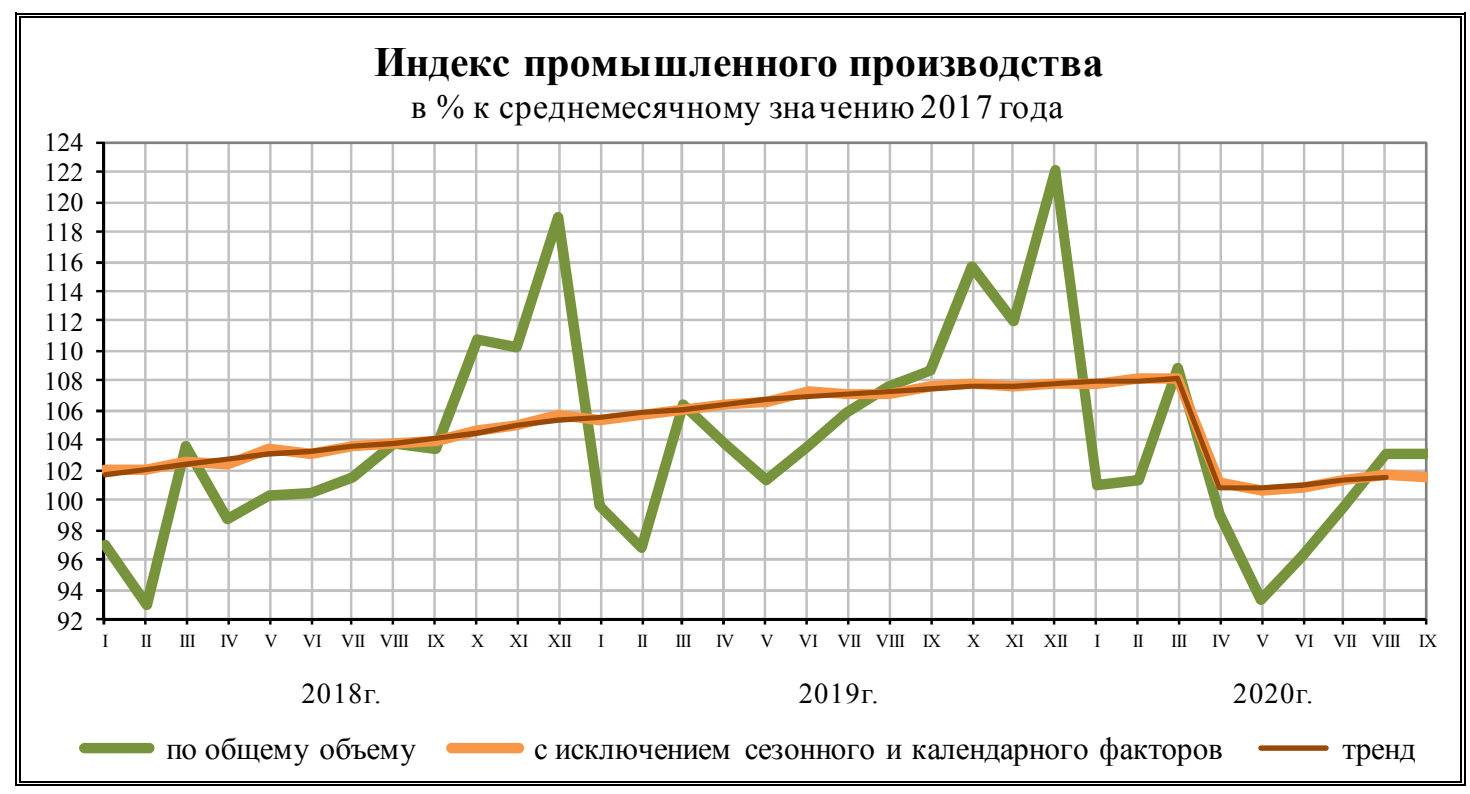

\subsection{1. Добыча полезных ископаемых}

Индекс производства по виду деятельности "Добыча полезных ископаемых" в сентябре 2020 г. по сравнению с соответствующим периодом предыдущего года составил 90,0\%, в январесентябре 2020 г. - 93,5\%. 
ДИНАМИКА ДОБЫЧИ ПОЛЕЗНЫХ ИСКОПАЕМЫХ

\begin{tabular}{|c|c|c|}
\hline & \multicolumn{2}{|c|}{$\bar{B} \% \mathrm{~K}$} \\
\hline & $\begin{array}{c}\text { соответствуюшему } \\
\text { периоду предьдущего года }\end{array}$ & $\begin{array}{c}\text { предььдущему } \\
\text { периоду }\end{array}$ \\
\hline \multicolumn{3}{|c|}{2019 г. } \\
\hline Январь & 106,0 & 96,6 \\
\hline Февраль & 106,3 & 92,2 \\
\hline Март & 105,8 & 110,1 \\
\hline І квартал & 106,0 & 96,0 \\
\hline Апрель & 105,8 & 96,7 \\
\hline Май & 103,7 & 100,9 \\
\hline Июнь & 103,1 & 97,8 \\
\hline ІІ квартал & 104,2 & 100,1 \\
\hline I полугодие & 105,1 & \\
\hline Июль & 103,0 & 104,1 \\
\hline Август & 103,0 & 101,3 \\
\hline Сентябрь & 102,5 & 98,7 \\
\hline III квартал & 102,8 & 103,3 \\
\hline Январь-сентябрь & 104,3 & \\
\hline Октябрь & 100,3 & 102,4 \\
\hline Ноябрь & 101,1 & 97,3 \\
\hline Декабрь & 101,6 & 104,7 \\
\hline IV квартал & 101,0 & 101,7 \\
\hline Год & 103,4 & \\
\hline \multicolumn{3}{|c|}{2020 г. } \\
\hline Январь & 100,6 & 95,5 \\
\hline Февраль & 103,1 & 94,6 \\
\hline Март & 99,8 & 106,5 \\
\hline І квартал & 101,1 & 96,1 \\
\hline Апрель & 99,1 & 96,0 \\
\hline Май & 87,5 & 89,1 \\
\hline Июнь & 87,0 & 97,2 \\
\hline II квартал & 91,2 & 90,3 \\
\hline I полугодие & 96,1 & \\
\hline Июль & 86,0 & 102,9 \\
\hline Август & 89,4 & 105,3 \\
\hline Сентябрь & 90,0 & 99,4 \\
\hline ІІІ квартал & 88,5 & 100,3 \\
\hline Январь-сентябрь & 93,5 & \\
\hline
\end{tabular}




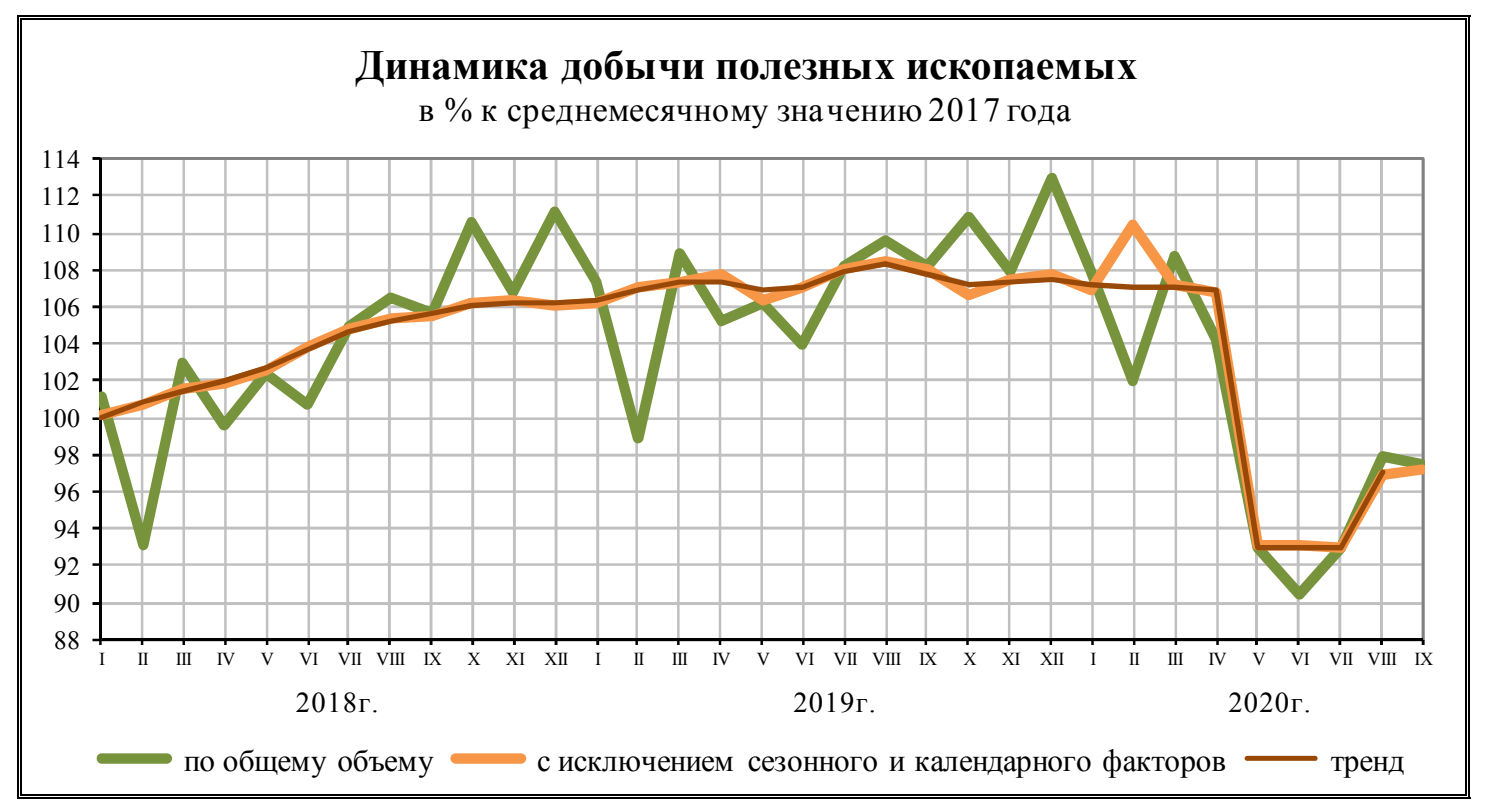

Таблица 3

ИНДЕКСЫ ПРОИЗВОДСТВА ПО ОСНОВНЫМ ВИДАМ ДОБЫВАЮЩИХ ПРОИЗВОДСТВ

\begin{tabular}{|c|c|c|c|}
\hline & \multicolumn{2}{|c|}{ Сентябрь 2020 г. в \% к } & \multirow{2}{*}{$\begin{array}{c}\text { Январь-сентябрь } \\
2020 \text { г. } \\
\text { в \% } \\
\text { январю-сентябрю } \\
20192 . \\
\end{array}$} \\
\hline & $\begin{array}{c}\text { сентябрю } \\
20192 .\end{array}$ & $\begin{array}{c}\text { aвгусmy } \\
2020 \text { г. }\end{array}$ & \\
\hline Добыча полезных ископаемых & 90,0 & 99,4 & $\mathbf{9 3 , 5}$ \\
\hline добыча угля & 91,4 & 99,9 & 93,5 \\
\hline добыча нефти и природного газа & 89,0 & 97,9 & 92,6 \\
\hline добыча металлических руд & 97,4 & 93,1 & 101,4 \\
\hline добыча прочих полезных ископаемых & 98,8 & 135,7 & 80,4 \\
\hline предоставление услуг в области добычи полезных ископаемых & 89,0 & 101,6 & 102,5 \\
\hline \multicolumn{4}{|c|}{$\begin{array}{l}\text { 1) Индексы рассчитаны в соответствии с Официальной статистической методологией исчисления индекса промыш- } \\
\text { ленного производства на основе данных о динамике производства важнейших товаров-представителей в физиче- } \\
\text { ском измерении, оцененньх в иенах базисного } 2018 \text { года. В качестве весов используется структура валовой добав- } \\
\text { ленной стоимости по видам экономической деятельности } 2018 \text { базисного года. }\end{array}$} \\
\hline
\end{tabular}

Таблица 4

ОБЪЕМ ОТГРУЖЕННЫХ ТОВАРОВ СОБСТВЕННОГО ПРОИЗВОДСТВА,

ВЫПОЛНЕННЫХ РАБОТ И УСЛУГ СОБСТВЕННЫМИ СИЛАМИ ПО ДОБЫЧЕ ПОЛЕЗНЫХ ИСКОПАЕМЫХ

в действующих ценах

\begin{tabular}{|c|c|c|c|c|}
\hline & \multirow{2}{*}{$\begin{array}{c}\text { Сентябрь } \\
2020 \text { г., } \\
\text { млрд } \\
\text { рублей }\end{array}$} & \multicolumn{2}{|c|}{$\overline{B \% \kappa}$} & \multirow[b]{2}{*}{$\begin{array}{c}\text { Январь- } \\
\text { сентябрь } \\
2020 \text { г. } \\
\text { в\% к } \\
\text { январю- } \\
\text { сентябрю } \\
20192 . \\
\end{array}$} \\
\hline & & $\begin{array}{c}\text { сентябрю } \\
20192 .\end{array}$ & $\begin{array}{c}\text { aвгусmy } \\
2020 \text { z. }\end{array}$ & \\
\hline Добыча полезных ископаемых & 1251,2 & 82,5 & 100,0 & 74,3 \\
\hline добыча угля & 90,9 & 84,2 & 101,0 & 74,0 \\
\hline добыча нефти и природного газа & 764,9 & 72,3 & 94,1 & 65,8 \\
\hline добыча металлических руд & 160,2 & 140,6 & 109,7 & 115,8 \\
\hline добыча прочих полезных ископаемых & 66,7 & 137,0 & 172,9 & 88,9 \\
\hline
\end{tabular}


По данным обследования деловой активности в октябре 2020 г., в котором приняли участие 539 организаций, осуществляющих добычу полезных ископаемых (без малых предприятий), значение индекса предпринимательской уверенности составило (-3\%).

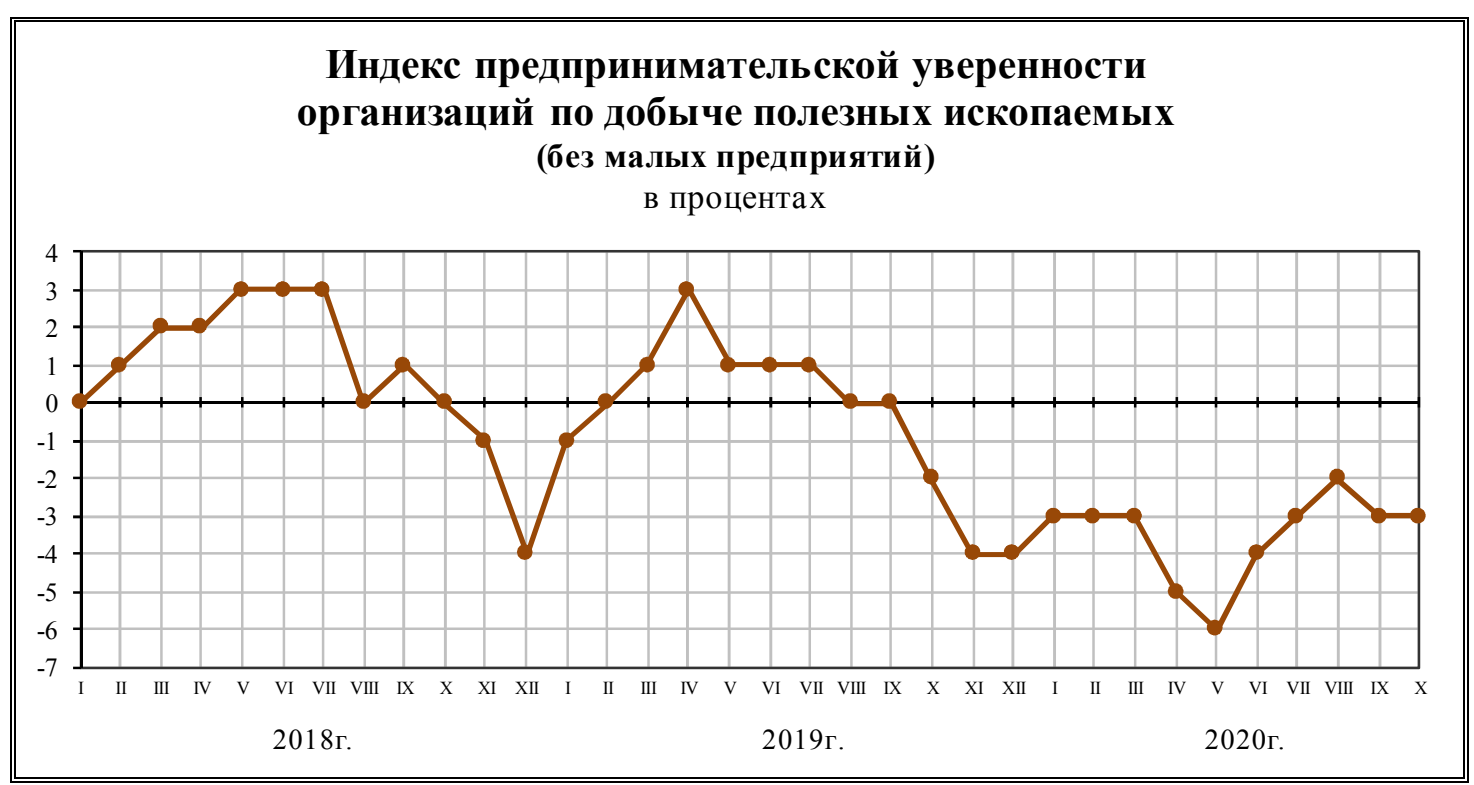

Таблица 5

ИНДЕКС ПРЕДПРИНИМАТЕЛЬСКОЙ УВЕРЕННОСТИ

ОРГАНИЗАЦИЙ ПО ДОБЫЧЕ ПОЛЕЗНЫХ ИСКОПАЕМЫХ

(без малых предприятий)

в процентах

\begin{tabular}{|c|c|c|c|}
\hline & \multicolumn{3}{|c|}{20202.} \\
\hline & август & сентябрь & октябрь \\
\hline Добыча полезных ископаемых & -2 & -3 & -3 \\
\hline добыча угля & -8 & -7 & -6 \\
\hline добыча нефти и природного газа & 2 & 4 & 3 \\
\hline добыча металлических руд & 9 & 7 & 8 \\
\hline добыча прочих полезных ископаемых & -3 & -5 & -8 \\
\hline
\end{tabular}

Таблица 6

ДОБЫЧА ОТДЕЛЬНЫХ ВИДОВ ПОЛЕЗНЫХ ИСКОПАЕМЫХ

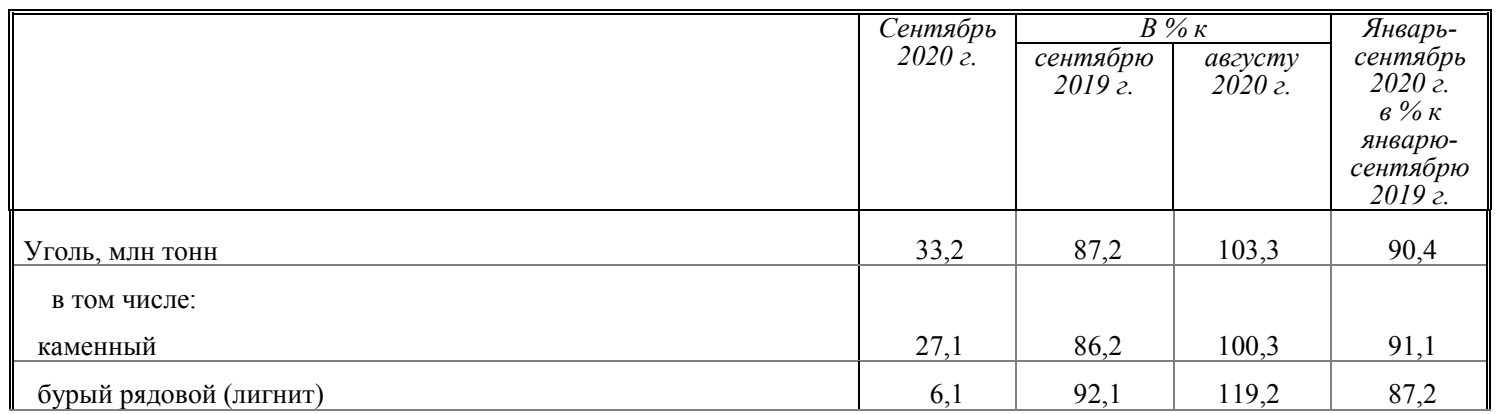




\begin{tabular}{|c|c|c|c|c|}
\hline & \multirow{2}{*}{$\begin{array}{c}\text { Сентялбрь } \\
2020 \text { г. }\end{array}$} & \multicolumn{2}{|c|}{ 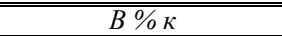 } & \multirow[b]{2}{*}{$\begin{array}{c}\text { Январь- } \\
\text { сентябрр } \\
2020 \text { г. } \\
\text { в\% } \\
\text { январю- } \\
\text { сентябрю } \\
2019 \text { г. } \\
\end{array}$} \\
\hline & & $\begin{array}{c}\text { сентябрю } \\
2019 \text { г. }\end{array}$ & $\begin{array}{l}\text { августу } \\
2020 \text { г. }\end{array}$ & \\
\hline $\begin{array}{l}\text { Нефть обезвоженная, обессоленная и стабилизированная, } \\
\text { включая газовый конденсат, млн тонн }\end{array}$ & 40,6 & 87,8 & 97,3 & 92,2 \\
\hline Газ горючий природный (газ естественный), млрд м³ & 48,3 & 99,6 & 104,8 & 90,6 \\
\hline $\begin{array}{l}\text { Газ нефтяной попутный (газ горючий } \\
\text { природный нефтяных месторождений), млрд м³ }\end{array}$ & 7,7 & 97,1 & 100,2 & 100,9 \\
\hline $\begin{array}{l}\text { Газ горючий природный сжиженный и } \\
\text { регазифицированный, млн тонн }\end{array}$ & 2,4 & 99,7 & 99,8 & 103,8 \\
\hline Руды медные & & 190,2 & 105,8 & 133,4 \\
\hline Концентрат железорудный, млн тонн & 8,5 & 103,4 & 99,7 & 102,9 \\
\hline Концентраты золотосодержащие & & 95,3 & 91,4 & 101,1 \\
\hline Концентраты свинцовые & & 96,2 & 98,2 & 100,2 \\
\hline $\begin{array}{l}\text { Гранит, песчаник и прочий камень для памятников } \\
\text { или строительства, млн тонн }\end{array}$ & 7,2 & 184,3 & 95,5 & 175,6 \\
\hline Пески природные, млн м ${ }^{3}$ & 28,6 & 85,4 & 83,6 & 90,5 \\
\hline Гранулы, крошка и порошок; галька, гравий, млн м³ & 29,7 & 90,4 & 98,4 & 94,1 \\
\hline $\begin{array}{l}\text { Алмазы природные (кроме технических) необработанные, } \\
\text { распиленные, расколотые или грубо обработанные }\end{array}$ & & 99,4 & в 2,7p. & 56,1 \\
\hline Услуги в области добычи нефти и природного газа, млрд рублей ${ }^{1)}$ & 166,0 & 89,9 & 103,3 & 102,8 \\
\hline
\end{tabular}

\subsection{2. Обрабатывающие производства}

Индекс производства по виду деятельности "Обрабатывающие производства" в сентябре 2020 г. по сравнению с соответствующим периодом предыдущего года составил 98,4\%, в январесентябре 2020 г. - 100,0\%.

\section{ДИНАМИКА ПО ОБРАБАТЫВАЮЩИМ ПРОИЗВОДСТВАМ}

\begin{tabular}{|c|c|c|}
\hline & \multicolumn{2}{|c|}{$\bar{B} \% \mathrm{~K}$} \\
\hline & $\begin{array}{c}\text { соответствующему } \\
\text { периоду предыдущего года }\end{array}$ & $\begin{array}{c}\text { предылдущему } \\
\text { периоду }\end{array}$ \\
\hline \multicolumn{3}{|c|}{2019 г. } \\
\hline Январь & 99,3 & 71,7 \\
\hline Февраль & 103,0 & 103,6 \\
\hline Март & 101,2 & 112,0 \\
\hline І квартал & 101,2 & 81,1 \\
\hline Апрель & 104,9 & 100,8 \\
\hline Май & 98,5 & 97,2 \\
\hline Июнь & 103,1 & 107,6 \\
\hline ІІ квартал & 102,2 & 110,4 \\
\hline I полугодие & 101,7 & \\
\hline
\end{tabular}




\begin{tabular}{|c|c|c|}
\hline & \multicolumn{2}{|c|}{$\overline{l B \% \kappa}$} \\
\hline & $\begin{array}{c}\text { соответствуюшему } \\
\text { периоду предыдущего года }\end{array}$ & $\begin{array}{c}\text { предылуущему } \\
\text { периоду }\end{array}$ \\
\hline Июль & 105,5 & 101,0 \\
\hline Август & 104,6 & 102,0 \\
\hline Сентябрь & 106,9 & 101,8 \\
\hline ІІІ квартал & 105,7 & 107,0 \\
\hline Январь-сентябрь & 103,1 & \\
\hline Октябрь & 107,7 & 107,4 \\
\hline Ноябрь & 101,8 & 94,0 \\
\hline Декабрь & 104,5 & 112,6 \\
\hline IV квартал & 104,7 & 109,3 \\
\hline Год & 103,5 & \\
\hline \multicolumn{3}{|c|}{2020 г. } \\
\hline Январь & 104,2 & 71,5 \\
\hline Февраль & 107,6 & 107,0 \\
\hline Март & 105,9 & 110,3 \\
\hline І квартал & 105,9 & 81,9 \\
\hline Апрель & 92,4 & 87,9 \\
\hline Май & 95,4 & 100,2 \\
\hline Июнь & 97,0 & 109,5 \\
\hline ІІ квартал & 94,9 & 99,0 \\
\hline I полугодие & 100,2 & \\
\hline Июль & 99,9 & 104,0 \\
\hline Август & 100,4 & 102,5 \\
\hline Сентябрь & 98,4 & 99,7 \\
\hline ІІІ квартал & 99,6 & 112,2 \\
\hline Январь-сентябрь & 100,0 & \\
\hline
\end{tabular}

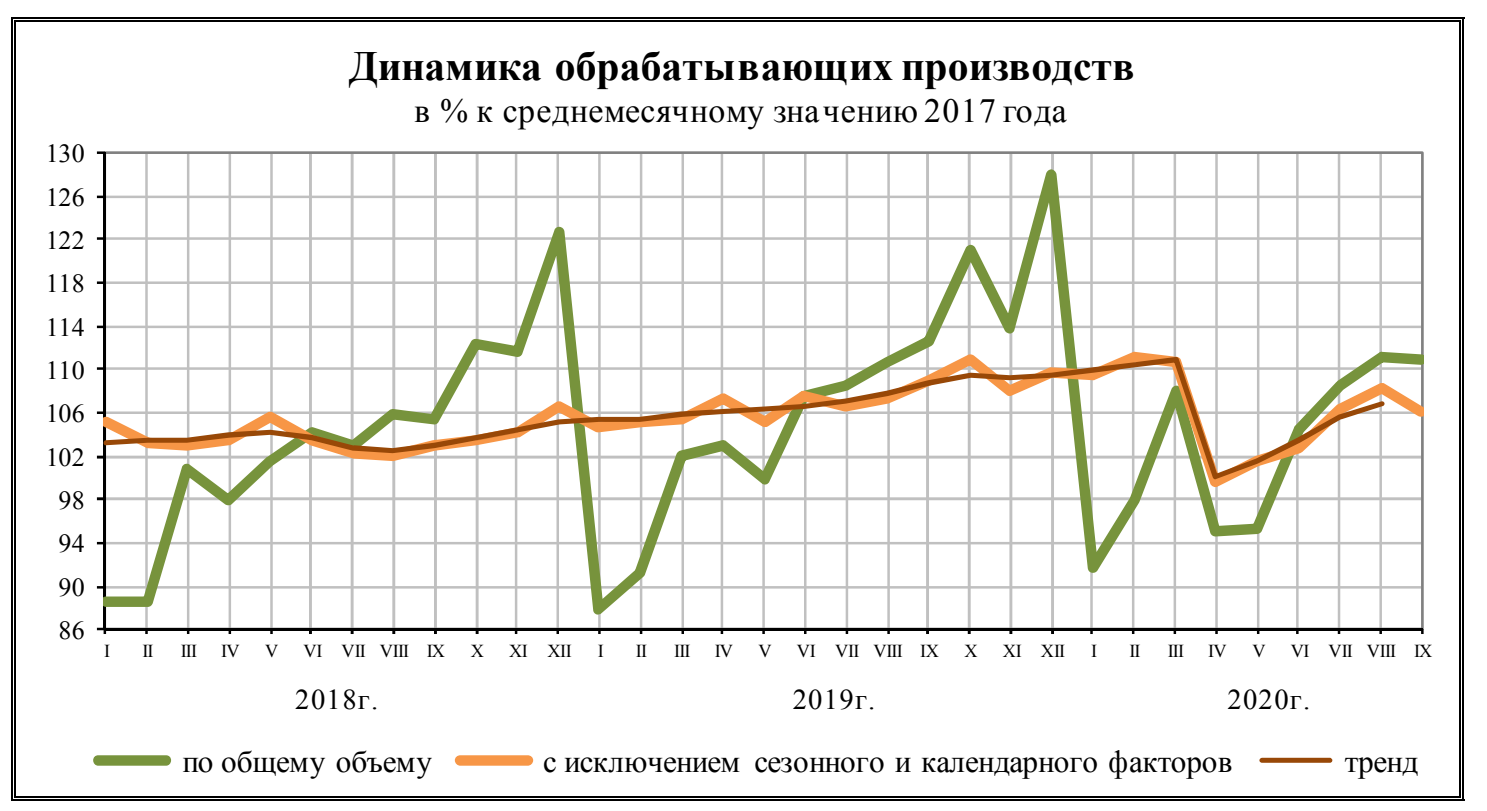


ИНДЕКСЫ ПРОИЗВОДСТВА

ПО ОСНОВНЫМ ВИДАМ ОБРАБАТЫВАЮЩИХ ПРОИЗВОДСТВ

\begin{tabular}{|c|c|c|c|}
\hline & \multicolumn{2}{|c|}{ Сентябрь 2020 г. в \% к } & \multirow{2}{*}{$\begin{array}{c}\text { Январь-сентябрь } \\
2020 \text { г. } \\
\text { в\% к } \\
\text { январю-сентябрю } \\
2019 \text { г. } \\
\end{array}$} \\
\hline & $\begin{array}{l}\text { сентябрю } \\
2019 \text { z. }\end{array}$ & $\begin{array}{l}\text { aвzycmy } \\
20202 \text {. }\end{array}$ & \\
\hline Обрабатывающие производства & 98,4 & 99,7 & 100,0 \\
\hline \multicolumn{4}{|l|}{ из них: } \\
\hline производство напитков & 103,5 & 90,0 & 102,2 \\
\hline производство табачных изделий & 102,0 & 90,4 & 104,1 \\
\hline производство текстильных изделий & 114,5 & 105,2 & 110,2 \\
\hline производство одежды & 104,4 & 99,5 & 100,5 \\
\hline производство кожи и изделий из кожи & 90,2 & 105,2 & 86,3 \\
\hline $\begin{array}{l}\text { обработка древесины и производство изделий } \\
\text { из дерева и пробки, кроме мебели, производство изделий } \\
\text { из соломки и материалов для плетения }\end{array}$ & 107,4 & 96,9 & 101,0 \\
\hline производство бумаги и бумажных изделий & 104,5 & 98,8 & 101,0 \\
\hline $\begin{array}{l}\text { деятельность полиграфическая и копирование } \\
\text { носителей информации }\end{array}$ & 100,2 & 115,0 & 100,5 \\
\hline производство кокса и нефтепродуктов & 95,4 & 94,8 & 98,6 \\
\hline $\begin{array}{l}\text { производство химических веществ } \\
\text { и химических продуктов }\end{array}$ & 106,7 & 98,0 & 106,1 \\
\hline $\begin{array}{l}\text { производство лекарственных средств и материалов, } \\
\text { применяемых в медицинских целях }\end{array}$ & 122,4 & 115,3 & 124,2 \\
\hline производство резиновых и пластмассовых изделий & 106,6 & 99,8 & 100,9 \\
\hline $\begin{array}{l}\text { производство прочей неметаллической } \\
\text { минеральной продукции }\end{array}$ & 96,2 & 96,9 & 95,3 \\
\hline производство металлургическое & 98,1 & 99,7 & 97,6 \\
\hline $\begin{array}{l}\text { производство готовых металлических изделий, } \\
\text { кроме машин и оборудования }\end{array}$ & 93,7 & 95,3 & 105,7 \\
\hline $\begin{array}{l}\text { производство компьютеров, } \\
\text { электронных и оптических изделий }\end{array}$ & 89,6 & 83,8 & 103,5 \\
\hline производство электрического оборудования & 104,6 & 112,9 & 99,2 \\
\hline $\begin{array}{l}\text { производство машин и оборудования, } \\
\text { не включенных в другие группировки }\end{array}$ & 105,1 & 94,7 & 107,0 \\
\hline $\begin{array}{l}\text { производство автотранспортных средств, } \\
\text { прицепов и полуприцепов }\end{array}$ & 103,3 & 148,3 & 80,2 \\
\hline производство прочих транспортных средств и оборудования & 88,3 & 109,6 & 94,3 \\
\hline производство мебели & 116,6 & 113,5 & 103,1 \\
\hline производство прочих готовых изделий & 102,0 & 98,2 & 100,8 \\
\hline ремонт и монтаж машин и оборудования & 92,8 & 112,3 & 94,8 \\
\hline $\begin{array}{l}\text { 1) Индексы рассчитаны в соответствии с Официальной ст } \\
\text { ленного производства на основе данных о динамике прои } \\
\text { ском измерении, оцененных в иенах базисного } 2018 \text { года. } \\
\text { ленной стоимости по видам экономической деятельности }\end{array}$ & $\begin{array}{l}\text { ой методс } \\
\text { ажнейших } \\
\text { весов исп } \\
\text { өого года. }\end{array}$ & $\begin{array}{l}\text { исчисле } \\
\text { в-предс } \\
\text { ся стру }\end{array}$ & $\begin{array}{l}\text { индекса промьии- } \\
\text { ителей в физиче- } \\
\text { ра валовой добав- }\end{array}$ \\
\hline
\end{tabular}


ОБЪЕМ ОТГРУЖЕННЫХ ТОВАРОВ СОБСТВЕННОГО ПРОИЗВОДСТВА, ВЫПОЛНЕННЫХ РАБОТ И УСЛУГ СОБСТВЕННЫМИ СИЛАМИ ПО ОСНОВНЫМ ВИДАМ ОБРАБАТЫВАЮЩИХ ПРОИЗВОДСТВ

в действующих ценах

\begin{tabular}{|c|c|c|c|c|}
\hline & \multirow{2}{*}{$\begin{array}{c}\text { Сентябрь } \\
2020 \text { г., } \\
\text { млрд } \\
\text { рублей }\end{array}$} & \multicolumn{2}{|c|}{$B \% \kappa$} & \multirow[b]{2}{*}{$\begin{array}{c}\text { Январь- } \\
\text { сентябрь } \\
2020 \text { г. } \\
\text { в\% к } \\
\text { январю- } \\
\text { сентябрю } \\
2019 \text { г. }\end{array}$} \\
\hline & & $\begin{array}{c}\text { сентябрю } \\
2019 \text { г. }\end{array}$ & $\begin{array}{c}\text { августу } \\
2020 \text {. }\end{array}$ & \\
\hline Обрабатывающие производства & 3999,5 & 103,3 & 106,3 & $\mathbf{9 7 , 6}$ \\
\hline $\begin{array}{l}\text { из них: } \\
\text { производство пищевых продуктов }\end{array}$ & 577,9 & 110,1 & 104,4 & 110,9 \\
\hline производство напитков & 71,3 & 103,2 & 95,9 & 94,0 \\
\hline производство табачных изделий & 23,9 & 130,9 & 83,4 & 128,4 \\
\hline производство текстильных изделий & 23,5 & 119,9 & 106,6 & 114,0 \\
\hline производство одежды & 17,9 & 101,3 & 96,0 & 109,3 \\
\hline производство кожи и изделий из кожи & 6,1 & 90,6 & 115,1 & 79,7 \\
\hline $\begin{array}{l}\text { обработка древесины и производство изделий } \\
\text { из дерева и пробки, кроме мебели, производство изделий } \\
\text { из соломки и материалов для плетения }\end{array}$ & 66,2 & 117,3 & 101,7 & 105,0 \\
\hline производство бумаги и бумажных изделий & 83,0 & 112,8 & 104,2 & 95,5 \\
\hline $\begin{array}{l}\text { деятельность полиграфическая и } \\
\text { копирование носителей информации }\end{array}$ & 22,8 & 98,6 & 112,8 & 96,8 \\
\hline производство кокса и нефтепродуктов & 614,1 & 80,6 & 93,9 & 75,2 \\
\hline производство химических веществ и химических продуктов & 281,9 & 111,8 & 102,9 & 97,6 \\
\hline $\begin{array}{l}\text { производство лекарственных средств и материалов, } \\
\text { применяемых в медицинских целях }\end{array}$ & 81,3 & 128,8 & 126,7 & 132,7 \\
\hline производство резиновых и пластмассовых изделий & 121,4 & 120,1 & 102,8 & 106,4 \\
\hline производство прочей неметаллической минеральной продукции & 165,2 & 109,9 & 103,1 & 103,0 \\
\hline производство металлургическое & 688,1 & 118,5 & 105,3 & 112,3 \\
\hline $\begin{array}{l}\text { производство готовых металлических изделий, } \\
\text { кроме машин и оборудования }\end{array}$ & 242,6 & 101,0 & 115,4 & 106,8 \\
\hline производство компьютеров, электронных и оптических изделий & 120,6 & 83,9 & 102,1 & 92,0 \\
\hline производство электрического оборудования & 96,1 & 109,0 & 110,0 & 101,1 \\
\hline $\begin{array}{l}\text { производство машин и оборудования, } \\
\text { не включенных в другие группировки }\end{array}$ & 111,9 & 106,3 & 106,2 & 104,5 \\
\hline производство автотранспортных средств, прицепов и полуприцепов & 258,6 & 108,7 & 141,1 & 87,1 \\
\hline производство прочих транспортных средств и оборудования & 172,0 & 88,8 & 129,1 & 92,3 \\
\hline производство мебели & 27,1 & 116,8 & 109,3 & 101,9 \\
\hline производство прочих готовых изделий & 20,4 & 104,8 & 87,0 & 107,0 \\
\hline ремонт и монтаж машин и оборудования & 105,6 & 104,9 & 123,1 & 99,2 \\
\hline
\end{tabular}

По данным обследования деловой активности в октябре 2020 г., в котором приняли участие 3273 организации обрабатывающих производств (без малых предприятий), значение индекса предпринимательской уверенности составило (-5\%). 


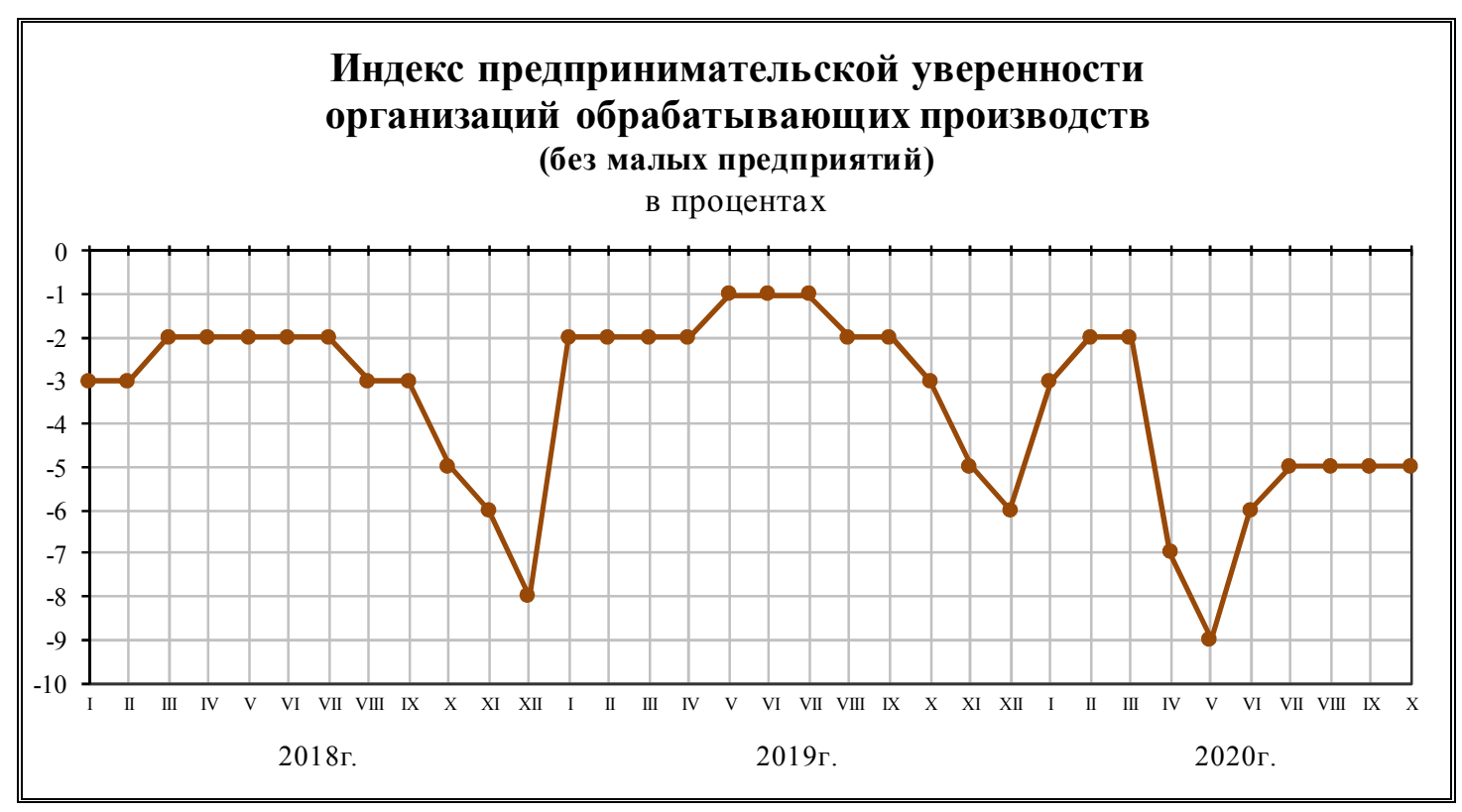

Таблица 10

\section{ИНДЕКС ПРЕДПРИНИМАТЕЛЬСКОЙ УВЕРЕННОСТИ ОРГАНИЗАЦИЙ ОБРАБАТЫВАЮЩИХ ПРОИЗВОДСТВ (без малых предприятий)}

в процентах

\begin{tabular}{|c|c|c|c|}
\hline & \multicolumn{3}{|c|}{20202.} \\
\hline & август & сентябрь & октябрь \\
\hline Обрабатывающие производства & -5 & -5 & -5 \\
\hline производство пищевых продуктов & -5 & -4 & -5 \\
\hline производство напитков & -6 & -13 & -14 \\
\hline производство табачных изделий & 0 & 0 & -7 \\
\hline производство текстильных изделий & -1 & 2 & 3 \\
\hline производство одежды & -7 & -8 & -6 \\
\hline производство кожи и изделий из кожи & -3 & 0 & 1 \\
\hline $\begin{array}{l}\text { обработка древесины и производство изделий } \\
\text { из дерева и пробки, кроме мебели, производство } \\
\text { изделий из соломки и материалов для плетения }\end{array}$ & -4 & -5 & -3 \\
\hline производство бумаги и бумажных изделий & -1 & 0 & 1 \\
\hline $\begin{array}{l}\text { деятельность полиграфическая и копирование } \\
\text { носителей информации }\end{array}$ & -9 & -10 & -12 \\
\hline производство кокса и нефтепродуктов & -2 & 1 & 1 \\
\hline производство химических веществ и химических продуктов & -5 & -4 & -7 \\
\hline $\begin{array}{l}\text { производство лекарственных средств и материалов, } \\
\text { применяемых в медицинских целях }\end{array}$ & 1 & 2 & 1 \\
\hline производство резиновых и пластмассовых изделий & -5 & -6 & -5 \\
\hline $\begin{array}{l}\text { производство прочей неметаллической } \\
\text { минеральной продукции }\end{array}$ & -7 & -10 & -12 \\
\hline производство металлургическое & -6 & -10 & -11 \\
\hline
\end{tabular}




\begin{tabular}{|c|c|c|c|}
\hline & \multicolumn{3}{|c|}{20202.} \\
\hline & aвгуcm & сентябрь & октябрь \\
\hline $\begin{array}{l}\text { производство готовых металлических изделий, } \\
\text { кроме машин и оборудования }\end{array}$ & -3 & -5 & -6 \\
\hline $\begin{array}{l}\text { производство компьютеров, } \\
\text { электронных и оптических изделий }\end{array}$ & -5 & -6 & -3 \\
\hline производство электрического оборудования & -4 & -5 & -5 \\
\hline $\begin{array}{l}\text { производство машин и оборудования, } \\
\text { не включенных в другие группировки }\end{array}$ & -4 & -4 & -6 \\
\hline производство автотранспортных средств, прицепов и полуприцепов & -8 & -4 & -5 \\
\hline производство прочих транспортных средств и оборудования & 1 & -1 & -1 \\
\hline производство мебели & -6 & -5 & -5 \\
\hline производство прочих готовых изделий & -5 & -3 & -3 \\
\hline ремонт и монтаж машин и оборудования & -9 & -7 & -5 \\
\hline
\end{tabular}

Производство пищевых продуктов. Индекс производства пищевых продуктов в сентябре 2020 г. по сравнению с соответствующим периодом предыдущего года составил $102,2 \%$, в январе-сентябре 2020 г. - 104,6\%.

Таблица 11

ДИНАМИКА ПРОИЗВОДСТВА ПИЩЕВЫХ ПРОДУКТОВ

\begin{tabular}{|c|c|c|}
\hline & \multicolumn{2}{|c|}{ 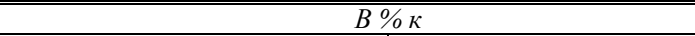 } \\
\hline & $\begin{array}{c}\text { соответствующему } \\
\text { периоду предыдущего года }\end{array}$ & $\begin{array}{c}\text { предыдучщему } \\
\text { периоду }\end{array}$ \\
\hline \multicolumn{3}{|c|}{2019 г. } \\
\hline Январь & 100,0 & 86,1 \\
\hline Февраль & 103,1 & 104,3 \\
\hline Март & 101,1 & 110,4 \\
\hline І квартал & 101,4 & 88,1 \\
\hline Апрель & 105,5 & 99,5 \\
\hline Май & 102,3 & 96,6 \\
\hline Июнь & 102,1 & 99,1 \\
\hline ІІ квартал & 103,3 & 104,9 \\
\hline I полугодие & 102,4 & \\
\hline Июль & 108,2 & 110,1 \\
\hline Август & 102,0 & 101,0 \\
\hline Сентябрь & 106,4 & 103,1 \\
\hline ІІІ квартал & 105,5 & 110,0 \\
\hline Январь-сентябрь & 103,5 & \\
\hline Октябрь & 105,2 & 105,3 \\
\hline Ноябрь & 105,3 & 96,0 \\
\hline Декабрь & 107,7 & 98,4 \\
\hline IV квартал & 106,1 & 104,4 \\
\hline Год & 104,2 & \\
\hline
\end{tabular}




\begin{tabular}{|c|c|c|}
\hline & \multicolumn{2}{|c|}{$\overline{B \quad B \% \kappa}$} \\
\hline & $\begin{array}{c}\text { соответствующему } \\
\text { периоду предыдущего года }\end{array}$ & $\begin{array}{c}\text { предьдущему } \\
\text { периоду }\end{array}$ \\
\hline \multicolumn{3}{|c|}{2020 г. } \\
\hline Январь & 109,9 & 87,8 \\
\hline Февраль & 109,1 & 103,6 \\
\hline Март & 109,2 & 110,4 \\
\hline І квартал & 109,4 & 90,9 \\
\hline Апрель & 103,8 & 94,7 \\
\hline Май & 102,0 & 94,9 \\
\hline Июнь & 104,7 & 101,7 \\
\hline ІІ квартал & 103,5 & 99,2 \\
\hline I полугодие & 106,4 & \\
\hline Июль & 99,5 & 104,6 \\
\hline Август & 102,2 & 103,7 \\
\hline Сентябрь & 102,2 & 103,1 \\
\hline III квартал & 101,3 & 107,7 \\
\hline Январь-сентябрь & 104,6 & \\
\hline
\end{tabular}

Таблица 12

ПРОИЗВОДСТВО ОТДЕЛЬНЫХ ВИДОВ ПИЩЕВЫХ ПРОДУКТОВ

\begin{tabular}{|c|c|c|c|c|}
\hline & "Сентябрь & & & \\
\hline & $\begin{array}{l}2020 \text { г., } \\
\text { тысс. тонн }\end{array}$ & $\begin{array}{c}\text { сентябрю } \\
2019 \text { г. }\end{array}$ & $\begin{array}{l}\text { августу } \\
2020 \text { z. }\end{array}$ & $\begin{array}{c}\text { сентябрь } \\
2020 \text { г. } \\
\text { в\% \% } \\
\text { январю- } \\
\text { сентябрю } \\
2019 \text { г. } \\
\end{array}$ \\
\hline $\begin{array}{l}\text { Мясо крупного рогатого скота, свинина, } \\
\text { баранина, козлятина, конина и мясо } \\
\text { прочих животных семейства лошадиных, } \\
\text { оленина и мясо прочих животных семейства } \\
\text { оленьих (оленевых) парные, остывшие или охлажденные }\end{array}$ & 259 & 112,4 & 102,4 & 111,6 \\
\hline Мясо и субпродукты пищевые домашней птицы & 395 & 97,7 & 98,5 & 99,8 \\
\hline $\begin{array}{l}\text { Изделия колбасные, включая изделия колбасные } \\
\text { для детского питания }\end{array}$ & 202 & 103,1 & 97,1 & 103,4 \\
\hline $\begin{array}{l}\text { Полуфабрикаты мясные, мясосодержащие, } \\
\text { охлажденные, замороженные }\end{array}$ & 341 & 109,1 & 102,2 & 108,5 \\
\hline Консервы мясные, млн усл. банок & 39,8 & 86,2 & 91,9 & 111,7 \\
\hline Рыба мороженая & 217 & 96,0 & 69,8 & 99,4 \\
\hline Консервы рыбные, млн усл. банок & 47,5 & 89,6 & 118,5 & 98,6 \\
\hline Пресервы рыбные, млн усл. банок & 21,6 & 99,1 & 109,6 & 105,5 \\
\hline Картофель переработанный и консервированный & 35,2 & 129,2 & 105,7 & 109,0 \\
\hline Соки из фруктов и овощей, млн усл. банок & 153 & 108,6 & 177,7 & 99,3 \\
\hline $\begin{array}{l}\text { Овощи (кроме картофеля), приготовленные } \\
\text { или консервированные с уксусом } \\
\text { или уксусной кислотой, млн усл. банок }\end{array}$ & 80,9 & 140,3 & 122,8 & 98,1 \\
\hline
\end{tabular}




\begin{tabular}{|c|c|c|c|c|}
\hline & Сентябрь & & & Январь- \\
\hline & $\begin{array}{c}2020 \text { г., } \\
\text { тыс. тонн }\end{array}$ & $\begin{array}{c}\text { сентяябрю } \\
2019 \text { г. }\end{array}$ & $\begin{array}{c}\text { августу } \\
2020 \text { г. }\end{array}$ & $\begin{array}{c}\text { сентябрь } \\
2020 \text { г. } \\
\text { в\% } \\
\text { январю- } \\
\text { сентябрю } \\
2019 \text { г. } \\
\end{array}$ \\
\hline Масла растительные и их фракции нерафинированные & 449 & 101,7 & 119,3 & 111,3 \\
\hline из них подсолнечное & 311 & 97,6 & 120,5 & 111,7 \\
\hline Маргарин & 37,0 & 85,3 & 97,4 & 96,2 \\
\hline Молоко, кроме сырого & 438 & 99,9 & 98,5 & 100,7 \\
\hline Масло сливочное & 22,7 & 97,6 & 91,0 & 106,4 \\
\hline Сыры & 48,3 & 103,1 & 97,2 & 106,1 \\
\hline Мука пшеничная и пшенично-ржаная & 730 & 94,6 & 103,2 & 99,1 \\
\hline Крупа & 130 & 101,4 & 136,9 & 100,3 \\
\hline Изделия хлебобулочные недлительного хранения & 464 & 97,5 & 100,1 & 98,5 \\
\hline $\begin{array}{l}\text { Печенье и пряники имбирные и аналогичные изделия; } \\
\text { печенье сладкое; вафли и вафельные облатки; } \\
\text { торты и пирожные длительного хранения }\end{array}$ & 145 & 94,0 & 95,5 & 99,7 \\
\hline Изделия макаронные и аналогичные мучные изделия & 126 & 100,2 & 107,4 & 105,6 \\
\hline Шоколад и кондитерские сахаристые изделия & 175 & 99,2 & 111,3 & 96,3 \\
\hline $\begin{array}{l}\text { Чай зеленый (неферментированный), } \\
\text { чай черный (ферментированный) и чай частично } \\
\text { ферментированный, в упаковках массой не более } 3 \text { кг }\end{array}$ & 11,2 & 123,2 & 109,7 & 117,8 \\
\hline Комбикорма, млн тонн & 2,5 & 100,7 & 97,4 & 102,4 \\
\hline Корм готовый для непродуктивных животных & 105 & 112,8 & 104,0 & 114,3 \\
\hline
\end{tabular}

Производство напитков. Индекс производства напитков в сентябре 2020 г. по сравнению с соответствующим периодом предыдущего года составил $103,5 \%$, в январе-сентябре 2020 г. $-102,2 \%$.

ДИНАМИКА ПРОИЗВОДСТВА НАПИТКОВ

\begin{tabular}{|c|c|c|}
\hline & \multicolumn{2}{|c|}{ 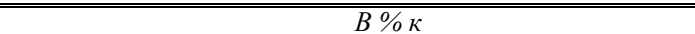 } \\
\hline & $\begin{array}{c}\text { соответствующему } \\
\text { периоду предыдущего года }\end{array}$ & $\begin{array}{c}\text { предыдущему } \\
\text { периоду }\end{array}$ \\
\hline \multicolumn{3}{|c|}{2019 г. } \\
\hline Январь & 113,4 & 73,6 \\
\hline Февраль & 105,8 & 112,5 \\
\hline Март & 104,8 & 121,7 \\
\hline І квартал & 107,5 & 85,5 \\
\hline Апрель & 105,8 & 115,9 \\
\hline Май & 105,0 & 108,0 \\
\hline Июнь & 106,3 & 100,6 \\
\hline ІІ квартал & 105,7 & 143,8 \\
\hline I полугодие & 106,4 & \\
\hline
\end{tabular}




\begin{tabular}{|c|c|c|}
\hline & \multicolumn{2}{|c|}{ 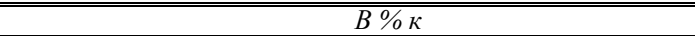 } \\
\hline & $\begin{array}{c}\text { соответствующему } \\
\text { периоду предыдущего года }\end{array}$ & $\begin{array}{c}\text { предьдущему } \\
\text { периоду }\end{array}$ \\
\hline Июль & 99,6 & 92,3 \\
\hline Август & 94,9 & 89,2 \\
\hline Сентябрь & 105,8 & 96,6 \\
\hline ІІІ квартал & 100,1 & 87,3 \\
\hline Январь-сентябрь & 104,1 & \\
\hline Октябрь & 105,1 & 102,6 \\
\hline Ноябрь & 108,6 & 107,0 \\
\hline Декабрь & 110,0 & 99,2 \\
\hline IV квартал & 107,9 & 100,5 \\
\hline Год & 105,0 & \\
\hline \multicolumn{3}{|c|}{2020 г. } \\
\hline Январь & 97,3 & 65,1 \\
\hline Февраль & 101,0 & 116,9 \\
\hline Март & 100,1 & 120,6 \\
\hline І квартал & 99,6 & 79,0 \\
\hline Апрель & 96,2 & 111,4 \\
\hline Май & 91,8 & 103,0 \\
\hline Июнь & 103,2 & 113,2 \\
\hline ІІ квартал & 97,1 & 140,2 \\
\hline I полугодие & 98,1 & \\
\hline Июль & 114,7 & 102,6 \\
\hline Август & 111,1 & 86,4 \\
\hline Сентябрь & 103,5 & 90,0 \\
\hline ІІІ квартал & 109,8 & 98,9 \\
\hline Январь-сентябрь & 102,2 & \\
\hline
\end{tabular}

Таблица 14

ПРОИЗВОДСТВО ОТДЕЛЬНЫХ ВИДОВ НАПИТКОВ

\begin{tabular}{|c|c|c|c|c|}
\hline & \multirow{2}{*}{$\begin{array}{c}\text { Сентябрь } \\
2020 \text { г. }\end{array}$} & \multicolumn{2}{|c|}{$B \% \kappa$} & \multirow[b]{2}{*}{$\begin{array}{c}\text { Январь- } \\
\text { сентябрь } \\
2020 \text { г. } \\
\text { в\% \% } \\
\text { январю- } \\
\text { сентябрю } \\
2019 \text { г. } \\
\end{array}$} \\
\hline & & $\begin{array}{c}\text { сентябрю } \\
2019 \text { г. }\end{array}$ & $\begin{array}{c}\text { aвzycmy } \\
2020 \text { 2. }\end{array}$ & \\
\hline Водка ${ }^{1)}$, млн дкл & 7,7 & 98,4 & 105,6 & 97,7 \\
\hline Вино ${ }^{1)}$, млн дкл & 3,1 & 104,8 & 91,1 & 98,3 \\
\hline Пиво, кроме отходов пивоварения, млн дкл & 58,9 & 102,6 & 80,4 & 104,0 \\
\hline $\begin{array}{l}\text { Воды питьевые, в том числе газированные, расфасованные в емкости, } \\
\text { не содержащие добавки сахара или других подслащивающих } \\
\text { или вкусоароматических веществ, млн полулитров }\end{array}$ & 702 & 102,6 & 90,5 & 100,5 \\
\hline Напитки безалкогольные прочие, млн дкл & 56,2 & 109,0 & 79,9 & 99,6 \\
\hline
\end{tabular}


Производство табачных изделий. Индекс производства табачных изделий в сентябре 2020 г. по сравнению с соответствующим периодом предыдущего года составил 102,0\%, в январе-сентябре 2020 г. - 104,1\%.

ДИНАМИКА ПРОИЗВОДСТВА ТАБАЧНЫХ ИЗДЕЛИЙ

\begin{tabular}{|c|c|c|}
\hline & \multicolumn{2}{|c|}{$\overline{P B \% \kappa}$} \\
\hline & $\begin{array}{c}\text { соответствующему } \\
\text { периоду предыдущего года }\end{array}$ & $\begin{array}{c}\text { предыдущему } \\
\text { периоду }\end{array}$ \\
\hline \multicolumn{3}{|c|}{2019 г. } \\
\hline Январь & 109,5 & 82,2 \\
\hline Февраль & 91,3 & 133,3 \\
\hline Март & 90,2 & 113,1 \\
\hline І квартал & 95,0 & 93,4 \\
\hline Апрель & 77,8 & 102,9 \\
\hline Май & 87,2 & 102,9 \\
\hline Июнь & 61,3 & 83,8 \\
\hline ІІ квартал & 75,4 & 116,8 \\
\hline I полугодие & 82,8 & \\
\hline Июль & 86,9 & 101,5 \\
\hline Август & 88,2 & 124,3 \\
\hline Сентябрь & 110,6 & 87,3 \\
\hline ІІІ квартал & 95,2 & 100,8 \\
\hline Январь-сентябрь & 86,4 & \\
\hline Октябрь & 105,8 & 105,3 \\
\hline Ноябрь & 93,5 & 86,1 \\
\hline Декабрь & 104,3 & 94,9 \\
\hline IV квартал & 101,2 & 92,0 \\
\hline Гod & 89,6 & \\
\hline \multicolumn{3}{|c|}{2020 г. } \\
\hline Январь & 110,9 & 87,4 \\
\hline Февраль & 112,8 & 135,6 \\
\hline Март & 97,1 & 97,4 \\
\hline І квартал & 106,1 & 98,0 \\
\hline Апрель & 82,9 & 87,8 \\
\hline Май & 100,8 & 125,2 \\
\hline Июнь & 119,2 & 99,1 \\
\hline ІІ квартал & 101,0 & 110,1 \\
\hline I полугодие & 102,9 & \\
\hline Июль & 120,7 & 102,8 \\
\hline Август & 98,5 & 101,5 \\
\hline Сентябрь & 102,0 & 90,4 \\
\hline III квартал & 107,1 & 107,0 \\
\hline Январь-сентябрь & 104,1 & \\
\hline
\end{tabular}


ПРОИЗВОДСТВО ОТДЕЛЬНЫХ ВИДОВ ТАБАЧНЫХ ИЗДЕЛИЙ

\begin{tabular}{|c|c|c|c|c|}
\hline & \multirow{2}{*}{$\begin{array}{c}\text { Сентябрь } \\
2020 \text { г. }\end{array}$} & \multicolumn{2}{|c|}{$\bar{B} \% \kappa$} & \multirow[b]{2}{*}{$\begin{array}{c}\text { Январь- } \\
\text { сентябрь } \\
2020 \text { г. } \\
\text { в\% } \\
\text { январю- } \\
\text { сентябрю } \\
2019 \text { г. } \\
\end{array}$} \\
\hline & & $\begin{array}{c}\text { сентябрю } \\
2019 \text { 2. }\end{array}$ & $\begin{array}{c}\text { aвzycmy } \\
2020 \text { 2. }\end{array}$ & \\
\hline Сигареты, млрд штук & 19,7 & 99,0 & 88,7 & 101,7 \\
\hline $\begin{array}{l}\text { Табак промышленно изготовленный и заменители табака } \\
\text { промышленно изготовленные прочие, } \\
\text { не включенные в другие группировки, тыс. тонн }\end{array}$ & 2,4 & 127,5 & 125,2 & 118,5 \\
\hline
\end{tabular}

Производство текстильных изделий. Индекс производства текстильных изделий в сентябре 2020 г. по сравнению с соответствующим периодом предыдущего года составил $114,5 \%$, в январе-сентябре 2020 г. - 110,2\%.

ДИНАМИКА ПРОИЗВОДСТВА ТЕКСТИЛЬНЫХ ИЗДЕЛИЙ

\begin{tabular}{|c|c|c|}
\hline & \multicolumn{2}{|c|}{$B \% \kappa$} \\
\hline & $\begin{array}{c}\text { соответствуюшему } \\
\text { периоду предьдущего года }\end{array}$ & $\begin{array}{c}\text { предылдущему } \\
\text { периоду }\end{array}$ \\
\hline \multicolumn{3}{|c|}{2019 г. } \\
\hline Январь & 98,2 & 84,8 \\
\hline Февраль & 101,7 & 112,2 \\
\hline Март & 95,0 & 102,2 \\
\hline I квартал & 98,2 & 91,4 \\
\hline Апрель & 98,3 & 102,6 \\
\hline Май & 96,6 & 89,2 \\
\hline Июнь & 96,0 & 104,8 \\
\hline ІІ квартал & 96,9 & 101,7 \\
\hline I полугодие & 97,6 & \\
\hline Июль & 100,2 & 107,5 \\
\hline Август & 102,8 & 103,3 \\
\hline Сентябрь & 110,3 & 102,9 \\
\hline ІІІ квартал & 104,4 & 110,0 \\
\hline Январь-сентябрь & 99,9 & \\
\hline Октябрь & 106,5 & 103,6 \\
\hline Ноябрь & 105,2 & 95,1 \\
\hline Декабрь & 108,7 & 103,7 \\
\hline IV квартал & 106,8 & 104,4 \\
\hline Год & 101,7 & \\
\hline \multicolumn{3}{|c|}{2020 г. } \\
\hline Январь & 107,5 & 83,8 \\
\hline
\end{tabular}




\begin{tabular}{|c|c|c|}
\hline & \multicolumn{2}{|c|}{ 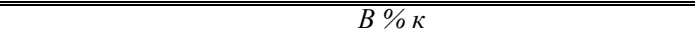 } \\
\hline & $\begin{array}{c}\text { соответствующему } \\
\text { периоду предьдущего года }\end{array}$ & $\begin{array}{c}\text { предыдушему } \\
\text { периоду }\end{array}$ \\
\hline Февраль & 105,7 & 110,4 \\
\hline Март & 118,9 & 114,9 \\
\hline І квартал & 110,9 & 94,9 \\
\hline Апрель & 103,7 & 89,5 \\
\hline Май & 101,9 & 87,5 \\
\hline Июнь & 115,4 & 118,8 \\
\hline ІІ квартал & 107,0 & 98,2 \\
\hline I полугодие & 108,9 & \\
\hline Июль & 110,7 & 103,1 \\
\hline Август & 111,9 & 104,5 \\
\hline Сентябрь & 114,5 & 105,2 \\
\hline ІІІ квартал & 112,4 & 115,5 \\
\hline Январь-сентябрь & 110,2 & \\
\hline
\end{tabular}

Таблица 18

\section{ПРОИЗВОДСТВО ОТДЕЛЬНЫХ ВИДОВ \\ ТЕКСТИЛЬНЫХ ИЗДЕЛИЙ}

\begin{tabular}{|c|c|c|c|c|}
\hline & \multirow{2}{*}{$\begin{array}{l}\text { Сентябрь } \\
2020 \text { г. }\end{array}$} & \multicolumn{2}{|c|}{$B \% \kappa$} & \multirow[b]{2}{*}{$\begin{array}{c}\text { Январь- } \\
\text { сентябрь } \\
2020 \text { г. } \\
\text { в\% к } \\
\text { январю- } \\
\text { сентябрю } \\
20192 . \\
\end{array}$} \\
\hline & & $\begin{array}{c}\text { сентябрю } \\
20192 .\end{array}$ & $\begin{array}{c}\text { aвzусmy } \\
2020 \text { г. }\end{array}$ & \\
\hline Пряжа хлопчатобумажная (кроме швейных ниток), тыс. тонн & 3,1 & 94,1 & 91,3 & 89,5 \\
\hline Нитки швейные синтетические, млн усл. катушек & 9,6 & 116,4 & 114,9 & 117,8 \\
\hline Ткани, млн м² & 536 & 102,4 & 97,6 & 107,8 \\
\hline $\begin{array}{l}\text { в том числе: } \\
\text { шерстяные, тыс. } \text { м }^{2}\end{array}$ & 757 & 130,3 & 117,0 & 93,1 \\
\hline льняные & 2,2 & 92,7 & 115,0 & 87,9 \\
\hline хлопчатобумажные & 76,5 & 107,2 & 99,2 & 104,4 \\
\hline $\begin{array}{l}\text { из синтетических и искусственных волокон } \\
\text { и нитей (включая штапельные) }\end{array}$ & 36,2 & 106,2 & 104,0 & 99,8 \\
\hline марля, кроме узких тканей & 49,6 & 100,1 & 100,7 & 100,6 \\
\hline материалы нетканые, кроме ватинов & 368 & 101,4 & 96,2 & 110,5 \\
\hline Полотна трикотажные или вязаные, тыс. тонн & 2,9 & 111,5 & 116,3 & 96,7 \\
\hline Белье постельное, млн штук & 6,8 & 102,0 & 123,8 & 98,7 \\
\hline Палатки, тыс. штук & 3,7 & 100,8 & 113,6 & 85,0 \\
\hline Канаты, веревки, шпагат и сети, кроме отходов, тыс. тонн & 2,2 & 156,4 & 92,6 & 114,2 \\
\hline
\end{tabular}

Производство одежды. Индекс производства одежды в сентябре 2020 г. по сравнению с соответствующим периодом предыдущего года составил $104,4 \%$, в январе-сентябре 2020 г. - 100,5\%. 
ДИНАМИКА ПРОИЗВОДСТВА ОДЕЖДЫ

\begin{tabular}{|c|c|c|}
\hline & \multicolumn{2}{|c|}{$B \% \kappa$} \\
\hline & $\begin{array}{c}\text { соответствующему } \\
\text { периоду предыдущего года }\end{array}$ & $\begin{array}{c}\text { предылдущему } \\
\text { периоду }\end{array}$ \\
\hline \multicolumn{3}{|c|}{2019 г. } \\
\hline Январь & 93,1 & 88,2 \\
\hline Февраль & 101,4 & 117,9 \\
\hline Март & 105,2 & 109,4 \\
\hline І квартал & 100,2 & 97,3 \\
\hline Апрель & 109,8 & 109,4 \\
\hline Май & 94,9 & 89,0 \\
\hline Июнь & 94,5 & 99,1 \\
\hline ІІ квартал & 99,7 & 112,7 \\
\hline I полугодие & 99,9 & \\
\hline Июль & 101,9 & 101,1 \\
\hline Август & 105,7 & 106,0 \\
\hline Сентябрь & 104,4 & 95,6 \\
\hline ІІІ квартал & 104,0 & 98,8 \\
\hline Январь-сентябрь & 101,3 & \\
\hline Октябрь & 108,7 & 106,2 \\
\hline Ноябрь & 107,9 & 94,6 \\
\hline Декабрь & 114,9 & 101,7 \\
\hline IV квартал & 110,5 & 101,9 \\
\hline Год & 103,5 & \\
\hline \multicolumn{3}{|c|}{2020 г. } \\
\hline Январь & 106,0 & 81,4 \\
\hline Февраль & 104,8 & 116,6 \\
\hline Март & 99,3 & 103,6 \\
\hline І квартал & 103,1 & 90,9 \\
\hline Апрель & 74,2 & 81,7 \\
\hline Май & 100,3 & 120,3 \\
\hline Июнь & 107,3 & 106,1 \\
\hline ІІ квартал & 93,9 & 101,8 \\
\hline I полугодие & 97,8 & \\
\hline Июль & 112,3 & 105,8 \\
\hline Август & 100,3 & 94,6 \\
\hline Сентябрь & 104,4 & 99,5 \\
\hline ІІІ квартал & 105,7 & 112,0 \\
\hline Январь-сентябрь & 100,5 & \\
\hline
\end{tabular}


ПРОИЗВОДСТВо ОтДЕЛЬНЫХ ВИДОВ ОДЕжДЫ

\begin{tabular}{|c|c|c|c|c|}
\hline & Сентябрь & & & Январь- \\
\hline & 20202. & $\begin{array}{l}\text { сентябрю } \\
20192 .\end{array}$ & $\begin{array}{l}\text { aвгусmy } \\
20202 .\end{array}$ & $\begin{array}{c}\text { сентябрь } \\
2020 \text { г. } \\
\text { в\% к } \\
\text { январю- } \\
\text { сентябрю } \\
20192 .\end{array}$ \\
\hline $\begin{array}{l}\text { Комплекты, костюмы, куртки (пиджаки) и блейзеры мужские } \\
\text { производственные и профессиональные, млн штук }\end{array}$ & 4,7 & 102,1 & 100,7 & 107,2 \\
\hline $\begin{array}{l}\text { Куртки мужские или для мальчиков из текстильных материалов, } \\
\text { кроме трикотажных или вязаных, тыс. штук }\end{array}$ & 141 & 114,6 & 88,4 & 82,6 \\
\hline Спецодежда прочая, млрд рублей ${ }^{1)}$ & 1,7 & 94,4 & 88,0 & 125,8 \\
\hline Изделия трикотажные или вязаные, млн штук & 11,5 & 103,1 & 90,0 & 92,8 \\
\hline $\begin{array}{l}\text { Платья женские или для девочек из текстильных материалов, } \\
\text { кроме трикотажных или вязаных, тыс. штук }\end{array}$ & 320 & 79,7 & 81,8 & 79,3 \\
\hline Пальто с верхом из натурального меха, тыс. штук & 6,1 & 100,1 & 87,7 & 88,2 \\
\hline Изделия чулочно-носочные трикотажные или вязаные, млн пар & 21,2 & 133,2 & 136,6 & 97,4 \\
\hline
\end{tabular}

Производство кожи и изделий из кожи. Индекс производства кожи и изделий из кожи в сентябре 2020 г. по сравнению с соответствующим периодом предыдущего года составил 90,2\%, в январе-сентябре 2020 г. - 86,3\%.

Таблица 21

ДИНАМИКА ПРОИЗВОДСТВА КОЖИ И ИЗДЕЛИЙ ИЗ КОЖИ

\begin{tabular}{|c|c|c|}
\hline & \multicolumn{2}{|c|}{ 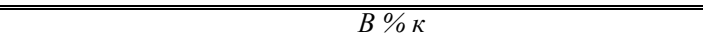 } \\
\hline & $\begin{array}{c}\text { соответствующему } \\
\text { периоду предыдущего года }\end{array}$ & $\begin{array}{c}\text { предьдущему } \\
\text { периоду }\end{array}$ \\
\hline \multicolumn{3}{|c|}{2019 г. } \\
\hline Январь & 93,7 & 80,2 \\
\hline Февраль & 100,4 & 121,2 \\
\hline Март & 97,6 & 105,6 \\
\hline І квартал & 97,4 & 91,0 \\
\hline Апрель & 99,8 & 108,5 \\
\hline Май & 96,7 & 90,5 \\
\hline Июнь & 96,3 & 96,1 \\
\hline ІІ квартал & 97,6 & 110,3 \\
\hline I полугодие & 97,5 & \\
\hline Июль & 104,8 & 98,5 \\
\hline Август & 93,9 & 103,3 \\
\hline Сентябрь & 103,1 & 104,9 \\
\hline ІІІ квартал & 100,6 & 96,2 \\
\hline Январь-сентябрь & 98,4 & \\
\hline Октябрь & 104,7 & 105,5 \\
\hline Ноябрь & 94,2 & 89,7 \\
\hline
\end{tabular}




\begin{tabular}{|c|c|c|}
\hline & \multicolumn{2}{|c|}{ 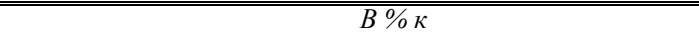 } \\
\hline & $\begin{array}{c}\text { соответствующему } \\
\text { периоду предьдуущего года }\end{array}$ & $\begin{array}{c}\text { предылущему } \\
\text { периоду }\end{array}$ \\
\hline Декабрь & 95,9 & 98,1 \\
\hline IV квартал & 98,3 & 101,9 \\
\hline Год & 98,4 & \\
\hline \multicolumn{3}{|c|}{2020 г. } \\
\hline Январь & 99,4 & 83,2 \\
\hline Февраль & 100,2 & 122,0 \\
\hline Март & 100,7 & 106,2 \\
\hline I квартал & 100,2 & 92,7 \\
\hline Апрель & 56,8 & 61,1 \\
\hline Май & 69,3 & 110,4 \\
\hline Июнь & 87,6 & 121,5 \\
\hline ІІ квартал & 71,2 & 77,6 \\
\hline I полугодие & 84,6 & \\
\hline Июль & 89,3 & 100,4 \\
\hline Август & 89,9 & 104,0 \\
\hline Сентябрь & 90,2 & 105,2 \\
\hline ІІІ квартал & 89,8 & 122,6 \\
\hline Январь-сентябрр & 86,3 & \\
\hline
\end{tabular}

Таблица 22

ПРОИЗВОДСТВО ОТДЕЛЬНЫХ ВИДОВ КОЖИ И ИЗДЕЛИЙ ИЗ КОЖИ

\begin{tabular}{|c|c|c|c|c|}
\hline & \multirow{2}{*}{$\begin{array}{c}\text { Сентябрь } \\
2020 \text { г. }\end{array}$} & \multicolumn{2}{|c|}{$\overline{B \% \kappa}$} & \multirow[b]{2}{*}{$\begin{array}{c}\text { Январь- } \\
\text { сентябрь } \\
2020 \text { г. } \\
\text { в\% к } \\
\text { январю- } \\
\text { сентябрю } \\
2019 \text { г. }\end{array}$} \\
\hline & & $\begin{array}{l}\text { сентябрюю } \\
2019 \text { г. }\end{array}$ & $\begin{array}{l}\text { aвzycmy } \\
2020 \text {. }\end{array}$ & \\
\hline $\begin{array}{l}\text { Кожа из нецелых шкур крупного рогатого скота } \\
\text { без волосяного покрова, млн дм² }\end{array}$ & 18,0 & 50,9 & 94,8 & 81,3 \\
\hline $\begin{array}{l}\text { Чемоданы, сумки дамские и аналогичные изделия } \\
\text { из натуральной кожи, сочетаний кожи, листов пластмассы, } \\
\text { текстильных материалов, вулканизированных волокон или } \\
\text { картона; наборы дорожнее, используемые для личной гигиены, } \\
\text { шитья или для чистки одежды или обуви, млн рублей }{ }^{1)}\end{array}$ & 326 & 76,7 & 116,9 & 78,4 \\
\hline Обувь, млн пар & 8,3 & 92,8 & 103,6 & 84,6 \\
\hline $\begin{array}{l}\text { из нее: } \\
\text { обувь водонепроницаемая на подошве и с верхом } \\
\text { из резины или пластмассы, кроме обуви } \\
\text { с защитным металлическим подноском }\end{array}$ & 1,6 & 97,9 & 89,2 & 99,2 \\
\hline $\begin{array}{l}\text { обувь на подошве и с верхом из резины или пластмассы, } \\
\text { кроме водонепроницаемой или спортивной обуви }\end{array}$ & 1,2 & 87,6 & 102,2 & 98,0 \\
\hline $\begin{array}{l}\text { обувь с верхом из кожи, кроме спортивной обуви, } \\
\text { обуви с защитным металлическим подноском } \\
\text { и различной специальной обуви }\end{array}$ & 1,8 & 94,1 & 103,4 & 85,7 \\
\hline $\begin{array}{l}\text { обувь с верхом из текстильных материалов, } \\
\text { кроме спортивной обуви }\end{array}$ & 2,6 & 84,5 & 115,7 & 67,3 \\
\hline $\begin{array}{l}\text { обувь защитная и прочая, не включенная } \\
\text { в другие группировки, тыс. пар }\end{array}$ & 632 & 98,6 & 98,8 & 91,7 \\
\hline
\end{tabular}


Обработка древесины и производство изделий из дерева и пробки, кроме мебели, производство изделий из соломки и материалов для плетения. Индекс производства по обработке древесины и производству изделий из дерева и пробки, кроме мебели, производства изделий из соломки и материалов для плетения в сентябре 2020 г. по сравнению с соответствующим периодом предыдущего года составил $107,4 \%$, в январе-сентябре 2020 г. $-101,0 \%$.

ДИНАМИКА ОБРАБОТКИ ДРЕВЕСИНЫ И ПРОИЗВОДСТВА ИЗДЕЛИЙ ИЗ ДЕРЕВА И ПРОБКИ, КРОМЕ МЕБЕЛИ, ПРОИЗВОДСТВА ИЗДЕЛИЙ ИЗ СОЛОМКИ И МАТЕРИАЛОВ ДЛЯ ПЛЕТЕНИЯ

\begin{tabular}{|c|c|c|}
\hline & \multicolumn{2}{|c|}{ 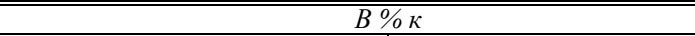 } \\
\hline & $\begin{array}{c}\text { соответствуюшему } \\
\text { периоуу предыдуущего года }\end{array}$ & $\begin{array}{c}\text { предылущему } \\
\text { периоду }\end{array}$ \\
\hline \multicolumn{3}{|c|}{2019 г. } \\
\hline Январь & 110,9 & 93,1 \\
\hline Февраль & 105,4 & 101,7 \\
\hline Март & 107,7 & 114,3 \\
\hline І квартал & 107,9 & 98,5 \\
\hline Апрель & 109,2 & 96,9 \\
\hline Май & 107,0 & 96,4 \\
\hline Июнь & 108,7 & 106,4 \\
\hline ІІ квартал & 108,3 & 105,9 \\
\hline I полугодие & 108,1 & \\
\hline Июль & 112,8 & 105,4 \\
\hline Август & 107,5 & 98,5 \\
\hline Сентябрь & 103,8 & 93,9 \\
\hline III квартал & 108,0 & 105,3 \\
\hline Январь-сентябрь & 108,1 & \\
\hline Октябрь & 99,5 & 97,5 \\
\hline Ноябрь & 97,6 & 93,2 \\
\hline Декабрь & 104,4 & 109,5 \\
\hline IV квартал & 100,5 & 91,5 \\
\hline Гod & 106,1 & \\
\hline \multicolumn{3}{|c|}{2020 г. } \\
\hline Январь & 101,6 & 90,5 \\
\hline Февраль & 109,1 & 109,3 \\
\hline Март & 101,4 & 106,2 \\
\hline I квартал & 103,9 & 101,8 \\
\hline Апрель & 87,6 & 83,7 \\
\hline Май & 93,6 & 103,0 \\
\hline Июнь & 101,2 & 115,0 \\
\hline ІІ квартал & 94,1 & 96,0 \\
\hline I полугодие & 98,9 & \\
\hline Июль & 102,8 & 107,1 \\
\hline Август & 104,2 & 99,9 \\
\hline Сентябрь & 107,4 & 96,9 \\
\hline ІІІ квартал & 104,8 & 117,1 \\
\hline Январь-сентябрь & 101,0 & \\
\hline
\end{tabular}


ОБРАБОТКА ДРЕВЕСИНЫ И ПРОИЗВОДСТВО ОТДЕЛЬНЫХ ВИДОВ ИЗДЕЛИЙ ИЗ ДЕРЕВА И ПРОБКИ

\begin{tabular}{|c|c|c|c|c|}
\hline & \multirow{2}{*}{$\begin{array}{l}\text { Сентябрь } \\
2020 \text { г. }\end{array}$} & \multicolumn{2}{|c|}{$\bar{B} \% \kappa$} & \multirow[b]{2}{*}{$\begin{array}{c}\text { Январь- } \\
\text { сентябрь } \\
2020 \text { г. } \\
\text { в \% к } \\
\text { январю- } \\
\text { сентябрю } \\
20192 .\end{array}$} \\
\hline & & $\begin{array}{c}\text { сентябрю } \\
2019 \text { 2. }\end{array}$ & $\begin{array}{c}\text { aвzycmy } \\
2020 \text { z. }\end{array}$ & \\
\hline $\begin{array}{l}\text { Лесоматериалы, продольно распиленные } \\
\text { или расколотые, разделенные на слои или лущеные, } \\
\text { толщиной более } 6 \text { мм; деревянные железнодорожные } \\
\text { или трамвайные шпалы, непропитанные, тыс. м }\end{array}$ & 2448 & 96,8 & 97,3 & 95,5 \\
\hline $\begin{array}{l}\text { из них: } \\
\text { пиломатериалы хвойных пород }\end{array}$ & 2270 & 97,7 & 96,9 & 96,8 \\
\hline пиломатериалы лиственных пород & 171 & 89,4 & 105,6 & 83,2 \\
\hline Брикеты топливные из отходов деревопереработки, тыс. тонн & 15,6 & 110,4 & 99,5 & 107,5 \\
\hline $\begin{array}{l}\text { Лесоматериалы необработанные, окрашенные, } \\
\text { протравленные обработанные креозотом } \\
\text { или другими консервантами, тыс. } \text { м }^{3}\end{array}$ & 11,6 & 137,2 & 84,1 & 130,3 \\
\hline Фанера, тыс. м ${ }^{3}$ & 343 & 99,6 & 101,5 & 93,8 \\
\hline $\begin{array}{l}\text { Плиты древесностружечные и аналогичные плиты из древесины } \\
\text { или других одревесневших материалов, тыс. усл. } \text { м }^{3}\end{array}$ & 940 & 115,6 & 96,6 & 94,4 \\
\hline $\begin{array}{l}\text { Плиты древесноволокнистые из древесины } \\
\text { или других одревесневших материалов, млн усл. м² }\end{array}$ & 60,2 & 101,7 & 98,6 & 89,9 \\
\hline Окна и их коробки деревянные, тыс. м² & 47,8 & 90,7 & 105,2 & 81,2 \\
\hline Двери, их коробки и пороги деревянные, тыс. м² & 1430 & 115,1 & 106,9 & 98,5 \\
\hline
\end{tabular}

Производство бумаги и бумажных изделий. Индекс производства бумаги и бумажных изделий в сентябре 2020 г. по сравнению с соответствующим периодом предыдущего года составил $104,5 \%$, в январе-сентябре 2020 г. - 101,0\%.

ДИНАМИКА ПРОИЗВОДСТВА БУМАГИ И БУМАЖНЫХ ИЗДЕЛИЙ

\begin{tabular}{|c|c|c|}
\hline & \multicolumn{2}{|c|}{$B \% \kappa$} \\
\hline & $\begin{array}{c}\text { соответствующему } \\
\text { периоду предьдучщего года }\end{array}$ & $\begin{array}{c}\text { предылучщему } \\
\text { периоду }\end{array}$ \\
\hline \multicolumn{3}{|c|}{2019 г. } \\
\hline Январь & 105,2 & 94,3 \\
\hline Февраль & 103,7 & 98,1 \\
\hline Март & 104,2 & 111,1 \\
\hline І квартал & 104,4 & 97,0 \\
\hline Апрель & 106,3 & 99,4 \\
\hline Май & 102,8 & 96,8 \\
\hline Июнь & 101,4 & 98,0 \\
\hline ІІ квартал & 103,5 & 102,9 \\
\hline I полугодие & 103,9 & \\
\hline Июль & 104,5 & 105,8 \\
\hline Август & 104,3 & 99,8 \\
\hline
\end{tabular}




\begin{tabular}{|c|c|c|}
\hline & \multicolumn{2}{|c|}{ 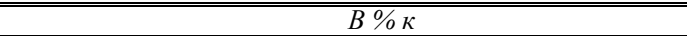 } \\
\hline & $\begin{array}{c}\text { соответствующему } \\
\text { периоду предыдущего года }\end{array}$ & $\begin{array}{c}\text { предьдущему } \\
\text { периоду }\end{array}$ \\
\hline Сентябрь & 103,9 & 97,1 \\
\hline ІІІ квартал & 104,2 & 102,1 \\
\hline Январь-сентябрь & 104,0 & \\
\hline Октябрь & 105,4 & 105,7 \\
\hline Ноябрь & 105,6 & 99,4 \\
\hline Декабрь & 108,1 & 103,5 \\
\hline IV квартал & 106,4 & 104,4 \\
\hline Год & 104,6 & \\
\hline \multicolumn{3}{|c|}{2020 г. } \\
\hline Январь & 100,1 & 87,4 \\
\hline Февраль & 105,1 & 103,1 \\
\hline Март & 104,2 & 110,1 \\
\hline І квартал & 103,2 & 94,1 \\
\hline Апрель & 99,2 & 94,6 \\
\hline Май & 95,0 & 92,7 \\
\hline Июнь & 99,6 & 102,8 \\
\hline ІІ квартал & 97,9 & 97,6 \\
\hline I полугодие & 100,5 & \\
\hline Июль & 99,0 & 105,2 \\
\hline Август & 102,8 & 103,6 \\
\hline Сентябрь & 104,5 & 98,8 \\
\hline ІІІ квартал & 102,1 & 106,4 \\
\hline Январь-сентябрь & 101,0 & \\
\hline
\end{tabular}

ПРОИЗВОДСТВО ОТДЕЛЬНЫХ ВИДОВ БУМАГИ И БУМАЖНЫХ ИЗДЕЛИЙ

\begin{tabular}{|c|c|c|c|c|}
\hline & \multirow{2}{*}{$\begin{array}{l}\text { Сентябрь } \\
2020 \text { г. }\end{array}$} & \multicolumn{2}{|c|}{$B \% \kappa$} & \multirow[b]{2}{*}{$\begin{array}{c}\text { Январь- } \\
\text { сентябрь } \\
2020 \text { г. } \\
\text { в\% к } \\
\text { январю- } \\
\text { сентябрю } \\
20192 . \\
\end{array}$} \\
\hline & & $\begin{array}{l}\text { сентябрю } \\
2019 \text { 2. }\end{array}$ & $\begin{array}{l}\text { aвгусmy } \\
2020 \text { 2. }\end{array}$ & \\
\hline $\begin{array}{l}\text { Целлюлоза древесная и целлюлоза } \\
\text { из прочих волокнистых материалов, тыс. тонн }\end{array}$ & 732 & 110,2 & 103,6 & 106,5 \\
\hline Бумага и картон, тыс. тонн & 783 & 104,6 & 99,5 & 104,2 \\
\hline $\begin{array}{l}\text { из них: } \\
\text { бумага газетная в рулонах или листах }\end{array}$ & 100 & 81,1 & 94,4 & 88,9 \\
\hline бумага офсетная & 31,5 & 89,1 & 110,5 & 95,8 \\
\hline картон тарный (крафт-лайнер) небеленый, немелованный & 165 & 122,4 & 106,8 & 126,7 \\
\hline $\begin{array}{l}\text { Ящики и коробки складывающиеся из негофрированной } \\
\text { бумаги или негофрированного картона, млн м² }\end{array}$ & 69,0 & 95,8 & 102,3 & 99,7 \\
\hline $\begin{array}{l}\text { Полотенца санитарно-гигиенические и тампоны } \\
\text { из бумажной массы, бумаги, целлюлозной ваты } \\
\text { и полотна из целлюлозных волокон, млн штук }\end{array}$ & 140 & 86,0 & 100,3 & 86,9 \\
\hline Бланки из бумаги или картона, млн штук & 151 & 92,7 & 105,3 & 90,0 \\
\hline Обои, млн усл кусков & 18,8 & 132,1 & 95,5 & 94,4 \\
\hline
\end{tabular}


Деятельность полиграфическая и копирование носителей информациИ. Индекс производства полиграфической деятельности и копирования носителей информации в сентябре 2020 г. по сравнению с соответствующим периодом предыдущего года составил $100,2 \%$, в январе-сентябре 2020 г. - 100,5\%.

ДИНАМИКА ПОЛИГРАФИЧЕСКОЙ ДЕЯТЕЛЬНОСТИ И КОПИРОВАНИЯ НОСИТЕЛЕЙ ИНФОРМАЦИИ

\begin{tabular}{|c|c|c|}
\hline & \multicolumn{2}{|c|}{$B \% \kappa$} \\
\hline & $\begin{array}{c}\text { соответствующему } \\
\text { периоду предьдущего года }\end{array}$ & $\begin{array}{c}\text { предылдущему } \\
\text { периоду }\end{array}$ \\
\hline \multicolumn{3}{|c|}{2019 г. } \\
\hline Январь & 107,8 & 78,5 \\
\hline Февраль & 94,4 & 108,1 \\
\hline Март & 104,9 & 116,5 \\
\hline І квартал & 102,0 & 82,3 \\
\hline Апрель & 103,8 & 105,2 \\
\hline Май & 92,7 & 88,1 \\
\hline Июнь & 99,3 & 111,5 \\
\hline ІІ квартал & 98,6 & 113,6 \\
\hline I полугодие & 100,2 & \\
\hline Июль & 84,9 & 96,7 \\
\hline Август & 100,8 & 103,1 \\
\hline Сентябрь & 116,1 & 106,4 \\
\hline ІІІ квартал & 100,6 & 103,7 \\
\hline Январь-сентябрь & 99,9 & \\
\hline Октябрь & 92,7 & 101,2 \\
\hline Ноябрь & 107,1 & 98,1 \\
\hline Декабрь & 104,0 & 96,6 \\
\hline IV квартал & 101,3 & 104,0 \\
\hline Год & 100,1 & \\
\hline \multicolumn{3}{|c|}{2020 г. } \\
\hline Январь & 118,0 & 89,2 \\
\hline Февраль & 103,5 & 94,9 \\
\hline Март & 106,0 & 119,2 \\
\hline І квартал & 108,8 & 88,8 \\
\hline Апрель & 98,4 & 97,7 \\
\hline Май & 97,1 & 86,9 \\
\hline Июнь & 96,4 & 110,7 \\
\hline ІІ квартал & 97,3 & 101,6 \\
\hline I полугодие & 102,7 & \\
\hline Июль & 96,7 & 96,9 \\
\hline Август & 92,7 & 98,9 \\
\hline Сентябрь & 100,2 & 115,0 \\
\hline ІІІ квартал & 96,5 & 103,0 \\
\hline Январь-сентябрь & 100,5 & \\
\hline
\end{tabular}


УСЛУГИ В СФЕРЕ ПОЛИГРАФИЧЕСКОЙ ДЕЯТЕЛЬНОСТИ И КОПИРОВАНИЯ НОСИТЕЛЕЙ ИНФОРМАЦИИ ${ }^{1)}$

\begin{tabular}{|c|c|c|c|c|}
\hline & \multirow{2}{*}{$\begin{array}{c}\text { Сентябрь } \\
2020 \text { г., } \\
\text { млн рублей }\end{array}$} & \multicolumn{2}{|c|}{$B \% \kappa$} & \multirow[b]{2}{*}{$\begin{array}{c}\text { Январь- } \\
\text { сентябрь } \\
2020 \text { г. } \\
\text { в\% \% } \\
\text { январю- } \\
\text { сентябрю } \\
2019 \text { г. } \\
\end{array}$} \\
\hline & & $\begin{array}{c}\text { сентябрю } \\
20192 .\end{array}$ & $\begin{array}{l}\text { aвzycmy } \\
2020 \text { г. }\end{array}$ & \\
\hline $\begin{array}{l}\text { Услуги полиграфические и услуги, } \\
\text { связанные с печатанием, млрд рублей }\end{array}$ & 11,4 & 100,0 & 103,7 & 95,8 \\
\hline $\begin{array}{l}\text { из них: } \\
\text { по печатанию газет }\end{array}$ & 851 & 98,1 & 100,9 & 89,7 \\
\hline $\begin{array}{l}\text { по печатанию журналов и периодических изданий, } \\
\text { выходящих реже четырех раз в неделю }\end{array}$ & 651 & 52,7 & 106,1 & 48,4 \\
\hline $\begin{array}{l}\text { по печатанию книг, географических карт, гидрограф } \\
\text { или аналогичных карт всех видов, репродукций, } \\
\text { чертежей и фотографий, открыток, млрд рублей }\end{array}$ & 1,1 & 88,9 & 98,4 & 85,5 \\
\hline по печатанию этикеток и ярлыков, млрд рублей & 3,2 & 134,3 & 107,7 & 119,1 \\
\hline по подготовке к печати & 92,7 & 94,5 & 117,0 & 82,2 \\
\hline
\end{tabular}

Производство кокса и нефтепродуктов. Индекс производства кокса и нефтепродуктов в сентябре 2020 г. по сравнению с соответствующим периодом предыдущего года составил 95,4\%, в январе-сентябре 2020 г. - 98,6\%.

\section{ДИНАМИКА ПРОИЗВОДСТВА КОКСА И НЕФТЕПРОДУКТОВ}

\begin{tabular}{|c|c|c|}
\hline & \multicolumn{2}{|c|}{$\bar{B} \% \mathrm{~K}$} \\
\hline & $\begin{array}{c}\text { соответствующему } \\
\text { периоду предыдушего года }\end{array}$ & $\begin{array}{c}\text { предьлушщему } \\
\text { периоду }\end{array}$ \\
\hline \multicolumn{3}{|c|}{2019 г. } \\
\hline Январь & 104,3 & 100,3 \\
\hline Февраль & 104,4 & 90,8 \\
\hline Март & 99,8 & 104,6 \\
\hline І квартал & 102,8 & 99,4 \\
\hline Апрель & 100,8 & 93,8 \\
\hline Май & 95,6 & 101,2 \\
\hline Июнь & 96,6 & 102,2 \\
\hline II квартал & 97,7 & 95,0 \\
\hline I полугодие & 100,2 & \\
\hline Июль & 100,8 & 109,1 \\
\hline Август & 104,5 & 100,4 \\
\hline Сентябрь & 100,9 & 93,0 \\
\hline ІІІ квартал & 102,0 & 108,8 \\
\hline Январь-сентябрь & 100,8 & \\
\hline Октябрь & 106,5 & 104,9 \\
\hline Ноябрь & 102,7 & 99,6 \\
\hline
\end{tabular}




\begin{tabular}{|c|c|c|}
\hline & \multicolumn{2}{|c|}{ 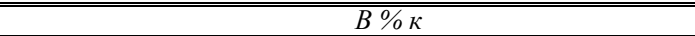 } \\
\hline & $\begin{array}{c}\text { соответствующему } \\
\text { периоду предьдучего года }\end{array}$ & $\begin{array}{c}\text { предыдущему } \\
\text { периоду }\end{array}$ \\
\hline Декабрь & 102,4 & 104,2 \\
\hline IV квартал & 103,9 & 101,1 \\
\hline Гоd & 101,6 & \\
\hline \multicolumn{3}{|c|}{2020 г. } \\
\hline Январь & 102,2 & 100,0 \\
\hline Февраль & 107,2 & 95,3 \\
\hline Март & 108,5 & 105,9 \\
\hline І квартал & 105,8 & 101,3 \\
\hline Апрель & 101,1 & 87,4 \\
\hline Май & 95,4 & 95,5 \\
\hline Июнь & 92,3 & 98,9 \\
\hline ІІ квартал & 96,3 & 86,3 \\
\hline I полугодие & 101,2 & \\
\hline Июль & 92,3 & 109,1 \\
\hline Август & 93,6 & 101,8 \\
\hline Сентябрь & 95,4 & 94,8 \\
\hline ІІІ квартал & 93,8 & 106,0 \\
\hline Январь-сентябрь & 98,6 & \\
\hline
\end{tabular}

Таблица 30

ПРОИЗВОДСТВО КОКСА И ОТДЕЛЬНЫХ ВИДОВ НЕФТЕПРОДУКТОВ

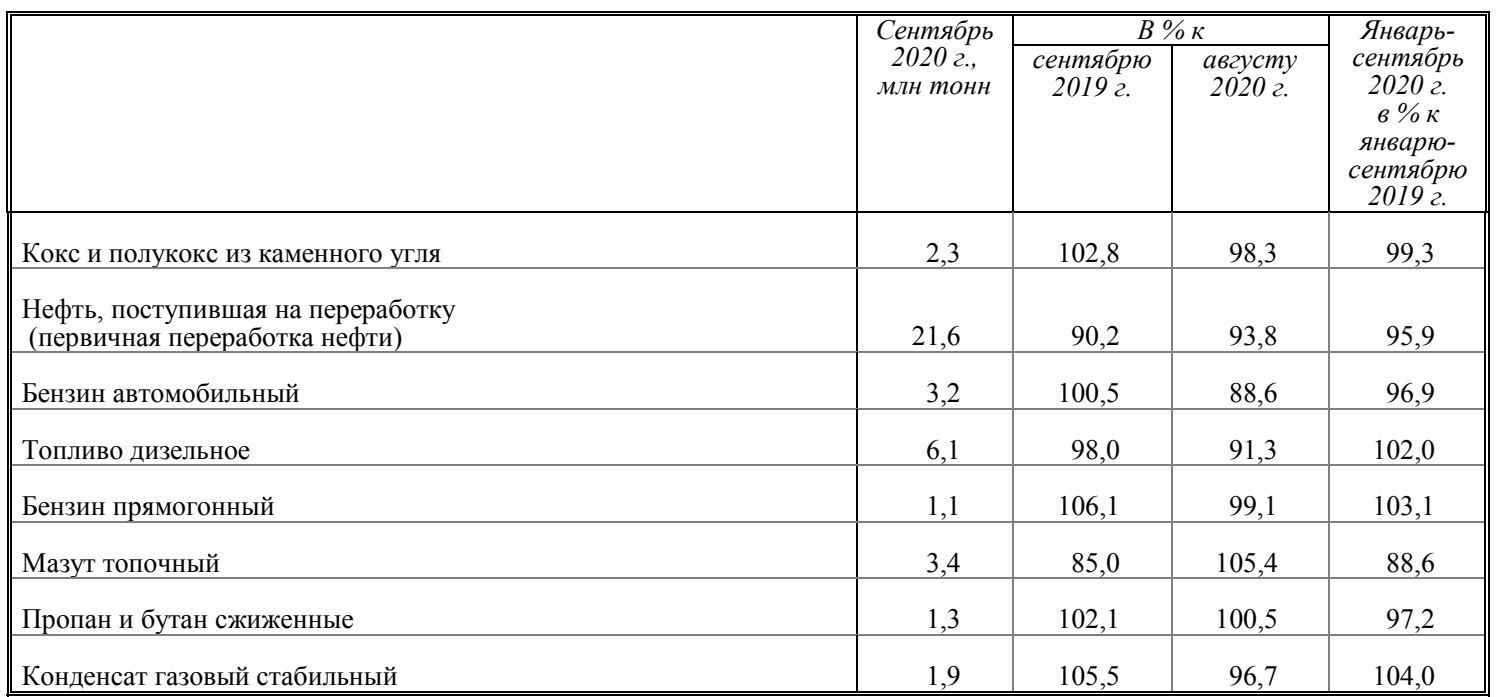

Глубина переработки нефтяного сырья в январе-сентябре 2020 г. составила 84,1\% (в январе-сентябре 2019 г. - 82,9\%).

Производство химических веществ и химических продуктов. Индекс производства химических веществ и химических продуктов в сентябре 2020 г. по сравнению с соответствующим периодом предыдущего года составил 106,7\%, в январе-сентябре 2020 г. $106,1 \%$. 
ДИНАМИКА ПРОИЗВОДСТВА ХИМИЧЕСКИХ ВЕЩЕСТВ И ХИМИЧЕСКИХ ПРОДУКТОВ

\begin{tabular}{|c|c|c|}
\hline & \multicolumn{2}{|c|}{$\bar{B} \% \kappa$} \\
\hline & $\begin{array}{c}\text { соответствуюшему } \\
\text { периоду предыдущего года }\end{array}$ & $\begin{array}{c}\text { предьлдущему } \\
\text { периоду }\end{array}$ \\
\hline \multicolumn{3}{|c|}{2019 г. } \\
\hline Январь & 100,8 & 94,6 \\
\hline Февраль & 101,5 & 95,6 \\
\hline Март & 102,6 & 111,7 \\
\hline І квартал & 101,6 & 100,7 \\
\hline Апрель & 103,6 & 97,6 \\
\hline Май & 102,2 & 99,1 \\
\hline Июнь & 103,9 & 98,2 \\
\hline ІІ квартал & 103,2 & 102,2 \\
\hline I полугодие & 102,4 & \\
\hline Июль & 104,4 & 98,7 \\
\hline Август & 105,2 & 101,8 \\
\hline Сентябрь & 105,9 & 97,6 \\
\hline III квартал & 105,1 & 97,6 \\
\hline Январь-сентябрь & 103,3 & \\
\hline Октябрь & 107,1 & 102,9 \\
\hline Ноябрь & 103,1 & 100,0 \\
\hline Декабрь & 100,8 & 104,1 \\
\hline IV квартал & 103,7 & 103,2 \\
\hline Год & 103,4 & \\
\hline \multicolumn{3}{|c|}{2020 г. } \\
\hline Январь & 105,0 & 98,6 \\
\hline Февраль & 110,4 & 100,5 \\
\hline Март & 109,4 & 110,7 \\
\hline І квартал & 108,3 & 105,2 \\
\hline Апрель & 103,4 & 92,3 \\
\hline Май & 104,0 & 99,6 \\
\hline Июнь & 102,5 & 96,8 \\
\hline ІІ квартал & 103,3 & 97,5 \\
\hline I полугодие & 105,8 & \\
\hline Июль & 107,6 & 103,6 \\
\hline Август & 106,3 & 100,6 \\
\hline Сентябрь & 106,7 & 98,0 \\
\hline ІІІ квартал & 106,9 & 100,9 \\
\hline Январь-сентябрь & 106,1 & \\
\hline
\end{tabular}


ПРОИЗВОДСТВО ОТДЕЛЬНЫХ ВИДОВ

ХИМИЧЕСКИХ ВЕЩЕСТВ И ХИМИЧЕСКИХ ПРОДУКТОВ

\begin{tabular}{|c|c|c|c|c|}
\hline & \multirow{2}{*}{$\begin{array}{l}\text { Сентябрь } \\
2020 \text { г., } \\
\text { тьсс. тонн }\end{array}$} & \multicolumn{2}{|c|}{ 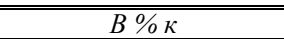 } & \multirow[b]{2}{*}{$\begin{array}{c}\text { Январь- } \\
\text { сентябрь } \\
2020 \text { г. } \\
в \% \text { \% } \\
\text { январю- } \\
\text { сентябрю } \\
2019 \text { г. } \\
\end{array}$} \\
\hline & & $\begin{array}{l}\text { сентябрю } \\
2019 \text { 2. }\end{array}$ & $\begin{array}{l}\text { aвгусmy } \\
2020 \text { г. }\end{array}$ & \\
\hline Олеум, кислота серная, млн тонн & 1,2 & 111,4 & 100,9 & 105,2 \\
\hline Гидроксид натрия (сода каустическая) & 108 & 101,1 & 108,9 & 98,4 \\
\hline Карбонат динатрия (карбонат натрия, сода кальцинированная) & 282 & 96,7 & 101,0 & 97,5 \\
\hline Сера техническая газовая & 478 & 95,1 & 91,8 & 96,5 \\
\hline Бензолы & 92,3 & 92,7 & 87,2 & 98,8 \\
\hline Аммиак, млн тонн & 1,4 & 92,0 & 92,5 & 100,4 \\
\hline $\begin{array}{l}\text { Удобрения минеральные или химические } \\
\text { (в пересчете на } 100 \text { \% питательных веществ) }\end{array}$ & 2014 & 104,3 & 99,6 & 103,5 \\
\hline $\begin{array}{l}\text { в том числе: } \\
\text { азотные }\end{array}$ & 821 & 94,6 & 101,5 & 101,5 \\
\hline фосфорные & 344 & 104,7 & 94,7 & 104,4 \\
\hline калийные & 849 & 115,4 & 99,9 & 105,3 \\
\hline Пластмассы в первичных формах & 852 & 125,6 & 95,9 & 116,4 \\
\hline $\begin{array}{l}\text { из них: } \\
\text { полимеры этилена в первичных формах }\end{array}$ & 269 & 183,2 & 87,5 & 152,0 \\
\hline полимеры стирола в первичных формах & 50,4 & 107,2 & 99,0 & 104,9 \\
\hline $\begin{array}{l}\text { полимеры винилхлорида или прочих } \\
\text { галогенированных олефинов в первичных формах }\end{array}$ & 94,0 & 97,4 & 111,0 & 100,6 \\
\hline $\begin{array}{l}\text { полиацетали, прочие полимеры простых эфиров и эпоксидные } \\
\text { смолы в первичных формах; поликарбонаты, алкидные смолы, } \\
\text { полимеры сложных эфиров аллилового спирта и прочие } \\
\text { полимеры сложных эфиров в первичных формах }\end{array}$ & 55,5 & 99,2 & 94,5 & 103,9 \\
\hline полиамиды в первичных формах & 12,9 & 94,9 & 117,3 & 91,0 \\
\hline $\begin{array}{l}\text { смолы карбамидоформальдегидные, } \\
\text { тиокарбамидоформальдегидные и } \\
\text { меламиноформальдегидные смолы в первичных формах }\end{array}$ & 115 & 102,5 & 93,9 & 90,1 \\
\hline Каучуки синтетические в первичных формах & 122 & 104,1 & 103,4 & 99,4 \\
\hline Гербициды & 5,7 & 131,8 & 124,8 & 130,1 \\
\hline Фунгициды & 1,8 & 168,8 & 97,7 & 112,4 \\
\hline Материалы лакокрасочные на основе полимеров & 98,4 & 113,9 & 86,4 & 105,3 \\
\hline $\begin{array}{l}\text { Материалы лакокрасочные и аналогичные для нанесения } \\
\text { покрытий прочие; краски художественные и полиграфические }\end{array}$ & 41,7 & 110,4 & 100,8 & 102,1 \\
\hline Мыло туалетное твердое & 6,2 & 112,2 & 111,3 & 116,2 \\
\hline Средства моющие & 176 & 96,2 & 98,8 & 104,5 \\
\hline $\begin{array}{l}\text { Средства для дезодорирования и ароматизации } \\
\text { воздуха в помещениях, млн штук }\end{array}$ & 15,4 & 94,5 & 90,6 & 94,1 \\
\hline
\end{tabular}




\begin{tabular}{|c|c|c|c|c|}
\hline & \multirow{2}{*}{$\begin{array}{c}\text { Сентябрь } \\
2020 \text { г., } \\
\text { тыс. тонн }\end{array}$} & \multicolumn{2}{|c|}{$B \% \kappa$} & \multirow[b]{2}{*}{$\begin{array}{c}\text { Январь- } \\
\text { сентябрь } \\
2020 \text { г. } \\
\text { в\% \% } \\
\text { январю- } \\
\text { сентябрю } \\
2019 \text { г. }\end{array}$} \\
\hline & & $\begin{array}{c}\text { сентябрю } \\
2019 \text { г. }\end{array}$ & $\begin{array}{l}\text { августу } \\
2020 \text {. }\end{array}$ & \\
\hline Волокна синтетические & 15,2 & 101,4 & 94,9 & 98,6 \\
\hline Волокна искусственные & 1,4 & 79,5 & 98,5 & 90,6 \\
\hline
\end{tabular}

Производство лекарственных средств и материалов, применяемых В медицинских целях. Индекс производства лекарственных средств и материалов, применяемых в медицинских целях, в сентябре 2020 г. по сравнению с соответствующим периодом предыдущего года составил 122,4\%, в январе-сентябре 2020 г. - 124,2\%.

Таблица 33

ДИНАМИКА ПРОИЗВОДСТВА ЛЕКАРСТВЕННЫХ СРЕДСТВ И МАТЕРИАЛОВ, ПРИМЕНЯЕМЫХ В МЕДИЦИНСКИХ ЦЕЛЯХ

\begin{tabular}{|c|c|c|}
\hline & \multicolumn{2}{|c|}{$\bar{B} \% \mathrm{\%}$} \\
\hline & $\begin{array}{c}\text { соответствующему } \\
\text { периоду предыдущего года }\end{array}$ & $\begin{array}{c}\text { предылдущему } \\
\text { периоду }\end{array}$ \\
\hline \multicolumn{3}{|c|}{2019 г. } \\
\hline Январь & 126,1 & 84,4 \\
\hline Февраль & 124,1 & 120,4 \\
\hline Март & 111,6 & 108,8 \\
\hline I квартал & 119,7 & 96,8 \\
\hline Апрель & 158,5 & 122,7 \\
\hline Май & 98,7 & 74,5 \\
\hline Июнь & 120,4 & 106,1 \\
\hline ІІ квартал & 125,9 & 116,0 \\
\hline I полугодие & 122,0 & \\
\hline Июль & 123,2 & 98,8 \\
\hline Август & 112,5 & 99,7 \\
\hline Сентябрь & 145,8 & 123,4 \\
\hline III квартал & 127,2 & 99,5 \\
\hline Январь-сентябрь & 123,7 & \\
\hline Октябрь & 133,0 & 114,9 \\
\hline Ноябрь & 142,3 & 88,8 \\
\hline Декабрь & 135,8 & 101,9 \\
\hline IV квартал & 137,0 & 122,4 \\
\hline Гоod & 127,3 & \\
\hline \multicolumn{3}{|c|}{2020 г. } \\
\hline Январь & 104,4 & 64,9 \\
\hline Февраль & 126,1 & 145,4 \\
\hline Март & 121,5 & 104,9 \\
\hline І квартал & 118,2 & 83,7 \\
\hline Апрель & 119,8 & 120,9 \\
\hline
\end{tabular}




\begin{tabular}{|c|c|c|}
\hline & \multicolumn{2}{|c|}{ 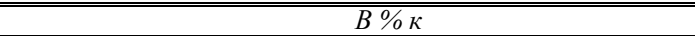 } \\
\hline & $\begin{array}{c}\text { соответствуюшему } \\
\text { периоду предыдущего года }\end{array}$ & $\begin{array}{c}\text { предылущему } \\
\text { периоду }\end{array}$ \\
\hline Май & 132,5 & 82,5 \\
\hline Июнь & 136,5 & 109,3 \\
\hline ІІ квартал & 129,6 & 126,3 \\
\hline I полугодие & 123,9 & \\
\hline Июль & 121,9 & 88,3 \\
\hline Август & 131,0 & 107,2 \\
\hline Сентябрь & 122,4 & 115,3 \\
\hline ІІІ квартал & 125,1 & 96,5 \\
\hline Январь-сентябрь & 124,2 & \\
\hline
\end{tabular}

Таблица 34

ПРОИЗВОДСТВО ОТДЕЛЬНЫХ ВИДОВ ЛЕКАРСТВЕННЫХ СРЕДСТВ И МАТЕРИАЛОВ, ПРИМЕНЯЕМЫХ В МЕДИЦИНСКИХ ЦЕЛЯХ

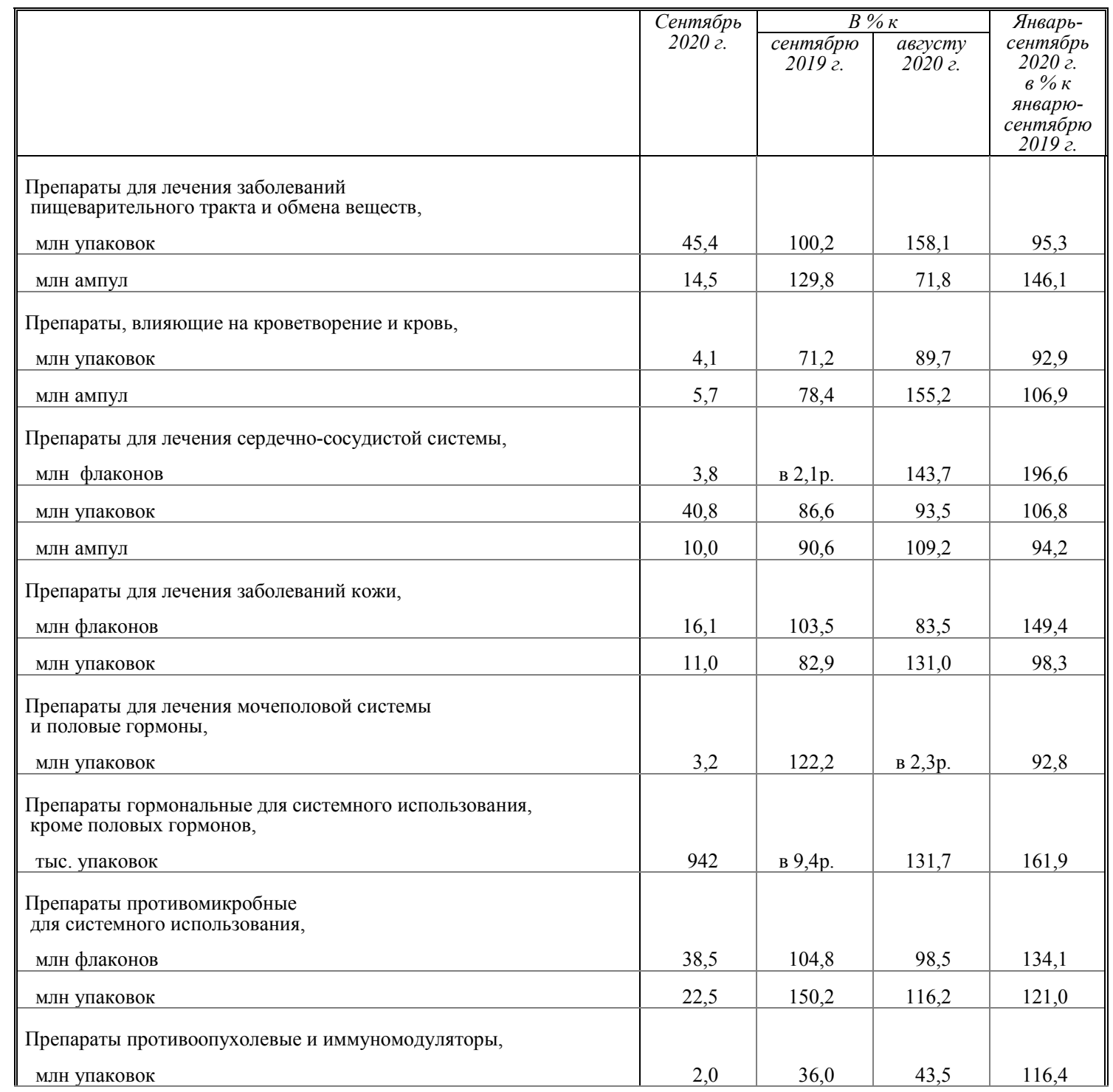




\begin{tabular}{|c|c|c|c|c|}
\hline & \multirow{2}{*}{$\begin{array}{c}\text { Сентябрь } \\
2020 \text { г. }\end{array}$} & \multicolumn{2}{|c|}{$B \% \kappa$} & \multirow[b]{2}{*}{$\begin{array}{c}\text { Январь- } \\
\text { сентябрь } \\
2020 \text { г. } \\
\text { в\% \% } \\
\text { январю- } \\
\text { сентябрю } \\
2019 \text { г. }\end{array}$} \\
\hline & & $\begin{array}{c}\text { сентябрю } \\
2019 \text { г. }\end{array}$ & $\begin{array}{l}\text { августу } \\
2020 \text {. }\end{array}$ & \\
\hline $\begin{array}{l}\text { Препараты для лечения костно-мышечной системы, } \\
\text { млн упаковок }\end{array}$ & 14,8 & 90,8 & 99,5 & 100,5 \\
\hline млн ампул & 4,0 & 96,0 & 113,0 & 101,0 \\
\hline $\begin{array}{l}\text { Препараты для лечения нервной системы, } \\
\text { млн упаковок }\end{array}$ & 53,3 & 106,3 & 103,2 & 107,8 \\
\hline млн ампул & 15,7 & 64,4 & 115,6 & 94,0 \\
\hline $\begin{array}{l}\text { Препараты противопаразитарные, инсектициды и репелленты, } \\
\text { тыс. упаковок }\end{array}$ & 925 & 131,0 & 96,2 & 90,5 \\
\hline $\begin{array}{l}\text { Препараты для лечения органов дыхательной системы, } \\
\text { млн упаковок }\end{array}$ & 25,4 & 96,1 & 106,0 & 89,3 \\
\hline млн ампул & 6,0 & 102,4 & 76,1 & 137,3 \\
\hline $\begin{array}{l}\text { Препараты для лечения заболеваний органов чувств, } \\
\text { млн упаковок }\end{array}$ & 5,2 & 70,9 & 149,7 & 90,2 \\
\hline
\end{tabular}

Производство резиновых и пластмассовых изделий. Индекс производства резиновых и пластмассовых изделий в сентябре 2020 г. по сравнению с соответствующим периодом предыдущего года составил 106,6\%, в январе-сентябре 2020 г. - 100,9\%.

ДИНАМИКА ПРОИЗВОДСТВА

РЕЗИНОВЫХ И ПЛАСТМАССОВЫХ ИЗДЕЛИЙ

\begin{tabular}{|c|c|c|}
\hline & \multicolumn{2}{|c|}{$\overline{8} B \% \kappa$} \\
\hline & $\begin{array}{c}\text { соответствующему } \\
\text { периоду предыдущего года }\end{array}$ & $\begin{array}{c}\text { предыдущему } \\
\text { периоду }\end{array}$ \\
\hline \multicolumn{3}{|c|}{2019 г. } \\
\hline Январь & 90,9 & 76,9 \\
\hline Февраль & 92,3 & 112,3 \\
\hline Март & 94,3 & 112,8 \\
\hline І квартал & 92,6 & 83,2 \\
\hline Апрель & 105,4 & 107,8 \\
\hline Май & 93,9 & 94,2 \\
\hline Июнь & 96,9 & 106,9 \\
\hline ІІ квартал & 98,7 & 118,8 \\
\hline I полугодие & 95,8 & \\
\hline Июль & 103,4 & 105,3 \\
\hline Август & 101,3 & 100,9 \\
\hline Сентябрь & 103,2 & 97,6 \\
\hline III квартал & 102,6 & 107,7 \\
\hline Январь-сентябрь & 98,2 & \\
\hline
\end{tabular}




\begin{tabular}{|c|c|c|}
\hline & \multicolumn{2}{|c|}{ 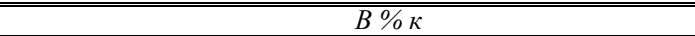 } \\
\hline & $\begin{array}{c}\text { соответствующему } \\
\text { периоду предыдущего года }\end{array}$ & $\begin{array}{c}\text { предьдущему } \\
\text { периоду }\end{array}$ \\
\hline Октябрь & 101,0 & 101,5 \\
\hline Ноябрь & 100,1 & 92,6 \\
\hline Декабрь & 98,6 & 95,7 \\
\hline IV квартал & 99,9 & 93,9 \\
\hline Год & 98,6 & \\
\hline \multicolumn{3}{|c|}{2020 г. } \\
\hline Январь & 101,4 & 79,1 \\
\hline Февраль & 108,1 & 119,7 \\
\hline Март & 106,6 & 111,3 \\
\hline І квартал & 105,6 & 87,9 \\
\hline Апрель & 87,1 & 88,1 \\
\hline Май & 91,4 & 98,9 \\
\hline Июнь & 101,2 & 118,2 \\
\hline ІІ квартал & 93,2 & 105,0 \\
\hline I полугодие & 98,9 & \\
\hline Июль & 102,0 & 106,2 \\
\hline Август & 104,3 & 103,2 \\
\hline Сентябрь & 106,6 & 99,8 \\
\hline ІІІ квартал & 104,3 & 120,4 \\
\hline Январь-сентябрь & 100,9 & \\
\hline
\end{tabular}

Таблица 36

ПРОИЗВОДСТВО ОТДЕЛЬНЫХ ВИДОВ

РЕЗИНОВЫХ И ПЛАСТМАССОВЫХ ИЗДЕЛИЙ

\begin{tabular}{|c|c|c|c|c|}
\hline & \multirow{2}{*}{$\begin{array}{l}\text { Сентябрь } \\
2020 \text { г. }\end{array}$} & \multicolumn{2}{|c|}{$B \% \kappa$} & \multirow[b]{2}{*}{$\begin{array}{c}\text { Январь- } \\
\text { сентябрь } \\
2020 \text { г. } \\
\text { в\% к } \\
\text { январю- } \\
\text { сентябрю } \\
2019 \text { г. } \\
\end{array}$} \\
\hline & & $\begin{array}{c}\text { сентябрю } \\
2019 \text { г. }\end{array}$ & $\begin{array}{l}\text { aвzycmy } \\
2020 \text { г. }\end{array}$ & \\
\hline $\begin{array}{l}\text { Шины и покрышки пневматические } \\
\text { для легковых автомобилей новые, млн штук }\end{array}$ & 3,9 & 96,1 & 109,9 & 80,6 \\
\hline $\begin{array}{l}\text { Шины и покрышки пневматические для автобусов, } \\
\text { троллейбусов и грузовых автомобилей новые, тыс. штук }\end{array}$ & 639 & 102,8 & 116,0 & 108,3 \\
\hline $\begin{array}{l}\text { Шины и покрышки пневматические } \\
\text { для сельскохозяйственных машин; } \\
\text { шины и покрышки пневматические прочие новые, тыс. штук }\end{array}$ & 149 & 123,0 & 97,3 & 113,5 \\
\hline Трубы, трубки и шланги и их фитинги пластмассовые, тыс. тонн & 68,3 & 111,3 & 94,2 & 107,2 \\
\hline $\begin{array}{l}\text { Плиты, листы, пленка и полосы (ленты) полимерные, } \\
\text { неармированные или не комбинированные } \\
\text { с другими материалами, тыс. тонн }\end{array}$ & 118 & 107,3 & 93,4 & 108,2 \\
\hline $\begin{array}{l}\text { Плиты, листы, пленка и полосы (ленты) прочие } \\
\text { пластмассовые пористые, тыс. тонн }\end{array}$ & 31,8 & 118,4 & 101,0 & 114,6 \\
\hline $\begin{array}{l}\text { Плиты, листы, пленка и полосы (ленты) прочие } \\
\text { пластмассовые непористые, тыс. тонн }\end{array}$ & 39,3 & 112,6 & 101,4 & 104,6 \\
\hline
\end{tabular}


Производство прочей неметаллической минеральной продукции. Индекс производства прочей неметаллической минеральной продукции в сентябре 2020 г. по сравнению с соответствующим периодом предыдущего года составил 96,2\%, в январе-сентябре 2020 г. $-95,3 \%$.

ДИНАМИКА ПРОИЗВОДСТВА ПРОЧЕЙ НЕМЕТАЛЛИЧЕСКОЙ МИНЕРАЛЬНОЙ ПРОДУКЦИИ

\begin{tabular}{|c|c|c|}
\hline & \multicolumn{2}{|c|}{$B \% \kappa$} \\
\hline & $\begin{array}{c}\text { соответствующему } \\
\text { периоду предыдущего года }\end{array}$ & $\begin{array}{c}\text { предылучщему } \\
\text { периоду }\end{array}$ \\
\hline \multicolumn{3}{|c|}{2019 г. } \\
\hline Январь & 103,2 & 76,8 \\
\hline Февраль & 107,2 & 113,0 \\
\hline Март & 107,7 & 118,2 \\
\hline І квартал & 106,2 & 81,0 \\
\hline Апрель & 113,2 & 110,6 \\
\hline Май & 110,8 & 110,2 \\
\hline Июнь & 111,2 & 109,6 \\
\hline ІІ квартал & 111,7 & 141,0 \\
\hline I полугодие & 109,3 & \\
\hline Июль & 114,3 & 105,7 \\
\hline Август & 111,5 & 99,0 \\
\hline Сентябрь & 111,5 & 95,9 \\
\hline ІІІ квартал & 112,4 & 113,3 \\
\hline Январь-сентябрь & 110,5 & \\
\hline Октябрь & 108,3 & 97,6 \\
\hline Ноябрь & 104,1 & 81,5 \\
\hline Декабрь & 97,8 & 89,5 \\
\hline IV квартал & 103,4 & 80,2 \\
\hline Год & 108,8 & \\
\hline \multicolumn{3}{|c|}{2020 г. } \\
\hline Январь & 104,1 & 81,8 \\
\hline Февраль & 104,7 & 113,5 \\
\hline Март & 102,2 & 115,4 \\
\hline І квартал & 103,6 & 80,8 \\
\hline Апрель & 84,2 & 91,1 \\
\hline Май & 89,6 & 117,3 \\
\hline Июнь & 94,9 & 116,0 \\
\hline ІІ квартал & 89,5 & 122,4 \\
\hline I полугодие & 95,6 & \\
\hline Июль & 93,8 & 104,4 \\
\hline Август & 95,1 & 100,4 \\
\hline Сентябрь & 96,2 & 96,9 \\
\hline ІІІ квартал & 95,0 & 119,7 \\
\hline Январь-сентябрь & 95,3 & \\
\hline
\end{tabular}


ПРОИЗВОДСТВО ОТДЕЛЬНЫХ ВИДОВ ПРОЧЕЙ НЕМЕТАЛЛИЧЕСКОЙ МИНЕРАЛЬНОЙ ПРОДУКЦИИ

\begin{tabular}{|c|c|c|c|c|}
\hline & \multirow{2}{*}{$\begin{array}{l}\text { Сентябрь } \\
2020 \text { 2. }\end{array}$} & \multicolumn{2}{|c|}{$B \% \kappa$} & \multirow[b]{2}{*}{$\begin{array}{c}\text { Январь- } \\
\text { сентябрь } \\
2020 \text { г. } \\
\text { в\% к } \\
\text { январю- } \\
\text { сентябрю } \\
2019 \text { г. } \\
\end{array}$} \\
\hline & & $\begin{array}{c}\text { сентябрюю } \\
2019 \text { 2. }\end{array}$ & $\begin{array}{c}\text { aвгусmy } \\
2020 \text { г. }\end{array}$ & \\
\hline $\begin{array}{l}\text { Стекло листовое литое, прокатное, тянутое или выдувное, } \\
\text { но не обработанное другим способом, млн м² }\end{array}$ & 9,4 & 100,6 & 98,0 & 84,1 \\
\hline $\begin{array}{l}\text { Стекло листовое термически полированное и стекло } \\
\text { листовое с матовой или полированной поверхностью, } \\
\text { но не обработанное другим способом, млн м }\end{array}$ & 10,6 & 99,1 & 94,4 & 85,7 \\
\hline $\begin{array}{l}\text { Ленты, ровинг (ровница) и пряжа из стекловолокна, } \\
\text { стекловолокно рубленое, тыс. тонн }\end{array}$ & 11,4 & 98,5 & 91,9 & 99,8 \\
\hline $\begin{array}{l}\text { Сетки, холсты, маты, матрасы, плиты и прочие изделия } \\
\text { из стекловолокна, кроме стеклотканей, млн м }\end{array}$ & 7,8 & 110,5 & 94,6 & 96,8 \\
\hline $\begin{array}{l}\text { Посуда из стекла столовая и кухонная, принадлежности } \\
\text { из стекла туалетные и канцелярские, украшения для интерьера } \\
\text { и аналогичные изделия из стекла, млн штук }\end{array}$ & 19,2 & 81,5 & 106,0 & 83,9 \\
\hline $\begin{array}{l}\text { Цементы огнеупорные, строительные растворы, } \\
\text { бетоны и аналогичные составы, не включенные } \\
\text { в другие группировки, тыс. тонн }\end{array}$ & 94,2 & 79,7 & 93,8 & 77,6 \\
\hline $\begin{array}{l}\text { Плитки керамические глазурованные } \\
\text { для внутренней облицовки стен, млн м² }\end{array}$ & 5,6 & 97,4 & 96,1 & 95,8 \\
\hline Плитки керамические для полов, млн м² & 9,1 & 100,5 & 100,7 & 89,0 \\
\hline Плитки керамические фасадные и ковры из них, тыс. м² & 700 & 88,5 & 89,4 & 86,6 \\
\hline $\begin{array}{l}\text { Кирпич керамический неогнеупорный строительный, } \\
\text { млн усл. кирпичей }\end{array}$ & 474 & 89,0 & 96,8 & 97,2 \\
\hline Изделия санитарно-технические из керамики, млн штук & 1,2 & 96,4 & 95,1 & 90,5 \\
\hline $\begin{array}{l}\text { Портландцемент, цемент глиноземистый, цемент шлаковый } \\
\text { и аналогичные гидравлические цементы, млн тонн }\end{array}$ & 5,8 & 96,2 & 93,3 & 95,5 \\
\hline Плиты из цемента, бетона или искусственного камня, млн м² & 3,2 & 104,6 & 94,9 & 108,1 \\
\hline $\begin{array}{l}\text { Кирпич строительный (включая камни) из цемента, } \\
\text { бетона или искусственного камня, млн усл. кирпичей }\end{array}$ & 189 & 89,0 & 100,1 & 89,4 \\
\hline Блоки стеновые силикатные, млн усл. кирпичей & 429 & 90,1 & 98,6 & 92,7 \\
\hline $\begin{array}{l}\text { Блоки и прочие изделия сборные строительные } \\
\text { для зданий и сооружений из цемента, } \\
\text { бетона или искусственного камня, млн м }{ }^{3}\end{array}$ & 2,0 & 96,8 & 99,5 & 95,2 \\
\hline Бетон, готовый для заливки (товарный бетон), млн м ${ }^{3}$ & 3,7 & 97,0 & 104,3 & 97,7 \\
\hline Трубы и муфты хризотилцементные, км усл. труб & 206 & 111,6 & 93,3 & 109,4 \\
\hline $\begin{array}{l}\text { Смеси асфальтобетонные дорожные, аэродромные и } \\
\text { асфальтобетон горячие, тыс. тонн }\end{array}$ & 8363 & 90,2 & 95,7 & 100,7 \\
\hline Материалы рулонные кровельные и гидроизоляционные, млн м² & 60,3 & 105,4 & 94,7 & 105,7 \\
\hline Материалы и изделия минеральные теплоизоляционные, млн м ${ }^{3}$ & 3,3 & 102,7 & 94,6 & 100,8 \\
\hline
\end{tabular}

Производство металлургическое. Индекс производства металлургического в сентябре 2020 г. по сравнению с соответствующим периодом предыдущего года составил 98,1\%, в январе-сентябре 2020 г. - 97,6\%. 
ДИНАМИКА

ПРОИЗВОДСТВА МЕТАЛЛУРГИЧЕСКОГО

\begin{tabular}{|c|c|c|}
\hline & \multicolumn{2}{|c|}{$B \% \kappa$} \\
\hline & $\begin{array}{c}\text { соответствуюшему } \\
\text { периоду предылучщего года }\end{array}$ & $\begin{array}{c}\text { предылущему } \\
\text { периоду }\end{array}$ \\
\hline \multicolumn{3}{|c|}{2019 г. } \\
\hline Январь & 104,5 & 85,6 \\
\hline Февраль & 105,8 & 104,0 \\
\hline Март & 100,6 & 107,8 \\
\hline I квартал & 103,5 & 87,5 \\
\hline Апрель & 104,4 & 101,9 \\
\hline Май & 102,4 & 102,9 \\
\hline Июнь & 109,1 & 105,1 \\
\hline ІІ квартал & 105,3 & 112,4 \\
\hline I полугодие & 104,4 & \\
\hline Июль & 102,0 & 99,6 \\
\hline Август & 108,5 & 108,6 \\
\hline Сентябрь & 106,0 & 95,0 \\
\hline III квартал & 105,5 & 107,9 \\
\hline Январь-сентябрь & 104,8 & \\
\hline Октябрь & 100,6 & 100,5 \\
\hline Ноябрь & 99,2 & 91,7 \\
\hline Декабрь & 105,1 & 105,0 \\
\hline IV квартал & 101,6 & 95,8 \\
\hline Год & 104,0 & \\
\hline \multicolumn{3}{|c|}{2020 г. } \\
\hline Январь & 102,5 & 83,5 \\
\hline Февраль & 101,6 & 103,2 \\
\hline Март & 102,8 & 109,0 \\
\hline I квартал & 102,3 & 88,1 \\
\hline Апрель & 94,1 & 93,3 \\
\hline Май & 92,3 & 100,9 \\
\hline Июнь & 94,4 & 107,5 \\
\hline II квартал & 93,6 & 102,9 \\
\hline I полугодие & 97,7 & \\
\hline Июль & 100,7 & 106,2 \\
\hline Август & 93,4 & 100,7 \\
\hline Сентябрь & 98,1 & 99,7 \\
\hline ІІІ квартал & 97,4 & 112,1 \\
\hline Январь-сентябрь & 97,6 & \\
\hline
\end{tabular}


ПРОИЗВОДСТВО ОТДЕЛЬНЫХ ВИДОВ ПРОДУКЦИИ ПРОИЗВОДСТВА МЕТАЛЛУРГИЧЕСКОГО

\begin{tabular}{|c|c|c|c|c|}
\hline & \multirow{2}{*}{$\begin{array}{l}\text { Сентябрь } \\
20202 .\end{array}$} & \multicolumn{2}{|c|}{$\bar{B} B \% \kappa$} & \multirow[b]{2}{*}{$\begin{array}{c}\text { Январь- } \\
\text { сентябрь } \\
2020 \text { г. } \\
\text { в\% к } \\
\text { январю- } \\
\text { сентябрю } \\
2019 \text { г. } \\
\end{array}$} \\
\hline & & $\begin{array}{l}\text { сентябрю } \\
20192 .\end{array}$ & $\begin{array}{l}\text { aвzycmy } \\
2020 \text { 2. }\end{array}$ & \\
\hline $\begin{array}{l}\text { Чугун зеркальный и передельный в чушках, } \\
\text { болванках или в прочих первичных формах, млн тонн }\end{array}$ & 4,3 & 103,3 & 99,2 & 101,7 \\
\hline Ферросилиций, тыс. тонн & 76,9 & 112,9 & 97,9 & 102,0 \\
\hline $\begin{array}{l}\text { Сталь нелегированная в слитках или в прочих } \\
\text { первичных формах и полуфабрикаты } \\
\text { из нелегированной стали, млн тонн }\end{array}$ & 5,0 & 101,4 & 99,5 & 98,6 \\
\hline $\begin{array}{l}\text { Сталь нержавеющая в слитках или прочих } \\
\text { первичных формах и полуфабрикаты } \\
\text { из нержавеющей стали, тыс. тонн } \\
\end{array}$ & 15,6 & 83,7 & 85,5 & 101,9 \\
\hline $\begin{array}{l}\text { Сталь легированная прочая в слитках или в прочих } \\
\text { первичных формах и полуфабрикаты } \\
\text { из прочей легированной стали, млн тонн } \\
\end{array}$ & 1,2 & 103,8 & 96,4 & 99,0 \\
\hline Прокат готовый, млн тонн & 5,1 & 103,2 & 97,9 & 99,2 \\
\hline $\begin{array}{l}\text { Трубы стальные для нефте- и } \\
\text { газопроводов бесшовные, тыс. тонн }\end{array}$ & 50,8 & 94,2 & 105,6 & 91,1 \\
\hline $\begin{array}{l}\text { Трубы обсадные, насосно-компрессорные трубы } \\
\text { и бурильные трубы, используемые для бурения нефтяных } \\
\text { или газовых скважин, бесшовные стальные, тыс. тонн }\end{array}$ & 122 & 81,8 & 100,3 & 92,7 \\
\hline $\begin{array}{l}\text { в том числе: } \\
\text { обсадные бесшовные стальные }\end{array}$ & 71,1 & 80,1 & 110,0 & 88,1 \\
\hline насосно-компрессорные бесшовные стальные & 47,6 & 82,8 & 89,3 & 99,3 \\
\hline $\begin{array}{l}\text { бурильные для бурения нефтяных } \\
\text { и газовых скважин бесшовные стальные }\end{array}$ & 3,7 & 109,5 & 91,5 & 106,9 \\
\hline Трубы круглого сечения прочие стальные, тыс. тонн & 219 & 107,8 & 108,1 & 88,0 \\
\hline $\begin{array}{l}\text { Проволока холоднотянутая } \\
\text { из нелегированной стали, тыс. тонн }\end{array}$ & 147 & 126,5 & 96,0 & 105,3 \\
\hline Проволока холоднотянутая из нержавеющей стали, тонн & 320 & 53,1 & 75,2 & 78,8 \\
\hline $\begin{array}{l}\text { Проволока холоднотянутая } \\
\text { из прочей легированной стали, тыс. тонн }\end{array}$ & 4,9 & 34,6 & 108,9 & 33,6 \\
\hline $\begin{array}{l}\text { Серебро необработанное или полуобработанное, } \\
\text { или в виде порошка }\end{array}$ & & 99,8 & 112,9 & 98,1 \\
\hline $\begin{array}{l}\text { Золото необработанное или полуобработанное, } \\
\text { или в виде порошка }\end{array}$ & & 96,4 & 101,3 & 95,6 \\
\hline $\begin{array}{l}\text { Платина и металлы платиновой группы необработанные } \\
\text { или полуобработанные, или в виде порошка }\end{array}$ & & 140,0 & 114,0 & 100,1 \\
\hline Алюминий первичный & & 89,4 & 94,9 & 101,4 \\
\hline Оксид алюминия (глинозем), кроме искусственного корунда & & 98,6 & 96,5 & 102,7 \\
\hline Порошки алюминиевые и чешуйки & & 89,1 & 104,5 & 104,5 \\
\hline $\begin{array}{l}\text { Прутки, катанка и профили из алюминия } \\
\text { или алюминиевых сплавов }\end{array}$ & & 116,3 & 103,4 & 93,9 \\
\hline Проволока алюминиевая & & 108,6 & 77,1 & 153,3 \\
\hline $\begin{array}{l}\text { Плиты, листы, полосы и ленты алюминиевые } \\
\text { толщиной более 0,2 мм }\end{array}$ & & 99,8 & 93,9 & 101,5 \\
\hline
\end{tabular}




\begin{tabular}{|c|c|c|c|c|}
\hline & \multirow{2}{*}{$\begin{array}{c}\text { Сентяббрь } \\
2020 \text { г. }\end{array}$} & \multicolumn{2}{|c|}{$B \% \kappa$} & \multirow[b]{2}{*}{$\begin{array}{c}\text { Январь- } \\
\text { сентябрь } \\
2020 \text { г. } \\
\text { в\% \% } \\
\text { январю- } \\
\text { сентябрю } \\
2019 \text { г. } \\
\end{array}$} \\
\hline & & $\begin{array}{c}\text { сентябрюю } \\
2019 \text { г. }\end{array}$ & $\begin{array}{l}\text { aвгycmy } \\
2020 \text {. }\end{array}$ & \\
\hline Фольга алюминиевая толщиной не более 0,2 мм & & 112,0 & 96,2 & 98,6 \\
\hline Трубы и трубки, и фитинги для труб и трубок, алюминиевые & & 75,0 & 119,9 & 87,5 \\
\hline Свинец необработанный & & 103,5 & 105,2 & 96,3 \\
\hline Цинк необработанный & & 106,5 & 111,8 & 103,2 \\
\hline Медь рафинированная необработанная & & 100,0 & 92,5 & 102,5 \\
\hline Сплавы медные необработанные & & 86,7 & 109,8 & 82,4 \\
\hline Порошки и чешуйки медные & & 118,9 & 165,0 & 130,8 \\
\hline Проволока медная & & 95,0 & 90,9 & 109,2 \\
\hline Никель необработанный & & 114,7 & 107,2 & 95,9 \\
\hline Магний необработанный & & 52,1 & 98,4 & 74,8 \\
\hline Сплавы на основе магния & & 121,7 & 96,0 & 87,8 \\
\hline Кобальт необработанный & & 120,0 & 110,6 & 107,5 \\
\hline Титан необработанный & & 48,4 & 103,2 & 71,3 \\
\hline Проволока, прутки, профили титановые & & 55,8 & 107,1 & 88,6 \\
\hline
\end{tabular}

Производство готовых металлических изделий, кроме машин и оборудования. Индекс производства готовых металлических изделий, кроме машин и оборудования в сентябре 2020 г. по сравнению с соответствующим периодом предыдущего года составил 93,7\%, в январе-сентябре 2020 г. - 105,7\%.

ДИНАМИКА ПРОИЗВОДСТВА ГОТОВЫХ МЕТАЛЛИЧЕСКИХ ИЗДЕЛИЙ, КРОМЕ МАШИН И ОБОРУДОВАНИЯ

\begin{tabular}{|c|c|c|}
\hline & \multicolumn{2}{|c|}{ 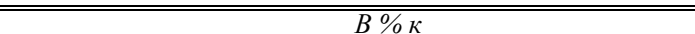 } \\
\hline & $\begin{array}{c}\text { соответствующему } \\
\text { периоду предьдущчего года }\end{array}$ & $\begin{array}{l}\text { предьгдущему } \\
\text { nериоду }\end{array}$ \\
\hline \multicolumn{3}{|c|}{2019 г. } \\
\hline Январь & 75,8 & 39,5 \\
\hline Февраль & 90,0 & 106,6 \\
\hline Март & 121,9 & 131,2 \\
\hline І квартал & 94,9 & 52,1 \\
\hline Апрель & 116,7 & 97,5 \\
\hline Май & 79,1 & 78,1 \\
\hline Июнь & 110,1 & 126,3 \\
\hline ІІ квартал & 102,0 & 108,9 \\
\hline I полугодие & 98,0 & \\
\hline Июль & 135,7 & 128,4 \\
\hline Август & 102,9 & 85,1 \\
\hline
\end{tabular}




\begin{tabular}{|c|c|c|}
\hline & \multicolumn{2}{|c|}{ 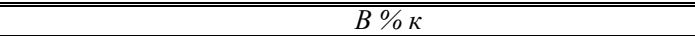 } \\
\hline & $\begin{array}{c}\text { соответствующему } \\
\text { периоду предьдучего года }\end{array}$ & $\begin{array}{c}\text { предылдущему } \\
\text { периоду }\end{array}$ \\
\hline Сентябрь & 109,0 & 119,3 \\
\hline ІІІ квартал & 115,9 & 131,1 \\
\hline Январь-сентябрь & 104,2 & \\
\hline Октябрь & 139,5 & 154,7 \\
\hline Ноябрь & 100,5 & 80,3 \\
\hline Декабрь & 123,2 & 143,2 \\
\hline IV квартал & 121,1 & 161,9 \\
\hline Год & 110,1 & \\
\hline \multicolumn{3}{|c|}{2020 г. } \\
\hline Январь & 98,5 & 31,6 \\
\hline Февраль & 120,1 & 130,0 \\
\hline Март & 124,7 & 136,2 \\
\hline I квартал & 115,7 & 50,0 \\
\hline Апрель & 77,6 & 60,7 \\
\hline Май & 113,5 & 114,2 \\
\hline Июнь & 121,6 & 135,3 \\
\hline ІІ квартал & 104,2 & 97,4 \\
\hline I полугодие & 109,3 & \\
\hline Июль & 93,1 & 98,3 \\
\hline Август & 117,3 & 107,2 \\
\hline Сентябрь & 93,7 & 95,3 \\
\hline ІІІ квартал & 101,3 & 127,4 \\
\hline Январь-сентябрь & 105,7 & \\
\hline
\end{tabular}

ПРОИЗВОДСТВО ОТДЕЛЬНЫХ ВИДОВ ГОТОВЫХ МЕТАЛЛИЧЕСКИХ ИЗДЕЛИЙ, КРОМЕ МАШИН И ОБОРУДОВАНИЯ

\begin{tabular}{|c|c|c|c|c|}
\hline & Сентябрь & & & Январь- \\
\hline & 20202. & $\begin{array}{l}\text { сентябрю } \\
2019 \text { г. }\end{array}$ & $\begin{array}{l}\text { aвzycmy } \\
20202 .\end{array}$ & $\begin{array}{c}\text { сентябрь } \\
2020 \text { г. } \\
\text { в\% \% } \\
\text { январю- } \\
\text { сентябрю } \\
20192 .\end{array}$ \\
\hline Конструкции и детали конструкций из черных металлов, тыс. тонн & 526 & 104,3 & 95,5 & 97,2 \\
\hline Конструкции и детали конструкций из алюминия прочие, тыс. тонн & 12,5 & 121,0 & 108,0 & 96,2 \\
\hline $\begin{array}{l}\text { Котлы водогрейные центрального отопления для производства } \\
\text { горячей воды или пара низкого давления, млн кВт }\end{array}$ & 1,9 & 90,1 & 102,5 & 95,2 \\
\hline $\begin{array}{l}\text { Инструменты рабочие сменные для станков или для ручного } \\
\text { инструмента (с механическим приводом или без него), млн штук }\end{array}$ & 1,4 & 94,4 & 82,2 & 105,8 \\
\hline $\begin{array}{l}\text { Проволока скрученная, канаты, шнуры плетеные, } \\
\text { стропы и аналогичные изделия из черных металлов } \\
\text { без электрической изоляции, тыс. тонн }\end{array}$ & 17,4 & 100,9 & 101,9 & 97,0 \\
\hline $\begin{array}{l}\text { Ткань металлическая, решетки, сетки и ограждения } \\
\text { из проволоки из черных металлов или меди, тыс. тонн }\end{array}$ & 24,4 & 106,4 & 101,2 & 95,5 \\
\hline
\end{tabular}


Производство компьютеров, электронных и оптических изделий. Индекс производства компьютеров, электронных и оптических изделий в сентябре 2020 г. по сравнению с соответствующим периодом предыдущего года составил 89,6\%, в январе-сентябре 2020 г. - $103,5 \%$.

ДИНАМИКА ПРОИЗВОДСТВА КОМПЬЮТЕРОВ, ЭЛЕКТРОННЫХ И ОПТИЧЕСКИХ ИЗДЕЛИЙ

\begin{tabular}{|c|c|c|}
\hline & \multicolumn{2}{|c|}{$B \% \kappa$} \\
\hline & $\begin{array}{c}\text { соответствуюшему } \\
\text { периоду предыдучщего года }\end{array}$ & $\begin{array}{c}\text { предылдущему } \\
\text { периоду }\end{array}$ \\
\hline \multicolumn{3}{|c|}{2019 г. } \\
\hline Январь & 90,2 & 31,5 \\
\hline Февраль & 95,9 & 119,8 \\
\hline Март & 96,7 & 132,1 \\
\hline І квартал & 94,7 & 45,4 \\
\hline Апрель & 93,6 & 100,6 \\
\hline Май & 90,2 & 98,9 \\
\hline Июнь & 144,6 & 177,3 \\
\hline ІІ квартал & 109,5 & 157,7 \\
\hline I полугодие & 103,9 & \\
\hline Июль & 103,1 & 66,2 \\
\hline Август & 114,9 & 120,0 \\
\hline Сентябрь & 143,5 & 122,3 \\
\hline III квартал & 120,5 & 113,8 \\
\hline Январь-сентябрь & 110,2 & \\
\hline Октябрь & 137,7 & 130,9 \\
\hline Ноябрь & 94,2 & 68,0 \\
\hline Декабрь & 107,3 & 141,1 \\
\hline IV квартал & 113,0 & 138,3 \\
\hline Гоd & 111,1 & \\
\hline \multicolumn{3}{|c|}{2020 г. } \\
\hline Январь & 117,6 & 34,5 \\
\hline Февраль & 146,5 & 149,3 \\
\hline Март & 111,5 & 100,6 \\
\hline І квартал & 124,2 & 50,0 \\
\hline Апрель & 82,3 & 74,3 \\
\hline Май & 97,8 & 117,6 \\
\hline Июнь & 70,1 & 127,0 \\
\hline ІІ квартал & 83,4 & 102,4 \\
\hline I полугодие & 97,6 & \\
\hline Июль & 122,5 & 115,7 \\
\hline Август & 130,8 & 128,1 \\
\hline
\end{tabular}




\begin{tabular}{|c|c|c|}
\hline & \multicolumn{2}{|c|}{$\overline{B \bar{O} \% \kappa}$} \\
\hline & $\begin{array}{c}\text { соответствующему } \\
\text { периоду предьдучего года }\end{array}$ & $\begin{array}{c}\text { предылдущему } \\
\text { периоду }\end{array}$ \\
\hline Сентябрь & 89,6 & 83,8 \\
\hline ІІІ квартал & 114,3 & 158,0 \\
\hline Январь-сентябрь & 103,5 & \\
\hline
\end{tabular}
ПРОИЗВОДСТВО ОТДЕЛЬНЫХ ВИДОВ КОМПЬЮТЕРОВ,
ЭЛЕКТРОННЫХ И ОПТИЧЕСКИХ ИЗДЕЛИЙ

\begin{tabular}{|c|c|c|c|c|}
\hline & \multirow{2}{*}{$\begin{array}{c}\text { Сентябрь } \\
2020 \text { г. }\end{array}$} & \multicolumn{2}{|c|}{$B \% \kappa$} & \multirow[b]{2}{*}{$\begin{array}{c}\text { Январь- } \\
\text { сентябрь } \\
2020 \text { г. } \\
в \% \text { \% } \\
\text { январю- } \\
\text { сентябрю } \\
20192 . \\
\end{array}$} \\
\hline & & $\begin{array}{c}\text { сентябрю } \\
20192 .\end{array}$ & $\begin{array}{c}\text { aвzусmy } \\
2020 \text { z. }\end{array}$ & \\
\hline $\begin{array}{l}\text { Лампы и трубки электронные вакуумные или газонаполненные } \\
\text { с термокатодом, холодным катодом, фотокатодом, } \\
\text { включая трубки электронно-лучевые, млрд рублей }{ }^{1)}\end{array}$ & 1,9 & 89,8 & 107,5 & 82,8 \\
\hline Платы печатные смонтированные, млн штук & 2,7 & 155,0 & 113,2 & 109,6 \\
\hline $\begin{array}{l}\text { Аппаратура радиолокационная, } \\
\text { радионавигационная и радиоаппаратура } \\
\text { дистанционного управления, млрд рублей }{ }^{1)}\end{array}$ & 13,2 & 149,9 & 138,2 & 89,4 \\
\hline Компьютеры, их части и принадлежности, млрд рублей ${ }^{1)}$ & 7,4 & в $2,3 \mathrm{p}$. & 135,4 & 173,6 \\
\hline $\begin{array}{l}\text { Приемники телевизионные, совмещенные или не совмещенные } \\
\text { с широковещательными радиоприемниками или аппаратурой } \\
\text { для записи или воспроизведения звука или изображения, тыс. штук }\end{array}$ & 771 & 111,2 & 121,3 & 94,6 \\
\hline $\begin{array}{l}\text { Оборудование и приборы для облучения, реабилитации, } \\
\text { электрическое диагностическое и терапевтическое, } \\
\text { применяемые в медицинских целях, млрд рублей1) }\end{array}$ & 3,3 & 116,2 & 95,0 & 151,0 \\
\hline
\end{tabular}

Производство электрического оборудования. Индекс производства электрического оборудования в сентябре 2020 г. по сравнению с соответствующим периодом предыдущего года составил 104,6\%, в январе-сентябре 2020 г. - 99,2\%.

ДИНАМИКА ПРОИЗВОДСТВА ЭЛЕКТРИЧЕСКОГО ОБОРУДОВАНИЯ

\begin{tabular}{|c|c|c|}
\hline & \multicolumn{2}{|c|}{ 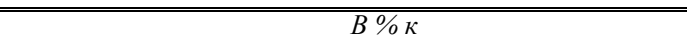 } \\
\hline & $\begin{array}{c}\text { соответствующему } \\
\text { периоду предыдущего года }\end{array}$ & $\begin{array}{c}\text { предыдущему } \\
\text { периоду }\end{array}$ \\
\hline \multicolumn{3}{|c|}{2019 г. } \\
\hline Январь & 91,2 & 52,4 \\
\hline Февраль & 98,7 & 118,1 \\
\hline Март & 102,2 & 121,4 \\
\hline І квартал & 97,8 & 71,3 \\
\hline Апрель & 107,0 & 101,0 \\
\hline Май & 96,1 & 92,2 \\
\hline
\end{tabular}




\begin{tabular}{|c|c|c|}
\hline & \multicolumn{2}{|c|}{ 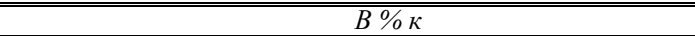 } \\
\hline & $\begin{array}{c}\text { соответствующему } \\
\text { периоду предьдучего года }\end{array}$ & $\begin{array}{c}\text { предылдущему } \\
\text { периоду }\end{array}$ \\
\hline Июнь & 108,5 & 118,6 \\
\hline ІІ квартал & 103,9 & 120,8 \\
\hline I полугодие & 101,1 & \\
\hline Июль & 107,3 & 97,3 \\
\hline Август & 96,1 & 103,9 \\
\hline Сентябрь & 108,5 & 106,0 \\
\hline ІІІ квартал & 104,0 & 110,8 \\
\hline Январь-сентябрь & 102,0 & \\
\hline Октябрь & 102,1 & 98,0 \\
\hline Ноябрь & 104,6 & 96,3 \\
\hline Декабрь & 96,7 & 115,2 \\
\hline IV квартал & 101,1 & 105,6 \\
\hline Год & 101,7 & \\
\hline \multicolumn{3}{|c|}{2020 г. } \\
\hline Январь & 109,6 & 59,4 \\
\hline Февраль & 113,1 & 121,8 \\
\hline Март & 106,4 & 114,2 \\
\hline І квартал & 109,4 & 77,4 \\
\hline Апрель & 77,1 & 73,2 \\
\hline Май & 91,0 & 108,8 \\
\hline Июнь & 98,2 & 128,1 \\
\hline ІІ квартал & 88,8 & 98,2 \\
\hline I полугодие & 98,3 & \\
\hline Июль & 99,4 & 98,5 \\
\hline Август & 98,2 & 102,6 \\
\hline Сентябрь & 104,6 & 112,9 \\
\hline ІІІ квартал & 100,7 & 125,6 \\
\hline Январь-сентябрь & 99,2 & \\
\hline
\end{tabular}

Таблица 46

ПРОИЗВОДСТВО ОТДЕЛЬНЫХ ВИДОВ ЭЛЕКТРИЧЕСКОГО ОБОРУДОВАНИЯ

\begin{tabular}{|c|c|c|c|c|}
\hline & \multirow{2}{*}{$\begin{array}{c}\text { Сентябрь } \\
2020 \text { г. }\end{array}$} & \multicolumn{2}{|c|}{$B \% \kappa$} & \multirow[b]{2}{*}{$\begin{array}{c}\text { Январь- } \\
\text { сентябрь } \\
2020 \text { г. } \\
\text { в\% к } \\
\text { январю- } \\
\text { сентябрю } \\
2019 \text { г. } \\
\end{array}$} \\
\hline & & $\begin{array}{l}\text { сентябрю } \\
2019 \text { г. }\end{array}$ & $\begin{array}{l}\text { августу } \\
2020 \text {. }\end{array}$ & \\
\hline $\begin{array}{l}\text { Электродвигатели мощностью не более } 37,5 \text { Вт; } \\
\text { электродвигатели постоянного тока прочие; } \\
\text { генераторы постоянного тока, тыс. штук }\end{array}$ & 57,9 & 96,7 & 93,8 & 92,8 \\
\hline $\begin{array}{l}\text { Электродвигатели переменного и постоянного тока } \\
\text { универсальные мощностью более } 37,5 \text { Вт, тыс. штук }\end{array}$ & 25,0 & 97,7 & 101,4 & 69,3 \\
\hline Электродвигатели переменного тока однофазные, тыс. штук & 14,7 & 113,8 & 105,9 & 95,0 \\
\hline
\end{tabular}




\begin{tabular}{|c|c|c|c|c|}
\hline & \multirow{2}{*}{$\begin{array}{l}\text { Сентябрь } \\
2020 \text { г. }\end{array}$} & \multicolumn{2}{|c|}{$B \% \kappa$} & \multirow[b]{2}{*}{$\begin{array}{c}\text { Январь- } \\
\text { сентябрь } \\
2020 \text { г. } \\
\text { в\% \% } \\
\text { январю- } \\
\text { сентябрю } \\
2019 \text { г. } \\
\end{array}$} \\
\hline & & $\begin{array}{c}\text { сентябрю } \\
2019 \text { г. }\end{array}$ & $\begin{array}{l}\text { августу } \\
2020 \text { г. }\end{array}$ & \\
\hline $\begin{array}{l}\text { Электродвигатели переменного тока многофазные } \\
\text { мощностью не более } 750 \text { Вт, тыс. штук }\end{array}$ & 8,8 & 90,1 & 76,4 & 106,4 \\
\hline Генераторы переменного тока (синхронные генераторы), тыс. кВт & 304 & 84,2 & в $2,8 \mathrm{p}$. & 70,4 \\
\hline $\begin{array}{l}\text { Аккумуляторы свинцовые, кроме используемых } \\
\text { для запуска поршневых двигателей, тыс. штук }\end{array}$ & 16,2 & 78,2 & 60,4 & 73,5 \\
\hline Трансформаторы электрические, млн кВ·А & 5,3 & 119,0 & 131,0 & 100,4 \\
\hline Провода обмоточные изолированные, тыс. тонн & 2,5 & 85,3 & 99,8 & 92,8 \\
\hline Холодильники и морозильники бытовые, тыс. штук & 417 & 116,9 & 107,2 & 91,0 \\
\hline Машины стиральные бытовые, тыс. штук & 601 & 115,1 & 109,2 & 102,0 \\
\hline
\end{tabular}

Производство машин и оборудования, не включенных в другие группировки. Индекс производства машин и оборудования, не включенных в другие группировки, в сентябре 2020 г. по сравнению с соответствующим периодом предыдущего года составил $105,1 \%$, в январе-сентябре 2020 г. - 107,0\%.

ДИНАМИКА ПРОИЗВОДСТВА МАШИН И ОБОРУДОВАНИЯ, НЕ ВКЛЮЧЕННЫХ В ДРУГИЕ ГРУППИРОВКИ

\begin{tabular}{|c|c|c|}
\hline & \multicolumn{2}{|c|}{$\bar{B} \% \mathrm{~K}$} \\
\hline & $\begin{array}{c}\text { соответствующему } \\
\text { периоду предьлдущего года }\end{array}$ & $\begin{array}{l}\text { предьдучщему } \\
\text { периоду }\end{array}$ \\
\hline \multicolumn{3}{|c|}{2019 г. } \\
\hline Январь & 106,5 & 49,5 \\
\hline Февраль & 113,8 & 130,0 \\
\hline Март & 105,5 & 108,2 \\
\hline І квартал & 108,5 & 80,4 \\
\hline Апрель & 114,0 & 106,0 \\
\hline Май & 113,9 & 93,0 \\
\hline Июнь & 116,6 & 112,8 \\
\hline ІІ квартал & 114,9 & 119,9 \\
\hline I полугодие & 111,9 & \\
\hline Июль & 129,6 & 98,4 \\
\hline Август & 112,9 & 92,9 \\
\hline Сентябрь & 114,3 & 102,4 \\
\hline III квартал & 118,9 & 99,8 \\
\hline Январь-сентябрь & 114,2 & \\
\hline Октябрь & 130,2 & 109,8 \\
\hline Ноябрь & 110,3 & 93,1 \\
\hline Декабрь & 92,0 & 123,9 \\
\hline IV квартал & 110,8 & 111,9 \\
\hline Год & 112,3 & \\
\hline
\end{tabular}




\begin{tabular}{|c|c|c|}
\hline & \multicolumn{2}{|c|}{ 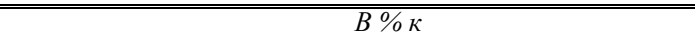 } \\
\hline & $\begin{array}{c}\text { соответствующему } \\
\text { периоду предьдучего года }\end{array}$ & $\begin{array}{c}\text { предылдущему } \\
\text { периоду }\end{array}$ \\
\hline \multicolumn{3}{|c|}{2020 г. } \\
\hline Январь & 124,0 & 66,8 \\
\hline Февраль & 107,0 & 112,2 \\
\hline Март & 112,2 & 113,5 \\
\hline І квартал & 113,6 & 84,8 \\
\hline Апрель & 93,8 & 88,6 \\
\hline Май & 99,5 & 98,7 \\
\hline Июнь & 105,3 & 119,3 \\
\hline ІІ квартал & 99,5 & 105,2 \\
\hline I полугодие & 106,0 & \\
\hline Июль & 108,3 & 101,2 \\
\hline Август & 113,6 & 97,5 \\
\hline Сентябрь & 105,1 & 94,7 \\
\hline ІІІ квартал & 109,0 & 109,2 \\
\hline Январь-сентябрь & 107,0 & \\
\hline
\end{tabular}

ПРОИЗВОДСТВО ОТДЕЛЬНЫХ ВИДОВ МАШИН И ОБОРУДОВАНИЯ, НЕ ВКЛЮЧЕННЫХ В ДРУГИЕ ГРУППИРОВКИ

\begin{tabular}{|c|c|c|c|c|}
\hline & \multirow{2}{*}{$\begin{array}{l}\text { Сентябрь } \\
2020 \text { г. }\end{array}$} & \multicolumn{2}{|c|}{$\bar{B} \% \mathrm{\kappa}$} & \multirow[b]{2}{*}{$\begin{array}{c}\text { Январь- } \\
\text { сентябрь } \\
2020 \text { г. } \\
\text { в\% к } \\
\text { январю- } \\
\text { сентябрю } \\
20192 .\end{array}$} \\
\hline & & $\begin{array}{c}\text { сентябрю } \\
2019 \text { г. }\end{array}$ & $\begin{array}{l}\text { aвгусmy } \\
2020 \text { г. }\end{array}$ & \\
\hline Турбины на водяном паре и прочие паровые турбины, тыс. кВт & 422 & в 2,9p. & 102,5 & в 4,1p. \\
\hline $\begin{array}{l}\text { Насосы роторные объемные прочие } \\
\text { для перекачки жидкостей, тыс. штук }\end{array}$ & 2,3 & 64,7 & 187,2 & 80,0 \\
\hline $\begin{array}{l}\text { Насосы центробежные подачи жидкостей прочие; } \\
\text { насосы прочие, тыс. штук }\end{array}$ & 78,7 & 97,7 & 98,4 & 82,8 \\
\hline Подшипники шариковые или роликовые, млн штук & 3,4 & 94,2 & 103,3 & 90,8 \\
\hline Краны башенные строительные, штук & 2 & 100,0 & 100,0 & 122,7 \\
\hline Лифты, тыс. штук & 3,0 & 115,8 & 96,9 & 116,3 \\
\hline Камеры холодильные сборные, тыс. штук & 3,3 & 108,9 & 111,5 & 92,4 \\
\hline Тракторы для сельского хозяйства прочие, штук & 545 & 133,3 & 82,8 & 93,3 \\
\hline Комбайны зерноуборочные, штук & 144 & в $3,9 \mathrm{p}$. & 54,5 & 102,5 \\
\hline Станки металлорежущие, штук & 511 & 134,2 & 118,5 & 95,2 \\
\hline Машины кузнечно-прессовые, штук & 320 & 87,7 & 97,0 & 81,8 \\
\hline Экскаваторы, штук & 227 & 106,6 & 102,3 & 77,4 \\
\hline $\begin{array}{l}\text { Оборудование для производства хлебобулочных изделий, } \\
\text { млн рублей }{ }^{1)}\end{array}$ & 245 & 155,0 & 164,5 & 91,0 \\
\hline
\end{tabular}


Производство автотранспортных средств, прицепов и полуприцепов. Индекс производства автотранспортных средств, прицепов и полуприцепов в сентябре 2020 г. по сравнению с соответствующим периодом предыдущего года составил 103,3\%, в январесентябре 2020 г. - 80,2\%.

ДИНАМИКА ПРОИЗВОДСТВА АВТОТРАНСПОРТНЫХ СРЕДСТВ, ПРИЦЕПОВ И ПОЛУПРИЦЕПОВ

\begin{tabular}{|c|c|c|}
\hline & \multicolumn{2}{|c|}{ 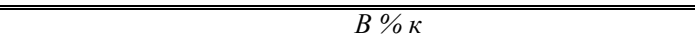 } \\
\hline & $\begin{array}{c}\text { соответствующему } \\
\text { периоду предьдущего года }\end{array}$ & $\begin{array}{c}\text { предылушему } \\
\text { периоду }\end{array}$ \\
\hline \multicolumn{3}{|c|}{2019 г. } \\
\hline Январь & 96,9 & 69,3 \\
\hline Февраль & 106,5 & 136,8 \\
\hline Март & 101,7 & 103,8 \\
\hline І квартал & 102,0 & 80,6 \\
\hline Апрель & 105,3 & 107,1 \\
\hline Май & 94,6 & 81,6 \\
\hline Июнь & 95,6 & 112,8 \\
\hline ІІ квартал & 98,5 & 109,9 \\
\hline I полугодие & 100,2 & \\
\hline Июль & 106,0 & 86,2 \\
\hline Август & 97,7 & 106,2 \\
\hline Сентябрь & 99,3 & 113,8 \\
\hline ІІІ квартал & 101,0 & 94,9 \\
\hline Январь-сентябрь & 100,4 & \\
\hline Октябрь & 95,1 & 107,2 \\
\hline Ноябрь & 87,3 & 89,8 \\
\hline Декабрь & 93,8 & 96,3 \\
\hline IV квартал & 92,1 & 109,5 \\
\hline Гod & 98,0 & \\
\hline \multicolumn{3}{|c|}{2020 г. } \\
\hline Январь & 87,9 & 64,9 \\
\hline Февраль & 89,8 & 139,8 \\
\hline Март & 89,0 & 102,9 \\
\hline І квартал & 89,0 & 78,0 \\
\hline Апрель & 40,4 & 48,7 \\
\hline Май & 59,4 & 119,8 \\
\hline Июнь & 79,5 & 151,0 \\
\hline II квартал & 59,8 & 73,2 \\
\hline I полугодие & 73,4 & \\
\hline Июль & 98,2 & 106,5 \\
\hline Август & 79,3 & 85,7 \\
\hline Сентябрь & 103,3 & 148,3 \\
\hline ІІІ квартал & 93,6 & 150,4 \\
\hline Январь-сентябрь & 80,2 & \\
\hline
\end{tabular}


ПРОИЗВОДСТВО ОТДЕЛЬНЫХ ВИДОВ АВТОТРАНСПОРТНЫХ СРЕДСТВ, ПРИЦЕПОВ И ПОЛУПРИЦЕПОВ

\begin{tabular}{|c|c|c|c|c|}
\hline & \multirow{2}{*}{$\begin{array}{c}\text { Сентябрь } \\
2020 \text { г. }\end{array}$} & \multicolumn{2}{|c|}{$B \% \kappa$} & \multirow[b]{2}{*}{$\begin{array}{c}\text { Январь- } \\
\text { сентябрь } \\
2020 \text { г. } \\
\text { в\% к } \\
\text { январю- } \\
\text { сентябрю } \\
2019 \text { г. } \\
\end{array}$} \\
\hline & & $\begin{array}{c}\text { сентябрю } \\
2019 \text { с. }\end{array}$ & $\begin{array}{c}\text { августу } \\
2020 \text { г. }\end{array}$ & \\
\hline $\begin{array}{l}\text { Двигатели внутреннего сгорания } \\
\text { для автотранспортных средств, тыс. штук }\end{array}$ & 29,8 & 92,4 & 163,9 & 84,4 \\
\hline Автомобили легковые, тыс. штук & 142 & 105,7 & 172,5 & 74,1 \\
\hline $\begin{array}{l}\text { Автобусы, имеющие технически допустимую } \\
\text { максимальную массу более } 5 \text { т, штук }\end{array}$ & 1469 & 97,1 & 150,8 & 91,3 \\
\hline Средства автотранспортные грузовые, тыс. штук & 14,6 & 100,2 & 117,6 & 83,5 \\
\hline Автомобили пожарные, штук & 89 & 88,1 & 97,8 & 113,0 \\
\hline $\begin{array}{l}\text { Средства транспортные для коммунального хозяйства } \\
\text { и содержания дорог, штук }\end{array}$ & 474 & 87,8 & 127,1 & 77,4 \\
\hline
\end{tabular}

Производство прочих транспортных средств и оборудования. Индекс производства прочих транспортных средств и оборудования в сентябре 2020 г. по сравнению с соответствующим периодом предыдущего года составил 88,3\%, в январе-сентябре 2020 г. $94,3 \%$.

ДИНАМИКА ПРОИЗВОДСТВА

ПРОЧИХ ТРАНСПОРТНЫХ СРЕДСТВ И ОБОРУДОВАНИЯ

\begin{tabular}{|c|c|c|}
\hline & \multicolumn{2}{|c|}{$\bar{B} \% \mathrm{\kappa}$} \\
\hline & $\begin{array}{c}\text { соответствующему } \\
\text { периоду предьдуцего года }\end{array}$ & $\begin{array}{c}\text { предылучщему } \\
\text { периоду }\end{array}$ \\
\hline \multicolumn{3}{|c|}{2019 г. } \\
\hline Январь & 63,9 & 22,3 \\
\hline Февраль & 97,6 & 125,9 \\
\hline Март & 90,4 & 146,7 \\
\hline I квартал & 83,8 & 42,7 \\
\hline Апрель & 104,8 & 107,5 \\
\hline Май & 96,0 & 93,6 \\
\hline Июнь & 82,1 & 116,7 \\
\hline ІІ квартал & 94,3 & 146,4 \\
\hline I полугодие & 89,0 & \\
\hline Июль & 101,8 & 77,4 \\
\hline Август & 110,4 & 109,4 \\
\hline Сентябрь & 119,0 & 130,9 \\
\hline ІІІ квартал & 110,4 & 98,4 \\
\hline Январь-сентябрь & 96,0 & \\
\hline
\end{tabular}




\begin{tabular}{|c|c|c|}
\hline & \multicolumn{2}{|c|}{ 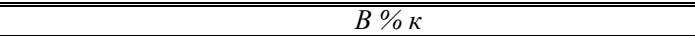 } \\
\hline & $\begin{array}{c}\text { соответствующему } \\
\text { периоду предыдущего года }\end{array}$ & $\begin{array}{c}\text { предылущему } \\
\text { периоду }\end{array}$ \\
\hline Октябрь & 99,4 & 99,9 \\
\hline Ноябрь & 105,9 & 119,9 \\
\hline Декабрь & 105,5 & 164,5 \\
\hline IV квартал & 103,6 & 169,2 \\
\hline Год & 99,0 & \\
\hline \multicolumn{3}{|c|}{2020 г. } \\
\hline Январь & 104,9 & 22,1 \\
\hline Февраль & 108,0 & 129,7 \\
\hline Март & 84,2 & 114,4 \\
\hline І квартал & 96,6 & 39,6 \\
\hline Апрель & 75,4 & 96,2 \\
\hline Май & 85,8 & 106,5 \\
\hline Июнь & 104,3 & 141,9 \\
\hline ІІ квартал & 88,5 & 135,0 \\
\hline I полугодие & 92,1 & \\
\hline Июль & 104,4 & 77,5 \\
\hline Август & 105,3 & 110,4 \\
\hline Сентябрь & 88,3 & 109,6 \\
\hline III квартал & 99,3 & 108,5 \\
\hline Январь-сентябрь & 94,3 & \\
\hline
\end{tabular}

Таблица 52

ПРОИЗВОДСТВО ОТДЕЛЬНЫХ ВИДОВ ПРОЧИХ ТРАНСПОРТНЫХ СРЕДСТВ И ОБОРУДОВАНИЯ

\begin{tabular}{|c|c|c|c|c|}
\hline & \multirow{2}{*}{$\begin{array}{c}\text { Сентябрь } \\
20202 .\end{array}$} & \multicolumn{2}{|c|}{ 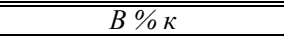 } & \multirow[b]{2}{*}{$\begin{array}{c}\text { Январь- } \\
\text { сентябрь } \\
2020 \text { г. } \\
\text { в\% \% } \\
\text { январю- } \\
\text { сентябрю } \\
2019 \text { г. } \\
\end{array}$} \\
\hline & & $\begin{array}{c}\text { сентябрюю } \\
2019 \text { г. }\end{array}$ & $\begin{array}{c}\text { aвгусту } \\
2020 \text { г. }\end{array}$ & \\
\hline Суда прогулочные и спортивные, тыс. штук & 7,2 & 105,0 & 103,6 & 98,1 \\
\hline Электровозы магистральные, штук & 30 & 81,1 & 103,4 & 93,5 \\
\hline Тепловозы маневровые и промышленные, штук & 28 & 59,6 & 127,3 & 86,9 \\
\hline Вагоны пассажирские железнодорожные, штук & 151 & 120,8 & 85,8 & 121,0 \\
\hline Вагоны грузовые магистральные широкой колеи, тыс. штук & 5,0 & 78,1 & 115,2 & 71,6 \\
\hline
\end{tabular}

Производство мебели. Индекс производства мебели в сентябре 2020 г. по сравнению с соответствующим периодом предыдущего года составил 116,6\%, в январе-сентябре 2020 г. $103,1 \%$. 
ДИНАМИКА ПРОИЗВОДСТВА МЕБЕЛИ

\begin{tabular}{|c|c|c|}
\hline & \multicolumn{2}{|c|}{$\bar{B} \% \kappa$} \\
\hline & $\begin{array}{c}\text { соответствующему } \\
\text { периоду предьдучеего года }\end{array}$ & $\begin{array}{c}\text { предььдущему } \\
\text { периоду }\end{array}$ \\
\hline \multicolumn{3}{|c|}{2019 г. } \\
\hline Январь & 102,8 & 70,0 \\
\hline Февраль & 99,3 & 107,6 \\
\hline Март & 97,5 & 100,8 \\
\hline І квартал & 99,8 & 76,9 \\
\hline Апрель & 105,9 & 104,1 \\
\hline Май & 91,4 & 84,5 \\
\hline Июнь & 95,5 & 105,8 \\
\hline ІІ квартал & 97,6 & 97,9 \\
\hline I полугодие & 98,7 & \\
\hline Июль & 104,8 & 116,7 \\
\hline Август & 101,8 & 104,6 \\
\hline Сентябрь & 109,6 & 106,2 \\
\hline ІІІ квартал & 105,4 & 120,3 \\
\hline Январь-сентябрь & 101,1 & \\
\hline Октябрь & 108,6 & 110,2 \\
\hline Ноябрь & 101,8 & 95,3 \\
\hline Декабрь & 105,0 & 109,0 \\
\hline IV квартал & 105,1 & 116,1 \\
\hline Год & 102,3 & \\
\hline \multicolumn{3}{|c|}{2020 г. } \\
\hline Январь & 101,8 & 67,8 \\
\hline Февраль & 109,3 & 115,5 \\
\hline Март & 105,8 & 97,7 \\
\hline І квартал & 105,7 & 77,4 \\
\hline Апрель & 69,6 & 68,4 \\
\hline Май & 88,5 & 107,5 \\
\hline Июнь & 107,5 & 128,5 \\
\hline ІІ квартал & 88,5 & 81,3 \\
\hline I полугодие & 96,8 & \\
\hline Июль & 115,2 & 125,0 \\
\hline Август & 109,2 & 99,2 \\
\hline Сентябрь & 116,6 & 113,5 \\
\hline ІІІ квартал & 113,7 & 155,8 \\
\hline Январь-сентябрь & 103,1 & \\
\hline
\end{tabular}


ПРОИЗВОДСТВО ОТДЕЛЬНЫХ ВИДОВ МЕБЕЛИ

\begin{tabular}{|c|c|c|c|c|}
\hline & Сентябрь & & & Январь- \\
\hline & $\begin{array}{c}2020 \text { г., } \\
\text { тыс.. штукк }\end{array}$ & $\begin{array}{c}\text { сентябрю } \\
2019 \text { z. }\end{array}$ & $\begin{array}{c}\text { aвгусmy } \\
2020 \text { 2. }\end{array}$ & $\begin{array}{c}\text { сентябрь } \\
2020 \text { г. } \\
\text { в\% к } \\
\text { январю- } \\
\text { сентябрю } \\
20192 . \\
\end{array}$ \\
\hline Мебель деревянная для офисов, млрд рублей ${ }^{1)}$ & 1,9 & 98,9 & 110,5 & 93,7 \\
\hline Столы кухонные, для столовой и гостиной & 218 & 126,7 & 102,5 & 95,9 \\
\hline Шкафы кухонные, для спальни, столовой и гостиной & 785 & 103,3 & 108,8 & 82,8 \\
\hline Матрасы беспружинные & 85,9 & 99,8 & 102,8 & 99,4 \\
\hline $\begin{array}{l}\text { Диваны, софы, кушетки с деревянным каркасом, } \\
\text { трансформируемые в кровати }\end{array}$ & 192 & 104,9 & 104,4 & 95,8 \\
\hline Кровати деревянные & 260 & 135,4 & 122,1 & 106,9 \\
\hline Мебель из пластмассовых материалов, млн рублей ${ }^{1)}$ & 123 & в 2,1p. & в $2,1 \mathrm{p}$. & 152,2 \\
\hline
\end{tabular}

Производство прочих готовых изделий. Индекс производства прочих готовых изделий в сентябре 2020 г. по сравнению с соответствующим периодом предыдущего года составил $102,0 \%$, в январе-сентябре 2020 г. - 100,8\%.

\section{ДИНАМИКА ПРОИЗВОДСТВА ПРОЧИХ ГОТОВЫХ ИЗДЕЛИЙ}

\begin{tabular}{|c|c|c|}
\hline & \multicolumn{2}{|c|}{ 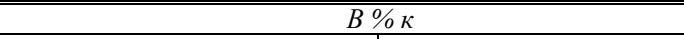 } \\
\hline & $\begin{array}{c}\text { соответствующему } \\
\text { периоду предыдущего года }\end{array}$ & $\begin{array}{c}\text { предылущему } \\
\text { периоду }\end{array}$ \\
\hline \multicolumn{3}{|c|}{2019 Г. } \\
\hline Январь & 97,1 & 71,0 \\
\hline Февраль & 100,7 & 122,9 \\
\hline Март & 83,1 & 101,5 \\
\hline I квартал & 92,7 & 74,6 \\
\hline Апрель & 96,2 & 110,7 \\
\hline Май & 104,2 & 97,6 \\
\hline Июнь & 90,4 & 88,5 \\
\hline ІІ квартал & 97,0 & 112,8 \\
\hline I полугодие & 94,9 & \\
\hline Июль & 108,3 & 110,6 \\
\hline Август & 97,5 & 102,2 \\
\hline Сентябрь & 110,2 & 107,8 \\
\hline ІІІ квартал & 105,3 & 105,1 \\
\hline Январь-сентябрь & 98,3 & \\
\hline
\end{tabular}




\begin{tabular}{|c|c|c|}
\hline & \multicolumn{2}{|c|}{$\overline{8 B \% \kappa}$} \\
\hline & $\begin{array}{c}\text { соответствующему } \\
\text { периоду предыдущего года }\end{array}$ & $\begin{array}{l}\text { предыдущему } \\
\text { периоду }\end{array}$ \\
\hline Октябрь & 102,2 & 108,5 \\
\hline Ноябрь & 92,5 & 100,1 \\
\hline Декабрь & 120,0 & 107,0 \\
\hline IV квартал & 104,9 & 117,6 \\
\hline Год & 99,9 & \\
\hline \multicolumn{3}{|c|}{2020 г. } \\
\hline Январь & 110,1 & 65,1 \\
\hline Февраль & 99,4 & 111,0 \\
\hline Март & 101,3 & 103,5 \\
\hline І квартал & 103,1 & 74,0 \\
\hline Апрель & 64,1 & 70,1 \\
\hline Май & 83,9 & 127,6 \\
\hline Июнь & 127,9 & 134,9 \\
\hline ІІ квартал & 92,0 & 98,8 \\
\hline I полугодие & 96,3 & \\
\hline Июль & 112,9 & 97,6 \\
\hline Август & 111,9 & 101,3 \\
\hline Сентябрь & 102,0 & 98,2 \\
\hline ІІІ квартал & 108,9 & 126,5 \\
\hline Январь-сентябрь & 100,8 & \\
\hline
\end{tabular}

Таблица 56

\section{ПРОИЗВОДСТВО ОТДЕЛЬНЫХ ВИДОВ ПРОЧИХ ГОТОВЫХ ИЗДЕЛИЙ ${ }^{1)}$}

\begin{tabular}{|c|c|c|c|c|}
\hline & Сентябрь & & & Январь- \\
\hline & $\begin{array}{c}2020 \text { г., } \\
\text { млн рублей }\end{array}$ & $\begin{array}{c}\text { сентябрю } \\
20192 .\end{array}$ & $\begin{array}{l}\text { aвгусmy } \\
2020 \text { z. }\end{array}$ & $\begin{array}{c}\text { сентябрь } \\
2020 \text { г. } \\
\text { в\% к } \\
\text { январю- } \\
\text { сентябрю } \\
20192 .\end{array}$ \\
\hline $\begin{array}{l}\text { Изделия ювелирные и их части; } \\
\text { ювелирные изделия из золота или ювелирные изделия } \\
\text { из серебра и их части, млрд рублей }\end{array}$ & 6,1 & 82,7 & 101,3 & 72,2 \\
\hline Инструменты музыкальные & 17,8 & 48,9 & 92,4 & 47,8 \\
\hline Игры и игрушки & 929 & 129,6 & 116,9 & 107,5 \\
\hline $\begin{array}{l}\text { Снаряды, инвентарь и оборудование для занятий } \\
\text { физкультурой, гимнастикой и атлетикой, } \\
\text { занятий в спортзалах, фитнес-центрах }\end{array}$ & 239 & 107,2 & 112,6 & 118,7 \\
\hline
\end{tabular}




\subsection{3. Обеспечение электрической энергией, газом и паром; кондиционирование воздуха}

Индекс производства по виду деятельности "Обеспечение электрической энергией, газом и паром; кондиционирование воздуха" в сентябре 2020 г. по сравнению с соответствующим периодом предыдущего года составил 97,4\% в январе-сентябре 2020 г. - 97,3\%.

ДИНАМИКА ПРОИЗВОДСТВА ПО ВИДУ ДЕЯТЕЛЬНОСТИ

"ОБЕСПЕЧЕНИЕ ЭЛЕКТРИЧЕСКОЙ ЭНЕРГИЕЙ, ГАЗОМ И ПАРОМ; КОНДИЦИОНИРОВАНИЕ ВОЗДУХА"

\begin{tabular}{|c|c|c|}
\hline & \multicolumn{2}{|c|}{ 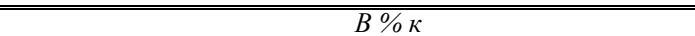 } \\
\hline & $\begin{array}{c}\text { соответствующему } \\
\text { периоду предьдуущего года }\end{array}$ & $\begin{array}{c}\text { предылушему } \\
\text { периоду }\end{array}$ \\
\hline \multicolumn{3}{|c|}{2019 г. } \\
\hline Январь & 102,0 & 100,0 \\
\hline Февраль & 99,1 & 89,3 \\
\hline Март & 95,1 & 99,2 \\
\hline I квартал & 98,8 & 105,1 \\
\hline Апрель & 99,8 & 84,7 \\
\hline Май & 99,4 & 83,9 \\
\hline Июнь & 99,6 & 91,1 \\
\hline ІІ квартал & 99,6 & 70,3 \\
\hline I полугодие & 99,1 & \\
\hline Июль & 98,9 & 100,7 \\
\hline Август & 99,2 & 102,5 \\
\hline Сентябрь & 102,1 & 106,2 \\
\hline ІІІ квартал & 100,0 & 92,0 \\
\hline Январь-сентябрь & 99,4 & \\
\hline Октябрь & 101,6 & 123,2 \\
\hline Ноябрь & 100,0 & 113,8 \\
\hline Декабрь & 95,4 & 108,2 \\
\hline IV квартал & 99,0 & 145,1 \\
\hline Год & 99,2 & \\
\hline \multicolumn{3}{|c|}{2020 г. } \\
\hline Январь & 94,3 & 98,8 \\
\hline Февраль & 98,9 & 93,8 \\
\hline Март & 97,0 & 97,3 \\
\hline I квартал & 96,6 & 102,9 \\
\hline Апрель & 99,0 & 86,4 \\
\hline Май & 96,6 & 81,8 \\
\hline Июнь & 96,3 & 90,9 \\
\hline II квартал & 97,3 & 70,9 \\
\hline I полугодие & 97,0 & \\
\hline Июль & 98,9 & 103,4 \\
\hline Август & 97,9 & 101,5 \\
\hline
\end{tabular}




\begin{tabular}{|c|c|c|}
\hline & \multicolumn{2}{|c|}{$\overline{B \%} \%$} \\
\hline & $\begin{array}{c}\text { соответствуюшему } \\
\text { периоду предыдущего года }\end{array}$ & $\begin{array}{c}\text { предылуциему } \\
\text { периоду }\end{array}$ \\
\hline Сентябрь & 97,4 & 105,7 \\
\hline ІІІ квартал & 98,1 & 92,6 \\
\hline Январь-сентябрь & 97,3 & \\
\hline
\end{tabular}

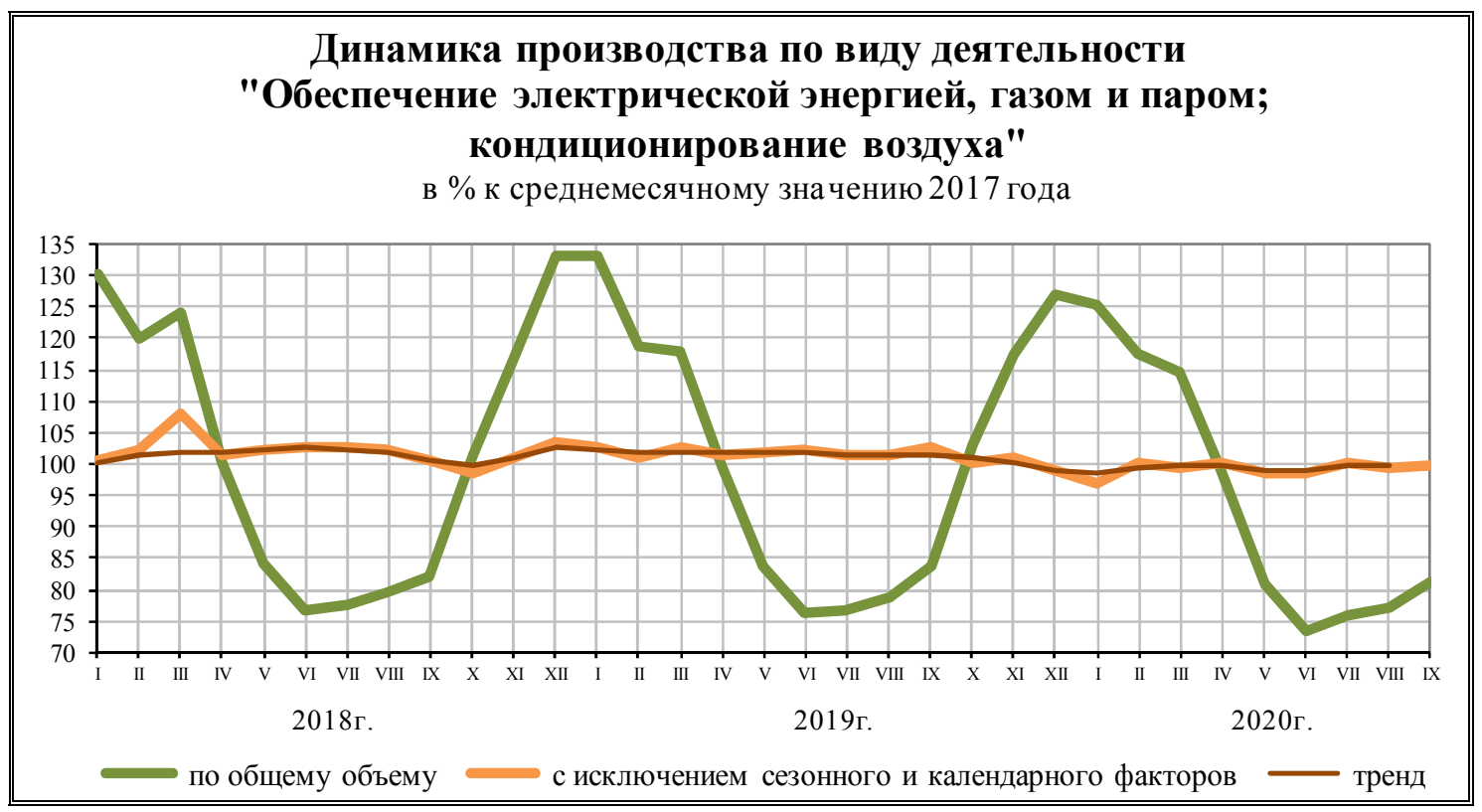

Таблица 58

ОБЪЕМ ОТГРУЖЕННЫХ ТОВАРОВ СОБСТВЕННОГО ПРОИЗВОДСТВА, ВЫПОЛНЕННЫХ РАБОТ И УСЛУГ СОБСТВЕННЫМИ СИЛАМИ ПО ВИДУ ДЕЯТЕЛЬНОСТИ "ОБЕСПЕЧЕНИЕ ЭЛЕКТРИЧЕСКОЙ ЭНЕРГИЕЙ, ГАЗОМ И ПАРОМ; КОНДИЦИОНИРОВАНИЕ ВОЗДУХА"

в действующих ценах

\begin{tabular}{|c|c|c|c|c|}
\hline & \multirow{2}{*}{$\begin{array}{c}\text { Сентябрь } \\
2020 \text { г., } \\
\text { млрд } \\
\text { рублей }\end{array}$} & \multicolumn{2}{|c|}{$B \% \kappa$} & \multirow[b]{2}{*}{$\begin{array}{c}\text { Январь- } \\
\text { сентябрь } \\
2020 \text { г. } \\
\text { в\% к } \\
\text { январю- } \\
\text { сентябрю } \\
20192 .\end{array}$} \\
\hline & & $\begin{array}{l}\text { сентябрю } \\
20192 .\end{array}$ & $\begin{array}{l}\text { aвzycmy } \\
2020 \text { 2. }\end{array}$ & \\
\hline $\begin{array}{l}\text { Обеспечение электрической энергией, газом и паром; } \\
\text { кондиционирование воздуха }\end{array}$ & 390,1 & 101,5 & 107,3 & 99,6 \\
\hline $\begin{array}{l}\text { в том числе: } \\
\text { производство, передача и распределение электроэнергии }\end{array}$ & 311,8 & 103,0 & 103,5 & 100,0 \\
\hline производство и распределение газообразного топлива & 11,9 & 94,8 & 110,4 & 99,9 \\
\hline $\begin{array}{l}\text { производство, передача и распределение } \\
\text { пара и горячей воды; кондиционирование воздуха }\end{array}$ & 66,4 & 96,0 & 128,3 & 98,4 \\
\hline
\end{tabular}

По данным обследования деловой активности в октябре 2020 г., в котором приняли участие 285 организаций, осуществляющих обеспечение электрической энергией, газом и паром; кондиционирование воздуха (без малых предприятий), значение индекса предпринимательской уверенности составило 5\%, в сентябре 2020 г. - 3\%, в августе 2020 г. - (-1\%). 


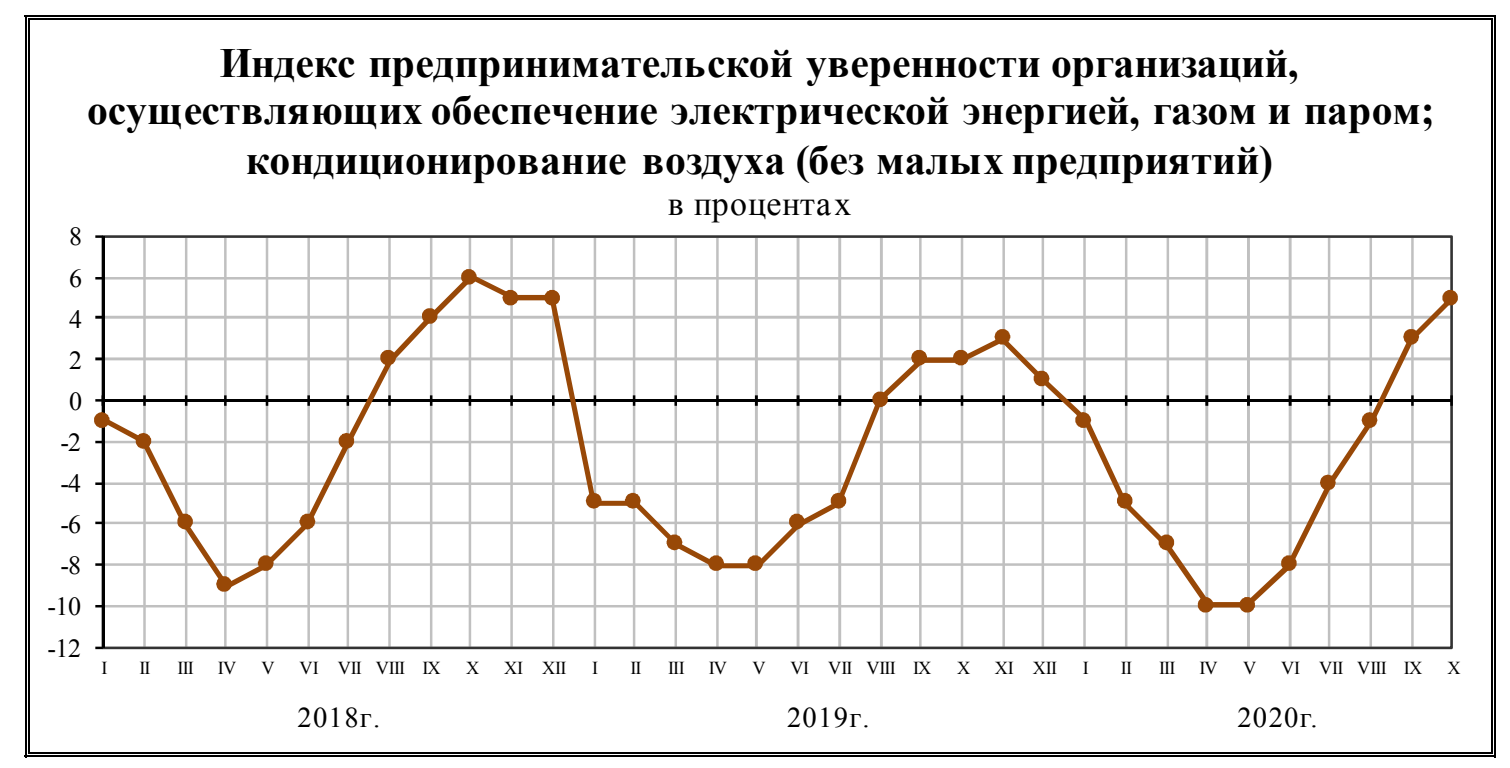

Таблица 59

ПРОИЗВОДСТВО ЭЛЕКТРО- И ТЕПЛОЭНЕРГИИ

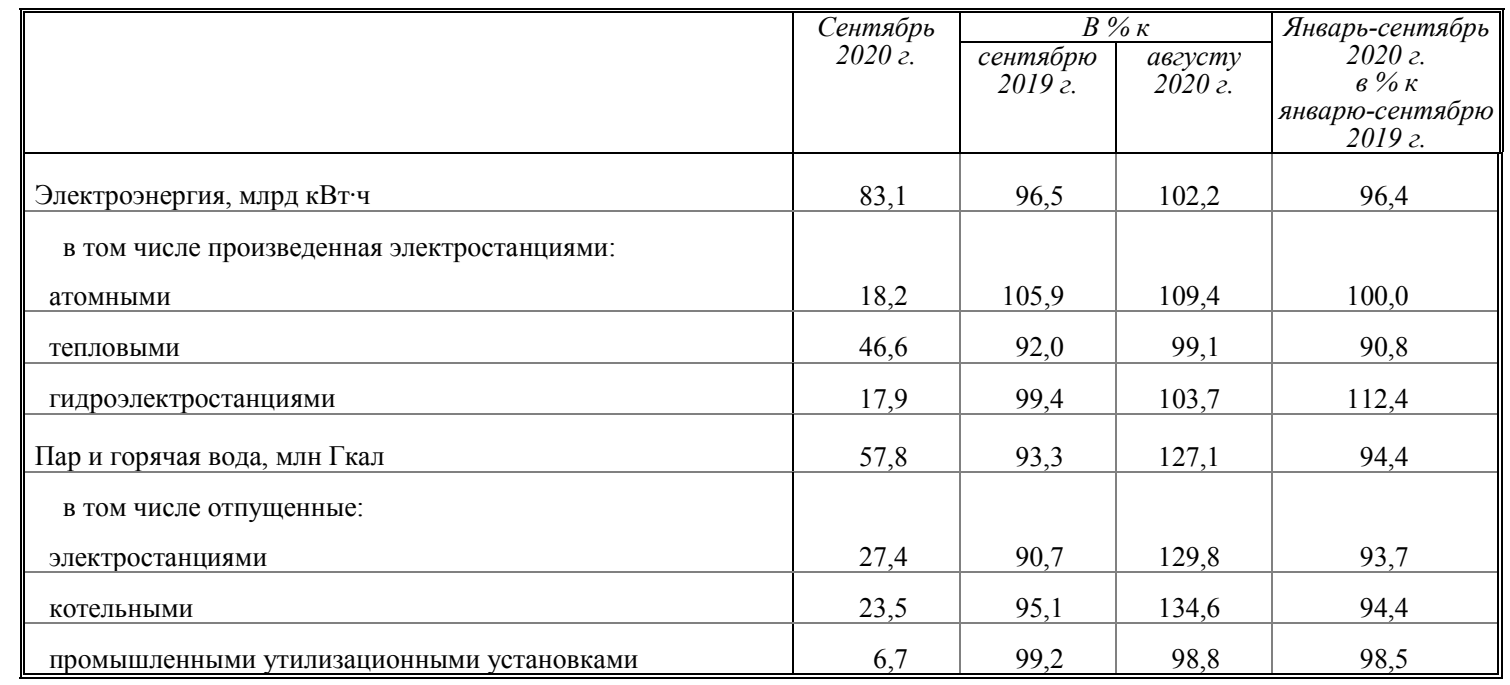

Доля электроэнергии, произведенной атомными электростанциями, в общей выработке электроэнергии увеличилась с 18,9\% в январе-сентябре 2019 г. до 19,5\% в январе-сентябре 2020 г., гидроэлектростанциями - с 17,5\% до 20,4\%, тепловыми электростанциями - уменьшилась с $63,4 \%$ до $59,8 \%$ соответственно.

\subsection{4. Водоснабжение; водоотведение, организация сбора и утилизации отходов, деятельность по ликвидации загрязнений}

Индекс производства по виду деятельности "Водоснабжение; водоотведение, организация сбора и утилизации отходов, деятельность по ликвидации загрязнений" в сентябре 2020 г. по сравнению с соответствующим периодом предыдущего года составил 96,2\%, в январе-сентябре 2020 г. $-94,2 \%$. 
ДИНАМИКА ПРОИЗВОДСТВАПО ВИДУ ДЕЯТЕЛЬНОСТИ

"ВОДОСНАБЖЕНИЕ; ВОДООТВЕДЕНИЕ, ОРГАНИЗАЦИЯ СБОРА И УТИЛИЗАЦИИ ОТХОДОВ, ДЕЯТЕЛЬНОСТЬ ПО ЛИКВИДАЦИИ ЗАГРЯЗНЕНИЙ"

\begin{tabular}{|c|c|c|}
\hline & \multicolumn{2}{|c|}{ 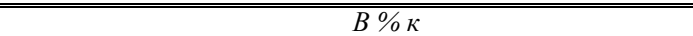 } \\
\hline & $\begin{array}{c}\text { соответствуюшему } \\
\text { периоду предыдуцчего года }\end{array}$ & $\begin{array}{c}\text { предылущему } \\
\text { периоду }\end{array}$ \\
\hline \multicolumn{3}{|c|}{2019 г. } \\
\hline Январь & 102,6 & 80,4 \\
\hline Февраль & 105,5 & 102,6 \\
\hline Март & 110,4 & 112,1 \\
\hline I квартал & 106,3 & 85,6 \\
\hline Апрель & 111,9 & 104,7 \\
\hline Май & 106,4 & 99,1 \\
\hline Июнь & 102,6 & 98,4 \\
\hline ІІ квартал & 106,9 & 112,4 \\
\hline I полугодие & 106,6 & \\
\hline Июль & 105,2 & 103,2 \\
\hline Август & 106,8 & 100,1 \\
\hline Сентябрь & 100,1 & 99,3 \\
\hline ІІІ квартал & 104,0 & 101,6 \\
\hline Январь-сентябрь & 105,6 & \\
\hline Октябрь & 95,3 & 98,4 \\
\hline Ноябрь & 94,4 & 97,5 \\
\hline Декабрь & 97,5 & 104,9 \\
\hline IV квартал & 95,7 & 97,9 \\
\hline Год & 102,9 & \\
\hline \multicolumn{3}{|c|}{2020 г. } \\
\hline Январь & 102,2 & 84,3 \\
\hline Февраль & 103,3 & 103,8 \\
\hline Март & 94,3 & 102,3 \\
\hline I квартал & 99,7 & 89,2 \\
\hline Апрель & 87,3 & 96,9 \\
\hline Май & 90,8 & 103,0 \\
\hline Июнь & 90,7 & 98,3 \\
\hline ІІ квартал & 89,6 & 101,0 \\
\hline I полугодие & 94,4 & \\
\hline Июль & 90,5 & 102,9 \\
\hline Август & 94,8 & 104,9 \\
\hline Сентябрь & 96,2 & 100,7 \\
\hline ІІІ квартал & 93,8 & 106,4 \\
\hline Январь-сентябрь & 94,2 & \\
\hline
\end{tabular}




\section{5. СЕЛЬСКОЕ И ЛЕСНОЕ ХОЗЯЙСТВО}

\subsection{1. Сельское хозяйство}

Объем производства продукции сельского хозяйства всех сельхозпроизводителей (сельхозорганизации, крестьянские (фермерские) хозяйства, хозяйства населения) в сентябре 2020 г. в действующих ценах, по предварительной оценке, составил 1327,4 млрд рублей, в январесентябре 2020 г. - 4252,2 млрд рублей.

ДИНАМИКА ПРОИЗВОДСТВА ПРОДУКЦИИ СЕЛЬСКОГО ХОЗЯЙСТВА ${ }^{1)}$

\begin{tabular}{|c|c|c|}
\hline & \multicolumn{2}{|c|}{ 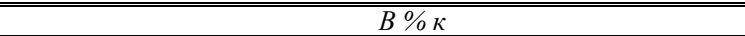 } \\
\hline & $\begin{array}{c}\text { соответствующему } \\
\text { периоду предыдущего года }\end{array}$ & $\begin{array}{c}\text { предыдущему } \\
\text { периоду }\end{array}$ \\
\hline \multicolumn{3}{|c|}{2019 г. } \\
\hline Январь & 100,9 & 56,0 \\
\hline Февраль & 101,2 & 110,4 \\
\hline Март & 101,7 & 144,4 \\
\hline І квартал & 101,3 & 30,3 \\
\hline Апрель & 101,6 & 113,2 \\
\hline Май & 101,2 & 111,5 \\
\hline Июнь & 101,3 & 103,7 \\
\hline ІІ квартал & 101,4 & 159,6 \\
\hline I полугодие & 101,4 & \\
\hline Июль & 106,4 & 184,3 \\
\hline Август & 103,6 & 128,0 \\
\hline Сентябрь & 105,8 & 186,8 \\
\hline III квартал & 105,3 & в 3,0p. \\
\hline Январь-сентябрь & 103,8 & \\
\hline Октябрь & 105,4 & 75,5 \\
\hline Ноябрь & 106,0 & 58,2 \\
\hline Декабрь & 105,8 & 46,8 \\
\hline IV квартал & 105,6 & 71,7 \\
\hline Год & 104,3 & \\
\hline \multicolumn{3}{|c|}{2020 г. } \\
\hline Январь & 102,9 & 54,4 \\
\hline Февраль & 103,1 & 110,6 \\
\hline Март & 103,0 & 144,2 \\
\hline І квартал & 103,0 & 29,6 \\
\hline
\end{tabular}




\begin{tabular}{|c|c|c|}
\hline & \multicolumn{2}{|c|}{$\bar{B} \% \kappa$} \\
\hline & $\begin{array}{c}\text { соответствующему } \\
\text { периоду предыдущего года }\end{array}$ & $\begin{array}{c}\text { предьидущему } \\
\text { периоду }\end{array}$ \\
\hline Апрель & 103,1 & 113,3 \\
\hline Май & 103,2 & 111,6 \\
\hline Июнь & 103,0 & 103,5 \\
\hline ІІ квартал & 103,1 & 159,7 \\
\hline I полугодие & 103,0 & \\
\hline Июль $^{2)}$ & 104,2 & 186,4 \\
\hline Август ${ }^{2)}$ & 104,1 & 127,8 \\
\hline Сентябрь & 101,4 & 182,0 \\
\hline III квартал & 102,7 & в 3,0p. \\
\hline Январь-сентябрь & 103,3 & \\
\hline $\begin{array}{l}\text { 1) Данныле уточне } \\
\text { 2) Даннье уточне } \\
\text { категориям хо }\end{array}$ & $\begin{array}{l}\text { ательных итогов. } \\
\text { формации об объемах про }\end{array}$ & за 9 месяцев по всем \\
\hline
\end{tabular}

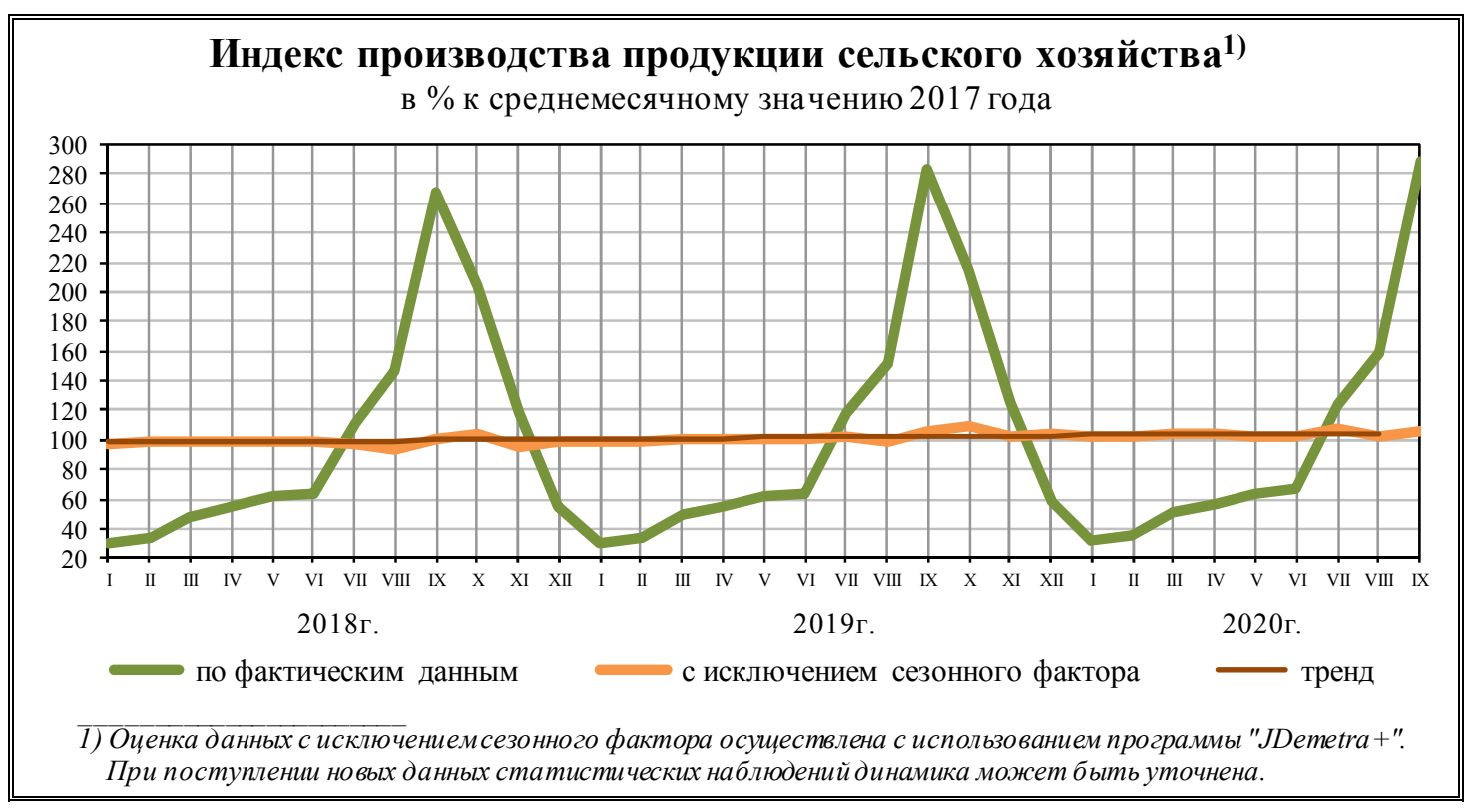

Растениеводство. К 20 октября 2020 г., по данным Минсельхоза России, в хозяйствах всех категорий (сельхозорганизации, фермеры, население) зерна (в первоначально оприходованном весе) намолочено 130,9 млн тонн, что на $10,2 \%$ больше, чем на соответствующую дату предыдущего года.

Зерновые и зернобобовые культуры обмолочены на 94,3\% посевных площадей (к этому времени в 2019 г. - на 94,1\%).

Сахарная свекла убрана с 75,8\% площадей (к этому времени в 2019 г. - с 65,8\%), подсолнечник обмолочен с 86,1\% посевов $(65,7 \%)$, лен-долгунец вытереблен с $89,5 \%$ площадей (год назад к этому времени - с 83,6\%). 
УБОРКА УРОЖАЯ

В ХОЗЯЙСТВАХ ВСЕХ КАТЕГОРИЙ

на 20 октября

\begin{tabular}{|c|c|c|c|c|}
\hline & 20202. & 202 & & Справочно \\
\hline & &,+- & $\%$ & 20192 \\
\hline $\begin{array}{l}\text { Обмолочено зерновых и зернобобовых культур, } \\
\text { млн га }\end{array}$ & 45,3 & $+1,3$ & 102,8 & 44,0 \\
\hline в \% к площади посева & 94,3 & & & 94,1 \\
\hline $\begin{array}{l}\text { Намолочено зерна (в первоначально } \\
\text { оприходованном весе) - всего, млн тонн }\end{array}$ & 130,9 & $+12,1$ & 110,2 & 118,8 \\
\hline с 1 га, центнеров & 28,9 & $+1,9$ & 107,0 & 27,0 \\
\hline в том числе пшеницы - всего, млн тонн & 87,2 & $+9,8$ & 112,8 & 77,4 \\
\hline с 1 га, центнеров & 30,3 & $+2,1$ & 107,4 & 28,2 \\
\hline Убрано сахарной свеклы, тыс. га & 704 & -50 & 93,4 & 754 \\
\hline в \% к площади посадки & 75,8 & & & 65,8 \\
\hline $\begin{array}{l}\text { Накопано сахарной свеклы - всего, } \\
\text { млн тонн }\end{array}$ & 25,4 & $-8,4$ & 75,0 & 33,8 \\
\hline с 1 га, центнеров & 360 & -88 & 80,4 & 448 \\
\hline Убрано подсолнечника, млн га & 7,3 & $+1,7$ & 130,7 & 5,6 \\
\hline в \% к площади посева & 86,1 & & & 65,7 \\
\hline $\begin{array}{l}\text { Намолочено семян подсолнечника - всего, } \\
\text { млн тонн }\end{array}$ & 11,6 & $+0,9$ & 108,2 & 10,7 \\
\hline с 1 га, центнеров & 15,9 & $-3,3$ & 82,8 & 19,2 \\
\hline Убрано льна-долгунца, тыс. га & 48 & +6 & 113,4 & 42 \\
\hline в \% к площади посева & 89,5 & & & 83,6 \\
\hline
\end{tabular}

Животноводство. На конец сентября 2020 г. поголовье крупного рогатого скота в хозяйствах всех сельхозпроизводителей, по расчетам, составляло 18,9 млн голов (на $0,6 \%$ больше по сравнению с соответствующей датой предыдущего года), из него коров - 8,0 млн (на $0,3 \%$ больше), свиней - 26,8 млн (на 4,4\% больше), овец и коз - 23,8 млн (на 1,1\% меньше), птицы - 561,0 млн голов (на $0,1 \%$ больше).

В структуре поголовья скота на хозяйства населения приходилось 40,7\% поголовья крупного рогатого скота, 10,1\% свиней, 45,6\% овец и коз (на конец сентября 2019 г. - соответственно $41,4 \%, 10,9 \%, 45,9 \%)$. 
ДИНАМИКА ПОГОЛОВЬЯ СКОТА В ХОЗЯЙСТВАХ ВСЕХ КАТЕГОРИЙ

на конец месяца, в процентах

\begin{tabular}{|c|c|c|c|c|c|c|c|c|}
\hline & \multicolumn{2}{|c|}{ "Крупньй рогатьй скот } & \multicolumn{2}{|c|}{ "Из него коровьл } & \multicolumn{2}{|c|}{ Свиньи } & \multicolumn{2}{|c|}{ Овизы и козьл } \\
\hline & $\begin{array}{c}\text { к соответ- } \\
\text { ствуюшей } \\
\text { дате пре- } \\
\text { дыдущего } \\
\text { года }\end{array}$ & $\begin{array}{c}\text { к соответ- } \\
\text { ствуюшей } \\
\text { дате пре- } \\
\text { дыдушего } \\
\text { месяциа }\end{array}$ & $\begin{array}{c}\text { соответ- } \\
\text { ствуюшей } \\
\text { дате пре- } \\
\text { дыдушего } \\
\text { года }\end{array}$ & $\begin{array}{c}\text { к соответ- } \\
\text { ствуюшей } \\
\text { дате пре- } \\
\text { дыдущуего } \\
\text { месяцуа }\end{array}$ & $\begin{array}{l}\text { к соответ- } \\
\text { ствуюшей } \\
\text { дате пре- } \\
\text { дылуичего } \\
\text { года }\end{array}$ & $\begin{array}{l}\text { к соответ- } \\
\text { ствуюшей } \\
\text { дате пре- } \\
\text { дыдущего } \\
\quad \text { месяца }\end{array}$ & $\begin{array}{c}\text { к соответ- } \\
\text { ствуюшей } \\
\text { дате пре- } \\
\text { дыдущуего } \\
\text { года }\end{array}$ & $\begin{array}{l}\text { к соответ- } \\
\text { ствуюшей } \\
\text { дате пре- } \\
\text { дыдучего } \\
\text { месяча }\end{array}$ \\
\hline \multicolumn{9}{|c|}{2019 г. $^{1)}$} \\
\hline Январь & 99,2 & 100,2 & 99,5 & 99,8 & 103,1 & 101,4 & 94,0 & 99,1 \\
\hline Февраль & 99,2 & 100,8 & 99,5 & 100,3 & 102,8 & 100,4 & 96,2 & 101,8 \\
\hline Март & 99,1 & 101,5 & 99,6 & 100,4 & 103,3 & 101,7 & 95,7 & 101,6 \\
\hline Апрель & 99,0 & 101,2 & 99,6 & 100,4 & 102,8 & 100,6 & 95,9 & 103,7 \\
\hline Май & 99,0 & 101,3 & 99,7 & 100,6 & 103,7 & 101,8 & 95,0 & 101,5 \\
\hline Июнь & 99,2 & 100,5 & 99,7 & 100,0 & 104,3 & 101,4 & 95,0 & 100,5 \\
\hline Июль & 99,3 & 99,6 & 99,9 & 100,0 & 105,2 & 100,7 & 94,9 & 99,2 \\
\hline Август & 99,5 & 99,6 & 100,1 & 99,8 & 105,7 & 100,5 & 95,9 & 98,7 \\
\hline Сентябрь & 99,5 & 98,9 & 100,1 & 99,8 & 104,6 & 99,5 & 97,0 & 98,0 \\
\hline Октябрь & 99,6 & 99,0 & 100,2 & 99,7 & 105,1 & 99,3 & 97,5 & 98,5 \\
\hline Ноябрь & 99,8 & 98,5 & 100,2 & 99,5 & 105,8 & 99,6 & 97,6 & 97,5 \\
\hline Декабрь & 99,9 & 99,0 & 100,3 & 100,1 & 106,1 & 99,0 & 97,8 & 97,8 \\
\hline \multicolumn{9}{|c|}{2020 г. } \\
\hline Январь & 99,9 & 100,3 & 100,4 & 99,9 & 106,1 & 101,5 & 97,9 & 99,2 \\
\hline Февраль & 99,9 & 100,7 & 100,3 & 100,2 & 107,3 & 101,5 & 96,6 & 100,5 \\
\hline Март & 99,8 & 101,4 & 100,3 & 100,4 & 106,4 & 100,8 & 97,6 & 102,6 \\
\hline Апрель & 100,0 & 101,4 & 100,3 & 100,4 & 107,9 & 101,5 & 98,3 & 104,0 \\
\hline Май & 100,3 & 101,6 & 100,1 & 100,5 & 106,6 & 101,2 & 98,6 & 102,4 \\
\hline Июнь & 100,3 & 100,5 & 100,4 & 100,2 & 105,3 & 100,1 & 99,2 & 101,1 \\
\hline Июль & 100,5 & 99,8 & 100,4 & 100,0 & 104,7 & 100,1 & 99,1 & 99,1 \\
\hline Август & 100,4 & 99,5 & 100,4 & 99,8 & 104,6 & 100,4 & 99,3 & 99,0 \\
\hline Сентябрь & 100,6 & 99,0 & 100,3 & 99,6 & 104,4 & 99,4 & 98,9 & 97,6 \\
\hline
\end{tabular}

В сельскохозяйственных организациях на конец сентября 2020 г. по сравнению с соответствующей датой 2019 г. поголовье крупного рогатого скота выросло на 1,1\%, коров - на $0,6 \%$, свиней - на 5,7\%, птицы - на 0,6\%, поголовье овец и коз сократилось на 1,7\%.

В январе-сентябре 2020 г. в хозяйствах всех категорий, по расчетам, произведено скота и птицы на убой (в живом весе) 10,9 млн тонн, молока - 24,9 млн тонн, яиц - 34,2 млрд штук. 


\section{ПРОИЗВОДСТВО ОСНОВНЫХ ВИДОВ ПРОДУКЦИИ ЖИВОТНОВОДСТВА} В ХОЗЯЙСТВАХ ВСЕХ КАТЕГОРИЙ

\begin{tabular}{|c|c|c|c|c|c|c|c|}
\hline & \multirow{3}{*}{$\begin{array}{c}\text { Сентябрь } \\
2020 \text { г., } \\
\text { млн тонн }\end{array}$} & \multicolumn{2}{|c|}{$B \% \kappa$} & \multirow{3}{*}{$\begin{array}{c}\text { Январь- } \\
\text { сентябрь } \\
2020 \text { г. } \\
\text { в\% \% } \\
\text { январю- } \\
\text { сентябрю } \\
20192 .\end{array}$} & \multicolumn{3}{|c|}{ Справочно } \\
\hline & & \multirow{2}{*}{$\begin{array}{c}\text { сентябрю } \\
20192 .\end{array}$} & \multirow{2}{*}{$\begin{array}{l}\text { aвzусту } \\
2020 \text { z. }\end{array}$} & & \multicolumn{2}{|c|}{ сентябрь 2019 г. в \% к } & \multirow[b]{2}{*}{$\begin{array}{c}\text { январь- } \\
\text { сентябрь } \\
2019 \text { г. } \\
\text { в\% к } \\
\text { январю- } \\
\text { сентябрю } \\
2018 \text { г. }\end{array}$} \\
\hline & & & & & $\begin{array}{c}\text { сентябрю } \\
2018 \text { г. }\end{array}$ & $\begin{array}{l}\text { aвгусту } \\
2019 \text { г. }\end{array}$ & \\
\hline $\begin{array}{l}\text { Скот и птица на убой } \\
\text { (в живом весе) }\end{array}$ & 1,3 & 104,1 & 110,9 & 104,0 & 104,5 & 112,2 & 101,8 \\
\hline Молоко & 2,8 & 100,9 & 89,6 & 102,7 & 103,7 & 90,3 & 101,7 \\
\hline Яйца, млрд штук & 3,7 & 100,3 & 93,9 & 100,6 & 101,1 & 94,1 & 99,5 \\
\hline
\end{tabular}

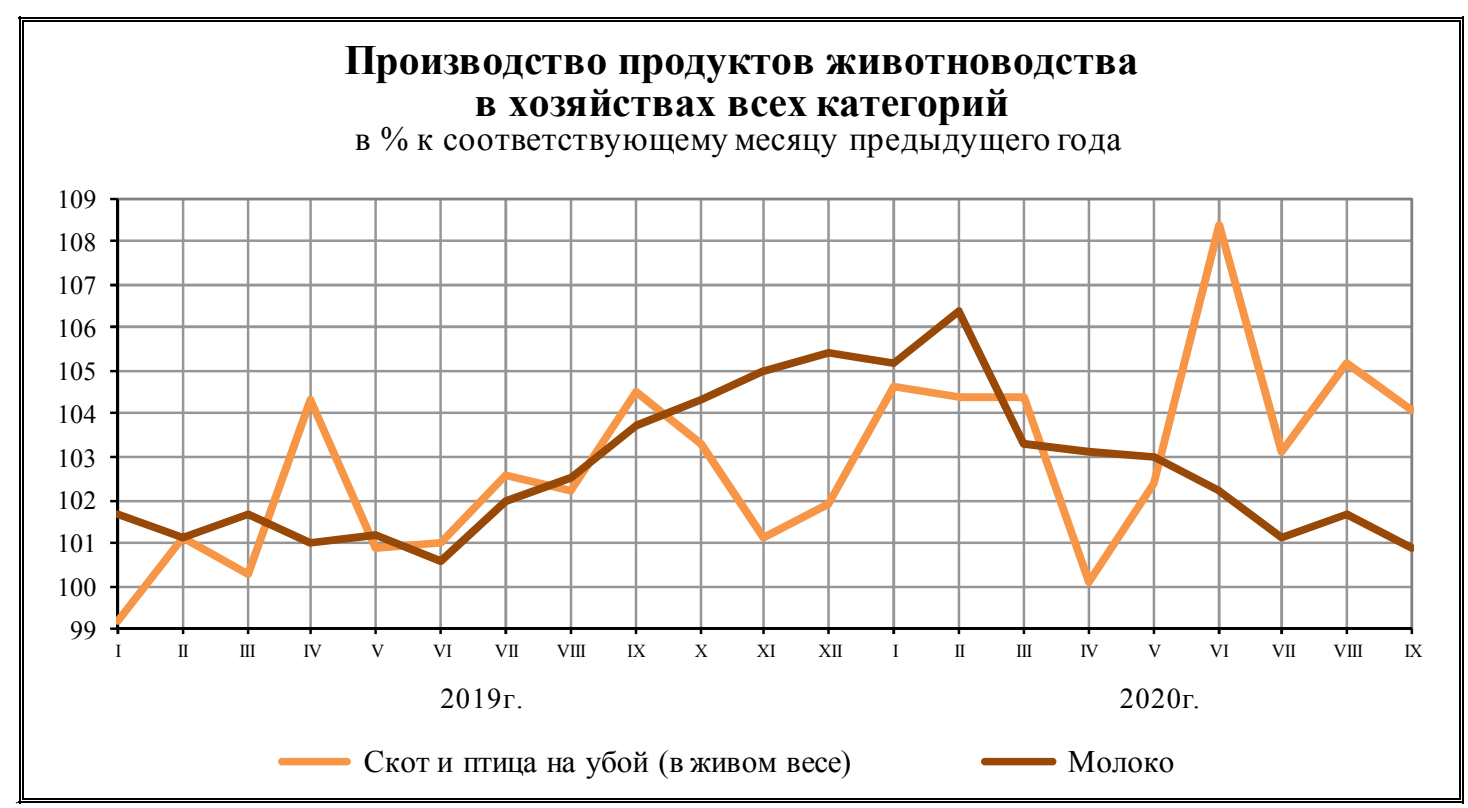

В сельскохозяйственных организациях в сентябре 2020 г. по сравнению с сентябрем 2019 г. производство скота и птицы на убой (в живом весе) выросло на 5,9\% (в сентябре 2019 г. по сравнению с сентябрем 2018 г. - на 6,6\%), молока - на 3,3\% (на 6,5\%), производство яиц на $0,4 \%$ (на 1,4\%).

В сельскохозяйственных организациях (кроме микропредприятий) надои молока на 1 корову в январе-сентябре 2020 г. составили 5233 килограмма против 4920 килограммов в январесентябре 2019 г., яйценоскость кур-несушек в сельскохозяйственных организациях (кроме субъектов малого предпринимательства) - 233 штуки яиц против 232 штук год назад.

В январе-сентябре 2020 г. в структуре производства скота и птицы на убой (в живом весе) отмечалось увеличение удельного веса производства свиней на убой по сравнению с соответствующим периодом предыдущего года. 


\section{ПРОИЗВОДСТВО ОСНОВНЫХ ВИДОВ СКОТА И ПТИЦЫ НА УБОЙ СЕЛЬСКОХОЗЯЙСТВЕННЫМИ ОРГАНИЗАЦИЯМИ}

\begin{tabular}{|c|c|c|c|c|c|c|}
\hline & \multicolumn{4}{|c|}{ Сентябрь 2020 г. } & \multirow{3}{*}{$\begin{array}{c}\text { Январь- } \\
\text { сентябрь } \\
2020 \text { г. } \\
\text { в\% к } \\
\text { январю- } \\
\text { сентябрю } \\
20192 .\end{array}$} & \multirow{3}{*}{$\begin{array}{c}\text { Справочно } \\
\text { январь- } \\
\text { сентябрь } \\
2019 \text { г. } \\
\text { в\% к } \\
\text { январю- } \\
\text { сентябрю } \\
20182 . \\
\end{array}$} \\
\hline & \multirow{2}{*}{$\begin{array}{l}\text { mblc. } \\
\text { тонн }\end{array}$} & \multicolumn{2}{|c|}{$6 \% \kappa$} & \multirow[b]{2}{*}{\begin{tabular}{|c} 
доля производства \\
отдельных видов \\
скота и птиць в \\
обшем объеме \\
производства \\
скота и птицьв \\
на убой, \% \\
\end{tabular}} & & \\
\hline & & $\begin{array}{c}\text { сентябрю } \\
20192 .\end{array}$ & $\begin{array}{c}\text { aвгусту } \\
2020 \text { z. }\end{array}$ & & & \\
\hline Скот и птица на убой (в живом весе) & 1029,6 & 105,9 & 102,3 & 100 & 105,4 & 102,5 \\
\hline из них: & & & & & & \\
\hline крупный рогатый скот & 87,3 & 102,3 & 108,1 & 8,5 & 102,3 & 102,3 \\
\hline свиньи & 411,2 & 111,9 & 103,0 & 39,9 & 112,3 & 106,1 \\
\hline птица & 525,8 & 102,2 & 100,5 & 51,1 & 101,2 & 100,2 \\
\hline
\end{tabular}

К началу октября 2020 г. обеспеченность скота кормами в расчете на 1 условную голову скота в сельхозорганизациях была выше на $0,3 \%$, чем на соответствующую дату предыдущего года.

\section{НАЛИЧИЕ КОРМОВ В СЕЛЬСКОХОЗЯЙСТВЕННЫХ ОРГАНИЗАЦИЯХ на 1 октября}

\begin{tabular}{|c|c|c|c|}
\hline & 20202. & & \\
\hline & & 20192. & 20182. \\
\hline Наличие кормов, млн тонн кормовых единиц & 14,7 & 14,3 & 14,2 \\
\hline в том числе концентрированных & 4,6 & 4,6 & 4,6 \\
\hline в расчете на 1 условную голову скота, ц корм. единиц & 7,3 & 7,3 & 7,5 \\
\hline
\end{tabular}

Реализация продукции. В январе-сентябре 2020 г. по сравнению с соответствующим периодом предыдущего года возросла продажа сельхозорганизациями основных продуктов сельского хозяйства.

За этот период реализовано по всем каналам 44,7 млн тонн зерна, 9,0 млн тонн скота и птицы (в живом весе), 13,0 млн тонн молока, 24,3 млрд штук яиц.

ОБЪЕМ РЕАЛИЗАЦИИ СЕЛЬСКОХОЗЯЙСТВЕННЫХ ПРОДУКТОВ СЕЛЬСКОХОЗЯЙСТВЕННЫМИ ОРГАНИЗАЦИЯМИ

\begin{tabular}{|c|c|c|c|c|c|c|c|}
\hline & \multirow{3}{*}{$\begin{array}{c}\text { Сентябрь } \\
2020 \text { г., } \\
\text { млн тонн }\end{array}$} & \multicolumn{2}{|c|}{$\bar{B} \% \mathrm{~K}$} & \multirow{3}{*}{$\begin{array}{c}\text { Январь- } \\
\text { сентябрь } \\
2020 \text { г. } \\
\text { в\% к } \\
\text { январю- } \\
\text { сентябрю } \\
20192 .\end{array}$} & \multicolumn{3}{|c|}{ Справочно } \\
\hline & & \multirow{2}{*}{$\begin{array}{c}\text { сентябрю } \\
2019 \text { г. }\end{array}$} & \multirow{2}{*}{$\begin{array}{c}\text { aвzycmy } \\
2020 \text { z. }\end{array}$} & & \multicolumn{2}{|c|}{ сентябрь 2019 г. в \% к } & \multirow[b]{2}{*}{$\begin{array}{c}\text { январь- } \\
\text { сентябрь } \\
2019 \text { г. } \\
\text { в \% к } \\
\text { январю- } \\
\text { сентябрю } \\
2018 \text { г. }\end{array}$} \\
\hline & & & & & $\begin{array}{c}\text { сентябрю } \\
20182 .\end{array}$ & $\begin{array}{c}\text { aвгусту } \\
20192 .\end{array}$ & \\
\hline Зерно & 10,8 & 110,2 & 111,6 & 114,3 & 115,0 & 121,7 & 84,2 \\
\hline Скот и птица (в живом весе) & 1,0 & 106,0 & 102,4 & 105,5 & 103,5 & 102,9 & 101,6 \\
\hline
\end{tabular}




\begin{tabular}{|c|c|c|c|c|c|c|c|}
\hline & \multirow{3}{*}{$\begin{array}{c}\text { Сентябрь } \\
2020 \text { г., } \\
\text { млн тонн }\end{array}$} & \multicolumn{2}{|c|}{$\overline{B \quad \% \kappa}$} & \multirow{3}{*}{$\begin{array}{c}\text { Январь- } \\
\text { сентябрь } \\
2020 \text { г. } \\
\text { в\% к } \\
\text { январю- } \\
\text { сентябрю } \\
2019 \text { г. }\end{array}$} & \multicolumn{3}{|c|}{ Справочно } \\
\hline & & \multirow{2}{*}{$\begin{array}{c}\text { сентябрю } \\
2019 \text { г. }\end{array}$} & \multirow{2}{*}{$\begin{array}{c}\text { aвzycmy } \\
2020 \text { z. }\end{array}$} & & \multirow{2}{*}{$\begin{array}{c}\text { сентябррь } 2 \\
\text { сентябрю } \\
2018 \text { г. }\end{array}$} & \multirow{2}{*}{\begin{tabular}{c|}
19 г. в\% \% \\
aвzусmy \\
20192.
\end{tabular}} & \multirow[b]{2}{*}{$\begin{array}{c}\text { январь- } \\
\text { сентябрь } \\
2019 \text { г. } \\
\text { в\% \% } \\
\text { январю- } \\
\text { сентябрю } \\
2018 \text { г. } \\
\end{array}$} \\
\hline & & & & & & & \\
\hline Молоко & 1,4 & 104,8 & 94,3 & 106,1 & 106,4 & 94,3 & 104,0 \\
\hline Яйца, млрд штук & 2,7 & 103,0 & 102,2 & 101,7 & 102,8 & 100,6 & 99,8 \\
\hline
\end{tabular}

1.5.2. Лесозаготовки

Таблица 8

ПРОИЗВОДСТВО ОТДЕЛЬНЫХ ВИДОВ ПРОДУКЦИИ ПО ВИДУ ДЕЯТЕЛЬНОСТИ "ЛЕСОЗАГОТОВКИ"

\begin{tabular}{|c|c|c|c|c|}
\hline & \multirow{2}{*}{$\begin{array}{c}\text { Сентябрь } \\
2020 \text { г., } \\
\text { млн } \\
\text { плотн. } м^{3}\end{array}$} & \multicolumn{2}{|c|}{$\overline{B \% \kappa}$} & \multirow{2}{*}{$\begin{array}{c}\text { Январь-сентябрь } \\
2020 \text { г. } \\
\text { в\% } \\
\text { январю-сентябрю } \\
2019 \text { г. } \\
\end{array}$} \\
\hline & & $\begin{array}{l}\text { сентябрю } \\
2019 \text { г. }\end{array}$ & $\begin{array}{c}\text { aвzусту } \\
2020 \text {. }\end{array}$ & \\
\hline Лесоматериалы хвойных пород & 6,2 & 99,9 & 95,9 & 97,0 \\
\hline $\begin{array}{l}\text { Лесоматериалы лиственных пород, } \\
\text { за исключением тропических пород }\end{array}$ & 3,1 & 99,0 & 98,2 & 100,6 \\
\hline Древесина топливная & 1,1 & 96,4 & 102,5 & 93,4 \\
\hline
\end{tabular}

\section{6. РЫБОЛОВСТВО И РЫБОВОДСТВО}

Оборот организаций с основным видом деятельности "Рыболовство и рыбоводство" в сентябре 2020 г. составил 32,1 млрд рублей, что в действующих ценах на $17,7 \%$ больше, чем в соответствующем периоде предыдущего года, в январе-сентябре 2020 г. - на 9\% больше.

Таблица 1

РЫБА И ПРОЧАЯ ПРОДУКЦИЯ РЫБОЛОВСТВА

\begin{tabular}{|c|c|c|c|c|}
\hline & Сентябрь & & & Январь- \\
\hline & $\begin{array}{c}2020 \text { г., } \\
\text { тысс. тонн }\end{array}$ & $\begin{array}{c}\text { сентябрю } \\
2019 \text { 2. }\end{array}$ & $\begin{array}{l}\text { aвгусmy } \\
2020 \text { г. }\end{array}$ & $\begin{array}{c}\text { сентябрь } \\
2020 \text { г. } \\
\text { в\% к } \\
\text { январю- } \\
\text { сентябрю } \\
20192 .\end{array}$ \\
\hline Рыба морская живая & 21,8 & 146,3 & в $2,4 \mathrm{p}$. & 124,2 \\
\hline Рыба морская свежая или охлажденная & 63,1 & 102,4 & 104,8 & 99,0 \\
\hline Ракообразные немороженые & 3,7 & 56,4 & 168,7 & 65,3 \\
\hline Рыба пресноводная живая & 0,9 & 48,0 & 141,7 & 54,1 \\
\hline Рыба пресноводная свежая или охлажденная & 10,8 & 79,3 & 76,8 & 74,4 \\
\hline
\end{tabular}




\section{7. СТРОИТЕЛЬСТВО}

Строительная деятельность. Объем работ, выполненных по виду деятельности "Строительство", в сентябре 2020 г. составил 949,4 млрд рублей, или 99,9\% (в сопоставимых ценах) к уровню соответствующего периода предыдущего года, в январе-сентябре 2020 г. - 6382,0 млрд рублей, или 99,6\%.

ДИНАМИКА ОБЪЕМА РАБОТ,

ВЫПОЛНЕННЫХ ПО ВИДУ ДЕЯТЕЛЬНОСТИ "СТРОИТЕЛЬСТВО"

\begin{tabular}{|c|c|c|c|}
\hline & \multirow[t]{2}{*}{ "Млрд рублей } & \multicolumn{2}{|c|}{$\bar{B} \% \% \kappa$} \\
\hline & & $\begin{array}{c}\text { соответствующему } \\
\text { периоду предыдушего года }\end{array}$ & $\begin{array}{c}\text { предьлучщему } \\
\text { периоду }\end{array}$ \\
\hline \multicolumn{4}{|c|}{2019 г. } \\
\hline Январь & 445,7 & 100,0 & 39,1 \\
\hline Февраль & 446,5 & 100,1 & 99,5 \\
\hline Март & 575,6 & 100,3 & 128,2 \\
\hline І квартал & 1467,8 & 100,1 & 52,0 \\
\hline Апрель & 630,3 & 100,0 & 108,8 \\
\hline Май & 659,0 & 100,3 & 104,0 \\
\hline Июнь & 808,3 & 100,1 & 121,9 \\
\hline ІІ квартал & 2097,6 & 100,2 & 140,4 \\
\hline I полугодие & 3565,4 & 100,1 & \\
\hline Июль & 825,9 & 100,2 & 101,6 \\
\hline Август & 830,2 & 100,2 & 100,0 \\
\hline Сентябрь & 916,9 & 101,0 & 109,9 \\
\hline ІІІ квартал & 2573,0 & 100,5 & 120,6 \\
\hline Январь-сентябрь & 6138,4 & 100,3 & \\
\hline Октябрь & 891,8 & 101,1 & 96,8 \\
\hline Ноябрь & 877,6 & 100,3 & 97,9 \\
\hline Декабрь & 1224,3 & 100,4 & 139,0 \\
\hline IV квартал & 2993,7 & 100,9 & 114,6 \\
\hline Год & 9132,1 & 100,6 & \\
\hline \multicolumn{4}{|c|}{2020 г. } \\
\hline Январь & 476,7 & 101,0 & 38,7 \\
\hline Февраль & 480,7 & 102,3 & 100,6 \\
\hline Март & 605,1 & 100,1 & 125,4 \\
\hline І квартал & 1562,5 & 101,1 & 51,6 \\
\hline Апрель & 645,8 & 97,7 & 106,5 \\
\hline Май & 669,1 & 96,9 & 103,3 \\
\hline Июнь & 842,7 & 99,9 & 125,9 \\
\hline ІІ квартал & 2157,6 & 98,3 & 137,0 \\
\hline I полугодие & 3720,1 & 99,5 & \\
\hline Июль & 856,0 & 99,8 & 101,4 \\
\hline
\end{tabular}




\begin{tabular}{|c|c|c|c|}
\hline & "Млрд рублей & $\overline{B \overline{9}}$ & \\
\hline & & $\begin{array}{c}\text { соответствуюшему } \\
\text { периоду предыдущего года }\end{array}$ & $\begin{array}{c}\text { предысушщему } \\
\text { периоду }\end{array}$ \\
\hline Август & 856,5 & 99,4 & 99,7 \\
\hline Сентябрь & 949,4 & 99,9 & 110,6 \\
\hline ІІІ квартал & 2661,9 & 99,7 & 122,6 \\
\hline Январь-сентябрь & 6382,0 & 99,6 & \\
\hline
\end{tabular}

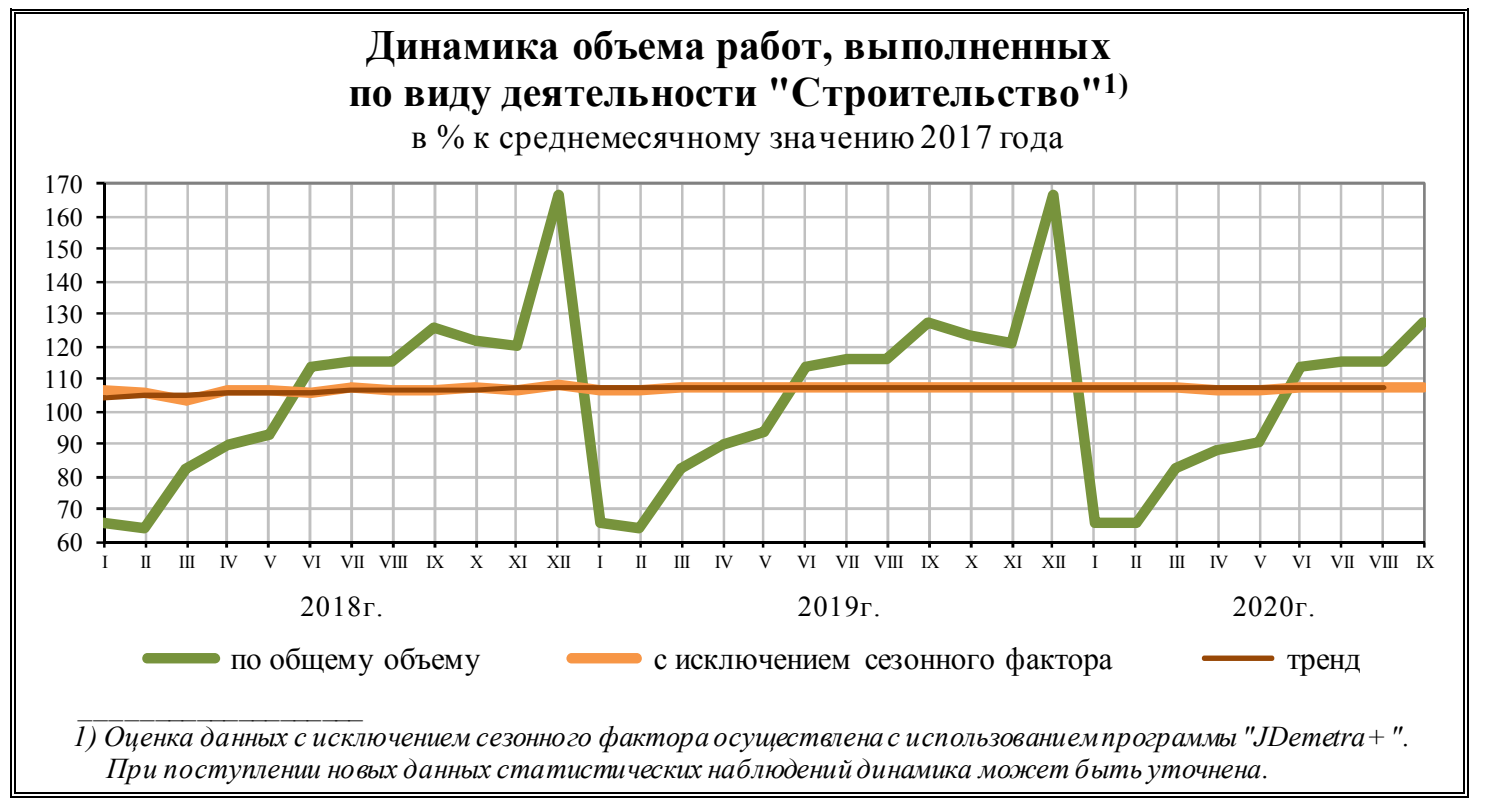

Таблица 2

ДИНАМИКА ОБЩЕГО ОБЪЕМА ЗАКЛЮЧЕННЫХ ДОГОВОРОВ СТРОИТЕЛЬНОГО ПОДРЯДА И ПРОЧИХ ЗАКАЗОВ (КОНТРАКТОВ)

(без субъектов малого предпринимательства)

на начало месяца

\begin{tabular}{|c|c|c|}
\hline & $\begin{array}{c}\text { Объем заключенных договоров } \\
\text { строительного подряда и прочих } \\
\text { заказов (контрактов), млрд рублей }\end{array}$ & $\begin{array}{c}\text { Обеспеченность строительных } \\
\text { организаиий договорами и прочими } \\
\text { заказами (контрактами), месячев }\end{array}$ \\
\hline \multicolumn{3}{|c|}{2019 г. } \\
\hline Январь & 458,8 & 1,3 \\
\hline Февраль & 557,8 & 3,5 \\
\hline Март & 569,2 & 4,2 \\
\hline Апрель & 564,2 & 3,3 \\
\hline Май & 558,9 & 2,7 \\
\hline Июнь & 552,4 & 2,7 \\
\hline Июль & 556,9 & 2,4 \\
\hline Август & 568,1 & 2,3 \\
\hline Сентябрь & 539,0 & 2,2 \\
\hline Октябрь & 494,5 & 1,8 \\
\hline Ноябрь & 473,2 & 1,7 \\
\hline Декабрь & 458,7 & 1,9 \\
\hline
\end{tabular}




\begin{tabular}{|c|c|c|}
\hline & $\begin{array}{c}\text { Объем заключенных договоров } \\
\text { строительного подряда и прочих } \\
\text { заказов (контрактов), млрд рублей }\end{array}$ & $\begin{array}{l}\text { Обеспеченность строчтельных } \\
\text { организачий договорами и прочими } \\
\text { заказами (контрактами), месячев }\end{array}$ \\
\hline \multicolumn{3}{|c|}{2020 г. } \\
\hline Январь & 459,5 & 1,3 \\
\hline Февраль & 563,2 & 3,9 \\
\hline Март & 517,7 & 3,2 \\
\hline Апрель & 558,7 & 3,0 \\
\hline Май & 556,5 & 3,1 \\
\hline Июнь & 543,9 & 2,8 \\
\hline Июль & 549,3 & 2,3 \\
\hline Август & 571,1 & 2,3 \\
\hline Сентябрь & 532,9 & 2,2 \\
\hline Октябрь & 555,6 & 2,1 \\
\hline
\end{tabular}

Ввод в действие (в эксплуатацию) зданий. Из числа введенных в действие в январе-сентябре 2020 г. зданий 94,6\% составляют здания жилого назначения.

\section{ВВОД В ДЕЙСТВИЕ (В ЭКСПЛУАТАЦИЮ) ЗДАНИЙ ПО ИХ ВИДАМ} в январе-сентябре 2020 года

\begin{tabular}{|c|c|c|c|}
\hline & $\begin{array}{c}\text { Количество зданий, } \\
\text { единии }\end{array}$ & $\begin{array}{c}\text { Обичй строительный } \\
\text { объем зданий, } \\
\text { тыс. } \text { м }^{3} \\
\end{array}$ & $\begin{array}{c}\text { Общзая площцадь } \\
\text { зданий, } \\
\text { тыс. } м^{2} \\
\end{array}$ \\
\hline Введено в действие зданий & 203123 & 360244,0 & 81333,2 \\
\hline $\begin{array}{l}\text { в том числе: } \\
\text { жилого назначения }\end{array}$ & 192073 & 230093,9 & 62728,6 \\
\hline нежилого назначения & 11050 & 130150,1 & 18604,6 \\
\hline $\begin{array}{l}\text { из них зданий: } \\
\text { промышленных }\end{array}$ & 1709 & 32396,5 & 3270,9 \\
\hline сельскохозяйственных & 1957 & 24758,5 & 4206,0 \\
\hline коммерческих & 3349 & 29168,1 & 4200,1 \\
\hline административных & 657 & 4867,2 & 1011,8 \\
\hline учебных & 471 & 11402,4 & 2517,1 \\
\hline здравоохранения & 281 & 2131,2 & 520,4 \\
\hline других & 2626 & 25426,3 & 2878,3 \\
\hline
\end{tabular}

Стройки. В соответствии с федеральной адресной инвестиционной программой, утвержденной Минэкономразвития России на 2020 г. (с уточнениями на 1 октября 2020 г.), выделены ассигнования в размере 697,3 млрд рублей, из них из федерального бюджета - 665,6 млрд рублей, на строительство 1486 объектов капитального строительства, приобретение объектов недвижимости и реализацию мероприятий (укрупненных инвестиционных проектов) (далее - объекты). Из общего количества объектов по 380 объектам было намечено провести только проектные и изыскательские работы. Из 356 объектов, намеченных к вводу в 2020 г., введено в эксплуатацию 33 объекта, из них 23 - на полную мощность, 10 объектов - частично. 
ОБЪЕКТЫ, ПРЕДУСМОТРЕННЫЕ ФЕДЕРАЛЬНОЙ АДРЕСНОЙ ИНВЕСТИЦИОННОЙ ПРОГРАММОЙ

единиц

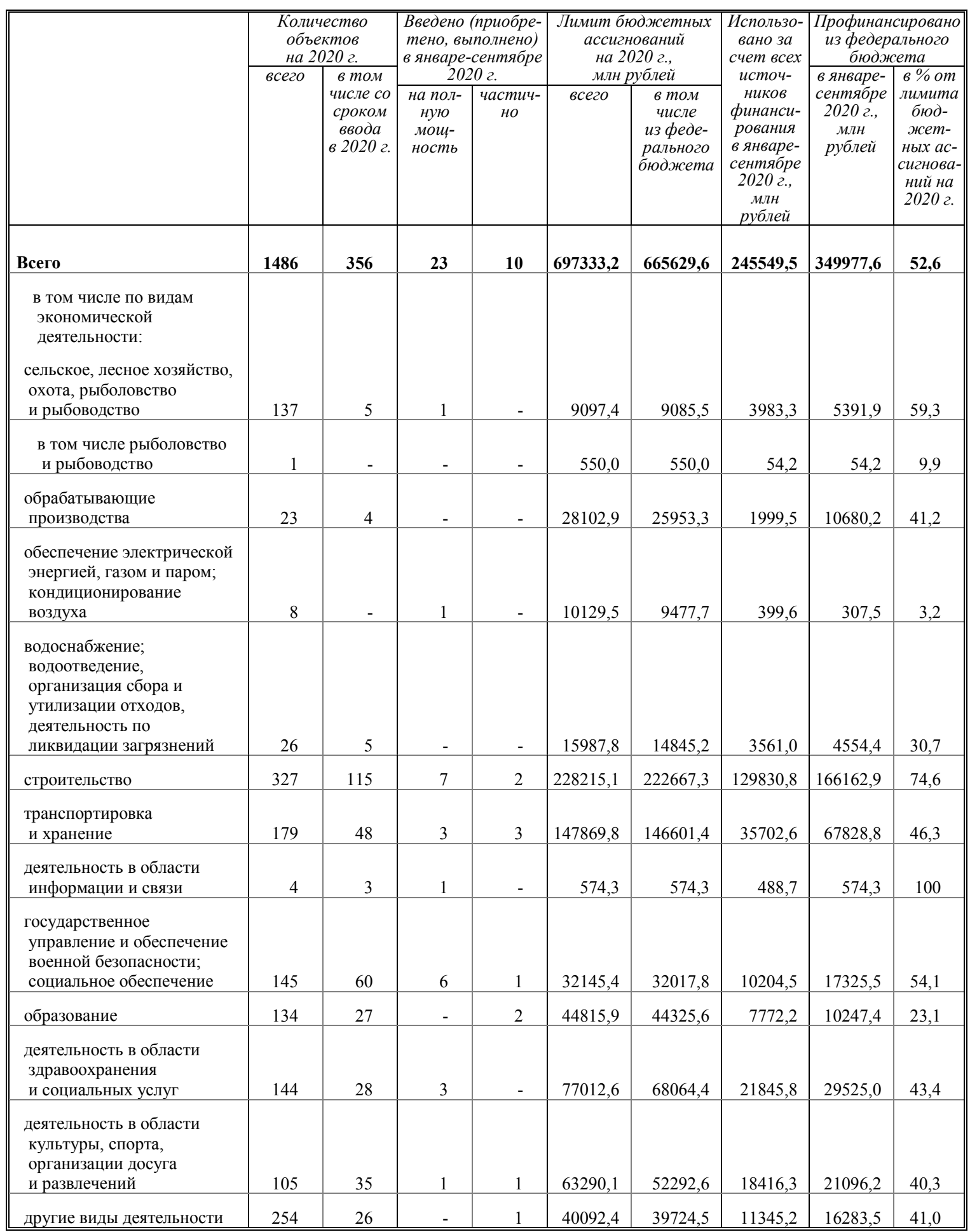


Из бюджетов субъектов Российской Федерации и прочих источников профинансировано 15 млрд рублей.

На 1 октября 2020 г. полностью профинансировано 615 объектов. На 368 объектах (без объектов, по которым проводятся проектные и изыскательские работы для строительства будущих лет) техническая готовность составляла от 51,0\% до 99,9\%.

Ввод в действие производственных мощностей и объектов.

ВВОД В ДЕЙСТВИЕ ПРОИЗВОДСТВЕННЫХ МОЩНОСТЕЙ

\begin{tabular}{|c|c|c|}
\hline & $\begin{array}{c}\text { Январь-сентябрь } \\
2020 \text { г. }\end{array}$ & $\frac{\text { Справочно }}{\text { январь-сентябрь } 2019 \text { г. }}$ \\
\hline \multicolumn{3}{|l|}{ Помещения для скота, тыс. мест } \\
\hline крупного рогатого скота & 67,7 & 74,3 \\
\hline свиней & 1217,2 & 361,4 \\
\hline овец & 49,2 & 38,7 \\
\hline Помещения для птицы, тыс. птицемест & 1158,3 & 1811,0 \\
\hline Зерносеменохранилища, тыс. тонн единовременного хранения & 412,7 & 354,5 \\
\hline Зерносушилки стационарные, тонн в час & 1470,5 & 644,5 \\
\hline $\begin{array}{l}\text { Хранилища для картофеля, овощей и фруктов, } \\
\text { тыс.тонн единовременного хранения }\end{array}$ & 294,9 & 84,0 \\
\hline Скважины эксплуатационного бурения, единиц & & \\
\hline нефтяные & 3150 & 3898 \\
\hline газовые & 10 & 15 \\
\hline Мощности по производству: & & \\
\hline автомобилей легковых, тыс. штук & - & 25,0 \\
\hline готовых лекарственных препаратов, млн штук & 60,9 & 532,2 \\
\hline $\begin{array}{l}\text { удобрений минеральных (в пересчете на } 100 \% \\
\text { питательных веществ), тыс. тонн }\end{array}$ & 135,9 & 395,0 \\
\hline мяса, тонн в смену & 198,0 & 110,2 \\
\hline колбасных изделий, тонн в смену & 2,6 & 88,5 \\
\hline хлебобулочных изделий, тонн в сутки & 44,9 & 2,9 \\
\hline цельномолочной продукции, тонн в смену & 75,5 & 178,0 \\
\hline $\begin{array}{l}\text { Предприятия мельничные сортового помола, } \\
\text { тонн переработки зерна в сутки }\end{array}$ & 1248,8 & - \\
\hline Цехи комбикормовые, тонн в сутки & 697,8 & 935,8 \\
\hline Пиломатериалы, тыс. м³ & 286,6 & 630,1 \\
\hline Плитки керамической, тыс.м² & 4500,0 & 930,0 \\
\hline Электростанции турбинные, тыс. кВт & 656,3 & 1914,1 \\
\hline Линии электропередачи напряжением 35 кВ и выше, км & 391,2 & 1756,1 \\
\hline $\begin{array}{l}\text { Линии электропередачи для электрификации } \\
\text { сельского хозяйства напряжением 6-20 кВ, км }\end{array}$ & 478,0 & 520,7 \\
\hline
\end{tabular}




\begin{tabular}{|c|c|c|}
\hline & $\begin{array}{c}\text { Январь-сентяборь } \\
2020 \text { 己. }\end{array}$ & $\frac{\text { Справочно }}{\text { январь-сентябрь } 2019 \text { г. }}$ \\
\hline $\begin{array}{l}\text { Линии электропередачи для электрификации } \\
\text { сельского хозяйства напряжением } 0,4 \text { кB, км }\end{array}$ & 842,4 & 1040,8 \\
\hline $\begin{array}{l}\text { Трансформаторные понизительные подстанции } \\
\text { напряжением } 35 \text { кВ и выше, тыс. кВ·A }\end{array}$ & 1115,2 & 1744,2 \\
\hline $\begin{array}{l}\text { Станции технического обслуживания } \\
\text { легковых автомобилей, единиц }\end{array}$ & 97 & 120 \\
\hline Торговые предприятия, тыс. м² торговой площади & 1397,9 & 1662,7 \\
\hline Рынки и павильоны, торговых мест & 627 & 185 \\
\hline Предприятия общественного питания, тыс. посадочных мест & 10,7 & 12,6 \\
\hline Газопроводы магистральные и отводы от них, км & 374,1 & 717,3 \\
\hline Автомобильные дороги с твердым покрытием, км & 624,0 & 545,4 \\
\hline $\begin{array}{l}\text { в том числе: } \\
\text { общего пользования }\end{array}$ & 436,0 & 471,6 \\
\hline необщего пользования & 188,0 & 73,8 \\
\hline $\begin{array}{l}\text { Мосты } \\
\text { единиц }\end{array}$ & 37 & 23 \\
\hline погон. тыс. м & 9,8 & 5,0 \\
\hline Городские АТС, тыс. номеров & 9,6 & 1,8 \\
\hline АТС в сельской местности, тыс. номеров & 1,3 & 3,3 \\
\hline Радиорелейные линии связи, тыс. км & 4,8 & 9,5 \\
\hline Волоконно-оптические линии связи (передачи), тыс. км & 3,2 & 5,8 \\
\hline
\end{tabular}

Жилищное строительство. В сентябре 2020 г. возведено 694 многоквартирных дома. Населением построено $31,8^{1)}$ тыс. жилых домов, из них 5,3 тыс. - на земельных участках, предназначенных для ведения садоводства. Всего построено 101,1 тыс. новых квартир (без учета квартир в жилых домах на участках для ведения садоводства - 95,8 тыс.).

В январе-сентябре 2020 г. возведено 4,8 тыс. многоквартирных домов. Населением построено $187,2^{1)}$ тыс. жилых домов, из них 26,1 тыс. - на земельных участках, предназначенных для ведения садоводства. Всего построено 620,8 тыс. новых квартир (без учета квартир в жилых домах на участках для ведения садоводства - 594,7 тыс.).

Общая площадь жилых помещений в построенных индивидуальными застройщиками жилых домах составила 25,1 млн кв. метров (из них 2,5 млн кв. метров - на земельных участках, предназначенных для ведения садоводства), или $52,6 \%$ от общего объема жилья, введенного в январе-сентябре 2020 года.

1) Данные приведень с учетом жильх домов, построенных населением на земельных участках, предназначенных для ведения садоводства. Ранее, до августа 2019 г., такие дома не учитывались. Изменения связаны с тем, что в полном объеме начали действовать нормы Федерального закона от 29.07.2017 № 217-Ф3 "О ведении гражданами садоводства и огородничества для собственных нужд и о внесении изменений в отдельные законодательные актьл Российской Федерации". 
ДИНАМИКА ВВОДА В ДЕЙСТВИЕ ЖИЛЫХ ДОМОВ

\begin{tabular}{|c|c|c|c|}
\hline & \multirow{2}{*}{$\begin{array}{c}\text { Млн } м^{2} \\
\text { общей площуади } \\
\text { жильхх помещчений }\end{array}$} & \multicolumn{2}{|c|}{$B \% \kappa$} \\
\hline & & $\begin{array}{c}\text { соответствуюшему } \\
\text { периоду предыдущчего года }\end{array}$ & $\begin{array}{c}\text { предьлуущему } \\
\text { периоду }\end{array}$ \\
\hline \multicolumn{4}{|c|}{2019 г. } \\
\hline Январь & 4,2 & 84,0 & \\
\hline Февраль & 5,0 & 97,8 & 120,9 \\
\hline Март & 5,6 & 101,9 & 112,2 \\
\hline І квартал & 14,8 & 94,8 & \\
\hline Апрель & 4,8 & 106,8 & 85,0 \\
\hline Май & 4,6 & 130,2 & 95,9 \\
\hline Июнь & 5,9 & 110,8 & 128,2 \\
\hline II квартал & 15,3 & 114,6 & 103,0 \\
\hline I полугодие & 30,1 & 103,9 & \\
\hline Июль & 6,2 & 125,3 & 105,1 \\
\hline $\begin{array}{l}\text { Август } \\
\text { с учетом жильхх домов на участках } \\
\text { для ведения садоводства }\end{array}$ & 6,0 & & \\
\hline $\begin{array}{l}\text { без учета жильх домов на участках } \\
\text { для ведения садоводства }\end{array}$ & 5,8 & 110,6 & 93,0 \\
\hline $\begin{array}{l}\text { Сентябрь } \\
\text { с учетом жильх домов на участках } \\
\text { для ведения садоводства }\end{array}$ & 6,6 & & 109,6 \\
\hline $\begin{array}{l}\text { без учета жильх домов на участках } \\
\text { для ведения садоводства }\end{array}$ & 6,5 & 103,1 & 112,3 \\
\hline $\begin{array}{l}\text { III квартал } \\
\text { с учетом жильх домов на участках } \\
\text { для ведения садоводства }\end{array}$ & 18,8 & & \\
\hline $\begin{array}{l}\text { без учета жильх домов на участках } \\
\text { для ведения садоводства }\end{array}$ & 18,5 & 112,1 & 120,6 \\
\hline $\begin{array}{l}\text { Январь-сентябрь } \\
\text { с учетом жильх домов на участках } \\
\text { для ведения садоводства }\end{array}$ & 48,9 & & \\
\hline $\begin{array}{l}\text { без учета жильх домов на участках } \\
\text { для ведения садоводства }\end{array}$ & 48,6 & 106,9 & \\
\hline $\begin{array}{l}\text { Октябрь } \\
\text { с учетом жильх домов на участках } \\
\text { для ведения садоводства }\end{array}$ & 6,7 & & 102,2 \\
\hline $\begin{array}{l}\text { без учета жильх домов на участках } \\
\text { для ведения садоводства }\end{array}$ & 6,5 & 110,9 & 100,8 \\
\hline $\begin{array}{l}\text { Ноябрь } \\
\text { с учетом жильх домов на участках } \\
\text { для ведения садоводства }\end{array}$ & 7,9 & & 117,7 \\
\hline $\begin{array}{l}\text { без учета жильх домов на участках } \\
\text { для ведения садоводства }\end{array}$ & 7,8 & 113,7 & 119,0 \\
\hline $\begin{array}{l}\text { Декабрь } \\
\text { с учетом жильх домов на участках } \\
\text { для ведения садоводства }\end{array}$ & 18,5 & & в 2,3p. \\
\hline $\begin{array}{l}\text { без учета жильх домов на участках } \\
\text { для ведения садоводства }\end{array}$ & 17,4 & 99,8 & в 2,2p. \\
\hline
\end{tabular}




\begin{tabular}{|c|c|c|c|}
\hline & \multirow{2}{*}{$\begin{array}{c}\text { Млн } м^{2} \\
\text { общей площади } \\
\text { жильх помещений } \\
\end{array}$} & \multicolumn{2}{|c|}{ 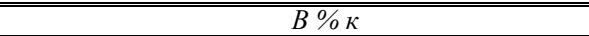 } \\
\hline & & $\begin{array}{c}\text { соответствующему } \\
\text { периоду предьдущего года }\end{array}$ & $\begin{array}{c}\text { предыцдущему } \\
\text { периоду }\end{array}$ \\
\hline IV квартал & & & \\
\hline $\begin{array}{l}\text { с учетом жсилых домов на участках } \\
\text { для ведения садоводства }\end{array}$ & 33,1 & & 176,4 \\
\hline $\begin{array}{l}\text { без учета жилых домов на участках } \\
\text { для ведения садоводства }\end{array}$ & 31,7 & 105,1 & 172,0 \\
\hline Год & & & \\
\hline $\begin{array}{l}\text { с учетом жильх домов на участках } \\
\text { для ведения садоводства }\end{array}$ & 82,0 & & \\
\hline $\begin{array}{l}\text { без учета жилых домов на участках } \\
\text { для ведения садоводства }\end{array}$ & 80,3 & 106,2 & \\
\hline \multicolumn{4}{|c|}{2020 г. } \\
\hline $\begin{array}{l}\text { Январь } \\
\text { с учетом жильхх домов на участках } \\
\text { для ведения садоводства }\end{array}$ & 5,0 & & \\
\hline $\begin{array}{l}\text { без учета жилых домов на участках } \\
\text { для ведения садоводства }\end{array}$ & 4,8 & 114,3 & \\
\hline $\begin{array}{l}\text { Февраль } \\
\text { с учетом жильх домов на участках } \\
\text { для ведения садоводства }\end{array}$ & 4,9 & & 99,0 \\
\hline $\begin{array}{l}\text { без учета жилых домов на участках } \\
\text { для ведения садоводства }\end{array}$ & 4,6 & 93,0 & 98,4 \\
\hline $\begin{array}{l}\text { Март } \\
\text { с учетом жильх домов на участках } \\
\text { для ведения садоводства }\end{array}$ & 5,5 & & 110,8 \\
\hline $\begin{array}{l}\text { без учета жилых домов на участках } \\
\text { для ведения садоводства }\end{array}$ & 5,3 & 92,4 & 111,2 \\
\hline $\begin{array}{l}\text { I квартал } \\
\text { с учетом жильх домов на участках } \\
\text { для ведения садоводства }\end{array}$ & 15,4 & & \\
\hline $\begin{array}{l}\text { без учета жилых домов на участках } \\
\text { для ведения садоводства }\end{array}$ & 14,7 & 98,7 & \\
\hline $\begin{array}{l}\text { Апрель } \\
\text { с учетом жильх домов на участках } \\
\text { для ведения садоводства }\end{array}$ & 3,2 & & 58,6 \\
\hline $\begin{array}{l}\text { без учета жилых домов на участках } \\
\text { для ведения садоводства }\end{array}$ & 3,0 & 63,5 & 58,5 \\
\hline $\begin{array}{l}\text { Май } \\
\text { с учетом жильх домов на участках } \\
\text { для ведения садоводства }\end{array}$ & 3,6 & & 113,9 \\
\hline $\begin{array}{l}\text { без учета жилых домов на участках } \\
\text { для ведения садоводства }\end{array}$ & 3,5 & 75,6 & 114,2 \\
\hline $\begin{array}{l}\text { Июнь } \\
\text { с учетом жильх домов на участках } \\
\text { для ведения садоводства }\end{array}$ & 5,8 & & 158,4 \\
\hline $\begin{array}{l}\text { без учета жилых домов на участках } \\
\text { для ведения садоводства }\end{array}$ & 5,5 & 93,6 & 158,7 \\
\hline $\begin{array}{l}\text { ІІ квартал } \\
\text { с учетом жильх домов на участках } \\
\text { для ведения садоводства }\end{array}$ & 12,6 & & 82,0 \\
\hline $\begin{array}{l}\text { без учета жилых домов на участках } \\
\text { для ведения садоводства }\end{array}$ & 12,0 & 78,8 & 82,2 \\
\hline
\end{tabular}




\begin{tabular}{|c|c|c|c|}
\hline & \multirow{2}{*}{$\begin{array}{c}\text { Млн } м^{2} \\
\text { общей площади } \\
\text { жильхх помещений }\end{array}$} & \multicolumn{2}{|c|}{$\bar{B} \% \kappa$} \\
\hline & & $\begin{array}{c}\text { соответствуюшему } \\
\text { периоду предьдуущего года }\end{array}$ & $\begin{array}{c}\text { предыдучему } \\
\text { периоду }\end{array}$ \\
\hline I полугодие & & & \\
\hline $\begin{array}{l}\text { с учетом жилых домов на участках } \\
\text { для ведения садоводства }\end{array}$ & 28,0 & & \\
\hline $\begin{array}{l}\text { без учета жилых домов на участках } \\
\text { для ведения садоводства }\end{array}$ & 26,7 & 88,6 & \\
\hline $\begin{array}{l}\text { Июль } \\
\text { с учетом жильх домов на участках } \\
\text { для ведения садоводства }\end{array}$ & 5,6 & & 97,2 \\
\hline $\begin{array}{l}\text { без учета жилых домов на участках } \\
\text { для ведения садоводства }\end{array}$ & 5,3 & 85,1 & 95,5 \\
\hline $\begin{array}{l}\text { Август } \\
\text { с учетом жилых домов на участках } \\
\text { для ведения садоводства }\end{array}$ & 6,4 & 107,5 & 115,0 \\
\hline $\begin{array}{l}\text { без учета жилых домов на участках } \\
\text { для ведения садоводства }\end{array}$ & 6,0 & 104,9 & 114,7 \\
\hline $\begin{array}{l}\text { Сентябрь } \\
\text { с учетом жильх домов на участках } \\
\text { для ведения садоводства }\end{array}$ & 7,8 & 118,4 & 120,8 \\
\hline $\begin{array}{l}\text { без учета жилых домов на участках } \\
\text { для ведения садоводства }\end{array}$ & 7,3 & 112,9 & 120,3 \\
\hline $\begin{array}{l}\text { III квартал } \\
\text { с учетом жильх домов на участках } \\
\text { для ведения садоводства }\end{array}$ & 19,8 & 105,7 & 157,4 \\
\hline $\begin{array}{l}\text { без учета жилых домов на участках } \\
\text { для ведения садоводства }\end{array}$ & 18,6 & 100,9 & 154,5 \\
\hline $\begin{array}{l}\text { Январь-сентябрь } \\
\text { с учетом жильх домов на участках } \\
\text { для ведения садоводства }\end{array}$ & 47,8 & 97,7 & \\
\hline $\begin{array}{l}\text { без учета жилых домов на участках } \\
\text { для ведения садоводства }\end{array}$ & 45,3 & 93,3 & \\
\hline
\end{tabular}

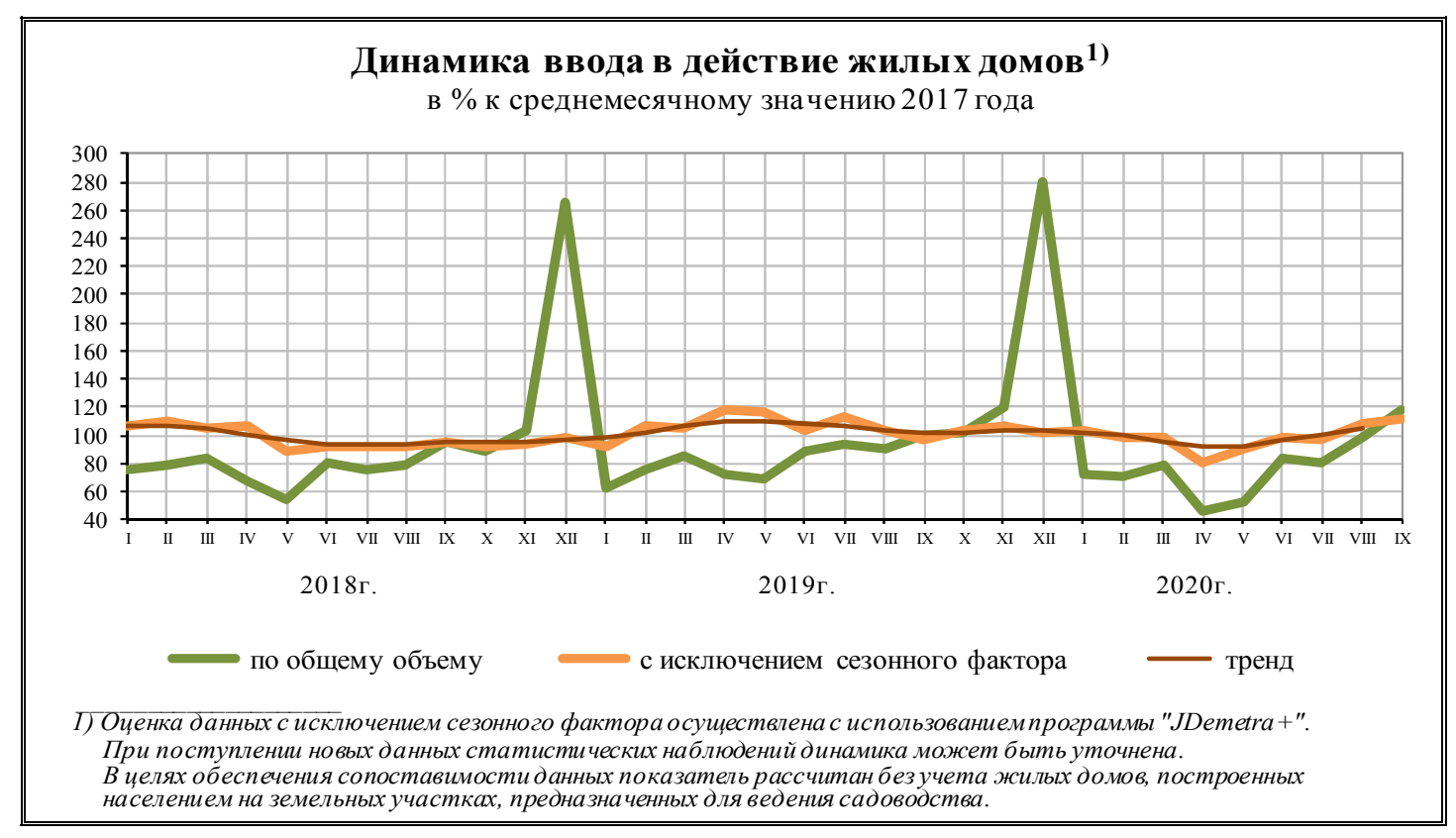




\section{Строительство объектов социально-культурной сферы.}

ВВОД В ДЕЙСТВИЕ МОЩНОСТЕЙ И ОБЪЕКТОВ СОЦИАЛЬНО-КУЛЬТУРНОЙ СФЕРЫ

\begin{tabular}{|c|c|c|}
\hline & $\begin{array}{l}\text { Январь-сентябрь } \\
2020 \text { г. }\end{array}$ & \begin{tabular}{|c|} 
Справочно \\
январь-сентябрь 2019 2.
\end{tabular} \\
\hline Газовые сети, км & 3044,8 & 3215,2 \\
\hline Тепловые сети, км & 40,2 & 129,2 \\
\hline Водопровод, км & 536,1 & 399,1 \\
\hline Канализация, км & 125,1 & 156,3 \\
\hline Гостиницы, мест & 5821 & 7331 \\
\hline Санатории, коек & 80 & 541 \\
\hline Дома отдыха, мест & 579 & 1145 \\
\hline $\begin{array}{l}\text { Образовательные организации высшего образования, } \\
\text { тыс. м² общей площади учебно-лабораторных зданий }\end{array}$ & 5,1 & 51,3 \\
\hline $\begin{array}{l}\text { Профессиональные образовательные организации, } \\
\text { тыс. м² общей площади учебно-лабораторных зданий }\end{array}$ & 16,8 & 6,3 \\
\hline Общеобразовательные организации, тыс. ученических мест & 81,8 & 87,5 \\
\hline Дошкольные образовательные организации, тыс. мест & 43,1 & 34,5 \\
\hline Больничные организации, коек & 2136 & 1092 \\
\hline $\begin{array}{l}\text { Амбулаторно-поликлинические организации, } \\
\text { посещений в смену }\end{array}$ & 13038 & 5809 \\
\hline $\begin{array}{l}\text { Дома-интернаты для престарелых, } \\
\text { инвалидов (взрослых и детей), мест }\end{array}$ & 352 & 529 \\
\hline Учреждения культуры клубного типа, мест & 5101 & 4747 \\
\hline Торгово-развлекательные центры, тыс. м² общей площади & 557,5 & 294,0 \\
\hline Торгово-офисные центры, тыс. м² общей площади & 351,0 & 633,3 \\
\hline Торгово-выставочные комплексы, тыс. м² общей площади & 64,9 & 138,3 \\
\hline Культовые сооружения, единиц & 163 & 149 \\
\hline Театры, мест & 250 & 550 \\
\hline Концертные и киноконцертные залы, мест & 989 & 100 \\
\hline
\end{tabular}

В январе-сентябре 2020 г. введены следующие объекты туризма и спорта: туристские базы на 510 мест, мотели на 298 мест, кемпинги на 30 мест, 15 плавательных бассейнов с длиной дорожек 25 метров и 50 метров, 14 спортивных сооружений с искусственным льдом, 60 физкультурнооздоровительных комплексов, спортивные залы площадью 79,9 тыс. кв. метров, стадионы на 5,3 тыс. мест. 


\subsection{TPAНСПОРT}

Грузовые перевозки. В январе-сентябре 2020 г. грузооборот транспорта, по предварительным данным, составил 3980,6 млрд тонно-километров, в том числе железнодорожного 1876,9 млрд, автомобильного - 192,3 млрд, морского - 30,1 млрд, внутреннего водного - 52,6 млрд, воздушного - 4,9 млрд, трубопроводного - 1823,8 млрд тонно-километров.

Таблица 1

ГРУЗООБОРОТ ПО ВИДАМ ТРАНСПОРТА

\begin{tabular}{|c|c|c|c|c|c|c|c|}
\hline & \multirow{3}{*}{$\begin{array}{c}\text { Сентябрь } \\
2020 \text { г., } \\
\text { млрд } \\
\text { т-км }\end{array}$} & \multicolumn{2}{|c|}{$B \% \kappa$} & \multirow{3}{*}{$\begin{array}{c}\text { Январь- } \\
\text { сентябрь } \\
2020 \text { г. } \\
\text { в\% } \\
\text { январю- } \\
\text { сентябрю } \\
20192 .\end{array}$} & \multicolumn{3}{|c|}{ Справочно } \\
\hline & & \multirow{2}{*}{$\begin{array}{c}\text { сентябрю } \\
20192 .\end{array}$} & \multirow{2}{*}{$\begin{array}{l}\text { aвгусmy } \\
2020 \text { 2. }\end{array}$} & & \multicolumn{2}{|c|}{ сентябрь 2019 г. в \% к } & \multirow[b]{2}{*}{$\begin{array}{c}\text { январь- } \\
\text { сентябрь } \\
2019 \text { г. } \\
\text { в\% к } \\
\text { январю- } \\
\text { сентябрю } \\
20182 . \\
\end{array}$} \\
\hline & & & & & $\begin{array}{c}\text { сентябрюо } \\
20182 .\end{array}$ & $\begin{array}{l}\text { августу } \\
20192 .\end{array}$ & \\
\hline Грузооборот транспорта & 449,1 & 96,6 & 100,3 & 94,1 & 100,6 & 98,7 & 101,2 \\
\hline в том числе: & & & & & & & \\
\hline железнодорожного & 211,8 & 99,5 & 97,6 & 96,4 & 101,4 & 99,5 & 100,9 \\
\hline автомобильного & 22,5 & 90,5 & 94,3 & 95,3 & 103,3 & 100,7 & 106,1 \\
\hline морского & 4,6 & 119,4 & 125,5 & 107,2 & 93,0 & 109,8 & 101,8 \\
\hline внутреннего водного & 10,9 & 134,5 & 140,6 & 97,3 & 101,5 & 92,0 & 100,3 \\
\hline $\begin{array}{l}\text { воздушного } \\
\text { (транспортная авиация) }^{1)}\end{array}$ & 0,6 & 91,5 & 99,2 & 91,7 & 91,7 & 106,3 & 92,9 \\
\hline трубопроводного & 198,7 & 92,6 & 102,0 & 91,5 & 99,6 & 97,8 & 101,0 \\
\hline
\end{tabular}

ДИНАМИКА ГРУЗООБОРОТА ТРАНСПОРТА

\begin{tabular}{|c|c|c|c|}
\hline & \multirow[t]{2}{*}{ Млрд т-км } & \multicolumn{2}{|c|}{$\bar{B} \% \mathrm{~K}$} \\
\hline & & $\begin{array}{c}\text { соответствуюшему } \\
\text { периоду предьдущего года }\end{array}$ & $\begin{array}{c}\text { предылущему } \\
\text { периоду }\end{array}$ \\
\hline \multicolumn{4}{|c|}{2019 г. } \\
\hline Январь & 481,7 & 102,4 & 97,9 \\
\hline Февраль & 439,4 & 101,9 & 91,2 \\
\hline Март & 494,9 & 102,5 & 112,6 \\
\hline І квартал & 1416,0 & 102,3 & 97,4 \\
\hline Апрель & 476,0 & 102,6 & 96,2 \\
\hline Май & 478,1 & 101,0 & 100,5 \\
\hline Июнь & 455,7 & 100,6 & 95,3 \\
\hline ІІ квартал & 1409,8 & 101,4 & 99,6 \\
\hline I полугодие & 2825,8 & 101,9 & \\
\hline
\end{tabular}




\begin{tabular}{|c|c|c|c|}
\hline & \multirow[t]{2}{*}{ Млрд m-км } & \multicolumn{2}{|c|}{ 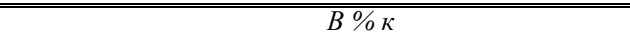 } \\
\hline & & $\begin{array}{c}\text { соответствующему } \\
\text { периоду предьдущего года }\end{array}$ & $\begin{array}{l}\text { предыдущему } \\
\text { периоду }\end{array}$ \\
\hline Июль & 468,7 & 99,2 & 102,9 \\
\hline Август & 470,9 & 99,8 & 100,5 \\
\hline Сентябрь & 464,8 & 100,6 & 98,7 \\
\hline ІІІ квартал & 1404,4 & 99,8 & 99,6 \\
\hline Январь-сентябрь & 4230,2 & 101,2 & \\
\hline Октябрь & 489,6 & 100,3 & 105,3 \\
\hline Ноябрь & 468,6 & 98,8 & 95,7 \\
\hline Декабрь & 485,5 & 98,7 & 103,6 \\
\hline IV квартал & 1443,7 & 99,3 & 102,8 \\
\hline Год & 5674,0 & 100,7 & \\
\hline \multicolumn{4}{|c|}{2020 г. } \\
\hline Январь & 462,4 & 96,0 & 95,2 \\
\hline Февраль & 437,3 & 99,5 & 94,6 \\
\hline Март & 461,6 & 93,3 & 105,5 \\
\hline І квартал & 1361,3 & 96,1 & 94,3 \\
\hline Апрель & 447,6 & 94,0 & 97,0 \\
\hline Май & 433,0 & 90,6 & 96,7 \\
\hline Июнь & 412,1 & 90,4 & 95,2 \\
\hline ІІ квартал & 1292,7 & 91,7 & 95,0 \\
\hline I полугодие ${ }^{I)}$ & 2654,0 & 93,9 & \\
\hline Июль & 429,9 & 91,7 & 104,3 \\
\hline Август ${ }^{1)}$ & 447,7 & 95,1 & 104,1 \\
\hline Сентябрь & 449,1 & 96,6 & 100,3 \\
\hline ІІІ квартал & 1326,6 & 94,5 & 102,6 \\
\hline Январь-сентябрь & 3980,6 & 94,1 & \\
\hline
\end{tabular}

Таблица 3

\section{ПЕРЕВОЗКИ ГРУЗОВ ТРАНСПОРТОМ}

\begin{tabular}{|c|c|c|c|c|c|c|c|}
\hline & \multirow{3}{*}{$\begin{array}{l}\text { Сентяббрь } \\
2020 \text { г., } \\
\text { млн тонн }\end{array}$} & \multicolumn{2}{|c|}{$\overline{B \% \kappa}$} & \multirow{3}{*}{\begin{tabular}{c|} 
Январь- \\
сентябрь \\
2020 г. \\
в\% к \\
январю- \\
сентябрю \\
20192.
\end{tabular}} & \multicolumn{3}{|c|}{ Справочно } \\
\hline & & \multirow{2}{*}{$\begin{array}{c}\text { сентяябрю } \\
20192 .\end{array}$} & \multirow{2}{*}{$\begin{array}{l}\text { августу } \\
2020 \text {. }\end{array}$} & & \multirow{2}{*}{$\begin{array}{c}\text { сентябрь } 2 \\
\text { сентябрю } \\
2018 \text { г. }\end{array}$} & \multirow{2}{*}{$\begin{array}{l}92.6 \% \kappa \\
\text { aвzуcmy } \\
20192 .\end{array}$} & \multirow[b]{2}{*}{$\begin{array}{c}\text { январь- } \\
\text { сентябрь } \\
2019 \text { г. } \\
\text { в\% \% } \\
\text { январю- } \\
\text { сентябрю } \\
2018 \text { г. }\end{array}$} \\
\hline & & & & & & & \\
\hline Перевозки грузов транспортом & 712,0 & 89,3 & 98,0 & 93,4 & 105,5 & 100,1 & 101,8 \\
\hline $\begin{array}{c}\text { в том числе: } \\
\text { железнодорожным }\end{array}$ & 105,3 & 99,3 & 97,4 & 96,4 & 101,0 & 97,3 & 99,1 \\
\hline
\end{tabular}




\begin{tabular}{|c|c|c|c|c|c|c|c|}
\hline & \multirow{3}{*}{$\begin{array}{c}\text { Сентябрь } \\
2020 \text { г., } \\
\text { млн тонн }\end{array}$} & \multicolumn{2}{|c|}{$\bar{B} \bar{c} \%$} & \multirow{3}{*}{$\begin{array}{c}\text { Январь- } \\
\text { сентябрь } \\
2020 \text { г. } \\
\text { в\% к } \\
\text { январю- } \\
\text { сентябрю } \\
20192 .\end{array}$} & \multicolumn{3}{|c|}{ Справочно } \\
\hline & & \multirow{2}{*}{$\begin{array}{c}\text { сентябрю } \\
2019 \text { г. }\end{array}$} & \multirow{2}{*}{$\begin{array}{c}\text { августу } \\
2020 \text { г. }\end{array}$} & & \multirow{2}{*}{\begin{tabular}{|c|} 
сентяябрь 2 \\
сентябрю \\
2018 г.
\end{tabular}} & \multirow{2}{*}{$\begin{array}{c}\frac{19 \text { г. в\% \% }}{\text { августу }} \\
2019 \text { г. }\end{array}$} & \multirow[b]{2}{*}{$\begin{array}{c}\text { январь- } \\
\text { сентябрь } \\
2019 \text { г. } \\
\text { в\% \% } \\
\text { январю- } \\
\text { сентябрю } \\
2018 \text { г. }\end{array}$} \\
\hline & & & & & & & \\
\hline автомобильным & 502,5 & 86,0 & 96,6 & 93,2 & 108,1 & 101,4 & 103,4 \\
\hline морским & 2,6 & 150,5 & 122,5 & 120,9 & 76,7 & 96,8 & 80,2 \\
\hline внутренним водным & 19,7 & 136,6 & 134,2 & 99,8 & 89,5 & 86,0 & 92,5 \\
\hline $\begin{array}{l}\text { воздушным } \\
(\text { (транспортная авиация) })^{1)}\end{array}$ & 0,1 & 104,0 & 108,4 & 97,5 & 93,7 & 104,2 & 95,8 \\
\hline трубопроводным & 81,7 & 90,4 & 100,8 & 90,4 & 98,7 & 98,1 & 99,2 \\
\hline в том числе: & & & & & & & \\
\hline газ & 38,2 & 97,0 & 103,3 & 88,8 & 96,5 & 101,6 & 97,2 \\
\hline нефть & 40,2 & 84,0 & 98,7 & 91,1 & 101,3 & 96,0 & 101,5 \\
\hline нефтепродукты & 3,3 & 106,2 & 97,9 & 101,4 & 88,7 & 87,8 & 94,6 \\
\hline
\end{tabular}

Пассажирские перевозки. Пассажирооборот транспорта общего пользования в январе-сентябре 2020 г. составил 240,2 млрд пасс.-километров, в том числе железнодорожного 61,2 млрд, автомобильного - 58,9 млрд, воздушного - 119,9 млрд пасс.-километров.

ПАССАЖИРООБОРОТ

ТРАНСПОРТА ОБЩЕГО ПОЛЬЗОВАНИЯ

\begin{tabular}{|c|c|c|c|c|c|c|c|}
\hline & \multirow{2}{*}{$\begin{array}{c}\text { Сентябрь } \\
2020 \text { г., } \\
\text { млрд } \\
\text { пасс.-км }\end{array}$} & \multicolumn{2}{|c|}{$\bar{B} \bar{c} \% \kappa$} & \multirow[b]{2}{*}{$\begin{array}{c}\text { Январь- } \\
\text { сентябрь } \\
2020 \text { г. } \\
\text { в\% \% } \\
\text { январю- } \\
\text { сентябрю } \\
2019 \text { г. }\end{array}$} & \multicolumn{3}{|c|}{ Справочно } \\
\hline & & $\begin{array}{c}\text { сентябрю } \\
2019 \text { г. }\end{array}$ & $\begin{array}{c}\text { августу } \\
2020 \text { г. }\end{array}$ & & \begin{tabular}{|l|} 
сентябрь 22 \\
сентябрю \\
2018 г. \\
\end{tabular} & \begin{tabular}{|l|}
19 2. $6 \% \mathrm{~K}$ \\
aвzycmy \\
2019 z.
\end{tabular} & $\begin{array}{c}\text { январь- } \\
\text { сентябрь } \\
2019 \text { г. } \\
\text { в\% к } \\
\text { январю- } \\
\text { сентябрю } \\
2018 \text { г. }\end{array}$ \\
\hline $\begin{array}{l}\text { Пассажирооборот транспорта } \\
\text { общего пользования }{ }^{1)}\end{array}$ & 33,7 & 62,7 & 90,6 & 54,9 & 105,7 & 85,8 & 107,5 \\
\hline $\begin{array}{l}\text { в том числе: } \\
\text { железнодорожного }\end{array}$ & 8,2 & 68,3 & 74,3 & 58,4 & 100,7 & 69,4 & 103,2 \\
\hline автомобильного (автобусы) & 7,8 & 80,2 & 108,4 & 69,8 & 98,7 & 100,5 & 98,5 \\
\hline $\begin{array}{l}\text { воздушного } \\
\text { (транспортная авиация) })^{2)}\end{array}$ & 17,6 & 55,1 & 93,1 & 48,3 & 110,1 & 89,9 & 113,1 \\
\hline
\end{tabular}


ДИНАМИКА ПАССАЖИРООБОРОТА

ТРАНСПОРТА ОБЩЕГО ПОЛЬЗОВАНИЯ ${ }^{1)}$

\begin{tabular}{|c|c|c|c|}
\hline & \multirow{2}{*}{$\begin{array}{c}\text { Млрд } \\
\text { пасс.-км }\end{array}$} & \multicolumn{2}{|c|}{$\overline{B \% \kappa}$} \\
\hline & & $\begin{array}{c}\text { соответствующему } \\
\text { периоду предырущего года }\end{array}$ & $\begin{array}{c}\text { предырушщему } \\
\text { периоду }\end{array}$ \\
\hline \multicolumn{4}{|c|}{2019 г. } \\
\hline Январь & 39,8 & 106,5 & 99,2 \\
\hline Февраль & 35,4 & 106,8 & 88,8 \\
\hline Март & 41,5 & 110,1 & 117,4 \\
\hline I квартал & 116,7 & 107,8 & 93,6 \\
\hline Апрель & 41,8 & 107,2 & 100,6 \\
\hline Май & 47,1 & 111,2 & 112,7 \\
\hline Июнь & 54,1 & 107,0 & 115,0 \\
\hline II квартал & 143,0 & 108,4 & 122,5 \\
\hline I полугодие & 259,7 & 108,1 & \\
\hline Июль & 61,7 & 107,2 & 114,1 \\
\hline Август & 62,7 & 107,0 & 101,5 \\
\hline Сентябрь & 53,8 & 105,7 & 85,8 \\
\hline ІІІ квартал & 178,2 & 106,6 & 124,7 \\
\hline Январь-сентябрь & 437,9 & 107,5 & \\
\hline Октябрь & 48,1 & 108,4 & 89,3 \\
\hline Ноябрь & 42,3 & 105,1 & 88,0 \\
\hline Декабрь & 42,3 & 105,4 & 100,0 \\
\hline IV квартал & 132,6 & 106,4 & 74,4 \\
\hline Год & 570,5 & 107,3 & \\
\hline \multicolumn{4}{|c|}{2020 г. } \\
\hline Январь & 42,4 & 106,5 & 100,3 \\
\hline Февраль & 37,3 & 105,6 & 88,0 \\
\hline Март & 31,5 & 75,9 & 84,4 \\
\hline I квартал & 111,2 & 95,3 & 83,9 \\
\hline Апрель & 6,7 & 16,1 & 21,4 \\
\hline Май & 8,2 & 17,5 & 122,4 \\
\hline Июнь & 15,3 & 28,3 & 186,1 \\
\hline ІІ квартал & 30,3 & 21,2 & 27,3 \\
\hline I полугодие & 141,5 & 54,5 & \\
\hline Июль & 27,7 & 44,9 & 180,7 \\
\hline Август ${ }^{2)}$ & 37,2 & 59,4 & 134,4 \\
\hline
\end{tabular}




\begin{tabular}{|c|c|c|c|}
\hline & \multirow{2}{*}{$\begin{array}{c}\text { Млрд } \\
\text { пасс.-км }\end{array}$} & \multicolumn{2}{|c|}{$\bar{B} \overline{0 \% \kappa}$} \\
\hline & & $\begin{array}{c}\text { соответствуюшему } \\
\text { периоду предыдущего года }\end{array}$ & $\begin{array}{c}\text { предьлуциему } \\
\text { периоду }\end{array}$ \\
\hline Сентябрь & 33,7 & 62,7 & 90,6 \\
\hline ІІІ квартал & 98,7 & 55,3 & в $3,2 p$. \\
\hline Январь-сентябрь & 240,2 & 54,9 & \\
\hline
\end{tabular}

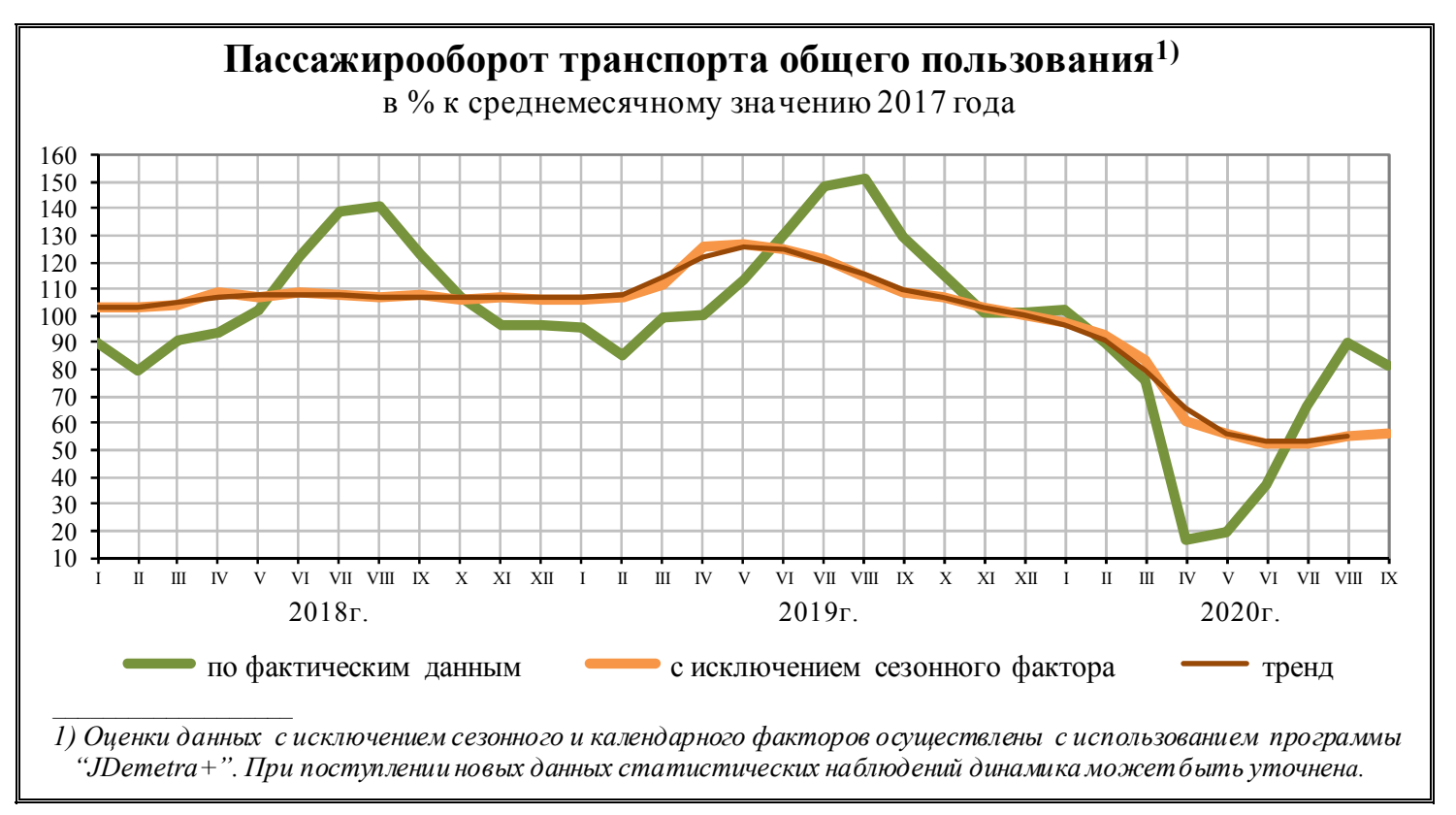

\section{Аварийность на транспорте.}

\section{ЧИСЛО ПРОИСШЕСТВИЙ, ПОГИБШИХ И РАНЕНЫХ НА ТРАНСПОРТЕ} в январе-сентябре

\begin{tabular}{|c|c|c|c|c|c|c|}
\hline & \multicolumn{2}{|c|}{$\begin{array}{c}\text { Число происшествий, } \\
\text { единии }\end{array}$} & \multicolumn{2}{|c|}{$\begin{array}{c}\text { Число погибших, } \\
\text { человек }\end{array}$} & \multicolumn{2}{|c|}{$\begin{array}{l}\text { Число раненыхх, } \\
\text { человек }\end{array}$} \\
\hline & 20202. & $\frac{\text { cправочно }}{2019 \text { г. }}$ & 20202. & $\frac{\text { справочно }}{2019 \text { г. }}$ & 2020 2. & $\frac{\text { справочно }}{2019 \text { 2. }}$ \\
\hline $\begin{array}{l}\text { На железнодорожном транспорте } \\
\text { общего пользования }{ }^{1,2)}\end{array}$ & 6 & 13 & - & 2 & - & - \\
\hline На автомобильных дорогах и улицах, тысяч & 105,9 & 118,1 & 11,4 & 11,9 & 134,5 & 152,7 \\
\hline На морском транспорте ${ }^{1,4)}$ & 22 & 32 & 2 & 11 & 1 & 2 \\
\hline На внутреннем водном транспорте ${ }^{1)}$ & 2 & 2 & 2 & 1 & - & - \\
\hline На воздушном транспорте ${ }^{5)}$ & 30 & 24 & 26 & 66 & 27 & 100 \\
\hline \multicolumn{7}{|c|}{$\begin{array}{l}\text { 1) По данным Ространснадзора. } \\
\text { 2) Данные за январь-август. } \\
\text { 3) По данным МВД России. } \\
\text { 4) Без учета аварийных случаев с рыбопромысловыми судами. } \\
\text { 5) По данным Росавиачии. }\end{array}$} \\
\hline
\end{tabular}




\section{2. РЫНКИ ТОВАРОВ И УСЛУГ}

\section{1. РОЗНИЧНАЯ ТОРГОВЛЯ}

Оборот розничной торговли в сентябре 2020 г. составил 2897,3 млрд рублей, или $97,0 \%$ (в сопоставимых ценах) к уровню соответствующего периода предыдущего года, в январе-сентябре 2020 г. - 23925,5 млрд рублей, или 95,2\%.

Таблица 1

ДИНАМИКА ОБОРОТА РОЗНИЧНОЙ ТОРГОВЛИ

\begin{tabular}{|c|c|c|c|}
\hline & \multirow[t]{2}{*}{ 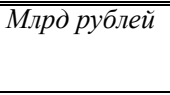 } & \multicolumn{2}{|c|}{ 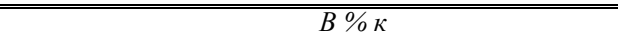 } \\
\hline & & $\begin{array}{c}\text { соответствующему } \\
\text { периоду предыдущего года }\end{array}$ & $\begin{array}{c}\text { предыдущему } \\
\text { периоду }\end{array}$ \\
\hline \multicolumn{4}{|c|}{2019 Г. } \\
\hline Январь & 2507,5 & 102,2 & 75,1 \\
\hline Февраль & 2454,6 & 102,3 & 97,4 \\
\hline Март & 2690,4 & 102,4 & 109,2 \\
\hline І квартал & 7652,5 & 102,3 & 85,0 \\
\hline Апрель & 2656,9 & 102,0 & 98,5 \\
\hline Май & 2703,2 & 101,9 & 101,5 \\
\hline Июнь & 2741,0 & 101,8 & 101,5 \\
\hline II квартал & 8101,1 & 101,9 & 105,0 \\
\hline I полугодие & 15753,6 & 102,1 & \\
\hline Июль & 2807,0 & 101,5 & 102,4 \\
\hline Август & 2897,5 & 101,1 & 103,4 \\
\hline Сентябрь & 2856,2 & 100,9 & 98,7 \\
\hline ІІІ квартал & 8560,7 & 101,2 & 105,8 \\
\hline Январь-сентябрь & 24314,3 & 101,8 & \\
\hline Октябрь & 2904,6 & 101,9 & 101,4 \\
\hline Ноябрь & 2932,5 & 102,6 & 100,5 \\
\hline Декабрь & 3472,9 & 101,8 & 118,0 \\
\hline IV квартал & 9310,0 & 102,1 & 108,2 \\
\hline Год & 33624,3 & 101,9 & \\
\hline \multicolumn{4}{|c|}{2020 г. } \\
\hline Январь & 2639,8 & 102,7 & 75,7 \\
\hline Февраль & 2628,9 & 104,7 & 99,3 \\
\hline Март & 2917,5 & 105,7 & 110,2 \\
\hline І квартал & 8186,2 & 104,4 & 86,9 \\
\hline Апрель & 2125,3 & 77,4 & 72,1 \\
\hline Май & 2273,6 & 81,4 & 106,7 \\
\hline Июнь & 2642,5 & 92,9 & 115,8 \\
\hline ІІ квартал & 7041,4 & 84,0 & 84,5 \\
\hline I полугодие & 15227,6 & 93,9 & \\
\hline
\end{tabular}




\begin{tabular}{|c|c|c|c|}
\hline & \multirow[t]{2}{*}{ Млрд рублей } & \multicolumn{2}{|c|}{$\overline{B \% \kappa}$} \\
\hline & & $\begin{array}{c}\text { соответствующему } \\
\text { периоду предьдучщего года }\end{array}$ & $\begin{array}{c}\text { предырушему } \\
\text { периоду }\end{array}$ \\
\hline Июль & 2861,5 & 98,1 & 108,1 \\
\hline Август & 2939,1 & 97,3 & 102,7 \\
\hline Сентябрь & 2897,3 & 97,0 & 98,3 \\
\hline ІІІ квартал & 8697,9 & 97,5 & 122,8 \\
\hline Январь-сентябрь & 23925,5 & 95,2 & \\
\hline
\end{tabular}

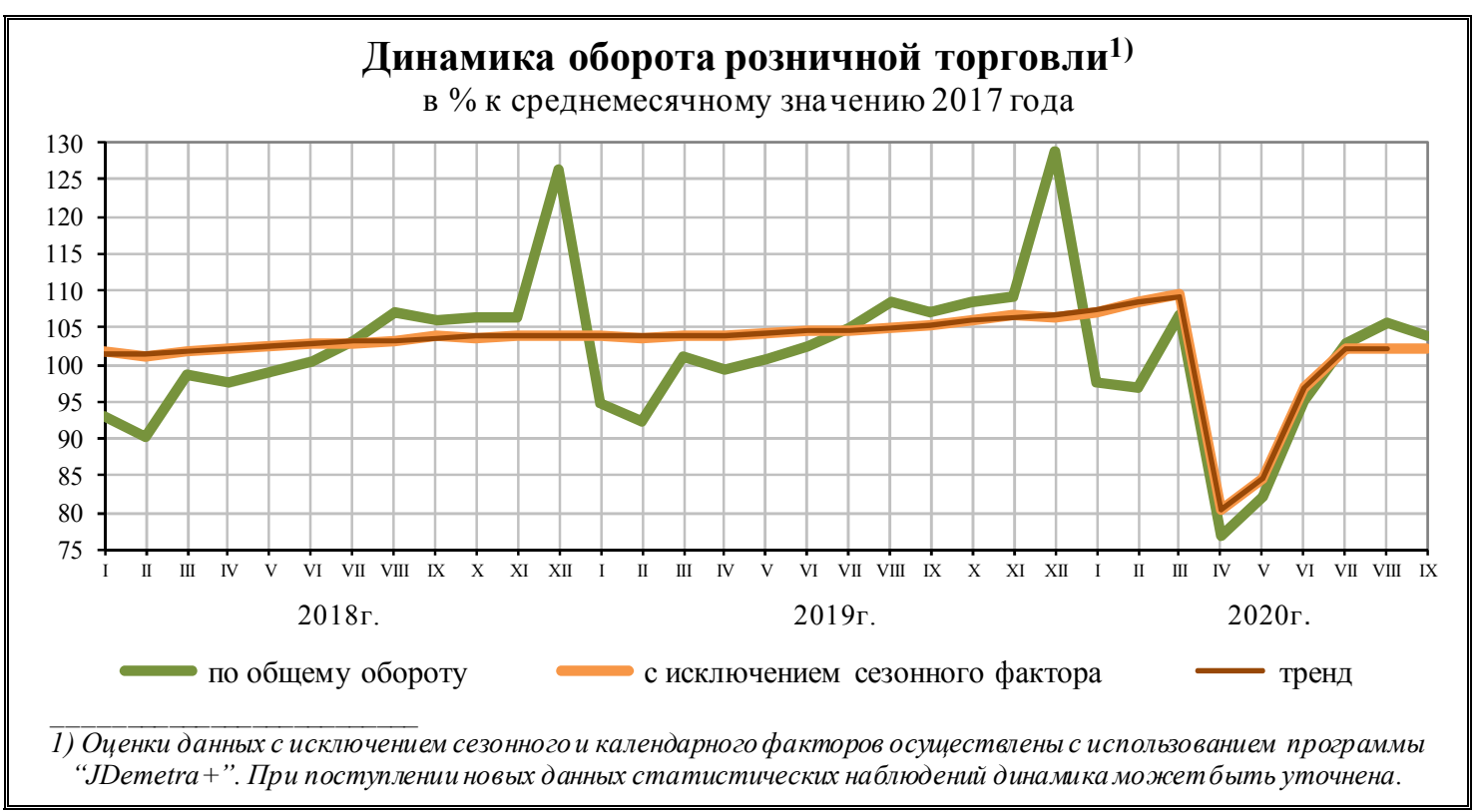

В сентябре 2020 г. оборот розничной торговли на 94,9\% формировался торгующими организациями и индивидуальными предпринимателями, осуществляющими деятельность вне рынка, доля розничных рынков и ярмарок составила 5,1\% (в сентябре 2019 г. - 94,5\% и 5,5\% соответственно).

ОБОРОТ РОЗНИЧНОЙ ТОРГОВЛИ ТОРГУЮЩИХ ОРГАНИЗАЦИЙ И ПРОДАЖА ТОВАРОВ НА РОЗНИЧНЫХ РЫНКАХ И ЯРМАРКАХ

\begin{tabular}{|c|c|c|c|c|c|c|c|}
\hline & \multirow{3}{*}{$\begin{array}{l}\text { Сентябрь } \\
2020 \text { г., } \\
\text { млрд } \\
\text { рублей }\end{array}$} & \multicolumn{2}{|c|}{$\bar{B} \% \kappa$} & \multirow{3}{*}{$\begin{array}{c}\text { Январь- } \\
\text { сентябрь } \\
2020 \text { г. } \\
\text { в\% к } \\
\text { январю- } \\
\text { сентябрю } \\
2019 \text { г. }\end{array}$} & \multicolumn{3}{|c|}{ Справочно } \\
\hline & & \multirow{2}{*}{$\begin{array}{l}\text { сентябрю } \\
20192 .\end{array}$} & \multirow{2}{*}{$\begin{array}{l}\text { aвгусmy } \\
20202 .\end{array}$} & & \multicolumn{2}{|c|}{ сентябрь 2019 г. в \% к } & \multirow[b]{2}{*}{$\begin{array}{c}\text { январь- } \\
\text { сентябрь } \\
2019 \text { г. } \\
\text { в\% } \\
\text { январю- } \\
\text { сентябрю } \\
2018 \text { г. } \\
\end{array}$} \\
\hline & & & & & $\begin{array}{l}\text { сентябрю } \\
2018 \text { г. }\end{array}$ & $\begin{array}{l}\text { августу } \\
2019 \text { г. }\end{array}$ & \\
\hline Всего & 2897,3 & $\mathbf{9 7 , 0}$ & 98,3 & 95,2 & 100,9 & 98,7 & 101,8 \\
\hline $\begin{array}{l}\text { в том числе: } \\
\text { оборот розничной торговли } \\
\text { торгующих организаций }{ }^{1)}\end{array}$ & 2750,6 & 97,4 & 98,2 & 95,8 & 101,5 & 98,6 & 102,2 \\
\hline $\begin{array}{l}\text { продажа товаров на розничных } \\
\text { рынках и ярмарках }\end{array}$ & 146,7 & 89,8 & 101,6 & 83,2 & 92,1 & 99,5 & 95,0 \\
\hline
\end{tabular}


В сентябре 2020 г. в структуре оборота розничной торговли удельный вес пищевых продуктов, включая напитки, и табачных изделий составил 46,4\%, непродовольственных товаров - 53,6\% (в сентябре 2019 г. - 47,0\% и 53,0\% соответственно).

ДИНАМИКА ОБОРОТА РОЗНИЧНОЙ ТОРГОВЛИ

ПИЩЕВЫМИ ПРОДУКТАМИ, ВКЛЮЧАЯ НАПИТКИ,

И ТАБАЧНЫМИ ИЗДЕЛИЯМИ, НЕПРОДОВОЛЬСТВЕННЫМИ ТОВАРАМИ

\begin{tabular}{|c|c|c|c|c|c|c|}
\hline & \multicolumn{3}{|c|}{$\begin{array}{c}\text { Пищеевые продукты, } \\
\text { включая напитки, и табачные изделия }\end{array}$} & \multicolumn{3}{|c|}{$\begin{array}{c}\text { Непродовольственньее } \\
\text { товарьи }\end{array}$} \\
\hline & \multirow{2}{*}{$\begin{array}{c}\text { млрд } \\
\text { рублей }\end{array}$} & \multicolumn{2}{|c|}{$6 \% \mathrm{~K}$} & \multirow{2}{*}{$\begin{array}{c}\text { млрд } \\
\text { рублей }\end{array}$} & \multicolumn{2}{|c|}{$\begin{array}{r}6 \% \kappa \\
\end{array}$} \\
\hline & & $\begin{array}{l}\text { соответст- } \\
\text { вующему пе- } \\
\text { риоду предь- } \\
\text { дущего года }\end{array}$ & $\begin{array}{c}\text { предььушему } \\
\text { периоду }\end{array}$ & & \begin{tabular}{|c|} 
соответст- \\
вуюшему пе- \\
риоду предылду- \\
щего года
\end{tabular} & $\begin{array}{l}\text { предьидущему } \\
\text { периоду }\end{array}$ \\
\hline \multicolumn{7}{|c|}{2019 г. } \\
\hline Январь & 1215,8 & 102,1 & 75,5 & 1291,7 & 102,2 & 74,7 \\
\hline Февраль & 1195,2 & 102,0 & 97,6 & 1259,4 & 102,7 & 97,3 \\
\hline Март & 1311,0 & 102,4 & 109,2 & 1379,4 & 102,5 & 109,3 \\
\hline І квартал & 3722,0 & 102,2 & 86,0 & 3930,5 & 102,4 & 84,0 \\
\hline Апрель & 1288,4 & 101,8 & 97,9 & 1368,5 & 102,2 & 99,1 \\
\hline Май & 1319,3 & 102,3 & 102,0 & 1383,9 & 101,6 & 100,9 \\
\hline Июнь & 1316,9 & 101,8 & 100,1 & 1424,1 & 101,9 & 102,8 \\
\hline I квартал & 3924,6 & 102,0 & 104,3 & 4176,5 & 101,9 & 105,7 \\
\hline I полугодие & 7646,6 & 102,1 & & 8107,0 & 102,1 & \\
\hline Июль & 1338,6 & 101,5 & 101,9 & 1468,4 & 101,5 & 103,0 \\
\hline Август & 1357,0 & 101,0 & 102,0 & 1540,5 & 101,3 & 104,7 \\
\hline Сентябрь & 1341,9 & 100,8 & 99,2 & 1514,3 & 101,1 & 98,2 \\
\hline ІІІ квартал & 4037,5 & 101,1 & 103,7 & 4523,2 & 101,3 & 107,8 \\
\hline Январь-сентябрь & 11684,1 & 101,7 & & 12630,2 & 101,8 & \\
\hline Октябрь & 1373,7 & 101,6 & 102,2 & 1530,9 & 102,2 & 100,8 \\
\hline Ноябрь & 1390,1 & 102,0 & 100,7 & 1542,4 & 103,1 & 100,4 \\
\hline Декабрь & 1672,9 & 101,9 & 119,6 & 1800,0 & 101,8 & 116,5 \\
\hline IV квартал & 4436,7 & 101,8 & 109,5 & 4873,3 & 102,4 & 107,0 \\
\hline Год & 16120,8 & 101,8 & & 17503,5 & 102,0 & \\
\hline \multicolumn{7}{|c|}{2020 г. } \\
\hline Январь & 1276,8 & 102,3 & 75,8 & 1363,0 & 103,0 & 75,6 \\
\hline Февраль & 1269,7 & 103,8 & 98,9 & 1359,2 & 105,6 & 99,7 \\
\hline Март & 1413,0 & 104,8 & 110,2 & 1504,5 & 106,5 & 110,2 \\
\hline І квартал & 3959,5 & 103,7 & 87,6 & 4226,7 & 105,1 & 86,2 \\
\hline Апрель & 1217,7 & 90,9 & 85,0 & 907,6 & 64,6 & 60,1 \\
\hline Май & 1252,8 & 91,5 & 102,7 & 1020,8 & 71,8 & 112,2 \\
\hline Июнь & 1322,7 & 96,4 & 105,4 & 1319,8 & 89,9 & 128,7 \\
\hline II квартал & 3793,2 & 93,0 & 93,5 & 3248,2 & 75,6 & 76,0 \\
\hline I полугодие & 7752,7 & 98,2 & & 7474,9 & 89,9 & \\
\hline Июль & 1370,4 & 98,0 & 103,5 & 1491,1 & 98,3 & 112,6 \\
\hline Август & 1362,3 & 95,9 & 99,9 & 1576,8 & 98,8 & 105,3 \\
\hline
\end{tabular}




\begin{tabular}{|c|c|c|c|c|c|c|}
\hline & \multicolumn{3}{|c|}{$\begin{array}{c}\text { Пищевые продуктыл, } \\
\text { включая напитки, и табачные изделия }\end{array}$} & \multicolumn{3}{|c|}{$\begin{array}{c}\text { Непродовольственнье } \\
\text { товары }\end{array}$} \\
\hline & \multirow{2}{*}{$\begin{array}{c}\text { млрд } \\
\text { рублей }\end{array}$} & \multicolumn{2}{|c|}{$6 \% \kappa$} & \multirow{2}{*}{$\begin{array}{c}\text { млрд } \\
\text { рублей }\end{array}$} & \multicolumn{2}{|c|}{$6 \% \kappa$} \\
\hline & & $\begin{array}{l}\text { соответст- } \\
\text { вующему пе- } \\
\text { риоду преды- } \\
\text { дущего года }\end{array}$ & $\begin{array}{l}\text { предыручщему } \\
\text { периоду }\end{array}$ & & \begin{tabular}{|c|} 
соответст- \\
вуюшему nе- \\
pиоду предblдy- \\
щеего года
\end{tabular} & $\begin{array}{c}\text { nредыручщему } \\
\text { периоду }\end{array}$ \\
\hline Сентябрь & 1344,1 & 95,4 & 98,8 & 1553,2 & 98,7 & 98,0 \\
\hline ІІІ квартал & 4076,8 & 96,4 & 107,6 & 4621,1 & 98,6 & 140,7 \\
\hline Январь-сентябрь & 11829,5 & 97,6 & & 12096,0 & 93,0 & \\
\hline
\end{tabular}

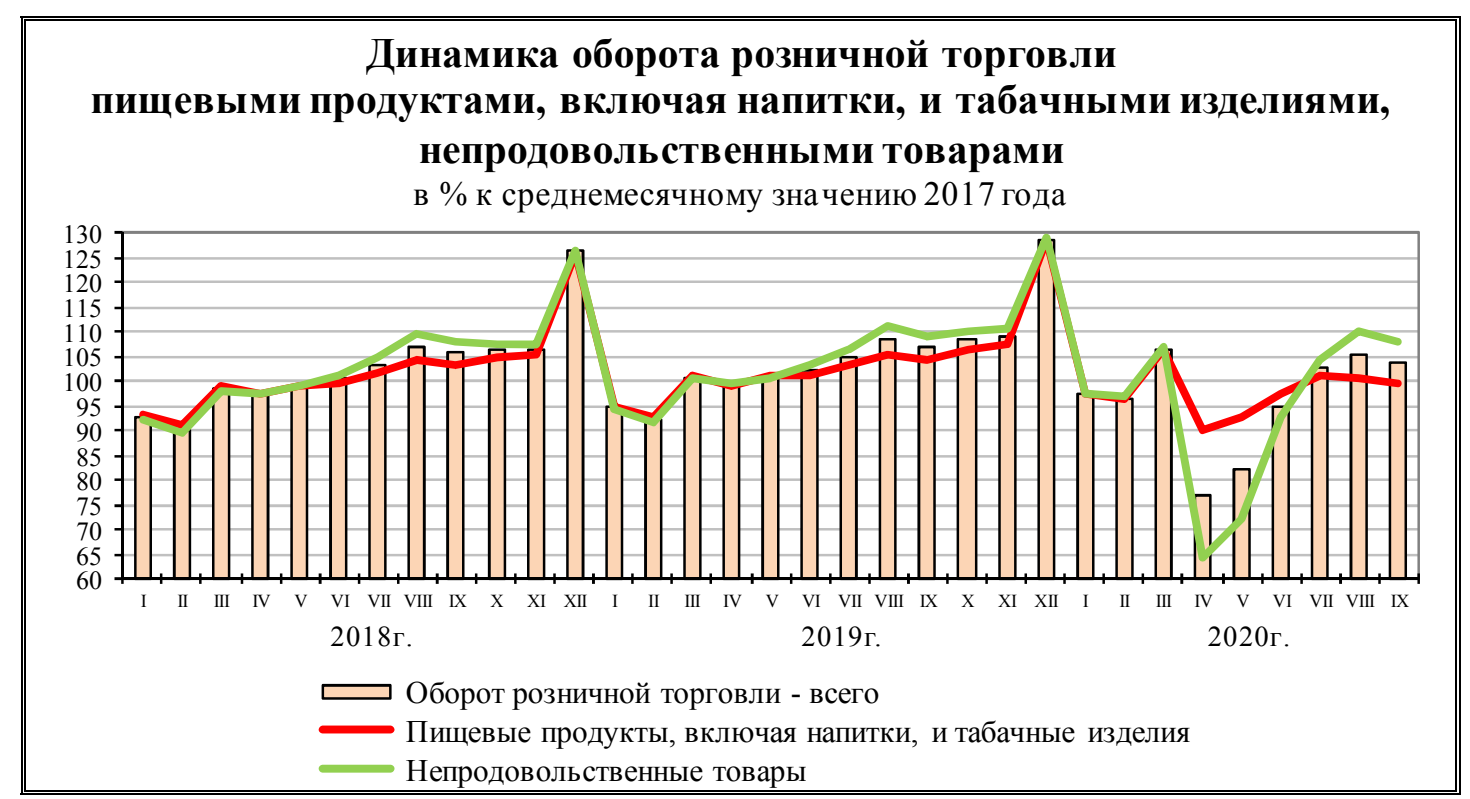

Таблица 4

ТОВАРНЫЕ ЗАПАСЫ

В ОРГАНИЗАЦИЯХ РОЗНИЧНОЙ ТОРГОВЛИ

на конец месяца

\begin{tabular}{||l|c|c||}
\hline \multicolumn{3}{|c|}{ 2019 г. } \\
\hline \multicolumn{2}{|c||}{$\begin{array}{c}\text { Уровень запасов, } \\
\text { в днях торговли }\end{array}$} \\
\hline Январь & 1637,9 & 39 \\
\hline Февраль & 1648,4 & 39 \\
\hline Март & 1708,4 & 38 \\
\hline Апрель & 1717,9 & 39 \\
\hline Май & 1699,7 & 38 \\
\hline Июнь & 1668,1 & 36 \\
\hline Июль & 1696,6 & 37 \\
\hline Август & 1721,2 & 36 \\
\hline Сентябрь & 1784,5 & 38 \\
\hline Октябрь & 1866,0 & 40 \\
\hline Ноябрь & 1957,2 & 41 \\
\hline Декабрь & 2025,4 & 35 \\
\hline
\end{tabular}




\begin{tabular}{|c|c|c|}
\hline & $\begin{array}{c}\text { Tоварные запасы, } \\
\text { млрд рублей }\end{array}$ & $\begin{array}{l}\text { Уровень запасов, } \\
\text { в днях торговли }\end{array}$ \\
\hline \multicolumn{3}{|c|}{2020 г. } \\
\hline Январь & 1888,2 & 42 \\
\hline Февраль & 1918,2 & 41 \\
\hline Март & 1966,9 & 39 \\
\hline Апрель & 1868,7 & 46 \\
\hline Май & 1835,5 & 43 \\
\hline Июнь & 1929,7 & 39 \\
\hline Июль & 1935,8 & 37 \\
\hline Август & 1968,5 & 37 \\
\hline Сентябрь & 2022,3 & 39 \\
\hline
\end{tabular}

ИЗМЕНЕНИЕ ПРОДАЖИ И ЗАПАСОВ ОСНОВНЫХ ПРОДУКТОВ ПИТАНИЯ И НЕПРОДОВОЛЬСТВЕННЫХ ТОВАРОВ В ОРГАНИЗАЦИЯХ РОЗНИЧНОЙ ТОРГОВЛИ, НЕ ОТНОСЯЩИХСЯ К СУБЪЕКТАМ МАЛОГО ПРЕДПРИНИМАТЕЛЬСТВА

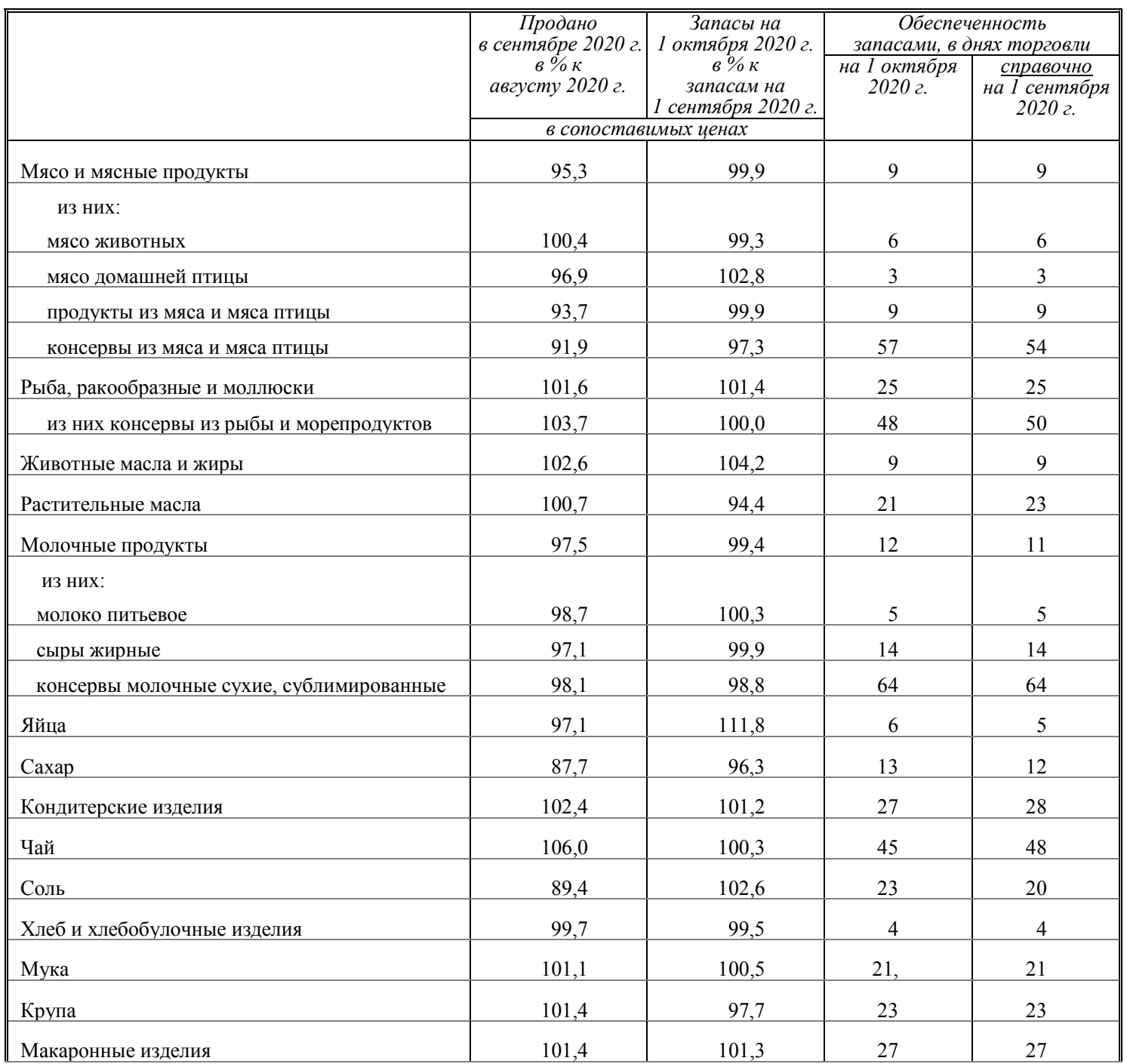




\begin{tabular}{|c|c|c|c|c|}
\hline & \multirow{2}{*}{$\begin{array}{c}\text { Продано } \\
\text { в сентябре } 2020 \text { г. } \\
\text { в\% \% } \\
\text { августу } 2020 \text { г. }\end{array}$} & \multirow{2}{*}{$\begin{array}{c}\text { 3апасы на } \\
1 \text { октября } 2020 \text { г. } \\
\text { в\% \% } \\
\text { запасам на } \\
1 \text { сентября } 2020 \text { г. }\end{array}$} & \multicolumn{2}{|c|}{$\begin{array}{c}\text { Обеспеченность } \\
\text { запасами, в днях торговли }\end{array}$} \\
\hline & & & \multirow[t]{2}{*}{$\begin{array}{l}\text { на 1 октября } \\
2020 \text { г. }\end{array}$} & \multirow[t]{2}{*}{ 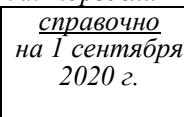 } \\
\hline & в сопостав & имых ченах & & \\
\hline Свежий картофель & 88,0 & 114,1 & 6 & 4 \\
\hline Свежие овощи & 96,8 & 107,3 & 5 & 5 \\
\hline Свежие фрукты & 96,9 & 95,4 & 6 & 6 \\
\hline Мужская, женская и детская одежда & 90,1 & 108,0 & 83 & 70 \\
\hline Обувь & 105,9 & 105,2 & 91 & 92 \\
\hline Компьютеры & 92,5 & 101,5 & 41 & 37 \\
\hline Мобильные телефоны & 88,1 & 102,3 & 63 & 54 \\
\hline Телевизоры & 101,3 & 120,3 & 84 & 71 \\
\hline Холодильники и морозильники & 93,3 & 104,5 & 38 & 34 \\
\hline Стиральные машины & 99,4 & 109,7 & 40 & 36 \\
\hline Мебель & 94,1 & 99,8 & 30 & 28 \\
\hline Строительные материалы & 101,4 & 100,5 & 85 & 86 \\
\hline Автомобили легковые ${ }^{1)}$ & 105,2 & 111,9 & 19 & 18 \\
\hline Бензины автомобильные & 93,3 & 106,9 & 7 & 6 \\
\hline Газовое моторное топливо ${ }^{1)}$ & 96,9 & 99,3 & 4 & 4 \\
\hline $\begin{array}{l}\text { Изделия, применяемые в медицинских целях, } \\
\text { ортопедические изделия }\end{array}$ & 101,0 & 100,9 & 67 & 67 \\
\hline Лекарственные средства & 112,0 & 103,8 & 45 & 48 \\
\hline
\end{tabular}

В сентябре 2020 г. объемы продаж через Интернет по крупным и средним торгующим организациям по сравнению с августом 2020 г. выросли на 0,5\% (в сопоставимых ценах), с сентябрем 2019 г. - рост составил в 2,3 раза. Доля онлайн-продаж в общем обороте розничной торговли этих выросла до 5,4\% против 2,6\% в сентябре 2019 года. В общем объеме интернет-торговли более 60\% приходится на долю DNS, OZON, WILDBERRIES, М.Видео, Ситилинк.

\section{2. РЕСТОРАНЫ, КАФЕ И БАРЫ}

Оборот общественного питания в сентябре 2020 г. составил 132,6 млрд рублей, или 86,0\% к уровню соответствующего периода предыдущего года, в январе-сентябре 2020 г. - 947,5 млрд рублей, или 77,2\%.

Таблица 1

ДИНАМИКА ОБОРОТА ОБЩЕСТВЕННОГО ПИТАНИЯ

\begin{tabular}{|c|c|c|c|}
\hline & \multirow{2}{*}{$\begin{array}{c}\text { Млрд } \\
\text { рублей }\end{array}$} & \multicolumn{2}{|c|}{$\bar{B} B \% \kappa$} \\
\hline & & $\begin{array}{c}\text { соответствуюшему } \\
\text { периоду предьдущего года }\end{array}$ & $\begin{array}{c}\text { предырушему } \\
\text { периоду }\end{array}$ \\
\hline \multicolumn{4}{|c|}{2019 г. } \\
\hline Январь & 122,8 & 106,1 & 79,0 \\
\hline Февраль & 119,4 & 106,7 & 97,0 \\
\hline
\end{tabular}




\begin{tabular}{|c|c|c|c|}
\hline & \multirow{2}{*}{$\begin{array}{c}\text { Млрд } \\
\text { рублей }\end{array}$} & \multicolumn{2}{|c|}{ 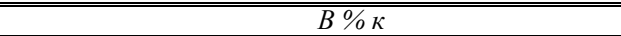 } \\
\hline & & $\begin{array}{c}\text { соответствующему } \\
\text { периоду предыдущего года }\end{array}$ & $\begin{array}{c}\text { предьлушему } \\
\text { периоду }\end{array}$ \\
\hline Март & 127,5 & 108,3 & 106,5 \\
\hline І квартал & 369,7 & 107,0 & 85,8 \\
\hline Апрель & 130,0 & 107,2 & 101,7 \\
\hline Май & 132,9 & 105,3 & 102,1 \\
\hline Июнь & 135,8 & 103,2 & 101,8 \\
\hline ІІ квартал & 398,7 & 105,2 & 107,1 \\
\hline I полугодие & 768,4 & 106,1 & \\
\hline Июль & 137,3 & 103,6 & 101,0 \\
\hline Август & 142,8 & 104,4 & 103,7 \\
\hline Сентябрь & 151,5 & 104,8 & 105,4 \\
\hline III квартал & 431,6 & 104,3 & 107,4 \\
\hline Январь-сентябрь & 1200,0 & 105,4 & \\
\hline Октябрь & 150,8 & 105,5 & 99,4 \\
\hline Ноябрь & 146,2 & 105,9 & 96,7 \\
\hline Декабрь & 168,4 & 105,6 & 115,1 \\
\hline IV квартал & 465,4 & 105,7 & 107,0 \\
\hline Год & 1665,4 & 105,5 & \\
\hline \multicolumn{4}{|c|}{2020 г. } \\
\hline Январь & 134,0 & 106,3 & 79,5 \\
\hline Февраль & 130,4 & 106,7 & 97,4 \\
\hline Март & 126,1 & 96,7 & 96,6 \\
\hline І квартал & 390,5 & 103,1 & 83,8 \\
\hline Апрель & 63,0 & 47,4 & 49,8 \\
\hline Май & 64,1 & 47,1 & 101,5 \\
\hline Июнь & 78,0 & 56,2 & 121,5 \\
\hline II квартал & 205,1 & 50,3 & 52,2 \\
\hline I полугодие & 595,6 & 75,7 & \\
\hline Июль & 100,6 & 71,8 & 128,9 \\
\hline Август & 118,7 & 81,3 & 117,5 \\
\hline Сентябрь & 132,6 & 86,0 & 111,5 \\
\hline III квартал & 351,9 & 79,9 & 170,6 \\
\hline Январь-сентябрь & 947,5 & 77,2 & \\
\hline
\end{tabular}

\section{3. РЫНОК ПЛАТНЫХ УСЛУГ НАСЕЛЕНИЮ}

В сентябре 2020 г., по предварительным данным, населению было оказано платных услуг на 778,6 млрд рублей, в январе-сентябре 2020 г. - на 6367,2 млрд рублей. 
ДИНАМИКА ОБЪЕМА ПЛАТНЫХ УСЛУГ НАСЕЛЕНИЮ

\begin{tabular}{|c|c|c|}
\hline & \multicolumn{2}{|c|}{$B \% \kappa$} \\
\hline & $\begin{array}{c}\text { соответствующему } \\
\text { периоду предьидущего года }\end{array}$ & $\begin{array}{c}\text { предылушщему } \\
\text { периоду }\end{array}$ \\
\hline \multicolumn{3}{|c|}{2019 г. } \\
\hline Январь & 99,9 & 90,9 \\
\hline Февраль & 101,5 & 99,5 \\
\hline Март & 100,4 & 103,7 \\
\hline І квартал & 100,4 & 95,3 \\
\hline Апрель & 100,5 & 100,3 \\
\hline Май & 100,3 & 98,7 \\
\hline Июнь & 99,6 & 100,6 \\
\hline ІІ квартал & 100,2 & 101,9 \\
\hline I полугодие & 100,1 & \\
\hline Июль & 100,0 & 100,9 \\
\hline Август & 100,5 & 100,7 \\
\hline Сентябрь & 101,2 & 99,1 \\
\hline ІІІ квартал & 100,9 & 101,4 \\
\hline Январь-сентябрь & 100,2 & \\
\hline Октябрь & 101,1 & 100,8 \\
\hline Ноябрь & 100,3 & 100,6 \\
\hline Декабрь & 100,9 & 105,6 \\
\hline IV квартал & 100,2 & 103,2 \\
\hline Год & 100,5 & \\
\hline \multicolumn{3}{|c|}{2020 г. } \\
\hline Январь & 100,8 & 90,5 \\
\hline Февраль & 100,1 & 98,8 \\
\hline Март & 93,7 & 97,0 \\
\hline I квартал & 98,1 & 92,4 \\
\hline Апрель & 61,8 & 66,4 \\
\hline Май & 61,1 & 98,1 \\
\hline Июнь & 68,6 & 113,6 \\
\hline ІІ квартал & 63,9 & 66,8 \\
\hline I полугодие & 80,6 & \\
\hline Июль & 76,8 & 112,7 \\
\hline Август ${ }^{1)}$ & 83,2 & 109,1 \\
\hline Сентябрь & 87,8 & 104,3 \\
\hline ІІІ квартал & 82,6 & 130,8 \\
\hline Январь-сентябрь & 81,3 & \\
\hline
\end{tabular}




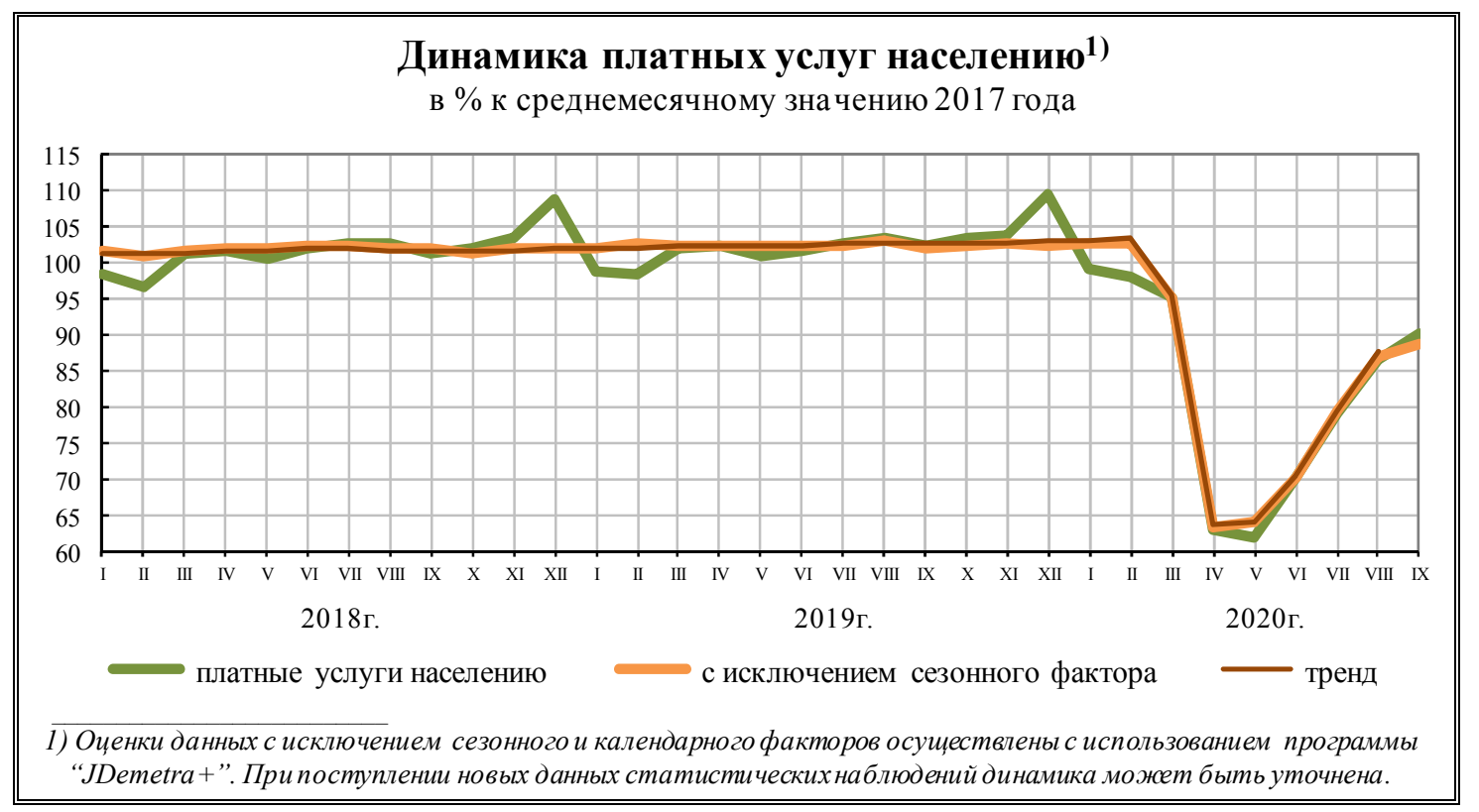

Таблица 2

ОБЪЕМ ПЛАТНЫХ УСЛУГ НАСЕЛЕНИЮ ПО ВИДАМ

\begin{tabular}{|c|c|c|c|c|c|}
\hline & \multicolumn{4}{|c|}{ Сентябрь 2020 г. } & \multirow{3}{*}{$\begin{array}{c}\text { Январь-сентябрь } \\
2020 \text { г. } \\
\text { в\% } \\
\text { январю-сентябрю } \\
2019 \text { г. } \\
\end{array}$} \\
\hline & \multirow{2}{*}{$\begin{array}{c}\text { млрд } \\
\text { рублей }\end{array}$} & \multicolumn{3}{|c|}{$6 \% \mathrm{~K}$} & \\
\hline & & $\begin{array}{c}\text { сентякрюю } \\
2019 \text { г. }\end{array}$ & $\begin{array}{c}\text { августу } \\
2020 \text { 2. }\end{array}$ & итогу & \\
\hline Платные услуги & 778,6 & 87,8 & 104,3 & 100 & 81,3 \\
\hline $\begin{array}{l}\text { в том числе: } \\
\text { бытовые }\end{array}$ & 89,8 & 92,2 & 101,0 & 11,5 & 82,6 \\
\hline транспортные & 134,9 & 70,4 & 102,9 & 17,3 & 60,1 \\
\hline почтовой связи, курьерские & 5,2 & 115,9 & 104,2 & 0,7 & 101,8 \\
\hline телекоммуникационные & 119,5 & 95,8 & 101,0 & 15,3 & 94,4 \\
\hline жилищные & 60,9 & 94,2 & 101,3 & 7,8 & 95,2 \\
\hline коммунальные & 139,9 & 96,3 & 101,1 & 18,0 & 95,8 \\
\hline культуры & 8,3 & 56,2 & 122,2 & 1,1 & 49,1 \\
\hline туристские & 10,3 & 52,9 & 103,4 & 1,3 & 45,1 \\
\hline физической культуры и спорта & 6,0 & 75,8 & 114,7 & 0,8 & 61,6 \\
\hline медицинские & 65,0 & 105,5 & 104,9 & 8,4 & 86,2 \\
\hline гостиниц и аналогичных средств размещения & 19,0 & 78,8 & 95,6 & 2,4 & 62,6 \\
\hline $\begin{array}{l}\text { специализированных коллективных } \\
\text { средств размещения }\end{array}$ & 14,9 & 88,4 & 93,6 & 1,9 & 55,4 \\
\hline из них санаторно-курортных организаций & 11,5 & 90,6 & 93,7 & 1,5 & 56,0 \\
\hline ветеринарные & 1,8 & 88,4 & 109,6 & 0,2 & 87,0 \\
\hline юридические & 9,7 & 96,0 & 100,2 & 1,2 & 90,2 \\
\hline системы образования & 64,6 & 99,1 & 140,0 & 8,3 & 84,5 \\
\hline $\begin{array}{l}\text { услуги, предоставляемые гражданам } \\
\text { пожилого возраста и инвалидам }\end{array}$ & 2,3 & 95,2 & 100,8 & 0,3 & 97,7 \\
\hline прочие виды платных услуг & 26,5 & 81,6 & 106,6 & 3,5 & 78,6 \\
\hline
\end{tabular}


ОБЪЕМ БЫТОВЫХ УСЛУГ НАСЕЛЕНИЮ ПО ВИДАМ

\begin{tabular}{|c|c|c|c|c|c|}
\hline & \multicolumn{4}{|c|}{ Сентябрь 2020 г. } & \multirow{3}{*}{\begin{tabular}{|c|} 
Январь-сентябрь \\
2020 г. \\
в \% к \\
январю-сентябрю \\
2019 г. \\
\end{tabular}} \\
\hline & \multirow{2}{*}{$\begin{array}{c}\text { млн } \\
\text { рублей }\end{array}$} & \multicolumn{3}{|c|}{$6 \% \kappa$} & \\
\hline & & $\begin{array}{c}\text { сентябрю } \\
20192 .\end{array}$ & $\begin{array}{c}\text { aвzycmy } \\
2020 \text { г. }\end{array}$ & umozy & \\
\hline Бытовые услуги & 89815,7 & 92,2 & 101,0 & 100 & 82,6 \\
\hline $\begin{array}{l}\text { в том числе: } \\
\text { ремонт, окраска и пошив обуви }\end{array}$ & 974,7 & 83,9 & 107,1 & 1,1 & 69,3 \\
\hline $\begin{array}{l}\text { ремонт и пошив швейных, } \\
\text { меховых и кожаных изделий, } \\
\text { головных уборов и изделий } \\
\text { текстильной галантереи, ремонт, } \\
\text { пошив и вязание трикотажных изделий }\end{array}$ & 2424,3 & 82,1 & 105,0 & 2,7 & 68,7 \\
\hline $\begin{array}{l}\text { ремонт и техническое обслуживание } \\
\text { бытовой радиоэлектронной аппаратуры, } \\
\text { бытовых машин и приборов, } \\
\text { ремонт и изготовление металлоизделий }\end{array}$ & 3780,5 & 90,8 & 101,5 & 4,2 & 74,0 \\
\hline $\begin{array}{l}\text { техобслуживание и ремонт транспортных } \\
\text { средств, машин и оборудования }\end{array}$ & 28434,7 & 98,2 & 99,4 & 31,7 & 88,3 \\
\hline изготовление и ремонт мебели & 2861,5 & 96,8 & 99,5 & 3,2 & 76,6 \\
\hline $\begin{array}{l}\text { химическая чистка и крашение, } \\
\text { услуги прачечных }\end{array}$ & 819,5 & 79,3 & 104,0 & 0,9 & 65,2 \\
\hline $\begin{array}{l}\text { ремонт и строительство жилья } \\
\text { и других построек }\end{array}$ & 23765,4 & 90,5 & 102,6 & 26,5 & 80,8 \\
\hline услуги фотоателье & 1166,3 & 79,4 & 103,2 & 1,3 & 66,4 \\
\hline услуги бань и душевых & 1881,1 & 79,6 & 121,9 & 2,1 & 61,6 \\
\hline услуги парикмахерских & 11476,5 & 93,1 & 99,7 & 12,8 & 75,3 \\
\hline $\begin{array}{l}\text { услуги предприятий по прокату, } \\
\text { включая каршеринг }\end{array}$ & 2826,1 & 74,2 & 96,8 & 3,1 & 120,9 \\
\hline ритуальные услуги & 5957,5 & 100,7 & 99,8 & 6,6 & 101,5 \\
\hline прочие виды бытовых услуг & 3447,8 & 84,3 & 98,7 & 3,8 & 76,0 \\
\hline
\end{tabular}

По результатам выборочного обследования деловой активности в сфере услуг, в III квартале 2020 г. баланс оценок изменения экономической ситуации, как и во II квартале 2020 г., имел отрицательное значение.

Таблица 4

\section{ИЗМЕНЕНИЕ ЭКОНОМИЧЕСКОЙ СИТУАЦИИ В СФЕРЕ УСЛУГ}

в \% от числа обследованных организаций

\begin{tabular}{|c|c|c|c|c|c|c|c|}
\hline \multirow{2}{*}{$\begin{array}{c}\text { По отношению } \\
\kappa \text { предыдущему кварталу }\end{array}$} & \multicolumn{4}{|c|}{20192.} & \multicolumn{3}{|c|}{20202.} \\
\hline & І квартал & II квартал & ІІІ квартал & IV квартал & І квартал & II квартал & III квартал \\
\hline Улучшение & 10 & 15 & 17 & 14 & 5 & 2 & 15 \\
\hline Без изменений & 66 & 67 & 67 & 67 & 74 & 41 & 53 \\
\hline Ухудшение & 24 & 18 & 16 & 19 & 21 & 57 & 32 \\
\hline Баланс ${ }^{1)}$ & -14 & -3 & 1 & -5 & -16 & -55 & -17 \\
\hline
\end{tabular}


ИЗМЕНЕНИЕ ЭКОНОМИЧЕСКОЙ СИТУАЦИИ В ОРГАНИЗАЦИЯХ СФЕРЫ УСЛУГ

в процентах

\begin{tabular}{|c|c|c|c|c|c|c|c|}
\hline \multirow{2}{*}{$\begin{array}{c}\text { По отнотению } \\
\text { к предыдущему кварталу }\end{array}$} & \multicolumn{4}{|c|}{20192.} & \multicolumn{3}{|c|}{20202.} \\
\hline & I квартал & II квартал & III квартал & IV квартал & I квартал & II квартал & III квартал \\
\hline $\begin{array}{l}\text { Деятельность в области } \\
\text { пассажирского транспорта, } \\
\text { кроме железнодорожного }\end{array}$ & -17 & -4 & -4 & -10 & -16 & -57 & -18 \\
\hline Деятельность в области связи & -7 & -4 & -4 & 0 & -14 & -34 & -19 \\
\hline $\begin{array}{l}\text { Деятельность гостиниц } \\
\text { и прочих мест } \\
\text { для временного проживания }\end{array}$ & -18 & 5 & 18 & -4 & -24 & -72 & -5 \\
\hline Страхование & 5 & 6 & 5 & 2 & -1 & -26 & -7 \\
\hline Деятельность ломбардов & -16 & -12 & -13 & -9 & -4 & -43 & -17 \\
\hline $\begin{array}{l}\text { Техническое обслуживание и } \\
\text { ремонт транспортных средств }\end{array}$ & -24 & 6 & -5 & -3 & -22 & -49 & -14 \\
\hline $\begin{array}{l}\text { Ремонт бытовых изделий } \\
\text { и предметов личного } \\
\text { пользования }\end{array}$ & -19 & -11 & -8 & -12 & -18 & -57 & -29 \\
\hline $\begin{array}{l}\text { Предоставление } \\
\text { персональных услуг }\end{array}$ & -12 & -7 & -11 & -5 & -14 & -50 & -16 \\
\hline Туристская деятельность & -10 & 19 & 20 & -19 & -12 & -76 & -19 \\
\hline $\begin{array}{l}\text { Деятельность санаторно- } \\
\text { курортных учреждений }\end{array}$ & -29 & 7 & 31 & -5 & -25 & -73 & -6 \\
\hline Стоматологическая практика & -9 & -6 & -2 & -1 & -9 & -57 & -7 \\
\hline $\begin{array}{l}\text { Деятельность по организации } \\
\text { отдыха и развлечений, } \\
\text { культуры и спорта }\end{array}$ & -5 & -9 & -5 & -2 & -10 & -62 & -28 \\
\hline Рекламная деятельность & -25 & -9 & -5 & -3 & -23 & -63 & -32 \\
\hline $\begin{array}{l}\text { Предоставление } \\
\text { посреднических услуг при } \\
\text { покупке, продаже и аренде } \\
\text { недвижимого имущества }\end{array}$ & -13 & -7 & -10 & -5 & -12 & -44 & -27 \\
\hline $\begin{array}{l}\text { Деятельность автомобильного } \\
\text { грузового транспорта }\end{array}$ & -18 & -4 & 6 & -5 & -20 & -40 & -18 \\
\hline
\end{tabular}

Индикатор делового климата в сфере услуг - индекс предпринимательской уверенности в III квартале 2020 г. составил (-9\%).

Таблица 6

\section{ИНДЕКС ПРЕДПРИНИМАТЕЛЬСКОЙ УВЕРЕННОСТИ И ЕГО КОМПОНЕНТЫ В ОРГАНИЗАЦИЯХ СФЕРЫ УСЛУГ}

\begin{tabular}{|c|c|c|c|c|c|c|c|}
\hline & \multicolumn{4}{|c|}{20192.} & \multicolumn{3}{|c|}{20202.} \\
\hline & І квартал & ІІ квартал & ІІІ квартал & IV квартал & Іквартал & II квартал & III квартал \\
\hline $\begin{array}{l}\text { Индекс предпринимательской } \\
\text { уверенности, в \% }\end{array}$ & -8 & 1 & 1 & -6 & -8 & -40 & -9 \\
\hline
\end{tabular}




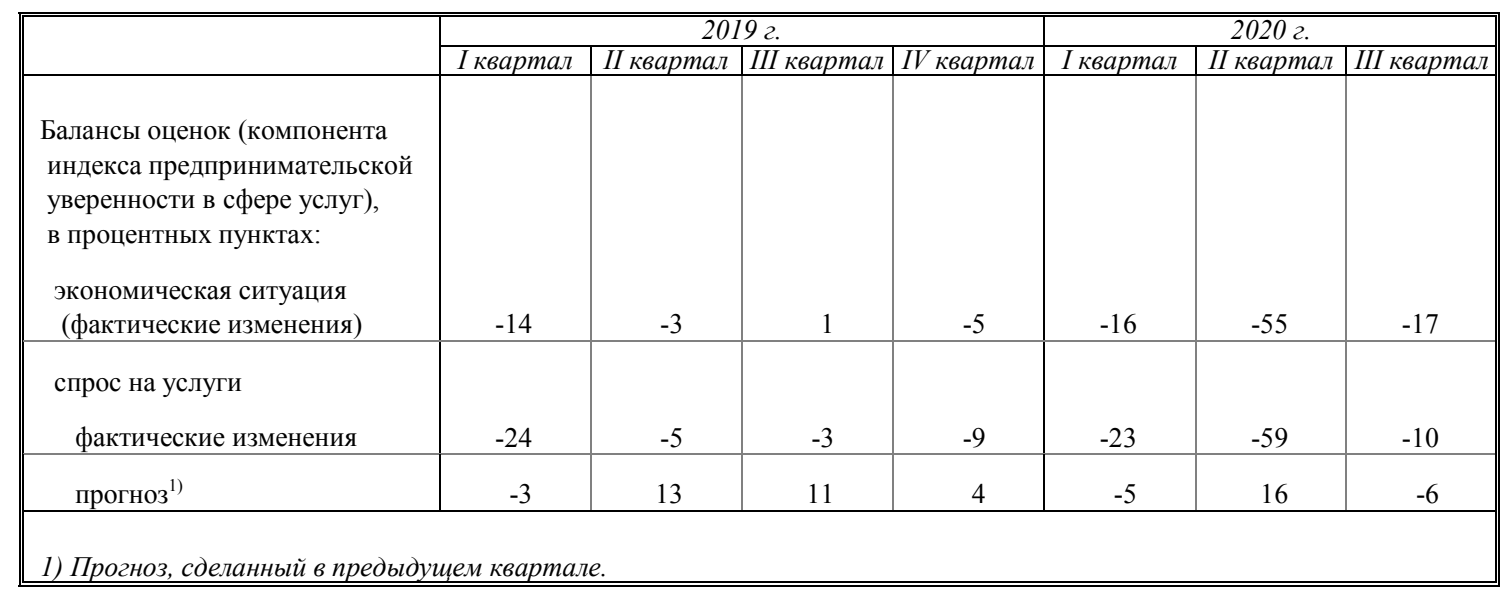

Как и в предыдущие периоды, в III квартале 2020 г. основными факторами, ограничивающими деятельность организаций сферы услуг, являются недостаточный спрос на услуги (отметило 54\% опрошенных руководителей), недостаток финансовых средств - 48\%, неопределенность экономической ситуации - 56\%.

Таблица 7

\section{ПРОГНОЗНЫЕ ОЦЕНКИ ОСНОВНЫХ ПОКАЗАТЕЛЕЙ ДЕЯТЕЛЬНОСТИ ОРГАНИЗАЦИЙ СФЕРЫ УСЛУГ}

в \% от числа обследованных организаций

\begin{tabular}{|c|c|c|c|c|}
\hline & & $\begin{array}{l}\text { квартале } 2 \\
\text { I квартало. }\end{array}$ & $\begin{array}{l}0 \text { г. по сравнен } \\
2020 \text { г. (прогно }\end{array}$ & \\
\hline & увеличение & $\begin{array}{c}\text { без } \\
\text { изменений }\end{array}$ & уменьшение & баланс' \\
\hline Спрос на услуги организации & 22 & 55 & 23 & -1 \\
\hline Объем оказанных услуг & 22 & 54 & 24 & -2 \\
\hline Цены (тарифы) на услуги & 8 & 79 & 13 & -5 \\
\hline Инвестиции & 8 & 75 & 17 & -9 \\
\hline Прибыль & 19 & 55 & 26 & -7 \\
\hline Собственная конкурентная позиция & 9 & 78 & 13 & -4 \\
\hline Средняя численность работников & 7 & 82 & 11 & -4 \\
\hline
\end{tabular}

Баланс оценок ожидаемого изменения экономической ситуации (разность долей респондентов, отметивших "улучшение" и "ухудшение" показателя) в IV квартале 2020 г. по сравнению с III кварталом 2020 г. в целом в сфере услуг составил (-4\%), в том числе в туристских и экскурсионных организациях (-18\%), в организациях, занимающихся ремонтом предметов личного потребления и хозяйственно-бытового назначения (-12\%). 


\section{4. ОПТОВАЯ ТОРГОВЛЯ}

Оборот оптовой торговли в сентябре 2020 г. составил 7448,3 млрд рублей, или $101,5 \%$ (в сопоставимых ценах) к соответствующему месяцу предыдущего года. На долю субъектов малого предпринимательства приходилось $34,2 \%$ оборота оптовой торговли.

Таблица 1

\section{ДИНАМИКА ОБОРОТА ОПТОВОЙ ТОРГОВЛИ}

\begin{tabular}{|c|c|c|c|c|c|c|}
\hline & \multicolumn{3}{|c|}{ Оборот оптовой торговли } & \multirow{2}{*}{\multicolumn{3}{|c|}{$\begin{array}{c}\text { В том числе оборот оптовой торговли } \\
\text { организаций оптовой торговли }\end{array}$}} \\
\hline & \multirow{3}{*}{$\begin{array}{c}\text { млрд } \\
\text { рублей }\end{array}$} & \multicolumn{2}{|c|}{$6 \% \kappa$} & & & \\
\hline & & cоomвem- & npedbl- & \multirow{2}{*}{$\begin{array}{c}\text { млрд } \\
\text { рублей }\end{array}$} & \multicolumn{2}{|c|}{$6 \% \kappa$} \\
\hline & & $\begin{array}{c}\text { ствуюшему } \\
\text { периоду } \\
\text { предьдущего } \\
\text { года }\end{array}$ & $\begin{array}{l}\text { дущему } \\
\text { периоду }\end{array}$ & & $\begin{array}{c}\text { соответ- } \\
\text { ствуюшему } \\
\text { периоду } \\
\text { предьдущего } \\
\text { года } \\
\end{array}$ & $\begin{array}{l}\text { предь- } \\
\text { душему } \\
\text { периоду }\end{array}$ \\
\hline \multicolumn{7}{|c|}{2019 г. } \\
\hline Январь & 5635,4 & 91,9 & 69,6 & 4514,0 & 90,9 & 70,5 \\
\hline Февраль & 6124,7 & 94,2 & 109,0 & 4880,1 & 92,7 & 108,4 \\
\hline Март & 7045,8 & 94,3 & 116,2 & 5586,2 & 92,6 & 115,6 \\
\hline І квартал & 18805,9 & 93,6 & 82,9 & 14980,3 & 92,1 & 83,7 \\
\hline Апрель & 7084,2 & 98,4 & 100,6 & 5541,8 & 97,7 & 99,3 \\
\hline Май & 6704,4 & 93,9 & 94,9 & 5222,3 & 92,3 & 94,5 \\
\hline Июнь & 6867,3 & 98,2 & 104,9 & 5368,0 & 97,1 & 105,2 \\
\hline II квартал & 20655,9 & 96,8 & 111,8 & 16132,1 & 95,7 & 109,6 \\
\hline I полугодие & 39461,8 & 95,3 & & 31112,4 & 94,0 & \\
\hline Июль & 7060,0 & 106,1 & 104,6 & 5560,8 & 105,6 & 105,4 \\
\hline Август & 7219,9 & 103,5 & 102,2 & 5681,4 & 102,9 & 102,1 \\
\hline Сентябрь & 7348,1 & 106,1 & 102,0 & 5789,6 & 106,7 & 102,1 \\
\hline III квартал & 21628,0 & 105,2 & 108,4 & 17031,8 & 105,0 & 109,3 \\
\hline Январь-сентябрь & 61089,8 & 98,9 & & 48144,2 & 98,0 & \\
\hline Октябрь & 7575,8 & 110,1 & 104,7 & 5956,0 & 110,1 & 104,4 \\
\hline Ноябрь & 7420,5 & 108,6 & 97,0 & 5841,0 & 108,1 & 97,1 \\
\hline Декабрь & 8118,2 & 106,7 & 109,1 & 6326,5 & 105,1 & 108,1 \\
\hline IV квартал & 23114,5 & 108,4 & 107,9 & 18123,5 & 107,7 & 107,4 \\
\hline Год & 84204,3 & 101,6 & & 66267,7 & 100,7 & \\
\hline \multicolumn{7}{|c|}{2020 г. } \\
\hline Январь & 5775,1 & 106,5 & 69,5 & 4632,8 & 106,7 & 71,6 \\
\hline Февраль & 6205,7 & 106,1 & 108,6 & 4960,2 & 106,5 & 108,2 \\
\hline Март & 7176,2 & 106,0 & 116,0 & 5810,4 & 108,2 & 117,5 \\
\hline І квартал & 19157,0 & 106,2 & 86,7 & 15403,4 & 107,2 & 88,9 \\
\hline Апрель & 5955,1 & 87,5 & 83,1 & 4945,9 & 92,9 & 85,2 \\
\hline Май & 5665,8 & 89,3 & 96,8 & 4594,0 & 92,9 & 94,5 \\
\hline Июнь & 6551,5 & 99,0 & 116,3 & 5204,0 & 100,6 & 113,9 \\
\hline II квартал & 18172,4 & 91,9 & 96,8 & 14743,9 & 95,5 & 97,7 \\
\hline I полугодие & 37329,4 & 98,7 & & 30147,3 & 101,1 & \\
\hline
\end{tabular}




\begin{tabular}{|c|c|c|c|c|c|c|}
\hline & \multicolumn{3}{|c|}{ Оборот оптовой торговли } & \multirow{2}{*}{\multicolumn{3}{|c|}{$\begin{array}{c}\text { В том числе оборот оптовой торговли } \\
\text { организаций оптовой торговли }\end{array}$}} \\
\hline & \multirow{3}{*}{$\begin{array}{c}\text { млрд } \\
\text { рублей }\end{array}$} & \multicolumn{2}{|c|}{$6 \% \kappa$} & & & \\
\hline & & cоответ- & $n p e d b l-$ & \multirow{2}{*}{$\begin{array}{c}\text { млрд } \\
\text { рублей }\end{array}$} & \multicolumn{2}{|c|}{$6 \% \kappa$} \\
\hline & & $\begin{array}{c}\text { ствуюшему } \\
\text { периоду } \\
\text { предьдучщего } \\
\text { года }\end{array}$ & $\begin{array}{l}\text { душему } \\
\text { периоду }\end{array}$ & & $\begin{array}{c}\text { соответ- } \\
\text { ствующему } \\
\text { периоду } \\
\text { предьдуцего } \\
\text { года } \\
\end{array}$ & $\begin{array}{l}\text { предь- } \\
\text { думему } \\
\text { периоду }\end{array}$ \\
\hline Июль & 6920,3 & 101,5 & 107,3 & 5470,1 & 101,9 & 106,8 \\
\hline Август ${ }^{1)}$ & 7099,4 & 100,4 & 101,1 & 5625,8 & 101,1 & 101,3 \\
\hline Сентябрь & 7448,3 & 101,5 & 103,2 & 5904,4 & 102,1 & 103,2 \\
\hline ІІІ квартал & 21468,0 & 101,1 & 119,3 & 17000,3 & 101,7 & 116,4 \\
\hline Январь-сентябрь & 58797,4 & 99,6 & & 47147,6 & 101,3 & \\
\hline
\end{tabular}

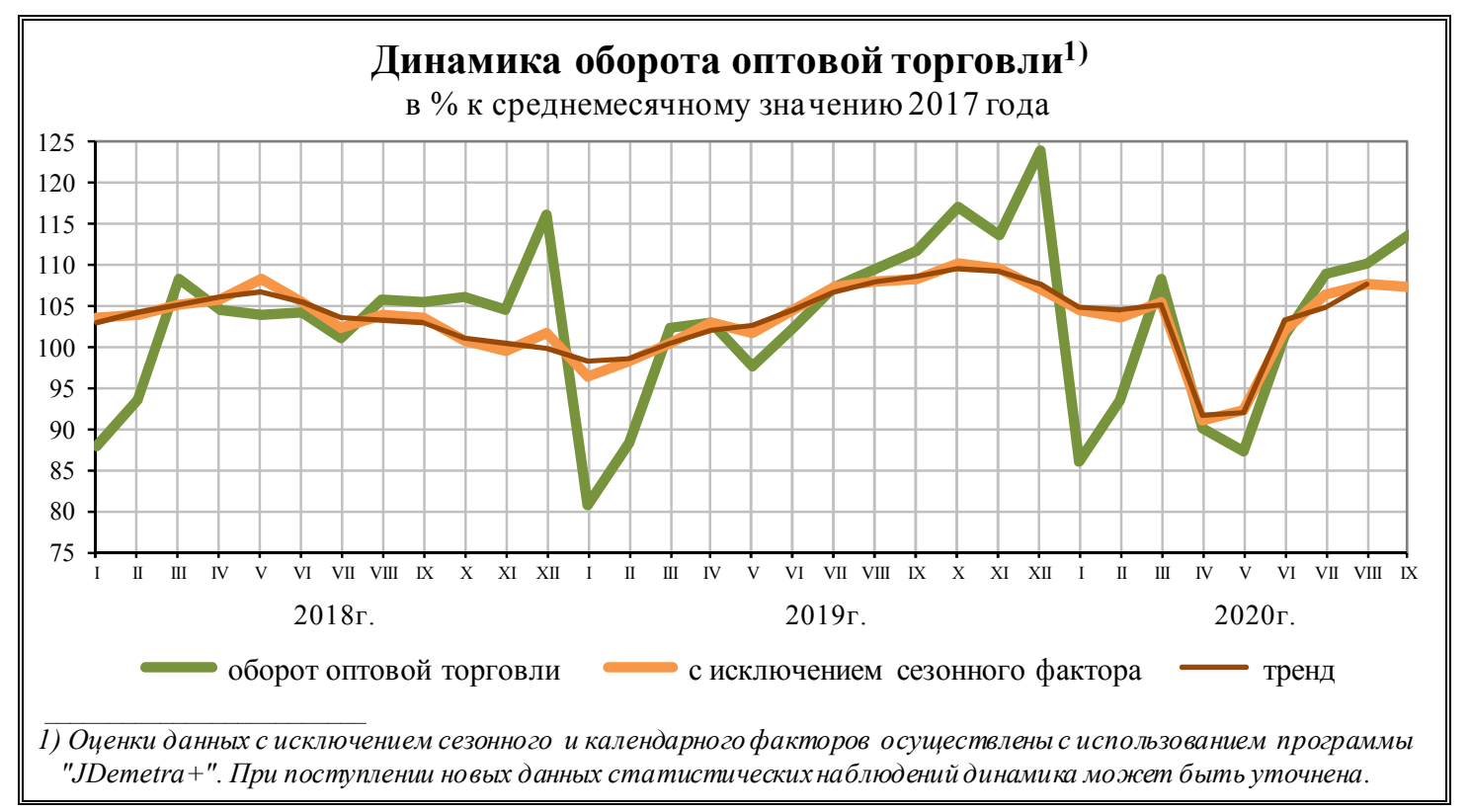

В сентябре 2020 г. оборот оптовой торговли на 79,3\% формировался организациями оптовой торговли (в сентябре 2019 г. - на 78,8\%), оборот которых составил 5904,4 млрд рублей, или $102,1 \%$ (в сопоставимых ценах) к сентябрю 2019 года.

Таблица 2

СТРУКТУРА ОБОРОТА ОПТОВОЙ ТОРГОВЛИ

ПО ВИДАМ ДЕЯТЕЛЬНОСТИ ОРГАНИЗАЦИЙ ОПТОВОЙ ТОРГОВЛИ

(без субъектов малого предпринимательства и организаций со средней численностью работников до 15 человек, не являющихся субъектами малого предпринимательства)

удельный вес, в процентах; в фактических ценах

\begin{tabular}{|c|c|c|}
\hline & $\begin{array}{l}\text { Сентябрь } \\
2020 \text { г. }\end{array}$ & сентягорь 2019 С. \\
\hline $\begin{array}{l}\text { Организации, осуществлявшие торговлю оптовую, включая торговлю через } \\
\text { агентов, кроме торговли автотранспортными средствами и мотоциклами }\end{array}$ & 100 & 100 \\
\hline $\begin{array}{l}\text { в том числе осуществлявшие торговлю оптовую: } \\
\text { через агентов (за вознаграждение или на договорной основе) }\end{array}$ & 1,2 & 2,9 \\
\hline сельскохозяйственным сырьем и живыми животными & 4,8 & 3,6 \\
\hline
\end{tabular}




\begin{tabular}{|c|c|c|}
\hline & $\begin{array}{l}\text { Сентябрь } \\
2020 \text { г. }\end{array}$ & $\frac{\text { Справочно }}{\text { сентябрь 2019 2. }}$ \\
\hline пищевыми продуктами, напитками и табачными изделиями & 21,9 & 20,0 \\
\hline из них: & & \\
\hline мясом и мясными продуктами & 2,1 & 2,1 \\
\hline молочными продуктами, яйцами и пищевыми маслами и жирами & 1,9 & 1,5 \\
\hline напитками & 4,2 & 3,6 \\
\hline табачными изделиями & 7,1 & 6,6 \\
\hline непродовольственными потребительскими товарами & 17,8 & 17,5 \\
\hline $\begin{array}{l}\text { из них: } \\
\text { бытовыми электротоварами }\end{array}$ & 2,9 & 2,9 \\
\hline фармацевтической продукцией и изделиями, применяемыми в медицинских целях & 8,9 & 8,6 \\
\hline прочими бытовыми товарами & 2,8 & 2,1 \\
\hline информационным и коммуникационным оборудованием & 4,0 & 2,6 \\
\hline машинами и оборудованием & 6,3 & 5,3 \\
\hline несельскохозяйственными промежуточными продуктами, отходами и ломом & 37,9 & 42,5 \\
\hline $\begin{array}{l}\text { из них: } \\
\text { твердым, жидким и газообразным топливом и подобными продуктами }\end{array}$ & 25,8 & 32,6 \\
\hline металлами и металлическими рудами & 3,8 & 3,2 \\
\hline $\begin{array}{l}\text { лесоматериалами, строительными материалами и } \\
\text { санитарно-техническим оборудованием }\end{array}$ & 2,9 & 2,2 \\
\hline неспециализированную & 6,1 & 5,6 \\
\hline
\end{tabular}

В III квартале 2020 г. в обследовании конъюнктуры и деловой активности приняли участие руководители 5,2 тыс. организаций оптовой торговли, включая малые предприятия (без микропредприятий), из которых 75,1\% оценили общую экономическую ситуацию, сложившуюся в этой сфере деятельности, как удовлетворительную, 19,5\% прогнозируют ее улучшение в IV квартале 2020 г., 68,0\% считают, что экономическая ситуация не изменится, а 12,5\% - что ухудшится.

Индекс предпринимательской уверенности в оптовой торговле в III квартале 2020 г. составил 4,9\% против 6,3\% в III квартале 2019 года.

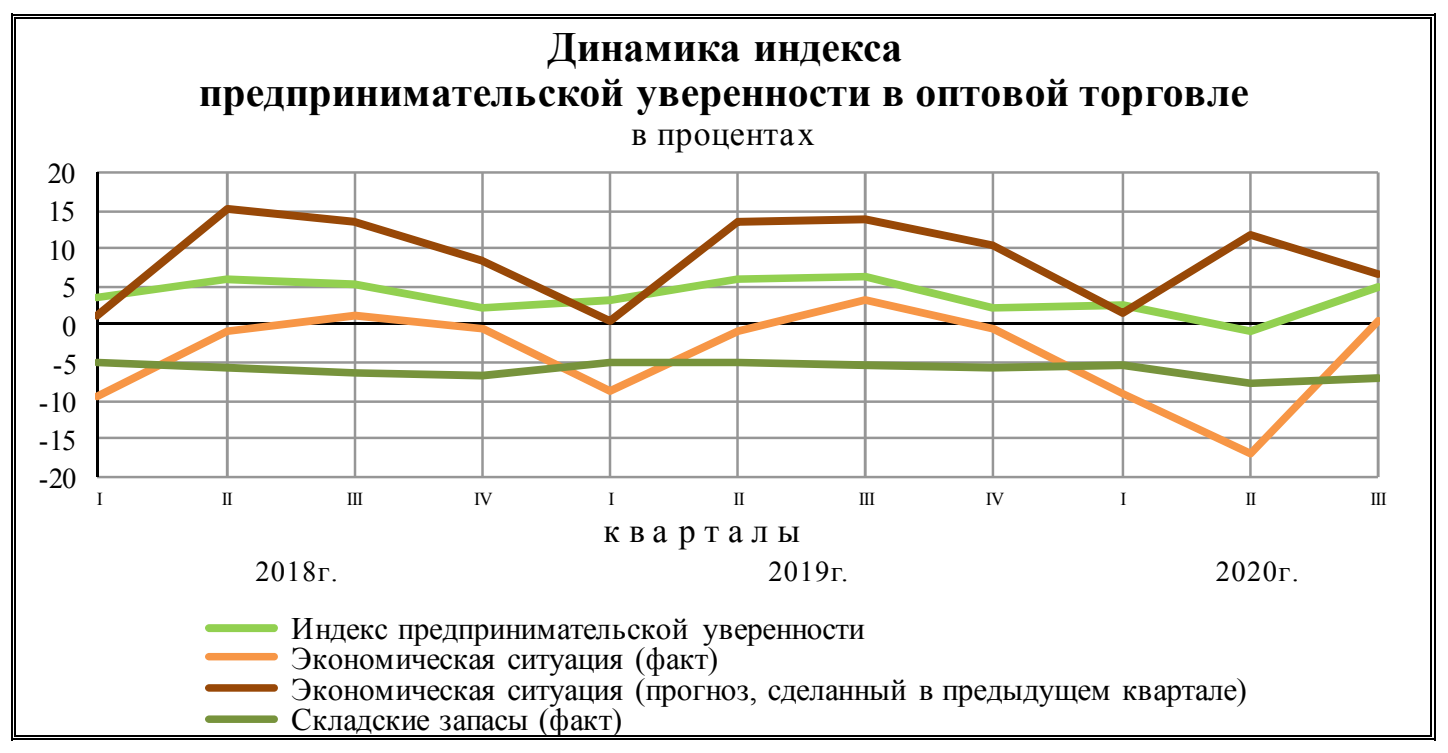




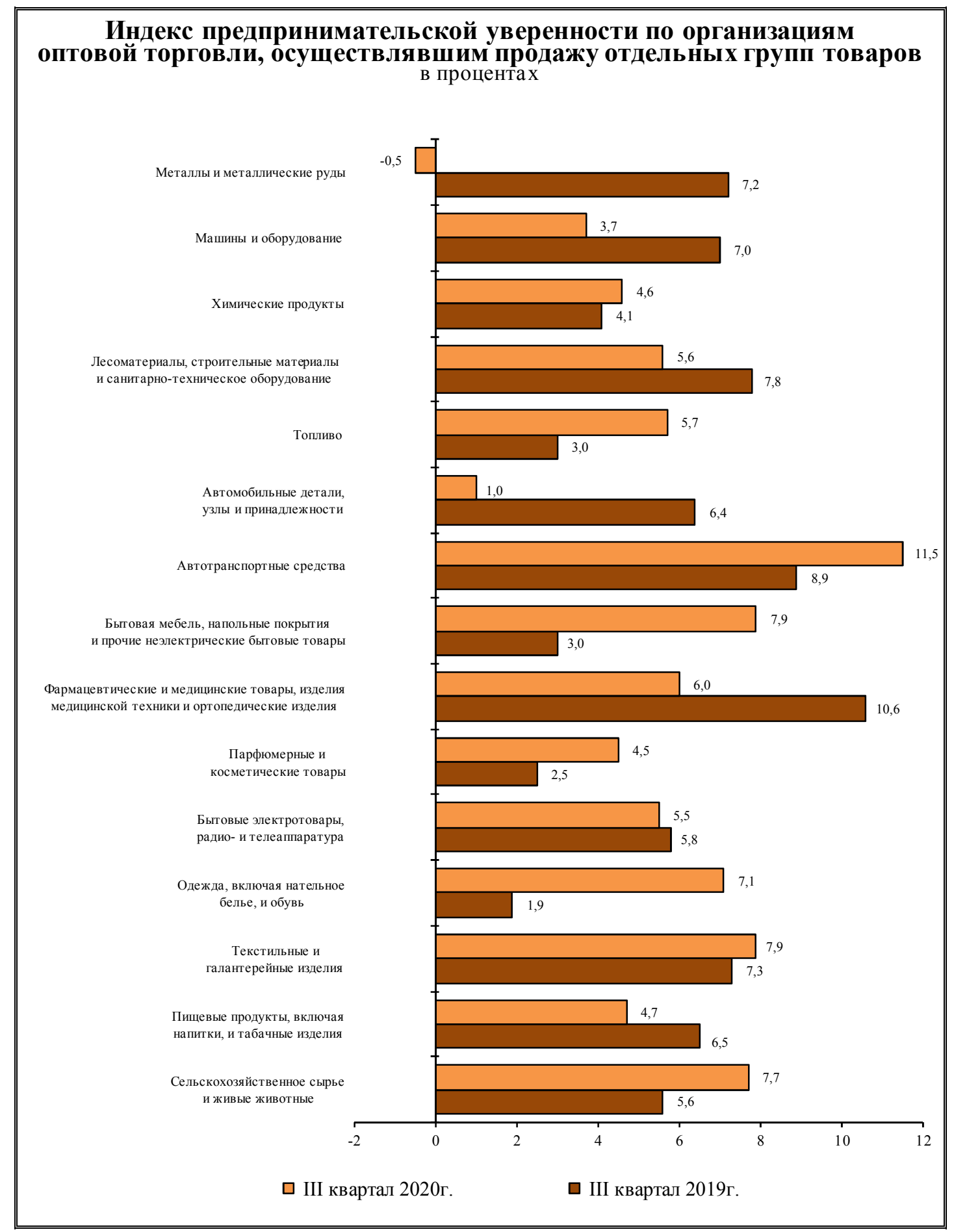

Среди факторов, ограничивающих деятельность оптовых организаций в наибольшей степени, респонденты выделяют неплатежеспособность покупателей - 63,1\%, высокий уровень налогов - 56,4\%, высокие транспортные расходы - 45,3\%, недостаток финансовых средств - 34,8\%. 
Запасы топлива.

Таблица 3

ЗАПАСЫ УГЛЯ И МАЗУТА ТОПОЧНОГО НА СКЛАДАХ ДОБЫВАЮЩИХ ОРГАНИЗАЦИЙ, ОРГАНИЗАЦИЙ ОПТОВОЙ ТОРГОВЛИ И У ПОТРЕБИТЕЛЕЙ

тыс. тонн

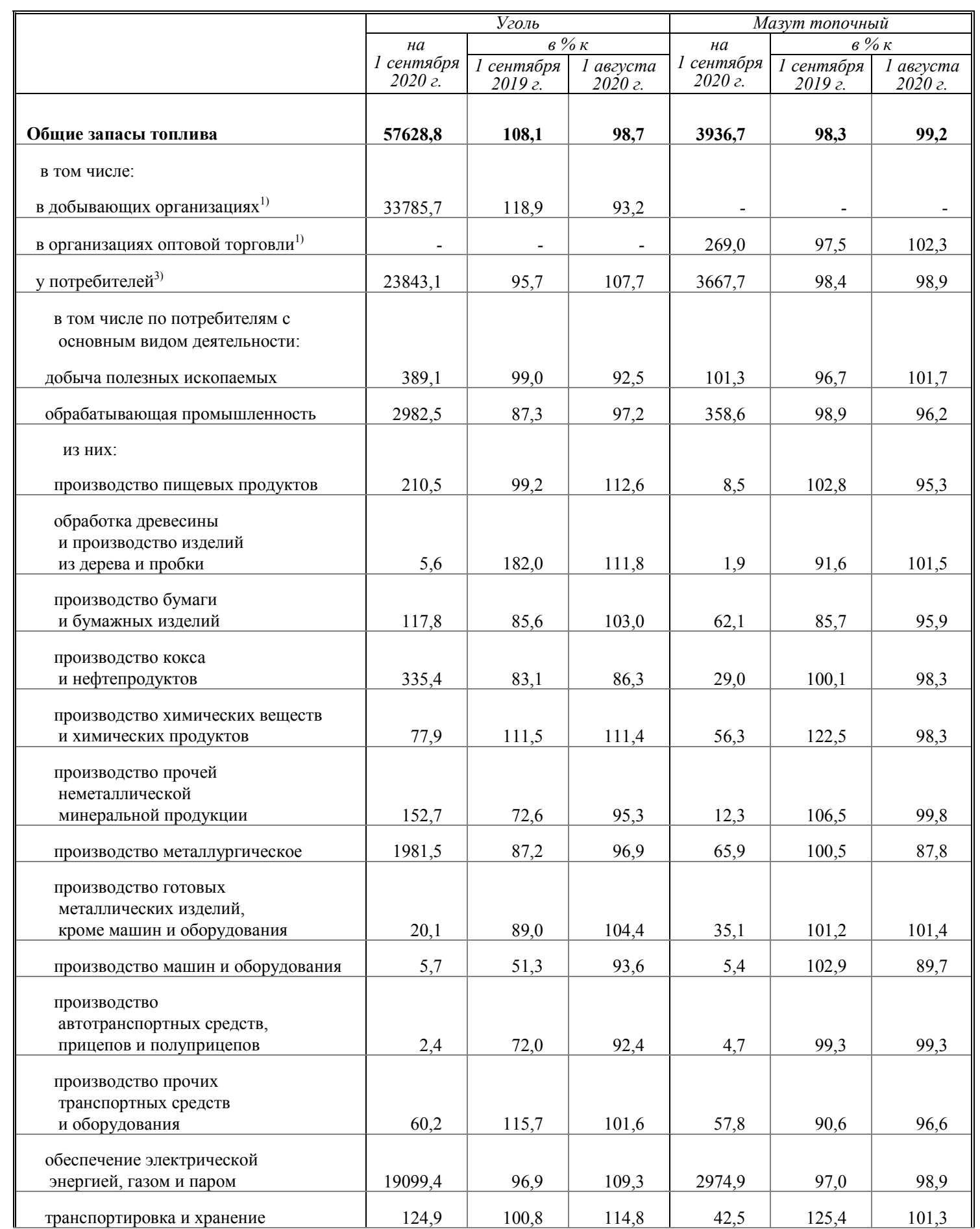




\begin{tabular}{|c|c|c|c|c|c|c|}
\hline & \multicolumn{3}{|c|}{ Уголь } & \multicolumn{3}{|c|}{ "Мазут топочныий } \\
\hline & \multirow{2}{*}{$\begin{array}{l}\text { на } \\
1 \text { сентября } \\
2020 \text { г. }\end{array}$} & \multicolumn{2}{|c|}{$6 \% \kappa$} & \multirow{2}{*}{\begin{tabular}{c|}
\multicolumn{1}{|c|}{} \\
1 сентября \\
2020 2. \\
\end{tabular}} & \multicolumn{2}{|c|}{$6 \% \kappa$} \\
\hline & & $\begin{array}{c}1 \text { сентября } \\
2019 \text { г. }\end{array}$ & $\begin{array}{l}1 \text { aвгуста } \\
2020 \text { z. }\end{array}$ & & $\begin{array}{c}1 \text { сентября } \\
2019 \text { г. }\end{array}$ & $\begin{array}{c}1 \text { августа } \\
2020 \text { z. }\end{array}$ \\
\hline $\begin{array}{l}\text { деятельность гостиниц и } \\
\text { предприятий общественного питания }\end{array}$ & 4,5 & 93,6 & 112,4 & 0,8 & 113,3 & 84,9 \\
\hline прочие потребители & 1242,7 & 98,5 & 116,7 & 189,6 & 119,4 & 103,0 \\
\hline $\begin{array}{l}\text { Из строки "у потребителей" } \\
\text { жилищно-коммунальное хозяйство }\end{array}$ & 309,7 & 109,2 & 109,5 & 73,4 & 130,0 & 99,4 \\
\hline $\begin{array}{l}\text { 1) По данным ФГБУ "ЦДУ ТЭК". } \\
\text { 2) Данные приведень без субъектов мал } \\
\text { до } 15 \text { человек, не являющихся субъекп } \\
\text { 2) Без данных по микропредприятиям. }\end{array}$ & $\begin{array}{l}\text { едприн } \\
\text { алого }\end{array}$ & $\begin{array}{l}\text { пельства } \\
\text { принимап }\end{array}$ & ганизаци & средней & сленность & аботников \\
\hline
\end{tabular}

Запасы угля для продажи населению и организациям социальной сферы на 1 сентября 2020 г. были созданы на топливных складах 45 субъектов Российской Федерации (на 1 сентября 2019 г. - 43 субъектов) и составили 0,5 млн тонн, что на 12,6\% меньше, чем на соответствующую дату предыдущего года. Из 17 субъектов Российской Федерации, где запасы угля были меньше, чем на 1 сентября 2019 г., в 9 субъектах они сократились более чем на $30 \%$.

В котельных, находящихся в ведении муниципалитетов, и в ведомственных котельных запасы угля на 1 сентября 2020 г. составили 3,9 млн тонн, что на 1,9\% больше, чем на соответствующую дату предыдущего года. По сравнению с 1 сентября 2019 г. запасы угля увеличились в 45 субъектах Российской Федерации, уменьшились - в 30 субъектах.

\section{Структура запасов угля и мазута топочного у потребителей на 1 сентября 2020 года \\ в процентах}

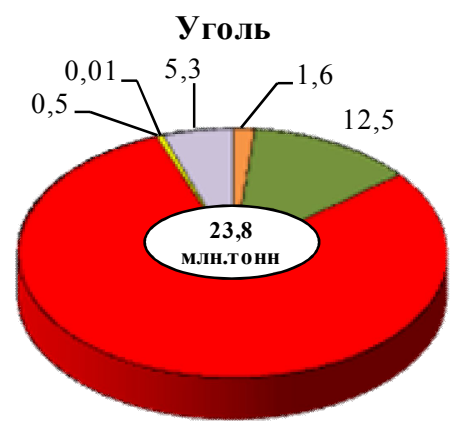

80,1

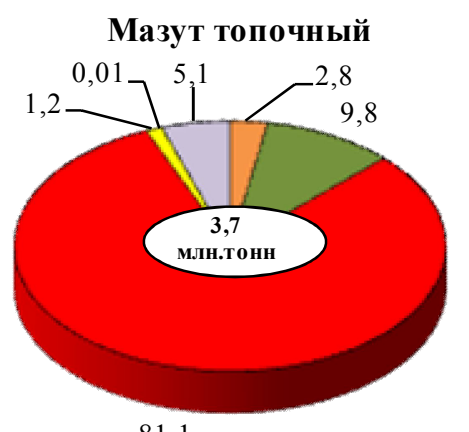

81,1

Основной вид деятельности потребителей:

口 добыча полезных ископаемых

口 обрабатывающие производства

口 обеспечение электрической энергией, газом и паром

$\square$ транспортировка и хранение

$\square$ деятельность гостиниц и предприятий общественного питания

$\square$ прочие потребители

В объеме запасов угля и мазута топочного, сосредоточенных у потребителей на 1 сентября 2020 г., доля жилищно-коммунального хозяйства составила 1,3\% и 2,0\% соответственно. 


\section{5. ВНЕШНЯЯ ТОРГОВЛЯ}

Внешнеторговый оборот России, по данным Банка России ${ }^{1)}$ (по методологии платежного баланса), в августе 2020 г. составил (в фактически действовавших ценах) 42,8 млрд долларов США (3159,2 млрд рублей), в том числе экспорт - 23,3 млрд долларов (1716,8 млрд рублей), импорт - 19,5 млрд долларов (1442,4 млрд рублей).

Сальдо торгового баланса в августе 2020 г. сложилось положительное, 3,7 млрд долларов (в августе 2019 г. - положительное, 12,4 млрд долларов).

Таблица 1

\section{ДИНАМИКА ВНЕШНЕТОРГОВОГО ОБОРОТА РОССИИ}

(по данным Банка России)

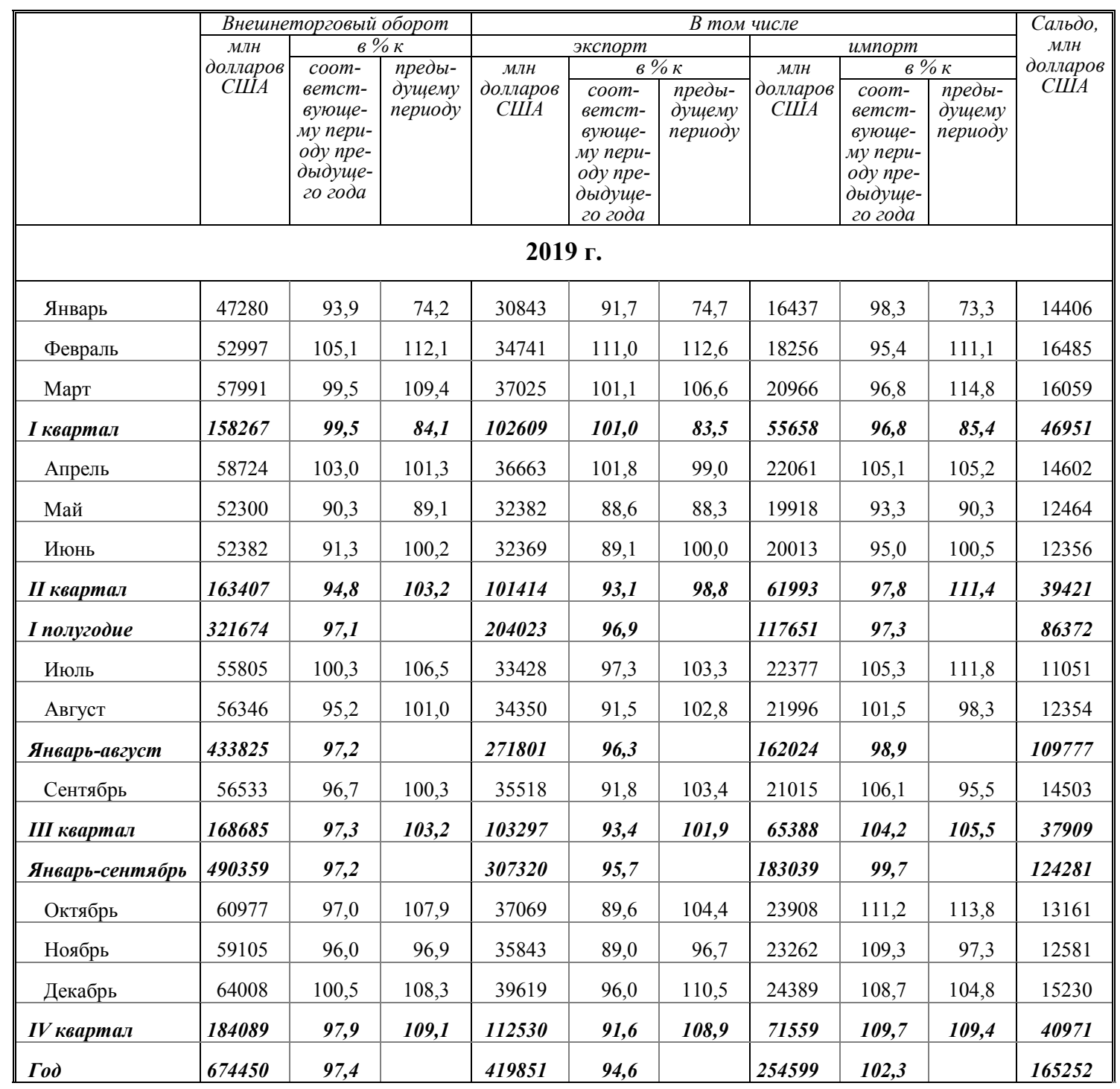

1) Информация представлена по состоянию на 12 октября 2020 года. 


\begin{tabular}{|c|c|c|c|c|c|c|c|c|c|c|}
\hline & \multicolumn{3}{|c|}{ Внешнеторговый оборот } & \multicolumn{6}{|c|}{ В том числе } & \multirow{4}{*}{$\begin{array}{c}\text { Сальдо, } \\
\text { млн } \\
\text { долларов } \\
\text { США }\end{array}$} \\
\hline & \multirow{3}{*}{\begin{tabular}{|c|} 
млн \\
долларов \\
США
\end{tabular}} & \multicolumn{2}{|c|}{$6 \% \kappa$} & \multicolumn{3}{|c|}{ экспорт } & \multicolumn{3}{|c|}{ uмnорm } & \\
\hline & & \multirow[b]{2}{*}{\begin{tabular}{|c|} 
coom- \\
ветст- \\
вуюше- \\
му пери- \\
оду пре- \\
дьдуще- \\
го года
\end{tabular}} & \multirow{2}{*}{$\begin{array}{l}\text { преды- } \\
\text { душему } \\
\text { периоду }\end{array}$} & \multirow{2}{*}{$\begin{array}{c}\text { млн } \\
\text { долларов } \\
\text { США }\end{array}$} & \multicolumn{2}{|c|}{$6 \% \mathrm{~K}$} & \multirow{2}{*}{\begin{tabular}{|c|} 
млн \\
долларов \\
США
\end{tabular}} & \multicolumn{2}{|c|}{$8 \% \kappa$} & \\
\hline & & & & & $\begin{array}{c}\text { coom- } \\
\text { ветст- } \\
\text { вуюше- } \\
\text { му пери- } \\
\text { оду пре- } \\
\text { дыдуще- } \\
\text { го года }\end{array}$ & $\begin{array}{l}\text { предь- } \\
\text { дущему } \\
\text { периоду }\end{array}$ & & \begin{tabular}{|c|} 
соот- \\
ветст- \\
вуюше- \\
му пери- \\
оду пре- \\
дыдуще- \\
го года
\end{tabular} & $\begin{array}{l}\text { предь- } \\
\text { думему } \\
\text { периоду }\end{array}$ & \\
\hline \multicolumn{11}{|c|}{2020 г. } \\
\hline Январь & 47498 & 100,5 & 74,2 & 30379 & 98,5 & 76,7 & 17119 & 104,1 & 70,2 & 13260 \\
\hline Февраль & 47175 & 89,0 & 99,3 & 28504 & 82,0 & 93,8 & 18671 & 102,3 & 109,1 & 9833 \\
\hline Март & 50200 & 86,6 & 106,4 & 29753 & 80,4 & 104,4 & 20447 & 97,5 & 109,5 & 9306 \\
\hline І квартал & 144875 & 91,5 & 78,7 & 88637 & 86,4 & 78,8 & 56238 & 101,0 & 78,6 & 32399 \\
\hline Апрель & 42315 & 72,1 & 84,3 & 24726 & 67,4 & 83,1 & 17589 & 79,7 & 86,0 & 7137 \\
\hline Май & 37890 & 72,4 & 89,5 & 20599 & 63,6 & 83,3 & 17291 & 86,8 & 98,3 & 3308 \\
\hline Июнь & 43143 & 82,4 & 113,9 & 24020 & 74,2 & 116,6 & 19123 & 95,6 & 110,6 & 4897 \\
\hline ІІ квартал & 123347 & 75,5 & 85,1 & 69344 & 68,4 & 78,2 & 54003 & 87,1 & 96,0 & 15341 \\
\hline I полугодие & 268222 & 83,4 & & 157981 & 77,4 & & 110241 & 93,7 & & 47740 \\
\hline Июль & 43685 & 78,3 & 101,3 & 24234 & 72,5 & 100,9 & 19451 & 86,9 & 101,7 & 4783 \\
\hline Август & 42808 & 76,0 & 98,0 & 23263 & 67,7 & 96,0 & 19545 & 88,9 & 100,5 & 3718 \\
\hline Январь-август & 354714 & 81,8 & & 205478 & 75,6 & & 149236 & 92,1 & & 56242 \\
\hline
\end{tabular}

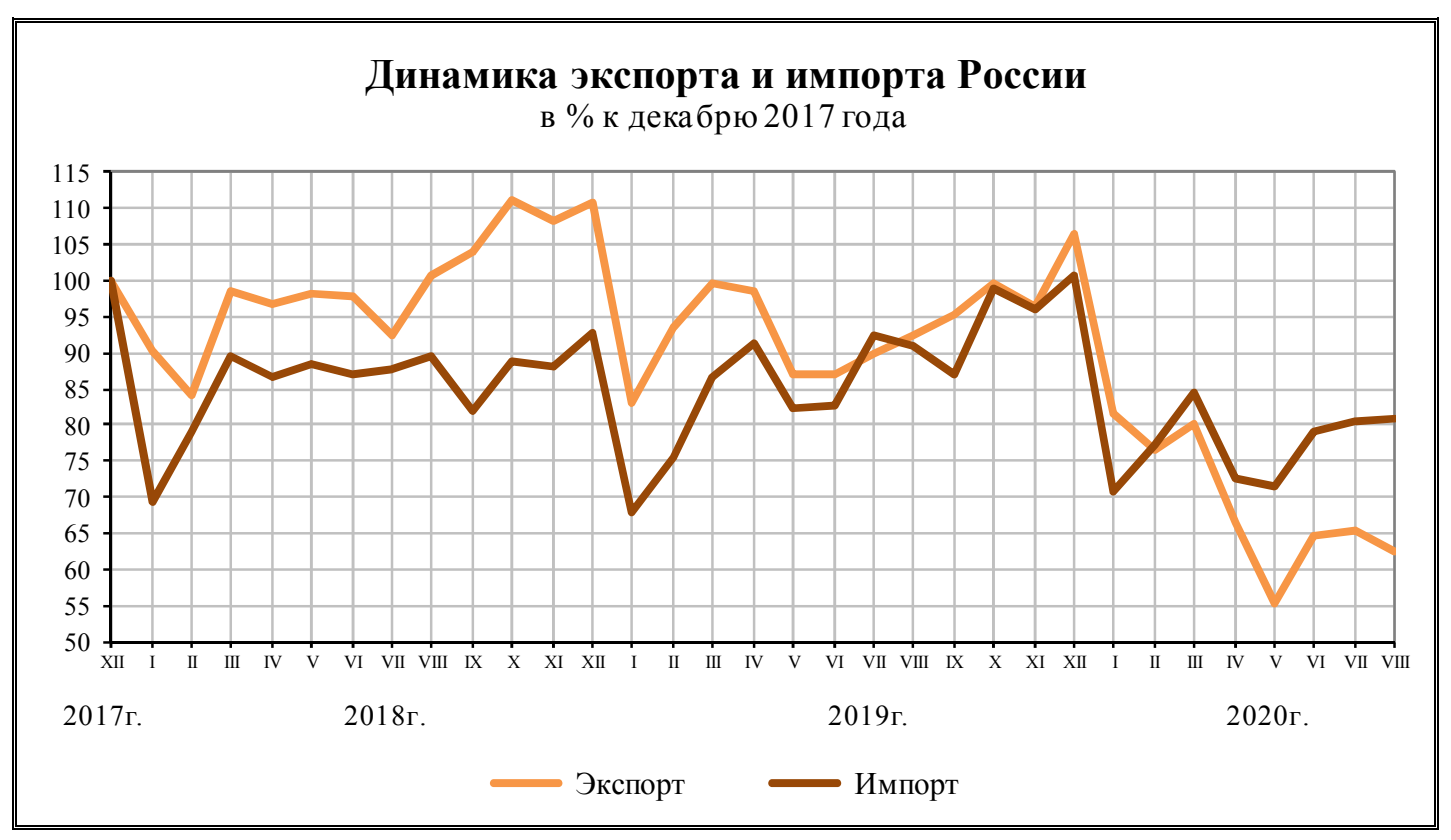

В августе 2020 г. внешнеторговый оборот России со странами дальнего зарубежья составил в текущих ценах 36,8 млрд долларов США (2712,3 млрд рублей) и по сравнению с соответствующим месяцем 2019 г. снизился на $25,3 \%$, с государствами-участниками СНГ - 6,1 млрд долларов США (446,9 млрд рублей) и снизился на 15,0\%. 


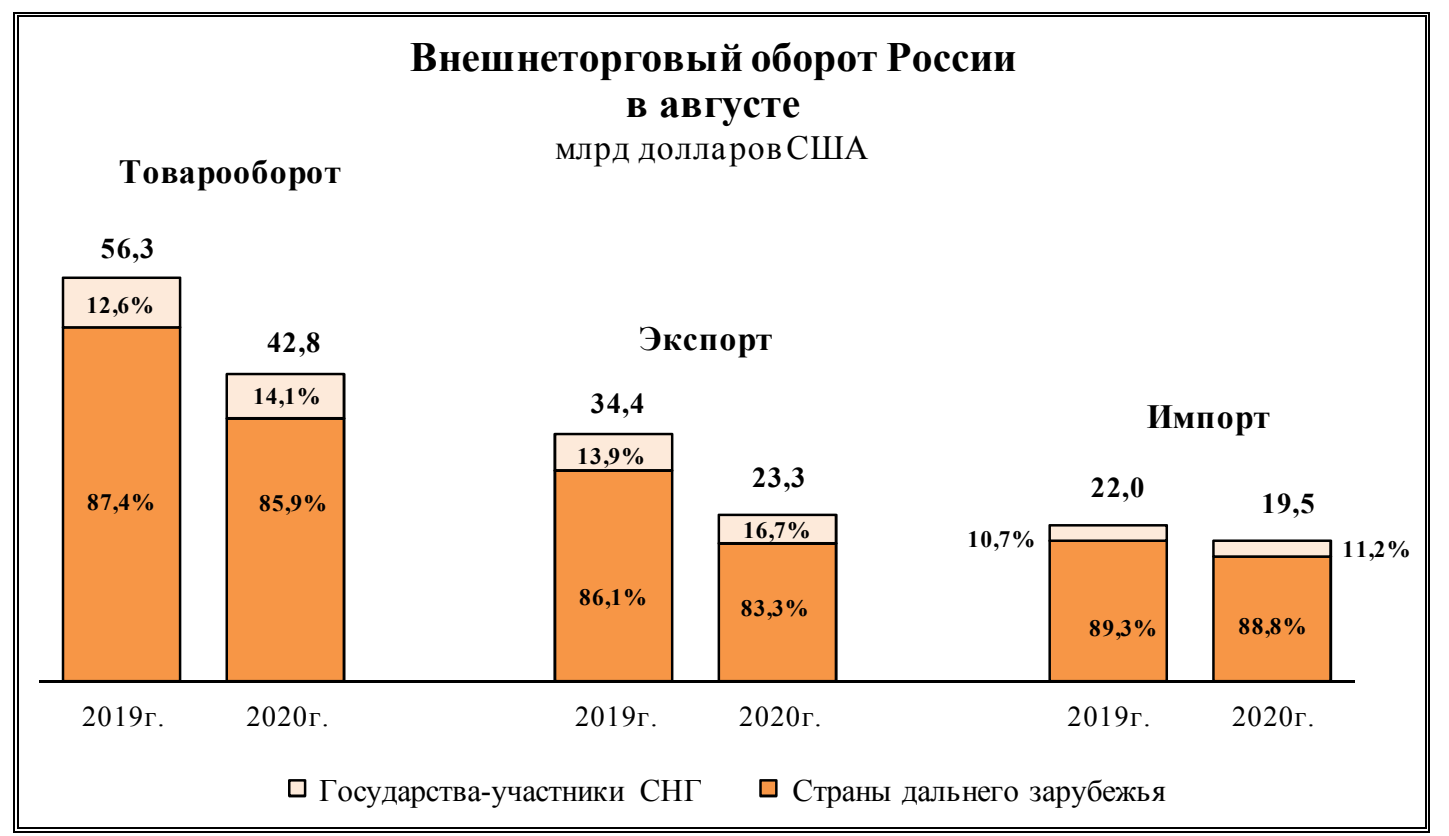

Таблица 2

ДИНАМИКА ЭКСПОРТА И ИМПОРТА

ПО СТРАНАМ ДАЛЬНЕГО ЗАРУБЕЖЬЯ И ГОСУДАРСТВАМ-УЧАСТНИКАМ СНГ (по данным Банка России)

\begin{tabular}{|c|c|c|c|c|c|c|c|c|}
\hline & \multicolumn{4}{|c|}{ Страныл дальнего зарубежья } & \multicolumn{4}{|c|}{ ГГосударства-участники СНГ } \\
\hline & \multicolumn{2}{|c|}{ экспорт } & \multicolumn{2}{|c|}{ uмnopm } & \multicolumn{2}{|c|}{ экспорт } & \multicolumn{2}{|c|}{ unnopm } \\
\hline & $\begin{array}{c}\text { млн } \\
\text { долларов } \\
\text { США }\end{array}$ & $\begin{array}{l}\text { в\% к со- } \\
\text { ответст- } \\
\text { вуюшему } \\
\text { периоду } \\
\text { предылу- } \\
\text { щего года }\end{array}$ & $\begin{array}{c}\text { млн } \\
\text { долларов } \\
\text { США }\end{array}$ & \begin{tabular}{|c|} 
в\% к со- \\
ответст- \\
вуюшему \\
периоду \\
предылу- \\
щего года
\end{tabular} & $\begin{array}{c}\text { млн } \\
\text { долларов } \\
\text { США }\end{array}$ & $\begin{array}{c}\text { в\% к со- } \\
\text { ответст- } \\
\text { вуюшему } \\
\text { периоду } \\
\text { предыду- } \\
\text { щеего года }\end{array}$ & $\begin{array}{c}\text { млн } \\
\text { долларов } \\
\text { США }\end{array}$ & $\begin{array}{c}\text { в\% к со- } \\
\text { ответст- } \\
\text { вуюшему } \\
\text { периоду } \\
\text { предылу- } \\
\text { щего года }\end{array}$ \\
\hline \multicolumn{9}{|c|}{2019 г. } \\
\hline Январь & 27232 & 91,7 & 14590 & 98,5 & 3611 & 91,9 & 1847 & 96,5 \\
\hline Февраль & 30363 & 113,0 & 16214 & 94,8 & 4378 & 98,9 & 2042 & 100,9 \\
\hline Mapт & 32207 & 101,3 & 18722 & 96,9 & 4818 & 99,7 & 2244 & 95,6 \\
\hline I квартал & 89802 & 101,6 & 49527 & 96,7 & 12806 & 97,1 & 6132 & 97,6 \\
\hline Апрель & 31519 & 100,9 & 19601 & 104,7 & 5144 & 108,0 & 2460 & 108,3 \\
\hline Май & 27987 & 87,8 & 17611 & 92,8 & 4395 & 94,5 & 2307 & 97,4 \\
\hline Июнь & 28013 & 88,6 & 17633 & 94,2 & 4356 & 92,5 & 2380 & 101,4 \\
\hline ІІ квартал & 87519 & 92,4 & 54845 & 97,2 & 13895 & 98,4 & 7148 & 102,3 \\
\hline I полугодие & 177321 & 96,8 & 104372 & 97,0 & 26701 & 97,8 & 13280 & 100,1 \\
\hline Июль & 28837 & 96,7 & 19931 & 104,7 & 4591 & 100,7 & 2446 & 111,1 \\
\hline Август & 29587 & 90,4 & 19636 & 100,8 & 4763 & 99,5 & 2360 & 108,2 \\
\hline Январь-август & 235745 & 96,0 & 143938 & 98,5 & 36056 & 98,3 & 18086 & 102,4 \\
\hline
\end{tabular}




\begin{tabular}{|c|c|c|c|c|c|c|c|c|}
\hline & \multicolumn{4}{|c|}{ Страны дальнего зарубежья } & \multicolumn{4}{|c|}{ ГГосударства-участники СНГ } \\
\hline & \multicolumn{2}{|c|}{ экспорт } & \multicolumn{2}{|c|}{ uмnорm } & \multicolumn{2}{|c|}{ экспорт } & \multicolumn{2}{|c|}{ илnорт } \\
\hline & $\begin{array}{c}\text { млн } \\
\text { долларов } \\
\text { США }\end{array}$ & $\begin{array}{c}\text { в\% к со- } \\
\text { ответст- } \\
\text { вуюшему } \\
\text { периоду } \\
\text { предыду- } \\
\text { щего года }\end{array}$ & $\begin{array}{c}\text { млн } \\
\text { долларов } \\
\text { США }\end{array}$ & $\begin{array}{l}\text { в\% к со- } \\
\text { ответст- } \\
\text { вуюшему } \\
\text { периоду } \\
\text { предыду- } \\
\text { щего года }\end{array}$ & $\begin{array}{c}\text { млн } \\
\text { долларов } \\
\text { США }\end{array}$ & $\begin{array}{l}\text { в\% к со- } \\
\text { ответст- } \\
\text { вуюшему } \\
\text { периоду } \\
\text { предылуу- } \\
\text { щего года }\end{array}$ & $\begin{array}{c}\text { млн } \\
\text { долларов } \\
\text { США }\end{array}$ & $\begin{array}{l}\text { в\% к со- } \\
\text { ответст- } \\
\text { вуюшему } \\
\text { периоду } \\
\text { предьдуу- } \\
\text { щего года }\end{array}$ \\
\hline Сентябрь & 30804 & 90,7 & 18708 & 105,1 & 4714 & 100,3 & 2307 & 115,1 \\
\hline ІІІ квартал & 89229 & 92,4 & 58275 & 103,4 & 14069 & 100,2 & 7113 & 111,3 \\
\hline Январь-сентябрь & 266550 & 95,3 & 162647 & 99,2 & 40770 & 98,6 & 20393 & 103,7 \\
\hline Октябрь & 32284 & 90,1 & 21493 & 111,7 & 4785 & 87,0 & 2415 & 106,6 \\
\hline Ноябрь & 30779 & 86,8 & 20821 & 109,4 & 5064 & 105,5 & 2441 & 108,1 \\
\hline Декабрь & 33958 & 93,7 & 21747 & 108,4 & 5661 & 112,3 & 2642 & 111,8 \\
\hline IV квартал & 97021 & 90,2 & 64060 & 109,8 & 15510 & 101,1 & 7499 & 108,9 \\
\hline Год & 363571 & 93,9 & 226708 & 102,0 & 56280 & 99,3 & 27891 & 105,1 \\
\hline \multicolumn{9}{|c|}{2020 г. } \\
\hline Январь & 26897 & 98,8 & 15278 & 104,7 & 3482 & 96,4 & 1841 & 99,7 \\
\hline Февраль & 24699 & 81,3 & 16613 & 102,5 & 3805 & 86,9 & 2058 & 100,8 \\
\hline Март & 25931 & 80,5 & 18310 & 97,8 & 3822 & 79,3 & 2137 & 95,2 \\
\hline І квартал & 77527 & 86,3 & 50201 & 101,4 & 11110 & 86,8 & 6036 & 98,4 \\
\hline Апрель & 21484 & 68,2 & 15738 & 80,3 & 3242 & 63,0 & 1851 & 75,2 \\
\hline Май & 17247 & 61,6 & 15470 & 87,8 & 3352 & 76,3 & 1821 & 78,9 \\
\hline Июнь & 19989 & 71,4 & 17046 & 96,7 & 4031 & 92,5 & 2077 & 87,3 \\
\hline ІІ квартал & 58720 & 67,1 & 48254 & 88,0 & 10624 & 76,5 & 5749 & 80,4 \\
\hline І полугодие & 136247 & 76,8 & 98455 & 94,3 & 21734 & 81,4 & 11785 & 88,7 \\
\hline Июль & 20070 & 69,6 & 17339 & 87,0 & 4164 & 90,7 & 2112 & 86,3 \\
\hline Август & 19388 & 65,5 & 17365 & 88,4 & 3875 & 81,4 & 2180 & 92,4 \\
\hline Январь-август & 175705 & 74,5 & 133159 & 92,5 & 29773 & 82,6 & 16077 & 88,9 \\
\hline
\end{tabular}

Внешнеторговый оборот, по данным ФТС России ${ }^{1)}$, в августе 2020 г. составил 42,1 млрд долларов США. Экспорт составил 23,1 млрд долларов, в том числе в страны дальнего зарубежья - 19,4 млрд долларов, в государства-участники СНГ - 3,6 млрд долларов. Импорт составил 19,0 млрд долларов, в том числе из стран дальнего зарубежья - 16,9 млрд долларов, из государствучастников СНГ - 2,1 млрд долларов.

1) Информация представлена по состоянию на 7 октября 2020 2. и включает данные таможенной статистики внешней торговли и взаимной торговли с государствами-членами Евразийского экономического союза (EАЭС). 
ДИНАМИКА ВНЕШНЕТОРГОВОГО ОБОРОТА РОССИИ

(по данным ФТС России)

\begin{tabular}{|c|c|c|c|c|c|c|c|c|c|}
\hline & \multirow{2}{*}{\multicolumn{3}{|c|}{$\begin{array}{c}\text { Внешнеторговый } \\
\text { оборот }\end{array}$}} & \multicolumn{6}{|c|}{ В том числе } \\
\hline & & & & \multicolumn{3}{|c|}{ экспорт } & \multicolumn{3}{|c|}{ импорт } \\
\hline & \multirow{2}{*}{$\begin{array}{c}\text { млн } \\
\text { долларов } \\
\text { США }\end{array}$} & \multicolumn{2}{|c|}{\begin{tabular}{|c|} 
\\
\end{tabular}} & \multirow{2}{*}{$\begin{array}{c}\text { млн } \\
\text { долларов } \\
\text { США }\end{array}$} & \multicolumn{2}{|c|}{$6 \% \kappa$} & \multirow{2}{*}{$\begin{array}{c}\text { млн } \\
\text { долларов } \\
\text { США }\end{array}$} & \multicolumn{2}{|c|}{$6 \% \mathrm{~K}$} \\
\hline & & \begin{tabular}{|c|} 
соответ- \\
ствующе- \\
му пери- \\
оду пре- \\
дыдуще- \\
го года \\
\end{tabular} & $\begin{array}{l}\text { предьл- } \\
\text { душему } \\
\text { периоду }\end{array}$ & & \begin{tabular}{|c|} 
соответ- \\
ствуюше- \\
му пери- \\
оду пре- \\
дыдуше- \\
го года \\
\end{tabular} & $\begin{array}{l}\text { предьл- } \\
\text { душему } \\
\text { периоду }\end{array}$ & & \begin{tabular}{|c|} 
соответ- \\
ствуюше- \\
му пери- \\
оду пре- \\
дыдуще- \\
го года \\
\end{tabular} & $\begin{array}{l}\text { предь- } \\
\text { душему } \\
\text { периоду }\end{array}$ \\
\hline \multicolumn{10}{|c|}{2019 г. } \\
\hline Январь & 47979 & 96,7 & 76,4 & 32397 & 95,3 & 78,1 & 15582 & 99,7 & 72,9 \\
\hline Февраль & 52770 & 104,7 & 110,0 & 35155 & 110,0 & 108,5 & 17615 & 95,6 & 113,0 \\
\hline Март & 57389 & 99,5 & 108,8 & 37211 & 100,5 & 105,8 & 20178 & 97,5 & 114,6 \\
\hline І квартал & 158138 & 100,3 & 84,6 & 104763 & 101,7 & 84,3 & 53375 & 97,5 & 85,2 \\
\hline Апрель & 57629 & 102,2 & 100,4 & 36600 & 100,3 & 98,4 & 21029 & 105,7 & 104,2 \\
\hline Май & 51894 & 90,2 & 90,0 & 32691 & 88,6 & 89,3 & 19202 & 93,2 & 91,3 \\
\hline Июнь & 52089 & 90,9 & 100,4 & 32673 & 88,8 & 99,9 & 19416 & 94,6 & 101,1 \\
\hline ІІ квартал & 161612 & 94,4 & 102,2 & 101964 & 92,5 & 97,3 & 59647 & 97,7 & 111,8 \\
\hline I полугодие & 319750 & 97,2 & & 206727 & 97,0 & & 113023 & 97,6 & \\
\hline Июль & 55327 & 100,6 & 106,2 & 33788 & 97,5 & 103,4 & 21540 & 105,7 & 110,9 \\
\hline Август & 55809 & 94,7 & 100,9 & 34653 & 91,0 & 102,6 & 21157 & 101,5 & 98,2 \\
\hline Январь-август & 430887 & 97,3 & & 275168 & 96,3 & & 155719 & 99,2 & \\
\hline Сентябрь & 55930 & 95,8 & 100,2 & 35833 & 90,6 & 103,4 & 20097 & 106,5 & 95,0 \\
\hline III квартал & 167066 & 96,9 & 103,4 & 104273 & 92,9 & 102,3 & 62793 & 104,5 & 105,3 \\
\hline Январь-сентябрь & 486816 & 97,1 & & 311000 & 95,6 & & 175816 & 100,0 & \\
\hline Октябрь & 60574 & 96,9 & 108,3 & 37453 & 89,8 & 104,5 & 23122 & 111,0 & 115,0 \\
\hline Ноябрь & 58512 & 95,2 & 96,6 & 36241 & 88,3 & 96,8 & 22271 & 109,1 & 96,3 \\
\hline Декабрь & 62913 & 100,1 & 107,5 & 39773 & 95,9 & 109,7 & 23140 & 108,2 & 103,9 \\
\hline IV квартал & 182000 & 97,4 & 108,9 & 113467 & 91,4 & 108,8 & 68532 & 109,4 & 109,1 \\
\hline Год & 668816 & 97,2 & & 424468 & 94,4 & & 244348 & 102,5 & \\
\hline \multicolumn{10}{|c|}{2020 г. } \\
\hline Январь & 47071 & 98,1 & 74,8 & 30975 & 95,6 & 77,9 & 16096 & 103,3 & 69,6 \\
\hline Февраль & 46794 & 88,7 & 99,4 & 28880 & 82,2 & 93,2 & 17913 & 101,7 & 111,3 \\
\hline Март & 49941 & 87,0 & 106,7 & 30359 & 81,6 & 105,1 & 19582 & 97,0 & 109,3 \\
\hline I квартал & 143806 & 90,9 & 79,0 & 90214 & 86,1 & 79,5 & 53592 & 100,4 & 78,2 \\
\hline Апрель & 41701 & 72,4 & 83,5 & 24826 & 67,8 & 81,8 & 16875 & 80,2 & 86,2 \\
\hline Май & 38141 & 73,5 & 91,5 & 21349 & 65,3 & 86,0 & 16791 & 87,4 & 99,5 \\
\hline Июнь & 43003 & 82,6 & 112,7 & 24425 & 74,8 & 114,4 & 18578 & 95,7 & 110,6 \\
\hline II квартал & 122845 & 76,0 & 85,4 & 70600 & 69,2 & 78,3 & 52245 & 87,6 & 97,5 \\
\hline I полугодие & 266651 & 83,4 & & 160814 & 77,8 & & 105836 & 93,6 & \\
\hline Июль & 43158 & 78,0 & 100,4 & 24251 & 71,8 & 99,3 & 18907 & 87,8 & 101,8 \\
\hline Август & 42099 & 75,4 & 97,5 & 23065 & 66,6 & 95,1 & 19034 & 90,0 & 100,7 \\
\hline Январь-август & 351908 & 81,7 & & 208131 & 75,6 & & 143777 & 92,3 & \\
\hline
\end{tabular}


ДИНАМИКА ЭКСПОРТА И ИМПОРТА ПО СТРАНАМ ДАЛЬНЕГО ЗАРУБЕЖЬЯ И ГОСУДАРСТВАМ-УЧАСТНИКАМ СНГ (по данным ФТС России)

\begin{tabular}{|c|c|c|c|c|c|c|c|c|}
\hline & \multicolumn{4}{|c|}{ Страны дальнего зарубежья } & \multicolumn{4}{|c|}{ Государства-участники СНГ } \\
\hline & \multicolumn{2}{|c|}{ экспорт } & \multicolumn{2}{|c|}{ импорт } & \multicolumn{2}{|c|}{ экспорт } & \multicolumn{2}{|c|}{ uмnорт } \\
\hline & $\begin{array}{c}\text { млн } \\
\text { долларов } \\
\text { США }\end{array}$ & $\begin{array}{c}\text { в\% к со- } \\
\text { ответст- } \\
\text { вуюшему } \\
\text { периоду } \\
\text { предылд- } \\
\text { щего года } \\
\end{array}$ & $\begin{array}{c}\text { мллн } \\
\text { долларов } \\
\text { США }\end{array}$ & $\begin{array}{c}\text { в\% к со- } \\
\text { ответст- } \\
\text { вуюшему } \\
\text { периоду } \\
\text { предылду- } \\
\text { щего года }\end{array}$ & $\begin{array}{c}\text { млн } \\
\text { долларов } \\
\text { США }\end{array}$ & $\begin{array}{c}\text { в\% к со- } \\
\text { ответст- } \\
\text { вуюшему } \\
\text { периоду } \\
\text { предылу- } \\
\text { щего года } \\
\end{array}$ & $\begin{array}{c}\text { млн } \\
\text { долларов } \\
\text { США }\end{array}$ & $\begin{array}{c}\text { в\% к со- } \\
\text { ответст- } \\
\text { вуюшему } \\
\text { периоду } \\
\text { предылду- } \\
\text { щего года }\end{array}$ \\
\hline \multicolumn{9}{|c|}{2019 г. } \\
\hline Январь & 28956 & 95,7 & 13779 & 100,0 & 3440 & 92,7 & 1803 & 97,3 \\
\hline Февраль & 30966 & 111,9 & 15572 & 94,8 & 4189 & 97,4 & 2043 & 102,7 \\
\hline Март & 32557 & 100,7 & 17966 & 97,9 & 4654 & 99,1 & 2212 & 95,1 \\
\hline I квартал & 92480 & 102,5 & 47317 & 97,4 & 12283 & 96,6 & 6058 & 98,2 \\
\hline Апрель & 31645 & 99,0 & 18609 & 105,5 & 4955 & 109,7 & 2420 & 107,9 \\
\hline Май & 28467 & 87,8 & 16927 & 92,5 & 4224 & 94,1 & 2276 & 98,1 \\
\hline Июнь & 28469 & 88,5 & 17064 & 93,9 & 4204 & 90,7 & 2353 & 100,0 \\
\hline ІІ квартал & 88581 & 91,7 & 52600 & 97,2 & 13383 & 98,1 & 7048 & 101,9 \\
\hline I полугодие & 181061 & 96,9 & 99917 & 97,3 & 25667 & 97,4 & 13106 & 100,2 \\
\hline Июль & 29374 & 97,1 & 19104 & 105,2 & 4414 & 100,4 & 2436 & 109,7 \\
\hline Август & 30087 & 90,3 & 18827 & 101,0 & 4566 & 96,4 & 2330 & 105,6 \\
\hline Январь-август & 240521 & 96,1 & 137847 & 98,8 & 34646 & 97,6 & 17872 & 102,1 \\
\hline Сентябрь & 31315 & 89,6 & 17849 & 105,7 & 4518 & 98,7 & 2248 & 112,8 \\
\hline ІІІ квартал & 90776 & 92,1 & 55780 & 103,9 & 13497 & 98,4 & 7014 & 109,2 \\
\hline Январь-сентябрь & 271837 & 95,3 & 155696 & 99,6 & 39164 & 97,8 & 20120 & 103,2 \\
\hline Октябрь & 32805 & 90,2 & 20753 & 111,9 & 4648 & 87,1 & 2368 & 103,4 \\
\hline Ноябрь & 31273 & 86,1 & 19907 & 109,8 & 4968 & 104,6 & 2363 & 103,5 \\
\hline Декабрь & 34598 & 94,4 & 20533 & 108,1 & 5176 & 107,9 & 2607 & 109,1 \\
\hline IV квартал & 98676 & 90,3 & 61193 & 109,9 & 14792 & 99,4 & 7339 & 105,4 \\
\hline Год & 370512 & 93,9 & 216890 & 102,3 & 53955 & 98,2 & 27459 & 103,7 \\
\hline \multicolumn{9}{|c|}{2020 г. } \\
\hline Январь & 27608 & 95,3 & 14341 & 104,1 & 3367 & 97,9 & 1755 & 97,4 \\
\hline Февраль & 25236 & 81,5 & 15896 & 102,1 & 3645 & 87,0 & 2018 & 98,7 \\
\hline Март & 26743 & 82,1 & 17478 & 97,3 & 3615 & 77,7 & 2104 & 95,1 \\
\hline І квартал & 79587 & 86,1 & 47715 & 100,8 & 10627 & 86,5 & 5877 & 97,0 \\
\hline Апрель & 21721 & 68,6 & 15016 & 80,7 & 3106 & 62,7 & 1860 & 76,9 \\
\hline Май & 18046 & 63,4 & 15002 & 88,6 & 3304 & 78,2 & 1789 & 78,6 \\
\hline Июнь & 20571 & 72,3 & 16568 & 97,1 & 3854 & 91,7 & 2010 & 85,4 \\
\hline II квартал & 60337 & 68,1 & 46586 & 88,6 & 10263 & 76,7 & 5659 & 80,3 \\
\hline I полугодие & 139924 & 77,3 & 94301 & 94,4 & 20890 & 81,4 & 11536 & 88,0 \\
\hline Июль & 20284 & 69,1 & 16828 & 88,1 & 3967 & 89,9 & 2079 & 85,4 \\
\hline Август & 19438 & 64,6 & 16895 & 89,7 & 3627 & 79,4 & 2139 & 91,8 \\
\hline Январь-август & 179646 & 74,7 & 128023 & 92,9 & 28485 & 82,2 & 15754 & 88,2 \\
\hline
\end{tabular}


ВНЕШНЕТОРГОВЫЙ ОБОРОТ РОССИИ

С ОСНОВНЫМИ СТРАНАМИ-ПАРТНЕРАМИ

(по данным ФТС России)

в январе-августе 2020 года

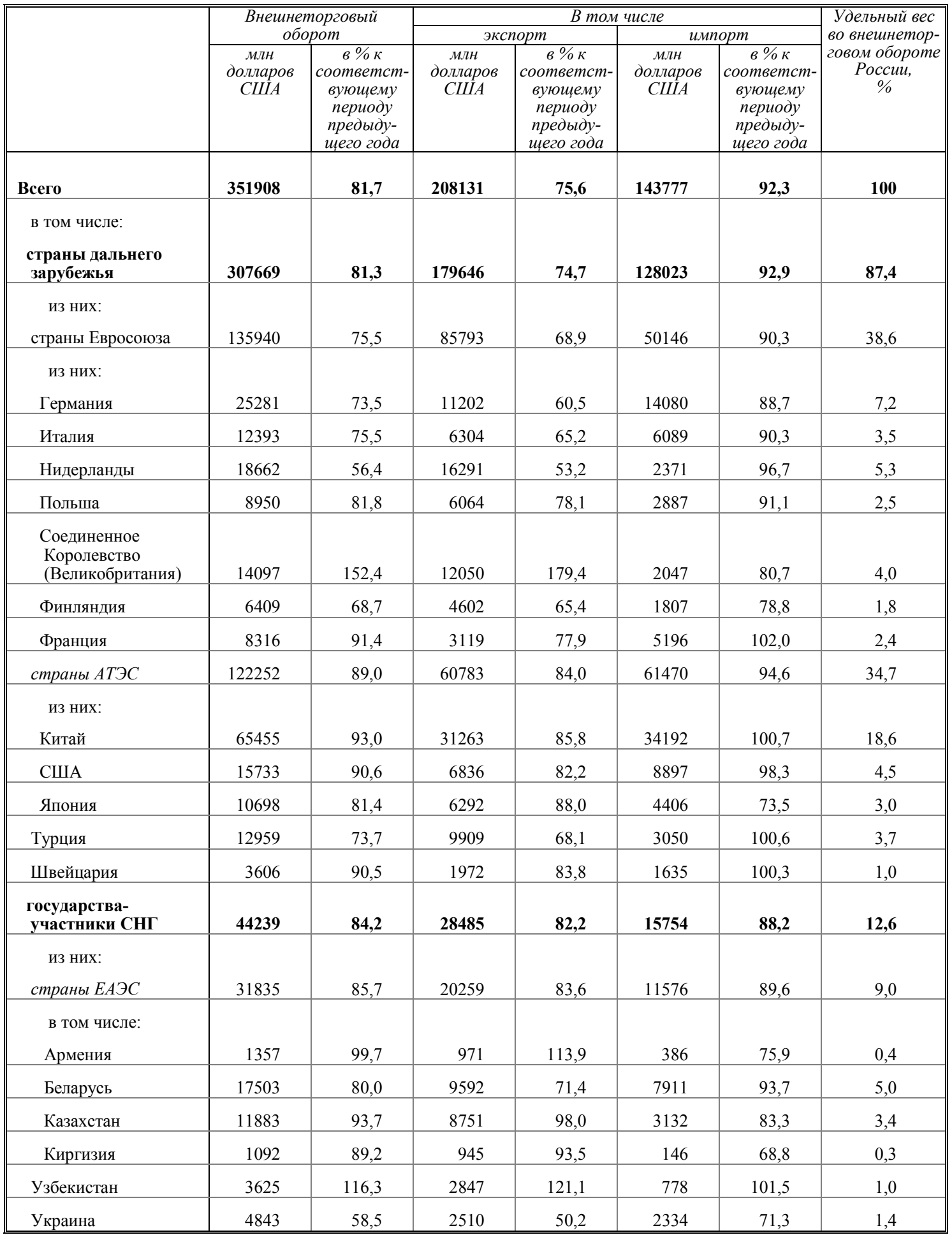


ТОВАРНАЯ СТРУКТУРА ЭКСПОРТА И ИМПОРТА РОССИИ

\begin{tabular}{|c|c|c|c|c|}
\hline & \multicolumn{2}{|c|}{$\begin{array}{l}\text { Aвzycm } \\
20202 .\end{array}$} & \multicolumn{2}{|c|}{$\begin{array}{c}\text { Январь-август } \\
2020 \text { г. }\end{array}$} \\
\hline & $\begin{array}{c}\text { млн } \\
\text { долларов } \\
\text { США }\end{array}$ & \begin{tabular}{|c|} 
в \% к \\
соответст- \\
вуюшему \\
периоду предыл- \\
дущего года \\
\end{tabular} & $\begin{array}{c}\text { млн } \\
\text { долларов } \\
\text { США }\end{array}$ & \begin{tabular}{|c|} 
в\% к \\
соответст- \\
вуюшему \\
периоду преды - \\
дущего года \\
\end{tabular} \\
\hline \multicolumn{5}{|c|}{ Экспорm } \\
\hline $\begin{array}{l}\text { Продовольственные товары и сельскохозяйственное } \\
\text { сырье (кроме текстильного) }\end{array}$ & 2554 & 109,9 & 17326 & 115,2 \\
\hline Минеральные продукты & 10839 & 50,4 & 113020 & 63,1 \\
\hline Продукция химической промышленности, каучук & 1949 & 83,6 & 15309 & 87,0 \\
\hline Кожевенное сырье, пушнина и изделия из них & 8,8 & 62,6 & 100 & 72,9 \\
\hline Древесина и целлюлозно-бумажные изделия & 1036 & 98,8 & 8020 & 93,3 \\
\hline Текстиль, текстильные изделия и обувь & 121 & 94,4 & 896 & 104,8 \\
\hline Металлы, драгоценные камни и изделия из них & 4588 & 110,3 & 37096 & 111,9 \\
\hline Машины, оборудование и транспортные средства & 1711 & 74,5 & 13537 & 82,9 \\
\hline Прочие товары & 258 & 27,9 & 2826 & 63,8 \\
\hline \multicolumn{5}{|c|}{ Илипорm } \\
\hline $\begin{array}{l}\text { Продовольственные товары и сельскохозяйственное } \\
\text { сырье (кроме текстильного) }\end{array}$ & 2194 & 100,0 & 18980 & 98,8 \\
\hline Минеральные продукты & 353 & 72,3 & 2795 & 81,3 \\
\hline Продукция химической промышленности, каучук & 3255 & 80,7 & 26809 & 89,9 \\
\hline Кожевенное сырье, пушнина и изделия из них & 104 & 72,8 & 601 & 71,7 \\
\hline Древесина и целлюлозно-бумажные изделия & 300 & 93,8 & 2162 & 89,9 \\
\hline Текстиль, текстильные изделия и обувь & 1576 & 95,4 & 9672 & 95,4 \\
\hline Металлы, драгоценные камни и изделия из них & 1395 & 77,0 & 10430 & 83,1 \\
\hline Машины, оборудование и транспортные средства & 9059 & 94,0 & 66850 & 93,7 \\
\hline Прочие товары & 797 & 86,5 & 5478 & 91,9 \\
\hline
\end{tabular}

Товарооборот России по неэнергетическим товарам в августе 2020 г. составил 31,6 млрд долларов США, или 90,9\% к соответствующему периоду предыдущего года, в том числе экспорт 12,7 млрд долларов, или 92,4\%, импорт - 18,9 млрд долларов, или 89,9\%.

Таблица 7

ТОВАРНЫЙ СОСТАВ ЭКСПОРТА

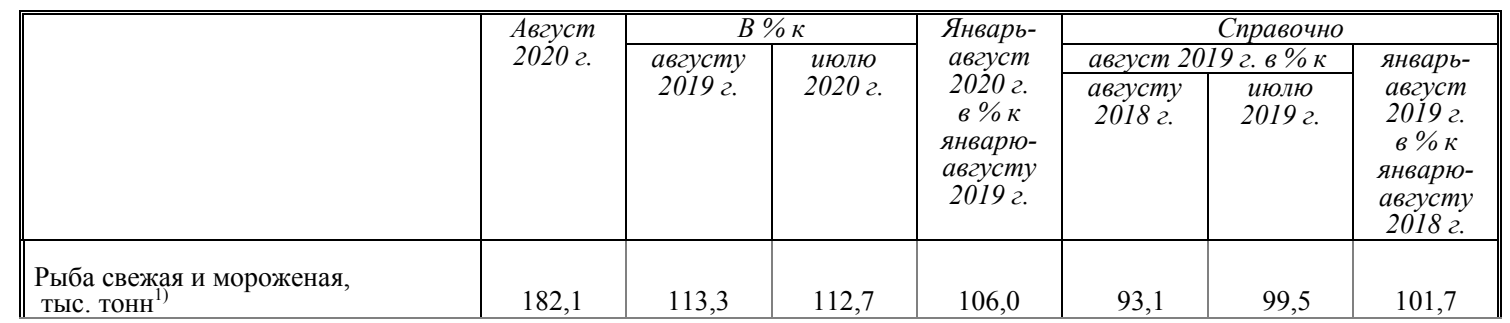




\begin{tabular}{|c|c|c|c|c|c|c|c|}
\hline & \multirow{2}{*}{$\begin{array}{l}\text { Aвгусm } \\
2020 \text { 2. }\end{array}$} & \multicolumn{2}{|c|}{$\bar{B} \overline{\mathrm{B} \% \mathrm{~K}}$} & \multirow[b]{2}{*}{$\begin{array}{c}\text { Январь- } \\
\text { авууст } \\
2020 \text { г. } \\
\text { в\% к } \\
\text { январю- } \\
\text { августу } \\
2019 \text { г. }\end{array}$} & \multicolumn{3}{|c|}{ Справочно } \\
\hline & & $\begin{array}{c}\text { августу } \\
2019 \text {. }\end{array}$ & $\begin{array}{c}\text { июлю } \\
2020 \text { г. }\end{array}$ & & $\begin{array}{l}\frac{\text { aвгусm } 2}{a \text { aвycmy }} \\
2018 \text { 2. }\end{array}$ & $\begin{array}{l}\text { 2. } 6 \% \kappa \\
\text { июлю } \\
2019 \text { 2. }\end{array}$ & $\begin{array}{c}\text { январь- } \\
\text { август } \\
2019 \text { г. } \\
\text { в\% \% } \\
\text { январю- } \\
\text { августу } \\
2018 \text { г. }\end{array}$ \\
\hline $\begin{array}{l}\text { Ракообразные и моллюски, } \\
\text { тыс. тонн }{ }^{1)}\end{array}$ & 13,0 & 132,9 & 91,5 & 94,0 & 133,7 & 61,4 & 110,6 \\
\hline Пшеница и меслин, тыс. тонн & 4649,1 & 95,1 & 199,4 & 106,5 & 104,1 & 163,3 & 66,5 \\
\hline $\begin{array}{l}\text { Мука пшеничная или } \\
\text { пшенично-ржаная, тыс. тонн }\end{array}$ & 18,3 & 99,9 & 101,3 & 95,6 & 135,5 & 75,9 & 125,2 \\
\hline Крупа, тыс. тонн & 2,8 & 114,0 & 73,5 & 95,9 & 146,2 & 121,7 & 107,5 \\
\hline $\begin{array}{l}\text { Масло подсолнечное, } \\
\text { сафлоровое или хлопковое } \\
\text { и их фракции, тыс. тонн }\end{array}$ & 318,2 & 124,1 & 106,0 & 136,2 & 198,6 & 116,0 & 137,3 \\
\hline Макаронные изделия, тыс. тонн & 10,5 & 103,1 & 119,0 & 110,9 & 96,8 & 112,0 & 102,7 \\
\hline $\begin{array}{l}\text { Кондитерские мучные изделия, } \\
\text { тыс. тонн }\end{array}$ & 23,9 & 106,4 & 107,8 & 109,3 & 111,7 & 113,7 & 116,8 \\
\hline $\begin{array}{l}\text { Соль, пригодная для } \\
\text { употребления в пищу, тыс. тонн }\end{array}$ & 5,2 & 115,3 & 97,8 & 117,7 & 124,1 & 112,1 & 102,1 \\
\hline Фосфаты кальция, тыс. тонн & 148,5 & 60,8 & 167,7 & 82,6 & 89,5 & 90,1 & 95,4 \\
\hline $\begin{array}{l}\text { Руды и концентраты железные, } \\
\text { тыс. тонн }\end{array}$ & 1492,9 & 69,9 & 54,8 & 109,7 & 152,3 & 116,7 & 129,2 \\
\hline Уголь каменный, млн тонн & 16,1 & 88,7 & 107,1 & 89,9 & 98,1 & 138,4 & 105,9 \\
\hline Кокс и полукокс, тыс. тонн & 190,5 & 109,1 & 67,9 & 80,0 & 99,7 & 81,2 & 103,8 \\
\hline $\begin{array}{l}\text { Нефть сырая, включая } \\
\text { газовый конденсат } \\
\text { природный, млн тонн }\end{array}$ & 15,5 & 64,1 & 85,1 & 90,6 & 110,3 & 101,5 & 104,2 \\
\hline Нефтепродукты, млн тонн & 8,2 & 77,0 & 77,0 & 101,9 & 84,1 & 105,5 & 89,7 \\
\hline $\begin{array}{l}\text { из них топлива жидкие, } \\
\text { не содержащие биодизель }\end{array}$ & 3,6 & 85,1 & 87,1 & 101,6 & 87,9 & 104,9 & 90,3 \\
\hline Газ природный, млрд м ${ }^{3}$ & 17,2 & 104,2 & 135,0 & 86,0 & 88,6 & 103,0 & 96,4 \\
\hline Электроэнергия, млрд кВт·ч & 0,4 & 23,7 & 75,8 & 49,3 & 89,4 & 148,0 & 118,2 \\
\hline Аммиак безводный, тыс. тонн & 317,7 & 88,4 & 109,5 & 93,9 & 199,9 & 78,2 & 115,1 \\
\hline $\begin{array}{l}\text { Углеводороды ациклические, } \\
\text { тыс. тонн }\end{array}$ & 54,2 & 19,4 & 26,0 & 59,3 & в 4,8p. & 127,1 & 117,9 \\
\hline Удобрения, тыс. тонн & 2948,2 & 106,9 & 85,4 & 102,4 & 110,6 & 94,7 & 99,7 \\
\hline $\begin{array}{l}\text { из них: } \\
\text { удобрения минеральные } \\
\text { азотные в физическом весе }\end{array}$ & 1196,0 & 97,3 & 78,8 & 99,6 & 90,9 & 91,2 & 103,5 \\
\hline $\begin{array}{l}\text { в пересчете на } 100 \% \\
\text { питательных веществ }\end{array}$ & 1422,1 & в 2,9p. & в 2,5p. & 125,9 & 89,2 & 86,5 & 105,3 \\
\hline $\begin{array}{l}\text { удобрения минеральные } \\
\text { калийные в физическом весе }\end{array}$ & 847,5 & 124,6 & 77,9 & 107,7 & 185,1 & 81,0 & 107,5 \\
\hline $\begin{array}{l}\text { в пересчете на } 100 \% \\
\text { питательных веществ }\end{array}$ & 515,6 & 125,3 & 77,8 & 108,6 & 186,4 & 81,4 & 103,3 \\
\hline Каучук синтетический, тыс. тонн & 85,4 & 105,3 & 102,1 & 89,9 & 97,6 & 102,4 & 99,3 \\
\hline $\begin{array}{l}\text { Шины пневматические } \\
\text { резиновые, тыс. штук }\end{array}$ & 2519,3 & 94,8 & 121,8 & 94,5 & 105,5 & 140,7 & 99,8 \\
\hline
\end{tabular}




\begin{tabular}{|c|c|c|c|c|c|c|c|}
\hline & \multirow{3}{*}{$\begin{array}{l}\text { Aвzусm } \\
2020 \text { 2. }\end{array}$} & \multicolumn{2}{|c|}{ 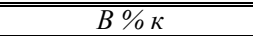 } & \multirow{3}{*}{$\begin{array}{c}\text { Январь- } \\
\text { август } \\
2020 \text { г. } \\
\text { в\% \% } \\
\text { январю- } \\
\text { августу } \\
2019 \text { г. }\end{array}$} & \multicolumn{3}{|c|}{ Справочно } \\
\hline & & \multirow{2}{*}{$\begin{array}{c}\text { aвгусту } \\
2019 \text { г. }\end{array}$} & \multirow{2}{*}{$\begin{array}{l}\text { июлю } \\
2020 \text { г. }\end{array}$} & & \multicolumn{2}{|c|}{ август 2019 г. в\% \% } & \multirow[b]{2}{*}{$\begin{array}{c}\text { январь- } \\
\text { август } \\
2019 \text { г. } \\
\text { в\% } \\
\text { январю- } \\
\text { августу } \\
2018 \text { г. } \\
\end{array}$} \\
\hline & & & & & $\begin{array}{l}\text { августу } \\
2018 \text { г. }\end{array}$ & $\begin{array}{l}\text { июлю } \\
2019 \text { г. }\end{array}$ & \\
\hline $\begin{array}{l}\text { Лесоматериалы необработанные, } \\
\text { млн м }{ }^{3}\end{array}$ & 1,5 & 132,9 & 91,5 & 94,1 & 69,2 & 80,2 & 83,1 \\
\hline $\begin{array}{l}\text { Лесоматериалы обработанные } \\
\text { млн тонн }\end{array}$ & 1,7 & 99,5 & 88,7 & 95,7 & 99,5 & 94,2 & 103,9 \\
\hline млн м ${ }^{3}$ & 3,3 & 115,1 & 100,8 & 100,8 & 101,6 & 95,9 & 105,3 \\
\hline Фанера клееная, тыс. м ${ }^{3}$ & 210,9 & 87,3 & 93,2 & 100,2 & 109,3 & 95,6 & 101,7 \\
\hline Целлюлоза древесная, тыс. тонн & 201,8 & 116,8 & 106,8 & 107,5 & 95,9 & 104,6 & 99,5 \\
\hline Бумага газетная, тыс. тонн & 105,5 & 92,3 & 119,0 & 92,7 & 109,9 & 112,3 & 110,0 \\
\hline Ткани хлопчатобумажные, млн м² & 9,0 & 92,0 & 24,1 & 135,0 & 131,1 & 106,8 & 125,5 \\
\hline $\begin{array}{l}\text { Черные металлы (кроме чугуна, } \\
\text { ферросплавов, отходов и лома), } \\
\text { млн долларов }\end{array}$ & 802,2 & 82,4 & 102,1 & 83,4 & 68,0 & 82,3 & 79,4 \\
\hline Чугун передельный, тыс. тонн & 427,7 & 106,1 & 151,8 & 80,6 & 183,7 & 184,4 & 84,3 \\
\hline Ферросплавы, тыс. тонн & 58,5 & 96,8 & 91,9 & 88,2 & 94,8 & 81,4 & 103,8 \\
\hline $\begin{array}{l}\text { Трубы из черных металлов, } \\
\text { тыс. тонн }\end{array}$ & 119,6 & 54,1 & 104,9 & 103,1 & 120,7 & 85,7 & 74,6 \\
\hline Медь рафинированная, тыс. тонн & 63,8 & 94,7 & 109,6 & 100,9 & 110,0 & 199,0 & 100,1 \\
\hline Проволока медная, тыс. тонн & 11,0 & 66,3 & 72,3 & 122,4 & 108,4 & 195,0 & 92,4 \\
\hline Никель необработанный, тыс. тонн & 10,1 & в $6,5 \mathrm{p}$. & 54,9 & 87,4 & 11,8 & 12,9 & 94,2 \\
\hline $\begin{array}{l}\text { Алюминий необработанный, } \\
\text { тыс. тонн }\end{array}$ & 199,5 & 82,7 & 67,9 & 79,6 & 68,0 & 99,8 & 103,7 \\
\hline $\begin{array}{l}\text { Машины, оборудование и } \\
\text { транспортные средства, } \\
\text { млн долларов }\end{array}$ & 1711,4 & 74,5 & 93,3 & 82,9 & 121,9 & 94,7 & 102,0 \\
\hline
\end{tabular}

РАСПРЕДЕЛЕНИЕ ЭКСПОРТА РОССИЙСКОЙ ФЕДЕРАЦИИ ОСНОВНЫХ ТОВАРОВ ПО СТРАНАМ ЕАЭС

в январе-августе 2020 года

(по данным ФТС России)

\begin{tabular}{|c|c|c|c|c|c|}
\hline & \multirow{2}{*}{$\begin{array}{c}\text { Экспортировано } \\
\text { в государства- } \\
\text { члены ЕАЭС } \\
\end{array}$} & \multicolumn{4}{|c|}{ В том числе в странь } \\
\hline & & Армения & Беларусь & Казахстан & Киргизия \\
\hline $\begin{array}{l}\text { Масло подсолнечное, сафлоровое или } \\
\text { хлопковое и их фракции, тыс. тонн }\end{array}$ & 167,3 & 15,7 & 50,7 & 77,6 & 23,2 \\
\hline $\begin{array}{l}\text { Шоколад и прочие готовые пищевые } \\
\text { продукты, содержащие какао, тыс. тонн }\end{array}$ & 57,7 & 5,0 & 15,5 & 30,9 & 6,3 \\
\hline Кондитерские мучные изделия, тыс. тонн & 114,3 & 4,2 & 39,2 & 58,5 & 12,4 \\
\hline Сигареты и сигары, млн долларов & 60,9 & 5,3 & 3,1 & 46,8 & 5,7 \\
\hline
\end{tabular}




\begin{tabular}{|c|c|c|c|c|c|}
\hline & \multirow{2}{*}{$\begin{array}{c}\text { Экспортировано } \\
\text { в государства- } \\
\text { члены ЕАЭС }\end{array}$} & \multicolumn{4}{|c|}{ В том числе в страны } \\
\hline & & Армения & Беларусь & Казахстан & Киргизия \\
\hline Кокс и полукокс, тыс. тонн & 678,3 & 0,1 & 16,9 & 641,0 & 20,3 \\
\hline $\begin{array}{l}\text { Нефть сырая, включая газовый конденсат } \\
\text { природный, млн тонн }\end{array}$ & 7,9 & - & 7,9 & 0,0 & 0,0 \\
\hline Нефтепродукты, тыс. тонн & 1768,2 & 309,1 & 38,6 & 492,1 & 928,5 \\
\hline Газ природный, млрд м ${ }^{3}$ & 20,6 & 1,4 & 11,7 & 7,5 & - \\
\hline Электроэнергия, млн кВт·ч & 818,7 & - & 24,7 & 794,0 & - \\
\hline Лекарственные средства, млн долларов & 172,4 & 16,3 & 49,6 & 81,4 & 25,0 \\
\hline Удобрения минеральные, тыс. тонн & 700,0 & 29,6 & 197,0 & 400,1 & 73,2 \\
\hline Каучук синтетический, тыс. тонн & 20,8 & 0,1 & 20,0 & 0,7 & 0,0 \\
\hline $\begin{array}{l}\text { Шины пневматические } \\
\text { резиновые, тыс. штук }\end{array}$ & 3533,2 & 154,5 & 953,4 & 2287,1 & 138,2 \\
\hline Лесоматериалы обработанные, тыс. тонн & 381,3 & 10,5 & 16,1 & 234,1 & 120,5 \\
\hline $\begin{array}{l}\text { Прокат плоский из железа и } \\
\text { нелегированной стали, тыс. тонн }\end{array}$ & 757,9 & 10,7 & 425,8 & 274,9 & 46,5 \\
\hline Трубы из черных металлов, тыс. тонн & 511,5 & 20,3 & 177,2 & 286,9 & 27,2 \\
\hline Проволока медная, тыс. тонн & 9,0 & 0,4 & 7,2 & 1,4 & 0,0 \\
\hline Алюминий необработанный, тыс. тонн & 66,3 & 20,1 & 21,8 & 24,4 & 0,0 \\
\hline $\begin{array}{l}\text { Комбинированные холодильники - } \\
\text { морозильники, штук }\end{array}$ & 258647 & 5452 & 67937 & 158912 & 26346 \\
\hline $\begin{array}{l}\text { Аппаратура телефонной и телеграфной } \\
\text { связи, тыс. штук }\end{array}$ & 1544,5 & 94,0 & 651,0 & 527,2 & 272,3 \\
\hline Приемники телевизионные, штук & 359002 & 14904 & 123314 & 212585 & 8199 \\
\hline Автомобили легковые, штук & 31964 & 879 & 20393 & 10457 & 235 \\
\hline Автомобили грузовые, штук & 4553 & 593 & 2371 & 1512 & 77 \\
\hline $\begin{array}{l}\text { Части и принадлежности к автомобилям, } \\
\text { млн долларов }\end{array}$ & 238,0 & 7,6 & 96,8 & 130,8 & 2,7 \\
\hline
\end{tabular}

Экспорт рыбы, ракообразных и моллюсков, включая выловленные (добытые) и проданные вне зоны действия таможенного контроля, в августе 2020 г. составил 409,1 млн долларов США (98,5\% к соответствующему периоду предыдущего года).

Экспорт товаров, необходимых для эксплуатации транспортных средств и обеспечения жизнедеятельности экипажей, осуществляющих международные рейсы, в августе 2020 г. составил 51,9 млн долларов США.

Удельный вес основных видов топливно-энергетических ресурсов (нефти сырой, нефтепродуктов, газа природного, угля каменного, кокса и полукокса, электроэнергии) в общем объеме экспорта в августе 2020 г. составил 41,3\% (в августе 2019 г. - 57,6\%), металлов (черных металлов, меди рафинированной, никеля необработанного, алюминия необработанного) - 8,6\% $(6,4 \%)$, машин, оборудования и транспортных средств - 7,4\% (6,6\%). 
ЭКСПОРТ НЕФТИ И ОТДЕЛЬНЫХ ВИДОВ НЕФТЕПРОДУКТОВ

\begin{tabular}{|c|c|c|c|c|}
\hline & \multirow{2}{*}{$\begin{array}{l}\text { Aвгусm } \\
2020 \text { z. }\end{array}$} & \multicolumn{2}{|c|}{$B \% \kappa$} & \multirow{2}{*}{$\begin{array}{c}\text { Январь-август } \\
2020 г . \\
6 \% \kappa \\
\text { январю-августу } \\
2019 z . \\
\end{array}$} \\
\hline & & $\begin{array}{l}\text { августу } \\
2019 \text { 2. }\end{array}$ & $\begin{array}{l}\text { июлю } \\
20202 .\end{array}$ & \\
\hline \multicolumn{5}{|c|}{ Всего } \\
\hline Нефть сырая, включая газовый конденсат природ & & & & \\
\hline тыс. тонн & 15520,8 & 64,1 & 85,1 & 90,6 \\
\hline млн долларов & 4615,9 & 43,0 & 91,3 & 60,1 \\
\hline удельный вес экспорта в производстве (добыче), \% & 37,2 & & & \\
\hline \multicolumn{5}{|l|}{ Бензин автомобильный } \\
\hline тыс. тонн & 333,0 & 114,4 & 114,0 & 139,4 \\
\hline млн долларов & 99,4 & 59,0 & 114,4 & 97,0 \\
\hline удельный вес экспорта в производстве, \% & 9,2 & & & \\
\hline Дизельное топливо, не содержащее биодизель & & & & \\
\hline тыс. тонн & 2835,1 & 68,8 & 65,6 & 103,4 \\
\hline млн долларов & 907,3 & 39,8 & 74,1 & 70,1 \\
\hline удельный вес экспорта в производстве, \% & 42,1 & & & \\
\hline \multicolumn{5}{|l|}{ в том числе: } \\
\hline Нефть сырая, включая газовый конденсат природ & & & & \\
\hline тыс. тонн & 14374,6 & 64,2 & 86,3 & 92,4 \\
\hline млн долларов & 4308,0 & 42,6 & 93,1 & 61,3 \\
\hline удельный вес экспорта в производстве (добыче), \% & 34,5 & & & \\
\hline \multicolumn{5}{|l|}{ Бензин автомобильный } \\
\hline тыс. тонн & 256,4 & 118,4 & 123,4 & 147,3 \\
\hline млн долларов & 74,0 & 56,3 & 127,3 & 102,5 \\
\hline удельный вес экспорта в производстве, \% & 7,0 & & & \\
\hline \multicolumn{5}{|l|}{ Дизельное топливо, не содержащее биодизель } \\
\hline тыс. тонн & 2691,4 & 67,4 & 68,1 & 105,2 \\
\hline млн долларов & 865,5 & 39,0 & 76,9 & 71,5 \\
\hline удельный вес экспорта в производстве, \% & 40,0 & & & \\
\hline \multicolumn{5}{|c|}{ в государства-участники СНГ } \\
\hline Нефть сырая, включая газовый конденсат природ & & & & \\
\hline тыс. тонн & 1146,2 & 62,5 & 72,7 & 65,7 \\
\hline млн долларов & 307,9 & 49,9 & 71,5 & 39,2 \\
\hline удельный вес экспорта в производстве (добыче), \% & 2,7 & & & \\
\hline \multicolumn{5}{|l|}{ Бензин автомобильный } \\
\hline тыс. тонн & 76,6 & 102,7 & 90,8 & 109,0 \\
\hline млн долларов & 25,4 & 68,4 & 88,3 & 71,9 \\
\hline удельный вес экспорта в производстве, \% & 2,1 & & & \\
\hline
\end{tabular}




\begin{tabular}{|c|c|c|c|c|}
\hline & \multirow{2}{*}{$\begin{array}{l}\text { Aвгуст } \\
2020 \text { z. }\end{array}$} & \multicolumn{2}{|c|}{$B \% \mathrm{~K}$} & \multirow{2}{*}{$\begin{array}{c}\text { Январь-август } \\
2020 \text { г. } \\
\text { в\% к } \\
\text { январю-августу } \\
2019 \text { г. } \\
\end{array}$} \\
\hline & & $\begin{array}{c}\text { августу } \\
2019 \text { г. }\end{array}$ & $\begin{array}{c}\text { июлю } \\
2020 \text { г. }\end{array}$ & \\
\hline $\begin{array}{l}\text { Дизельное топливо, не содержащее биодизель } \\
\text { тыс. тонн }\end{array}$ & 143,7 & 110,6 & 38,9 & 76,4 \\
\hline млн долларов & 41,8 & 64,4 & 42,1 & 49,4 \\
\hline удельный вес экспорта в производстве, \% & 2,1 & & & \\
\hline
\end{tabular}

Таблица 10

ЭКСПОРТ РОССИЙСКОЙ ФЕДЕРАЦИИ

НЕЭНЕРГЕТИЧЕСКИХ НЕСЫРЬЕВЫХ ТОВАРОВ ПО ПЕРЕДЕЛАМ ${ }^{1)}$

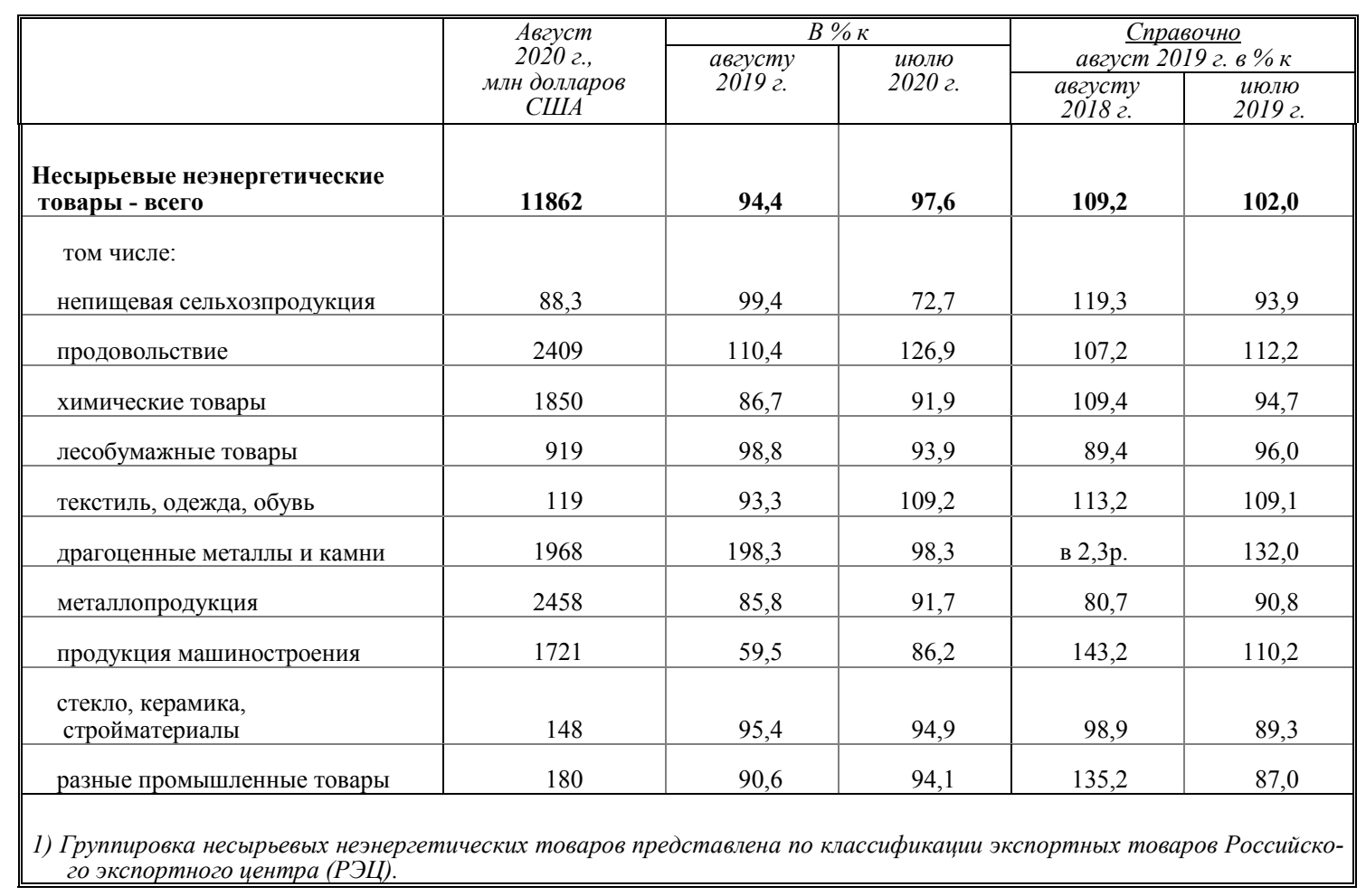

Таблица 11

ТОВАРНЫЙ СОСТАВ ИМПОРТА

\begin{tabular}{|c|c|c|c|c|c|c|c|}
\hline & \multirow{3}{*}{$\begin{array}{l}\text { Aвzycm } \\
20202 .\end{array}$} & \multicolumn{2}{|c|}{$B \% \kappa$} & \multirow{3}{*}{$\begin{array}{c}\text { Январь- } \\
\text { август } \\
2020 \text { г. } \\
в \% \kappa \\
\text { январю- } \\
\text { августу } \\
2019 \text { г. }\end{array}$} & \multicolumn{3}{|c|}{ Справочно } \\
\hline & & \multirow{2}{*}{$\begin{array}{l}\text { aвzусmy } \\
2019 \text { 2. }\end{array}$} & \multirow{2}{*}{$\begin{array}{l}\text { июлю } \\
20202 .\end{array}$} & & \multicolumn{2}{|c|}{ август 2019 г. в\% } & \multirow[b]{2}{*}{$\begin{array}{c}\text { январь- } \\
\text { август } \\
2019 \text { г. } \\
\text { в\% \% } \\
\text { январю- } \\
\text { августу } \\
2018 \text { г. }\end{array}$} \\
\hline & & & & & $\begin{array}{c}\text { aвгусmy } \\
2018 \text { 2. }\end{array}$ & $\begin{array}{c}\text { июлю } \\
2019 \text { г. }\end{array}$ & \\
\hline $\begin{array}{l}\text { Мясо свежее и мороженое } \\
\text { (без мяса птицы), тыс. тонн }\end{array}$ & 22,8 & 74,3 & 130,4 & 68,2 & 87,3 & 111,1 & 99,1 \\
\hline $\begin{array}{l}\text { Мясо птицы свежее и мороженое, } \\
\text { тыс. тонн }\end{array}$ & 20,0 & 114,3 & 97,9 & 101,9 & 87,9 & 89,7 & 102,2 \\
\hline
\end{tabular}




\begin{tabular}{|c|c|c|c|c|c|c|c|}
\hline & \multirow{3}{*}{$\begin{array}{l}\text { Aвzусm } \\
20202 .\end{array}$} & \multicolumn{2}{|c|}{$B \% \kappa$} & \multirow{3}{*}{$\begin{array}{c}\text { Январь- } \\
\text { август } \\
2020 \text { г. } \\
в \% \kappa \\
\text { январю- } \\
\text { августу } \\
2019 \text { г. }\end{array}$} & \multicolumn{3}{|c|}{ Справочно } \\
\hline & & \multirow{2}{*}{$\begin{array}{l}\text { aвzycmy } \\
20192 .\end{array}$} & \multirow{2}{*}{$\begin{array}{c}\text { июлю } \\
2020 \text { г. }\end{array}$} & & \multicolumn{2}{|c|}{ август 2019 г. в\% \% } & \multirow[b]{2}{*}{$\begin{array}{c}\text { январь- } \\
\text { август } \\
2019 \text { г. } \\
\text { в\% к } \\
\text { январю- } \\
\text { августу } \\
2018 \text { г. }\end{array}$} \\
\hline & & & & & $\begin{array}{c}\text { aвгусmy } \\
2018 \text { г. }\end{array}$ & $\begin{array}{c}\text { июлю } \\
2019 \text { г. }\end{array}$ & \\
\hline $\begin{array}{l}\text { Рыба свежая и мороженая, } \\
\text { тыс. тонн }\end{array}$ & 23,7 & 99,0 & 112,9 & 89,9 & 104,9 & 103,6 & 99,9 \\
\hline $\begin{array}{l}\text { Ракообразные и моллюски, } \\
\text { тыс. тонн }\end{array}$ & 4,3 & 92,8 & 138,7 & 96,9 & 96,9 & 86,4 & 89,7 \\
\hline $\begin{array}{l}\text { Молоко и сливки несгущенные, } \\
\text { тыс. тонн }\end{array}$ & 22,3 & 115,7 & 91,9 & 119,0 & 91,8 & 99,4 & 86,7 \\
\hline $\begin{array}{l}\text { Молоко и сливки сгущенные, } \\
\text { тыс. тонн }\end{array}$ & 13,8 & 101,6 & 94,4 & 81,6 & 114,7 & 103,4 & 127,8 \\
\hline из них молоко и сливки сухие & 8,8 & 90,7 & 93,3 & 66,0 & 109,6 & 94,8 & 144,7 \\
\hline $\begin{array}{c}\text { Масло сливочное и прочие } \\
\text { молочные жиры, тыс. тонн }\end{array}$ & 10,4 & 102,1 & 93,3 & 113,4 & 123,9 & 100,3 & 139,1 \\
\hline из него масло сливочное & 8,7 & 93,5 & 94,7 & 105,4 & 129,0 & 104,6 & 139,4 \\
\hline $\begin{array}{l}\text { Картофель свежий или } \\
\text { охлажденный, тыс. тонн }\end{array}$ & 1,5 & 25,6 & 19,4 & 99,6 & 108,0 & 27,7 & 53,5 \\
\hline $\begin{array}{l}\text { Томаты свежие или охлажденные, } \\
\text { тыс. тонн }\end{array}$ & 10,4 & 77,1 & 45,8 & 95,9 & 105,9 & 64,8 & 92,0 \\
\hline $\begin{array}{l}\text { Бананы, включая плантайны, } \\
\text { свежие или сушеные, тыс. тонн }\end{array}$ & 93,7 & 100,9 & 96,5 & 100,9 & 99,0 & 98,3 & 96,4 \\
\hline Цитрусовые плоды, тыс. тонн & 63,7 & 174,2 & 159,1 & 93,3 & 99,1 & 79,8 & 107,7 \\
\hline $\begin{array}{l}\text { из них: } \\
\text { апельсины свежие или сушеные }\end{array}$ & 23,1 & в 2,1p. & 174,0 & 97,4 & 74,5 & 61,8 & 99,8 \\
\hline $\begin{array}{l}\text { мандарины, клементины, } \\
\text { вилкинги и аналогичные } \\
\text { гибриды цитрусовых, } \\
\text { свежие или сушеные }\end{array}$ & 11,9 & 164,8 & 152,9 & 88,5 & 101,5 & 79,7 & 114,6 \\
\hline Яблоки свежие, тыс. тонн & 43,0 & 108,8 & 78,6 & 114,0 & 72,1 & 108,6 & 86,8 \\
\hline Кофе, тыс. тонн & 20,7 & 96,2 & 106,9 & 103,9 & 157,1 & 113,8 & 114,9 \\
\hline Чай, тыс. тонн & 13,0 & 111,2 & 106,5 & 102,9 & 76,9 & 94,9 & 85,9 \\
\hline Злаки, тыс. тонн & 31,4 & 104,9 & 84,2 & 121,8 & 148,8 & 86,7 & 73,4 \\
\hline $\begin{array}{l}\text { из них: } \\
\text { пшеница и меслин }\end{array}$ & 10,2 & 131,7 & 146,7 & 61,3 & в $2,7 \mathrm{p}$ & 47,1 & 58,8 \\
\hline $\begin{array}{l}\text { Масло пальмовое и его фракции, } \\
\text { тыс. тонн }\end{array}$ & 97,4 & 76,9 & 100,6 & 99,7 & 123,9 & в $3,4 \mathrm{p}$. & 102,0 \\
\hline $\begin{array}{l}\text { Масло кокосовое (копровое), } \\
\text { пальмоядровое или масло } \\
\text { бабассу, тыс. тонн }\end{array}$ & 5,6 & 40,3 & 73,4 & 112,0 & 142,8 & в 5,7p. & 117,7 \\
\hline $\begin{array}{l}\text { Готовые или консервированные } \\
\text { продукты из мяса, тыс. тонн }\end{array}$ & 1,8 & 143,5 & 103,9 & 123,2 & 73,3 & 85,4 & 93,2 \\
\hline $\begin{array}{l}\text { Готовая или } \\
\text { консервированная рыба, тыс. тонн }\end{array}$ & 5,4 & 89,3 & 97,7 & 99,1 & 105,2 & 113,2 & 100,2 \\
\hline
\end{tabular}




\begin{tabular}{|c|c|c|c|c|c|c|c|}
\hline & \multirow{3}{*}{$\begin{array}{l}\text { Aвгусm } \\
2020 \text { 2. }\end{array}$} & \multicolumn{2}{|c|}{$\bar{B} \% \kappa$} & \multirow{3}{*}{$\begin{array}{c}\text { Январь- } \\
\text { август } \\
2020 \text { г. } \\
в \% \kappa \\
\text { январю- } \\
\text { августу } \\
2019 \text { г. }\end{array}$} & \multicolumn{3}{|c|}{ Справочно } \\
\hline & & \multirow{2}{*}{$\begin{array}{l}\text { aвzуcmy } \\
20192 .\end{array}$} & \multirow{2}{*}{$\begin{array}{l}\text { июлю } \\
20202 .\end{array}$} & & \multicolumn{2}{|c|}{ август 2019 г. в \% к } & \multirow[b]{2}{*}{$\begin{array}{c}\text { январь- } \\
\text { август } \\
2019 \text { г. } \\
\text { в\% к } \\
\text { январю- } \\
\text { августу } \\
2018 \text { г. }\end{array}$} \\
\hline & & & & & $\begin{array}{l}\text { aвгусmy } \\
2018 \text { г. }\end{array}$ & $\begin{array}{l}\text { июлю } \\
2019 \text { г. }\end{array}$ & \\
\hline Сахар белый, тыс. тонн & 6,1 & 49,0 & 54,0 & 71,3 & 82,4 & 57,1 & 96,0 \\
\hline $\begin{array}{l}\text { Шоколад и прочие } \\
\text { готовые пищевые продукты, } \\
\text { содержащие какао, тыс. тонн }\end{array}$ & 10,2 & 106,6 & 147,0 & 94,9 & 103,3 & 112,0 & 111,6 \\
\hline Макаронные изделия, тыс. тонн & 6,5 & 92,2 & 95,2 & 99,4 & 115,5 & 83,6 & 106,5 \\
\hline $\begin{array}{l}\text { Кондитерские мучные изделия, } \\
\text { тыс. тонн }\end{array}$ & 13,3 & 111,6 & 119,4 & 98,4 & 88,5 & 96,0 & 90,6 \\
\hline $\begin{array}{l}\text { Алкогольные и безалкогольные } \\
\text { напитки, млн долларов }\end{array}$ & 230,3 & 93,9 & 107,7 & 90,9 & 110,1 & 93,7 & 106,5 \\
\hline пиво солодовое, млн литров & 45,0 & 140,7 & 97,1 & 117,9 & 115,4 & 85,5 & 112,4 \\
\hline вина виноградные, млн литров & 25,9 & 72,9 & 97,0 & 78,8 & 89,5 & 99,0 & 101,9 \\
\hline $\begin{array}{l}\text { крепкие спиртные напитки, } \\
\text { включая водку, } \\
\text { млн литров } 100 \% \text { спирта }\end{array}$ & 6,1 & 79,1 & 104,2 & 86,5 & 127,1 & 104,4 & 113,1 \\
\hline Сигареты и сигары, млн долларов & 7,9 & 174,7 & в $2,4 \mathrm{p}$. & 95,7 & 72,0 & 91,8 & 41,6 \\
\hline $\begin{array}{l}\text { Соль, пригодная для } \\
\text { употребления в пищу, тыс. тонн }\end{array}$ & 52,7 & 130,1 & 78,9 & 109,8 & 83,8 & 84,0 & 110,5 \\
\hline Уголь каменный, тыс. тонн & 1657,4 & 85,7 & 118,4 & 94,2 & 89,8 & 102,3 & 103,8 \\
\hline Нефтепродукты, тыс. тонн & 48,4 & 100,5 & 108,3 & 171,3 & 117,8 & 98,9 & 112,4 \\
\hline $\begin{array}{l}\text { Лекарственные средства, } \\
\text { млн долларов }\end{array}$ & 473,1 & 57,4 & 129,8 & 76,5 & 126,6 & 92,3 & 105,3 \\
\hline $\begin{array}{l}\text { Шины пневматические } \\
\text { резиновые, тыс. штук }\end{array}$ & 2659,4 & 74,9 & 110,6 & 80,6 & 116,8 & 113,2 & 107,7 \\
\hline Ткани хлопчатобумажные, млн м² & 25,3 & 84,0 & 114,6 & 92,5 & 152,3 & 113,5 & 126,9 \\
\hline $\begin{array}{l}\text { Одежда трикотажная и } \\
\text { текстильная, млн долларов }\end{array}$ & 872,5 & 103,2 & 113,9 & 92,9 & 102,7 & 102,8 & 101,4 \\
\hline Обувь кожаная, тыс. пар & 5111,3 & 62,8 & 116,1 & 82,4 & 91,0 & 124,5 & 96,6 \\
\hline $\begin{array}{l}\text { Черные металлы (кроме чугуна, } \\
\text { ферросплавов, отходов и лома), } \\
\text { млн долларов }\end{array}$ & 270,6 & 67,9 & 88,4 & 72,2 & 96,2 & 82,7 & 94,5 \\
\hline $\begin{array}{l}\text { Трубы из черных металлов, } \\
\text { тыс. тонн }\end{array}$ & 31,3 & 18,0 & 84,9 & 39,7 & в $3,8 \mathrm{p}$. & в $2,3 \mathrm{p}$ & в $2,1 \mathrm{p}$. \\
\hline $\begin{array}{l}\text { Машины, оборудование и } \\
\text { транспортные средства, } \\
\text { млн долларов }\end{array}$ & 9058,6 & 94,0 & 98,9 & 93,7 & 95,6 & 97,6 & 96,8 \\
\hline $\begin{array}{l}\text { Вычислительные машины и } \\
\text { их блоки, млн долларов }\end{array}$ & 558,4 & 114,7 & 100,0 & 117,2 & 89,1 & 102,2 & 86,0 \\
\hline $\begin{array}{l}\text { Аппаратура телефонной и } \\
\text { телеграфной связи, тыс. штук }\end{array}$ & 15518,5 & 189,3 & 155,7 & 125,3 & 95,0 & 90,6 & 101,7 \\
\hline Вагоны грузовые, штук & 55 & 12,1 & 42,3 & 42,4 & в $5,2 \mathrm{p}$. & 88,0 & в 2,3p. \\
\hline
\end{tabular}




\begin{tabular}{|c|c|c|c|c|c|c|c|}
\hline & \multirow{3}{*}{$\begin{array}{l}\text { A6rycm } \\
2020 \text { 2. }\end{array}$} & \multicolumn{2}{|c|}{ 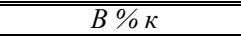 } & \multirow{3}{*}{$\begin{array}{c}\text { Январь- } \\
\text { август } \\
2020 \text { г. } \\
\text { в\% \% } \\
\text { январю- } \\
\text { августу } \\
2019 \text { г. }\end{array}$} & \multicolumn{3}{|c|}{ Справочно } \\
\hline & & \multirow{2}{*}{$\begin{array}{l}\text { августу } \\
2019 \text { г. }\end{array}$} & \multirow{2}{*}{$\begin{array}{l}\text { июлю } \\
2020 \text { 2. }\end{array}$} & & \multicolumn{2}{|c|}{ август 2019 г. в\% \% } & \multirow[b]{2}{*}{$\begin{array}{c}\text { январь- } \\
\text { август } \\
2019 \text { г. } \\
\text { в\% } \\
\text { январю- } \\
\text { августу } \\
2018 \text { г. } \\
\end{array}$} \\
\hline & & & & & $\begin{array}{c}\text { августу } \\
2018 \text { г. }\end{array}$ & $\begin{array}{l}\text { июлю } \\
2019 \text { г. }\end{array}$ & \\
\hline $\begin{array}{l}\text { Тракторы, включая седельные } \\
\text { тягачи, штук }\end{array}$ & 9622 & 95,7 & 149,2 & 116,4 & 148,1 & 80,3 & 92,4 \\
\hline Автомобили легковые, штук & 18491 & 71,2 & 108,3 & 65,8 & 109,1 & 94,5 & 105,9 \\
\hline Автомобили грузовые, штук & 2130 & 89,9 & 119,7 & 66,5 & 92,1 & 96,5 & 118,6 \\
\hline $\begin{array}{l}\text { Кузова для легковых автомобилей, } \\
\text { млн долларов }\end{array}$ & 108,0 & 65,3 & 126,0 & 55,4 & 107,5 & 79,5 & 131,6 \\
\hline $\begin{array}{l}\text { Части и принадлежности к } \\
\text { автомобилям, млн долларов }\end{array}$ & 564,8 & 77,1 & 97,5 & 77,7 & 98,2 & 99,7 & 97,7 \\
\hline Мебель, млн долларов & 161,2 & 97,9 & 102,7 & 91,9 & 101,4 & 99,6 & 101,0 \\
\hline
\end{tabular}

Таблица 12

\section{РАСПРЕДЕЛЕНИЕ ИМПОРТА РОССИЙСКОЙ ФЕДЕРАЦИИ ОСНОВНЫХ ТОВАРОВ ПО СТРАНАМ ЕАЭС \\ в январе-августе 2020 года \\ (по данным ФТС России)}

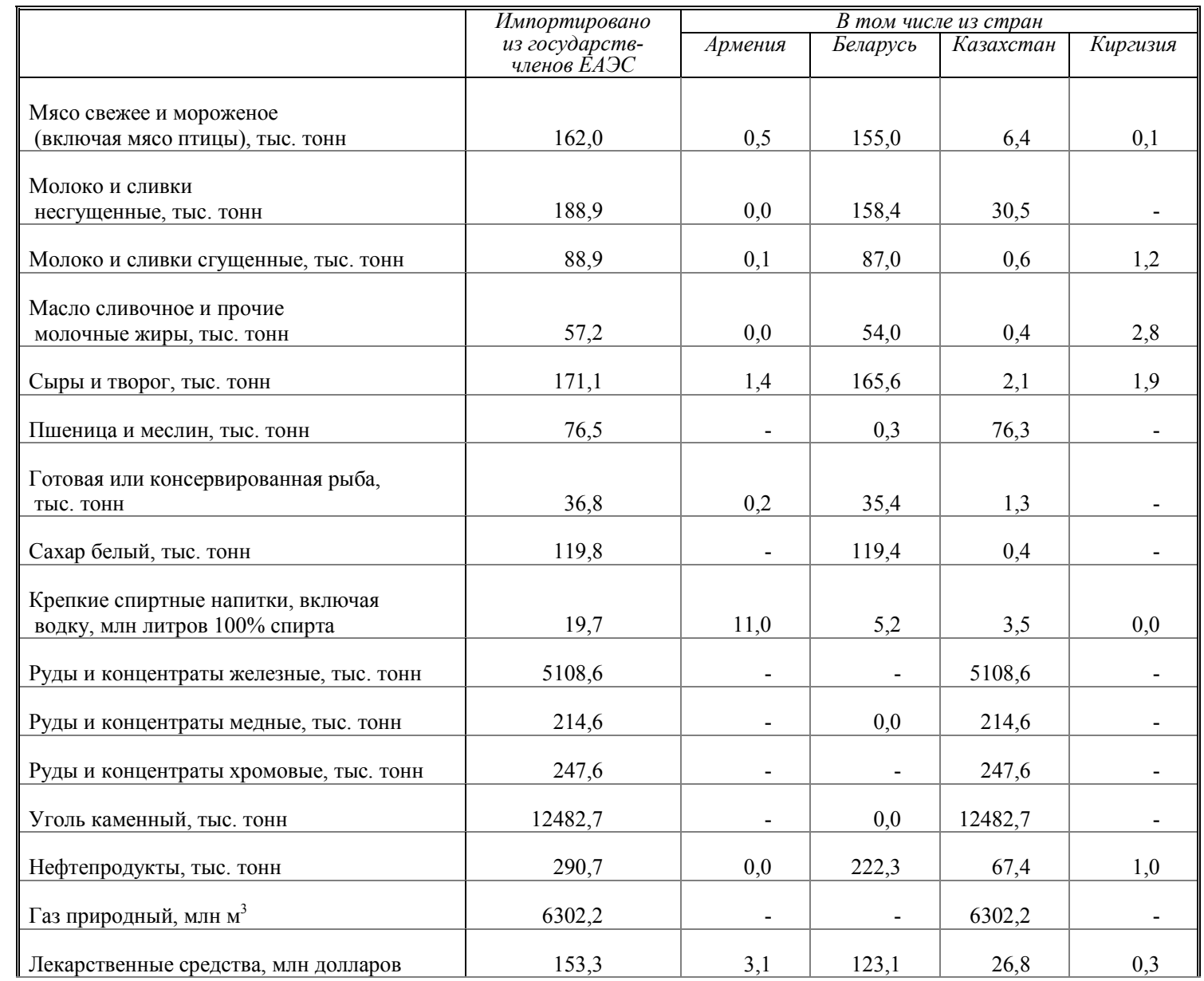




\begin{tabular}{|c|c|c|c|c|c|}
\hline & \multirow{2}{*}{$\begin{array}{c}\text { Импортировано } \\
\text { из государств- } \\
\text { иленов ЕАЭС }\end{array}$} & \multicolumn{4}{|c|}{ В в том числе из стран } \\
\hline & & Армения & Беларусь & Казахстан & Киргизия \\
\hline $\begin{array}{l}\text { Шины пневматические } \\
\text { резиновые, тыс. штук }\end{array}$ & 1847,5 & - & 1844,2 & 2,9 & 0,4 \\
\hline Плиты древесностружечные, тыс. м³ & 418,5 & - & 417,7 & 0,8 & - \\
\hline $\begin{array}{l}\text { Прокат плоский из железа и } \\
\text { нелегированной стали, тыс. тонн }\end{array}$ & 897,1 & - & 24,3 & 872,8 & 0,0 \\
\hline Трубы из черных металлов, тыс. тонн & 126,6 & 0,0 & 43,5 & 83,1 & 0,0 \\
\hline $\begin{array}{l}\text { Алюминий } \\
\text { необработанный, тыс. тонн }\end{array}$ & 5,7 & - & 0,1 & 5,5 & - \\
\hline $\begin{array}{l}\text { Комбинированные холодильники - } \\
\text { морозильники, штук }\end{array}$ & 354223 & - & 354217 & 6 & - \\
\hline $\begin{array}{l}\text { Тракторы, включая седельные } \\
\text { тягачи, штук }\end{array}$ & 18775 & - & 18773 & 2 & - \\
\hline Автомобили легковые, штук & 21316 & - & 21245 & 71 & - \\
\hline Автомобили грузовые, штук & 2237 & - & 1824 & 405 & 8 \\
\hline $\begin{array}{l}\text { Части и принадлежности } \\
\text { к автомобилям, млн долларов }\end{array}$ & 192,0 & 3,8 & 167,8 & 15,0 & 5,3 \\
\hline Мебель, млн долларов & 175,5 & 6,1 & 168,7 & 0,7 & 0,0 \\
\hline
\end{tabular}

В общем объеме импорта удельный вес машин, оборудования и транспортных средств в августе 2020 г. составил 47,6\% (в августе 2019 г. - 45,6\%).

Импорт товаров, необходимых для эксплуатации транспортных средств и обеспечения жизнедеятельности экипажей, осуществляющих международные рейсы, в августе 2020 г. составил 48,7 млн долларов США.

Таблица 13

ИМПОРТ СЕЛЬСКОХОЗЯЙСТВЕННОЙ ПРОДУКЦИИ, СЫРЬЯ И ПРОДОВОЛЬСТВИЯ (ПО ПЕРЕЧНЮ ТОВАРОВ, ЗАПРЕЩЕННЫХ К ВВОЗУ НА ТЕРРИТОРИЮ РОССИЙСКОЙ ФЕДЕРАЦИИ ИЗ СТРАН ЕС, США, КАНАДЫ, АВСТРАЛИИ, НОРВЕГИИ, УКРАИНЫ, РЕСПУБЛИКИ АЛБАНИЯ, ЧЕРНОГОРИИ, РЕСПУБЛИКИ ИСЛАНДИЯ, КНЯЖЕСТВА ЛИХТЕНШТЕЙН, ТУРЕЦКОЙ РЕСПУБЛИКИ)

\begin{tabular}{|c|c|c|c|c|}
\hline & \multicolumn{2}{|c|}{$\begin{array}{l}\text { Январь-август } \\
2020 \text { 2. }\end{array}$} & \multicolumn{2}{|c|}{$\begin{array}{l}\text { В том числе } \\
\text { август } 2020 \text { г. }\end{array}$} \\
\hline & $\begin{array}{l}\text { mblc. } \\
\text { тонн }\end{array}$ & $\begin{array}{l}\text { в\% к } \\
\text { январю- } \\
\text { августу } \\
20192 .\end{array}$ & $\begin{array}{l}\text { mblc. } \\
\text { тонн }\end{array}$ & $\begin{array}{l}\text { в \% к } \\
\text { aвzуcmy } \\
20192 .\end{array}$ \\
\hline $\begin{array}{l}\text { Свиньи живые (за исключением чистопородных } \\
\text { племенных животных) }\end{array}$ & - & - & - & - \\
\hline Мясо крупного рогатого скота, свежее или охлажденное & 39,6 & 87,7 & 4,9 & 88,7 \\
\hline Мясо крупного рогатого скота, замороженное & 131,1 & 89,7 & 17,2 & 79,3 \\
\hline Свинина свежая, охлажденная или замороженная & 3,3 & 5,2 & 0,6 & 17,9 \\
\hline $\begin{array}{l}\text { Пищевые субпродукты крупного рогатого скота, свиней, } \\
\text { овец, коз, лошадей, ослов, мулов или лошаков, свежие, } \\
\text { охлажденные или замороженные (за исключением товаров } \\
\text { для производства фармацевтической продукции) }\end{array}$ & 48,9 & 84,7 & 5,8 & 75,7 \\
\hline $\begin{array}{l}\text { Мясо и пищевые субпродукты домашней птицы, указанной в } \\
\text { товарной позиции 0105, свежие, охлажденные или замороженные }\end{array}$ & 151,1 & 101,9 & 20,0 & 114,3 \\
\hline
\end{tabular}




\begin{tabular}{|c|c|c|c|c|}
\hline & \multicolumn{2}{|c|}{$\begin{array}{c}\text { Январь-август } \\
2020 z .\end{array}$} & \multicolumn{2}{|c|}{$\begin{array}{c}\text { В том числе } \\
\text { август } 2020 \text { г. }\end{array}$} \\
\hline & $\begin{array}{l}\text { mblc. } \\
\text { тонн }\end{array}$ & $\begin{array}{l}\text { в\% к } \\
\text { январю- } \\
\text { августу } \\
20192 \text {. }\end{array}$ & $\begin{array}{l}\text { тысс. } \\
\text { тонн }\end{array}$ & $\begin{array}{l}8 \% \kappa \\
\text { aвгусmy } \\
20192\end{array}$ \\
\hline $\begin{array}{l}\text { Свиной жир, отделенный от тощего мяса, и жир } \\
\text { домашней птицы, не вытопленные или не } \\
\text { извлеченные другим способом, свежие, охлажденные, } \\
\text { замороженные, соленые, в рассоле, сушеные или копченые }\end{array}$ & 2,3 & 39,6 & 0,2 & 83,5 \\
\hline Мясо соленое, в рассоле, сушеное или копченое & 0,3 & 106,3 & 0,03 & в 5,8p. \\
\hline $\begin{array}{l}\text { Живая рыба (за исключением мальков лосося атлантического } \\
\text { (Salmo salar), форели (Salmo trutta, Oncorhynchus mykiss), } \\
\text { живой декоративной рыбы) }\end{array}$ & 1,7 & 128,8 & 0,2 & 104,3 \\
\hline $\begin{array}{l}\text { Рыба и ракообразные, моллюски и прочие водные } \\
\text { беспозвоночные (за исключением молоди (спата) устриц, } \\
\text { мидий и белоногой креветки) }\end{array}$ & 271,5 & 90,7 & 30,2 & 95,4 \\
\hline $\begin{array}{l}\text { Молоко и молочная продукция (за исключением } \\
\text { специализированного безлактозного молока и } \\
\text { специализированной безлактозной молочной продукции } \\
\text { для диетического лечебного питания и } \\
\text { диетического профилактического питания) }\end{array}$ & 719,2 & 106,2 & 89,1 & 105,6 \\
\hline $\begin{array}{l}\text { Овощи, съедобные корнеплоды и клубнеплоды } \\
\text { (за исключением картофеля семенного, лука-севка, } \\
\text { кукурузы сахарной гибридной для посева, гороха для посева) }\end{array}$ & 1630,5 & 96,4 & 58,5 & 87,3 \\
\hline Фрукты и орехи & 3729,1 & 104,5 & 395,9 & 123,0 \\
\hline $\begin{array}{l}\text { Жир свиной (включая лярд) и жир домашней птицы, } \\
\text { кроме жира товарной позиции } 0209 \text { или } 1503\end{array}$ & 0,2 & 42,0 & 0,04 & 49,9 \\
\hline $\begin{array}{l}\text { Жир крупного рогатого скота, овец или коз, } \\
\text { кроме жира товарной позиции } 1503\end{array}$ & 7,4 & 72,3 & 1,0 & 91,2 \\
\hline $\begin{array}{l}\text { Лярд-стеарин, лярд-ойль, олеостеарин, олео-ойль } \\
\text { и животное масло, неэмульгированные или несмешанные, } \\
\text { или не приготовленные каким-либо иным способом }\end{array}$ & - & - & - & - \\
\hline $\begin{array}{l}\text { Колбасы и аналогичные продукты из мяса, } \\
\text { мясных субпродуктов или крови; готовые пищевые продукты, } \\
\text { изготовленные на их основе }\end{array}$ & 17,9 & 121,0 & 2,6 & 155,3 \\
\hline $\begin{array}{l}\text { Пищевые или готовые продукты (за исключением } \\
\text { биологически активных добавок; витаминно-минеральных } \\
\text { комплексов; вкусоароматических добавок; } \\
\text { концентратов белков (животного и растительного } \\
\text { происхождения) и их смесей; пищевых волокон; } \\
\text { пищевых добавок (в том числе комплексных) }\end{array}$ & 70,5 & 73,8 & 9,4 & 91,9 \\
\hline $\begin{array}{l}\text { Пищевые или готовые продукты, изготовленные } \\
\text { по технологиям производства сыра и содержащие 1,5 мас.\% } \\
\text { или более молочного жира }\end{array}$ & 25,1 & 109,7 & 3,2 & 102,5 \\
\hline $\begin{array}{l}\text { Соль (включая соль столовую и денатурированную) } \\
\text { и хлорид натрия чистый, вода морская }\end{array}$ & 833,5 & 94,6 & 121,9 & 94,7 \\
\hline $\begin{array}{l}\text { 1) Постановление Правительства Российской Федерации от } \\
\text { ства Российской Федерации от 13.08.2015 № 842, посn } \\
\text { 30.06.2017 № 293, постановления Правительства Российско } \\
\text { вительства Российской Федерачии от } 30.11 .2015 \text { № } 1296 \text { (в } \\
\text { дерации от 02.06.2017 № 672). }\end{array}$ & $\begin{array}{l}\text { № } 778 \\
\text { Правь } \\
\text { й от } 2 \\
\text { останс } \\
\end{array}$ & $\begin{array}{l}\text { акиии по } \\
\text { ства Ро } \\
2017 \text { № } 1 \\
\text { я Прави }\end{array}$ & $\begin{array}{l}\text { совлен } \\
\text { ской } \\
\text { посто } \\
\text { ства } P\end{array}$ & $\begin{array}{l}\text { равитель- } \\
\text { рации от } \\
\text { ение Пра- } \\
\text { йской Фе- }\end{array}$ \\
\hline
\end{tabular}


ИМПОРТ РОССИЙСКОЙ ФЕДЕРАЦИИ

ПРОДОВОЛЬСТВЕННЫХ ТОВАРОВ И СЕЛЬСКОХОЗЯЙСТВЕННОГО СЫРЬЯ ДЛЯ ИХ ПРОИЗВОДСТВА

\begin{tabular}{|c|c|c|c|c|c|c|c|}
\hline & \multicolumn{3}{|c|}{$\begin{array}{c}\text { Январь-август } \\
2020 \text { г. }\end{array}$} & \multicolumn{2}{|c|}{$\begin{array}{c}\text { В том числе } \\
\text { август } 2020 \text { г. }\end{array}$} & \multirow{2}{*}{\multicolumn{2}{|c|}{$\begin{array}{c}\text { Справочно } \\
\text { январь-август } 2019 \text { г. } \\
\text { в\% к }\end{array}$}} \\
\hline & \multirow{2}{*}{$\begin{array}{c}\text { млн } \\
\text { долларов } \\
\text { США }\end{array}$} & \multicolumn{2}{|c|}{$6 \% \mathrm{~K}$} & \multirow{2}{*}{$\begin{array}{c}\text { млн } \\
\text { долларов } \\
\text { США }\end{array}$} & \multirow{2}{*}{$\begin{array}{l}6 \% \kappa \\
\text { aвzусту } \\
20192\end{array}$} & & \\
\hline & & $\begin{array}{l}\text { январю- } \\
\text { августу } \\
2019 \text { г. }\end{array}$ & итогу & & & $\begin{array}{l}\text { январю- } \\
\text { августу } \\
2018 \text { г. }\end{array}$ & итогу \\
\hline $\begin{array}{l}\text { Продовольственные товары } \\
\text { и сельскохозяйственное сырье } \\
\text { для их производства - всего } \\
\end{array}$ & 18980 & $\mathbf{9 8 , 8}$ & 100 & 2194 & 100,0 & 98,6 & 100 \\
\hline $\begin{array}{l}\text { в том числе: } \\
\text { страны дальнего } \\
\text { зарубежья }\end{array}$ & 14920 & 98,3 & 78,6 & 1689 & 98,8 & 96,6 & 79,0 \\
\hline Страны ЕC & 4315 & 94,2 & 22,7 & 547 & 97,4 & 97,6 & 23,8 \\
\hline Аргентина & 501 & 96,0 & 2,6 & 54,9 & 91,4 & 105,4 & 2,7 \\
\hline Бразилия & 962 & 98,2 & 5,1 & 109 & 102,8 & 109,0 & 5,1 \\
\hline Египет & 356 & 107,5 & 1,9 & 6,4 & 96,0 & 89,1 & 1,7 \\
\hline Израиль & 175 & 100,5 & 0,9 & 3,7 & 88,9 & 87,9 & 0,9 \\
\hline Иран & - & - & - & - & - & 105,9 & 1,5 \\
\hline Исландия & 3,9 & 41,9 & 0,0 & 0,4 & в $2,5 \mathrm{p}$. & 105,7 & 0,0 \\
\hline Китай & 949 & 86,8 & 5,0 & 94,6 & 84,0 & 86,4 & 5,7 \\
\hline Марокко & 149 & 64,1 & 0,8 & 1,8 & 83,1 & 109,8 & 1,2 \\
\hline Пакистан & 72,7 & 62,4 & 0,4 & 0,2 & 18,7 & 136,8 & 0,6 \\
\hline Парагвай & 331 & 76,9 & 1,7 & 74,7 & 86,3 & 73,4 & 2,2 \\
\hline Сербия & 293 & 104,4 & 1,5 & 26,2 & 94,7 & 100,7 & 1,5 \\
\hline Турция & 897 & 116,5 & 4,7 & 81,3 & 130,5 & 112,2 & 4,0 \\
\hline Фарерские острова (Дания) & 149 & 99,3 & 0,8 & 17,2 & 110,9 & 72,0 & 0,8 \\
\hline Чили & 395 & 81,1 & 2,1 & 39,0 & 72,7 & 85,9 & 2,5 \\
\hline Эквадор & 855 & 99,7 & 4,5 & 81,9 & 96,0 & 96,9 & 4,5 \\
\hline ЮАР & 236 & 134,9 & 1,2 & 55,4 & 198,4 & 92,0 & 0,9 \\
\hline $\begin{array}{l}\text { государства- } \\
\text { участники СНГ }\end{array}$ & 4059 & 100,6 & 21,4 & 504 & 104,4 & 107,0 & 21,0 \\
\hline Азербайджан & 362 & 104,3 & 1,9 & 17,6 & 90,4 & 106,6 & 1,8 \\
\hline Беларусь & 2732 & 98,1 & 14,4 & 359 & 100,5 & 105,1 & 14,5 \\
\hline Украина & 61,8 & 126,6 & 0,3 & 7,0 & 121,5 & 48,8 & 0,3 \\
\hline
\end{tabular}


ИМПОРТ ОТДЕЛЬНЫХ ПРОДОВОЛЬСТВЕННЫХ ТОВАРОВ, ЗАПРЕЩЕННЫХ К ВВОЗУ НА ТЕРРИТОРИЮ РОССИЙСКОЙ ФЕДЕРАЦИИ ИЗ РЯДА СТРАН ${ }^{1)}$ в январе-августе 2020 года

\begin{tabular}{|c|c|c|c|c|c|c|c|c|c|}
\hline & \multicolumn{3}{|c|}{$\begin{array}{c}\text { Молоко и сливки, несгущенные } \\
\text { (код ТН ВЭДЕАЭС-0401) }\end{array}$} & \multicolumn{3}{|c|}{$\begin{array}{c}\text { Пахта, свернувшиеся молоко } \\
\text { и сливки, иогурт, кефир } \\
\text { (код ТН ВЭДЕАЭС - 0403) }\end{array}$} & \multicolumn{3}{|c|}{$\begin{array}{c}\text { Молочная сыворотка; } \\
\text { продуктьы из натуральныхх } \\
\text { компонентов молока } \\
\text { (код ТН ВЭД ЕАЭС - 0404) }\end{array}$} \\
\hline & \multirow{2}{*}{$\begin{array}{l}\text { mblc. } \\
\text { тонн }\end{array}$} & \multicolumn{2}{|c|}{$8 \% \kappa$} & \multirow{2}{*}{$\begin{array}{l}\text { mblc. } \\
\text { тонн }\end{array}$} & \multicolumn{2}{|c|}{$8 \% \kappa$} & \multirow{2}{*}{$\begin{array}{l}\text { mblc. } \\
\text { тонн }\end{array}$} & \multicolumn{2}{|c|}{$6 \% \kappa$} \\
\hline & & $\begin{array}{l}\text { январю- } \\
\text { августу } \\
20192 . \\
\end{array}$ & umozy & & $\begin{array}{l}\text { январю- } \\
\text { августу } \\
20192 . \\
\end{array}$ & umozy & & $\begin{array}{l}\text { январю- } \\
\text { августу } \\
20192 .\end{array}$ & umozy \\
\hline Импорт - всего & 199,6 & 119,0 & 100 & 95,1 & 107,3 & 100 & 39,5 & 94,8 & 100 \\
\hline $\begin{array}{l}\text { в том числе: } \\
\text { страны дальнего } \\
\text { зарубежья }\end{array}$ & 10,6 & 132,4 & 5,3 & $\mathbf{0 , 1}$ & 105,7 & 0,2 & 3,4 & 45,9 & 8,6 \\
\hline $\begin{array}{l}\text { государства- } \\
\text { участники СНГ }\end{array}$ & 188,9 & 118,3 & 94,7 & 95,0 & 107,3 & 99,8 & 36,1 & 105,4 & 91,4 \\
\hline Беларусь & 158,4 & 115,3 & 79,4 & 89,8 & 109,2 & 94,4 & 35,9 & 105,7 & 91,0 \\
\hline Казахстан & 30,5 & 136,6 & 15,3 & 4,6 & 81,6 & 4,9 & 0,1 & 67,0 & 0,2 \\
\hline $\begin{array}{l}\text { 1) Постановление } \\
\text { тельства Россл } \\
\text { от 30.06.2017 № } \\
\end{array}$ & $\begin{array}{l}\text { oü } \Phi \\
3, \text { noc } \\
\end{array}$ & $\begin{array}{l}\text { а Росс } \\
\text { виии от } \\
\text { вления I }\end{array}$ & $\begin{array}{l}\check{u} \text { Фед } \\
8.2015 \\
\text { тельсл }\end{array}$ & $\begin{array}{l}\text { uu om } \\
842, \\
\text { Poccui }\end{array}$ & $\begin{array}{l}.08 .2014 \\
\text { пановлен } \\
\dot{u} \text { Федера }\end{array}$ & $\begin{array}{l}778 \text { (в } \\
\text { Правин } \\
\text { от } 25 .\end{array}$ & $\begin{array}{l}\text { акции } \\
\text { ства } 1 \\
017 \text { № }\end{array}$ & $\begin{array}{l}\text { пановле } \\
\text { ийской }\end{array}$ & $\begin{array}{l}\text { Прави- } \\
\text { ерации }\end{array}$ \\
\hline
\end{tabular}

ЭКСПОРТ И ИМПОРТ

ВЫСОКОТЕХНОЛОГИЧНОЙ ПРОДУКЦИИ

\begin{tabular}{|c|c|c|c|c|}
\hline & \multicolumn{2}{|c|}{ Экспорт } & \multicolumn{2}{|c|}{ Импорт } \\
\hline & $\begin{array}{c}\text { млн } \\
\text { долларов } \\
\text { США }\end{array}$ & $\begin{array}{c}\text { в\% к } \\
\text { соответствуюшему } \\
\text { периоду } \\
\text { предьлдущего года }\end{array}$ & $\begin{array}{c}\text { млн } \\
\text { долларов } \\
\text { США }\end{array}$ & $\begin{array}{c}\text { в\% к } \\
\text { соответствуюшему } \\
\text { периоду } \\
\text { предылушчего года }\end{array}$ \\
\hline \multicolumn{5}{|c|}{2019 г. } \\
\hline Январь & 2692 & 81,6 & 9971 & 97,6 \\
\hline Январь-февраль & 6025 & 88,3 & 21295 & 95,1 \\
\hline І квартал & 9946 & 90,8 & 34803 & 95,8 \\
\hline Январь-апрель & 14089 & 91,7 & 48770 & 98,4 \\
\hline Январь-май & 17813 & 92,0 & 61384 & 97,2 \\
\hline I полугодие & 22283 & 94,3 & 74319 & 96,5 \\
\hline Январь-июль & 26767 & 98,0 & 88886 & 97,8 \\
\hline Январь-август & 31043 & 99,5 & 103148 & 97,9 \\
\hline Январь-сентябрь & 34923 & 99,1 & 116700 & 98,6 \\
\hline Январь-октябрь & 39460 & 99,0 & 132336 & 100,0 \\
\hline
\end{tabular}




\begin{tabular}{|c|c|c|c|c|}
\hline & \multicolumn{2}{|c|}{ 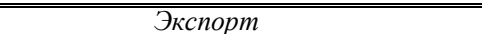 } & \multicolumn{2}{|c|}{ Импорт } \\
\hline & $\begin{array}{c}\text { млн } \\
\text { долларов } \\
\text { США }\end{array}$ & $\begin{array}{c}\text { в\% к } \\
\text { соответствуюшему } \\
\text { периоду } \\
\text { предыдущего года }\end{array}$ & $\begin{array}{c}\text { млн } \\
\text { долларов } \\
\text { США }\end{array}$ & $\begin{array}{c}\text { в\% } \\
\text { соответствуюшему } \\
\text { периоду } \\
\text { предьдущего года }\end{array}$ \\
\hline Январь-ноябрь & 43912 & 99,5 & 147607 & 101,1 \\
\hline Год & 49190 & 99,9 & 163067 & 101,9 \\
\hline \multicolumn{5}{|c|}{2020 г. } \\
\hline Январь & 3259 & 121,1 & 10303 & 103,3 \\
\hline Январь-февраль & 6846 & 113,6 & 21996 & 103,3 \\
\hline I квартал & 10753 & 108,1 & 34709 & 99,7 \\
\hline Январь-апрель & 14314 & 101,6 & 45390 & 93,1 \\
\hline Январь-май & 17731 & 99,5 & 56346 & 91,8 \\
\hline I полугодие & 21518 & 96,6 & 68787 & 92,6 \\
\hline Январь-июль & 25160 & 94,0 & 81474 & 91,7 \\
\hline Январь-август & 28720 & 92,5 & 94406 & 91,5 \\
\hline
\end{tabular}

Таблица 17

УРОВЕНЬ СРЕДНИХ ФАКТИЧЕСКИХ ЦЕН ЭКСПОРТНЫХ ОПЕРАЦИЙ ${ }^{1)}$

\begin{tabular}{|c|c|c|c|c|c|}
\hline & \multirow{2}{*}{$\begin{array}{c}\text { Средняя } \\
\text { фактическая } \\
\text { цена за } 1 \text { тонну } \\
\text { в августе } 2020 \text { г., } \\
\text { долларов США } \\
\end{array}$} & \multicolumn{2}{|c|}{ В том числе } & \multicolumn{2}{|c|}{ Aвгуст 2020 г. в\% \% } \\
\hline & & $\begin{array}{c}\text { стрраны } \\
\text { дальнего } \\
\text { зарубежья }\end{array}$ & \begin{tabular}{|c|} 
государства- \\
участники \\
СНГ
\end{tabular} & $\begin{array}{c}\text { августу } \\
20192 .\end{array}$ & $\begin{array}{l}\text { июлю } \\
2020 \text { г. }\end{array}$ \\
\hline Пшеница и меслин & 208,0 & 209,6 & 191,3 & 110,2 & 105,5 \\
\hline $\begin{array}{l}\text { Мука пшеничная или } \\
\text { пшенично-ржаная }\end{array}$ & 302,7 & 296,2 & 309,1 & 100,1 & 96,2 \\
\hline Крупа & 449,5 & 545,6 & 424,7 & 89,9 & 85,3 \\
\hline $\begin{array}{l}\text { Масло подсолнечное, } \\
\text { сафлоровое или хлопковое } \\
\text { и его фракции }\end{array}$ & 733,1 & 714,3 & 848,4 & 103,1 & 102,5 \\
\hline Фосфаты кальция & 130,3 & 133,5 & 120,8 & 107,3 & 115,6 \\
\hline Руды и концентраты железные & 79,7 & 79,7 & 139,6 & 72,7 & 110,9 \\
\hline Уголь каменный & 59,1 & 59,0 & 70,9 & 77,5 & 92,6 \\
\hline Кокс и полукокс & 176,8 & 156,2 & 196,6 & 76,7 & 104,9 \\
\hline $\begin{array}{l}\text { Нефть сырая, включая газовый } \\
\text { конденсат природный }\end{array}$ & 297,4 & 299,7 & 268,6 & 67,1 & 107,2 \\
\hline Нефтепродукты & 285,8 & 285,0 & 306,0 & 60,0 & 111,7 \\
\hline Газ природный, за 1000 м³ & 92,7 & $\ldots$ & $\ldots$ & 57,2 & 106,2 \\
\hline Электроэнергия, за 1000 кВт·ч & 39,5 & 39,5 & 39,6 & 89,9 & 90,1 \\
\hline Аммиак безводный & 185,8 & 189,0 & 175,3 & 90,0 & 108,7 \\
\hline
\end{tabular}




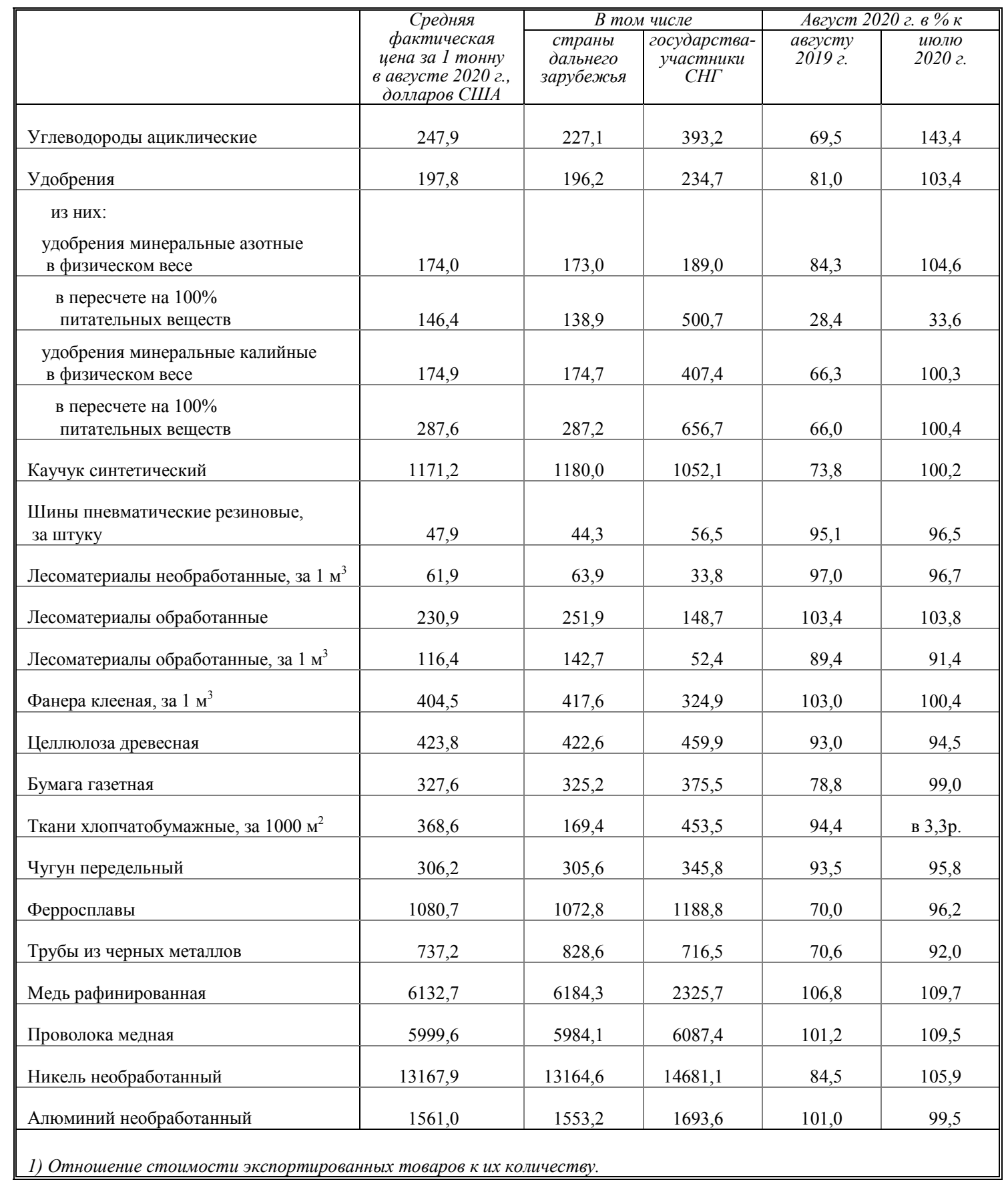

\section{МИРОВЫЕ ЦЕНЫ НА ОТДЕЛЬНЫЕ ТОВАРЫ}

(по данным Минфина России)

\begin{tabular}{|c|c|c|c|}
\hline & \multirow{2}{*}{\begin{tabular}{|c|} 
Цена за 1 тонну \\
в сентябре 2020 г., \\
долларов США \\
\end{tabular}} & \multicolumn{2}{|c|}{ Сентябрь 2020 г. в\% \% } \\
\hline & & $\begin{array}{c}\text { сентяббрю } \\
2019 \text { 2. }\end{array}$ & $\begin{array}{l}\text { aвгусту } \\
2020 \text { z. }\end{array}$ \\
\hline Нефть (Юралс), за 1 тонну / за 1 баррель & $298,6 / 40,9$ & 67,0 & 91,9 \\
\hline Бензин (Нафта) & 362,5 & 76,1 & 95,8 \\
\hline
\end{tabular}




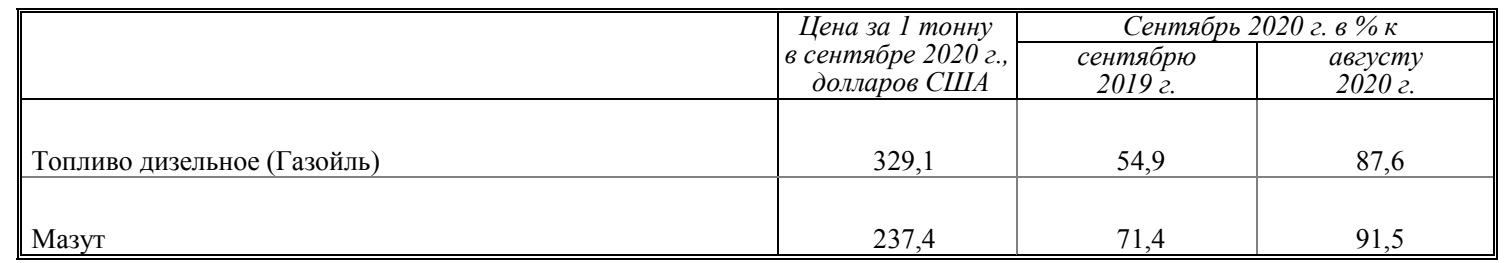

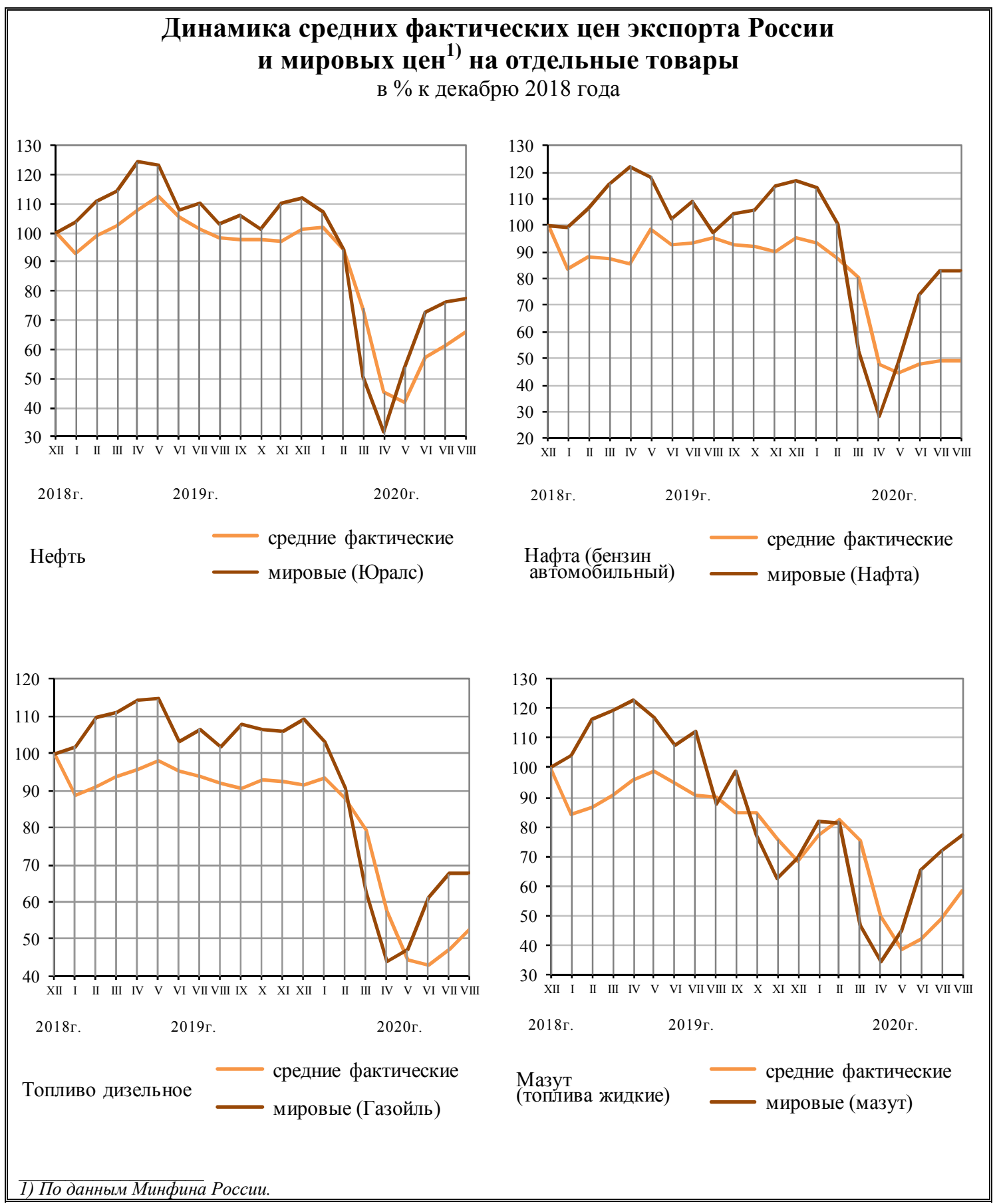




\section{УРОВЕНЬ СРЕДНИХ ФАКТИЧЕСКИХ ЦЕН} ИМПОРТНЫХ ОПЕРАЦИЙ ${ }^{1)}$

\begin{tabular}{|c|c|c|c|c|c|}
\hline \multirow{2}{*}{\multicolumn{2}{|c|}{\begin{tabular}{|c|c|} 
& Средняя \\
& рактическая \\
цена за 1 тонну & в августе 2020 2., \\
долларов США
\end{tabular}}} & \multicolumn{2}{|c|}{ В том числе } & \multicolumn{2}{|c|}{ Август 2020 г. в\% \% } \\
\hline & & $\begin{array}{c}\text { страньл } \\
\text { дальнего } \\
\text { зарубежья }\end{array}$ & $\begin{array}{c}\text { государства- } \\
\text { участники } \\
\text { СНГ }\end{array}$ & $\begin{array}{c}\text { aвzycmy } \\
2019 \text { z. }\end{array}$ & $\begin{array}{l}\text { июлю } \\
2020 \text { г. }\end{array}$ \\
\hline $\begin{array}{l}\text { Мясо свежее и мороженое } \\
\text { (без мяса птицы) }\end{array}$ & 3347,0 & 3323,0 & 3387,5 & 95,7 & 95,7 \\
\hline Мясо птицы свежее и мороженое & 1279,3 & 1281,9 & 1277,7 & 72,3 & 96,0 \\
\hline Молоко и сливки несгущенные & 718,3 & 786,9 & 717,6 & 82,9 & 99,5 \\
\hline Молоко и сливки сгущенные & 2166,7 & 2919,1 & 2106,4 & 91,9 & 98,2 \\
\hline Сыры и творог & 3812,9 & 4961,4 & 3710,9 & 92,4 & 100,8 \\
\hline $\begin{array}{l}\text { Картофель свежий } \\
\text { или охлажденный }\end{array}$ & 419,6 & 559,9 & 206,5 & 146,4 & 122,5 \\
\hline Томаты свежие или охлажденные & 644,3 & 1008,7 & 592,0 & 108,8 & 70,4 \\
\hline Цитрусовые плоды & 1000,9 & 1000,8 & 1121,7 & 100,4 & 99,9 \\
\hline $\begin{array}{l}\text { Бананы, включая плантайны, } \\
\text { свежие или сушеные }\end{array}$ & 732,5 & 732,5 & 425,0 & 100,0 & 100,3 \\
\hline Уголь каменный & 13,4 & 146,9 & 13,1 & 88,4 & 95,7 \\
\hline Нефтепродукты & 1418,2 & 1711,4 & 540,1 & 89,0 & 94,6 \\
\hline $\begin{array}{l}\text { Шины пневматические } \\
\text { резиновые, за штуку }\end{array}$ & 55,8 & 58,6 & 31,9 & 100,3 & 98,0 \\
\hline Волокно хлопковое, нечесаное & 1438,2 & - & 1438,2 & 83,7 & 105,2 \\
\hline $\begin{array}{l}\text { Ткани хлопчатобумажные, } \\
\text { за } 1000 \text { м }^{2}\end{array}$ & 482,3 & 884,0 & 318,2 & 124,9 & 83,1 \\
\hline Обувь кожаная, за 1 пару & 30,9 & 31,6 & 18,5 & 102,7 & 115,6 \\
\hline Трубы из черных металлов & 1668,0 & 2740,2 & 870,4 & 156,0 & 84,5 \\
\hline $\begin{array}{l}\text { Аппаратура телефонной и } \\
\text { телеграфной связи, за } 1 \text { штуку }\end{array}$ & 57,1 & 57,4 & 23,2 & 63,6 & 57,9 \\
\hline Вагоны грузовые, за 1 штуку & 35824,7 & 33275,7 & 36196,5 & 84,4 & 75,7 \\
\hline $\begin{array}{l}\text { Тракторы, включая седельные } \\
\text { тягачи, за } 1 \text { штуку }\end{array}$ & 8147,5 & 7545,4 & 9457,9 & 129,0 & 66,3 \\
\hline Автомобили легковые, за 1 штуку & 21422,2 & 25504,6 & 7742,8 & 85,5 & 101,9 \\
\hline Автомобили грузовые, за 1 штуку & 38435,8 & 35339,4 & 62935,2 & 73,3 & 70,2 \\
\hline
\end{tabular}




\section{3. ДЕМОГРАФИЯ ОРГАНИЗАЦИЙ ${ }^{1)}$}

В сентябре 2020 г. зарегистрировано 19,8 тыс. организаций (в сентябре 2019 г. - 22,7 тыс.), количество официально ликвидированных организаций составило 50,6 тыс. (в сентябре 2019 г. 55,3 тыс. организаций).

Таблица 1

ДЕМОГРАФИЯ ОРГАНИЗАЦИЙ

ПО ВИДАМ ЭКОНОМИЧЕСКОЙ ДЕЯТЕЛЬНОСТИ

единиц

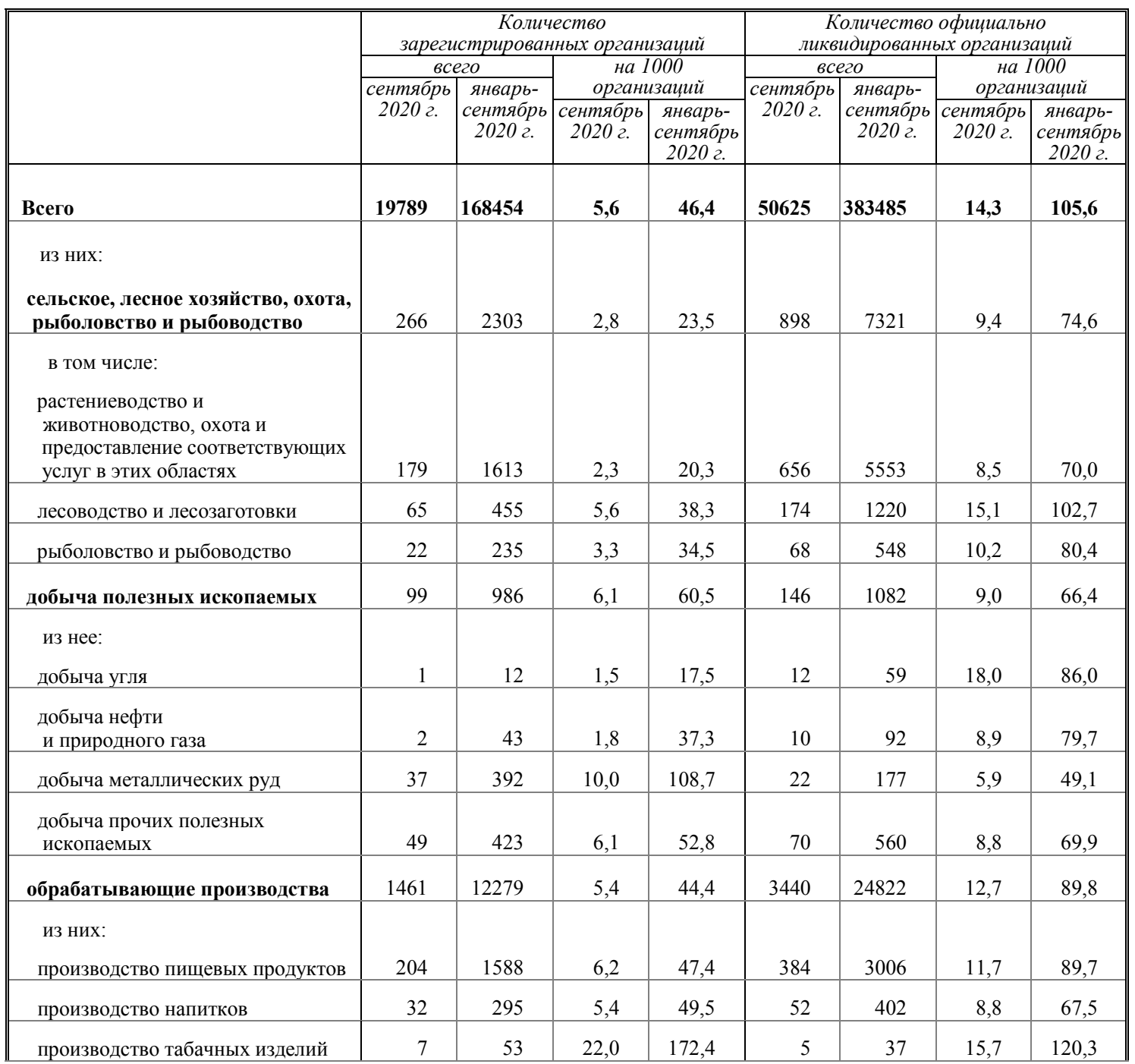

1) Исключая филиальи, представительства и другие обособленные подразделения. 


\begin{tabular}{|c|c|c|c|c|c|c|c|c|}
\hline & \multicolumn{4}{|c|}{$\begin{array}{c}\text { Количество } \\
\text { зарегистрированньх организаций }\end{array}$} & \multicolumn{4}{|c|}{$\begin{array}{c}\text { Количество официально } \\
\text { ликвидированных организаций }\end{array}$} \\
\hline & \multicolumn{2}{|c|}{ всего } & \multirow{2}{*}{\multicolumn{2}{|c|}{$\begin{array}{c}\text { на } 1000 \\
\text { организациий } \\
\end{array}$}} & \multicolumn{2}{|c|}{ всего } & \multirow{2}{*}{\multicolumn{2}{|c|}{$\begin{array}{c}\text { на } 1000 \\
\text { организаций }\end{array}$}} \\
\hline & \multirow{2}{*}{\begin{tabular}{|c|} 
сентябрь \\
2020 2.
\end{tabular}} & \multirow{2}{*}{\begin{tabular}{|c|} 
январь- \\
сентябрь \\
20202. \\
\end{tabular}} & & & \multirow{2}{*}{$\begin{array}{c}\text { сентябрь } \\
2020 \text { 2. }\end{array}$} & \multirow{2}{*}{\begin{tabular}{|c|} 
январь- \\
сентябрь \\
20202.
\end{tabular}} & & \\
\hline & & & \begin{tabular}{|c|} 
сентябрь \\
2020 2.
\end{tabular} & \begin{tabular}{|c|} 
январь- \\
сентябрь \\
2020 2. \\
\end{tabular} & & & \begin{tabular}{|c|} 
сентябрь \\
2020 2.
\end{tabular} & \begin{tabular}{|c|} 
январь- \\
сентябрь \\
2020 2. \\
\end{tabular} \\
\hline $\begin{array}{l}\text { производство текстильных } \\
\text { изделий }\end{array}$ & 32 & 276 & 5,5 & 46,3 & 71 & 566 & 12,2 & 95,0 \\
\hline производство одежды & 55 & 493 & 4,8 & 41,9 & 202 & 1264 & 17,7 & 107,5 \\
\hline $\begin{array}{l}\text { производство кожи } \\
\text { и изделий из кожи }\end{array}$ & 6 & 66 & 3,5 & 37,4 & 24 & 153 & 14,0 & 86,8 \\
\hline $\begin{array}{l}\text { обработка древесины и } \\
\text { производство изделий из дерева } \\
\text { и пробки, кроме мебели, } \\
\text { производство изделий из соломки } \\
\text { и материалов для плетения }\end{array}$ & 97 & 878 & 5,0 & 43,3 & 347 & 2373 & 17,8 & 117,1 \\
\hline $\begin{array}{c}\text { производство бумаги } \\
\text { и бумажных изделий }\end{array}$ & 16 & 147 & 4,6 & 41,5 & 48 & 315 & 13,8 & 88,9 \\
\hline $\begin{array}{l}\text { деятельность полиграфическая } \\
\text { и копирование носителей } \\
\text { информации }\end{array}$ & 36 & 301 & 3,0 & 24,1 & 185 & 1262 & 15,4 & 101,2 \\
\hline $\begin{array}{l}\text { производство кокса } \\
\text { и нефтепродуктов }\end{array}$ & 2 & 37 & 1,9 & 33,3 & 14 & 135 & 13,2 & 121,4 \\
\hline $\begin{array}{l}\text { производство химических } \\
\text { веществ и химических продуктов }\end{array}$ & 62 & 566 & 6,1 & 56,0 & 103 & 726 & 10,2 & 71,8 \\
\hline $\begin{array}{l}\text { производство лекарственных } \\
\text { средств и материалов, } \\
\text { применяемых в медицинских } \\
\text { целях }\end{array}$ & 15 & 131 & 8,1 & 70,6 & 16 & 125 & 8,6 & 67,4 \\
\hline $\begin{array}{c}\text { производство резиновых } \\
\text { и пластмассовых изделий }\end{array}$ & 64 & 650 & 4,1 & 40,3 & 191 & 1356 & 12,1 & 84,1 \\
\hline $\begin{array}{l}\text { производство прочей } \\
\text { неметаллической минеральной } \\
\text { продукции }\end{array}$ & 112 & 976 & 5,2 & 44,1 & 301 & 2037 & 13,9 & 91,9 \\
\hline производство металлургическое & 21 & 131 & 6,1 & 37,3 & 48 & 302 & 14,0 & 86,0 \\
\hline $\begin{array}{l}\text { производство готовых } \\
\text { металлических изделий, } \\
\text { кроме машин и оборудования }\end{array}$ & 273 & 2058 & 7,4 & 55,4 & 417 & 3238 & 11,4 & 87,2 \\
\hline $\begin{array}{l}\text { производство компьютеров, } \\
\text { электронных и } \\
\text { оптических изделий }\end{array}$ & 26 & 207 & 3,3 & 25,6 & 83 & 525 & 10,5 & 65,0 \\
\hline $\begin{array}{l}\text { производство электрического } \\
\text { оборудования }\end{array}$ & 29 & 315 & 3,8 & 41,0 & 86 & 542 & 11,3 & 70,6 \\
\hline $\begin{array}{l}\text { производство машин } \\
\text { и оборудования, не включенных } \\
\text { в другие группировки }\end{array}$ & 88 & 654 & 6,0 & 44,1 & 145 & 1081 & 9,9 & 72,9 \\
\hline $\begin{array}{l}\text { производство автотранспортных } \\
\text { средств, прицепов } \\
\text { и полуприцепов }\end{array}$ & 14 & 97 & 4,9 & 33,4 & 28 & 226 & 9,8 & 77,7 \\
\hline $\begin{array}{l}\text { производство прочих } \\
\text { транспортных средств } \\
\text { и оборудования }\end{array}$ & 14 & 107 & 4,4 & 33,3 & 35 & 249 & 11,1 & 77,4 \\
\hline производство мебели & 82 & 702 & 5,6 & 46,5 & 235 & 1716 & 16,1 & 113,8 \\
\hline $\begin{array}{l}\text { производство прочих } \\
\text { готовых изделий }\end{array}$ & 46 & 312 & 6,5 & 43,1 & 86 & 617 & 12,1 & 85,2 \\
\hline
\end{tabular}




\begin{tabular}{|c|c|c|c|c|c|c|c|c|}
\hline & \multicolumn{4}{|c|}{$\begin{array}{c}\text { Количество } \\
\text { зарегистрированных организаций }\end{array}$} & \multicolumn{4}{|c|}{$\begin{array}{c}\text { Количество официально } \\
\text { ликвидированньхх организаций }\end{array}$} \\
\hline & \multicolumn{2}{|c|}{ всего } & \multirow{2}{*}{\multicolumn{2}{|c|}{$\begin{array}{c}\text { на } 1000 \\
\text { организаций }\end{array}$}} & \multicolumn{2}{|c|}{ всего } & \multirow{2}{*}{\multicolumn{2}{|c|}{$\begin{array}{c}\text { на } 1000 \\
\text { организаций }\end{array}$}} \\
\hline & сентябрь & & & & сентябрь & & & \\
\hline & 20202 & $\begin{array}{c}\text { сентябрь } \\
2020 \text { 2. }\end{array}$ & \begin{tabular}{|c|} 
сентябри \\
2020 г.
\end{tabular} & \begin{tabular}{|c|} 
январь- \\
сентябрь \\
2020 2. \\
\end{tabular} & 20202. & $\begin{array}{c}\text { сентябрь } \\
2020 \text { 2. }\end{array}$ & \begin{tabular}{|c|} 
сентябрь \\
2020 2.
\end{tabular} & \begin{tabular}{|c|} 
январь- \\
сентябрь \\
20202. \\
\end{tabular} \\
\hline $\begin{array}{l}\text { обеспечение электрической } \\
\text { энергией, газом и паром; } \\
\text { кондиционирование воздуха }\end{array}$ & 75 & 580 & 4,1 & 31,4 & 150 & 1240 & 8,3 & 67,2 \\
\hline $\begin{array}{l}\text { в том числе: } \\
\text { производство, передача } \\
\text { и распределение электроэнергии }\end{array}$ & 32 & 249 & 4,5 & 34,0 & 56 & 516 & 7,8 & 70,5 \\
\hline $\begin{array}{l}\text { производство и распределение } \\
\text { газообразного топлива }\end{array}$ & 7 & 35 & 5,7 & 27,9 & 17 & 84 & 13,8 & 67,0 \\
\hline $\begin{array}{l}\text { производство, передача и } \\
\text { распределение пара и горячей } \\
\text { воды; кондиционирование } \\
\text { воздуха }\end{array}$ & 36 & 296 & 3,7 & 29,9 & 77 & 640 & 7,9 & 64,7 \\
\hline $\begin{array}{l}\text { водоснабжение; водоотведение, } \\
\text { организация сбора и утилизации } \\
\text { отходов, деятельность по } \\
\text { ликвидации загрязнений }\end{array}$ & 122 & 1058 & 5,4 & 45,5 & 273 & 1980 & 12,0 & 85,2 \\
\hline строительство & 3578 & 33362 & 8,6 & 78,6 & 7667 & 59275 & 18,5 & 139,6 \\
\hline $\begin{array}{l}\text { торговля оптовая и розничная; } \\
\text { ремонт автотранспортных } \\
\text { средств и мотоциклов }\end{array}$ & 6108 & 52946 & 6,2 & 51,7 & 19754 & 153776 & 20,2 & 150,3 \\
\hline $\begin{array}{l}\text { в том числе: } \\
\text { торговля оптовая и розничная } \\
\text { автотранспортными средствами } \\
\text { и мотоциклами и их ремонт }\end{array}$ & 551 & 4988 & 5,8 & 50,7 & 1794 & 13431 & 19,0 & 136,6 \\
\hline $\begin{array}{l}\text { торговля оптовая, кроме оптовой } \\
\text { торговли автотранспортными } \\
\text { средствами и мотоциклами }\end{array}$ & 4334 & 38816 & 6,6 & 56,7 & 13724 & 111184 & 21,1 & 162,4 \\
\hline $\begin{array}{l}\text { торговля розничная, кроме } \\
\text { торговли автотранспортными } \\
\text { средствами и мотоциклами }\end{array}$ & 1223 & 9142 & 5,3 & 38,0 & 4236 & 29161 & 18,3 & 121,4 \\
\hline транспортировка и хранение & 1386 & 11373 & 6,6 & 53,3 & 3152 & 23485 & 15,1 & 110,0 \\
\hline $\begin{array}{l}\text { в том числе: } \\
\text { деятельность сухопутного и } \\
\text { трубопроводного транспорта }\end{array}$ & 967 & 7790 & 10,2 & 80,8 & 1732 & 13218 & 18,2 & 137,2 \\
\hline $\begin{array}{l}\text { в том числе: } \\
\text { деятельность железнодорожного } \\
\text { транспорта: междугородные и } \\
\text { международные пассажирские } \\
\text { перевозки }\end{array}$ & 3 & 10 & 3,5 & 10,5 & 16 & 137 & 18,4 & 143,7 \\
\hline $\begin{array}{l}\text { деятельность железнодорожного } \\
\text { транспорта: грузовые перевозки }\end{array}$ & 26 & 175 & 12,5 & 82,7 & 32 & 251 & 15,4 & 118,6 \\
\hline $\begin{array}{l}\text { деятельность прочего } \\
\text { сухопутного пассажирского } \\
\text { транспорта }\end{array}$ & 101 & 692 & 6,2 & 42,0 & 245 & 1597 & 15,1 & 96,9 \\
\hline $\begin{array}{l}\text { деятельность автомобильного } \\
\text { грузового транспорта } \\
\text { и услуги по перевозкам }\end{array}$ & 834 & 6907 & 11,0 & 90,2 & 1438 & 11208 & 19,0 & 146,4 \\
\hline $\begin{array}{l}\text { деятельность трубопроводного } \\
\text { транспорта }\end{array}$ & 3 & 6 & 11,7 & 22,3 & 1 & 25 & 3,9 & 93,1 \\
\hline
\end{tabular}




\begin{tabular}{|c|c|c|c|c|c|c|c|c|}
\hline & \multicolumn{4}{|c|}{$\begin{array}{c}\text { Количество } \\
\text { зарегистрированных организаций }\end{array}$} & \multicolumn{4}{|c|}{$\begin{array}{c}\text { Количество официально } \\
\text { ликвидированньх организаций }\end{array}$} \\
\hline & \multicolumn{2}{|c|}{ всего } & \multirow{2}{*}{\multicolumn{2}{|c|}{$\begin{array}{c}\text { на } 1000 \\
\text { организациий }\end{array}$}} & \multicolumn{2}{|c|}{ всего } & \multirow{2}{*}{\multicolumn{2}{|c|}{$\begin{array}{c}\text { на } 1000 \\
\text { организаций }\end{array}$}} \\
\hline & \multirow{2}{*}{\begin{tabular}{|c|} 
сентябрь \\
2020 2.
\end{tabular}} & \multirow{2}{*}{\begin{tabular}{|c|} 
январь- \\
сентябрь \\
20202.
\end{tabular}} & & & \multirow{2}{*}{\begin{tabular}{|l|} 
сентябрь \\
2020 2.
\end{tabular}} & \multirow{2}{*}{\begin{tabular}{|c|} 
январь- \\
сентябрь \\
2020 2.
\end{tabular}} & & \\
\hline & & & \begin{tabular}{|c|} 
сентябрь \\
2020 г. \\
\end{tabular} & \begin{tabular}{|c|} 
январь- \\
сентябрь \\
2020 2. \\
\end{tabular} & & & \begin{tabular}{|c|} 
сентябрь \\
2020 2.
\end{tabular} & \begin{tabular}{|c|} 
январь- \\
сентябрь \\
2020 2. \\
\end{tabular} \\
\hline деятельность водного транспорта & 15 & 91 & 5,2 & 30,6 & 37 & 255 & 12,8 & 85,7 \\
\hline $\begin{array}{l}\text { деятельность воздушного } \\
\text { и космического транспорта }\end{array}$ & 5 & 45 & 4,5 & 39,5 & 16 & 128 & 14,5 & 112,4 \\
\hline $\begin{array}{l}\text { складское хозяйство и } \\
\text { вспомогательная транспортная } \\
\text { деятельность }\end{array}$ & 355 & 3038 & 3,4 & 27,9 & 1292 & 9356 & 12,2 & 85,8 \\
\hline $\begin{array}{c}\text { деятельность почтовой связи } \\
\text { и курьерская деятельность }\end{array}$ & 44 & 409 & 11,4 & 104,0 & 75 & 528 & 19,4 & 134,3 \\
\hline $\begin{array}{l}\text { деятельность гостиниц и } \\
\text { предприятий общественного } \\
\text { питания }\end{array}$ & 575 & 4366 & 6,5 & 48,7 & 1274 & 8559 & 14,3 & 95,5 \\
\hline $\begin{array}{l}\text { в том числе: } \\
\text { деятельность по предоставлению } \\
\text { мест для временного проживания }\end{array}$ & 90 & 662 & 5,5 & 40,5 & 189 & 1300 & 11,6 & 79,6 \\
\hline $\begin{array}{l}\text { деятельность по предоставлению } \\
\text { продуктов питания и напитков }\end{array}$ & 485 & 3704 & 6,7 & 50,5 & 1085 & 7259 & 14,9 & 99,1 \\
\hline $\begin{array}{c}\text { деятельность в области } \\
\text { информации и связи }\end{array}$ & 691 & 5143 & 6,4 & 46,5 & 1434 & 10371 & 13,2 & 93,7 \\
\hline $\begin{array}{l}\text { из нее: } \\
\text { деятельность издательская }\end{array}$ & 22 & 211 & 1,6 & 14,6 & 202 & 1359 & 14,6 & 94,1 \\
\hline $\begin{array}{l}\text { деятельность в сфере } \\
\text { телекоммуникаций }\end{array}$ & 28 & 236 & 2,5 & 19,9 & 129 & 1083 & 11,3 & 91,4 \\
\hline $\begin{array}{l}\text { деятельность в области } \\
\text { информационных технологий }\end{array}$ & 186 & 1297 & 9,5 & 65,3 & 263 & 1791 & 13,4 & 90,1 \\
\hline $\begin{array}{l}\text { деятельность финансовая } \\
\text { и страховая }\end{array}$ & 273 & 2288 & 5,3 & 43,3 & 657 & 5338 & 12,8 & 101,0 \\
\hline $\begin{array}{c}\text { деятельность по операциям } \\
\text { с недвижимым имуществом }\end{array}$ & 881 & 7025 & 2,8 & 22,3 & 2300 & 15879 & 7,4 & 50,3 \\
\hline $\begin{array}{l}\text { деятельность профессиональная, } \\
\text { научная и техническая }\end{array}$ & 1811 & 14820 & 6,0 & 48,3 & 4213 & 30572 & 14,1 & 99,6 \\
\hline $\begin{array}{l}\text { из нее научные исследования } \\
\text { и разработки }\end{array}$ & 130 & 1051 & 4,5 & 35,3 & 339 & 2236 & 11,6 & 75,1 \\
\hline $\begin{array}{l}\text { деятельность административная } \\
\text { и сопутствующие } \\
\text { дополнительные услуги }\end{array}$ & 869 & 7353 & 6,1 & 49,9 & 2418 & 17306 & 16,9 & 117,4 \\
\hline $\begin{array}{l}\text { из нее деятельность } \\
\text { туристических агентств и прочих } \\
\text { организаций, предоставляющих } \\
\text { услуги в сфере туризма }\end{array}$ & 91 & 969 & 2,6 & 26,6 & 558 & 3859 & 15,8 & 105,8 \\
\hline $\begin{array}{l}\text { государственное управление } \\
\text { и обеспечение военной } \\
\text { безопасности; социальное } \\
\text { обеспечение }\end{array}$ & 49 & 603 & 0,7 & 8,7 & 160 & 2438 & 2,3 & 35,0 \\
\hline образование & 207 & 1375 & 1,7 & 11,3 & 383 & 3184 & 3,2 & 26,1 \\
\hline
\end{tabular}




\begin{tabular}{|c|c|c|c|c|c|c|c|c|}
\hline & \multicolumn{4}{|c|}{$\begin{array}{c}\text { Количество } \\
\text { зарегистрированных организаций }\end{array}$} & \multicolumn{4}{|c|}{$\begin{array}{c}\text { Количество официально } \\
\text { ликвидированньхх организачий }\end{array}$} \\
\hline & \multicolumn{2}{|c|}{ всего } & \multirow{2}{*}{\multicolumn{2}{|c|}{$\begin{array}{c}\text { на } 1000 \\
\text { организаций }\end{array}$}} & \multicolumn{2}{|c|}{ всего } & \multirow{2}{*}{\multicolumn{2}{|c|}{$\begin{array}{c}\text { на } 1000 \\
\text { организаций }\end{array}$}} \\
\hline & \multirow{2}{*}{$\begin{array}{c}\text { сентябрь } \\
2020 \text { г. }\end{array}$} & \multirow{2}{*}{$\begin{array}{c}\text { январь- } \\
\text { сентябрь } \\
2020 \text { 2. }\end{array}$} & & & \multirow{2}{*}{$\begin{array}{l}\text { сентябрь } \\
2020 \text { г. }\end{array}$} & \multirow{2}{*}{$\begin{array}{l}\text { январь- } \\
\text { сентябрь } \\
2020 \text { 2. }\end{array}$} & & \\
\hline & & & \begin{tabular}{|c|} 
сентябри \\
2020 г.
\end{tabular} & \begin{tabular}{|c|} 
январь- \\
сентябрь \\
2020 2. \\
\end{tabular} & & & \begin{tabular}{|c|} 
сентябрь \\
2020 2.
\end{tabular} & \begin{tabular}{|c|} 
январь- \\
сентябрь \\
2020 2. \\
\end{tabular} \\
\hline $\begin{array}{l}\text { деятельность в области } \\
\text { здравоохранения и } \\
\text { социальных услуг } \\
\end{array}$ & 385 & 2910 & 5,0 & 37,7 & 448 & 2912 & 5,8 & 37,7 \\
\hline $\begin{array}{l}\text { из нее деятельность в области } \\
\text { здравоохранения }\end{array}$ & 275 & 2048 & 4,7 & 34,9 & 352 & 2200 & 6,0 & 37,4 \\
\hline $\begin{array}{l}\text { деятельность в области } \\
\text { культуры, спорта, организации } \\
\text { досуга и развлечений }\end{array}$ & 365 & 2744 & 5,1 & 38,5 & 579 & 4221 & 8,2 & 59,2 \\
\hline
\end{tabular}

Таблица 2

ДЕМОГРАФИЯ ОРГАНИЗАЦИЙ ПО ФОРМАМ СОБСТВЕННОСТИ

единиц

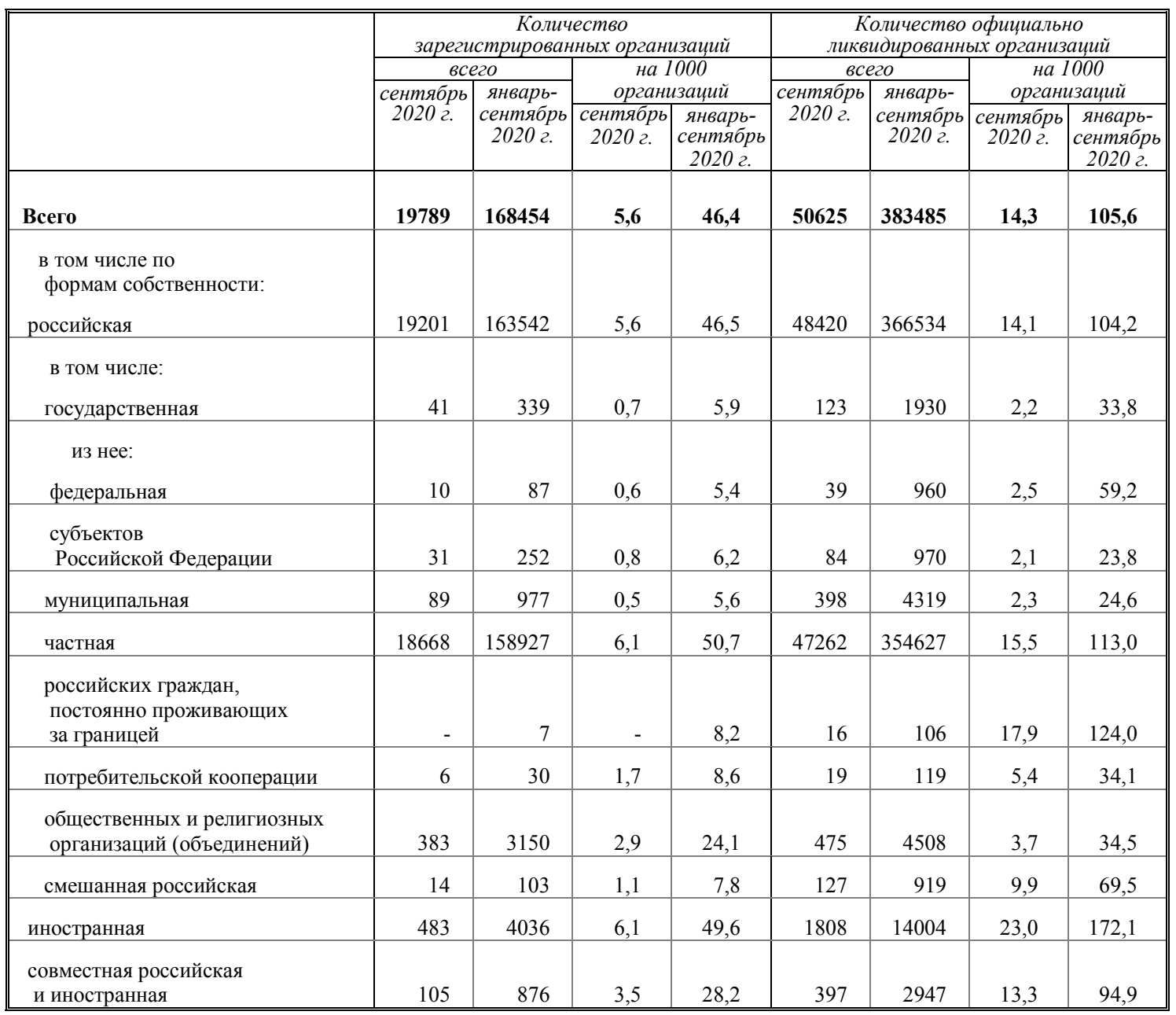




\section{4. ЦЕНЫ}

\section{ИНДЕКСЫ ЦЕН И ТАРИФОВ}

на конец периода, в процентах

\begin{tabular}{|c|c|c|c|c|c|c|c|}
\hline & \multicolumn{3}{|c|}{ К К предьдуцему месяиу } & \multicolumn{2}{|c|}{ Сентябрь 2020 г. к } & \multirow[b]{2}{*}{\begin{tabular}{|c|} 
Январь- \\
сентябрь \\
2020 г. \\
к январю- \\
сентябрю \\
2019 г. \\
\end{tabular}} & \multirow[b]{2}{*}{$\begin{array}{c}\text { Справочно } \\
\text { сентябрь } \\
2019 \text { г. } \\
\text { кдекабрю } \\
2018 \text { г. }\end{array}$} \\
\hline & июль & aвгycm & сентябрь & $\begin{array}{l}\text { декабрю } \\
2019 \text { г. }\end{array}$ & $\begin{array}{l}\text { сентябрю } \\
20192 .\end{array}$ & & \\
\hline Индекс потребительских цен & 100,4 & 100,0 & 99,9 & 102,9 & 103,7 & 103,0 & 102,3 \\
\hline $\begin{array}{l}\text { Индекс цен производителей } \\
\text { промышленных товаров } 1)\end{array}$ & 104,3 & 101,0 & 100,6 & 100,7 & 100,0 & 95,4 & 97,2 \\
\hline $\begin{array}{l}\text { Индекс цен производителей } \\
\text { сельскохозяйственной продукции }\end{array}$ & 101,0 & 100,5 & 100,5 & 102,6 & 102,7 & 97,9 & 95,7 \\
\hline $\begin{array}{l}\text { Сводный индекс цен } \\
\text { на продукцию (затраты, услуги) } \\
\text { инвестиционного назначения }\end{array}$ & 100,9 & 100,9 & 100,6 & 104,6 & 105,5 & 105,8 & 104,2 \\
\hline $\begin{array}{l}\text { Индекс тарифов на грузовые } \\
\text { перевозки }\end{array}$ & 99,7 & 100,0 & 100,1 & 103,5 & 98,5 & 101,4 & 106,0 \\
\hline
\end{tabular}

\section{Индексы цен и тарифов \\ в сентябре 2019 и 2020 годов}

на конец периода, в \% к декабрю предыдущего года

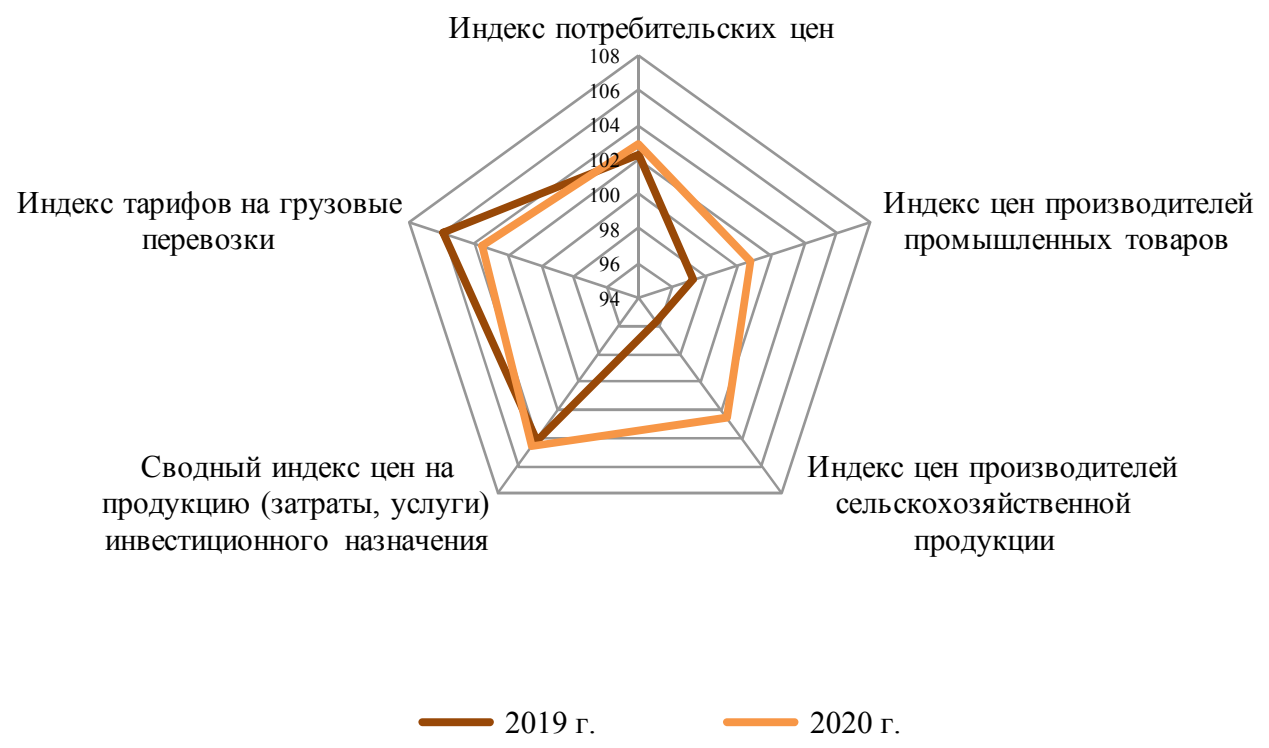




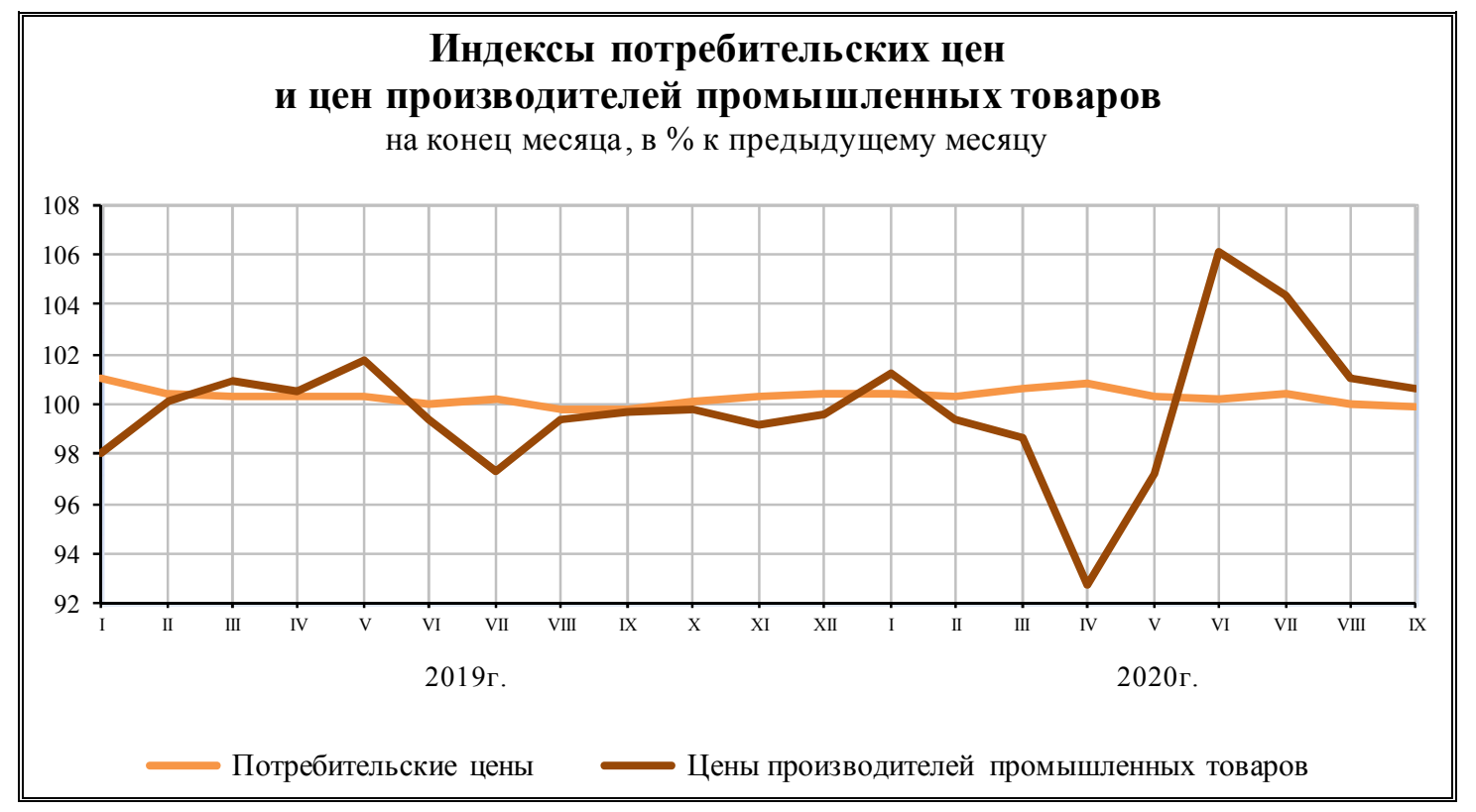

\section{1. ПОТРЕБИТЕЛЬСКИЕ ЦЕНЫ}

В сентябре 2020 г. по сравнению с предыдущим месяцем индекс потребительских цен составил 99,9\%, в том числе на продовольственные товары - 99,6\%, непродовольственные товары - 100,6\%, услуги - 99,6\%.

Таблица 1

\section{ИНДЕКСЫ ПОТРЕБИТЕЛЬСКИХ ЦЕН И ТАРИФОВ НА ТОВАРЫ И УСЛУГИ}

на конец периода, в процентах

\begin{tabular}{|c|c|c|c|c|c|c|c|c|}
\hline & \multicolumn{2}{|c|}{ Всего } & \multicolumn{6}{|c|}{ В том числе на } \\
\hline & \multirow{2}{*}{$\begin{array}{l}\text { к преды- } \\
\text { душему } \\
\text { периоду }\end{array}$} & \multirow{2}{*}{$\begin{array}{c}\text { к декабрю } \\
\text { предьду- } \\
\text { ццего года }\end{array}$} & \multicolumn{2}{|c|}{$\begin{array}{c}\text { продовольственнье } \\
\text { товарьи }\end{array}$} & \multicolumn{2}{|c|}{$\begin{array}{c}\text { непродовольственные } \\
\text { товары }\end{array}$} & \multicolumn{2}{|c|}{ услуги } \\
\hline & & & $\begin{array}{l}\text { киредь- } \\
\text { дущему } \\
\text { периоду }\end{array}$ & $\begin{array}{c}\text { к декабрю } \\
\text { предьлу- } \\
\text { щуего года }\end{array}$ & $\begin{array}{l}\text { к предь- - } \\
\text { дущему } \\
\text { периоду }\end{array}$ & $\begin{array}{c}\text { к декабрю } \\
\text { предьлуу- } \\
\text { uцего года }\end{array}$ & $\begin{array}{l}\text { к преды- } \\
\text { дущему } \\
\text { периоду }\end{array}$ & $\begin{array}{c}\text { к декабрю } \\
\text { предьлду- } \\
\text { щего года }\end{array}$ \\
\hline \multicolumn{9}{|c|}{2019 г. } \\
\hline Январь & 101,0 & 101,0 & 101,3 & 101,3 & 100,6 & 100,6 & 101,1 & 101,1 \\
\hline Февраль & 100,4 & 101,5 & 100,8 & 102,1 & 100,3 & 100,9 & 100,2 & 101,3 \\
\hline Март & 100,3 & 101,8 & 100,5 & 102,6 & 100,3 & 101,2 & 100,1 & 101,5 \\
\hline І квартал & 101,8 & 101,8 & 102,6 & 102,6 & 101,2 & 101,2 & 101,5 & 101,5 \\
\hline Апрель & 100,3 & 102,1 & 100,4 & 103,1 & 100,2 & 101,3 & 100,2 & 101,7 \\
\hline Май & 100,3 & 102,4 & 100,4 & 103,5 & 100,2 & 101,6 & 100,4 & 102,1 \\
\hline Июнь & 100,0 & 102,5 & 99,5 & 103,0 & 100,2 & 101,7 & 100,6 & 102,7 \\
\hline II квартал & 100,7 & 102,5 & 100,4 & 103,0 & 100,6 & 101,7 & 101,2 & 102,7 \\
\hline Июль & 100,2 & 102,7 & 99,7 & 102,7 & 100,2 & 101,9 & 100,9 & 103,6 \\
\hline
\end{tabular}




\begin{tabular}{|c|c|c|c|c|c|c|c|c|}
\hline & \multicolumn{2}{|c|}{ Всего } & \multicolumn{6}{|c|}{ В том числе на } \\
\hline & \multirow{2}{*}{$\begin{array}{l}\text { к преды- } \\
\text { дущему } \\
\text { периоду }\end{array}$} & \multirow{2}{*}{$\begin{array}{c}\text { к декабрю } \\
\text { предьду- } \\
\text { щего года }\end{array}$} & \multicolumn{2}{|c|}{$\begin{array}{c}\text { продовольственные } \\
\text { товары }\end{array}$} & \multicolumn{2}{|c|}{$\begin{array}{c}\text { непродовольственные } \\
\text { товары }\end{array}$} & \multicolumn{2}{|c|}{ услуги } \\
\hline & & & $\begin{array}{l}\text { к предь- } \\
\text { дущему } \\
\text { периоду }\end{array}$ & $\begin{array}{c}\text { к декабрю } \\
\text { предыцу- } \\
\text { щего года }\end{array}$ & $\begin{array}{l}\text { к преды- } \\
\text { дущему } \\
\text { периоду }\end{array}$ & $\begin{array}{c}\text { к декабрю } \\
\text { предыцу- } \\
\text { щего года }\end{array}$ & $\begin{array}{l}\text { к преды- } \\
\text { дущему } \\
\text { периоду }\end{array}$ & $\begin{array}{c}\text { к декабрю } \\
\text { предыцу- } \\
\text { щего года }\end{array}$ \\
\hline Август & 99,8 & 102,4 & 99,1 & 101,7 & 100,2 & 102,1 & 100,2 & 103,8 \\
\hline Сентябрь & 99,8 & 102,3 & 99,6 & 101,3 & 100,2 & 102,3 & 99,8 & 103,6 \\
\hline ІІІ квартал & 99,8 & 102,3 & 98,4 & 101,3 & 100,5 & 102,3 & 100,9 & 103,6 \\
\hline Октябрь & 100,1 & 102,4 & 100,2 & 101,5 & 100,3 & 102,6 & 99,8 & 103,4 \\
\hline Ноябрь & 100,3 & 102,7 & 100,5 & 101,9 & 100,2 & 102,8 & 100,1 & 103,5 \\
\hline Декабрь & 100,4 & 103,0 & 100,7 & 102,6 & 100,1 & 103,0 & 100,2 & 103,8 \\
\hline IV квартал & 100,8 & 103,0 & 101,3 & 102,6 & 100,7 & 103,0 & 100,2 & 103,8 \\
\hline \multicolumn{9}{|c|}{2020 г. } \\
\hline Январь & 100,4 & 100,4 & 100,7 & 100,7 & 100,2 & 100,2 & 100,2 & 100,2 \\
\hline Февраль & 100,3 & 100,7 & 100,6 & 101,3 & 100,0 & 100,3 & 100,4 & 100,6 \\
\hline Март & 100,6 & 101,3 & 101,0 & 102,2 & 100,5 & 100,8 & 100,1 & 100,7 \\
\hline І квартал & 101,3 & 101,3 & 102,2 & 102,2 & 100,8 & 100,8 & 100,7 & 100,7 \\
\hline Апрель & 100,8 & 102,1 & 101,7 & 104,0 & 100,4 & 101,2 & 100,1 & 100,8 \\
\hline Май & 100,3 & 102,4 & 100,2 & 104,2 & 100,3 & 101,4 & 100,5 & 101,3 \\
\hline Июнь & 100,2 & 102,6 & 100,2 & 104,3 & 100,3 & 101,8 & 100,1 & 101,4 \\
\hline ІІ квартал & 101,3 & 102,6 & 102,1 & 104,3 & 101,0 & 101,8 & 100,7 & 101,4 \\
\hline Июль & 100,4 & 103,0 & 99,9 & 104,3 & 100,3 & 102,1 & 101,0 & 102,4 \\
\hline Август & 100,0 & 103,0 & 99,2 & 103,5 & 100,4 & 102,5 & 100,4 & 102,8 \\
\hline Сентябрь & 99,9 & 102,9 & 99,6 & 103,1 & 100,6 & 103,1 & 99,6 & 102,4 \\
\hline ІІІ квартал & 100,2 & 102,9 & 98,8 & 103,1 & 101,3 & 103,1 & 100,9 & 102,4 \\
\hline
\end{tabular}

Базовый индекс потребительских цен (БИПЦ), исключающий изменения цен, вызванные сезонными и административными факторами, в сентябре 2020 г. составил 100,3\%, с начала года - 102,7\% (в сентябре 2019 г. - 100,2\%, с начала года - 102,6\%).

В сентябре 2020 г. цены на продовольственные товары снизились на $0,4 \%$ (в сентябре 2019 г. - на $0,4 \%)$.

Таблица 2

\section{ИНДЕКСЫ ЦЕН НА ОТДЕЛЬНЫЕ ГРУППЫ И ВИДЫ} ПРОДОВОЛЬСТВЕННЫХ ТОВАРОВ

на конец периода, в процентах

\begin{tabular}{|c|c|c|c|c|c|c|c|}
\hline & \multicolumn{3}{|c|}{ К киредыдущему месяиу } & \multicolumn{2}{|c|}{ Сентябрь 2020 г. к } & \multirow[b]{2}{*}{$\begin{array}{c}\text { Январь- } \\
\text { сентябрь } \\
2020 \text { 2. } \\
\text { к январю- } \\
\text { сентябрю } \\
20192 . \\
\end{array}$} & \multirow[b]{2}{*}{$\begin{array}{c}\text { Справочно } \\
\text { сентябрь } \\
2019 \text { 2. } \\
\text { кдекабрю } \\
2018 \text { 2. }\end{array}$} \\
\hline & июль & aвzусm & сентябрь & $\begin{array}{c}\text { декабрю } \\
2019 \text { г. }\end{array}$ & $\begin{array}{c}\text { сентябрю } \\
20192 .\end{array}$ & & \\
\hline Продукты питания & 99,9 & 99,1 & 99,5 & 103,1 & 104,6 & 103,5 & 101,3 \\
\hline из них: & & & & & & & \\
\hline хлеб и хлебобулочные изделия & 100,5 & 100,5 & 100,5 & 104,6 & 105,5 & 105,0 & 105,5 \\
\hline
\end{tabular}




\begin{tabular}{|c|c|c|c|c|c|c|c|}
\hline & \multicolumn{3}{|c|}{ К кредыдущему месяиу } & \multicolumn{2}{|c|}{ Сентябрь 2020 г. к } & \multirow[b]{2}{*}{$\begin{array}{c}\text { Январь- } \\
\text { сентябрь } \\
2020 \text { г. } \\
\text { к январю- } \\
\text { сентябрю } \\
20192 .\end{array}$} & \multirow[b]{2}{*}{$\begin{array}{c}\text { Справочно } \\
\text { сентябрь } \\
2019 \text { г. } \\
\text { к декабрю } \\
2018 \text { г. }\end{array}$} \\
\hline & июль & авгусm & сентябрь & $\begin{array}{c}\text { декабрю } \\
2019 \text { г. }\end{array}$ & $\begin{array}{c}\text { сентяльрю } \\
2019 \text { г. }\end{array}$ & & \\
\hline крупа и бобовые & 100,3 & 99,9 & 99,6 & 117,2 & 122,9 & 120,4 & 109,9 \\
\hline макаронные изделия & 100,4 & 100,2 & 100,3 & 109,0 & 109,5 & 107,5 & 105,2 \\
\hline мясо и птица & 100,6 & 100,5 & 99,7 & 101,3 & 100,5 & 100,2 & 100,9 \\
\hline рыба и морепродукты пищевые & 100,1 & 100,1 & 100,5 & 102,5 & 103,5 & 104,0 & 104,2 \\
\hline молоко и молочная продукция & 99,9 & 100,1 & 100,0 & 102,1 & 103,9 & 105,3 & 104,3 \\
\hline масло сливочное & 100,1 & 100,3 & 100,2 & 102,7 & 105,9 & 108,1 & 106,7 \\
\hline масло подсолнечное & 100,5 & 100,3 & 102,6 & 107,2 & 106,6 & 101,0 & 97,6 \\
\hline яйца куриные & 100,2 & 99,0 & 101,0 & 89,3 & 100,8 & 100,1 & 84,2 \\
\hline сахар-песок & 102,2 & 102,8 & 107,8 & 133,1 & 112,1 & 85,1 & 82,2 \\
\hline плодоовощная продукция & 97,5 & 91,7 & 93,8 & 102,5 & 109,8 & 103,4 & 91,4 \\
\hline Алкогольные напитки & 100,1 & 100,1 & 100,1 & 102,6 & 102,6 & 102,1 & 101,2 \\
\hline
\end{tabular}

Цены на непродовольственные товары в сентябре 2020 г. выросли на 0,6\% (в сентябре 2019 г. - на 0,2\%).

Таблица 3

\section{ИНДЕКСЫ ЦЕН НА ОТДЕЛЬНЫЕ ГРУППЫ НЕПРОДОВОЛЬСТВЕННЫХ ТОВАРОВ}

на конец периода, в процентах

\begin{tabular}{|c|c|c|c|c|c|c|c|}
\hline & \multicolumn{3}{|c|}{ К предыдущему месяиу } & \multicolumn{2}{|c|}{ Сентябрь 2020 г.к } & \multirow{2}{*}{$\begin{array}{c}\text { Январь- } \\
\text { сентябрь } \\
2020 \text { г. } \\
\text { к январю- } \\
\text { сентябрю } \\
2019 \text { г. }\end{array}$} & \multirow{2}{*}{$\begin{array}{c}\text { Справочно } \\
\text { сентябрь } \\
2019 \text { г. } \\
\text { к декабрю } \\
2018 \text { г. }\end{array}$} \\
\hline & июль & aвгусm & сентябрь & $\begin{array}{c}\text { декабрю } \\
2019 \text { г. }\end{array}$ & \begin{tabular}{|c|} 
сентяябрю \\
2019 г.
\end{tabular} & & \\
\hline Ткани & 100,2 & 100,2 & 100,2 & 101,2 & 101,6 & 101,3 & 101,0 \\
\hline Одежда и белье & 100,1 & 100,3 & 100,5 & 100,9 & 101,8 & 101,8 & 101,4 \\
\hline Трикотажные изделия & 100,1 & 100,3 & 100,5 & 101,0 & 101,9 & 101,9 & 101,4 \\
\hline Обувь & 99,8 & 100,3 & 100,5 & 100,5 & 101,0 & 101,0 & 100,7 \\
\hline Моющие и чистящие средства & 100,3 & 100,1 & 100,3 & 104,0 & 105,4 & 104,8 & 103,5 \\
\hline Табачные изделия & 100,5 & 100,6 & 100,6 & 106,1 & 109,3 & 110,4 & 107,8 \\
\hline $\begin{array}{l}\text { Электротовары и другие } \\
\text { бытовые приборы }\end{array}$ & 100,2 & 100,4 & 100,5 & 104,4 & 103,9 & 102,1 & 100,9 \\
\hline Телерадиотовары & 100,3 & 100,1 & 100,2 & 99,8 & 98,1 & 95,9 & 95,9 \\
\hline Строительные материалы & 100,2 & 100,4 & 100,5 & 102,9 & 103,0 & 102,3 & 102,5 \\
\hline Бензин автомобильный & 100,9 & 100,3 & 100,1 & 102,2 & 102,4 & 101,8 & 101,7 \\
\hline Медикаменты & 100,0 & 100,3 & 100,8 & 106,9 & 108,8 & 108,2 & 105,0 \\
\hline
\end{tabular}



на $0,2 \%)$.

Цены и тарифы на услуги в сентябре 2020 г. снизились на 0,4\% (в сентябре 2019 г. -

Таблица 4

ИНДЕКСЫ ЦЕН И ТАРИФОВ

НА ОТДЕЛЬНЫЕ ГРУППЫ И ВИДЫ УСЛУГ

на конец периода, в процентах

\begin{tabular}{|c|c|c|c|c|c|c|c|}
\hline & \multicolumn{3}{|c|}{ К предьгдущему месячу } & \multicolumn{2}{|c|}{ Сентябрь 2020 г. к } & \multirow[b]{2}{*}{$\begin{array}{l}\text { Январь- } \\
\text { сентябрь } \\
2020 \text { г. } \\
\text { кянварю- } \\
\text { сентябрю } \\
2019 \text { г. }\end{array}$} & \multirow{2}{*}{$\begin{array}{l}\text { Справочно } \\
\text { сентябрь } \\
2019 \text { г. } \\
\text { кекабрю } \\
2018 \text { г. }\end{array}$} \\
\hline & июль & aвzycm & сентябрь & $\begin{array}{l}\text { декабрю } \\
2019 \text { г. }\end{array}$ & $\begin{array}{l}\text { сентябрю } \\
20192 .\end{array}$ & & \\
\hline Жилищно-коммунальные услуги & 102,1 & 100,3 & 100,1 & 103,3 & 103,3 & 102,9 & 104,4 \\
\hline жилищные услуги & 100,4 & 100,1 & 100,1 & 103,0 & 103,0 & 103,3 & 103,1 \\
\hline $\begin{array}{l}\text { из них: } \\
\text { оплата жилья в домах государ- } \\
\text { ственного и муниципального } \\
\text { жилищных фондов }\end{array}$ & 100,4 & 100,1 & 100,0 & 102,6 & 102,7 & 102,8 & 104,1 \\
\hline $\begin{array}{l}\text { содержание и ремонт жилья для } \\
\text { граждан-собственников жилья }\end{array}$ & 100,6 & 100,2 & 100,1 & 102,3 & 102,5 & 102,7 & 103,0 \\
\hline $\begin{array}{l}\text { услуги по организации и выпол- } \\
\text { нению работ по эксплуатации } \\
\text { домов ЖК, ЖСК, ТСЖ }\end{array}$ & 100,7 & 100,2 & 100,0 & 101,5 & 101,7 & 101,8 & 103,3 \\
\hline коммунальные услуги & 103,1 & 100,3 & 100,1 & 103,5 & 103,5 & 102,7 & 105,1 \\
\hline $\begin{array}{l}\text { из них: } \\
\text { водоснабжение холодное }\end{array}$ & 103,5 & 100,0 & 100,4 & 103,8 & 103,9 & 103,5 & 104,9 \\
\hline водоотведение & 104,4 & 100,0 & 100,3 & 104,7 & 104,8 & 104,4 & 105,9 \\
\hline водоснабжение горячее & 103,2 & 100,1 & 100,1 & 103,3 & 103,1 & 102,4 & 104,4 \\
\hline отопление & 103,3 & 100,0 & 100,1 & 103,3 & 103,4 & 102,6 & 103,9 \\
\hline газоснабжение & 100,4 & 102,5 & 100,0 & 103,0 & 103,0 & 102,0 & 103,7 \\
\hline электроснабжение & 104,0 & 100,0 & 100,0 & 103,9 & 103,9 & 103,0 & 104,2 \\
\hline Медицинские услуги & 100,2 & 100,4 & 100,4 & 103,5 & 104,1 & 104,0 & 103,2 \\
\hline Услуги пассажирского транспорта & 100,5 & 102,2 & 95,4 & 100,7 & 100,5 & 102,7 & 106,4 \\
\hline Услуги связи & 100,2 & 99,8 & 99,4 & 103,6 & 105,1 & 105,4 & 102,6 \\
\hline Услуги организаций культуры & 100,1 & 100,2 & 100,1 & 101,0 & 102,9 & 103,7 & 102,4 \\
\hline Санаторно-оздоровительные услуги & 108,4 & 99,9 & 93,0 & 105,2 & 102,9 & 102,9 & 105,3 \\
\hline Услуги дошкольного воспитания & 100,0 & 100,1 & 100,6 & 101,8 & 102,3 & 103,0 & 103,3 \\
\hline Услуги образования & 100,1 & 100,1 & 101,3 & 101,5 & 102,1 & 104,8 & 105,0 \\
\hline Бытовые услуги & 100,4 & 100,3 & 100,3 & 102,4 & 103,1 & 102,7 & 102,4 \\
\hline Услуги зарубежного туризма & 100,0 & 100,0 & 100,0 & 99,5 & 99,0 & 99,2 & 100,8 \\
\hline Услуги физкультуры и спорта & 100,2 & 100,1 & 100,6 & 101,4 & 101,6 & 101,9 & 102,6 \\
\hline Услуги страхования & 100,4 & 100,1 & 100,2 & 100,8 & 100,9 & 100,3 & 99,4 \\
\hline
\end{tabular}


Росстат наряду с традиционной классификацией публикует индекс потребительских цен в группировке классификатора индивидуального потребления по целям (международный классификатор СОІСОР), которая является одной из четырех функциональных классификаций СНС и используется при разработке показателей индивидуального потребления в составе ВВП. Формирование ИПЦ в группировке КИПЦ обеспечивает сопоставление динамики цен на товары и услуги, исходя из направления их использования.

Таблица 5

\section{ИНДЕКСЫ ПОТРЕБИТЕЛЬСКИХ ЦЕН В ГРУППИРОВКЕ КЛАССИФИКАТОРА ИНДИВИДУАЛЬНОГО ПОТРЕБЛЕНИЯ ПО ЦЕЛЯМ (КИПЦ)}

на конец периода, в процентах

\begin{tabular}{|c|c|c|c|c|c|c|c|}
\hline & \multicolumn{3}{|c|}{ "К предьлдущему месяиу } & \multicolumn{2}{|c|}{ Сентябрь 2020 г. к } & \multirow[b]{2}{*}{\begin{tabular}{|c|} 
Январь- \\
сентябрь \\
2020 г. \\
к январю- \\
сентябрю \\
2019 г. \\
\end{tabular}} & \multirow{2}{*}{$\begin{array}{c}\text { Справочно } \\
\text { сентябрь } \\
2019 \text { г. } \\
\text { к декабрю } \\
2018 \text { г. }\end{array}$} \\
\hline & июль & aвгусm & сентябрь & $\begin{array}{l}\text { декабрю } \\
2019 \text { г. }\end{array}$ & $\begin{array}{l}\text { сентябрю } \\
2019 \text { 2. }\end{array}$ & & \\
\hline Все товары и услуги & 100,4 & 100,0 & 99,9 & 102,9 & 103,7 & 103,0 & 102,3 \\
\hline $\begin{array}{l}\text { Продукты питания и } \\
\text { безалкогольные напитки }\end{array}$ & 99,9 & 99,0 & $\mathbf{9 9 , 5}$ & 103,3 & 104,9 & 103,6 & 101,2 \\
\hline продукты питания & 99,9 & 98,9 & 99,4 & 103,3 & 104,9 & 103,6 & 101,1 \\
\hline безалкогольные напитки & 100,3 & 100,2 & 100,4 & 103,8 & 104,6 & 103,5 & 102,7 \\
\hline $\begin{array}{l}\text { Алкогольные напитки, } \\
\text { табачные изделия }\end{array}$ & 100,2 & 100,2 & 100,2 & 103,5 & 104,2 & 103,9 & 102,6 \\
\hline алкогольные напитки & 100,1 & 100,1 & 100,1 & 102,6 & 102,6 & 102,1 & 101,2 \\
\hline табачные изделия & 100,5 & 100,6 & 100,6 & 106,1 & 109,3 & 110,4 & 107,8 \\
\hline Одежда и обувь & 100,0 & 100,3 & 100,5 & 100,8 & 101,6 & 101,5 & 101,2 \\
\hline одежда & 100,1 & 100,3 & 100,5 & 100,9 & 101,8 & 101,7 & 101,3 \\
\hline обувь & 99,9 & 100,3 & 100,5 & 100,6 & 101,1 & 101,1 & 100,8 \\
\hline $\begin{array}{l}\text { Жилищные услуги, вода, } \\
\text { электроэнергия, газ } \\
\text { и другие виды топлива }\end{array}$ & 101,9 & 100,3 & 100,2 & 103,2 & 103,3 & 102,8 & 104,1 \\
\hline фактическая арендная плата за жилье & 100,0 & 100,2 & 100,3 & 100,4 & 100,5 & 100,8 & 101,3 \\
\hline $\begin{array}{l}\text { текущее содержание и ремонт } \\
\text { жилого помещения }\end{array}$ & 100,3 & 100,4 & 100,6 & 102,9 & 103,1 & 102,3 & 102,2 \\
\hline $\begin{array}{l}\text { водоснабжение и другие } \\
\text { коммунальные услуги }\end{array}$ & 101,4 & 100,1 & 100,1 & 103,8 & 103,8 & 103,8 & 105,5 \\
\hline $\begin{array}{l}\text { электроэнергия, газ } \\
\text { и другие виды топлива }\end{array}$ & 103,0 & 100,4 & 100,1 & 103,4 & 103,4 & 102,5 & 104,0 \\
\hline $\begin{array}{l}\text { Предметы домашнего обихода, } \\
\text { бытовая техника } \\
\text { и повседневный уход за домом }\end{array}$ & 100,2 & 100,3 & 100,4 & 103,1 & 103,5 & 102,7 & 102,2 \\
\hline $\begin{array}{l}\text { мебель, предметы домашнего обихода, } \\
\text { художественного оформления, } \\
\text { ковры, другие покрытия } \\
\text { для пола и их ремонт }\end{array}$ & 100,2 & 100,4 & 100,6 & 102,2 & 102,7 & 102,1 & 102,5 \\
\hline текстильные изделия для дома & 100,2 & 100,3 & 100,2 & 102,1 & 102,9 & 102,7 & 102,2 \\
\hline бытовые приборы, включая ремонт & 100,2 & 100,4 & 100,5 & 104,6 & 103,8 & 102,0 & 100,9 \\
\hline $\begin{array}{c}\text { стеклянные изделия, столовая } \\
\text { посуда и домашняя утварь }\end{array}$ & 100,5 & 100,5 & 100,3 & 103,3 & 104,1 & 103,5 & 102,8 \\
\hline
\end{tabular}




\begin{tabular}{|c|c|c|c|c|c|c|c|}
\hline & \multicolumn{3}{|c|}{ К предьдущему месяиу } & \multicolumn{2}{|c|}{ Сентябрь 2020 г. к } & \multirow[b]{2}{*}{$\begin{array}{c}\text { Январь- } \\
\text { сентябрь } \\
2020 \text { 2. } \\
\text { к январю- } \\
\text { сентябрю } \\
2019 \text { 2. } \\
\end{array}$} & \multirow{2}{*}{$\begin{array}{c}\text { Справочно } \\
\text { сентябрь } \\
2019 \text { г. } \\
\text { к декабрю } \\
2018 \text { 2. }\end{array}$} \\
\hline & июль & авгусm & сентябрь & $\begin{array}{l}\text { декабрю } \\
2019 \text { г. }\end{array}$ & $\begin{array}{c}\text { сентябрю } \\
20192 .\end{array}$ & & \\
\hline $\begin{array}{l}\text { инструменты и оборудование } \\
\text { для дома и сада }\end{array}$ & 100,0 & 100,2 & 100,2 & 103,6 & 103,6 & 102,1 & 101,5 \\
\hline $\begin{array}{l}\text { товары и услуги для } \\
\text { повседневного ухода за жильем }\end{array}$ & 100,3 & 100,2 & 100,2 & 103,5 & 104,9 & 104,3 & 103,1 \\
\hline Здравоохранение & 100,5 & 100,3 & 100,5 & 105,7 & 106,8 & 106,1 & 104,4 \\
\hline $\begin{array}{l}\text { медикаменты, лечебное } \\
\text { оборудование и аппаратура }\end{array}$ & 100,1 & 100,4 & 100,9 & 107,1 & 108,9 & 108,0 & 104,9 \\
\hline амбулаторные услуги & 100,2 & 100,4 & 100,4 & 103,7 & 104,3 & 104,1 & 103,2 \\
\hline услуги больниц & 104,7 & 100,0 & 97,4 & 104,1 & 101,2 & 101,2 & 105,7 \\
\hline Транспорт & 100,5 & 100,7 & 99,7 & 102,8 & 103,1 & 102,6 & 103,0 \\
\hline покупка транспортных средств & 100,3 & 100,6 & 100,9 & 104,5 & 105,1 & 103,3 & 103,0 \\
\hline $\begin{array}{c}\text { эксплуатация личных } \\
\text { транспортных средств }\end{array}$ & 100,7 & 100,2 & 100,2 & 101,9 & 102,3 & 101,8 & 101,7 \\
\hline транспортные услуги & 100,5 & 102,2 & 95,4 & 100,7 & 100,5 & 102,7 & 106,4 \\
\hline Связь & 100,2 & 99,7 & 99,5 & 103,1 & 103,6 & 103,2 & 101,2 \\
\hline почтовые услуги & 100,0 & 100,0 & 100,0 & 100,1 & 104,8 & 105,4 & 103,4 \\
\hline $\begin{array}{l}\text { телефонное и факсимильное } \\
\text { оборудование }\end{array}$ & 100,3 & 99,9 & 100,5 & 99,8 & 98,4 & 96,1 & 96,1 \\
\hline $\begin{array}{l}\text { услуги телефонной } \\
\text { и документальной связи }\end{array}$ & 100,2 & 99,7 & 99,2 & 104,0 & 104,8 & 104,9 & 102,3 \\
\hline $\begin{array}{l}\text { Организация отдыха и } \\
\text { культурные мероприятия }\end{array}$ & 100,5 & 100,2 & 99,8 & 101,6 & 102,1 & 101,9 & 101,9 \\
\hline $\begin{array}{l}\text { аудиовизуальное, фотографическое } \\
\text { оборудование и оборудование } \\
\text { для обработки информации }\end{array}$ & 100,0 & 100,2 & 100,5 & 101,9 & 101,1 & 99,1 & 98,3 \\
\hline $\begin{array}{l}\text { другие товары и оборудование } \\
\text { для отдыха, сада } \\
\text { и домашние животные }\end{array}$ & 100,3 & 100,3 & 100,2 & 103,5 & 104,3 & 103,6 & 102,8 \\
\hline $\begin{array}{l}\text { услуги по организации отдыха и } \\
\text { культурных мероприятий }\end{array}$ & 100,2 & 100,2 & 100,4 & 101,5 & 103,5 & 104,2 & 103,2 \\
\hline $\begin{array}{l}\text { газеты, книги, канцелярские } \\
\text { принадлежности }\end{array}$ & 100,5 & 100,8 & 100,4 & 103,4 & 104,0 & 103,7 & 104,4 \\
\hline организация комплексного отдыха & 101,0 & 100,1 & 98,9 & 100,4 & 100,0 & 100,2 & 101,5 \\
\hline Образование & 100,0 & 100,0 & 101,5 & 101,7 & 102,5 & 105,6 & 105,3 \\
\hline $\begin{array}{l}\text { основное общее и среднее } \\
\text { (полное) общее образование }\end{array}$ & 100,0 & 100,0 & 101,9 & 102,1 & 104,3 & 104,7 & 102,5 \\
\hline среднее профессиональное образование & 100,0 & 100,0 & 103,3 & 103,3 & 103,3 & 105,9 & 106,2 \\
\hline высшее профессиональное образование & 100,0 & 100,0 & 101,1 & 101,1 & 101,1 & 106,7 & 107,5 \\
\hline образование, не определенное по уровню & 100,1 & 100,2 & 100,9 & 101,6 & 102,0 & 103,1 & 103,3 \\
\hline Гостиницы, кафе и рестораны & 100,3 & 100,4 & 100,1 & 101,5 & 101,8 & 102,2 & 102,7 \\
\hline общественное питание & 100,1 & 100,3 & 100,2 & 101,3 & 101,8 & 102,2 & 102,7 \\
\hline гостиничные услуги & 102,2 & 101,8 & 98,9 & 103,4 & 102,2 & 101,5 & 103,4 \\
\hline Другие товары и услуги & 100,1 & 100,6 & 100,6 & 102,9 & 103,2 & 102,4 & 102,6 \\
\hline личные услуги & 100,4 & 100,3 & 100,4 & 103,2 & 104,1 & 103,5 & 103,4 \\
\hline $\begin{array}{l}\text { предметы личного обихода, } \\
\text { не отнесенные к другим категориям }\end{array}$ & 100,7 & 102,5 & 102,0 & 108,1 & 109,0 & 105,0 & 103,0 \\
\hline социальная защита & 100,0 & 100,1 & 100,4 & 101,9 & 101,9 & 102,7 & 103,6 \\
\hline страхование & 100,4 & 100,1 & 100,2 & 100,8 & 100,9 & 100,3 & 99,4 \\
\hline
\end{tabular}




\begin{tabular}{|c|c|c|c|c|c|c|c|}
\hline & \multicolumn{3}{|c|}{ К кредыдущему месяиу } & \multicolumn{2}{|c|}{ Сентябрь 2020 г. к } & \multirow[b]{2}{*}{\begin{tabular}{|c|} 
Январь- \\
сентябрь \\
2020 г. \\
кянарю- \\
сентябрю \\
20192. \\
\end{tabular}} & \multirow[b]{2}{*}{\begin{tabular}{|c|} 
Справочно \\
сентябрь \\
2019 г. \\
кдекабрю \\
2018 г.
\end{tabular}} \\
\hline & июль & август & сентябрь & $\begin{array}{c}\text { декабрю } \\
2019 \text { г. }\end{array}$ & $\begin{array}{c}\text { сентяббрю } \\
2019 \text { г. }\end{array}$ & & \\
\hline финансовые услуги & 97,0 & 100,3 & 100,0 & 97,6 & 94,6 & 96,3 & 101,8 \\
\hline $\begin{array}{c}\text { другие услуги, не отнесенные } \\
\text { к перечисленным категориям }\end{array}$ & 100,2 & 100,1 & 100,1 & 102,3 & 103,9 & 103,6 & 102,3 \\
\hline
\end{tabular}

Стоимость фиксированного набора потребительских товаров и услуг для межрегиональных сопоставлений покупательной способности населения в расчете на месяц в среднем по России в конце сентября 2020 г. составила 16767,8 рубля. За месяц его стоимость снизилась на $0,2 \%$ (с начала года - выросла на $3,4 \%$ ).

\section{СТОИМОСТЬ ФИКСИРОВАННОГО НАБОРА \\ ПОТРЕБИТЕЛЬСКИХ ТОВАРОВ И УСЛУГ в сентябре 2020 года}

\begin{tabular}{|c|c|c|c|c|}
\hline \multirow[t]{2}{*}{ "Федеральные округа } & \multirow{2}{*}{$\begin{array}{c}\text { Стоимость } \\
\text { набора, } \\
\text { рублей }\end{array}$} & \multirow{2}{*}{$\begin{array}{c}\text { Изменение } \\
\text { стоимости } \\
\text { набора к предь- } \\
\text { дущему месяиу, } \\
\% \\
\end{array}$} & \multicolumn{2}{|c|}{$\begin{array}{c}\text { Максимальная и минимальная } \\
\text { стоимость набора внутри федерального округа }\end{array}$} \\
\hline & & & $\begin{array}{c}\text { субъект } \\
\text { Российской Федераиии }\end{array}$ & $\begin{array}{c}\text { стоимость } \\
\text { набора, } \\
\text { рублей }\end{array}$ \\
\hline Центральный & 19521,4 & 99,8 & $\begin{array}{l}\text { г. Москва } \\
\text { Орловская область }\end{array}$ & $\begin{array}{l}23693,8 \\
14344,5\end{array}$ \\
\hline Северо-Западный & 17606,7 & 99,5 & $\begin{array}{l}\text { Мурманская область } \\
\text { Новгородская область }\end{array}$ & $\begin{array}{l}19600,7 \\
15206,4\end{array}$ \\
\hline Южный & 15637,1 & 100,0 & $\begin{array}{l}\text { Краснодарский край } \\
\text { Астраханская область }\end{array}$ & $\begin{array}{l}17117,5 \\
14779,5\end{array}$ \\
\hline Северо-Кавказский & 15527,7 & 100,2 & $\begin{array}{l}\text { Ставропольский край } \\
\text { Республика Ингушетия }\end{array}$ & $\begin{array}{l}16476,4 \\
13857,0\end{array}$ \\
\hline Приволжский & 14926,4 & 99,8 & $\begin{array}{l}\text { Нижегородская область } \\
\text { Саратовская область }\end{array}$ & $\begin{array}{l}16000,0 \\
13874,0\end{array}$ \\
\hline Уральский & 15813,2 & 99,6 & $\begin{array}{l}\text { Тюменская область } \\
\text { Челябинская область }\end{array}$ & $\begin{array}{l}17951,7 \\
14243,4\end{array}$ \\
\hline Сибирский & 15455,7 & 99,8 & $\begin{array}{l}\text { Республика Алтай } \\
\text { Кемеровская область }\end{array}$ & $\begin{array}{l}16949,7 \\
14412,8\end{array}$ \\
\hline Дальневосточный & 19143,2 & 99,9 & $\begin{array}{l}\text { Чукотский авт. округ } \\
\text { Забайкальский край }\end{array}$ & $\begin{array}{l}28260,7 \\
16063,9\end{array}$ \\
\hline
\end{tabular}

Стоимость фиксированного набора в Москве в конце сентября 2020 г. составила 23693,8 рубля и за месяц снизилась на $0,3 \%$ (с начала года - увеличилась на $2,8 \%$ ), в Санкт-Петербурге 18189,8 рубля и за месяц снизилась на $0,6 \%$ (с начала года - увеличилась на $3,1 \%$ ).

В III квартале 2020 г. по сравнению с предыдущим кварталом индексы цен на первичном и вторичном рынках жилья, по предварительным данным, составили соответственно 103,7\% и $103,2 \%$.

На первичном рынке жилья цены выросли от 103,1\% на квартиры улучшенного качества до $107,7 \%$ на элитные квартиры.

На вторичном рынке повышение цен составило от 102,3\% на элитные квартиры до 103,5\% на квартиры среднего качества. 


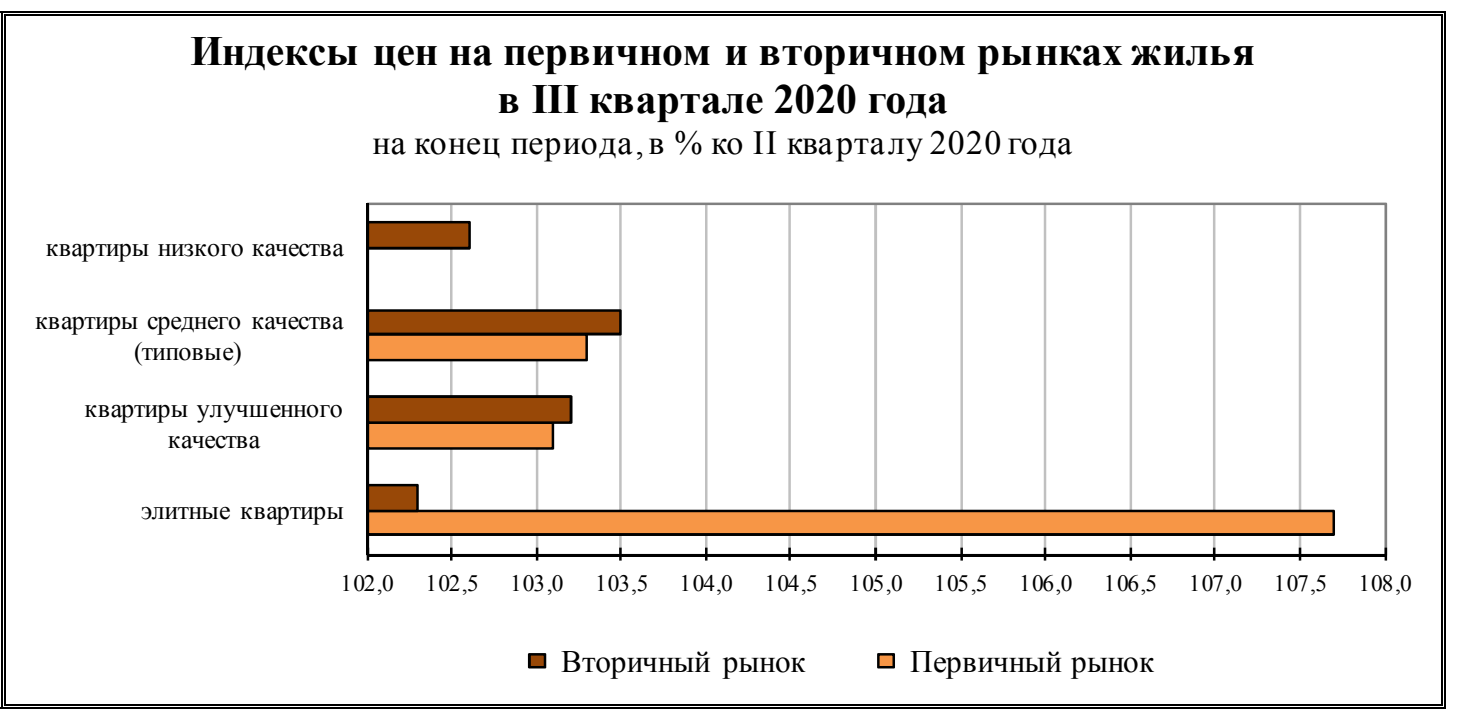

Таблица 7

ИНДЕКСЫ ЦЕН НА РЫНКЕ ЖИЛЬЯ

на конец периода

\begin{tabular}{|c|c|c|c|c|c|c|c|c|}
\hline & \multicolumn{4}{|c|}{ ППервичный рынок } & \multicolumn{4}{|c|}{ Вторичный рынок } \\
\hline & $\begin{array}{r}\text { III кварт } \\
\text { в } \%\end{array}$ & $\begin{array}{l}\text { ал } 2020 z . \\
\text { о к }\end{array}$ & III $\frac{c n p a}{\kappa в a p m}$ & 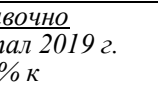 & $\begin{array}{r}\text { III кварт } \\
6 \%\end{array}$ & $\begin{array}{l}\text { aл } 2020 \text { г. } \\
\text { \% к }\end{array}$ & III $\frac{\text { cnpat }}{\mathrm{sapm}}$ & $\begin{array}{l}\frac{\text { авочно }}{\text { пал } 20192 .} \\
\% \text { к }\end{array}$ \\
\hline & \begin{tabular}{|c|} 
II кварталу \\
2020 2. \\
\end{tabular} & $\begin{array}{c}\text { IV кварталу } \\
2019 \text { г. }\end{array}$ & \begin{tabular}{|c|} 
II кварталу \\
2019 г. \\
\end{tabular} & $\begin{array}{c}I V \text { кварталу } \\
2018 \text { г. }\end{array}$ & $\begin{array}{c}\text { II кварталу } \\
2020 \text { z. }\end{array}$ & $\begin{array}{c}I V \text { кварталу } \\
2019 \text { г. }\end{array}$ & $\begin{array}{c}\text { II кварталу } \\
2019 \text { г. }\end{array}$ & $\mid \begin{array}{c}I V \text { кварталу } \\
2018 \text { z. }\end{array}$ \\
\hline Все типы квартир & 103,7 & 108,0 & 102,1 & 106,0 & 103,2 & 104,9 & 101,8 & 103,4 \\
\hline $\begin{array}{l}\text { в том числе: } \\
\text { квартиры низкого } \\
\text { качества }\end{array}$ & $\ldots$ & $\ldots$ & $\ldots$ & $\ldots$ & 102,6 & 104,3 & 101,1 & 102,3 \\
\hline $\begin{array}{c}\text { квартиры среднего } \\
\text { качества (типовые) }\end{array}$ & 103,3 & 108,3 & 101,8 & 105,5 & 103,5 & 105,1 & 101,0 & 103,2 \\
\hline $\begin{array}{l}\text { квартиры } \\
\text { улучшенного } \\
\text { качества }\end{array}$ & 103,1 & 108,5 & 102,3 & 105,9 & 103,2 & 104,9 & 102,6 & 104,0 \\
\hline элитные квартиры & 107,7 & 105,1 & 101,8 & 108,3 & 102,3 & 104,2 & 102,4 & 101,6 \\
\hline
\end{tabular}

Таблица 8

СРЕДНИЕ ЦЕНЫ ЖИЛЫХ ПОМЕЩЕНИЙ РАЗНЫХ ТИПОВ

НА ПЕРВИЧНОМ И ВТОРИЧНОМ РЫНКАХ ЖИЛЬЯ

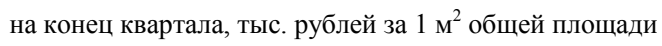

\begin{tabular}{|c|c|c|c|c|}
\hline & \multicolumn{2}{|c|}{ Первичный рынок } & \multicolumn{2}{|c|}{ Вторичный рынок } \\
\hline & $\begin{array}{c}\text { III квартал } \\
2020 \text { 2. }\end{array}$ & $\frac{\text { справочно }}{\text { III квартал } 20192 .}$ & $\begin{array}{c}\text { III квартал } \\
2020 \text { 2. }\end{array}$ & III квартал 20192. \\
\hline Все типы квартир & 76,2 & 62,9 & 63,9 & 58,3 \\
\hline $\begin{array}{l}\text { в том числе: } \\
\text { квартиры низкого качества }\end{array}$ & $\ldots$ & $\ldots$ & 51,3 & 49,1 \\
\hline квартиры среднего качества (типовые) & 77,6 & 59,5 & 58,3 & 53,3 \\
\hline квартиры улучшенного качества & 65,7 & 58,4 & 69,1 & 63,1 \\
\hline элитные квартиры & 167,9 & 154,4 & 101,0 & 85,2 \\
\hline
\end{tabular}




\section{2. ЦЕНЫ ПРОИЗВОДИТЕЛЕЙ}

\subsection{1. Индексы и уровни цен производителей промышленных товаров}

Индекс цен производителей промышленных товаров в сентябре 2020 г. относительно предыдущего месяца, по предварительным данным, составил 100,6\%, из него в добыче полезных ископаемых - 100,8\%, в обрабатывающих производствах - $100,7 \%$, в обеспечении электрической энергией, газом и паром; кондиционировании воздуха - $100,0 \%$, в водоснабжении; водоотведении, организации сбора и утилизации отходов, деятельности по ликвидации загрязнений - $100,0 \%$.

Таблица 1

\section{ИНДЕКСЫ ЦЕН ПРОИЗВОДИТЕЛЕЙ ПРОМЫШЛЕННЫХ ТОВАРОВ}

на конец периода, в процентах

\begin{tabular}{|c|c|c|c|c|c|c|c|c|c|c|}
\hline & \multicolumn{2}{|c|}{ Всего } & \multicolumn{8}{|c|}{ В том числе } \\
\hline & \multirow{4}{*}{$\begin{array}{l}\text { к предь- } \\
\text { дущемеу } \\
\text { периоду }\end{array}$} & \multirow{4}{*}{$\begin{array}{c}\kappa \text { декабрю } \\
\text { предылу- } \\
\text { щзего года }\end{array}$} & \multicolumn{2}{|c|}{$\begin{array}{c}\text { добыча полезныхх } \\
\text { ископаемых }\end{array}$} & \multicolumn{2}{|c|}{$\begin{array}{c}\text { обрабатьваюоие } \\
\text { производства }\end{array}$} & \multirow{2}{*}{\multicolumn{2}{|c|}{\begin{tabular}{|c|} 
обеспечение элек- \\
трической энергией, \\
газом и паром; \\
кондиционирование \\
воздуха \\
\end{tabular}}} & \multirow{3}{*}{\multicolumn{2}{|c|}{$\begin{array}{l}\text { водоснабжение; во- } \\
\text { доотведение, орга- } \\
\text { низаџия сбора и ути- } \\
\text { лизации отходов, де- } \\
\text { ятельность по лик- } \\
\text { видации загрязнений }\end{array}$}} \\
\hline & & & \multirow[t]{3}{*}{$\begin{array}{l}\text { к предь- } \\
\text { дущеему } \\
\text { периоду }\end{array}$} & \multirow[t]{3}{*}{$\left|\begin{array}{c}\kappa \text { декабрю } \\
\text { предыду- } \\
\text { щего года }\end{array}\right|$} & \multirow[t]{3}{*}{$\begin{array}{l}\text { к предь- } \\
\text { душему } \\
\text { периоду }\end{array}$} & \multirow[t]{3}{*}{$\begin{array}{c}\text { к декабрю } \\
\text { предылуу- } \\
\text { щего года }\end{array}$} & & & & \\
\hline & & & & & & & \multirow{2}{*}{$\begin{array}{l}\text { к предь- } \\
\text { дущему } \\
\text { периоду }\end{array}$} & \multirow{2}{*}{$\begin{array}{l}\kappa \text { декабрю } \\
\text { nредblду- } \\
\text { щеего года }\end{array}$} & & \\
\hline & & & & & & & & & \begin{tabular}{|c|}
$\kappa$ преды- \\
душему \\
периоду
\end{tabular} & $\begin{array}{l}\text { к декабрю } \\
\text { предылу- } \\
\text { щчего года }\end{array}$ \\
\hline \multicolumn{11}{|c|}{2019 г. } \\
\hline Январь & 98,0 & 98,0 & 95,9 & 95,9 & 98,6 & 98,6 & 99,1 & 99,1 & 99,9 & 99,9 \\
\hline Февраль & 100,1 & 98,1 & 101,5 & 97,3 & 99,4 & 98,0 & 101,3 & 100,3 & 100,1 & 99,9 \\
\hline Март & 100,9 & 99,0 & 104,0 & 101,3 & 99,6 & 97,6 & 100,6 & 101,0 & 101,7 & 101,6 \\
\hline I квартал & 99,0 & 99,0 & 101,3 & 101,3 & 97,6 & 97,6 & 101,0 & 101,0 & 101,6 & 101,6 \\
\hline Апрель & 100,5 & 99,4 & 100,7 & 102,0 & 100,5 & 98,1 & 99,7 & 100,7 & 100,0 & 101,6 \\
\hline Май & 101,8 & 101,2 & 102,9 & 104,9 & 101,6 & 99,6 & 101,2 & 101,9 & 100,0 & 101,7 \\
\hline Июнь & 99,4 & 100,6 & 98,3 & 103,1 & 100,0 & 99,6 & 99,0 & 100,8 & 100,0 & 101,6 \\
\hline ІІ квартал & 101,7 & 100,6 & 101,8 & 103,1 & 102,0 & 99,6 & 99,8 & 100,8 & 100,0 & 101,6 \\
\hline Июль & 97,3 & 98,0 & 89,6 & 92,4 & 99,7 & 99,3 & 101,4 & 102,2 & 101,7 & 103,4 \\
\hline Август & 99,4 & 97,4 & 99,3 & 91,8 & 99,3 & 98,6 & 100,4 & 102,6 & 100,3 & 103,7 \\
\hline Сентябрь & 99,7 & 97,2 & 99,5 & 91,3 & 100,0 & 98,6 & 98,9 & 101,4 & 100,0 & 103,7 \\
\hline ІІІ квартал & 96,5 & 97,2 & 88,6 & 91,3 & 99,0 & 98,6 & 100,6 & 101,4 & 102,0 & 103,7 \\
\hline Октябрь & 99,8 & 96,9 & 98,7 & 90,2 & 100,0 & 98,6 & 100,5 & 102,0 & 100,0 & 103,7 \\
\hline Ноябрь & 99,2 & 96,1 & 99,2 & 89,5 & 99,1 & 97,6 & 99,5 & 101,4 & 100,0 & 103,7 \\
\hline Декабрь & 99,6 & 95,7 & 101,6 & 90,8 & 98,9 & 96,6 & 99,6 & 101,1 & 100,0 & 103,7 \\
\hline IV квартал & 98,5 & 95,7 & 99,5 & 90,8 & 98,0 & 96,6 & 99,6 & 101,1 & 100,0 & 103,7 \\
\hline \multicolumn{11}{|c|}{2020 г. } \\
\hline Январь & 101,2 & 101,2 & 102,3 & 102,3 & 100,6 & 100,6 & 102,7 & 102,7 & 100,2 & 100,2 \\
\hline Февраль & 99,4 & 100,5 & 97,4 & 99,7 & 100,1 & 100,7 & 99,0 & 101,6 & 100,2 & 100,4 \\
\hline Март & 98,7 & 99,2 & 92,9 & 92,6 & 100,3 & 101,0 & 101,0 & 102,7 & 100,0 & 100,4 \\
\hline І квартал & 99,2 & 99,2 & 92,6 & 92,6 & 101,0 & 101,0 & 102,7 & 102,7 & 100,4 & 100,4 \\
\hline
\end{tabular}




\begin{tabular}{|c|c|c|c|c|c|c|c|c|c|c|}
\hline & \multicolumn{2}{|c|}{ Всего } & \multicolumn{8}{|c|}{ В том числе } \\
\hline & \multirow{4}{*}{$\begin{array}{c}\text { к преды- } \\
\text { дущему } \\
\text { периоду }\end{array}$} & \multirow{4}{*}{$\begin{array}{c}\kappa \text { декабрю } \\
\text { предылду- } \\
\text { щчего года }\end{array}$} & \multicolumn{2}{|c|}{$\begin{array}{c}\text { добыча полезныхх } \\
\text { ископаемых }\end{array}$} & \multicolumn{2}{|c|}{$\begin{array}{c}\text { обрабатьвающие } \\
\text { производства }\end{array}$} & \multirow{2}{*}{\multicolumn{2}{|c|}{$\begin{array}{c}\text { обеспечение элек- } \\
\text { трической энергией, } \\
\text { газом и паром; } \\
\text { кондиционирование } \\
\text { воздуха }\end{array}$}} & \multirow{3}{*}{\multicolumn{2}{|c|}{$\begin{array}{l}\text { водоснабжение; во- } \\
\text { доотведение, орга- } \\
\text { низация сбора и ути- } \\
\text { лизации отходов, де- } \\
\text { ятельность по лик- } \\
\text { видации загрязнений }\end{array}$}} \\
\hline & & & \multirow[t]{3}{*}{$\begin{array}{l}\text { к предь- } \\
\text { дущему } \\
\text { периоду }\end{array}$} & \multirow[t]{3}{*}{$\begin{array}{c}\text { к декабрю } \\
\text { предылуу- } \\
\text { щего года }\end{array}$} & \multirow[t]{3}{*}{$\begin{array}{l}\text { к преды- } \\
\text { дущему } \\
\text { периоду }\end{array}$} & \multirow[t]{3}{*}{$\begin{array}{c}\text { к декабрю } \\
\text { предылу- } \\
\text { щчего года }\end{array}$} & & & & \\
\hline & & & & & & & к предbl- & к декабрю & & \\
\hline & & & & & & & $\begin{array}{l}\text { душему } \\
\text { периоду }\end{array}$ & $\begin{array}{l}\text { предылуу- } \\
\text { щегго года }\end{array}$ & \begin{tabular}{|l|} 
креды- \\
дущему \\
периоду
\end{tabular} & $\begin{array}{l}\text { к декабрю } \\
\text { предьлду- } \\
\text { щего года }\end{array}$ \\
\hline Апрель & 92,8 & 92,0 & 76,0 & 70,4 & 97,3 & 98,2 & 98,6 & 101,2 & 100,0 & 100,4 \\
\hline Май & 97,2 & 89,5 & 85,6 & 60,3 & 99,7 & 98,0 & 99,9 & 101,0 & 100,0 & 100,4 \\
\hline Июнь & 106,1 & 94,9 & 132,3 & 79,8 & 101,6 & 99,5 & 98,9 & 99,9 & 100,0 & 100,5 \\
\hline ІІ квартал & 95,7 & 94,9 & 86,2 & 79,8 & 98,6 & 99,5 & 97,3 & 99,9 & 100,0 & 100,5 \\
\hline Июль & 104,3 & 99,1 & 114,5 & 91,3 & 101,7 & 101,2 & 102,5 & 102,4 & 103,4 & 103,9 \\
\hline Август & 101,0 & 100,1 & 101,1 & 92,3 & 100,7 & 101,9 & 103,4 & 105,8 & 100,2 & 104,1 \\
\hline Сентябрь & 100,6 & 100,7 & 100,8 & 93,0 & 100,7 & 102,6 & 100,0 & 105,9 & 100,0 & 104,1 \\
\hline ІІІ квартал & 106,1 & 100,7 & 116,6 & 93,0 & 103,1 & 102,6 & 106,0 & 105,9 & 103,7 & 104,1 \\
\hline
\end{tabular}

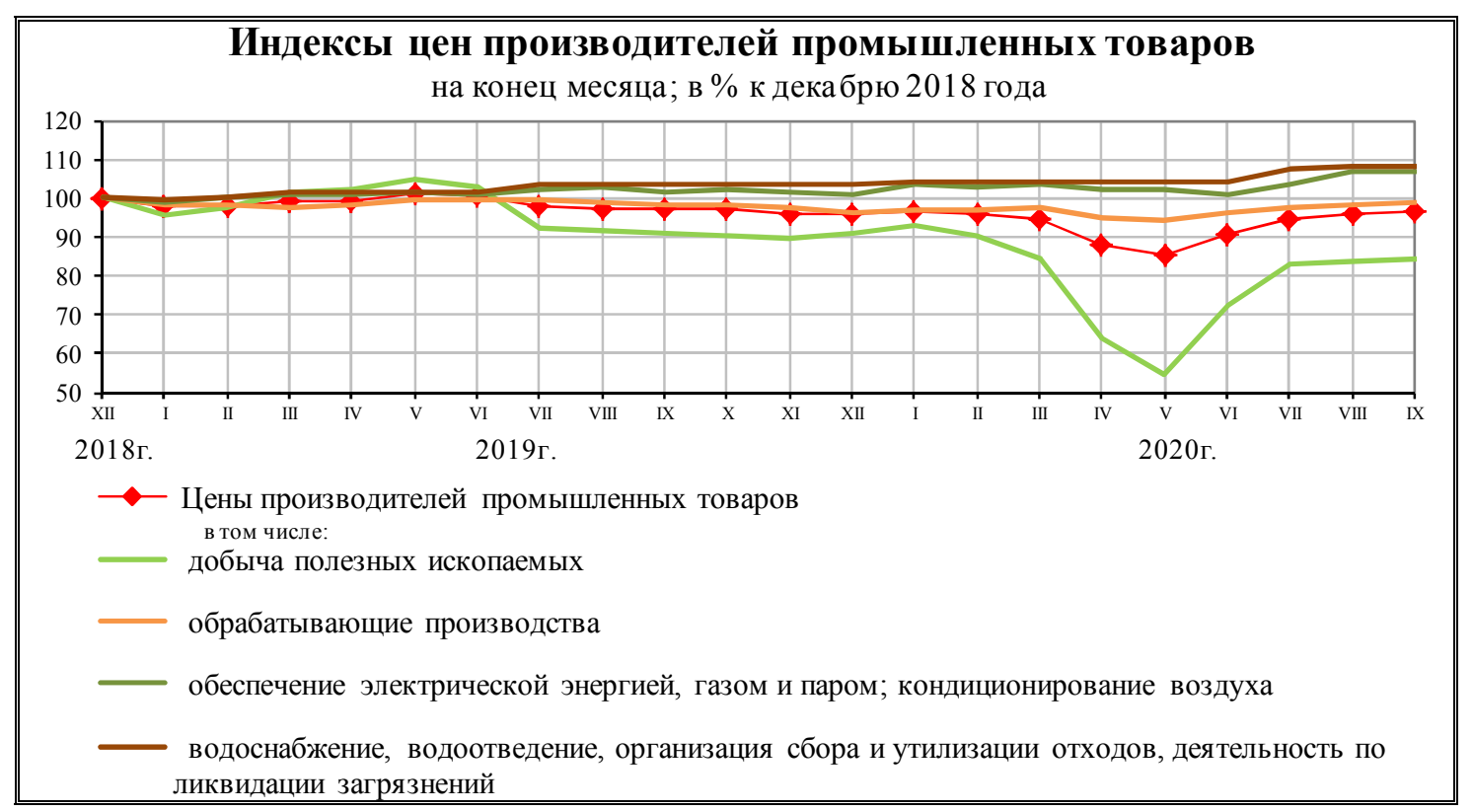

Таблица 2

ИНДЕКСЫ ЦЕН ПРОИЗВОДИТЕЛЕЙ

ПО ОТДЕЛЬНЫМ ВИДАМ ЭКОНОМИЧЕСКОЙ ДЕЯТЕЛЬНОСТИ

на конец периода, в процентах

\begin{tabular}{|c|c|c|c|c|c|c|c|}
\hline & \multicolumn{3}{|c|}{ К предылущему месяиу } & \multicolumn{2}{|c|}{ Сентябрь 2020 г. к } & \multirow[b]{2}{*}{$\begin{array}{c}\text { Январь- } \\
\text { сентябрь } \\
2020 \text { г. } \\
\text { к январю- } \\
\text { сентябрю } \\
20192 . \\
\end{array}$} & \multirow[b]{2}{*}{\begin{tabular}{|c|} 
Справочно \\
сентябрь \\
2019 2. \\
кдекабрю \\
2018 2.
\end{tabular}} \\
\hline & июль & aвzуcm & сентябрь & $\begin{array}{c}\text { декабрю } \\
2019 \text { г. }\end{array}$ & $\begin{array}{c}\text { сентябррю } \\
20192 .\end{array}$ & & \\
\hline Добыча полезных ископаемых & 114,5 & 101,1 & 100,8 & 93,0 & 92,8 & 82,0 & 91,3 \\
\hline $\begin{array}{l}\text { из нее: } \\
\text { добыча угля }\end{array}$ & 93,8 & 97,2 & 99,5 & 87,8 & 78,3 & 74,7 & 84,5 \\
\hline
\end{tabular}




\begin{tabular}{|c|c|c|c|c|c|c|c|}
\hline & \multicolumn{3}{|c|}{ К предьрдущему месяиу } & \multicolumn{2}{|c|}{ Сентябрь 2020 г. к } & \multirow[b]{2}{*}{\begin{tabular}{|c|} 
Январь- \\
сентябрь \\
2020 г. \\
к январю- \\
сентябрю \\
20192. \\
\end{tabular}} & \multirow[b]{2}{*}{$\begin{array}{c}\text { Справочно } \\
\text { сентябрь } \\
2019 \text { г. } \\
\text { кдекабрю } \\
2018 \text { г. }\end{array}$} \\
\hline & июль & август & сентябрь & $\begin{array}{c}\text { декабрю } \\
2019 \text { г. }\end{array}$ & \begin{tabular}{|c|} 
сентябрю \\
20192. \\
\end{tabular} & & \\
\hline добыча нефти и природного газа & 122,1 & 100,8 & 99,8 & 87,1 & 89,4 & 75,9 & 87,9 \\
\hline добыча металлических руд & 104,8 & 107,5 & 105,8 & 142,6 & 122,6 & 107,6 & 114,3 \\
\hline добыча прочих полезных ископаемых & 95,8 & 88,8 & 101,7 & 89,1 & 88,4 & 98,5 & 104,3 \\
\hline Обрабатывающие производства & 101,7 & 100,7 & 100,7 & 102,6 & 101,5 & 99,0 & 98,6 \\
\hline $\begin{array}{l}\text { из них: } \\
\text { производство пищевых продуктов }\end{array}$ & 101,5 & 100,9 & 100,5 & 106,6 & 105,4 & 101,4 & 98,5 \\
\hline производство напитков & 100,8 & 100,2 & 100,1 & 103,0 & 104,4 & 103,8 & 103,2 \\
\hline производство табачных изделий & 102,4 & 101,6 & 101,9 & 109,8 & 114,2 & 110,7 & 103,5 \\
\hline производство текстильных изделий & 99,7 & 99,6 & 100,2 & 104,7 & 104,2 & 103,0 & 99,0 \\
\hline производство одежды & 99,5 & 99,6 & 101,3 & 100,6 & 104,6 & 105,7 & 101,2 \\
\hline производство кожи и изделий из кожи & 99,6 & 101,7 & 99,2 & 99,9 & 99,9 & 99,1 & 98,0 \\
\hline $\begin{array}{l}\text { обработка древесины и производство } \\
\text { изделий из дерева и пробки, } \\
\text { кроме мебели, производство изделий } \\
\text { из соломки и материалов для плетения }\end{array}$ & 100,5 & 100,3 & 101,8 & 105,1 & 103,6 & 99,2 & 98,2 \\
\hline производство бумаги и бумажных изделий & 101,1 & 100,2 & 99,5 & 98,9 & 97,2 & 93,0 & 96,0 \\
\hline $\begin{array}{l}\text { деятельность полиграфическая } \\
\text { и копирование носителей информации }\end{array}$ & 98,5 & 101,7 & 100,7 & 105,1 & 105,2 & 104,1 & 96,0 \\
\hline производство кокса и нефтепродуктов & 108,7 & 98,7 & 99,2 & 94,6 & 92,8 & 87,7 & 89,4 \\
\hline $\begin{array}{l}\text { из них: } \\
\text { производство кокса }\end{array}$ & 95,8 & 93,4 & 97,4 & 89,9 & 80,6 & 80,1 & 88,3 \\
\hline производство нефтепродуктов & 109,0 & 98,8 & 99,3 & 94,6 & 93,1 & 87,9 & 89,5 \\
\hline $\begin{array}{l}\text { производство химических веществ } \\
\text { и химических продуктов }\end{array}$ & 100,4 & 101,6 & 102,7 & 99,4 & 96,0 & 91,5 & 94,7 \\
\hline $\begin{array}{l}\text { производство лекарственных } \\
\text { средств и материалов, применяемых } \\
\text { в медицинских целях }\end{array}$ & 100,8 & 99,9 & 100,1 & 100,7 & 102,4 & 103,0 & 102,1 \\
\hline $\begin{array}{l}\text { производство резиновых и } \\
\text { пластмассовых изделий }\end{array}$ & 99,7 & 100,0 & 100,2 & 101,9 & 101,1 & 101,4 & 103,2 \\
\hline $\begin{array}{l}\text { производство прочей неметаллической } \\
\text { минеральной продукции }\end{array}$ & 100,4 & 98,5 & 102,8 & 102,9 & 103,9 & 103,3 & 105,4 \\
\hline производство металлургическое & 98,5 & 103,5 & 103,3 & 110,1 & 105,0 & 102,5 & 100,7 \\
\hline $\begin{array}{l}\text { производство готовых металлических } \\
\text { изделий, кроме машин и оборудования }\end{array}$ & 101,2 & 101,1 & 102,0 & 106,8 & 107,5 & 103,5 & 101,3 \\
\hline $\begin{array}{l}\text { производство компьютеров, } \\
\text { электронных и оптических изделий }\end{array}$ & 101,0 & 99,8 & 99,1 & 98,5 & 98,7 & 100,6 & 102,9 \\
\hline $\begin{array}{l}\text { производство электрического } \\
\text { оборудования }\end{array}$ & 101,4 & 100,5 & 100,6 & 104,8 & 105,0 & 102,2 & 101,2 \\
\hline $\begin{array}{l}\text { производство машин и оборудования, } \\
\text { не включенных в другие группировки }\end{array}$ & 101,4 & 100,8 & 99,9 & 104,2 & 104,5 & 104,5 & 102,7 \\
\hline $\begin{array}{l}\text { производство автотранспортных средств, } \\
\text { прицепов и полуприцепов }\end{array}$ & 99,3 & 102,0 & 99,4 & 106,3 & 106,6 & 104,9 & 102,9 \\
\hline $\begin{array}{l}\text { производство прочих транспортных } \\
\text { средств и оборудования }\end{array}$ & 98,9 & 99,9 & 99,7 & 95,7 & 96,4 & 101,6 & 104,0 \\
\hline производство мебели & 100,3 & 100,5 & 100,2 & 101,6 & 102,1 & 101,7 & 104,2 \\
\hline производство прочих готовых изделий & 101,1 & 107,3 & 101,4 & 116,4 & 117,2 & 110,2 & 105,6 \\
\hline ремонт и монтаж машин и оборудования & 100,0 & 99,4 & 99,7 & 103,9 & 104,2 & 104,4 & 101,9 \\
\hline
\end{tabular}




\begin{tabular}{|c|c|c|c|c|c|c|c|}
\hline & \multicolumn{3}{|c|}{ К К предьлдущему месяиу } & \multicolumn{2}{|c|}{ Сентябрь 2020 г. к } & \multirow[b]{2}{*}{$\begin{array}{c}\text { Январь- } \\
\text { сентябрь } \\
2020 \text { 2. } \\
\text { к январю- } \\
\text { сентябрю } \\
2019 \text { 2. } \\
\end{array}$} & \multirow[b]{2}{*}{$\begin{array}{c}\text { Справочно } \\
\text { сентябрь } \\
2019 \text { г. } \\
\text { к декабрю } \\
2018 \text { г. }\end{array}$} \\
\hline & июль & aвгусm & сентябрь & $\begin{array}{c}\text { декабрю } \\
2019 \text { г. }\end{array}$ & $\begin{array}{c}\text { сентябрю } \\
2019 \text { 2. } \\
\\
\end{array}$ & & \\
\hline $\begin{array}{l}\text { Обеспечение электрической } \\
\text { энергией, газом и паром; } \\
\text { кондиционирование воздуха }\end{array}$ & 102,5 & 103,4 & 100,0 & 105,9 & 105,7 & 102,6 & 101,4 \\
\hline $\begin{array}{l}\text { в том числе: } \\
\text { производство, передача и } \\
\text { распределение электроэнергии }\end{array}$ & 103,0 & 104,4 & 100,1 & 107,3 & 107,1 & 102,5 & 100,4 \\
\hline $\begin{array}{l}\text { производство и распределение } \\
\text { газообразного топлива }\end{array}$ & 100,4 & 100,3 & 100,8 & 102,9 & 103,0 & 102,0 & 101,4 \\
\hline $\begin{array}{l}\text { производство, передача и } \\
\text { распределение пара и горячей воды; } \\
\text { кондиционирование воздуха }\end{array}$ & 101,7 & 101,4 & 99,9 & 103,0 & 102,9 & 103,0 & 103,8 \\
\hline $\begin{array}{l}\text { Водоснабжение; водоотведение, } \\
\text { организация сбора и утилизации } \\
\text { отходов, деятельность по } \\
\text { ликвидации загрязнений }\end{array}$ & 103,4 & 100,2 & 100,0 & 104,1 & 105,0 & 106,0 & 103,7 \\
\hline
\end{tabular}

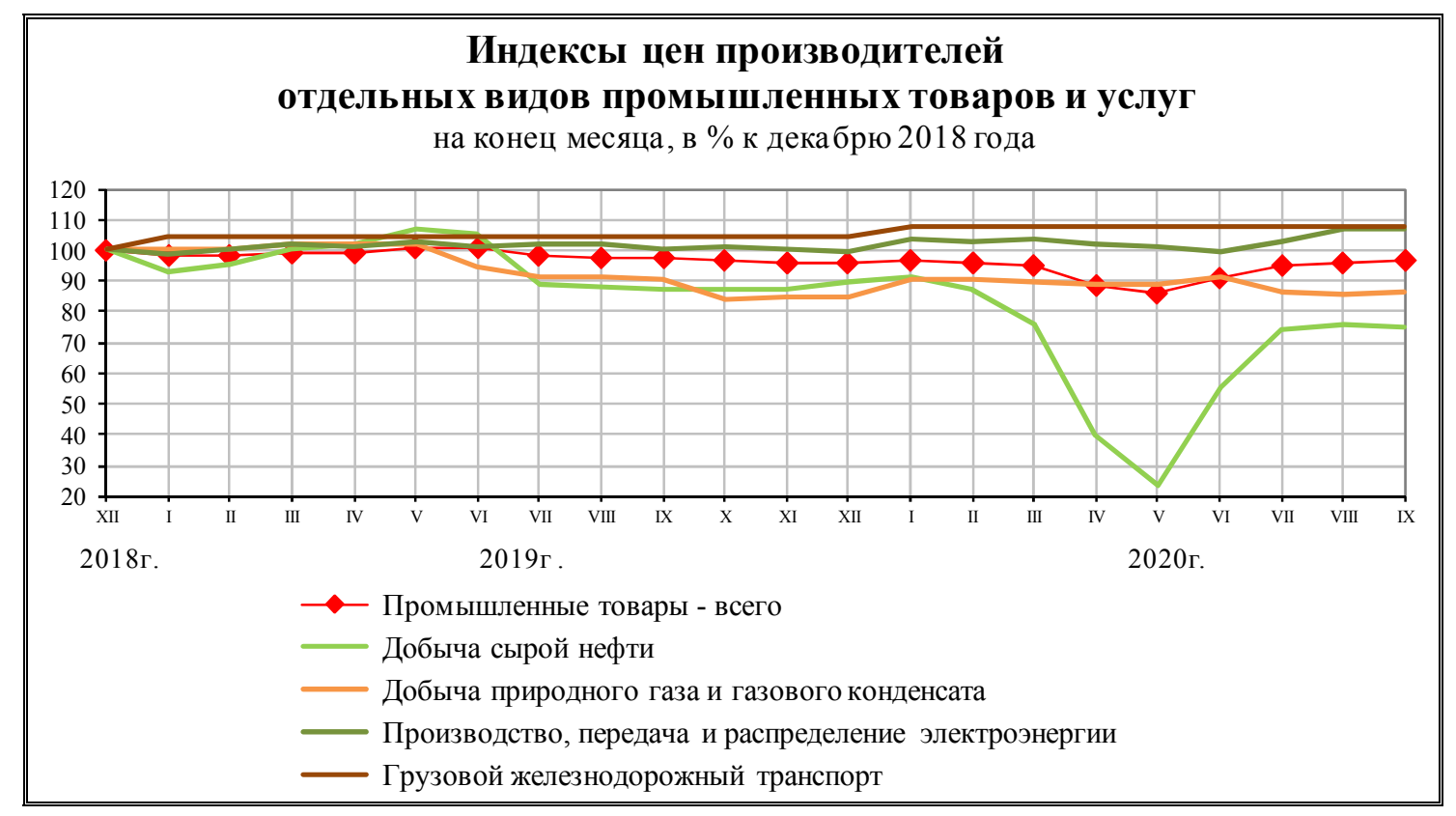

Таблица 3

СРЕДНИЕ ЦЕНЫ И ИНДЕКСЫ ЦЕН НА ПРИОБРЕТЕННЫЕ ПРОМЫШЛЕННЫМИ ОРГАНИЗАЦИЯМИ ОТДЕЛЬНЫЕ ВИДЫ ЭНЕРГОРЕСУРСОВ И ИХ СООТНОШЕНИЯ С ЦЕНАМИ ПРОИЗВОДИТЕЛЕЙ ПРОМЫШЛЕННЫХ ТОВАРОВ

на конец периода

\begin{tabular}{|c|c|c|c|c|c|}
\hline & \multirow{2}{*}{$\begin{array}{c}\text { Средняя иена } \\
\text { приобретения } \\
\text { в августе } 2020 \text { г., } \\
\text { рублей за тонну }\end{array}$} & \multicolumn{2}{|c|}{$\begin{array}{c}\text { Соотношение средних } \\
\text { иен приобретения } u \\
\text { производителей, раз } \\
\end{array}$} & \multicolumn{2}{|c|}{$\begin{array}{c}\text { Индекс иен } \\
\text { в августе } 2020 \text { г. в \% } \\
\text { к декабрю } 2019 \text { г. }\end{array}$} \\
\hline & & $\begin{array}{l}\text { aвzycm } \\
2020 \text { z. }\end{array}$ & $\frac{\text { справочно }}{\text { декабрь } 2019 \text { 2. }}$ & $\begin{array}{l}\text { приобре- } \\
\text { тения }\end{array}$ & $\begin{array}{l}\text { произво- } \\
\text { дителей }\end{array}$ \\
\hline Уголь коксующийся & 6343 & 3,1 & 2,6 & 83,8 & 78,6 \\
\hline
\end{tabular}




\begin{tabular}{|c|c|c|c|c|c|}
\hline & \multirow{2}{*}{$\begin{array}{c}\text { Средняя иена } \\
\text { приобретения } \\
\text { в августе } 2020 \text { г., } \\
\text { рублей за тонну }\end{array}$} & \multicolumn{2}{|c|}{$\begin{array}{c}\text { Соотношение средних } \\
\text { иен приобретения } и \\
\text { прочзводителей, раз }\end{array}$} & \multicolumn{2}{|c|}{$\begin{array}{c}\text { Индекс иен } \\
\text { в августе } 2020 \text { г. в \% } \\
\text { к декабрю } 2019 \text { г. }\end{array}$} \\
\hline & & $\begin{array}{l}\text { aвzycm } \\
20202 \text {. }\end{array}$ & $\frac{\text { справочно }}{\text { декабрь } 2019 \text { 2. }}$ & $\begin{array}{l}\text { приобре- } \\
\text { тения }\end{array}$ & $\begin{array}{l}\text { произво- } \\
\text { дителей }\end{array}$ \\
\hline $\begin{array}{l}\text { Уголь, за исключением антрацита, } \\
\text { угля коксующегося и угля бурого }\end{array}$ & 2216 & 1,7 & 1,3 & 100,2 & 92,3 \\
\hline Нефть сырая & 21749 & 1,3 & 1,2 & 86,0 & 83,9 \\
\hline $\begin{array}{l}\text { Газ горючий природный } \\
\text { (газ естественный), тыс.м }\end{array}$ & 5039 & 2,2 & 3,1 & 101,8 & 100,9 \\
\hline Бензин автомобильный & 56746 & 2,0 & 2,3 & 102,4 & 119,0 \\
\hline Топливо дизельное & 52128 & 1,8 & 1,7 & 97,1 & 91,1 \\
\hline Мазут топочный & 12326 & 1,2 & 1,7 & 98,6 & 97,1 \\
\hline Битумы нефтяные дорожные & 18246 & 1,4 & 1,2 & 96,9 & 135,3 \\
\hline Электроэнергия, тыс.кВт·ч & 2768 & 2,5 & 2,7 & 104,5 & 112,8 \\
\hline Пар и горячая вода, Гкал & 1287 & 1,0 & 1,0 & 103,3 & 103,1 \\
\hline
\end{tabular}

\subsection{2. Индексы цен производителей сельскохозяйственной продукции}

В сентябре 2020 г. индекс цен производителей сельскохозяйственной продукции, по предварительным данным, составил 100,5\%, в том числе в растениеводстве - 101,3\%, в животноводстве - 100,0\%.

Таблица 4

ИНДЕКСЫ ЦЕН ПРОИЗВОДИТЕЛЕЙ СЕЛЬСКОХОЗЯЙСТВЕННОЙ ПРОДУКЦИИ

на конец периода, в процентах

\begin{tabular}{|c|c|c|c|c|c|c|}
\hline & \multicolumn{2}{|c|}{ Всего } & \multicolumn{4}{|c|}{ В том числе } \\
\hline & \multirow{2}{*}{$\begin{array}{l}\text { к предь- } \\
\text { дущему } \\
\text { периоду }\end{array}$} & \multirow{2}{*}{$\begin{array}{c}\text { к декабрю } \\
\text { предьлдущего } \\
\text { года }\end{array}$} & \multicolumn{2}{|c|}{ растениеводство } & \multicolumn{2}{|c|}{ животноводство } \\
\hline & & & $\begin{array}{l}\text { к преды- } \\
\text { душему } \\
\text { периоду }\end{array}$ & $\begin{array}{c}\text { к декабрю } \\
\text { предьдучщего } \\
\text { года }\end{array}$ & $\begin{array}{l}\text { к преды- } \\
\text { дущему } \\
\text { периоду }\end{array}$ & $\begin{array}{c}\text { к декабрю } \\
\text { предылушеего } \\
\text { года }\end{array}$ \\
\hline \multicolumn{7}{|c|}{2019 г. } \\
\hline Январь & 100,2 & 100,2 & 102,4 & 102,4 & 99,1 & 99,1 \\
\hline Февраль & 99,9 & 100,1 & 103,7 & 106,3 & 97,9 & 97,0 \\
\hline Март & 99,6 & 99,8 & 100,6 & 106,8 & 99,1 & 96,1 \\
\hline І квартал & 99,8 & 99,8 & 106,8 & 106,8 & 96,1 & 96,1 \\
\hline Апрель & 100,3 & 100,0 & 100,7 & 107,6 & 100,1 & 96,2 \\
\hline Май & 99,0 & 99,1 & 98,9 & 106,4 & 99,1 & 95,3 \\
\hline Июнь & 98,1 & 97,2 & 97,5 & 103,8 & 98,4 & 93,8 \\
\hline II квартал & 97,4 & 97,2 & 97,1 & 103,8 & 97,6 & 93,8 \\
\hline Июль & 99,8 & 97,0 & 98,7 & 102,4 & 100,5 & 94,2 \\
\hline Август & 99,9 & 96,9 & 97,6 & 99,9 & 101,2 & 95,4 \\
\hline Сентябрь & 98,8 & 95,7 & 97,3 & 97,2 & 99,6 & 95,0 \\
\hline ІІІ квартал & 98,5 & 95,7 & 93,7 & 97,2 & 101,3 & 95,0 \\
\hline
\end{tabular}




\begin{tabular}{|c|c|c|c|c|c|c|}
\hline & \multicolumn{2}{|c|}{ Всего } & \multicolumn{4}{|c|}{ В В том числе } \\
\hline & \multirow{2}{*}{$\begin{array}{l}\text { к преды- } \\
\text { дущему } \\
\text { периоду }\end{array}$} & \multirow{2}{*}{$\begin{array}{c}\text { к декабрю } \\
\text { предьдущего } \\
\text { года }\end{array}$} & \multicolumn{2}{|c|}{ растениеводство } & \multicolumn{2}{|c|}{ животноводство } \\
\hline & & & $\begin{array}{l}\text { к преды- } \\
\text { дущему } \\
\text { периоду }\end{array}$ & $\begin{array}{c}\text { к декабрю } \\
\text { предыдучщего } \\
\text { года }\end{array}$ & $\begin{array}{l}\text { к преды- } \\
\text { дущему } \\
\text { периоду }\end{array}$ & $\begin{array}{c}\text { кекабрю } \\
\text { предыдущего } \\
\text { года } \\
\end{array}$ \\
\hline Октябрь & 99,5 & 95,2 & 99,0 & 96,3 & 99,7 & 94,7 \\
\hline Ноябрь & 100,3 & 95,5 & 99,8 & 96,1 & 100,5 & 95,2 \\
\hline Декабрь & 100,0 & 95,5 & 101,4 & 97,5 & 99,3 & 94,5 \\
\hline IV квартал & 99,8 & 95,5 & 100,2 & 97,5 & 99,6 & 94,5 \\
\hline \multicolumn{7}{|c|}{2020 г. } \\
\hline Январь & 99,5 & 99,5 & 101,4 & 101,4 & 98,3 & 98,3 \\
\hline Февраль & 100,2 & 99,7 & 103,1 & 104,5 & 98,4 & 96,7 \\
\hline Март & 100,1 & 99,8 & 99,4 & 103,8 & 100,6 & 97,2 \\
\hline І квартал & 99,8 & 99,8 & 103,8 & 103,8 & 97,2 & 97,2 \\
\hline Апрель & 101,6 & 101,4 & 100,0 & 103,8 & 102,8 & 99,9 \\
\hline Май & 99,4 & 100,9 & 101,3 & 105,1 & 98,2 & 98,1 \\
\hline Июнь & 99,7 & 100,5 & 99,8 & 104,9 & 99,6 & 97,7 \\
\hline ІІ квартал & 100,7 & 100,5 & 101,1 & 104,9 & 100,5 & 97,7 \\
\hline Июль & 101,0 & 101,5 & 99,2 & 104,1 & 102,2 & 99,8 \\
\hline Август & 100,5 & 102,1 & 99,5 & 103,6 & 101,2 & 101,0 \\
\hline Сентябрь & 100,5 & 102,6 & 101,3 & 104,9 & 100,0 & 101,0 \\
\hline ІІІ квартал & 102,0 & 102,6 & 100,0 & 104,9 & 103,4 & 101,0 \\
\hline
\end{tabular}

Таблица 5

ИНДЕКСЫ ЦЕН ПРОИЗВОДИТЕЛЕЙ ОТДЕЛЬНЫХ ВИДОВ И ГРУПП СЕЛЬСКОХОЗЯЙСТВЕННОЙ ПРОДУКЦИИ

на конец периода, в процентах

\begin{tabular}{|c|c|c|c|c|c|c|c|}
\hline & \multicolumn{3}{|c|}{ К предьгущему месяиу } & \multicolumn{2}{|c|}{ Сентябрь 2020 г. к } & \multirow[b]{2}{*}{$\begin{array}{c}\text { Январь- } \\
\text { сентябрь } \\
2020 \text { г. } \\
\kappa \text { январю- } \\
\text { сентябрю } \\
2019 \text { 2. }\end{array}$} & \multirow{2}{*}{$\begin{array}{c}\text { Справочно } \\
\text { сентябрь } \\
2019 \text { г. } \\
\text { кдекабрю } \\
2018 \text { 2. }\end{array}$} \\
\hline & июль & авгусm & сентябрь & $\begin{array}{c}\text { декабрю } \\
2019 \text { г. }\end{array}$ & \begin{tabular}{|c|} 
сентябрю \\
2019 г.
\end{tabular} & & \\
\hline Растениеводство & 99,2 & 99,5 & 101,3 & 104,9 & 105,8 & 98,0 & 97,2 \\
\hline зерновые и зернобобовые культуры & 100,4 & 100,1 & 101,0 & 110,2 & 110,6 & 103,6 & 103,3 \\
\hline семена подсолнечника & 100,6 & 100,2 & 101,5 & 111,9 & 105,2 & 99,7 & 101,2 \\
\hline овощи & 84,1 & 90,2 & 101,1 & 63,5 & 100,2 & 96,1 & 62,9 \\
\hline картофель & 101,9 & 100,2 & 98,1 & 114,0 & 106,4 & 99,6 & 103,4 \\
\hline Животноводство & 102,2 & 101,2 & 100,0 & 101,0 & 100,6 & $\mathbf{9 7 , 8}$ & 95,0 \\
\hline крупный рогатый скот & 100,1 & 99,3 & 99,8 & 101,0 & 101,5 & 103,0 & 102,5 \\
\hline овцы и козы & 99,6 & 100,5 & 99,8 & 99,7 & 97,7 & 109,4 & 104,2 \\
\hline свиньи & 107,6 & 104,8 & 99,3 & 113,7 & 105,2 & 93,0 & 90,9 \\
\hline птица сельскохозяйственная & 100,8 & 100,0 & 99,6 & 98,0 & 96,1 & 96,4 & 95,7 \\
\hline молоко сырое крупного рогатого скота & 98,7 & 99,7 & 100,9 & 97,0 & 101,6 & 103,5 & 101,6 \\
\hline яйца куриные в скорлупе свежие & 101,7 & 99,3 & 101,6 & 86,0 & 100,6 & 100,6 & 85,0 \\
\hline
\end{tabular}




\subsection{3. Индексы цен на продукцию инвестиционного назначения}

В сентябре 2020 г. сводный индекс цен на продукцию (затраты, услуги) инвестиционного назначения, по предварительным данным, составил 100,6\%, в том числе индекс цен производителей на строительную продукцию - 100,3\%, индекс цен приобретения машин и оборудования инвестиционного назначения - 100,9\%, на прочую продукцию (затраты, услуги) инвестиционного назначения - 101,3\%.

Таблица 6

ИНДЕКСЫ ЦЕН НА ПРОДУКЦИЮ (ЗАТРАТЫ, УСЛУГИ) ИНВЕСТИЦИОННОГО НАЗНАЧЕНИЯ

на конец периода, в процентах

\begin{tabular}{|c|c|c|c|c|c|c|c|c|}
\hline & \multirow{3}{*}{\multicolumn{2}{|c|}{$\begin{array}{c}\text { Сводньй индекс иен } \\
\text { на продукиию } \\
\text { (затрать, услуги) } \\
\text { инвестиционного } \\
\text { назначения } \\
\end{array}$}} & \multicolumn{6}{|c|}{ "В том числе индексы иенн } \\
\hline & & & \multicolumn{2}{|c|}{$\begin{array}{c}\text { производителей } \\
\text { на строительную } \\
\text { продукциюю } \\
\end{array}$} & \multirow{2}{*}{\multicolumn{2}{|c|}{$\begin{array}{c}\text { приобретения машин } \\
\text { и оборудования } \\
\text { инвестиционного } \\
\text { назначения } \\
\end{array}$}} & \multirow{2}{*}{\multicolumn{2}{|c|}{$\begin{array}{c}\text { на прочую продукиию } \\
\text { (затратьи, услуги) } \\
\text { инвестиционного } \\
\text { назначения } \\
\end{array}$}} \\
\hline & & & \multirow{2}{*}{$\begin{array}{l}\text { к преды- } \\
\text { дущему } \\
\text { периоду }\end{array}$} & \multirow{2}{*}{$\begin{array}{l}\text { к декабрю } \\
\text { предыду- } \\
\text { щего года }\end{array}$} & & & & \\
\hline & $\begin{array}{l}\text { к преды- } \\
\text { дущему } \\
\text { периоду }\end{array}$ & \begin{tabular}{|c|} 
к декабрю \\
предылду- \\
щего года \\
\end{tabular} & & & $\begin{array}{l}\text { к преды- } \\
\text { дущему } \\
\text { периоду }\end{array}$ & $\begin{array}{c}\text { к декабрю } \\
\text { предьлду- } \\
\text { щчего года }\end{array}$ & $\begin{array}{l}\text { к преды- } \\
\text { дущему } \\
\text { периоду }\end{array}$ & $\begin{array}{c}\text { к декабрю } \\
\text { предыду- } \\
\text { щего года }\end{array}$ \\
\hline \multicolumn{9}{|c|}{2019 г. } \\
\hline Январь & 100,9 & 100,9 & 100,7 & 100,7 & 101,3 & 101,3 & 100,8 & 100,8 \\
\hline Февраль & 100,1 & 101,0 & 100,5 & 101,2 & 100,0 & 101,2 & 97,8 & 98,6 \\
\hline Mapт & 100,6 & 101,5 & 100,5 & 101,7 & 100,3 & 101,5 & 102,0 & 100,7 \\
\hline I квартал & 101,5 & 101,5 & 101,7 & 101,7 & 101,5 & 101,5 & 100,7 & 100,7 \\
\hline Апрель & 100,3 & 101,8 & 100,4 & 102,1 & 100,5 & 102,0 & 99,3 & 100,0 \\
\hline Май & 100,7 & 102,5 & 100,4 & 102,4 & 100,9 & 102,9 & 101,7 & 101,7 \\
\hline Июнь & 100,2 & 102,7 & 100,5 & 102,9 & 100,5 & 103,4 & 97,8 & 99,4 \\
\hline II квартал & 101,2 & 102,7 & 101,2 & 102,9 & 101,9 & 103,4 & 98,7 & 99,4 \\
\hline Июль & 100,2 & 102,9 & 100,5 & 103,5 & 100,0 & 103,4 & 98,9 & 98,3 \\
\hline Август & 101,0 & 103,9 & 100,4 & 103,8 & 102,8 & 106,3 & 98,1 & 96,4 \\
\hline Сентябрь & 100,3 & 104,2 & 100,3 & 104,2 & 100,3 & 106,7 & 100,0 & 96,4 \\
\hline ІІІ квартал & 101,5 & 104,2 & 101,2 & 104,2 & 103,2 & 106,7 & 97,0 & 96,4 \\
\hline Октябрь & 100,3 & 104,5 & 100,4 & 104,5 & 100,2 & 106,9 & 100,2 & 96,6 \\
\hline Ноябрь & 100,3 & 104,8 & 100,3 & 104,9 & 100,3 & 107,2 & 99,9 & 96,5 \\
\hline Декабрь & 100,3 & 105,1 & 100,2 & 105,0 & 100,0 & 107,1 & 101,8 & 98,2 \\
\hline IV квартал & 100,8 & 105,1 & 100,8 & 105,0 & 100,4 & 107,1 & 101,9 & 98,2 \\
\hline \multicolumn{9}{|c|}{2020 г. } \\
\hline Январь & 100,2 & 100,2 & 100,3 & 100,3 & 99,2 & 99,2 & 103,2 & 103,2 \\
\hline Февраль & 100,6 & 100,8 & 100,3 & 100,6 & 101,8 & 101,0 & 98,2 & 101,4 \\
\hline Mapт & 102,7 & 103,5 & 100,4 & 100,9 & 106,8 & 107,9 & 100,5 & 101,8 \\
\hline I квартал & 103,5 & 103,5 & 100,9 & 100,9 & 107,9 & 107,9 & 101,8 & 101,8 \\
\hline Апрель & 100,4 & 103,9 & 100,2 & 101,2 & 101,2 & 109,1 & 98,6 & 100,4 \\
\hline Май & 99,7 & 103,6 & 100,3 & 101,5 & 98,7 & 107,8 & 99,5 & 99,9 \\
\hline Июнь & 98,6 & 102,2 & 100,1 & 101,6 & 97,8 & 105,3 & 93,7 & 93,6 \\
\hline II квартал & 98,7 & 102,2 & 100,6 & 101,6 & 97,7 & 105,3 & 91,9 & 93,6 \\
\hline
\end{tabular}




\begin{tabular}{|c|c|c|c|c|c|c|c|c|}
\hline & \multirow{3}{*}{\multicolumn{2}{|c|}{$\begin{array}{c}\text { Сводньй индекс иен } \\
\text { на продукцию } \\
\text { (затратыл, услуги) } \\
\text { инвестиционого } \\
\text { назначения } \\
\end{array}$}} & \multicolumn{6}{|c|}{ В том числе индексы цеен } \\
\hline & & & \multicolumn{2}{|c|}{$\begin{array}{c}\text { производителей } \\
\text { на строительную } \\
\text { продукцию }\end{array}$} & \multirow{2}{*}{\multicolumn{2}{|c|}{$\begin{array}{c}\text { приобретения машин } \\
\text { и оборудования } \\
\text { инвестиционного } \\
\text { назначения }\end{array}$}} & \multirow{2}{*}{\multicolumn{2}{|c|}{$\begin{array}{c}\text { на прочую продукциюю } \\
\text { (затратыл, услуги) } \\
\text { инвестиционного } \\
\text { назначения }\end{array}$}} \\
\hline & & & \multirow{2}{*}{$\begin{array}{l}\text { к преды- } \\
\text { дущемеу } \\
\text { периоду }\end{array}$} & \multirow{2}{*}{$\begin{array}{l}\kappa \text { декабрю } \\
\text { предылу- } \\
\text { щего года }\end{array}$} & & & & \\
\hline & $\begin{array}{l}\text { к преды- } \\
\text { дущему } \\
\text { периоду }\end{array}$ & $\begin{array}{c}\text { к декабрю } \\
\text { предылуу- } \\
\text { щего года } \\
\end{array}$ & & & $\begin{array}{l}\text { к преды- } \\
\text { дущему } \\
\text { периоду } \\
\end{array}$ & $\begin{array}{c}\text { к декабрю } \\
\text { предьлуу- } \\
\text { щего года }\end{array}$ & $\begin{array}{l}\text { к преды- } \\
\text { душему } \\
\text { периоду } \\
\end{array}$ & $\begin{array}{c}\text { к декабрю } \\
\text { предьлду- } \\
\text { щегго года } \\
\end{array}$ \\
\hline Июль & 100,9 & 103,1 & 100,1 & 101,7 & 101,6 & 107,1 & 101,8 & 95,3 \\
\hline Август & 100,9 & 103,9 & 100,4 & 102,1 & 101,8 & 108,9 & 100,2 & 95,5 \\
\hline Сентябрь & 100,6 & 104,6 & 100,3 & 102,4 & 100,9 & 109,9 & 101,3 & 96,8 \\
\hline III квартал & 102,3 & 104,6 & 100,8 & 102,4 & 104,3 & 109,9 & 103,4 & 96,8 \\
\hline
\end{tabular}

Таблица 7

СВОДНЫЕ ИНДЕКСЫ ЦЕН НА ПРОДУКЦИЮ (ЗАТРАТЫ, УСЛУГИ) ИНВЕСТИЦИОННОГО НАЗНАЧЕНИЯ ПО ОТДЕЛЬНЫМ ВИДАМ ЭКОНОМИЧЕСКОЙ ДЕЯТЕЛЬНОСТИ

на конец периода, в процентах

\begin{tabular}{|c|c|c|c|c|c|c|c|}
\hline & \multicolumn{3}{|c|}{ К кредылдущему месяиу } & \multicolumn{2}{|c|}{ Сентябрь 2020 г. к } & \multirow[b]{2}{*}{\begin{tabular}{|c|} 
Январь- \\
сентябрь \\
2020 г. \\
к январю- \\
сентябрю \\
2019 г.
\end{tabular}} & \multirow{2}{*}{\begin{tabular}{c|} 
Справочно \\
сентябрь \\
2019 г. \\
кекабрю \\
2018 г.
\end{tabular}} \\
\hline & июль & aвгу $\mathrm{cm}$ & сентябрь & $\begin{array}{l}\text { декабрю } \\
2019 \text { г. }\end{array}$ & $\begin{array}{c}\text { сентябрю } \\
2019 \text { г. }\end{array}$ & & \\
\hline $\begin{array}{l}\text { Сельское, лесное хозяйство, охота, } \\
\text { рыболовство и рыбоводство }\end{array}$ & 101,1 & 101,2 & 100,6 & 106,4 & 107,0 & 106,5 & 103,9 \\
\hline Добыча полезных ископаемых & 101,2 & 100,7 & 100,9 & 102,4 & 103,6 & 103,5 & 102,0 \\
\hline Обрабатывающие производства & 101,1 & 101,0 & 100,7 & 106,1 & 106,9 & 107,1 & 104,8 \\
\hline $\begin{array}{l}\text { из них: } \\
\text { производство пищевых продуктов }\end{array}$ & 101,2 & 101,6 & 100,8 & 107,8 & 108,3 & 108,1 & 105,4 \\
\hline производство напитков & 101,3 & 101,7 & 100,9 & 108,7 & 109,1 & 108,6 & 105,4 \\
\hline $\begin{array}{l}\text { обработка древесины и производство } \\
\text { изделий из дерева и пробки, кроме } \\
\text { мебели, производство изделий из } \\
\text { соломки и материалов для плетения }\end{array}$ & 101,2 & 101,2 & 100,7 & 107,5 & 108,2 & 108,7 & 105,3 \\
\hline производство бумаги и бумажных изделий & 101,2 & 101,4 & 100,8 & 108,1 & 108,7 & 108,8 & 105,8 \\
\hline производство кокса и нефтепродуктов & 100,8 & 100,7 & 100,6 & 104,6 & 105,5 & 105,8 & 104,1 \\
\hline $\begin{array}{l}\text { производство химических веществ } \\
\text { и химических продуктов }\end{array}$ & 100,8 & 100,8 & 100,6 & 105,2 & 106,0 & 106,6 & 105,3 \\
\hline $\begin{array}{l}\text { производство резиновых и } \\
\text { пластмассовых изделий }\end{array}$ & 101,3 & 101,5 & 100,8 & 108,0 & 108,4 & 108,6 & 105,6 \\
\hline $\begin{array}{l}\text { производство прочей неметаллической } \\
\text { минеральной продукции }\end{array}$ & 101,2 & 101,3 & 100,7 & 107,3 & 108,0 & 108,3 & 105,2 \\
\hline производство металлургическое & 101,2 & 101,3 & 100,7 & 107,2 & 107,7 & 108,0 & 105,4 \\
\hline $\begin{array}{l}\text { производство готовых металлических } \\
\text { изделий, кроме машин и оборудования }\end{array}$ & 101,2 & 101,0 & 100,6 & 106,6 & 107,4 & 108,0 & 104,8 \\
\hline $\begin{array}{l}\text { производство компьютеров, } \\
\text { электронных и оптических изделий }\end{array}$ & 101,2 & 101,1 & 100,6 & 106,7 & 107,9 & 108,6 & 105,2 \\
\hline $\begin{array}{l}\text { производство электрического } \\
\text { оборудования }\end{array}$ & 101,2 & 101,1 & 100,6 & 106,6 & 107,5 & 107,9 & 105,0 \\
\hline $\begin{array}{l}\text { производство машин и оборудования, } \\
\text { не включенных в другие группировки }\end{array}$ & 101,3 & 101,1 & 100,7 & 107,3 & 108,1 & 108,5 & 105,2 \\
\hline $\begin{array}{l}\text { производство автотранспортных средств, } \\
\text { прицепов и полуприцепов }\end{array}$ & 101,3 & 101,1 & 100,6 & 107,2 & 108,0 & 108,4 & 104,5 \\
\hline $\begin{array}{l}\text { производство прочих транспортных } \\
\text { средств и оборудования }\end{array}$ & 101,2 & 100,9 & 100,6 & 106,3 & 108,7 & 111,5 & 109,1 \\
\hline
\end{tabular}




\begin{tabular}{|c|c|c|c|c|c|c|c|}
\hline & \multicolumn{3}{|c|}{ К К предылдущему месяиу } & \multicolumn{2}{|c|}{ "Сентябрь 2020 г. к } & \multirow[b]{2}{*}{\begin{tabular}{|c|} 
Январь- \\
сентябрь \\
2020 г. \\
кянварю- \\
сентябрю \\
2019 г.
\end{tabular}} & \multirow[b]{2}{*}{\begin{tabular}{|l} 
Справочно \\
сентябрь \\
2019 г. \\
кдекабрю \\
2018 г.
\end{tabular}} \\
\hline & июль & август & сентябрь & $\begin{array}{c}\text { декабрю } \\
2019 \text { г. }\end{array}$ & $\begin{array}{c}\text { сентябрю } \\
20192 . \\
\end{array}$ & & \\
\hline $\begin{array}{l}\text { Обеспечение электрической } \\
\text { энергией, газом и паром; } \\
\text { кондиционирование воздуха }\end{array}$ & 100,7 & 100,8 & 100,5 & 105,5 & 106,3 & 106,8 & 105,5 \\
\hline $\begin{array}{l}\text { Водоснабжение; водоотведение, } \\
\text { организация сбора и утилизации } \\
\text { отходов, деятельность по } \\
\text { ликвидации загрязнений }\end{array}$ & 100,3 & 100,8 & 100,5 & 104,3 & 105,2 & 106,1 & 105,0 \\
\hline Строительство & 100,5 & 100,6 & 100,5 & 103,9 & 104,5 & 104,4 & 103,8 \\
\hline $\begin{array}{l}\text { Торговля оптовая и розничная; } \\
\text { ремонт автотранспортных } \\
\text { средств и мотоциклов }\end{array}$ & 100,7 & 100,8 & 100,5 & 104,4 & 105,1 & 105,4 & 104,7 \\
\hline Транспортировка и хранение & 100,8 & 101,0 & 100,4 & 105,7 & 106,9 & 107,8 & 106,0 \\
\hline $\begin{array}{l}\text { Деятельность гостиниц и предприятий } \\
\text { общественного питания }\end{array}$ & 100,8 & 101,0 & 100,6 & 105,3 & 106,1 & 106,8 & 105,2 \\
\hline $\begin{array}{l}\text { Деятельность в области } \\
\text { информации и связи }\end{array}$ & 101,4 & 100,8 & 100,1 & 105,2 & 106,0 & 106,8 & 104,2 \\
\hline Деятельность финансовая и страховая & 100,7 & 101,0 & 100,5 & 106,0 & 106,8 & 107,0 & 104,8 \\
\hline $\begin{array}{l}\text { Деятельность по операциям } \\
\text { с недвижимым имуществом }\end{array}$ & 100,3 & 100,6 & 100,4 & 103,8 & 104,7 & 105,3 & 105,3 \\
\hline $\begin{array}{l}\text { Деятельность профессиональная, } \\
\text { научная и техническая }\end{array}$ & 100,4 & 100,7 & 100,3 & 103,2 & 104,4 & 105,0 & 104,9 \\
\hline $\begin{array}{l}\text { Деятельность административная } \\
\text { и сопутствующие } \\
\text { дополнительные услуги }\end{array}$ & 101,2 & 101,4 & 100,7 & 107,2 & 107,9 & 108,4 & 105,5 \\
\hline $\begin{array}{l}\text { Государственное управление } \\
\text { и обеспечение военной безопасности; } \\
\text { социальное обеспечение }\end{array}$ & 100,5 & 100,7 & 100,3 & 104,0 & 105,0 & 105,8 & 105,4 \\
\hline Образование & 101,4 & 101,1 & 100,4 & 107,0 & 107,9 & 108,1 & 105,4 \\
\hline $\begin{array}{l}\text { Деятельность в области здравоохранения } \\
\text { и социальных услуг }\end{array}$ & 101,2 & 101,7 & 100,8 & 108,8 & 111,3 & 110,9 & 106,6 \\
\hline $\begin{array}{l}\text { Деятельность в области культуры, } \\
\text { спорта, организации досуга } \\
\text { и развлечений }\end{array}$ & 100,8 & 100,9 & 100,4 & 105,5 & 106,5 & 106,8 & 105,1 \\
\hline Предоставление прочих видов услуг & 100,4 & 100,9 & 100,4 & 104,3 & 105,2 & 104,6 & 104,2 \\
\hline
\end{tabular}

Таблица 8

\section{ИНДЕКСЫ ЦЕН ПРИОБРЕТЕНИЯ СТРОИТЕЛЬНЫМИ ОРГАНИЗАЦИЯМИ ОСНОВНЫХ ВИДОВ МАТЕРИАЛОВ}

на конец периода, в процентах

\begin{tabular}{|c|c|c|c|c|c|c|c|}
\hline & \multicolumn{3}{|c|}{ К К предьлдущему месяиу } & \multicolumn{2}{|c|}{ Сентябрь 2020 г. к } & \multirow[b]{2}{*}{$\begin{array}{c}\text { Январь- } \\
\text { сентябрь } \\
2020 \text { г. } \\
\text { кянварю- } \\
\text { сентябрю } \\
2019 \text { г. } \\
\end{array}$} & \multirow[b]{2}{*}{$\begin{array}{c}\text { Справочно } \\
\text { сентябрь } \\
2019 \text { г. } \\
\text { кдекабрю } \\
2018 \text { г. }\end{array}$} \\
\hline & июль & aвzycm & сентябрь & $\begin{array}{l}\text { декабрю } \\
2019 \text { г. }\end{array}$ & $\begin{array}{c}\text { сентябрю } \\
2019 \text { 2. }\end{array}$ & & \\
\hline $\begin{array}{l}\text { Кирпич керамический неогнеупорный } \\
\text { строительный }\end{array}$ & 100,2 & 100,3 & 100,7 & 103,4 & 103,0 & 102,7 & 103,2 \\
\hline Цементы общестроительные & 100,2 & 100,5 & 100,1 & 103,9 & 102,5 & 102,3 & 103,3 \\
\hline
\end{tabular}




\begin{tabular}{|c|c|c|c|c|c|c|c|}
\hline & \multicolumn{3}{|c|}{ К К предыдущему месяиу } & \multicolumn{2}{|c|}{ Сентябрь 2020 г. к } & \multirow[b]{2}{*}{\begin{tabular}{|c|} 
Январь- \\
сентябрь \\
2020 г. \\
к январю- \\
сентябрю \\
2019 г. \\
\end{tabular}} & \multirow[b]{2}{*}{\begin{tabular}{|c|} 
Справочно \\
сентябрь \\
2019 г. \\
$\kappa$ декабрю \\
2018 г.
\end{tabular}} \\
\hline & июль & авгу $\mathrm{cm}$ & сентябрь & $\begin{array}{l}\text { декабрю } \\
20192 .\end{array}$ & $\begin{array}{c}\text { сентябрю } \\
20192 . \\
\end{array}$ & & \\
\hline $\begin{array}{l}\text { Бетон, готовый для заливки } \\
\text { (товарный бетон) }\end{array}$ & 99,4 & 100,1 & 99,3 & 99,1 & 100,5 & 101,9 & 101,7 \\
\hline Растворы строительные & 100,3 & 99,9 & 100,2 & 100,3 & 102,2 & 102,3 & 99,5 \\
\hline Щебень & 100,2 & 99,9 & 99,7 & 98,1 & 98,2 & 101,3 & 103,2 \\
\hline $\begin{array}{l}\text { Пески природные, не включенные } \\
\text { в другие группировки }\end{array}$ & 97,4 & 98,2 & 100,0 & 104,2 & 104,5 & 108,8 & 98,2 \\
\hline $\begin{array}{l}\text { Плитки керамические глазурованные } \\
\text { для внутренней облицовки стен }\end{array}$ & 100,1 & 102,4 & 100,0 & 104,1 & 104,4 & 104,4 & 103,9 \\
\hline $\begin{array}{l}\text { Линолеум и твердые неполимерные } \\
\text { материалы для покрытия пола, } \\
\text { т.е. упругие напольные покрытия, } \\
\text { такие как виниловое покрытие, } \\
\text { линолеум и аналогичные изделия }\end{array}$ & 99,8 & 100,1 & 100,1 & 98,2 & 101,1 & 101,5 & 100,1 \\
\hline $\begin{array}{l}\text { Стекло листовое литое, прокатное, } \\
\text { тянутое или выдувное, но не } \\
\text { обработанное другим способом }\end{array}$ & 102,1 & 100,7 & 100,9 & 104,4 & 104,8 & 102,8 & 116,7 \\
\hline
\end{tabular}

\subsection{4. Индексы тарифов на грузовые перевозки}

Индекс тарифов на грузовые перевозки в среднем по всем видам транспорта в сентябре 2020 г., по предварительным данным, составил 100,1\%.

Таблица 9

\section{ИНДЕКСЫ ТАРИФОВ НА ГРУЗОВЫЕ ПЕРЕВОЗКИ ОТДЕЛЬНЫМИ ВИДАМИ ТРАНСПОРТА}

на конец периода, в процентах

\begin{tabular}{|c|c|c|c|c|c|c|c|c|}
\hline & \multicolumn{2}{|c|}{ Всего } & \multicolumn{6}{|c|}{ Из него транспорт } \\
\hline & \multirow{2}{*}{$\begin{array}{l}\text { к преды- } \\
\text { дущему } \\
\text { периоду }\end{array}$} & \multirow{2}{*}{$\begin{array}{c}\text { к декабрю } \\
\text { предьду- } \\
\text { щего года }\end{array}$} & \multicolumn{2}{|c|}{ железнодорожный } & \multicolumn{2}{|c|}{ автомобильньй } & \multicolumn{2}{|c|}{ трубопроводньій } \\
\hline & & & $\begin{array}{l}\text { к преды- } \\
\text { дущему } \\
\text { периоду }\end{array}$ & $\begin{array}{c}\text { к декабрю } \\
\text { предььду- } \\
\text { щего года }\end{array}$ & $\begin{array}{l}\text { к преды- } \\
\text { дущему } \\
\text { периоду }\end{array}$ & $\begin{array}{l}\text { к декабрю } \\
\text { предыцу- } \\
\text { щего года }\end{array}$ & $\begin{array}{l}\text { к предьи- } \\
\text { душему } \\
\text { периоду }\end{array}$ & $\begin{array}{c}\text { к декабрю } \\
\text { предылду- } \\
\text { щего года }\end{array}$ \\
\hline \multicolumn{9}{|c|}{2019 г. } \\
\hline Январь & 97,6 & 97,6 & 104,2 & 104,2 & 100,1 & 100,1 & 90,5 & 90,5 \\
\hline Февраль & 100,4 & 97,9 & 100,0 & 104,2 & 102,0 & 102,0 & 99,9 & 90,5 \\
\hline Март & 100,0 & 97,9 & 100,0 & 104,2 & 100,1 & 102,2 & 99,8 & 90,3 \\
\hline I квартал & 97,9 & 97,9 & 104,2 & 104,2 & 102,2 & 102,2 & 90,3 & 90,3 \\
\hline Апрель & 105,0 & 102,8 & 100,0 & 104,2 & 99,9 & 102,1 & 112,7 & 101,8 \\
\hline Май & 100,0 & 102,9 & 100,0 & 104,2 & 100,0 & 102,1 & 100,1 & 101,8 \\
\hline Июнь & 99,9 & 102,8 & 100,0 & 104,2 & 100,0 & 102,0 & 99,9 & 101,7 \\
\hline ІІ квартал & 104,9 & 102,8 & 100,0 & 104,2 & 99,9 & 102,0 & 112,6 & 101,7 \\
\hline Июль & 103,1 & 105,9 & 100,0 & 104,2 & 100,0 & 102,0 & 107,6 & 109,4 \\
\hline Август & 100,2 & 106,1 & 100,0 & 104,2 & 100,1 & 102,1 & 100,3 & 109,7 \\
\hline Сентябрь & 99,9 & 106,0 & 100,0 & 104,2 & 100,0 & 102,1 & 99,8 & 109,5 \\
\hline ІІІ квартал & 103,2 & 106,0 & 100,0 & 104,2 & 100,0 & 102,1 & 107,7 & 109,5 \\
\hline
\end{tabular}




\begin{tabular}{|c|c|c|c|c|c|c|c|c|}
\hline & \multicolumn{2}{|c|}{ Всего } & \multicolumn{6}{|c|}{ "Из него транспорт } \\
\hline & \multirow{2}{*}{$\begin{array}{l}\text { к преды- } \\
\text { дущему } \\
\text { периоду }\end{array}$} & \multirow{2}{*}{$\begin{array}{c}\text { к декабрю } \\
\text { предыду- } \\
\text { щего года }\end{array}$} & \multicolumn{2}{|c|}{ железнодорожный } & \multicolumn{2}{|c|}{ автомобильный } & \multicolumn{2}{|c|}{ трубопроводный } \\
\hline & & & $\begin{array}{l}\text { к преды- } \\
\text { дущему } \\
\text { периоду }\end{array}$ & $\begin{array}{c}\text { к декабрю } \\
\text { предыду- } \\
\text { щего года }\end{array}$ & $\begin{array}{l}\text { к преды- } \\
\text { дущему } \\
\text { периоду }\end{array}$ & $\begin{array}{c}\text { к декабрю } \\
\text { предыдуд- } \\
\text { щего года }\end{array}$ & $\begin{array}{l}\text { к преды- } \\
\text { дущему } \\
\text { периоду }\end{array}$ & $\begin{array}{c}\text { к декабрю } \\
\text { предылуу- } \\
\text { щего года } \\
\end{array}$ \\
\hline Октябрь & 95,8 & 101,6 & 100,0 & 104,2 & 100,0 & 102,0 & 90,1 & 98,7 \\
\hline Ноябрь & 100,0 & 101,6 & 100,0 & 104,2 & 100,1 & 102,1 & 100,0 & 98,7 \\
\hline Декабрь & 99,9 & 101,5 & 100,0 & 104,2 & 100,0 & 102,1 & 99,9 & 98,5 \\
\hline IV квартал & 95,7 & 101,5 & 100,0 & 104,2 & 100,0 & 102,1 & 90,0 & 98,5 \\
\hline \multicolumn{9}{|c|}{2020 г. } \\
\hline Январь & 98,9 & 98,9 & 103,5 & 103,5 & 100,4 & 100,4 & 94,5 & 94,5 \\
\hline Февраль & 100,1 & 99,0 & 100,0 & 103,5 & 100,2 & 100,6 & 100,3 & 94,7 \\
\hline Март & 100,8 & 99,8 & 100,0 & 103,5 & 100,5 & 101,1 & 101,4 & 96,0 \\
\hline І квартал & 99,8 & 99,8 & 103,5 & 103,5 & 101,1 & 101,1 & 96,0 & 96,0 \\
\hline Апрель & 104,2 & 104,0 & 100,0 & 103,5 & 97,0 & 98,0 & 110,1 & 105,7 \\
\hline Май & 99,8 & 103,8 & 100,0 & 103,5 & 99,9 & 97,9 & 99,5 & 105,2 \\
\hline Июнь & 99,9 & 103,7 & 100,0 & 103,5 & 99,9 & 97,9 & 99,9 & 105,0 \\
\hline ІІ квартал & 103,9 & 103,7 & 100,0 & 103,5 & 96,8 & 97,9 & 109,4 & 105,0 \\
\hline Июль & 99,7 & 103,4 & 100,0 & 103,5 & 100,1 & 98,0 & 99,3 & 104,3 \\
\hline Август & 100,0 & 103,4 & 100,0 & 103,5 & 98,6 & 96,7 & 100,3 & 104,6 \\
\hline Сентябрь & 100,1 & 103,5 & 100,0 & 103,5 & 100,1 & 96,8 & 100,2 & 104,8 \\
\hline III квартал & 99,8 & 103,5 & 100,0 & 103,5 & 98,9 & 96,8 & 99,8 & 104,8 \\
\hline
\end{tabular}

Таблица 10

ИНДЕКСЫ ТАРИФОВ НА ГРУЗОВЫЕ ПЕРЕВОЗКИ ПО ВИДАМ ТРАНСПОРТА

на конец периода, в процентах

\begin{tabular}{|c|c|c|c|c|c|c|c|}
\hline & \multicolumn{3}{|c|}{ "К предылущему месяиу } & \multicolumn{2}{|c|}{ Сентябрь 2020 г. к } & \multirow[b]{2}{*}{\begin{tabular}{|c|} 
Январь- \\
сентябрь \\
2020 г. \\
к январю- \\
сентябрю \\
2019 г. \\
\end{tabular}} & \multirow[b]{2}{*}{\begin{tabular}{|c|} 
Справочно \\
сентябрь \\
2019 г. \\
к декабрю \\
2018 г.
\end{tabular}} \\
\hline & июль & авгусm & $\begin{array}{c}\text { сен- } \\
\text { тябр }\end{array}$ & $\begin{array}{c}\text { декабрю } \\
2019 \text { г. }\end{array}$ & \begin{tabular}{|c|} 
сентябрюю \\
2019 г.
\end{tabular} & & \\
\hline Грузовой транспорт & 99,7 & 100,0 & 100,1 & 103,5 & 98,5 & 101,4 & 106,0 \\
\hline $\begin{array}{l}\text { в том числе: } \\
\text { железнодорожный }\end{array}$ & 100,0 & 100,0 & 100,0 & 103,5 & 103,5 & 103,5 & 104,2 \\
\hline автомобильный & 100,1 & 98,6 & 100,1 & 96,8 & 96,8 & 99,8 & 102,1 \\
\hline морской & 99,8 & 101,3 & 100,7 & 105,8 & 105,6 & 103,7 & 99,3 \\
\hline внутренний водный & 99,2 & 100,4 & 100,5 & 101,2 & 98,4 & 100,4 & 104,7 \\
\hline воздушный & 99,9 & 100,3 & 100,5 & 104,5 & 104,1 & 103,9 & 105,4 \\
\hline трубопроводный & 99,3 & 100,3 & 100,2 & 104,8 & 94,5 & 99,7 & 109,5 \\
\hline
\end{tabular}

\subsection{5. Индексы тарифов на услуги связи для юридических лиц}

Индекс тарифов на услуги связи для юридических лиц в III квартале 2020 г., по предварительным данным, составил 100,1\%. 
ИНДЕКСЫ ТАРИФОВ НА УСЛУГИ СВЯЗИ ДЛЯ ЮРИДИЧЕСКИХ ЛИЦ

на конец периода, в процентах

\begin{tabular}{|c|c|c|c|c|c|c|c|c|}
\hline & \multicolumn{2}{|c|}{ Всего } & \multicolumn{6}{|c|}{ Из них } \\
\hline & \multirow{2}{*}{$\begin{array}{c}\text { креды- } \\
\text { дущему } \\
\text { кварталу }\end{array}$} & \multirow{2}{*}{$\begin{array}{c}\text { кIV квар- } \\
\text { талу предь- } \\
\text { дущего года }\end{array}$} & \multicolumn{2}{|c|}{$\begin{array}{c}\text { услуги } \\
\text { нациоональной почты }\end{array}$} & \multicolumn{2}{|c|}{$\begin{array}{c}\text { услуги местной } \\
\text { теледонной связи }\end{array}$} & \multicolumn{2}{|c|}{$\begin{array}{c}\text { услуги документальной } \\
\text { электросвязи }\end{array}$} \\
\hline & & & $\begin{array}{c}\text { к преды- } \\
\text { дущему } \\
\text { кварталу }\end{array}$ & $\begin{array}{c}\kappa I V \text { квар- } \\
\text { талу преды-- } \\
\text { дущеего года }\end{array}$ & $\begin{array}{c}\text { к преды- } \\
\text { дущему } \\
\text { кварталу } \\
\end{array}$ & \begin{tabular}{|c|}
$I V$ квар- \\
талу преды- \\
дущчего года
\end{tabular} & $\begin{array}{c}\text { к преды- } \\
\text { дущему } \\
\text { кварталу } \\
\end{array}$ & $\begin{array}{c}\text { к IV квар- } \\
\text { малу предь- } \\
\text { дущего года }\end{array}$ \\
\hline \multicolumn{9}{|c|}{2019 г. } \\
\hline I квартал & 101,4 & 101,4 & 100,1 & 100,1 & 100,2 & 100,2 & 102,7 & 102,7 \\
\hline II квартал & 101,0 & 102,4 & 102,3 & 102,5 & 100,1 & 100,2 & 100,0 & 102,7 \\
\hline III квартал & 100,4 & 102,8 & 100,4 & 102,8 & 101,7 & 101,9 & 100,1 & 102,8 \\
\hline IV квартал & 100,2 & 103,1 & 100,6 & 103,4 & 100,0 & 101,9 & 100,0 & 102,8 \\
\hline \multicolumn{9}{|c|}{2020 г. } \\
\hline I квартал & $100,7^{1)}$ & $100,7^{1)}$ & $100,0^{1)}$ & $100,0^{1)}$ & 100,0 & 100,0 & 100,8 & 100,8 \\
\hline II квартал & 100,0 & $100,7^{1)}$ & 100,1 & $100,1^{1)}$ & 100,0 & 100,0 & 99,7 & 100,5 \\
\hline III квартал & 100,1 & 100,8 & 100,2 & 100,3 & 100,0 & 100,0 & 100,0 & 100,5 \\
\hline
\end{tabular}

В III квартале 2020 г. для юридических лиц в группе услуг национальной почты плата за доставку центральных газет выросла на 9,3\%.

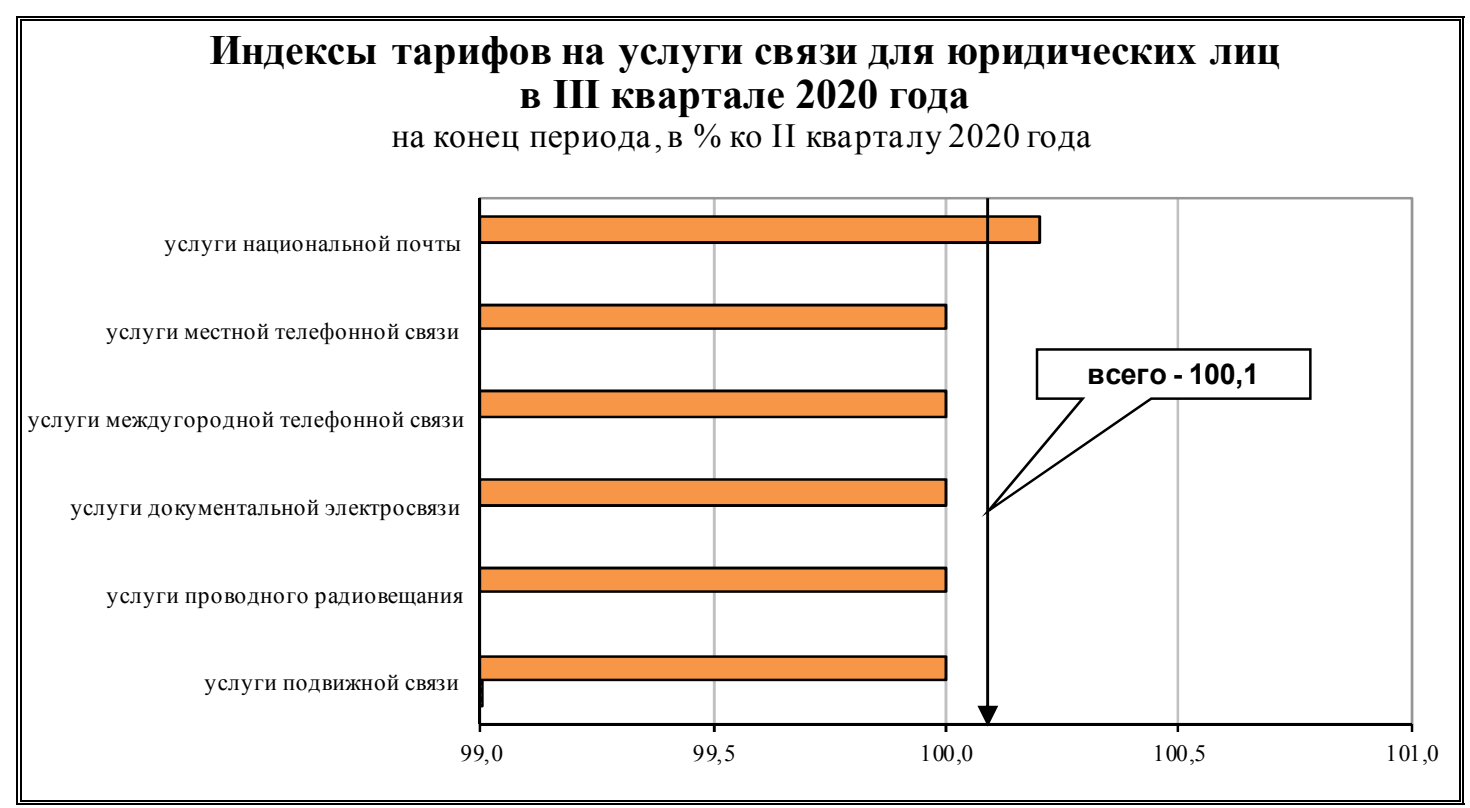




\section{5. ФИНАНСЫ}

\section{1. ГОСУДАРСТВЕННЫЕ ФИНАНСЫ}

\subsection{1. Исполнение бюджета (по данным Федерального казначейства)}

ИСПОЛНЕНИЕ КОНСОЛИДИРОВАННОГО БЮДЖЕТА РОССИЙСКОЙ ФЕДЕРАЦИИ И БЮДЖЕТОВ ГОСУДАРСТВЕННЫХ ВНЕБЮДЖЕТНЫХ ФОНДОВ

млрд рублей

\begin{tabular}{|c|c|c|c|}
\hline & Доходbl & Pacxodbl & $\begin{array}{l}\text { Профииит, } \\
\text { дефицич (-) }\end{array}$ \\
\hline \multicolumn{4}{|c|}{2019 г. } \\
\hline Январь & 2460,8 & 1784,9 & 675,9 \\
\hline Январь-февраль & 5044,6 & 4479,0 & 565,6 \\
\hline І квартал & 8693,4 & 7358,6 & 1334,7 \\
\hline Январь-апрель & 12594,6 & 10704,7 & 1890,0 \\
\hline Январь-май & 15620,4 & 13070,7 & 2549,7 \\
\hline I полугодие & 18583,5 & 15946,2 & 2637,4 \\
\hline Январь-июль & 22508,5 & 18951,6 & 3557,0 \\
\hline Январь-август & 25657,8 & 21675,5 & 3982,3 \\
\hline Январь-сентябрь & 28630,6 & 24637,1 & 3993,5 \\
\hline Январь-октябрь & 32160,0 & 27703,6 & 4456,4 \\
\hline Январь-ноябрь & 34936,3 & 30730,8 & 4205,5 \\
\hline Год & 39110,3 & 36995,3 & 2115,0 \\
\hline \multicolumn{4}{|c|}{2020 г. } \\
\hline Январь & 2590,2 & 2222,4 & 367,8 \\
\hline Январь-февраль & 5134,0 & 5070,6 & 63,4 \\
\hline І квартал & 9223,3 & 8601,9 & 621,4 \\
\hline Январь-апрель & 13187,2 & 12244,7 & 942,5 \\
\hline Январь-май & 15374,0 & 14986,5 & 387,5 \\
\hline I полугодие & 17876,1 & 18725,9 & $-849,8$ \\
\hline Январь-июль & 21013,6 & 22278,9 & $-1265,3$ \\
\hline Январь-август & 23670,8 & 25237,4 & $-1566,6$ \\
\hline
\end{tabular}




\section{СТРУКТУРА КОНСОЛИДИРОВАННОГО БЮДЖЕТА РОССИЙСКОЙ ФЕДЕРАЦИИ И БЮДЖЕТОВ ГОСУДАРСТВЕННЫХ ВНЕБЮДЖЕТНЫХ ФОНДОВ в январе-августе 2020 года}

\begin{tabular}{|c|c|c|c|c|}
\hline & \multirow[t]{2}{*}{$\begin{array}{c}\text { Млрд } \\
\text { рублей }\end{array}$} & \multirow[t]{2}{*}{$\begin{array}{l}\% \kappa \\
\text { umozy }\end{array}$} & \multicolumn{2}{|c|}{$\frac{\text { Справочно }}{\text { январь-август } 20192 .}$} \\
\hline & & & $\begin{array}{c}\text { млрд } \\
\text { рублей }\end{array}$ & $\begin{array}{l}8 \% \kappa \\
\text { umozy }\end{array}$ \\
\hline Доходы & 23670,8 & 100 & 25657,8 & 100 \\
\hline $\begin{array}{l}\text { из них: } \\
\text { налог на прибыль организаций }\end{array}$ & 2711,1 & 11,5 & 3256,2 & 12,7 \\
\hline налог на доходы физических лиц & 2537,1 & 10,7 & 2472,9 & 9,6 \\
\hline $\begin{array}{l}\text { страховые взносы на обязательное } \\
\text { социальное страхование }\end{array}$ & 5153,5 & 21,8 & 5059,0 & 19,7 \\
\hline $\begin{array}{l}\text { налог на добавленную стоимость: } \\
\text { на товары (работы, услуги), реализуемые } \\
\text { на территории Российской Федерации }\end{array}$ & 2589,7 & 10,9 & 2627,8 & 10,2 \\
\hline $\begin{array}{l}\text { на товары, ввозимые на территорию } \\
\text { Российской Федерации }\end{array}$ & 1735,4 & 7,3 & 1797,6 & 7,0 \\
\hline $\begin{array}{l}\text { акцизы по подакцизным товарам (продукции): } \\
\text { производимым на территории Российской Федерации }\end{array}$ & 1192,3 & 5,0 & 795,8 & 3,1 \\
\hline ввозимым на территорию Российской Федерации & 57,6 & 0,2 & 54,6 & 0,2 \\
\hline налоги на совокупный доход & 390,7 & 1,7 & 434,6 & 1,7 \\
\hline налоги на имущество & 820,9 & 3,5 & 863,4 & 3,4 \\
\hline $\begin{array}{l}\text { налоги, сборы и регулярные платежи за пользование } \\
\text { природными ресурсами }\end{array}$ & 2730,5 & 11,5 & 4260,5 & 16,6 \\
\hline доходы от внешнеэкономической деятельности & 1126,4 & 4,8 & 1994,1 & 7,8 \\
\hline $\begin{array}{l}\text { доходы от использования имущества, находящегося } \\
\text { в государственной и муниципальной собственности }\end{array}$ & 625,3 & 2,6 & 893,3 & 3,5 \\
\hline платежи при пользовании природными ресурсами & 328,7 & 1,4 & 300,3 & 1,2 \\
\hline безвозмездные поступления & 1176,9 & 5,0 & 94,8 & 0,4 \\
\hline Расходы & 25237,4 & 100 & 21675,5 & 100 \\
\hline $\begin{array}{l}\text { из них на: } \\
\text { общегосударственные вопросы }\end{array}$ & 1509,6 & 6,0 & 1306,4 & 6,0 \\
\hline национальную оборону & 1927,9 & 7,6 & 1751,3 & 8,1 \\
\hline $\begin{array}{l}\text { национальную безопасность и правоохранительную } \\
\text { деятельность }\end{array}$ & 1384,1 & 5,5 & 1253,2 & 5,8 \\
\hline национальную экономику & 2899,7 & 11,5 & 2382,6 & 11,0 \\
\hline $\begin{array}{l}\text { из нее на: } \\
\text { топливно-энергетический комплекс }\end{array}$ & 40,6 & 0,2 & 37,8 & 0,2 \\
\hline сельское хозяйство и рыболовство & 259,3 & 1,0 & 258,6 & 1,2 \\
\hline транспорт & 573,3 & 2,3 & 459,1 & 2,1 \\
\hline дорожное хозяйство (дорожные фонды) & 1010,5 & 4,0 & 866,7 & 4,0 \\
\hline связь и информатику & 101,4 & 0,4 & 75,3 & 0,3 \\
\hline $\begin{array}{l}\text { прикладные научные исследования в области } \\
\text { национальной экономики }\end{array}$ & 123,2 & 0,5 & 98,9 & 0,5 \\
\hline другие вопросы в области национальной экономики & 654,0 & 2,6 & 469,4 & 2,2 \\
\hline жилищно-коммунальное хозяйство & 907,7 & 3,6 & 791,6 & 3,7 \\
\hline социально-культурные мероприятия & 15919,9 & 63,1 & 13495,1 & 62,3 \\
\hline обслуживание государственного и муниципального долга & 521,3 & 2,1 & 541,3 & 2,5 \\
\hline
\end{tabular}


РАСПРЕДЕЛЕНИЕ ДОХОДОВ И РАСХОДОВ КОНСОЛИДИРОВАННОГО БЮДЖЕТА РОССИЙСКОЙ ФЕДЕРАЦИИ И БЮДЖЕТОВ ГОСУДАРСТВЕННЫХ ВНЕБЮДЖЕТНЫХ ФОНДОВ ПО УРОВНЯМ БЮДЖЕТНОЙ СИСТЕМЫ

млрд рублей

\begin{tabular}{|c|c|c|c|c|c|c|c|c|}
\hline & \multicolumn{4}{|c|}{$\begin{array}{l}\text { Январь-август } \\
2020 \text { г. } \\
\end{array}$} & \multicolumn{4}{|c|}{$\frac{\text { Справочно }}{\text { январь-август } 2019 \text { г. }}$} \\
\hline & \begin{tabular}{|c|} 
феде- \\
ральньй \\
бюджет
\end{tabular} & $\begin{array}{c}\text { бюдже- } \\
\text { тьл госу- } \\
\text { дарст- } \\
\text { венных } \\
\text { внебюд- } \\
\text { жетных } \\
\text { фондов }\end{array}$ & \begin{tabular}{|c|} 
консоли- \\
дирован- \\
нье бюд- \\
жетьл \\
субъектов \\
Россий- \\
ской \\
Федера- \\
ичи \\
\end{tabular} & \begin{tabular}{|c|} 
бюдже- \\
тьл тер- \\
ритори- \\
альных \\
государ- \\
ственных \\
внебюд- \\
жетных \\
фондов \\
\end{tabular} & \begin{tabular}{|c|} 
феде- \\
ральньй \\
бюджет
\end{tabular} & \begin{tabular}{|c|} 
бюдже- \\
тьл госу- \\
дарст- \\
венных \\
внебюд- \\
жетных \\
фондов
\end{tabular} & \begin{tabular}{|c|} 
консоли- \\
дирован- \\
нье бюд- \\
жетьи \\
субъектов \\
Россий- \\
ской \\
Федера- \\
ичии \\
\end{tabular} & \begin{tabular}{|c|} 
бюдже- \\
тьл тер- \\
ритори- \\
альных \\
государ- \\
ственных \\
внебюд- \\
жетных \\
фондов \\
\end{tabular} \\
\hline Доходы & 11688,3 & 8308,1 & 8899,3 & 1638,4 & 13256,7 & 7335,1 & 8627,0 & 1515,6 \\
\hline $\begin{array}{l}\text { из них: } \\
\text { налог на прибыль организаций }\end{array}$ & 725,9 & - & 1985,2 & - & 839,5 & - & 2416,6 & - \\
\hline налог на доходы физических лиц & - & - & 2537,1 & - & - & - & 2472,9 & - \\
\hline $\begin{array}{l}\text { страховые взносы на обязательное } \\
\text { социальное страхование }\end{array}$ & - & 5153,5 & - & - & - & 5059,0 & - & - \\
\hline $\begin{array}{c}\text { налог на добавленную стоимость: } \\
\text { на товары (работы, услуги), } \\
\text { реализуемые на территории } \\
\text { Российской Федерации }\end{array}$ & 2589,7 & - & $-0,0$ & - & 2627,7 & - & 0,1 & - \\
\hline $\begin{array}{l}\text { на товары, ввозимые на территорию } \\
\text { Российской Федерации }\end{array}$ & 1735,4 & - & 0,0 & - & 1797,5 & - & 0,1 & - \\
\hline $\begin{array}{l}\text { акцизы по подакцизным товарам } \\
\text { (продукции): } \\
\text { производимым на территории } \\
\text { Российской Федерации }\end{array}$ & 673,1 & - & 519,2 & - & 309,0 & - & 486,8 & - \\
\hline $\begin{array}{l}\text { ввозимым на территорию } \\
\text { Российской Федерации }\end{array}$ & 57,6 & - & 0,0 & - & 54,6 & - & 0,0 & - \\
\hline налоги на совокупный доход & - & 0,7 & 390,0 & - & - & 0,2 & 434,5 & - \\
\hline налоги на имущество & 0,5 & - & 820,4 & - & 0,1 & - & 863,3 & - \\
\hline $\begin{array}{l}\text { налоги, сборы и регулярные платежи } \\
\text { за пользование природными ресурсами }\end{array}$ & 2681,2 & - & 49,4 & - & 4207,0 & - & 53,5 & - \\
\hline $\begin{array}{l}\text { доходы от внешнеэкономической } \\
\text { деятельности }\end{array}$ & 1126,4 & - & - & - & 1994,1 & - & - & - \\
\hline $\begin{array}{l}\text { доходы от использования имущества, } \\
\text { находящегося в государственной } \\
\text { и муниципальной собственности }\end{array}$ & 391,6 & 22,3 & 211,4 & 0,0 & 586,0 & 39,2 & 268,1 & 0,1 \\
\hline $\begin{array}{c}\text { платежи при пользовании } \\
\text { природными ресурсами }\end{array}$ & 305,2 & - & 23,5 & - & 276,6 & - & 23,6 & - \\
\hline безвозмездные поступления & 1102,5 & 3172,9 & 2133,1 & 1631,6 & 22,2 & 2292,4 & 1348,5 & 1507,9 \\
\hline Расходы & 13256,8 & 8271,7 & 9008,4 & 1563,9 & 10582,4 & 7125,2 & 7613,3 & 1431,3 \\
\hline $\begin{array}{l}\text { из них на: } \\
\text { общегосударственные вопросы }\end{array}$ & 906,6 & 77,2 & 535,2 & 8,1 & 755,9 & 74,2 & 482,0 & 8,0 \\
\hline национальную оборону & 1926,9 & - & 3,0 & - & 1750,8 & - & 2,6 & - \\
\hline $\begin{array}{l}\text { национальную безопасность } \\
\text { и правоохранительную деятельность }\end{array}$ & 1290,2 & - & 95,2 & - & 1174,7 & - & 79,6 & - \\
\hline национальную экономику & 1539,3 & - & 1658,9 & - & 1221,6 & - & 1432,5 & - \\
\hline $\begin{array}{l}\text { из нее на: } \\
\text { топливно-энергетический комплекс }\end{array}$ & 13,6 & - & 30,9 & - & 13,5 & - & 28,9 & - \\
\hline сельское хозяйство и рыболовство & 165,5 & - & 157,2 & - & 173,0 & - & 152,4 & - \\
\hline
\end{tabular}




\begin{tabular}{|c|c|c|c|c|c|c|c|c|}
\hline & \multicolumn{4}{|c|}{$\begin{array}{c}\text { Январь-август } \\
2020 \text { г. }\end{array}$} & \multicolumn{4}{|c|}{$\frac{\text { Справочно }}{\text { январь-август } 20192 .}$} \\
\hline & \begin{tabular}{|c|} 
феде- \\
ральньй \\
бюджет
\end{tabular} & $\begin{array}{c}\text { бюдже- } \\
\text { ты госу- } \\
\text { дарст- } \\
\text { венных } \\
\text { внебюд- } \\
\text { жетных } \\
\text { фондов }\end{array}$ & \begin{tabular}{|c|} 
консоли- \\
дирован- \\
нье бюд- \\
жетьи \\
субъектов \\
Россий- \\
ской \\
Федера- \\
цчии \\
\end{tabular} & \begin{tabular}{|c|} 
бюдже- \\
тьл тер- \\
ритори- \\
альных \\
государ- \\
ственных \\
внебюд- \\
жетных \\
фондов \\
\end{tabular} & \begin{tabular}{|c|} 
феде- \\
ральньй \\
бюджет
\end{tabular} & $\left|\begin{array}{c}\text { бюдже- } \\
\text { ты госу- } \\
\text { дарст- } \\
\text { венных } \\
\text { внебюд- } \\
\text { жетных } \\
\text { фондов }\end{array}\right|$ & $\begin{array}{c}\text { консоли- } \\
\text { дирован- } \\
\text { нье бюд- } \\
\text { жетьи } \\
\text { субъектов } \\
\text { Россий- } \\
\text { ской } \\
\text { Федера- } \\
\text { ичии }\end{array}$ & \begin{tabular}{|c|} 
бюдже- \\
тьл тер- \\
ритори- \\
альныхх \\
государ- \\
ственных \\
внебюд- \\
жетных \\
фондов \\
\end{tabular} \\
\hline транспорт & 182,8 & - & 412,7 & - & 121,7 & - & 339,7 & - \\
\hline $\begin{array}{l}\text { дорожное хозяйство } \\
\text { (дорожные фонды) }\end{array}$ & 427,1 & - & 692,2 & - & 383,7 & - & 580,6 & - \\
\hline связь и информатику & 26,8 & - & 74,7 & - & 27,2 & - & 48,4 & - \\
\hline $\begin{array}{l}\text { прикладные научные исследования } \\
\text { в области национальной экономики }\end{array}$ & 122,9 & - & 0,3 & - & 98,4 & - & 0,5 & - \\
\hline $\begin{array}{c}\text { другие вопросы в области } \\
\text { национальной экономики }\end{array}$ & 507,7 & - & 217,6 & - & 326,8 & - & 216,7 & - \\
\hline жилищно-коммунальное хозяйство & 252,2 & - & 690,9 & - & 143,4 & - & 660,2 & - \\
\hline социально-культурные мероприятия & 5817,6 & 8194,5 & 5931,3 & 1555,8 & 4339,7 & 7051,0 & 4864,1 & 1423,3 \\
\hline $\begin{array}{l}\text { обслуживание государственного и } \\
\text { муниципального долга }\end{array}$ & 456,4 & - & 64,9 & - & 471,4 & - & 69,9 & - \\
\hline $\begin{array}{l}\text { межбюджетные трансферты общего } \\
\text { характера бюджетам бюджетной } \\
\text { системы Российской Федерации }\end{array}$ & 919,9 & - & 0,1 & - & 590,8 & - & 0,4 & - \\
\hline Профицит, дефицит (-) & $-1568,5$ & 36,5 & $-109,1$ & $\mathbf{7 4 , 5}$ & 2674,3 & 209,9 & 1013,7 & 84,3 \\
\hline
\end{tabular}

Таблица 4

ИСПОЛНЕНИЕ ФЕДЕРАЛЬНОГО БЮДЖЕТА

млрд рублей

\begin{tabular}{|c|c|c|c|}
\hline & Дооходы & Pacxodbl & $\begin{array}{l}\text { Профииит, } \\
\text { дефиичит (-) }\end{array}$ \\
\hline \multicolumn{4}{|c|}{2019 г. } \\
\hline Январь & 1486,3 & 1119,6 & 366,7 \\
\hline Январь-февраль & 2844,0 & 2465,3 & 378,7 \\
\hline І квартал & 4590,0 & 3924,1 & 665,9 \\
\hline Январь-апрель & 6361,1 & 5545,3 & 815,8 \\
\hline Январь-май & 7867,4 & 6584,2 & 1283,3 \\
\hline I полугодие & 9549,9 & 7854,1 & 1695,7 \\
\hline Январь-июль & 11471,3 & 9320,2 & 2151,1 \\
\hline Январь-август & 13256,7 & 10582,4 & 2674,3 \\
\hline Январь-сентябрь & 15034,7 & 11948,3 & 3086,5 \\
\hline Январь-октябрь & 16671,2 & 13515,3 & 3155,9 \\
\hline Январь-ноябрь & 18025,6 & 14926,3 & 3099,3 \\
\hline Год & 20187,2 & 18213,2 & 1974,0 \\
\hline \multicolumn{4}{|c|}{2020 г. } \\
\hline Январь & 1556,5 & 1624,4 & $-67,8$ \\
\hline Январь-февраль & 2818,9 & 2982,2 & $-163,3$ \\
\hline І квартал & 4731,3 & 4618,0 & 113,4 \\
\hline
\end{tabular}




\begin{tabular}{||c|c|c|c||}
\hline & Доходь & Paсходыl & $\begin{array}{c}\text { Профицит, } \\
\text { дефичит (-) }\end{array}$ \\
\hline Январь-апрель & 7002,0 & 6755,3 & 246,7 \\
\hline Январь-май & 7891,0 & 8164,7 & $-273,7$ \\
\hline І полугодие & $\mathbf{9 0 9 1 , 9}$ & $\mathbf{9 9 1 5 , 0}$ & $\mathbf{- 8 2 3 , 1}$ \\
\hline Январь-июль & 10399,7 & 11794,9 & $-1395,2$ \\
\hline Январь-август & $\mathbf{1 1 6 8 8 , 3}$ & $\mathbf{1 3 2 5 6 , 8}$ & $\mathbf{- 1 5 6 8 , 5}$ \\
\hline \hline
\end{tabular}

Доходы федерального бюджета в январе-августе 2020 г. составили 56,8\% от прогнозируемого на 2020 г. объема доходов, утвержденного Федеральным законом "О федеральном бюджете на 2020 год и на плановый период 2021 и 2022 годов" от 02.12.2019 № 380-ФЗ в редакции Федерального закона от 18.03.2020 № 52-Ф3.

Таблица 5

\section{ИСПОЛНЕНИЕ РАСХОДНОЙ ЧАСТИ ФЕДЕРАЛЬНОГО БЮДЖЕТА}

\begin{tabular}{|c|c|c|c|}
\hline & \multirow{2}{*}{$\begin{array}{c}\text { Утвержденнье } \\
\text { бюджетные } \\
\text { назначения } \\
\text { на } 2020 \text { г.'), } \\
\text { млрд рублей }\end{array}$} & \multicolumn{2}{|c|}{$\begin{array}{c}\text { Фактическое исполнение } \\
\text { в январе-август } 2020 \text { г. }\end{array}$} \\
\hline & & $\begin{array}{l}\text { млрд } \\
\text { рублей }\end{array}$ & $\begin{array}{c}\text { в\% } \% \\
\text { утвержденным } \\
\text { бюджетным } \\
\text { назначениям } \\
\text { на } 2020 \text { г. }\end{array}$ \\
\hline Расходы & 23734,2 & 13256,8 & 55,9 \\
\hline $\begin{array}{l}\text { из них на: } \\
\text { общегосударственные вопросы }\end{array}$ & 3639,1 & 906,6 & 24,9 \\
\hline национальную оборону & 3308,9 & 1926,9 & 58,2 \\
\hline национальную безопасность и правоохранительную деятельность & 2359,1 & 1290,2 & 54,7 \\
\hline национальную экономику & 3190,7 & 1539,3 & 48,2 \\
\hline $\begin{array}{l}\text { из нее на: } \\
\text { топливно-энергетический комплекс }\end{array}$ & 21,6 & 13,6 & 62,9 \\
\hline сельское хозяйство и рыболовство & 295,8 & 165,5 & 56,0 \\
\hline транспорт & 340,4 & 182,8 & 53,7 \\
\hline дорожное хозяйство (дорожные фонды) & 900,5 & 427,1 & 47,4 \\
\hline связь и информатику & 122,2 & 26,8 & 21,9 \\
\hline прикладные научные исследования в области национальной экономики & 255,6 & 122,9 & 48,1 \\
\hline другие вопросы в области национальной экономики & 1067,2 & 507,7 & 47,6 \\
\hline жилищно-коммунальное хозяйство & 384,0 & 252,2 & 65,7 \\
\hline социально-культурные мероприятия & 8363,5 & 5817,6 & 69,6 \\
\hline обслуживание государственного и муниципального долга & 897,0 & 456,4 & 50,9 \\
\hline $\begin{array}{l}\text { межбюджетные трансферты общего характера бюджетам } \\
\text { бюджетной системы Российской Федерации }\end{array}$ & 1290,3 & 919,9 & 71,3 \\
\hline
\end{tabular}

Процентные платежи (обслуживание государственного и муниципального долга) в январе-августе 2020 г. составили 456,4 млрд рублей, их удельный вес в общем объеме произведенных расходов федерального бюджета составил $3,4 \%$. 

рублей.

Дефицит федерального бюджета в январе-августе 2020 г. сложился в сумме 1568,5 млрд

Таблица 6

ИСТОЧНИКИ ФИНАНСИРОВАНИЯ ДЕФИЦИТА ФЕДЕРАЛЬНОГО БЮДЖЕТА

млрд рублей

\begin{tabular}{|c|c|c|}
\hline & $\begin{array}{l}\text { Январь-август } \\
2020 \text { г. }\end{array}$ & $\begin{array}{c}\text { Справочно } \\
\text { январь-август } \\
2019 \text { г. } \\
\end{array}$ \\
\hline Общее финансирование 1) $^{1}$ & 1568,5 & $-2674,3$ \\
\hline $\begin{array}{l}\text { в том числе: } \\
\text { источники внутреннего финансирования } 2)\end{array}$ & 1873,7 & $-2929,7$ \\
\hline $\begin{array}{l}\text { в том числе: } \\
\text { государственные (муниципальные) ценные бумаги, номинальная } \\
\text { стоимость которых указана в валюте Российской Федерации }\end{array}$ & 1499,1 & 1155,1 \\
\hline изменение остатков средств на счетах по учету средств бюджета 2 ) & 429,6 & $-3913,3$ \\
\hline иные источники внутреннего финансирования дефицитов бюджетов & $-55,0$ & $-171,4$ \\
\hline $\begin{array}{l}\text { из них: } \\
\text { акции и иные формы участия в капитале, находящиеся } \\
\text { в государственной и муниципальной собственности }\end{array}$ & 7,6 & 5,5 \\
\hline государственные запасы драгоценных металлов и драгоценных камней & $-7,1$ & $-1,1$ \\
\hline курсовая разница & 2378,3 & $-406,2$ \\
\hline $\begin{array}{l}\text { бюджетные кредиты, предоставленные внутри страны } \\
\text { в валюте Российской Федерации }\end{array}$ & 2,0 & 17,0 \\
\hline прочие источники внутреннего финансирования дефицитов бюджетов & $-2189,7$ & $-10,2$ \\
\hline операции по управлению остатками средств на единых счетах бюджетов & $-247,5$ & 223,3 \\
\hline источники внешнего финансирования & $-305,2$ & 255,4 \\
\hline $\begin{array}{l}\text { в том числе: } \\
\text { государственные ценные бумаги, номинальная стоимость которых } \\
\text { указана в иностранной валюте }\end{array}$ & $-286,8$ & 282,7 \\
\hline $\begin{array}{l}\text { кредиты иностранных государств, включая целевые } \\
\text { иностранные кредиты (заимствования), международных финансовых } \\
\text { организаций, иных субъектов международного права, } \\
\text { иностранных юридических лиц в иностранной валюте }\end{array}$ & $-4,5$ & $-2,6$ \\
\hline иные источники внешнего финансирования & $-13,9$ & $-24,6$ \\
\hline \multicolumn{3}{|c|}{$\begin{array}{l}\text { 1) С учетом погашения основной суммы задолженности (долга). } \\
\text { Величина превышения доходов над расходами (профицит) имеет положстельный знак, а величина дефицита - от- } \\
\text { рицательный знак. Профиџит или дефиџит покрываются за счет финансирования такой же величины, но с проти- } \\
\text { воположным знаком. } \\
\text { 2) Включая остатки денежных средств бюджетов. }\end{array}$} \\
\hline
\end{tabular}

Поступление нефтегазовых доходов в федеральный бюджет в январе-августе 2020 г. составило 3407,0 млрд рублей, в том числе налог на добычу полезных ископаемых в виде углеводородного сырья - 2525,6 млрд рублей, вывозные таможенные пошлины на нефть сырую, газ природный и товары, выработанные из нефти - 688,8 млрд рублей, налог на дополнительный доход от добычи углеводородного сырья - 98,8 млрд рублей, акциз на нефтяное сырье, направленное на переработку - 93,7 млрд рублей.

Совокупный объем средств Фонда национального благосостояния на 1 сентября 2020 г. составил 13256,7 млрд рублей и по сравнению с 1 августа 2020 г. увеличился на 2,3\%. 


\subsection{2. Налоговая статистика (по данным Федеральной налоговой службы)}

ПОСТУПЛЕНИЕ НАЛОГОВ,

СБОРОВ И ИНЫХ ОБЯЗАТЕЛЬНЫХ ПЛАТЕЖЕЙ

В КОНСОЛИДИРОВАННЫЙ БЮДЖЕТ РОССИЙСКОЙ ФЕДЕРАЦИИ ${ }^{1)}$

млрд рублей

\begin{tabular}{|c|c|c|c|c|c|c|}
\hline & \multicolumn{3}{|c|}{$\begin{array}{c}\text { Январь-август } \\
2020 \text { г. }\end{array}$} & \multicolumn{3}{|c|}{$\begin{array}{c}\text { В\% к } \\
\text { январю-августу } 2019 \text { г. }\end{array}$} \\
\hline & \multirow{2}{*}{$\begin{array}{l}\text { консолиди- } \\
\text { рованный } \\
\text { бюджет }\end{array}$} & \multicolumn{2}{|c|}{ в том числе } & \multirow{2}{*}{$\begin{array}{l}\text { консолиди- } \\
\text { рованныий } \\
\text { бюджет }\end{array}$} & \multicolumn{2}{|c|}{ в том числе } \\
\hline & & $\begin{array}{c}\text { феде- } \\
\text { ральный } \\
\text { бюджет }\end{array}$ & \begin{tabular}{|l} 
консолиди- \\
рованньее \\
бюджеть \\
субъектов \\
Российской \\
Федерачии \\
\end{tabular} & & $\begin{array}{l}\text { феде- } \\
\text { ральный } \\
\text { бюджет }\end{array}$ & \begin{tabular}{|c|} 
консолиди- \\
рованные \\
бюджеть \\
субъектов \\
Российской \\
Федерации \\
\end{tabular} \\
\hline Всего & 13198,3 & 6882,6 & 6315,7 & 87,8 & 83,0 & 93,7 \\
\hline из них: & & & & & & \\
\hline налог на прибыль организаций & 2711,0 & 725,9 & 1985,1 & 83,3 & 86,5 & 82,1 \\
\hline $\begin{array}{l}\text { из него зачисляемый в бюджеты } \\
\text { бюджетной системы Российской } \\
\text { Федерации по соответствующим ставкам }\end{array}$ & 2258,0 & 345,8 & 1912,2 & 80,8 & 77,5 & 81,4 \\
\hline налог на доходы физических лиц & 2536,4 & _ & 2536,4 & 102,6 & ـ & 102,6 \\
\hline $\begin{array}{l}\text { налог на добавленную стоимость } \\
\text { на товары (работы, услуги) }\end{array}$ & 2730,6 & 2730,6 & - & 98,5 & 98,5 & - \\
\hline $\begin{array}{l}\text { из него налог на добавленную стоимость } \\
\text { на товары (работы, услуги), реализуемые } \\
\text { на территории Российской Федерации }\end{array}$ & 2589,7 & 2589,7 & - & 98,6 & 98,6 & - \\
\hline $\begin{array}{l}\text { акцизы по подакцизным товарам (продукции), } \\
\text { прозводимым на территории } \\
\text { Российской Федерации }\end{array}$ & 1192,4 & 673,1 & 519,3 & в $1,5 \mathrm{p}$. & в 2,2p. & 106,3 \\
\hline $\begin{array}{l}\text { из них на: } \\
\text { табачную продукцию }\end{array}$ & 372,0 & 372,0 & - & 114,3 & 114,3 & - \\
\hline автомобильный бензин & 267,6 & 89,4 & 178,2 & 97,4 & 83,5 & 106,2 \\
\hline дизельное топливо & 202,2 & 67,5 & 134,6 & 101,2 & 86,4 & 110,7 \\
\hline пиво & 111,8 & - & 111,8 & 108,3 & - & 108,3 \\
\hline налоги на имущество & 820,3 & - & 820,3 & 95,0 & - & 95,0 \\
\hline из них налог на имущество физических лиц & 9,5 & - & 9,5 & 73,0 & - & 73,0 \\
\hline $\begin{array}{l}\text { налоги, сборы и регулярные платежи } \\
\text { за пользование природными ресурсами }\end{array}$ & 2730,5 & 2681,2 & 49,4 & 64,1 & 63,7 & 92,3 \\
\hline $\begin{array}{l}\text { из них налог на добычу } \\
\text { полезных ископаемых }\end{array}$ & 2604,6 & 2557,7 & 46,9 & 62,5 & 62,1 & 92,5 \\
\hline
\end{tabular}

В январе-августе 2020 г. в консолидированный бюджет Российской Федерации поступило федеральных налогов и сборов на сумму 11904,1 млрд рублей $(90,6 \%$ от общей суммы налоговых доходов), региональных - 707,7 млрд рублей (5,4\%), местных - 116,9 млрд рублей (0,9\%), налогов со специальным налоговым режимом - 408,7 млрд рублей $(3,1 \%)$. 


\begin{tabular}{|c|c|c|}
\hline & $\begin{array}{l}\text { Январь-август } \\
20202 .\end{array}$ & $\begin{array}{c}\text { В\%к } \\
\text { январю-августу } \\
2019 \text {. } \\
\end{array}$ \\
\hline Всего & 4568,5 & 101,6 \\
\hline $\begin{array}{l}\text { в том числе: } \\
\text { страховые и другие взносы на обязательное пенсионное страхование, } \\
\text { зачисляемые в Пенсионный фонд Российской Федерации }\end{array}$ & 3477,1 & 100,4 \\
\hline $\begin{array}{l}\text { страховые взносы на обязательное социальное страхование на случай } \\
\text { временной нетрудоспособности и в связи с материнством }\end{array}$ & 234,3 & 115,0 \\
\hline $\begin{array}{l}\text { страховые взносы на обязательное медицинское страхование } \\
\text { работающего населения, зачисляемые в бюджет Федерального фонда } \\
\text { обязательного медицинского страхования }\end{array}$ & 857,1 & 103,4 \\
\hline
\end{tabular}

Совокупная задолженность по налогам и сборам, страховым взносам, пеням и налоговым санкциям в бюджетную систему Российской Федерации (включая задолженность по единому социальному налогу, страховым взносам и платежам в государственные внебюджетные фонды) на 1 сентября 2020 г. составила 1981,6 млрд рублей.

Таблица 9

\section{СТРУКТУРА СОВОКУПНОЙ ЗАДОЛЖЕННОСТИ В БЮДЖЕТНУЮ СИСТЕМУ РОССИЙСКОЙ ФЕДЕРАЦИИ ПО НАЛОГАМ И СБОРАМ, СТРАХОВЫМ ВЗНОСАМ, ПЕНЯМ И НАЛОГОВЫМ САНКЦИЯМ} на 1 сентября 2020 года

\begin{tabular}{|c|c|c|c|c|c|c|}
\hline & \multirow{2}{*}{\multicolumn{2}{|c|}{$\begin{array}{c}\text { Совокупная задол- } \\
\text { женность по налогам } \\
\text { и сборам, страховым } \\
\text { взносам, пеням } \\
\text { и налоговым санкииям }\end{array}$}} & \multicolumn{4}{|c|}{ Из нее } \\
\hline & & & \multicolumn{2}{|c|}{ недоимка } & \multicolumn{2}{|c|}{$\begin{array}{l}\text { урегулированная } \\
\text { задолженность по } \\
\text { налогам и сборам }\end{array}$} \\
\hline & \begin{tabular}{|l|} 
млрд \\
рублей \\
\end{tabular} & $\begin{array}{l}6 \% \kappa \\
\text { umozy }\end{array}$ & $\begin{array}{l}\text { млрд } \\
\text { рублей }\end{array}$ & $\begin{array}{l}6 \% \kappa \\
\text { umozy }\end{array}$ & $\begin{array}{c}\text { млрд } \\
\text { рублей }\end{array}$ & $\begin{array}{l}6 \% \kappa \\
\text { umozy }\end{array}$ \\
\hline Всего & 1981,6 & 100 & 697,8 & 100 & 130,6 & 100 \\
\hline $\begin{array}{l}\text { из нее: } \\
\text { по федеральным налогам и сборам }\end{array}$ & 1187,0 & 59,9 & 357,3 & 51,2 & 56,4 & 43,2 \\
\hline $\begin{array}{l}\text { из них: } \\
\text { налог на прибыль организаций }\end{array}$ & 235,0 & 11,9 & 67,7 & 9,7 & 13,0 & 10,0 \\
\hline $\begin{array}{l}\text { налог на добавленную стоимость } \\
\text { на товары (работы, услуги) }\end{array}$ & 695,1 & 35,1 & 214,3 & 30,7 & 32,7 & 25,0 \\
\hline $\begin{array}{l}\text { из него налог на добавленную стоимость } \\
\text { на товары (работы, услуги), реализуемые } \\
\text { на территории Российской Федерации }\end{array}$ & 693,4 & 35,0 & 213,1 & 30,5 & 32,6 & 25,0 \\
\hline $\begin{array}{l}\text { налоги, сборы и регулярные платежи } \\
\text { за пользование природными ресурсами }\end{array}$ & 34,9 & 1,8 & 12,8 & 1,8 & 0,9 & 0,7 \\
\hline из них налог на добычу полезных ископаемых & 33,5 & 1,7 & 12,3 & 1,8 & 0,9 & 0,7 \\
\hline $\begin{array}{l}\text { акцизы по подакцизным товарам (продукции), } \\
\text { производимым на территории Российской Федерации }\end{array}$ & 80,3 & 4,1 & 12,3 & 1,8 & 2,3 & 1,7 \\
\hline по региональным налогам и сборам & 176,0 & 8,9 & 72,7 & 10,4 & 17,2 & 13,2 \\
\hline по местным налогам и сборам & 96,7 & 4,9 & 46,2 & 6,6 & 8,0 & 6,1 \\
\hline по налогам со специальным налоговым режимом & 69,8 & 3,5 & 42,7 & 6,1 & 4,8 & 3,7 \\
\hline по единому социальному налогу & 4,4 & 0,2 & 0,4 & 0,1 & 0,1 & 0,0 \\
\hline по страховым взносам & 446,0 & 22,5 & 178,2 & 25,5 & 44,1 & 33,7 \\
\hline
\end{tabular}




\section{2. ФИНАНСОВАЯ ДЕЯТЕЛЬНОСТЬ ОРГАНИЗАЦИЙ (без субъектов малого предпринимательства)}

\subsection{1. Финансовые результаты деятельности организаций}

В январе-августе 2020 г., по оперативным данным, сальдированный финансовый результат (прибыль минус убыток) организаций (без субъектов малого предпринимательства, кредитных организаций, государственных (муниципальных) учреждений, некредитных финансовых организаций) в действующих ценах составил 6502,8 млрд рублей $(37,2$ тыс. организаций получили прибыль в размере 10138,7 млрд рублей, 18,5 тыс. организаций имели убыток на сумму 3635,9 млрд рублей).

Таблица 1

ФИНАНСОВЫЕ РЕЗУЛЬТАТЫ ДЕЯТЕЛЬНОСТИ ОРГАНИЗАЦИЙ ПО ВИДАМ ЭКОНОМИЧЕСКОЙ ДЕЯТЕЛЬНОСТИ в январе-августе 2020 года

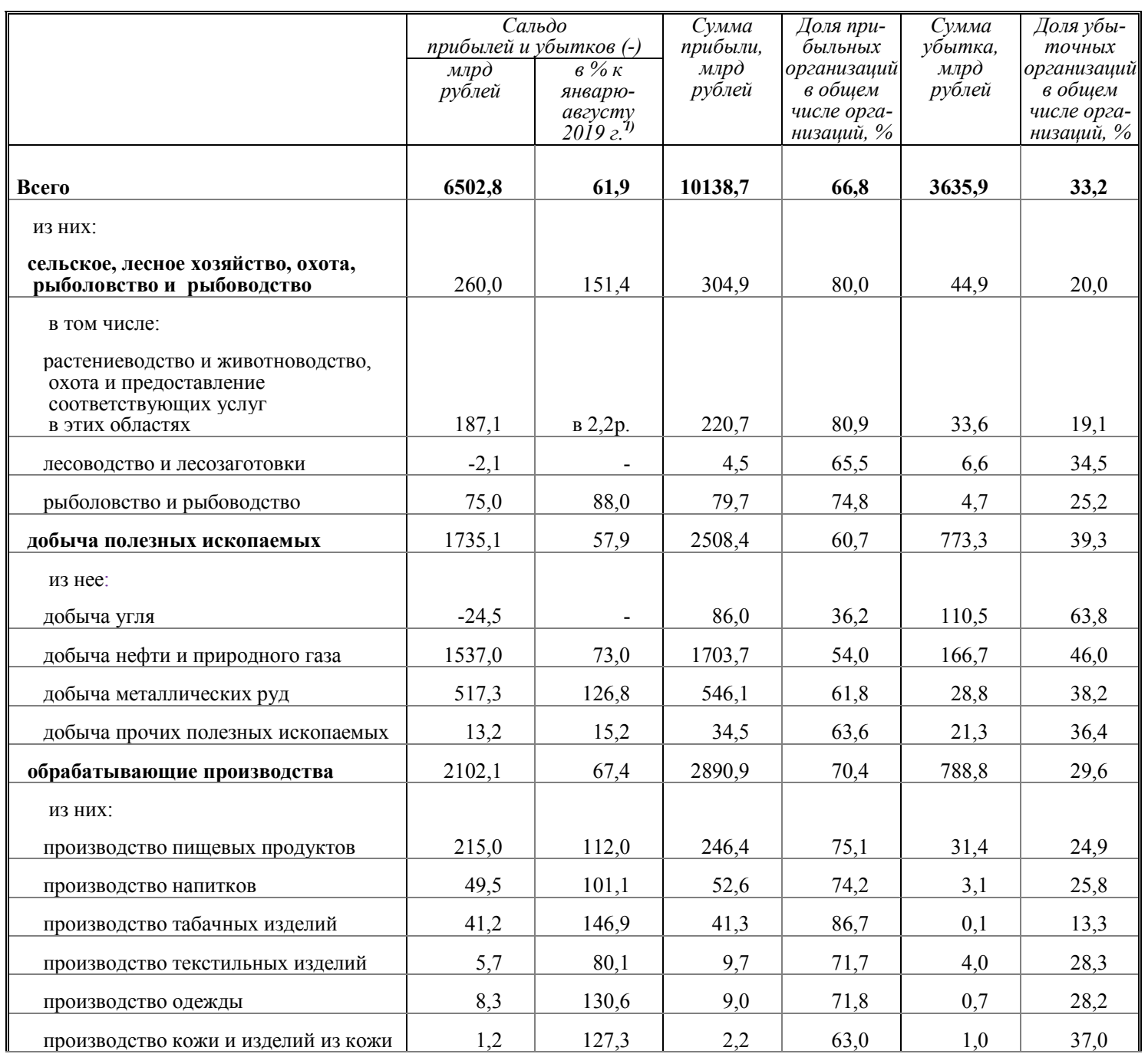




\begin{tabular}{|c|c|c|c|c|c|c|}
\hline & \multicolumn{2}{|c|}{$\begin{array}{c}\text { Сальдо } \\
\text { прибылей и убытков (-) }\end{array}$} & \multirow{2}{*}{$\begin{array}{l}\text { Сумма } \\
\text { прибыли, } \\
\text { млрд } \\
\text { рублей }\end{array}$} & \multirow{2}{*}{\begin{tabular}{|c|} 
Доля при- \\
быльныхх \\
организачий \\
в общем \\
числе орга- \\
низаций, \% \\
\end{tabular}} & \multirow{2}{*}{$\begin{array}{c}\text { Сумма } \\
\text { убиткка, } \\
\text { млрд } \\
\text { рублей }\end{array}$} & \multirow{2}{*}{\begin{tabular}{|c} 
Доля убы- \\
точныхх \\
организачий \\
в обшем \\
числе орга- \\
низачий, \% \\
\end{tabular}} \\
\hline & $\begin{array}{c}\text { млрд } \\
\text { рублей }\end{array}$ & $\begin{array}{l}\text { в\% к } \\
\text { январю- } \\
\text { августу } \\
2019 \text { 2. }\end{array}$ & & & & \\
\hline $\begin{array}{l}\text { обработка древесины и производство } \\
\text { изделий из дерева и пробки, кроме } \\
\text { мебели, производство изделий из } \\
\text { соломки и материалов для плетения }\end{array}$ & $-15,4$ & - & 25,0 & 61,5 & 40,4 & 38,5 \\
\hline $\begin{array}{c}\text { производство бумаги } \\
\text { и бумажных изделий }\end{array}$ & 39,7 & 39,4 & 56,5 & 72,1 & 16,8 & 27,9 \\
\hline $\begin{array}{l}\text { деятельность полиграфическая и } \\
\text { копирование носителей информации }\end{array}$ & 11,5 & 88,5 & 12,9 & 59,8 & 1,4 & 40,2 \\
\hline производство кокса и нефтепродуктов & 656,8 & 72,7 & 778,3 & 72,8 & 121,5 & 27,2 \\
\hline $\begin{array}{l}\text { из них: } \\
\text { производство кокса }\end{array}$ & 6,3 & 69,9 & 7,3 & 83,3 & 1,0 & 16,7 \\
\hline производство нефтепродуктов & 650,5 & 72,7 & 771,0 & 72,0 & 120,5 & 28,0 \\
\hline $\begin{array}{l}\text { производство химических веществ } \\
\text { и химических продуктов }\end{array}$ & 87,9 & 20,6 & 226,0 & 76,6 & 138,1 & 23,4 \\
\hline $\begin{array}{l}\text { производство лекарственных средств } \\
\text { и материалов, применяемых } \\
\text { в медицинских целях }\end{array}$ & 88,2 & 169,7 & 93,1 & 82,8 & 4,9 & 17,2 \\
\hline $\begin{array}{c}\text { производство резиновых } \\
\text { и пластмассовых изделий }\end{array}$ & 41,4 & 103,5 & 46,9 & 77,9 & 5,5 & 22,1 \\
\hline $\begin{array}{l}\text { производство прочей } \\
\text { неметаллической } \\
\text { минеральной продукции }\end{array}$ & 49,6 & 65,0 & 81,5 & 65,9 & 31,9 & 34,1 \\
\hline производство металлургическое & 583,8 & 73,2 & 704,4 & 67,6 & 120,6 & 32,4 \\
\hline $\begin{array}{l}\text { производство готовых } \\
\text { металлических изделий, } \\
\text { кроме машин и оборудования }\end{array}$ & 91,9 & 111,2 & 124,9 & 68,0 & 33,0 & 32,0 \\
\hline $\begin{array}{l}\text { производство компьютеров, } \\
\text { электронных и оптических изделий }\end{array}$ & 45,0 & 56,8 & 75,7 & 70,1 & 30,7 & 29,9 \\
\hline $\begin{array}{l}\text { производство электрического } \\
\text { оборудования }\end{array}$ & 26,2 & 107,1 & 33,6 & 72,4 & 7,4 & 27,6 \\
\hline $\begin{array}{l}\text { производство машин и оборудования, } \\
\text { не включенных в другие группировки }\end{array}$ & 29,8 & 61,1 & 70,9 & 70,1 & 41,1 & 29,9 \\
\hline $\begin{array}{l}\text { производство автотранспортных } \\
\text { средств, прицепов и полуприцепов }\end{array}$ & $-4,1$ & - & 37,1 & 57,9 & 41,2 & 42,1 \\
\hline $\begin{array}{l}\text { производство прочих транспортных } \\
\text { средств и оборудования }\end{array}$ & 18,2 & 25,8 & 118,7 & 60,1 & 100,5 & 39,9 \\
\hline производство мебели & 1,4 & 62,1 & 3,2 & 66,7 & 1,8 & 33,3 \\
\hline производство прочих готовых изделий & 5,8 & в $5,2 \mathrm{p}$. & 6,8 & 74,2 & 1,0 & 25,8 \\
\hline $\begin{array}{l}\text { обеспечение электрической } \\
\text { энергией, газом и паром; } \\
\text { кондиционирование воздуха }\end{array}$ & 388,0 & 71,1 & 572,7 & 49,4 & 184,7 & 50,6 \\
\hline $\begin{array}{l}\text { в том числе: } \\
\text { производство, передача } \\
\text { и распределение электроэнергии }\end{array}$ & 459,2 & 88,3 & 504,6 & 71,2 & 45,4 & 28,8 \\
\hline $\begin{array}{l}\text { производство и распределение } \\
\text { газообразного топлива }\end{array}$ & $-70,0$ & - & 24,8 & 76,6 & 94,8 & 23,4 \\
\hline $\begin{array}{l}\text { производство, передача } \\
\text { и распределение пара и горячей воды; } \\
\text { кондиционирование воздуха }\end{array}$ & $-1,2$ & - & 43,3 & 37,8 & 44,5 & 62,2 \\
\hline $\begin{array}{l}\text { водоснабжение; водоотведение, } \\
\text { организация сбора и утилизации } \\
\text { отходов, деятельность по } \\
\text { ликвидации загрязнений }\end{array}$ & 26,8 & 78,7 & 41,9 & 51,6 & 15,1 & 48,4 \\
\hline
\end{tabular}




\begin{tabular}{|c|c|c|c|c|c|c|}
\hline & \multicolumn{2}{|c|}{$\begin{array}{c}\text { Сальдо } \\
\text { прибылей и убытков (-) }\end{array}$} & \multirow{2}{*}{$\begin{array}{c}\text { Сумма } \\
\text { прибыли, } \\
\text { млрд } \\
\text { рублей }\end{array}$} & \multirow{2}{*}{\begin{tabular}{|c|} 
Доля при- \\
быльных \\
организаций \\
в общем \\
числе орга- \\
низаций, \% \\
\end{tabular}} & \multirow{2}{*}{$\begin{array}{c}\text { Сумма } \\
\text { убытка, } \\
\text { млрд } \\
\text { рублей }\end{array}$} & \multirow{2}{*}{\begin{tabular}{|c|} 
Доля убы-- \\
точныхх \\
организациии \\
в общемем \\
числе орга- \\
низаций, \% \\
\end{tabular}} \\
\hline & $\begin{array}{c}\text { млрд } \\
\text { рублей }\end{array}$ & $\begin{array}{l}\text { в\% к } \\
\text { январю- } \\
\text { августу } \\
2019 \text {.. } \\
\end{array}$ & & & & \\
\hline строительство & 121,6 & 124,0 & 248,0 & 71,8 & 126,4 & 28,2 \\
\hline $\begin{array}{l}\text { из него: } \\
\text { строительство зданий }\end{array}$ & 72,3 & 130,1 & 129,2 & 72,9 & 56,9 & 27,1 \\
\hline $\begin{array}{l}\text { строительство инженерных } \\
\text { сооружений }\end{array}$ & 25,5 & 84,8 & 75,5 & 71,0 & 50,0 & 29,0 \\
\hline $\begin{array}{l}\text { торговля оптовая и розничная; } \\
\text { ремонт автотранспортных } \\
\text { средств и мотоциклов }\end{array}$ & 672,2 & 44,9 & 1445,4 & 76,8 & 773,2 & 23,2 \\
\hline $\begin{array}{l}\text { в том числе: } \\
\text { торговля оптовая и розничная } \\
\text { автотранспортными средствами } \\
\text { и мотоциклами и их ремонт }\end{array}$ & 97,4 & 141,7 & 108,5 & 78,9 & 11,1 & 21,1 \\
\hline $\begin{array}{l}\text { торговля оптовая, кроме оптовой } \\
\text { торговли автотранспортными } \\
\text { средствами и мотоциклами }\end{array}$ & 329,0 & 26,1 & 1008,6 & 79,3 & 679,6 & 20,7 \\
\hline $\begin{array}{l}\text { торговля розничная, кроме торговли } \\
\text { автотранспортными средствами } \\
\text { и мотоциклами }\end{array}$ & 245,8 & 144,3 & 328,3 & 67,0 & 82,5 & 33,0 \\
\hline транспортировка и хранение & 391,3 & 44,7 & 706,8 & 59,8 & 315,5 & 40,2 \\
\hline $\begin{array}{l}\text { в том числе: } \\
\text { деятельность сухопутного } \\
\text { и трубопроводного транспорта }\end{array}$ & 212,5 & 47,4 & 346,2 & 50,5 & 133,7 & 49,5 \\
\hline $\begin{array}{l}\text { в том числе: } \\
\text { деятельность железнодорожного } \\
\text { транспорта: междугородные } \\
\text { и международные } \\
\text { пассажирские перевозки }\end{array}$ & $-13,5$ & - & 16,7 & 26,7 & 30,2 & 73,3 \\
\hline $\begin{array}{l}\text { деятельность железнодорожного } \\
\text { транспорта: грузовые перевозки }\end{array}$ & 9,0 & 9,6 & 39,9 & 74,8 & 30,9 & 25,2 \\
\hline $\begin{array}{l}\text { деятельность прочего сухопутного } \\
\text { пассажирского транспорта }\end{array}$ & $-60,7$ & - & 4,4 & 30,4 & 65,1 & 69,6 \\
\hline $\begin{array}{l}\text { деятельность автомобильного } \\
\text { грузового транспорта } \\
\text { и услуги по перевозкам }\end{array}$ & 16,3 & 107,7 & 22,6 & 71,0 & 6,3 & 29,0 \\
\hline $\begin{array}{l}\text { деятельность трубопроводного } \\
\text { транспорта }\end{array}$ & 261,4 & 110,6 & 262,6 & 86,2 & 1,2 & 13,8 \\
\hline деятельность водного транспорта & 9,6 & 77,0 & 21,4 & 60,6 & 11,8 & 39,4 \\
\hline $\begin{array}{l}\text { деятельность воздушного } \\
\text { и космического транспорта }\end{array}$ & $-59,0$ & - & 50,9 & 51,5 & 109,9 & 48,5 \\
\hline $\begin{array}{l}\text { складское хозяйство и } \\
\text { вспомогательная } \\
\text { транспортная деятельность }\end{array}$ & 226,5 & 57,4 & 284,0 & 67,7 & 57,5 & 32,3 \\
\hline $\begin{array}{l}\text { деятельность почтовой связи } \\
\text { и курьерская деятельность }\end{array}$ & 1,7 & 196,1 & 4,3 & 73,2 & 2,6 & 26,8 \\
\hline $\begin{array}{l}\text { деятельность гостиниц } \\
\text { и предприятий } \\
\text { общественного питания }\end{array}$ & $-43,2$ & - & 20,0 & 36,2 & 63,2 & 63,8 \\
\hline $\begin{array}{l}\text { в том числе: } \\
\text { деятельность по предоставлению } \\
\text { мест для временного проживания }\end{array}$ & $-44,4$ & - & 4,3 & 32,5 & 48,7 & 67,5 \\
\hline $\begin{array}{l}\text { деятельность по предоставлению } \\
\text { продуктов питания и напитков }\end{array}$ & 1,2 & 8,9 & 15,7 & 39,7 & 14,5 & 60,3 \\
\hline
\end{tabular}




\begin{tabular}{|c|c|c|c|c|c|c|}
\hline & \multicolumn{2}{|c|}{$\begin{array}{c}\text { Сальдо } \\
\text { прибылей и убытков (-) }\end{array}$} & \multirow{2}{*}{$\begin{array}{c}\text { Сумма } \\
\text { прибьли, } \\
\text { млрд } \\
\text { рублей }\end{array}$} & \multirow{2}{*}{\begin{tabular}{c|} 
Доля при- \\
быльныхх \\
организаиий \\
в общем \\
числе орга- \\
низаций, \% \\
\end{tabular}} & \multirow{2}{*}{$\begin{array}{c}\text { Сумма } \\
\text { убитка, } \\
\text { млрд } \\
\text { рублей }\end{array}$} & \multirow{2}{*}{\begin{tabular}{|c|} 
Доля убы- \\
точных \\
организаций \\
в общеме \\
числе орга- \\
низачий, \% \\
\end{tabular}} \\
\hline & $\begin{array}{c}\text { млрд } \\
\text { рублей }\end{array}$ & $\begin{array}{l}\text { в\% } \\
\text { январю- } \\
\text { августу } \\
2019 \text { 2. }\end{array}$ & & & & \\
\hline $\begin{array}{l}\text { деятельность в области } \\
\text { информации и связи }\end{array}$ & 295,7 & 96,3 & 393,8 & 61,9 & 98,1 & 38,1 \\
\hline $\begin{array}{l}\text { из нее: } \\
\text { деятельность издательская }\end{array}$ & 13,0 & 107,3 & 15,8 & 56,4 & 2,8 & 43,6 \\
\hline $\begin{array}{l}\text { деятельность в сфере } \\
\text { телекоммуникаций }\end{array}$ & 99,7 & 63,4 & 131,8 & 71,7 & 32,1 & 28,3 \\
\hline $\begin{array}{l}\text { деятельность в области } \\
\text { информационных технологий }\end{array}$ & 48,7 & 106,8 & 61,0 & 64,4 & 12,3 & 35,6 \\
\hline $\begin{array}{c}\text { деятельность по операциям } \\
\text { с недвижимым имуществом }\end{array}$ & 116,7 & 43,5 & 298,3 & 64,8 & 181,6 & 35,2 \\
\hline $\begin{array}{l}\text { деятельность профессиональная, } \\
\text { научная и техническая }\end{array}$ & 244,4 & 60,7 & 440,6 & 58,5 & 196,2 & 41,5 \\
\hline $\begin{array}{l}\text { из нее научные исследования } \\
\text { и разработки }\end{array}$ & 13,8 & 39,7 & 53,4 & 56,8 & 39,6 & 43,2 \\
\hline $\begin{array}{l}\text { деятельность административная } \\
\text { и сопутствующие } \\
\text { дополнительные услуги }\end{array}$ & 126,5 & 128,2 & 157,2 & 72,6 & 30,7 & 27,4 \\
\hline $\begin{array}{l}\text { из нее деятельность туристических } \\
\text { агентств и прочих организаций, } \\
\text { предоставляющих услуги } \\
\text { в сфере туризма }\end{array}$ & $-6,9$ & - & 0,7 & 39,7 & 7,6 & 60,3 \\
\hline $\begin{array}{l}\text { государственное управление } \\
\text { и обеспечение военной безопасности; } \\
\text { социальное обеспечение }\end{array}$ & 30,3 & 115,3 & 30,6 & 79,2 & 0,3 & 20,8 \\
\hline образование & 6,1 & в 2,1p. & 8,1 & 72,3 & 2,0 & 27,7 \\
\hline $\begin{array}{l}\text { деятельность в области } \\
\text { здравоохранения и социальных услуг }\end{array}$ & 11,1 & 59,3 & 28,5 & 53,1 & 17,4 & 46,9 \\
\hline $\begin{array}{l}\text { из нее деятельность } \\
\text { в области здравоохранения }\end{array}$ & 10,2 & 57,7 & 27,3 & 49,2 & 17,1 & 50,8 \\
\hline $\begin{array}{l}\text { деятельность в области культуры, } \\
\text { спорта, организации досуга } \\
\text { и развлечений }\end{array}$ & 10,2 & 65,3 & 31,7 & 53,0 & 21,5 & 47,0 \\
\hline $\begin{array}{l}\text { из нее: } \\
\text { деятельность библиотек, архивов, } \\
\text { музеев и прочих объектов культуры }\end{array}$ & $-0,9$ & - & 0,1 & 50,0 & 1,0 & 50,0 \\
\hline $\begin{array}{l}\text { деятельность в области спорта, } \\
\text { отдыха и развлечений }\end{array}$ & $-8,7$ & - & 7,8 & 54,1 & 16,5 & 45,9 \\
\hline предоставление прочих видов услуг & 7,9 & 140,6 & 10,9 & 63,8 & 3,0 & 36,2 \\
\hline $\begin{array}{l}\text { 1) Темпьы изменения сальдированного фин } \\
\text { периодом предыдущего года рассчита } \\
\text { галтерского учета; с учетом коррект } \\
\text { менений учетной политики, законодап } \\
\text { мых периодах был получен отрищатель }\end{array}$ & $\begin{array}{l}\text { ового ре } \\
\text { lо сопос } \\
\text { вки дан } \\
\text { нысх ак } \\
\check{\iota} \text { сальди }\end{array}$ & $\begin{array}{l}\text { пата оти } \\
\text { иому крус } \\
\text { оответс } \\
\text { др. Проч } \\
\text { ный финс }\end{array}$ & $\begin{array}{l}\text { го пери } \\
\text { анизаи } \\
\text { щего } \\
\text { значае } \\
\text { sй резу }\end{array}$ & $\begin{array}{l}\text { по сравнен } \\
\text { соответсп } \\
\text { да предыду } \\
\text { то в однол } \\
\text { ат. } \\
\end{array}$ & $\begin{array}{l}\text { с соотве } \\
\text { и с метод } \\
\text { его года, } \\
\text { ии обоих с }\end{array}$ & $\begin{array}{l}\text { иствуюшим } \\
\text { ологией бух- } \\
\text { сходя из из- } \\
\text { поставляе- } \\
\end{array}$ \\
\hline
\end{tabular}

В январе-августе 2020 г., по оперативным данным, доля убыточных организаций по сравнению с соответствующим периодом предыдущего года увеличилась на 3,2 процентного пункта и составила $33,2 \%$. 


\subsection{2. Состояние платежей и расчетов в организациях}

На конец августа 2020 г. суммарная задолженность по обязательствам организаций, по оперативным данным, в целом по России составила 124883,1 млрд рублей, из нее просроченная - 4940,7 млрд рублей, или 4,0\% от общей суммы задолженности (на конец августа 2019 г. $3,7 \%$, на конец июля 2020 г. - 4,0\%).

Таблица 2

\section{РАЗМЕР И СТРУКТУРА ЗАДОЛЖЕННОСТИ ОРГАНИЗАЦИЙ}

на конец месяца

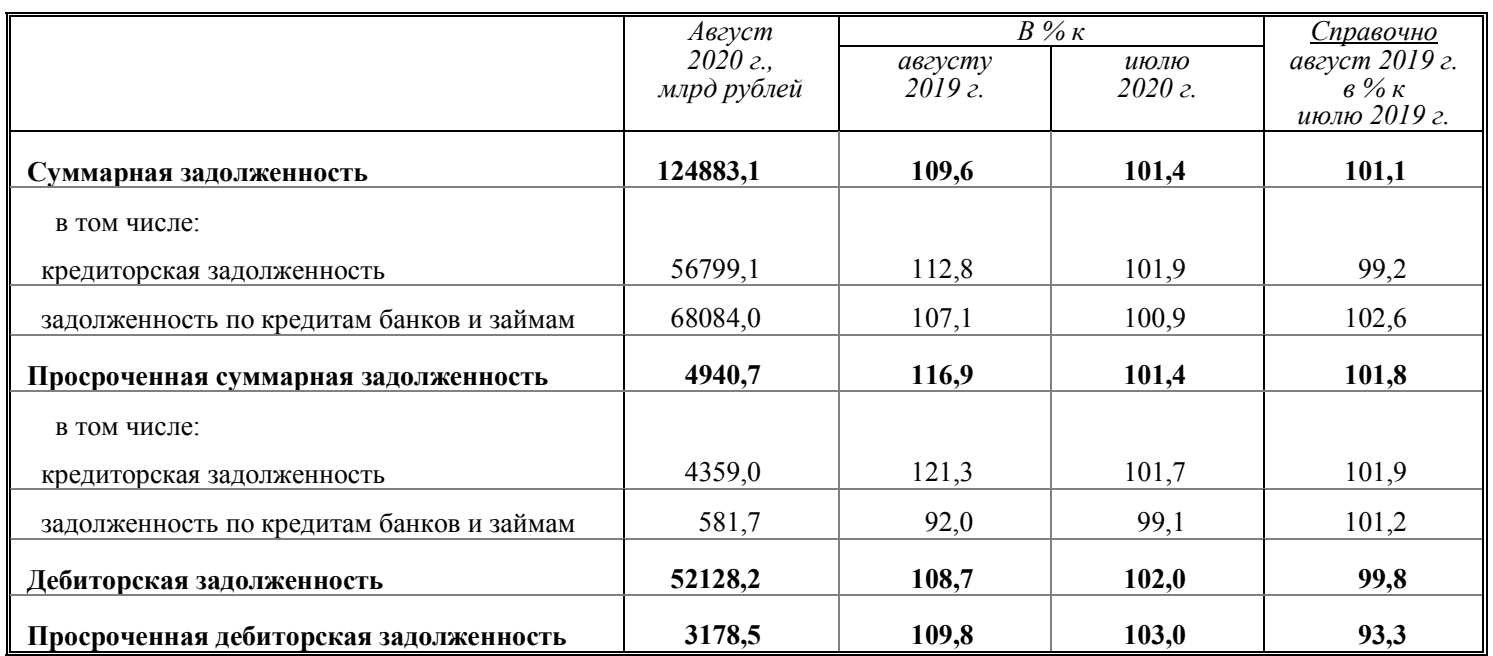

Кредиторская задолженность в целом по России на конец августа 2020 г., по оперативным данным, составила 56799,1 млрд рублей, из нее просроченная - 4359,0 млрд рублей, или 7,7\% от общей суммы кредиторской задолженности (на конец августа 2019 г. - 7,1\%, на конец июля 2020 г. - 7,7\%).

Таблица 3

СТРУКТУРА И ДИНАМИКА

ПРОСРОЧЕННОЙ КРЕДИТОРСКОЙ ЗАДОЛЖЕННОСТИ ОРГАНИЗАЦИЙ

на конец месяца

\begin{tabular}{|c|c|c|c|c|c|}
\hline & \multirow[b]{2}{*}{$\begin{array}{c}\text { Количество } \\
\text { организаций, } \\
\text { имеюших } \\
\text { просроченную } \\
\text { кредиторскую } \\
\text { задолюенность, } \\
\text { единиц }\end{array}$} & \multirow{2}{*}{$\begin{array}{c}\text { Просроченная } \\
\text { кредиторская } \\
\text { задолженность, } \\
\text { млрд рублей }\end{array}$} & \multicolumn{3}{|c|}{ Из нее } \\
\hline & & & поставщикам & $\begin{array}{l}\text { в бюджеть } \\
\text { всех уровней }\end{array}$ & $\begin{array}{c}\text { по платежам } \\
\text { в государ- } \\
\text { ственные } \\
\text { внебюджетные } \\
\text { фонды }\end{array}$ \\
\hline \multicolumn{6}{|c|}{2019 г. } \\
\hline Январь & 6512 & 3197,4 & 2257,0 & 52,9 & 42,6 \\
\hline Февраль & 6597 & 3268,9 & 2298,7 & 56,5 & 43,3 \\
\hline Март & 6665 & 3687,9 & 2582,9 & 58,4 & 48,4 \\
\hline Апрель & 6669 & 3538,5 & 2395,9 & 59,3 & 45,8 \\
\hline Май & 6690 & 3613,1 & 2499,7 & 60,4 & 45,5 \\
\hline Июнь & 6786 & 3429,0 & 2267,6 & 59,8 & 44,8 \\
\hline Июль & 6765 & 3524,3 & 2310,3 & 60,8 & 45,2 \\
\hline Август & 6737 & 3592,9 & 2348,8 & 61,8 & 44,9 \\
\hline
\end{tabular}




\begin{tabular}{|c|c|c|c|c|c|}
\hline & \multirow[b]{2}{*}{$\begin{array}{c}\text { Количество } \\
\text { организачий, } \\
\text { имеюших } \\
\text { просроченную } \\
\text { кредиторскую } \\
\text { задолженность, } \\
\text { единиц } \\
\end{array}$} & \multirow{2}{*}{\begin{tabular}{|c|} 
Просроченная \\
кредиторская \\
задолженность, \\
млрд рублей
\end{tabular}} & \multicolumn{3}{|c|}{ Из нее } \\
\hline & & & поставщикам & $\begin{array}{l}\text { в бюджетьи } \\
\text { всех уровней }\end{array}$ & $\begin{array}{c}\text { по платежам } \\
\text { в государ- } \\
\text { ственные } \\
\text { внебюджетные } \\
\text { фондыл }\end{array}$ \\
\hline Сентябрь & 6791 & 3858,1 & 2609,9 & 61,4 & 42,7 \\
\hline Октябрь & 6776 & 3957,5 & 2701,2 & 61,5 & 43,5 \\
\hline Ноябрь & 6730 & 4076,2 & 2790,8 & 62,6 & 43,6 \\
\hline Декабрь & 6697 & 3898,2 & 2645,0 & 63,2 & 42,7 \\
\hline \multicolumn{6}{|c|}{2020 г. } \\
\hline Январь & 6314 & 3530,2 & 2534,8 & 53,0 & 33,7 \\
\hline Февраль & 6339 & 3720,0 & 2655,2 & 55,0 & 34,8 \\
\hline Март & 6394 & 3891,7 & 2839,4 & 60,4 & 34,3 \\
\hline Апрель & 6492 & 3845,5 & 2734,9 & 69,5 & 39,1 \\
\hline Май & 6561 & 4146,0 & 3006,9 & 77,6 & 40,9 \\
\hline Июнь & 6773 & 3977,5 & 2835,6 & 81,5 & 42,5 \\
\hline Июль & 6708 & 4284,9 & 3079,1 & 79,6 & 43,3 \\
\hline Август & 6743 & 4359,0 & 3038,1 & 68,8 & 43,3 \\
\hline
\end{tabular}

\section{ПРОСРОЧЕННАЯ КРЕДИТОРСКАЯ ЗАДОЛЖЕННОСТЬ ОРГАНИЗАЦИЙ ПО ВИДАМ ЭКОНОМИЧЕСКОЙ ДЕЯТЕЛЬНОСТИ} в августе 2020 года

Таблица 4

на конец месяца

\begin{tabular}{|c|c|c|c|c|c|}
\hline & \multirow[b]{2}{*}{\begin{tabular}{|c|} 
Количество \\
организачий, \\
имеючих \\
просроченную \\
кредиторскую \\
задолжен- \\
ность, единии
\end{tabular}} & \multirow{2}{*}{$\begin{array}{c}\text { Просроченная } \\
\text { кредиторская } \\
\text { задолжен- } \\
\text { ность, } \\
\text { млрд рублей }\end{array}$} & \multicolumn{3}{|c|}{ Из нее } \\
\hline & & & поставщикам & $\begin{array}{l}\text { в бюджеть } \\
\text { всех уровней }\end{array}$ & $\begin{array}{c}\text { по платежам } \\
\text { в государ- } \\
\text { ственные } \\
\text { внебюджет- } \\
\text { ные фонды }\end{array}$ \\
\hline Всего & 6743 & 4359,0 & 3038,1 & 68,8 & 43,3 \\
\hline $\begin{array}{l}\text { из них: } \\
\text { сельское, лесное хозяйство, охота, } \\
\text { рыболовство и рыбоводство }\end{array}$ & 371 & 109,3 & 15,1 & 1,1 & 1,0 \\
\hline $\begin{array}{l}\text { в том числе: } \\
\text { растениеводство и животноводство, } \\
\text { охота и предоставление } \\
\text { соответствующих услуг в этих областях }\end{array}$ & 339 & 105,6 & 14,4 & 1,1 & 1,0 \\
\hline лесоводство и лесозаготовки & 17 & 0,7 & 0,6 & 0,0 & 0,0 \\
\hline рыболовство и рыбоводство & 15 & 3,0 & 0,1 & 0,0 & 0,0 \\
\hline добыча полезных ископаемых & 298 & 253,7 & 204,5 & 6,4 & 5,0 \\
\hline $\begin{array}{l}\text { из нее: } \\
\text { добыча угля }\end{array}$ & 74 & 147,2 & 125,8 & 2,1 & 3,4 \\
\hline добыча нефти и природного газа & 60 & 58,8 & 38,6 & 1,3 & 0,0 \\
\hline добыча металлических руд & 41 & 13,0 & 10,0 & 1,5 & 1,2 \\
\hline добыча прочих полезных ископаемых & 64 & 2,0 & 1,3 & 0,1 & 0,1 \\
\hline обрабатывающие производства & 1532 & 1938,0 & 1483,8 & 20,6 & 14,2 \\
\hline $\begin{array}{l}\text { из них: } \\
\text { производство пищевых продуктов }\end{array}$ & 145 & 9,0 & 7,1 & 0,3 & 0,2 \\
\hline
\end{tabular}




\begin{tabular}{|c|c|c|c|c|c|}
\hline & \multirow[b]{2}{*}{$\begin{array}{c}\text { Количество } \\
\text { организаций, } \\
\text { имеюших } \\
\text { просроченную } \\
\text { кредиторскую } \\
\text { задолэен- } \\
\text { ность, единиц } \\
\end{array}$} & \multirow[b]{2}{*}{$\begin{array}{c}\text { Просроченная } \\
\text { кредиторская } \\
\text { задолюен- } \\
\text { ность, } \\
\text { млрд рублей }\end{array}$} & \multicolumn{3}{|c|}{ Из нее } \\
\hline & & & поставщикам & $\begin{array}{l}\text { в бюджетьи } \\
\text { всех уровней }\end{array}$ & $\begin{array}{c}\text { по платежам } \\
\text { в государ- } \\
\text { ственные } \\
\text { внебюджет- } \\
\text { ные фонды }\end{array}$ \\
\hline производство напитков & 31 & 7,4 & 5,3 & 0,8 & 0,0 \\
\hline производство табачных изделий & $\ldots{ }^{1)}$ & $\ldots^{1)}$ & - & - & - \\
\hline производство текстильных изделий & 26 & 6,6 & 6,0 & 0,4 & 0,2 \\
\hline производство одежды & 8 & 0,1 & 0,1 & 0,0 & 0,0 \\
\hline производство кожи и изделий из кожи & 11 & 0,1 & 0,1 & 0,0 & 0,0 \\
\hline $\begin{array}{l}\text { обработка древесины и производство } \\
\text { изделий из дерева и пробки, кроме } \\
\text { мебели, производство изделий из } \\
\text { соломки и материалов для плетения }\end{array}$ & 49 & 5,2 & 3,0 & 0,3 & 0,4 \\
\hline $\begin{array}{c}\text { производство бумаги } \\
\text { и бумажных изделий }\end{array}$ & 28 & 11,0 & 9,3 & 0,7 & 0,2 \\
\hline $\begin{array}{l}\text { деятельность полиграфическая и } \\
\text { копирование носителей информации }\end{array}$ & 12 & 0,1 & 0,1 & 0,0 & 0,0 \\
\hline производство кокса и нефтепродуктов & 37 & 975,5 & 965,6 & 1,6 & 0,0 \\
\hline $\begin{array}{l}\text { из них: } \\
\text { производство кокса }\end{array}$ & 3 & 1,3 & 1,3 & - & - \\
\hline производство нефтепродуктов & 34 & 974,2 & 964,3 & 1,6 & 0,0 \\
\hline $\begin{array}{l}\text { производство химических веществ } \\
\text { и химических продуктов }\end{array}$ & 96 & 33,1 & 28,2 & 1,0 & 1,4 \\
\hline $\begin{array}{l}\text { производство лекарственных } \\
\text { средств и материалов, } \\
\text { применяемых в медицинских целях }\end{array}$ & 23 & 21,4 & 21,1 & 0,1 & 0,1 \\
\hline $\begin{array}{l}\text { производство резиновых } \\
\text { и пластмассовых изделий }\end{array}$ & 52 & 2,7 & 2,1 & 0,1 & 0,1 \\
\hline $\begin{array}{l}\text { производство прочей неметаллической } \\
\text { минеральной продукции }\end{array}$ & 147 & 19,7 & 14,3 & 1,0 & 0,6 \\
\hline производство металлургическое & 111 & 272,8 & 243,6 & 2,4 & 1,4 \\
\hline $\begin{array}{l}\text { производство готовых металлических } \\
\text { изделий, кроме машин и оборудования }\end{array}$ & 166 & 82,5 & 40,8 & 4,0 & 2,9 \\
\hline $\begin{array}{l}\text { производство компьютеров, } \\
\text { электронных и оптических изделий }\end{array}$ & 110 & 18,9 & 6,6 & 1,3 & 1,1 \\
\hline $\begin{array}{l}\text { производство электрического } \\
\text { оборудования }\end{array}$ & 69 & 12,2 & 7,8 & 1,0 & 1,0 \\
\hline $\begin{array}{l}\text { производство машин и оборудования, } \\
\text { не включенных в другие группировки }\end{array}$ & 131 & 182,8 & 22,0 & 3,5 & 3,0 \\
\hline $\begin{array}{l}\text { производство автотранспортных } \\
\text { средств, прицепов и полуприцепов }\end{array}$ & 72 & 134,4 & 20,4 & 0,5 & 0,6 \\
\hline $\begin{array}{l}\text { производство прочих транспортных } \\
\text { средств и оборудования }\end{array}$ & 81 & 123,4 & 66,6 & 0,5 & 0,3 \\
\hline производство мебели & 9 & 0,1 & 0,0 & 0,0 & 0,0 \\
\hline производство прочих готовых изделий & 16 & 1,2 & 0,2 & 0,5 & 0,4 \\
\hline $\begin{array}{l}\text { обеспечение электрической } \\
\text { энергией, газом и паром; } \\
\text { кондиционирование воздуха }\end{array}$ & 1297 & 698,9 & 571,4 & 10,8 & 7,6 \\
\hline $\begin{array}{l}\text { в том числе: } \\
\text { производство, передача } \\
\text { и распределение электроэнергии }\end{array}$ & 217 & 257,6 & 213,9 & 2,4 & 0,7 \\
\hline
\end{tabular}




\begin{tabular}{|c|c|c|c|c|c|}
\hline & \multirow[b]{2}{*}{$\begin{array}{c}\text { Количество } \\
\text { организаций, } \\
\text { имеющих } \\
\text { просроченную } \\
\text { кредиторскую } \\
\text { задолюен- } \\
\text { ность, единиц } \\
\end{array}$} & \multirow{2}{*}{$\begin{array}{c}\text { Просроченная } \\
\text { кредиторская } \\
\text { задолюен- } \\
\text { ность, } \\
\text { млрд рублей }\end{array}$} & \multicolumn{3}{|c|}{ Из нее } \\
\hline & & & поставщикам & $\begin{array}{l}\text { в бюджетьи } \\
\text { всех уровней }\end{array}$ & $\begin{array}{l}\text { по платежам } \\
\text { в государ- } \\
\text { ственные } \\
\text { внебюджет- } \\
\text { ные фондыl }\end{array}$ \\
\hline $\begin{array}{l}\text { производство и распределение } \\
\text { газообразного топлива }\end{array}$ & 43 & 181,7 & 181,2 & 0,1 & 0,1 \\
\hline $\begin{array}{l}\text { производство, передача } \\
\text { и распределение пара и горячей воды; } \\
\text { кондиционирование воздуха }\end{array}$ & 1037 & 259,6 & 176,3 & 8,3 & 6,8 \\
\hline $\begin{array}{l}\text { водоснабжение; водоотведение, } \\
\text { организация сбора и утилизации } \\
\text { отходов, деятельность по } \\
\text { ликвидации загрязнений }\end{array}$ & 642 & 55,1 & 42,1 & 4,7 & 2,8 \\
\hline строительство & 348 & 258,9 & 83,7 & 8,0 & 5,4 \\
\hline $\begin{array}{l}\text { из него: } \\
\text { строительство зданий }\end{array}$ & 115 & 207,6 & 50,4 & 3,3 & 2,4 \\
\hline $\begin{array}{l}\text { строительство инженерных } \\
\text { сооружений }\end{array}$ & 127 & 38,9 & 23,7 & 3,6 & 2,4 \\
\hline $\begin{array}{l}\text { торговля оптовая и розничная; } \\
\text { ремонт автотранспортных средств } \\
\text { И мотоциклов }\end{array}$ & 417 & 662,3 & 409,6 & 1,1 & 0,3 \\
\hline $\begin{array}{l}\text { в том числе: } \\
\text { торговля оптовая и розничная } \\
\text { автотранспортными средствами } \\
\text { и мотоциклами и их ремонт }\end{array}$ & 44 & 17,5 & 6,8 & 0,7 & 0,2 \\
\hline $\begin{array}{l}\text { торговля оптовая, кроме оптовой } \\
\text { торговли автотранспортными } \\
\text { средствами и мотоциклами }\end{array}$ & 273 & 620,0 & 379,0 & 0,2 & 0,1 \\
\hline $\begin{array}{l}\text { торговля розничная, кроме торговли } \\
\text { автотранспортными средствами } \\
\text { и мотоциклами }\end{array}$ & 100 & 24,8 & 23,8 & 0,2 & 0,0 \\
\hline транспортировка и хранение & 487 & 97,0 & 61,2 & 7,6 & 3,5 \\
\hline $\begin{array}{l}\text { в том числе: } \\
\text { деятельность сухопутного } \\
\text { и трубопроводного транспорта }\end{array}$ & 294 & 45,7 & 36,2 & 2,0 & 1,8 \\
\hline $\begin{array}{l}\text { в том числе: } \\
\text { деятельность железнодорожного } \\
\text { транспорта: междугородные } \\
\text { и международные } \\
\text { пассажирские перевозки }\end{array}$ & 3 & 17,5 & 16,8 & - & - \\
\hline $\begin{array}{l}\text { деятельность железнодорожного } \\
\text { транспорта: грузовые перевозки }\end{array}$ & 21 & 6,0 & 4,6 & 0,4 & 0,0 \\
\hline $\begin{array}{l}\text { деятельность прочего сухопутного } \\
\text { пассажирского транспорта }\end{array}$ & 191 & 11,3 & 8,0 & 1,2 & 1,6 \\
\hline $\begin{array}{l}\text { деятельность автомобильного } \\
\text { грузового транспорта } \\
\text { и услуги по перевозкам }\end{array}$ & 59 & 3,9 & 3,1 & 0,4 & 0,2 \\
\hline $\begin{array}{l}\text { деятельность трубопроводного } \\
\text { транспорта }\end{array}$ & 20 & 7,0 & 3,7 & - & - \\
\hline деятельность водного транспорта & 25 & 21,7 & 2,8 & 4,5 & 0,2 \\
\hline $\begin{array}{l}\text { деятельность воздушного } \\
\text { и космического транспорта }\end{array}$ & 15 & 15,7 & 12,3 & 0,1 & 0,6 \\
\hline $\begin{array}{l}\text { складское хозяйство и вспомогательная } \\
\text { транспортная деятельность }\end{array}$ & 153 & 13,9 & 9,9 & 1,0 & 0,9 \\
\hline $\begin{array}{l}\text { деятельность почтовой связи } \\
\text { и курьерская деятельность }\end{array}$ & - & - & - & - & - \\
\hline
\end{tabular}




\begin{tabular}{|c|c|c|c|c|c|}
\hline & \multirow[b]{2}{*}{\begin{tabular}{|c|} 
Количество \\
организачий, \\
имеючих \\
просроченную \\
кредиторскую \\
задолжен- \\
ность, единиц \\
\end{tabular}} & \multirow[b]{2}{*}{$\begin{array}{c}\text { Просроченная } \\
\text { кредиторская } \\
\text { задолжен- } \\
\text { ность, } \\
\text { млрд рублей }\end{array}$} & \multicolumn{3}{|c|}{ Из нее } \\
\hline & & & поставщикам & $\begin{array}{l}\text { в бюджетьл } \\
\text { всех уровней }\end{array}$ & $\begin{array}{c}\text { по платежам } \\
\text { в государ- } \\
\text { ственные } \\
\text { внебюджет- } \\
\text { ные фонды }\end{array}$ \\
\hline $\begin{array}{l}\text { деятельность гостиниц и предприятий } \\
\text { общественного питания }\end{array}$ & 80 & 2,9 & 2,3 & 0,0 & 0,0 \\
\hline $\begin{array}{l}\text { в том числе: } \\
\text { деятельность по предоставлению } \\
\text { мест для временного проживания }\end{array}$ & 38 & 1,7 & 1,6 & 0,0 & 0,0 \\
\hline $\begin{array}{l}\text { деятельность по предоставлению } \\
\text { продуктов питания и напитков }\end{array}$ & 42 & 1,2 & 0,7 & 0,0 & 0,0 \\
\hline $\begin{array}{l}\text { деятельность в области } \\
\text { информации и связи }\end{array}$ & 85 & 25,0 & 19,6 & 2,7 & 0,1 \\
\hline $\begin{array}{l}\text { из нее: } \\
\text { деятельность издательская }\end{array}$ & 13 & 6,1 & 2,8 & 2,5 & 0,0 \\
\hline $\begin{array}{l}\text { деятельность в сфере } \\
\text { телекоммуникаций }\end{array}$ & 22 & 7,3 & 6,1 & 0,1 & 0,0 \\
\hline $\begin{array}{l}\text { деятельность в области } \\
\text { информационных технологий }\end{array}$ & 14 & 2,2 & 1,7 & 0,1 & 0,0 \\
\hline $\begin{array}{l}\text { деятельность по операциям } \\
\text { с недвижимым имуществом }\end{array}$ & 489 & 68,0 & 49,1 & 3,3 & 1,5 \\
\hline $\begin{array}{l}\text { деятельность профессиональная, } \\
\text { научная и техническая }\end{array}$ & 283 & 149,1 & 59,6 & 1,2 & 0,9 \\
\hline $\begin{array}{l}\text { из нее научные исследования } \\
\text { и разработки }\end{array}$ & 108 & 40,4 & 11,1 & 0,7 & 0,4 \\
\hline $\begin{array}{l}\text { деятельность административная } \\
\text { и сопутствующие } \\
\text { дополнительные услуги }\end{array}$ & 111 & 32,7 & 32,0 & 0,3 & 0,2 \\
\hline $\begin{array}{l}\text { из нее деятельность туристических } \\
\text { агентств и прочих организаций, } \\
\text { предоставляющих услуги } \\
\text { в сфере туризма }\end{array}$ & - & - & - & - & - \\
\hline $\begin{array}{l}\text { государственное управление } \\
\text { и обеспечение военной безопасности; } \\
\text { социальное обеспечение }\end{array}$ & 9 & 0,3 & 0,3 & 0,0 & 0,0 \\
\hline образование & 115 & 0,8 & 0,2 & 0,2 & 0,2 \\
\hline $\begin{array}{l}\text { деятельность в области } \\
\text { здравоохранения и социальных услуг }\end{array}$ & 55 & 1,7 & 1,2 & 0,2 & 0,2 \\
\hline $\begin{array}{l}\text { из нее деятельность } \\
\text { в области здравоохранения }\end{array}$ & 54 & 1,6 & 1,2 & 0,2 & 0,1 \\
\hline $\begin{array}{l}\text { деятельность в области культуры, } \\
\text { спорта, организации досуга } \\
\text { и развлечений }\end{array}$ & 33 & 3,8 & 1,1 & 0,5 & 0,3 \\
\hline $\begin{array}{l}\text { из нее: } \\
\text { деятельность библиотек, архивов, } \\
\text { музеев и прочих объектов культуры }\end{array}$ & .. $^{1)}$ & ... $^{1)}$ & $\ldots^{1)}$ & $\ldots{ }^{1)}$ & $\ldots^{1)}$ \\
\hline $\begin{array}{l}\text { деятельность в области спорта, } \\
\text { отдыха и развлечений }\end{array}$ & 29 & 3,5 & 1,1 & 0,5 & 0,3 \\
\hline предоставление прочих видов услуг & 91 & 1,5 & 1,3 & 0,1 & 0,1 \\
\hline
\end{tabular}


Задолженность по полученным кредитам банков и займам в целом по России на конец августа 2020 г., по оперативным данным, составила 68084,0 млрд рублей, в том числе просроченная - 581,7 млрд рублей, или $0,9 \%$ от общего объема задолженности по полученным кредитам банков и займам (на конец августа 2019 г. - 1,0\%, на конец июля 2020 г. $0,9 \%)$.

Таблица 5

\section{РАЗМЕР И СТРУКТУРА ПРОСРОЧЕННОЙ ЗАДОЛЖЕННОСТИ ПО КРЕДИТАМ БАНКОВ И ЗАЙМАМ ПО ВИДАМ ЭКОНОМИЧЕСКОЙ ДЕЯТЕЛЬНОСТИ в августе 2020 года}

на конец месяца

\begin{tabular}{|c|c|c|c|}
\hline & Млрд & & \\
\hline & рублей & $\begin{array}{c}\text { июлю } \\
2020 \text { г. } \\
\end{array}$ & umozy \\
\hline Всего & $\mathbf{5 8 1 , 7}$ & 99,1 & 100 \\
\hline $\begin{array}{l}\text { из них: } \\
\text { сельское, лесное хозяйство, охота, } \\
\text { рыболовство и рыбоводство }\end{array}$ & 12,3 & 65,1 & 2,1 \\
\hline $\begin{array}{l}\text { в том числе: } \\
\text { растениеводство и животноводство, охота и } \\
\text { предоставление соответствующих услуг в этих областях }\end{array}$ & 12,1 & 64,6 & 2,1 \\
\hline лесоводство и лесозаготовки & 0,2 & 100,0 & 0,0 \\
\hline рыболовство и рыбоводство & - & - & - \\
\hline добыча полезных ископаемых & 178,6 & 101,2 & 30,7 \\
\hline $\begin{array}{l}\text { из нее: } \\
\text { добыча угля }\end{array}$ & 116,9 & 101,6 & 20,1 \\
\hline добыча нефти и природного газа & 55,4 & 100,1 & 9,5 \\
\hline добыча металлических руд & 3,9 & 100,0 & 0,7 \\
\hline добыча прочих полезных ископаемых & 2,4 & 111,0 & 0,4 \\
\hline обрабатывающие производства & 166,1 & 99,3 & 28,6 \\
\hline $\begin{array}{l}\text { из них: } \\
\text { производство пищевых продуктов }\end{array}$ & 5,1 & 100,1 & 0,9 \\
\hline производство напитков & 2,2 & 100,0 & 0,4 \\
\hline производство табачных изделий & - & - & - \\
\hline производство текстильных изделий & 0,2 & 100,0 & 0,0 \\
\hline производство одежды & 0,0 & 26,7 & 0,0 \\
\hline производство кожи и изделий из кожи & 1,6 & 101,8 & 0,3 \\
\hline $\begin{array}{l}\text { обработка древесины и производство изделий } \\
\text { из дерева и пробки, кроме мебели, производство изделий } \\
\text { из соломки и материалов для плетения }\end{array}$ & 4,1 & 79,0 & 0,7 \\
\hline производство бумаги и бумажных изделий & 0,0 & 100,0 & 0,0 \\
\hline $\begin{array}{l}\text { деятельность полиграфическая и } \\
\text { копирование носителей информации }\end{array}$ & 0,0 & 66,7 & 0,0 \\
\hline производство кокса и нефтепродуктов & 13,5 & 100,1 & 2,3 \\
\hline $\begin{array}{l}\text { из них: } \\
\text { производство кокса }\end{array}$ & - & - & - \\
\hline производство нефтепродуктов & 13,5 & 100,1 & 2,3 \\
\hline
\end{tabular}




\begin{tabular}{|c|c|c|c|}
\hline & \multirow{2}{*}{$\begin{array}{c}\text { Млрд } \\
\text { рублей }\end{array}$} & \multicolumn{2}{|c|}{ 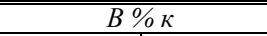 } \\
\hline & & $\begin{array}{l}\text { июлю } \\
20202 .\end{array}$ & umozy \\
\hline производство химических веществ и химических продуктов & 5,9 & 101,3 & 1,0 \\
\hline $\begin{array}{l}\text { производство лекарственных средств и материалов, } \\
\text { применяемых в медицинских целях }\end{array}$ & 1,3 & 100,0 & 0,2 \\
\hline производство резиновых и пластмассовых изделий & 0,3 & 100,0 & 0,1 \\
\hline производство прочей неметаллической минеральной продукции & 16,4 & 94,1 & 2,8 \\
\hline производство металлургическое & 43,8 & 102,1 & 7,5 \\
\hline $\begin{array}{l}\text { производство готовых металлических изделий, } \\
\text { кроме машин и оборудования }\end{array}$ & 16,0 & 98,5 & 2,7 \\
\hline производство компьютеров, электронных и оптических изделий & 7,0 & 100,5 & 1,2 \\
\hline производство электрического оборудования & 1,0 & 98,4 & 0,2 \\
\hline $\begin{array}{l}\text { производство машин и оборудования, } \\
\text { не включенных в другие группировки }\end{array}$ & 25,5 & 100,2 & 4,4 \\
\hline $\begin{array}{l}\text { производство автотранспортных средств, } \\
\text { прицепов и полуприцепов }\end{array}$ & 0,6 & 100,2 & 0,1 \\
\hline производство прочих транспортных средств и оборудования & 20,6 & 100,2 & 3,5 \\
\hline производство мебели & 0,0 & 100,0 & 0,0 \\
\hline производство прочих готовых изделий & - & - & - \\
\hline $\begin{array}{l}\text { обеспечение электрической энергией, газом и паром; } \\
\text { кондиционирование воздуха }\end{array}$ & 19,5 & 99,9 & 3,4 \\
\hline $\begin{array}{l}\text { в том числе: } \\
\text { производство, передача и распределение электроэнергии }\end{array}$ & 14,8 & 100,0 & 2,6 \\
\hline производство и распределение газообразного топлива & 0,0 & 100,0 & 0,0 \\
\hline $\begin{array}{l}\text { производство, передача и распределение } \\
\text { пара и горячей воды; кондиционирование воздуха }\end{array}$ & 4,7 & 99,7 & 0,8 \\
\hline $\begin{array}{l}\text { водоснабжение; водоотведение, организация сбора и } \\
\text { утилизации отходов, деятельность по ликвидации загрязнений }\end{array}$ & 4,6 & 100,0 & 0,8 \\
\hline строительство & 60,9 & 100,3 & 10,5 \\
\hline $\begin{array}{l}\text { из него: } \\
\text { строительство зданий }\end{array}$ & 18,9 & 100,0 & 3,2 \\
\hline строительство инженерных сооружений & 40,4 & 100,0 & 7,0 \\
\hline $\begin{array}{l}\text { торговля оптовая и розничная; } \\
\text { ремонт автотранспортных средств и мотоциклов }\end{array}$ & 58,4 & 100,6 & 10,0 \\
\hline $\begin{array}{l}\text { в том числе: } \\
\text { торговля оптовая и розничная автотранспортными } \\
\text { средствами и мотоциклами и их ремонт }\end{array}$ & 1,9 & 101,1 & 0,3 \\
\hline $\begin{array}{l}\text { торговля оптовая, кроме оптовой торговли } \\
\text { автотранспортными средствами и мотоциклами }\end{array}$ & 55,3 & 100,5 & 9,5 \\
\hline $\begin{array}{l}\text { торговля розничная, кроме торговли } \\
\text { автотранспортными средствами и мотоциклами }\end{array}$ & 1,2 & 105,8 & 0,2 \\
\hline транспортировка и хранение & 23,8 & 96,9 & 4,1 \\
\hline $\begin{array}{l}\text { в том числе: } \\
\text { деятельность сухопутного и трубопроводного транспорта }\end{array}$ & 3,0 & 99,3 & 0,5 \\
\hline $\begin{array}{l}\text { в том числе: } \\
\text { деятельность железнодорожного транспорта: } \\
\text { междугородные и международные пассажирские перевозки }\end{array}$ & - & - & - \\
\hline
\end{tabular}




\begin{tabular}{|c|c|c|c|}
\hline & \multirow{2}{*}{$\begin{array}{c}\text { Млрд } \\
\text { рублей }\end{array}$} & \multicolumn{2}{|c|}{ 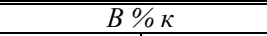 } \\
\hline & & $\begin{array}{l}\text { июлю } \\
20202 .\end{array}$ & umozy \\
\hline деятельность железнодорожного транспорта: грузовые перевозки & 0,2 & 100,0 & 0,1 \\
\hline деятельность прочего сухопутного пассажирского транспорта & 0,2 & 91,0 & 0,0 \\
\hline $\begin{array}{l}\text { деятельность автомобильного грузового транспорта } \\
\text { и услуги по перевозкам }\end{array}$ & 2,6 & 100,0 & 0,4 \\
\hline деятельность трубопроводного транспорта & - & - & - \\
\hline деятельность водного транспорта & 18,1 & 96,1 & 3,1 \\
\hline деятельность воздушного и космического транспорта & - & - & - \\
\hline $\begin{array}{l}\text { складское хозяйство и вспомогательная } \\
\text { транспортная деятельность }\end{array}$ & 2,7 & 100,2 & 0,5 \\
\hline деятельность почтовой связи и курьерская деятельность & - & - & - \\
\hline $\begin{array}{l}\text { деятельность гостиниц и } \\
\text { предприятий общественного питания }\end{array}$ & 3,7 & 125,8 & 0,6 \\
\hline $\begin{array}{l}\text { в том числе: } \\
\text { деятельность по предоставлению мест } \\
\text { для временного проживания }\end{array}$ & 3,7 & 126,0 & 0,6 \\
\hline $\begin{array}{l}\text { деятельность по предоставлению } \\
\text { продуктов питания и напитков }\end{array}$ & 0,0 & 100,1 & 0,0 \\
\hline деятельность в области информации и связи & 10,3 & 100,0 & 1,8 \\
\hline $\begin{array}{l}\text { из нее: } \\
\text { деятельность издательская }\end{array}$ & 0,1 & 99,9 & 0,0 \\
\hline деятельность в сфере телекоммуникаций & 0,0 & 100,0 & 0,0 \\
\hline деятельность в области информационных технологий & 5,8 & 100,2 & 1,0 \\
\hline $\begin{array}{l}\text { деятельность по операциям } \\
\text { с недвижимым имуществом }\end{array}$ & 36,5 & 100,1 & 6,3 \\
\hline $\begin{array}{l}\text { деятельность профессиональная, } \\
\text { научная и техническая }\end{array}$ & 2,9 & 99,6 & 0,5 \\
\hline из нее научные исследования и разработки & 0,8 & 97,3 & 0,1 \\
\hline $\begin{array}{l}\text { деятельность административная и } \\
\text { сопутствующие дополнительные услуги }\end{array}$ & 2,5 & 99,8 & 0,4 \\
\hline $\begin{array}{l}\text { из нее деятельность туристических агентств и прочих } \\
\text { организаций, предоставляющих услуги в сфере туризма }\end{array}$ & - & - & - \\
\hline $\begin{array}{l}\text { государственное управление и обеспечение } \\
\text { военной безопасности; социальное обеспечение }\end{array}$ & 0,3 & 100,4 & 0,1 \\
\hline образование & 0,1 & 101,3 & 0,0 \\
\hline $\begin{array}{l}\text { деятельность в области здравоохранения } \\
\text { и социальных услуг }\end{array}$ & 0,2 & 97,7 & 0,0 \\
\hline из нее деятельность в области здравоохранения & 0,2 & 97,7 & 0,0 \\
\hline $\begin{array}{l}\text { деятельность в области культуры, спорта, } \\
\text { организации досуга и развлечений }\end{array}$ & 0,9 & 96,2 & 0,1 \\
\hline $\begin{array}{l}\text { из нее: } \\
\text { деятельность библиотек, архивов, } \\
\text { музеев и прочих объектов культуры }\end{array}$ & - & - & - \\
\hline деятельность в области спорта, отдыха и развлечений & 0,8 & 96,1 & 0,1 \\
\hline предоставление прочих видов услуг & 0,1 & 99,5 & 0,0 \\
\hline
\end{tabular}


Дебиторская задолженность в целом по России на конец августа 2020 г., по оперативным данным, составила 52128,2 млрд рублей, из нее просроченная - 3178,5 млрд рублей, или $6,1 \%$ от общего объема дебиторской задолженности (на конец августа 2019 г. - 6,0\%, на конец июля 2020 г. - 6,0\%).

Таблица 6

\section{СТРУКТУРА И ДИНАМИКА
ПРОСРОЧЕННОЙ ДЕБИТОРСКОЙ ЗАДОЛЖЕННОСТИ ОРГАНИЗАЦИЙ}

на конец месяца

\begin{tabular}{|c|c|c|c|c|c|}
\hline & \multirow{3}{*}{$\begin{array}{c}\text { Количество } \\
\text { организаций, } \\
\text { имеющих } \\
\text { просроченную } \\
\text { дебиторскую } \\
\text { задолженность, } \\
\text { единиц } \\
\end{array}$} & \multirow{3}{*}{$\begin{array}{c}\text { Просроченная } \\
\text { дебиторская } \\
\text { задолюен- } \\
\text { ность, } \\
\text { млрд рублей }\end{array}$} & \multicolumn{3}{|c|}{ Из нее } \\
\hline & & & \multirow[t]{2}{*}{ покупателей } & \multicolumn{2}{|c|}{ из нее } \\
\hline & & & & $\begin{array}{c}\text { по полученнымм } \\
\text { векселям }\end{array}$ & \begin{tabular}{|c|} 
государственных \\
заказчиков по \\
оплате за \\
поставленную \\
продукиию \\
\end{tabular} \\
\hline \multicolumn{6}{|c|}{2019 г. } \\
\hline Январь & 12491 & 2650,7 & 1890,8 & 0,8 & 25,5 \\
\hline Февраль & 12738 & 2767,1 & 1972,4 & 0,8 & 26,0 \\
\hline Март & 13055 & 2901,5 & 2078,5 & 0,9 & 27,7 \\
\hline Апрель & 13118 & 2832,0 & 1971,5 & 0,9 & 26,9 \\
\hline Май & 13138 & 2930,0 & 2082,2 & 0,9 & 26,3 \\
\hline Июнь & 13505 & 2891,6 & 2081,9 & 1,0 & 25,0 \\
\hline Июль & 13454 & 3101,6 & 2082,0 & 0,9 & 25,6 \\
\hline Август & 13437 & 2893,6 & 2073,9 & 0,9 & 27,1 \\
\hline Сентябрь & 13594 & 2978,6 & 2045,1 & 0,8 & 27,9 \\
\hline Октябрь & 13541 & 2983,7 & 2123,5 & 0,8 & 25,7 \\
\hline Ноябрь & 13540 & 3019,4 & 2170,1 & 0,8 & 29,4 \\
\hline Декабрь & 13624 & 2661,0 & 1897,2 & 0,8 & 20,4 \\
\hline \multicolumn{6}{|c|}{2020 г. } \\
\hline Январь & 13174 & 2836,2 & 1944,7 & 0,4 & 21,1 \\
\hline Февраль & 13811 & 2766,2 & 2043,4 & 0,4 & 16,0 \\
\hline Март & 14253 & 2813,4 & 2060,1 & 0,3 & 15,6 \\
\hline Апрель & 14549 & 2994,5 & 2198,7 & 0,4 & 17,1 \\
\hline Май & 14756 & 3128,2 & 2300,0 & 0,4 & 18,4 \\
\hline Июнь & 15287 & 3035,1 & 2186,8 & 0,4 & 22,1 \\
\hline Июль & 15422 & 3086,3 & 2268,2 & 0,4 & 22,5 \\
\hline Август & 15502 & 3178,5 & 2286,3 & 0,5 & 19,3 \\
\hline
\end{tabular}




\section{ПРОСРОЧЕННАЯ ДЕБИТОРСКАЯ ЗАДОЛЖЕННОСТЬ ОРГАНИЗАЦИЙ ПО ВИДАМ ЭКОНОМИЧЕСКОЙ ДЕЯТЕЛЬНОСТИ \\ в августе 2020 года}

на конец месяца

\begin{tabular}{|c|c|c|c|}
\hline & $\begin{array}{c}\text { Количество организаиий, } \\
\text { имеющих просроченную } \\
\text { дебиторскую } \\
\text { задолженность, единии } \\
\end{array}$ & $\begin{array}{c}\text { Просроченная } \\
\text { дебиторская } \\
\text { задолженность, } \\
\text { млрд рублей } \\
\end{array}$ & $\begin{array}{c}\text { Из нее } \\
\text { покупателей }\end{array}$ \\
\hline Всего & 15502 & 3178,5 & 2286,3 \\
\hline $\begin{array}{l}\text { из них: } \\
\text { сельское, лесное хозяйство, охота, } \\
\text { рыболовство и рыбоводство }\end{array}$ & 647 & 13,1 & 9,6 \\
\hline $\begin{array}{l}\text { в том числе: } \\
\text { растениеводство и животноводство, охота и } \\
\text { предоставление соответствующих услуг в этих областях }\end{array}$ & 565 & 11,4 & 8,1 \\
\hline лесоводство и лесозаготовки & 41 & 0,9 & 0,8 \\
\hline рыболовство и рыбоводство & 41 & 0,8 & 0,7 \\
\hline добыча полезных ископаемых & 470 & 501,7 & 455,8 \\
\hline $\begin{array}{l}\text { из нее: } \\
\text { добыча угля }\end{array}$ & 83 & 134,1 & 127,6 \\
\hline добыча нефти и природного газа & 77 & 206,2 & 176,4 \\
\hline добыча металлических руд & 78 & 34,8 & 28,9 \\
\hline добыча прочих полезных ископаемых & 123 & 4,2 & 3,8 \\
\hline обрабатывающие производства & 2972 & 762,0 & 469,2 \\
\hline $\begin{array}{l}\text { из них: } \\
\text { производство пищевых продуктов }\end{array}$ & 403 & 14,7 & 10,4 \\
\hline производство напитков & 73 & 11,4 & 10,6 \\
\hline производство табачных изделий & - & - & - \\
\hline производство текстильных изделий & 46 & 3,6 & 3,4 \\
\hline производство одежды & 23 & 1,0 & 0,3 \\
\hline производство кожи и изделий из кожи & 23 & 2,6 & 0,3 \\
\hline $\begin{array}{l}\text { обработка древесины и производство изделий } \\
\text { из дерева и пробки, кроме мебели, производство } \\
\text { изделий из соломки и материалов для плетения }\end{array}$ & 77 & 2,5 & 2,1 \\
\hline производство бумаги и бумажных изделий & 76 & 9,9 & 7,4 \\
\hline $\begin{array}{l}\text { деятельность полиграфическая и } \\
\text { копирование носителей информации }\end{array}$ & 51 & 0,7 & 0,7 \\
\hline производство кокса и нефтепродуктов & 52 & 170,2 & 62,0 \\
\hline $\begin{array}{l}\text { из них: } \\
\text { производство кокса }\end{array}$ & 3 & 0,2 & 0,2 \\
\hline производство нефтепродуктов & 48 & 170,0 & 61,9 \\
\hline $\begin{array}{l}\text { производство химических веществ } \\
\text { и химических продуктов }\end{array}$ & 176 & 39,8 & 23,7 \\
\hline $\begin{array}{l}\text { производство лекарственных средств и материалов, } \\
\text { применяемых в медицинских целях }\end{array}$ & 51 & 10,9 & 10,5 \\
\hline производство резиновых и пластмассовых изделий & 133 & 6,9 & 6,3 \\
\hline $\begin{array}{l}\text { производство прочей неметаллической } \\
\text { минеральной продукции }\end{array}$ & 277 & 15,9 & 14,0 \\
\hline
\end{tabular}




\begin{tabular}{|c|c|c|c|}
\hline & $\begin{array}{c}\text { Количество организаций, } \\
\text { имеющцих просроченную } \\
\text { дебиторскую } \\
\text { задолженность, единиц } \\
\end{array}$ & \begin{tabular}{|c|} 
Просроченная \\
дебиторская \\
задолженность, \\
млрд рублей \\
\end{tabular} & $\begin{array}{c}\text { Из нее } \\
\text { покупателей }\end{array}$ \\
\hline производство металлургическое & 147 & 116,5 & 96,2 \\
\hline $\begin{array}{l}\text { производство готовых металлических изделий, } \\
\text { кроме машин и оборудования }\end{array}$ & 313 & 89,0 & 66,6 \\
\hline $\begin{array}{l}\text { производство компьютеров, } \\
\text { электронных и оптических изделий }\end{array}$ & 188 & 20,5 & 14,8 \\
\hline производство электрического оборудования & 150 & 10,1 & 9,4 \\
\hline $\begin{array}{l}\text { производство машин и оборудования, } \\
\text { не включенных в другие группировки }\end{array}$ & 226 & 49,7 & 31,7 \\
\hline $\begin{array}{l}\text { производство автотранспортных } \\
\text { средств, прицепов и полуприцепов }\end{array}$ & 93 & 20,4 & 12,0 \\
\hline $\begin{array}{l}\text { производство прочих транспортных } \\
\text { средств и оборудования }\end{array}$ & 126 & 133,3 & 71,6 \\
\hline производство мебели & 20 & 0,3 & 0,3 \\
\hline производство прочих готовых изделий & 39 & 0,9 & 0,8 \\
\hline $\begin{array}{l}\text { обеспечение электрической энергией, } \\
\text { газом и паром; кондиционирование воздуха }\end{array}$ & 1929 & 498,6 & 415,7 \\
\hline $\begin{array}{l}\text { в том числе: } \\
\text { производство, передача и } \\
\text { распределение электроэнергии }\end{array}$ & 378 & 237,5 & 200,3 \\
\hline производство и распределение газообразного топлива & 100 & 76,8 & 59,9 \\
\hline $\begin{array}{l}\text { производство, передача и распределение } \\
\text { пара и горячей воды; кондиционирование воздуха }\end{array}$ & 1451 & 184,3 & 155,5 \\
\hline $\begin{array}{l}\text { водоснабжение; водоотведение, } \\
\text { организация сбора и утилизации отходов, } \\
\text { деятельность по ликвидации загрязнений }\end{array}$ & 1041 & 67,7 & 64,6 \\
\hline строительство & 910 & 235,5 & 136,1 \\
\hline $\begin{array}{l}\text { из него: } \\
\text { строительство зданий }\end{array}$ & 353 & 169,6 & 76,4 \\
\hline строительство инженерных сооружений & 263 & 42,6 & 39,2 \\
\hline $\begin{array}{l}\text { торговля оптовая и розничная; } \\
\text { ремонт автотранспортных средств и мотоциклов }\end{array}$ & 2282 & 615,2 & 387,5 \\
\hline $\begin{array}{l}\text { в том числе: } \\
\text { торговля оптовая и розничная автотранспортными } \\
\text { средствами и мотоциклами и их ремонт }\end{array}$ & 208 & 24,1 & 19,2 \\
\hline $\begin{array}{l}\text { торговля оптовая, кроме оптовой торговли } \\
\text { автотранспортными средствами и мотоциклами }\end{array}$ & 1733 & 563,5 & 349,4 \\
\hline $\begin{array}{l}\text { торговля розничная, кроме торговли } \\
\text { автотранспортными средствами и мотоциклами }\end{array}$ & 341 & 27,6 & 18,9 \\
\hline транспортировка и хранение & 1057 & 104,9 & 74,6 \\
\hline $\begin{array}{l}\text { в том числе: } \\
\text { деятельность сухопутного и трубопроводного транспорта }\end{array}$ & 473 & 44,0 & 36,7 \\
\hline $\begin{array}{l}\text { в том числе: } \\
\text { деятельность железнодорожного транспорта: } \\
\text { междугородные и международные } \\
\text { пассажирские перевозки }\end{array}$ & 8 & 19,5 & 17,9 \\
\hline $\begin{array}{l}\text { деятельность железнодорожного транспорта: } \\
\text { грузовые перевозки }\end{array}$ & 49 & 8,2 & 4,5 \\
\hline $\begin{array}{l}\text { деятельность прочего сухопутного } \\
\text { пассажирского транспорта }\end{array}$ & 237 & 3,3 & 2,5 \\
\hline
\end{tabular}




\begin{tabular}{|c|c|c|c|}
\hline & $\begin{array}{c}\text { Количество организачий, } \\
\text { имеющих просроченную } \\
\text { дебиторскую } \\
\text { задолженность, единиц } \\
\end{array}$ & \begin{tabular}{|} 
Просроченная \\
дебиторская \\
задолженность, \\
млрд рублей \\
\end{tabular} & $\begin{array}{c}\text { Из нее } \\
\text { покупателей }\end{array}$ \\
\hline $\begin{array}{l}\text { деятельность автомобильного } \\
\text { грузового транспорта и услуги по перевозкам }\end{array}$ & 149 & 10,2 & 10,0 \\
\hline деятельность трубопроводного транспорта & 30 & 2,8 & 1,8 \\
\hline деятельность водного транспорта & 44 & 3,4 & 2,8 \\
\hline деятельность воздушного и космического транспорта & 26 & 15,6 & 3,7 \\
\hline $\begin{array}{l}\text { складское хозяйство и вспомогательная } \\
\text { транспортная деятельность }\end{array}$ & 485 & 37,0 & 26,6 \\
\hline деятельность почтовой связи и курьерская деятельность & 29 & 4,9 & 4,8 \\
\hline $\begin{array}{l}\text { деятельность гостиниц и предприятий } \\
\text { общественного питания }\end{array}$ & 210 & 3,8 & 2,7 \\
\hline $\begin{array}{l}\text { в том числе: } \\
\text { деятельность по предоставлению } \\
\text { мест для временного проживания }\end{array}$ & 118 & 1,0 & 0,8 \\
\hline $\begin{array}{l}\text { деятельность по предоставлению } \\
\text { продуктов питания и напитков }\end{array}$ & 92 & 2,8 & 1,9 \\
\hline деятельность в области информации и связи & 511 & 45,9 & 31,3 \\
\hline $\begin{array}{l}\text { из нее: } \\
\text { деятельность издательская }\end{array}$ & 65 & 5,3 & 3,8 \\
\hline деятельность в сфере телекоммуникаций & 93 & 22,2 & 13,6 \\
\hline деятельность в области информационных технологий & 109 & 4,0 & 3,8 \\
\hline $\begin{array}{l}\text { деятельность по операциям } \\
\text { с недвижимым имуществом }\end{array}$ & 1268 & 92,9 & 78,5 \\
\hline $\begin{array}{l}\text { деятельность профессиональная, } \\
\text { научная и техническая }\end{array}$ & 911 & 200,0 & 126,4 \\
\hline из нее научные исследования и разработки & 255 & 41,8 & 27,7 \\
\hline $\begin{array}{l}\text { деятельность административная } \\
\text { и сопутствующие дополнительные услуги }\end{array}$ & 441 & 27,5 & 26,9 \\
\hline $\begin{array}{l}\text { из нее деятельность туристических агентств } \\
\text { и прочих организаций, } \\
\text { предоставляющих услуги в сфере туризма }\end{array}$ & 9 & 0,1 & 0,1 \\
\hline $\begin{array}{l}\text { государственное управление и обеспечение } \\
\text { военной безопасности; социальное обеспечение }\end{array}$ & 30 & 1,0 & 0,7 \\
\hline образование & 293 & 0,7 & 0,6 \\
\hline $\begin{array}{l}\text { деятельность в области здравоохранения } \\
\text { и социальных услуг }\end{array}$ & 187 & 2,9 & 2,0 \\
\hline из нее деятельность в области здравоохранения & 178 & 2,9 & 2,0 \\
\hline $\begin{array}{l}\text { деятельность в области культуры, } \\
\text { спорта, организации досуга и развлечений }\end{array}$ & 112 & 1,3 & 0,8 \\
\hline $\begin{array}{l}\text { из нее: } \\
\text { деятельность библиотек, архивов, } \\
\text { музеев и прочих объектов культуры }\end{array}$ & 9 & 0,1 & 0,1 \\
\hline деятельность в области спорта, отдыха и развлечений & 86 & 0,9 & 0,6 \\
\hline предоставление прочих видов услуг & 231 & 3,8 & 3,3 \\
\hline
\end{tabular}




\section{3. ДЕНЕЖНО-КРЕДИТНАЯ СИСТЕМА}

По данным Банка России, объем денежной массы (М2) на 1 сентября 2020 г. составил 55294,2 млрд рублей и увеличился по сравнению с 1 сентября 2019 г. на 16,2\%, по сравнению с 1 августа 2020 г. - на 1,1\% при увеличении потребительских цен на 3,6\% и 0,0\% соответственно.

Таблица 1

ДИНАМИКА ДЕНЕЖНОЙ МАССЫ

(по данным Банка России)

на начало месяца

\begin{tabular}{|c|c|c|c|c|c|c|}
\hline & \multicolumn{2}{|c|}{ Денежная масса (М2) } & \multicolumn{3}{|c|}{ В том числе, млрд рублей } & \multirow{3}{*}{$\begin{array}{c}\text { Удельный вес } \\
\text { МО в } \mathrm{M2}, \\
\%\end{array}$} \\
\hline & \multirow[t]{2}{*}{$\begin{array}{c}\text { млрд } \\
\text { рублей }\end{array}$} & \multirow{2}{*}{$\begin{array}{c}\text { в\%к } \\
\text { предьлушщему } \\
\text { месячу }\end{array}$} & \multirow{2}{*}{$\begin{array}{c}\text { наличные деньги } \\
\text { вне банковской } \\
\text { системы (МО) }\end{array}$} & \multicolumn{2}{|c|}{$\begin{array}{c}\text { безналичные } \\
\text { средства }\end{array}$} & \\
\hline & & & & $\begin{array}{c}\text { переводные } \\
\text { депозиты }\end{array}$ & $\begin{array}{c}\text { другие } \\
\text { депозиты }\end{array}$ & \\
\hline \multicolumn{7}{|c|}{2019 г. } \\
\hline Январь & 47109,3 & 104,9 & 9339,0 & 12285,1 & 25485,2 & 19,8 \\
\hline Февраль & 45721,2 & 97,1 & 8989,9 & 11758,4 & 24972,9 & 19,7 \\
\hline Март & 46212,6 & 101,1 & 9029,7 & 11914,4 & 25268,5 & 19,5 \\
\hline Апрель & 46141,2 & 99,8 & 8980,6 & 11830,1 & 25330,6 & 19,5 \\
\hline Май & 46435,9 & 100,6 & 9113,8 & 12060,1 & 25262,1 & 19,6 \\
\hline Июнь & 46735,3 & 100,6 & 9110,7 & 11977,7 & 25646,9 & 19,5 \\
\hline Июль & 47349,4 & 101,3 & 9192,8 & 12524,8 & 25631,7 & 19,4 \\
\hline Август & 47351,0 & 100,0 & 9254,2 & 12489,6 & 25607,2 & 19,5 \\
\hline Сентябрь & 47584,1 & 100,5 & 9367,6 & 12585,8 & 25630,7 & 19,7 \\
\hline Октябрь & 48266,8 & 101,4 & 9411,9 & 13018,2 & 25836,8 & 19,5 \\
\hline Ноябрь & 48082,4 & 99,6 & 9354,6 & 12780,7 & 25947,1 & 19,5 \\
\hline Декабрь & 49195,3 & 102,3 & 9394,0 & 13133,8 & 26667,5 & 19,1 \\
\hline \multicolumn{7}{|c|}{2020 г. } \\
\hline Январь & 51660,3 & 105,0 & 9658,4 & 14203,3 & 27798,6 & 18,7 \\
\hline Февраль & 50622,9 & 98,0 & 9489,0 & 13868,5 & 27265,5 & 18,7 \\
\hline Март & 51314,2 & 101,4 & 9670,8 & 14353,1 & 27290,2 & 18,8 \\
\hline Апрель & 52327,0 & 102,0 & 10241,0 & 14895,4 & 27190,6 & 19,6 \\
\hline Май & 52951,7 & 101,2 & 10912,0 & 15079,4 & 26960,4 & 20,6 \\
\hline Июнь & 53068,0 & 100,2 & 11209,3 & 15262,1 & 26596,6 & 21,1 \\
\hline Июль & 54392,6 & 102,5 & 11516,4 & 16300,9 & 26575,3 & 21,2 \\
\hline Август & 54687,4 & 100,5 & 11817,8 & 16270,4 & 26599,2 & 21,6 \\
\hline Сентябрь & 55294,2 & 101,1 & 11951,3 & 17076,1 & 26266,8 & 21,6 \\
\hline
\end{tabular}

Состояние системы кредитных организаций. Количество действующих кредитных организаций, имеющих право на осуществление банковских операций, на 1 октября 2020 г. составило 417 единиц и сократилось по сравнению с 1 октября 2019 г. - на 37 организаций, по сравнению с 1 сентября 2020 г. - осталось без изменения. 
ОТДЕЛЬНЫЕ ПОКАЗАТЕЛИ ДЕЯТЕЛЬНОСТИ КРЕДИТНЫХ ОРГАНИЗАЦИЙ (по данным Банка России)

на начало месяца

\begin{tabular}{|c|c|c|c|c|c|c|}
\hline & \multicolumn{3}{|c|}{20202.} & \multicolumn{3}{|c|}{ Справочно 2019 г. } \\
\hline & январь & сентябрь & октябрь & январь & сентябрь & октябрь \\
\hline $\begin{array}{l}\text { Количество действующих кредитных организаций, } \\
\text { единиц }\end{array}$ & 442 & 417 & 417 & 484 & 455 & 454 \\
\hline $\begin{array}{l}\text { из них имеющих лицензии (разрешения), } \\
\text { предоставляющие право на: }\end{array}$ & & & & & & \\
\hline привлечение вкладов населения & 365 & 345 & 345 & 400 & 377 & 376 \\
\hline осуществление операций в иностранной валюте & 435 & 410 & 410 & 475 & 448 & 447 \\
\hline проведение операций с драгметаллами & 200 & 190 & 190 & 214 & 201 & 200 \\
\hline $\begin{array}{l}\text { Число филиалов действующих кредитных организаций } \\
\text { на территории Российской Федерации, единиц }\end{array}$ & 618 & 550 & 544 & 709 & 654 & 647 \\
\hline из них филиалы ПАО Сбербанк & 88 & 88 & 88 & 90 & 88 & 88 \\
\hline $\begin{array}{l}\text { Зарегистрированный уставный капитал } \\
\text { действующих кредитных организаций, млрд рублей }\end{array}$ & 2822,7 & 2865,8 & 2883,6 & 2655,4 & 2788,2 & 2833,9 \\
\hline $\begin{array}{l}\text { Остатки средств на корреспондентских счетах } \\
\text { кредитных организаций в Банке России, млрд рублей }\end{array}$ & 2625,5 & 2905,6 & 3039,7 & 1898,2 & 2109,9 & 2674,2 \\
\hline
\end{tabular}

Сумма средств организаций на счетах в кредитных организациях на 1 сентября 2020 г. составила 12747,7 млрд рублей и по сравнению с 1 сентября 2019 г. увеличилась на 24,6\%, по сравнению с 1 августа 2020 г. - на 8,3\%; сумма бюджетных средств и средств внебюджетных фондов на счетах составила 62,0 млрд рублей и увеличилась по сравнению с 1 сентября 2019 г. на 31,6\%, по сравнению с 1 августа 2020 г. снизилась на 12,4\%.

Объем кредитов, депозитов и прочих размещенных средств, предоставленных организациям, физическим лицам и кредитным организациям (в рублях и иностранной валюте), включая кредиты, предоставленные иностранным государствам, на 1 сентября 2020 г. составил 72509,3 млрд рублей.

Таблица 3

КРЕДИТЫ, ДЕПОЗИТЫ И ПРОЧИЕ РАЗМЕЩЕННЫЕ СРЕДСТВА (по данным Банка России)

на начало месяца, млрд рублей

\begin{tabular}{|c|c|c|c|c|}
\hline & \multirow{2}{*}{$\begin{array}{c}\text { Общиий объем } \\
\text { размещенных } \\
\text { средств }\end{array}$} & \multicolumn{3}{|c|}{ Из него } \\
\hline & & $\begin{array}{c}\text { кредитьл и прочие } \\
\text { размешенные средства, } \\
\text { предоставленные } \\
\text { организачиям }\end{array}$ & $\begin{array}{c}\text { кредитьl, депозитыл } \\
\text { и прочие размещенные } \\
\text { средства, предостав- } \\
\text { ленные кредитныли } \\
\text { организачиям } \\
\end{array}$ & $\begin{array}{c}\text { кредитыл, } \\
\text { предоставленные } \\
\text { физическим лицам }\end{array}$ \\
\hline \multicolumn{5}{|c|}{2019 г. } \\
\hline Январь & 62302,4 & 38011,0 & 9335,6 & 14901,4 \\
\hline Февраль & 62448,7 & 37741,8 & 9562,2 & 15092,3 \\
\hline Март & 62655,5 & 37783,7 & 9541,7 & 15277,8 \\
\hline Апрель & 62930,1 & 37889,3 & 9455,6 & 15535,0 \\
\hline Май & 63037,0 & 37899,6 & 9241,1 & 15846,3 \\
\hline Июнь & 63302,1 & 38013,4 & 9137,3 & 16101,3 \\
\hline Июль & 63253,9 & 37890,5 & 8981,2 & 16328,6 \\
\hline
\end{tabular}




\begin{tabular}{|c|c|c|c|c|}
\hline & \multirow{2}{*}{$\begin{array}{c}\text { Обичий объем } \\
\text { размещенньх } \\
\text { средств }\end{array}$} & \multicolumn{3}{|c|}{ Из него } \\
\hline & & $\begin{array}{c}\text { кредитьл и прочие } \\
\text { размещенные средства, } \\
\text { предоставленные } \\
\text { организачиям }\end{array}$ & $\begin{array}{c}\text { кредитыл, депозитьл } \\
\text { и прочие размещеннье } \\
\text { средства, предостав- } \\
\text { леннье кредитным } \\
\text { организациям } \\
\end{array}$ & $\begin{array}{c}\text { кредитьл, } \\
\text { предоставленные } \\
\text { физическим лицам }\end{array}$ \\
\hline Август & 63440,7 & 37986,4 & 8873,6 & 16527,0 \\
\hline Сентябрь & 64172,0 & 38733,2 & 8548,8 & 16830,9 \\
\hline Октябрь & 64193,6 & 38577,2 & 8452,3 & 17104,2 \\
\hline Ноябрь & 64353,4 & 38806,9 & 8234,2 & 17250,4 \\
\hline Декабрь & 64912,4 & 39035,1 & 8341,5 & 17475,2 \\
\hline \multicolumn{5}{|c|}{2020 г. } \\
\hline Январь & 65675,3 & 39003,7 & 8960,1 & 17650,7 \\
\hline Февраль & 64851,1 & 38823,7 & 8175,7 & 17787,1 \\
\hline Март & 66181,7 & 39456,7 & 8653,9 & 18000,6 \\
\hline Апрель & 70068,4 & 42049,7 & 9636,2 & 18304,5 \\
\hline Май & 69641,3 & 42049,5 & 9340,2 & 18170,7 \\
\hline Июнь & 69224,0 & 41626,0 & 9309,4 & 18210,0 \\
\hline Июль & 69928,8 & 41713,5 & 9748,1 & 18388,0 \\
\hline Август & 71713,9 & 42898,1 & 10022,4 & 18703,3 \\
\hline Сентябрь & 72509,3 & 43603,0 & 9749,6 & 19065,1 \\
\hline
\end{tabular}

Доля кредитов и прочих размещенных средств (в рублях и иностранной валюте), предоставленных организациям на срок свыше 1 года, в общем объеме выданных им кредитов и прочих размещенных средств, распределенных по срокам погашения, на 1 сентября 2020 г. составила $74,9 \%$ против 74,6\% на 1 августа 2020 года.

СВЕДЕНИЯ О ЖИЛИЩНЫХ КРЕДИТАХ, ПРЕДОСТАВЛЕННЫХ ФИЗИЧЕСКИМ ЛИЦАМ (по данным Банка России)

\begin{tabular}{|c|c|c|c|c|}
\hline & \multicolumn{2}{|c|}{$\begin{array}{c}\text { Объем предоставленных кредитов } \\
\text { за месяи, млрд рублей } \\
\end{array}$} & \multicolumn{2}{|c|}{$\begin{array}{c}\text { Средневзвешенная ставка по кредитам, } \\
\text { выданным в течение месяияа, \% }\end{array}$} \\
\hline & $\begin{array}{c}\text { жилищные } \\
\text { кредиты }\end{array}$ & $\begin{array}{c}\text { из них ипотечные } \\
\text { жилищные кредитьл }\end{array}$ & $\begin{array}{l}\text { жилищные } \\
\text { кредить }\end{array}$ & $\begin{array}{c}\text { из них ипотечные } \\
\text { жилищные кредить }\end{array}$ \\
\hline \multicolumn{5}{|c|}{2019 г. } \\
\hline \multicolumn{5}{|l|}{ Январь } \\
\hline в рублях & 169,6 & 168,4 & 9,88 & 9,87 \\
\hline в иностранной валюте & - & - & - & - \\
\hline \multicolumn{5}{|l|}{ Февраль } \\
\hline в рублях & 228,8 & 226,5 & 10,15 & 10,15 \\
\hline в иностранной валюте & 0,0 & 0,0 & 10,00 & 10,00 \\
\hline \multicolumn{5}{|l|}{ Март } \\
\hline в рублях & 227,3 & 224,2 & 10,41 & 10,42 \\
\hline в иностранной валюте & 0,1 & 0,1 & 7,58 & 7,58 \\
\hline \multicolumn{5}{|l|}{ Апрель } \\
\hline в рублях & 243,4 & 239,6 & 10,55 & 10,56 \\
\hline в иностранной валюте & 0,1 & 0,1 & 9,12 & 9,12 \\
\hline
\end{tabular}




\begin{tabular}{|c|c|c|c|c|}
\hline & \multicolumn{2}{|c|}{$\begin{array}{c}\text { Объем предоставленных кредитов } \\
\text { за месяи, млрд рублей } \\
\end{array}$} & \multicolumn{2}{|c|}{$\begin{array}{c}\text { Средневзвешенная ставка по кредитам, } \\
\text { выданным в течение месяча, \% }\end{array}$} \\
\hline & $\begin{array}{c}\text { жилищные } \\
\text { кредиты }\end{array}$ & \begin{tabular}{|c|} 
из них ипотечныее \\
жилищные кредиты
\end{tabular} & $\begin{array}{c}\text { жилищные } \\
\text { кредиты }\end{array}$ & $\begin{array}{c}\text { из них ипотечные } \\
\text { жилищные кредиты }\end{array}$ \\
\hline \multicolumn{5}{|l|}{ Май } \\
\hline в рублях & 190,4 & 190,1 & 10,53 & 10,53 \\
\hline в иностранной валюте & 0,2 & 0,0 & 5,32 & 12,00 \\
\hline \multicolumn{5}{|l|}{ Июнь } \\
\hline в рублях & 215,2 & 214,8 & 10,29 & 10,28 \\
\hline в иностранной валюте & 0,0 & 0,0 & 8,74 & 10,00 \\
\hline \multicolumn{5}{|l|}{ Июль } \\
\hline в рублях & 222,4 & 222,0 & 10,24 & 10,24 \\
\hline в иностранной валюте & 0,0 & - & 5,00 & - \\
\hline \multicolumn{5}{|l|}{ Август } \\
\hline в рублях & 236,4 & 236,0 & 9,92 & 9,91 \\
\hline в иностранной валюте & - & - & - & - \\
\hline \multicolumn{4}{|l|}{ Сентябрь } & 9,68 \\
\hline в иностранной валюте & 0,0 & 0,0 & 4,04 & 10,00 \\
\hline $\begin{array}{l}\text { Октябрь } \\
\text { в рублях }\end{array}$ & 271,7 & 271,3 & 9,40 & 9,40 \\
\hline в иностранной валюте & 0,0 & 0,0 & 9,04 & 9,04 \\
\hline \multicolumn{5}{|l|}{ Ноябрь } \\
\hline в рублях & 271,0 & 270,3 & 9,19 & 9,19 \\
\hline в иностранной валюте & 0,4 & 0,4 & 5,00 & 5,00 \\
\hline \multicolumn{5}{|l|}{ Декабрь } \\
\hline в рублях & 345,5 & 345,1 & 9,01 & 9,00 \\
\hline в иностранной валюте & 0,0 & 0,0 & 10,00 & 10,00 \\
\hline \multicolumn{5}{|c|}{2020 г. } \\
\hline \multicolumn{5}{|l|}{ Январь } \\
\hline в иностранной валюте & - & - & - & - \\
\hline \multicolumn{5}{|l|}{ Февраль } \\
\hline в рублях & 267,8 & 267,5 & 8,69 & 8,69 \\
\hline в иностранной валюте & 0,0 & 0,0 & 9,00 & 9,00 \\
\hline \multicolumn{5}{|l|}{ Март } \\
\hline в рублях & 306,0 & 305,5 & 8,62 & 8,62 \\
\hline в иностранной валюте & 0,0 & 0,0 & 9,02 & 9,02 \\
\hline $\begin{array}{l}\text { Апрель } \\
\text { в рублях }\end{array}$ & 203,6 & 203,4 & 8,33 & 8,32 \\
\hline в иностранной валюте & - & - & - & - \\
\hline \multicolumn{5}{|l|}{ Май } \\
\hline в рублях & 198,9 & 198,7 & 7,40 & 7,40 \\
\hline в иностранной валюте & - & - & - & - \\
\hline \multicolumn{5}{|l|}{ Июнь } \\
\hline в рублях & 276,4 & 276,1 & 7,51 & 7,50 \\
\hline в иностранной валюте & - & - & - & - \\
\hline
\end{tabular}




\begin{tabular}{|c|c|c|c|c|}
\hline & \multicolumn{2}{|c|}{$\begin{array}{c}\text { Объем предоставленных кредитов } \\
\text { за месяц, млрд рублей } \\
\end{array}$} & \multicolumn{2}{|c|}{$\begin{array}{c}\text { Средневзвешенная ставка по кредитам, } \\
\text { выданным в течение месяча, \% }\end{array}$} \\
\hline & $\begin{array}{c}\text { жилищцные } \\
\text { кредитьл }\end{array}$ & $\begin{array}{c}\text { из них ипотечные } \\
\text { жилищные кредить }\end{array}$ & $\begin{array}{c}\text { жилищьные } \\
\text { кредиты }\end{array}$ & $\begin{array}{c}\text { из них ипотечные } \\
\text { жилицные кредиты }\end{array}$ \\
\hline \multicolumn{5}{|l|}{ Июль } \\
\hline в рублях & 362,4 & 362,0 & 7,28 & 7,28 \\
\hline в иностранной валюте & 0,0 & 0,0 & 7,64 & 7,64 \\
\hline \multicolumn{5}{|l|}{ Август } \\
\hline в рублях & 393,3 & 392,3 & 7,17 & 7,16 \\
\hline в иностранной валюте & - & - & - & - \\
\hline
\end{tabular}

Таблица 5

ЗАДОЛЖЕННОСТЬ ПО КРЕДИТАМ, ПРЕДОСТАВЛЕННЫМ ФИЗИЧЕСКИМ ЛИЦАМ

на начало месяца, млрд рублей

\begin{tabular}{|c|c|c|c|c|c|c|}
\hline & \multicolumn{3}{|c|}{$\begin{array}{l}\text { Задолженность } \\
\text { по кредитам }\end{array}$} & \multicolumn{3}{|c|}{$\begin{array}{c}\text { Из общей суммы задолюсенности - } \\
\text { задолюенность перед ПАО Сбербанк }\end{array}$} \\
\hline & \multirow[t]{2}{*}{ всего } & \multicolumn{2}{|c|}{ из нее } & \multirow{2}{*}{ всего } & \multicolumn{2}{|c|}{ из нее } \\
\hline & & $\begin{array}{c}\text { по жилищным } \\
\text { кредитам }\end{array}$ & $\begin{array}{c}\text { из нее } \\
\text { по ипотечнымм } \\
\text { жилишцным } \\
\text { кредитам } \\
\end{array}$ & & $\begin{array}{c}\text { по жилищным } \\
\text { кредитам }\end{array}$ & $\begin{array}{c}\text { из нее } \\
\text { по ипотечнымм } \\
\text { жилищунымм } \\
\text { кредитам }\end{array}$ \\
\hline \multicolumn{7}{|c|}{2019 г. } \\
\hline Январь & 14856,6 & 6434,2 & 6410,4 & 6169,4 & 3608,5 & 3594,1 \\
\hline Февраль & 15005,8 & 6552,4 & 6522,3 & 6233,1 & 3590,8 & 3571,4 \\
\hline Март & 15190,0 & 6662,4 & 6632,3 & 6306,9 & 3679,4 & 3664,9 \\
\hline Апрель & 15449,3 & 6763,2 & 6733,5 & 6392,6 & 3713,7 & 3699,1 \\
\hline Май & 15761,2 & 6875,6 & 6845,6 & 6498,9 & 3756,8 & 3742,5 \\
\hline Июнь & 16014,8 & 6948,4 & 6924,8 & 6583,2 & 3776,9 & 3762,9 \\
\hline Июль & 16242,1 & 7027,3 & 7003,9 & 6667,2 & 3808,3 & 3794,8 \\
\hline Август & 16441,4 & 7048,6 & 7025,7 & 6760,8 & 3842,5 & 3829,4 \\
\hline Сентябрь & 16745,4 & 7155,3 & 7132,9 & 6876,5 & 3884,5 & 3871,7 \\
\hline Октябрь & 17016,5 & 7260,4 & 7238,1 & 6995,9 & 3932,1 & 3919,5 \\
\hline Ноябрь & 17159,2 & 7295,0 & 7272,9 & 7100,6 & 3987,5 & 3975,3 \\
\hline Декабрь & 17386,1 & 7422,0 & 7400,2 & 7199,9 & 4035,4 & 4023,5 \\
\hline \multicolumn{7}{|c|}{2020 г. } \\
\hline Январь & 17564,2 & 7512,5 & 7491,5 & 7240,4 & 4057,9 & 4046,2 \\
\hline Февраль & 17704,0 & 7560,0 & 7539,4 & 7300,1 & 4070,6 & 4059,2 \\
\hline Март & 17916,8 & 7674,6 & 7654,5 & 7374,9 & 4104,9 & 4093,7 \\
\hline Апрель & 18217,3 & 7781,7 & 7761,6 & 7455,5 & 4129,5 & 4118,7 \\
\hline Май & 18083,2 & 7833,0 & 7813,4 & 7422,6 & 4147,4 & 4136,8 \\
\hline Июнь & 18103,4 & 7890,4 & 7871,4 & 7442,0 & 4167,2 & 4156,8 \\
\hline Июль & 18281,6 & 7984,8 & 7966,1 & 7530,1 & 4221,0 & 4210,8 \\
\hline Август & 18569,2 & 8149,5 & 8131,1 & 7665,5 & 4311,2 & 4301,2 \\
\hline Сентябрь & 18929,5 & 8335,6 & 8317,1 & 7847,0 & 4415,6 & 4405,9 \\
\hline
\end{tabular}


Объем просроченной задолженности по жилищным кредитам, предоставленным кредитными организациями физическим лицам, на 1 сентября 2020 г. составил 80,6 млрд рублей (1,0\% от общей задолженности по жилищным кредитам) и увеличился по сравнению с 1 сентября 2019 г. на 4,5\%; из нее по ипотечным жилищным кредитам - 73,7 млрд рублей (0,9\% от общей задолженности по ипотечным жилищным кредитам) и увеличился соответственно на $0,7 \%$.

С 27 июля 2020 г. ключевая ставка, установленная Банком России, составляет 4,25\% годовых.

Объем депозитов, кредитов и прочих привлеченных кредитными организациями средств (в рублях и иностранной валюте) на 1 сентября 2020 г. составил 64909,4 млрд рублей.

Таблица 6

ДЕПОЗИТЫ, КРЕДИТЫ И ПРОЧИЕ

ПРИВЛЕЧЕННЫЕ КРЕДИТНЫМИ ОРГАНИЗАЦИЯМИ СРЕДСТВА

(по данным Банка России)

на начало месяца, млрд рублей

\begin{tabular}{|c|c|c|c|c|c|}
\hline & \multirow{2}{*}{$\begin{array}{l}\text { Общий объем } \\
\text { привлеченных } \\
\text { средств }\end{array}$} & \multicolumn{4}{|c|}{ В В том числе } \\
\hline & & $\begin{array}{c}\text { депозитьл и прочие } \\
\text { привлеченнье } \\
\text { средства } \\
\text { юридических лиц }\end{array}$ & $\begin{array}{c}\text { депозитьл, } \\
\text { кредитьл и прочие } \\
\text { привлеченнье } \\
\text { средства } \\
\text { кредитньхх } \\
\text { организачий } \\
\end{array}$ & $\begin{array}{c}\text { вклады (депозить) } \\
\text { и прочие } \\
\text { привлеченнье } \\
\text { средства } \\
\text { физических лич }\end{array}$ & $\begin{array}{c}\text { средства } \\
\text { на счетах } \\
\text { индивидуальньхх } \\
\text { предпринимателей }\end{array}$ \\
\hline \multicolumn{6}{|c|}{2019 г. } \\
\hline Январь & 59782,1 & 21652,0 & 9190,3 & 28460,2 & 479,5 \\
\hline Февраль & 58487,5 & 21213,3 & 9057,8 & 27744,4 & 472,0 \\
\hline Март & 58533,8 & 21293,5 & 8609,0 & 28168,3 & 462,9 \\
\hline Апрель & 58523,7 & 21345,7 & 8502,0 & 28215,5 & 460,5 \\
\hline Май & 59110,7 & 21690,1 & 8175,2 & 28810,3 & 435,1 \\
\hline Июнь & 59109,1 & 22091,0 & 7746,4 & 28805,7 & 466,1 \\
\hline Июль & 58579,6 & 21556,2 & 7550,0 & 28982,5 & 490,9 \\
\hline Август & 59040,6 & 22232,3 & 7251,9 & 29054,1 & 502,3 \\
\hline Сентябрь & 60061,0 & 22921,1 & 7142,8 & 29462,8 & 534,3 \\
\hline Октябрь & 59737,8 & 22594,6 & 7225,5 & 29351,1 & 566,6 \\
\hline Ноябрь & 59761,9 & 22813,3 & 7009,2 & 29382,9 & 556,4 \\
\hline Декабрь & 60116,3 & 22926,0 & 7017,9 & 29597,4 & 575,0 \\
\hline \multicolumn{6}{|c|}{2020 г. } \\
\hline Январь & 60988,6 & 21684,0 & 8147,1 & 30549,0 & 608,4 \\
\hline Февраль & 59898,2 & 21946,7 & 7190,4 & 30173,6 & 587,7 \\
\hline Март & 60673,0 & 22022,9 & 7242,2 & 30820,8 & 587,0 \\
\hline Апрель & 63802,1 & 23537,0 & 8207,2 & 31465,7 & 592,2 \\
\hline Май & 63411,6 & 23244,2 & 8116,3 & 31480,3 & 570,8 \\
\hline Июнь & 62417,5 & 22640,8 & 7980,2 & 31180,0 & 616,5 \\
\hline Июль & 63388,3 & 22826,0 & 8197,4 & 31693,0 & 671,9 \\
\hline Август & 65119,4 & 23417,3 & 8880,8 & 32107,8 & 713,4 \\
\hline Сентябрь & 64909,4 & 23200,1 & 8707,0 & 32215,4 & 786,9 \\
\hline
\end{tabular}


ОБЪЕМ ПРИВЛЕЧЕННЫХ КРЕДИТНЫМИ ОРГАНИЗАЦИЯМИ ВКЛАДОВ (ДЕПОЗИТОВ) ФИЗИЧЕСКИХ ЛИЦ на 1 сентября 2020 года

\begin{tabular}{|c|c|c|c|c|c|}
\hline & \multicolumn{2}{|c|}{$\overline{B c e r o}^{I I}$} & \multicolumn{3}{|c|}{ "Из них в ПАО Сбербанке) } \\
\hline & $\begin{array}{c}\text { млрд } \\
\text { рублей }\end{array}$ & $\begin{array}{c}\% \% \kappa \\
1 \text { сентября } \\
2019 \text { г. } \\
\end{array}$ & $\begin{array}{l}\text { млрд } \\
\text { рублей }\end{array}$ & $\begin{array}{c}\text { в\% к общему } \\
\text { объему вкладов } \\
\text { физических лии }\end{array}$ & $\begin{array}{c}\% \% \kappa \\
1 \text { сентября } \\
2019 \text { 2. } \\
\end{array}$ \\
\hline Всего & 32215,4 & 109,3 & 14498,0 & 45,0 & 111,7 \\
\hline $\begin{array}{l}\text { в том числе на счетах: } \\
\text { рублевых }\end{array}$ & 25557,6 & 110,6 & 11913,4 & 46,6 & 112,2 \\
\hline валютных & 6657,8 & 104,9 & 2584,6 & 38,8 & 109,5 \\
\hline
\end{tabular}

Таблица 8

СРЕДНЕВЗВЕШЕННЫЕ ПРОЦЕНТНЫЕ СТАВКИ

(по данным Банка России)

в августе 2020 года

процентов годовых

\begin{tabular}{|c|c|c|c|c|}
\hline \multirow[t]{2}{*}{ Со сроком } & \multicolumn{2}{|c|}{ По предоставленньми кредитам } & \multicolumn{2}{|c|}{ По привлеченным вкладам (депозитам) } \\
\hline & $\begin{array}{c}\text { физическим } \\
\text { личам }\end{array}$ & $\begin{array}{c}\text { нефинансовым } \\
\text { организачиям }\end{array}$ & $\begin{array}{c}\text { физических } \\
\text { лии }\end{array}$ & $\begin{array}{c}\text { нефинансовыхх } \\
\text { организаций }\end{array}$ \\
\hline \multicolumn{5}{|c|}{ В рублях } \\
\hline "до востребования" & - & - & 2,62 & - \\
\hline $\begin{array}{l}\text { до } 30 \text { дней, включая } \\
\text { "до востребования" }\end{array}$ & 12,13 & 4,94 & 2,57 & 3,14 \\
\hline $\begin{array}{l}\text { до } 30 \text { дней, кроме } \\
\text { "до востребования" }\end{array}$ & - & - & 2,50 & - \\
\hline от 31 до 90 дней & 9,84 & 6,97 & 2,83 & 3,76 \\
\hline от 91 до 180 дней & 15,58 & 7,94 & 3,08 & 4,15 \\
\hline от 181 дня до 1 года & 13,60 & 4,22 & 3,56 & 4,14 \\
\hline $\begin{array}{l}\text { до } 1 \text { года, включая } \\
\text { "до востребования" }\end{array}$ & 13,47 & 6,02 & 3,18 & 3,18 \\
\hline $\begin{array}{l}\text { до } 1 \text { года, кроме } \\
\text { "до востребования" }\end{array}$ & - & - & 3,24 & - \\
\hline от 1 года до 3 лет & 13,49 & 6,86 & 4,06 & 4,12 \\
\hline свыше 3 лет & 10,37 & 7,17 & 4,29 & 3,87 \\
\hline свыше 1 года & 10,72 & 6,97 & 4,07 & 4,11 \\
\hline \multicolumn{5}{|c|}{ В долларах США } \\
\hline "до востребования" & - & - & 0,07 & - \\
\hline $\begin{array}{l}\text { до } 30 \text { дней, включая } \\
\text { "до востребования" }\end{array}$ & - & 1,99 & 0,47 & 0,12 \\
\hline $\begin{array}{l}\text { до } 30 \text { дней, кроме } \\
\text { "до востребования" }\end{array}$ & - & - & 0,70 & - \\
\hline от 31 до 90 дней & - & 3,32 & 0,44 & 0,30 \\
\hline от 91 до 180 дней & - & 4,17 & 0,38 & 0,29 \\
\hline
\end{tabular}




\begin{tabular}{|c|c|c|c|c|}
\hline \multirow{2}{*}{ Со сроком } & \multicolumn{2}{|c|}{ "По предоставленным кредитам } & \multicolumn{2}{|c|}{ "По привлеченным вкладам (депозитам) } \\
\hline & $\begin{array}{c}\text { физическим } \\
\text { лищам }\end{array}$ & $\begin{array}{l}\text { нефинансовым } \\
\text { организачиям }\end{array}$ & $\begin{array}{c}\text { физических } \\
\text { лич }\end{array}$ & $\begin{array}{c}\text { нефинансовых } \\
\text { организаций }\end{array}$ \\
\hline от 181 дня до 1 года & - & 2,96 & 0,35 & 0,67 \\
\hline $\begin{array}{l}\text { до } 1 \text { года, включая } \\
\text { "до востребования" }\end{array}$ & - & 3,20 & 0,38 & 0,20 \\
\hline $\begin{array}{l}\text { до } 1 \text { года, кроме } \\
\text { "до востребования" }\end{array}$ & - & - & 0,41 & - \\
\hline от 1 года до 3 лет & - & 4,44 & 0,56 & 0,67 \\
\hline свыше 3 лет & - & 4,38 & 0,94 & - \\
\hline свыше 1 года & - & 4,40 & 0,57 & 0,67 \\
\hline \multicolumn{5}{|c|}{ В евро } \\
\hline "до востребования" & - & - & 0,01 & - \\
\hline $\begin{array}{l}\text { до } 30 \text { дней, включая } \\
\text { "до востребования" }\end{array}$ & - & - & 0,01 & - \\
\hline $\begin{array}{l}\text { до } 30 \text { дней, кроме } \\
\text { "до востребования" }\end{array}$ & - & - & - & - \\
\hline от 31 до 90 дней & - & 2,46 & 0,10 & - \\
\hline от 91 до 180 дней & - & 3,68 & 0,12 & - \\
\hline от 181 дня до 1 года & - & 2,54 & 0,14 & - \\
\hline $\begin{array}{l}\text { до } 1 \text { года, включая } \\
\text { "до востребования" }\end{array}$ & - & 2,61 & 0,04 & - \\
\hline $\begin{array}{l}\text { до } 1 \text { года, кроме } \\
\text { "до востребования" }\end{array}$ & - & - & 0,14 & - \\
\hline от 1 года до 3 лет & - & 3,64 & 0,34 & - \\
\hline свыше 3 лет & - & 3,16 & 0,24 & - \\
\hline свыше 1 года & - & 3,18 & 0,29 & - \\
\hline
\end{tabular}

Рынок государственных ценных бумаг. По данным Банка России, объем государственных ценных бумаг на конец сентября 2020 г. составил 11258,7 млрд рублей и увеличился по сравнению с соответствующей датой 2019 г. на 28,5\%, по сравнению с концом августа 2020 г. на $8,0 \%$.

Таблица 9

ОСНОВНЫЕ ПОКАЗАТЕЛИ

РЫНКА ГОСУДАРСТВЕННЫХ ЦЕННЫХ БУМАГ (ГКО-ОФЗ) (по данным Банка России)

млрд рублей

\begin{tabular}{|c|c|c|c|c|c|c|}
\hline & \multicolumn{3}{|c|}{$2020 z}$. & \multicolumn{3}{|c|}{ Справочно 20192. } \\
\hline & январь & aвгусm & сентябрь & январь & aвгу $\mathrm{cm}$ & сентябрь \\
\hline $\begin{array}{l}\text { Объем государственных ценных } \\
\text { бумаг (ГКО-ОФЗ) в в обращении }\end{array}$ & 8818,1 & 10424,4 & 11258,7 & 7353,4 & 8674,3 & 8765,0 \\
\hline в том числе: & & & & & & \\
\hline ОФЗ-ПД & 6605,3 & 7782,4 & 7873,3 & 4991,3 & 6273,5 & 6343,6 \\
\hline ОФЗ-АД & 315,5 & 315,5 & 315,5 & 380,6 & 377,9 & 377,9 \\
\hline ОФЗ-ПК & 1498,9 & 1864,3 & 2580,9 & 1722,1 & 1732,1 & 1747,1 \\
\hline ОФЗ-ИН & 398,3 & 462,2 & 489,0 & 259,4 & 290,8 & 296,4 \\
\hline Оборот рынка (по номиналу) & 160,1 & 132,1 & 150,6 & 188,1 & 197,7 & 149,1 \\
\hline
\end{tabular}




\begin{tabular}{|c|c|c|c|c|c|c|}
\hline & \multicolumn{3}{|c|}{20202.} & \multicolumn{3}{|c|}{ Справочно 20192. } \\
\hline & январь & aвгусm & сентябрь & январь & aвгycm & сентябрь \\
\hline Дюрация рыночного портфеля, дней ${ }^{2}$ & 1807 & 1773 & 1771 & 1660 & 1706 & 1693 \\
\hline $\begin{array}{l}\text { Объем выручки, полученной в результате } \\
\text { размещения и доразмещения ГКО-ОФ3 }\end{array}$ & 217,9 & 181,6 & 822,2 & 37,9 & 87,2 & 74,8 \\
\hline Объем погашений/купонных выплат в срок & 344,3 & 58,9 & 37,2 & 79,7 & 61,2 & 21,8 \\
\hline Перечислено средств в бюджет ${ }^{3)}$ & $-126,4$ & 122,7 & 785,0 & $-41,8$ & 26,0 & 53,1 \\
\hline
\end{tabular}

Таблица 10

ИНДИКАТОРЫ РЫНОЧНОГО ПОРТФЕЛЯ

ГОСУДАРСТВЕННЫХ ЦЕННЫХ БУМАГ НА ВТОРИЧНОМ РЫНКЕ

(по данным Банка России)

в сентябре 2020 года

процентов годовых

\begin{tabular}{||l|c|c||}
\hline & 1 сентября & 30 сентября \\
\hline ОФЗ-ПД & 5,77 & 5,97 \\
\hline ОФЗ-АД & 5,22 & 5,18 \\
\hline ОФЗ-ПК & 6,22 & 5,78 \\
\hline ОФЗ-ИН & 2,54 & 2,60 \\
\hline \multicolumn{2}{|l|}{ 1) Средняя из эффективных доходностей, взвеменная по срокам до погашения и по объему в обрашении. } \\
\hline
\end{tabular}

Валютный рынок. По данным Банка России, международные резервы Российской Федерации на 1 октября 2020 г. составили 583,4 млрд долларов США и по сравнению с 1 октября 2019 г. увеличились на 9,9\%, по сравнению с 1 сентября 2020 г. снизился на 1,8\%.

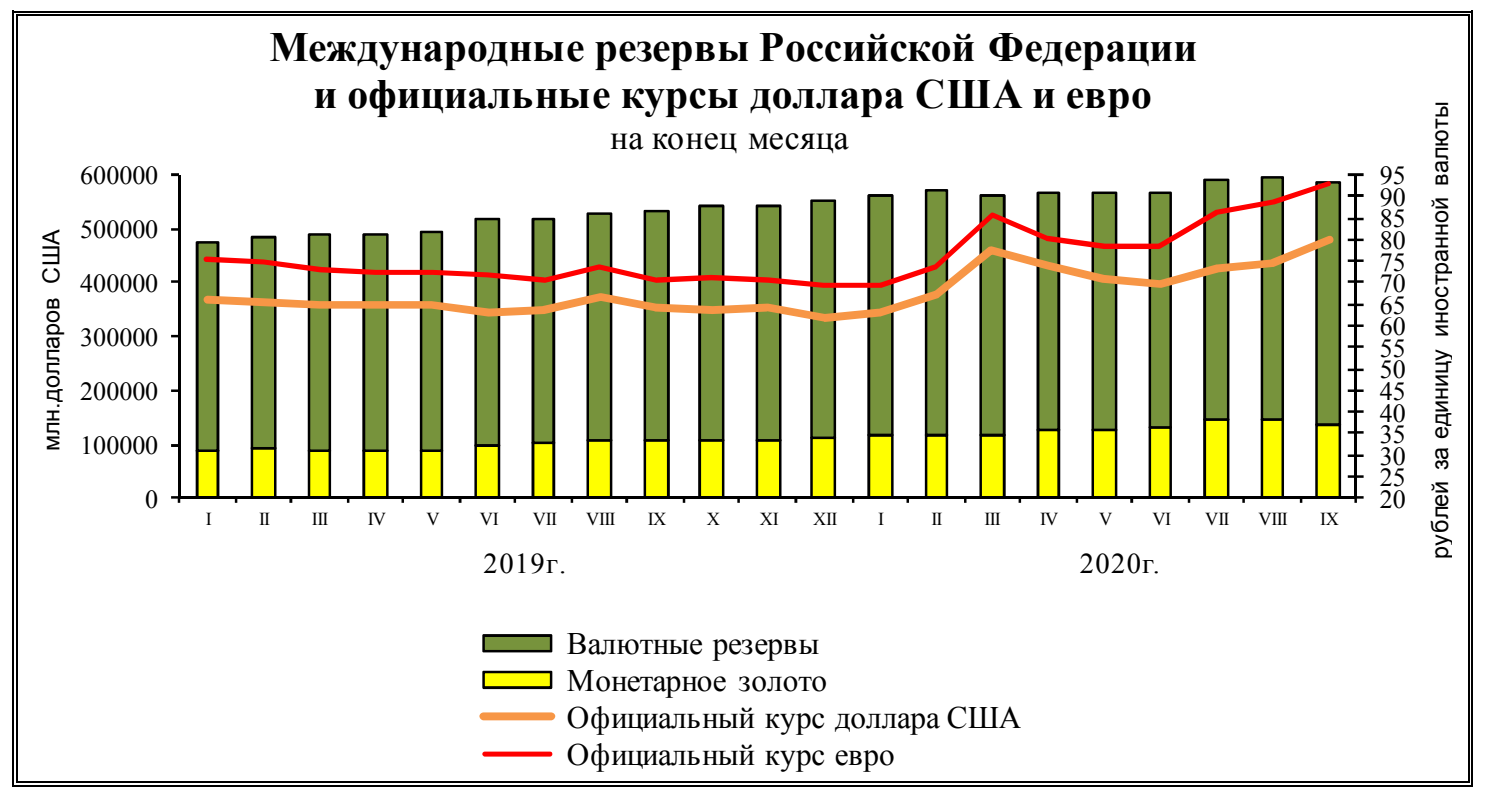


ДИНАМИКА ОФИЦИАЛЬНЫХ КУРСОВ ИНОСТРАННЫХ ВАЛЮТ

(российских рублей за единицу иностранной валюты)

(по данным Банка России)

на конец месяца

\begin{tabular}{|c|c|c|c|c|c|c|}
\hline & \multirow{2}{*}{$\begin{array}{c}\text { Доллар } \\
\text { США }\end{array}$} & \multicolumn{2}{|c|}{$\bar{B} \bar{c} \% \kappa$} & \multirow[t]{2}{*}{ Евро } & \multicolumn{2}{|c|}{$\bar{B} \overline{B \% \kappa}$} \\
\hline & & $\begin{array}{c}\text { предыдущему } \\
\text { месяиу }\end{array}$ & $\begin{array}{c}\text { кониу преды- } \\
\text { душего года }\end{array}$ & & $\begin{array}{l}\text { предыдуще- } \\
\text { му месяиу }\end{array}$ & $\begin{array}{l}\text { кониу преды- } \\
\text { душего года }\end{array}$ \\
\hline \multicolumn{7}{|c|}{2019 г. } \\
\hline Январь & 66,10 & 95,1 & 95,1 & 75,57 & 95,1 & 95,1 \\
\hline Февраль & 65,76 & 99,5 & 94,7 & 74,82 & 99,0 & 94,2 \\
\hline Март & 64,73 & 98,4 & 93,2 & 72,72 & 97,2 & 91,5 \\
\hline Апрель & 64,69 & 99,9 & 93,1 & 72,20 & 99,3 & 90,9 \\
\hline Май & 65,06 & 100,6 & 93,7 & 72,42 & 100,3 & 91,1 \\
\hline Июнь & 63,08 & 97,0 & 90,8 & 71,82 & 99,2 & 90,4 \\
\hline Июль & 63,38 & 100,5 & 91,2 & 70,60 & 98,3 & 88,8 \\
\hline Август & 66,49 & 104,9 & 95,7 & 73,38 & 103,9 & 92,4 \\
\hline Сентябрь & 64,42 & 96,9 & 92,7 & 70,32 & 95,8 & 88,5 \\
\hline Октябрь & 63,87 & 99,2 & 91,9 & 71,01 & 101,0 & 89,4 \\
\hline Ноябрь & 64,08 & 100,3 & 92,2 & 70,55 & 99,4 & 88,8 \\
\hline Декабрь & 61,91 & 96,6 & 89,1 & 69,34 & 98,3 & 87,3 \\
\hline \multicolumn{7}{|c|}{2020 г. } \\
\hline Январь & 63,04 & 101,8 & 101,8 & 69,42 & 100,1 & 100,1 \\
\hline Февраль & 66,99 & 106,3 & 108,2 & 73,72 & 106,2 & 106,3 \\
\hline Март & 77,73 & 116,0 & 125,6 & 85,74 & 116,3 & 123,6 \\
\hline Апрель & 73,69 & 94,8 & 119,0 & 80,05 & 93,4 & 115,4 \\
\hline Май & 70,75 & 96,0 & 114,3 & 78,55 & 98,1 & 113,3 \\
\hline Июнь & 69,95 & 98,9 & 113,0 & 78,68 & 100,2 & 113,5 \\
\hline Июль & 73,36 & 104,9 & 118,5 & 86,25 & 109,6 & 124,4 \\
\hline Август & 74,64 & 101,7 & 120,6 & 88,74 & 102,9 & 128,0 \\
\hline Сентябрь & 79,68 & 106,8 & 128,7 & 93,02 & 104,8 & 134,2 \\
\hline
\end{tabular}

Таблица 12

ИНДЕКСЫ РЕАЛЬНОГО ЭФФЕКТИВНОГО КУРСА РУБЛЯ К ИНОСТРАННЫМ ВАЛЮТАМ И РЕАЛЬНОГО КУРСА РУБЛЯ К ДОЛЛАРУ США И ЕВРО

(по данным Банка России)

в процентах

\begin{tabular}{|c|c|c|c|c|c|c|}
\hline & \multirow{3}{*}{\multicolumn{2}{|c|}{$\begin{array}{c}\text { Прирост (снижение) реального } \\
\text { эффективного курса рубля } \\
\text { к иностранньм валютам }\end{array}$}} & \multicolumn{4}{|c|}{ Прирост (снижение) реального курса рубля к } \\
\hline & & & \multicolumn{2}{|c|}{ доллару США } & \multicolumn{2}{|c|}{ евро } \\
\hline & & & \multirow{2}{*}{$\begin{array}{c}\text { к предьлушщему } \\
\text { периоду }\end{array}$} & \multirow{2}{*}{$\begin{array}{c}\text { к декабрю } \\
\text { предьлдущего } \\
\text { года }\end{array}$} & \multirow{2}{*}{$\begin{array}{c}\text { к предылдущему } \\
\text { периоду }\end{array}$} & \multirow{2}{*}{$\begin{array}{c}\text { к декабрю } \\
\text { предьдучщего } \\
\text { года }\end{array}$} \\
\hline & $\begin{array}{c}\text { к предьгдущему } \\
\text { периоду }\end{array}$ & $\begin{array}{c}\text { к декабрю } \\
\text { предылдущего } \\
\text { года }\end{array}$ & & & & \\
\hline \multicolumn{7}{|c|}{2019 г. } \\
\hline Январь & 0,3 & 0,3 & 0,8 & 0,8 & 1,0 & 1,0 \\
\hline Февраль & 2,2 & 2,5 & 2,2 & 3,0 & 2,9 & 3,9 \\
\hline Март & 1,2 & 3,8 & 0,8 & 3,9 & 1,2 & 5,1 \\
\hline Апрель & 1,2 & 5,1 & 0,6 & 4,5 & 1,2 & 6,4 \\
\hline Май & 0,5 & 5,6 & $-0,2$ & 4,2 & 0,4 & 6,8 \\
\hline
\end{tabular}




\begin{tabular}{|c|c|c|c|c|c|c|}
\hline & \multirow{3}{*}{\multicolumn{2}{|c|}{$\begin{array}{l}\text { Прирост (снижсение) реального } \\
\text { эфрективного курса рубля } \\
\text { к иностранным валютам } \\
\end{array}$}} & \multicolumn{4}{|c|}{ Прирост (снижение) реального курса рубля к } \\
\hline & & & \multicolumn{2}{|c|}{ доллару США } & \multicolumn{2}{|c|}{ евро } \\
\hline & & & \multirow{2}{*}{$\begin{array}{c}\text { кредььдущему } \\
\text { периоду }\end{array}$} & \multirow{2}{*}{$\begin{array}{c}\text { к декабрю } \\
\text { предьдущего } \\
\text { года }\end{array}$} & \multirow{2}{*}{$\begin{array}{c}\text { к предырдущему } \\
\text { периоду }\end{array}$} & \multirow{2}{*}{$\begin{array}{c}\text { кдекабрю } \\
\text { предьдуущего } \\
\text { года }\end{array}$} \\
\hline & $\begin{array}{c}\text { к предыдучщему } \\
\text { периоду }\end{array}$ & $\begin{array}{c}\text { к декабрю } \\
\text { предььуущего } \\
\text { года }\end{array}$ & & & & \\
\hline Июнь & 0,3 & 6,0 & 0,9 & 5,2 & $-0,0$ & 6,8 \\
\hline Июль & 1,5 & 7,5 & 1,7 & 6,9 & 2,0 & 8,9 \\
\hline Август & $-2,9$ & 4,4 & $-3,7$ & 2,9 & $-3,0$ & 5,7 \\
\hline Сентябрь & 1,1 & 5,5 & 0,6 & 3,5 & 1,8 & 7,6 \\
\hline Октябрь & 0,3 & 5,9 & 0,8 & 4,4 & 0,7 & 8,3 \\
\hline Ноябрь & 0,6 & 6,6 & 1,1 & 5,5 & 1,2 & 9,7 \\
\hline Декабрь & 1,4 & 8,1 & 2,0 & 7,6 & 1,3 & 11,1 \\
\hline Год & 2,5 & & $-0,9$ & & 4,7 & \\
\hline \multicolumn{7}{|c|}{2020 г. } \\
\hline Январь & 1,5 & 1,5 & 1,9 & 1,9 & 2,4 & 2,4 \\
\hline Февраль & $-1,7$ & $-0,1$ & $-3,1$ & $-1,3$ & $-1,3$ & 1,2 \\
\hline Март & $-11,1$ & $-11,2$ & $-11,8$ & $-12,9$ & $-13,4$ & $-12,4$ \\
\hline Апрель & 0,0 & $-11,2$ & $-1,2$ & $-13,9$ & $-0,6$ & $-13,0$ \\
\hline Май & 3,8 & $-7,7$ & 4,0 & $-10,5$ & 4,1 & $-9,4$ \\
\hline Июнь & 2,6 & $-5,4$ & 4,5 & $-6,5$ & 1,3 & $-8,4$ \\
\hline Июль & $-3,3$ & $-7,0$ & $-3,1$ & $-9,4$ & $-3,9$ & $-11,9$ \\
\hline Август & $-5,1$ & $-13,2$ & $-3,8$ & $-12,8$ & $-6,7$ & $-17,9$ \\
\hline Сентябрь ${ }^{2)}$ & $-2,3$ & $-15,2$ & $-2,9$ & $-15,4$ & $-2,0$ & $-19,5$ \\
\hline
\end{tabular}

В сентябре 2020 г. по сравнению с предыдущим месяцем индекс потребительских цен составил 99,9\%, изменение официального курса доллара США и евро к рублю - 106,8\% и 104,8\% соответственно.

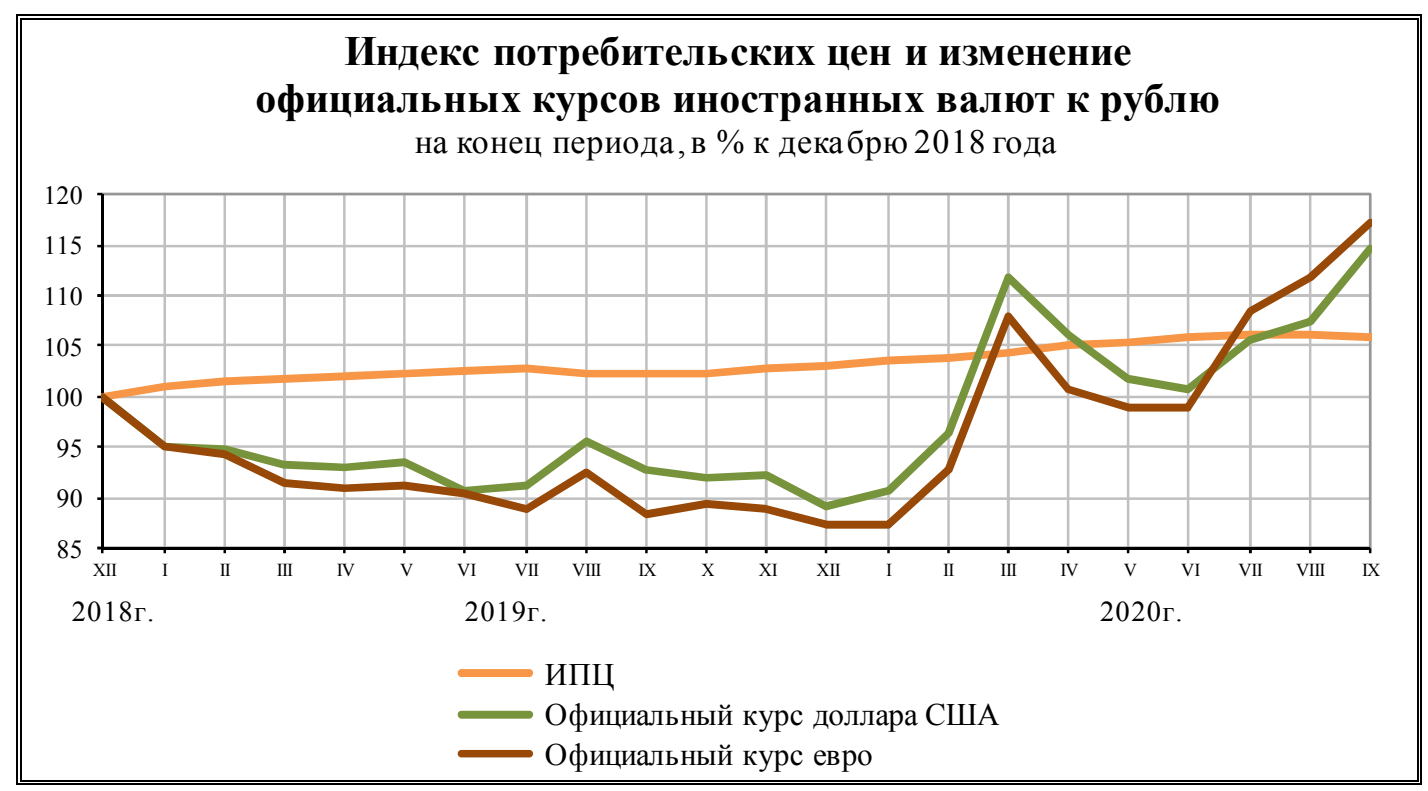




\section{III СОЦИАЛЬНАЯ СФЕРА}

\section{1. УРОВЕНЬ ЖИЗНИ НАСЕЛЕНИЯ}

В январе-сентябре 2020 г. объем денежных доходов населения сложился в размере 43679,0 млрд рублей и снизился на 0,7\% по сравнению с январем-сентябрем 2019 года.

Денежные расходы населения в январе-сентябре 2020 г. составили 41055,9 млрд рублей и снизились на 5,4\% по сравнению с соответствующим периодом предыдущего года. Население израсходовало на покупку товаров и оплату услуг 34432,2 млрд рублей, что на 6,3\% меньше, чем в январе-сентябре 2019 года. За этот период сбережения населения составили 2623,2 млрд рублей и увеличились в 4,6 раза по сравнению с январем-сентябрем 2019 года.

Таблица 1

ОСНОВНЫЕ ПОКАЗАТЕЛИ,

ХАРАКТЕРИЗУЮЩИЕ УРОВЕНЬ ЖИЗНИ НАСЕЛЕНИЯ

Таблица 1.1

\begin{tabular}{|c|c|c|c|c|c|c|c|}
\hline & \multirow{3}{*}{$\begin{array}{l}\text { III квар- } \\
\text { тал } \\
2020 \text { 2. }\end{array}$} & \multicolumn{2}{|c|}{$B \% \kappa$} & \multirow{3}{*}{$\begin{array}{c}\text { Январь- } \\
\text { сентябрь } \\
2020 \text { г. } \\
\text { в\% к } \\
\text { январю- } \\
\text { сентябрю } \\
2019 \text { г. }\end{array}$} & \multicolumn{3}{|c|}{ Справочно } \\
\hline & & \multirow{2}{*}{$\begin{array}{l}\text { III квар- } \\
\text { талу } \\
2019^{2} \text {. }\end{array}$} & \multirow{2}{*}{$\begin{array}{l}\text { II квар- } \\
\text { талу } \\
2020 \text { г. }\end{array}$} & & \multicolumn{2}{|c|}{$\begin{array}{c}\text { III квартал } 20192 . \\
\text { в\% к }\end{array}$} & \multirow{2}{*}{$\begin{array}{c}\text { январь- } \\
\text { сентябрь } \\
2019 \text { г. } \\
\text { в\% к } \\
\text { январю- } \\
\text { сентябрю } \\
2018 \text { г. } \\
\end{array}$} \\
\hline & & & & & $\begin{array}{c}\text { III квар- } \\
\text { талу } \\
2018 \text { г. }\end{array}$ & $\begin{array}{c}\text { II квар- } \\
\text { талу } \\
2019 \text { г. }\end{array}$ & \\
\hline Денежные доходы населения ${ }^{1)}$ : & & & & & & & \\
\hline $\begin{array}{l}\text { денежные доходы } \\
\text { (в среднем на душу населения), } \\
\text { рублей в месяц }\end{array}$ & 35043 & 99,8 & 107,3 & 99,3 & 108,0 & 101,7 & 106,4 \\
\hline реальные денежные доходы & & 96,4 & 106,7 & 96,4 & 103,5 & 101,6 & 101,5 \\
\hline $\begin{array}{l}\text { реальные располагаемые } \\
\text { денежные доходы }\end{array}$ & & 95,2 & 105,2 & 95,7 & 102,9 & 101,3 & 100,9 \\
\hline
\end{tabular}

Таблица 1.2

\begin{tabular}{|c|c|c|c|c|c|c|c|}
\hline & \multirow{3}{*}{$\begin{array}{l}\text { Aвгусm } \\
2020 \text { г. }\end{array}$} & \multicolumn{2}{|c|}{$B \% \kappa$} & \multirow{3}{*}{$\begin{array}{c}\text { Январь- } \\
\text { август } \\
2020 \text { г. } \\
\text { в\% к } \\
\text { январю- } \\
\text { августу } \\
20192 .\end{array}$} & \multicolumn{3}{|c|}{ Справочно } \\
\hline & & \multirow{2}{*}{$\begin{array}{l}\text { августу } \\
2019 \text { г. }\end{array}$} & \multirow{2}{*}{$\begin{array}{c}\text { июлю } \\
2020 \text { г. }\end{array}$} & & \multicolumn{2}{|c|}{ август 2019 г. в\% к } & \multirow[b]{2}{*}{$\begin{array}{c}\text { январь- } \\
\text { август } \\
2019 \text { г. } \\
\text { в \% к } \\
\text { январю- } \\
\text { августу } \\
2018 \text { г. }\end{array}$} \\
\hline & & & & & $\begin{array}{c}\text { aвzусmy } \\
2018 \text { 2. }\end{array}$ & $\begin{array}{c}\text { июлю } \\
2019 \text { г. }\end{array}$ & \\
\hline \multicolumn{8}{|c|}{$\begin{array}{l}\text { Среднемесячная начисленная } \\
\text { заработная плата работников } \\
\text { организаций: }\end{array}$} \\
\hline номинальная, рублей & 47649 & 103,7 & 95,1 & 105,6 & 106,8 & 96,5 & 107,2 \\
\hline реальная & & 100,1 & 95,1 & 102,6 & 102,4 & 96,7 & 102,2 \\
\hline
\end{tabular}




\begin{tabular}{|c|c|c|c|c|c|c|c|}
\hline & \multirow{3}{*}{$\begin{array}{l}\text { Сентябрь } \\
2020 \text { г. }\end{array}$} & \multicolumn{2}{|c|}{$B \% \kappa$} & \multirow{3}{*}{$\begin{array}{c}\text { Январь- } \\
\text { сентябрь } \\
2020 \text { г. } \\
\text { в\% к } \\
\text { январю- } \\
\text { сентябрю } \\
2019 \text { 2. }\end{array}$} & \multicolumn{3}{|c|}{ Справочно } \\
\hline & & \multirow{2}{*}{$\begin{array}{l}\text { сентябрю } \\
2019 \text { 2. }\end{array}$} & \multirow{2}{*}{$\begin{array}{l}\text { aвгycmy } \\
2020 \text { 2. }\end{array}$} & & \multicolumn{2}{|c|}{ сентябрь 2019 г. в \% к } & \multirow[b]{2}{*}{$\begin{array}{c}\text { январь- } \\
\text { сентябрь } \\
2019 \text { г. } \\
\text { в\% к } \\
\text { январю- } \\
\text { сентябрю } \\
2018 \text { г. } \\
\end{array}$} \\
\hline & & & & & \begin{tabular}{|c|} 
сентябрю \\
2018 г.
\end{tabular} & $\begin{array}{l}\text { aвzycmy } \\
20192 .\end{array}$ & \\
\hline Пенсии ${ }^{1)}$ : & & & & & & & \\
\hline $\begin{array}{l}\text { средний размер } \\
\text { назначенных пенсий, рублей }\end{array}$ & 15018 & 105,8 & 100,1 & 105,8 & 106,1 & 100,2 & 106,0 \\
\hline $\begin{array}{l}\text { реальный размер } \\
\text { назначенных пенсий }\end{array}$ & & 102,0 & 100,2 & 102,7 & 102,0 & 100,3 & 101,1 \\
\hline
\end{tabular}

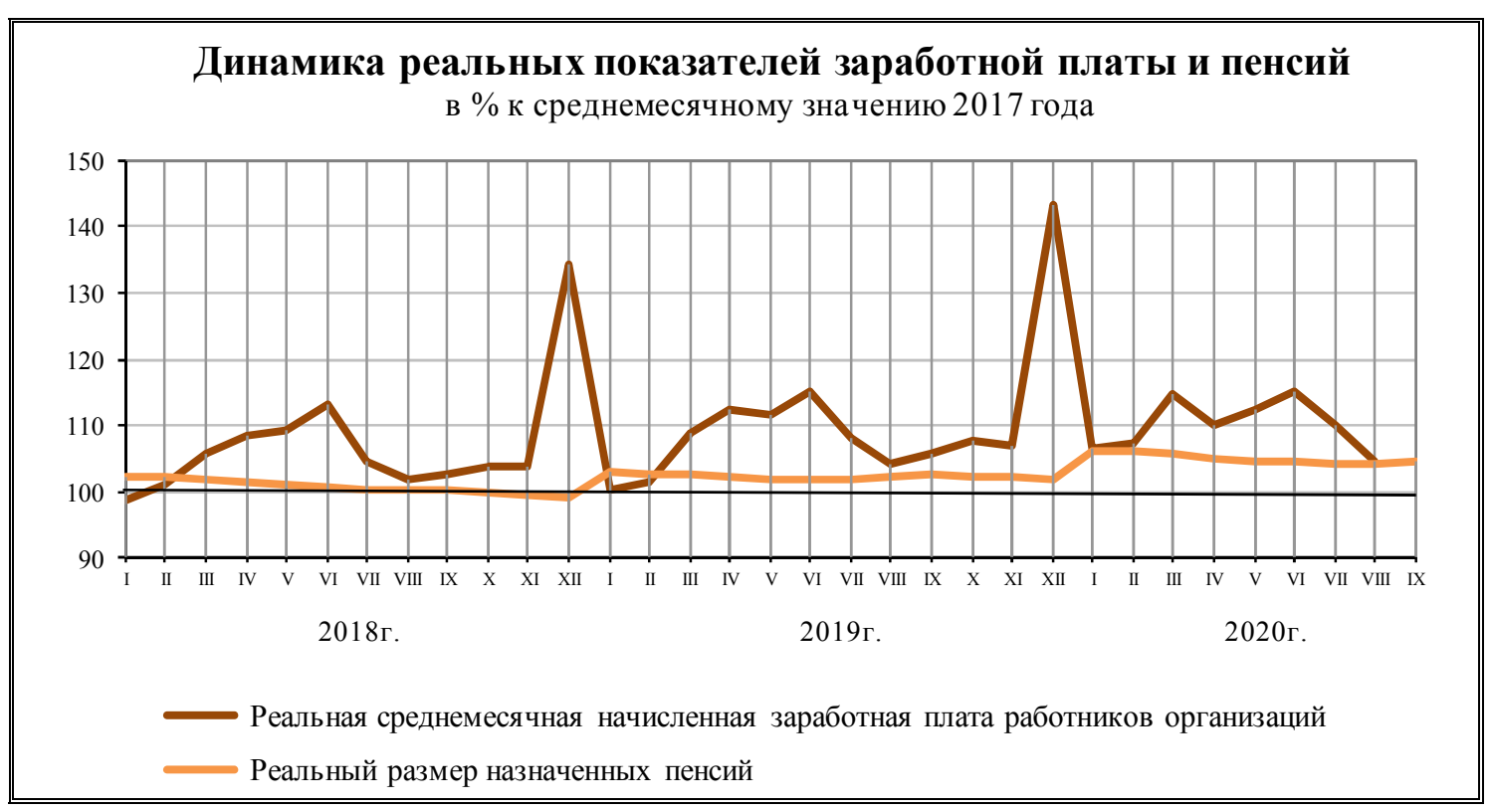

\section{1. ДЕНЕЖНЫЕ ДОХОДЫ}

Реальные денежные доходы, по оценке, в III квартале 2020 г. по сравнению с соответствующим периодом предыдущего года снизились на 3,6\%, в январе-сентябре 2020 г. по сравнению с январем-сентябрем 2019 г. - снизились на 3,6\%.

Реальные располагаемые денежные доходы (доходы за вычетом обязательных платежей, скорректированные на индекс потребительских цен), по оценке, в III квартале 2020 г. по сравнению с соответствующим периодом предыдущего года снизились на 4,8\%, в январесентябре 2020 г. по сравнению с январем-сентябрем 2019 г. - снизились на 4,3\%. 
ДИНАМИКА ДЕНЕЖНЫХ ДОХОДОВ НАСЕЛЕНИЯ

\begin{tabular}{|c|c|c|c|c|}
\hline & \multicolumn{2}{|c|}{ Реальные денежные доходы в \% к } & \multicolumn{2}{|c|}{ Реальные располагаемые денежные доходы в \% к } \\
\hline & $\begin{array}{c}\text { соответствующему } \\
\text { периоду } \\
\text { предыдущего } \\
\text { года } \\
\end{array}$ & $\begin{array}{c}\text { предьидущему } \\
\text { периоду }\end{array}$ & $\begin{array}{c}\text { соответствующему } \\
\text { периоду } \\
\text { предьлдущего } \\
\text { года } \\
\end{array}$ & $\begin{array}{c}\text { предьдущему } \\
\text { периоду }\end{array}$ \\
\hline \multicolumn{5}{|c|}{2019 г. $^{1)}$} \\
\hline I квартал & 99,3 & 76,2 & 98,4 & 76,6 \\
\hline II квартал & 101,5 & 113,1 & 101,0 & 113,3 \\
\hline І полугодие & 100,5 & & 99,7 & \\
\hline III квартал & 103,5 & 101,6 & 102,9 & 101,3 \\
\hline Январь-сентябрь & 101,5 & & 100,9 & \\
\hline IV квартал & 102,3 & 116,8 & 101,8 & 115,9 \\
\hline Год & 101,7 & & 101,0 & \\
\hline \multicolumn{5}{|c|}{2020 г. $^{2)}$} \\
\hline I квартал & 101,7 & 75,7 & 100,7 & 75,7 \\
\hline II квартал & 91,7 & 102,0 & 91,6 & 103,2 \\
\hline I полугодие & 96,4 & & 95,9 & \\
\hline III квартал & 96,4 & 106,7 & 95,2 & 105,2 \\
\hline Январь-сентябрь & 96,4 & & 95,7 & \\
\hline $\begin{array}{l}\text { 1) Предварительн } \\
\text { 2) Оценка. Данньл } \\
\text { ных показател }\end{array}$ & tные. & публикованнь & связи с корректировкой & России отдель- \\
\hline
\end{tabular}

В структуре денежных доходов населения в III квартале 2020 г. по сравнению с соответствующим периодом 2019 г. возросла доля оплаты труда и социальных выплат при снижении доли доходов от предпринимательской деятельности и прочих денежных поступлений.

Таблица 3

СТРУКТУРА ДЕНЕЖНЫХ ДОХОДОВ НАСЕЛЕНИЯ ${ }^{1)}$

в \% к итогу

\begin{tabular}{|c|c|c|c|c|c|c|c|}
\hline & \multirow{2}{*}{$\begin{array}{c}\text { Всего } \\
\text { денежниьх } \\
\text { доходов }\end{array}$} & \multicolumn{6}{|c|}{ В том числе } \\
\hline & & $\begin{array}{c}\text { доходьи от } \\
\text { предприни- } \\
\text { мательской } \\
\text { деятельности }\end{array}$ & $\begin{array}{c}\text { оплата } \\
\text { труда }\end{array}$ & $\begin{array}{c}\text { из нее зара- } \\
\text { ботная } \\
\text { плата ра- } \\
\text { ботников } \\
\text { организаций }\end{array}$ & $\begin{array}{c}\text { социиальные } \\
\text { выплатыл }\end{array}$ & $\begin{array}{c}\text { доходьи от } \\
\text { собствен- } \\
\text { ности }\end{array}$ & $\begin{array}{c}\text { прочие } \\
\text { денежнье } \\
\text { поступления }\end{array}$ \\
\hline \multicolumn{8}{|c|}{2019 г. } \\
\hline I квартал & 100 & 6,0 & 61,8 & 43,6 & 19,1 & 4,1 & 9,0 \\
\hline
\end{tabular}




\begin{tabular}{|c|c|c|c|c|c|c|c|}
\hline & \multirow{2}{*}{$\begin{array}{c}\text { Всего } \\
\text { денежных } \\
\text { доходов }\end{array}$} & \multicolumn{6}{|c|}{ 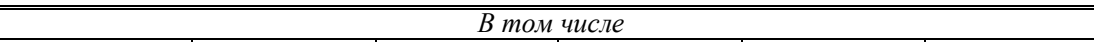 } \\
\hline & & $\begin{array}{c}\text { доходы от } \\
\text { предприни- } \\
\text { мательской } \\
\text { деятельности }\end{array}$ & $\begin{array}{c}\text { оплата } \\
\text { труда }\end{array}$ & $\begin{array}{l}\text { из нее зара- } \\
\text { ботная } \\
\text { плата ра- } \\
\text { ботников } \\
\text { организаиий }\end{array}$ & $\begin{array}{c}\text { соииальные } \\
\text { выплатыл }\end{array}$ & $\begin{array}{c}\text { доходы от } \\
\text { собствен- } \\
\text { ности }\end{array}$ & $\begin{array}{c}\text { прочие } \\
\text { денежные } \\
\text { поступления }\end{array}$ \\
\hline II квартал & 100 & 5,7 & 60,6 & 42,0 & 19,5 & 4,3 & 9,9 \\
\hline III квартал & 100 & 6,2 & 56,2 & 38,9 & 19,2 & 4,6 & 13,8 \\
\hline IV квартал & 100 & 6,2 & 54,5 & 37,2 & 18,5 & 4,4 & 16,4 \\
\hline Год & 100 & 6,0 & 58,0 & 40,2 & 19,0 & 4,4 & 12,6 \\
\hline \multicolumn{8}{|c|}{2020 г. } \\
\hline I квартал & 100 & 5,9 & 63,8 & 46,3 & 22,2 & 4,1 & 4,0 \\
\hline II квартал & 100 & 4,0 & 61,8 & 43,8 & 22,1 & 4,0 & 8,1 \\
\hline III квартал & 100 & 5,6 & 57,1 & 40,4 & 22,9 & 4,3 & 10,1 \\
\hline
\end{tabular}

\section{Реальные располагаемые денежные доходы населения ${ }^{1)}$} в \% к среднеквартальному значению 2017 года

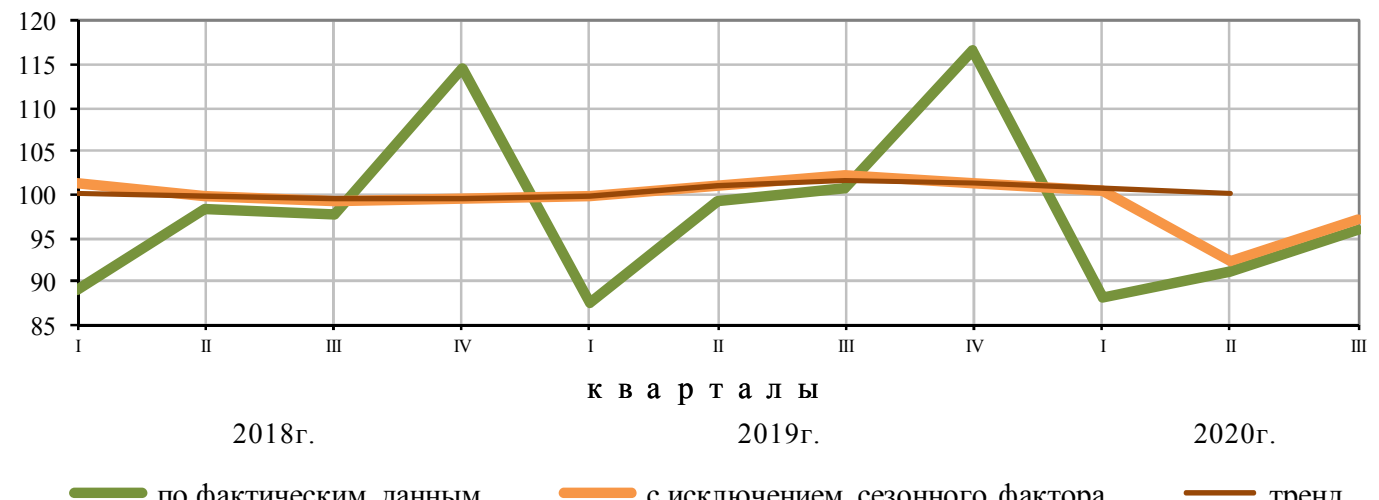

по фактическим данным $\rightleftharpoons$ исключением сезонного фактора $\longrightarrow$ тренд

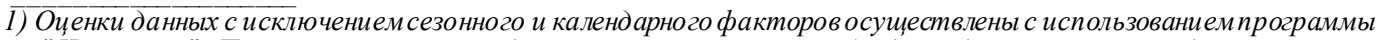
"JDemetra+". При поступлении новых данных статистических наблюдений динамика может быть уточнена .

Заработная плата. Среднемесячная начисленная заработная плата работников организаций в августе 2020 г. составила 47649 рублей и по сравнению с соответствующим периодом предыдущего года выросла на 3,7\% (в январе-августе 2020 г. - на 5,6\%). 
ДИНАМИКА СРЕДНЕМЕСЯЧНОЙ НОМИНАЛЬНОЙ И РЕАЛЬНОЙ НАЧИСЛЕННОЙ ЗАРАБОТНОЙ ПЛАТЫ РАБОТНИКОВ ОРГАНИЗАЦИЙ

\begin{tabular}{|c|c|c|c|c|c|}
\hline & \multirow{3}{*}{$\begin{array}{c}\text { Среднемесячная } \\
\text { номинальная } \\
\text { начисленная } \\
\text { заработная плата, } \\
\text { рублей } \\
\end{array}$} & \multicolumn{2}{|c|}{$\bar{B} \% \kappa$} & \multirow{2}{*}{\multicolumn{2}{|c|}{$\begin{array}{c}\text { Реальная начисленная } \\
\text { заработная плата в \% к }\end{array}$}} \\
\hline & & \multirow{2}{*}{$\begin{array}{c}\text { соответствую- } \\
\text { щему периоду } \\
\text { предыдущего года }\end{array}$} & \multirow{2}{*}{$\begin{array}{c}\text { предылучщему } \\
\text { периоду }\end{array}$} & & \\
\hline & & & & $\begin{array}{c}\text { соответствую- } \\
\text { шему периоду } \\
\text { предыдушего года }\end{array}$ & $\begin{array}{c}\text { предььдущему } \\
\text { периоду }\end{array}$ \\
\hline \multicolumn{6}{|c|}{2019 г. } \\
\hline Январь & 42263 & 106,1 & 75,6 & 101,1 & 74,8 \\
\hline Февраль & 43062 & 105,2 & 101,5 & 100,0 & 101,1 \\
\hline Март & 46324 & 107,7 & 107,5 & 102,3 & 107,2 \\
\hline І квартал & 43944 & 106,5 & 93,6 & 101,3 & 91,6 \\
\hline Апрель & 48030 & 108,4 & 103,5 & 103,1 & 103,2 \\
\hline Май & 47926 & 106,8 & 99,7 & 101,6 & 99,4 \\
\hline Июнь & 49348 & 107,7 & 102,9 & 102,9 & 102,9 \\
\hline ІІ квартал & 48453 & 107,7 & 110,2 & 102,6 & 109,2 \\
\hline I полугодие & 46210 & 107,1 & & 101,9 & \\
\hline Июль & 46509 & 107,7 & 94,1 & 103,0 & 93,9 \\
\hline Август & 44961 & 106,8 & 96,5 & 102,4 & 96,7 \\
\hline Январь-август & 46112 & 107,2 & & 102,2 & \\
\hline Сентябрь & 45541 & 107,2 & 101,1 & 103,1 & 101,3 \\
\hline ІІІ квартал & 45726 & 107,4 & 94,3 & 103,0 & 94,2 \\
\hline Январь-сентябрь & 46057 & 107,2 & & 102,3 & \\
\hline Октябрь & 46549 & 107,7 & 102,1 & 103,8 & 102,0 \\
\hline Ноябрь & 46285 & 106,3 & 99,4 & 102,7 & 99,1 \\
\hline Декабрь & 62239 & 110,1 & 134,5 & 106,9 & 134,0 \\
\hline IV квартал & 51684 & 108,2 & 113,0 & 104,6 & 112,7 \\
\hline Год & 47867 & 109,5 & & 104,8 & \\
\hline \multicolumn{6}{|c|}{2020 г. } \\
\hline Январь & 46674 & 109,1 & 74,8 & 106,5 & 74,5 \\
\hline Февраль & 47257 & 108,1 & 100,8 & 105,7 & 100,5 \\
\hline Март & 50948 & 108,6 & 107,7 & 105,9 & 107,1 \\
\hline I квартал & 48390 & 108,8 & 93,5 & 106,2 & 92,4 \\
\hline Апрель & 49306 & 101,0 & 96,5 & 98,0 & 95,7 \\
\hline Май & 50747 & 104,0 & 102,7 & 101,0 & 102,4 \\
\hline Июнь & 52123 & 103,8 & 102,6 & 100,6 & 102,4 \\
\hline II квартал & 50784 & 103,0 & 104,9 & 99,9 & 103,3 \\
\hline I полугодие & 49600 & 105,8 & & 102,9 & \\
\hline Июль & 50145 & 106,4 & 96,0 & 102,9 & 95,7 \\
\hline Август & 47649 & 103,7 & 95,1 & 100,1 & 95,1 \\
\hline Январь-август & 49440 & 105,6 & & 102,6 & \\
\hline
\end{tabular}




\section{СРЕДНЕМЕСЯЧНАЯ НАЧИСЛЕННАЯ ЗАРАБОТНАЯ ПЛАТА РАБОТНИКОВ ОРГАНИЗАЦИЙ \\ (БЕЗ ВЫПЛАТ СОЩИАЛЬНОГО ХАРАКТЕРА) ПО ВИДАМ ЭКОНОМИЧЕСКОЙ ДЕЯТЕЛЬНОСТИ}

\begin{tabular}{|c|c|c|c|c|c|c|}
\hline & \multicolumn{3}{|c|}{ Aвгуст 2020 г. } & \multicolumn{3}{|c|}{ Январь-август 2020 г. } \\
\hline & \multirow[t]{2}{*}{ рублей } & \multicolumn{2}{|c|}{$6 \% \mathrm{~K}$} & \multirow[t]{2}{*}{ рублей } & \multicolumn{2}{|c|}{$6 \% \mathrm{~K}$} \\
\hline & & $\begin{array}{l}\text { aвzycmy } \\
2019 \text { 2. }\end{array}$ & $\begin{array}{l}\text { июлю } \\
2020 \text { 2. }\end{array}$ & & $\begin{array}{l}\text { январю- } \\
\text { августу } \\
20192 .\end{array}$ & $\begin{array}{l}\text { общерос- } \\
\text { сийскому } \\
\text { уровню } \\
\text { средне- } \\
\text { месячной } \\
\text { заработ- } \\
\text { ной } \\
\text { платьл }\end{array}$ \\
\hline Всего & 47649 & 103,7 & 95,1 & 49440 & 105,6 & 100 \\
\hline $\begin{array}{l}\text { из них: } \\
\text { сельское, лесное хозяйство, охота, } \\
\text { рыболовство и рыбоводство }\end{array}$ & 35400 & 105,3 & 97,4 & 33248 & 107,8 & 67 \\
\hline $\begin{array}{l}\text { в том числе: } \\
\text { растениеводство и животноводство, } \\
\text { охота и предоставление соответствующих услуг } \\
\text { в этих областях }\end{array}$ & 32224 & 106,1 & 99,2 & 29741 & 107,9 & 60 \\
\hline лесоводство и лесозаготовки & 34940 & 100,0 & 93,7 & 36036 & 104,0 & 73 \\
\hline рыболовство и рыбоводство & 93801 & 98,7 & 90,2 & 93337 & 106,9 & 189 \\
\hline добыча полезных ископаемых & 91055 & 102,8 & 100,0 & 92250 & 105,7 & 187 \\
\hline $\begin{array}{l}\text { из нее: } \\
\text { добыча угля }\end{array}$ & 62260 & 95,5 & 102,1 & 61197 & 97,8 & 124 \\
\hline добыча нефти и природного газа & 136352 & 100,1 & 102,0 & 144792 & 104,3 & в $2,9 \mathrm{p}$. \\
\hline добыча металлических руд & 79947 & 110,7 & 94,6 & 78906 & 110,7 & 160 \\
\hline обрабатывающие производства & 45165 & 101,8 & 95,9 & 45190 & 103,9 & 91 \\
\hline $\begin{array}{l}\text { из них: } \\
\text { производство пищевых продуктов }\end{array}$ & 36446 & 100,1 & 97,8 & 36453 & 105,6 & 74 \\
\hline производство напитков & 45047 & 102,1 & 95,8 & 45221 & 104,2 & 92 \\
\hline производство табачных изделий & 97121 & 95,6 & 87,8 & 117359 & 107,4 & в $2,4 \mathrm{p}$. \\
\hline производство текстильных изделий & 27631 & 102,6 & 95,1 & 27820 & 106,8 & 56 \\
\hline производство одежды & 21137 & 98,5 & 96,8 & 21072 & 101,2 & 43 \\
\hline производство кожи и изделий из кожи & 27745 & 107,7 & 105,4 & 25762 & 102,5 & 52 \\
\hline $\begin{array}{l}\text { обработка древесины и производство } \\
\text { изделий из дерева и пробки, } \\
\text { кроме мебели, производство изделий } \\
\text { из соломки и материалов для плетения }\end{array}$ & 30466 & 100,4 & 97,8 & 29878 & 101,7 & 60 \\
\hline производство бумаги и бумажных изделий & 48595 & 104,3 & 98,8 & 50104 & 105,2 & 101 \\
\hline $\begin{array}{l}\text { деятельность полиграфическая } \\
\text { и копирование носителей информации }\end{array}$ & 34229 & 95,8 & 95,6 & 34917 & 100,0 & 71 \\
\hline производство кокса и нефтепродуктов & 85281 & 102,6 & 106,5 & 83508 & 98,5 & 169 \\
\hline $\begin{array}{l}\text { в том числе: } \\
\text { производство кокса }\end{array}$ & 52755 & 102,5 & 94,3 & 54429 & 104,3 & 110 \\
\hline производство нефтепродуктов & 88458 & 102,6 & 107,3 & 86372 & 98,1 & 175 \\
\hline $\begin{array}{l}\text { производство химических веществ } \\
\text { и химических продуктов }\end{array}$ & 55673 & 103,9 & 96,7 & 56574 & 104,0 & 114 \\
\hline $\begin{array}{l}\text { производство лекарственных } \\
\text { средств и материалов, } \\
\text { применяемых в медицинских целях }\end{array}$ & 65483 & 106,0 & 89,2 & 69627 & 109,5 & 141 \\
\hline
\end{tabular}




\begin{tabular}{|c|c|c|c|c|c|c|}
\hline & \multicolumn{3}{|c|}{ Aвгуст 2020 г. } & \multicolumn{3}{|c|}{ Январь-август 2020 г. } \\
\hline & \multirow[t]{2}{*}{ рублей } & \multicolumn{2}{|c|}{$6 \% \kappa$} & \multirow[t]{2}{*}{ рублей } & \multicolumn{2}{|c|}{$6 \% \kappa$} \\
\hline & & $\begin{array}{l}\text { aвzусmy } \\
20192 .\end{array}$ & $\begin{array}{l}\text { июлю } \\
2020 \text { 2. }\end{array}$ & & $\begin{array}{l}\text { январю- } \\
\text { августу } \\
20192 .\end{array}$ & $\begin{array}{l}\text { общерос- } \\
\text { сийскому } \\
\text { уровню } \\
\text { средне- } \\
\text { месячной } \\
\text { заработ- } \\
\text { ной } \\
\text { платьл }\end{array}$ \\
\hline $\begin{array}{l}\text { производство резиновых } \\
\text { и пластмассовых изделий }\end{array}$ & 37454 & 104,5 & 99,3 & 36800 & 103,9 & 74 \\
\hline $\begin{array}{l}\text { производство прочей неметаллической } \\
\text { минеральной продукции }\end{array}$ & 40809 & 102,6 & 97,6 & 39532 & 105,1 & 80 \\
\hline производство металлургическое & 53695 & 104,6 & 94,5 & 56459 & 106,5 & 114 \\
\hline $\begin{array}{l}\text { производство готовых } \\
\text { металлических изделий, } \\
\text { кроме машин и оборудования }\end{array}$ & 42347 & 100,5 & 96,4 & 42110 & 103,5 & 85 \\
\hline $\begin{array}{l}\text { производство компьютеров, } \\
\text { электронных и оптических изделий }\end{array}$ & 56613 & 104,7 & 97,0 & 54455 & 102,2 & 110 \\
\hline производство электрического оборудования & 45384 & 99,7 & 95,4 & 44816 & 102,7 & 91 \\
\hline $\begin{array}{l}\text { производство машин и оборудования, } \\
\text { не включенных в другие группировки }\end{array}$ & 45241 & 100,9 & 96,9 & 45605 & 104,4 & 92 \\
\hline $\begin{array}{l}\text { производство автотранспортных средств, } \\
\text { прицепов и полуприцепов }\end{array}$ & 40645 & 94,9 & 77,3 & 44665 & 99,9 & 90 \\
\hline $\begin{array}{l}\text { производство прочих транспортных средств } \\
\text { и оборудования }\end{array}$ & 52694 & 100,3 & 94,5 & 52215 & 103,2 & 106 \\
\hline производство мебели & 29154 & 94,9 & 101,6 & 27229 & 97,5 & 55 \\
\hline производство прочих готовых изделий & 36869 & 102,2 & 93,9 & 37708 & 103,5 & 76 \\
\hline ремонт и монтаж машин и оборудования & 50777 & 99,9 & 96,9 & 50397 & 103,4 & 102 \\
\hline $\begin{array}{l}\text { обеспечение электрической энергией, } \\
\text { газом и паром; кондиционирование воздуха }\end{array}$ & 52247 & 104,4 & 93,9 & 52804 & 105,9 & 107 \\
\hline $\begin{array}{l}\text { водоснабжение; водоотведение, } \\
\text { организация сбора и утилизации отходов, } \\
\text { деятельность по ликвидации загрязнений }\end{array}$ & 35070 & 98,5 & 95,8 & 35788 & 104,7 & 72 \\
\hline строительство & 42554 & 96,9 & 99,0 & 42160 & 101,6 & 85 \\
\hline $\begin{array}{l}\text { торговля оптовая и розничная; ремонт } \\
\text { автотранспортных средств и мотоциклов }\end{array}$ & 39928 & 96,6 & 96,8 & 41756 & 102,8 & 85 \\
\hline $\begin{array}{l}\text { из нее: } \\
\text { торговля оптовая, кроме оптовой } \\
\text { торговли автотранспортными } \\
\text { средствами и мотоциклами }\end{array}$ & 47426 & 94,7 & 94,9 & 51766 & 103,4 & 105 \\
\hline $\begin{array}{l}\text { торговля розничная, кроме торговли } \\
\text { автотранспортными } \\
\text { средствами и мотоциклами }\end{array}$ & 33819 & 100,5 & 99,4 & 33498 & 103,1 & 68 \\
\hline транспортировка и хранение & 52423 & 100,4 & 97,9 & 52786 & 103,6 & 107 \\
\hline $\begin{array}{l}\text { в том числе: } \\
\text { деятельность сухопутного } \\
\text { и трубопроводного транспорта }\end{array}$ & 54656 & 101,4 & 99,8 & 54766 & 104,0 & 111 \\
\hline $\begin{array}{l}\text { в том числе: } \\
\text { деятельность железнодорожного транспорта: } \\
\text { междугородные и международные } \\
\text { пассажирские перевозки }\end{array}$ & 57714 & 100,8 & 86,2 & 59259 & 97,6 & 120 \\
\hline $\begin{array}{l}\text { деятельность железнодорожного транспорта: } \\
\text { грузовые перевозки }\end{array}$ & 64257 & 103,1 & 92,1 & 65459 & 104,5 & 132 \\
\hline
\end{tabular}




\begin{tabular}{|c|c|c|c|c|c|c|}
\hline & \multicolumn{3}{|c|}{ Aвгуст 2020 г. } & \multicolumn{3}{|c|}{ Январь-август 2020 г. } \\
\hline & \multirow[t]{2}{*}{ рублей } & \multicolumn{2}{|c|}{$6 \% \kappa$} & \multirow{2}{*}{ рублей } & \multicolumn{2}{|c|}{$6 \% \kappa$} \\
\hline & & $\begin{array}{l}\text { aвzycmy } \\
20192 \text {. }\end{array}$ & $\begin{aligned} \text { июлю } \\
2020 \text { 2. }\end{aligned}$ & & $\begin{array}{l}\text { январю- } \\
\text { августу } \\
20192 .\end{array}$ & $\begin{array}{l}\text { общерос- } \\
\text { сийскому } \\
\text { уровню- } \\
\text { средне- } \\
\text { месячной } \\
\text { заработ- } \\
\text { ной } \\
\text { платьл } \\
\end{array}$ \\
\hline $\begin{array}{l}\text { деятельность автомобильного грузового } \\
\text { транспорта и услуги по перевозкам }\end{array}$ & 39734 & 99,6 & 99,7 & 40029 & 103,1 & 81 \\
\hline деятельность трубопроводного транспорта & 110799 & 106,6 & 125,5 & 106360 & 111,1 & в 2,2p. \\
\hline деятельность водного транспорта & 72391 & 103,5 & 100,4 & 65997 & 103,3 & 134 \\
\hline $\begin{array}{l}\text { деятельность воздушного } \\
\text { и космического транспорта }\end{array}$ & 115682 & 88,0 & 100,5 & 119525 & 92,2 & в $2,4 \mathrm{p}$. \\
\hline $\begin{array}{l}\text { складское хозяйство и вспомогательная } \\
\text { транспортная деятельность }\end{array}$ & 50215 & 100,1 & 95,0 & 50716 & 103,8 & 103 \\
\hline $\begin{array}{l}\text { деятельность почтовой связи и } \\
\text { курьерская деятельность }\end{array}$ & 28486 & 114,0 & 95,1 & 29667 & 118,8 & 60 \\
\hline $\begin{array}{l}\text { деятельность гостиниц и предприятий } \\
\text { общественного питания }\end{array}$ & 25252 & 92,5 & 98,7 & 26302 & 93,2 & 53 \\
\hline деятельность в области информации и связи & 80209 & 107,1 & 95,9 & 83121 & 109,5 & 168 \\
\hline деятельность финансовая и страховая & 97207 & 104,0 & 90,6 & 105680 & 107,3 & в $2,1 \mathrm{p}$. \\
\hline $\begin{array}{l}\text { деятельность по операциям } \\
\text { с недвижимым имуществом }\end{array}$ & 35337 & 97,2 & 95,0 & 37489 & 104,2 & 76 \\
\hline $\begin{array}{l}\text { деятельность профессиональная, } \\
\text { научная и техническая }\end{array}$ & 72788 & 101,4 & 93,4 & 74602 & 105,0 & 151 \\
\hline из нее научные исследования и разработки & 80685 & 104,9 & 91,7 & 80271 & 104,9 & 162 \\
\hline $\begin{array}{l}\text { деятельность административная } \\
\text { и сопутствующие дополнительные услуги }\end{array}$ & 34138 & 96,4 & 98,0 & 36258 & 104,3 & 73 \\
\hline $\begin{array}{l}\text { государственное управление и обеспечение } \\
\text { военной безопасности; социальное обеспечение }\end{array}$ & 48544 & 105,8 & 86,7 & 50602 & 108,4 & 102 \\
\hline образование & 28158 & 111,3 & 94,6 & 37698 & 105,4 & 76 \\
\hline $\begin{array}{l}\text { деятельность в области здравоохранения } \\
\text { и социальных услуг }\end{array}$ & 49567 & 120,5 & 94,7 & 47995 & 113,1 & 97 \\
\hline $\begin{array}{l}\text { деятельность в области культуры, спорта, } \\
\text { организации досуга и развлечений }\end{array}$ & 43997 & 108,4 & 102,9 & 45548 & 99,8 & 92 \\
\hline $\begin{array}{l}\text { из нее: } \\
\text { деятельность творческая, деятельность в области } \\
\text { искусства и организации развлечений }\end{array}$ & 38630 & 110,7 & 102,5 & 42604 & 99,9 & 86 \\
\hline $\begin{array}{l}\text { деятельность библиотек, архивов, } \\
\text { музеев и прочих объектов культуры }\end{array}$ & 37072 & 101,3 & 89,6 & 39851 & 102,2 & 81 \\
\hline $\begin{array}{l}\text { деятельность в области спорта, } \\
\text { отдыха и развлечений }\end{array}$ & 52644 & 110,3 & 111,3 & 51387 & 96,6 & 104 \\
\hline
\end{tabular}

Просроченная задолженность по заработной плате, по сведениям, представленным организациями (не относящимися к субъектам малого предпринимательства). Суммарная задолженность по заработной плате по кругу наблюдаемых видов экономической деятельности на 1 октября 2020 г. составила 1828 млн рублей и по сравнению с 1 сентября 2020 г. снизилась на 7 млн рублей $(0,3 \%)$.

Объем просроченной задолженности по заработной плате, сложившийся на 1 октября 2020 г., составлял менее $1 \%$ месячного фонда заработной платы работников наблюдаемых видов экономической деятельности. 
Из общей суммы просроченной задолженности на долги, образовавшиеся в 2020 г., приходится 836 млн рублей $(45,7 \%)$, в 2019 г. - 414 млн рублей $(22,7 \%)$, в 2018 г. и ранее - 578 млн рублей $(31,6 \%)$.

Таблица 6

\section{ДИНАМИКА ПРОСРОЧЕННОЙ ЗАДОЛЖЕННОСТИ ПО ЗАРАБОТНОЙ ПЛАТЕ}

на начало месяца

\begin{tabular}{|c|c|c|c|c|c|c|c|}
\hline & \multirow{2}{*}{\multicolumn{2}{|c|}{\begin{tabular}{|c|} 
Просроченная задолюсенность \\
по заработной плате \\
\end{tabular}}} & \multicolumn{4}{|c|}{ В том числе задолженность } & \multirow{5}{*}{$\begin{array}{c}\text { Численность } \\
\text { работников, } \\
\text { перед кото- } \\
\text { рыми имеется } \\
\text { просроченная } \\
\text { задолжен- } \\
\text { ность по зара- } \\
\text { ботной плате, } \\
\text { тьсс. человек }\end{array}$} \\
\hline & & & \multirow{3}{*}{\multicolumn{2}{|c|}{$\begin{array}{c}\text { из-за несвоевременного } \\
\text { получения денежных } \\
\text { средств из бюджетов } \\
\text { всех уровней }\end{array}$}} & \multirow{2}{*}{\multicolumn{2}{|c|}{$\begin{array}{c}\text { из-за отсутствия } \\
\text { собственных средств }\end{array}$}} & \\
\hline & \multirow{3}{*}{$\begin{array}{c}\text { млн } \\
\text { рублей }\end{array}$} & \multirow{3}{*}{\begin{tabular}{|c|} 
в\% к \\
предь- \\
дущему \\
месяиу
\end{tabular}} & & & & & \\
\hline & & & & & \multirow[t]{2}{*}{$\begin{array}{c}\text { млн } \\
\text { рублей }\end{array}$} & \multirow{2}{*}{$\begin{array}{l}\text { в\% к } \\
\text { предь- } \\
\text { дущему } \\
\text { месяиу }\end{array}$} & \\
\hline & & & $\begin{array}{c}\text { млн } \\
\text { рублей }\end{array}$ & $\begin{array}{c}\text { в\% к } \\
\text { предь-- } \\
\text { душему } \\
\text { месяиу }\end{array}$ & & & \\
\hline \multicolumn{8}{|c|}{2019 г. } \\
\hline Январь & 2420 & 78,8 & 9 & 28,4 & 2411 & 79,4 & 36,7 \\
\hline Февраль & 2711 & 112,0 & 27 & в 2,9p. & 2684 & 111,3 & 42,0 \\
\hline Март & 2556 & 94,3 & 76 & в 2,8p. & 2480 & 92,4 & 41,9 \\
\hline Апрель & 2920 & 114,2 & 106 & 138,9 & 2814 & 113,5 & 47,1 \\
\hline Май & 2901 & 99,3 & 31 & 29,6 & 2870 & 102,0 & 43,2 \\
\hline Июнь & 2949 & 101,6 & 23 & 73,0 & 2926 & 102,0 & 45,1 \\
\hline Июль & 2570 & 87,2 & 6 & 27,8 & 2564 & 87,6 & 41,0 \\
\hline Август & 2753 & 107,1 & 1,7 & 26,9 & 2751 & 107,3 & 42,5 \\
\hline Сентябрь & 2605 & 94,6 & 7 & в 3,8p. & 2598 & 94,5 & 40,0 \\
\hline Октябрь & 2555 & 98,1 & 41 & в $6,4 \mathrm{p}$. & 2514 & 96,7 & 39,2 \\
\hline Ноябрь & 2638 & 103,3 & 41 & 100,4 & 2597 & 103,3 & 42,8 \\
\hline Декабрь & 2908 & 110,2 & 27 & 65,2 & 2881 & 110,9 & 43,1 \\
\hline \multicolumn{8}{|c|}{2020 г. } \\
\hline Январь & 2114 & 72,7 & 14 & 52,6 & 2100 & 72,9 & 34,0 \\
\hline Февраль & 2251 & 106,5 & 16 & 110,8 & 2235 & 106,5 & 33,8 \\
\hline Март & 2207 & 98,0 & 4 & 22,9 & 2203 & 98,6 & 34,1 \\
\hline Апрель & 2153 & $\ldots^{2)}$ & 7 & $\ldots^{2)}$ & 2146 & $\ldots^{2)}$ & 33,7 \\
\hline Май & 2209 & $\ldots^{2)}$ & 3 & $\ldots^{2)}$ & 2206 & $\ldots^{2)}$ & 36,4 \\
\hline Июнь & 2416 & $\ldots^{2)}$ & 7 & $\ldots^{2)}$ & 2409 & $\ldots^{2)}$ & 39,5 \\
\hline Июль & 2194 & 90,8 & 8 & 118,9 & 2186 & 90,7 & 33,3 \\
\hline Август & 2177 & 99,2 & 7 & 79,1 & 2170 & 99,3 & 32,4 \\
\hline Сентябрь & 1835 & 84,3 & 5 & 69,9 & 1830 & 84,3 & 27,9 \\
\hline Октябрь & 1828 & 99,7 & - & - & 1828 & 99,9 & 27,4 \\
\hline $\begin{array}{l}\text { 1) По кругу } \\
\text { 2) Темпьр р } \\
\text { данныхх. }\end{array}$ & $\partial$ & & Hoc & & ого $n_{t}$ & атель & иью \\
\hline
\end{tabular}


На 1 октября 2020 г. просроченная задолженность по заработной плате отсутствовала в 14 субъектах Российской Федерации. За месяц она снизилась в 30 субъектах, осталась без изменения - в 13 субъектах, выросла - в 27 субъектах, образовалась - в 1 субъекте Российской Федерации.

Задолженность из-за несвоевременного получения денежных средств из бюджетов всех уровней по кругу наблюдаемых видов экономической деятельности на 1 октября 2020 г. отсутствовала.

\section{ПРОСРОЧЕННАЯ ЗАДОЛЖЕННОСТЬ ПО ЗАРАБОТНОЙ ПЛАТЕ ПО ВИДАМ ЭКОНОМИЧЕСКОЙ ДЕЯТЕЛЬНОСТИ}

на 1 октября 2020 года

\begin{tabular}{|c|c|c|c|c|c|c|c|c|c|c|c|c|}
\hline & \multicolumn{6}{|c|}{ Млн рублей } & \multicolumn{6}{|c|}{ "В\% \% 1 сентября 2020 г. } \\
\hline & \multirow[t]{2}{*}{ всего } & \multicolumn{5}{|c|}{ в том числе } & \multirow[t]{2}{*}{ всего } & \multicolumn{5}{|c|}{ в том числе } \\
\hline & & \begin{tabular}{|c|} 
из-за \\
несвое- \\
времен- \\
ного \\
получе- \\
ния \\
денеж- \\
ньих \\
сред- \\
ств из \\
бюд- \\
жетов \\
всех \\
уровней
\end{tabular} & $\begin{array}{c}\text { феде- } \\
\text { раль- } \\
\text { ного } \\
\text { бюд- } \\
\text { жета }\end{array}$ & \begin{tabular}{|c|}
\multicolumn{1}{c}{ из них } \\
бюд- \\
жетов \\
субъ- \\
ектов \\
Россий- \\
ской \\
Феде- \\
рации
\end{tabular} & \begin{tabular}{|c|} 
мест- \\
нырх \\
бюд- \\
жетов
\end{tabular} & \begin{tabular}{|c|} 
из-за \\
отсут- \\
ствия \\
собст- \\
венных \\
сред- \\
ств
\end{tabular} & & \begin{tabular}{|c|} 
из-за \\
несвое- \\
времен- \\
ного \\
получе- \\
ния \\
денеж- \\
ньих \\
сред- \\
ств из \\
бюд- \\
жетов \\
всех \\
уровней
\end{tabular} & \begin{tabular}{|c|} 
феде- \\
раль- \\
ного \\
бюд- \\
жета \\
\end{tabular} & $\begin{array}{c}\text { из них } \\
\text { бюд- } \\
\text { жетов } \\
\text { субъ- } \\
\text { ектов } \\
\text { Россий- } \\
\text { ской } \\
\text { Феде- } \\
\text { рации }\end{array}$ & $\begin{array}{c}\text { мест- } \\
\text { нырх } \\
\text { бюд- } \\
\text { жетов }\end{array}$ & $\begin{array}{l}\text { из-за } \\
\text { отсут- } \\
\text { ствия } \\
\text { собст- } \\
\text { венных } \\
\text { сред- } \\
\text { ств }\end{array}$ \\
\hline Всего & 1828 & - & - & - & - & 1828 & 99,7 & - & - & - & - & 99,9 \\
\hline $\begin{array}{l}\text { том числе: } \\
\text { сельское хозяйство, } \\
\text { охота и предо- } \\
\text { ставление услуг } \\
\text { в этих областях, } \\
\text { лесозаготовки }\end{array}$ & 75 & - & - & - & - & 75 & 124,6 & - & - & - & - & 124,6 \\
\hline $\begin{array}{l}\text { рыболовство } \\
\text { и рыбоводство }\end{array}$ & - & - & - & - & - & - & - & - & - & - & - & - \\
\hline $\begin{array}{l}\text { добыча полезных } \\
\text { ископаемых }\end{array}$ & 395 & - & - & - & - & 395 & 100,0 & - & - & - & - & 100,0 \\
\hline $\begin{array}{l}\text { из нее: } \\
\text { добыча угля }\end{array}$ & 357 & - & - & - & - & 357 & 101,1 & - & - & - & - & 101,1 \\
\hline $\begin{array}{l}\text { добыча нефти } \\
\text { и природного газа }\end{array}$ & - & - & - & - & - & - & - & - & - & - & - & - \\
\hline $\begin{array}{l}\text { добыча } \\
\text { металлических руд }\end{array}$ & 3 & - & - & - & - & 3 & 100,0 & - & - & - & - & 100,0 \\
\hline $\begin{array}{l}\text { обрабатывающие } \\
\text { производства }\end{array}$ & 779 & - & - & - & - & 779 & 97,2 & - & - & - & - & 97,2 \\
\hline $\begin{array}{l}\text { в том числе: } \\
\text { производство } \\
\text { пищевых продуктов }\end{array}$ & 88 & - & - & - & - & 88 & 102,3 & - & - & - & - & 102,3 \\
\hline производство напитков & - & - & - & - & - & - & - & - & - & - & - & - \\
\hline $\begin{array}{l}\text { производство } \\
\text { табачных изделий }\end{array}$ & - & - & - & - & - & - & - & - & - & - & - & - \\
\hline $\begin{array}{l}\text { производство } \\
\text { текстильных изделий }\end{array}$ & 8 & - & - & - & - & 8 & 100,5 & - & - & - & - & 100,5 \\
\hline
\end{tabular}




\begin{tabular}{|c|c|c|c|c|c|c|c|c|c|c|c|c|}
\hline & \multicolumn{6}{|c|}{ Млн рублей } & \multicolumn{6}{|c|}{ В \% к 1 сентября 2020 г. } \\
\hline & \multirow[t]{2}{*}{ всего } & \multicolumn{5}{|c|}{ в том числе } & \multirow[t]{2}{*}{ всего } & \multicolumn{5}{|c|}{ в том числе } \\
\hline & & \begin{tabular}{|c|} 
из-за \\
несвое-- \\
времен- \\
ного \\
получе- \\
ния \\
денеж- \\
ньих \\
сред- \\
ств из \\
бюд- \\
жетов \\
всех \\
уровнеи
\end{tabular} & $\begin{array}{c}\text { феде- } \\
\text { раль- } \\
\text { ного } \\
\text { бюд- } \\
\text { жета }\end{array}$ & \begin{tabular}{|c|} 
из них \\
бюд- \\
жетов \\
субъ- \\
ектов \\
Россий- \\
ской \\
Феде- \\
рации
\end{tabular} & $\begin{array}{c}\text { мест- } \\
\text { нblх } \\
\text { бюд- } \\
\text { жетов }\end{array}$ & \begin{tabular}{|c|} 
из-за \\
отсут- \\
ствия \\
собст- \\
венньхх \\
сред- \\
ств
\end{tabular} & & \begin{tabular}{|c|} 
из-за \\
несвое- \\
времен- \\
ного \\
получе- \\
ния \\
денеж- - \\
ньх \\
сред- \\
ств из \\
бюд- \\
жетов \\
всех \\
уровней
\end{tabular} & $\begin{array}{l}\text { феде- } \\
\text { раль- } \\
\text { ного } \\
\text { бюд- } \\
\text { жета }\end{array}$ & \begin{tabular}{|c|}
\multicolumn{1}{|c|}{ бзих } \\
бюд- \\
жетов \\
субъ- \\
ектов \\
Россий- \\
ской \\
Феде- \\
рации
\end{tabular} & $\begin{array}{c}\text { мест- } \\
\text { нblх } \\
\text { бюд- } \\
\text { жетов }\end{array}$ & $\begin{array}{c}\text { из-за } \\
\text { отсут- } \\
\text { ствия } \\
\text { собст- } \\
\text { венньух } \\
\text { сред- } \\
\text { ств }\end{array}$ \\
\hline производство одежды & - & - & - & - & - & - & - & - & - & - & - & - \\
\hline $\begin{array}{c}\text { производство кожи } \\
\text { и изделий из кожи }\end{array}$ & 10 & - & - & - & - & 10 & 106,3 & - & - & - & - & 106,3 \\
\hline $\begin{array}{l}\text { обработка древесины } \\
\text { и производство } \\
\text { изделий из дерева } \\
\text { и пробки, кроме } \\
\text { мебели, производство } \\
\text { изделий из соломки } \\
\text { и материалов } \\
\text { для плетения }\end{array}$ & 17 & - & - & - & - & 17 & 121,9 & - & - & - & - & 121,9 \\
\hline $\begin{array}{c}\text { производство бумаги } \\
\text { и бумажных изделий }\end{array}$ & 11 & - & - & - & - & 11 & 101,3 & - & - & - & - & 101,3 \\
\hline $\begin{array}{l}\text { деятельность } \\
\text { полиграфическая } \\
\text { и копирование } \\
\text { носителей } \\
\text { информации } \\
\end{array}$ & 0,9 & - & - & - & - & 0,9 & 113,2 & - & - & - & - & 113,2 \\
\hline $\begin{array}{c}\text { производство кокса } \\
\text { и нефтепродуктов }\end{array}$ & - & - & - & - & - & - & - & - & - & - & - & - \\
\hline $\begin{array}{l}\text { в том числе: } \\
\text { производство кокса }\end{array}$ & - & - & - & - & - & - & - & - & - & - & - & - \\
\hline $\begin{array}{l}\text { производство } \\
\text { нефтепродуктов }\end{array}$ & - & - & - & - & - & - & - & - & - & - & - & - \\
\hline $\begin{array}{l}\text { производство } \\
\text { химических веществ } \\
\text { и химических } \\
\text { продуктов }\end{array}$ & 50 & - & - & - & - & 50 & 100,0 & - & - & - & - & 100,0 \\
\hline $\begin{array}{l}\text { производство } \\
\text { лекарственных } \\
\text { средств и материалов, } \\
\text { применяемых в } \\
\text { медицинских целях }\end{array}$ & 38 & - & - & - & - & 38 & 91,9 & - & - & - & - & 91,9 \\
\hline $\begin{array}{l}\text { производство } \\
\text { резиновых и } \\
\text { пластмассовых } \\
\text { изделий }\end{array}$ & - & - & - & - & - & - & - & - & - & - & - & - \\
\hline $\begin{array}{l}\text { производство прочей } \\
\text { неметаллической } \\
\text { минеральной } \\
\text { продукции }\end{array}$ & 15 & - & - & - & - & 15 & 51,9 & - & - & - & - & 51,9 \\
\hline $\begin{array}{l}\text { производство } \\
\text { металлургическое }\end{array}$ & 3 & - & - & - & - & 3 & 51,0 & - & - & - & - & 51,0 \\
\hline
\end{tabular}




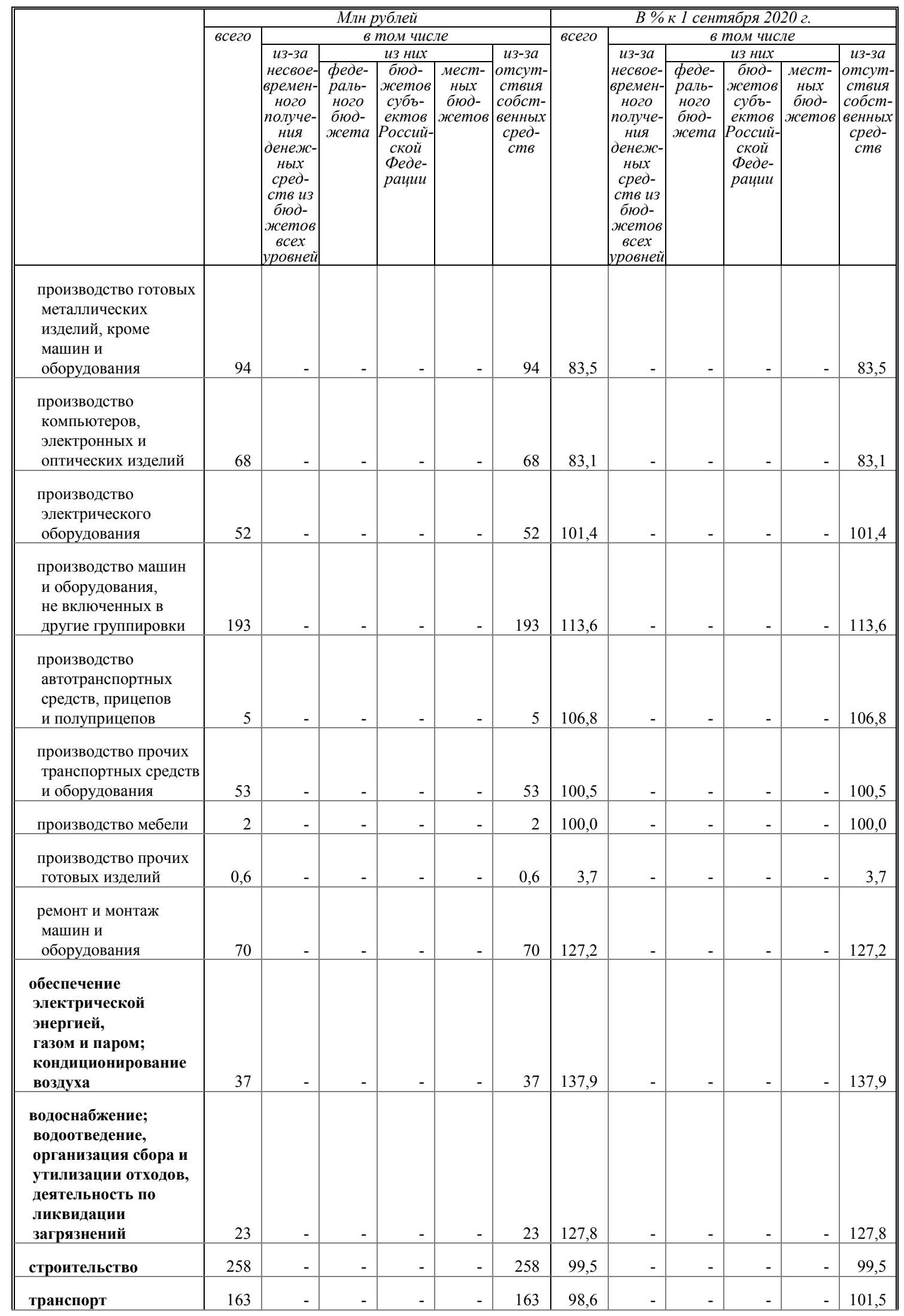




\begin{tabular}{|c|c|c|c|c|c|c|c|c|c|c|c|c|}
\hline & \multicolumn{6}{|c|}{ Млн рублей } & \multicolumn{6}{|c|}{ В \% \% 1 сентября 2020 г. } \\
\hline & \multirow[t]{3}{*}{ всего } & \multicolumn{5}{|c|}{ в том числе } & \multirow[t]{3}{*}{ всего } & \multicolumn{5}{|c|}{ в том числе } \\
\hline & & \multirow[b]{2}{*}{\begin{tabular}{|c|} 
из-за \\
несвое- \\
времен- \\
ного \\
получе- \\
ния \\
денеж- \\
ньхх \\
сред- \\
ств из \\
бюд- \\
жетов \\
всех \\
уровней
\end{tabular}} & \multicolumn{3}{|c|}{ из них } & \multirow[b]{2}{*}{\begin{tabular}{|c|} 
из-за \\
отсут- \\
ствия \\
собст- \\
венньхх \\
сред- \\
ств
\end{tabular}} & & \multirow[b]{2}{*}{\begin{tabular}{|c|} 
из-за \\
несвое- \\
времен- \\
ного \\
получе- \\
ния \\
денеж- \\
ньхх \\
сред- \\
ств из \\
бюд- \\
жетов \\
всех \\
уровней
\end{tabular}} & \multicolumn{3}{|c|}{ из них } & \multirow[b]{2}{*}{$\begin{array}{c}\text { из-за } \\
\text { отсут- } \\
\text { ствия } \\
\text { собст- } \\
\text { венных } \\
\text { сред- } \\
\text { ств }\end{array}$} \\
\hline & & & $\begin{array}{c}\text { феде- } \\
\text { раль- } \\
\text { ного } \\
\text { бюд- } \\
\text { жета }\end{array}$ & \begin{tabular}{|c|} 
бюд- \\
жетов \\
субъ- \\
ектов \\
Россий- \\
ской \\
Феде- \\
рации
\end{tabular} & \begin{tabular}{|c|} 
мест- \\
нblх \\
бюд- \\
жетов
\end{tabular} & & & & $\begin{array}{l}\text { феде- } \\
\text { раль- } \\
\text { ного } \\
\text { бюд- } \\
\text { жета }\end{array}$ & \begin{tabular}{|c|} 
бюд- \\
жетов \\
субъ- \\
ектов \\
Россий- \\
ской \\
Феде- \\
рации
\end{tabular} & $\begin{array}{c}\text { мест- } \\
\text { ньlх } \\
\text { бюд- } \\
\text { жетов }\end{array}$ & \\
\hline $\begin{array}{l}\text { управление } \\
\text { недвижимым } \\
\text { имуществом } \\
\text { за вознаграждение } \\
\text { или на договорной } \\
\text { основе }\end{array}$ & 16 & - & - & - & - & 16 & 88,5 & - & - & - & - & 88,5 \\
\hline $\begin{array}{l}\text { научные } \\
\text { исследования } \\
\text { и разработки }\end{array}$ & 10 & - & - & - & - & 10 & 70,7 & - & - & - & - & 70,7 \\
\hline образование & 29 & - & - & - & - & 29 & 145,3 & - & - & - & - & 145,3 \\
\hline $\begin{array}{l}\text { деятельность } \\
\text { в области } \\
\text { здравоохранения } \\
\text { и социальных услуг }\end{array}$ & 25 & - & - & - & - & 25 & 68,3 & - & - & - & - & 68,3 \\
\hline $\begin{array}{l}\text { деятельность в } \\
\text { области культуры, } \\
\text { искусства, отдыха и } \\
\text { развлечений, теле- и } \\
\text { радиовещания }\end{array}$ & 18 & - & - & - & - & 18 & 93,4 & - & - & - & - & 93,4 \\
\hline
\end{tabular}

Задолженность по заработной плате из-за отсутствия собственных средств организаций за сентябрь 2020 г. снизилась на 2 млн рублей $(0,1 \%)$ и на 1 октября 2020 г. составила 1828 млн рублей, или 100\% общего объема просроченной задолженности по заработной плате.

Пенсии. В сентябре 2020 г. средний размер назначенных пенсий составил 15018 рублей и по сравнению с сентябрем 2019 г. увеличился на 5,8\%.

Таблица 8

ДИНАМИКА СРЕДНЕГО РАЗМЕРА НАЗНАЧЕННЫХ ПЕНСИЙ ${ }^{1)}$

\begin{tabular}{|c|c|c|c|c|c|}
\hline & \multirow{2}{*}{$\begin{array}{c}\text { Средний размер } \\
\text { назначенныхх } \\
\text { пенсий, } \\
\text { рублей }\end{array}$} & \multicolumn{3}{|c|}{$\begin{array}{c}\text { Реальный размер назначенных пенсий } \\
6 \% \kappa\end{array}$} & \multirow{2}{*}{\begin{tabular}{|c} 
Средний размер \\
назначенных \\
пенсий в \% к \\
среднему размеру \\
начисленной \\
заработной платьл \\
работников \\
организачий \\
\end{tabular}} \\
\hline & & $\begin{array}{c}\text { соответствую- } \\
\text { щему периоду } \\
\text { предылушщего } \\
\text { года }\end{array}$ & $\begin{array}{c}\text { предыдушему } \\
\text { периоду }\end{array}$ & $\begin{array}{c}\text { декабрю } \\
\text { предьлдущего } \\
\text { года }\end{array}$ & \\
\hline \multicolumn{6}{|c|}{2019 г. } \\
\hline Январь & 14102 & 100,8 & 104,1 & 104,1 & 33,4 \\
\hline Февраль & 14116 & 100,6 & 99,7 & 103,8 & 32,8 \\
\hline Mapт & 14129 & 100,6 & 99,8 & 103,5 & 32,6 \\
\hline І квартал & 14116 & 100,7 & 103,2 & & 32,1 \\
\hline
\end{tabular}




\begin{tabular}{|c|c|c|c|c|c|}
\hline & \multirow{2}{*}{$\begin{array}{c}\text { Средний размер } \\
\text { назначенных } \\
\text { пенсий, } \\
\text { рублей }\end{array}$} & \multicolumn{3}{|c|}{$\begin{array}{c}\text { Реальный размер назначенных пенсий } \\
\text { в\% \% }\end{array}$} & \multirow{2}{*}{\begin{tabular}{|c} 
Средний размер \\
назначенных \\
пенсий в \% к \\
среднему размеру \\
начисленной \\
заработной плать \\
работников \\
организаций \\
\end{tabular}} \\
\hline & & $\begin{array}{c}\text { соответствую- } \\
\text { щему периоду } \\
\text { предьдущего } \\
\text { года }\end{array}$ & $\begin{array}{c}\text { предыруущему } \\
\text { периоду }\end{array}$ & $\begin{array}{c}\text { декабрю } \\
\text { предьдущего } \\
\text { года }\end{array}$ & \\
\hline Апрель & 14141 & 100,7 & 99,8 & 103,3 & 29,4 \\
\hline Май & 14138 & 100,7 & 99,6 & 102,9 & 29,5 \\
\hline Июнь & 14141 & 101,2 & 100,0 & 102,9 & 28,7 \\
\hline ІІ квартал & 14140 & 100,9 & 99,3 & & 29,2 \\
\hline I полугодие & 14128 & 100,8 & & & 30,6 \\
\hline Июль & 14150 & 101,4 & 99,9 & 102,8 & 30,4 \\
\hline Август & 14174 & 101,7 & 100,4 & 103,2 & 31,5 \\
\hline Сентябрь & 14198 & 102,0 & 100,3 & 103,6 & 31,2 \\
\hline III квартал & 14174 & 101,7 & 100,1 & & 31,0 \\
\hline Январь-сентябрь & 14143 & 101,1 & & & 30,7 \\
\hline Октябрь & 14205 & 102,3 & 99,9 & 103,5 & 30,5 \\
\hline Ноябрь & 14224 & 102,6 & 99,9 & 103,3 & 30,7 \\
\hline Декабрь & 14242 & 103,1 & 99,8 & 103,1 & 22,9 \\
\hline IV квартал & 14224 & 102,6 & 100,1 & & 27,5 \\
\hline Год & 14163 & 101,5 & & & 29,6 \\
\hline \multicolumn{6}{|c|}{2020 г. } \\
\hline Январь & 14904 & 103,2 & 104,2 & 104,2 & 31,9 \\
\hline Февраль & 14924 & 103,3 & 99,8 & 104,0 & 31,6 \\
\hline Март & 14943 & 103,1 & 99,6 & 103,6 & 29,3 \\
\hline І квартал & 14924 & 103,2 & 103,7 & & 30,8 \\
\hline Апрель & 14980 & 102,8 & 99,4 & 103,0 & 30,4 \\
\hline Май & 14979 & 102,8 & 99,7 & 102,7 & 29,5 \\
\hline Июнь & 14978 & 102,6 & 99,8 & 102,5 & 28,7 \\
\hline ІІ квартал & 14979 & 102,7 & 98,8 & & 29,5 \\
\hline I полугодие & 14951 & 103,0 & & & 30,1 \\
\hline Июль & 14976 & 102,4 & 99,6 & 102,1 & 29,9 \\
\hline Август ${ }^{2)}$ & 14997 & 102,2 & 100,2 & 102,3 & 31,5 \\
\hline Сентябрь ${ }^{2)}$ & 15018 & 102,0 & 100,2 & 102,5 & .3) \\
\hline III квартал & 14997 & 102,2 & 99,6 & & ... $^{3)}$ \\
\hline Январь-сентябри ${ }^{2)}$ & 14967 & 102,7 & & & $\ldots^{3)}$ \\
\hline $\begin{array}{l}\text { 1) Данные за периоды, кроме оп } \\
\text { основных показателей пенсио } \\
\text { 2) Оиенка. } \\
\text { 3) Данные публикуются после } \\
\text { работников организаиий. }\end{array}$ & $\begin{array}{l}\text { mчетных (январь, } \\
\text { нноого обеспечени } \\
\text { получения отчел }\end{array}$ & $\begin{array}{l}\text { апрель, июль, окп } \\
\text { 1, утвержденной } n \\
\text { пных данных о }\end{array}$ & $\begin{array}{l}\text { иябрь), рассчитат } \\
\text { риказом Росстап } \\
\text { реднем размере }\end{array}$ & $\begin{array}{l}\text { ны на основе } M \\
\text { па от } 23 \text { июня } 2 \\
\text { начисленной }\end{array}$ & $\begin{array}{l}\text { Іетодики расчетов } \\
009 \text { г. № } 118 . \\
\text { аработной платы }\end{array}$ \\
\hline
\end{tabular}




\section{2. СОЦИАЛЬНО-ЭКОНОМИЧЕСКАЯ ДИФФЕРЕНЦИАЦИЯ НАСЕЛЕНИЯ ${ }^{1)}$}

Таблица 1

РАСПРЕДЕЛЕНИЕ ОБЩЕГО ОБЪЕМА ДЕНЕЖНЫХ ДОХОДОВ НАСЕЛЕНИЯ

в процентах

\begin{tabular}{|c|c|c|}
\hline & $\begin{array}{c}\text { Январь-сентябрь } \\
2020 \text { c. }^{2}\end{array}$ & $\frac{\text { Справочно }}{\text { январь-сентябрь } 20192 .}$ \\
\hline Денежные доходы & 100 & 100 \\
\hline $\begin{array}{l}\text { в том числе по 20-ти процентным группам населен } \\
\text { первая (с наименьшими доходами) }\end{array}$ & 5,7 & 5,6 \\
\hline вторая & 10,5 & 10,3 \\
\hline третья & 15,4 & 15,3 \\
\hline четвертая & 22,8 & 22,7 \\
\hline пятая (с наивысшими доходами) & 45,6 & 46,1 \\
\hline Коэффициент Джини (индекс концентрации доходов) & 0,395 & 0,401 \\
\hline Коэффициент фондов, раз & 13,7 & 14,4 \\
\hline
\end{tabular}

В январе-сентябре 2020 г., по предварительным данным, на долю 10\% наиболее обеспеченного населения приходилось 29,1\% общего объема денежных доходов (в январе-сентябре 2019 г. - 29,5\%), а на долю 10\% наименее обеспеченного населения - 2,1\% (2,1\%).

Таблица 2

РАСПРЕДЕЛЕНИЕ НАСЕЛЕНИЯ ПО ВЕЛИЧИНЕ СРЕДНЕДУШЕВЫХ ДЕНЕЖНЫХ ДОХОДОВ

в \% от общей численности населения

\begin{tabular}{|c|c|c|}
\hline & 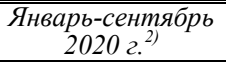 & $\frac{\text { Справочно }}{\text { январь-сентябрь } 2019 \text { г. }}$ \\
\hline Все население & 100 & 100 \\
\hline \multicolumn{3}{|c|}{$\begin{array}{l}\text { в том числе со среднедушевыми } \\
\text { денежными доходами в месяц, рублей }\end{array}$} \\
\hline до 7000,0 & 3,8 & 4,2 \\
\hline $7000,1-10000,0$ & 6,2 & 6,4 \\
\hline $10000,1-14000,0$ & 10,6 & 10,8 \\
\hline $14000,1-19000,0$ & 13,9 & 13,8 \\
\hline $19000,1-27000,0$ & 18,9 & 18,5 \\
\hline $27000,1-45000,0$ & 25,0 & 24,6 \\
\hline $45000,1-60000,0$ & 9,7 & 9,6 \\
\hline $60000,1-75000,0$ & 5,0 & 5,0 \\
\hline $75000,1-100000,0$ & 3,8 & 3,9 \\
\hline свыше 100000,0 & 3,1 & 3,2 \\
\hline
\end{tabular}

1) Здесь и далее в подразделе - данные рассчитаны с использованием величины макроэкономического показателя среднедушевых денежных доходов населения, определенной в соответствии с Методологическими положениями по расчету показателей денежных доходов и расходов населения (приказ Росстата от 2 июля 2014 2. № 465 с изменениями от 20 ноября 2018 года). 


\section{3. ИСПОЛЬЗОВАНИЕ ДЕНЕЖНЫХ ДОХОДОВ}

Таблица 1

ДИНАМИКА ДЕНЕЖНЫХ ДОХОДОВ И РАСХОДОВ НАСЕЛЕНИЯ ${ }^{1)}$

млрд рублей

\begin{tabular}{|c|c|c|c|}
\hline & $\begin{array}{c}\text { Денежные доходы } \\
\text { населения }\end{array}$ & $\begin{array}{c}\text { Денежные расходы } \\
\text { населения }\end{array}$ & $\begin{array}{c}\text { Прирост (+), уменьшение (-) } \\
\text { сбережсений населения }\end{array}$ \\
\hline \multicolumn{4}{|c|}{2019 г. } \\
\hline I квартал & 13316,8 & 13509,8 & $-193,0$ \\
\hline II квартал & 15197,6 & 14537,5 & $+660,1$ \\
\hline I полугодие & 28514,4 & 28047,2 & $+467,2$ \\
\hline III квартал & 15462,7 & 15360,5 & $+102,2$ \\
\hline Январь-сентябрь & 43977,1 & 43407,7 & $+569,4$ \\
\hline IV квартал & 18103,0 & 16538,1 & $+1564,9$ \\
\hline Год & 62080,1 & 59945,8 & $+2134,3$ \\
\hline \multicolumn{4}{|c|}{2020 г. } \\
\hline I квартал ${ }^{2)}$ & 13875,6 & 14178,4 & $-302,8$ \\
\hline II квартал ${ }^{2)}$ & 14376,0 & 11763,0 & $+2613,0$ \\
\hline I полугодие ${ }^{2)}$ & 28251,6 & 25941,4 & $+2310,2$ \\
\hline III квартал & 15427,4 & 15114,5 & $+312,9$ \\
\hline Январь-сентябрь & 43679,0 & 41055,9 & $+2623,1$ \\
\hline
\end{tabular}

Таблица 2

СТРУКТУРА ИСПОЛЬЗОВАНИЯ ДЕНЕЖНЫХ ДОХОДОВ НАСЕЛЕНИЯ ${ }^{1)}$

в процентах

\begin{tabular}{|c|c|c|c|c|c|c|c|c|}
\hline & \multirow{3}{*}{$\begin{array}{c}\text { Денежные } \\
\text { доходыл }\end{array}$} & \multicolumn{7}{|c|}{ В В том числе использовано на } \\
\hline & & \multirow{2}{*}{$\begin{array}{c}\text { покупку } \\
\text { товаров } \\
\text { и оплату } \\
\text { услуге }\end{array}$} & \multicolumn{2}{|c|}{ из них на } & \multirow[b]{2}{*}{$\begin{array}{c}\text { оплату обя- } \\
\text { зательных } \\
\text { платежей } \\
u \text { взносов } u \\
\text { прочие } \\
\text { расходьь }\end{array}$} & \multirow{2}{*}{$\begin{array}{c}\text { прирост } \\
(+), \text { умень- } \\
\text { шение (-) } \\
\text { сбере-- } \\
\text { жении }^{4), 5)}\end{array}$} & \multicolumn{2}{|c|}{ из них } \\
\hline & & & $\begin{array}{l}\text { покупку } \\
\text { товаров }\end{array}$ & $\begin{array}{l}\text { оплату } \\
\text { услуз }\end{array}$ & & & \begin{tabular}{|c|} 
во вкладах \\
на рублевых \\
и валютных \\
счетах \\
банков в \\
рублевом \\
эквива- \\
ленте
\end{tabular} & $\begin{array}{c}\text { в наличньх } \\
\text { деньгах на } \\
\text { руках в } \\
\text { рублях и } \\
\text { иностран- } \\
\text { ной валюте } \\
\text { в рублевом } \\
\text { эквива- } \\
\text { ленте } \\
\end{array}$ \\
\hline \multicolumn{9}{|c|}{2019 г. } \\
\hline I квартал & 100 & 86,3 & 64,0 & 19,6 & 15,1 & $-1,4$ & $+1,8$ & $-1,5$ \\
\hline II квартал & 100 & 80,7 & 59,7 & 17,8 & 15,0 & $+4,3$ & $+5,9$ & $+0,7$ \\
\hline I полугодие & 100 & 83,3 & 61,7 & 18,6 & 15,1 & $+1,6$ & $+4,0$ & $-0,3$ \\
\hline III квартал & 100 & 83,9 & 61,9 & 18,0 & 15,4 & $+0,7$ & $+1,3$ & $+0,9$ \\
\hline
\end{tabular}




\begin{tabular}{|c|c|c|c|c|c|c|c|c|}
\hline & \multirow{3}{*}{$\begin{array}{c}\text { Денежниве } \\
\text { доходы }\end{array}$} & \multicolumn{7}{|c|}{ В том числе использовано на } \\
\hline & & \multirow{2}{*}{$\begin{array}{c}\text { покупку } \\
\text { товаров } \\
\text { и оплату } \\
\text { услуг }{ }^{2}\end{array}$} & \multicolumn{2}{|c|}{ из них на } & \multirow[b]{2}{*}{$\begin{array}{c}\text { оплату обя- } \\
\text { зательных } \\
\text { платежей } \\
\text { и взносов } u \\
\text { прочие } \\
\text { расходы }\end{array}$} & \multirow{2}{*}{$\begin{array}{c}\text { прирост } \\
(+), \text { умень- } \\
\text { шение (-) } \\
\text { сбере-- } \\
\text { жений }^{4), 5}\end{array}$} & \multicolumn{2}{|c|}{ из них } \\
\hline & & & $\begin{array}{l}\text { покупку } \\
\text { товаров }\end{array}$ & $\begin{array}{l}\text { оплату } \\
\text { услуз }\end{array}$ & & & \begin{tabular}{|c|} 
во вкладах \\
на рублевых \\
и валютных \\
счетах \\
банков в \\
рублевом \\
эквива- \\
ленте
\end{tabular} & \begin{tabular}{|c|} 
в наличньхх \\
деньгах на \\
руках в \\
рублях и \\
иностран- \\
ной валюте \\
в рублевом \\
эквива- \\
ленте \\
\end{tabular} \\
\hline Январь-сентябрь & 100 & 83,5 & 61,8 & 18,4 & 15,2 & $+1,3$ & $+3,0$ & $+0,1$ \\
\hline IV квартал & 100 & 75,8 & 56,3 & 17,2 & 15,6 & $+8,6$ & $+7,4$ & $+1,0$ \\
\hline Год & 100 & 81,3 & 60,2 & 18,1 & 15,3 & $+3,4$ & $+4,3$ & $+0,4$ \\
\hline \multicolumn{9}{|c|}{2020 г. } \\
\hline I квартал & 100 & 87,1 & 65,2 & 19,6 & 15,1 & $-2,2$ & $-2,9$ & $+2,5$ \\
\hline II квартал & 100 & 67,7 & 54,1 & 12,9 & 14,1 & $+18,2$ & $+7,0$ & $+7,8$ \\
\hline I полугодие & 100 & 77,2 & 59,6 & 16,2 & 14,6 & $+8,2$ & $+2,2$ & $+5,2$ \\
\hline III квартал & 100 & 81,8 & 62,5 & 16,8 & 16,2 & $+2,0$ & $+0,6$ & $+3,9$ \\
\hline Январь-сентябрь & 100 & 78,8 & 60,6 & 16,4 & 15,2 & $+6,0$ & $+1,6$ & $+4,7$ \\
\hline \multicolumn{9}{|c|}{ 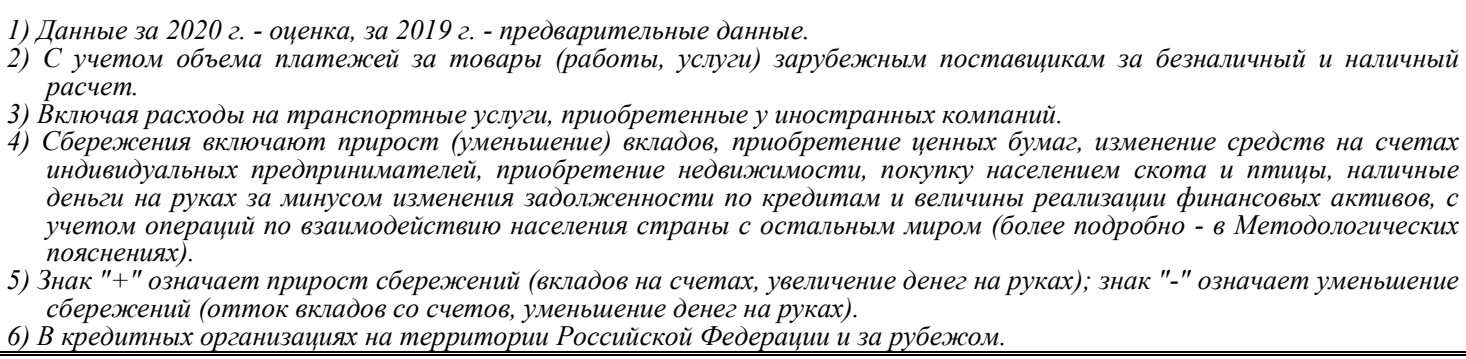 } \\
\hline
\end{tabular}

\section{Изменения в структуре использования денежных доходов населения}

в \% к денежным доходам

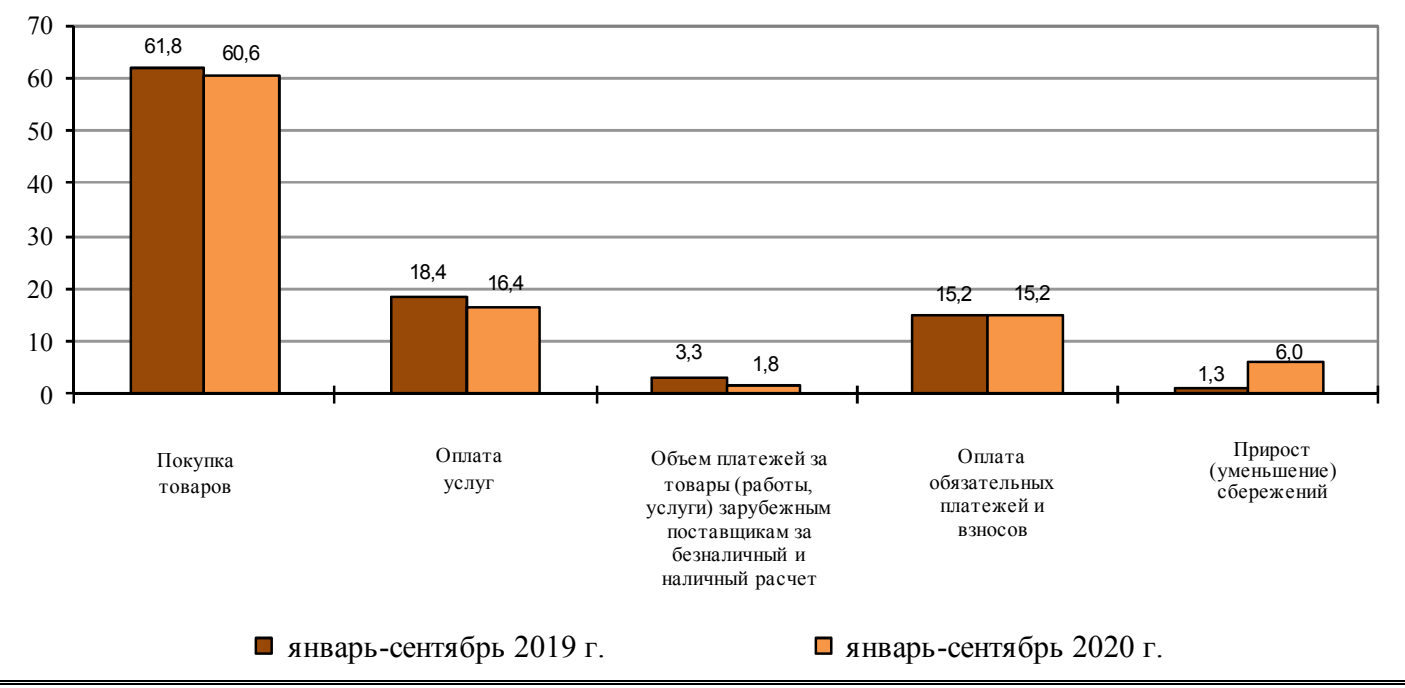


ДЕНЕЖНЫЕ СБЕРЕЖЕНИЯ НАСЕЛЕНИЯ

ВО ВКЛАДАХ И НАЛИЧНЫХ ДЕНЬГАХ ${ }^{1)}$

на начало месяца

\begin{tabular}{|c|c|c|c|c|c|c|c|}
\hline & \multirow{3}{*}{$\begin{array}{c}\text { Всего } \\
\text { сбережений } \\
\text { населения } \\
\text { во вкладах } \\
\text { и наличных } \\
\text { деньгах, } \\
\text { млрд рублей }\end{array}$} & \multicolumn{6}{|c|}{ В том числе } \\
\hline & & \multicolumn{3}{|c|}{ остатки вкладов } & \multicolumn{3}{|c|}{ остатки наличных денег } \\
\hline & & всего & $\begin{array}{c}\text { из них } \\
\text { на рублевых } \\
\text { счетах }\end{array}$ & $\begin{array}{c}\text { остатки } \\
\text { вкладов } \\
\text { в \% к } \\
\text { итогу }\end{array}$ & всего & $\begin{array}{c}\text { из них } \\
\text { в рублях }\end{array}$ & $\begin{array}{c}\text { остатки } \\
\text { наличных } \\
\text { денег } \\
\text { в\% } \\
\text { итогу } \\
\end{array}$ \\
\hline \multicolumn{8}{|c|}{2019 г. } \\
\hline Январь & 39642,1 & 28577,8 & 22348,4 & 72,1 & 11064,3 & 6152,3 & 27,9 \\
\hline Февраль & 38453,1 & 27858,0 & 21761,1 & 72,4 & 10595,1 & 5907,6 & 27,6 \\
\hline Март & 38867,4 & 28266,3 & 22085,7 & 72,7 & 10601,0 & 5923,9 & 27,3 \\
\hline Апрель & 38841,9 & 28332,6 & 22150,2 & 72,9 & 10509,3 & 5892,0 & 27,1 \\
\hline Май & 39519,5 & 28919,5 & 22720,4 & 73,2 & 10600,1 & 5972,1 & 26,8 \\
\hline Июнь & 39535,0 & 28912,7 & 22651,5 & 73,1 & 10622,3 & 5967,9 & 26,9 \\
\hline Июль & 39617,3 & 29096,3 & 22920,2 & 73,4 & 10520,9 & 6021,4 & 26,6 \\
\hline Август & 39723,3 & 29170,2 & 22928,5 & 73,4 & 10553,1 & 6071,0 & 26,6 \\
\hline Сентябрь & 40229,0 & 29590,6 & 23112,0 & 73,6 & 10638,4 & 6174,3 & 26,4 \\
\hline Октябрь & 40138,3 & 29473,8 & 23147,5 & 73,4 & 10664,5 & 6218,4 & 26,6 \\
\hline Ноябрь & 40090,1 & 29501,6 & 23243,0 & 73,6 & 10588,5 & 6159,2 & 26,4 \\
\hline Декабрь & 40327,6 & 29709,3 & 23480,5 & 73,7 & 10618,3 & 6193,7 & 26,3 \\
\hline \multicolumn{8}{|c|}{2020 г. } \\
\hline Январь & 41531,7 & 30668,6 & 24566,4 & 73,8 & 10863,1 & 6457,4 & 26,2 \\
\hline Февраль & 41013,3 & 30304,0 & 24109,1 & 73,9 & 10709,4 & 6297,5 & 26,1 \\
\hline Март & 41660,4 & 30828,5 & 24498,1 & 74,0 & 10831,9 & 6413,8 & 26,0 \\
\hline Апрель & 42845,7 & 31633,2 & 24517,8 & 73,8 & 11212,6 & 6787,3 & 26,2 \\
\hline Май & 43303,4 & 31645,0 & 24972,8 & 73,1 & 11658,3 & 7141,3 & 26,9 \\
\hline Июнь & 43391,7 & 31349,8 & 24880,0 & 72,2 & 12041,9 & 7436,2 & 27,8 \\
\hline Июль & 44198,6 & 31868,5 & 25423,1 & 72,1 & 12330,1 & 7639,9 & 27,9 \\
\hline Август & 44941,9 & 32313,7 & 25528,8 & 71,9 & 12628,2 & 7845,3 & 28,1 \\
\hline Сентябрь & 45243,4 & 32437,1 & 25552,1 & 71,7 & 12806,3 & 7927,5 & 28,3 \\
\hline Октябрь & 45745,2 & 32820,7 & 25577,7 & 71,7 & 12924,5 & 8007,9 & 28,3 \\
\hline
\end{tabular}


ПОКУПАТЕЛЬНАЯ СПОСОБНОСТЬ

СРЕДНЕДУШЕВЫХ ДЕНЕЖНЫХ ДОХОДОВ НАСЕЛЕНИЯ ПО ОСНОВНЫМ ПРОДУКТАМ ПИТАНИЯ

килограммов в месяц

\begin{tabular}{|c|c|c|}
\hline & $\begin{array}{c}\text { Январь-сентябрь } \\
2020 \text { г. }\end{array}$ & $\begin{array}{c}\frac{\text { Справочно }}{\text { январь-сентябрь }} \\
2019 \text { 2. } \\
\end{array}$ \\
\hline Говядина (кроме бескостного мяса) & 94,0 & 99,1 \\
\hline Свинина (кроме бескостного мяса) & 126,0 & 122,2 \\
\hline Баранина (кроме бескостного мяса) & 78,3 & 82,2 \\
\hline $\begin{array}{l}\text { Куры охлажденные и мороженые } \\
\text { (кроме куриных окорочков) }\end{array}$ & 234,6 & 226,5 \\
\hline Молоко питьевое, литров & 485,6 & 510,0 \\
\hline Яйца куриные, штук & 5426 & 5510 \\
\hline $\begin{array}{l}\text { Рыба мороженая } \\
\text { (кроме лососевых пород и рыбного филе) }\end{array}$ & 165,6 & 173,7 \\
\hline Сахар-песок & 932,4 & 765,8 \\
\hline Соль поваренная пищевая & 2426,4 & 2467,8 \\
\hline $\begin{array}{l}\text { Чай черный байховый } \\
\text { (включая пакетированный) }\end{array}$ & 29,4 & 31,0 \\
\hline Масло подсолнечное & 325,3 & 332,0 \\
\hline Маргарин & 245,7 & 252,0 \\
\hline Вермишель & 441,5 & 479,8 \\
\hline Картофель & 1168,2 & 1157,9 \\
\hline Капуста свежая белокочанная & 1307,2 & 872,2 \\
\hline Лук репчатый & 1016,0 & 919,9 \\
\hline Морковь & 926,9 & 849,7 \\
\hline Яблоки & 284,4 & 339,3 \\
\hline Хлеб ржаной, ржано-пшеничный & 618,7 & 664,3 \\
\hline Хлеб и булочные изделия из пшеничной муки & 508,4 & 544,8 \\
\hline Мука пшеничная & 857,0 & 924,5 \\
\hline Рис & 433,8 & 492,1 \\
\hline Крупы & 588,6 & 682,9 \\
\hline Масло сливочное & 53,0 & 57,8 \\
\hline
\end{tabular}




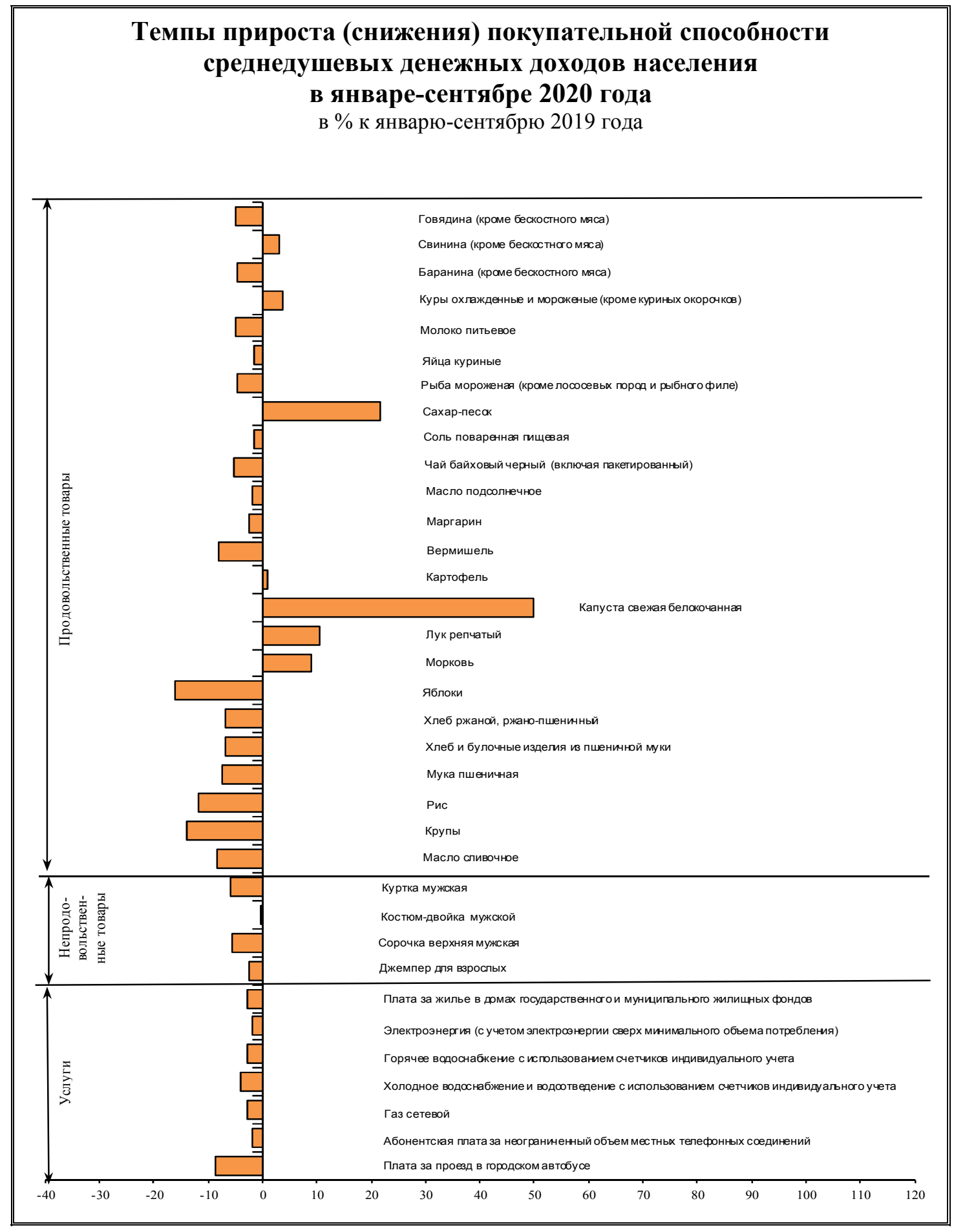




\section{2. ЗАНЯТОСТЬ И БЕЗРАБОТИЦА}

По итогам выборочного обследования в сентябре 2020 г. численность рабочей силы в возрасте 15 лет и старше составила 75,3 млн человек, или $51 \%$ от общей численности населения страны, в их числе 70,5 млн человек были заняты в экономике и 4,8 млн человек не имели занятия, но активно его искали и готовы были приступить к работе в течение недели (в соответствии с методологией Международной Организации Труда они классифицируются как безработные).

Таблица 1

ДИНАМИКА ЧИСЛЕННОСТИ РАБОЧЕЙ СИЛЫ В ВОЗРАСТЕ 15 ЛЕТ И СТАРШЕ

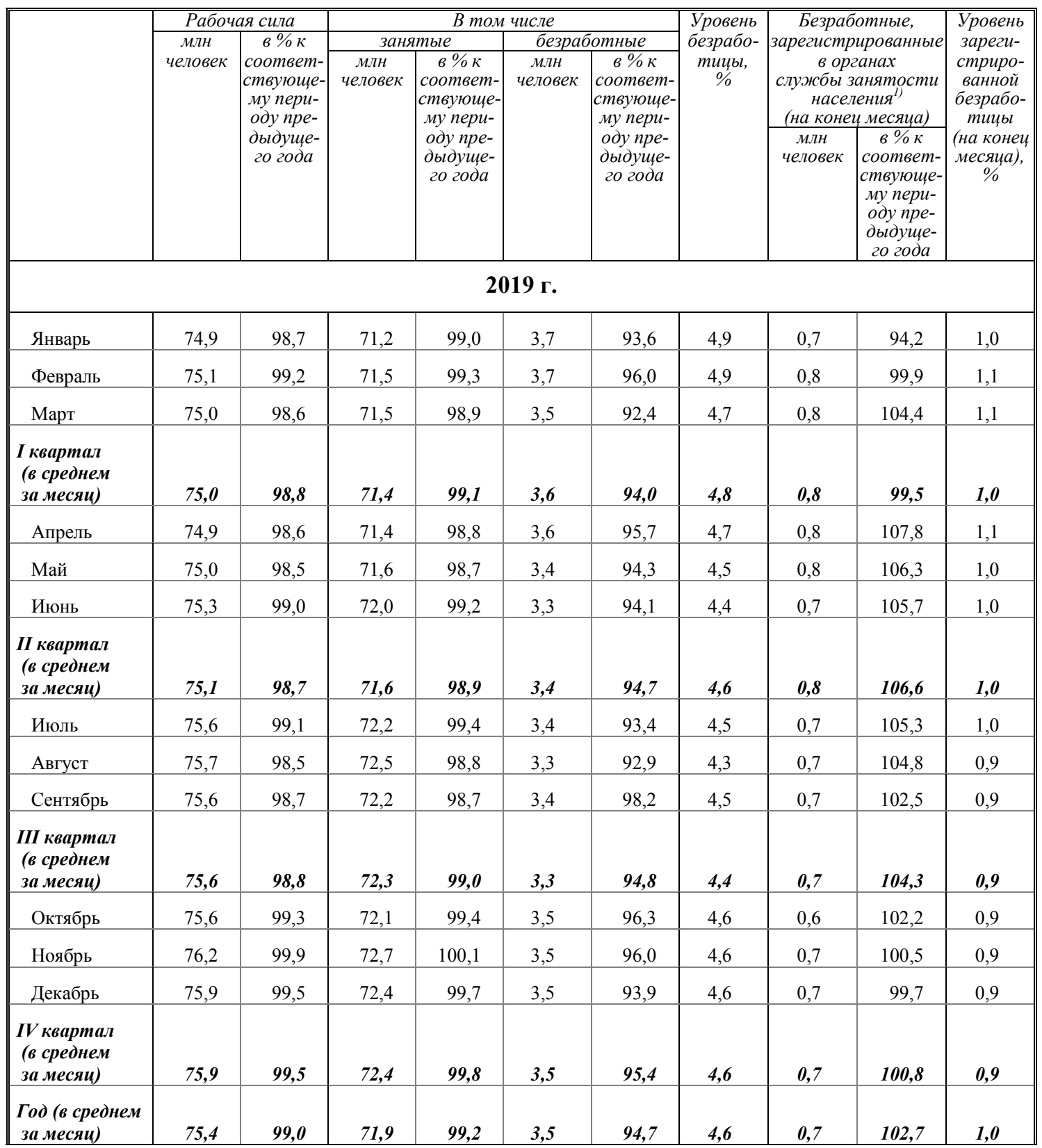




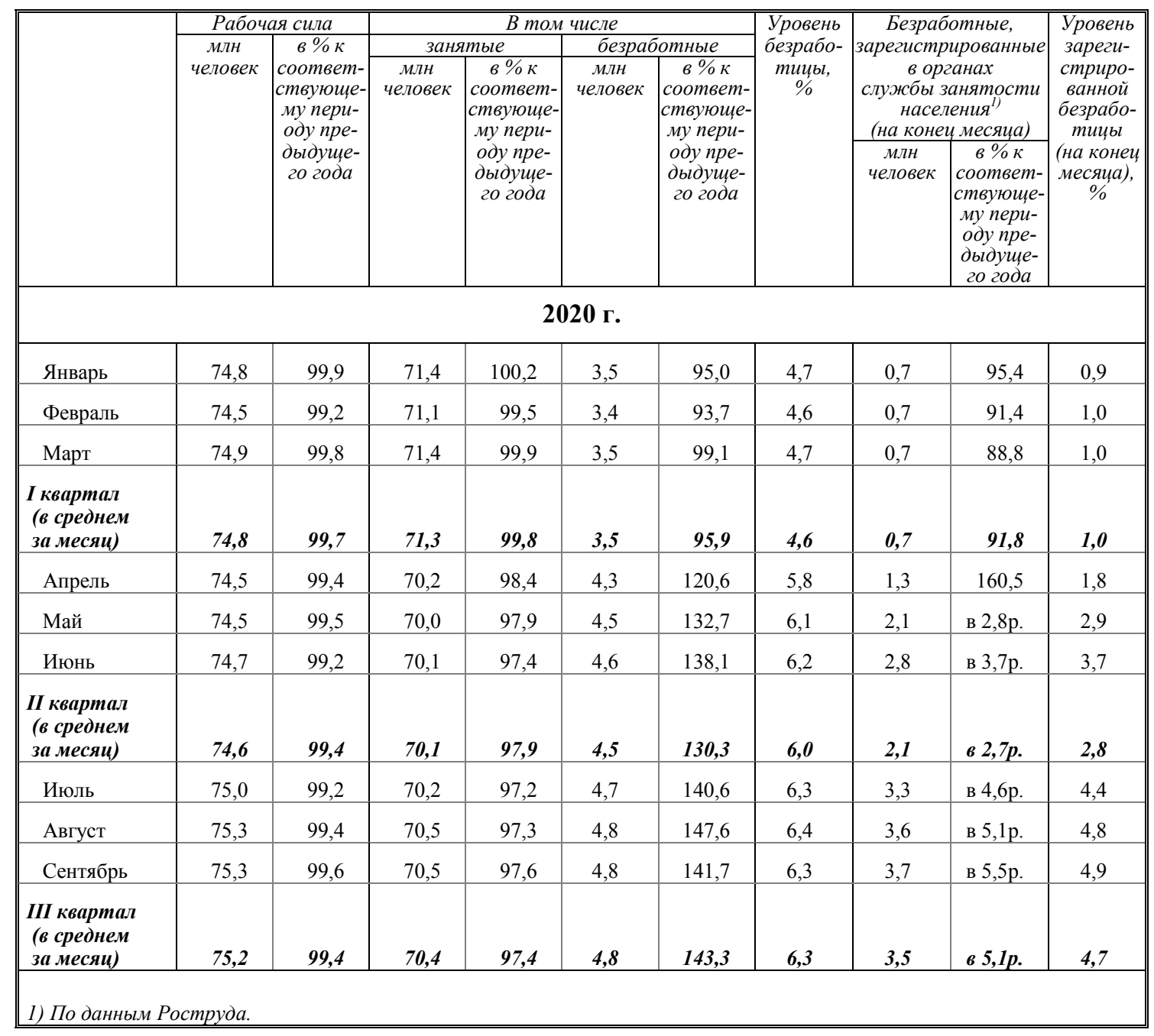

По данным выборочного обследования рабочей силы, проведенного по состоянию на вторую неделю сентября 2020 г., уровень занятости населения (доля занятого населения в общей численности населения соответствующего возраста) в возрасте 15 лет и старше составил $58,3 \%$.

Таблица 2

ДИНАМИКА УРОВНЯ ЗАНЯТОСТИ НАСЕЛЕНИЯ В ВОЗРАСТЕ 15 ЛЕТ И СТАРШЕ

в процентах

\begin{tabular}{|c|c|c|c|c|c|c|}
\hline & \multicolumn{5}{|c|}{ Уровень занятости } & \multirow{2}{*}{$\begin{array}{c}\text { Удельный вес женщиин } \\
\text { в численности } \\
\text { занятого населения } \\
\end{array}$} \\
\hline & всего & мужчинь & женщиины & город & село & \\
\hline \multicolumn{7}{|c|}{2019 г. } \\
\hline Январь & 58,8 & 66,7 & 52,3 & 61,1 & 52,0 & 48,6 \\
\hline Февраль & 59,1 & 66,9 & 52,6 & 61,2 & 52,7 & 48,7 \\
\hline Март & 59,1 & 67,0 & 52,5 & 61,2 & 52,5 & 48,6 \\
\hline Апрель & 59,0 & 66,7 & 52,5 & 60,8 & 53,4 & 48,7 \\
\hline Май & 59,1 & 67,0 & 52,6 & 61,1 & 53,0 & 48,6 \\
\hline
\end{tabular}




\begin{tabular}{|c|c|c|c|c|c|c|}
\hline & \multicolumn{5}{|c|}{ Уровень занятости } & \multirow{2}{*}{$\begin{array}{c}\text { Удельный вес женщин } \\
\text { в численности } \\
\text { занятого населения }\end{array}$} \\
\hline & всего & мужчинь & женщиины & город & село & \\
\hline Июнь & 59,4 & 67,3 & 52,9 & 61,7 & 52,5 & 48,7 \\
\hline Июль & 59,7 & 67,4 & 53,2 & 61,7 & 53,5 & 48,8 \\
\hline Август & 59,9 & 67,8 & 53,3 & 61,8 & 54,0 & 48,7 \\
\hline Сентябрь & 59,6 & 67,5 & 53,1 & 61,8 & 53,2 & 48,7 \\
\hline Октябрь & 59,5 & 67,6 & 52,9 & 61,6 & 53,5 & 48,6 \\
\hline Ноябрь & 60,0 & 67,7 & 53,7 & 62,2 & 53,5 & 48,9 \\
\hline Декабрь & 59,8 & 67,7 & 53,3 & 62,1 & 52,9 & 48,7 \\
\hline \multicolumn{7}{|c|}{2020 г. } \\
\hline Январь & 59,1 & 67,1 & 52,3 & 61,1 & 52,8 & 48,5 \\
\hline Февраль & 58,9 & 66,6 & 52,4 & 61,2 & 51,7 & 48,7 \\
\hline Март & 59,1 & 66,5 & 52,9 & 61,1 & 53,0 & 49,0 \\
\hline Апрель & 58,1 & 65,3 & 52,2 & 60,2 & 51,8 & 49,1 \\
\hline Май & 58,0 & 65,3 & 51,8 & 60,3 & 50,8 & 48,9 \\
\hline Июнь & 58,0 & 65,7 & 51,6 & 60,2 & 51,4 & 48,7 \\
\hline Июль & 58,1 & 65,8 & 51,7 & 59,9 & 52,6 & 48,7 \\
\hline Август & 58,3 & 66,4 & 51,7 & 60,4 & 52,0 & 48,4 \\
\hline Сентябрь & 58,3 & 65,9 & 52,1 & 60,4 & 52,2 & 48,8 \\
\hline
\end{tabular}

В августе 2020 г. в общей численности занятого населения 31,9 млн человек, или 45,3\% составляли штатные (без учета совместителей) работники организаций, не относящихся к субъектам малого предпринимательства. На условиях совместительства и по договорам гражданскоправового характера для работы в этих организациях привлекалось еще 1,3 млн человек (в эквиваленте полной занятости). Число замещенных рабочих мест работниками списочного состава, совместителями и лицами, выполнявшими работы по договорам гражданско-правового характера, в организациях (без субъектов малого предпринимательства) в августе 2020 г. составило 33,2 млн человек и было меньше, чем в августе 2019 г., на 142 тыс. человек, или на 0,4\%.

Таблица 3

\section{ДИНАМИКА ЧИСЛА ЗАМЕЩЕННЫХ РАБОЧИХ МЕСТ В ОРГАНИЗАЦИЯХ}

(без субъектов малого предпринимательства)

\begin{tabular}{|c|c|c|c|c|c|c|c|}
\hline & \multirow{3}{*}{$\begin{array}{l}\text { Aвгуст } \\
2020 \text { г., } \\
\text { млн }\end{array}$} & \multicolumn{2}{|c|}{$B \% \kappa$} & \multirow{3}{*}{$\begin{array}{c}\text { Январь- } \\
\text { август } \\
2020 \text { г. } \\
\text { в\% } \\
\text { январю- } \\
\text { августу } \\
2019 \text { г. }\end{array}$} & \multicolumn{3}{|c|}{ Справочно } \\
\hline & & \multirow{2}{*}{$\begin{array}{c}\text { августу } \\
2019 \text { z. }\end{array}$} & \multirow{2}{*}{$\begin{array}{l}\text { июлю } \\
2020 \text { г. }\end{array}$} & & \multicolumn{2}{|c|}{ август 2019 г. в\% } & \multirow[b]{2}{*}{$\begin{array}{c}\text { январь- } \\
\text { август } \\
2019 \text { г. } \\
\text { в\% } \\
\text { январю- } \\
\text { августу } \\
2018 \text { 2. }\end{array}$} \\
\hline & & & & & $\begin{array}{l}\text { августу } \\
2018 \text { г. }\end{array}$ & $\begin{array}{c}\text { июлю } \\
2019 \text { г. }\end{array}$ & \\
\hline Всего замещенных рабочих мест & 33,2 & 99,6 & 99,7 & 100,9 & 100,5 & 99,5 & 101,1 \\
\hline $\begin{array}{l}\text { в том числе: } \\
\text { работниками списочного состава } \\
\text { (без внешних совместителей) }\end{array}$ & 31,9 & 99,7 & 99,8 & 101,0 & 100,4 & 99,6 & 101,1 \\
\hline внешними совместителями & 0,5 & 102,3 & 101,4 & 99,8 & 96,0 & 97,4 & 95,5 \\
\hline $\begin{array}{l}\text { работниками, выполнявшими } \\
\text { работы по договорам } \\
\text { гражданско-правового характера }\end{array}$ & 0,8 & 94,9 & 96,4 & 97,3 & 108,5 & 98,3 & 105,1 \\
\hline
\end{tabular}




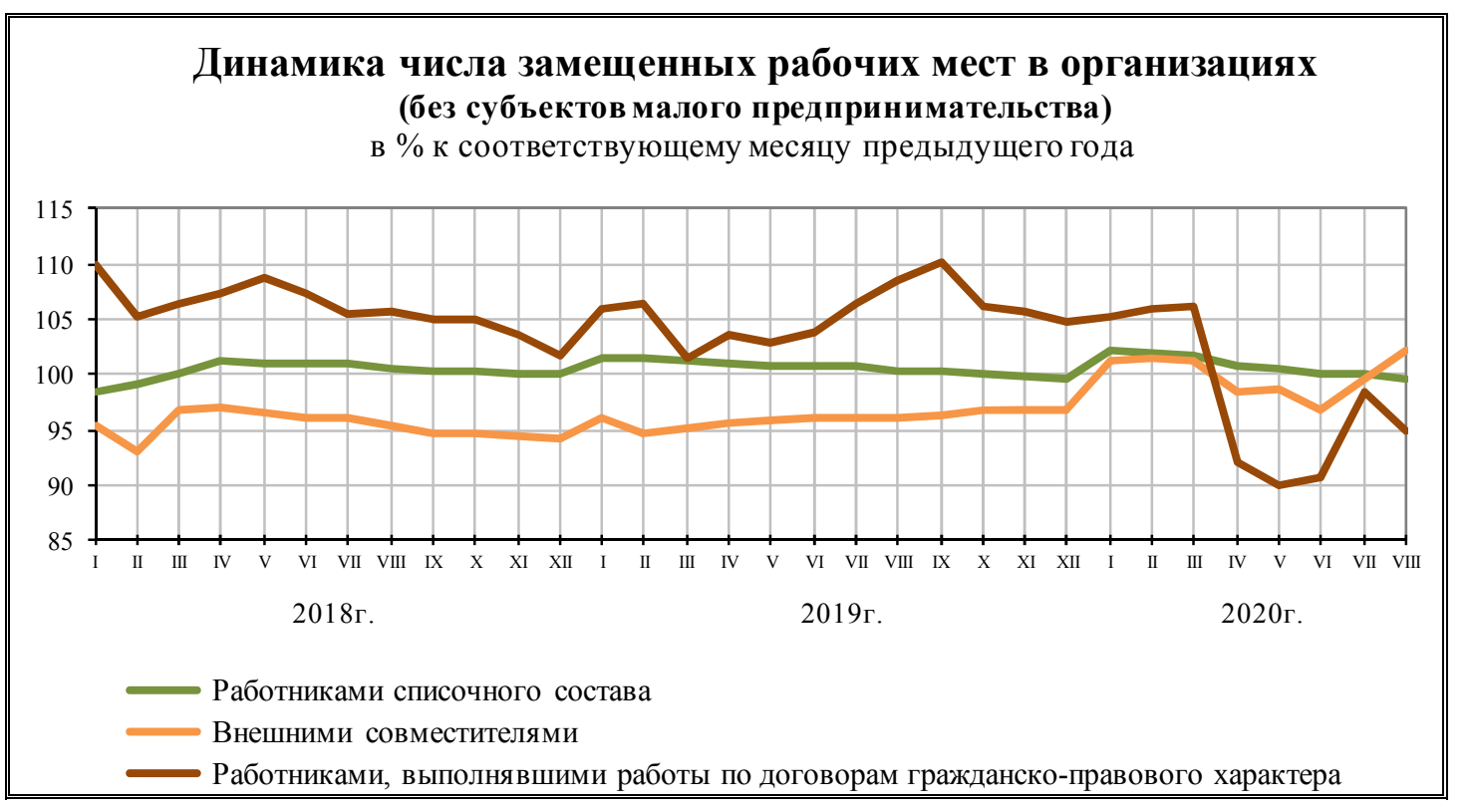

В августе 2020 г. в общем количестве замещенных рабочих мест в организациях удельный вес рабочих мест внешних совместителей составлял 1,4\%, лиц, выполнявших работы по гражданско-правовым договорам, - 2,5\%.

Таблица 4

\section{ЧИСЛО ЗАМЕЩЕННЫХ РАБОЧИХ МЕСТ В ОРГАНИЗАЦИЯХ ПО ВИДАМ ЭКОНОМИЧЕСКОЙ ДЕЯТЕЛЬНОСТИ (без субъектов малого предпринимательства) в августе 2020 года}

\begin{tabular}{|c|c|c|c|c|c|}
\hline & \multirow{2}{*}{\begin{tabular}{|c|} 
Всего \\
замещенных \\
рабочих \\
мест, \\
тысяч
\end{tabular}} & \multicolumn{3}{|c|}{ В том числе работниками } & \multirow[b]{2}{*}{$\begin{array}{c}\text { Число } \\
\text { замещенных } \\
\text { рабочих } \\
\text { мест, } \\
\text { в\% \% } \\
\text { августу } \\
20192 .\end{array}$} \\
\hline & & \begin{tabular}{|c|} 
списочного \\
состава \\
(без внешних \\
совмести- \\
телей)
\end{tabular} & $\begin{array}{l}\text { внешними } \\
\text { совмести- } \\
\text { телями }\end{array}$ & \begin{tabular}{|c|} 
выполнявши- \\
ми работьл \\
по договорам \\
гражданско- \\
правового \\
характера \\
\end{tabular} & \\
\hline Всего & 33245,4 & 31938,1 & 462,6 & 844,7 & 99,6 \\
\hline $\begin{array}{l}\text { из них: } \\
\text { сельское, лесное хозяйство, охота, } \\
\text { рыболовство и рыбоводство }\end{array}$ & 955,0 & 924,9 & 5,9 & 24,2 & 97,7 \\
\hline $\begin{array}{l}\text { в том числе: } \\
\text { растениеводство и животноводство, } \\
\text { охота и предоставление } \\
\text { соответствующих услуг в этих областях }\end{array}$ & 793,1 & 769,7 & 4,3 & 19,2 & 97,0 \\
\hline лесоводство и лесозаготовки & 116,8 & 111,4 & 1,1 & 4,4 & 99,9 \\
\hline рыболовство и рыбоводство & 45,0 & 43,8 & 0,6 & 0,6 & 105,7 \\
\hline добыча полезных ископаемых & 956,7 & 948,8 & 2,1 & 5,9 & 99,3 \\
\hline $\begin{array}{l}\text { из нее: } \\
\text { добыча угля }\end{array}$ & 135,7 & 134,7 & 0,3 & 0,7 & 94,6 \\
\hline добыча нефти и природного газа & 210,3 & 209,1 & 0,3 & 0,8 & 102,1 \\
\hline добыча металлических руд & 198,0 & 196,0 & 0,5 & 1,6 & 100,0 \\
\hline
\end{tabular}




\begin{tabular}{|c|c|c|c|c|c|}
\hline & \multirow{2}{*}{\begin{tabular}{|c|} 
Всего \\
замещенных \\
рабочих \\
мест, \\
тысяч
\end{tabular}} & \multicolumn{3}{|c|}{ В в том числе работниками } & \multirow[b]{2}{*}{$\begin{array}{c}\text { Число } \\
\text { замешенных } \\
\text { рабочих } \\
\text { мест, } \\
\text { в\% к } \\
\text { августу } \\
2019 \text { г. } \\
\end{array}$} \\
\hline & & $\begin{array}{c}\text { списочного } \\
\text { состава } \\
\text { (без внешних } \\
\text { совмести- } \\
\text { телей) }\end{array}$ & $\begin{array}{l}\text { внешними } \\
\text { совмести- } \\
\text { телями }\end{array}$ & \begin{tabular}{|c|} 
выполнявши- \\
ми работьл \\
по договорам \\
гражданско- \\
правового \\
характера \\
\end{tabular} & \\
\hline обрабатывающие производства & 5125,5 & 5058,2 & 25,2 & 42,1 & 97,9 \\
\hline $\begin{array}{l}\text { из них: } \\
\text { производство пищевых продуктов }\end{array}$ & 754,0 & 741,6 & 3,2 & 9,3 & 98,1 \\
\hline производство напитков & 89,5 & 87,5 & 0,4 & 1,6 & 96,2 \\
\hline производство табачных изделий & 5,9 & 5,8 & 0,1 & 0,0 & 97,3 \\
\hline производство текстильных изделий & 51,0 & 50,3 & 0,3 & 0,5 & 100,8 \\
\hline производство одежды & 83,7 & 83,2 & 0,2 & 0,3 & 101,7 \\
\hline производство кожи и изделий из кожи & 24,2 & 24,0 & 0,1 & 0,1 & 88,4 \\
\hline $\begin{array}{l}\text { обработка древесины и производство изделий } \\
\text { из дерева и пробки, кроме мебели, производство } \\
\text { изделий из соломки и материалов для плетения }\end{array}$ & 115,8 & 113,5 & 0,4 & 2,0 & 94,4 \\
\hline производство бумаги и бумажных изделий & 90,1 & 89,2 & 0,3 & 0,7 & 100,1 \\
\hline $\begin{array}{l}\text { деятельность полиграфическая } \\
\text { и копирование носителей информации }\end{array}$ & 31,3 & 30,5 & 0,3 & 0,6 & 88,0 \\
\hline производство кокса и нефтепродуктов & 133,5 & 133,1 & 0,1 & 0,4 & 103,0 \\
\hline $\begin{array}{l}\text { из них: } \\
\text { производство кокса }\end{array}$ & 12,0 & 11,9 & 0,0 & 0,0 & 102,7 \\
\hline производство нефтепродуктов & 121,5 & 121,1 & 0,1 & 0,3 & 103,0 \\
\hline $\begin{array}{l}\text { производство химических веществ } \\
\text { и химических продуктов }\end{array}$ & 314,9 & 311,5 & 1,2 & 2,2 & 99,3 \\
\hline $\begin{array}{l}\text { производство лекарственных средств и } \\
\text { материалов, применяемых в медицинских целях }\end{array}$ & 81,5 & 77,1 & 0,7 & 3,7 & 108,2 \\
\hline $\begin{array}{l}\text { производство резиновых и } \\
\text { пластмассовых изделий }\end{array}$ & 140,8 & 138,9 & 0,8 & 1,1 & 97,9 \\
\hline $\begin{array}{l}\text { производство прочей неметаллической } \\
\text { минеральной продукции }\end{array}$ & 290,1 & 285,4 & 1,6 & 3,1 & 96,4 \\
\hline производство металлургическое & 422,6 & 419,5 & 1,8 & 1,3 & 96,6 \\
\hline $\begin{array}{l}\text { производство готовых металлических изделий, } \\
\text { кроме машин и оборудования }\end{array}$ & 452,4 & 447,1 & 2,2 & 3,1 & 97,5 \\
\hline $\begin{array}{l}\text { производство компьютеров, } \\
\text { электронных и оптических изделий }\end{array}$ & 349,5 & 343,2 & 3,6 & 2,6 & 97,8 \\
\hline производство электрического оборудования & 180,9 & 178,2 & 1,3 & 1,4 & 98,2 \\
\hline $\begin{array}{l}\text { производство машин и оборудования, } \\
\text { не включенных в другие группировки }\end{array}$ & 292,1 & 287,6 & 1,8 & 2,7 & 96,7 \\
\hline $\begin{array}{l}\text { производство автотранспортных средств, } \\
\text { прицепов и полуприцепов }\end{array}$ & 246,8 & 245,1 & 0,9 & 0,9 & 92,7 \\
\hline $\begin{array}{l}\text { производство прочих транспортных } \\
\text { средств и оборудования }\end{array}$ & 594,5 & 591,2 & 1,6 & 1,7 & 101,6 \\
\hline производство мебели & 49,0 & 48,6 & 0,2 & 0,2 & 91,8 \\
\hline производство прочих готовых изделий & 40,3 & 39,3 & 0,5 & 0,5 & 90,6 \\
\hline ремонт и монтаж машин и оборудования & 291,0 & 287,0 & 1,7 & 2,4 & 97,5 \\
\hline $\begin{array}{l}\text { обеспечение электрической энергией, } \\
\text { газом и паром; кондиционирование воздуха }\end{array}$ & 1284,5 & 1268,3 & 5,7 & 10,5 & 99,3 \\
\hline $\begin{array}{l}\text { водоснабжение; водоотведение, } \\
\text { организация сбора и утилизации отходов, } \\
\text { деятельность по ликвидации загрязнений }\end{array}$ & 442,5 & 431,6 & 2,9 & 8,0 & 99,6 \\
\hline строительство & 1029,1 & 997,2 & 8,8 & 23,1 & 97,3 \\
\hline
\end{tabular}




\begin{tabular}{|c|c|c|c|c|c|}
\hline & \multirow{2}{*}{\begin{tabular}{|c|} 
Всего \\
замещенных \\
рабочих \\
мест, \\
тысяч
\end{tabular}} & \multicolumn{3}{|c|}{ В В том числе работниками } & \multirow[b]{2}{*}{$\begin{array}{c}\text { Число } \\
\text { замещенньх } \\
\text { рабочих } \\
\text { мест, } \\
\text { в\% к } \\
\text { августу } \\
20192 . \\
\end{array}$} \\
\hline & & \begin{tabular}{|c|} 
списочного \\
состава \\
(без внешних \\
совмести- \\
телей)
\end{tabular} & $\begin{array}{l}\text { внешними } \\
\text { совмести- } \\
\text { телями }\end{array}$ & \begin{tabular}{|c|} 
выполнявши- \\
ми работьл \\
по договорам \\
гражданско- \\
правового \\
характера \\
\end{tabular} & \\
\hline $\begin{array}{l}\text { торговля оптовая и розничная; ремонт } \\
\text { автотранспортных средств и мотоциклов }\end{array}$ & 2652,9 & 2590,1 & 19,3 & 43,5 & 102,9 \\
\hline $\begin{array}{l}\text { из нее: } \\
\text { торговля оптовая, кроме оптовой торговли } \\
\text { автотранспортными средствами и мотоциклами }\end{array}$ & 792,9 & 762,9 & 10,5 & 19,5 & 99,6 \\
\hline $\begin{array}{l}\text { торговля розничная, кроме торговли } \\
\text { автотранспортными средствами и мотоциклами }\end{array}$ & 1717,0 & 1688,2 & 6,9 & 21,9 & 104,5 \\
\hline транспортировка и хранение & 2636,3 & 2597,1 & 11,5 & 27,7 & 99,6 \\
\hline $\begin{array}{l}\text { в том числе: } \\
\text { деятельность сухопутного и } \\
\text { трубопроводного транспорта }\end{array}$ & 1328,3 & 1312,4 & 3,6 & 12,2 & 97,5 \\
\hline $\begin{array}{l}\text { в том числе: } \\
\text { деятельность железнодорожного транспорта: } \\
\text { междугородные и международные } \\
\text { пассажирские перевозки }\end{array}$ & 128,4 & 127,3 & 0,1 & 0,9 & 85,9 \\
\hline $\begin{array}{l}\text { деятельность железнодорожного транспорта: } \\
\text { грузовые перевозки }\end{array}$ & 297,6 & 293,8 & 0,2 & 3,5 & 95,3 \\
\hline $\begin{array}{l}\text { деятельность прочего сухопутного } \\
\text { пассажирского транспорта }\end{array}$ & 427,2 & 422,6 & 1,9 & 2,7 & 99,8 \\
\hline $\begin{array}{l}\text { деятельность автомобильного грузового } \\
\text { транспорта и услуги по перевозкам }\end{array}$ & 270,7 & 264,7 & 1,3 & 4,7 & 100,8 \\
\hline деятельность трубопроводного транспорта & 204,4 & 204,0 & 0,1 & 0,3 & 100,5 \\
\hline деятельность водного транспорта & 40,1 & 39,3 & 0,3 & 0,5 & 92,6 \\
\hline $\begin{array}{l}\text { деятельность воздушного и } \\
\text { космического транспорта }\end{array}$ & 82,3 & 80,3 & 0,5 & 1,5 & 97,1 \\
\hline $\begin{array}{l}\text { складское хозяйство и вспомогательная } \\
\text { транспортная деятельность }\end{array}$ & 883,4 & 866,9 & 4,6 & 11,9 & 102,7 \\
\hline $\begin{array}{l}\text { деятельность почтовой связи } \\
\text { и курьерская деятельность }\end{array}$ & 302,2 & 298,1 & 2,6 & 1,6 & 102,0 \\
\hline $\begin{array}{l}\text { деятельность гостиниц и предприятий } \\
\text { общественного питания }\end{array}$ & 371,0 & 360,4 & 5,6 & 5,0 & 92,6 \\
\hline деятельность в области информации и связи & 931,5 & 791,6 & 11,8 & 128,1 & 104,9 \\
\hline деятельность финансовая и страховая & 1111,4 & 891,8 & 9,4 & 210,2 & 97,6 \\
\hline $\begin{array}{l}\text { деятельность по операциям } \\
\text { с недвижимым имуществом }\end{array}$ & 484,4 & 456,9 & 10,3 & 17,2 & 94,6 \\
\hline $\begin{array}{l}\text { деятельность профессиональная, } \\
\text { научная и техничесая } \\
\end{array}$ & 1447,8 & 1386,0 & 34,3 & 27,6 & 98,5 \\
\hline из нее научные исследования и разработки & 626,7 & 600,4 & 19,7 & 6,6 & 96,5 \\
\hline $\begin{array}{l}\text { деятельность административная } \\
\text { и сопутствующие дополнительные услуги }\end{array}$ & 691,5 & 652,8 & 9,8 & 28,9 & 101,9 \\
\hline $\begin{array}{l}\text { государственное управление и обеспечение } \\
\text { военной безопасности; социальное обеспечение }\end{array}$ & 3333,8 & 3271,2 & 12,0 & 50,6 & 101,2 \\
\hline образование & 4803,3 & 4606,2 & 130,9 & 66,2 & 99,8 \\
\hline $\begin{array}{l}\text { деятельность в области здравоохранения } \\
\text { и социальных услуг }\end{array}$ & 4047,8 & 3857,7 & 97,8 & 92,4 & 99,3 \\
\hline $\begin{array}{l}\text { деятельность в области культуры, } \\
\text { спорта, организации досуга и развлечений }\end{array}$ & 803,8 & 742,2 & 39,9 & 21,6 & 100,4 \\
\hline $\begin{array}{l}\text { из нее: } \\
\text { деятельность творческая, деятельность } \\
\text { в области искусства и организации развлечений }\end{array}$ & 275,1 & 251,9 & 15,7 & 7,4 & 101,2 \\
\hline $\begin{array}{l}\text { деятельность библиотек, архивов, } \\
\text { музеев и прочих объектов культуры }\end{array}$ & 218,5 & 209,8 & 5,0 & 3,7 & 97,5 \\
\hline $\begin{array}{l}\text { деятельность в области спорта, } \\
\text { отдыха и развлечений }\end{array}$ & 296,9 & 267,6 & 19,0 & 10,3 & 102,6 \\
\hline
\end{tabular}


Безработица. В сентябре 2020 г., по итогам выборочного обследования рабочей силы, 4,8 млн человек в возрасте 15 лет и старше классифицировались как безработные (в соответствии с методологией Международной Организации Труда).

Уровень безработицы населения в возрасте 15 лет и старше в сентябре 2020 г. составил $6,3 \%$ (без исключения сезонного фактора).

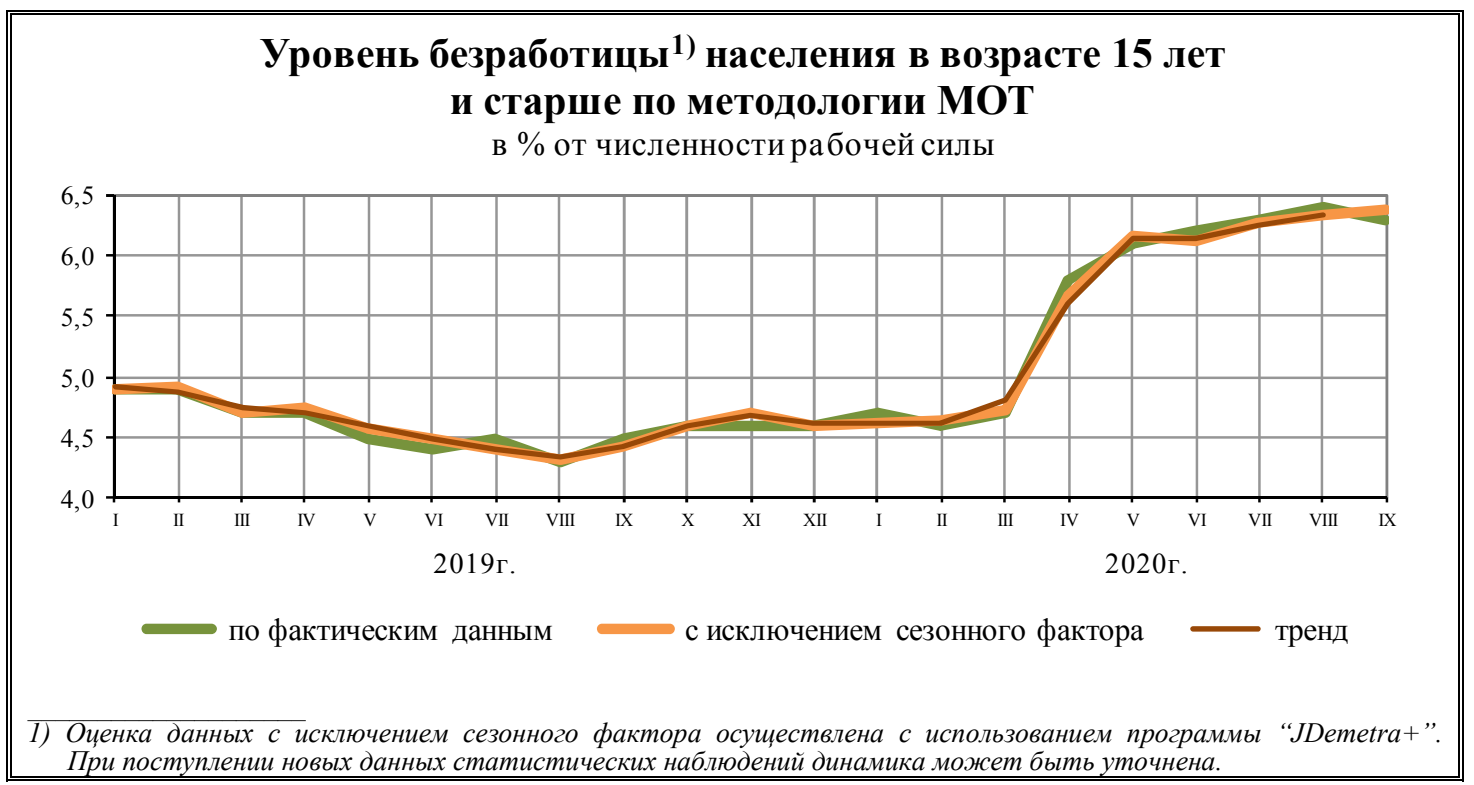

Средний возраст безработных в возрасте 15 лет и старше в сентябре 2020 г. составил 36,8 года. Молодежь до 25 лет составляет среди безработных 16,2\%, лица в возрасте 50 лет и старше $18,0 \%$.

Средняя продолжительность поиска работы безработными в сентябре 2020 г. у женщин составила 6,4 месяца, у мужчин - 6,6 месяца.

\section{ДИНАМИКА ЧИСЛЕННОСТИ БЕЗРАБОТНЫХ В ВОЗРАСТЕ 15 ЛЕТ И СТАРШЕ} ПО ПРОДОЛЖИТЕЛЬНОСТИ ПОИСКА РАБОТЫ

\begin{tabular}{|c|c|c|c|c|c|c|c|c|}
\hline & \multirow{2}{*}{$\begin{array}{c}\text { Общая } \\
\text { численность } \\
\text { безработных, } \\
\text { тысс. человек } \\
\end{array}$} & \multicolumn{6}{|c|}{ Из них ищут работу, в \% к общей численности безработных } & \multirow{2}{*}{$\begin{array}{c}\text { Среднее } \\
\text { время поиска } \\
\text { работьи, } \\
\text { месячев }\end{array}$} \\
\hline & & $\begin{array}{c}\text { менее } 1 \\
\text { месяца }\end{array}$ & $\begin{array}{c}\text { от } 1 \\
\text { до } 3 \\
\text { месяичев }\end{array}$ & $\begin{array}{c}\text { от } 3 \\
\text { до } 6 \\
\text { месяцев } \\
\end{array}$ & $\begin{array}{c}\text { от } 6 \\
\text { до } 9 \\
\text { месячев }\end{array}$ & $\begin{array}{c}\text { от } 9 \\
\text { до } 12 \\
\text { месячев } \\
\end{array}$ & $\begin{array}{c}12 \text { меся- } \\
\text { цеев } u \\
\text { более }\end{array}$ & \\
\hline \multicolumn{9}{|c|}{2019 г. } \\
\hline Январь & 3667 & 10,8 & 19,4 & 20,8 & 14,5 & 10,0 & 24,5 & 7,2 \\
\hline Февраль & 3655 & 9,6 & 20,8 & 20,5 & 13,5 & 11,9 & 23,8 & 7,2 \\
\hline Март & 3518 & 9,9 & 20,8 & 17,6 & 13,8 & 12,4 & 25,5 & 7,4 \\
\hline Апрель & 3554 & 11,3 & 19,5 & 21,0 & 14,6 & 10,4 & 23,2 & 7,1 \\
\hline Май & 3402 & 10,8 & 22,0 & 19,2 & 11,9 & 9,1 & 27,0 & 7,3 \\
\hline Июнь & 3334 & 12,8 & 21,2 & 18,1 & 11,2 & 11,2 & 25,5 & 7,1 \\
\hline Июль & 3364 & 16,4 & 23,8 & 19,4 & 9,9 & 8,3 & 22,2 & 6,4 \\
\hline Август & 3258 & 16,2 & 25,0 & 18,6 & 8,9 & 9,5 & 21,9 & 6,4 \\
\hline
\end{tabular}




\begin{tabular}{|c|c|c|c|c|c|c|c|c|}
\hline & \multirow{2}{*}{\begin{tabular}{|c|} 
Общчая \\
численность \\
безработных, \\
тыс. человек \\
\end{tabular}} & \multicolumn{6}{|c|}{ "Из них ищут работу, в \% к общей численности безработных } & \multirow{2}{*}{$\begin{array}{c}\text { Среднее } \\
\text { время поиска } \\
\text { работы, } \\
\text { месяцев } \\
\end{array}$} \\
\hline & & $\begin{array}{l}\text { менее } 1 \\
\text { месяиа }\end{array}$ & $\begin{array}{c}\text { от } 1 \\
\text { до } 3 \\
\text { месяиев }\end{array}$ & $\begin{array}{c}\text { от } 3 \\
\text { до } 6 \\
\text { месяиев }\end{array}$ & $\begin{array}{c}\text { от } 6 \\
\text { до 9 } \\
\text { месяиев }\end{array}$ & $\begin{array}{c}\text { от } 9 \\
\text { до } 12 \\
\text { месяиев }\end{array}$ & $\begin{array}{c}12 \text { меся- } \\
\text { иев } и \\
\text { более }\end{array}$ & \\
\hline Сентябрь & 3371 & 12,2 & 28,8 & 19,7 & 9,0 & 9,8 & 20,6 & 6,3 \\
\hline Октябрь & 3476 & 13,0 & 24,7 & 21,1 & 9,3 & 8,1 & 23,9 & 6,6 \\
\hline Ноябрь & 3507 & 12,1 & 21,8 & 22,3 & 12,1 & 8,8 & 22,9 & 6,8 \\
\hline Декабрь & 3473 & 11,3 & 23,0 & 24,0 & 9,0 & 8,7 & 24,1 & 6,8 \\
\hline \multicolumn{9}{|c|}{2020 г. } \\
\hline Январь & 3482 & 9,6 & 22,5 & 23,5 & 11,5 & 10,4 & 22,6 & 6,9 \\
\hline Февраль & 3425 & 8,9 & 26,1 & 16,9 & 12,1 & 9,5 & 26,4 & 7,2 \\
\hline Март & 3485 & 9,4 & 21,4 & 21,3 & 13,7 & 9,8 & 24,4 & 7,1 \\
\hline Апрель & 4286 & 15,5 & 25,5 & 22,9 & 11,8 & 9,0 & 15,4 & 5,7 \\
\hline Май & 4513 & 10,5 & 32,5 & 20,0 & 11,7 & 8,3 & 16,9 & 5,9 \\
\hline Июнь & 4606 & 10,3 & 33,4 & 22,1 & 10,8 & 8,5 & 15,0 & 5,7 \\
\hline Июль & 4731 & 12,1 & 28,9 & 23,8 & 9,6 & 9,0 & 16,6 & 5,9 \\
\hline Август & 4808 & 10,7 & 28,4 & 26,1 & 10,1 & 6,1 & 18,5 & 6,0 \\
\hline Сентябрь & 4777 & 8,7 & 23,8 & 27,4 & 11,5 & 9,2 & 19,3 & 6,5 \\
\hline
\end{tabular}

Из 4,8 млн безработных 1,4 млн составляют сельские жители, 3,3 млн - городские. Большинство безработных искали работу от 3 до 6 месяцев - 27,4\% (в городской местности - 29,3\%, в сельской - 23,2\%). В состоянии застойной безработицы находились $26,6 \%$ сельских безработных и $16,1 \%$ городских.

По данным проведенного обследования, в сентябре 2020 г. 38,0\% безработных использовали в качестве способа поиска работы обращение в органы службы занятости населения, 70,6\% безработных - обращение к друзьям, родственникам и знакомым.

Численность не занятых трудовой деятельностью граждан, состоящих на учете в органах службы занятости населения (по данным Роструда). К концу сентября 2020 г. в органах службы занятости населения, по данным Роструда, состояли на учете 4,0 млн не занятых трудовой деятельностью граждан, из них 3,7 млн человек имели статус безработного, в том числе 3,3 млн человек получали пособие по безработице.

Таблица 6

ДИНАМИКА ЧИСЛЕННОСТИ НЕ ЗАНЯТЫХ ТРУДОВОЙ ДЕЯТЕЛЬНОСТЬЮ ГРАЖДАН, СОСТОЯЩИХ НА УЧЕТЕ В ОРГАНАХ СЛУЖБЫ ЗАНЯТОСТИ НАСЕЛЕНИЯ (по данным Роструда)

на конец месяца

\begin{tabular}{|c|c|c|c|c|}
\hline & \multirow{3}{*}{$\begin{array}{c}\text { Численность } \\
\text { не занятых трудовой } \\
\text { деятельностью } \\
\text { граждан, } \\
\text { тыс. человек } \\
\end{array}$} & \multicolumn{3}{|c|}{ Из них зарегистрированные безработные } \\
\hline & & \multirow{2}{*}{$\begin{array}{c}\text { тысс. } \\
\text { человек }\end{array}$} & \multicolumn{2}{|c|}{$6 \% \mathrm{~K}$} \\
\hline & & & $\begin{array}{c}\text { соответствующему } \\
\text { периоду предыдущего } \\
\text { года }\end{array}$ & $\begin{array}{c}\text { предыдущему } \\
\text { периоду }\end{array}$ \\
\hline \multicolumn{5}{|c|}{2019 г. } \\
\hline Январь & 896 & 733 & 94,2 & 105,8 \\
\hline Февраль & 957 & 798 & 99,9 & 108,8 \\
\hline Март & 956 & 818 & 104,4 & 102,6 \\
\hline Апрель & 940 & 817 & 107,8 & 99,8 \\
\hline
\end{tabular}




\begin{tabular}{|c|c|c|c|c|}
\hline & \multirow{3}{*}{$\begin{array}{c}\text { Численность } \\
\text { не занятых трудовой } \\
\text { деятельностью } \\
\text { граждан, } \\
\text { тыс. человек } \\
\end{array}$} & \multicolumn{3}{|c|}{ Из них зарегистрированные безработные } \\
\hline & & \multirow{2}{*}{$\begin{array}{c}\text { тьлс. } \\
\text { человек }\end{array}$} & \multicolumn{2}{|c|}{$6 \%$} \\
\hline & & & $\begin{array}{c}\text { соответствующему } \\
\text { периоду предыдущего } \\
\text { года } \\
\end{array}$ & $\begin{array}{c}\text { предьдучщему } \\
\text { периоду }\end{array}$ \\
\hline Май & 899 & 776 & 106,3 & 95,0 \\
\hline Июнь & 863 & 746 & 105,7 & 96,1 \\
\hline Июль & 857 & 727 & 105,3 & 97,5 \\
\hline Август & 842 & 712 & 104,8 & 98,0 \\
\hline Сентябрь & 798 & 666 & 102,5 & 93,5 \\
\hline Октябрь & 782 & 645 & 102,2 & 96,9 \\
\hline Ноябрь & 797 & 664 & 100,5 & 103,0 \\
\hline Декабрь & 782 & 691 & 99,7 & 104,1 \\
\hline Год (в среднем за месяи) & 864 & 733 & 102,7 & \\
\hline \multicolumn{5}{|c|}{2020 г. } \\
\hline Январь & 839 & 700 & 95,4 & 101,2 \\
\hline Февраль & 869 & 730 & 91,4 & 104,3 \\
\hline Март & 855 & 727 & 88,8 & 99,6 \\
\hline Апрель & 1834 & 1311 & 160,5 & 180,4 \\
\hline Май & 2543 & 2143 & в $2,8 \mathrm{p}$. & 163,5 \\
\hline Июнь & 3152 & 2787 & в $3,7 \mathrm{p}$. & 130,0 \\
\hline Июль & 3637 & 3311 & в 4,6p. & 118,8 \\
\hline Август & 3953 & 3644 & в 5,1p. & 110,1 \\
\hline Сентябрь & 3989 & 3687 & в 5,5p. & 101,2 \\
\hline
\end{tabular}

В сентябре 2020 г. получили статус безработного 415,5 тыс. человек, трудоустроено за месяц 207,8 тыс. человек. Размеры трудоустройства безработных были на 125,9 тыс. человек, или в 2,5p. больше, чем в сентябре 2019 года.

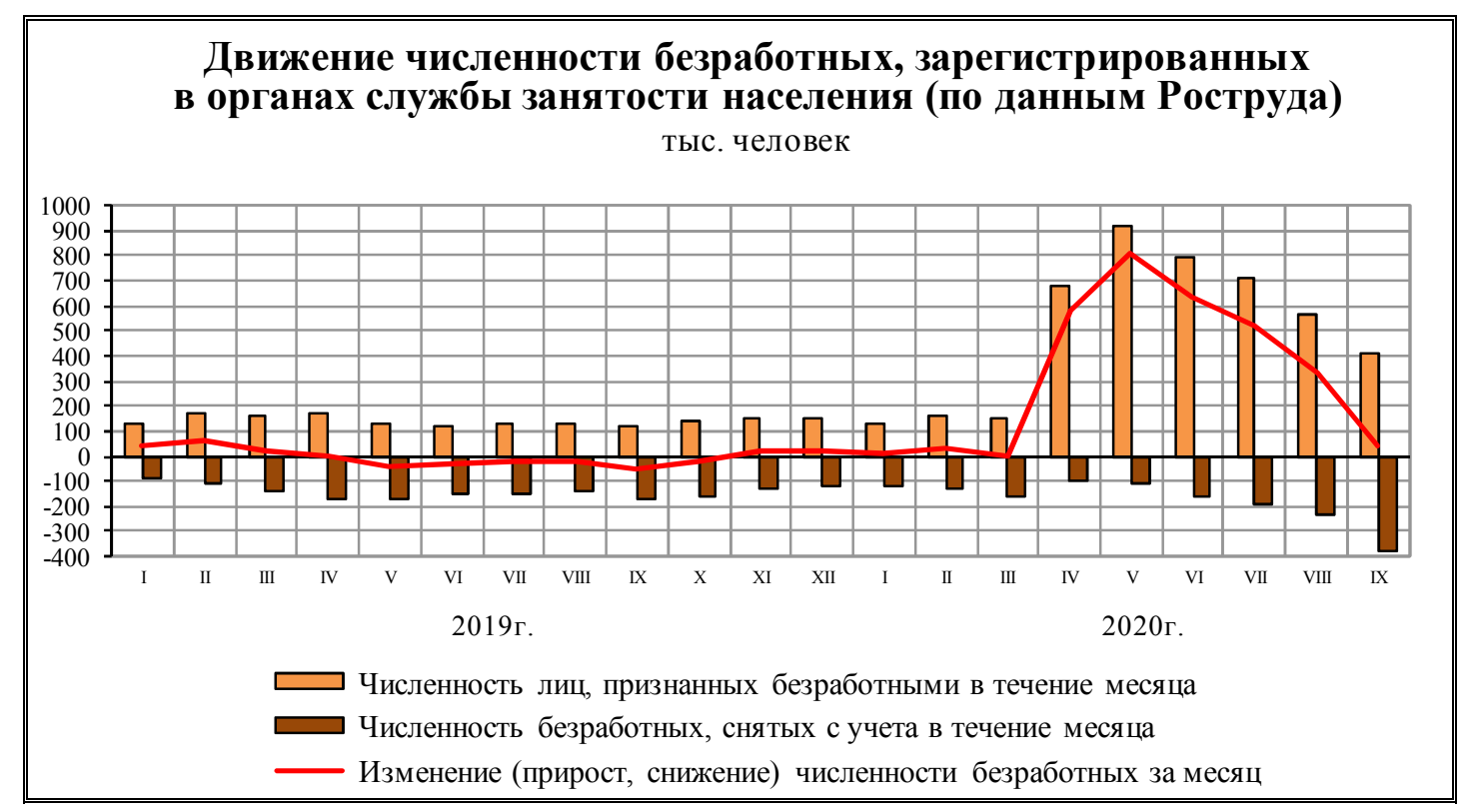


В сентябре 2020 г. нагрузка не занятого трудовой деятельностью населения, зарегистрированного в органах службы занятости населения, на 100 заявленных вакансий составила 224,9 человека.

Таблица 7

ДИНАМИКА ПОТРЕБНОСТИ РАБОТОДАТЕЛЕЙ В РАБОТНИКАХ, ЗАЯВЛЕННОЙ В ОРГАНЫ СЛУЖБЫ ЗАНЯТОСТИ НАСЕЛЕНИЯ

на конец месяца

\begin{tabular}{|c|c|c|c|c|}
\hline & \multirow{3}{*}{$\begin{array}{c}\text { Потребность работодателей } \\
\text { в работниках, заявленная } \\
\text { в органы службы } \\
\text { занятости населения, } \\
\text { тыс. человек }\end{array}$} & \multicolumn{3}{|c|}{$\begin{array}{c}\text { Нагрузка не занятого трудовой деятельностью населения } \\
\text { на } 100 \text { заявленных вакансий }\end{array}$} \\
\hline & & \multirow{2}{*}{ человек } & \multicolumn{2}{|c|}{$6 \% \kappa$} \\
\hline & & & $\begin{array}{c}\begin{array}{c}\text { соответствуюшему } \\
\text { месяиу предыдууего } \\
\text { года }\end{array} \\
\end{array}$ & $\begin{array}{l}\text { предылушему } \\
\text { месяиу }\end{array}$ \\
\hline \multicolumn{5}{|c|}{2019 г. } \\
\hline Январь & 1461 & 61,3 & 89,5 & 114,2 \\
\hline Февраль & 1512 & 63,3 & 92,8 & 103,3 \\
\hline Март & 1537 & 62,2 & 97,8 & 98,3 \\
\hline Апрель & 1572 & 59,8 & 100,3 & 96,1 \\
\hline Май & 1733 & 51,9 & 100,0 & 86,8 \\
\hline Июнь & 1764 & 48,9 & 101,7 & 94,2 \\
\hline Июль & 1755 & 48,8 & 102,5 & 99,8 \\
\hline Август & 1744 & 48,3 & 102,0 & 98,9 \\
\hline Сентябрь & 1722 & 46,3 & 100,2 & 95,9 \\
\hline Октябрь & 1651 & 47,4 & 100,0 & 102,4 \\
\hline Ноябрь & 1579 & 50,5 & 99,6 & 106,5 \\
\hline Декабрь & 1488 & 52,6 & 98,0 & 104,2 \\
\hline \multicolumn{5}{|c|}{2020 г. } \\
\hline Январь & 1464 & 57,3 & 93,5 & 108,9 \\
\hline Февраль & 1496 & 58,1 & 91,8 & 101,4 \\
\hline Март & 1493 & 57,3 & 92,1 & 98,6 \\
\hline Апрель & 1346 & 136,2 & в 2,3p. & в $2,4 \mathrm{p}$. \\
\hline Май & 1385 & 183,7 & в $3,5 \mathrm{p}$. & 134,9 \\
\hline Июнь & 1518 & 207,6 & в 4,2p. & 113,0 \\
\hline Июль & 1639 & 221,9 & в 4,5p. & 106,9 \\
\hline Август & 1692 & 233,6 & в $4,8 \mathrm{p}$. & 105,3 \\
\hline Сентябрь & 1774 & 224,9 & в 4,9p. & 96,3 \\
\hline
\end{tabular}

Забастовки. В январе-сентябре 2020 г. была зафиксирована 1 забастовка с участием 79 человек. Потери рабочего времени составили 158 человеко-дней. 


\section{3. ОКРУЖАЮЩАЯ СРЕДА (по данным Росгидромета)}

В январе-сентябре 2020 г. службами мониторинга природной среды зафиксирован 171 случай экстремально высокого и высокого загрязнения атмосферного воздуха (10 ПДК и более). Кроме того, зафиксировано 9 случаев аварийного загрязнения.

ЗАГРЯЗНЕНИЕ АТМОСФЕРНОГО ВОЗДУХА

\begin{tabular}{|c|c|c|c|}
\hline & $\begin{array}{c}\text { Январь-сентябрь } \\
2020 \text { г. }\end{array}$ & $\begin{array}{c}B \% \kappa \\
\text { январю-сентябрю } \\
20192 .\end{array}$ & \begin{tabular}{|c|} 
Справочно \\
январь-сентябрь 2019 г. \\
в \% к \\
январю-сентябрю 2018 г. \\
\end{tabular} \\
\hline Число зафиксированных случаев & 171 & в 4,6p. & 57,8 \\
\hline $\begin{array}{c}\text { в том числе: } \\
\text { экстремально высокого загрязнения }\end{array}$ & 4 & 133,3 & 75,0 \\
\hline высокого загрязнения & 167 & в 4,9p. & 56,7 \\
\hline
\end{tabular}

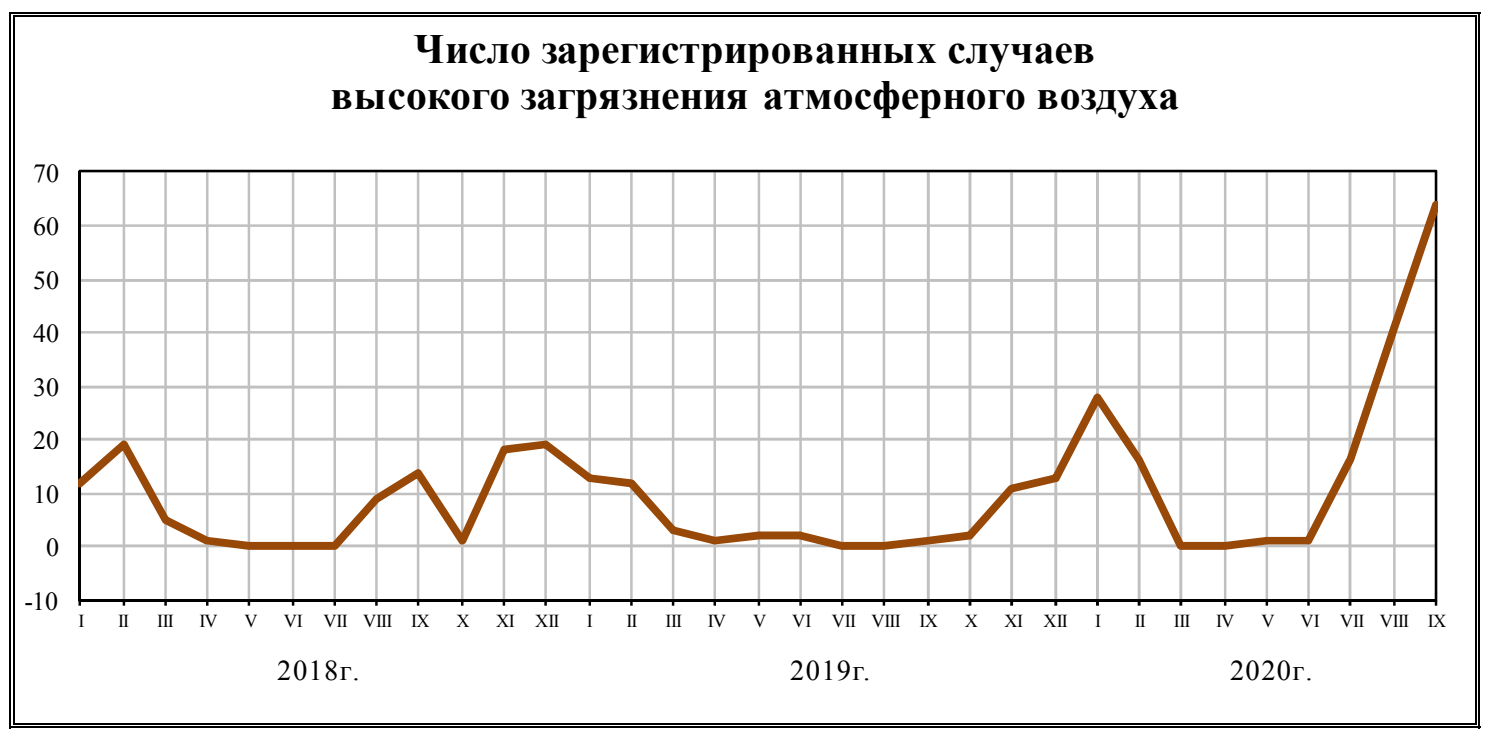

Таблица 2

ПЕРЕЧЕНЬ ГОРОДОВ РОССИЙСКОЙ ФЕДЕРАЦИИ, В КОТОРЫХ БЫЛИ ЗАРЕГИСТРИРОВАНЫ СЛУЧАИ ВЫСОКОГО ЗАГРЯЗНЕНИЯ АТМОСФЕРНОГО ВОЗДУХА в январе-сентябре 2020 года ${ }^{1)}$

\begin{tabular}{|c|c|c|c|}
\hline & $\begin{array}{c}\text { Вешество, } \\
\text { обусловившее выссокий } \\
\text { уровень загрязнения } \\
\text { атмосферного воздуха }\end{array}$ & $\begin{array}{c}\text { Число случаев } \\
\text { высокого загрязнения } \\
\text { атмосферного } \\
\text { воздуха } \\
\end{array}$ & $\begin{array}{c}\text { Максимальное } \\
\text { превышение } \\
\text { допустимой } \\
\text { концентраичи, раз } \\
\end{array}$ \\
\hline Кызыл (Республика Тыва) & бенз(а)пирен & 1 & 63,7 \\
\hline Чита & бенз(а)пирен & 8 & 52,5 \\
\hline Самара & сероводород & 109 & 48,0 \\
\hline Минусинск (Красноярский край) & бенз(а)пирен & 1 & 47,6 \\
\hline Улан-Удэ & бенз(а)пирен & 4 & 42,0 \\
\hline \multirow{2}{*}{ Селенгинск²) (Республика Бурятия) } & сероводород & 16 & 30,8 \\
\hline & бенз(а)пирен & 2 & 23,6 \\
\hline
\end{tabular}




\begin{tabular}{|c|c|c|c|}
\hline & $\begin{array}{c}\text { Вешество, } \\
\text { обусловившее выссокий } \\
\text { уровень загрязнения } \\
\text { атмосферного воздуха }\end{array}$ & $\begin{array}{c}\text { Число случаев } \\
\text { высокого загрязнения } \\
\text { атмосферного } \\
\text { воздуха } \\
\end{array}$ & $\begin{array}{c}\text { Максимальное } \\
\text { превышение } \\
\text { допустимой } \\
\text { концентрации, раз }\end{array}$ \\
\hline Абакан (Республика Хакасия) & бенз(а)пирен & 1 & 28,5 \\
\hline Черногорск (Республика Хакасия) & бенз(а)пирен & 1 & 26,0 \\
\hline Красноярск & бенз(а)пирен & 4 & 25,9 \\
\hline Лесосибирск (Красноярский край) & бенз(а)пирен & 1 & 22,0 \\
\hline Канск (Красноярский край) & бенз(а)пирен & 1 & 21,5 \\
\hline
\end{tabular}

Кроме того, случаи высокого загрязнения атмосферного воздуха были отмечены в городе Оренбург, рабочем поселке Чегдомын (Хабаровский край), городах Новокузнецк (Кемеровская область), Комсомольск-на-Амуре (Хабаровский край), Омск и Шелехов (Иркутская область).

В январе-сентябре 2020 г. службами мониторинга природной среды зафиксировано 2236 случаев экстремально высокого и высокого загрязнения водных объектов.

ЗАГРЯЗНЕНИЕ ВОДНЫХ ОБЪЕКТОВ ${ }^{1)}$

\begin{tabular}{|c|c|c|c|}
\hline & $\begin{array}{c}\text { Январь-сентябрь } \\
2020 \text { г. }\end{array}$ & $\begin{array}{c}B \% \kappa \\
\text { январю-сентябрю } \\
2019 \text { г. }\end{array}$ & $\begin{array}{c}\text { Справочно } \\
\text { январь-сентябрь } 2019 \text { г. } \\
\text { в\% К } \\
\text { январю-сентябрю } 20182 .\end{array}$ \\
\hline Число зафиксированных случаев & 2236 & 87,7 & 115,4 \\
\hline $\begin{array}{l}\text { в том числе: } \\
\text { экстремально высокого загрязнения }\end{array}$ & 462 & 75,4 & 115,0 \\
\hline высокого загрязнения & 1774 & 91,6 & 115,6 \\
\hline
\end{tabular}

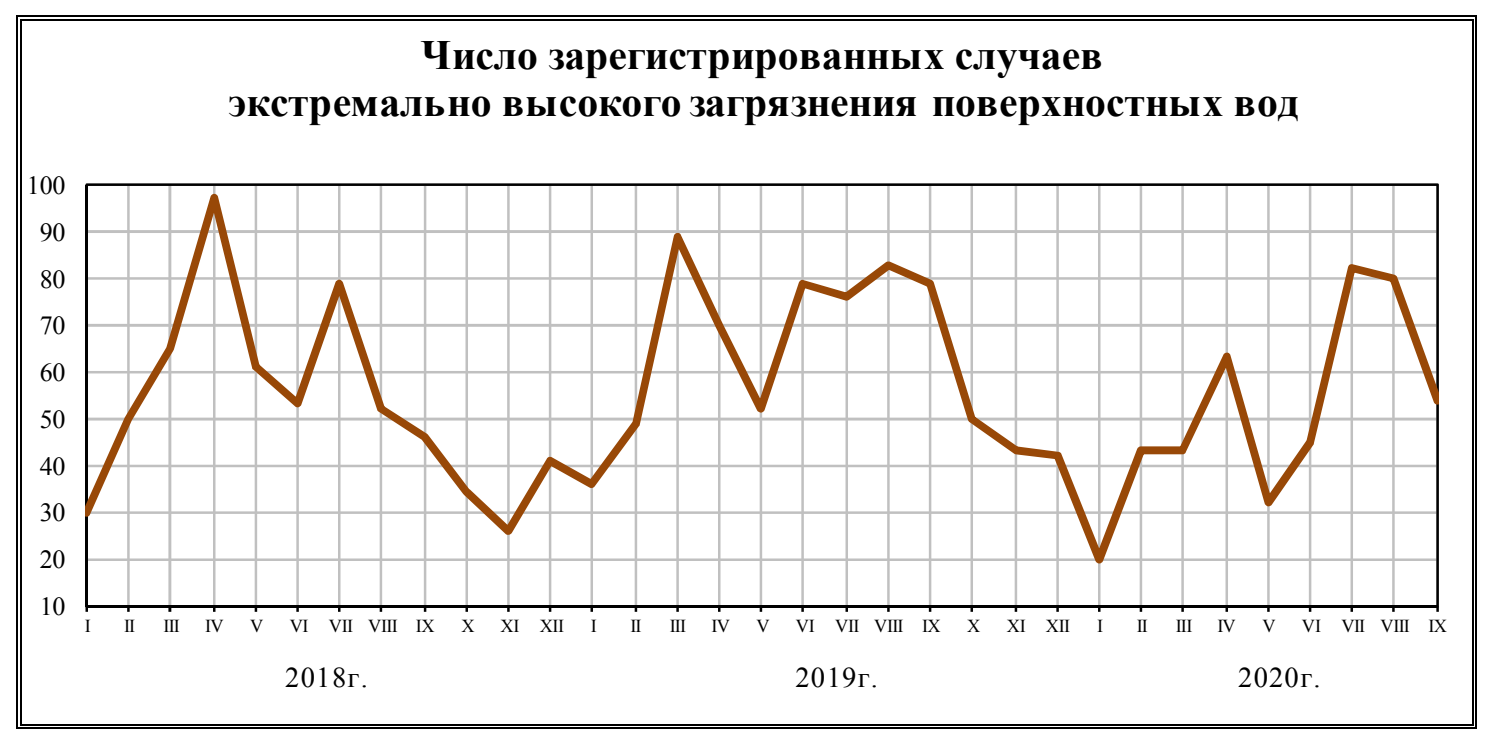

В январе-сентябре 2020 г. отмечено 19 случаев аварийного загрязнения водных объектов и 1 случай аварийного загрязнения почв (в январе-сентябре 2019 г. - 26 и 9 случаев соответственно). 


\section{4. ЗАБОЛЕВАЕМОСТЬ (по данным Роспотребнадзора)}

В августе 2020 г. зарегистрирован 1 случай заболевания корью (за аналогичный месяц 2019 г. - 212 случаев заболевания), не зарегистрировано ни одного случая заболевания дифтерией как и в предыдущем году.

Среди заболевших инфекционными болезнями в январе-августе 2020 г. дети в возрасте 0-17 лет составляли: по коклюшу - 94,0\%, острым кишечным инфекциям - 69,6\%, менингококковой инфекции - 60,3\%, паротиту эпидемическому - 53,7\%, острому гепатиту А - 26,3\%.

ЗАБОЛЕВАЕМОСТЬ НАСЕЛЕНИЯ

ОТДЕЛЬНЫМИ ИНФЕКЦИОННЫМИ ЗАБОЛЕВАНИЯМИ

\begin{tabular}{|c|c|c|c|c|c|c|}
\hline & \multirow{3}{*}{$\begin{array}{c}\text { Август } \\
2020 \text { г., } \\
\text { тысс. } \\
\text { человек }\end{array}$} & \multicolumn{2}{|c|}{$B \% \kappa$} & \multicolumn{3}{|c|}{ Справочно } \\
\hline & & \multirow{2}{*}{$\begin{array}{l}\text { aвгусту } \\
2019 \text { 2. }\end{array}$} & \multirow{2}{*}{$\begin{array}{c}\text { июлю } \\
2020 \text { 2. }\end{array}$} & \multirow{2}{*}{$\begin{array}{c}\text { август } \\
2019 \text { г., } \\
\text { тьсс. } \\
\text { человек }\end{array}$} & \multicolumn{2}{|c|}{$8 \% \kappa$} \\
\hline & & & & & $\begin{array}{l}\text { августу } \\
20182 .\end{array}$ & $\begin{array}{r}\text { июлю } \\
2019 \text { г. }\end{array}$ \\
\hline \multicolumn{7}{|c|}{ Кишечные инфекции } \\
\hline Острые кишечные инфекции & 30,5 & 47,3 & 132,7 & 64,5 & 86,2 & 109,9 \\
\hline из них бактериальная & & & & & & \\
\hline дизентерия (шигеллез) & 0,2 & 40,6 & 129,5 & 0,6 & 60,5 & 94,4 \\
\hline Сальмонеллезные инфекции & 2,1 & 56,4 & 108,7 & 3,8 & 96,1 & 87,1 \\
\hline \multicolumn{7}{|c|}{ Гenamumbl } \\
\hline Острые гепатиты & 0,2 & 50,3 & 123,3 & 0,4 & 71,0 & 86,0 \\
\hline \multicolumn{7}{|l|}{ из них: } \\
\hline гепатит A & 0,1 & 49,0 & 151,9 & 0,2 & 64,1 & 83,9 \\
\hline гепатит В & 0,0 & 54,4 & 75,6 & 0,1 & 80,3 & 93,4 \\
\hline гепатит C & 0,1 & 51,9 & 117,0 & 0,1 & 84,8 & 90,6 \\
\hline \multicolumn{7}{|c|}{ Некоторые инфекции, управляемые средствами специфической профилактики } \\
\hline Краснуха & - & - & - & 0,0 & - & 25,0 \\
\hline Коклюш & 0,0 & 4,1 & 102,1 & 1,2 & 129,1 & 96,7 \\
\hline Паротит эпидемический & 0,0 & 7,1 & в $2,0 \mathrm{p}$. & 0,1 & 116,7 & 77,8 \\
\hline
\end{tabular}




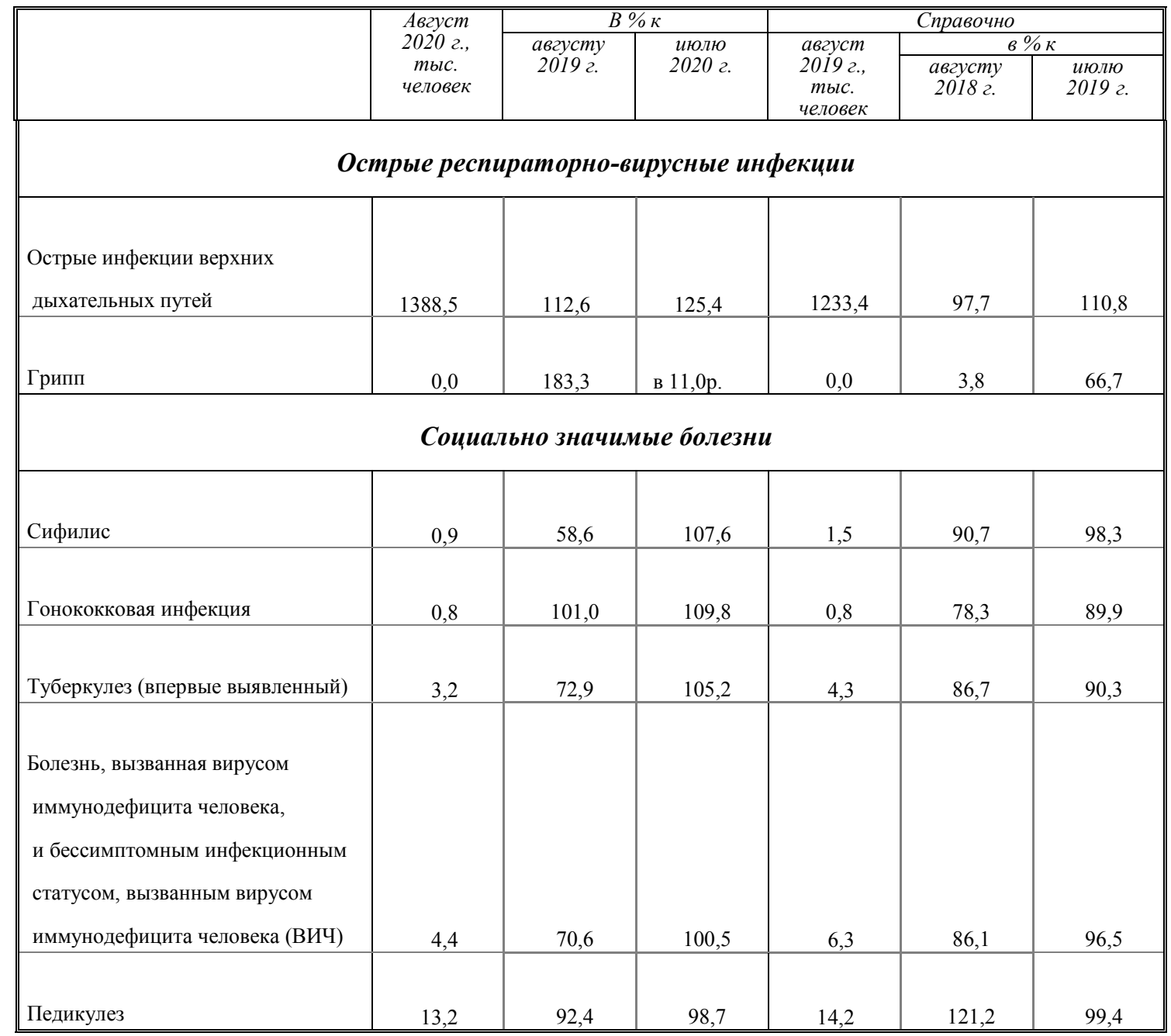

Самые высокие показатели заболеваемости туберкулезом на 100 тыс. человек населения в январе-августе 2020 г. зафиксированы в Чукотском автономном округе - в 3,7 раза выше среднероссийского показателя, Республике Тыва, Новосибирской и Кемеровской областях, Приморском и Хабаровском краях (в 2,1-2,7 раза выше, чем в среднем по России).

При относительно благополучной ситуации в целом по стране в ряде субъектов Российской Федерации в январе-августе 2020 г. оставался значительным уровень заболеваемости сифилисом на 100 тыс. человек населения. Так, в Томской и Калужской областях он был в 2,4 раза выше среднероссийского показателя. Высокие показатели заболеваемости сифилисом наблюдались в Саратовской, Амурской, Архангельской и Московской областях, Республике Ингушетия, Республике Бурятия и Москве (в 1,8-2,1 раза выше, чем в среднем по России).

В январе-августе 2020 г. зарегистрирован 40191 человек с болезнью, вызванной вирусом иммунодефицита человека, и бессимптомным инфекционным статусом, вызванным вирусом иммунодефицита человека (ВИЧ), в том числе детей в возрасте 0-17 лет - 402 человека. Половина всех выявленных больных ВИЧ-инфекцией учтена в 13 субъектах Российской Федерации: Кемеровской, Свердловской, Челябинской, Иркутской, Самарской, Оренбургской, Новосибирской, Московской областях, Красноярском, Пермском, Краснодарском краях, Санкт-Петербурге, Москве. 
По оценке, численность постоянного населения Российской Федерации на 1 сентября 2020 г. составила 146,5 млн человек. С начала года численность населения сократилась на 277,8 тыс. человек, или на 0,19\% (за аналогичный период предыдущего года уменьшилась на 52,5 тыс. человек, или на 0,04\%). Миграционный прирост на 19,9\% компенсировал естественную убыль населения.

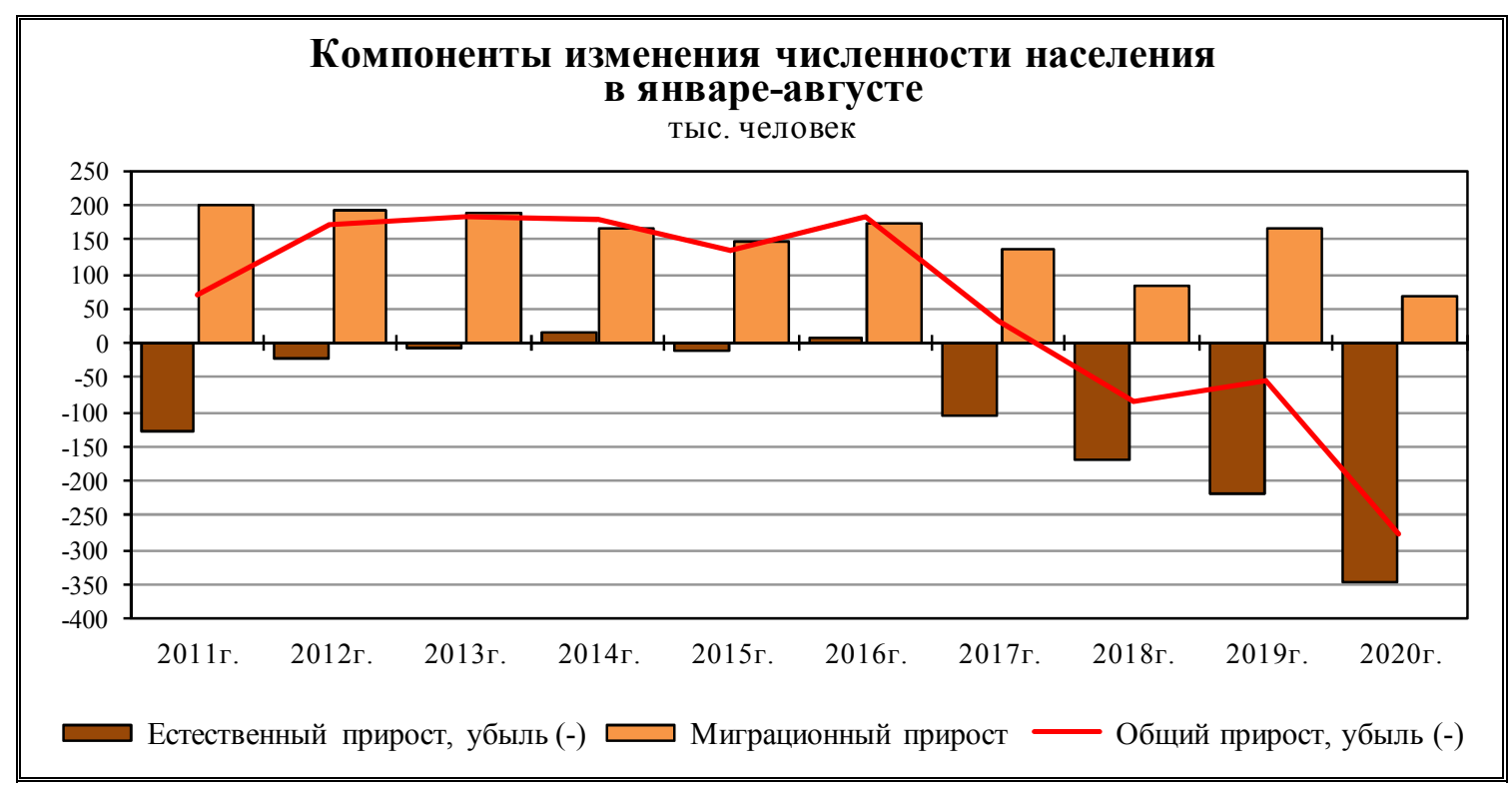

Общая характеристика воспроизводства населения В Российской Федерации.

Таблица 1

ПОКАЗАТЕЛИ ЕСТЕСТВЕННОГО ДВИЖЕНИЯ НАСЕЛЕНИЯ

\begin{tabular}{|c|c|c|c|c|c|c|}
\hline & \multicolumn{5}{|c|}{ Январь-август } & \multirow{3}{*}{$\begin{array}{c}\text { Справочно } \\
\text { на 1000 чело- } \\
\text { век населения } \\
\text { за } 2019 \text { г. } \\
\text { в иелом } \\
\end{array}$} \\
\hline & \multicolumn{3}{|c|}{ mblcя4 } & \multicolumn{2}{|c|}{ на 1000 человек населения ${ }^{\prime)}$} & \\
\hline & 20202. & 20192. & $\begin{array}{l}\text { прирост (+), } \\
\text { снижение (-) }\end{array}$ & 20202 & 20192 & \\
\hline Родившихся & 938,3 & 994,3 & $-56,0$ & 9,6 & 10,2 & 10,1 \\
\hline Умерших & 1285,2 & 1213,5 & $+71,7$ & 13,2 & 12,4 & 12,3 \\
\hline $\begin{array}{l}\text { из них детей } \\
\text { в возрасте до } 1 \text { года }\end{array}$ & 4,3 & 5,0 & $-0,7$ & $4,4^{2)}$ & $4,8^{2)}$ & $4,9^{2)}$ \\
\hline $\begin{array}{l}\text { Естественный } \\
\text { прирост (+), убыль (-) }\end{array}$ & $-346,9$ & $-219,2$ & & $-3,6$ & $-2,2$ & $-2,2$ \\
\hline Браков & 485,3 & 611,4 & $-126,1$ & 5,0 & 6,3 & 6,5 \\
\hline Разводов & 336,8 & 405,9 & $-69,1$ & 3,4 & 4,2 & 4,2 \\
\hline
\end{tabular}


В январе-августе 2020 г. по сравнению с аналогичным периодом 2019 г. в России отмечалось снижение числа родившихся (в 76 субъектах Российской Федерации) и увеличение числа умерших (в 66 субъектах).

В целом по стране в январе-августе 2020 г. число умерших превысило число родившихся в 1,4 раза (в январе-августе 2019 г. - в 1,2 раза), в 41 субъекте Российской Федерации это превышение составляло 1,5-2,4 раза.

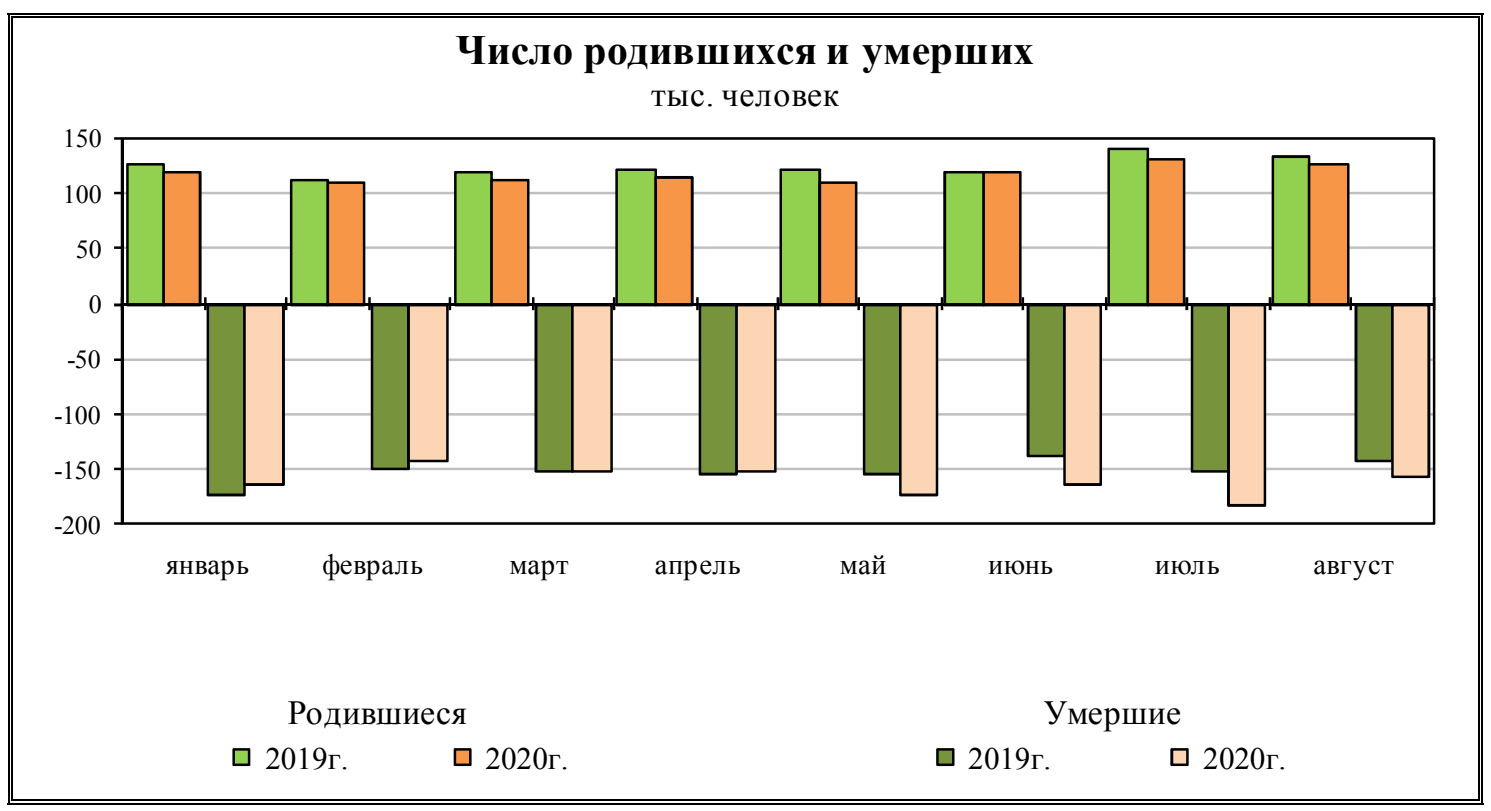

Естественный прирост населения в январе-августе 2020 г. зафиксирован в 14 субъектах Российской Федерации (в январе-августе 2019 г. - в 17 субъектах).

Общая характеристика миграционной ситуации В Российской Федерации.

Таблица 2

ОБЩИЕ ИТОГИ МИГРАЦИИ

\begin{tabular}{|c|c|c|c|c|}
\hline & \multicolumn{2}{|c|}{$\begin{array}{c}\text { Январь-август } \\
2020 \text { z. }\end{array}$} & \multicolumn{2}{|c|}{$\frac{\text { Справочно }}{\text { январь-август } 2019 \text { г. }}$} \\
\hline & человек & $\begin{array}{c}\text { на } 10 \text { тылс. } \\
\text { человек } \\
\text { населения }\end{array}$ & человек & $\begin{array}{c}\text { на } 10 \text { тылс. } \\
\text { человек } \\
\text { населения }\end{array}$ \\
\hline \multicolumn{5}{|l|}{ Миграция - всего } \\
\hline прибывшие & 2537365 & 259,6 & 3037000 & 310,8 \\
\hline выбывшие & 2468260 & 252,5 & 2870342 & 293,8 \\
\hline миграционный прирост (+), снижение (-) & +69105 & $+7,1$ & +166658 & $+17,0$ \\
\hline \multicolumn{5}{|l|}{ в том числе: } \\
\hline \multicolumn{5}{|l|}{ в пределах России } \\
\hline прибывшие & 2157345 & 220,7 & 2606585 & 266,8 \\
\hline выбывшие & 2157345 & 220,7 & 2606585 & 266,8 \\
\hline миграционный прирост (+), снижение (-) & - & - & - & - \\
\hline
\end{tabular}




\begin{tabular}{|c|c|c|c|c|}
\hline & \multicolumn{2}{|c|}{$\begin{array}{c}\text { Январь-август }_{2020} \text {. } \\
20\end{array}$} & \multicolumn{2}{|c|}{$\frac{\text { Справочно }}{\text { январь-август } 20192 .}$} \\
\hline & человек & $\begin{array}{c}\text { на } 10 \text { тысс. } \\
\text { человек } \\
\text { населения }\end{array}$ & человек & $\begin{array}{c}\text { на } 10 \text { тылск. } \\
\text { насовек } \\
\text { населения }\end{array}$ \\
\hline $\begin{array}{l}\text { международная миграция } \\
\text { прибывшие }\end{array}$ & 380020 & 38,9 & 430415 & 44,0 \\
\hline выбывшие & 310915 & 31,8 & 263757 & 27,0 \\
\hline миграционный прирост (+), снижение (-) & +69105 & $+7,1$ & +166658 & $+17,0$ \\
\hline $\begin{array}{l}\text { в том числе: } \\
\text { с государствами-участниками СНГ } \\
\text { прибывшие }\end{array}$ & 345932 & 35,4 & 385617 & 39,4 \\
\hline выбывшие & 273130 & 27,9 & 235815 & 24,1 \\
\hline миграционный прирост (+), снижение (-) & +72802 & $+7,5$ & +149802 & $+15,3$ \\
\hline $\begin{array}{l}\text { со странами дальнего зарубежья } \\
\text { прибывшие }\end{array}$ & 34088 & 3,5 & 44798 & 4,6 \\
\hline выбывшие & 37785 & 3,9 & 27942 & 2,9 \\
\hline миграционный прирост (+), снижение (-) & -3697 & $-0,4$ & +16856 & $+1,7$ \\
\hline
\end{tabular}

За январь-август 2020 г. число мигрантов, переселившихся в пределах России, сократилось на 449,2 тыс. человек, или на 17,2\% по сравнению с предыдущим годом.

Миграционный прирост населения России сократился на 97,6 тыс. человек, или на 58,5\%, что произошло в результате уменьшения числа прибывших в Российскую Федерацию и увеличения числа выбывших за ее пределы.

Число прибывших в Российскую Федерацию сократилось на 50,4 тыс. человек, или на $11,7 \%$, в том числе за счет иммигрантов из государств-участников СНГ на 39,7 тыс. человек, или на $10,3 \%$.

Число выбывших за пределы Российской Федерации выросло на 47,2 тыс. человек, или на 17,9\%, в том числе в страны государства-участники СНГ - на 37,3 тыс. человек, или на 15,8\%.

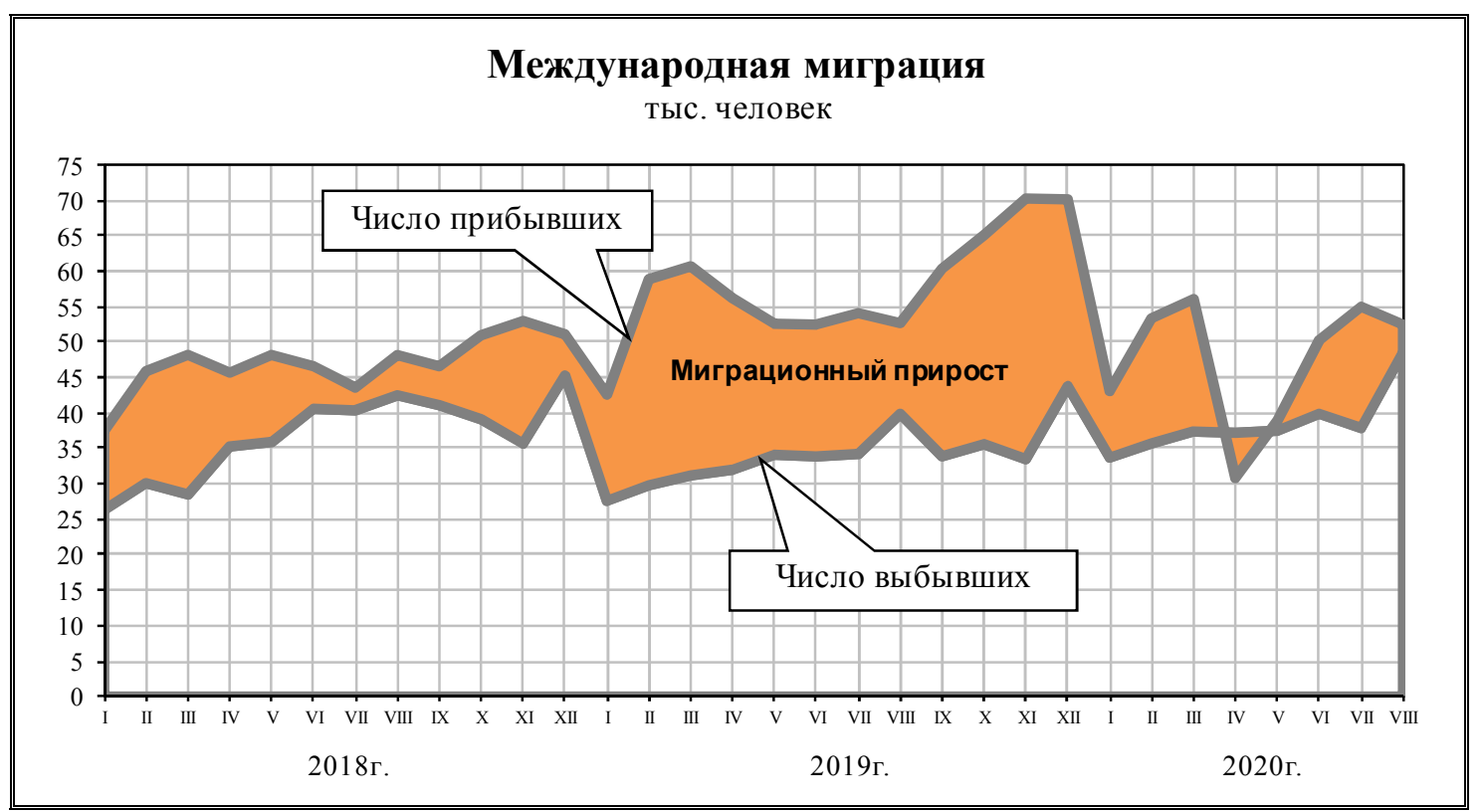


В январе-августе 2020 г. в обмене населением со всеми государствами-участниками СНГ, кроме Украины, отмечается сокращение миграционного прироста. Миграционный прирост в обмене с Украиной увеличился на 32,4\% по сравнению с соответствующим периодом предыдущего года.

Таблица 3

ПОКАЗАТЕЛИ МЕЖДУНАРОДНОЙ МИГРАЦИИ

человек

\begin{tabular}{|c|c|c|c|c|c|c|}
\hline & \multicolumn{3}{|c|}{$\begin{array}{c}\text { Январь-август } \\
20202 .\end{array}$} & \multicolumn{3}{|c|}{$\frac{\text { Справочно }}{\text { январь-август } 20192 .}$} \\
\hline & $\begin{array}{c}\text { число } \\
\text { прибьввиих }\end{array}$ & $\begin{array}{c}\text { число } \\
\text { выбывиших }\end{array}$ & $\begin{array}{l}\text { миграционный } \\
\text { прирост (+), } \\
\text { снижение (-) }\end{array}$ & $\begin{array}{c}\text { число } \\
\text { прибывиших }\end{array}$ & $\begin{array}{c}\text { число } \\
\text { выбывиих }\end{array}$ & $\begin{array}{l}\text { миграционный } \\
\text { прирост (+), } \\
\text { снижение (-) }\end{array}$ \\
\hline Международная миграция & 380020 & 310915 & +69105 & 430415 & 263757 & +166658 \\
\hline $\begin{array}{l}\text { в том числе: } \\
\text { с государствами- } \\
\text { участниками СНГ }\end{array}$ & 345932 & 273130 & +72802 & 385617 & 235815 & +149802 \\
\hline в том числе: & & & & & & \\
\hline Азербайджан & 21172 & 13637 & +7535 & 22458 & 11441 & +11017 \\
\hline Армения & 37752 & 41363 & -3611 & 49550 & 23735 & +25815 \\
\hline Беларусь & 8109 & 10313 & -2204 & 12103 & 8190 & +3913 \\
\hline Казахстан & 42211 & 37911 & +4300 & 54711 & 30015 & +24696 \\
\hline Киргизия & 28612 & 29067 & -455 & 35116 & 24991 & +10125 \\
\hline Республика Молдова & 13260 & 12233 & +1027 & 17323 & 13938 & +3385 \\
\hline Таджикистан & 61124 & 35902 & +25222 & 54860 & 26748 & +28112 \\
\hline Туркменистан & 6390 & 5620 & +770 & 6116 & 3866 & +2250 \\
\hline Узбекистан & 33182 & 31070 & +2112 & 38911 & 27210 & +11701 \\
\hline Украина & 94120 & 56014 & +38106 & 94469 & 65681 & +28788 \\
\hline $\begin{array}{l}\text { со странами } \\
\text { дальнего зарубежья }\end{array}$ & 34088 & 37785 & -3697 & 44798 & 27942 & +16856 \\
\hline в том числе: & & & & & & \\
\hline Абхазия & 592 & 783 & -191 & 908 & 695 & +213 \\
\hline Афганистан & 953 & 828 & +125 & 1051 & 510 & +541 \\
\hline Вьетнам & 3591 & 3403 & +188 & 3765 & 1815 & +1950 \\
\hline Германия & 810 & 1939 & -1129 & 1862 & 3010 & -1148 \\
\hline Греция & 136 & 176 & -40 & 188 & 168 & +20 \\
\hline Грузия & 3770 & 2911 & +859 & 4402 & 2550 & +1852 \\
\hline Израиль & 233 & 417 & -184 & 455 & 575 & -120 \\
\hline Индия & 2601 & 2635 & -34 & 2920 & 1587 & +1333 \\
\hline Канада & 62 & 122 & -60 & 116 & 215 & -99 \\
\hline
\end{tabular}




\begin{tabular}{|c|c|c|c|c|c|c|}
\hline & \multicolumn{3}{|c|}{$\begin{array}{c}\text { Январь-август } \\
2020 \text { г. }\end{array}$} & \multicolumn{3}{|c|}{$\begin{array}{c}\text { январь-августо } 2019 \text { г. } \\
\text { яново }\end{array}$} \\
\hline & $\begin{array}{c}\text { число } \\
\text { прибывших }\end{array}$ & $\begin{array}{c}\text { число } \\
\text { выбывиих }\end{array}$ & $\begin{array}{l}\text { миграчионный } \\
\text { прирост (+), } \\
\text { снижение (-) }\end{array}$ & $\begin{array}{c}\text { число } \\
\text { прибывших }\end{array}$ & $\begin{array}{c}\text { число } \\
\text { выбовьвих }\end{array}$ & $\begin{array}{l}\text { миграчионный } \\
\text { прирост (+), } \\
\text { снижение (-) }\end{array}$ \\
\hline Китай & 4490 & 6419 & -1929 & 8813 & 4157 & +4656 \\
\hline $\begin{array}{l}\text { Корейская Народно- } \\
\text { Демократическая Республика }\end{array}$ & 211 & 573 & -362 & 1031 & 450 & +581 \\
\hline Латвия & 677 & 583 & +94 & 908 & 623 & +285 \\
\hline Литва & 487 & 349 & +138 & 583 & 425 & +158 \\
\hline Сербия & 566 & 414 & +152 & 524 & 238 & +286 \\
\hline Сирийская Арабская Республика & 1211 & 1093 & +118 & 1210 & 522 & +688 \\
\hline США & 315 & 563 & -248 & 571 & 938 & -367 \\
\hline Турция & 959 & 1042 & -83 & 1593 & 892 & +701 \\
\hline Финляндия & 73 & 169 & -96 & 171 & 436 & -265 \\
\hline Эстония & 395 & 486 & -91 & 516 & 505 & +11 \\
\hline другие страны & 11956 & 12880 & -924 & 13211 & 7631 & +5580 \\
\hline
\end{tabular}


МЕТОДОЛОГИЧЕСКИЕ

ПОЯСНЕНИЯ 


\section{Валовой внутренний продукт}

Валовой внутренний продукт (ВВП) - обобщающий показатель экономической деятельности страны. Представляет собой на стадии производства сумму добавленной стоимости отраслей экономики в основных ценах и чистых налогов на продукты, а на стадии использования стоимость товаров и услуг, предназначенных для конечного потребления, накопления и экспорта. ВВП рассчитывается в текущих основных и рыночных ценах и в постоянных ценах.

Рыночная цена конечного покупателя включает торгово-транспортные наценки, налоги на производство и импорт и не включает субсидии на производство и импорт.

Для устранения влияния различных ставок налогов и субсидий в различных отраслях экономики на структуру производства показатели валовой добавленной стоимости приведены в оценке по основным ценам.

Основная цена - цена, получаемая производителем за единицу товара или услуги, без налогов на продукты, но включая субсидии на продукты.

Производство ВВП (публикуется в докладах № 3, 5, 6, 8, 9, 11, 12).

Индексы физического объема ВВП и его компонентов к соответствующему периоду предыдущего года рассчитаны как частное от деления показателя отчетного периода в среднегодовых ценах предыдущего года на соответствующий показатель соответствующего периода предыдущего года в среднегодовых ценах предыдущего года. Динамический ряд квартальных значений ВВП и его компонентов строится на основе сцепления индексов реального объема. При построении динамического ряда ВВП и его компоненты экстраполируются автономно. Структурные изменения по мере удаления от исходного периода обуславливают математическое расхождение между суммой компонентов и ВВП в целом. В качестве официального исходного периода для построения динамического ряда ВВП принят 2016 год. Используемая методология построения динамических рядов соответствует рекомендациям "Руководства СНC", разработанного под эгидой ООН и "Руководства по квартальным национальным счетам" МВФ.

Оценки данных о производстве ВВП с исключением сезонного и календарного факторов осуществляются с использованием методов X-13-ARIMA и TRAMO-SEATS программы "JDemetra+". Выбор оптимальных параметров модели сезонного сглаживания осуществляется автоматически, фиксируется в начале года и не меняется на его протяжении. Для учета календарных эффектов в программе используется актуальный российский календарь и задается параметр, учитывающий влияние количества рабочих дней (происходит деление на выходные и будние дни) и високосного года. В качестве исходной информации для осуществления сезонно-календарной корректировки применяются квартальные значения индексов физического объема ВВП в процентах к значению условного среднего квартала 2016 года.

Индексы физического объема ВВП и его компонентов к предыдущему периоду представляют собой частное от деления показателя отчетного периода на значение соответствующего показателя в предыдущем периоде на основе показателей абсолютных значений физических объемов, рассчитанных по всему динамическому ряду.

Использование ВВП (публикуется в докладах № 3, 6,9, 12).

Валовой внутренний продукт на стадии использования получается путем суммирования расходов на конечное потребление сектора домашних хозяйств, государственного управления и некоммерческих организаций, обслуживающих домашние хозяйства, валового накопления основного капитала, изменения запасов материальных оборотных средств, чистого приобретения ценностей и чистого (за вычетом импорта) экспорта.

Расходы на конечное потребление домашних хозяйств включают расходы домашних хозяйств на приобретение потребительских товаров и услуг, а также потребление товаров и услуг, полученных в натуральной форме.

Расходы на конечное потребление государственного управления и некоммерческих организаций, обслуживающих домашние хозяйства, состоят из расходов этих секторов на товары и услуги для индивидуального потребления, а также расходов сектора "государственного управления" на услуги коллективного потребления.

Валовое накопление показывает чистое приобретение резидентными единицами товаров и услуг, произведенных в текущем периоде или поступивших по импорту, но не потребленных в нем. 
Чистый экспорт определяется как разница между экспортом и импортом товаров и услуг.

12).

Формирование ВВП по источникам доходов (публикуется в докладах № 3, 6, 9,

Метод формирования ВВП по источникам доходов позволяет определить структуру ВВП с точки зрения первичных доходов: оплаты труда наемных работников (включая оплату труда и смешанные доходы, не наблюдаемые прямыми статистическими методами), налогов на производство и импорт, валовой прибыли экономики и валовых смешанных доходов.

Оплата труда наемных работников представляет собой вознаграждение в денежной или натуральной форме, выплачиваемое работодателем наемному работнику за работу, выполненную в отчетном периоде.

Она учитывается на основе начисленных сумм и включает в себя налоги на доходы и другие выплаты, которые подлежат уплате наемными работниками, даже если они фактически удерживаются нанимателями в административных интересах или по иным причинам, и выплачиваются непосредственно органам социального страхования, налоговым службам от лица наемного работника.

Особенностью расчета оплаты труда наемных работников в российских национальных счетах является то, что она включает помимо оплаты труда наемных работников, не наблюдаемой прямыми статистическими методами, и смешанные доходы, не наблюдаемые прямыми статистическими методами.

Оплата труда наемных работников и смешанные доходы, не наблюдаемые прямыми статистическими методами, определяются балансовым путем условно как разница между суммарными расходами на все нужды домашних хозяйств, включая прирост их финансовых активов за минусом обязательств, и формально зарегистрированными доходами. Расчеты по определению оплаты труда и смешанных доходов, не наблюдаемых прямыми статистическими методами, производятся по экономике в целом без разбивки по видам деятельности и территориям.

Показатель ненаблюдаемых смешанных доходов связан с информационными проблемами отнесения институциональных единиц к сектору домашних хозяйств с точки зрения их производственной деятельности.

Ненаблюдаемые смешанные доходы имеют место в тех случаях, когда доходы от производственной деятельности домашних хозяйств учтены не в секторе домашних хозяйств, а в секторе нефинансовых корпораций, либо, наоборот, доходы от производства сектора нефинансовых корпораций учтены в секторе домашних хозяйств. В этих случаях при сопоставлении суммарных расходов домашних хозяйств с их формально зарегистрированными доходами производится корректировка смешанных доходов домашних хозяйств и обратная корректировка валовой прибыли сектора нефинансовых корпораций на эту же величину.

Налоги на производство и импорт включают в себя налоги на продукты и импорт и другие налоги на производство. Налоги на продукты - это налоги, которые напрямую зависят от стоимости произведенной продукции и оказанных услуг. К ним относятся: налог на добавленную стоимость, акцизы и т.п. Налоги на импорт - это налоги на импортные товары и услуги. Другие налоги на производство - это налоги, связанные с использованием факторов производства (труда, земли, капитала). К ним относятся: налог на землю, налог на имущество предприятий, транспортный налог, предпринимательские и профессиональные лицензии и некоторые другие. Они не зависят от объема производства и не включают налоги на прибыль и иные доходы, получаемые предприятиями.

Термин "чистые" означает, что налоги показаны за вычетом соответствующих субсидий.

Валовая прибыль экономики и валовые смешанные доходы представляют собой ту часть добавленной стоимости, которая остается у производителей после вычета всех расходов, связанных с оплатой труда наемных работников и чистых налогов на производство и импорт. Валовая прибыль в СНС, в отличие от показателя прибыли от реализации, отражаемой в бухгалтерском учете, не содержит элементов оплаты труда, включаемых по методологии СНС в оплату труда, сверхнормативные выплаты по командировочным, представительским и другим расходам, не включает прибыль, образующуюся у владельцев активов в результате роста цен, и включает потребление основного капитала, равного стоимостной оценке его годового износа. Валовой смешанный доход - это элемент вознаграждения за работу, который не может быть отделен от дохода владельца или предпринимателя. 
Индекс выпуска товаров и услуг по базовым видам экономической деятельности исчисляется на основе данных об изменении физического объема производства продукции сельского хозяйства, промышленного производства (по видам деятельности "добыча полезных ископаемых", "обрабатывающие производства", "обеспечение электрической энергией, газом и паром; кондиционирование воздуха", "водоснабжение; водоотведение, организация сбора и утилизации отходов, деятельность по ликвидации загрязнений"), строительства, транспорта, розничной и оптовой торговли.

Индексы физического объема выпуска к предыдущему периоду рассчитаны исходя из показателей объема в реальном исчислении, которые получены путем последовательного перемножения значений базисного периода на индексы физического объема к соответствующему периоду предыдущего года. В качестве базисного периода для построения динамического ряда использованы значения выпуска по месяцам 2016 г. в среднегодовых ценах 2016 года.

\section{Индексы производительности труда}

(публикуется в докладах № 3, 9)

Индекс изменения производительности труда по экономике в целом рассчитан как частное от деления индексов физического объема ВВП и изменения совокупных затрат труда.

Индексы изменения ВВП и добавленной стоимости рассчитаны исходя из абсолютных значений этих показателей в постоянных ценах.

Индексы изменения совокупных затрат труда определены на основе трудовых затрат на всех видах работ, включая дополнительную работу и производство продукции для собственного потребления.

Индекс производительности труда показывает динамику того, насколько производительно используется труд для создания добавленной стоимости.

Изменение темпов роста производительности труда приведено по видам экономической деятельности, продукция которых реализуется преимущественно по рыночным ценам.

\section{Оборот организаций}

Оборот организаций включает стоимость отгруженных товаров собственного производства, выполненных работ и услуг собственными силами, а также выручку от продажи приобретенных на стороне товаров (без налога на добавленную стоимость, акцизов и аналогичных обязательных платежей).

Объем отгруженных товаров собственного производства представляет собой стоимость товаров, которые произведены юридическим лицом и фактически отгружены в отчетном периоде или отпущены им в порядке продажи, а также прямого обмена на сторону (другим юридическим и физическим лицам), независимо от того, поступили деньги на счет продавца или нет.

Данные по этому показателю представляют совокупность организаций с соответствующим основным видом деятельности и отражают коммерческую деятельность организаций.

Оборот организаций розничной торговли включает выручку от продажи товаров, приобретенных в целях перепродажи (за минусом НДС, налога с продаж и аналогичных обязательных платежей), стоимость отгруженных (переданных) товаров собственного производства, выручку от других видов деятельности (доход от сдачи в аренду зданий, складских и торговых площадей, транспортных средств и оборудования и т.п.). Не включаются в оборот доходы от продажи собственных основных средств, нематериальных активов, валютных ценностей, ценных бумаг.

Оборот организаций оптовой торговли включает выручку от продажи товаров, приобретенных в целях перепродажи (за минусом НДС, налога с продаж и аналогичных обязательных платежей), выручку от реализации посреднических услуг (сумму вознаграждений комиссионеров (поверенных, агентов) за минусом НДС), стоимость отгруженных (переданных) товаров собственного производства, выручку от других видов деятельности (доход от сдачи в аренду зданий, 
складских и торговых площадей, транспортных средств и оборудования и т.п.). Не включаются в оборот доходы от продажи собственных основных средств, нематериальных активов, валютных ценностей, ценных бумаг.

\section{Промышленное производство}

Индекс производства - относительный показатель, характеризующий изменение масштабов производства в сравниваемых периодах. Различают индивидуальные и сводные индексы производства. Индивидуальные индексы отражают изменение выпуска одного продукта и исчисляются как отношение объемов производства данного вида продукта в натурально-вещественном выражении в сравниваемых периодах. Сводный индекс производства характеризует совокупные изменения производства всех видов продукции и отражает изменение создаваемой в процессе производства стоимости в результате изменения только физического объема производимой продукции. Для исчисления сводного индекса производства индивидуальные индексы по конкретным видам продукции поэтапно агрегируются в индексы по видам деятельности, подгруппам, группам, подклассам, классам, разделам ОКВЭД2.

Индекс промышленного производства - агрегированный индекс производства по видам деятельности "Добыча полезных ископаемых", "Обрабатывающие производства", "Обеспечение электрической энергией, газом и паром; кондиционирование воздуха", "Водоснабжение; водоотведение, организация сбора и утилизации отходов, деятельность по ликвидации загрязнений".

Оценки данных по индексам производства с исключением сезонного и календарного факторов осуществляются с использованием метода TRAMO-SEATS программы "JDemetra+ ". Выбор наиболее оптимальной модели осуществляется автоматически. Модель фиксируется в начале года и не меняется на его протяжении. Для выполнения сезонной корректировки используется актуальный российский календарь с учетом всех праздничных дней, задаются параметры, учитывающие влияние количества торговых дней (рабочих и субботних дней) и високосного года (7 регрессоров). В качестве исходной информации для проведения сезонной корректировки применяются ежемесячные фактические значения индексов производства с 2014г., рассчитанные в процентах к среднемесячному значению 2017г., без построения прогнозных оценок.

Объем отгруженных товаров собственного производства, выполненных работ и услуг собственными силами - стоимость отгруженных или отпущенных в порядке продажи, а также прямого обмена (по договору мены) всех товаров собственного производства, работ и услуг, выполненных (оказанных) собственными силами.

Объем отгруженных товаров представляет собой стоимость товаров, которые произведены данным юридическим лицом и фактически отгружены (переданы) в отчетном периоде на сторону (другим юридическим и физическим лицам), включая товары, сданные по акту заказчику на месте, независимо от того, поступили деньги на счет продавца или нет.

Объем работ и услуг, выполненных собственными силами, представляет собой стоимость работ и услуг, оказанных (выполненных) организацией другим юридическим и физическим лицам.

Данные приводятся в фактических отпускных ценах без налога на добавленную стоимость, акцизов и аналогичных обязательных платежей.

Группировки по видам деятельности представляют собой совокупность соответствующих фактических видов деятельности, осуществляемых организациями, независимо от их основного вида деятельности.

\section{Сельское и лесное хозяйство}

Объем производства продукции сельского хозяйства всеми сельхозпроизводителями (сельхозорганизации, крестьянские (фермерские) хозяйства, индивидуальные предприниматели, хозяйства населения) формируется как объем производства готовой продукции растениеводства 
и животноводства и изменение стоимости незавершенного производства продукции растениеводства и животноводства по видам деятельности "Растениеводство", "Животноводство".

Индекс производства продукции сельского хозяйства - относительный показатель, характеризующий изменение объема производства сельскохозяйственной продукции в сравниваемых периодах. Различают индивидуальные и сводные индексы производства. Индивидуальные индексы отражают изменение производства одного продукта и исчисляются как отношение объемов производства данного вида продукции в натуральном выражении в сравниваемых периодах. Сводный индекс производства характеризует совокупные изменения производства всех видов продукции в результате изменения только физического объема производимой продукции.

Индекс производства продукции сельского хозяйства - агрегированный индекс производства продукции растениеводства и животноводства. Для исчисления индекса производства продукции сельского хозяйства к соответствующему периоду предыдущего года используется показатель ее объема в сопоставимых ценах предыдущего года.

Оценка представленных на графике данных по индексам производства с исключением сезонного фактора осуществляется с использованием метода TRAMO-SEATS программы "JDemetra+". При построении модели не учитываются календарные эффекты в связи с особенностями сельскохозяйственного производства.

Модель фиксируется в начале года и не меняется на его протяжении.

В качестве исходной информации для проведения сезонной корректировки применяются ежемесячные фактические значения индексов производства продукции сельского хозяйства с 2009 г., рассчитанные в процентах к среднемесячному значению 2017 года.

Данные о поголовье сельскохозяйственных животных, производстве и реализации основных сельскохозяйственных продуктов по всем сельхозпроизводителям определяются: по сельскохозяйственным организациям - на основании сведений форм федерального статистического наблюдения (по субъектам малого предпринимательства - с применением выборочного метода наблюдения); по хозяйствам населения, крестьянским (фермерским) хозяйствам и индивидуальным предпринимателям - по материалам выборочных обследований.

Производство скота и птицы на убой (в живом весе) включает проданные сельхозпроизводителями скот и птицу для забоя на мясо, а также забитые в сельскохозяйственных организациях, крестьянских (фермерских) хозяйствах, у индивидуальных предпринимателей, в хозяйствах населения.

Производство молока характеризуется фактически надоенным сырым коровьим, козьим, овечьим, кобыльим и буйволиным молоком. Молоко, высосанное молодняком при подсосном его содержании, в продукцию не включается.

Производство яиц включает их сбор от всех видов сельскохозяйственной птицы, в том числе и яйца, пошедшие на воспроизводство птицы (инкубация и др.).

Информация об обеспеченности скота кормами (публикуется в докладах № 1-4, 9-12).

\section{Строительство}

Объем работ, выполненных по виду деятельности "Строительство" - это строительные работы, выполненные организациями собственными силами на основании договоров и (или) контрактов, заключаемых с заказчиками, а также работы, выполненные хозяйственным способом. В стоимость этих работ включаются работы по строительству новых объектов, капитальному и текущему ремонту, реконструкции жилых и нежилых зданий и инженерных сооружений.

Данные приводятся с учетом объемов, выполненных субъектами малого предпринимательства, и объемов работ, не наблюдаемых прямыми статистическими методами в строительстве.

Индекс физического объема работ, выполненных по виду деятельности "Строительство", рассчитан в сопоставимых ценах. В качестве сопоставимых цен приняты среднегодовые цены предыдущего года. 
Оценка представленных на графике данных об объеме работ, выполненных по виду деятельности "Строительство" с исключением сезонного фактора осуществляется с использованием метода TRAMO-SEATS программы "JDemetra+". Выбор наиболее оптимальной модели осуществляется автоматически. Модель фиксируется в начале года и не меняется на его протяжении. В качестве исходной информации для проведения сезонной корректировки применяются ежемесячные значения индексов физического объема работ, выполненных по виду деятельности "Строительство" с 2009 г., рассчитанные к среднемесячному значению 2017 года.

Обеспеченность строительных организаций договорами, заказами (в месяцах) определяется исходя из общего объема заказов (контрактов) на последующие месяцы и объема произведенных работ, услуг за последний отчетный месяц по виду деятельности "Строительство".

Индекс предпринимательской уверенности в строительстве (публикуется в докладах № 2, 5, 8, 11) - качественный показатель, характеризующий обобщенное состояние экономического климата в строительном секторе. Индекс предпринимательской уверенности определяется как среднее арифметическое балансов оценок портфеля заказов и ожидаемого изменения численности занятых, в процентах. Балансы оценок показателей (в процентных пунктах) определяются как разность долей респондентов, отметивших "увеличение" и "уменьшение" показателя по сравнению с предыдущим периодом.

Обследование деловой активности проводится ежеквартально по состоянию на 10 день второго месяца отчетного квартала. В опросах участвуют 6 тыс. строительных организаций (без микропредприятий).

Ввод в действие зданий (публикуется в докладах № 3, 6, 9, 12).

К зданиям относится строительная система, состоящая из несущих и ограждающих или совмещенных (несущих и ограждающих) конструкций, образующих надземный замкнутый объем, предназначенный для проживания или пребывания людей в зависимости от функционального назначения и для выполнения различного вида производственных процессов.

Общий строительный объем зданий определяется как сумма строительного объема выше отметки плюс минус 0,00 (надземная часть) и ниже этой отметки (подземная часть). Строительный объем надземной и подземной частей здания определяется в пределах ограничивающих поверхностей, проветриваемых подполий под зданиями, проектируемыми для строительства на вечномерзлых грунтах.

Общая площадь здания определяется как сумма площадей всех этажей здания (включая технические, мансардные, цокольные и подвальные), измеренных в пределах внутренних поверхностей наружных стен, а также площадей балконов и лоджий. Площади помещений определяются по их размерам, измеряемым между отделанными поверхностями стен и перегородок в уровне пола.

Общий строительный объем и площадь жилых зданий определяется в соответствии со СНиП 31-01-2003.

Здания нежилого назначения распределены исходя из целей их использования.

Ввод в действие производственных мощностей и объектов социально-культурной сферы (публикуется в докладах № 3, 6, 9, 12) - показатели мощности (производительности, вместимости, пропускной способности, площади, протяженности и т.д.), созданной в результате осуществления инвестиций в основной капитал.

Число построенных квартир - количество квартир в законченных строительством жилых домах квартирного, гостиничного типа и общежитиях, квартир в нежилых зданиях, а также в построенных населением индивидуальных жилых домах. Индивидуальные жилые дома, построенные населением и предназначенные для проживания одной семьи, отражаются как одна квартиpa.

Общая площадь жилых помещений во введенных в эксплуатацию жилых и нежилых зданиях, жилых домах определяется как сумма площадей всех частей жилых помещений, включая площадь помещений вспомогательного использования, предназначенных для удовлетворения гражданами бытовых и иных нужд, связанных с их проживанием в жилом помещении, площадей лоджий, балконов, веранд, террас, подсчитываемых с соответствующими понижающими коэффициентами, а также жилых и подсобных помещений в построенных населением индивидуальных жилых домах. К помещениям вспомогательного использования относятся кухни, передние, холлы, внутриквартирные коридоры, ванные или душевые, туалеты, кладовые или хозяйственные встро- 
енные шкафы. В домах-интернатах для престарелых и инвалидов, ветеранов, специальных домах для одиноких престарелых, детских домах к подсобным помещениям относятся столовые, буфеты, клубы, читальни, спортивные залы, приемные пункты бытового обслуживания и медицинского обслуживания.

Оценка представленных на графике данных по динамике ввода в действие жилых домов с исключением сезонного фактора осуществляется с использованием метода TRAMO-SEATS программы "JDemetra+". Выбор наиболее оптимальной модели осуществляется автоматически. Модель фиксируется в начале года и не меняется на его протяжении. В качестве исходной информации для проведения сезонной корректировки применяются ежемесячные значения ввода в действие жилых домов с 2008 г., рассчитанные в процентах к среднемесячному значению 2017 года.

Средняя фактическая стоимость строительства 1 кв.метра общей площади жилых помещений во введенных в эксплуатацию жилых зданиях (публикуется в докладах № $1,4,7,10$ ) определяется как сумма фактически произведенных застройщиками капитальных затрат, приходящихся на 1 кв. метр общей площади законченных строительством за отчетный период жилых помещений (без пристроек, надстроек и встроенных помещений и без жилых помещений в построенных индивидуальными застройщиками жилых домах) независимо от даты начала строительства, степени комфортности, этажности, включая дома, строительство которых осуществлялось с нарушением нормативных сроков.

Инвестиционная активность организаций (публикуется в докладе № 11). Обследование инвестиционной активности организаций проводится ежегодно по состоянию на 10 октября, в организациях, не относящихся к субъектам малого и среднего предпринимательства, в средних организациях и малых предприятиях (без микропредприятий), осуществляющих деятельность по добыче полезных ископаемых, в обрабатывающих производствах, по обеспечению электрической энергией, газом и паром, кондиционированию воздуха; водоснабжению, водоотведению, организации сбора и утилизации отходов, деятельности по ликвидации загрязнений.

Основной целью обследования является получение информации об инвестиционной активности организаций в текущем году и их инвестиционных намерениях на следующий год. Обследование позволяет получить оценку взглядов руководителей организаций на процессы, происходящие в инвестиционной сфере.

\section{Транспорт}

Объем перевозок (погрузка) грузов - количество грузов в тоннах, перевезенных транспортом организаций всех видов экономической деятельности, на автомобильном транспорте включая оценку индивидуальных предпринимателей - владельцев грузовых автомобилей, осуществляющих коммерческие перевозки грузов.

Грузооборот транспорта - объем работы транспорта организаций всех видов экономической деятельности по перевозкам грузов, на автомобильном транспорте - включая предпринимателей (физических лиц). Единицей измерения является тонно-километр, т.е. перемещение 1 тонны груза на 1 километр. Исчисляется суммированием произведений массы перевезенных грузов каждой перевозки в тоннах на расстояние перевозки в километрах.

Пассажирооборот транспорта общего пользования - объем работы транспорта по перевозкам пассажиров, включая оценку перевозок пассажиров, пользующихся правом бесплатного проезда. Единицей измерения является пассажиро-километр, т.е. перемещение одного пассажира на 1 километр. Исчисляется суммированием произведений количества пассажиров каждой перевозки на расстояние перевозки в километрах.

Пассажирооборот транспорта общего пользования исчисляется как сумма пассажирооборота следующих видов транспорта: железнодорожного, автомобильного, воздушного, морского и внутреннего водного. Транспорт общего пользования - транспорт, осуществляющий общедоступное транспортное обслуживание населения.

Пассажирооборот автомобильного транспорта (автобусов) - объем работы автобусов по перевозке пассажиров по маршрутам регулярных перевозок. Данные приводятся без учета работы заказных автобусов (единичные перевозки по маршруту, определяемому заказчиком, юри- 
дическим или физическим лицом: перевозки туристско-экскурсионными автобусами, специальные автобусные перевозки (школьные, вахтовые, доставка работников на коммерческой основе на производственные объекты, удаленные от общих линий городского пассажирского транспорта, в отдаленных районах сельской местности и т.п.).

Оценки представленных на графике данных по пассажирообороту транспорта общего пользования с исключением сезонного и календарного факторов осуществляются с использованием метода TRAMO-SEATS программы "JDemetra+". Выбор наиболее оптимальной модели осуществляется автоматически. Модель фиксируется в начале года и не меняется на его протяжении. Для выполнения сезонной корректировки используется актуальный российский календарь с учетом всех праздничных дней. В качестве исходной информации для проведения сезонной корректировки применяются ежемесячные фактические значения объемов пассажирооборота транспорта общего пользования с 1992 г., рассчитанные в процентах к среднемесячному значению 2017 г., без построения прогнозных оценок. При поступлении новых статистических данных в течение отчетного года динамика уточняется. При построении текущей модели для наилучшего выполнения сглаживания динамического ряда используются данные с 2009 года.

Перевозки грузов, грузооборот и пассажирооборот транспорта включают данные как по организациям, для которых эта деятельность является основной, так и по организациям других видов деятельности.

Перевозки грузов, грузооборот и пассажирооборот транспорта формируются по данным сплошного федерального статистического наблюдения за организациями, не относящимися к субъектам малого предпринимательства, выборочного обследования малых предприятий (кроме микропредприятий), которые проводятся с квартальной периодичностью, ежеквартального выборочного обследования индивидуальных предпринимателей - владельцев грузовых автомобилей, осуществляющих коммерческие перевозки грузов, с распространением полученных данных на генеральную совокупность объектов наблюдения, а также сводных итогов, предоставляемых Росавиацией.

Аварийность на транспорте. Информация о происшествиях на транспорте и пострадавших в них представлена по данным Ространснадзора, МВД России и Росавиации.

Аварийность на железнодорожном транспорте характеризуется количеством крушений поездов и аварий, произошедших с пассажирскими поездами, и при перевозке опасных грузов, а также числом погибших и пострадавших в них людей. В число погибших и пострадавших включаются пассажиры и работники железнодорожного транспорта. Погибшим считается лицо, скончавшееся на месте аварийного случая или умершее от последствий такового.

Аварийность на автомобильных дорогах и улицах характеризуется количеством дорожно-транспортных происшествий (ДТП) и числом погибших и раненых в ДТП.

Дорожно-транспортное происшествие - событие, возникшее в процессе движения по дороге транспортного средства и с его участием, при котором погибли или ранены люди.

Раненый - лицо, получившее в месте дорожно-транспортного происшествия телесные повреждения, обусловившие его госпитализацию на срок не менее одних суток, либо необходимость амбулаторного лечения.

Аварийность на воздушном транспорте характеризуется числом происшествий и числом погибших и раненых в них людей.

Авиационные происшествия с воздушными судами в зависимости от тяжести наступивших последствий подразделяются на катастрофы и аварии (авиационные происшествия без человеческих жертв).

Катастрофа - авиационное происшествие, приведшее к гибели или пропаже без вести какого-либо лица из числа находившихся на борту воздушного судна. К катастрофам также относятся случаи гибели какого-либо лица из числа находившихся на борту в процессе эвакуации из воздушного судна.

Раненым в авиационном происшествии считается лицо, находившееся на борту и получившее травму, повлекшую потерю трудоспособности от одного дня и более.

Погибшим в дорожно-транспортном происшествии (ДТП) и на воздушном транспорте является лицо, погибшее на месте происшествия, либо умершее в течение 30 последующих суток. 
Аварийность на морском и внутреннем водном транспорте характеризуется количеством аварий, произошедших в прямой связи с эксплуатацией судна, а также числом погибших и раненых в них людей. Сведения об аварийности на внутреннем водном транспорте разрабатываются, начиная с отчета за январь-март.

\section{Деятельность в сфере телекоммуникаций}

Объем услуг в сфере телекоммуникаций - стоимость услуг электросвязи, услуг присоединения и пропуска трафика, услуг по обеспечению регулирования использования радиочастотного спектра и радиоэлектронных средств.

Информация об объеме услуг в сфере телекоммуникаций по видам в стоимостном и натуральном выражении и наличии средств связи приводится по данным Минкомсвязи России, сформированным по операторам, оказывающим услуги в сфере телекоммуникаций на основании лицензии (публикуется в докладах № 2, 5, 8, 11).

\section{Розничная торговля}

Оборот розничной торговли - выручка от продажи товаров населению для личного потребления или использования в домашнем хозяйстве за наличный расчет или оплаченных по кредитным карточкам, расчетным чекам банков, по перечислениям со счетов вкладчиков, по поручению физического лица без открытия счета, посредством платежных карт (электронных денег).

Стоимость товаров, проданных (отпущенных) отдельным категориям населения со скидкой, или полностью оплаченных органами социальной защиты, включается в оборот розничной торговли в полном объеме. В оборот розничной торговли не включается стоимость товаров, проданных (отпущенных) из розничной торговой сети юридическим лицам (в том числе организациям социальной сферы, спецпотребителям и т.п.) и индивидуальным предпринимателям, и оборот общественного питания.

Оборот розничной торговли включает данные как по организациям, для которых эта деятельность является основной, так и по организациям других видов деятельности, осуществляющим продажу товаров населению через собственные торговые заведения, или с оплатой через свою кассу. Оборот розничной торговли также включает стоимость товаров, проданных населению индивидуальными предпринимателями и физическими лицами на розничных рынках и ярмарках.

Оборот розничной торговли формируется по данным сплошного федерального статистического наблюдения за организациями, не относящимися к субъектам малого предпринимательства, которое проводится с месячной периодичностью, ежеквартальных выборочных обследований малых предприятий розничной торговли (за исключением микропредприятий) и розничных рынков и ярмарок, а также ежегодных выборочных обследований индивидуальных предпринимателей и микропредприятий с распространением полученных данных на генеральную совокупность объектов наблюдения.

Оборот розничной торговли приводится в фактических продажных ценах, включающих торговую наценку, налог на добавленную стоимость и аналогичные обязательные платежи.

Распределение оборота розничной торговли по формам собственности (публикуется в докладе № 3).

Структура формирования оборота розничной торговли по хозяйствующим субъектам (публикуется в докладах № 3, 5, 8, 11).

Динамика оборота розничной торговли определяется путем сопоставления величины оборота в сравниваемых периодах в сопоставимых ценах. 
Оценки данных по индексам физического объема оборота розничной торговли $\boldsymbol{c}$ исключением сезонного и календарного факторов осуществляются с использованием метода TRAMOSEATS программы "JDemetra+". Выбор наиболее оптимальной модели осуществляется автоматически. Модель фиксируется в начале года и не меняется на его протяжении. Для выполнения сезонной корректировки используется актуальный российский календарь с учетом всех праздничных дней, задаются параметры, учитывающие влияние количества торговых дней и високосного года (7 регрессоров). В качестве исходной информации для проведения сезонной корректировки используются ежемесячные фактические значения индексов физического объема оборота розничной торговли с 1999 г., рассчитанные в процентах к среднемесячному значению 2017 г., без построения прогнозных оценок. При поступлении новых статистических данных в течение отчетного года динамика уточняется в установленные сроки. При построении текущей модели для наилучшего выполнения сглаживания динамического ряда используются данные с 2008 года.

Под торговой сетью (публикуется в докладах № $1,4,7,10)$, в соответствии с п. 8 статьи 2 Федерального закона от 28.12.2009 № 381-Ф3 "Об основах государственного регулирования торговой деятельности в Российской Федерации", понимается совокупность двух и более торговых объектов, которые принадлежат на законном основании хозяйствующему субъекту или нескольким хозяйствующим субъектам, входящим в одну группу лиц в соответствии с Федеральным законом "О защите конкуренции", или совокупность двух и более торговых объектов, которые используются под единым коммерческим обозначением или иным средством индивидуализации. Информация по розничным торговым сетям формируется на основе их перечня, составленного органами государственной власти субъектов Российской Федерации.

Информация о результатах коньюнктурных обследований организаций розничной торговли (публикуется в докладах № 2, 5, 8, 11). Результаты обследований обобщаются в виде простых и композитных индикаторов деловой активности организаций. В качестве простых индикаторов используются балансы оценок показателей (в процентных пунктах), определяемые как разность долей респондентов, отметивших "увеличение" и "уменьшение" показателя по сравнению с предыдущим периодом. Композитным индикатором деловой активности является индекс предпринимательской уверенности, характеризующий обобщенное состояние предпринимательского климата в розничной торговле. Он рассчитывается как среднее арифметическое значение балансов оценок (в процентах) фактического экономического состояния организации, уровня складских запасов (берется с обратным знаком) и ожидаемого экономического состояния.

Информация о продаже алкогольной продукции населению (публикуется в докладах № 1, 4, 7, 10) приводится по данным Росалкогольрегулирования на основе данных деклараций об объеме производства, оборота и использования этилового спирта, алкогольной и спиртосодержащей продукции.

Сведения о продаже алкогольной продукции населению (в том числе в объектах общественного питания) не учитывают данные о продукции проданной (отпущенной) юридическим лицам и индивидуальным предпринимателям. Сведения о продаже алкогольной продукции приводятся в натуральном выражении в декалитрах (один декалитр равен 10 литрам).

В товарную группу "Водка и ликероводочные изделия" включаются следующие позиции: водка, ликероводочные изделия с содержанием спирта до $25 \%$, ликероводочные изделия с содержанием спирта свыше 25\%. В товарную группу "Винодельческая продукция (без шампанских и игристых вин)" включаются следующие позиции: вино, вино фруктовое (плодовое), вино ликерное, напитки винные.

Информация о качестве товаров, поступивших на потребительский рынок (публикуется в докладах № 1, 4, 7, 10) приводится на основании материалов о результатах контрольнонадзорных мероприятий, проводимых органами Роспотребнадзора. Объектами контроля являются юридические лица и индивидуальные предприниматели, осуществляющие торговую деятельность без образования юридического лица, реализующие товары в предприятиях розничной торговли, кроме рынков.

Ассортиментная структура продажи отдельных продовольственных и непродовольственных товаров (публикуется в докладе № 3).

Оборот общественного питания - выручка от продажи собственной кулинарной продукции и покупных товаров без кулинарной обработки населению для потребления, главным образом, на месте, а также организациям и индивидуальным предпринимателям для организации питания различных контингентов населения. 
В оборот общественного питания включается стоимость кулинарной продукции и покупных товаров, отпущенных: работникам организаций с последующим удержанием из заработной платы; на дом по заказам населения; на рабочие места по заказам организаций и индивидуальных предпринимателей; транспортным организациям в пути следования сухопутного, воздушного, водного транспорта; для обслуживания приемов, банкетов и т.п.; организациями общественного питания организациям социальной сферы (школам, больницам, санаториям, домам престарелых и т.п.) в объеме фактической стоимости питания; по абонементам, талонам и т.п. в объеме фактической стоимости питания; стоимость питания в учебных учреждениях, в том числе предоставляемого для отдельных категорий учащихся на льготной основе за счет средств бюджета, включается в объеме фактической стоимости питания.

Оборот общественного питания включает данные как по организациям, для которых эта деятельность является основной, так и по организациям других видов деятельности, осуществляющим продажу кулинарной продукции и покупных товаров для потребления, главным образом, на месте через собственные заведения общественного питания.

Оборот общественного питания формируется по данным сплошного федерального статистического наблюдения за организациями, не относящимися к субъектам малого предпринимательства, которое проводится с месячной периодичностью, ежеквартального выборочного обследования малых предприятий (за исключением микропредприятий), а также ежегодных выборочных обследований индивидуальных предпринимателей и микропредприятий с распространением полученных данных на генеральную совокупность объектов наблюдения.

Оборот общественного питания приводится в фактических продажных ценах, включающих наценку общественного питания, налог на добавленную стоимость и аналогичные обязательные платежи.

Динамика оборота общественного питания определяется путем сопоставления величины оборота в сравниваемых периодах в сопоставимых ценах.

В соответствии с требованиями системы национальных счетов оборот розничной торговли и оборот общественного питания организаций досчитываются на объемы деятельности, не наблюдаемой прямыми статистическими методами.

\section{Рынок платных услуг населению}

Объем платных услуг населению представляет собой денежный эквивалент объема услуг, оказанных резидентами российской экономики (юридическими лицами и физическими лицами, осуществляющими предпринимательскую деятельность без образования юридического лица (индивидуальными предпринимателями)) гражданам Российской Федерации, а также гражданам других государств (нерезидентам), потребляющим те или иные услуги на территории Российской Федерации. Этот показатель формируется в соответствии с методологией формирования официальной статистической информации об объеме платных услуг населению в разрезе видов услуг, утвержденной приказом Росстата от 29.09.2017 № 643 на основании данных форм федерального статистического наблюдения и оценки ненаблюдаемой деятельности на рынке услуг.

Данные об объеме платных услуг населению в распределении по видам приведены в соответствии с Общероссийским классификатором продукции по видам экономической деятельности. Динамика объема платных услуг населению определяется путем сопоставления величины объема в сравниваемых периодах в сопоставимых ценах.

В объем транспортных услуг, оказанных населению, услуги железнодорожного и авиационного транспорта включаются с месячным опозданием.

Оценки данных по индексам физического объема платных услуг населению с исключением сезонного и календарного факторов осуществляются с использованием метода TRAMOSEATS программы "JDemetra+". Выбор наиболее оптимальной модели осуществляется автоматически. Модель фиксируется в начале года и не меняется на его протяжении. Для выполнения сезонной корректировки используется актуальный российский календарь с учетом всех праздничных дней, задаются параметры, учитывающие влияние количества рабочих дней и високосного года (7 регрессоров). В качестве исходной информации для проведения сезонной корректировки 
используются ежемесячные фактические значения индексов физического объема платных услуг населению с 2000 г., рассчитанные в процентах к среднемесячному значению 2017 г., без построения прогнозных оценок. При поступлении новых статистических данных в течение отчетного года динамика уточняется в установленные сроки. При построении текущей модели для наилучшего выполнения сглаживания динамического ряда используются данные с 2006 года.

В ежеквартальных опросах деловой активности в сфере услуг (публикуется в докладах № 3, 6, 9, 12) участвуют около 6,0 тыс. организаций (кроме микропредприятий и некоммерческих организаций).

В качестве простых индикаторов результатов обследований используются балансы оценок показателей (в процентах), определяемые как разность долей респондентов, отметивших "увеличение" и "уменьшение" показателей по сравнению с предыдущим периодом, или как разность долей респондентов, оценивших "улучшение" и "ухудшение" ситуации по сравнению с предыдущим периодом.

Индекс предпринимательской уверенности - качественный показатель, характеризующий обобщенное состояние предпринимательского поведения в секторах экономики. Индекс предпринимательской уверенности в сфере услуг рассчитывается как среднее арифметическое значение балансов оценок изменения экономической ситуации и спроса на услуги в обследуемом периоде по сравнению с предыдущим, а также ожидаемого изменения спроса на услуги в следующем периоде (в процентах).

\section{Оптовая торговля}

Оборот оптовой торговли - выручка от реализации товаров, приобретенных ранее на стороне в целях перепродажи юридическим лицам и индивидуальным предпринимателям для профессионального использования (переработки или дальнейшей продажи).

Оборот оптовой торговли приводится в фактических продажных ценах, включающих торговую наценку, налог на добавленную стоимость, акциз, экспортную пошлину, таможенные сборы и аналогичные обязательные платежи. Сумма вознаграждения комиссионеров (поверенных, агентов) отражается по фактической стоимости, включая НДС.

Оборот оптовой торговли включает данные по организациям с основным видом экономической деятельности "оптовая торговля, включая торговлю через агентов, кроме торговли автотранспортными средствами и мотоциклами" и по организациям других видов деятельности, осуществляющих оптовую торговлю.

Оборот оптовой торговли формируется по данным сплошного федерального статистического наблюдения за организациями (предприятиями), не относящимися к субъектам малого предпринимательства, выборочного обследования малых предприятий оптовой торговли (кроме микропредприятий), которые проводятся с месячной периодичностью, а также ежегодных выборочных обследований микропредприятий и индивидуальных предпринимателей с распространением полученных по выборочным обследованиям данных на генеральную совокупность объектов наблюдения.

Кроме того, в соответствии с требованиями системы национальных счетов, оборот оптовой торговли досчитывается на объемы деятельности, не наблюдаемой прямыми статистическими методами.

Динамика оборота оптовой торговли определяется путем сопоставления величины оборота в сравниваемых периодах в сопоставимых ценах.

Динамика оборота оптовой торговли формируется с учетом индекса-дефлятора, при расчете которого используется годовая структура оборота оптовой торговли, индексы потребительских цен на отдельные виды товаров, индексы цен производителей промышленных товаров, индексы цен на приобретенные организациями отдельные виды товаров, индекс цен приобретения отдельных видов зерна, а также индексы средних фактических экспортных цен на отдельные топливно-энергетические товары (Методические указания по расчету индекса-дефлятора оборота оптовой торговли организаций оптовой торговли, утвержденные приказом Росстата от 19.11.2019 № 668). Оборот оптовой торговли в процентах к соответствующему периоду предыдущего года и предыдущему периоду отчетного года в сопоставимых ценах в целом по Российской Федерации 
может отличаться от данных по субъектам Российской Федерации из-за использования индексов средних фактических экспортных цен на топливно-энергетические товары, рассчитываемых только в целом по Российской Федерации.

Объемы оборота оптовой торговли ежеквартально уточняются по результатам выборочного обследования малых предприятий (кроме микропредприятий). Ежегодно (в марте текущего года) по данным годовых форм федерального статистического наблюдения уточняются объемы оборота оптовой торговли за все периоды предыдущего года, его динамика и годовая структура. При уточнении динамики оборота оптовой торговли используется индекс-дефлятор, откорректирован-ный с учетом обновленной годовой структуры оборота оптовой торговли.

Оценки данных по изменению объема оборота оптовой торговли в сопоставимых ценах в динамике с исключением сезонного и календарного факторов осуществляются с использованием метода TRAMO-SEATS программы "JDemetra+". Выбор наиболее оптимальной модели осуществляется автоматически. Модель фиксируется в начале года и не меняется на его протяжении. Для выполнения сезонной корректировки используется актуальный российский календарь с учетом всех праздничных дней, задаются параметры, учитывающие влияние количества торговых дней и високосного года (7 регрессоров). В качестве исходной информации для проведения сезонной корректировки используются ежемесячные фактические значения оборота оптовой торговли в сопоставимых ценах к декабрю 1999 г., рассчитанные в процентах к среднемесячному значению 2017 г., без построения прогнозных оценок. При поступлении новых статистических данных в течение отчетного года динамика уточняется. При построении текущей модели для наилучшего выполнения сглаживания динамического ряда используются данные с 2010 года.

Информация о запасах топлива (публикуется в докладах № 1-3, 7-12). Данные предоставляются ФГБУ "ЦДУ ТЭК". С ноября 2018 г. - за предыдущий отчетный месяц.

Информация о деятельности бирж (публикуется в докладе № 2) формируется по данным сплошного федерального статистического наблюдения за организаторами торговли, имеющими лицензию биржи (ст. 9 Федерального закона от 21.11.2011 № 325-Ф3 "Об организованных торгах" (с изменениями)), и осуществляющими деятельность по проведению биржевых торгов по сделкам с реальными товарами. В целях проведения федерального статистического наблюдения под реальным товаром понимается товар с немедленной поставкой, имеющийся на складе, или с поставкой в будущем, обладающий индивидуальными свойствами, качествами, в отличие от абстрактного товара в виде, например, фьючерсов, лишенных индивидуальных свойств.

В число бирж (на конец года) включаются биржи, осуществляющие организованную торговлю товарами, и биржи, имеющие торговые (биржевые) секции.

Индекс предпринимательской уверенности в оптовой торговле (публикуется в докладах № 3, 6, 9, 12) рассчитывается как среднее арифметическое "балансов" оценок изменения экономического положения в текущем квартале и ожидаемых изменений в следующем квартале, а также фактического уровня складских запасов (последний - с обратным знаком), в процентных пунктах.

\section{Внешняя торговля}

Информация о внешней торговле товарами представлена на основе данных Банка России и ФТС России.

Информация о внешней торговле Российской Федерации, сформированная Банком России по методологии платежного баланса, включает:

данные таможенной статистики внешней торговли, полученные на основе грузовых таможенных деклараций, заполняемых участниками внешнеэкономической деятельности, данные взаимной торговли с государствами-членами Евразийского экономического союза (ЕАЭС), полученные на основе статистической формы учета перемещения товаров, заполняемой участниками внешнеэкономической деятельности, сформированные ФТС России;

данные об объемах экспорта (импорта) товаров, не пересекающих таможенную границу Российской Федерации (рыбы и морепродуктов, выловленных (добытых) и проданных вне зоны действия таможенного контроля; топлива и товаров, приобретенных российскими (иностранными) 
транспортными средствами в иностранных (российских) портах, сформированные на основе форм федерального статистического наблюдения Федеральной службой государственной статистики;

досчеты Банка России к данным статистики внешней торговли, которые производятся в соответствии с методологическими положениями платежного баланса и включают оценку стоимости товаров, ввезенных (вывезенных) физическими лицами в пределах установленной беспошлинной квоты и в упрощенном (льготном) порядке, и другие элементы досчетов. России.

Информация о внешней торговле товарами представлена также на основе данных ФТС

Данные о внешнеторговом обороте приведены с учетом взаимной торговли с государствами-членами Евразийского экономического союза (ЕАЭС).

Таможенная статистика внешней торговли и статистика взаимной торговли формируется по всем товарам (в том числе ценностям, за исключением валютных ценностей, находящихся в обращении), ввоз и вывоз которых увеличивает или уменьшает материальные ресурсы страны, и не включает товары, не пересекающие таможенную границу России (рыба и морепродукты, выловленные (добытые) и проданные вне зоны действия таможенного контроля, топливо и товары, приобретенные российскими (иностранными) транспортными средствами в иностранных (российских) портах), а также данные по ввозу (вывозу) товаров физическими лицами в пределах установленных беспошлинных квот или перемещаемые через таможенную границу в упрощенном льготном порядке.

К странам Европейского союза относятся: Австрия, Бельгия, Болгария, Венгрия, Германия, Дания, Ирландия, Испания, Италия, Кипр, Латвия, Литва, Люксембург, Мальта, Нидерланды, Польша, Португалия, Румыния, Словакия, Словения, Финляндия, Франция, Хорватия, Чешская Республика, Швеция, Эстония, Греция.

Соединенное Королевство (Великобритания) вышла из состава Евросоюза 1 февраля 2020 года. До окончания переходного периода 31 декабря 2020 г. статданные по Евросоюзу публикуются с учетом Великобритании.

К государствам-участникам СНГ относятся: Азербайджан, Армения, Беларусь, Казахстан, Киргизия, Молдова, Россия, Таджикистан, Туркмения, Узбекистан, Украина.

К странам Азиатско-Тихоокеанского экономического сотрудничества (АТЭС) относятся: Австралия, Бруней-Даруссалам, Вьетнам, Гонконг, Индонезия, Китай, Канада, Малайзия, Мексика, Новая Зеландия, Папуа - Новая Гвинея, Перу, Республика Корея, Россия, Сингапур, США, Таиланд, Тайвань (Китай), Филиппины, Чили, Япония.

К странам Евразийского экономического союза (ЕАЭС) относятся: Республика Армения, Республика Беларусь, Республика Казахстан, Кыргызская Республика, Российская Федерация.

Внешнеторговый оборот - сумма экспорта и импорта.

Экспорт - вывоз товаров с территории Российской Федерации без обязательства об обратном ввозе. Экспорт включает вывоз из страны товаров отечественного производства, а также реэкспорт товаров. К товарам отечественного производства относятся также товары иностранного происхождения, ввезенные в страну и подвергшиеся существенной переработке, изменяющей основные качественные или технические характеристики товаров. К реэкспортным товарам относятся товары, ранее ввезенные на территорию Российской Федерации, а затем вывезенные с этой территории без уплаты таможенных пошлин, налогов и без применения к товарам запретов и ограничений экономического характера.

Импорт - ввоз товаров на территорию Российской Федерации без обязательства об обратном вывозе. В импорт включаются ввезенные товары, предназначенные для потребления в экономике страны и товары, ввозимые на территорию государства в соответствии с режимом реимпорта. К реимпортным товарам относятся товары, ранее вывезенные с территории Российской Федерации, а затем ввезенные на эту территорию без уплаты таможенных пошлин, налогов и без применения к товарам запретов и ограничений экономического характера.

Сальдо торгового баланса - разница между экспортом и импортом. Положительное сальдо - экспорт превышает импорт, отрицательное сальдо (ставится знак "минус") - импорт превышает экспорт. 
Удельный вес импорта потребительских, промежуточных и инвестиционных товаров в общем объеме импорта Российской Федерации (публикуется в докладах № 1, 4, 7, 10).

Данные об удельном весе импорта потребительских, промежуточных и инвестиционных товаров в общем объеме импорта Российской Федерации рассчитаны на основе Статистической методологии формирования официальной статистической информации об объемах внешней торговли в соответствии с классификационными группировками "Инвестиционные товары", "Потребительские товары", "Промежуточные товары" (приказ Росстата от 30.12.2015 № 831).

Потребительские товары - товары, непосредственно удовлетворяющие потребности человека и предназначенные для семейного и личного потребления.

Промежуточные товары - товары, используемые не для конечного потребления, а для дальнейшего производства товаров и услуг.

Инвестиционные товары - товары, служащие целям замены, обновления, качественного улучшения основных средств.

Высокотехнологичная продукция - инновационная продукция, при производстве которой используются результаты научно-исследовательских и опытно-конструкторских работ, соответствующих приоритетным направлениям развития науки, технологий и техники Российской Федерации (в соответствии с приказом Минпромторга России от 23.06.2017 № 1993).

Средние фактические экспортные (импортные) цены представляют собой отношение общей стоимости экспортируемого (импортируемого) товара к его количеству.

Внешняя торговля услугами (публикуется в докладах № 1, 4, 7, 10) - оказание услуг (выполнение работ) включающее в себя производство, распределение, маркетинг, доставку услуг.

Информация об экспорте (импорте) услуг приведена в соответствии с шестой версией Руководства МВФ по платежному балансу международной инвестиционной позиции (РПБ 6 ).

Услуга - полезный результат деятельности, удовлетворяющий определенные потребности, но не воплощающийся в материально-вещественной (материальной) форме.

Экспорт услуг - услуги, оказанные резидентами национальной экономики для нерезидентов. ки.

Импорт услуг - услуги, оказанные нерезидентами для резидентов национальной экономи-

\section{Международные туристские потоки}

(публикуется в докладах № 4, 7, 10, 1)

Официальная статистическая информация о числе въездных и выездных туристских поездок формируется в соответствии с Официальной статистической методологией оценки числа въездных и выездных туристских поездок, утвержденной приказом Росстата от 31.10.2019 № 640.

Въездная туристская поездка - путешествие посетителя с момента въезда в страну до момента выезда.

Выездная туристская поездка - путешествие посетителя с момента отъезда из страны постоянного проживания до момента возвращения.

Посетитель - путешественник, совершающий поездку в какое-либо основное место назначения, находящееся за пределами его/ее обычной среды, на срок менее года с любой главной целью (деловая поездка, отдых или иная личная цель), за исключением цели трудоустройства на предприятие, зарегистрированное в стране или месте посещения. Лица, проходящие долгосрочный курс обучения (один год и более), экипажи/команды общественных видов транспорта во время как регулярных, так и нерегулярных рейсов, рассматриваются как находящиеся в своей обычной среде и, следовательно, исключаются из категории посетителей. Также не относятся к категории посетителей дипломаты, сотрудники консульств и военнослужащие.

Путешественник - какое-либо лицо, перемещающееся между различными географическими пунктами с любой целью и в течение любого срока. 


\section{Характеристика хозяйствующих субъектов}

(публикуется в докладах № $1,4,7,10$ )

Статистический учет организаций и индивидуальных предпринимателей осуществляется органами государственной статистики с 1992 г. на основе сведений об их государственной регистрации. В соответствии с постановлением Правительства Российской Федерации от 17.05.2002 № 319 государственную регистрацию юридических лиц и индивидуальных предпринимателей осуществляют территориальные органы ФНС России.

Группировка хозяйствующих субъектов осуществляется по коду вида деятельности Общероссийского классификатора видов экономической деятельности (ОКВЭД), заявленному организациями и индивидуальными предпринимателями при государственной регистрации в качестве основного вида деятельности.

\section{Демография организаций}

Коэффициент рождаемости организаций - отношение количества зарегистрированных за отчетный период организаций к среднему количеству организаций, учтенных в Статрегистре Росстата, выраженное в промилле.

Коэффициент официальной ликвидации организаций - отношение количества официально ликвидированных за отчетный период организаций к среднему количеству организаций, учтенных в Статрегистре Росстата, выраженное в промилле.

\section{Малые предприятия}

Условия отнесения к малым предприятиям определены статьей 4 Федерального закона от 24 июля 2007г. № 209-Ф3 "О развитии малого и среднего предпринимательства в Российской Федерации".

Порядок осуществления выборочных обследований малых предприятий установлен постановлением Правительства Российской Федерации от 16 февраля 2008г. № 79 "О порядке проведения выборочных статистических наблюдений за деятельностью субъектов малого и среднего предпринимательства".

В разделе приводятся данные по малым предприятиям - юридическим лицам с численностью работников до 100 человек включительно и с предельным значением дохода, полученного от осуществления предпринимательской деятельности за предшествующий календарный год, до 800 млн.рублей.

Данные сформированы по виду экономической деятельности (ОКВЭД2) регистрации предприятия, учтенному в едином реестре субъектов малого и среднего предпринимательства.

\section{Инвестиции}

Финансовые вложения организаций (публикуется в докладах № $1,4,7,10$ ) - инвестиции организации в государственные и муниципальные ценные бумаги, ценные бумаги других организаций, в том числе долговые ценные бумаги, в которых дата и стоимость погашения определена (облигации, векселя); вклады в уставные (складочные) капиталы других организаций (в том числе дочерних и зависимых хозяйственных обществ); предоставленные другим организациям займы, депозитные вклады в кредитных организациях, дебиторская задолженность, приобретенная на основании уступки права требования, вклады организации-товарища по договору простого товарищества и пр. 
Накопленные финансовые вложения - объем накопленных финансовых вложений, произведенных юридическим лицом с начала их вложения с учетом их изъятия и выбытия в отчетном периоде.

Финансовые вложения, осуществленные организацией, в зависимости от срока погашения займов и кредитов подразделяются на долгосрочные и краткосрочные.

Долгосрочные финансовые вложения - вложения, осуществленные на срок более одного года с намерением получения доходов (дивидендов): инвестиции организаций в доходные активы (ценные бумаги) других организаций, уставные (складочные) капиталы других организаций, созданных на территории Российской Федерации или за ее пределами, государственные ценные бумаги (облигации и другие долговые обязательства) и т.п., а также предоставленные организацией другим организациям займы.

Краткосрочные финансовые вложения - вложения на срок не более одного года, осуществленные с намерением получения доходов (дивидендов): в дочерние и зависимые организации, инвестиции организации в ценные бумаги других организаций, государственные ценные бумаги и т.П., а также предоставленные другим организациям займы на срок не более одного года и пр.

Инвестиции в нефинансовые активы (публикуется в докладах № 1, 4, 7, 10).

Инвестиции в основной капитал - совокупность затрат, направленных на строительство, реконструкцию (включая расширение и модернизацию) объектов, которые приводят к увеличению их первоначальной стоимости, приобретение машин, оборудования, транспортных средств, производственного и хозяйственного инвентаря, бухгалтерский учет которых осуществляется в порядке, установленном для учета вложений во внеоборотные активы, инвестиции в объекты интеллектуальной собственности; культивируемые биологические ресурсы.

Данные об инвестициях в основной капитал приведены с учетом инвестиционной деятельности субъектов малого предпринимательства и инвестиций, не наблюдаемых прямыми статистическими методами.

В состав инвестиций в основной капитал включены затраты, осуществленные за счет денежных средств граждан и юридических лиц, привлеченных организациями-застройщиками для долевого строительства.

Затраты на приобретение объектов незавершенного строительства и основных средств на вторичном рынке в объеме инвестиций в основной капитал не учитываются.

Распределение инвестиций в основной капитал по видам экономической деятельности осуществляется в соответствии с классификатором ОКВЭД2, исходя из той сферы деятельности, в рамках которой будут функционировать создаваемые или приобретаемые основные фонды.

Инвестиции в основной капитал учитываются без налога на добавленную стоимость.

Индекс физического объема инвестиций в основной капитал рассчитан в сопоставимых ценах. В качестве сопоставимых цен приняты среднегодовые цены предыдущего года.

Оценка представленных на графике данных по инвестициям в основной капитал с исключением сезонного фактора осуществляется с использованием метода TRAMO-SEATS программы "JDemetra+". Выбор наиболее оптимальной модели осуществляется автоматически. Модель фиксируется в начале года и не меняется на его протяжении. В качестве исходной информации для проведения сезонной корректировки использованы квартальные фактические значения индексов физического объема инвестиций в основной капитал с 2000 г., рассчитанные в процентах к среднеквартальному значению 2017 г. (в постоянных ценах), без построения прогнозных оценок.

Инвестиции в основной капитал разрабатываются в соответствии с Общероссийским классификатором основных фондов (ОКОФ) ОК 013-2014 (СНС 2008), утвержденным приказом Росстандарта России от 12.12.2014 № 2018-ст.

Инвестиции в здания (кроме жилых) и сооружения - расходы на строительство зданий и сооружений, которые складываются из выполненных строительных работ и приходящихся на них прочих капитальных затрат. При этом в затраты на строительство зданий включается стоимость оборудования и коммуникаций внутри здания, необходимых для его эксплуатации.

Инвестиции в жилые здания и помещения - затраты на строительство жилых помещений, зданий или частей зданий, используемых полностью или главным образом как места прожи- 
вания: входящих в жилищный фонд (общего назначения, общежития, спальные корпуса школ интернатов, детских домов, дома для престарелых и инвалидов) и не входящих в жилищный фонд (дома щитовые, садовые дома, помещения контейнерного типа жилые, вагоны-дома передвижные, помещения, приспособленные под жилье (такие как вагоны и кузова железнодорожных вагонов, суда и другие подсобные объекты)).

Инвестиции на улучшение земель - затраты на мелиоративные работы; затраты на проведение культуртехнических работ на землях, не требующих осушения; террасирование крутых склонов; капитальные вложения на коренное улучшение земель; расчистку земельных участков, рекультивацию земли, изменение рельефа (планировку территории), расходы, связанные с предотвращением затопления, расходы, связанные с передачей прав собственности на землю.

Инвестиции в машины, оборудование, транспортные средства - затраты на приобретение машин, транспортных средств, оборудования, производственного и хозяйственного инвентаря, а также затраты на монтаж оборудования на месте его постоянной эксплуатации, проверку и испытание качества монтажа.

Инвестиции в объекты интеллектуальной собственности включают: затраты на научно-исследовательские, опытно-конструкторские и технологические работы, расходы на разведку недр и оценку запасов полезных ископаемых, затраты на создание и приобретение компьютерного программного обеспечения и баз данных, затраты на создание и приобретение произведений развлекательного жанра, литературы и искусства.

Инвестиции в непроизведенные нефинансовые активы - затраты на приобретение юридическими лицами в собственность земельных участков, объектов природопользования, контрактов, договоров аренды, лицензий, деловой репутации ("гудвилла") и деловых связей (маркетинговых активов). Затраты на приобретение земельных участков и объектов природопользования отражаются на основе документов, выданных государственными органами по земельным ресурсам и землеустройству согласно оплаченным или принятым к оплате счетам.

Финансовый лизинг (публикуется в докладе № 4).

Лизинговая деятельность - вид инвестиционной деятельности по приобретению имущества и передаче его в лизинг.

Финансовый лизинг - совокупность экономических и правовых отношений, возникающих в связи с реализацией договора лизинга, в том числе приобретением предмета лизинга.

Договор финансового лизинга - договор, в соответствии с которым арендодатель (лизингодатель) обязуется приобрести в собственность указанное арендатором (лизингополучателем) имущество у определенного им продавца и предоставить лизингополучателю это имущество за плату во временное владение и пользование. Договором лизинга может быть предусмотрено, что выбор продавца и приобретаемого имущества осуществляется лизингодателем.

Общая стоимость договоров финансового лизинга представляет собой общую сумму всех инвестиционных затрат лизингодателя, связанных с приобретением и использованием предмета финансового лизинга.

\section{Цены}

Индекс потребительских цен и тарифов на товары и услуги (ИПЦ) характеризует изменение во времени общего уровня цен и тарифов на товары и услуги, приобретаемые населением для непроизводственного потребления. ИПЦ измеряет отношение стоимости фиксированного перечня товаров и услуг в ценах текущего периода к его стоимости в ценах предыдущего (базисного) периода.

ИПЦ рассчитывается на базе данных регистрации цен на 520 видов товаров (услуг)представителей, которая осуществляется 21-25 числа каждого месяца более чем в 76 тыс. организаций торговли и сферы услуг в 282 городах на территории всех субъектов Российской Федерации.

Базовый индекс потребительских цен (БИПЦ) исключает изменения цен на отдельные товары и услуги, подверженные влиянию факторов, которые носят административный, а также сезонный характер. 
Стоимость фиксированного набора потребительских товаров и услуг для межрегиональных сопоставлений покупательной способности населения исчисляется на основе единых, установленных в целом по России, условных объемов потребления товаров и услуг, а также средних цен на них по России и ее субъектам. В состав набора включены 83 наименования товаров и услуг, в том числе 30 видов продовольственных товаров, 41 вид непродовольственных товаров и 12 видов услуг.

Индексы цен на первичном и вторичном рынках жилья (публикуется в докладах № 3, 6, 9, 12) рассчитываются на основе зарегистрированных цен на вновь построенные квартиры и на квартиры функционирующего жилого фонда, находящиеся в собственности, если они являются объектами совершения рыночных сделок.

Наблюдение ведется по выборочному кругу организаций, осуществляющих операции с недвижимостью в территориальных центрах и отдельных городах субъектов Российской Федерации. При регистрации цен на квартиры учитываются их количественные и качественные характеристики. Средние цены по Российской Федерации рассчитываются из средних цен, сложившихся в ее субъектах. В качестве весов используются данные о количестве проданной общей площади квартир отдельно на первичном и вторичном рынках жилья, накопленном за предыдущий год.

Индекс цен производителей промышленных товаров рассчитывается на основании регистрации цен на товары (услуги)-представители в базовых организациях. Наблюдение за ценами производителей осуществляется более чем в 10 тыс. организаций. Расчет средних цен и индексов цен производится более чем по 1200 товарам (услугам)-представителям. Цены производителей представляют собой фактически сложившиеся на момент регистрации цены указанных организаций на произведенные и отгруженные товары (оказанные услуги), предназначенные для реализации на внутреннем рынке (без косвенных товарных налогов - налога на добавленную стоимость, акциза и т.п.).

Рассчитанные по товарам (услугам)-представителям индексы цен производителей последовательно агрегируются в индексы цен соответствующих видов, групп, классов, разделов экономической деятельности. В качестве весов используются данные об объеме отгрузки в стоимостном выражении за базисный период.

Индекс цен производителей промышленных товаров - сводный показатель, агрегированный по видам деятельности "Добыча полезных ископаемых", "Обрабатывающие производства", "Обеспечение электрической энергией, газом и паром; кондиционирование воздуха", "Водоснабжение; водоотведение, организация сбора и утилизации отходов, деятельность по ликвидации загрязнений".

Индексы цен на приобретенные промышленными организациями отдельные виды товаров рассчитываются на основании регистрации цен на товары-представители по установленной номенклатуре. Средняя цена приобретения включает, помимо цены производства, налог на добавленную стоимость, акциз, транспортные, сбытовые, посреднические и другие расходы. Построение индексов цен приобретения осуществляется по сопоставимому кругу видов товаров в отчетном и базисном периодах и предусматривает систему взвешивания на основе данных о количестве приобретенной продукции за предыдущий год.

Индекс цен производителей сельскохозяйственной продукции исчисляется на основании регистрации в отобранных для наблюдения сельскохозяйственных организациях цен на основные виды товаров-представителей, реализуемых заготовительным, перерабатывающим организациям, на рынке, через собственную торговую сеть, населению непосредственно с транспортных средств, на ярмарках, биржах, аукционах, организациям, коммерческим структурам и т.п. Цены производителей сельскохозяйственной продукции приводятся с учетом надбавок и скидок за качество реализованной продукции без расходов на транспортировку, экспедирование, погрузку и разгрузку продукции, а также без налога на добавленную стоимость.

Сводный индекс цен на продукцию (затраты, услуги) инвестиционного назначения рассчитывается как агрегированный показатель из индексов цен производителей на строительную продукцию, приобретения машин и оборудования инвестиционного назначения и на прочую продукцию (затраты, услуги) инвестиционного назначения, взвешенных по доле этих элементов в общем объеме инвестиций в основной капитал.

Индекс цен производителей на строительную продукцию формируется из индексов цен на строительно-монтажные работы и на прочие затраты, включенные в сводный сметный рас- 
чет строительства, взвешенных по доле этих элементов в общем объеме инвестиций в жилища, здания и сооружения. Расчет индекса цен на строительно-монтажные работы проводится на основе данных формы отчетности о ценах на материалы, детали и конструкции, приобретенные базовыми подрядными организациями, а также на базе технологических моделей, разработанных по видам экономической деятельности с учетом территориальных особенностей строительства.

Индекс цен приобретения машин и оборудования инвестиционного назначения исчисляется на основе данных об изменении цен производителей этого оборудования, транспортных расходов, ставки налога на добавленную стоимость и других расходов.

Индекс цен на прочую продукцию (затраты, услуги) инвестиционного назначения определяется из индексов цен на основные составляющие этих работ (проектно-изыскательские работы, затраты на разведочное бурение, на формирование рабочего, продуктивного и племенного стада и другие затраты).

Индекс тарифов на грузовые перевозки характеризует изменение фактически действующих тарифов на грузовые перевозки за отчетный период без учета изменения за этот период структуры перевезенных грузов по разнообразным признакам: по виду и размеру отправки груза, скорости доставки, расстоянию перевозки, территории перевозки, типу подвижного состава, степени использования его грузоподъемности и др.

Сводный индекс тарифов на грузовые перевозки всеми видами транспорта рассчитывается исходя из индексов тарифов на перевозку грузов отдельными видами транспорта (железнодорожным, трубопроводным, морским, внутренним водным, автомобильным, воздушным), взвешенных на объемы доходов от перевозки грузов соответствующим видом транспорта за базисный период. По каждому виду транспорта регистрируются тарифы на услуги-представители. За услугу-представитель принимается перевозка одной тонны массового груза определенным видом транспорта на фиксированное расстояние. Регистрация тарифов осуществляется в выборочной совокупности транспортных организаций.

Индекс тарифов на услуги связи для юридических лиц (публикуется в докладах № 3, $6,9,12)$ характеризует общее изменение тарифов на услуги связи, оказываемые различным организациям (бюджетным и коммерческим).

Расчет индексов тарифов на услуги связи для юридических лиц основан на ежеквартальном наблюдении за тарифами на 16 видов услуг-представителей в столицах республик, центрах краев, областей, автономной области, автономных округов и городах федерального значения Российской Федерации.

\section{Финансы}

Бюджет - форма образования и расходования денежных средств, предназначенных для финансового обеспечения задач и функций государства и местного самоуправления.

Бюджетная система Российской Федерации состоит из бюджетов следующих уровней:

федеральный бюджет и бюджеты государственных внебюджетных фондов Российской Федерации;

бюджеты субъектов Российской Федерации и бюджеты территориальных государственных внебюджетных фондов;

местные бюджеты, в том числе:

бюджеты муниципальных районов, бюджеты городских округов, бюджеты городских округов с внутригородским делением, бюджеты внутригородских муниципальных образований городов федерального значения Москвы, Санкт-Петербурга и Севастополя;

бюджеты городских и сельских поселений, бюджеты внутригородских районов.

Федеральный бюджет и бюджеты государственных внебюджетных фондов Российской Федерации предназначены для исполнения расходных обязательств Российской Федерации. 
Бюджет субъекта Российской Федерации (региональный бюджет) и бюджет территориального государственного внебюджетного фонда предназначены для исполнения расходных обязательств субъекта Российской Федерации.

Консолидированный бюджет Российской Федерации образуют федеральный бюджет и свод консолидированных бюджетов субъектов Российской Федерации (без учета межбюджетных трансфертов между этими бюджетами).

Консолидированный бюджет субъекта Российской Федерации образуют бюджет субъекта Российской Федерации и свод бюджетов муниципальных образований, входящих в состав субъекта Российской Федерации (без учета межбюджетных трансфертов между этими бюджетами).

Доходы бюджета - поступающие в бюджет денежные средства, за исключением средств, являющихся в соответствии с Бюджетным кодексом Российской Федерации источниками финансирования дефицита бюджета.

Расходы бюджета - выплачиваемые из бюджета денежные средства, за исключением средств, являющихся в соответствии с Бюджетным кодексом Российской Федерации источниками финансирования дефицита бюджета.

Дефицит бюджета - превышение расходов бюджета над его доходами.

Профицит бюджета - превышение доходов бюджета над его расходами.

ние.

Источники финансирования дефицита бюджета подразделяются на внутренние и внеш-

Внутренние источники финансирования дефицита федерального бюджета - разница между средствами, поступившими от размещения государственных ценных бумаг Российской Федерации, номинальная стоимость которых указана в валюте Российской Федерации, и средствами, направленными на их погашение; разница между привлеченными и погашенными Российской Федерацией в валюте Российской Федерации бюджетными кредитами, предоставленными федеральному бюджету другими бюджетами бюджетной системы Российской Федерации; разница между привлеченными и погашенными Российской Федерацией в валюте Российской Федерации кредитами кредитных организаций, международных финансовых организаций; изменение остатков средств на счетах по учету средств федерального бюджета в течение соответствующего финансового года; иные источники финансирования дефицита федерального бюджета.

В состав иных источников включаются: поступления от продажи акций и иных форм участия в капитале, находящихся в собственности Российской Федерации; поступления от реализации государственных запасов драгоценных металлов и драгоценных камней из Государственного фонда драгоценных металлов и драгоценных камней Российской Федерации, уменьшенные на размер выплат на их приобретение; курсовая разница по средствам федерального бюджета; объем средств, направляемых на исполнение государственных гарантий Российской Федерации в валюте Российской Федерации; разница между средствами, полученными от возврата и суммой предоставленных из федерального бюджета юридическим лицам, другим бюджетам бюджетной системы Российской Федерации бюджетных кредитов в валюте Российской Федерации; разница между суммой средств, полученных от возврата бюджетных кредитов за счет средств целевых иностранных кредитов, предоставленных внутри страны, и суммой предоставленных внутри страны бюджетных кредитов за счет средств целевых иностранных кредитов; разница между суммой средств, полученных от возврата предоставленных внутри страны прочих бюджетных кредитов (ссуд), и суммой предоставленных внутри страны прочих бюджетных кредитов; разница между средствами, перечисленными с единого счета федерального бюджета, и средствами, зачисленными на единый счет федерального бюджета, при проведении операций по управлению остатками средств на едином счете федерального бюджета; прочие источники внутреннего финансирования дефицита федерального бюджета.

Внешние источники финансирования дефицита федерального бюджета - разница между средствами, поступившими от размещения государственных займов, которые осуществляются путем выпуска государственных ценных бумаг от имени Российской Федерации и номинальная стоимость которых указана в иностранной валюте, и средствами, направленными на их погашение; разница между привлеченными и погашенными Российской Федерацией в иностранной валюте кредитами иностранных государств, с учетом средств, перечисленных из федерального бюджета российским поставщикам товаров и (или) услуг на экспорт в счет погашения государст- 
венного внешнего долга Российской Федерации, международных финансовых организаций, иных субъектов международного права и иностранных юридических лиц; разница между привлеченными и погашенными Российской Федерацией в иностранной валюте кредитами кредитных организаций.

В состав иных источников внешнего финансирования включаются: объем средств, направляемых на исполнение государственных гарантий Российской Федерации в иностранной валюте; разница между средствами, поступившими в федеральный бюджет в погашение основного долга иностранных государств и (или) иностранных юридических лиц перед Российской Федерацией, и средствами, направленными на предоставление государственных финансовых и государственных экспортных кредитов; прочие источники внешнего финансирования дефицита федерального бюджета.

Фонд национального благосостояния представляет собой часть средств федерального бюджета, подлежащих обособленному учету и управлению в целях обеспечения софинансирования добровольных пенсионных накоплений граждан Российской Федерации, а также обеспечения сбалансированности (покрытия дефицита) федерального бюджета и бюджета Пенсионного фонда Российской Федерации.

Налог - обязательный, индивидуально безвозмездный платеж, взимаемый с организаций и физических лиц в форме отчуждения принадлежащих им на праве собственности, хозяйственного ведения или оперативного управления денежных средств в целях финансового обеспечения деятельности государства и (или) муниципальных образований.

Сбор - обязательный взнос, взимаемый с организаций и физических лиц, уплата которого является одним из условий совершения в отношении плательщиков сборов государственными органами, органами местного самоуправления, иными уполномоченными органами и должностными лицами юридически значимых действий, включая предоставление определенных прав или выдачу разрешений (лицензий), либо уплата которого обусловлена осуществлением в пределах территории, на которой введен сбор, отдельных видов предпринимательской деятельности.

Страховые взносы - обязательные платежи на обязательное пенсионное страхование, обязательное социальное страхование на случай временной нетрудоспособности и в связи с материнством, на обязательное медицинское страхование, взимаемые с организаций и физических лиц в целях финансового обеспечения реализации прав застрахованных лиц на получение страхового обеспечения по соответствующему виду обязательного социального страхования.

Федеральные налоги и сборы - налоги и сборы, устанавливаемые Налоговым кодексом Российской Федерации и обязательные к уплате на всей территории Российской Федерации.

Региональные налоги - налоги, устанавливаемые Налоговым кодексом Российской Федерации и законами субъектов Российской Федерации о налогах и обязательные к уплате на территориях соответствующих субъектов Российской Федерации.

Местные налоги и сборы - налоги и сборы, устанавливаемые Налоговым кодексом Российской Федерации и нормативными правовыми актами представительных органов муниципальных образований о налогах и сборах и обязательные к уплате на территориях соответствующих муниципальных образований.

Специальные налоговые режимы предусматривают особый порядок определения элементов налогообложения, а также освобождение от обязанности по уплате отдельных налогов и сборов и применяются в случаях и порядке, которые предусмотрены Налоговым кодексом Российской Федерации и иными актами законодательства о налогах и сборах.

Задолженность по налогам и сборам - суммарный объем выявленных и подтвержденных недополученных налоговых поступлений, законодательно установленных налогов и сборов, начисленных пени и штрафных санкций, в отношении которой применяется механизм урегулирования с целью ее снижения.

Совокупная задолженность по налогам и сборам, страховым взносам, пеням и налоговым санкциям включает в себя недоимку, задолженность по уплате пеней и санкций, урегулированную и невозможную к взысканию задолженность по налогам и сборам, страховым взносам, пеням и налоговым санкциям, в том числе задолженность организаций, индивидуальных предпринимателей и граждан, находящихся в процедурах банкротства.

Недоимка - сумма неуплаченного в установленный срок налога или сбора. 
Урегулированная задолженность - задолженность, в отношении которой применены методы урегулирования в виде реструктуризации, отсрочек, рассрочек или приостановления взыскания.

Информация об исполнении бюджетов государственных внебюджетных социальных фондов Российской Федерации публикуется в докладах № 4, 5, 8, 11.

Сальдированный финансовый результат (прибыль (+) убыток (-)) - конечный финансовый результат, выявленный на основании бухгалтерского учета всех хозяйственных операций организаций, представляет собой сумму сальдированного финансового результата (прибыль $(+)$, убыток (-)) от продажи товаров, продукции (работ, услуг), основных средств, иного имущества организаций и прочих доходов, уменьшенных на сумму прочих расходов.

Темпы изменения сальдированного финансового результата отчетного периода по сравнению с соответствующим периодом предыдущего года рассчитаны по сопоставимому кругу организаций; с учетом корректировки данных соответствующего периода предыдущего года, исходя из изменений учетной политики, законодательных актов и др. в соответствии с методологией бухгалтерского учета. Прочерк означает, что в одном или обоих сопоставляемых периодах был получен отрицательный сальдированный финансовый результат.

Рентабельность (публикуется в докладах № 2, 4, 7, 10).

Рентабельность проданных товаров, продукции (работ, услуг) рассчитывается как соотношение между величиной сальдированного финансового результата (прибыль минус убыток) от продажи и себестоимости проданных товаров, продукции, работ, услуг. В том случае, если сальдированный финансовый результат (прибыль минус убыток) от продажи отрицательный имеет место убыточность.

Рентабельность активов - соотношение сальдированного финансового результата (прибыль минус убыток) и стоимости активов организаций. В том случае, если сальдированный финансовый результат (прибыль минус убыток) отрицательный - имеет место убыточность.

Суммарная задолженность по обязательствам - кредиторская задолженность и задолженность по кредитам банков и займам.

Кредиторская задолженность - задолженность по расчетам с поставщиками и подрядчиками за поступившие материальные ценности, выполненные работы и оказанные услуги, в том числе задолженность, обеспеченная векселями выданными; задолженность по расчетам с дочерними и зависимыми обществами по всем видам операций; с рабочими и служащими по оплате труда, представляющая собой начисленные, но не выплаченные суммы оплаты труда; задолженность по отчислениям на государственное социальное страхование, пенсионное обеспечение и медицинское страхование работников организации, задолженность по всем видам платежей в бюджет и внебюджетные фонды; задолженность организации по платежам по обязательному и добровольному страхованию имущества и работников организации и другим видам страхования, в которых организация является страхователем; авансы полученные, включающие сумму полученных авансов от сторонних организаций по предстоящим расчетам по заключенным договорам, а также штрафы, пени и неустойки, признанные организацией или по которым получены решения суда (арбитражного суда) или другого органа, имеющего в соответствии с законодательством Российской Федерации право на принятие решения об их взыскании, и отнесенные на финансовые результаты организации, непогашенные суммы заемных средств, подлежащие погашению в соответствии с договорами.

Дебиторская задолженность - задолженность по расчетам с покупателями и заказчиками за товары, работы и услуги, в том числе задолженность, обеспеченная векселями полученными; задолженность по расчетам с дочерними и зависимыми обществами; суммы уплаченных другим организациям авансов по предстоящим расчетам в соответствии с заключенными договорами; задолженность по расчетам с прочими дебиторами, включающая в себя задолженность финансовых и налоговых органов (в том числе по переплате по налогам, сборам и прочим платежам в бюджет); задолженность работников организации по предоставленным им ссудам и займам за счет средств этой организации или кредита (ссуды на индивидуальное и кооперативное жилищное строительство, приобретение и благоустройство садовых участков, беспроцентные ссуды молодым семьям на улучшение жилищных условий или обзаведение домашним хозяйством и др.); задолженность подотчетных лиц; поставщиков по недостачам товарно-материальных ценностей, обнаруженным при приемке; задолженность по государственным заказам, федеральным программам за поставленные товары, работы и услуги, а также штрафы, пени и неустойки, признанные 
должником, или по которым получены решения суда (арбитражного суда) или другого органа, имеющего в соответствии с законодательством Российской Федерации право на принятие решения об их взыскании, и отнесенные на финансовые результаты организации.

7, 10).

Финансовая устойчивость и платежеспособность (публикуется в докладах № 2, 4,

Финансовая устойчивость организаций характеризуется состоянием финансовых ресурсов, обеспечивающих бесперебойный расширенный процесс производства и продажи продукции на основе роста прибыли.

Основными показателями финансовой устойчивости организаций являются следующие коэффициенты: коэффициент автономии, характеризующий долю собственных средств в общей величине источников средств организаций и определяющий степень независимости от кредиторов; коэффициент обеспеченности собственными оборотными средствами, который рассчитывается как отношение собственных оборотных активов к фактической стоимости всех оборотных активов, находящихся в наличии у организаций.

Платежеспособность характеризует возможности организаций своевременно расплачиваться по своим обязательствам.

Одним из показателей платежеспособности организаций является коэффициент текущей ликвидности, рассчитываемый как отношение фактической стоимости находящихся в наличии у организаций оборотных активов к наиболее срочным обязательствам организации в виде краткосрочных кредитов и займов, кредиторской задолженности.

Деятельность страховщиков (публикуется в докладах № 4, 5, 8, 11).

Страховщики - страховые организации и общества взаимного страхования, созданные в соответствии с законодательством Российской Федерации для осуществления деятельности по страхованию, перестрахованию, взаимному страхованию и получившие лицензии на осуществление соответствующего вида страховой деятельности в соответствии с Законом от 27.11.1992 № 4015-1 "Об организации страхового дела в Российской Федерации".

Страховые премии (взносы) - плата за страхование, которую страхователь (выгодоприобретатель) обязан уплатить страховщику в порядке и в сроки, которые установлены договором страхования.

Выплаты по договорам страхования - денежная сумма, которая определена в порядке, установленном федеральным законом и (или) договором страхования, и выплачивается страховщиком страхователю, застрахованному лицу, выгодоприобретателю при наступлении страхового случая.

Коэффициент выплат - отношение произведенных выплат по договорам страхования к страховым премиям (взносам).

Обязательное медицинское страхование (ОМС) - вид обязательного социального страхования, представляющий собой систему создаваемых государством правовых, экономических и организационных мер, направленных на обеспечение при наступлении страхового случая гарантий бесплатного оказания медицинской помощи за счет средств обязательного медицинского страхования. В соответствии с Федеральным законом от 29.11.2010 № 326-Ф3 "Об обязательном медицинском страховании в Российской Федерации" страховые медицинские организации с 01.01.2012 осуществляют свою деятельность в сфере обязательного медицинского страхования на основании договора о финансовом обеспечении ОМС, заключенного с территориальным фондом ОМС.

Перестрахование - деятельность по страхованию одним страховщиком (перестраховщиком) имущественных интересов другого страховщика (перестрахователя), связанных с принятым последним по договору страхования (основному договору) обязательством по страховой выплате.

Денежная масса (денежный агрегат М2) - это сумма наличных денег в обращении и остатков средств нефинансовых и финансовых (кроме кредитных) организаций - резидентов Российской Федерации и физических лиц - резидентов Российской Федерации на расчетных, текущих и иных счетах до востребования (в том числе счетах для расчетов с использованием банковских карт), срочных депозитов и иных привлеченных на срок средств, открытых в банковской системе Российской Федерации в рублях, а также начисленные проценты по ним. Таким образом, денежный агрегат М2 включает наличные деньги в обращении и безналичные средства. 
Наличные деньги в обращении (денежный агрегат М0) - наиболее ликвидная часть денежной массы, доступная для немедленного использования в качестве платежного средства. Включает банкноты и монеты в обращении.

В составе безналичных средств, включаемых в денежный агрегат М2, выделяют переводные депозиты и другие депозиты.

Переводные депозиты включают остатки средств нефинансовых и финансовых (кроме кредитных) организаций - резидентов Российской Федерации и физических лиц - резидентов Российской Федерации на расчетных, текущих и иных счетах до востребования (в том числе счетах для расчетов с использованием банковских карт), открытых в банковской системе Российской Федерации в рублях, а также начисленные проценты по ним.

Другие депозиты включают остатки средств нефинансовых и финансовых (кроме кредитных) организаций и физических лиц на срочных депозитах и иных привлеченных банковской системой Российской Федерации на срок средств в рублях, а также начисленные проценты по ним.

Международные резервы (резервные активы) Российской Федерации представляют собой высоколиквидные иностранные активы, имеющиеся в распоряжении Банка России и Правительства Российской Федерации по состоянию на отчетную дату.

Международные резервы состоят из средств в иностранной валюте, специальных прав заимствования (СДР), резервной позиции в МВФ и монетарного золота.

Кредитные организации, имеющие право на осуществление банковских операций, (действующие кредитные организации) - кредитные организации, зарегистрированные Банком России до 01.07.2002 или уполномоченным регистрирующим органом и имеющие право на осуществление банковских операций.

Филиалы действующих кредитных организаций - обособленные подразделения кредитных организаций, расположенные вне местонахождения кредитной организации и осуществляющие от ее имени все или часть банковских операций, предусмотренных лицензией Банка России, выданной кредитной организации.

По строке "филиалы ПАО Сбербанк" указываются филиалы ПАО Сбербанк, внесенные в Книгу государственной регистрации кредитных организаций и получившие порядковые номера.

Зарегистрированный уставный капитал кредитных организаций - суммарное значение содержащихся в Книге государственной регистрации кредитных организаций величин уставных капиталов зарегистрированных кредитных организаций.

Сумма средств организаций на счетах - средства на расчетных и прочих счетах финансовых (кроме кредитных организаций), коммерческих и некоммерческих организаций (включая средства на счетах физических лиц - индивидуальных предпринимателей), резидентов и нерезидентов, в валюте Российской Федерации и иностранной валюте.

Сумма бюджетных средств, государственных и других внебюджетных фондов на счетах кредитных организаций - средства бюджетов всех уровней, государственных и других внебюджетных фондов, внебюджетных фондов органов исполнительной власти субъектов Российской Федерации и местного самоуправления на расчетных счетах.

Кредиты, депозиты и прочие размещенные средства, предоставленные организациям (кроме органов государственной власти, местного самоуправления, государственных и внебюджетных фондов), физическим лицам и кредитным организациям, всего - задолженность клиентов (включая просроченную задолженность) перед кредитными организациями по всем предоставленным им средствам указанных видов. В общую величину задолженности, кроме соответствующих сумм, выделенных в том числе из общего итога (физическим лицам, организациям, кредитным организациям), включаются также кредиты иностранным государствам и задолженность (включая просроченную) по операциям с драгоценными металлами (кроме операций с кредитными организациями).

Кредиты, предоставленные в рублях/иностранной валюте физическим лицам, задолженность (включая просроченную) физических лиц - резидентов и нерезидентов (без учета индивидуальных предпринимателей) перед кредитными организациями.

Кредиты и прочие размещенные средства, предоставленные в рублях и иностранной валюте организациям, - задолженность (включая просроченную) финансовых (кроме кредитных) и нефинансовых организаций всех форм собственности - резидентов (включая кредиты физиче- 
ским лицам - индивидуальным предпринимателям) и нерезидентов по всем кредитам и прочим размещенным средствам.

Кредиты, депозиты и прочие размещенные средства, предоставленные кредитным организациям и банкам-нерезидентам в рублях/иностранной валюте, - задолженность (включая просроченную) по предоставленным межбанковским кредитам, депозитам и прочим размещенным средствам.

Объем предоставленных физическим лицам-резидентам жилищных кредитов (ипотечных жилищных кредитов - сумма средств, предоставленных в течение отчетного периода по кредитным договорам (дополнительным соглашениям).

Задолженность по жилищным кредитам в рублях и иностранной валюте, предоставленным физическим лицам, - остаток задолженности (включая просроченную) по кредитам, предоставленным кредитными организациями физическим лицам - резидентам Российской Федерации на приобретение и обустройство земли под предстоящее жилищное строительство (земельный кредит); для финансирования строительных работ (строительный кредит); для приобретения жилья (кредит на приобретение жилья).

Задолженность по ипотечным жилищным кредитам в рублях и иностранной валюте - остаток задолженности (включая просроченную) по жилищным кредитам, предоставленным физическим лицам-резидентам под залог недвижимости в порядке, установленном Федеральным законом от 16.07.1998 № 102-Ф3 "Об ипотеке (залоге недвижимости)".

Средневзвешенные процентные ставки по кредитам, предоставленным физическим лицам, нефинансовым организациям, по срокам погашения - средневзвешенные процентные ставки в годовом исчислении, рассчитанные исходя из годовых процентных ставок, установленных в кредитных договорах, и объемов предоставленных кредитов в отчетном месяце.

Вклады (депозиты), кредиты и прочие привлеченные кредитными организациями средства в рублях и иностранной валюте - денежные средства юридических, физических лиц, индивидуальных предпринимателей, включая средства нерезидентов Российской Федерации, без учета начисленных процентов.

Депозиты и прочие привлеченные средства юридических лиц - депозиты и прочие привлеченные средства (до востребования и срочные) органов государственного управления и внебюджетных фондов всех уровней, финансовых (кроме кредитных) и нефинансовых организаций всех форм собственности (включая депозитные сертификаты), депозиты индивидуальных предпринимателей, а также неисполненные обязательства по договорам на привлечение средств по депозитам и прочим привлеченным средствам.

Депозиты, кредиты и прочие привлеченные средства кредитных организаций включают депозиты (вклады), кредиты и прочие привлеченные средства кредитных организаций и банков-нерезидентов.

Вклады (депозиты) физических лиц - депозиты и прочие привлеченные кредитными организациями средства физических лиц (включая сберегательные сертификаты), неисполненные обязательства по договорам на привлечение средств по депозитам и прочим привлеченным средствам, а также средства на прочих счетах физических лиц. В расчет данного показателя не включаются средства индивидуальных предпринимателей, избирательных фондов физических лиц, переводы из Российской Федерации и в Российскую Федерацию.

Средства на счетах индивидуальных предпринимателей - денежные средства на счетах индивидуальных предпринимателей, осуществляющих свою деятельность без образования юридического лица.

Вклады (депозиты) до востребования - денежные средства, подлежащие возврату (получению) по первому требованию (на условиях до востребования), а также средства, подлежащие возврату (получению) при наступлении предусмотренного договором условия (события), конкретная дата которого неизвестна (на условиях "до наступления условия (события)").

Срочные вклады (депозиты) - вклады (депозиты), денежные средства, привлеченные кредитной организацией на условиях возврата вклада по истечении определенного договором срока. Размер процентной ставки по срочным вкладам определяется договором банковского вклада.

Средневзвешенные процентные ставки по вкладам (депозитам) физических лиц и нефинансовых организаций - средневзвешенные процентные ставки в годовом исчислении, 
рассчитанные исходя из годовых процентных ставок, установленных в договорах вклада (депозитных договорах), и объемов привлеченных вкладов (депозитов) в отчетном месяце.

Облигации федерального займа с постоянным доходом (ОФЗ-ПД) - облигации федерального займа с постоянной купонной ставкой.

Облигации федерального займа с амортизацией долга (ОФЗ-АД) - облигации федерального займа, погашение номинальной стоимости которых осуществляется частями. Купонная ставка является фиксированной для каждого купона; купонный доход начисляется на непогашенную часть номинальной стоимости.

Облигации федерального займа с переменным купоном (ОФЗ-ПК) - облигации федерального займа, значение купонной ставки которых меняется и определяется по средневзвешенной доходности ГКО.

Облигации федерального займа с индексируемым номиналом (ОФЗ-ИН) - облигации федерального займа, индексируемые в зависимости от уровня инфляции.

Дюрация рыночного портфеля - средний срок до выплат по ценным бумагам с учетом купонных выплат, взвешенный по объемам в обращении.

Объем выручки, полученной в результате размещения и доразмещения ГКО-ОФЗ сумма средств, полученных Министерством финансов Российской Федерации от размещения и доразмещения ГКО-ОФЗ.

Объем погашения/купонной выплаты - сумма средств, затраченная на погашение/купонную выплату.

Официальный курс доллара США к рублю рассчитывается и устанавливается Банком России каждый рабочий день на основе котировок межбанковского внутреннего валютного рынка по операциям "доллар США - рубль".

Официальный курс евро к рублю рассчитывается и устанавливается Банком России на основе официального курса доллара США по отношению к рублю и котировок межбанковского международного валютного рынка по операциям "доллар США - евро".

Индекс реального курса рубля к доллару США и евро за отчетный период по отношению к базовому периоду определяется как произведение индекса номинального курса рубля к доллару США и евро за отчетный период в сравнении с базовым и отношения индекса потребительских цен в Российской Федерации за отчетный период в сравнении с базовым к индексу потребительских цен в стране, в которой иностранная валюта является законным средством платежа, за отчетный период в сравнении с базовым. При этом индекс номинального курса рубля к доллару США/евро за отчетный период в сравнении с базовым определяется как отношение средних курсов рубля к иностранной валюте за отчетный и базовый периоды.

Индекс реального курса рубля к доллару США/евро, рассчитанный на основе индексов потребительских цен, характеризует изменение конкурентоспособности произведенных в России потребительских товаров и услуг по отношению к потребительским товарам и услугам, произведенным в стране, в которой иностранная валюта является законным платежным средством.

Индекс реального эффективного курса рубля к иностранным валютам определяется как среднее геометрическое взвешенное индексов реальных курсов рубля к иностранным валютам за отчетный период по отношению к базовому периоду. В качестве весовых коэффициентов используются доли внешнего товарооборота России со странами - основными торговыми партнерами в общем объеме внешнего товарооборота России с указанными странами.

Индекс реального эффективного курса рубля характеризует изменение конкурентоспособности произведенных в России потребительских товаров и услуг по отношению к потребительским товарам и услугам, произведенным за границей.

Ключевая ставка Банка России (далее - ключевая ставка) - процентная ставка, с помощью которой Банк России оказывает воздействие на формирование процентных ставок в экономике, оптимальных в сложившихся условиях для достижения поставленной цели по инфляции. Ключевая ставка устанавливается Советом директоров Банка России. К ключевой ставке приравнены минимальная / максимальная ставки по основным операциям Банка России по регулированию ликвидности банковского сектора (аукционам по предоставлению и абсорбированию Банком России рублевой ликвидности на срок 1 неделя), также она является центром процентного коридора Банка России, ограничивающего колебания однодневных ставок межбанковского кредитного рынка. 


\section{Уровень жизни населения}

\section{(денежные доходы населения, заработная плата, пенсии, прожиточный минимум)}

Расчет показателей денежных доходов и расходов населения производится в соответствии с Методологическими положениями по расчету показателей денежных доходов и расходов населения, утвержденными приказом Росстата от 02.07.2014 № 465 с изменениями от 20.11.2018. Информация публикуется ежеквартально в соответствии с распоряжением Правительства Российской Федерации от 20.03.2019 № 469-р (по Российской Федерации в докладах № 3, 6, 9, 12, по субъектам Российской Федерации - в докладах № 1, 4, 7, 10 соответственно).

Данные о денежных доходах и расходах населения формируются на основе официальной статистической информации о произведенных выплатах денежных средств населению и полученных от населения денежных средствах с использованием данных регулярной статистической отчетности хозяйствующих субъектов, органов государственного управления и финансовых учреждений, а также с использованием системы дооценок объемов доходов и расходов населения в неформальном секторе экономики. При отсутствии ряда показателей в необходимые сроки (это касается в основном банковских данных) производится их оценка.

При публикации объема денежных доходов и расходов населения за отчетный период производится уточнение предварительных показателей за предыдущий период. Пересмотр квартальных данных осуществляется по итогам разработки годового баланса денежных доходов и расходов населения.

Денежные доходы населения включают доходы лиц, работающих по найму; доходы от самостоятельной занятости (доходов от предпринимательской деятельности и другой производственной деятельности); социальные выплаты (пенсии, пособия, стипендии и другие выплаты); доходы от собственности (дивиденды, проценты, начисленные по денежным средствам на банковских счетах физических лиц в кредитных организациях; выплата доходов по государственным и другим ценным бумагам; инвестиционный доход (доход от собственности держателей полисов); прочие денежные поступления.

Номинальные денежные доходы в расчете на душу населения исчисляются делением общей суммы денежных доходов на численность постоянного населения.

Реальные денежные доходы - относительный показатель, характеризующий динамику денежных доходов населения по сравнению с изменением цен на товары и услуги и исчисленный путем деления индекса номинального размера денежных доходов населения (т.е. фактически сложившегося в отчетном периоде) на индекс потребительских цен за соответствующий временной период.

Реальные располагаемые денежные доходы - относительный показатель, характеризующий динамику располагаемых денежных доходов населения (денежные доходы за вычетом обязательных платежей) по сравнению с изменением цен на товары и услуги и исчисленный путем деления индекса номинального размера располагаемых денежных доходов населения (т.е. фактически сложившегося в отчетном периоде) на индекс потребительских цен за соответствующий временной период.

Получение данных с исключением сезонного и календарного факторов осуществляется с использованием метода X-13-ARIMA программы "JDemetra+". Выбор оптимальной модели осуществляется автоматически. Для выполнения сезонной корректировки используется актуальный российский календарь с учетом всех праздничных дней. В качестве исходной информации применяются квартальные фактические значения располагаемых денежных доходов и индекса потребительских цен с декабря 1992 г., рассчитанные в процентах к среднемесячному значению 2017 г., без построения прогнозных оценок.

Денежные расходы населения - включают расходы на покупку товаров и оплату услуг, платежи за товары (работы, услуги) зарубежным поставщикам за безналичный и наличный расчет, включая сальдо трансграничной Интернет-торговли; расходы на оплату обязательных платежей и разнообразных взносов; прочие расходы населения.

К сбережениям населения относятся: прирост (уменьшение) сбережений на рублевых и валютных счетах в банках Российской Федерации и за рубежом; прирост (уменьшение) средств в форме кредитов и займов от иностранных контрагентов; прирост (уменьшение) сбережений 
в ценных бумагах (включая векселя и долговые ценные бумаги); расходы на покупку недвижимости (включая сальдо операций с инструментами участия в капитале и недвижимостью за рубежом); прирост (уменьшение) наличных денег на руках у населения в рублях и в иностранной валюте в рублевом эквиваленте; прирост (уменьшение) прочих сбережений. Общий объем сбережений населения корректируется на величину финансовых обязательств (кредиты, ссуды) и на величину реализации финансовых активов (средств от продажи и погашения инвестиционных паев, от реализации долей участия в уставном капитале организаций и др.).

Среднемесячная номинальная заработная плата работников организаций исчисляется делением фонда начисленной заработной платы работников на среднесписочную численность работников и на количество месяцев в периоде.

В фонд заработной платы включаются начисленные суммы в денежной и неденежной формах за отработанное и неотработанное время, доплаты и надбавки, премии и единовременные поощрения, компенсационные выплаты, связанные с режимом работы и условиями труда, а также оплата питания и проживания, имеющая систематический характер.

Темпы роста (снижения) среднемесячной номинальной заработной платы рассчитываются по сопоставимой совокупности организаций отчетного и предыдущих периодов.

Реальная заработная плата характеризует покупательную способность заработной платы в отчетном периоде в связи с изменением цен на потребительские товары и услуги по сравнению с базисным периодом. Для этого рассчитывается индекс реальной заработной платы путем деления индекса номинальной заработной платы на индекс потребительских цен за один и тот же временной период.

Просроченной задолженностью по заработной плате считаются фактически начисленные работникам суммы заработной платы, но не выплаченные в срок, установленный коллективным договором или договором на расчетно-кассовое обслуживание, заключенным с банком. Число дней задержки считается, начиная со следующего дня после истечения этого срока.

С февраля 2017 г. данные разрабатываются в соответствии с ОКВЭД2 по следующим видам экономической деятельности: растениеводство и животноводство, охота и предоставление соответствующих услуг в этих областях; лесозаготовки; рыболовство и рыбоводство; добыча полезных ископаемых; обрабатывающие производства; обеспечение электрической энергией, газом и паром; кондиционирование воздуха; водоснабжение; водоотведение, организация сбора и утилизации отходов, деятельность по ликвидации загрязнений; строительство; транспорт; управление недвижимым имуществом за вознаграждение или на договорной основе; научные исследования и разработки; образование; деятельность в области здравоохранения и социальных услуг; деятельность в области культуры, искусства, отдыха и развлечений, теле- и радиовещания.

Средний размер назначенных пенсий определяется делением общей суммы назначенных пенсий на численность пенсионеров (по данным Пенсионного фонда Российской Федерации).

Реальный размер назначенных пенсий рассчитывается путем корректировки среднего размера назначенных пенсий на индекс потребительских цен за соответствующий временной период.

Показатели рассчитаны на основе Методики расчетов основных показателей пенсионного обеспечения, утвержденной приказом Росстата от 23 июня 2009 г. № 118.

Величина прожиточного минимума в соответствии с Федеральным законом от 24.10. 1997 № 134-Ф3 "О прожиточном минимуме в Российской Федерации" представляет собой стоимостную оценку потребительской корзины, а также обязательные платежи и сборы.

Величина прожиточного минимума определяется ежеквартально и устанавливается с января 2018 г. в целом по Российской Федерации нормативным правовым актом Минтруда России (в соответствии с постановлением Правительства Российской Федерации от 30.12.2017 № 1702 "О порядке установления величины прожиточного минимума на душу населения и по основным социально-демографическим группам населения в целом по Российской Федерации"); в порядке, установленном законами субъектов Российской Федерации, - в субъектах Российской Федерации.

Расчет величины прожиточного минимума соответствует порядку, введенному с 2013 г. Федеральным законом от 03.12.2012 № 233-Ф3 "О внесении изменений в Федеральный закон "О прожиточном минимуме в Российской Федерации". Согласно основным положениям указанного закона в составе потребительской корзины определяются: продукты питания - в натуральных 
показателях, непродовольственные товары и услуги - в соотношении со стоимостью продуктов питания (в объеме по 50\% от стоимости продуктов питания).

Расчет величины прожиточного минимума осуществляется согласно правилам исчисления величины прожиточного минимума на душу населения и по основным социально-демографическим группам населения в целом по Российской Федерации, утвержденным постановлением Правительства Российской Федерации от 29.01.2013 № 56.

Расчет стоимости потребительской корзины осуществляется согласно методическим рекомендациям по определению потребительской корзины для основных социально-демографических групп населения в субъектах Российской Федерации, утвержденным постановлением Правительства Российской Федерации от 28.01.2013 № 54. № 3, 6, 9, 12).

Социально-экономическая дифференциация населения (публикуется в докладах

Распределение общего объема денежных доходов по различным группам населения выражается через долю общего объема денежных доходов, которая приходится на каждую из 20 (10)-процентных групп населения, ранжированного по мере возрастания среднедушевых денежных доходов.

Коэффициент Джини (индекс концентрации доходов) характеризует степень отклонения линии фактического распределения общего объема доходов населения от линии их равномерного распределения. Величина коэффициента может варьировать от 0 до 1, при этом чем выше значение показателя, тем более неравномерно распределены доходы в обществе.

Коэффициент фондов (коэффициент дифференциации доходов) - характеризует степень социального расслоения и определяется как соотношение между средними уровнями денежных доходов $10 \%$ населения с самыми высокими доходами и $10 \%$ населения с самыми низкими доходами.

Распределение населения по величине среднедушевых денежных доходов характеризует дифференциацию населения по уровню материального достатка и представляет собой показатели численности (или долей) постоянного населения, сгруппированные в заданных интервалах по уровню среднедушевых денежных доходов.

Расчеты рядов распределения населения по величине среднедушевых денежных доходов и основанных на них показателей производятся с использованием результатов выборочных обследований домашних хозяйств, проводимых органами государственной статистики во всех субъектах Российской Федерации.

Покупательная способность среднедушевых денежных доходов населения (публикуется в докладах № 3, 6,9, 12) отражает потенциальные возможности населения по приобретению товаров и услуг и выражается через товарный эквивалент среднедушевых денежных доходов. Под товарным эквивалентом понимается количество какого-либо одного товара (услуги) с конкретными потребительскими свойствами, которое может быть приобретено при условии, что вся сумма денежных доходов будет направлена только на эти цели. Показатель рассчитывается нарастающим итогом с начала года.

\section{Занятость и безработица}

Численность рабочей силы - лица в возрасте 15 лет и старше, которые в рассматриваемый период (обследуемую неделю) считаются занятыми или безработными.

Занятые - лица в возрасте 15 лет и старше, которые в обследуемую неделю выполняли любую деятельность (хотя бы один час в неделю), связанную с производством товаров или оказанием услуг за оплату или прибыль. В численность занятых включаются также лица, временно отсутствовавшие на рабочем месте в течение короткого промежутка времени и сохранившие связь с рабочим местом во время отсутствия.

К безработным (в соответствии со стандартами Международной Организации Труда МОТ) относятся лица в возрасте 15 лет и старше, которые в рассматриваемый период удовлетворяли одновременно следующим критериям: а) не имели работы (доходного занятия); б) занимались поиском работы в течение последних четырех недель, используя при этом любые способы 
поиска работы; в) были готовы приступить к работе в течение обследуемой недели. Обучающиеся в образовательных организациях, пенсионеры и инвалиды учитывались в качестве безработных, если они не имели работы, занимались поиском работы и были готовы приступить к ней.

Информация о численности рабочей силы, занятых и общей численности безработных (применительно к стандартам МОТ) подготавливается по материалам выборочных обследований рабочей силы с ежемесячной периодичностью (по состоянию на вторую неделю). Обследование проводится во всех субъектах Российской Федерации на основе выборочного метода наблюдения с последующим распространением итогов на всю численность населения обследуемого возраста. Объем месячной выборки составляет около 77 тыс. человек в возрасте 15 лет и старше и обеспечивает представительные данные по Российской Федерации. В целях повышения репрезентативности данных о численности и составе рабочей силы показатели занятости и безработицы по субъектам Российской Федерации формируются в среднем за три последних месяца.

Уровень безработицы - отношение численности безработных к численности рабочей силы (занятых и безработных), рассчитанное в процентах. колебаний.

Данные о численности и составе рабочей силы приведены без корректировки сезонных

Оценка данных об уровне безработицы с исключением сезонного фактора осуществляется с использованием метода TRAMO-SEATS программы "JDemetra+". Выбор наиболее оптимальной модели осуществляется автоматически. В качестве исходной информации для проведения сезонной корректировки применяются ежемесячные значения уровня безработицы с января 2017 года.

При построении модели не учитываются календарные факторы, т.к. обследование проводится по состоянию на одну (вторую) неделю месяца. В случае попадания праздничного дня на обследуемую неделю, он условно приравнивается к рабочему дню.

Безработные, зарегистрированные в органах службы занятости населения (по данным Роструда), - трудоспособные граждане, не имеющие работы и заработка (трудового дохода), проживающие на территории Российской Федерации, зарегистрированные в органах службы занятости населения по месту жительства в целях поиска подходящей работы, ищущие работу и готовые приступить к ней. Информация о численности безработных, получивших официальный статус в органах службы занятости населения, разрабатывается Федеральной службой по труду и занятости.

Уровень зарегистрированной безработицы - отношение численности безработных, зарегистрированных в органах службы занятости населения (по данным Роструда), к численности рабочей силы в возрасте 15-72 лет, в процентах. Расчет производится по данным Федеральной службы по труду и занятости и Федеральной службы государственной статистики. При исчислении уровня зарегистрированной безработицы по субъектам Российской Федерации используется численность рабочей силы в возрасте 15-72 лет в среднем за предыдущий год.

Число замещенных рабочих мест в организациях определяется как суммарное количество среднесписочной численности работников, средней численности внешних совместителей и средней численности работников, выполнявших работы по договорам гражданско-правового характера. Число замещенных рабочих мест определяется без учета внутреннего совместительства.

Прием и увольнение работников (публикуется в докладах № 1, 4, 7, 10).

В численность принятых работников включаются лица, зачисленные в отчетном периоде в организацию приказом (распоряжением) о приеме на работу, переведенные на работу из другой организации.

В численность работников, принятых на дополнительно введенные (созданные) рабочие места, включаются работники, принятые в отчетном периоде на вновь образованные рабочие места в результате расширения, реорганизации производства, увеличения сменности работы и т.п.

В численность выбывших работников включаются все работники, оставившие работу в организации независимо от оснований (расторжение трудового договора по инициативе работника, инициативе работодателя, истечение срока трудового договора, по соглашению сторон, призыв или поступление на военную службу и др.), уход или перевод которых оформлен приказом (распоряжением). 
Численность требуемых работников на вакантные рабочие места - количество работников, которых предполагается принять на вакантные рабочие места.

В численность работников, работавших неполное рабочее время по инициативе работодателя, включаются работники списочного состава, работавшие в отчетном периоде неполное рабочее время по инициативе работодателя в соответствии со статьей 74 Трудового кодекса Российской Федерации.

В численность работников, работавших неполное рабочее время по соглашению между работником и работодателем, включаются работники (в целых единицах), работавшие в режиме неполного рабочего дня (недели), установленного как при приеме на работу, так и переведенные с согласия работника на неполное рабочее время.

В численность работников, находившихся в простое по вине работодателя и по причинам, не зависящим от работодателя и работника, включаются работники, находившиеся в простое полный рабочий день по причинам: не обеспечение работников оборудованием, инструментами, технической документацией, объемом работ, необходимыми для исполнения трудовых обязанностей, невыполнение договорных обязательств перед партнерами, приведшее к срыву графика поставки сырья или вывоза готовой продукции со склада, обстоятельства непредвиденного характера, например, аварии или перебои в подаче воды, тепла, электроэнергии, стихийные бедствия и т.п.

В численность работников, которым были предоставлены отпуска без сохранения заработной платы по заявлению работника, включаются работники, которым были предоставлены по их письменному заявлению отпуска без сохранения заработной платы по семейным обстоятельствам или другим уважительным причинам, в случаях, предусмотренных законодательством Российской Федерации, а также неоплаченные отпуска по инициативе работодателя.

Нагрузка незанятого населения на 100 заявленных вакансий рассчитывается как отношение численности лиц, не занятых трудовой деятельностью, состоящих на учете в органах службы занятости населения (по данным Роструда), к 100 вакансиям, сообщенным работодателями в эти органы.

Заявленная работодателями потребность в работниках - число вакансий (требуемых работников), сообщенных работодателями в органы службы занятости населения.

Под забастовкой подразумевается временный добровольный отказ работников от исполнения трудовых обязанностей (полностью или частично) в целях разрешения коллективного трудового спора. Забастовкой не считается приостановка работы из-за недопоставки оборудования, сырья, материалов, комплектующих деталей по причине забастовки в организациях-поставщиках.

Началом забастовки или окончанием забастовки считается дата принятия решения о начале или окончании забастовки на собрании трудового коллектива.

В численность работников, принимавших участие в забастовках, не входят работники, отсутствовавшие на своих рабочих местах по таким причинам, как болезнь, ежегодный отпуск, командировка и т.п.

Количество времени, не отработанное работниками, принимавшими участие в забастовках, определяется по каждой организации как количество времени, не отработанного вовлеченными работниками за каждый день забастовки.

7, 10).

Численность иностранных трудовых мигрантов (публикуется в докладах № 1, 4,

Сведения об осуществлении трудовой деятельности иностранными гражданами разрабатываются Министерством внутренних дел Российской Федерации на основании разрешений на работу, выданных иностранным гражданам, прибывшим в визовом порядке въезда, а также патентов на осуществление трудовой деятельности, выданных иностранным гражданам, прибывшим в порядке, не требующем получения визы.

В сведения об иностранных гражданах не включаются граждане Республики Беларусь, в отношении которых порядок регулирования привлечения иностранной рабочей силы не применяется. Граждане Республики Армения, Республики Казахстан, Киргизской Республики также осуществляют трудовую деятельность без разрешительных документов (разрешений на работу, патентов). По данным странам приведена численность по тем гражданам, которым выдается 
разрешение на работу или патент (являются квалифицированными специалистами или студентами, работающими во время обучения).

Численность иностранных граждан, получивших разрешение на работу, включает численность иностранных граждан, которые прибыли в Российскую Федерацию в порядке, требующем получения визы, в рамках квоты; квалифицированных специалистов; иностранных граждан, обучающихся в Российской Федерации по очной форме в профессиональной образовательной организации или образовательной организации высшего образования по основной профессиональной образовательной программе, имеющей государственную аккредитацию; иностранных граждан, прибывших для работы в организациях, зарегистрированных в государствах - членах ВТО и получивших разрешение на работу.

Численность иностранных граждан - высококвалифицированных специалистов, имеющих действующее разрешение на работу - количество иностранных граждан, относящихся к категории высококвалифицированных специалистов (критерии отнесения определены Федеральным законом от 25.07.2002 № 115-Ф3 "О правовом положении иностранных граждан в Российской Федерации"), у которых не истек срок действия и (или) не было аннулировано разрешение на работу на территории Российской Федерации.

Численность иностранных граждан, получивших патент, включает численность иностранных граждан, прибывших в Российскую Федерацию в порядке, не требующем получения визы, и получивших патент, подтверждающий право на временное осуществление на территории субъекта Российской Федерации трудовой деятельности у физических и юридических лиц, индивидуальных предпринимателей и иных лиц, чья деятельность подлежит регистрации. В численность иностранных граждан, получивших патент, включается численность иностранных граждан, переоформивших патент.

\section{Окружающая среда}

(публикуется в докладах № 3, 6, 9, 12)

\section{Приватизация жилья}

(публикуется в докладе № 2)

\section{Образование}

(публикуется в докладе № 12)

В разделе приведены данные, формируемые Министерством просвещения Российской Федерации об организациях, осуществлящих образовательную деятельность по образовательным программам начального общего, основного общего, среднего общего образования, профессиональных образовательных организациях, и данные, формируемые Министерством науки и высшего образования об образовательных организациях высшего образования.

Общее образование может быть получено в общеобразовательных организациях, профессиональных образовательных организациях, образовательных организациях высшего образования, иных организациях. К иным организациям относятся организации, осуществляющие обучение по образовательным программам начального общего образования, основного общего образования, среднего общего образования в качестве дополнительной к своей основной деятельности.

Среднее профессиональное образование по программам подготовки квалифицированных рабочих, служащих может быть получено в профессиональных образовательных организациях и образовательных организациях высшего образования, осуществляющих образовательную деятельность по образовательным программам подготовки квалифицированных рабочих, служащих; по программам подготовки специалистов среднего звена - в профессиональных образовательных организациях и образовательных организациях высшего образования, осуществляющих образовательную деятельность по образовательным программам подготовки специалистов среднего звена. 
Высшее образование по программам бакалавриата, специалитета и магистратуры может быть получено в образовательных организациях высшего образования и научных организациях по программам магистратуры: высшее образование по подготовке кадров высшей квалификации по программам подготовки научно-педагогических кадров в аспирантуре - в образовательных организациях высшего образования, организациях дополнительного профессионального образования, научных организациях и иных организациях.

В общую численность студентов, обучающихся по программам подготовки квалифицированных рабочих, служащих, специалистов среднего звена, программам бакалавриата, специалитета и магистратуры включены иностранные граждане, обучающиеся в Российской Федерации на условиях общего приема. С 2013г. - иностранные граждане и лица без гражданства, обучающиеся в Российской Федерации как на условиях общего приема, так и по международным соглашениям.

\section{Правонарушения}

Информация о незаконном производстве и обороте этилового спирта и алкогольной продукции (публикуется в докладах № 1, 4, 7, 10) формируется по данным квартальной формы федерального статистического наблюдения № 3-АЛК (прав) "Сведения о результатах проверок по выявлению незаконного производства и оборота этилового спирта и алкогольной продукции", утвержденной приказом Росстата от 06.09.2010 № 306.

Информация об административных правонарушениях в сфере экономики (публикуется в докладе № 5) формируется по данным годовой формы федерального статистического наблюдения № 1- АЭ "Сведения об административных правонарушениях в сфере экономики", утвержденной приказом Росстата от 22.07.2019 № 418.

Информация о числе зарегистрированных преступлений в разрезе субъектов Российской Федерации размещается в информационно-телекоммуникационной сети "Интернет" на официальном сайте Министерства внутренних дел Российской Федерации (https://мвд.pф) в разделе "Статистика и аналитика".

\section{Демография}

Естественное движение населения - обобщенное название совокупности рождений и смертей, изменяющих численность населения так называемым естественным путем. К естественному движению населения относят также браки и разводы, хотя они не меняют численность населения, но учитываются в том же порядке, что и рождения и смерти.

Сведения о рождениях, смертях, браках, разводах получаются на основании статистической разработки данных, содержащихся в записях актов о рождении, смерти, заключении и расторжении брака, составляемых органами записи актов гражданского состояния (далее ЗАГС). В число родившихся включены только родившиеся живыми.

Предварительные (помесячные) данные разрабатываются по дате регистрации события в органах ЗАГС без учета окончательных медицинских свидетельств о смерти. Годовые данные разрабатываются по дате свершения события с учетом запоздалой регистрации и окончательных медицинских свидетельств о смерти.

Источником информации о причинах смерти являются записи в медицинских свидетельствах о смерти, составляемых врачом относительно заболевания, несчастного случая, убийства, самоубийства и другого внешнего воздействия, послужившего причиной смерти, а также записи актов о смерти.

С 1 января 2011 г. разработка записей актов о смерти по причинам производится применительно к Краткой номенклатуре причин смерти 2010, основанной на Международной статистической классификации болезней и проблем, связанных со здоровьем, Х пересмотра (1989г.).

В соответствии со статьей 13.1 Федерального закона "Об актах гражданского состояния" от 15.11.1997 № 143-Ф3 с 1 октября 2018 г. был введен в действие Единый государственный 
реестр записей актов гражданского состояния (ЕГР ЗАГС). Согласно статье 13.2 указанного Федерального закона Росстат с 1 октября 2018 г. получает сведения о государственной регистрации рождений, смертей, заключения и расторжения браков из данного реестра. № 1, 3-12).

Коэффициенты естественного движения населения (публикуются в докладах

Общие коэффициенты рождаемости и смертности - отношение соответственно числа родившихся (живыми) и числа умерших к среднегодовой численности населения. Исчисляю на 1000 человек населения.

Коэффициент естественного прироста - разность общих коэффициентов рождаемости и смертности.

Общие коэффициенты брачности и разводимости - отношение числа зарегистрированных браков и разводов к среднегодовой численности населения. Исчисляются на 1000 человек населения.

Коэффициенты смертности по причинам смерти - отношение числа умерших от указанных причин смерти к среднегодовой численности населения. Исчисляются на 100000 человек населения.

Коэффициент младенческой смертности исчисляется как сумма двух составляющих, первая из которых - отношение числа умерших в возрасте до одного года из поколения родившихся в том году, для которого вычисляется коэффициент, к общему числу родившихся в том же году; а вторая - отношение числа умерших в возрасте до одного года из поколения родившихся в предыдущем году, к общему числу родившихся в предыдущем году. Исчисляется на 1000 родившихся живыми.

Все коэффициенты приведены в пересчете на год.

Миграция (публикуется в докладах № 1, 4-12).

Данные о миграции получены в результате разработки поступающих от территориальных органов Министерства внутренних дел Российской Федерации форм федерального статистического наблюдения (с 2019 г.), которые составляются при регистрации и снятии с регистрационного учета населения по месту жительства и при регистрации по месту пребывания на срок 9 месяцев и более. Формирование числа выбывших осуществляется автоматически в процессе электронной обработки данных о миграции населения при перемещениях в пределах Российской Федерации, а также по истечении срока пребывания у мигрантов независимо от места прежнего жительства.

Сведения о вынужденных переселенцах, беженцах и лицах, получивших временное убежище (публикуются в докладах № 1, 4, 7, 10) приведены по данным МВД России в отношении лиц, официально получивших этот статус в его региональных подразделениях.

Временное убежище - это возможность иностранного гражданина или лица без гражданства временно пребывать на территории Российской Федерации в соответствии с нормативными правовыми актами Российской Федерации. Временное убежище предоставляется иностранному гражданину или лицу без гражданства, если они имеют основания для признания беженцем, но ограничиваются заявлением в письменной форме с просьбой о предоставлении возможности временно пребывать на территории Российской Федерации или не имеют оснований для признания беженцем, но из гуманных побуждений не могут быть выдворены (депортированы) за пределы территории Российской Федерации. 


\section{НЕКОТОРЫЕ СТАТИСТИЧЕСКИЕ ПОКАЗАТЕЛИ СОЦИАЛЬНО- ЭКОНОМИЧЕСКОГО ПОЛОЖЕНИЯ СУБЬЕКТОВ РОССИЙСКОЙ ФЕДЕРАЦИИ}


ПРОМЫШЛЕННОЕ ПРОИЗВОДСТВО

ИНДЕКС ПРОМЫШЛЕННОГО ПРОИЗВОДСТВА

\begin{tabular}{|c|c|c|}
\hline & $\begin{array}{c}\text { Январь-сентябрь } 20202 . \\
\text { в\% к } \\
\text { январю-сентябрю } 20192 .\end{array}$ & $\begin{array}{c}\text { Сентябрь } 2020 \text { г. } \\
\text { \%\% к } \\
\text { сентябрю } 2019 \text { г. }\end{array}$ \\
\hline Российская Федерация & 97,1 & 95,0 \\
\hline Центральный федеральный округ & 103,6 & 103,5 \\
\hline Белгородская область & 101,8 & 101,3 \\
\hline Брянская область & 98,1 & 98,1 \\
\hline Владимирская область & 113,2 & 130,5 \\
\hline Воронежская область & 106,8 & 92,9 \\
\hline Ивановская область & 102,5 & 105,6 \\
\hline Калужская область & 96,1 & 92,3 \\
\hline Костромская область & 84,9 & 95,5 \\
\hline Курская область & 98,6 & 91,8 \\
\hline Липецкая область & 103,4 & 100,8 \\
\hline Московская область & 105,7 & 108,9 \\
\hline Орловская область & 103,5 & 112,3 \\
\hline Рязанская область & 103,7 & 101,5 \\
\hline Смоленская область & 103,3 & 98,3 \\
\hline Тамбовская область & 107,0 & 91,0 \\
\hline Тверская область & 93,8 & 94,2 \\
\hline Тульская область & 116,3 & 97,4 \\
\hline Ярославская область & 99,3 & 97,8 \\
\hline г. Москва & 103,2 & 104,0 \\
\hline Северо-Западный федеральный округ & 97,0 & 94,8 \\
\hline Республика Карелия & 122,1 & 127,2 \\
\hline Республика Коми & 94,0 & 86,2 \\
\hline Архангельская область & 91,2 & 67,2 \\
\hline $\begin{array}{l}\text { в том числе: } \\
\text { Ненецкий авт. округ }\end{array}$ & 88,9 & 69,6 \\
\hline Архангельская область без авт. округа & 94,7 & 64,9 \\
\hline Вологодская область & 101,6 & 100,5 \\
\hline Калининградская область & 90,8 & 110,0 \\
\hline Ленинградская область & 99,3 & 106,6 \\
\hline Мурманская область & 97,1 & 94,4 \\
\hline Новгородская область & 98,3 & 93,3 \\
\hline Псковская область & 99,7 & 95,8 \\
\hline г. Санкт-Петербург & 96,3 & 100,5 \\
\hline Южный федеральный округ & 98,6 & 100,3 \\
\hline Республика Адыгея & 106,2 & 104,4 \\
\hline Республика Калмыкия & 95,3 & 91,6 \\
\hline Республика Крым & 100,7 & 110,2 \\
\hline Краснодарский край & 99,0 & 93,3 \\
\hline Астраханская область & 98,6 & 108,8 \\
\hline Волгоградская область & 97,7 & 92,5 \\
\hline Ростовская область & 100,3 & 106,7 \\
\hline г. Севастополь & 72,1 & 96,4 \\
\hline Северо-Кавказский федеральный округ & 108,3 & 125,5 \\
\hline Республика Дагестан & 100,1 & 92,7 \\
\hline Республика Ингушетия & 107,3 & 58,3 \\
\hline Кабардино-Балкарская Республика & 114,4 & 95,1 \\
\hline Карачаево-Черкесская Республика & 88,4 & 79,4 \\
\hline Республика Северная Осетия - Алания & 130,7 & 164,6 \\
\hline Чеченская Республика & 106,6 & 99,0 \\
\hline Ставропольский край & 114,7 & 188,7 \\
\hline
\end{tabular}




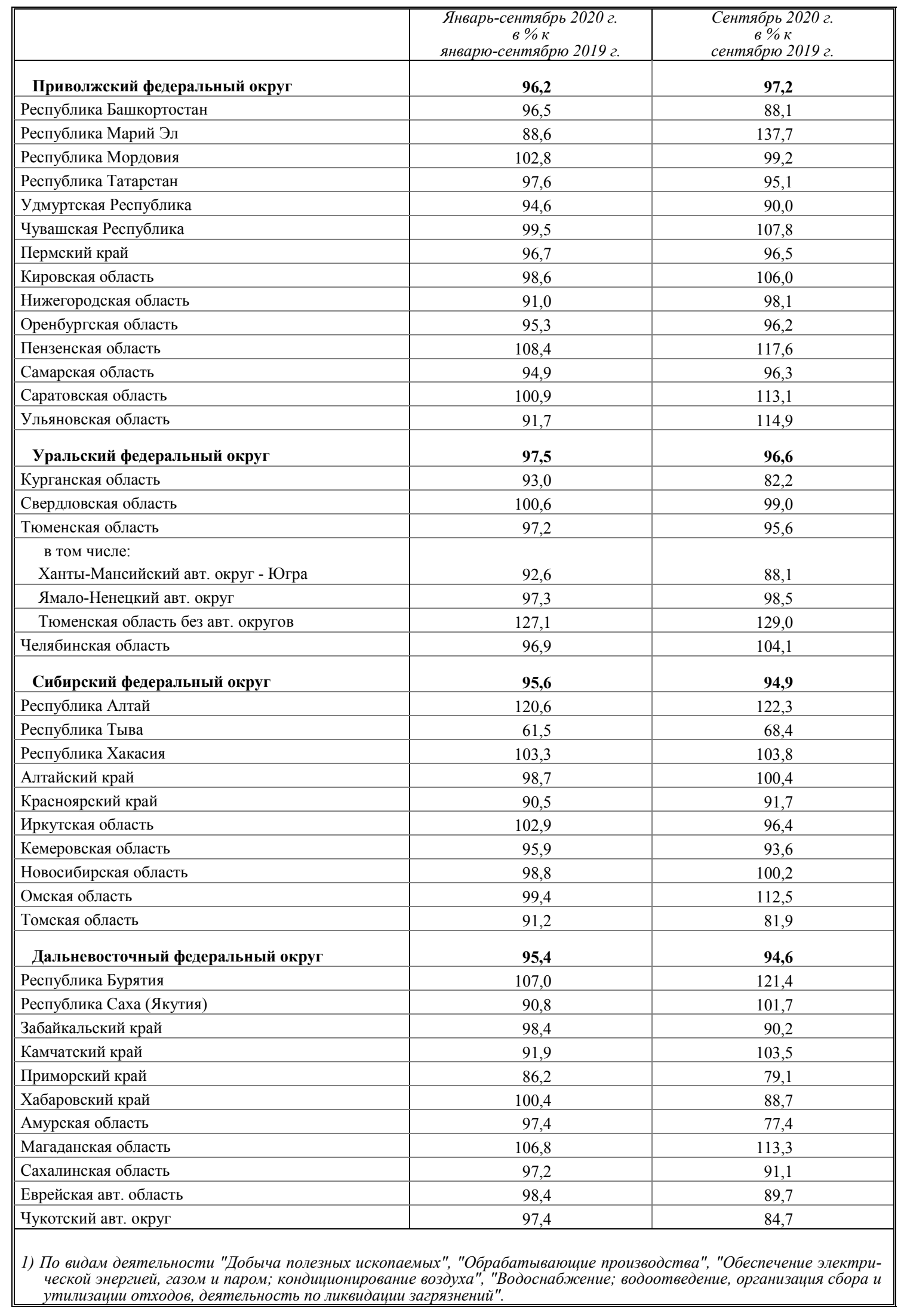


ИНДЕКС ПРОИЗВОДСТВА

ПО ВИДАМ ЭКОНОМИЧЕСКОЙ ДЕЯТЕЛЬНОСТИ

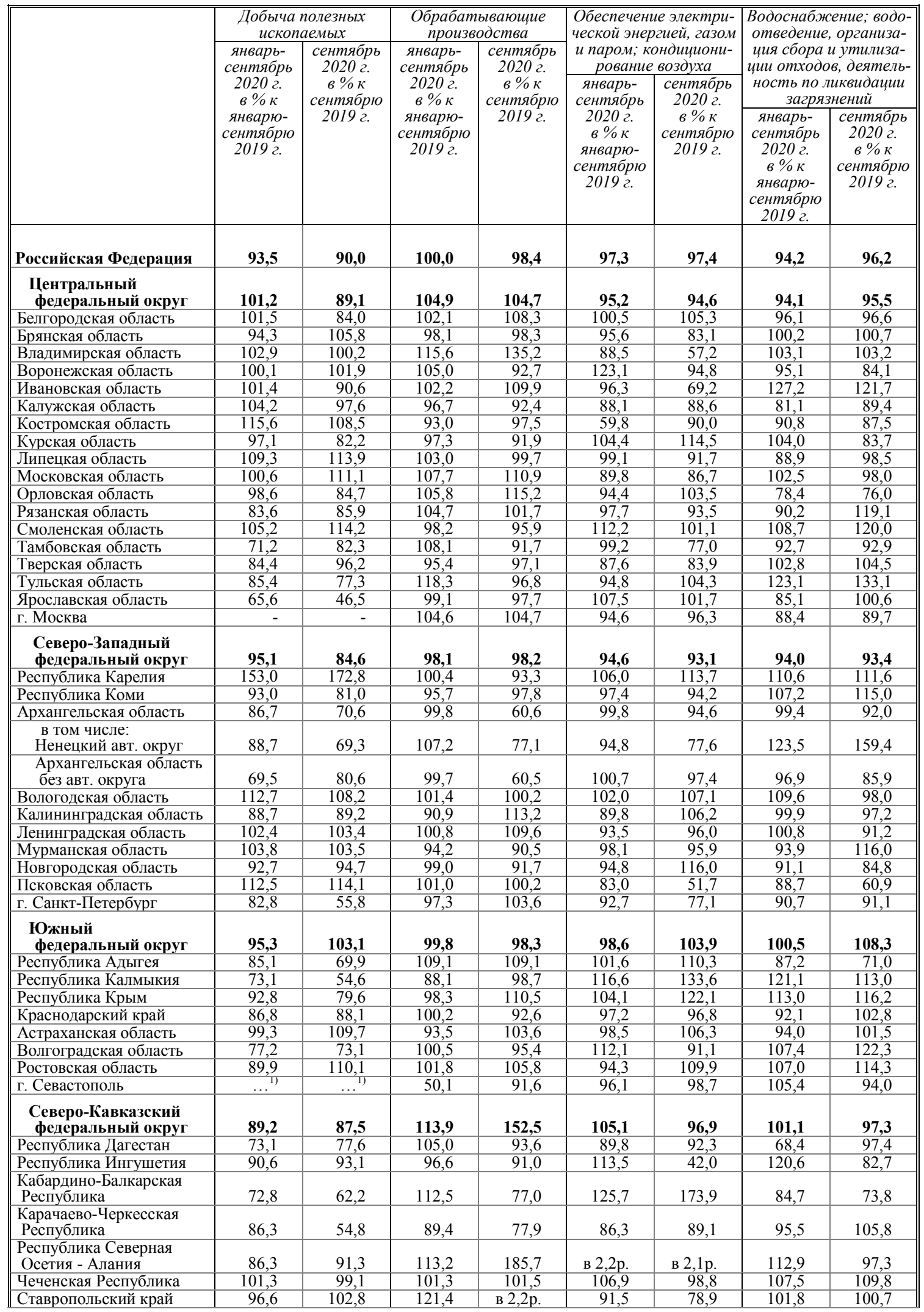




\begin{tabular}{|c|c|c|c|c|c|c|c|c|}
\hline & \multicolumn{2}{|c|}{$\begin{array}{c}\text { Добыча полезньхх } \\
\text { ископаемыхх }\end{array}$} & \multicolumn{2}{|c|}{$\begin{array}{c}\text { Обрабатьваюиие } \\
\text { производства }\end{array}$} & \multirow{2}{*}{\multicolumn{2}{|c|}{$\begin{array}{c}\text { Обеспечение электри- } \\
\text { ческой энергией, газом } \\
\text { и паром; кондициони- } \\
\text { рование воздуха }\end{array}$}} & \multirow{3}{*}{\multicolumn{2}{|c|}{$\begin{array}{c}\text { Водоснабжение; водо- } \\
\text { отведение, организа- } \\
\text { ция сбора и утилиза- } \\
\text { ции отходов, деятель- } \\
\text { ность по ликвидациии } \\
\text { загрязнений } \\
\end{array}$}} \\
\hline & \multirow{3}{*}{$\begin{array}{c}\text { январь- } \\
\text { сентябрь } \\
2020 \text { г. } \\
\text { в\% к } \\
\text { январю- } \\
\text { сентябрю } \\
20192 .\end{array}$} & \multirow{3}{*}{$\begin{array}{c}\text { сентябрь } \\
2020 \text { г. } \\
\text { в\% к } \\
\text { сентябрю } \\
2019 \text { г. }\end{array}$} & \multirow{3}{*}{$\begin{array}{c}\text { январь- } \\
\text { сентябрь } \\
2020 \text { г. } \\
\text { в\% к } \\
\text { январю- } \\
\text { сентябрю } \\
2019 \text { г. }\end{array}$} & \multirow{3}{*}{$\begin{array}{c}\text { сентябрь } \\
2020 \text { г. } \\
\text { в\% } \\
\text { сентябрю } \\
20192 .\end{array}$} & & & & \\
\hline & & & & & \multirow{2}{*}{\begin{tabular}{|c|} 
январь- \\
сентябрь \\
2020 г. \\
в \% к \\
январю- \\
сентябрю \\
20192. \\
\end{tabular}} & \multirow{2}{*}{\begin{tabular}{|c|} 
сентябрь \\
20202. \\
в\% \% \\
сентябрю \\
20192.
\end{tabular}} & & \\
\hline & & & & & & & \begin{tabular}{|c|} 
январь- \\
сентябрь \\
2020 г. \\
в\% \% \\
январю- \\
сентябрю \\
20192. \\
\end{tabular} & $\begin{array}{c}\text { сентябрь } \\
2020 \text { г. } \\
\text { в\% к } \\
\text { сентябрю } \\
20192 .\end{array}$ \\
\hline $\begin{array}{l}\text { Приволжский } \\
\text { федеральный округ }\end{array}$ & 92,5 & 91,1 & 98,1 & 100,7 & 95,0 & 94,7 & 94,0 & 101,9 \\
\hline Республика Башкортостан & 92,4 & 78,0 & 97,0 & 88,4 & 93,4 & 94,3 & 110,9 & 112,1 \\
\hline Республика Марий Эл & 111,5 & 99,3 & 87,7 & 141,3 & 92,4 & 85,2 & 123,5 & 106,8 \\
\hline Республика Мордовия & 100,9 & 117,8 & 105,7 & 101,9 & 86,3 & 75,5 & 69,7 & 78,7 \\
\hline Республика Татарстан & 89,8 & 88,1 & 104,3 & 101,6 & 84,0 & 71,7 & 90,1 & 104,1 \\
\hline Удмуртская Республика & 92,5 & 85,5 & 97,6 & 94,7 & 90,8 & 92,7 & 119,1 & 125,7 \\
\hline Чувашская Республика & 101,0 & 105,5 & 97,9 & 108,3 & 112,4 & 109,7 & 96,2 & 85,7 \\
\hline Пермский край & 95,2 & 94,3 & 98,7 & 98,7 & 89,4 & 89,0 & 93,5 & 95,9 \\
\hline Кировская область & 105,9 & 116,8 & 99,1 & 107,4 & 93,2 & 88,0 & 100,3 & 101,8 \\
\hline Нижегородская область & 94,2 & 108,6 & 90,5 & 98,0 & 96,6 & 101,6 & 87,0 & 92,3 \\
\hline Оренбургская область & 94,7 & 94,6 & 95,7 & 98,0 & 97,7 & 103,8 & 116,0 & 144,1 \\
\hline Пензенская область & 99,7 & 99,3 & 109,7 & 118,6 & 96,2 & 102,1 & 102,7 & 115,3 \\
\hline Самарская область & 96,5 & 94,9 & 93,4 & 99,1 & 101,4 & 87,1 & 79,1 & 84,5 \\
\hline Саратовская область & 91,6 & 86,8 & 101,6 & 114,7 & 102,6 & 121,0 & 104,9 & 113,9 \\
\hline Ульяновская область & 64,7 & 96,0 & 93,4 & 118,2 & 85,9 & 67,8 & 93,3 & 110,3 \\
\hline $\begin{array}{l}\text { Уральский } \\
\text { федеральный округ }\end{array}$ & 94,0 & 92,1 & 105,8 & 105,8 & 91,6 & 90,1 & 105,7 & 113,2 \\
\hline Курганская область & 100,7 & 81,6 & 95,9 & 83,3 & 80,3 & 70,0 & 89,9 & 120,2 \\
\hline Свердловская область & 102,1 & 103,4 & 100,9 & 98,6 & 98,6 & 97,0 & 98,8 & 111,1 \\
\hline Тюменская область & 93,7 & 91,5 & 114,8 & 114,6 & 89,7 & 87,7 & 115,9 & 124,4 \\
\hline $\begin{array}{l}\text { в том числе: } \\
\text { Ханты-Мансийский } \\
\text { авт. округ - Югра }\end{array}$ & 91,3 & 85,9 & 99,1 & 97,4 & 86,2 & 85,6 & 114,1 & 107,4 \\
\hline $\begin{array}{l}\text { Ямало-Ненецкий } \\
\text { авт. округ }\end{array}$ & 97,0 & 98,5 & 100,2 & 99,1 & 95,3 & 90,7 & 114,7 & 120,6 \\
\hline $\begin{array}{l}\text { Тюменская область } \\
\text { без авт. округов }\end{array}$ & 91,9 & 91,0 & 166,2 & 165,3 & 94,2 & 90,9 & 120,6 & 168,2 \\
\hline Челябинская область & 119,0 & 160,5 & 95,6 & 100,7 & 86,5 & 87,7 & 106,6 & 107,0 \\
\hline $\begin{array}{l}\text { Сибирский } \\
\text { федеральный округ }\end{array}$ & 91,9 & 86,6 & $\mathbf{9 7 , 8}$ & 100,2 & $\mathbf{9 7 , 4}$ & 100,5 & 129,1 & 146,7 \\
\hline Республика Алтай & 94,5 & 68,8 & 138,9 & 141,3 & 100,6 & 102,4 & 128,9 & 143,4 \\
\hline Республика Тыва & 56,5 & 65,0 & 92,1 & 95,5 & 96,8 & 96,8 & 102,1 & 79,4 \\
\hline Республика Хакасия & 104,8 & 106,0 & 100,9 & 93,5 & 105,9 & 114,8 & 91,3 & 97,0 \\
\hline Алтайский край & 113,9 & 96,6 & 99,1 & 100,3 & 87,7 & 103,9 & 105,0 & 100,2 \\
\hline Красноярский край & 87,8 & 82,6 & 91,7 & 96,1 & 95,3 & 98,4 & 95,5 & 164,0 \\
\hline Иркутская область & 99,6 & 93,7 & 112,4 & 104,1 & 102,5 & 95,8 & 99,1 & 93,3 \\
\hline Кемеровская область & 92,6 & 90,0 & 96,7 & 92,9 & 92,0 & 100,6 & в 2,6p. & в 2,7p. \\
\hline Новосибирская область & 89,8 & 91,9 & 101,3 & 101,5 & 97,5 & 100,0 & 104,6 & 118,3 \\
\hline Омская область & 73,8 & 83,9 & 99,8 & 113,5 & 95,4 & 99,5 & 106,7 & 104,5 \\
\hline Томская область & 83,0 & 64,3 & 105,8 & 111,2 & 91,8 & 87,5 & 100,7 & 91,8 \\
\hline $\begin{array}{l}\text { Дальневосточный } \\
\text { федеральный округ }\end{array}$ & 95,2 & 95,7 & 93,2 & 90,1 & 100,5 & 98,3 & 105,0 & 113,9 \\
\hline Республика Бурятия & 110,7 & 99,9 & 108,5 & 134,7 & 89,5 & 96,3 & 123,9 & 132,4 \\
\hline Республика Саха (Якутия) & 90,2 & 101,6 & 87,2 & 91,0 & 99,0 & 96,9 & 109,5 & 176,9 \\
\hline Забайкальский край & 97,6 & 87,5 & 104,4 & 105,8 & 99,4 & 98,3 & 88,6 & 95,1 \\
\hline Камчатский край & 108,9 & 127,3 & 88,1 & 100,6 & 99,1 & 99,1 & 97,3 & 67,3 \\
\hline Приморский край & 95,7 & 85,9 & 80,2 & 73,8 & 99,5 & 100,2 & 114,3 & 113,8 \\
\hline Хабаровский край & 102,0 & 95,7 & 99,1 & 81,4 & 101,1 & 104,6 & 102,4 & 101,8 \\
\hline Амурская область & 96,2 & 74,0 & 91,7 & 63,9 & 106,3 & 97,4 & 100,8 & 100,5 \\
\hline Магаданская область & 104,5 & 112,4 & 168,7 & 161,2 & 103,8 & 105,6 & 102,2 & 102,9 \\
\hline Сахалинская область & 96,8 & 90,8 & 102,6 & 95,7 & 104,6 & 97,7 & 102,5 & 101,5 \\
\hline Еврейская авт. область & 102,7 & 84,9 & 88,5 & 104,8 & 99,2 & 83,3 & 92,5 & 89,5 \\
\hline Чукотский авт. округ & 96,3 & 79,9 & 91,0 & в 2,1p. & 102,2 & 90,2 & 97,5 & 86,4 \\
\hline
\end{tabular}




\section{ОБЪЕМ ОТГРУЖЕННЫХ ТОВАРОВ СОБСТВЕННОГО ПРОИЗВОДСТВА, \\ ВЫПОЛНЕННЫХ РАБОТ И УСЛУГ СОБСТВЕННЫМИ СИЛАМИ ПО ВИДУ ЭКОНОМИЧЕСКОЙ ДЕЯТЕЛЬНОСТИ "ДОБЫЧА ПОЛЕЗНЫХ ИСКОПАЕМЫХ"}

в действующих ценах

\begin{tabular}{|c|c|c|c|c|}
\hline & \multicolumn{2}{|c|}{ Снварь-сентябрь 2020 г. } & \multirow{2}{*}{$\begin{array}{c}\text { Сентябрь } 2020 z . \\
\text { в\% к } \\
\text { сентябрю } 20192 .\end{array}$} & \multirow{2}{*}{$\begin{array}{c}\text { Справочно } \\
\text { январь-сентябрь } \\
2019 \text { г., } \\
\text { млн рублей } \\
\end{array}$} \\
\hline & млн рублей & \begin{tabular}{|c|}
$6 \% \kappa$ \\
январю-сентябрю \\
20192. \\
\end{tabular} & & \\
\hline Российская Федерация, млрд рублей & 10253 & 74,3 & 82,5 & 13805 \\
\hline Центральный федеральный округ & 1064408 & 58,9 & 71,9 & 1808162 \\
\hline Белгородская область & 128197 & 92,2 & 90,6 & 139108 \\
\hline Брянская область & 273 & 113,7 & 95,2 & 240 \\
\hline Владимирская область & 3708 & 97,4 & 82,7 & 3806 \\
\hline Воронежская область & 5870 & 98,7 & 96,3 & 5947 \\
\hline Ивановская область & 871 & 106,6 & 133,6 & 817 \\
\hline Калужская область & 2467 & 87,8 & 83,4 & 2809 \\
\hline Костромская область & 591 & 131,8 & 151,5 & 448 \\
\hline Курская область & 68836 & 78,7 & 129,6 & 87460 \\
\hline Липецкая область & 5310 & 95,9 & 94,6 & 5538 \\
\hline Московская область & 9470 & 93,7 & 99,1 & 10102 \\
\hline Орловская область & 176 & 77,8 & 76,0 & 227 \\
\hline Рязанская область & 1021 & 83,6 & 89,1 & 1222 \\
\hline Смоленская область & 1177 & 98,3 & 131,6 & 1197 \\
\hline Тамбовская область & 78,1 & 86,0 & 99,2 & 90,9 \\
\hline Тверская область & 687 & 93,1 & 45,6 & 738 \\
\hline Тульская область & 5454 & 101,9 & 96,8 & 5351 \\
\hline Ярославская область & 1275 & 149,6 & 152,4 & 852 \\
\hline г. Москва & 828945 & 53,8 & 66,4 & 1542210 \\
\hline Северо-Западный федеральный округ & 635364 & 78,1 & 85,3 & 813313 \\
\hline Республика Карелия & 59798 & 78,9 & 82,6 & 75798 \\
\hline Республика Коми & 212307 & 68,2 & 73,2 & 311076 \\
\hline Архангельская область & 193001 & 68,2 & 72,1 & 283018 \\
\hline $\begin{array}{l}\text { в том числе: } \\
\text { Ненецкий авт. округ }\end{array}$ & 173672 & 67,4 & 65,3 & 257549 \\
\hline Архангельская область без авт. округа & 19328 & 75,9 & 134,1 & 25469 \\
\hline Вологодская область & 585 & 113,1 & 129,2 & 517 \\
\hline Калининградская область & 10435 & 89,5 & 89,7 & 11666 \\
\hline Ленинградская область & 11294 & 101,9 & 101,5 & 11087 \\
\hline Мурманская область & 117316 & 129,0 & 167,0 & 90968 \\
\hline Новгородская область & 816 & 94,1 & 107,8 & 867 \\
\hline Псковская область & 1897 & 120,8 & 132,4 & 1571 \\
\hline г. Санкт-Петербург & 27916 & 104,4 & 44,7 & 26745 \\
\hline Южный федеральный округ & 253848 & 72,0 & 82,0 & 352415 \\
\hline Республика Адыгея & 2270 & 91,2 & 66,0 & 2489 \\
\hline Республика Калмыкия & $\ldots{ }^{1)}$ & $\ldots{ }^{1)}$ & $\ldots{ }^{1)}$ & $\ldots{ }^{1)}$ \\
\hline Республика Крым & 7115 & 89,1 & 68,3 & 7984 \\
\hline Краснодарский край & 17125 & 89,5 & 81,6 & 19134 \\
\hline Астраханская область & 175907 & 70,8 & 82,5 & 248372 \\
\hline Волгоградская область & 25461 & 54,9 & 69,4 & 46362 \\
\hline Ростовская область & 24170 & 94,7 & 103,4 & 25516 \\
\hline г. Севастополь & ${ }^{1)}$ & $\ldots{ }^{1)}$ & $\ldots^{1)}$ & $\ldots^{1)}$ \\
\hline $\begin{array}{c}\text { Северо-Кавказский } \\
\text { федеральный округ }\end{array}$ & 16799 & 90,9 & 93,6 & 18472 \\
\hline Республика Дагестан & 2450 & 64,3 & 67,4 & 3811 \\
\hline Республика Ингушетия & 560 & 67,4 & 97,1 & 831 \\
\hline Кабардино-Балкарская Республика & 150 & 96,9 & 71,6 & 155 \\
\hline Карачаево-Черкесская Республика & 2041 & 103,8 & 121,3 & 1965 \\
\hline Республика Северная Осетия - Алания & 395 & 85,3 & 102,7 & 463 \\
\hline Чеченская Республика & 3438 & 100,1 & 89,7 & 3436 \\
\hline Ставропольский край & 7765 & 99,4 & 99,4 & 7811 \\
\hline
\end{tabular}




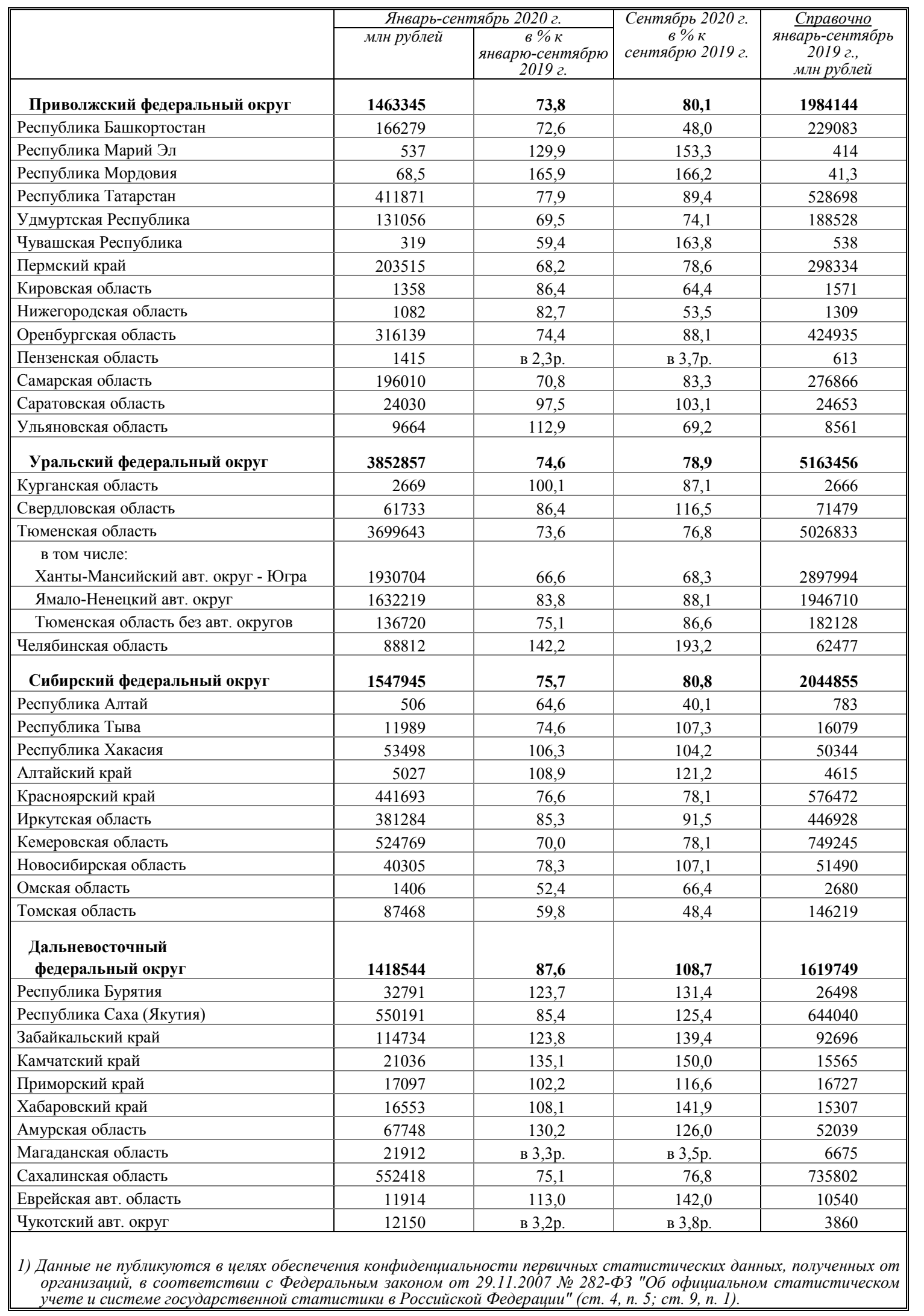




\section{ОБЪЕМ ОТГРУЖЕННЫХ ТОВАРОВ СОБСТВЕННОГО ПРОИЗВОДСТВА, ВЫПОЛНЕННЫХ РАБОТ И УСЛУГ СОБСТВЕННЫМИ СИЛАМИ ПО ВИДУ ЭКОНОМИЧЕСКОЙ ДЕЯТЕЛЬНОСТИ "ОБРАБАТЫВАЮЩИЕ ПРОИЗВОДСТВА"}

в действующих ценах

\begin{tabular}{|c|c|c|c|c|}
\hline & \multicolumn{2}{|c|}{ Снварь-сентябрь 2020 г. } & \multirow{2}{*}{$\begin{array}{c}\text { Сентябрь } 2020 \text { z. } \\
\text { в\% к } \\
\text { сентябрю } 2019 \text { г. }\end{array}$} & \multirow{2}{*}{$\begin{array}{c}\text { Справочно } \\
\text { январь-сентябрь } \\
2019 \text { г., } \\
\text { млн рублей } \\
\end{array}$} \\
\hline & млн рублей & $\begin{array}{c}\text { в\% к } \\
\text { январю-сентябрю } \\
20192 . \\
\end{array}$ & & \\
\hline Российская Федерация, млрд рублей & 31425 & 97,6 & 103,3 & 32198 \\
\hline Центральный федеральный округ & 10645461 & 102,0 & 106,2 & 10439557 \\
\hline Белгородская область & 528034 & 103,8 & 120,2 & 508634 \\
\hline Брянская область & 176734 & 100,2 & 105,9 & 176444 \\
\hline Владимирская область & 362705 & 106,9 & 107,8 & 339450 \\
\hline Воронежская область & 375551 & 115,0 & 102,1 & 326633 \\
\hline Ивановская область & 122824 & 108,2 & 127,0 & 113542 \\
\hline Калужская область & 590701 & 98,2 & 104,2 & 601461 \\
\hline Костромская область & 98515 & 95,0 & 92,2 & 103737 \\
\hline Курская область & 145774 & 104,1 & 116,7 & 140022 \\
\hline Липецкая область & 522351 & 102,6 & 102,8 & 509248 \\
\hline Московская область & 2058988 & 104,8 & 114,8 & 1964755 \\
\hline Орловская область & 89473 & 103,3 & 106,4 & 86647 \\
\hline Рязанская область & 228514 & 102,6 & 94,1 & 222645 \\
\hline Смоленская область & 153953 & 103,5 & 101,5 & 148769 \\
\hline Тамбовская область & 129978 & 111,3 & 106,6 & 116764 \\
\hline Тверская область & 229526 & 94,4 & 97,9 & 243233 \\
\hline Тульская область & 573135 & 120,9 & 117,4 & 473905 \\
\hline Ярославская область & 279313 & 101,7 & 98,0 & 274648 \\
\hline г. Москва & 3979393 & 97,3 & 101,4 & 4089019 \\
\hline $\begin{array}{l}\text { Северо-Западный } \\
\text { федеральный округ }\end{array}$ & 4386883 & 101,6 & 111,2 & 4319834 \\
\hline Республика Карелия & 87471 & 96,0 & 102,9 & 91078 \\
\hline Республика Коми & 136630 & 87,7 & 96,4 & 155765 \\
\hline Архангельская область & 168315 & 110,6 & 91,6 & 152184 \\
\hline $\begin{array}{l}\text { в том числе: } \\
\text { Ненецкий авт. округ }\end{array}$ & 1223 & 12,1 & 75,7 & 10130 \\
\hline Архангельская область без авт. округа & 167092 & 117,6 & 91,9 & 142054 \\
\hline Вологодская область & 519646 & 97,6 & 107,6 & 532449 \\
\hline Калининградская область & 406697 & 92,0 & 112,5 & 441975 \\
\hline Ленинградская область & 741064 & 94,4 & 118,4 & 785074 \\
\hline Мурманская область & 512661 & в 2,9p. & 195,7 & 174638 \\
\hline Новгородская область & 146636 & 100,5 & 108,8 & 145846 \\
\hline Псковская область & 86294 & 107,4 & 109,1 & 80383 \\
\hline г. Санкт-Петербург & 1581469 & 89,8 & 97,5 & 1760442 \\
\hline Южный федеральный округ & 1957245 & 93,2 & 96,7 & 2100249 \\
\hline Республика Адыгея & 37657 & 109,0 & 102,0 & 34563 \\
\hline Республика Калмыкия & 442 & 67,9 & 116,9 & 650 \\
\hline Республика Крым & 74904 & 107,0 & 104,8 & 70029 \\
\hline Краснодарский край & 638904 & 95,4 & 104,9 & 669609 \\
\hline Астраханская область & 53477 & 98,7 & 87,1 & 54171 \\
\hline Волгоградская область & 555430 & 87,2 & 82,6 & 636648 \\
\hline Ростовская область & 587540 & 94,1 & 103,0 & 624611 \\
\hline г. Севастополь & 8892 & 89,2 & 130,5 & 9967 \\
\hline $\begin{array}{c}\text { Северо-Кавказский } \\
\text { федеральный округ }\end{array}$ & 308673 & 101,6 & 115,6 & 303686 \\
\hline Республика Дагестан & 27521 & 99,0 & 92,6 & 27812 \\
\hline Республика Ингушетия & 1295 & 82,5 & 115,3 & 1570 \\
\hline Кабардино-Балкарская Республика & 25223 & 127,2 & 123,5 & 19826 \\
\hline Карачаево-Черкесская Республика & 18991 & 105,1 & 98,8 & 18061 \\
\hline Республика Северная Осетия - Алания & 12952 & 118,5 & 114,7 & 10933 \\
\hline Чеченская Республика & 8469 & 113,6 & 88,8 & 7457 \\
\hline Ставропольский край & 214223 & 98,3 & 121,8 & 218026 \\
\hline
\end{tabular}




\begin{tabular}{|c|c|c|c|c|}
\hline & \multicolumn{2}{|c|}{ Анварь-сентябрь 2020 г. } & \multirow{2}{*}{$\begin{array}{c}\text { Сентябрь } 2020 \text { г. } \\
\text { в\% \% } \\
\text { сентябрю } 2019 \text { г. }\end{array}$} & \multirow{2}{*}{$\begin{array}{c}\frac{\text { Справочно }}{\text { январь-сентябрь }} \\
2019 \text { г., } \\
\text { млн рублей }\end{array}$} \\
\hline & млн рублей & \begin{tabular}{|c|}
$в \% \kappa$ \\
январю-сентябрю \\
20192. \\
\end{tabular} & & \\
\hline Приволжский федеральный округ & 6295287 & 91,4 & 95,2 & 6890814 \\
\hline Республика Башкортостан & 846753 & 87,1 & 86,8 & 972370 \\
\hline Республика Марий Эл & 98520 & 79,9 & 110,3 & 123258 \\
\hline Республика Мордовия & 165889 & 106,8 & 98,9 & 155305 \\
\hline Республика Татарстан & 1401773 & 96,2 & 97,3 & 1457331 \\
\hline Удмуртская Республика & 224489 & 87,3 & 90,9 & 257225 \\
\hline Чувашская Республика & 155167 & 94,8 & 97,4 & 163642 \\
\hline Пермский край & 742373 & 87,0 & 86,7 & 853237 \\
\hline Кировская область & 178908 & 106,4 & 123,7 & 168077 \\
\hline Нижегородская область & 894672 & 85,7 & 90,7 & 1044085 \\
\hline Оренбургская область & 225597 & 92,1 & 95,4 & 244822 \\
\hline Пензенская область & 163847 & 112,4 & 121,8 & 145771 \\
\hline Самарская область & 734512 & 90,8 & 98,6 & 809159 \\
\hline Саратовская область & 290237 & 100,3 & 106,1 & 289304 \\
\hline Ульяновская область & 172550 & 83,3 & 96,7 & 207228 \\
\hline Уральский федеральный округ & 3581874 & 91,8 & 102,4 & 3900135 \\
\hline Курганская область & 84471 & 98,8 & 94,4 & 85466 \\
\hline Свердловская область & 1433781 & 99,6 & 105,6 & 1439852 \\
\hline Тюменская область & 1100235 & 85,2 & 107,4 & 1291007 \\
\hline $\begin{array}{l}\text { в том числе: } \\
\text { Ханты-Мансийский авт. округ - Югра }\end{array}$ & 408252 & 78,1 & 84,0 & 522718 \\
\hline Ямало-Ненецкий авт. округ & 226101 & 83,6 & 96,8 & 270450 \\
\hline Тюменская область без авт. округов & 465882 & 93,6 & 141,0 & 497839 \\
\hline Челябинская область & 963388 & 88,9 & 93,8 & 1083810 \\
\hline Сибирский федеральный округ & 3401983 & 99,5 & 103,6 & 3418260 \\
\hline Республика Алтай & 3028 & 138,0 & 155,1 & 2194 \\
\hline Республика Тыва & 442 & 97,5 & 139,1 & 453 \\
\hline Республика Хакасия & 76701 & 100,6 & 121,0 & 76227 \\
\hline Алтайский край & 257921 & 103,3 & 104,2 & 249578 \\
\hline Красноярский край & 1097696 & 109,1 & 104,7 & 1006478 \\
\hline Иркутская область & 359038 & 106,4 & 121,2 & 337548 \\
\hline Кемеровская область & 441988 & 91,1 & 96,5 & 485214 \\
\hline Новосибирская область & 396379 & 101,4 & 98,1 & 390842 \\
\hline Омская область & 630197 & 87,2 & 100,6 & 722751 \\
\hline Томская область & 138591 & 94,3 & 102,6 & 146975 \\
\hline $\begin{array}{l}\text { Дальневосточный } \\
\text { федеральный округ }\end{array}$ & 847660 & 102,7 & 105,6 & 825480 \\
\hline Республика Бурятия & 58322 & 115,1 & 154,5 & 50659 \\
\hline Республика Саха (Якутия) & 22678 & 83,3 & 94,4 & 27218 \\
\hline Забайкальский край & 19081 & 91,6 & 65,4 & 20820 \\
\hline Камчатский край & 86558 & 105,6 & 104,9 & 81978 \\
\hline Приморский край & 137682 & 71,0 & 66,5 & 193983 \\
\hline Хабаровский край & 236283 & 107,3 & 94,4 & 220110 \\
\hline Амурская область & 23559 & 101,8 & 103,0 & 23140 \\
\hline Магаданская область & 148024 & 131,3 & 172,6 & 112701 \\
\hline Сахалинская область & 46605 & 123,1 & 109,4 & 37853 \\
\hline Еврейская авт. область & 3291 & 77,0 & 68,3 & 4271 \\
\hline Чукотский авт. округ & 65576 & 124,3 & 103,2 & 52747 \\
\hline
\end{tabular}


ОБЪЕМ ОТГРУЖЕННЫХ ТОВАРОВ СОБСТВЕННОГО ПРОИЗВОДСТВА, ВЫПОЛНЕННЫХ

РАБОТ И УСЛУГ СОБСТВЕННЫМИ СИЛАМИ ПО ВИДУ ЭКОНОМИЧЕСКОЙ ДЕЯТЕЛЬНОСТИ "ОБЕСПЕЧЕНИЕ ЭЛЕКТРИЧЕСКОЙ ЭНЕРГИЕЙ, ГАЗОМ И ПАРОМ; КОНДИЦИОНИРОВАНИЕ ВОЗДУХА"

в действующих ценах

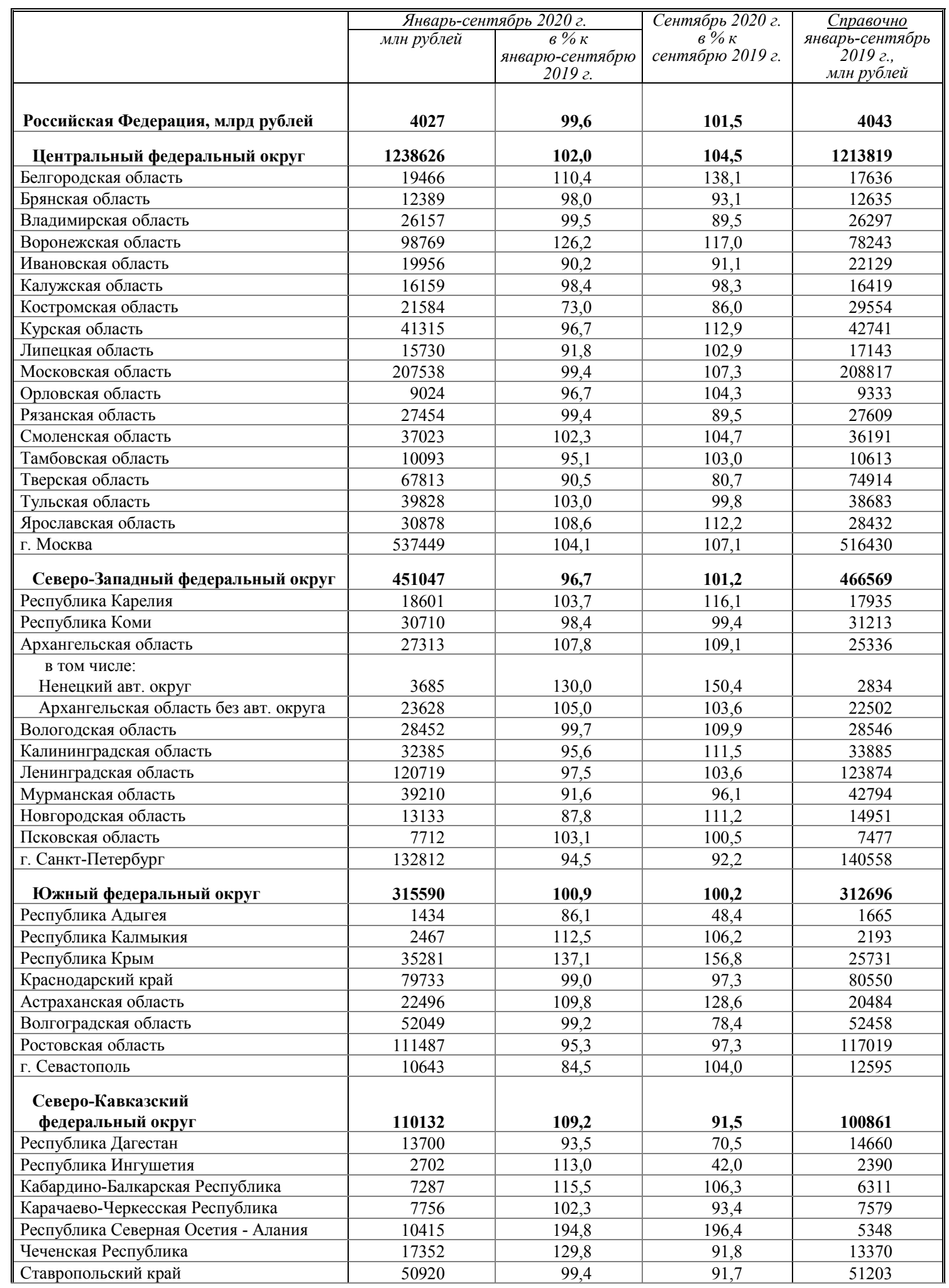




\begin{tabular}{|c|c|c|c|c|}
\hline & \multicolumn{2}{|c|}{ оянварь-сентябрь 2020 г. } & \multirow{2}{*}{$\begin{array}{c}\text { Сентябрь } 2020 z . \\
\text { в\% к } \\
\text { сентябрю } 20192 .\end{array}$} & \multirow{2}{*}{$\begin{array}{c}\text { Справочно } \\
\text { январь-сентябрь } \\
2019 \text { г., } \\
\text { млн рублей } \\
\end{array}$} \\
\hline & млн рублей & \begin{tabular}{|c|}
$в \% \kappa$ \\
январю-сентябрю \\
20192.
\end{tabular} & & \\
\hline Приволжский федеральный округ & 679470 & 95,6 & 95,4 & 710844 \\
\hline Республика Башкортостан & 96871 & 94,4 & 91,4 & 102610 \\
\hline Республика Марий Эл & 7853 & 97,3 & 90,7 & 8069 \\
\hline Республика Мордовия & 8090 & 99,6 & 103,5 & 8119 \\
\hline Республика Татарстан & 98076 & 86,3 & 84,4 & 113653 \\
\hline Удмуртская Республика & 25653 & 91,6 & 104,4 & 28015 \\
\hline Чувашская Республика & 16438 & 86,4 & 97,6 & 19030 \\
\hline Пермский край & 90666 & 103,3 & 105,7 & 87751 \\
\hline Кировская область & 26862 & 95,6 & 89,6 & 28093 \\
\hline Нижегородская область & 76775 & 98,7 & 90,5 & 77803 \\
\hline Оренбургская область & 45008 & 100,1 & 95,2 & 44946 \\
\hline Пензенская область & 15317 & 99,7 & 96,7 & 15357 \\
\hline Самарская область & 84605 & 98,5 & 93,4 & 85877 \\
\hline Саратовская область & 68836 & 95,0 & 112,5 & 72486 \\
\hline Ульяновская область & 18420 & 96,8 & 88,6 & 19035 \\
\hline Уральский федеральный округ & 492776 & 95,2 & 93,4 & 517674 \\
\hline Курганская область & 12923 & 87,7 & 100,1 & 14730 \\
\hline Свердловская область & 164570 & 93,6 & 96,9 & 175746 \\
\hline Тюменская область & 225334 & 93,6 & 89,0 & 240768 \\
\hline $\begin{array}{l}\text { в том числе: } \\
\text { Ханты-Мансийский авт. округ - Югра }\end{array}$ & 154716 & 92,6 & 88,3 & 167040 \\
\hline Ямало-Ненецкий авт. округ & 34229 & 97,4 & 91,6 & 35144 \\
\hline Тюменская область без авт. округов & 36389 & 94,3 & 90,3 & 38584 \\
\hline Челябинская область & 89949 & 104,1 & 97,7 & 86430 \\
\hline Сибирский федеральный округ & 472684 & 100,2 & 112,4 & 471632 \\
\hline Республика Алтай & 1924 & 89,6 & 85,9 & 2147 \\
\hline Республика Тыва & 3520 & 106,8 & 105,7 & 3295 \\
\hline Республика Хакасия & 41061 & 111,0 & 140,6 & 37006 \\
\hline Алтайский край & 28938 & 93,2 & 101,8 & 31036 \\
\hline Красноярский край & 124009 & 98,6 & 109,3 & 125723 \\
\hline Иркутская область & 95132 & 103,1 & 124,1 & 92274 \\
\hline Кемеровская область & 70941 & 101,9 & 107,6 & 69589 \\
\hline Новосибирская область & 45991 & 97,4 & 107,5 & 47205 \\
\hline Омская область & 36414 & 97,4 & 101,4 & 37372 \\
\hline Томская область & 24753 & 95,3 & 100,2 & 25984 \\
\hline $\begin{array}{l}\text { Дальневосточный } \\
\text { федеральный округ }\end{array}$ & 266215 & 107,0 & 109,7 & 248881 \\
\hline Республика Бурятия & 18800 & 101,9 & 120,5 & 18450 \\
\hline Республика Саха (Якутия) & 53795 & 116,7 & 114,6 & 46089 \\
\hline Забайкальский край & 23984 & 99,7 & 103,8 & 24057 \\
\hline Камчатский край & 13827 & 96,0 & 93,8 & 14400 \\
\hline Приморский край & 49251 & 107,7 & 104,5 & 45728 \\
\hline Хабаровский край & 40185 & 104,8 & 108,8 & 38356 \\
\hline Амурская область & 27884 & 106,4 & 113,3 & 26206 \\
\hline Магаданская область & 13647 & 104,0 & 110,4 & 13116 \\
\hline Сахалинская область & 13033 & 103,1 & 94,3 & 12638 \\
\hline Еврейская авт. область & 3352 & 107,8 & 89,4 & 3109 \\
\hline Чукотский авт. округ & 8457 & 125,6 & 145,1 & 6732 \\
\hline
\end{tabular}


ОБЪЕМ ОТГРУЖЕННЫХ ТОВАРОВ СОБСТВЕННОГО ПРОИЗВОДСТВА, ВЫПОЛНЕННЫХ РАБОТ И УСЛУГ СОБСТВЕННЫМИ СИЛАМИ ПО ВИДУ ЭКОНОМИЧЕСКОЙ ДЕЯТЕЛЬНОСТИ "ВОДОСНАБЖЕНИЕ; ВОДООТВЕДЕНИЕ, ОРГАНИЗАЦИЯ СБОРА И УТИЛИЗАЦИИ ОТХОДОВ, ДЕЯТЕЛЬНОСТЬ ПО ЛИКВИДАЦИИ ЗАГРЯЗНЕНИЙ"

в действующих ценах

\begin{tabular}{|c|c|c|c|c|}
\hline & \multicolumn{2}{|c|}{ Январь-сентябрь 2020 г. } & \multirow{2}{*}{$\begin{array}{c}\text { Сентябрь } 2020 z . \\
\text { в\% к } \\
\text { сентябрю } 20192 .\end{array}$} & \multirow{2}{*}{$\begin{array}{c}\text { Справочно } \\
\text { январь-сентябрь } \\
2019 \text { г., } \\
\text { млн рублей }\end{array}$} \\
\hline & млн рублей & $\begin{array}{c}\% \% \kappa \\
\text { январю-сентябрю } \\
2019 \text { 2. } \\
\end{array}$ & & \\
\hline Российская Федерация, млрд рублей & 891 & 105,9 & 113,0 & 841 \\
\hline Центральный федеральный округ & 264067 & 99,4 & 100,8 & 265683 \\
\hline Белгородская область & 8784 & 123,8 & 126,0 & 7094 \\
\hline Брянская область & 6471 & 98,7 & 99,2 & 6560 \\
\hline Владимирская область & 9669 & 107,9 & 107,2 & 8957 \\
\hline Воронежская область & 11427 & 111,0 & 98,1 & 10297 \\
\hline Ивановская область & 4363 & 133,1 & 130,7 & 3278 \\
\hline Калужская область & 7691 & 80,5 & 92,0 & 9557 \\
\hline Костромская область & 2995 & 98,7 & 90,9 & 3036 \\
\hline Курская область & 5979 & 112,0 & 97,6 & 5340 \\
\hline Липецкая область & 8184 & 91,5 & 100,3 & 8948 \\
\hline Московская область & 61662 & 103,2 & 99,7 & 59765 \\
\hline Орловская область & 2789 & 75,6 & 71,5 & 3688 \\
\hline Рязанская область & 4761 & 96,8 & 123,7 & 4920 \\
\hline Смоленская область & 8948 & 125,5 & 145,8 & 7132 \\
\hline Тамбовская область & 3093 & 96,9 & 92,7 & 3193 \\
\hline Тверская область & 6362 & 106,6 & 108,3 & 5967 \\
\hline Тульская область & 13096 & 135,9 & 149,0 & 9637 \\
\hline Ярославская область & 7084 & 82,7 & 107,7 & 8567 \\
\hline г. Москва & 90710 & 90,9 & 91,5 & 99746 \\
\hline Северо-Западный федеральный округ & 96802 & 97,9 & 95,9 & 98906 \\
\hline Республика Карелия & 2330 & 127,9 & 125,1 & 1822 \\
\hline Республика Коми & 6389 & 119,2 & 127,7 & 5358 \\
\hline Архангельская область & 4627 & 103,8 & 96,3 & 4460 \\
\hline $\begin{array}{l}\text { в том числе: } \\
\text { Ненецкий авт. округ }\end{array}$ & 467 & 128,2 & 166,8 & 365 \\
\hline Архангельская область без авт. округа & 4160 & 101,6 & 90,7 & 4095 \\
\hline Вологодская область & 6600 & 113,3 & 102,6 & 5824 \\
\hline Калининградская область & 5394 & 103,5 & 101,1 & 5211 \\
\hline Ленинградская область & 11827 & 108,7 & 101,6 & 10885 \\
\hline Мурманская область & 6785 & 99,8 & 125,0 & 6796 \\
\hline Новгородская область & 2367 & 91,6 & 88,6 & 2583 \\
\hline Псковская область & 3292 & 86,3 & 60,1 & 3814 \\
\hline г. Санкт-Петербург & 47190 & 90,5 & 89,7 & 52152 \\
\hline Южный федеральный округ & 73157 & 106,4 & 111,9 & 68781 \\
\hline Республика Адыгея & 1149 & 90,2 & 76,3 & 1273 \\
\hline Республика Калмыкия & $\ldots{ }^{1)}$ & $\ldots 1)$ & $\ldots 1)$ & $\ldots 1)$ \\
\hline Республика Крым & 6694 & 117,1 & 119,4 & 5714 \\
\hline Краснодарский край & 21155 & 95,9 & 96,8 & 22065 \\
\hline Астраханская область & 3994 & 108,7 & 110,9 & 3673 \\
\hline Волгоградская область & 16772 & 118,7 & 137,2 & 14132 \\
\hline Ростовская область & 20653 & 106,1 & 114,2 & 19459 \\
\hline г. Севастополь & ${ }^{11)}$ & $\ldots^{1)}$ & ${ }^{11)}$ & ${ }^{1{ }^{1)}}$ \\
\hline $\begin{array}{c}\text { Северо-Кавказский } \\
\text { федеральный округ }\end{array}$ & 14199 & 102,1 & 111,1 & 13904 \\
\hline Республика Дагестан & 1381 & 80,5 & 102,8 & 1716 \\
\hline Республика Ингушетия & 442 & 127,4 & в 4,7p. & 347 \\
\hline Кабардино-Балкарская Республика & 1075 & 84,8 & 77,4 & 1268 \\
\hline Карачаево-Черкесская Республика & 994 & 107,8 & 118,1 & 922 \\
\hline Республика Северная Осетия - Алания & 1013 & 102,8 & 81,5 & 985 \\
\hline Чеченская Республика & 1232 & 115,9 & 127,5 & 1063 \\
\hline Ставропольский край & 8062 & 106,0 & 105,4 & 7602 \\
\hline
\end{tabular}




\begin{tabular}{|c|c|c|c|c|}
\hline & \multicolumn{2}{|c|}{ яняварь-сентябрь 2020 г. } & \multirow{2}{*}{$\begin{array}{c}\text { Сентябрь } 2020 \text { г. } \\
\text { в\% к } \\
\text { сентябрю } 2019 \text { г. }\end{array}$} & \multirow{2}{*}{$\begin{array}{c}\frac{\text { Справочно }}{\text { январь-сентябрь }} \\
2019 \text { г., } \\
\text { млн рублей }\end{array}$} \\
\hline & млн рублей & $\begin{array}{c}\text { в\% к } \\
\text { январю-сентябрю } \\
2019 \text { г. } \\
\end{array}$ & & \\
\hline Приволжский федеральный округ & 168378 & 98,4 & 108,6 & 171140 \\
\hline Республика Башкортостан & 18273 & 106,6 & 112,3 & 17147 \\
\hline Республика Марий Эл & 4654 & 147,7 & 141,9 & 3150 \\
\hline Республика Мордовия & 2491 & 58,0 & 71,0 & 4292 \\
\hline Республика Татарстан & 21871 & 98,0 & 116,9 & 22311 \\
\hline Удмуртская Республика & 8482 & 143,4 & 167,6 & 5915 \\
\hline Чувашская Республика & 4319 & 96,3 & 83,7 & 4487 \\
\hline Пермский край & 21590 & 94,5 & 100,1 & 22850 \\
\hline Кировская область & 5712 & 104,7 & 103,2 & 5456 \\
\hline Нижегородская область & 20330 & 90,0 & 98,1 & 22599 \\
\hline Оренбургская область & 13594 & 121,0 & 150,1 & 11232 \\
\hline Пензенская область & 4474 & 105,5 & 121,6 & 4240 \\
\hline Самарская область & 27735 & 85,7 & 91,3 & 32347 \\
\hline Саратовская область & 8627 & 103,3 & 113,1 & 8351 \\
\hline Ульяновская область & 6226 & 92,1 & 115,3 & 6763 \\
\hline Уральский федеральный округ & 120901 & 109,6 & 125,6 & 110334 \\
\hline Курганская область & 2242 & 93,2 & 122,0 & 2405 \\
\hline Свердловская область & 52578 & 100,3 & 117,4 & 52422 \\
\hline Тюменская область & 40613 & 129,6 & 141,5 & 31332 \\
\hline $\begin{array}{l}\text { в том числе: } \\
\text { Ханты-Мансийский авт. округ - Югра }\end{array}$ & 18845 & 123,2 & 111,5 & 15302 \\
\hline Ямало-Ненецкий авт. округ & 10248 & 153,7 & 158,3 & 6669 \\
\hline Тюменская область без авт. округов & 11519 & 123,1 & 178,9 & 9360 \\
\hline Челябинская область & 25468 & 105,3 & 121,2 & 24175 \\
\hline Сибирский федеральный округ & 121421 & 144,2 & 164,7 & 84222 \\
\hline Республика Алтай & 353 & 138,8 & 154,2 & 254 \\
\hline Республика Тыва & 274 & 122,9 & 98,2 & 223 \\
\hline Республика Хакасия & 1399 & 94,8 & 101,1 & 1475 \\
\hline Алтайский край & 7373 & 103,7 & 116,6 & 7109 \\
\hline Красноярский край & 21626 & 99,1 & 161,5 & 21828 \\
\hline Иркутская область & 11159 & 101,3 & 94,5 & 11013 \\
\hline Кемеровская область & 49047 & в $3,2 \mathrm{p}$. & в 3,2p. & 15442 \\
\hline Новосибирская область & 14311 & 119,0 & 154,5 & 12023 \\
\hline Омская область & 9680 & 112,2 & 111,0 & 8629 \\
\hline Томская область & 6200 & 99,6 & 92,9 & 6226 \\
\hline $\begin{array}{l}\text { Дальневосточный } \\
\text { федеральный округ }\end{array}$ & 32186 & 114,0 & 119,2 & 28227 \\
\hline Республика Бурятия & 1863 & 148,8 & 156,5 & 1252 \\
\hline Республика Саха (Якутия) & 4883 & 117,8 & 173,4 & 4144 \\
\hline Забайкальский край & 1541 & 80,2 & 93,3 & 1923 \\
\hline Камчатский край & 2062 & 100,5 & 67,4 & 2053 \\
\hline Приморский край & 8001 & 116,1 & 116,1 & 6891 \\
\hline Хабаровский край & 6554 & 127,7 & 125,0 & 5134 \\
\hline Амурская область & 2816 & 104,9 & 114,9 & 2685 \\
\hline Магаданская область & 689 & 111,8 & 115,7 & 616 \\
\hline Сахалинская область & 3024 & 108,1 & 103,0 & 2797 \\
\hline Еврейская авт. область & 318 & 94,4 & 97,4 & 337 \\
\hline Чукотский авт. округ & 434 & 109,9 & 98,8 & 395 \\
\hline
\end{tabular}




\section{СЕЛЬСКОЕ ХОЗЯЙСТВО}

УБОРКА ЗЕРНОВЫХ И ЗЕРНОБОБОВЫХ КУЛЬТУР (БЕЗ КУКУРУЗЫ) В СЕЛЬСКОХОЗЯЙСТВЕННЫХ ОРГАНИЗАЦИЯХ

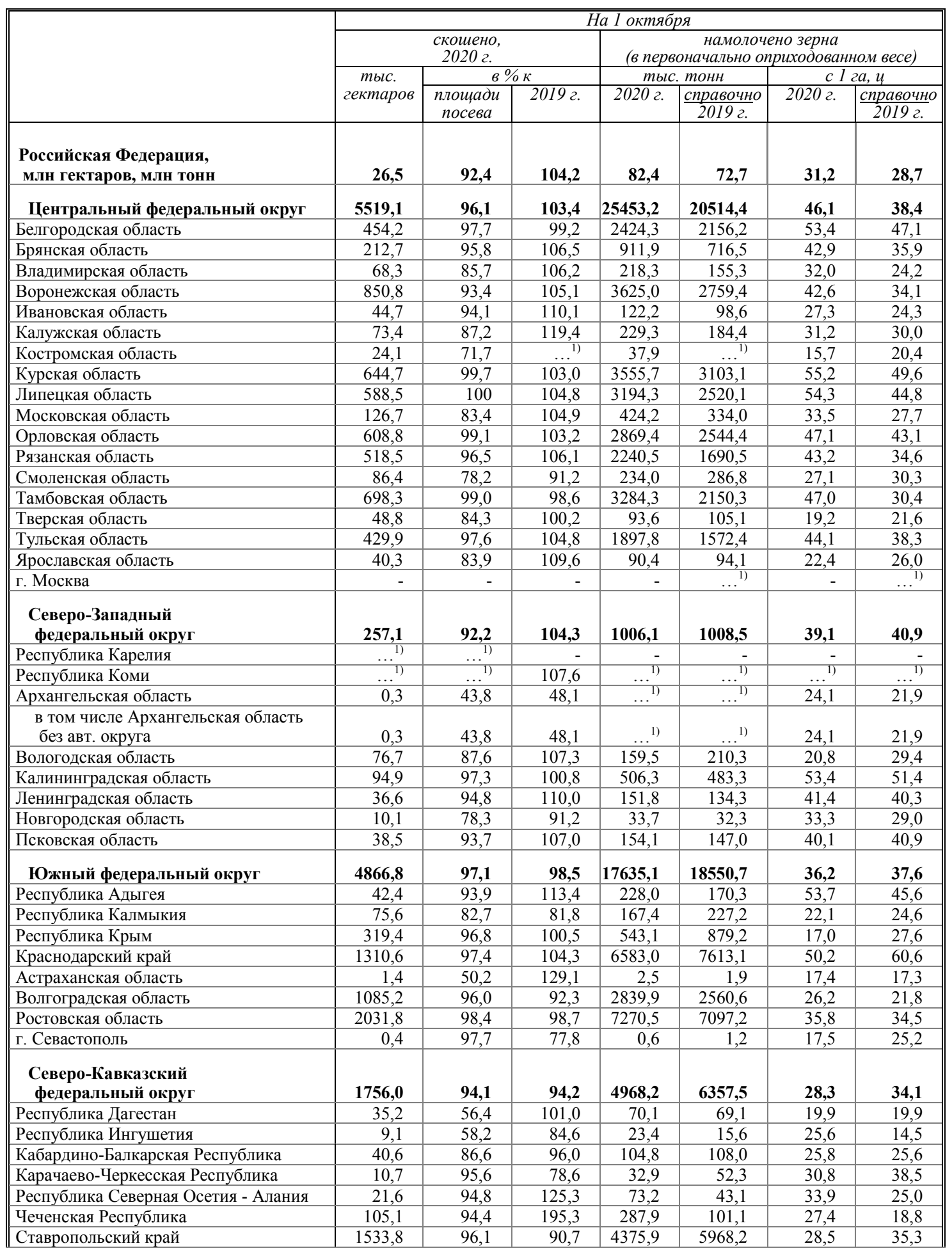




\begin{tabular}{|c|c|c|c|c|c|c|c|}
\hline & \multicolumn{7}{|c|}{ На 1 октября } \\
\hline & \multicolumn{3}{|c|}{$\begin{array}{l}\text { скошено, } \\
2020 \text { г. }\end{array}$} & \multicolumn{4}{|c|}{$\begin{array}{c}\text { намолочено зерна } \\
\text { (в первоначально оприходованном весе) }\end{array}$} \\
\hline & \multirow{2}{*}{$\begin{array}{c}\text { тысc. } \\
\text { гектаров }\end{array}$} & \multicolumn{2}{|c|}{$6 \% K$} & \multicolumn{2}{|c|}{ mblc. тонн } & \multicolumn{2}{|c|}{$c 12 a, u$} \\
\hline & & $\begin{array}{c}\text { площада } \\
\text { посева }\end{array}$ & 20192. & 2020 г. & $\frac{\text { справочно }}{2019 \text { г. }}$ & $2020 z$ & $\frac{\text { справочнс }}{2019 \text { г. }}$ \\
\hline Приволжский федеральный округ & 7702,2 & 94,1 & 108,2 & 21363,0 & 14689,0 & 27,8 & $\mathbf{2 0 , 7}$ \\
\hline Республика Башкортостан & 969,6 & 89,0 & 107,3 & 2311,3 & 1908,1 & 23,8 & 21,1 \\
\hline Республика Марий Эл & 117,9 & 98,5 & 112,8 & 316,7 & 231,5 & 26,9 & 22,2 \\
\hline Республика Мордовия & 381,5 & 98,6 & 107,9 & 1358,9 & 1025,8 & 35,6 & 29,0 \\
\hline Республика Татарстан & 1102,6 & 100 & 110,4 & 3874,9 & 3036,9 & 35,1 & 30,4 \\
\hline Удмуртская Республика & 261,1 & 91,6 & 109,7 & 616,5 & 582,4 & 23,6 & 24,5 \\
\hline Чувашская Республика & 173,0 & 92,4 & 104,1 & 568,0 & 481,5 & 32,8 & 29,0 \\
\hline Пермский край & 194,7 & 96,0 & 140,8 & 333,7 & 251,4 & 17,1 & 18,2 \\
\hline Кировская область & 280,2 & 96,5 & 110,7 & 698,6 & 667,7 & 24,9 & 26,4 \\
\hline Нижегородская область & 410,3 & 89,6 & 109,3 & 1232,5 & 900,8 & 30,0 & 24,0 \\
\hline Оренбургская область & 1148,4 & 91,1 & 110,7 & 1662,2 & 894,0 & 14,5 & 8,6 \\
\hline Пензенская область & 579,3 & 98,4 & 110,2 & 2400,4 & 1370,3 & 41,4 & 26,1 \\
\hline Самарская область & 682,1 & 87,3 & 101,3 & 2158,2 & 1215,2 & 32,5 & 18,1 \\
\hline Саратовская область & 970,3 & 96,5 & 103,3 & 2349,3 & 1295,0 & 24,2 & 13,8 \\
\hline Ульяновская область & 430,9 & 98,7 & 105,4 & 1481,8 & 828,2 & 34,4 & 20,3 \\
\hline Уральский федеральный округ & 1748,7 & 84,5 & 119,3 & 2887,7 & 2984,6 & 16,6 & 20,5 \\
\hline Курганская область & 565,4 & 90,6 & 126,8 & 830,0 & 846,9 & 14,8 & 19,2 \\
\hline Свердловская область & 221,0 & 79,0 & 108,8 & 520,1 & 547,3 & 23,5 & 26,9 \\
\hline Тюменская область & 530,5 & 96,3 & 129,9 & 1149,0 & 1035,5 & 21,7 & 25,4 \\
\hline $\begin{array}{l}\text { в том числе Тюменская область } \\
\text { без авт. округов }\end{array}$ & 530,5 & 96,3 & 129,9 & 1149,0 & 1035,5 & 21,7 & 25,4 \\
\hline Челябинская область & 431,8 & 70,2 & 105,8 & 388,6 & 554,9 & 9,1 & 13,8 \\
\hline Сибирский федеральный округ & 4479,3 & 85,4 & 104,5 & 8694,6 & 8334,5 & 19,6 & 19,6 \\
\hline Республика Алтай & 4,7 & 75,5 & 135,1 & 5,1 & 3,6 & 10,8 & 10,2 \\
\hline Республика Тыва & 1,1 & 70,7 & 24,2 & 1,0 & 4,4 & 8,9 & 9,6 \\
\hline Республика Хакасия & 25,3 & 51,3 & 117,3 & 56,8 & 41,1 & 22,5 & 19,0 \\
\hline Алтайский край & 1700,5 & 88,8 & 98,4 & 2455,5 & 2856,6 & 14,9 & 16,8 \\
\hline Красноярский край & 563,5 & 78,9 & 99,0 & 1945,0 & 1623,2 & 34,5 & 28,5 \\
\hline Иркутская область & 119,2 & 68,9 & 96,4 & 276,7 & 258,5 & 23,2 & 20,9 \\
\hline Кемеровская область & 271,4 & 91,9 & 114,4 & 657,8 & 535,4 & 24,4 & 22,7 \\
\hline Новосибирская область & 730,5 & 75,2 & 100,6 & 1506,7 & 1459,6 & 20,6 & 20,1 \\
\hline Омская область & 943,4 & 95,4 & 125,7 & 1475,0 & 1280,1 & 15,6 & 17,1 \\
\hline Томская область & 119,6 & 91,6 & 99,1 & 315,1 & 272,1 & 26,3 & 22,5 \\
\hline $\begin{array}{l}\text { Дальневосточный } \\
\text { федеральный округ }\end{array}$ & 179,7 & 62,9 & 102,7 & 378,6 & 291,7 & 21,1 & 16,7 \\
\hline Республика Бурятия & 9,0 & 21,6 & 88,7 & 10,2 & 13,8 & 11,4 & 13,6 \\
\hline Республика Саха (Якутия) & 6,1 & 90,2 & 93,9 & 6,3 & 7,5 & 10,4 & 11,5 \\
\hline Забайкальский край & 13,4 & 17,4 & 65,4 & 15,4 & 21,5 & 11,6 & 10,5 \\
\hline Камчатский край & - & - & - & - & - & - & - \\
\hline Приморский край & 12,7 & 68,8 & 119,1 & 30,0 & 22,9 & 23,7 & 21,5 \\
\hline Хабаровский край & 5,1 & 82,6 & 145,6 & 10,7 & 5,8 & 20,9 & 16,6 \\
\hline Амурская область & 133,1 & 98,3 & 107,6 & 305,3 & 220,1 & 23,0 & 17,9 \\
\hline Магаданская область & - & - & - & - & - & - & - \\
\hline Сахалинская область & - & - & - & - & - & - & - \\
\hline Еврейская авт.область & 0,4 & 58,7 & в 2,9p. & 0,6 & 0,2 & 16,0 & 11,7 \\
\hline Чукотский авт. округ & - & - & - & - & - & - & - \\
\hline
\end{tabular}




\section{ПРОИЗВОДСТВО ПРОДУКТОВ ЖИВОТНОВОДСТВА \\ В ХОЗЯЙСТВАХ ВСЕХ КАТЕГОРИЙ}

в январе-сентябре 2020 года

\begin{tabular}{|c|c|c|c|c|c|c|}
\hline & $\begin{array}{r}\text { Скот и } \\
\text { (в \%еl } \\
\end{array}$ & $\begin{array}{l}\text { ица на убой } \\
\text { рм весе) }\end{array}$ & & око & & u̧a \\
\hline & $\begin{array}{l}\text { тьсс. } \\
\text { тонн }\end{array}$ & \begin{tabular}{|c|} 
в \% к \\
январю- \\
сентябрю \\
20192. \\
\end{tabular} & $\begin{array}{l}\text { тысс. } \\
\text { тонн }\end{array}$ & $\begin{array}{c}\text { в\% } \\
\text { январю- } \\
\text { сентябрю } \\
20192 . \\
\end{array}$ & $\begin{array}{c}\text { млин } \\
\text { штук }\end{array}$ & \begin{tabular}{|c|} 
в\% к \\
январю- \\
сентябрю \\
2019 г. \\
\end{tabular} \\
\hline Российская Федерация, млн тонн, млрд штук & 10,9 & 104,0 & 24,9 & 102,7 & 34,2 & 100,6 \\
\hline Центральный федеральный округ & 4333,3 & 106,6 & 4786,0 & 104,1 & 7717,4 & 101,5 \\
\hline Белгородская область & 1324,6 & 101,4 & 519,7 & 100,5 & 1218,9 & 99,2 \\
\hline Брянская область & 328,8 & 101,8 & 237,0 & 100,7 & 202,8 & 86,3 \\
\hline Владимирская область & 28,1 & 78,9 & 320,8 & 103,9 & 443,3 & 106,6 \\
\hline Воронежская область & 416,7 & 105,2 & 795,6 & 105,8 & 621,9 & 100,1 \\
\hline Ивановская область & 25,9 & 91,4 & 120,6 & 102,1 & 309,5 & 102,7 \\
\hline Калужская область & 95,9 & 101,5 & 323,1 & 110,2 & 136,7 & 108,3 \\
\hline Костромская область & 13,6 & 104,9 & 87,1 & 106,3 & 616,5 & 116,2 \\
\hline Курская область & 477,2 & 124,5 & 260,8 & 111,0 & 142,4 & 107,6 \\
\hline Липецкая область & 280,2 & 104,7 & 227,8 & 104,8 & 585,8 & 105,1 \\
\hline Московская область & 228,0 & 99,3 & 527,3 & 104,7 & 100,0 & 99,9 \\
\hline Орловская область & 150,1 & 114,6 & 128,0 & 97,6 & 44,6 & 89,2 \\
\hline Рязанская область & 63,7 & 101,9 & 391,1 & 112,3 & 725,1 & 99,3 \\
\hline Смоленская область & 65,5 & 100,8 & 126,3 & 98,8 & 210,0 & 89,8 \\
\hline Тамбовская область & 458,5 & 114,9 & 154,3 & 100,0 & 103,0 & 92,3 \\
\hline Тверская область & 172,2 & 117,9 & 165,5 & 96,7 & 99,4 & 95,5 \\
\hline Тульская область & 137,2 & 122,5 & 139,2 & 101,1 & 384,8 & 101,5 \\
\hline Ярославская область & 65,8 & 96,3 & 252,5 & 104,0 & 1772,2 & 101,4 \\
\hline г. Москва & 1,2 & 93,5 & 9,3 & 46,1 & 0,7 & 83,8 \\
\hline Северо-Западный федеральный округ & 810,8 & 105,2 & 1512,4 & 104,8 & 3301,5 & 101,3 \\
\hline Республика Карелия & 2,4 & 95,4 & 48,4 & 100,4 & 6,4 & 102,3 \\
\hline Республика Коми & 25,1 & 100,3 & 42,3 & 98,7 & 93,2 & 105,3 \\
\hline Архангельская область & 5,0 & 97,2 & 104,0 & 106,6 & 45,7 & 108,4 \\
\hline $\begin{array}{l}\text { в том числе: } \\
\text { Ненецкий авт. округ }\end{array}$ & 0,3 & 124,3 & 2,9 & 106,3 & 0,0 & 110,0 \\
\hline Архангельская область без авт. округа & 4,7 & 95,9 & 101,1 & 106,6 & 45,7 & 108,4 \\
\hline Вологодская область & 36,5 & 110,6 & 442,7 & 105,5 & 467,7 & 103,7 \\
\hline Калининградская область & 86,2 & 126,7 & 165,7 & 113,7 & 189,2 & 98,6 \\
\hline Ленинградская область & 280,5 & 99,3 & 494,6 & 104,1 & 2366,1 & 102,1 \\
\hline Мурманская область & 1,5 & 100,8 & 12,9 & 95,6 & 3,5 & 186,8 \\
\hline Новгородская область & 115,2 & 101,0 & 49,9 & 100,7 & 64,6 & 67,7 \\
\hline Псковская область & 258,5 & 108,0 & 151,9 & 100,4 & 64,9 & 98,3 \\
\hline Южный федеральный округ & 965,7 & 99,9 & 2914,2 & 103,0 & 3752,2 & 97,5 \\
\hline Республика Адыгея & 21,2 & 110,3 & 97,2 & 101,3 & 76,5 & 104,3 \\
\hline Республика Калмыкия & 53,0 & 94,8 & 53,2 & 91,6 & 13,4 & 93,4 \\
\hline Республика Крым & 115,8 & 99,3 & 152,6 & 100,8 & 221,2 & 91,5 \\
\hline Краснодарский край & 399,0 & 107,6 & 1182,7 & 107,0 & 1164,4 & 91,6 \\
\hline Астраханская область & 48,9 & 100,5 & 142,6 & 100,1 & 299,8 & 97,1 \\
\hline Волгоградская область & 147,8 & 92,5 & 433,1 & 102,1 & 638,9 & 101,7 \\
\hline Ростовская область & 179,5 & 91,9 & 850,7 & 100,1 & 1335,4 & 102,2 \\
\hline г. Севастополь & 0,5 & 101,7 & 2,1 & 96,3 & 2,6 & 100,9 \\
\hline Северо-Кавказский федеральный округ & 702,7 & 102,4 & 2048,4 & 101,3 & 1184,6 & 99,3 \\
\hline Республика Дагестан & 107,8 & 100,7 & 692,8 & 100,7 & 164,9 & 98,2 \\
\hline Республика Ингушетия & 5,9 & 108,8 & 82,1 & 100,8 & 17,9 & 100,7 \\
\hline Кабардино-Балкарская Республика & 75,4 & 103,1 & 370,9 & 104,7 & 158,9 & 102,5 \\
\hline Карачаево-Черкесская Республика & 36,8 & 101,8 & 157,0 & 101,4 & 66,3 & 99,6 \\
\hline Республика Северная Осетия - Алания & 26,8 & 112,4 & 136,7 & 103,1 & 63,3 & 110,1 \\
\hline Чеченская Республика & 33,4 & 99,2 & 226,2 & 99,2 & 93,1 & 102,1 \\
\hline Ставропольский край & 416,8 & 102,3 & 382,7 & 100,0 & 620,3 & 97,4 \\
\hline
\end{tabular}




\begin{tabular}{|c|c|c|c|c|c|c|}
\hline & \multicolumn{2}{|c|}{$\begin{array}{c}\text { Скот и птииа на убой } \\
\text { (в живом весе) }\end{array}$} & \multicolumn{2}{|c|}{ Молоко } & \multicolumn{2}{|c|}{ Яйuฺa } \\
\hline & $\begin{array}{l}\text { тысс. } \\
\text { тонн }\end{array}$ & \begin{tabular}{|c|} 
в\% к \\
январю- \\
сентябрю \\
20192. \\
\end{tabular} & $\begin{array}{l}\text { mblc. } \\
\text { тонн }\end{array}$ & $\begin{array}{c}\text { в\%к } \\
\text { январю- } \\
\text { сентябрю } \\
20192 . \\
\end{array}$ & $\begin{array}{c}\text { млн } \\
\text { штук }\end{array}$ & $\begin{array}{c}\text { в\% к } \\
\text { январю- } \\
\text { сентябрю } \\
20192 . \\
\end{array}$ \\
\hline Приволжский федеральный округ & 2266,6 & 104,7 & 7740,0 & 102,8 & 8825,9 & 100,6 \\
\hline Республика Башкортостан & 263,7 & 111,0 & 1305,2 & 101,2 & 794,6 & 99,6 \\
\hline Республика Марий Эл & 257,9 & 104,6 & 145,8 & 105,5 & 275,0 & 107,4 \\
\hline Республика Мордовия & 265,1 & 109,0 & 363,2 & 103,7 & 1141,1 & 99,5 \\
\hline Республика Татарстан & 353,6 & 102,7 & 1482,3 & 102,2 & 1159,9 & 99,0 \\
\hline Удмуртская Республика & 113,7 & 105,0 & 664,6 & 104,8 & 832,6 & 100,1 \\
\hline Чувашская Республика & 79,7 & 92,7 & 344,4 & 103,5 & 224,7 & 105,4 \\
\hline Пермский край & 66,7 & 95,9 & 415,3 & 103,1 & 1017,3 & 104,8 \\
\hline Кировская область & 56,3 & 102,5 & 564,3 & 105,0 & 463,6 & 116,5 \\
\hline Нижегородская область & 116,3 & 99,1 & 495,1 & 103,0 & 957,9 & 93,3 \\
\hline Оренбургская область & 107,8 & 101,0 & 513,1 & 99,0 & 770,3 & 96,8 \\
\hline Пензенская область & 310,8 & 112,3 & 299,3 & 111,2 & 236,2 & 116,7 \\
\hline Самарская область & 107,8 & 103,7 & 359,5 & 102,8 & 81,5 & 96,8 \\
\hline Саратовская область & 119,4 & 97,5 & 609,0 & 100,8 & 717,6 & 98,8 \\
\hline Ульяновская область & 47,8 & 99,8 & 178,9 & 105,3 & 153,7 & 99,5 \\
\hline Уральский федеральный округ & 710,1 & 98,6 & 1558,5 & 101,3 & 3657,3 & 100,0 \\
\hline Курганская область & 41,9 & 100,5 & 157,6 & 97,9 & 78,5 & 100,9 \\
\hline Свердловская область & 193,9 & 107,7 & 604,2 & 103,5 & 1118,8 & 96,9 \\
\hline Тюменская область & 120,5 & 101,5 & 458,6 & 101,5 & 1217,0 & 99,5 \\
\hline $\begin{array}{l}\text { в том числе: } \\
\text { Ханты-Мансийский авт. округ - Югра }\end{array}$ & 13,9 & 99,9 & 23,2 & 106,4 & 42,0 & 113,7 \\
\hline Ямало-Ненецкий авт. округ & 0,8 & 108,8 & 1,9 & 103,5 & 0,3 & 100,6 \\
\hline Тюменская область без авт. округов & 105,7 & 101,6 & 433,5 & 101,3 & 1174,8 & 99,1 \\
\hline Челябинская область & 353,7 & 93,1 & 338,1 & 99,1 & 1243,0 & 103,4 \\
\hline Сибирский федеральный округ & 932,6 & 100,3 & 3550,5 & 101,9 & 4726,1 & 100,8 \\
\hline Республика Алтай & 17,9 & 110,3 & 60,0 & 99,6 & 6,8 & 98,9 \\
\hline Республика Тыва & 9,9 & 100,1 & 51,2 & 100,3 & 6,4 & 107,9 \\
\hline Республика Хакасия & 24,9 & 97,6 & 107,7 & 97,5 & 68,0 & 99,4 \\
\hline Алтайский край & 184,0 & 102,4 & 958,7 & 100,9 & 767,5 & 103,7 \\
\hline Красноярский край & 135,0 & 107,6 & 509,6 & 102,7 & 643,0 & 99,5 \\
\hline Иркутская область & 78,8 & 103,9 & 369,5 & 101,2 & 759,6 & 101,4 \\
\hline Кемеровская область & 69,8 & 78,5 & 242,1 & 100,3 & 888,6 & 109,3 \\
\hline Новосибирская область & 160,7 & 104,2 & 650,1 & 105,2 & 957,1 & 108,7 \\
\hline Омская область & 138,1 & 96,6 & 489,1 & 101,1 & 539,0 & 79,0 \\
\hline Томская область & 113,6 & 102,3 & 112,4 & 103,0 & 90,2 & 92,1 \\
\hline Дальневосточный федеральный округ & 140,7 & 101,8 & 800,2 & 99,8 & 1010,7 & 106,1 \\
\hline Республика Бурятия & 29,9 & 99,5 & 96,4 & 90,5 & 76,0 & 117,6 \\
\hline Республика Саха (Якутия) & 4,9 & 92,1 & 130,8 & 99,0 & 98,9 & 100,8 \\
\hline Забайкальский край & 23,3 & 101,4 & 283,7 & 100,3 & 45,2 & 100,4 \\
\hline Камчатский край & 6,9 & 108,3 & 17,4 & 102,4 & 45,6 & 123,7 \\
\hline Приморский край & 20,9 & 139,3 & 99,4 & 101,9 & 216,8 & 110,6 \\
\hline Хабаровский край & 10,0 & 102,9 & 18,4 & 91,3 & 250,8 & 111,7 \\
\hline Амурская область & 32,6 & 86,1 & 106,1 & 104,2 & 139,4 & 95,2 \\
\hline Магаданская область & 0,5 & 108,2 & 4,7 & 101,6 & 19,6 & 85,5 \\
\hline Сахалинская область & 10,5 & 121,2 & 36,1 & 115,8 & 104,7 & 98,3 \\
\hline Еврейская авт. область & 0,8 & 61,8 & 7,2 & 95,0 & 9,7 & 100,0 \\
\hline Чукотский авт. округ & 0,4 & 93,2 & 0,0 & 84,1 & 4,1 & в $2,5 \mathrm{p}$. \\
\hline
\end{tabular}




\section{СТРОИТЕЛЬСТВО}

ОБЪЕМ РАБОТ, ВЫПОЛНЕННЫХ ПО ВИДУ ДЕЯТЕЛЬНОСТИ "СТРОИТЕЛЬСТВО" в январе-сентябре 2020 года

\begin{tabular}{|c|c|c|}
\hline & Млн рублей & $\begin{array}{c}\text { B\% \% } \\
\text { январю-сентябрю } 2019 \text { г. }\end{array}$ \\
\hline Российская Федерация, млрд рублей ${ }^{1)}$ & 6382,0 & 99,6 \\
\hline Центральный федеральный округ & 1705883,3 & 103,4 \\
\hline Белгородская область & 94301,8 & 110,7 \\
\hline Брянская область & 31075,8 & 151,1 \\
\hline Владимирская область & 31944,4 & 107,8 \\
\hline Воронежская область & 87506,4 & 93,7 \\
\hline Ивановская область & 20014,6 & 80,7 \\
\hline Калужская область & 45657,1 & 113,2 \\
\hline Костромская область & 12802,7 & 129,3 \\
\hline Курская область & 53924,9 & 99,2 \\
\hline Липецкая область & 55927,1 & 109,0 \\
\hline Московская область & 403465,5 & 119,2 \\
\hline Орловская область & 21075,8 & 132,2 \\
\hline Рязанская область & 23248,5 & 55,1 \\
\hline Смоленская область & 20973,9 & 102,3 \\
\hline Тамбовская область & 22282,4 & 98,8 \\
\hline Тверская область & 28082,5 & 136,9 \\
\hline Тульская область & 57419,4 & 100,1 \\
\hline Ярославская область & 31217,7 & 122,8 \\
\hline г. Москва & 664962,8 & 95,4 \\
\hline Северо-Западный федеральный округ & 754483,3 & 93,0 \\
\hline Республика Карелия & 16698,0 & 72,5 \\
\hline Республика Коми & 27606,3 & 116,5 \\
\hline Архангельская область & 43238,5 & 86,4 \\
\hline $\begin{array}{l}\text { в том числе: } \\
\text { Ненецкий авт. округ }\end{array}$ & 21211,7 & 103,8 \\
\hline Архангельская область без авт. округа & 22026,8 & 75,4 \\
\hline Вологодская область & 63226,3 & 83,5 \\
\hline Калининградская область & 49164,1 & 92,4 \\
\hline Ленинградская область & 156011,6 & 85,1 \\
\hline Мурманская область & 61521,6 & 137,7 \\
\hline Новгородская область & 11454,6 & 99,0 \\
\hline Псковская область & 17348,5 & 86,5 \\
\hline г. Санкт-Петербург & 308213,9 & 94,3 \\
\hline Южный федеральный округ & 450351,2 & 95,6 \\
\hline Республика Адыгея & 13551,1 & 75,7 \\
\hline Республика Калмыкия & 4715,1 & 94,8 \\
\hline Республика Крым & 100091,5 & 86,1 \\
\hline Краснодарский край & 163226,2 & 94,6 \\
\hline Астраханская область & 19955,8 & 127,9 \\
\hline Волгоградская область & 50531,5 & 130,3 \\
\hline Ростовская область & 94006,0 & 96,5 \\
\hline г. Севастополь & 4274,0 & 48,1 \\
\hline Северо-Кавказский федеральный округ & 274226,1 & 94,7 \\
\hline Республика Дагестан & 109564,2 & 91,4 \\
\hline Республика Ингушетия & 10930,8 & 129,7 \\
\hline Кабардино-Балкарская Республика & 16977,5 & 100,2 \\
\hline Карачаево-Черкесская Республика & 8362,2 & 78,4 \\
\hline Республика Северная Осетия - Алания & 6022,8 & 39,4 \\
\hline Чеченская Республика & 28242,7 & 107,7 \\
\hline Ставропольский край & 94125,9 & 100,6 \\
\hline
\end{tabular}




\begin{tabular}{|c|c|c|}
\hline & Млн рублей & $\begin{array}{c}\text { В\% \% } \\
\text { январю-сентябрю } 2019 \text { г. }\end{array}$ \\
\hline Приволжский федеральный округ & 955112,1 & 97,6 \\
\hline Республика Башкортостан & 130458,5 & 84,8 \\
\hline Республика Марий Эл & 18855,9 & 123,3 \\
\hline Республика Мордовия & 16886,2 & 94,2 \\
\hline Республика Татарстан & 227213,4 & 98,1 \\
\hline Удмуртская Республика & 36318,3 & 136,1 \\
\hline Чувашская Республика & 24930,8 & 107,5 \\
\hline Пермский край & 96664,2 & 102,5 \\
\hline Кировская область & 20219,5 & 91,9 \\
\hline Нижегородская область & 122310,9 & 98,3 \\
\hline Оренбургская область & 61342,2 & 88,9 \\
\hline Пензенская область & 23777,1 & 90,6 \\
\hline Самарская область & 107724,6 & 103,4 \\
\hline Саратовская область & 46956,9 & 112,6 \\
\hline Ульяновская область & 21453,5 & 78,8 \\
\hline Уральский федеральный округ & 1086548,0 & 118,0 \\
\hline Курганская область & 15511,2 & 103,0 \\
\hline Свердловская область & 164016,4 & 106,2 \\
\hline Тюменская область & 847129,5 & 123,2 \\
\hline $\begin{array}{l}\text { в том числе: } \\
\text { Ханты-Мансийский авт. округ - Югра }\end{array}$ & 269923,7 & 112,5 \\
\hline Ямало-Ненецкий авт. округ & 453323,2 & 165,7 \\
\hline Тюменская область без авт. округов & 123882,5 & 74,5 \\
\hline Челябинская область & 59891,0 & 93,0 \\
\hline Сибирский федеральный округ & 559599,5 & 86,3 \\
\hline Республика Алтай & 6048,8 & 99,3 \\
\hline Республика Тыва & 5295,6 & 77,4 \\
\hline Республика Хакасия & 10600,2 & 92,8 \\
\hline Алтайский край & 47822,1 & 113,5 \\
\hline Красноярский край & 104553,1 & 104,6 \\
\hline Иркутская область & 92538,0 & 66,8 \\
\hline Кемеровская область & 98019,8 & 76,1 \\
\hline Новосибирская область & 72420,4 & 71,1 \\
\hline Омская область & 74125,7 & 99,8 \\
\hline Томская область & 48175,7 & 122,1 \\
\hline Дальневосточный федеральный округ & 407808,5 & 89,1 \\
\hline Республика Бурятия & 18845,8 & 95,6 \\
\hline Республика Саха (Якутия) & 71075,2 & 48,1 \\
\hline Забайкальский край & 25062,8 & 135,0 \\
\hline Камчатский край & 12398,4 & 89,9 \\
\hline Приморский край & 80559,4 & 118,4 \\
\hline Хабаровский край & 61124,2 & 121,7 \\
\hline Амурская область & 64463,6 & 103,0 \\
\hline Магаданская область & 17673,9 & 113,4 \\
\hline Сахалинская область & 45552,4 & 107,4 \\
\hline Еврейская авт. область & 7962,4 & 96,7 \\
\hline Чукотский авт. округ & 3090,4 & 49,6 \\
\hline
\end{tabular}


ВВОД В ДЕЙСТВИЕ ЗДАНИЙ ЖИЛОГО И НЕЖИЛОГО НАЗНАЧЕНИЯ в январе-сентябре 2020 года

\begin{tabular}{|c|c|c|c|}
\hline & $\begin{array}{c}\text { Количество зданий, } \\
\text { единиц }\end{array}$ & $\begin{array}{c}\text { Общчий строительный } \\
\text { объем зданий, } \\
\text { тыс. } \text { м }^{3} \\
\end{array}$ & $\begin{array}{c}\text { Общая площады зданий, } \\
\text { тьс. } м^{2}\end{array}$ \\
\hline Российская Федерация & 203123 & 360244,0 & 81333,2 \\
\hline Центральный федеральный округ & 49857 & 135374,3 & 26999,6 \\
\hline Белгородская область & 5190 & 5539,4 & 1164,9 \\
\hline Брянская область & 940 & 2226,8 & 533,8 \\
\hline Владимирская область & 2056 & 2545,6 & 617,8 \\
\hline Воронежская область & 2829 & 8058,1 & 1318,7 \\
\hline Ивановская область & 647 & 929,2 & 217,1 \\
\hline Калужская область & 3350 & 4232,5 & 966,7 \\
\hline Костромская область & 684 & 1090,2 & 279,2 \\
\hline Курская область & 1834 & 4966,8 & 869,8 \\
\hline Липецкая область & 4895 & 6748,6 & 1386,5 \\
\hline Московская область & 13799 & 45108,4 & 8310,0 \\
\hline Орловская область & 1293 & 2198,7 & 485,8 \\
\hline Рязанская область & 1424 & 3898,0 & 851,7 \\
\hline Смоленская область & 1147 & 1971,6 & 442,5 \\
\hline Тамбовская область & 1397 & 3428,3 & 711,8 \\
\hline Тверская область & 1775 & 2280,1 & 562,3 \\
\hline Тульская область & 1528 & 4401,5 & 857,3 \\
\hline Ярославская область & 2715 & 3820,5 & 816,5 \\
\hline г. Москва & 2354 & 31929,9 & 6607,5 \\
\hline Северо-Западный федеральный округ & 16590 & 35048,5 & 8406,5 \\
\hline Республика Карелия & 890 & 943,1 & 275,5 \\
\hline Республика Коми & 778 & 901,8 & 183,7 \\
\hline Архангельская область & 1184 & 1109,7 & 258,5 \\
\hline $\begin{array}{l}\text { в том числе: } \\
\text { Ненецкий авт. округ }\end{array}$ & 64 & 170,2 & 36,8 \\
\hline Архангельская область без авт. округа & 1120 & 939,4 & 221,7 \\
\hline Вологодская область & 1749 & 1707,7 & 371,4 \\
\hline Калининградская область & 2219 & 5588,3 & 1223,7 \\
\hline Ленинградская область & 6894 & 10893,3 & 2897,3 \\
\hline Мурманская область & 197 & 213,8 & 44,1 \\
\hline Новгородская область & 1023 & 901,6 & 235,4 \\
\hline Псковская область & 1139 & 1847,8 & 596,2 \\
\hline г. Санкт-Петербург & 517 & 10941,5 & 2320,7 \\
\hline Южный федеральный округ & 28066 & 37433,6 & 9295,7 \\
\hline Республика Адыгея & 873 & 899,7 & 234,2 \\
\hline Республика Калмыкия & 335 & 229,8 & 59,9 \\
\hline Республика Крым & 2686 & 1681,5 & 456,5 \\
\hline Краснодарский край & 11327 & 17570,6 & 4445,1 \\
\hline Астраханская область & 1812 & 1291,3 & 323,5 \\
\hline Волгоградская область & 2178 & 3913,8 & 860,1 \\
\hline Ростовская область & 6228 & 10180,2 & 2455,5 \\
\hline г. Севастополь & 2627 & 1666,9 & 460,9 \\
\hline Северо-Кавказский федеральный округ & 11451 & 15079,9 & 3618,3 \\
\hline Республика Дагестан & 1914 & 2502,8 & 610,7 \\
\hline Республика Ингушетия & 448 & 583,6 & 136,1 \\
\hline Кабардино-Балкарская Республика & 2478 & 1357,3 & 372,9 \\
\hline Карачаево-Черкесская Республика & 505 & 718,0 & 159,3 \\
\hline Республика Северная Осетия - Алания & 599 & 1462,2 & 358,8 \\
\hline Чеченская Республика & 2267 & 2552,2 & 620,5 \\
\hline Ставропольский край & 3240 & 5903,7 & 1359,9 \\
\hline
\end{tabular}




\begin{tabular}{|c|c|c|c|}
\hline & $\begin{array}{c}\text { Количество зданий, } \\
\text { единии }\end{array}$ & $\begin{array}{c}\text { Общий строительный } \\
\text { объем зданий, } \\
\text { тыс. } \text { м }^{3}\end{array}$ & $\begin{array}{c}\text { Общая площады зданий, } \\
\text { тыс. } м^{2}\end{array}$ \\
\hline Приволжский федеральный округ & 52373 & 66989,2 & 16349,8 \\
\hline Республика Башкортостан & 11440 & 8520,8 & 2077,1 \\
\hline Республика Марий Эл & 931 & 1549,3 & 365,5 \\
\hline Республика Мордовия & 897 & 1943,0 & 471,8 \\
\hline Республика Татарстан & 9435 & 14897,3 & 3764,9 \\
\hline Удмуртская Республика & 3023 & 2982,0 & 749,5 \\
\hline Чувашская Республика & 806 & 2552,9 & 655,9 \\
\hline Пермский край & 3622 & 3969,3 & 1076,4 \\
\hline Кировская область & 1373 & 1960,3 & 470,7 \\
\hline Нижегородская область & 4830 & 8810,4 & 1793 \\
\hline Оренбургская область & 2365 & 3088,8 & 774,2 \\
\hline Пензенская область & 2554 & 4625,6 & 1131,0 \\
\hline Самарская область & 4941 & 5124,2 & 1189,6 \\
\hline Саратовская область & 2505 & 3565,2 & 925,8 \\
\hline Ульяновская область & 3651 & 3400,2 & 904,3 \\
\hline Уральский федеральный округ & 16600 & 27420,4 & 6784,0 \\
\hline Курганская область & 1084 & 1881,3 & 380,2 \\
\hline Свердловская область & 5252 & 10265,7 & 2662,8 \\
\hline Тюменская область & 6895 & 8820,7 & 2139,0 \\
\hline $\begin{array}{l}\text { в том числе: } \\
\text { Ханты-Мансийский авт. округ - Югра }\end{array}$ & 2652 & 3318,9 & 833,1 \\
\hline Ямало-Ненецкий авт. округ & 331 & 848,9 & 182,9 \\
\hline Тюменская область без авт. округов & 3912 & 4652,8 & 1123,0 \\
\hline Челябинская область & 3369 & 6452,8 & 1602,0 \\
\hline Сибирский федеральный округ & 19609 & 31288,3 & 7246,2 \\
\hline Республика Алтай & 769 & 302,7 & 78,8 \\
\hline Республика Тыва & 583 & 250,5 & 92,7 \\
\hline Республика Хакасия & 731 & 849,1 & 237,0 \\
\hline Алтайский край & 1945 & 3679,7 & 799,5 \\
\hline Красноярский край & 3505 & 5841,5 & 1510,3 \\
\hline Иркутская область & 3194 & 4127,6 & 845,1 \\
\hline Кемеровская область & 3345 & 2543,3 & 637,5 \\
\hline Новосибирская область & 3060 & 10018,6 & 2239,8 \\
\hline Омская область & 1061 & 1909,3 & 462,0 \\
\hline Томская область & 1416 & 1765,9 & 343,5 \\
\hline Дальневосточный федеральный округ & 8418 & 11383,3 & 2548,4 \\
\hline Республика Бурятия & 1408 & 1061,9 & 255,6 \\
\hline Республика Саха (Якутия) & 2135 & 1420,0 & 348,9 \\
\hline Забайкальский край & 900 & 540,6 & 125,0 \\
\hline Камчатский край & 266 & 323,2 & 68,1 \\
\hline Приморский край & 1377 & 3263,8 & 756,5 \\
\hline Хабаровский край & 773 & 1835,6 & 320,4 \\
\hline Амурская область & 323 & 635,7 & 148,7 \\
\hline Магаданская область & 37 & 52,3 & 11,1 \\
\hline Сахалинская область & 1044 & 2114,3 & 487,3 \\
\hline Еврейская авт. область & 144 & 98,4 & 20,3 \\
\hline Чукотский авт. округ & 11 & 37,5 & 6,7 \\
\hline
\end{tabular}


СТРОИТЕЛЬСТВО ЖИЛЫХ ДОМОВ

в январе-сентябре 2020 года

\begin{tabular}{|c|c|c|}
\hline & 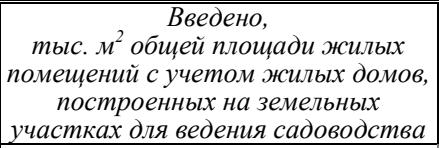 & $\begin{array}{c}\text { в\% } \\
\text { январю-сентябрю } \\
2019 \text { г. }\end{array}$ \\
\hline Российская Федерация & 47795,8 & 97,7 \\
\hline Центральный федеральный округ & 14482,9 & 85,5 \\
\hline Белгородская область & 795,2 & 92,9 \\
\hline Брянская область & 247,2 & 142,2 \\
\hline Владимирская область & 471,0 & 91,3 \\
\hline Воронежская область & 828,9 & 75,1 \\
\hline Ивановская область & 151,2 & 72,0 \\
\hline Калужская область & 508,6 & 120,9 \\
\hline Костромская область & 207,2 & 131,6 \\
\hline Курская область & 300,9 & 78,6 \\
\hline Липецкая область & 841,7 & 102,6 \\
\hline Московская область & 4411,5 & 76,6 \\
\hline Орловская область & 230,7 & 137,0 \\
\hline Рязанская область & 462,6 & 76,7 \\
\hline Смоленская область & 300,1 & 96,6 \\
\hline Тамбовская область & 296,1 & 62,3 \\
\hline Тверская область & 377,1 & 88,6 \\
\hline Тульская область & 411,1 & 111,5 \\
\hline Ярославская область & 575,0 & 105,1 \\
\hline г. Москва & 3066,9 & 84,3 \\
\hline Северо-Западный федеральный округ & 4717,6 & 102,3 \\
\hline Республика Карелия & 183,4 & 93,4 \\
\hline Республика Коми & 105,5 & 93,1 \\
\hline Архангельская область & 177,1 & 93,1 \\
\hline $\begin{array}{l}\text { в том числе: } \\
\text { Ненецкий авт. округ }\end{array}$ & 13,5 & 168,8 \\
\hline Архангельская область без авт. округа & 163,6 & 89,8 \\
\hline Вологодская область & 291,3 & 77,5 \\
\hline Калининградская область & 712,0 & 120,0 \\
\hline Ленинградская область & 1648,5 & 98,2 \\
\hline Мурманская область & 19,1 & 65,8 \\
\hline Новгородская область & 172,1 & 102,1 \\
\hline Псковская область & 161,5 & 82,2 \\
\hline г. Санкт-Петербург & 1247,1 & 116,7 \\
\hline Южный федеральный округ & 6220,6 & $\mathbf{9 8 , 9}$ \\
\hline Республика Адыгея & 162,7 & 93,4 \\
\hline Республика Калмыкия & 39,1 & 54,4 \\
\hline Республика Крым & 387,2 & 107,7 \\
\hline Краснодарский край & 2929,4 & 102,9 \\
\hline Астраханская область & 236,6 & 98,1 \\
\hline Волгоградская область & 466,1 & 123,4 \\
\hline Ростовская область & 1615 & 88,9 \\
\hline г. Севастополь & 384,4 & 96,1 \\
\hline Северо-Кавказский федеральный округ & 2457,1 & 105,8 \\
\hline Республика Дагестан & 500,8 & 90,3 \\
\hline Республика Ингушетия & 77,1 & 74,3 \\
\hline Кабардино-Балкарская Республика & 323,3 & 109,8 \\
\hline Карачаево-Черкесская Республика & 78,6 & 75,5 \\
\hline Республика Северная Осетия - Алания & 206,8 & 113,7 \\
\hline Чеченская Республика & 474,2 & 137,8 \\
\hline Ставропольский край & 796,3 & 107,7 \\
\hline
\end{tabular}




\begin{tabular}{|c|c|c|}
\hline & $\begin{array}{c}\text { Введено, } \\
\text { тыс. } \text { м }^{2} \text { обшей площзади жильхх } \\
\text { помещений с учетом жильх домов, } \\
\text { построенных на земельных } \\
\text { участках для ведения садоводства }\end{array}$ & $\begin{array}{c}\text { В\%к } \\
\text { январю-сентябрю } \\
2019 \text { г. }\end{array}$ \\
\hline Приволжский федеральный округ & 10543,1 & 104,5 \\
\hline Республика Башкортостан & 1699,1 & 109,6 \\
\hline Республика Марий Эл & 227,5 & 108,3 \\
\hline Республика Мордовия & 233,8 & 91,4 \\
\hline Республика Татарстан & 2071,5 & 116,9 \\
\hline Удмуртская Республика & 551,5 & 91,3 \\
\hline Чувашская Республика & 370,5 & 92,9 \\
\hline Пермский край & 710,3 & 115,0 \\
\hline Кировская область & 284,8 & 85,1 \\
\hline Нижегородская область & 1025,0 & 106,0 \\
\hline Оренбургская область & 581,1 & 90,9 \\
\hline Пензенская область & 599,7 & 105,9 \\
\hline Самарская область & 881,9 & 99,8 \\
\hline Саратовская область & 610,2 & 91,5 \\
\hline Ульяновская область & 696,2 & 112,0 \\
\hline Уральский федеральный округ & 3805,9 & 110,6 \\
\hline Курганская область & 152,6 & 87,7 \\
\hline Свердловская область & 1343,7 & 112,5 \\
\hline Тюменская область & 1314,3 & 109,5 \\
\hline $\begin{array}{l}\text { в том числе: } \\
\text { Ханты-Мансийский авт. округ - Югра }\end{array}$ & 532,5 & 176,2 \\
\hline Ямало-Ненецкий авт. округ & 76,6 & 110,1 \\
\hline Тюменская область без авт. округов & 705,2 & 85,2 \\
\hline Челябинская область & 995,3 & 113,9 \\
\hline Сибирский федеральный округ & 4108,3 & 103,3 \\
\hline Республика Алтай & 58,7 & 97,7 \\
\hline Республика Тыва & 43,6 & 86,0 \\
\hline Республика Хакасия & 156,1 & 112,2 \\
\hline Алтайский край & 474,9 & 98,6 \\
\hline Красноярский край & 719,8 & 95,5 \\
\hline Иркутская область & 517,1 & 103,1 \\
\hline Кемеровская область & 438,2 & 110,2 \\
\hline Новосибирская область & 1164,3 & 114,2 \\
\hline Омская область & 291,6 & 82,2 \\
\hline Томская область & 243,9 & 112,7 \\
\hline Дальневосточный федеральный округ & 1398,3 & 104,4 \\
\hline Республика Бурятия & 139,7 & 95,8 \\
\hline Республика Саха (Якутия) & 255,2 & 101,2 \\
\hline Забайкальский край & 97,4 & 90,6 \\
\hline Камчатский край & 26,3 & 164,0 \\
\hline Приморский край & 414,3 & 116,9 \\
\hline Хабаровский край & 128,6 & 76,9 \\
\hline Амурская область & 85,0 & 120,9 \\
\hline Магаданская область & 5,8 & 158,8 \\
\hline Сахалинская область & 234,9 & 116,0 \\
\hline Еврейская авт. область & 10,6 & 55,2 \\
\hline Чукотский авт. округ & 0,6 & - \\
\hline
\end{tabular}


ИНДИВИДУАЛЬНОЕ ЖИЛИЩНОЕ СТРОИТЕЛЬСТВО,

ОСУЩЕСТВЛЯЕМОЕ НАСЕЛЕНИЕМ

в январе-сентябре 2020 года

\begin{tabular}{|c|c|c|}
\hline & 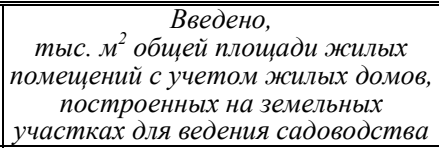 & $\begin{array}{c}B \% \kappa \\
\text { январю-сентябрю } \\
2019 \text { г. }\end{array}$ \\
\hline Российская Федерация & 25140,4 & 98,5 \\
\hline Центральный федеральный округ & 6971,6 & 84,8 \\
\hline Белгородская область & 665,4 & 89,4 \\
\hline Брянская область & 112,6 & 126,1 \\
\hline Владимирская область & 331,1 & 85,0 \\
\hline Воронежская область & 387,8 & 71,8 \\
\hline Ивановская область & 102,0 & 82,4 \\
\hline Калужская область & 383,0 & 120,5 \\
\hline Костромская область & 88,3 & 92,9 \\
\hline Курская область & 214,8 & 84,8 \\
\hline Липецкая область & 755,6 & 120,6 \\
\hline Московская область & 2116,0 & 70,9 \\
\hline Орловская область & 152,1 & 130,8 \\
\hline Рязанская область & 190,7 & 85,0 \\
\hline Смоленская область & 160,2 & 89,6 \\
\hline Тамбовская область & 221,7 & 54,2 \\
\hline Тверская область & 227,8 & 79,5 \\
\hline Тульская область & 217,2 & 78,7 \\
\hline Ярославская область & 297,7 & 88,6 \\
\hline г. Москва & 347,7 & 148,5 \\
\hline Северо-Западный федеральный округ & 1943,0 & 113,4 \\
\hline Республика Карелия & 83,3 & 86,6 \\
\hline Республика Коми & 68,4 & 84,3 \\
\hline Архангельская область & 102,7 & 113,2 \\
\hline $\begin{array}{l}\text { в том числе: } \\
\text { Ненецкий авт. округ }\end{array}$ & 5,7 & 138,7 \\
\hline Архангельская область без авт. округа & 97,0 & 112,0 \\
\hline Вологодская область & 170,1 & 80,6 \\
\hline Калининградская область & 302,1 & 152,5 \\
\hline Ленинградская область & 884,6 & 155,2 \\
\hline Мурманская область & 17,4 & 63,4 \\
\hline Новгородская область & 117,4 & 94,8 \\
\hline Псковская область & 112,8 & 82,2 \\
\hline г. Санкт-Петербург & 84,2 & 47,5 \\
\hline Южный федеральный округ & 3421,3 & 103,5 \\
\hline Республика Адыгея & 105,2 & 106,9 \\
\hline Республика Калмыкия & 32,9 & 76,7 \\
\hline Республика Крым & 334,2 & 137,8 \\
\hline Краснодарский край & 1376,2 & 104,5 \\
\hline Астраханская область & 192,6 & 124,5 \\
\hline Волгоградская область & 236,6 & 105,8 \\
\hline Ростовская область & 816,9 & 85,6 \\
\hline г. Севастополь & 326,6 & 119,3 \\
\hline Северо-Кавказский федеральный округ & 1628,6 & 106,6 \\
\hline Республика Дагестан & 317,8 & 98,6 \\
\hline Республика Ингушетия & 63,6 & 78,9 \\
\hline Кабардино-Балкарская Республика & 290,0 & 119,6 \\
\hline Карачаево-Черкесская Республика & 70,9 & 84,7 \\
\hline Республика Северная Осетия - Алания & 56,6 & 153,3 \\
\hline Чеченская Республика & 398,8 & 123,3 \\
\hline Ставропольский край & 431,0 & 98,3 \\
\hline
\end{tabular}




\begin{tabular}{|c|c|c|}
\hline & $\begin{array}{c}\text { Введено, } \\
\text { тысс. } \text { м }^{2} \text { обшей площзади жильхх } \\
\text { помешений с учетом жильх домов, } \\
\text { построенных на земельныхх } \\
\text { участках для ведения садоводства } \\
\end{array}$ & $\begin{array}{c}B \% \kappa \\
\text { январю-сентябрю } \\
2019 \text { 2. }^{l}\end{array}$ \\
\hline Приволжский федеральный округ & 6503,1 & 107,4 \\
\hline Республика Башкортостан & 1188,6 & 114,5 \\
\hline Республика Марий Эл & 102,6 & 86,6 \\
\hline Республика Мордовия & 124,6 & 95,7 \\
\hline Республика Татарстан & 1166,3 & 134,6 \\
\hline Удмуртская Республика & 316,7 & 98,5 \\
\hline Чувашская Республика & 100,2 & 100,0 \\
\hline Пермский край & 409,5 & 94,6 \\
\hline Кировская область & 150,3 & 88,1 \\
\hline Нижегородская область & 694,5 & 111,4 \\
\hline Оренбургская область & 312,9 & 92,5 \\
\hline Пензенская область & 404,1 & 100,8 \\
\hline Самарская область & 658,1 & 120,8 \\
\hline Саратовская область & 384,3 & 85,8 \\
\hline Ульяновская область & 490,5 & 94,2 \\
\hline Уральский федеральный округ & 1836,5 & 106,4 \\
\hline Курганская область & 114,1 & 86,7 \\
\hline Свердловская область & 669,7 & 100,2 \\
\hline Тюменская область & 628,3 & 132,8 \\
\hline $\begin{array}{l}\text { в том числе: } \\
\text { Ханты-Мансийский авт. округ - Югра }\end{array}$ & 200,7 & в $2,2 \mathrm{p}$. \\
\hline Ямало-Ненецкий авт. округ & 30,5 & 122,3 \\
\hline Тюменская область без авт. округов & 397,2 & 110,6 \\
\hline Челябинская область & 424,4 & 93,8 \\
\hline Сибирский федеральный округ & 2044,5 & 98,3 \\
\hline Республика Алтай & 56,0 & 101,8 \\
\hline Республика Тыва & 42,9 & 107,7 \\
\hline Республика Хакасия & 90,1 & 93,1 \\
\hline Алтайский край & 220,9 & 92,8 \\
\hline Красноярский край & 334,2 & 89,5 \\
\hline Иркутская область & 324,4 & 105,1 \\
\hline Кемеровская область & 341,7 & 140,5 \\
\hline Новосибирская область & 341,4 & 85,2 \\
\hline Омская область & 146,4 & 66,7 \\
\hline Томская область & 146,5 & 139,2 \\
\hline Дальневосточный федеральный округ & 771,8 & $\mathbf{9 7 , 8}$ \\
\hline Республика Бурятия & 107,2 & 96,3 \\
\hline Республика Саха (Якутия) & 150,9 & 114,7 \\
\hline Забайкальский край & 85,4 & 81,0 \\
\hline Камчатский край & 23,2 & 150,6 \\
\hline Приморский край & 172,2 & 89,2 \\
\hline Хабаровский край & 79,2 & 101,0 \\
\hline Амурская область & 37,1 & 181,1 \\
\hline Магаданская область & 3,3 & 142,4 \\
\hline Сахалинская область & 102,7 & 91,6 \\
\hline Еврейская авт. область & 10,6 & 55,2 \\
\hline Чукотский авт. округ & - & - \\
\hline
\end{tabular}




\section{РОЗНИЧНАЯ ТОРГОВЛЯ}

ОБОРОТ РОЗНИЧНОЙ ТОРГОВЛИ

\begin{tabular}{|c|c|c|c|c|}
\hline & \multicolumn{2}{|c|}{ Снварь-сентябрь 2020 г. } & \multicolumn{2}{|c|}{ Сентябрь 2020 г. в \% к } \\
\hline & млн рублей & \begin{tabular}{|c|}
$в \% \kappa$ \\
январю-сентябрю \\
20192. \\
\end{tabular} & $\begin{array}{l}\text { сентябрю } \\
2019 \text { 2. }\end{array}$ & $\begin{array}{l}\text { aвzусmy } \\
2020 \text { z. }\end{array}$ \\
\hline Российская Федерация, млрд рублей & 23925,5 & 95,2 & $\mathbf{9 7 , 0}$ & 98,3 \\
\hline Центральный федеральный округ & 8336727,2 & 96,0 & $\mathbf{9 8 , 3}$ & 99,4 \\
\hline Белгородская область & 269372,5 & 99,4 & 97,8 & 96,4 \\
\hline Брянская область & 184084,4 & 92,2 & 101,3 & 97,2 \\
\hline Владимирская область & 176395,5 & 97,6 & 93,5 & 94,4 \\
\hline Воронежская область & 416881,4 & 93,9 & 96,1 & 97,0 \\
\hline Ивановская область & 126031,9 & 92,6 & 87,6 & 96,2 \\
\hline Калужская область & 156685,0 & 97,2 & 98,1 & 97,5 \\
\hline Костромская область & 82365,6 & 98,9 & 102,6 & 99,6 \\
\hline Курская область & 167298,2 & 96,8 & 93,5 & 96,6 \\
\hline Липецкая область & 193116,4 & 93,0 & 89,8 & 95,7 \\
\hline Московская область & 1854861,9 & 95,9 & 97,1 & 96,5 \\
\hline Орловская область & 102132,3 & 96,7 & 96,1 & 95,2 \\
\hline Рязанская область & 157716,7 & 100,6 & 100,7 & 96,1 \\
\hline Смоленская область & 123289,1 & 91,8 & 91,5 & 95,3 \\
\hline Тамбовская область & 138942,1 & 88,4 & 90,0 & 103,2 \\
\hline Тверская область & 185631,1 & 100,5 & 95,7 & 92,0 \\
\hline Тульская область & 213678,4 & 91,8 & 85,3 & 96,9 \\
\hline Ярославская область & 174279,7 & 90,0 & 89,8 & 98,0 \\
\hline г. Москва & 3613965,1 & 96,8 & 101,6 & 102,9 \\
\hline Северо-Западный федеральный округ & 2439642,1 & 98,3 & 101,0 & 96,9 \\
\hline Республика Карелия & 98279,6 & 100,4 & 98,8 & 91,6 \\
\hline Республика Коми & 121136,9 & 98,9 & 99,5 & 95,8 \\
\hline Архангельская область & 206657,0 & 98,8 & 100,1 & 96,8 \\
\hline $\begin{array}{l}\text { в том числе: } \\
\text { Ненецкий авт. округ }\end{array}$ & 7298,7 & 99,4 & 94,3 & 103,4 \\
\hline Архангельская область без авт. округа & 199358,3 & 98,7 & 100,3 & 96,6 \\
\hline Вологодская область & 147709,9 & 99,2 & 96,3 & 97,9 \\
\hline Калининградская область & 133586,3 & 96,6 & 99,6 & 94,7 \\
\hline Ленинградская область & 351606,5 & 104,8 & 108,2 & 91,8 \\
\hline Мурманская область & 131654,8 & 96,8 & 93,4 & 101,9 \\
\hline Новгородская область & 88667,8 & 99,0 & 97,6 & 93,5 \\
\hline Псковская область & 92197,8 & 100,4 & 100,0 & 88,3 \\
\hline г. Санкт-Петербург & 1068145,6 & 95,8 & 101,1 & 99,7 \\
\hline Южный федеральный округ & 2466382,0 & 94,2 & 99,4 & 96,9 \\
\hline Республика Адыгея & 75085,6 & 100,0 & 108,6 & 99,7 \\
\hline Республика Калмыкия & 17378,6 & 101,1 & 104,1 & 94,7 \\
\hline Республика Крым & 195516,5 & 93,5 & 102,6 & 95,8 \\
\hline Краснодарский край & 1019824,5 & 93,6 & 99,2 & 97,4 \\
\hline Астраханская область & 127949,6 & 93,5 & 92,8 & 97,5 \\
\hline Волгоградская область & 294457,1 & 93,7 & 94,6 & 96,0 \\
\hline Ростовская область & 687350,6 & 95,1 & 100,5 & 96,3 \\
\hline г. Севастополь & 48819,5 & 92,7 & 99,8 & 97,2 \\
\hline Северо-Кавказский федеральный округ & 1072530,7 & 91,0 & 99,7 & 99,7 \\
\hline Республика Дагестан & 370875,2 & 90,3 & 98,7 & 96,2 \\
\hline Республика Ингушетия & 19403,5 & 96,5 & 100,3 & 101,3 \\
\hline Кабардино-Балкарская Республика & 87388,5 & 88,6 & 96,4 & 102,3 \\
\hline Карачаево-Черкесская Республика & 26352,0 & 87,4 & 93,3 & 95,8 \\
\hline Республика Северная Осетия - Алания & 77682,0 & 88,4 & 94,8 & 102,0 \\
\hline Чеченская Республика & 123529,0 & 95,5 & 108,8 & 106,6 \\
\hline Ставропольский край & 367300,5 & 91,4 & 99,6 & 100,4 \\
\hline
\end{tabular}




\begin{tabular}{|c|c|c|c|c|}
\hline & \multicolumn{2}{|c|}{ Январь-сентябрь 2020 г. } & \multicolumn{2}{|c|}{ Сентябрь 2020 г. в \% к } \\
\hline & млн рублей & \begin{tabular}{|c|} 
в\% к \\
январю-сентябрю \\
20192. \\
\end{tabular} & $\begin{array}{c}\text { сентябрю } \\
20192 .\end{array}$ & $\begin{array}{c}\text { aвгусmy } \\
2020 \text { г. }\end{array}$ \\
\hline Приволжский федеральный округ & 4136773,6 & 94,8 & 95,8 & 99,6 \\
\hline Республика Башкортостан & 616535,6 & 94,2 & 94,6 & 109,7 \\
\hline Республика Марий Эл & 64584,3 & 93,6 & 102,2 & 101,0 \\
\hline Республика Мордовия & 71304,0 & 95,4 & 94,6 & 94,5 \\
\hline Республика Татарстан & 659987,1 & 93,1 & 96,6 & 99,8 \\
\hline Удмуртская Республика & 171258,3 & 94,3 & 98,8 & 99,0 \\
\hline Чувашская Республика & 115245,8 & 91,5 & 95,2 & 102,5 \\
\hline Пермский край & 401904,0 & 93,8 & 92,7 & 97,6 \\
\hline Кировская область & 150108,6 & 95,3 & 94,8 & 93,5 \\
\hline Нижегородская область & 553972,5 & 92,7 & 91,9 & 96,2 \\
\hline Оренбургская область & 238874,7 & 97,2 & 95,3 & 96,7 \\
\hline Пензенская область & 163128,2 & 98,9 & 104,0 & 94,6 \\
\hline Самарская область & 493265,8 & 95,2 & 95,0 & 98,2 \\
\hline Саратовская область & 287911,9 & 100,4 & 100,3 & 93,9 \\
\hline Ульяновская область & 148692,9 & 98,4 & 99,8 & 96,3 \\
\hline Уральский федеральный округ & 2053565,7 & 96,3 & 95,6 & 97,2 \\
\hline Курганская область & 87974,9 & 95,9 & 95,8 & 92,5 \\
\hline Свердловская область & 824248,5 & 92,5 & 89,2 & 96,6 \\
\hline Тюменская область & 723317,2 & 98,1 & 100,2 & 99,7 \\
\hline $\begin{array}{l}\text { в том числе: } \\
\text { Ханты-Мансийский авт. округ - Югра }\end{array}$ & 316115,9 & 95,8 & 96,0 & 100,4 \\
\hline Ямало-Ненецкий авт. округ & 103556,1 & 96,8 & 101,9 & 104,3 \\
\hline Тюменская область без авт. округов & 303645,2 & 101,2 & 104,3 & 97,5 \\
\hline Челябинская область & 418025,1 & 100,5 & 100,0 & 95,1 \\
\hline Сибирский федеральный округ & 2097302,0 & 95,5 & 94,6 & 97,0 \\
\hline Республика Алтай & 21193,0 & 95,2 & 98,6 & 84,6 \\
\hline Республика Тыва & 17704,0 & 91,1 & 85,2 & 95,9 \\
\hline Республика Хакасия & 67901,0 & 97,9 & 99,1 & 98,2 \\
\hline Алтайский край & 251621,0 & 96,3 & 86,9 & 95,3 \\
\hline Красноярский край & 402853,4 & 93,1 & 98,7 & 100,0 \\
\hline Иркутская область & 281643,7 & 96,1 & 98,2 & 96,8 \\
\hline Кемеровская область & 295343,5 & 97,6 & 96,4 & 95,3 \\
\hline Новосибирская область & 390214,0 & 97,3 & 95,8 & 97,4 \\
\hline Омская область & 240101,2 & 89,4 & 86,0 & 96,4 \\
\hline Томская область & 128727,2 & 100,6 & 93,9 & 95,8 \\
\hline Дальневосточный федеральный округ & 1322538,4 & 95,0 & 96,1 & 100,0 \\
\hline Республика Бурятия & 143703,8 & 98,9 & 95,3 & 94,5 \\
\hline Республика Саха (Якутия) & 158963,4 & 91,7 & 103,4 & 101,4 \\
\hline Забайкальский край & 125230,5 & 95,2 & 98,7 & 97,3 \\
\hline Камчатский край & 44997,3 & 97,8 & 99,4 & 98,9 \\
\hline Приморский край & 291355,6 & 89,4 & 89,4 & 104,3 \\
\hline Хабаровский край & 245894,9 & 96,1 & 92,8 & 99,3 \\
\hline Амурская область & 138762,9 & 98,1 & 98,1 & 97,7 \\
\hline Магаданская область & 23975,0 & 93,5 & 93,4 & 102,5 \\
\hline Сахалинская область & 123032,1 & 101,1 & 102,1 & 100,1 \\
\hline Еврейская авт. область & 18646,9 & 92,4 & 98,9 & 98,6 \\
\hline Чукотский авт. округ & 7976,0 & 101,4 & 102,8 & 101,2 \\
\hline
\end{tabular}




\section{РЕСТОРАНЫ, КАФЕ И БАРЫ}

ОБОРОТ ОБЩЕСТВЕННОГО ПИТАНИЯ

\begin{tabular}{|c|c|c|c|c|}
\hline & \multicolumn{2}{|c|}{ Снварь-сентябрь 2020 г. } & \multicolumn{2}{|c|}{ Сентябрь 2020 г. в \% к } \\
\hline & $\begin{array}{c}\text { млн } \\
\text { рублей }\end{array}$ & \begin{tabular}{|c|} 
в \% к \\
январю-сентябрю \\
20192.
\end{tabular} & $\begin{array}{c}\text { сентябрю } \\
20192 .\end{array}$ & $\begin{array}{c}\text { aвгусmy } \\
2020 \text { z. }\end{array}$ \\
\hline Российская Федерация, млрд рублей & 947,5 & 77,2 & 86,0 & 111,5 \\
\hline Центральный федеральный округ & 282468,7 & 79,7 & 90,8 & 112,1 \\
\hline Белгородская область & 6599,4 & 96,4 & 128,5 & 163,0 \\
\hline Брянская область & 5859,0 & 62,2 & 86,0 & 116,8 \\
\hline Владимирская область & 6659,8 & 76,8 & 90,5 & 108,2 \\
\hline Воронежская область & 11044,2 & 81,1 & 79,9 & 106,7 \\
\hline Ивановская область & 4644,3 & 86,0 & 91,0 & 115,5 \\
\hline Калужская область & 6683,7 & 83,5 & 95,5 & 102,8 \\
\hline Костромская область & 2575,1 & 72,7 & 66,5 & 118,4 \\
\hline Курская область & 4634,5 & 89,9 & 101,7 & 107,4 \\
\hline Липецкая область & 4866,8 & 81,2 & 81,4 & 110,6 \\
\hline Московская область & 73517,6 & 75,2 & 75,7 & 102,3 \\
\hline Орловская область & 2565,0 & 76,6 & 80,3 & 110,1 \\
\hline Рязанская область & 4925,9 & 92,9 & 117,9 & 108,1 \\
\hline Смоленская область & 4128,4 & 77,0 & 81,6 & 116,1 \\
\hline Тамбовская область & 3764,4 & 81,2 & 106,5 & 105,1 \\
\hline Тверская область & 6063,0 & 87,5 & 77,1 & 86,1 \\
\hline Тульская область & 5646,5 & 86,0 & 86,1 & 105,8 \\
\hline Ярославская область & 8591,0 & 84,8 & 88,8 & 108,0 \\
\hline г. Москва & 119700,1 & 80,1 & 96,7 & 116,3 \\
\hline Северо-Западный федеральный округ & 106212,6 & 74,7 & 86,0 & 118,7 \\
\hline Республика Карелия & 3492,1 & 81,9 & 94,2 & 100,2 \\
\hline Республика Коми & 6641,2 & 99,2 & 99,1 & 112,6 \\
\hline Архангельская область & 9376,2 & 73,5 & 105,5 & 163,9 \\
\hline $\begin{array}{l}\text { в том числе: } \\
\text { Ненецкий авт. округ }\end{array}$ & 950,0 & 90,6 & 109,1 & 137,6 \\
\hline Архангельская область без авт. округа & 8426,2 & 72,0 & 105,1 & 166,9 \\
\hline Вологодская область & 4373,7 & 65,4 & 62,2 & 117,7 \\
\hline Калининградская область & 7426,9 & 69,5 & 100,6 & 97,6 \\
\hline Ленинградская область & 9848,9 & 68,0 & 72,3 & 103,4 \\
\hline Мурманская область & 8886,8 & 82,9 & 79,4 & 119,8 \\
\hline Новгородская область & 3527,6 & 91,9 & 90,1 & 98,2 \\
\hline Псковская область & 4215,0 & 93,1 & 105,5 & 96,0 \\
\hline г. Санкт-Петербург & 48424,3 & 69,8 & 80,1 & 120,3 \\
\hline Южный федеральный округ & 106141,7 & 84,7 & 105,5 & 101,6 \\
\hline Республика Адыгея & 2356,4 & 80,9 & 81,8 & 95,8 \\
\hline Республика Калмыкия & 286,3 & 55,6 & 50,2 & 124,8 \\
\hline Республика Крым & 7430,7 & 77,4 & 104,5 & 101,7 \\
\hline Краснодарский край & 51614,6 & 87,3 & 111,0 & 98,3 \\
\hline Астраханская область & 6382,5 & 82,9 & 102,7 & 120,2 \\
\hline Волгоградская область & 9573,8 & 83,2 & 97,6 & 99,3 \\
\hline Ростовская область & 24969,8 & 83,6 & 98,3 & 107,4 \\
\hline г. Севастополь & 3527,6 & 82,2 & 89,8 & 99,5 \\
\hline Северо-Кавказский федеральный округ & 72838,6 & 74,9 & 79,1 & 102,0 \\
\hline Республика Дагестан & 37719,5 & 73,8 & 78,4 & 101,5 \\
\hline Республика Ингушетия & 360,4 & 108,3 & 108,8 & 100,7 \\
\hline Кабардино-Балкарская Республика & 3181,3 & 78,7 & 102,5 & 104,2 \\
\hline Карачаево-Черкесская Республика & 569,6 & 74,9 & 64,2 & 95,2 \\
\hline Республика Северная Осетия - Алания & 2437,0 & 70,6 & 67,6 & 103,3 \\
\hline Чеченская Республика & 8520,9 & 88,7 & 76,3 & 105,4 \\
\hline Ставропольский край & 20050,0 & 70,6 & 78,2 & 101,1 \\
\hline
\end{tabular}




\begin{tabular}{|c|c|c|c|c|}
\hline & \multicolumn{2}{|c|}{ оянварь-сентябрь 2020 г. } & \multicolumn{2}{|c|}{ Сентябрь 2020 г. в \% к } \\
\hline & $\begin{array}{c}\text { млн } \\
\text { рублей }\end{array}$ & \begin{tabular}{|c|} 
в \% к \\
январю-сентябрю \\
20192.
\end{tabular} & $\begin{array}{c}\text { сентябрю } \\
20192 .\end{array}$ & $\begin{array}{c}\text { aвгусmy } \\
2020 \text { г. }\end{array}$ \\
\hline Приволжский федеральный округ & 139945,3 & 73,8 & 79,7 & 116,7 \\
\hline Республика Башкортостан & 15635,5 & 76,1 & 76,8 & 107,9 \\
\hline Республика Марий Эл & 3098,7 & 76,6 & 71,6 & 115,3 \\
\hline Республика Мордовия & 2873,3 & 78,4 & 81,3 & 116,3 \\
\hline Республика Татарстан & 25264,2 & 70,7 & 74,4 & 123,4 \\
\hline Удмуртская Республика & 7326,1 & 74,5 & 94,4 & 113,6 \\
\hline Чувашская Республика & 5932,3 & 72,1 & 76,2 & 118,7 \\
\hline Пермский край & 12924,3 & 69,5 & 80,0 & 129,3 \\
\hline Кировская область & 6734,1 & 75,6 & 86,3 & 109,3 \\
\hline Нижегородская область & 14234,9 & 66,2 & 66,8 & 119,0 \\
\hline Оренбургская область & 9677,7 & 75,0 & 72,2 & 114,1 \\
\hline Пензенская область & 6700,2 & 81,3 & 95,8 & 102,8 \\
\hline Самарская область & 15257,5 & 71,7 & 76,8 & 111,2 \\
\hline Саратовская область & 10098,8 & 84,1 & 91,2 & 109,9 \\
\hline Ульяновская область & 4187,8 & 83,6 & 103,0 & 143,6 \\
\hline Уральский федеральный округ & 95300,8 & 80,6 & 88,9 & 123,3 \\
\hline Курганская область & 2155,5 & 72,2 & 95,3 & 111,2 \\
\hline Свердловская область & 27749,3 & 68,5 & 80,2 & 134,9 \\
\hline Тюменская область & 48955,0 & 83,8 & 92,3 & 120,3 \\
\hline $\begin{array}{l}\text { в том числе: } \\
\text { Ханты-Мансийский авт. округ - Югра }\end{array}$ & 21410,7 & 81,5 & 90,5 & 126,7 \\
\hline Ямало-Ненецкий авт. округ & 10275,6 & 92,5 & 96,2 & 113,6 \\
\hline Тюменская область без авт. округов & 17268,7 & 82,0 & 92,4 & 117,1 \\
\hline Челябинская область & 16441,0 & 92,8 & 93,6 & 112,1 \\
\hline Сибирский федеральный округ & 80488,0 & $\mathbf{7 3 , 4}$ & 70,9 & 118,8 \\
\hline Республика Алтай & 743,7 & 85,1 & 98,3 & 79,8 \\
\hline Республика Тыва & 590,5 & 83,8 & 69,3 & 108,8 \\
\hline Республика Хакасия & 3890,2 & 90,4 & 83,7 & 103,9 \\
\hline Алтайский край & 6379,2 & 87,6 & 73,4 & 112,1 \\
\hline Красноярский край & 15967,0 & 69,2 & 73,0 & 123,2 \\
\hline Иркутская область & 8740,6 & 68,9 & 67,0 & 127,6 \\
\hline Кемеровская область & 12656,7 & 78,7 & 78,6 & 119,2 \\
\hline Новосибирская область & 16790,2 & 64,3 & 63,4 & 127,1 \\
\hline Омская область & 9910,9 & 79,0 & 71,3 & 106,9 \\
\hline Томская область & 4819,1 & 66,7 & 56,3 & 104,5 \\
\hline Дальневосточный федеральный округ & 64074,3 & 80,9 & 87,4 & 112,0 \\
\hline Республика Бурятия & 7281,0 & 86,7 & 77,0 & 110,2 \\
\hline Республика Саха (Якутия) & 13517,8 & 85,4 & 100,7 & 104,8 \\
\hline Забайкальский край & 5650,5 & 75,9 & 103,8 & 109,4 \\
\hline Камчатский край & 4427,9 & 91,6 & 98,6 & 115,4 \\
\hline Приморский край & 9574,9 & 65,4 & 56,3 & 109,7 \\
\hline Хабаровский край & 9688,8 & 67,7 & 73,9 & 126,4 \\
\hline Амурская область & 4566,2 & 91,5 & 96,3 & 108,9 \\
\hline Магаданская область & 1834,6 & 86,1 & 86,9 & 112,4 \\
\hline Сахалинская область & 5964,7 & 83,7 & 70,3 & 108,7 \\
\hline Еврейская авт. область & 453,4 & 63,0 & 73,8 & 182,6 \\
\hline Чукотский авт. округ & 1114,5 & 160,2 & 171,0 & 120,1 \\
\hline
\end{tabular}


РЫНОК ПЛАТНЫХ УСЛУГ НАСЕЛЕНИЮ

ОБЪЕМ ПЛАТНЫХ УСЛУГ НАСЕЛЕНИЮ

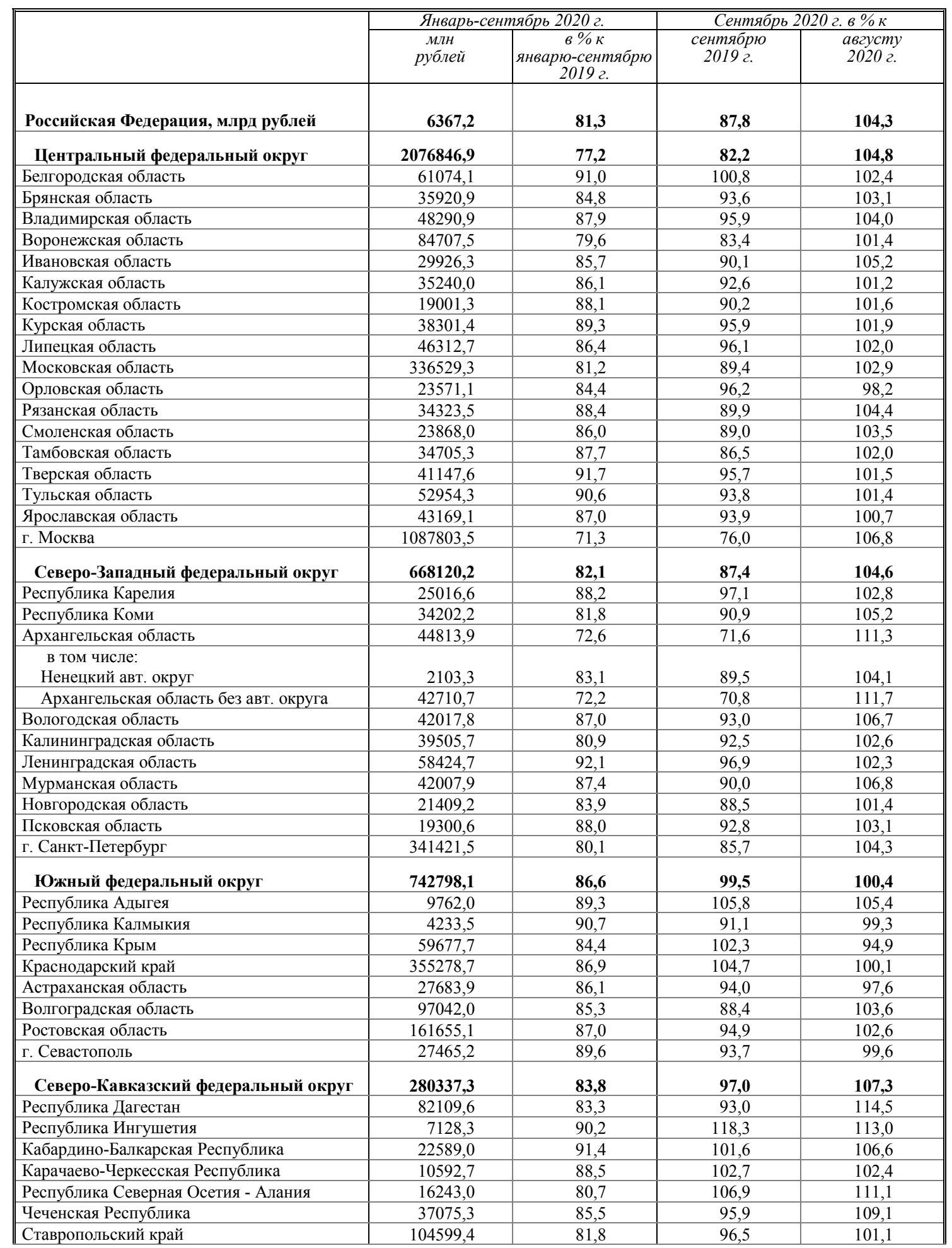




\begin{tabular}{|c|c|c|c|c|}
\hline & \multicolumn{2}{|c|}{ Январь-сентябрь 2020 г. } & \multicolumn{2}{|c|}{ Сентябрь 2020 г. в \% к } \\
\hline & $\begin{array}{c}\text { млн } \\
\text { рублей }\end{array}$ & \begin{tabular}{|c|} 
в \% к \\
январю-сентябрю \\
20192.
\end{tabular} & $\begin{array}{c}\text { сентябрю } \\
20192 .\end{array}$ & $\begin{array}{l}\text { aвгусту } \\
2020 \text { г. }\end{array}$ \\
\hline Приволжский федеральный округ & 1058580,5 & 84,1 & 88,3 & 105,8 \\
\hline Республика Башкортостан & 159422,4 & 76,9 & 76,5 & 108,6 \\
\hline Республика Марий Эл & 16299,9 & 85,9 & 95,7 & 106,3 \\
\hline Республика Мордовия & 17676,7 & 86,5 & 94,9 & 107,5 \\
\hline Республика Татарстан & 187025,8 & 85,4 & 91,9 & 104,3 \\
\hline Удмуртская Республика & 46161,1 & 87,6 & 89,3 & 100,5 \\
\hline Чувашская Республика & 34931,4 & 86,8 & 91,5 & 108,1 \\
\hline Пермский край & 104802,5 & 82,7 & 86,2 & 108,7 \\
\hline Кировская область & 39965,3 & 87,7 & 95,1 & 104,0 \\
\hline Нижегородская область & 122573,3 & 82,1 & 87,8 & 106,2 \\
\hline Оренбургская область & 60725,4 & 87,0 & 94,2 & 108,9 \\
\hline Пензенская область & 40720,3 & 89,9 & 96,0 & 101,9 \\
\hline Самарская область & 118592,6 & 84,7 & 87,6 & 103,9 \\
\hline Саратовская область & 70166,3 & 88,7 & 93,9 & 107,2 \\
\hline Ульяновская область & 39517,5 & 89,2 & 95,3 & 101,6 \\
\hline Уральский федеральный округ & 542010,7 & 80,2 & 87,1 & 107,6 \\
\hline Курганская область & 20245,4 & 81,2 & 80,1 & 105,7 \\
\hline Свердловская область & 236656,2 & 75,9 & 82,7 & 110,9 \\
\hline Тюменская область & 166631,6 & 81,3 & 89,4 & 106,5 \\
\hline $\begin{array}{l}\text { в том числе: } \\
\text { Ханты-Мансийский авт. округ - Югра }\end{array}$ & 74429,2 & 81,6 & 88,4 & 107,3 \\
\hline Ямало-Ненецкий авт. округ & 29432,4 & 74,2 & 83,5 & 108,4 \\
\hline Тюменская область без авт. округов & 62769,9 & 84,9 & 93,7 & 104,7 \\
\hline Челябинская область & 118477,6 & 88,2 & 96,5 & 102,5 \\
\hline Сибирский федеральный округ & 582742,2 & 85,6 & 90,5 & 104,2 \\
\hline Республика Алтай & 4575,9 & 92,6 & 109,2 & 101,4 \\
\hline Республика Тыва & 4501,9 & 83,8 & 95,0 & 111,6 \\
\hline Республика Хакасия & 13831,4 & 92,4 & 98,8 & 101,7 \\
\hline Алтайский край & 72002,0 & 91,3 & 92,3 & 102,8 \\
\hline Красноярский край & 115260,0 & 85,2 & 92,7 & 105,1 \\
\hline Иркутская область & 72507,4 & 83,5 & 85,0 & 104,6 \\
\hline Кемеровская область & 85348,0 & 86,7 & 90,1 & 101,3 \\
\hline Новосибирская область & 110402,7 & 82,7 & 86,1 & 106,1 \\
\hline Омская область & 66894,0 & 83,7 & 95,6 & 104,6 \\
\hline Томская область & 37419,1 & 87,2 & 91,7 & 104,3 \\
\hline Дальневосточный федеральный округ & 415749,6 & 81,0 & 87,7 & 100,7 \\
\hline Республика Бурятия & 30970,3 & 87,1 & 96,1 & 100,6 \\
\hline Республика Саха (Якутия) & 52790,1 & 73,7 & 79,1 & 92,4 \\
\hline Забайкальский край & 33658,3 & 87,7 & 95,9 & 104,3 \\
\hline Камчатский край & 20818,4 & 88,2 & 90,0 & 97,0 \\
\hline Приморский край & 98051,6 & 77,6 & 86,1 & 108,0 \\
\hline Хабаровский край & 89737,9 & 79,1 & 90,5 & 100,2 \\
\hline Амурская область & 33340,3 & 89,3 & 91,5 & 106,5 \\
\hline Магаданская область & 11086,2 & 89,1 & 89,8 & 100,6 \\
\hline Сахалинская область & 36026,4 & 82,8 & 80,4 & 90,9 \\
\hline Еврейская авт. область & 5753,4 & 81,8 & 85,5 & 104,2 \\
\hline Чукотский авт. округ & 3516,7 & 89,3 & 93,4 & 109,5 \\
\hline
\end{tabular}




\section{ОПТОВАЯ ТОРГОВЛЯ}

ОБОРОТ ОПТОВОЙ ТОРГОВЛИ

ОРГАНИЗАЦИЙ ОПТОВОЙ ТОРГОВЛИ

\begin{tabular}{|c|c|c|c|c|}
\hline & \multicolumn{2}{|c|}{ Январь-сентябрь 2020 г. } & \multicolumn{2}{|c|}{ Сентябрь 2020 г. в \% к } \\
\hline & $\begin{array}{c}\text { млн } \\
\text { рублей }\end{array}$ & \begin{tabular}{|c|} 
в \% к \\
январю-сентябрю \\
20192. \\
\end{tabular} & $\begin{array}{c}\text { сентябрю } \\
2019 \text { г. }\end{array}$ & $\begin{array}{c}\text { августу } \\
2020 \text { г. }\end{array}$ \\
\hline Российская Федерация, млрд рублей & 47147,6 & 101,3 & 102,1 & 103,2 \\
\hline Центральный федеральный округ & 24577281,0 & $\mathbf{9 9 , 1}$ & 98,5 & 104,1 \\
\hline Белгородская область & 450102,1 & 101,8 & 94,6 & 102,6 \\
\hline Брянская область & 155577,0 & 94,3 & 113,9 & 108,3 \\
\hline Владимирская область & 179780,5 & 105,0 & 109,9 & 96,7 \\
\hline Воронежская область & 795270,8 & 108,2 & 104,9 & 105,0 \\
\hline Ивановская область & 176016,8 & 88,8 & 103,5 & 102,9 \\
\hline Калужская область & 154076,5 & 89,0 & 92,1 & 101,6 \\
\hline Костромская область & 61757,3 & 94,2 & 97,5 & 105,7 \\
\hline Курская область & 179501,6 & 99,0 & 115,3 & 95,0 \\
\hline Липецкая область & 218065,3 & 103,7 & 102,0 & 103,7 \\
\hline Московская область & 3743803,0 & 100,4 & 110,1 & 106,3 \\
\hline Орловская область & 118874,6 & 98,0 & 104,7 & 112,5 \\
\hline Рязанская область & 234148,5 & 107,2 & 114,8 & 101,0 \\
\hline Смоленская область & 227801,2 & 96,3 & 97,8 & 99,7 \\
\hline Тамбовская область & 183066,0 & 107,3 & 96,2 & 106,1 \\
\hline Тверская область & 132554,1 & 109,6 & 140,2 & 99,0 \\
\hline Тульская область & 214704,1 & 93,6 & 95,8 & 104,1 \\
\hline Ярославская область & 276544,1 & 97,2 & 104,5 & 101,3 \\
\hline г. Москва & 17075637,6 & 98,4 & 94,9 & 103,8 \\
\hline Северо-Западный федеральный округ & 5595804,7 & 100,0 & 103,8 & 105,3 \\
\hline Республика Карелия & 58186,4 & 139,8 & 148,2 & 100,1 \\
\hline Республика Коми & 46411,5 & 103,4 & 104,7 & 101,3 \\
\hline Архангельская область & 101055,7 & 81,0 & 84,8 & 96,5 \\
\hline в том числе: Ненецкий авт. округ & 716,8 & 32,3 & 35,4 & 99,3 \\
\hline Архангельская область без авт. округа & 100338,9 & 81,9 & 85,7 & 96,5 \\
\hline Вологодская область & 164085,9 & 99,7 & 104,2 & 102,6 \\
\hline Калининградская область & 180507,8 & 100,8 & 127,9 & 106,4 \\
\hline Ленинградская область & 267406,5 & 91,3 & 100,3 & 95,2 \\
\hline Мурманская область & 68157,8 & 86,0 & 91,3 & 105,1 \\
\hline Новгородская область & 91527,5 & 106,3 & 92,4 & 94,0 \\
\hline Псковская область & 59441,2 & 95,7 & 108,8 & 101,6 \\
\hline г. Санкт-Петербург & 4559024,2 & 100,8 & 103,6 & 106,8 \\
\hline Южный федеральный округ & 3255745,3 & 103,0 & 107,6 & 102,1 \\
\hline Республика Адыгея & 27627,4 & 97,2 & 103,5 & 99,2 \\
\hline Республика Калмыкия & 3229,2 & 95,9 & 121,1 & 112,4 \\
\hline Республика Крым & 149072,8 & 116,5 & 135,3 & 90,8 \\
\hline Краснодарский край & 1330242,1 & 99,3 & 106,8 & 101,7 \\
\hline Астраханская область & 54837,6 & 93,0 & 86,4 & 114,4 \\
\hline Волгоградская область & 405605,2 & 93,3 & 96,3 & 96,3 \\
\hline Ростовская область & 1249370,0 & 110,2 & 110,2 & 105,9 \\
\hline г. Севастополь & 35761,0 & 102,7 & 124,0 & 92,6 \\
\hline Северо-Кавказский федеральный округ & 534885,7 & 93,9 & 100,3 & 102,7 \\
\hline Республика Дагестан & 61078,6 & 97,7 & 100,9 & 107,9 \\
\hline Республика Ингушетия & 2512,9 & 55,0 & 25,0 & 95,6 \\
\hline Кабардино-Балкарская Республика & 17307,8 & 99,3 & 109,5 & 121,0 \\
\hline Карачаево-Черкесская Республика & 19494,5 & 105,0 & 93,2 & 128,9 \\
\hline Республика Северная Осетия - Алания & 22363,9 & 96,6 & 93,8 & 106,4 \\
\hline Чеченская Республика & 22512,0 & 110,1 & 107,2 & 95,8 \\
\hline Ставропольский край & 389615,9 & 92,1 & 101,3 & 100,2 \\
\hline
\end{tabular}




\begin{tabular}{|c|c|c|c|c|}
\hline & \multicolumn{2}{|c|}{ Снварь-сентябрь 2020 г. } & \multicolumn{2}{|c|}{ Сентябрь 2020 г. в \% к } \\
\hline & $\begin{array}{c}\text { млн } \\
\text { рублей }\end{array}$ & \begin{tabular}{|c|} 
в \% к \\
январю-сентябрю \\
20192. \\
\end{tabular} & $\begin{array}{l}\text { сентябрю } \\
2019 \text { г. }\end{array}$ & $\begin{array}{l}\text { aвzуcmy } \\
20202 .\end{array}$ \\
\hline Приволжский федеральный округ & 4936178,8 & 100,5 & 98,3 & 101,3 \\
\hline Республика Башкортостан & 494017,0 & 91,8 & 88,9 & 102,0 \\
\hline Республика Марий Эл & 72764,5 & 109,2 & 123,1 & 112,2 \\
\hline Республика Мордовия & 65696,6 & 97,4 & 98,3 & 99,9 \\
\hline Республика Татарстан & 1052978,5 & 101,7 & 103,1 & 98,4 \\
\hline Удмуртская Республика & 167634,8 & 91,0 & 93,7 & 102,2 \\
\hline Чувашская Республика & 103050,5 & 93,5 & 86,7 & 93,1 \\
\hline Пермский край & 473795,4 & 104,4 & 103,7 & 98,7 \\
\hline Кировская область & 164809,6 & 106,4 & 107,7 & 100,7 \\
\hline Нижегородская область & 844960,6 & 108,2 & 103,5 & 104,8 \\
\hline Оренбургская область & 187273,5 & 96,3 & 74,4 & 94,8 \\
\hline Пензенская область & 224829,5 & 109,2 & 106,1 & 105,1 \\
\hline Самарская область & 657789,4 & 95,6 & 94,4 & 106,1 \\
\hline Саратовская область & 248086,7 & 95,0 & 90,4 & 100,7 \\
\hline Ульяновская область & 178492,2 & 104,9 & 108,6 & 93,6 \\
\hline Уральский федеральный округ & 2770867,9 & 93,7 & 100,9 & 102,8 \\
\hline Курганская область & 41937,5 & 87,1 & 86,3 & 103,9 \\
\hline Свердловская область & 1515254,9 & 105,6 & 117,6 & 101,9 \\
\hline Тюменская область & 467290,0 & 64,2 & 66,5 & 106,2 \\
\hline $\begin{array}{l}\text { в том числе: } \\
\text { Ханты-Мансийский авт. округ - Югра }\end{array}$ & 136342,4 & 114,6 & 109,3 & 103,4 \\
\hline Ямало-Ненецкий авт. округ & 70131,3 & 22,0 & 24,3 & 129,1 \\
\hline Тюменская область без авт. округов & 260816,2 & 89,8 & 86,2 & 103,3 \\
\hline Челябинская область & 746385,5 & 99,9 & 100,8 & 102,7 \\
\hline Сибирский федеральный округ & 3828682,7 & 98,2 & 101,7 & 105,3 \\
\hline Республика Алтай & 19269,9 & 77,0 & 87,6 & 93,1 \\
\hline Республика Тыва & 4536,7 & 88,1 & 109,6 & 103,8 \\
\hline Республика Хакасия & 46708,7 & 94,5 & 100,6 & 107,2 \\
\hline Алтайский край & 314237,3 & 78,4 & 80,8 & 104,6 \\
\hline Красноярский край & 660653,8 & 107,6 & 119,8 & 105,3 \\
\hline Иркутская область & 531087,3 & 103,1 & 89,8 & 99,3 \\
\hline Кемеровская область & 589539,2 & 92,2 & 95,7 & 98,9 \\
\hline Новосибирская область & 1116162,3 & 96,6 & 99,6 & 105,5 \\
\hline Омская область & 327696,5 & 103,2 & 103,0 & 103,3 \\
\hline Томская область & 218791,0 & 123,1 & 157,5 & 145,0 \\
\hline Дальневосточный федеральный округ & 1648125,8 & 96,4 & 98,6 & 101,8 \\
\hline Республика Бурятия & 59277,3 & 96,4 & 101,3 & 105,1 \\
\hline Республика Саха (Якутия) & 79713,0 & 107,7 & 79,6 & 83,0 \\
\hline Забайкальский край & 48856,9 & 86,6 & 104,5 & 104,2 \\
\hline Камчатский край & 71930,6 & 105,5 & 103,1 & 94,0 \\
\hline Приморский край & 748308,1 & 98,6 & 107,3 & 103,6 \\
\hline Хабаровский край & 371851,0 & 87,8 & 87,9 & 98,8 \\
\hline Амурская область & 98230,1 & 108,3 & 103,8 & 102,0 \\
\hline Магаданская область & 67815,8 & 102,9 & 111,2 & 112,8 \\
\hline Сахалинская область & 82266,2 & 90,0 & 85,2 & 102,6 \\
\hline Еврейская авт. область & 7596,0 & 91,8 & 125,8 & 98,1 \\
\hline Чукотский авт. округ & 12280,7 & 113,7 & 70,5 & в 2,3p. \\
\hline
\end{tabular}


ОТГРУЗКА БЕНЗИНОВ АВТОМОБИЛЬНЫХ НЕФТЕПЕРЕРАБАТЫВАЮЩИМИ ОРГАНИЗАЦИЯМИ ПОТРЕБИТЕЛЯМ СУБЫЕКТОВ РОССИЙСКОЙ ФЕДЕРАЦИИ

\begin{tabular}{|c|c|c|c|c|}
\hline & \multicolumn{2}{|c|}{ Январь-сентябрь 2020 г. } & \multicolumn{2}{|c|}{ Сентябрь 2020 г. в \% к } \\
\hline & $\begin{array}{l}\text { тьсс. } \\
\text { тонн }\end{array}$ & \begin{tabular}{|c|} 
в\% \% \\
январю-сентябрю \\
20192.
\end{tabular} & $\begin{array}{c}\text { сентябрю } \\
20192 .\end{array}$ & $\begin{array}{c}\text { августу } \\
2020 \text { г. }\end{array}$ \\
\hline Российская Федерация & 24606,1 & 93,2 & 101,2 & 88,3 \\
\hline Центральный федеральный округ & 6627,9 & 92,9 & $\mathbf{9 7 , 1}$ & 94,1 \\
\hline Белгородская область & 253,1 & 99,6 & 85,4 & 105,0 \\
\hline Брянская область & 105,8 & 95,3 & 90,5 & 109,1 \\
\hline Владимирская область & 212,7 & 150,1 & 138,1 & 91,4 \\
\hline Воронежская область & 459,8 & 106,3 & 130,0 & 84,2 \\
\hline Ивановская область & 87,5 & 97,5 & 106,0 & 81,0 \\
\hline Калужская область & 186,5 & 88,7 & 96,2 & 76,2 \\
\hline Костромская область & 23,1 & 97,2 & 101,0 & 89,9 \\
\hline Курская область & 122,3 & 95,2 & 74,8 & 154,6 \\
\hline Липецкая область & 177,0 & 84,7 & 76,5 & 89,1 \\
\hline Московская область & 2889,0 & 91,9 & 101,0 & 106,5 \\
\hline Орловская область & 119,0 & 96,8 & 96,3 & 81,6 \\
\hline Рязанская область & 336,3 & 91,2 & 97,6 & 84,8 \\
\hline Смоленская область & 119,7 & 88,4 & 69,7 & 109,5 \\
\hline Тамбовская область & 109,3 & 134,8 & 125,9 & 76,8 \\
\hline Тверская область & 140,5 & 99,2 & 93,6 & 63,9 \\
\hline Тульская область & 161,2 & 98,7 & 94,5 & 78,4 \\
\hline Ярославская область & 111,9 & 82,0 & 84,2 & 84,9 \\
\hline г. Москва & 1013,3 & 81,4 & 83,6 & 83,1 \\
\hline Северо-Западный федеральный округ & 2717,4 & 93,6 & 104,5 & 94,0 \\
\hline Республика Карелия & 72,3 & 73,7 & 43,1 & 67,1 \\
\hline Республика Коми & 135,4 & 155,4 & 173,3 & 125,0 \\
\hline Архангельская область & 137,0 & 88,5 & 122,8 & 147,8 \\
\hline $\begin{array}{l}\text { в том числе: } \\
\text { Ненецкий авт. округ }\end{array}$ & - & - & - & - \\
\hline Архангельская область без авт. округа & 137,0 & 88,5 & 122,8 & 147,8 \\
\hline Вологодская область & 135,0 & 94,4 & 114,2 & 90,6 \\
\hline Калининградская область & 135,7 & 91,5 & 154,3 & 85,5 \\
\hline Ленинградская область & 1146,1 & 102,1 & 109,2 & 93,6 \\
\hline Мурманская область & 106,7 & 90,6 & 101,2 & 89,1 \\
\hline Новгородская область & 71,8 & 82,6 & 124,0 & 82,8 \\
\hline Псковская область & 89,7 & 90,3 & 99,2 & 68,0 \\
\hline г. Санкт-Петербург & 687,6 & 81,2 & 85,4 & 91,7 \\
\hline Южный федеральный округ & 2829,3 & 89,4 & 102,6 & 75,3 \\
\hline Республика Адыгея & 223,5 & 93,6 & 112,1 & 107,1 \\
\hline Республика Калмыкия & - & - & - & - \\
\hline Республика Крым & 257,2 & 85,2 & 66,2 & 53,4 \\
\hline Краснодарский край & 1031,1 & 82,7 & 99,2 & 64,5 \\
\hline Астраханская область & 109,4 & 104,4 & 114,2 & 100,2 \\
\hline Волгоградская область & 527,1 & 87,3 & 110,8 & 88,4 \\
\hline Ростовская область & 681,1 & 101,6 & 113,3 & 82,2 \\
\hline г. Севастополь & - & - & - & - \\
\hline Северо-Кавказский федеральный округ & 737,3 & 86,0 & 82,9 & 85,3 \\
\hline Республика Дагестан & 131,7 & 87,0 & 92,7 & 92,0 \\
\hline Республика Ингушетия & 27,6 & 56,4 & 33,7 & 117,8 \\
\hline Кабардино-Балкарская Республика & 42,7 & 81,4 & 112,5 & 99,2 \\
\hline Карачаево-Черкесская Республика & 39,6 & 82,5 & 86,4 & 83,8 \\
\hline Республика Северная Осетия - Алания & 54,8 & 90,4 & 125,2 & 122,2 \\
\hline Чеченская Республика & 39,7 & 82,3 & 172,1 & 115,6 \\
\hline Ставропольский край & 401,3 & 89,6 & 77,4 & 74,1 \\
\hline
\end{tabular}




\begin{tabular}{|c|c|c|c|c|}
\hline & \multicolumn{2}{|c|}{ еянварь-сентябрь 2020 г. } & \multicolumn{2}{|c|}{ Сентябрь 2020 г. в \% к } \\
\hline & $\begin{array}{l}\text { mыс. } \\
\text { тонн }\end{array}$ & $\begin{array}{c}\% \% \kappa \\
\text { январю-сентябрю } \\
2019 \text { г. } \\
\end{array}$ & $\begin{array}{l}\text { сентябрю } \\
2019 \text { г. }\end{array}$ & $\begin{array}{l}\text { августу } \\
2020 \text {. }\end{array}$ \\
\hline Приволжский федеральный округ & 5156,4 & 95,1 & 105,2 & 88,0 \\
\hline Республика Башкортостан & 971,2 & 88,0 & 93,3 & 82,1 \\
\hline Республика Марий Эл & 70,4 & 93,0 & 97,6 & 75,5 \\
\hline Республика Мордовия & 25,3 & 116,9 & в $2,4 \mathrm{p}$. & 135,1 \\
\hline Республика Татарстан & 714,6 & 95,6 & 126,4 & 94,9 \\
\hline Удмуртская Республика & 83,2 & 119,7 & 91,3 & 72,2 \\
\hline Чувашская Республика & 71,4 & 104,2 & 124,3 & 109,0 \\
\hline Пермский край & 486,5 & 106,0 & 107,1 & 90,0 \\
\hline Кировская область & 178,7 & 99,2 & 93,7 & 78,5 \\
\hline Нижегородская область & 689,2 & 103,1 & 97,8 & 86,5 \\
\hline Оренбургская область & 236,0 & 99,1 & 92,3 & 86,2 \\
\hline Пензенская область & 72,3 & 106,5 & 28,3 & 53,0 \\
\hline Самарская область & 1200,0 & 91,4 & 144,5 & 93,2 \\
\hline Саратовская область & 264,2 & 90,8 & 82,7 & 90,9 \\
\hline Ульяновская область & 93,5 & 80,2 & 72,8 & 81,9 \\
\hline Уральский федеральный округ & 2037,3 & 96,2 & 104,7 & 87,2 \\
\hline Курганская область & 97,4 & 92,6 & 108,4 & 106,7 \\
\hline Свердловская область & 735,3 & 98,2 & 105,0 & 94,5 \\
\hline Тюменская область & 758,3 & 95,6 & 108,4 & 90,3 \\
\hline $\begin{array}{l}\text { в том числе: } \\
\text { Ханты-Мансийский авт. округ - Югра }\end{array}$ & 274,7 & 93,2 & 95,2 & 104,1 \\
\hline Ямало-Ненецкий авт. округ & 91,9 & 98,0 & 154,3 & 141,7 \\
\hline Тюменская область без авт. округов & 391,7 & 96,8 & 110,1 & 75,3 \\
\hline Челябинская область & 446,3 & 95,1 & 97,2 & 69,8 \\
\hline Сибирский федеральный округ & 3026,9 & 92,6 & $\mathbf{9 8 , 9}$ & 86,1 \\
\hline Республика Алтай & - & - & - & - \\
\hline Республика Тыва & - & - & - & - \\
\hline Республика Хакасия & 109,3 & 94,4 & 88,3 & 87,0 \\
\hline Алтайский край & 346,3 & 86,2 & 96,3 & 83,7 \\
\hline Красноярский край & 658,3 & 96,2 & 96,0 & 85,1 \\
\hline Иркутская область & 483,1 & 96,9 & 121,7 & 92,2 \\
\hline Кемеровская область & 354,3 & 83,9 & 83,2 & 89,9 \\
\hline Новосибирская область & 597,8 & 93,7 & 102,0 & 85,2 \\
\hline Омская область & 299,8 & 94,3 & 106,3 & 80,9 \\
\hline Томская область & 178,1 & 94,2 & 83,4 & 84,5 \\
\hline Дальневосточный федеральный округ & 1473,7 & 95,9 & 112,4 & 93,1 \\
\hline Республика Бурятия & 150,0 & 94,6 & 102,7 & 77,0 \\
\hline Республика Саха (Якутия) & 123,4 & 90,0 & 60,9 & 32,1 \\
\hline Забайкальский край & 151,6 & 82,1 & 105,7 & 103,6 \\
\hline Камчатский край & - & - & - & - \\
\hline Приморский край & 335,1 & 91,9 & 165,1 & 111,9 \\
\hline Хабаровский край & 607,9 & 106,0 & 102,4 & 112,8 \\
\hline Амурская область & 79,1 & 87,9 & 137,9 & 52,6 \\
\hline Магаданская область & - & - & - & - \\
\hline Сахалинская область & 20,9 & 90,4 & 104,3 & 152,2 \\
\hline Еврейская авт. область & 5,6 & 121,0 & в $2,7 \mathrm{p}$. & в $2,1 \mathrm{p}$ \\
\hline Чукотский авт. округ & - & - & - & - \\
\hline
\end{tabular}


ОТГРУЗКА ТОПЛИВА ДИЗЕЛЬНОГО НЕФТЕПЕРЕРАБАТЫВАЮЩИМИ ОРГАНИЗАЦИЯМИ ПОТРЕБИТЕЛЯМ СУБЪЕКТОВ РОССИЙСКОЙ ФЕДЕРАЦИИ

\begin{tabular}{|c|c|c|c|c|}
\hline & \multicolumn{2}{|c|}{ Снварь-сентябрь 2020 г. } & \multicolumn{2}{|c|}{ Сентябрь 2020 г. в \% к } \\
\hline & $\begin{array}{l}\text { тьсс. } \\
\text { тонн }\end{array}$ & \begin{tabular}{|c|} 
в \% к \\
январю-сентябрю \\
20192. \\
\end{tabular} & $\begin{array}{c}\text { сентябрю } \\
2019 z .\end{array}$ & $\begin{array}{l}\text { aвzуcmy } \\
2020 \text { 2. }\end{array}$ \\
\hline Российская Федерация & 27968,6 & 96,4 & 93,8 & 84,7 \\
\hline Центральный федеральный округ & 6143,4 & 89,9 & 80,5 & 87,7 \\
\hline Белгородская область & 270,8 & 104,2 & 139,7 & 85,2 \\
\hline Брянская область & 235,2 & 66,0 & 50,7 & 101,4 \\
\hline Владимирская область & 130,6 & в 2,2p. & 183,4 & 80,3 \\
\hline Воронежская область & 485,3 & 85,4 & 73,4 & 120,2 \\
\hline Ивановская область & 42,9 & 94,6 & 128,8 & 105,5 \\
\hline Калужская область & 204,8 & 80,3 & 79,1 & 98,7 \\
\hline Костромская область & 30,8 & 88,4 & 63,3 & 97,9 \\
\hline Курская область & 83,4 & 75,1 & 25,3 & 30,6 \\
\hline Липецкая область & 222,0 & 106,5 & 146,2 & 84,4 \\
\hline Московская область & 2021,5 & 84,4 & 99,5 & 104,2 \\
\hline Орловская область & 152,7 & 99,2 & 108,5 & 63,0 \\
\hline Рязанская область & 373,6 & 94,0 & 96,7 & 90,1 \\
\hline Смоленская область & 248,4 & 93,8 & 81,1 & 94,6 \\
\hline Тамбовская область & 229,2 & 96,0 & 70,1 & 49,1 \\
\hline Тверская область & 304,3 & 95,9 & 92,3 & 105,8 \\
\hline Тульская область & 147,5 & 82,3 & 55,7 & в $2,3 \mathrm{p}$ \\
\hline Ярославская область & 257,5 & 79,6 & 34,0 & 61,6 \\
\hline г. Москва & 702,8 & 106,1 & 42,6 & 44,9 \\
\hline Северо-Западный федеральный округ & 3362,9 & 94,7 & 102,2 & 83,0 \\
\hline Республика Карелия & 118,9 & 84,7 & 106,0 & 105,2 \\
\hline Республика Коми & 400,6 & 99,8 & 115,2 & 130,5 \\
\hline Архангельская область & 362,0 & 120,9 & 162,9 & 100,3 \\
\hline $\begin{array}{l}\text { в том числе: } \\
\text { Ненецкий авт. округ }\end{array}$ & - & - & - & - \\
\hline Архангельская область без авт. округа & 362,0 & 120,9 & 162,9 & 100,3 \\
\hline Вологодская область & 193,2 & 116,4 & 103,2 & 74,0 \\
\hline Калининградская область & 186,9 & 85,2 & 77,0 & 50,3 \\
\hline Ленинградская область & 1030,4 & 100,2 & 91,5 & 73,7 \\
\hline Мурманская область & 325,1 & 89,2 & 82,9 & 50,0 \\
\hline Новгородская область & 53,4 & 62,4 & 134,7 & 87,6 \\
\hline Псковская область & 114,0 & 76,3 & 95,5 & 132,7 \\
\hline г. Санкт-Петербург & 578,5 & 83,0 & 106,2 & 108,8 \\
\hline Южный федеральный округ & 1849,1 & 97,9 & 97,1 & 92,5 \\
\hline Республика Адыгея & 102,3 & 93,2 & 81,9 & 101,0 \\
\hline Республика Калмыкия & - & - & - & - \\
\hline Республика Крым & 50,7 & 57,7 & 68,2 & 95,9 \\
\hline Краснодарский край & 640,4 & 91,7 & 82,3 & 77,8 \\
\hline Астраханская область & 90,5 & 104,1 & 122,5 & 100,1 \\
\hline Волгоградская область & 436,3 & 113,6 & 118,5 & 91,7 \\
\hline Ростовская область & 528,9 & 101,1 & 109,0 & 110,6 \\
\hline г. Севастополь & - & - & - & - \\
\hline Северо-Кавказский федеральный округ & 268,2 & 89,0 & 65,9 & 50,2 \\
\hline Республика Дагестан & 14,6 & 97,8 & 107,4 & 58,5 \\
\hline Республика Ингушетия & 5,1 & 77,3 & 39,8 & 50,1 \\
\hline Кабардино-Балкарская Республика & 9,4 & 124,7 & 143,5 & 70,9 \\
\hline Карачаево-Черкесская Республика & 5,5 & 74,8 & 62,5 & 66,3 \\
\hline Республика Северная Осетия - Алания & 28,9 & 111,3 & 81,2 & 69,5 \\
\hline Чеченская Республика & 11,0 & 82,9 & 119,2 & в 2,6p. \\
\hline Ставропольский край & 193,7 & 85,8 & 59,1 & 43,0 \\
\hline
\end{tabular}




\begin{tabular}{|c|c|c|c|c|}
\hline & \multicolumn{2}{|c|}{ Январь-сентябрь 2020 г. } & \multicolumn{2}{|c|}{ Сентябрь 2020 г. в \% к } \\
\hline & $\begin{array}{l}\text { mblc. } \\
\text { тонн }\end{array}$ & \begin{tabular}{|c|} 
в к \\
январю-сентябрю \\
20192.
\end{tabular} & $\begin{array}{c}\text { сентябрю } \\
2019 \text { г. }\end{array}$ & $\begin{array}{l}\text { aвzуcmy } \\
2020 \text { г. }\end{array}$ \\
\hline Приволжский федеральный округ & 6715,3 & 106,5 & 110,5 & 83,0 \\
\hline Республика Башкортостан & 734,1 & 93,2 & 84,7 & 93,9 \\
\hline Республика Марий Эл & 23,5 & 144,9 & 82,6 & 49,3 \\
\hline Республика Мордовия & 23,8 & 102,5 & 98,4 & 63,7 \\
\hline Республика Татарстан & 1804,8 & 114,1 & 105,8 & 63,3 \\
\hline Удмуртская Республика & 59,3 & 134,4 & 80,2 & 60,3 \\
\hline Чувашская Республика & 34,7 & 112,0 & 27,6 & 58,4 \\
\hline Пермский край & 502,2 & 101,1 & 139,5 & 99,8 \\
\hline Кировская область & 160,8 & 114,1 & 134,4 & 92,1 \\
\hline Нижегородская область & 554,1 & 114,8 & 118,2 & 91,2 \\
\hline Оренбургская область & 317,8 & 111,3 & 79,3 & 73,3 \\
\hline Пензенская область & 280,0 & 114,2 & 89,7 & 98,5 \\
\hline Самарская область & 1734,9 & 109,1 & 190,9 & 93,0 \\
\hline Саратовская область & 299,4 & 74,1 & 67,2 & 90,1 \\
\hline Ульяновская область & 185,8 & 105,6 & 68,1 & 99,2 \\
\hline Уральский федеральный округ & 2550,5 & 97,2 & 95,0 & 101,6 \\
\hline Курганская область & 85,1 & 81,1 & 95,3 & 99,6 \\
\hline Свердловская область & 506,4 & 100,3 & 106,4 & 97,2 \\
\hline Тюменская область & 1468,6 & 95,0 & 85,5 & 112,9 \\
\hline $\begin{array}{l}\text { в том числе: } \\
\text { Ханты-Мансийский авт. округ - Югра }\end{array}$ & 614,2 & 88,8 & 97,2 & 144,9 \\
\hline Ямало-Ненецкий авт. округ & 342,2 & 98,1 & 73,3 & 129,6 \\
\hline Тюменская область без авт. округов & 512,2 & 101,3 & 78,4 & 80,7 \\
\hline Челябинская область & 490,4 & 104,6 & 115,6 & 83,5 \\
\hline Сибирский федеральный округ & 4155,5 & 93,5 & 97,6 & 81,2 \\
\hline Республика Алтай & 0,4 & в $2,1 \mathrm{p}$. & - & - \\
\hline Республика Тыва & - & - & - & - \\
\hline Республика Хакасия & 101,7 & 83,9 & 127,1 & 112,1 \\
\hline Алтайский край & 252,0 & 101,4 & 113,2 & 86,2 \\
\hline Красноярский край & 876,0 & 92,5 & 99,7 & 82,3 \\
\hline Иркутская область & 1047,3 & 108,8 & 110,5 & 75,6 \\
\hline Кемеровская область & 934,5 & 81,2 & 87,0 & 87,5 \\
\hline Новосибирская область & 341,6 & 80,0 & 66,6 & 69,4 \\
\hline Омская область & 521,2 & 104,1 & 113,4 & 79,8 \\
\hline Томская область & 80,9 & 92,1 & 61,3 & 83,6 \\
\hline Дальневосточный федеральный округ & 2923,7 & 95,4 & 81,3 & 77,4 \\
\hline Республика Бурятия & 279,9 & 95,1 & 101,8 & 95,5 \\
\hline Республика Саха (Якутия) & 237,8 & 89,6 & 72,7 & 96,6 \\
\hline Забайкальский край & 388,0 & 109,5 & 66,5 & 82,5 \\
\hline Камчатский край & - & - & - & - \\
\hline Приморский край & 410,6 & 55,4 & 46,8 & 56,5 \\
\hline Хабаровский край & 1103,1 & 113,9 & 92,4 & 79,5 \\
\hline Амурская область & 464,9 & 114,5 & 154,1 & 81,1 \\
\hline Магаданская область & - & - & - & - \\
\hline Сахалинская область & 18,3 & 59,9 & 24,4 & 36,6 \\
\hline Еврейская авт. область & 19,0 & в 5,1p. & 13,7 & 15,1 \\
\hline Чукотский авт. округ & 2,0 & - & - & - \\
\hline
\end{tabular}


ЗАПАСЫ УГЛЯ И МАЗУТА ТОПОЧНОГО У ПОТРЕБИТЕЛЕЙ
(без микропредПрИЯТЙ)

на 1 сентября 2020 года

\begin{tabular}{|c|c|c|c|c|c|c|}
\hline & \multicolumn{3}{|c|}{ Уголь } & \multicolumn{3}{|c|}{ Мазут топочньй } \\
\hline & \multirow{2}{*}{$\begin{array}{l}\text { тьсс. } \\
\text { тонн }\end{array}$} & \multicolumn{2}{|c|}{$6 \% \kappa$} & \multirow{2}{*}{$\begin{array}{l}\text { тьсс. } \\
\text { тонн }\end{array}$} & \multicolumn{2}{|c|}{$6 \% \kappa$} \\
\hline & & \begin{tabular}{|c|}
1 сентября \\
2019 г. \\
\end{tabular} & $\begin{array}{c}1 \text { aвzycma } \\
20202 \text {. }\end{array}$ & & $\begin{array}{c}1 \text { сентября } \\
2019 \text { 2. } \\
\end{array}$ & $\begin{array}{c}1 \text { aвzуста } \\
2020 \text { 2. }\end{array}$ \\
\hline Российская Федерация & 23843,1 & 95,7 & 107,7 & 3667,7 & 98,4 & 98,9 \\
\hline Центральный федеральный округ & 1582,3 & 85,7 & 100,3 & 1110,2 & 100,1 & 100,4 \\
\hline Белгородская область & 22,8 & 100,1 & 109,7 & 22,3 & 97,1 & 99,3 \\
\hline Брянская область & 5,3 & 95,7 & 105,5 & 3,8 & 86,5 & 103,3 \\
\hline Владимирская область & 7,0 & 101,7 & 118,5 & 24,3 & 90,2 & 101,6 \\
\hline Воронежская область & 35,6 & 91,7 & 108,5 & 68,0 & 114,4 & 99,3 \\
\hline Ивановская область & 57,6 & 72,4 & 101,9 & 15,7 & 85,9 & 100,5 \\
\hline Калужская область & 2,9 & 107,3 & 129,5 & 10,8 & 99,5 & 99,9 \\
\hline Костромская область & 18,2 & 76,5 & 121,4 & 58,8 & 90,9 & 95,2 \\
\hline Курская область & 45,8 & 105,4 & 103,4 & 22,0 & 99,9 & 99,1 \\
\hline Липецкая область & 225,8 & 99,9 & 83,0 & 80,6 & 112,0 & 100,1 \\
\hline Московская область & 536,1 & 84,6 & 100,1 & 153,2 & 96,6 & 99,2 \\
\hline Орловская область & 8,3 & 110,9 & 123,9 & 25,7 & 99,9 & 100,0 \\
\hline Рязанская область & 188,9 & 78,2 & 122,2 & 77,9 & 94,2 & 98,8 \\
\hline Смоленская область & 94,4 & 98,7 & 103,8 & 33,7 & 103,2 & 99,7 \\
\hline Тамбовская область & 15,6 & 98,9 & 122,4 & 24,8 & 103,0 & 100,1 \\
\hline Тверская область & 93,2 & 99,8 & 105,6 & 56,5 & 99,9 & 99,8 \\
\hline Тульская область & 203,1 & 70,9 & 94,2 & 26,9 & 123,4 & 100,7 \\
\hline Ярославская область & 17,8 & 104,1 & 118,2 & 25,2 & 101,5 & 99,6 \\
\hline г. Москва & 4,0 & 72,3 & 101,5 & 380,2 & 99,7 & 102,6 \\
\hline Северо-Западный федеральный округ & 848,9 & 102,8 & 112,0 & 634,3 & 104,0 & 103,1 \\
\hline Республика Карелия & 29,0 & 115,6 & 107,6 & 54,6 & 91,9 & 98,7 \\
\hline Республика Коми & 105,7 & 112,7 & 108,5 & 52,9 & 98,4 & 96,0 \\
\hline Архангельская область & 206,2 & 81,4 & 110,7 & 57,8 & 120,5 & 96,0 \\
\hline $\begin{array}{l}\text { в том числе: } \\
\text { Ненецкий авт. округ }\end{array}$ & 24,6 & 79,2 & 107,2 & - & - & - \\
\hline Архангельская область без авт. округа & 181,6 & 81,7 & 111,2 & 57,8 & 120,5 & 96,0 \\
\hline Вологодская область & 254,8 & 121,9 & 110,0 & 20,0 & 117,2 & 99,8 \\
\hline Калининградская область & 25,7 & 194,7 & 102,9 & 10,1 & 96,6 & 100,8 \\
\hline Ленинградская область & 25,0 & 70,2 & 83,6 & 41,3 & 122,2 & 114,3 \\
\hline Мурманская область & 150,7 & 107,8 & 131,6 & 149,8 & 103,0 & 112,1 \\
\hline Новгородская область & 25,7 & 90,7 & 108,9 & 3,1 & 106,3 & 108,1 \\
\hline Псковская область & 20,5 & 107,3 & 121,6 & 10,0 & 113,1 & 119,9 \\
\hline г. Санкт-Петербург & 5,5 & 67,7 & 96,9 & 235,0 & 101,9 & 100,6 \\
\hline Южный федеральный округ & 400,4 & 74,0 & 90,1 & 138,2 & 92,1 & 99,6 \\
\hline Республика Адыгея & 0,6 & 110,5 & 104,6 & $\ldots$ & 85,3 & 100,0 \\
\hline Республика Калмыкия & 0,3 & 105,1 & 100,3 & $\ldots$ & - & 85,7 \\
\hline Республика Крым & 22,8 & 89,9 & 97,9 & 15,0 & 94,8 & 99,9 \\
\hline Краснодарский край & 35,7 & 101,0 & 100,7 & 34,2 & 65,6 & 101,0 \\
\hline Астраханская область & 2,2 & 187,4 & 99,2 & 23,3 & 92,1 & 103,5 \\
\hline Волгоградская область & 6,5 & 126,1 & 107,0 & 21,3 & 165,1 & 93,0 \\
\hline Ростовская область & 327,0 & 70,4 & 88,2 & 38,8 & 100,5 & 99,8 \\
\hline г. Севастополь & 5,4 & 61,5 & 96,0 & 4,7 & 110,4 & 99,3 \\
\hline $\begin{array}{c}\text { Северо-Кавказский } \\
\text { федеральный округ }\end{array}$ & 6,9 & 129,5 & 114,5 & 133,2 & 100,6 & 101,1 \\
\hline Республика Дагестан & 1,4 & 162,5 & 100,0 & 3,8 & 94,9 & 100,0 \\
\hline Кабардино-Балкарская Республика & $\ldots$ & 50,0 & 87,5 & 0,4 & 100,0 & 100,0 \\
\hline Карачаево-Черкесская Республика & 0,4 & 120,7 & 107,4 & 0,3 & 37,1 & 100,0 \\
\hline Республика Северная Осетия - Алания & - & - & - & $\ldots$ & 100,0 & 0,2 \\
\hline Чеченская Республика & - & - & - & - & - & - \\
\hline Ставропольский край & 5,1 & 123,6 & 119,8 & 128,3 & 100,9 & 101,2 \\
\hline
\end{tabular}




\begin{tabular}{|c|c|c|c|c|c|c|}
\hline & \multicolumn{3}{|c|}{ Уголь } & \multicolumn{3}{|c|}{ Мазут топочньй } \\
\hline & \multirow{2}{*}{$\begin{array}{l}\text { тысc. } \\
\text { тонн }\end{array}$} & \multicolumn{2}{|c|}{$8 \% \kappa$} & \multirow{2}{*}{$\begin{array}{l}\text { тысc. } \\
\text { тонн }\end{array}$} & \multicolumn{2}{|c|}{$6 \% \kappa$} \\
\hline & & \begin{tabular}{|c|}
1 сентября \\
2019 г. \\
\end{tabular} & $\begin{array}{c}1 \text { aвzycma } \\
20202 .\end{array}$ & & $\begin{array}{c}1 \text { сентября } \\
2019 \text { z. }\end{array}$ & $\begin{array}{c}1 \text { aвгуста } \\
2020 \text { 2. }\end{array}$ \\
\hline Приволжский федеральный округ & 875,2 & 104,5 & 108,1 & 908,6 & 95,6 & 95,1 \\
\hline Республика Башкортостан & 56,5 & 120,2 & 94,1 & 139,6 & 99,3 & 89,7 \\
\hline Республика Марий Эл & 23,1 & 103,6 & 179,4 & 11,9 & 101,4 & 99,9 \\
\hline Республика Мордовия & 6,1 & 94,2 & 94,5 & $\ldots$ & 32,7 & 99,7 \\
\hline Республика Татарстан & 69,2 & 95,6 & 99,3 & 157,7 & 87,6 & 83,3 \\
\hline Удмуртская Республика & 75,5 & 106,5 & 104,2 & 45,0 & 97,8 & 99,6 \\
\hline Чувашская Республика & 3,7 & 90,5 & 103,8 & 26,6 & 95,9 & 100,0 \\
\hline Пермский край & 192,9 & 118,1 & 120,3 & 58,8 & 92,5 & 100,4 \\
\hline Кировская область & 171,9 & 85,0 & 108,0 & 31,2 & 111,6 & 95,9 \\
\hline Нижегородская область & 48,9 & 99,0 & 118,2 & 96,5 & 89,1 & 99,9 \\
\hline Оренбургская область & 126,4 & 110,8 & 100,6 & 85,6 & 91,7 & 100,0 \\
\hline Пензенская область & 8,2 & 88,2 & 116,2 & 20,2 & 96,1 & 100,3 \\
\hline Самарская область & 83,9 & 122,9 & 101,5 & 125,8 & 129,7 & 99,8 \\
\hline Саратовская область & 3,5 & 100,3 & 119,0 & 58,4 & 96,9 & 101,0 \\
\hline Ульяновская область & 5,3 & 124,1 & 102,7 & 40,7 & 100,8 & 103,8 \\
\hline Уральский федеральный округ & 2961,9 & 84,3 & 91,2 & 277,3 & 94,0 & 98,2 \\
\hline Курганская область & 107,2 & 103,7 & 106,0 & 6,5 & 64,8 & 68,2 \\
\hline Свердловская область & 1753,5 & 91,1 & 89,9 & 160,6 & 92,3 & 97,9 \\
\hline Тюменская область & 47,2 & 100,4 & 103,3 & 70,2 & 99,8 & 100,2 \\
\hline $\begin{array}{l}\text { в том числе: } \\
\text { Ханты-Мансийский авт. округ - Югра }\end{array}$ & 23,6 & 99,1 & 102,3 & $\ldots$ & 99,8 & 100,0 \\
\hline Ямало-Ненецкий авт. округ & 17,9 & 103,6 & 101,8 & $\ldots$ & 121,6 & 100,0 \\
\hline Тюменская область без авт. округов & 5,7 & 96,3 & 113,0 & 64,7 & 99,1 & 100,2 \\
\hline Челябинская область & 1054,0 & 73,2 & 91,5 & 40,0 & 98,6 & 103,5 \\
\hline Сибирский федеральный округ & 11671,3 & 98,2 & 112,6 & 218,8 & 105,8 & 96,2 \\
\hline Республика Алтай & 12,7 & 151,3 & 151,1 & 0,5 & в 7,6p. & 99,2 \\
\hline Республика Тыва & 33,5 & 88,1 & 130,4 & $\ldots$ & в 2,2p. & 170,0 \\
\hline Республика Хакасия & 260,6 & в 2,0p. & 144,1 & 5,3 & 90,2 & 87,0 \\
\hline Алтайский край & 1091,6 & 83,6 & 106,7 & 27,7 & 123,2 & 99,8 \\
\hline Красноярский край & 2708,0 & 88,3 & 105,0 & 55,2 & 101,1 & 87,3 \\
\hline Иркутская область & 2894,6 & 116,9 & 115,8 & 50,7 & 100,1 & 101,5 \\
\hline Кемеровская область & 1936,7 & 85,8 & 114,2 & 11,6 & 105,0 & 93,4 \\
\hline Новосибирская область & 1561,9 & 98,8 & 125,9 & 21,0 & 110,1 & 99,9 \\
\hline Омская область & 802,8 & 114,7 & 103,6 & 24,3 & 111,4 & 104,8 \\
\hline Томская область & 368,9 & 111,5 & 109,3 & 22,3 & 105,4 & 95,9 \\
\hline $\begin{array}{l}\text { Дальневосточный } \\
\text { федеральный округ }\end{array}$ & 5496,3 & 100,9 & 111,5 & 247,0 & 90,4 & $\mathbf{9 8 , 7}$ \\
\hline Республика Бурятия & 570,3 & 100,5 & 101,1 & 24,3 & в 2,2p. & 113,0 \\
\hline Республика Саха (Якутия) & 790,1 & 108,9 & 109,5 & $\ldots$ & 79,6 & 86,7 \\
\hline Забайкальский край & 658,8 & 99,7 & 116,9 & 18,1 & 150,4 & 83,0 \\
\hline Камчатский край & 140,6 & 116,3 & 116,2 & 58,9 & 122,3 & 90,0 \\
\hline Приморский край & 872,2 & 94,4 & 85,3 & 62,9 & 56,5 & 108,5 \\
\hline Хабаровский край & 1059,4 & 95,2 & 127,6 & 64,3 & 98,6 & 97,0 \\
\hline Амурская область & 711,3 & 99,7 & 127,6 & 7,4 & 46,2 & 102,4 \\
\hline Магаданская область & 231,5 & 123,8 & 120,5 & 5,2 & 126,0 & 137,1 \\
\hline Сахалинская область & 98,2 & 124,3 & 116,5 & 2,8 & 145,0 & 112,1 \\
\hline Еврейская авт. область & 76,9 & 94,2 & 124,0 & 1,1 & 153,6 & 79,8 \\
\hline Чукотский авт. округ & 287,0 & 105,0 & 134,6 & $\ldots$ & 36,4 & 100,0 \\
\hline
\end{tabular}




\section{III ДЕМОГРАФИЯ ОРГАНИЗАЦИЙ}

ДЕМОГРАФИЯ ОРГАНИЗАЦИЙ

в сентябре 2020 года

единиц

\begin{tabular}{|c|c|c|c|c|}
\hline & \multicolumn{2}{|c|}{$\begin{array}{c}\text { Количество } \\
\text { зарегистрированных организаичий }\end{array}$} & \multicolumn{2}{|c|}{$\begin{array}{c}\text { Количество официально } \\
\text { ликвидированньх организаций }\end{array}$} \\
\hline & всего & $\begin{array}{c}\text { на } 1000 \text { организаций, } \\
\text { учтенных органами } \\
\text { государственной } \\
\text { статистики }\end{array}$ & всего & $\begin{array}{c}\text { на } 1000 \text { организачий, } \\
\text { учтенных органами } \\
\text { государственной } \\
\text { статистики }\end{array}$ \\
\hline Российская Федерация & 19789 & 5,6 & 50625 & 14,3 \\
\hline Центральный федеральный округ & 7686 & 6,3 & 21703 & 17,8 \\
\hline Белгородская область & 122 & 4,0 & 244 & 8,1 \\
\hline Брянская область & 63 & 3,8 & 241 & 14,6 \\
\hline Владимирская область & 88 & 3,3 & 408 & 15,1 \\
\hline Воронежская область & 386 & 8,5 & 627 & 13,7 \\
\hline Ивановская область & 184 & 7,0 & 186 & 7,1 \\
\hline Калужская область & 107 & 4,7 & 180 & 7,9 \\
\hline Костромская область & 56 & 4,2 & 213 & 16,1 \\
\hline Курская область & 143 & 7,8 & 194 & 10,5 \\
\hline Липецкая область & 132 & 6,9 & 129 & 6,7 \\
\hline Московская область & 1257 & 6,4 & 3847 & 19,7 \\
\hline Орловская область & 66 & 5,5 & 95 & 8,0 \\
\hline Рязанская область & 120 & 5,0 & 123 & 5,1 \\
\hline Смоленская область & 174 & 7,1 & 348 & 14,3 \\
\hline Тамбовская область & 76 & 5,3 & 151 & 10,6 \\
\hline Тверская область & 160 & 5,5 & 367 & 12,6 \\
\hline Тульская область & 108 & 3,9 & 449 & 16,3 \\
\hline Ярославская область & 174 & 5,1 & 522 & 15,2 \\
\hline г. Москва & 4270 & 6,7 & 13379 & 20,9 \\
\hline Северо-Западный федеральный округ & 2646 & 5,8 & 7558 & 16,6 \\
\hline Республика Карелия & 70 & 3,8 & 52 & 2,8 \\
\hline Республика Коми & 49 & 3,2 & 133 & 8,6 \\
\hline Архангельская область & 55 & 2,8 & 216 & 11,1 \\
\hline $\begin{array}{l}\text { в том числе: } \\
\text { Ненецкий авт. округ }\end{array}$ & 2 & 2,2 & 7 & 7,6 \\
\hline Архангельская область без авт. округа & 53 & 2,8 & 209 & 11,2 \\
\hline Вологодская область & 271 & 8,0 & 582 & 17,2 \\
\hline Калининградская область & 143 & 3,7 & 622 & 15,9 \\
\hline Ленинградская область & 238 & 7,4 & 276 & 8,6 \\
\hline Мурманская область & 42 & 3,0 & 91 & 6,6 \\
\hline Новгородская область & 52 & 4,6 & 79 & 7,0 \\
\hline Псковская область & 45 & 3,7 & 205 & 16,7 \\
\hline г. Санкт-Петербург & 1681 & 6,5 & 5302 & 20,5 \\
\hline Южный федеральный округ & 1383 & 4,9 & 2589 & 9,1 \\
\hline Республика Адыгея & 23 & 3,8 & 102 & 16,9 \\
\hline Республика Калмыкия & 13 & 3,8 & 10 & 2,9 \\
\hline Республика Крым & 164 & 5,3 & 304 & 9,7 \\
\hline Краснодарский край & 596 & 5,4 & 1049 & 9,5 \\
\hline Астраханская область & 62 & 4,6 & 144 & 10,7 \\
\hline Волгоградская область & 111 & 3,2 & 178 & 5,2 \\
\hline Ростовская область & 352 & 4,7 & 748 & 10,0 \\
\hline г. Севастополь & 62 & 5,7 & 54 & 5,0 \\
\hline Северо-Кавказский федеральный округ & 500 & 4,8 & 664 & 6,4 \\
\hline Республика Дагестан & 131 & 4,6 & 20 & 0,7 \\
\hline Республика Ингушетия & 48 & 9,2 & 11 & 2,1 \\
\hline Кабардино-Балкарская Республика & 39 & 3,9 & 159 & 15,9 \\
\hline Карачаево-Черкесская Республика & 32 & 5,5 & 124 & 21,1 \\
\hline Республика Северная Осетия - Алания & 46 & 5,2 & 42 & 4,8 \\
\hline Чеченская Республика & 72 & 7,7 & 13 & 1,4 \\
\hline Ставропольский край & 132 & 3,7 & 295 & 8,2 \\
\hline
\end{tabular}




\begin{tabular}{|c|c|c|c|c|}
\hline & \multicolumn{2}{|c|}{$\begin{array}{c}\text { Количество } \\
\text { зарегистрированньхх организаций }\end{array}$} & \multicolumn{2}{|c|}{$\begin{array}{c}\text { Количество официально } \\
\text { ликвидированньхх организаций }\end{array}$} \\
\hline & всего & $\begin{array}{c}\text { на } 1000 \text { организаций, } \\
\text { учтенных органами } \\
\text { государственной } \\
\text { статистики }^{2)}\end{array}$ & всего & $\begin{array}{c}\text { на } 1000 \text { организачий, } \\
\text { учтенных органами } \\
\text { государственной } \\
\text { статистики }\end{array}$ \\
\hline Приволжский федеральный округ & 3785 & 6,0 & 7288 & 11,6 \\
\hline Республика Башкортостан & 696 & 9,1 & 814 & 10,7 \\
\hline Республика Марий Эл & 34 & 3,0 & 37 & 3,3 \\
\hline Республика Мордовия & 39 & 3,4 & 43 & 3,7 \\
\hline Республика Татарстан & 785 & 7,5 & 1075 & 10,3 \\
\hline Удмуртская Республика & 241 & 7,2 & 235 & 7,1 \\
\hline Чувашская Республика & 93 & 4,5 & 567 & 27,7 \\
\hline Пермский край & 244 & 4,2 & 857 & 14,7 \\
\hline Кировская область & 101 & 3,6 & 123 & 4,4 \\
\hline Нижегородская область & 437 & 5,6 & 1204 & 15,4 \\
\hline Оренбургская область & 103 & 3,4 & 357 & 11,7 \\
\hline Пензенская область & 94 & 4,3 & 196 & 9,0 \\
\hline Самарская область & 584 & 6,4 & 1368 & 15,1 \\
\hline Саратовская область & 211 & 5,1 & 176 & 4,3 \\
\hline Ульяновская область & 123 & 5,2 & 236 & 9,9 \\
\hline Уральский федеральный округ & 1378 & 4,8 & 3084 & 10,8 \\
\hline Курганская область & 34 & 2,9 & 86 & 7,4 \\
\hline Свердловская область & 588 & 4,9 & 1489 & 12,3 \\
\hline Тюменская область & 391 & 5,1 & 754 & 9,8 \\
\hline $\begin{array}{l}\text { в том числе: } \\
\text { Ханты-Мансийский авт. округ - Югра }\end{array}$ & 139 & 4,6 & 203 & 6,7 \\
\hline Ямало-Ненецкий авт. округ & 29 & 3,5 & 34 & 4,1 \\
\hline Тюменская область без авт. округов & 223 & 5,8 & 517 & 13,6 \\
\hline Челябинская область & 365 & 4,8 & 755 & 9,9 \\
\hline Сибирский федеральный округ & 2117 & 5,6 & 5602 & 14,9 \\
\hline Республика Алтай & 26 & 5,4 & 48 & 9,9 \\
\hline Республика Тыва & 13 & 3,8 & 22 & 6,4 \\
\hline Республика Хакасия & 51 & 6,6 & 76 & 9,9 \\
\hline Алтайский край & 400 & 9,0 & 398 & 9,0 \\
\hline Красноярский край & 294 & 4,7 & 1610 & 25,7 \\
\hline Иркутская область & 272 & 5,2 & 854 & 16,4 \\
\hline Кемеровская область & 146 & 3,9 & 634 & 16,8 \\
\hline Новосибирская область & 555 & 5,6 & 1233 & 12,6 \\
\hline Омская область & 235 & 6,3 & 565 & 15,1 \\
\hline Томская область & 125 & 4,7 & 162 & 6,1 \\
\hline Дальневосточный федеральный округ & 1088 & 5,9 & 2134 & 11,5 \\
\hline Республика Бурятия & 233 & 12,2 & 74 & 3,9 \\
\hline Республика Саха (Якутия) & 109 & 5,0 & 133 & 6,1 \\
\hline Забайкальский край & 65 & 5,2 & 100 & 8,0 \\
\hline Камчатский край & 32 & 3,4 & 58 & 6,2 \\
\hline Приморский край & 265 & 5,0 & 433 & 8,1 \\
\hline Хабаровский край & 196 & 5,7 & 896 & 26,1 \\
\hline Амурская область & 81 & 5,9 & 101 & 7,4 \\
\hline Магаданская область & 24 & 6,1 & 33 & 8,4 \\
\hline Сахалинская область & 69 & 5,0 & 294 & 21,1 \\
\hline Еврейская авт. область & 7 & 2,8 & 12 & 4,9 \\
\hline Чукотский авт. округ & 7 & 7,0 & - & - \\
\hline
\end{tabular}




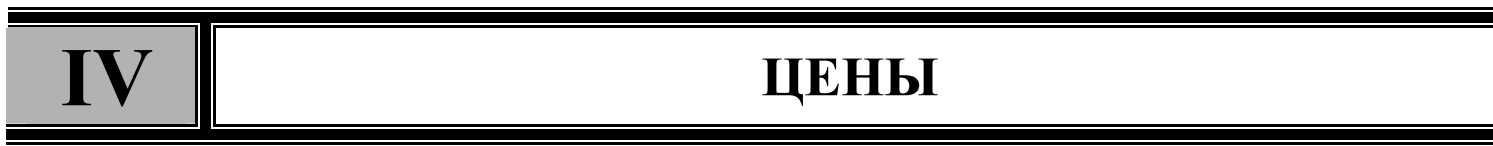

ИНДЕКСЫ ПОТРЕБИТЕЛЬСКИХ ЦЕН в сентябре 2020 года

в процентах

\begin{tabular}{|c|c|c|c|c|c|c|c|c|}
\hline & \multicolumn{4}{|c|}{ К предыдущему месячу } & \multicolumn{4}{|c|}{ К декабрю 2019 г. } \\
\hline & \multirow{2}{*}{$\begin{array}{l}\text { товары } \\
\text { и услуги }\end{array}$} & \multicolumn{3}{|c|}{ в том числе } & \multirow{2}{*}{$\begin{array}{l}\text { товары } \\
\text { и услуги }\end{array}$} & \multicolumn{3}{|c|}{ в том числе } \\
\hline & & $\begin{array}{c}\text { продо- } \\
\text { вольст- } \\
\text { венньее } \\
\text { товарыл }\end{array}$ & \begin{tabular}{|c|} 
непродо- \\
вольст- \\
венньее \\
товарыл \\
\end{tabular} & услуги & & \begin{tabular}{|c|} 
продо- \\
вольст- \\
венньее \\
товарыл \\
\end{tabular} & \begin{tabular}{|c|} 
непродо- \\
вольст- \\
венньее \\
товарьы \\
\end{tabular} & услуги \\
\hline Российская Федерация & 99,9 & 99,6 & 100,6 & 99,6 & 102,9 & 103,1 & 103,1 & 102,4 \\
\hline Центральный федеральный округ & 99,9 & 99,5 & 100,5 & 99,7 & 102,8 & 103,0 & 103,2 & 102,0 \\
\hline Белгородская область & 100,1 & 100,0 & 100,4 & 99,8 & 103,4 & 104,4 & 103,0 & 102,5 \\
\hline Брянская область & 99,8 & 99,6 & 100,2 & 99,6 & 102,9 & 103,7 & 102,2 & 102,3 \\
\hline Владимирская область & 100,0 & 99,6 & 100,7 & 99,6 & 103,3 & 103,5 & 103,7 & 102,3 \\
\hline Воронежская область & 100,1 & 99,6 & 100,7 & 100,0 & 104,3 & 103,5 & 104,1 & 105,4 \\
\hline Ивановская область & 99,9 & 99,6 & 100,5 & 99,3 & 103,6 & 104,3 & 104,1 & 101,9 \\
\hline Калужская область & 99,9 & 98,9 & 100,7 & 100,1 & 103,0 & 103,2 & 103,1 & 102,7 \\
\hline Костромская область & 99,9 & 99,6 & 100,5 & 99,5 & 103,0 & 103,2 & 103,4 & 101,9 \\
\hline Курская область & 99,7 & 98,7 & 100,7 & 99,6 & 103,4 & 103,3 & 104,0 & 102,3 \\
\hline Липецкая область & 100,2 & 99,8 & 100,5 & 100,3 & 103,5 & 103,3 & 104,0 & 102,9 \\
\hline Московская область & 99,8 & 99,5 & 100,4 & 99,4 & 102,2 & 102,9 & 102,7 & 101,0 \\
\hline Орловская область & 100,0 & 99,6 & 100,4 & 99,8 & 102,8 & 102,7 & 103,0 & 102,6 \\
\hline Рязанская область & 99,9 & 99,7 & 100,5 & 99,7 & 103,4 & 104,2 & 103,5 & 101,8 \\
\hline Смоленская область & 100,0 & 99,5 & 100,6 & 100,0 & 103,2 & 102,9 & 103,0 & 103,9 \\
\hline Тамбовская область & 100,0 & 99,6 & 100,4 & 99,9 & 103,2 & 102,9 & 104,1 & 102,4 \\
\hline Тверская область & 99,9 & 99,1 & 100,8 & 100,2 & 103,2 & 103,3 & 103,2 & 103,0 \\
\hline Тульская область & 99,7 & 99,1 & 100,5 & 100,0 & 103,2 & 102,7 & 103,9 & 103,4 \\
\hline Ярославская область & 99,8 & 99,3 & 100,5 & 99,7 & 103,3 & 103,5 & 104,0 & 102,1 \\
\hline г. Москва & 99,9 & 99,5 & 100,5 & 99,7 & 102,5 & 102,6 & 103,0 & 101,8 \\
\hline Северо-Западный федеральный округ & 99,8 & 99,2 & 100,6 & 99,7 & 102,9 & 102,6 & 103,1 & 103,1 \\
\hline Республика Карелия & 99,8 & 99,0 & 100,6 & 99,5 & 103,8 & 103,0 & 104,7 & 103,3 \\
\hline Республика Коми & 99,7 & 99,9 & 100,5 & 98,7 & 104,3 & 102,7 & 103,7 & 107,0 \\
\hline Архангельская область & 99,9 & 99,5 & 100,6 & 99,3 & 102,7 & 102,7 & 102,8 & 102,4 \\
\hline $\begin{array}{l}\text { в том числе: } \\
\text { Ненецкий авт. округ }\end{array}$ & 100,0 & 99,9 & 100,3 & 99,7 & 100,6 & 99,0 & 102,0 & 101,1 \\
\hline Архангельская область без авт. округа & 99,9 & 99,5 & 100,7 & 99,3 & 102,8 & 102,9 & 102,9 & 102,6 \\
\hline Вологодская область & 99,9 & 99,4 & 100,8 & 99,6 & 103,0 & 102,7 & 103,8 & 102,4 \\
\hline Калининградская область & 99,7 & 99,1 & 100,6 & 99,6 & 103,4 & 103,0 & 103,8 & 103,7 \\
\hline Ленинградская область & 99,8 & 99,2 & 100,3 & 99,8 & 102,3 & 101,9 & 102,2 & 103,0 \\
\hline Мурманская область & 99,9 & 99,7 & 100,2 & 99,8 & 102,5 & 102,7 & 103,4 & 101,4 \\
\hline Новгородская область & 99,9 & 99,6 & 100,3 & 99,7 & 103,4 & 103,9 & 103,4 & 102,6 \\
\hline Псковская область & 99,7 & 99,0 & 100,4 & 100,0 & 103,1 & 103,3 & 103,1 & 102,7 \\
\hline г. Санкт-Петербург & 99,8 & 99,0 & 100,7 & 99,8 & 102,7 & 102,4 & 102,9 & 102,9 \\
\hline Южный федеральный округ & 99,9 & 99,8 & 100,5 & 99,4 & 103,1 & 103,3 & 103,0 & 103,1 \\
\hline Республика Адыгея & 100,5 & 100,5 & 100,7 & 100,2 & 103,6 & 105,1 & 102,8 & 102,4 \\
\hline Республика Калмыкия & 99,9 & 99,7 & 100,7 & 98,9 & 102,7 & 102,4 & 103,3 & 102,3 \\
\hline Республика Крым & 99,9 & 99,9 & 100,4 & 99,2 & 103,2 & 103,8 & 102,7 & 102,5 \\
\hline Краснодарский край & 99,8 & 99,7 & 100,6 & 98,9 & 103,3 & 103,4 & 102,9 & 103,8 \\
\hline Астраханская область & 100,2 & 100,0 & 100,6 & 99,8 & 103,1 & 103,5 & 103,3 & 102,0 \\
\hline Волгоградская область & 100,2 & 100,0 & 100,7 & 99,8 & 102,9 & 102,6 & 103,8 & 102,2 \\
\hline Ростовская область & 99,9 & 99,6 & 100,4 & 99,8 & 102,9 & 103,3 & 102,5 & 103,0 \\
\hline г. Севастополь & 99,8 & 99,3 & 100,3 & 99,9 & 103,8 & 103,6 & 103,7 & 104,2 \\
\hline Северо-Кавказский федеральный округ & 99,9 & 99,9 & 100,4 & 99,4 & 102,8 & 102,8 & 103,1 & 102,1 \\
\hline Республика Дагестан & 99,7 & 100,1 & 100,4 & 96,8 & 102,8 & 102,4 & 104,0 & 101,7 \\
\hline Республика Ингушетия & 99,9 & 99,5 & 100,6 & 99,7 & 102,6 & 103,1 & 102,7 & 101,0 \\
\hline Кабардино-Балкарская Республика & 100,1 & 100,1 & 100,6 & 99,5 & 103,1 & 104,4 & 102,9 & 101,2 \\
\hline Карачаево-Черкесская Республика & 99,9 & 99,9 & 100,3 & 99,3 & 102,7 & 103,2 & 103,1 & 101,7 \\
\hline Республика Северная Осетия - Алания & 100,1 & 100,2 & 100,4 & 99,2 & 102,4 & 103,1 & 102,5 & 100,9 \\
\hline Чеченская Республика & 100,0 & 99,6 & 100,6 & 100,0 & 102,2 & 102,0 & 102,4 & 102,4 \\
\hline Ставропольский край & 100,1 & 99,5 & 100,3 & 100,4 & 102,9 & 103,1 & 102,9 & 102,8 \\
\hline
\end{tabular}




\begin{tabular}{|c|c|c|c|c|c|c|c|c|}
\hline & \multicolumn{4}{|c|}{ К предыдущеему месяиу } & \multicolumn{4}{|c|}{ К К декабрю 2019 г. } \\
\hline & \multirow{2}{*}{$\begin{array}{l}\text { товарьы } \\
\text { и услуги }\end{array}$} & \multicolumn{3}{|c|}{ в том числе } & \multirow{2}{*}{$\begin{array}{l}\text { товары } \\
\text { и услуги }\end{array}$} & \multicolumn{3}{|c|}{ в том числе } \\
\hline & & $\begin{array}{c}\text { продо- } \\
\text { вольст- } \\
\text { венньее } \\
\text { товарь }\end{array}$ & \begin{tabular}{|c|} 
непродо- \\
вольст- \\
венньее \\
товары \\
\end{tabular} & услуги & & $\begin{array}{c}\text { продо- } \\
\text { вольст- } \\
\text { венньее } \\
\text { товарь }\end{array}$ & \begin{tabular}{|c|} 
непродо- \\
вольст- \\
венньле \\
товарыл \\
\end{tabular} & услуги \\
\hline Приволжский федеральный округ & 100,0 & 99,6 & 100,7 & 99,6 & 103,1 & 103,3 & 103,3 & 102,5 \\
\hline Республика Башкортостан & 100,1 & 99,9 & 100,9 & 99,2 & 103,2 & 103,5 & 103,3 & 102,6 \\
\hline Республика Марий Эл & 99,8 & 99,3 & 100,5 & 99,7 & 103,0 & 103,4 & 102,9 & 102,3 \\
\hline Республика Мордовия & 99,7 & 99,4 & 100,3 & 99,6 & 102,3 & 102,4 & 102,7 & 101,8 \\
\hline Республика Татарстан & 100,1 & 99,6 & 100,5 & 100,0 & 102,7 & 103,0 & 103,3 & 101,5 \\
\hline Удмуртская Республика & 100,0 & 99,3 & 100,9 & 99,7 & 102,7 & 102,0 & 102,6 & 103,9 \\
\hline Чувашская Республика & 99,9 & 99,6 & 100,5 & 99,7 & 102,7 & 103,4 & 103,2 & 101,2 \\
\hline Пермский край & 99,8 & 99,1 & 100,7 & 99,5 & 102,4 & 102,4 & 102,7 & 102,1 \\
\hline Кировская область & 99,9 & 99,5 & 100,4 & 99,7 & 103,3 & 103,2 & 103,6 & 103,0 \\
\hline Нижегородская область & 100,1 & 99,7 & 100,8 & 99,9 & 103,6 & 103,5 & 104,1 & 103,3 \\
\hline Оренбургская область & 99,8 & 99,4 & 100,7 & 99,4 & 102,5 & 103,1 & 101,7 & 102,5 \\
\hline Пензенская область & 100,0 & 99,6 & 100,8 & 99,8 & 103,4 & 103,7 & 103,8 & 102,0 \\
\hline Самарская область & 100,0 & 99,5 & 100,9 & 99,4 & 103,4 & 103,0 & 104,1 & 103,1 \\
\hline Саратовская область & 99,8 & 99,7 & 100,2 & 99,7 & 104,0 & 105,2 & 103,7 & 102,4 \\
\hline Ульяновская область & 99,8 & 99,5 & 100,5 & 99,4 & 103,4 & 104,0 & 103,8 & 102,1 \\
\hline Уральский федеральный округ & 99,8 & 99,6 & 100,6 & 99,3 & 102,3 & 102,8 & 102,6 & 101,5 \\
\hline Курганская область & 100,1 & 100,0 & 100,9 & 99,1 & 103,4 & 104,5 & 103,4 & 101,5 \\
\hline Свердловская область & 100,0 & 99,9 & 100,7 & 99,5 & 102,3 & 102,4 & 102,8 & 101,5 \\
\hline Тюменская область & 99,7 & 99,3 & 100,4 & 99,2 & 101,8 & 102,2 & 101,8 & 101,4 \\
\hline в том числе: & & & & & & & & \\
\hline Ханты-Мансийский авт. округ - Югра & 99,7 & 99,4 & 100,4 & 98,9 & 102,2 & 102,5 & 102,3 & 101,5 \\
\hline Ямало-Ненецкий авт. округ & 99,9 & 99,2 & 100,6 & 100,0 & 101,5 & 102,1 & 102,8 & 98,9 \\
\hline Тюменская область без авт. округов & 99,7 & 99,2 & 100,3 & 99,7 & 102,2 & 101,9 & 101,8 & 103,4 \\
\hline Челябинская область & 99,8 & 99,3 & 100,8 & 99,1 & 102,9 & 103,7 & 103,2 & 101,5 \\
\hline Сибирский федеральный округ & 100,0 & 99,7 & 100,6 & 99,5 & 102,8 & 103,1 & 102,8 & 102,3 \\
\hline Республика Алтай & 99,9 & 99,6 & 100,5 & 99,4 & 102,5 & 103,0 & 102,6 & 101,8 \\
\hline Республика Тыва & 99,9 & 99,8 & 100,1 & 99,7 & 103,1 & 103,7 & 102,5 & 103,0 \\
\hline Республика Хакасия & 100,3 & 100,3 & 100,6 & 100,1 & 103,8 & 104,7 & 103,4 & 102,8 \\
\hline Алтайский край & 99,7 & 99,1 & 100,6 & 99,5 & 102,9 & 103,2 & 102,8 & 102,4 \\
\hline Красноярский край & 100,1 & 99,9 & 100,9 & 99,3 & 102,3 & 102,6 & 102,8 & 101,5 \\
\hline Иркутская область & 100,0 & 100,3 & 100,7 & 98,4 & 102,8 & 102,9 & 103,0 & 102,5 \\
\hline Кемеровская область & 100,7 & 100,1 & 100,9 & 101,5 & 102,9 & 102,8 & 102,6 & 103,4 \\
\hline Новосибирская область & 99,7 & 99,2 & 100,6 & 99,3 & 102,8 & 103,4 & 102,6 & 101,9 \\
\hline Омская область & 99,9 & 99,6 & 100,5 & 99,4 & 102,4 & 102,5 & 102,9 & 101,7 \\
\hline Томская область & 100,3 & 100,4 & 100,4 & 100,0 & 102,9 & 103,0 & 103,0 & 102,9 \\
\hline Дальневосточный федеральный округ & 100,1 & 100,1 & 100,5 & 99,8 & 103,1 & 103,6 & 103,1 & 102,6 \\
\hline Республика Бурятия & 100,0 & 99,5 & 100,5 & 99,8 & 104,2 & 105,3 & 103,5 & 103,3 \\
\hline Республика Саха (Якутия) & 100,6 & 100,7 & 101,0 & 100,0 & 102,5 & 102,5 & 102,9 & 101,9 \\
\hline Забайкальский край & 99,4 & 99,3 & 100,5 & 98,2 & 103,6 & 103,3 & 103,4 & 104,6 \\
\hline Камчатский край & 100,0 & 99,7 & 100,3 & 99,9 & 102,3 & 103,4 & 102,3 & 100,9 \\
\hline Приморский край & 100,3 & 100,3 & 100,5 & 99,9 & 103,0 & 103,3 & 103,1 & 102,6 \\
\hline Хабаровский край & 100,2 & 100,3 & 100,3 & 100,1 & 103,0 & 103,6 & 102,9 & 102,4 \\
\hline Амурская область & 100,0 & 100,5 & 100,4 & 98,9 & 104,4 & 105,0 & 104,3 & 103,7 \\
\hline Магаданская область & 99,9 & 99,6 & 100,1 & 100,0 & 103,0 & 104,7 & 104,0 & 99,8 \\
\hline Сахалинская область & 100,3 & 100,2 & 100,4 & 100,4 & 102,8 & 103,1 & 102,6 & 103,1 \\
\hline Еврейская авт. область & 100,6 & 100,6 & 100,7 & 100,2 & 104,1 & 104,8 & 103,9 & 103,3 \\
\hline Чукотский авт. округ & 99,6 & 99,2 & 100,0 & 100,3 & 101,5 & 102,2 & 100,3 & 101,4 \\
\hline
\end{tabular}




\section{СТОИМОСТЬ ФИКСИРОВАННОГО НАБОРА \\ ПОТРЕБИТЕЛЬСКИХ ТОВАРОВ И УСЛУГ в сентябре 2020 года}

\begin{tabular}{|c|c|c|c|c|}
\hline & \multicolumn{2}{|c|}{ Стоимость набора } & \multicolumn{2}{|c|}{ Изменение стоимости набора, в \% } \\
\hline & рублей & $\begin{array}{c}\text { в \% к } \\
\text { среднероссийской } \\
\text { стоимости }\end{array}$ & $\begin{array}{c}\text { к предылдущему } \\
\text { месячу }\end{array}$ & $\begin{array}{c}\kappa \text { декабрю } \\
2019 \text { г. }\end{array}$ \\
\hline Российская Федерация & 16767,8 & 100 & 99,8 & 103,4 \\
\hline Центральный федеральный округ & 19521,4 & 116 & 99,8 & 103,2 \\
\hline Белгородская область & 14759,2 & 88 & 100,0 & 103,6 \\
\hline Брянская область & 15369,3 & 92 & 99,4 & 102,8 \\
\hline Владимирская область & 16310,8 & 97 & 99,8 & 103,8 \\
\hline Воронежская область & 15243,7 & 91 & 99,8 & 103,1 \\
\hline Ивановская область & 15710,0 & 94 & 99,8 & 103,4 \\
\hline Калужская область & 16491,9 & 98 & 99,5 & 103,0 \\
\hline Костромская область & 15375,3 & 92 & 99,7 & 104,0 \\
\hline Курская область & 14709,2 & 88 & 99,4 & 103,2 \\
\hline Липецкая область & 14377,8 & 86 & 99,9 & 103,4 \\
\hline Московская область & 18307,2 & 109 & 99,6 & 103,3 \\
\hline Орловская область & 14344,5 & 86 & 99,6 & 102,9 \\
\hline Рязанская область & 15661,0 & 93 & 99,8 & 103,4 \\
\hline Смоленская область & 15676,6 & 93 & 99,6 & 103,3 \\
\hline Тамбовская область & 14502,9 & 86 & 99,8 & 102,8 \\
\hline Тверская область & 15711,5 & 94 & 99,6 & 102,8 \\
\hline Тульская область & 16231,1 & 97 & 100,3 & 104,6 \\
\hline Ярославская область & 16007,6 & 95 & 99,8 & 103,6 \\
\hline г. Москва & 23693,8 & 141 & 99,7 & 102,8 \\
\hline Северо-Западный федеральный округ & 17606,7 & 105 & 99,5 & 103,4 \\
\hline Республика Карелия & 17702,6 & 106 & 99,5 & 103,2 \\
\hline Республика Коми & 18134,5 & 108 & 99,7 & 104,4 \\
\hline Архангельская область & 18328,1 & 109 & 99,7 & 104,0 \\
\hline $\begin{array}{l}\text { в том числе: } \\
\text { Ненецкий авт. округ }\end{array}$ & 20923,0 & 125 & 100,0 & 101,8 \\
\hline Архангельская область без авт. округа & 18225,8 & 109 & 99,7 & 104,2 \\
\hline Вологодская область & 16581,7 & 99 & 99,5 & 103,7 \\
\hline Калининградская область & 17140,3 & 102 & 99,4 & 104,0 \\
\hline Ленинградская область & 17144,8 & 102 & 99,4 & 102,7 \\
\hline Мурманская область & 19600,7 & 117 & 99,7 & 102,8 \\
\hline Новгородская область & 15206,4 & 91 & 99,7 & 102,8 \\
\hline Псковская область & 15684,7 & 94 & 99,4 & 103,9 \\
\hline г. Санкт-Петербург & 18189,8 & 108 & 99,4 & 103,1 \\
\hline Южный федеральный округ & 15637,1 & 93 & 100,0 & 103,0 \\
\hline Республика Адыгея & 15107,4 & 90 & 100,3 & 103,4 \\
\hline Республика Калмыкия & 15752,5 & 94 & 100,3 & 102,6 \\
\hline Республика Крым & 15822,9 & 94 & 100,5 & 103,7 \\
\hline Краснодарский край & 17117,5 & 102 & 100,0 & 102,7 \\
\hline Астраханская область & 14779,5 & 88 & 100,2 & 102,7 \\
\hline Волгоградская область & 14949,6 & 89 & 100,1 & 103,3 \\
\hline Ростовская область & 16021,8 & 96 & 99,9 & 102,7 \\
\hline г. Севастополь & 16621,9 & 99 & 99,5 & 103,6 \\
\hline Северо-Кавказский федеральный округ & 15527,7 & 93 & 100,2 & 103,3 \\
\hline Республика Дагестан & 14972,7 & 89 & 100,2 & 103,3 \\
\hline Республика Ингушетия & 13857,0 & 83 & 100,0 & 103,1 \\
\hline Кабардино-Балкарская Республика & 15179,8 & 91 & 100,3 & 102,7 \\
\hline Карачаево-Черкесская Республика & 15070,4 & 90 & 100,0 & 103,3 \\
\hline Республика Северная Осетия - Алания & 14618,4 & 87 & 100,6 & 104,0 \\
\hline Чеченская Республика & 16009,0 & 95 & 100,1 & 102,4 \\
\hline Ставропольский край & 16476,4 & 98 & 100,2 & 103,9 \\
\hline
\end{tabular}




\begin{tabular}{|c|c|c|c|c|}
\hline & \multicolumn{2}{|c|}{ Стоимость набора } & \multicolumn{2}{|c|}{ "Изменение стоимости набора, в \% } \\
\hline & рублей & \begin{tabular}{|c|} 
в\% к \\
среднероссийской \\
стоимости
\end{tabular} & $\begin{array}{c}\text { к предьлдущему } \\
\text { месяиу }\end{array}$ & $\begin{array}{c}\kappa \text { декабрю } \\
2019 \text { г. }\end{array}$ \\
\hline Приволжский федеральный округ & 14926,4 & 89 & 99,8 & 103,9 \\
\hline Республика Башкортостан & 15410,8 & 92 & 100,2 & 104,1 \\
\hline Республика Марий Эл & 14831,9 & 88 & 99,5 & 103,9 \\
\hline Республика Мордовия & 14024,1 & 84 & 99,6 & 102,9 \\
\hline Республика Татарстан & 14415,9 & 86 & 99,6 & 103,5 \\
\hline Удмуртская Республика & 15188,8 & 91 & 99,7 & 103,7 \\
\hline Чувашская Республика & 14063,0 & 84 & 99,6 & 103,1 \\
\hline Пермский край & 15652,3 & 93 & 99,4 & 103,3 \\
\hline Кировская область & 15076,5 & 90 & 99,7 & 104,7 \\
\hline Нижегородская область & 16000,0 & 95 & 99,8 & 102,9 \\
\hline Оренбургская область & 14115,0 & 84 & 99,7 & 102,3 \\
\hline Пензенская область & 14598,3 & 87 & 99,7 & 103,1 \\
\hline Самарская область & 15648,6 & 93 & 100,0 & 104,6 \\
\hline Саратовская область & 13874,0 & 83 & 99,8 & 104,9 \\
\hline Ульяновская область & 15370,2 & 92 & 99,8 & 103,7 \\
\hline Уральский федеральный округ & 15813,2 & 94 & 99,6 & 103,3 \\
\hline Курганская область & 15275,4 & 91 & 100,1 & 103,1 \\
\hline Свердловская область & 15697,0 & 94 & 99,9 & 103,2 \\
\hline Тюменская область & 17951,7 & 107 & 99,5 & 103,1 \\
\hline $\begin{array}{l}\text { в том числе: } \\
\text { Ханты-Мансийский авт. округ - Югра }\end{array}$ & & & & \\
\hline Ханты-Мансийский авт. округ - Югра & 19451,5 & $\begin{array}{l}116 \\
117\end{array}$ & 99,9 & $\begin{array}{l}103,6 \\
1016\end{array}$ \\
\hline Ямало-Ненецкий авт. округ & 19667,3 & 117 & 99,5 & 101,6 \\
\hline Тюменская область без авт. округов & 15674,5 & 93 & 99,0 & 102,9 \\
\hline Челябинская область & 14243,4 & 85 & 99,4 & 103,6 \\
\hline Сибирский федеральный округ & 15455,7 & 92 & 99,8 & 103,4 \\
\hline Республика Алтай & 16949,7 & 101 & 100,0 & 104,0 \\
\hline Республика Тыва & 14812,7 & 88 & 99,8 & 104,1 \\
\hline Республика Хакасия & 15988,3 & 95 & 100,1 & 103,9 \\
\hline Алтайский край & 15182,2 & 91 & 98,9 & 103,7 \\
\hline Красноярский край & 16744,9 & 100 & 99,7 & 103,0 \\
\hline Иркутская область & 15609,9 & 93 & 99,7 & 103,1 \\
\hline Кемеровская область & 14412,8 & 86 & 100,8 & 103,0 \\
\hline Новосибирская область & 15994,3 & 95 & 99,3 & 104,1 \\
\hline Омская область & 14684,9 & 88 & 99,6 & 103,5 \\
\hline Томская область & 16266,4 & 97 & 99,8 & 103,5 \\
\hline Дальневосточный федеральный округ & 19143,2 & 114 & 99,9 & 103,7 \\
\hline Республика Бурятия & 16212,1 & 97 & 100,1 & 104,7 \\
\hline Республика Саха (Якутия) & 21074,4 & 126 & 100,4 & 103,2 \\
\hline Забайкальский край & 16063,9 & 96 & 99,0 & 104,0 \\
\hline Камчатский край & 26063,2 & 155 & 100,0 & 102,2 \\
\hline Приморский край & 18976,3 & 113 & 100,0 & 102,6 \\
\hline Хабаровский край & 19746,2 & 118 & 99,9 & 103,5 \\
\hline Амурская область & 17759,8 & 106 & 100,0 & 106,3 \\
\hline Магаданская область & 23576,1 & 141 & 99,6 & 103,6 \\
\hline Сахалинская область & 20298,8 & 121 & 99,8 & 104,8 \\
\hline Еврейская авт. область & 19322,4 & 115 & 100,1 & 104,3 \\
\hline Чукотский авт. округ & 28260,7 & 169 & 99,8 & 103,6 \\
\hline
\end{tabular}


ИНДЕКСЫ ЦЕН НА ПЕРВИЧНОМ И ВТОРИЧНОМ РЫНКАХ ЖИЛЬЯ

в ІІІ квартале 2020 года

на конец квартала, в процентах

\begin{tabular}{|c|c|c|c|c|}
\hline & \multicolumn{2}{|c|}{ Первичный рынок } & \multicolumn{2}{|c|}{ Вторичный рынок } \\
\hline & $\begin{array}{c}\text { ко II кварталу } \\
2020 \text { z. }\end{array}$ & $\begin{array}{c}\text { к IV кварталу } \\
2019 \text { 2. }\end{array}$ & $\begin{array}{c}\text { ко II кварталу } \\
2020 \text { z. }\end{array}$ & $\begin{array}{c}\text { к IV кварталу } \\
2019 \text { z. }\end{array}$ \\
\hline Российская Федерация & 103,7 & 108,0 & 103,2 & 104,9 \\
\hline Центральный федеральный округ & 104,7 & 107,2 & 106,4 & 108,0 \\
\hline Белгородская область & 102,2 & 103,5 & 104,9 & 104,9 \\
\hline Брянская область & 103,2 & 108,3 & 101,6 & 100,4 \\
\hline Владимирская область & 102,5 & 111,4 & 102,1 & 102,9 \\
\hline Воронежская область & 107,1 & 111,7 & 100,5 & 102,4 \\
\hline Ивановская область & 102,0 & 104,9 & 101,2 & 100,4 \\
\hline Калужская область & 103,7 & 112,9 & 96,5 & 96,6 \\
\hline Костромская область & 103,1 & 108,3 & 100,6 & 105,3 \\
\hline Курская область & 105,3 & 110,9 & 102,4 & 107,8 \\
\hline Липецкая область & 102,2 & 104,8 & 101,0 & 102,9 \\
\hline Московская область & 102,5 & 108,6 & 100,4 & 102,2 \\
\hline Орловская область & 105,1 & 114,8 & 101,2 & 95,5 \\
\hline Рязанская область & 106,4 & 116,2 & 106,6 & 104,6 \\
\hline Смоленская область & 102,0 & 105,9 & 105,3 & 105,2 \\
\hline Тамбовская область & 104,1 & 107,0 & 100,0 & 113,8 \\
\hline Тверская область & 101,2 & 103,6 & 101,2 & 101,4 \\
\hline Тульская область & 103,9 & 118,5 & 99,3 & 101,6 \\
\hline Ярославская область & 100,6 & 100,7 & 101,2 & 99,7 \\
\hline г. Москва & 105,4 & 104,0 & 110,2 & 112,2 \\
\hline Северо-Западный федеральный округ & 103,8 & 108,5 & 102,9 & 104,6 \\
\hline Республика Карелия & 102,0 & 103,6 & 104,1 & 105,7 \\
\hline Республика Коми & 105,2 & 105,6 & 100,8 & 102,4 \\
\hline Архангельская область & 103,1 & 105,8 & 99,2 & 101,1 \\
\hline $\begin{array}{l}\text { в том числе: } \\
\text { Ненецкий авт. округ }\end{array}$ & $\ldots$ & $\ldots$ & 99,9 & 93,1 \\
\hline Архангельская область без авт. округа & 103,1 & 105,8 & 99,2 & 101,1 \\
\hline Вологодская область & 102,5 & 108,2 & 101,5 & 102,8 \\
\hline Калининградская область & 103,1 & 107,8 & 100,3 & 102,4 \\
\hline Ленинградская область & 101,2 & 104,3 & 100,7 & 100,9 \\
\hline Мурманская область & $\ldots$ & $\ldots$ & 103,4 & 102,9 \\
\hline Новгородская область & 109,0 & 112,3 & 101,8 & 102,1 \\
\hline Псковская область & 100,8 & 101,8 & 103,5 & 104,6 \\
\hline г. Санкт-Петербург & 103,9 & 108,8 & 103,9 & 106,0 \\
\hline Южный федеральный округ & 104,0 & 110,6 & 101,0 & 101,6 \\
\hline Республика Адыгея & 108,7 & 115,4 & 106,9 & 100,0 \\
\hline Республика Калмыкия & 99,6 & 105,0 & 102,6 & 101,6 \\
\hline Республика Крым & 106,8 & 111,4 & 101,0 & 106,9 \\
\hline Краснодарский край & 103,8 & 113,3 & 100,5 & 100,9 \\
\hline Астраханская область & 103,1 & 109,6 & 101,8 & 101,1 \\
\hline Волгоградская область & 104,8 & 108,0 & 101,4 & 101,9 \\
\hline Ростовская область & 103,6 & 106,2 & 101,4 & 102,2 \\
\hline г. Севастополь & 103,0 & 108,0 & 99,4 & 98,5 \\
\hline Северо-Кавказский федеральный округ & 102,8 & 109,2 & 103,1 & 111,1 \\
\hline Республика Дагестан & 100,2 & 100,6 & 99,8 & 100,4 \\
\hline Республика Ингушетия & 100,5 & 99,5 & 100,3 & 100,2 \\
\hline Кабардино-Балкарская Республика & 106,4 & 109,3 & 102,6 & 102,6 \\
\hline Карачаево-Черкесская Республика & 103,3 & 105,3 & 97,6 & 98,9 \\
\hline Республика Северная Осетия - Алания & 103,5 & 131,0 & 106,2 & 124,3 \\
\hline Чеченская Республика & 101,6 & 101,8 & 100,5 & 100,8 \\
\hline Ставропольский край & 103,5 & 106,0 & 100,7 & 100,4 \\
\hline
\end{tabular}




\begin{tabular}{|c|c|c|c|c|}
\hline & \multicolumn{2}{|c|}{ ППервичныій рынок } & \multicolumn{2}{|c|}{ Вторичный рынок } \\
\hline & $\begin{array}{c}\text { ко II кварталу } \\
2020 \text { г. } \\
\end{array}$ & $\begin{array}{c}\text { кIV кварталу } \\
2019 \text { г. }\end{array}$ & $\begin{array}{c}\text { ко II кварталу } \\
2020 \text { z. }\end{array}$ & $\begin{array}{c}\text { кIV кварталу } \\
2019 \text { г. }\end{array}$ \\
\hline Приволжский федеральный округ & 102,0 & 104,7 & 102,2 & 104,5 \\
\hline Республика Башкортостан & 100,9 & 103,4 & 101,7 & 101,6 \\
\hline Республика Марий Эл & 102,0 & 103,2 & 100,9 & 102,7 \\
\hline Республика Мордовия & 99,9 & 100,0 & 102,6 & 101,7 \\
\hline Республика Татарстан & 102,7 & 106,2 & 102,3 & 104,0 \\
\hline Удмуртская Республика & 100,6 & 104,0 & 101,1 & 103,3 \\
\hline Чувашская Республика & 100,6 & 101,5 & 101,7 & 103,2 \\
\hline Пермский край & 101,6 & 102,2 & 107,5 & 111,4 \\
\hline Кировская область & 102,5 & 106,3 & 101,7 & 102,4 \\
\hline Нижегородская область & 104,8 & 109,6 & 102,1 & 104,3 \\
\hline Оренбургская область & 100,3 & 103,1 & 100,6 & 102,6 \\
\hline Пензенская область & 104,7 & 109,4 & 103,1 & 106,7 \\
\hline Самарская область & 100,6 & 102,0 & 103,9 & 106,0 \\
\hline Саратовская область & 103,5 & 107,4 & 102,8 & 108,9 \\
\hline Ульяновская область & 103,5 & 106,4 & 101,9 & 104,3 \\
\hline Уральский федеральный округ & 104,1 & 107,6 & 102,6 & 102,8 \\
\hline Курганская область & 97,9 & 103,8 & 98,4 & 103,2 \\
\hline Свердловская область & 103,9 & 107,5 & 102,5 & 102,2 \\
\hline Тюменская область & 106,0 & 109,6 & 103,6 & 104,7 \\
\hline $\begin{array}{l}\text { в том числе: } \\
\text { Ханты-Мансийский авт. округ - Югра }\end{array}$ & 99,4 & 114,0 & 103,5 & 107,8 \\
\hline Ямало-Ненецкий авт. округ & 100,0 & 100,0 & 106,9 & 101,1 \\
\hline Тюменская область без авт. округов & 107,4 & 109,2 & 103,6 & 103,1 \\
\hline Челябинская область & 99,7 & 102,1 & 95,9 & 100,3 \\
\hline Сибирский федеральный округ & 102,4 & 107,4 & 103,0 & 104,4 \\
\hline Республика Алтай & 100,0 & 104,9 & 106,2 & 109,8 \\
\hline Республика Тыва & $\ldots$ & $\ldots$ & 100,0 & 101,0 \\
\hline Республика Хакасия & 102,1 & 104,9 & 104,6 & 105,0 \\
\hline Алтайский край & 102,2 & 104,6 & 107,2 & 106,4 \\
\hline Красноярский край & 103,9 & 107,2 & 102,5 & 104,2 \\
\hline Иркутская область & 102,0 & 118,9 & 102,4 & 104,0 \\
\hline Кемеровская область & 100,9 & 107,0 & 101,8 & 102,1 \\
\hline Новосибирская область & 99,9 & 104,7 & 99,8 & 102,4 \\
\hline Омская область & 106,8 & 105,6 & 103,8 & 104,1 \\
\hline Томская область & 101,7 & 105,6 & 106,5 & 108,0 \\
\hline Дальневосточный федеральный округ & 103,4 & 114,3 & 103,7 & 106,4 \\
\hline Республика Бурятия & 106,0 & 124,1 & 101,2 & 109,1 \\
\hline Республика Саха (Якутия) & 105,3 & 106,8 & 99,7 & 100,4 \\
\hline Забайкальский край & 98,1 & 111,7 & 108,3 & 113,0 \\
\hline Камчатский край & 100,0 & 102,0 & 106,4 & 108,4 \\
\hline Приморский край & 101,6 & 112,8 & 102,1 & 105,7 \\
\hline Хабаровский край & 105,2 & 123,1 & 104,7 & 103,4 \\
\hline Амурская область & 105,6 & 119,6 & 106,8 & 115,2 \\
\hline Магаданская область & 100,8 & 100,8 & 104,0 & 103,9 \\
\hline Сахалинская область & 106,8 & 108,4 & 104,0 & 110,5 \\
\hline Еврейская авт. область & 98,8 & 95,0 & 100,8 & 102,4 \\
\hline Чукотский авт. округ & $\ldots$ & $\ldots$ & $\ldots$ & $\ldots$ \\
\hline
\end{tabular}


ИНДЕКСЫ ЦЕН (ТАРИФОВ) ПРОИЗВОДИТЕЛЕЙ

в сентябре 2020 года

в процентах

\begin{tabular}{|c|c|c|c|c|c|c|c|c|}
\hline & \multicolumn{4}{|c|}{ К К предьгуциему месяиу } & \multicolumn{4}{|c|}{ К К декабрю 2019 г. } \\
\hline & $\begin{array}{l}\text { промьиш- } \\
\text { ленныхх } \\
\text { товаров }\end{array}$ & \begin{tabular}{|c|} 
на реали- \\
зованную \\
сельско- \\
хозяйст- \\
венную \\
продук- \\
цию
\end{tabular} & \begin{tabular}{|c|} 
сводный \\
индекс \\
иен на про- \\
дукцию \\
(затраты, \\
услуги) $и н-$ \\
вестици- \\
онного наз- \\
начения \\
\end{tabular} & \begin{tabular}{|} 
тарифыл \\
на гру- \\
зовьер пе- \\
ревозки
\end{tabular} & $\begin{array}{c}\text { промыиш- } \\
\text { ленныхх } \\
\text { товаров }\end{array}$ & $\begin{array}{c}\text { на реали- } \\
\text { зованную } \\
\text { сельско- } \\
\text { хозяйст- } \\
\text { венную } \\
\text { продук- } \\
\text { цию }\end{array}$ & \begin{tabular}{|c|} 
сводный \\
индекс \\
иен на про- \\
дукцию \\
(затратьи, \\
услуги) ин- \\
вестици- \\
онного наз- \\
начения \\
\end{tabular} & \begin{tabular}{|} 
тарифыл \\
на гру- \\
зовье пе- \\
ревозки
\end{tabular} \\
\hline Российская Федерация & 100,6 & 100,5 & 100,6 & 100,1 & 100,7 & 102,6 & 104,6 & 103,5 \\
\hline $\begin{array}{l}\text { Центральный } \\
\text { федеральный округ }\end{array}$ & 100,4 & 100,3 & 100,6 & 100,1 & 102,9 & 105,3 & 104,8 & 104,8 \\
\hline Белгородская область & 103,8 & 98,4 & 100,7 & 100,0 & 116,1 & 107,1 & 106,9 & 99,5 \\
\hline Брянская область & 100,8 & 101,1 & 101,2 & 100,0 & 103,7 & 105,2 & 106,4 & 103,4 \\
\hline Владимирская область & 98,9 & 98,9 & 100,1 & 100,2 & 100,9 & 95,9 & 101,9 & 102,4 \\
\hline Воронежская область & 100,8 & 101,8 & 100,7 & 100,2 & 109,7 & 106,3 & 103,4 & 103,7 \\
\hline Ивановская область & 101,8 & 102,4 & 100,7 & 100,0 & 105,5 & 101,0 & 105,7 & 100,5 \\
\hline Калужская область & 99,7 & 101,3 & 100,9 & 100,0 & 101,1 & 88,9 & 105,5 & 100,3 \\
\hline Костромская область & 100,5 & 102,4 & 100,2 & 100,0 & 106,7 & 96,4 & 104,8 & 101,1 \\
\hline Курская область & 102,5 & 102,6 & 100,9 & 100,0 & 116,2 & 110,3 & 107,8 & 102,9 \\
\hline Липецкая область & 102,6 & 100,2 & 100,7 & 100,3 & 112,9 & 103,0 & 106,7 & 102,8 \\
\hline Московская область & 100,5 & 97,4 & 100,7 & 100,0 & 102,8 & 100,1 & 104,4 & 100,0 \\
\hline Орловская область & 101,7 & 100,7 & 100,7 & 100,0 & 110,8 & 109,1 & 107,1 & 102,6 \\
\hline Рязанская область & 100,7 & 99,9 & 100,6 & 100,0 & 100,0 & 102,6 & 104,4 & 100,2 \\
\hline Смоленская область & 101,2 & 99,5 & 100,8 & 100,9 & 104,8 & 119,1 & 108,4 & 107,8 \\
\hline Тамбовская область & 101,1 & 99,9 & 100,7 & 100,0 & 111,3 & 105,5 & 106,0 & 103,0 \\
\hline Тверская область & 100,0 & 99,5 & 100,5 & 100,0 & 106,8 & 106,6 & 105,8 & 101,0 \\
\hline Тульская область & 100,0 & 104,9 & 100,6 & 100,0 & 102,7 & 109,4 & 106,1 & 98,1 \\
\hline Ярославская область & 100,0 & 100,6 & 100,6 & 100,0 & 102,9 & 91,5 & 105,2 & 103,3 \\
\hline г. Москва & 99,8 & 111,1 & 100,9 & 100,0 & 100,3 & 92,4 & 104,6 & 106,2 \\
\hline $\begin{array}{l}\text { Северо-Западный } \\
\text { федеральный округ }\end{array}$ & 101,0 & 98,9 & 100,6 & 100,0 & 105,4 & 101,4 & 105,9 & 101,2 \\
\hline Республика Карелия & 109,4 & 99,6 & 100,7 & 100,3 & 123,0 & 100,4 & 106,5 & 102,6 \\
\hline Республика Коми & 100,5 & 100,6 & 100,3 & 100,0 & 97,9 & 101,5 & 103,2 & 103,4 \\
\hline Архангельская область & 99,6 & 99,5 & 100,7 & 101,5 & 103,3 & 102,0 & 109,2 & 102,1 \\
\hline $\begin{array}{l}\text { в том числе: } \\
\text { Ненецкий авт. округ }\end{array}$ & 99,5 & 100,3 & 100,4 & 100,0 & 107,2 & 102,7 & 110,0 & 103,1 \\
\hline $\begin{array}{l}\text { Архангельская область } \\
\text { без авт. округа }\end{array}$ & 99,7 & 99,4 & 100,8 & 101,6 & 101,4 & 101,8 & 107,1 & 102,0 \\
\hline Вологодская область & 102,8 & 100,8 & 100,3 & 100,0 & 107,4 & 101,5 & 106,3 & 105,7 \\
\hline Калининградская область & 99,2 & 98,6 & 101,0 & 100,0 & 106,9 & 98,3 & 106,4 & 102,6 \\
\hline Ленинградская область & 100,3 & 98,6 & 100,3 & 100,0 & 103,6 & 87,5 & 103,0 & 103,3 \\
\hline Мурманская область & 103,5 & 100,1 & 100,6 & 100,7 & 112,6 & 97,9 & 107,7 & 108,4 \\
\hline Новгородская область & 100,3 & 100,4 & 100,4 & 100,9 & 103,2 & 100,5 & 102,8 & 110,8 \\
\hline Псковская область & 99,0 & 96,8 & 100,2 & 101,7 & 107,3 & 109,7 & 104,1 & 107,8 \\
\hline г. Санкт-Петербург & 100,4 & - & 100,8 & 100,0 & 104,4 & - & 107,4 & 99,6 \\
\hline $\begin{array}{l}\text { Южный } \\
\text { федеральный округ }\end{array}$ & 101,1 & 100,7 & 100,4 & 100,9 & 102,7 & 105,3 & 105,0 & 110,6 \\
\hline Республика Адыгея & 101,7 & 98,9 & 100,5 & 100,0 & 103,8 & 102,4 & 104,7 & 100,0 \\
\hline Республика Калмыкия & 98,7 & 100,5 & 99,8 & 100,0 & 91,5 & 101,8 & 102,4 & 102,1 \\
\hline Республика Крым & 100,3 & 102,8 & 99,7 & 100,0 & 106,2 & 99,0 & 111,1 & 100,9 \\
\hline Краснодарский край & 101,7 & 100,8 & 100,4 & 101,6 & 104,1 & 106,7 & 103,9 & 120,0 \\
\hline Астраханская область & 108,8 & 91,9 & 103,5 & 101,2 & 110,9 & 79,5 & 111,0 & 106,3 \\
\hline Волгоградская область & 99,3 & 100,0 & 100,5 & 100,0 & 96,7 & 101,0 & 104,3 & 94,5 \\
\hline Ростовская область & 100,5 & 100,7 & 100,2 & 100,1 & 103,4 & 106,4 & 106,0 & 103,4 \\
\hline г. Севастополь & 99,8 & 99,7 & 100,6 & 100,0 & 104,6 & 111,7 & 106,5 & 100,0 \\
\hline $\begin{array}{l}\text { Северо-Кавказский } \\
\text { федеральный округ }\end{array}$ & 100,9 & 101,2 & 100,4 & 100,0 & 101,6 & 100,8 & 106,2 & 86,4 \\
\hline Республика Дагестан & 100,6 & 101,1 & 100,6 & 100,0 & 99,2 & 102,9 & 106,0 & 77,5 \\
\hline Республика Ингушетия & 102,5 & 103,1 & 101,2 & - & 101,4 & 106,2 & 103,5 & - \\
\hline $\begin{array}{l}\text { Кабардино-Балкарская } \\
\text { Республика }\end{array}$ & 100,0 & 99,7 & 99,6 & 100,0 & 101,3 & 112,7 & 110,5 & 100,0 \\
\hline $\begin{array}{l}\text { Карачаево-Черкесская } \\
\text { Республика }\end{array}$ & 99,7 & 97,0 & 100,6 & 100,0 & 105,2 & 76,9 & 105,4 & 101,9 \\
\hline $\begin{array}{l}\text { Республика Северная } \\
\text { Осетия - Алания }\end{array}$ & 100,0 & 101,8 & 99,3 & 100,0 & 98,4 & 108,2 & 104,8 & 100,0 \\
\hline Чеченская Республика & 100,2 & 97,7 & 100,5 & 100,0 & 102,1 & 86,0 & 101,0 & 102,0 \\
\hline Ставропольский край & 101,3 & 101,5 & 100,7 & 100,0 & 101,9 & 101,9 & 107,0 & 85,4 \\
\hline
\end{tabular}




\begin{tabular}{|c|c|c|c|c|c|c|c|c|}
\hline & \multicolumn{4}{|c|}{ "К предылущтему месяиу } & \multicolumn{4}{|c|}{ "К декабрю 2019 г. } \\
\hline & \begin{tabular}{|l|} 
промыиш- \\
ленньхх \\
товаров
\end{tabular} & \begin{tabular}{|c|} 
на реали- \\
зованную \\
сельско- \\
хозяйст- \\
венную \\
продук- \\
иию
\end{tabular} & \begin{tabular}{|c|} 
сводньий \\
индекс \\
цен на про- \\
дукиию \\
(затратьи, \\
услуги) ин- \\
вестици- \\
онного наз- \\
начения \\
\end{tabular} & $\begin{array}{l}\text { тарифыл } \\
\text { на гру- } \\
\text { зовые пе- } \\
\text { ревозки }\end{array}$ & \begin{tabular}{|l|} 
промыли- \\
ленныхх \\
товаров
\end{tabular} & $\begin{array}{c}\text { на реали- } \\
\text { зованную } \\
\text { сельско- } \\
\text { хозяйст- } \\
\text { венную } \\
\text { продук- } \\
\text { иию }\end{array}$ & $\begin{array}{c}\text { сводньй } \\
\text { индекс } \\
\text { иен на про- } \\
\text { дукиию } \\
\text { (затраты, } \\
\text { услуги) ин- } \\
\text { вестици- } \\
\text { онного наз- } \\
\text { начения }\end{array}$ & $\begin{array}{l}\text { тарифыл } \\
\text { на гру- } \\
\text { зовье пе- } \\
\text { ревозки }\end{array}$ \\
\hline $\begin{array}{l}\text { Приволжский } \\
\text { федеральный округ }\end{array}$ & 100,5 & 100,1 & 100,6 & 100,0 & 101,1 & 99,8 & 105,1 & 105,0 \\
\hline Республика Башкортостан & 99,5 & 100,3 & 99,6 & 100,0 & 103,8 & 103,9 & 106,8 & 101,8 \\
\hline Республика Марий Эл & 100,0 & 96,3 & 100,4 & 100,0 & 100,6 & 92,9 & 105,7 & 100,2 \\
\hline Республика Мордовия & 100,7 & 100,8 & 100,4 & 100,0 & 102,8 & 96,8 & 105,5 & 113,0 \\
\hline Республика Татарстан & 101,3 & 100,4 & 100,1 & 100,0 & 100,4 & 96,5 & 103,2 & 109,2 \\
\hline Удмуртская Республика & 100,4 & 100,7 & 101,4 & 100,0 & 99,6 & 99,4 & 106,5 & 100,0 \\
\hline Чувашская Республика & 100,1 & 103,5 & 100,3 & 100,0 & 102,5 & 96,5 & 104,0 & 101,2 \\
\hline Пермский край & 101,2 & 100,5 & 100,6 & 100,0 & 96,3 & 88,1 & 106,2 & 117,2 \\
\hline Кировская область & 99,8 & 100,5 & 100,7 & 100,0 & 102,9 & 98,9 & 105,4 & 100,1 \\
\hline Нижегородская область & 100,3 & 98,2 & 100,2 & 100,0 & 103,4 & 98,1 & 106,3 & 102,7 \\
\hline Оренбургская область & 101,3 & 99,9 & 100,4 & 100,0 & 98,3 & 106,2 & 105,5 & 100,2 \\
\hline Пензенская область & 99,6 & 100,0 & 100,0 & 100,0 & 109,2 & 102,3 & 106,0 & 101,3 \\
\hline Самарская область & 100,4 & 102,2 & 100,4 & 100,0 & 99,8 & 105,3 & 106,4 & 101,7 \\
\hline Саратовская область & 100,1 & 100,7 & 101,0 & 100,0 & 104,7 & 103,8 & 108,4 & 103,6 \\
\hline Ульяновская область & 100,1 & 100,1 & 100,2 & 99,9 & 104,3 & 107,3 & 105,2 & 100,7 \\
\hline $\begin{array}{l}\text { Уральский } \\
\text { федеральный округ }\end{array}$ & 100,0 & 101,1 & 100,2 & 100,0 & 93,9 & 100,1 & 102,9 & $\mathbf{9 7 , 3}$ \\
\hline Курганская область & 100,6 & 100,3 & 100,6 & 100,0 & 101,2 & 105,5 & 106,7 & 102,4 \\
\hline Свердловская область & 101,0 & 101,0 & 100,5 & 100,0 & 104,2 & 94,4 & 105,9 & 100,9 \\
\hline Тюменская область & 99,5 & 100,4 & 99,9 & 100,0 & 88,7 & 93,7 & 106,6 & 94,5 \\
\hline $\begin{array}{l}\text { в том числе: } \\
\text { Ханты-Мансийский } \\
\text { авт. округ - Югра }\end{array}$ & 97,4 & 101,6 & 99,5 & 100,0 & 83,8 & 117,8 & 109,7 & 91,6 \\
\hline Ямало-Ненецкий авт. округ & 100,3 & 100,0 & 99,9 & 100,0 & 95,8 & 110,3 & 101,7 & 103,1 \\
\hline $\begin{array}{l}\text { Тюменская область } \\
\text { без авт. округов }\end{array}$ & 107,9 & 100,4 & 100,6 & 100,0 & 142,1 & 93,4 & 104,9 & 103,4 \\
\hline Челябинская область & 100,4 & 101,6 & 100,5 & 100,0 & 103,5 & 108,3 & 104,8 & 103,3 \\
\hline $\begin{array}{l}\text { Сибирский } \\
\text { федеральный округ }\end{array}$ & 101,0 & 101,6 & 100,5 & 100,1 & $\mathbf{9 9 , 8}$ & $\mathbf{9 7 , 9}$ & 104,9 & 109,5 \\
\hline Республика Алтай & 99,9 & 100,6 & 100,5 & 97,9 & 107,1 & 99,1 & 103,1 & 100,0 \\
\hline Республика Тыва & 99,5 & 100,1 & 100,5 & 100,0 & 128,0 & 102,4 & 104,8 & 101,2 \\
\hline Республика Хакасия & 100,9 & 100,4 & 100,8 & 100,0 & 107,7 & 99,2 & 107,9 & 101,2 \\
\hline Алтайский край & 100,5 & 102,8 & 100,4 & 100,0 & 105,3 & 101,5 & 105,2 & 100,6 \\
\hline Красноярский край & 103,0 & 99,6 & 100,5 & 100,0 & 101,3 & 98,7 & 105,1 & 103,1 \\
\hline Иркутская область & 101,4 & 100,4 & 100,5 & 100,0 & 98,7 & 97,1 & 103,4 & 103,4 \\
\hline Кемеровская область & 100,2 & 102,3 & 100,7 & 100,0 & 93,9 & 97,6 & 106,9 & 100,2 \\
\hline Новосибирская область & 100,1 & 102,9 & 100,7 & 100,2 & 103,3 & 92,9 & 105,4 & 104,0 \\
\hline Омская область & 98,7 & 100,1 & 100,6 & 100,0 & 99,4 & 100,1 & 107,2 & 103,1 \\
\hline Томская область & 100,4 & 101,2 & 100,7 & 100,0 & 94,1 & 106,0 & 105,4 & 151,0 \\
\hline $\begin{array}{l}\text { Дальневосточный } \\
\text { федеральный округ }\end{array}$ & 101,0 & 100,2 & 100,5 & 100,1 & 107,8 & 100,2 & 105,0 & 103,6 \\
\hline Республика Бурятия & 100,6 & 98,7 & 100,0 & 100,0 & 105,2 & 98,2 & 102,7 & 94,6 \\
\hline Республика Саха (Якутия) & 102,3 & 100,1 & 99,8 & 100,1 & 110,3 & 96,3 & 101,2 & 101,4 \\
\hline Забайкальский край & 99,5 & 100,0 & 100,4 & 100,0 & 103,7 & 104,3 & 106,6 & 103,5 \\
\hline Камчатский край & 103,2 & 99,2 & 100,6 & 100,0 & 104,5 & 99,4 & 105,7 & 101,2 \\
\hline Приморский край & 100,2 & 101,2 & 101,1 & 100,6 & 105,3 & 101,4 & 111,8 & 105,7 \\
\hline Хабаровский край & 99,6 & 100,8 & 100,7 & 100,0 & 101,7 & 85,2 & 104,2 & 103,5 \\
\hline Амурская область & 103,2 & 100,0 & 100,6 & 100,0 & 129,1 & 104,9 & 106,8 & 100,8 \\
\hline Магаданская область & 100,2 & 101,2 & 100,8 & 100,0 & 106,2 & 105,6 & 106,6 & 115,9 \\
\hline Сахалинская область & 100,4 & 99,8 & 100,4 & 101,0 & 99,9 & 93,1 & 104,3 & 107,7 \\
\hline Еврейская авт. область & 100,8 & 100,0 & 100,4 & 100,0 & 111,3 & 100,0 & 104,9 & 103,0 \\
\hline Чукотский авт. округ & 100,0 & 98,5 & - & 100,0 & 115,6 & 96,2 & - & 107,6 \\
\hline
\end{tabular}




\section{V \\ ФИНАНСЫ}

\section{ГОСУДАРСТВЕННЫЕ ФИНАНСЫ}

ПОСТУПЛЕНИЕ НАЛОГОВ, СБОРОВ И ИНЫХ ОБЯЗАТЕЛЬНЫХ ПЛАТЕЖЕЙ
В КОНСОЛИДИРОВАННЫЙ БЮДЖЕТ РОССИЙСКОЙ ФЕДЕРАЦИИ

(по данным Федеральной налоговой службы) в январе-августе 2020 года

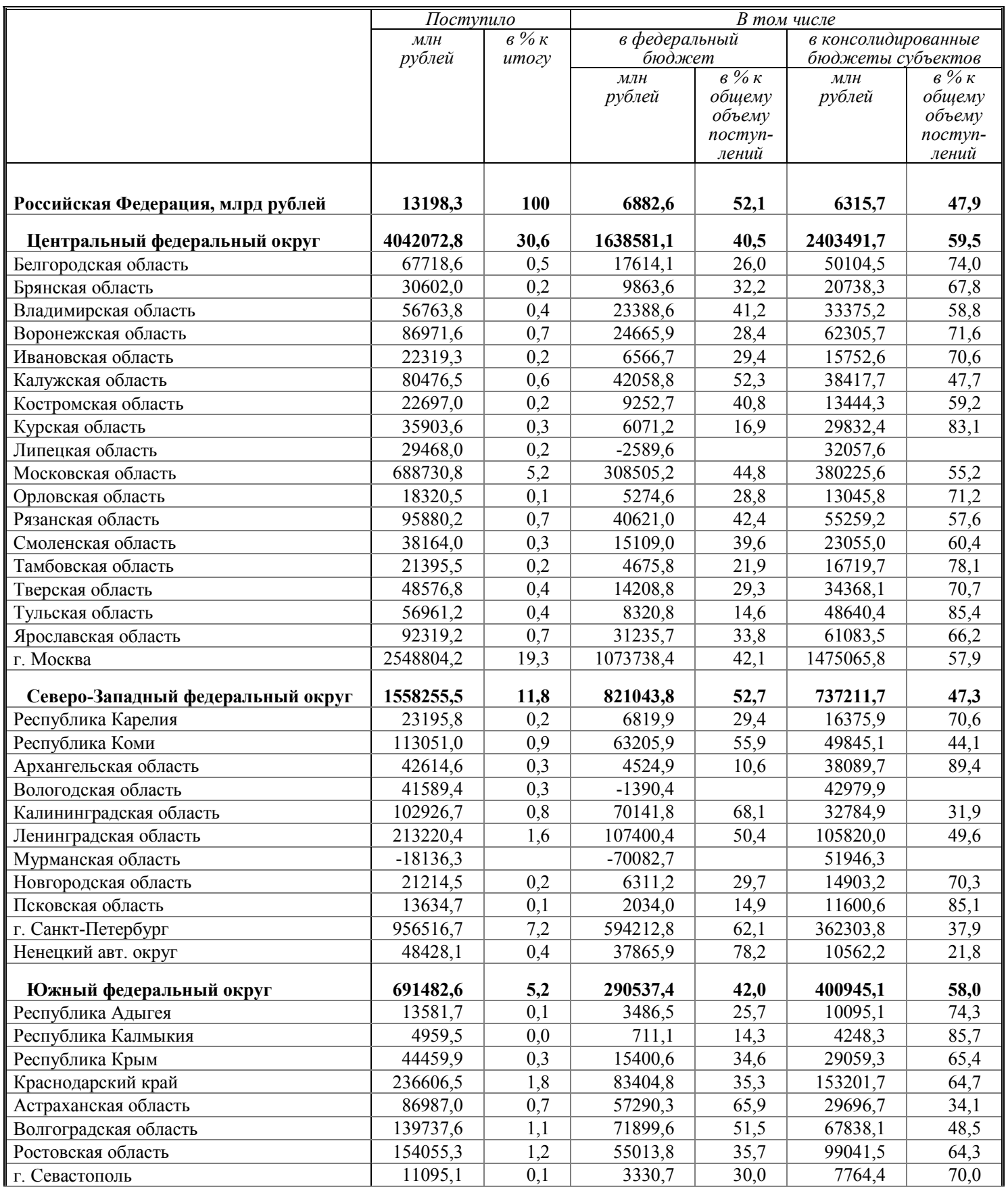




\begin{tabular}{|c|c|c|c|c|c|c|}
\hline & \multicolumn{2}{|c|}{ ППоступило } & \multicolumn{4}{|c|}{ В том числе } \\
\hline & \multirow[t]{2}{*}{$\begin{array}{c}\text { млн } \\
\text { рублей }\end{array}$} & \multirow[t]{2}{*}{$\begin{array}{l}\text { в\% \% } \\
\text { итогу }\end{array}$} & \multicolumn{2}{|c|}{$\begin{array}{l}\text { в федеральный } \\
\text { бюджет }\end{array}$} & \multicolumn{2}{|c|}{$\begin{array}{l}\text { в консолидированнье } \\
\text { бюджеть субъектов }\end{array}$} \\
\hline & & & $\begin{array}{c}\text { млн } \\
\text { рублей }\end{array}$ & $\begin{array}{c}\text { в\% к } \\
\text { общему } \\
\text { объему } \\
\text { поступ- } \\
\text { лений }\end{array}$ & $\begin{array}{c}\text { млн } \\
\text { рублей }\end{array}$ & $\begin{array}{c}\text { в\%к } \\
\text { общему } \\
\text { объему } \\
\text { поступ- } \\
\text { лений }\end{array}$ \\
\hline Северо-Кавказский федеральный округ & 138601,8 & 1,1 & 42073,7 & 30,4 & 96528,1 & 69,6 \\
\hline Республика Дагестан & 26391,5 & 0,2 & 7252,1 & 27,5 & 19139,4 & 72,5 \\
\hline Республика Ингушетия & 2928,4 & 0,0 & 586,5 & 20,0 & 2341,8 & 80,0 \\
\hline Кабардино-Балкарская Республика & 10044,1 & 0,1 & 2389,3 & 23,8 & 7654,8 & 76,2 \\
\hline Карачаево-Черкесская Республика & 6295,5 & 0,0 & 1874,6 & 29,8 & 4420,9 & 70,2 \\
\hline Республика Северная Осетия - Алания & 10355,4 & 0,1 & 1913,8 & 18,5 & 8441,6 & 81,5 \\
\hline Чеченская Республика & 10726,5 & 0,1 & 1416,7 & 13,2 & 9309,8 & 86,8 \\
\hline Ставропольский край & 71860,3 & 0,5 & 26640,6 & 37,1 & 45219,7 & 62,9 \\
\hline Приволжский федеральный округ & 1982158,3 & 15,0 & 1107184,1 & $\mathbf{5 5 , 9}$ & 874974,2 & 44,1 \\
\hline Республика Башкортостан & 237615,8 & 1,8 & 126352,0 & 53,2 & 111263,8 & 46,8 \\
\hline Республика Марий Эл & 15235,6 & 0,1 & 5524,7 & 36,3 & 9710,9 & 63,7 \\
\hline Республика Мордовия & 23993,1 & 0,2 & 7005,9 & 29,2 & 16987,2 & 70,8 \\
\hline Республика Татарстан & 416592,5 & 3,2 & 261346,3 & 62,7 & 155246,2 & 37,3 \\
\hline Удмуртская Республика & 111175,8 & 0,8 & 76136,4 & 68,5 & 35039,4 & 31,5 \\
\hline Чувашская Республика & 35776,7 & 0,3 & 13960,0 & 39,0 & 21816,7 & 61,0 \\
\hline Пермский край & 229905,3 & 1,7 & 136832,8 & 59,5 & 93072,5 & 40,5 \\
\hline Кировская область & 29273,2 & 0,2 & 7052,6 & 24,1 & 22220,6 & 75,9 \\
\hline Нижегородская область & 204891,2 & 1,6 & 77751,2 & 37,9 & 127140,0 & 62,1 \\
\hline Оренбургская область & 193756,5 & 1,5 & 146477,6 & 75,6 & 47278,9 & 24,4 \\
\hline Пензенская область & 36837,8 & 0,3 & 12117,4 & 32,9 & 24720,4 & 67,1 \\
\hline Самарская область & 299957,2 & 2,3 & 176143,9 & 58,7 & 123813,3 & 41,3 \\
\hline Саратовская область & 95673,5 & 0,7 & 43250,9 & 45,2 & 52422,5 & 54,8 \\
\hline Ульяновская область & 51474,2 & 0,4 & 17232,5 & 33,5 & 34241,7 & 66,5 \\
\hline Уральский федеральный округ & 2934695,7 & 22,2 & 2234928,3 & 76,2 & 699767,5 & 23,8 \\
\hline Курганская область & 20326,2 & 0,2 & 7349,4 & 36,2 & 12976,7 & 63,8 \\
\hline Свердловская область & 239199,1 & 1,8 & 84355,7 & 35,3 & 154843,4 & 64,7 \\
\hline Тюменская область & 161205,7 & 1,2 & 105665,2 & 65,5 & 55540,5 & 34,5 \\
\hline Челябинская область & 153018,5 & 1,2 & 57825,7 & 37,8 & 95192,8 & 62,2 \\
\hline Ханты-Мансийский авт. округ - Югра & 1544162,7 & 11,7 & 1318214,0 & 85,4 & 225948,6 & 14,6 \\
\hline Ямало-Ненецкий авт. округ & 816783,6 & 6,2 & 661518,2 & 81,0 & 155265,4 & 19,0 \\
\hline Сибирский федеральный округ & 1202354,0 & 9,1 & $\mathbf{5 7 2 6 8 1 , 5}$ & 47,6 & 629672,5 & 52,4 \\
\hline Республика Алтай & 4925,1 & 0,0 & 1463,1 & 29,7 & 3462,0 & 70,3 \\
\hline Республика Тыва & 3827,8 & 0,0 & $-35,0$ & & 3862,8 & \\
\hline Республика Хакасия & 14467,0 & 0,1 & 1987,7 & 13,7 & 12479,3 & 86,3 \\
\hline Алтайский край & 58273,3 & 0,4 & 18037,6 & 31,0 & 40235,6 & 69,0 \\
\hline Красноярский край & 436986,6 & 3,3 & 259091,1 & 59,3 & 177895,5 & 40,7 \\
\hline Иркутская область & 248860,5 & 1,9 & 142451,0 & 57,2 & 106409,5 & 42,8 \\
\hline Кемеровская область & 66017,8 & 0,5 & $-10682,7$ & & 76700,4 & \\
\hline Новосибирская область & 125409,2 & 1,0 & 34557,7 & 27,6 & 90851,4 & 72,4 \\
\hline Омская область & 131346,6 & 1,0 & 46298,2 & 35,2 & 85048,4 & 64,8 \\
\hline Томская область & 112240,3 & 0,9 & 79512,8 & 70,8 & 32727,5 & 29,2 \\
\hline Дальневосточный федеральный округ & 648709,8 & 4,9 & 175609,1 & 27,1 & 473100,7 & 72,9 \\
\hline Республика Бурятия & 16588,9 & 0,1 & $-2164,9$ & & 18753,8 & \\
\hline Республика Саха (Якутия) & 138909,3 & 1,1 & 52889,3 & 38,1 & 86020,1 & 61,9 \\
\hline Забайкальский край & 23118,1 & 0,2 & $-2520,1$ & & 25638,2 & \\
\hline Камчатский край & 23150,8 & 0,2 & 1811,6 & 7,8 & 21339,2 & 92,2 \\
\hline Приморский край & 74523,0 & 0,6 & 7265,2 & 9,7 & 67257,8 & 90,3 \\
\hline Хабаровский край & 89995,3 & 0,7 & 22854,9 & 25,4 & 67140,4 & 74,6 \\
\hline Амурская область & 7155,8 & 0,1 & $-33234,6$ & & 40390,3 & \\
\hline Магаданская область & 10662,4 & 0,1 & $-7346,1$ & & 18008,5 & \\
\hline Сахалинская область & 250348,0 & 1,9 & 139043,4 & 55,5 & 111304,6 & 44,5 \\
\hline Еврейская авт. область & 4422,3 & 0,0 & 128,2 & 2,9 & 4294,2 & 97,1 \\
\hline Чукотский авт. округ & 9836,0 & 0,1 & $-3117,6$ & & 12953,6 & \\
\hline
\end{tabular}


СОВОКУПНАЯ ЗАДОЛЖЕННОСТЬ ПО НАЛОГАМ И СБОРАМ,

СТРАХОВЫМ ВЗНОСАМ, ПЕНЯМ И НАЛОГОВЫМ САНКЦИЯМ

В БЮДЖЕТНУЮ СИСТЕМУ РОССИЙСКОЙ ФЕДЕРАЦИИ

(по данным Федеральной налоговой службы)

на 1 сентября 2020 года

\begin{tabular}{|c|c|c|c|c|}
\hline & \multicolumn{2}{|c|}{$\begin{array}{c}\text { Совокупная задолженность } \\
\text { по налогам и сборам, страховым } \\
\text { взносам, пеням и налоговым санкциям }\end{array}$} & \multicolumn{2}{|c|}{$\begin{array}{c}\text { Из нее по федеральнымм } \\
\text { налогам и сборам }\end{array}$} \\
\hline & $\begin{array}{c}\text { млн } \\
\text { рублей }\end{array}$ & $\begin{array}{c}8 \% \kappa \\
\text { umozy }\end{array}$ & $\begin{array}{c}\text { млн } \\
\text { рублей }\end{array}$ & $\begin{array}{l}\text { в \% } \\
\text { uтогу }\end{array}$ \\
\hline Российская Федерация, млрд рублей & 1981,6 & 100 & 1187,0 & 100 \\
\hline Центральный федеральный округ & 874496,9 & 44,1 & 568143,9 & 47,9 \\
\hline Белгородская область & 6574,6 & 0,3 & 3398,2 & 0,3 \\
\hline Брянская область & 6734,3 & 0,3 & 3426,2 & 0,3 \\
\hline Владимирская область & 15219,8 & 0,8 & 7847,8 & 0,7 \\
\hline Воронежская область & 9729,5 & 0,5 & 3907,3 & 0,3 \\
\hline Ивановская область & 9375,3 & 0,5 & 3909,2 & 0,3 \\
\hline Калужская область & 9441,0 & 0,5 & 4240,4 & 0,4 \\
\hline Костромская область & 4050,4 & 0,2 & 1322,8 & 0,1 \\
\hline Курская область & 7444,9 & 0,4 & 4434,4 & 0,4 \\
\hline Липецкая область & 7334,8 & 0,4 & 4025,6 & 0,3 \\
\hline Московская область & 151198,0 & 7,6 & 83059,4 & 7,0 \\
\hline Орловская область & 4368,1 & 0,2 & 1726,1 & 0,1 \\
\hline Рязанская область & 14196,1 & 0,7 & 9556,2 & 0,8 \\
\hline Смоленская область & 12518,1 & 0,6 & 9351,9 & 0,8 \\
\hline Тамбовская область & 7887,6 & 0,4 & 5013,7 & 0,4 \\
\hline Тверская область & 14636,0 & 0,7 & 7573,7 & 0,6 \\
\hline Тульская область & 13852,2 & 0,7 & 6358,9 & 0,5 \\
\hline Ярославская область & 14977,0 & 0,8 & 7316,4 & 0,6 \\
\hline г. Москва & 564959,3 & 28,5 & 401675,9 & 33,8 \\
\hline Северо-Западный федеральный округ & 173738,7 & 8,8 & 97635,2 & 8,2 \\
\hline Республика Карелия & 5260,9 & 0,3 & 2471,5 & 0,2 \\
\hline Республика Коми & 11994,4 & 0,6 & 7843,0 & 0,7 \\
\hline Архангельская область & 6538,5 & 0,3 & 3394,5 & 0,3 \\
\hline Вологодская область & 8735,2 & 0,4 & 3333,9 & 0,3 \\
\hline Калининградская область & 15953,9 & 0,8 & 10123,3 & 0,9 \\
\hline Ленинградская область & 17806,1 & 0,9 & 8739,2 & 0,7 \\
\hline Мурманская область & 9928,3 & 0,5 & 5530,8 & 0,5 \\
\hline Новгородская область & 4982,7 & 0,3 & 2207,3 & 0,2 \\
\hline Псковская область & 3895,3 & 0,2 & 1472,1 & 0,1 \\
\hline г. Санкт-Петербург & 87349,8 & 4,4 & 51546,6 & 4,3 \\
\hline Ненецкий авт. округ & 1293,7 & 0,1 & 972,9 & 0,1 \\
\hline Южный федеральный округ & 143558,0 & 7,2 & 75199,9 & 6,3 \\
\hline Республика Адыгея & 2607,4 & 0,1 & 856,3 & 0,1 \\
\hline Республика Калмыкия & 3651,1 & 0,2 & 2010,6 & 0,2 \\
\hline Республика Крым & 5349,1 & 0,3 & 3419,3 & 0,3 \\
\hline Краснодарский край & 61614,0 & 3,1 & 31923,0 & 2,7 \\
\hline Астраханская область & 8247,9 & 0,4 & 3919,9 & 0,3 \\
\hline Волгоградская область & 26286,9 & 1,3 & 15231,9 & 1,3 \\
\hline Ростовская область & 35036,7 & 1,8 & 17510,3 & 1,5 \\
\hline г. Севастополь & 764,9 & 0,0 & 328,7 & 0,0 \\
\hline Северо-Кавказский федеральный округ & 123431,6 & 6,2 & 81807,9 & 6,9 \\
\hline Республика Дагестан & 24553,2 & 1,2 & 9896,6 & 0,8 \\
\hline Республика Ингушетия & 4327,3 & 0,2 & 1775,7 & 0,1 \\
\hline Кабардино-Балкарская Республика & 53384,3 & 2,7 & 48611,9 & 4,1 \\
\hline Карачаево-Черкесская Республика & 6924,9 & 0,3 & 3918,7 & 0,3 \\
\hline Республика Северная Осетия - Алания & 8809,3 & 0,4 & 4403,3 & 0,4 \\
\hline Чеченская Республика & 5904,7 & 0,3 & 1866,9 & 0,2 \\
\hline Ставропольский край & 19527,8 & 1,0 & 11334,9 & 1,0 \\
\hline
\end{tabular}




\begin{tabular}{|c|c|c|c|c|}
\hline & \multicolumn{2}{|c|}{$\begin{array}{c}\text { Совокупная задолженность } \\
\text { по налогам и сборам, страховым } \\
\text { взносам, пеням и налоговым санкичиям }\end{array}$} & \multicolumn{2}{|c|}{$\begin{array}{c}\text { Из нее по федеральным } \\
\text { налогам и сборам }\end{array}$} \\
\hline & $\begin{array}{c}\text { млн } \\
\text { рублей } \\
\end{array}$ & $\begin{array}{l}6 \% \kappa \\
\text { umozy } \\
\end{array}$ & $\begin{array}{c}\text { млн } \\
\text { рублей }\end{array}$ & $\begin{array}{l}8 \% \kappa \\
\text { umory }\end{array}$ \\
\hline Приволжский федеральный округ & 243860,9 & 12,3 & 137318,1 & 11,6 \\
\hline Республика Башкортостан & 26347,4 & 1,3 & 13147,1 & 1,1 \\
\hline Республика Марий Эл & 3593,4 & 0,2 & 2032,4 & 0,2 \\
\hline Республика Мордовия & 6977,7 & 0,4 & 2384,7 & 0,2 \\
\hline Республика Татарстан & 23812,6 & 1,2 & 12812,0 & 1,1 \\
\hline Удмуртская Республика & 13388,2 & 0,7 & 8185,6 & 0,7 \\
\hline Чувашская Республика & 10033,3 & 0,5 & 5638,5 & 0,5 \\
\hline Пермский край & 26256,8 & 1,3 & 13964,0 & 1,2 \\
\hline Кировская область & 10290,0 & 0,5 & 5619,9 & 0,5 \\
\hline Нижегородская область & 26343,2 & 1,3 & 15052,9 & 1,3 \\
\hline Оренбургская область & 16160,2 & 0,8 & 9970,2 & 0,8 \\
\hline Пензенская область & 8754,9 & 0,4 & 5304,2 & 0,4 \\
\hline Самарская область & 37548,1 & 1,9 & 23859,6 & 2,0 \\
\hline Саратовская область & 15271,3 & 0,8 & 7056,8 & 0,6 \\
\hline Ульяновская область & 19083,9 & 1,0 & 12290,1 & 1,0 \\
\hline Уральский федеральный округ & 152204,8 & 7,7 & 88835,9 & 7,5 \\
\hline Курганская область & 4826,5 & 0,2 & 2093,0 & 0,2 \\
\hline Свердловская область & 38707,5 & 2,0 & 20588,2 & 1,7 \\
\hline Тюменская область & 15048,3 & 0,8 & 9126,5 & 0,8 \\
\hline Челябинская область & 36493,6 & 1,8 & 21085,2 & 1,8 \\
\hline Ханты-Мансийский авт. округ - Югра & 33915,6 & 1,7 & 20780,6 & 1,8 \\
\hline Ямало-Ненецкий авт. округ & 23213,3 & 1,2 & 15162,4 & 1,3 \\
\hline Сибирский федеральный округ & 174610,8 & 8,8 & 90504,9 & 7,6 \\
\hline Республика Алтай & 2083,0 & 0,1 & 1014,5 & 0,1 \\
\hline Республика Тыва & 1477,0 & 0,1 & 553,3 & 0,0 \\
\hline Республика Хакасия & 6123,3 & 0,3 & 1749,1 & 0,1 \\
\hline Алтайский край & 15830,6 & 0,8 & 6716,0 & 0,6 \\
\hline Красноярский край & 25831,2 & 1,3 & 12769,3 & 1,1 \\
\hline Иркутская область & 29106,1 & 1,5 & 16632,4 & 1,4 \\
\hline Кемеровская область & 35229,7 & 1,8 & 17723,4 & 1,5 \\
\hline Новосибирская область & 29932,1 & 1,5 & 17221,3 & 1,5 \\
\hline Омская область & 20593,9 & 1,0 & 11308,1 & 1,0 \\
\hline Томская область & 8403,7 & 0,4 & 4817,5 & 0,4 \\
\hline Дальневосточный федеральный округ & 95746,7 & 4,8 & 47535,0 & 4,0 \\
\hline Республика Бурятия & 5735,2 & 0,3 & 2370,5 & 0,2 \\
\hline Республика Саха (Якутия) & 12974,1 & 0,7 & 6992,6 & 0,6 \\
\hline Забайкальский край & 7669,7 & 0,4 & 3707,4 & 0,3 \\
\hline Камчатский край & 4236,5 & 0,2 & 1816,3 & 0,2 \\
\hline Приморский край & 15173,8 & 0,8 & 6366,6 & 0,5 \\
\hline Хабаровский край & 24912,9 & 1,3 & 11646,4 & 1,0 \\
\hline Амурская область & 7121,7 & 0,4 & 3396,1 & 0,3 \\
\hline Магаданская область & 3051,2 & 0,2 & 1437,7 & 0,1 \\
\hline Сахалинская область & 12748,0 & 0,6 & 8812,9 & 0,7 \\
\hline Еврейская авт. область & 1883,7 & 0,1 & 830,9 & 0,1 \\
\hline Чукотский авт. округ & 239,9 & 0,0 & 157,6 & 0,0 \\
\hline
\end{tabular}




\section{ФИНАНСОВАЯ ДЕЯТЕЛЬНОСТЬ ОРГАНИЗАЦИЙ ${ }^{1)}$}

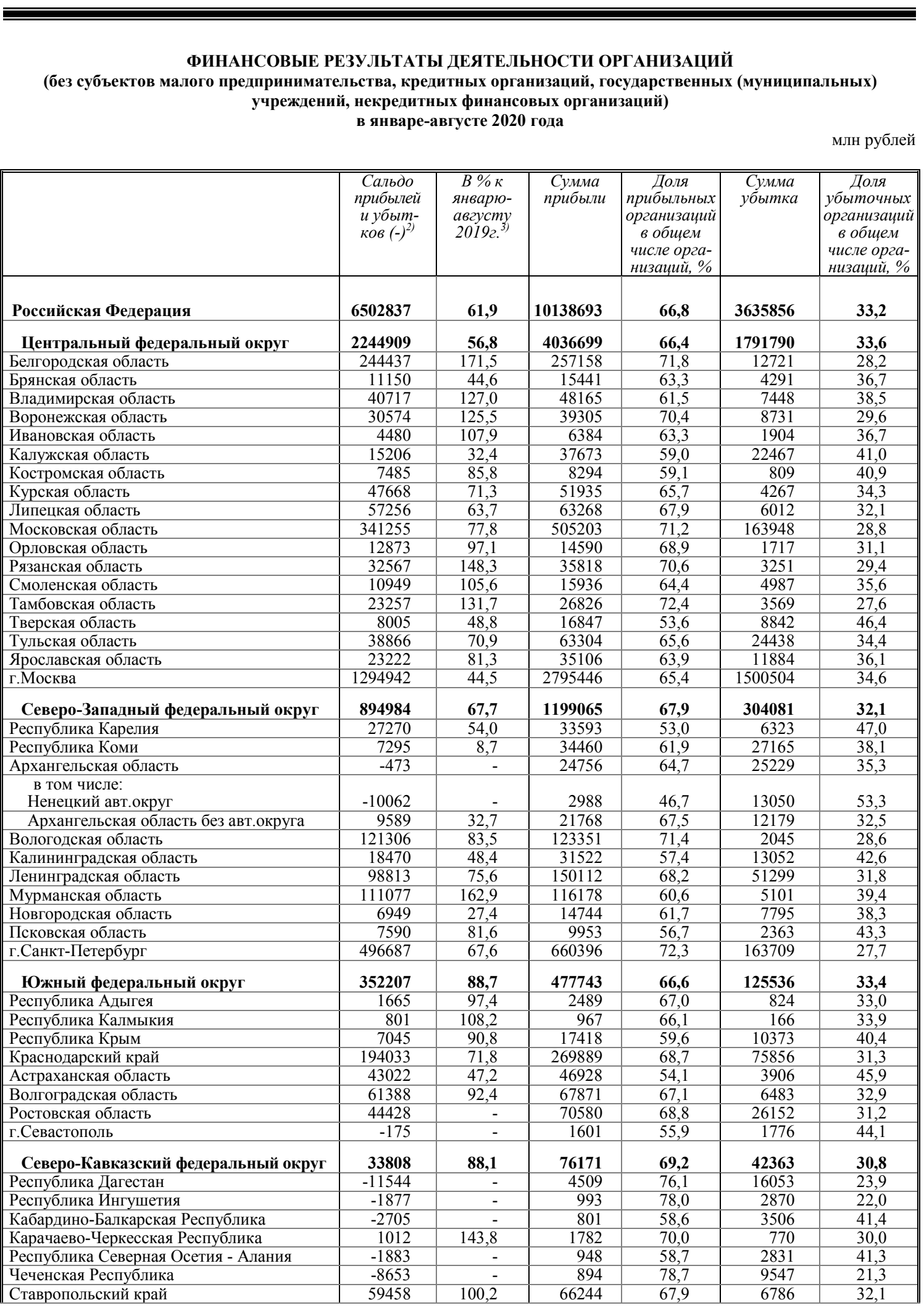




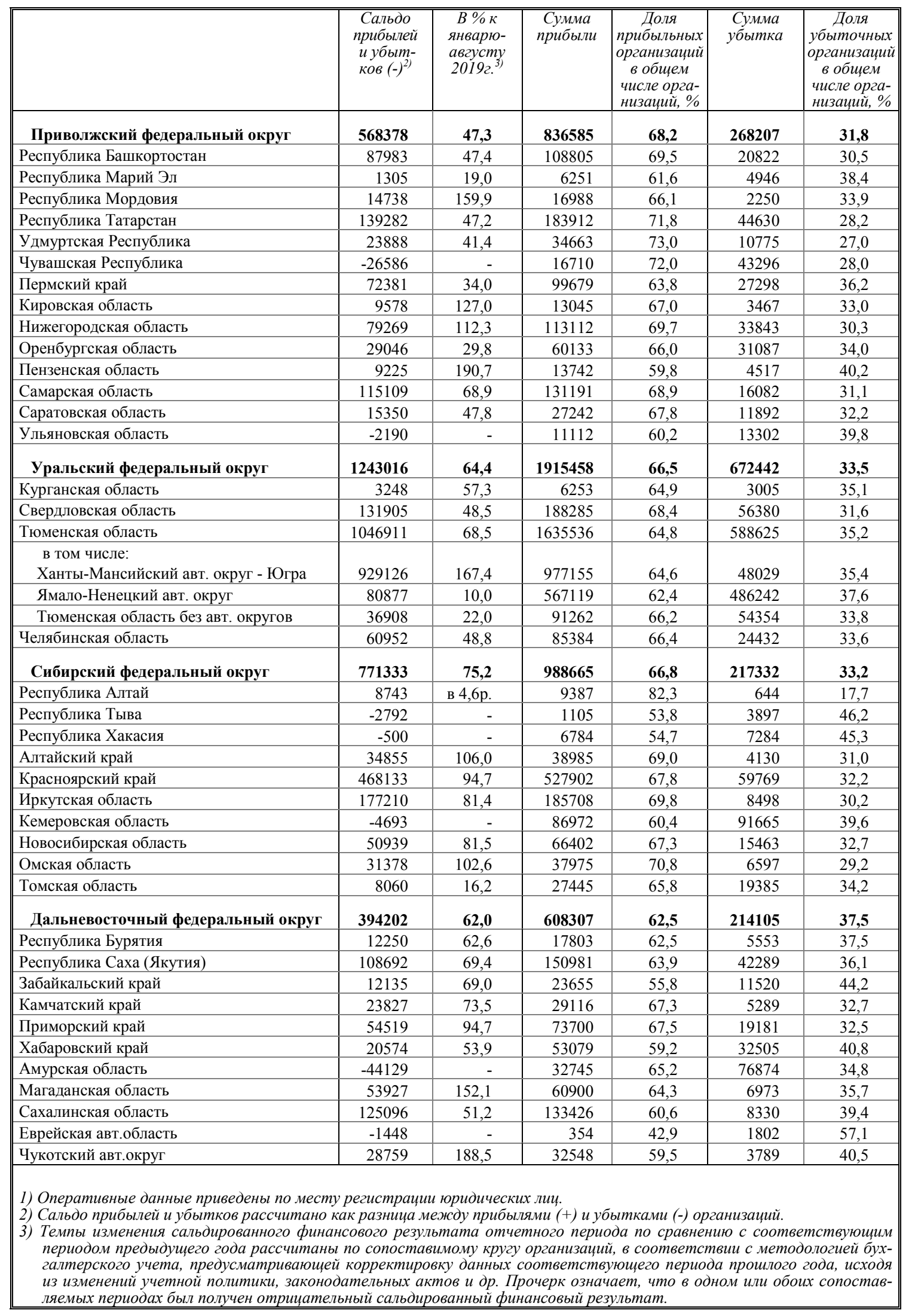


КРЕДИТОРСКАЯ И ДЕБИТОРСКАЯ ЗАДОЛЖЕННОСТЬ ОРГАНИЗАЦИЙ

(без субъектов малого предпринимательства, кредитных организаций, государственных (муниципальных) учреждений, некредитных финансовых организаций)

в августе 2020 года

на конец месяца, млн рублей

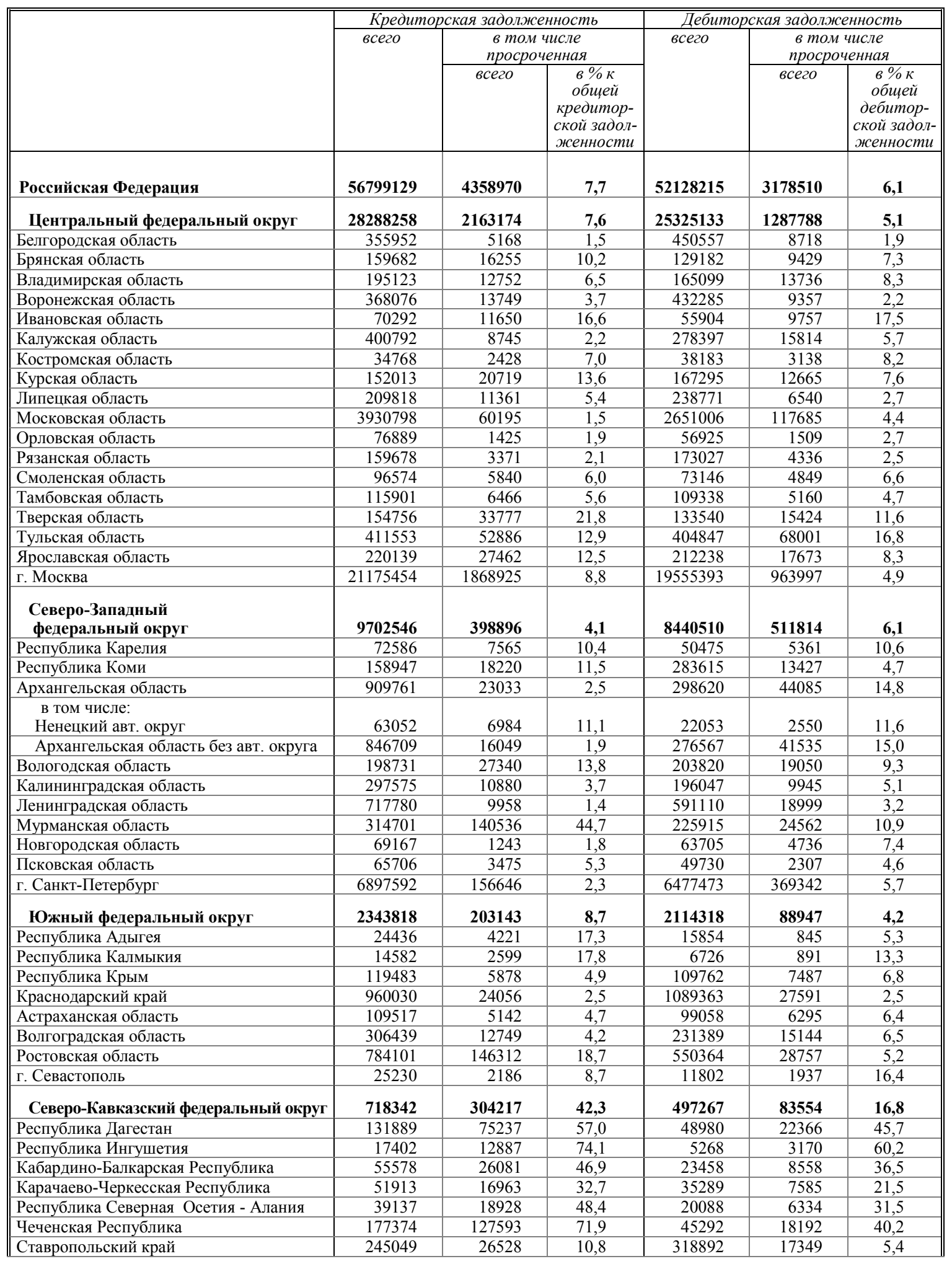




\begin{tabular}{|c|c|c|c|c|c|c|}
\hline & \multicolumn{3}{|c|}{ ККредиторская задолженность } & \multicolumn{3}{|c|}{ ДДебиторская задолженность } \\
\hline & \multirow[t]{2}{*}{ всего } & \multicolumn{2}{|c|}{$\begin{array}{c}\text { в том числе } \\
\text { просроченная }\end{array}$} & \multirow[t]{2}{*}{ всего } & \multicolumn{2}{|c|}{$\begin{array}{c}\text { в том числе } \\
\text { просроченная }\end{array}$} \\
\hline & & всего & $\begin{array}{c}\text { в\%к } \\
\text { обшей } \\
\text { кредитор- } \\
\text { ской задол- } \\
\text { женности }\end{array}$ & & всего & $\begin{array}{c}\text { в\%к } \\
\text { обшей } \\
\text { дебитор- } \\
\text { ской задол- } \\
\text { женности }\end{array}$ \\
\hline Республика Марий Эл & 45677 & 554 & 1,2 & 40997 & 1495 & 3,6 \\
\hline Республика Мордовия & 174026 & 1977 & 1,1 & 101638 & 3260 & 3,2 \\
\hline Республика Татарстан & 1053615 & 18917 & 1,8 & 1260570 & 39374 & 3,1 \\
\hline Удмуртская Республика & 238460 & 11817 & 5,0 & 260350 & 7977 & 3,1 \\
\hline Нижегородская область & 1365852 & 120742 & 8,8 & 1222060 & 134703 & 11,0 \\
\hline Оренбургская область & 202247 & 20412 & 10,1 & 785131 & 19621 & 2,5 \\
\hline Пензенская область & 135439 & 5405 & 4,0 & 112241 & 4567 & 4,1 \\
\hline Самарская область & 722759 & 32179 & 4,5 & 543187 & 33252 & 6,1 \\
\hline Саратовская область & 185950 & 13964 & 7,5 & 189963 & 15680 & 8,3 \\
\hline Ульяновская область & 183077 & 13078 & 7,1 & 122168 & 11520 & 9,4 \\
\hline Уральский федеральный округ & 4481119 & 209812 & 4,7 & 4897527 & 406142 & 8,3 \\
\hline Курганская область & 82834 & 3171 & 3,8 & 61182 & 9926 & 16,2 \\
\hline Свердловская область & 1285668 & 89983 & 7,0 & 1040886 & 102721 & 9,9 \\
\hline Тюменская область & 2501023 & 78753 & 3,1 & 3297209 & 242262 & 7,3 \\
\hline Сибирский федеральный округ & 3168735 & 351327 & 11,1 & 3257487 & $\mathbf{3 0 3 1 5 7}$ & 9,3 \\
\hline Республика Алтай & 16470 & 190 & 1,2 & 14786 & 1777 & 12,0 \\
\hline Республика Тыва & 10706 & 4033 & 37,7 & 7246 & 1412 & 19,5 \\
\hline Республика Хакасия & 33086 & 6639 & 20,1 & 35133 & 3570 & 10,2 \\
\hline Алтайский край & 116584 & 4876 & 4,2 & 98368 & 3822 & 3,9 \\
\hline Красноярский край & 885361 & 38778 & 4,4 & 1247582 & 63090 & 5,1 \\
\hline Иркутская область & 285266 & 12036 & 4,2 & 358681 & 15896 & 4,4 \\
\hline Кемеровская область & 775100 & 246420 & 31,8 & 715204 & 184648 & 25,8 \\
\hline Новосибирская область & 419196 & 16850 & 4,0 & 346082 & 15117 & 4,4 \\
\hline Омская область & 415208 & 4030 & 1,0 & 187906 & 5682 & 3,0 \\
\hline Томская область & 211758 & 17475 & 8,3 & 246499 & 8143 & 3,3 \\
\hline $\begin{array}{l}\text { Дальневосточный } \\
\text { федеральный округ }\end{array}$ & 1919810 & 105239 & 5,5 & 1655023 & 131172 & 7,9 \\
\hline Республика Бурятия & 88466 & 3449 & 3,9 & 59274 & 4052 & 6,8 \\
\hline Республика Саха (Якутия) & 178323 & 12101 & 6,8 & 190567 & 17579 & 9,2 \\
\hline Забайкальский край & 63940 & 6926 & 10,8 & 89051 & 12051 & 13,5 \\
\hline Камчатский край & 75947 & 1921 & 2,5 & 76563 & 10372 & 13,5 \\
\hline Приморский край & 541896 & 9590 & 1,8 & 426751 & 33937 & 8,0 \\
\hline Хабаровский край & 342892 & 53949 & 15,7 & 306513 & 30128 & 9,8 \\
\hline
\end{tabular}




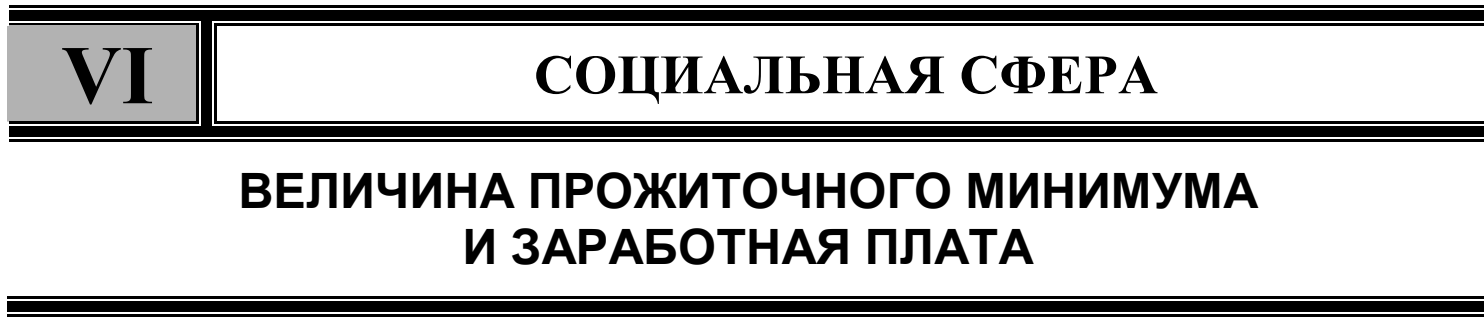

\section{ВЕЛИЧИНА ПРОЖИТОЧНОГО МИНИМУМА \\ за II квартал 2020 года}

(по состоянию на 21 октября 2020 года)

рублей в месяц

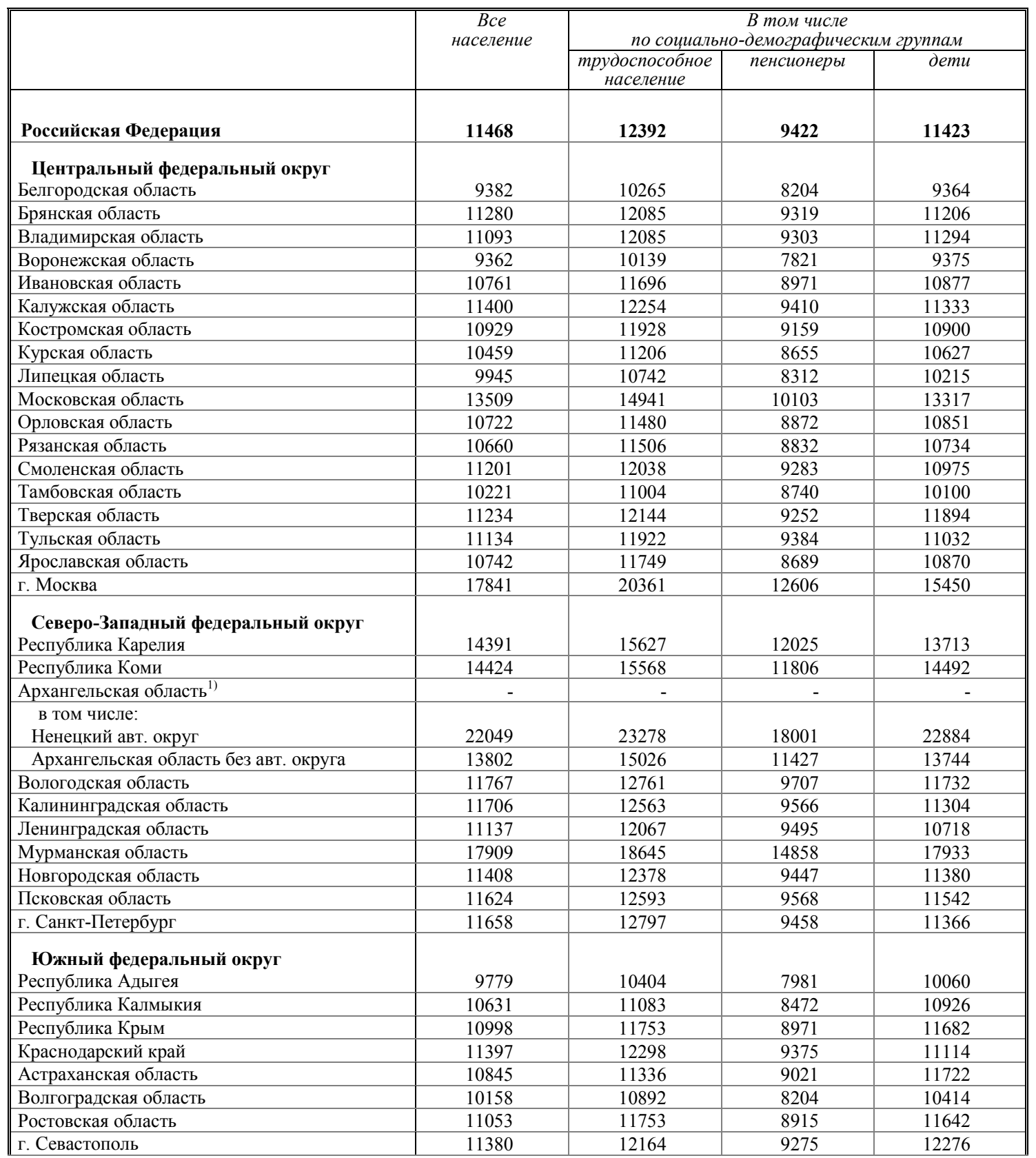




\begin{tabular}{|c|c|c|c|c|}
\hline & \multirow[t]{2}{*}{$\begin{array}{c}\text { Все } \\
\text { население }\end{array}$} & \multicolumn{3}{|c|}{$\begin{array}{c}\text { В том числе } \\
\text { по сочиально-демографическим группам }\end{array}$} \\
\hline & & $\begin{array}{c}\begin{array}{c}\text { трудоспособное } \\
\text { население }\end{array} \\
\end{array}$ & пенсионерь & дети \\
\hline $\begin{array}{l}\text { Северо-Кавказский федеральный округ } \\
\text { Республика Дагестан }\end{array}$ & 10462 & 10717 & 8200 & 10757 \\
\hline Республика Ингушетия & 10571 & 10601 & 8282 & 11015 \\
\hline Кабардино-Балкарская Республика & 12576 & 12998 & 9679 & 13815 \\
\hline Карачаево-Черкесская Республика & 10424 & 10950 & 8382 & 10840 \\
\hline Республика Северная Осетия - Алания & 10047 & 10599 & 8045 & 10470 \\
\hline Чеченская Республика & 11190 & 11563 & 9176 & 11168 \\
\hline Ставропольский край & 10081 & 10749 & 8162 & 10621 \\
\hline \multicolumn{2}{|l|}{ Приволжский федеральный округ } & 10641 & 8155 & 10077 \\
\hline Республика Марий Эл & 10067 & 10735 & 8222 & 10415 \\
\hline Республика Мордовия & 9378 & 10079 & 7693 & 9796 \\
\hline Республика Татарстан & 9668 & 10294 & 7889 & 9713 \\
\hline Удмуртская Республика & 10384 & 10995 & 8415 & 10518 \\
\hline Чувашская Республика & 9763 & 10361 & 7939 & 9851 \\
\hline Пермский край & 10844 & 11633 & 8914 & 11124 \\
\hline Кировская область & 10666 & 11395 & 8678 & 10954 \\
\hline Нижегородская область & 10686 & 11540 & 8842 & 11031 \\
\hline Оренбургская область & 9856 & 10515 & 8137 & 10289 \\
\hline Пензенская область & 9610 & 10396 & 7953 & 10002 \\
\hline Самарская область & 10979 & 12126 & 8751 & 11000 \\
\hline Саратовская область & 9844 & 10615 & 8132 & 10191 \\
\hline Ульяновская область & 10642 & 11417 & 8716 & 10917 \\
\hline \multicolumn{2}{|l|}{ Уральский федеральный округ } & 11190 & 8676 & 11027 \\
\hline Свердловская область & 10990 & 11713 & 8962 & 11696 \\
\hline Тюменская область ${ }^{1)}$ & - & - & - & - \\
\hline $\begin{array}{l}\text { в том числе: } \\
\text { Ханты-Мансийский авт. округ - Югра }\end{array}$ & 16281 & 17500 & 13236 & 16306 \\
\hline Ямало-Ненецкий авт. округ & 16759 & 17511 & 13191 & 16753 \\
\hline Тюменская область без авт. округов & 11593 & 12196 & 9238 & 11956 \\
\hline Челябинская область & 11228 & 12032 & 9288 & 11694 \\
\hline \multicolumn{2}{|l|}{ Сибирский федеральный округ } & 11155 & 8903 & 10801 \\
\hline Республика Тыва & 11253 & 11634 & 8881 & 11902 \\
\hline Республика Хакасия & 11772 & 12399 & 9395 & 12507 \\
\hline Алтайский край & 10460 & 11190 & 8960 & 10611 \\
\hline Красноярский край & 13149 & 13919 & 10248 & 13763 \\
\hline Иркутская область & 12243 & 13012 & 9881 & 12759 \\
\hline Кемеровская область & 10727 & 11354 & 8624 & 11254 \\
\hline Новосибирская область & 12284 & 13054 & 9823 & 12729 \\
\hline Омская область & 10495 & 11101 & 8412 & 10870 \\
\hline Томская область & 12218 & 12959 & 9815 & 12927 \\
\hline \multicolumn{5}{|l|}{ Дальневосточный федеральный округ } \\
\hline Республика Бурятия & 12341 & 12810 & 9734 & 12968 \\
\hline Республика Саха (Якутия) & 17721 & 18728 & 14215 & 18559 \\
\hline Забайкальский край & 13397 & 13909 & 10561 & 14199 \\
\hline Камчатский край & 21176 & 22232 & 16780 & 22693 \\
\hline Приморский край & 13963 & 14779 & 11224 & 15409 \\
\hline Хабаровский край & 15320 & 16246 & 12314 & 16372 \\
\hline Амурская область & 12950 & 13752 & 10491 & 13547 \\
\hline Магаданская область & 20588 & 21767 & 16309 & 21880 \\
\hline Сахалинская область & 15906 & 16932 & 12757 & 17300 \\
\hline Еврейская авт. область & 15733 & 16717 & 12713 & 16479 \\
\hline Чукотский авт. округ & 22188 & 22798 & 17063 & 22982 \\
\hline
\end{tabular}


СРЕДНЕМЕСЯЧНАЯ НОМИНАЛЬНАЯ

НАЧИСЛЕННАЯ ЗАРАБОТНАЯ ПЛАТА РАБОТНИКОВ ОРГАНИЗАЦИЙ

\begin{tabular}{|c|c|c|c|c|c|}
\hline & \multicolumn{2}{|c|}{ Январь-август 2020 г. } & \multicolumn{3}{|c|}{ Aвгуст 2020 г. } \\
\hline & \multirow{2}{*}{ рублей } & \multirow{2}{*}{$\begin{array}{c}в \% \kappa \\
\text { январю- } \\
\text { августу } \\
20192 .\end{array}$} & \multirow[t]{2}{*}{ рублей } & \multicolumn{2}{|c|}{$6 \% \kappa$} \\
\hline & & & & $\begin{array}{l}\text { aвгусту } \\
2019 \text { г. }\end{array}$ & $\begin{array}{l}\text { июлю } \\
2020 \text { г. }\end{array}$ \\
\hline Российская Федерация & 49440 & 105,6 & 47649 & 103,7 & 95,1 \\
\hline Центральный федеральный округ & 62730 & 106,0 & 60047 & 103,7 & 93,3 \\
\hline Белгородская область & 36450 & 108,4 & 36674 & 106,6 & 94,2 \\
\hline Брянская область & 31284 & 106,2 & 31226 & 105,4 & 97,0 \\
\hline Владимирская область & 33314 & 105,8 & 32390 & 102,4 & 95,3 \\
\hline Воронежская область & 35329 & 105,9 & 34731 & 105,7 & 94,0 \\
\hline Ивановская область & 27434 & 105,2 & 26115 & 101,1 & 93,3 \\
\hline Калужская область & 42213 & 104,3 & 40492 & 101,5 & 89,3 \\
\hline Костромская область & 30860 & 100,1 & 30179 & 103,1 & 95,0 \\
\hline Курская область & 34713 & 108,9 & 34354 & 105,7 & 95,2 \\
\hline Липецкая область & 35616 & 104,9 & 35513 & 105,5 & 96,9 \\
\hline Московская область & 55253 & 101,5 & 53724 & 101,5 & 95,6 \\
\hline Орловская область & 30910 & 107,1 & 30832 & 106,7 & 96,9 \\
\hline Рязанская область & 35358 & 105,9 & 35324 & 104,2 & 98,2 \\
\hline Смоленская область & 31956 & 104,2 & 31374 & 103,7 & 100,4 \\
\hline Тамбовская область & 29762 & 107,4 & 29895 & 106,6 & 98,0 \\
\hline Тверская область & 34384 & 104,7 & 32065 & 97,5 & 96,0 \\
\hline Тульская область & 39133 & 105,3 & 38760 & 104,7 & 95,1 \\
\hline Ярославская область & 36901 & 104,5 & 36705 & 105,6 & 95,7 \\
\hline г. Москва & 96290 & 106,2 & 90304 & 103,3 & 91,7 \\
\hline $\begin{array}{c}\text { Северо-Западный } \\
\text { федеральный округ }\end{array}$ & 55217 & 104,2 & 53103 & 102,7 & 93,7 \\
\hline Республика Карелия & 45197 & 107,7 & 42066 & 108,2 & 93,1 \\
\hline Республика Коми & 56238 & 106,5 & 54789 & 106,2 & 95,2 \\
\hline Архангельская область & 54642 & 105,6 & 51972 & 105,8 & 94,7 \\
\hline $\begin{array}{l}\text { в том числе: } \\
\text { Ненецкий авт. округ }\end{array}$ & 92382 & 104,9 & 89141 & 104,8 & 101,0 \\
\hline Архангельская область без авт. округа & 51363 & 105,5 & 48764 & 105,9 & 93,7 \\
\hline Вологодская область & 41464 & 107,4 & 38787 & 101,3 & 98,3 \\
\hline Калининградская область & 36203 & 104,3 & 36102 & 102,3 & 96,1 \\
\hline Ленинградская область & 47431 & 102,3 & 47057 & 100,1 & 95,4 \\
\hline Мурманская область & 66908 & 107,1 & 61272 & 107,5 & 88,7 \\
\hline Новгородская область & 31730 & 102,5 & 32029 & 103,8 & 95,3 \\
\hline Псковская область & 30852 & 107,3 & 30119 & 105,0 & 95,9 \\
\hline г. Санкт-Петербург & 66056 & 103,1 & 63279 & 101,5 & 93,0 \\
\hline Южный федеральный округ & 35093 & 104,5 & 34121 & 100,7 & 97,1 \\
\hline Республика Адыгея & 31025 & 105,6 & 30436 & 105,4 & 100,1 \\
\hline Республика Калмыкия & 30636 & 112,1 & 30415 & 114,0 & 99,1 \\
\hline Республика Крым & 32978 & 103,4 & 30318 & 97,1 & 95,4 \\
\hline Краснодарский край & 36602 & 102,7 & 35182 & 96,3 & 98,2 \\
\hline Астраханская область & 38285 & 106,6 & 38413 & 103,3 & 100,1 \\
\hline Волгоградская область & 34542 & 105,8 & 34683 & 106,3 & 96,2 \\
\hline Ростовская область & 34159 & 105,5 & 33686 & 103,9 & 95,5 \\
\hline г. Севастополь & 34528 & 107,2 & 32811 & 102,2 & 97,6 \\
\hline $\begin{array}{c}\text { Северо-Кавказский } \\
\text { федеральный округ }\end{array}$ & 30411 & 107,8 & 29788 & 107,9 & 96,1 \\
\hline Республика Дагестан & 28916 & 110,0 & 26961 & 110,5 & 94,8 \\
\hline Республика Ингушетия & 29556 & 107,9 & 29173 & 111,5 & 101,1 \\
\hline Кабардино-Балкарская Республика & 28850 & 109,2 & 27089 & 108,8 & 96,9 \\
\hline Карачаево-Черкесская Республика & 28924 & 110,7 & 28115 & 113,3 & 91,5 \\
\hline Республика Северная Осетия - Алания & 29619 & 106,5 & 28258 & 107,3 & 96,3 \\
\hline Чеченская Республика & 28855 & 107,2 & 28555 & 107,6 & 99,3 \\
\hline Ставропольский край & 32574 & 106,7 & 33010 & 106,7 & 95,8 \\
\hline
\end{tabular}




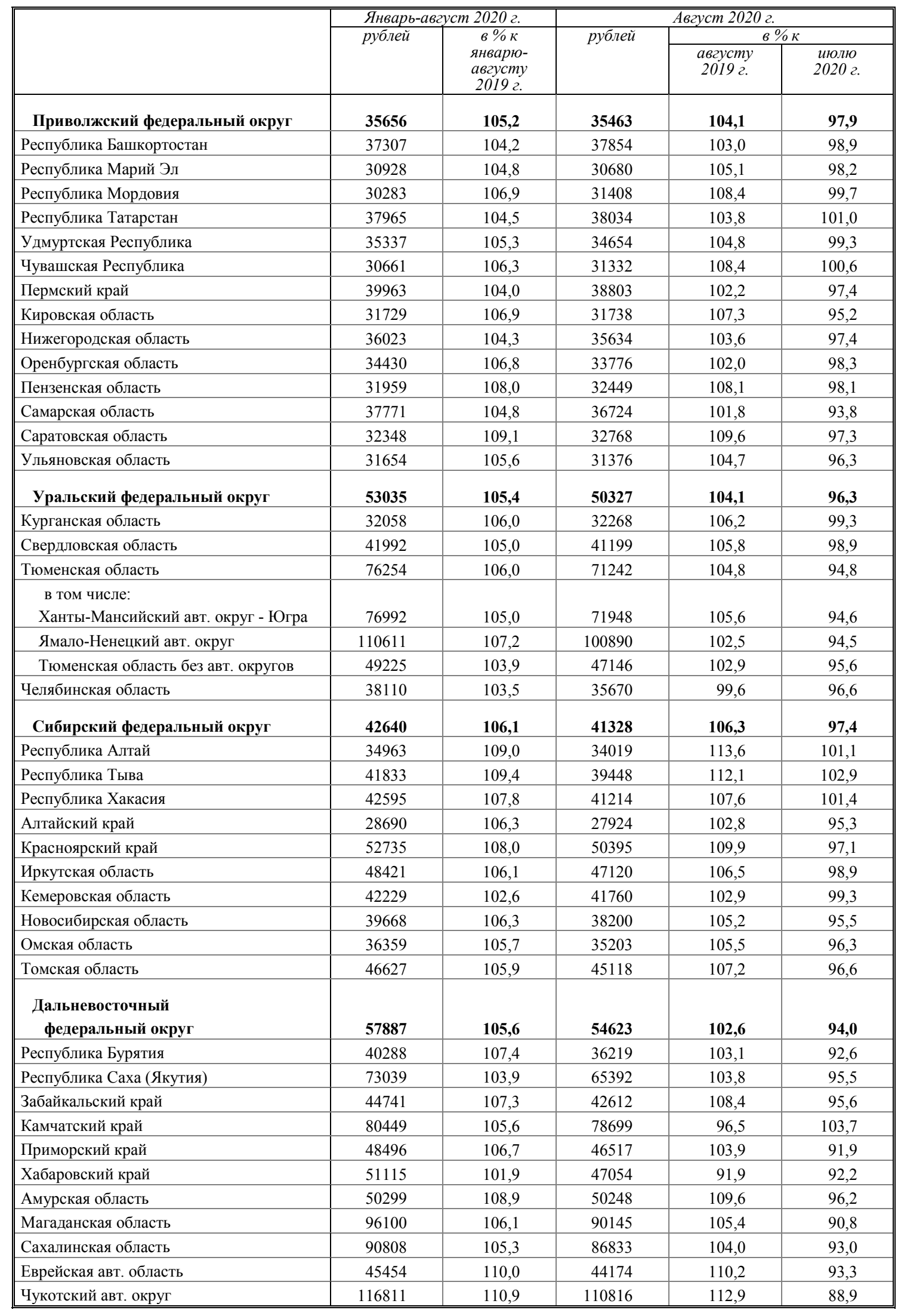


ЗАНЯТОСТЬ И БЕЗРАБОТИЦА

ЧИСЛЕННОСТЬ И СОСТАВ РАБОЧЕЙ СИЛЫ В ВОЗРАСТЕ 15 ЛЕТ И СТАРШЕ

в среднем в июле-сентябре 2020 года

(по данным выборочных обследований рабочей силы)

\begin{tabular}{|c|c|c|c|c|c|c|}
\hline & Численность & $B m$ & iсле & Уровень & Уровень & Уровень \\
\hline & $\begin{array}{c}\text { рабочей сильл, } \\
\text { тысс. } \\
\text { человек } \\
\end{array}$ & занятые & $\begin{array}{l}\text { безра- } \\
\text { ботныле }\end{array}$ & \begin{tabular}{|c|} 
участия в \\
рабочей силе, \\
в \% \\
\end{tabular} & $\begin{array}{c}\text { занятости, } \\
\text { в \% }\end{array}$ & $\begin{array}{c}\text { безрабо- } \\
\text { тицьь } \\
\text { в\% }\end{array}$ \\
\hline Российская Федерация & 75173,7 & 70401,7 & 4771,9 & 62,2 & 58,3 & 6,3 \\
\hline $\begin{array}{l}\text { Центральный } \\
\text { федеральный округ }\end{array}$ & 21320,0 & 20379,1 & 940,8 & 64,1 & 61,2 & 4,4 \\
\hline Белгородская область & 839,6 & 794,2 & 45,4 & 64,6 & 61,1 & 5,4 \\
\hline Брянская область & 585,3 & 559,4 & 25,9 & 58,2 & 55,6 & 4,4 \\
\hline Владимирская область & 716,9 & 670,0 & 46,9 & 62,3 & 58,2 & 6,5 \\
\hline Воронежская область & 1170,4 & 1118,5 & 51,9 & 59,1 & 56,5 & 4,4 \\
\hline Ивановская область & 515,1 & 483,7 & 31,4 & 60,8 & 57,1 & 6,1 \\
\hline Калужская область & 539,8 & 511,6 & 28,2 & 63,7 & 60,3 & 5,2 \\
\hline Костромская область & 319,3 & 299,6 & 19,7 & 60,7 & 57,0 & 6,2 \\
\hline Курская область & 556,6 & 530,2 & 26,4 & 59,8 & 57,0 & 4,7 \\
\hline Липецкая область & 596,2 & 570,5 & 25,7 & 62,2 & 59,5 & 4,3 \\
\hline Московская область & 4140,0 & 3973,2 & 166,8 & 65,6 & 63,0 & 4,0 \\
\hline Орловская область & 351,4 & 330,1 & 21,3 & 56,3 & 52,9 & 6,1 \\
\hline Рязанская область & 540,7 & 511,3 & 29,4 & 57,1 & 54,0 & 5,4 \\
\hline Смоленская область & 470,2 & 444,0 & 26,2 & 58,5 & 55,3 & 5,6 \\
\hline Тамбовская область & 497,9 & 473,0 & 24,8 & 57,1 & 54,3 & 5,0 \\
\hline Тверская область & 664,1 & 633,9 & 30,2 & 62,2 & 59,4 & 4,5 \\
\hline Тульская область & 790,2 & 748,4 & 41,8 & 62,2 & 58,9 & 5,3 \\
\hline Ярославская область & 659,9 & 605,9 & 54,0 & 62,7 & 57,6 & 8,2 \\
\hline г. Москва & 7366,4 & 7121,8 & 244,6 & 68,3 & 66,0 & 3,3 \\
\hline $\begin{array}{l}\text { Северо-Западный } \\
\text { федеральный округ }\end{array}$ & 7470,5 & 7029,4 & 441,2 & 63,8 & 60,0 & 5,9 \\
\hline Республика Карелия & 305,2 & 277,3 & 28,0 & 59,8 & 54,3 & 9,2 \\
\hline Республика Коми & 424,5 & 390,7 & 33,8 & 63,2 & 58,2 & 8,0 \\
\hline Архангельская область & 553,4 & 509,2 & 44,3 & 58,9 & 54,2 & 8,0 \\
\hline $\begin{array}{l}\text { в том числе: } \\
\text { Ненецкий авт. округ }\end{array}$ & 21,7 & 19,8 & 2,0 & 64,7 & 58,8 & 9,0 \\
\hline $\begin{array}{l}\text { Архангельская область } \\
\text { без авт. округа }\end{array}$ & 531,7 & 489,4 & 42,3 & 58,7 & 54,0 & 8,0 \\
\hline Вологодская область & 578,3 & 535,2 & 43,1 & 60,7 & 56,2 & 7,5 \\
\hline Калининградская область & 525,5 & 488,1 & 37,4 & 63,0 & 58,6 & 7,1 \\
\hline Ленинградская область & 978,3 & 915,1 & 63,2 & 62,0 & 58,0 & 6,5 \\
\hline Мурманская область & 413,6 & 378,4 & 35,1 & 67,2 & 61,5 & 8,5 \\
\hline Новгородская область & 284,8 & 267,7 & 17,0 & 57,0 & 53,6 & 6,0 \\
\hline Псковская область & 309,6 & 287,8 & 21,8 & 58,3 & 54,2 & 7,0 \\
\hline г. Санкт-Петербург & 3097,3 & 2979,8 & 117,5 & 67,6 & 65,1 & 3,8 \\
\hline Южный федеральный округ & 8123,6 & 7601,5 & 522,1 & 59,6 & 55,8 & 6,4 \\
\hline Республика Адыгея & 201,8 & 184,8 & 17,0 & 54,5 & 49,9 & 8,4 \\
\hline Республика Калмыкия & 135,5 & 121,5 & 14,0 & 62,6 & 56,2 & 10,3 \\
\hline Республика Крым & 935,6 & 876,8 & 58,8 & 59,2 & 55,5 & 6,3 \\
\hline Краснодарский край & 2769,8 & 2607,2 & 162,5 & 59,7 & 56,2 & 5,9 \\
\hline Астраханская область & 503,0 & 463,0 & 40,0 & 61,5 & 56,6 & 8,0 \\
\hline Волгоградская область & 1249,5 & 1135,4 & 114,2 & 59,5 & 54,1 & 9,1 \\
\hline Ростовская область & 2104,7 & 1999,1 & 105,6 & 59,7 & 56,7 & 5,0 \\
\hline г. Севастополь & 223,7 & 213,7 & 10,0 & 60,4 & 57,7 & 4,5 \\
\hline $\begin{array}{c}\text { Северо-Кавказский } \\
\text { федеральный округ }\end{array}$ & 4568,3 & 3884,5 & 683,8 & 60,0 & 51,0 & 15,0 \\
\hline Республика Дагестан & 1285,9 & 1084,3 & 201,6 & 55,0 & 46,4 & 15,7 \\
\hline Республика Ингушетия & 261,2 & 179,7 & 81,5 & 71,8 & 49,4 & 31,2 \\
\hline Кабардино-Балкарская Республика & 466,8 & 396,0 & 70,8 & 67,8 & 57,5 & 15,2 \\
\hline Карачаево-Черкесская Республика & 203,4 & 173,5 & 29,9 & 54,2 & 46,2 & 14,7 \\
\hline $\begin{array}{l}\text { Республика Северная } \\
\text { Осетия - Алания }\end{array}$ & 299,3 & 253,6 & 45,7 & 53,5 & 45,3 & 15,3 \\
\hline Чеченская Республика & 676,4 & 518,6 & 157,8 & 68,2 & 52,3 & 23,3 \\
\hline Ставропольский край & 1375,2 & 1278,7 & 96,5 & 59,9 & 55,7 & 7,0 \\
\hline
\end{tabular}




\begin{tabular}{|c|c|c|c|c|c|c|}
\hline & \multirow{2}{*}{\begin{tabular}{|c|} 
Численность \\
рабочей сильl, \\
тьсс. \\
человек \\
\end{tabular}} & \multicolumn{2}{|c|}{ В том числе } & \multirow{2}{*}{\begin{tabular}{|c|} 
Уровень \\
участия в \\
рабочей силе, \\
в\% \\
\end{tabular}} & \multirow{2}{*}{$\begin{array}{c}\text { Уровень } \\
\text { занятости, } \\
\text { в \% }\end{array}$} & \multirow{2}{*}{$\begin{array}{c}\text { Уровень } \\
\text { безрабо- } \\
\text { тицыь, } \\
\text { в\% } \\
\end{array}$} \\
\hline & & занятые & $\begin{array}{c}\text { безра- } \\
\text { ботные }\end{array}$ & & & \\
\hline $\begin{array}{l}\text { Приволжский } \\
\text { федеральный округ }\end{array}$ & 14777,8 & 13950,6 & 827,2 & 61,0 & 57,6 & 5,6 \\
\hline Республика Башкортостан & 1938,0 & 1811,2 & 126,8 & 59,3 & 55,5 & 6,5 \\
\hline Республика Марий Эл & 325,0 & 301,8 & 23,3 & 58,8 & 54,6 & 7,2 \\
\hline Республика Мордовия & 409,9 & 389,7 & 20,2 & 60,1 & 57,2 & 4,9 \\
\hline Республика Татарстан & 2032,2 & 1951,5 & 80,7 & 64,0 & 61,4 & 4,0 \\
\hline Удмуртская Республика & 793,2 & 741,1 & 52,2 & 65,3 & 61,0 & 6,6 \\
\hline Чувашская Республика & 606,0 & 568,8 & 37,1 & 60,6 & 56,9 & 6,1 \\
\hline Пермский край & 1243,0 & 1170,2 & 72,8 & 59,0 & 55,5 & 5,9 \\
\hline Кировская область & 638,4 & 603,9 & 34,5 & 60,6 & 57,4 & 5,4 \\
\hline Нижегородская область & 1736,5 & 1653,0 & 83,5 & 64,4 & 61,3 & 4,8 \\
\hline Оренбургская область & 967,8 & 899,8 & 68,0 & 61,0 & 56,7 & 7,0 \\
\hline Пензенская область & 646,3 & 609,9 & 36,3 & 57,8 & 54,5 & 5,6 \\
\hline Самарская область & 1682,7 & 1595,3 & 87,4 & 63,3 & 60,0 & 5,2 \\
\hline Саратовская область & 1161,3 & 1087,9 & 73,4 & 56,5 & 53,0 & 6,3 \\
\hline Ульяновская область & 597,4 & 566,5 & 30,8 & 57,2 & 54,3 & 5,2 \\
\hline $\begin{array}{l}\text { Уральский } \\
\text { федеральный округ }\end{array}$ & 6272,4 & $\mathbf{5 8 8 6 , 4}$ & 386,0 & 63,1 & 59,2 & 6,2 \\
\hline Курганская область & 361,3 & 331,4 & 29,9 & 53,0 & 48,7 & 8,3 \\
\hline Свердловская область & 2109,6 & 1978,5 & 131,2 & 60,1 & 56,4 & 6,2 \\
\hline Тюменская область & 1952,7 & 1875,4 & 77,2 & 66,8 & 64,2 & 4,0 \\
\hline $\begin{array}{l}\text { в том числе: } \\
\text { Ханты-Мансийский } \\
\text { авт. округ - Югра }\end{array}$ & 912,4 & 881,3 & 31,1 & 70,3 & 67,9 & 3,4 \\
\hline Ямало-Ненецкий авт. округ & 307,6 & 299,5 & 8,1 & 73,5 & 71,5 & 2,6 \\
\hline $\begin{array}{l}\text { Тюменская область } \\
\text { без авт. округов }\end{array}$ & 732,7 & 694,6 & 38,0 & 60,8 & 57,7 & 5,2 \\
\hline Челябинская область & 1848,8 & 1701,0 & 147,7 & 65,3 & 60,0 & 8,0 \\
\hline $\begin{array}{l}\text { Сибирский } \\
\text { федеральный округ }\end{array}$ & 8404,6 & 7710,6 & 693,9 & 60,5 & 55,5 & 8,3 \\
\hline Республика Алтай & 101,8 & 86,5 & 15,3 & 63,5 & 53,9 & 15,0 \\
\hline Республика Тыва & 139,7 & 109,6 & 30,1 & 64,1 & 50,3 & 21,5 \\
\hline Республика Хакасия & 245,6 & 221,6 & 24,0 & 57,9 & 52,2 & 9,8 \\
\hline Алтайский край & 1090,2 & 1024,5 & 65,7 & 57,0 & 53,6 & 6,0 \\
\hline Красноярский край & 1439,7 & 1326,5 & 113,2 & 61,7 & 56,9 & 7,9 \\
\hline Иркутская область & 1162,4 & 1074,3 & 88,1 & 61,2 & 56,6 & 7,6 \\
\hline Кемеровская область & 1278,3 & 1175,9 & 102,4 & 58,7 & 54,0 & 8,0 \\
\hline Новосибирская область & 1375,7 & 1272,7 & 103,0 & 60,0 & 55,5 & 7,5 \\
\hline Омская область & 1030,5 & 932,2 & 98,2 & 65,1 & 58,9 & 9,5 \\
\hline Томская область & 540,6 & 486,8 & 53,8 & 61,3 & 55,2 & 10,0 \\
\hline $\begin{array}{l}\text { Дальневосточный } \\
\text { федеральный округ }\end{array}$ & 4236,4 & 3959,6 & 276,8 & 64,4 & 60,2 & 6,5 \\
\hline Республика Бурятия & 429,5 & 384,3 & 45,2 & 57,0 & 51,0 & 10,5 \\
\hline Республика Саха (Якутия) & 500,4 & 464,1 & 36,3 & 67,5 & 62,6 & 7,3 \\
\hline Забайкальский край & 522,9 & 471,6 & 51,3 & 62,6 & 56,4 & 9,8 \\
\hline Камчатский край & 181,7 & 175,2 & 6,5 & 70,2 & 67,7 & 3,6 \\
\hline Приморский край & 1000,2 & 946,0 & 54,3 & 63,3 & 59,8 & 5,4 \\
\hline Хабаровский край & 723,2 & 692,1 & 31,0 & 66,8 & 63,9 & 4,3 \\
\hline Амурская область & 403,5 & 378,0 & 25,6 & 63,0 & 59,0 & 6,3 \\
\hline Магаданская область & 87,9 & 82,8 & 5,1 & 75,7 & 71,3 & 5,8 \\
\hline Сахалинская область & 276,1 & 260,3 & 15,8 & 69,3 & 65,3 & 5,7 \\
\hline Еврейская авт. область & 79,5 & 75,2 & 4,3 & 62,0 & 58,6 & 5,4 \\
\hline Чукотский авт. округ & 31,6 & 30,1 & 1,5 & 81,1 & 77,3 & 4,7 \\
\hline
\end{tabular}


УРОВЕНЬ ЗАРЕГИСТРИРОВАННОЙ БЕЗРАБОТИЦЫ

на конец месяца, в процентах

\begin{tabular}{|c|c|c|c|}
\hline \multirow{3}{*}{\begin{tabular}{||l|} 
\\
Российская Федерация \\
\end{tabular}} & \multirow{3}{*}{$\begin{array}{c}\text { Сентябрь } \\
2020 \text { г. } \\
\\
\\
\mathbf{4 , 9} \\
\end{array}$} & \multicolumn{2}{|c|}{ Справочно } \\
\hline & & \multirow{2}{*}{$\begin{array}{c}\text { сентябрь } \\
2019 \text { 2. } \\
\\
\mathbf{0 , 9} \\
\end{array}$} & \multirow{2}{*}{$\begin{array}{c}\text { aвzycm } \\
2020 \text { 2. } \\
\\
\mathbf{4 , 8}\end{array}$} \\
\hline & & & \\
\hline Центральный федеральный округ & 3,3 & 0,6 & 3,3 \\
\hline Белгородская область & 2,3 & 0,6 & 2,4 \\
\hline Брянская область & 3,2 & 0,8 & 3,5 \\
\hline Владимирская область & 4,3 & 0,9 & 4,3 \\
\hline Воронежская область & 4,3 & 0,8 & 4,1 \\
\hline Ивановская область & 5,0 & 0,7 & 4,9 \\
\hline Калужская область & 2,4 & 0,4 & 2,6 \\
\hline Костромская область & 5,8 & 0,7 & 5,7 \\
\hline Курская область & 3,5 & 0,6 & 3,6 \\
\hline Липецкая область & 1,4 & 0,4 & 1,6 \\
\hline Московская область & 3,6 & 0,5 & 3,5 \\
\hline Орловская область & 3,6 & 0,8 & 3,8 \\
\hline Рязанская область & 3,3 & 0,7 & 3,2 \\
\hline Смоленская область & 4,5 & 1,0 & 4,5 \\
\hline Тамбовская область & 2,0 & 0,6 & 2,1 \\
\hline Тверская область & 3,3 & 0,6 & 3,2 \\
\hline Тульская область & 2,8 & 0,4 & 2,8 \\
\hline Ярославская область & 4,7 & 1,1 & 4,7 \\
\hline г. Москва & 3,1 & 0,4 & 3,0 \\
\hline Северо-Западный федеральный округ & 4,2 & 0,7 & 4,2 \\
\hline Республика Карелия & 5,5 & 1,7 & 5,8 \\
\hline Республика Коми & 5,1 & 1,3 & 5,2 \\
\hline Архангельская область & 5,0 & 1,4 & 5,0 \\
\hline $\begin{array}{l}\text { в том числе: } \\
\text { Ненецкий авт. округ }\end{array}$ & 4,1 & 1,5 & 3,8 \\
\hline Архангельская область без авт. округа & 5,0 & 1,4 & 5,1 \\
\hline Вологодская область & 5,9 & 1,0 & 6,0 \\
\hline Калининградская область & 6,9 & 0,8 & 6,8 \\
\hline Ленинградская область & 3,4 & 0,4 & 3,4 \\
\hline Мурманская область & 2,9 & 1,3 & 2,8 \\
\hline Новгородская область & 4,3 & 0,9 & 4,3 \\
\hline Псковская область & 3,7 & 0,7 & 3,9 \\
\hline г. Санкт-Петербург & 3,5 & 0,4 & 3,5 \\
\hline Южный федеральный округ & 5,0 & 0,7 & 4,9 \\
\hline Республика Адыгея & 7,0 & 0,9 & 6,6 \\
\hline Республика Калмыкия & 7,7 & 1,3 & 7,2 \\
\hline Республика Крым & 5,2 & 0,4 & 4,9 \\
\hline Краснодарский край & 4,6 & 0,5 & 4,9 \\
\hline Астраханская область & 7,9 & 0,8 & 7,5 \\
\hline Волгоградская область & 3,6 & 0,7 & 3,9 \\
\hline Ростовская область & 5,5 & 0,8 & 5,2 \\
\hline г. Севастополь & 1,3 & 0,2 & 1,4 \\
\hline Северо-Кавказский федеральный округ & 12,5 & 2,6 & 11,8 \\
\hline Республика Дагестан & 10,2 & 1,5 & 8,8 \\
\hline Республика Ингушетия & 25,0 & 9,4 & 24,0 \\
\hline Кабардино-Балкарская Республика & 16,1 & 1,3 & 15,1 \\
\hline Карачаево-Черкесская Республика & 13,1 & 1,3 & 12,6 \\
\hline Республика Северная Осетия - Алания & 8,8 & 1,7 & 8,2 \\
\hline Чеченская Республика & 25,9 & 8,0 & 25,8 \\
\hline Ставропольский край & 6,0 & 0,7 & 5,7 \\
\hline
\end{tabular}




\begin{tabular}{|c|c|c|c|}
\hline & Сентябрь & & \\
\hline & 2020 z. & $\begin{array}{c}\text { сентябррь } \\
2019 \text { г. }\end{array}$ & $\begin{array}{l}\text { aвгусm } \\
2020 z .\end{array}$ \\
\hline Приволжский федеральный округ & 4,8 & 0,8 & 4,8 \\
\hline Республика Башкортостан & 6,8 & 0,9 & 6,7 \\
\hline Республика Марий Эл & 3,2 & 0,7 & 3,3 \\
\hline Республика Мордовия & 3,4 & 0,8 & 3,3 \\
\hline Республика Татарстан & 3,8 & 0,5 & 3,9 \\
\hline Удмуртская Республика & 3,6 & 0,8 & 3,9 \\
\hline Чувашская Республика & 4,5 & 0,7 & 4,9 \\
\hline Пермский край & 4,9 & 1,2 & 5,6 \\
\hline Кировская область & 4,4 & 1,1 & 4,6 \\
\hline Нижегородская область & 3,6 & 0,4 & 3,5 \\
\hline Оренбургская область & 7,8 & 1,2 & 7,4 \\
\hline Пензенская область & 5,2 & 0,8 & 5,1 \\
\hline Самарская область & 4,2 & 0,8 & 4,1 \\
\hline Саратовская область & 5,3 & 0,8 & 5,1 \\
\hline Ульяновская область & 5,2 & 0,4 & 5,1 \\
\hline Уральский федеральный округ & 4,9 & 0,9 & 4,8 \\
\hline Курганская область & 7,0 & 1,3 & 6,6 \\
\hline Свердловская область & 5,7 & 1,0 & 5,5 \\
\hline Тюменская область & 3,5 & 0,5 & 3,7 \\
\hline $\begin{array}{l}\text { в том числе: } \\
\text { Ханты-Мансийский авт. округ - Югра }\end{array}$ & 3,2 & 0,4 & 3,2 \\
\hline Ямало-Ненецкий авт. округ & 2,3 & 0,5 & 2,3 \\
\hline Тюменская область без авт. округов & 4,4 & 0,5 & 4,8 \\
\hline Челябинская область & 4,9 & 1,1 & 4,9 \\
\hline Сибирский федеральный округ & 5,7 & 1,1 & 5,5 \\
\hline Республика Алтай & 13,3 & 2,0 & 12,8 \\
\hline Республика Тыва & 23,6 & 3,6 & 24,4 \\
\hline Республика Хакасия & 5,5 & 1,3 & 5,5 \\
\hline Алтайский край & 3,5 & 1,2 & 3,5 \\
\hline Красноярский край & 4,9 & 0,7 & 5,0 \\
\hline Иркутская область & 5,5 & 1,0 & 5,3 \\
\hline Кемеровская область & 6,6 & 1,4 & 6,2 \\
\hline Новосибирская область & 5,5 & 0,9 & 5,3 \\
\hline Омская область & 5,6 & 1,0 & 5,5 \\
\hline Томская область & 5,6 & 1,0 & 5,3 \\
\hline Дальневосточный федеральный округ & 4,4 & 1,2 & 4,5 \\
\hline Республика Бурятия & 6,3 & 1,1 & 6,6 \\
\hline Республика Саха (Якутия) & 6,5 & 1,6 & 6,5 \\
\hline Забайкальский край & 6,8 & 1,1 & 7,0 \\
\hline Камчатский край & 2,1 & 1,2 & 2,0 \\
\hline Приморский край & 2,8 & 1,0 & 3,3 \\
\hline Хабаровский край & 3,8 & 0,8 & 3,6 \\
\hline Амурская область & 5,3 & 2,2 & 5,2 \\
\hline Магаданская область & 2,4 & 1,1 & 2,4 \\
\hline Сахалинская область & 0,8 & 0,4 & 0,8 \\
\hline Еврейская авт. область & 5,5 & 1,0 & 5,2 \\
\hline Чукотский авт. округ & 2,1 & 1,8 & 2,2 \\
\hline
\end{tabular}


ЧИСЛЕННОСТЬ НЕ ЗАНЯТЫХ ТРУДОВОЙ ДЕЯТЕЛЬНОСТЬЮ ГРАЖДАН, СОСТОЯЩИХ НА УЧЕТЕ В ОРГАНАХ СЛУЖБЫ ЗАНЯТОСТИ НАСЕЛЕНИЯ (по данным Федеральной службы по труду и занятости)

на конец месяца, тыс. человек

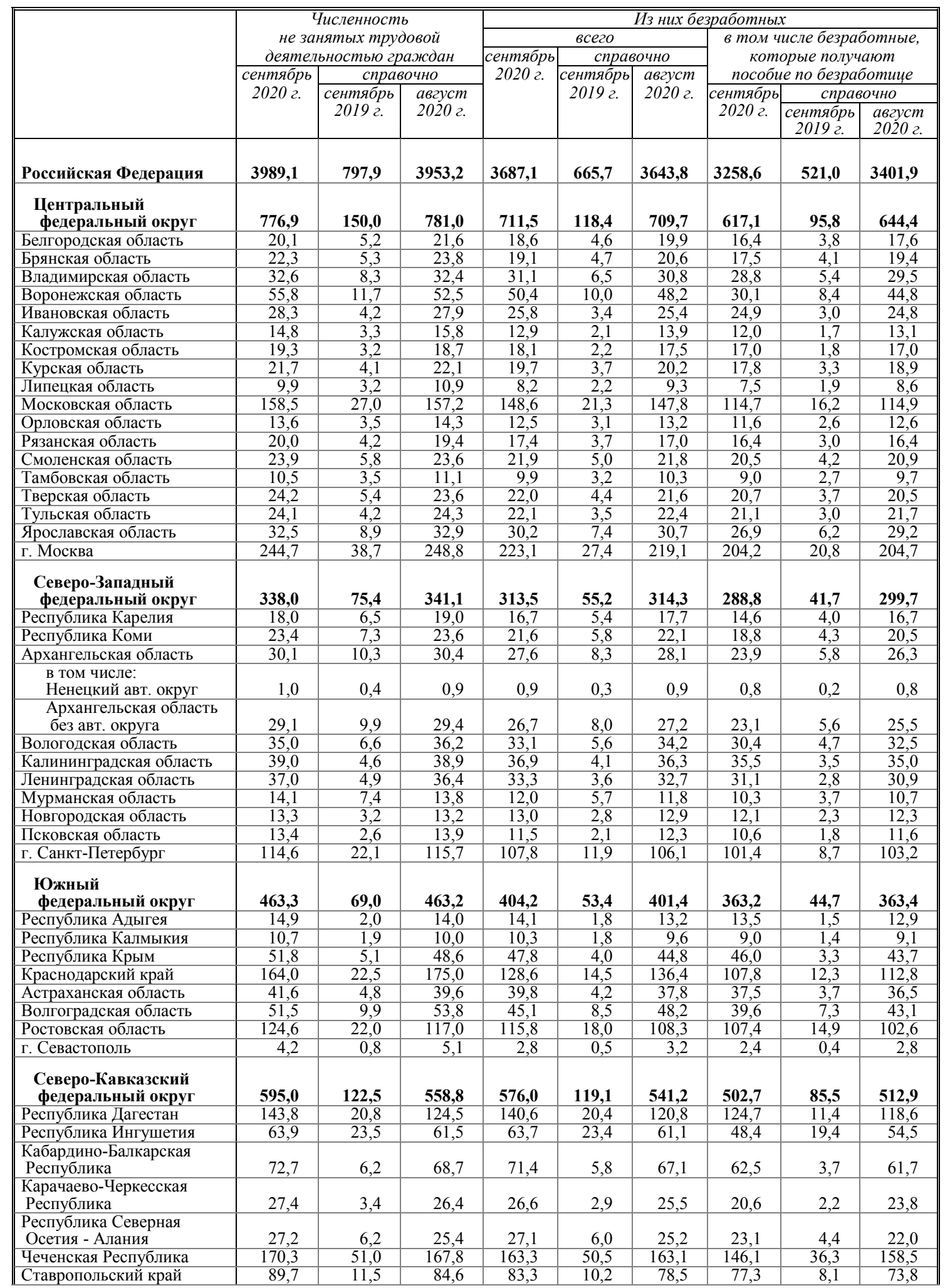




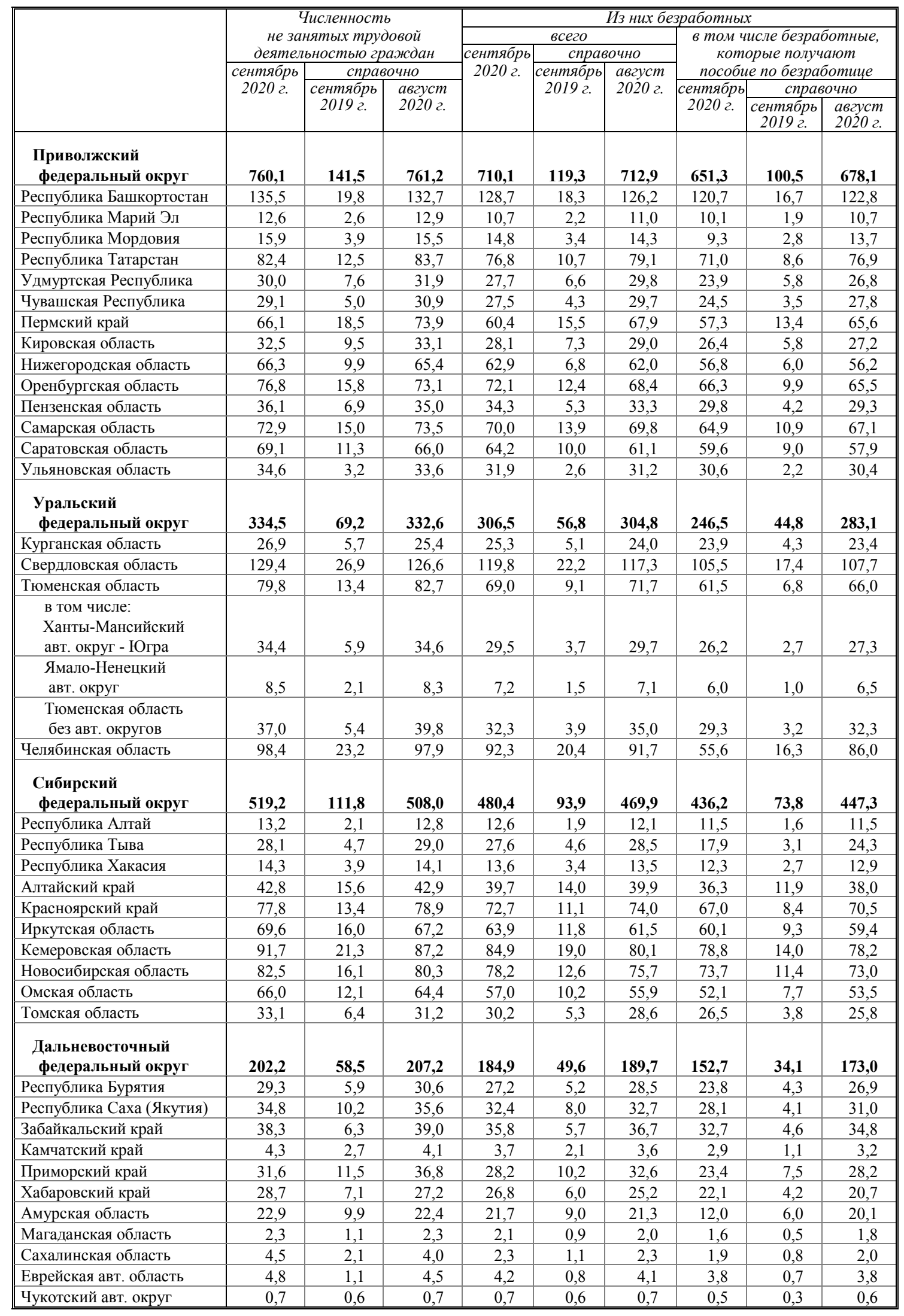


ПОТРЕБНОСТЬ РАБОТОДАТЕЛЕЙ В РАБОТНИКАХ, ЗАЯВЛЕННАЯ В ОРГАНЫ СЛУЖБЫ ЗАНЯТОСТИ НАСЕЛЕНИЯ (по данным Федеральной службы по труду и занятости)

на конец месяца, человек

\begin{tabular}{|c|c|c|c|}
\hline \multirow{3}{*}{ Российская Федерация } & \multirow{3}{*}{$\begin{array}{c}\text { Сентябрь } \\
2020 \text { г. } \\
\\
\mathbf{1 7 7 4 0 4 4} \\
\end{array}$} & \multicolumn{2}{|c|}{ Справочно } \\
\hline & & \multirow{2}{*}{$\begin{array}{c}\text { сентябрь } \\
2019 \text { г. } \\
\\
\mathbf{1 7 2 1 8 8 5}\end{array}$} & \multirow{2}{*}{$\begin{array}{r}\text { aвzycm } \\
20202 . \\
\mathbf{1 6 9 2 4 6 3} \\
\end{array}$} \\
\hline & & & \\
\hline Центральный федеральный округ & 405086 & 379387 & 374056 \\
\hline Белгородская область & 23650 & 25321 & 22991 \\
\hline Брянская область & 9775 & 9146 & 9207 \\
\hline Владимирская область & 22177 & 21025 & 22350 \\
\hline Воронежская область & 22677 & 22187 & 19761 \\
\hline Ивановская область & 11974 & 10384 & 11323 \\
\hline Калужская область & 11600 & 11825 & 11105 \\
\hline Костромская область & 8646 & 7949 & 8021 \\
\hline Курская область & 12302 & 9317 & 11292 \\
\hline Липецкая область & 10861 & 11274 & 11057 \\
\hline Московская область & 51431 & 46355 & 50115 \\
\hline Орловская область & 7557 & 6520 & 7066 \\
\hline Рязанская область & 11232 & 10132 & 10821 \\
\hline Смоленская область & 10762 & 9045 & 10127 \\
\hline Тамбовская область & 12339 & 11583 & 11233 \\
\hline Тверская область & 15212 & 14666 & 14687 \\
\hline Тульская область & 24587 & 24493 & 23195 \\
\hline Ярославская область & 12335 & 13077 & 12506 \\
\hline г. Москва & 125969 & 115088 & 107199 \\
\hline Северо-Западный федеральный округ & 160564 & 165437 & 154392 \\
\hline Республика Карелия & 5049 & 5647 & 5480 \\
\hline Республика Коми & 14393 & 11989 & 14208 \\
\hline Архангельская область & 14357 & 14892 & 13442 \\
\hline $\begin{array}{l}\text { в том числе: } \\
\text { Ненецкий авт. округ }\end{array}$ & 884 & 598 & 825 \\
\hline Архангельская область без авт. округа & 13473 & 14294 & 12617 \\
\hline Вологодская область & 14514 & 16269 & 14802 \\
\hline Калининградская область & 14528 & 17939 & 12701 \\
\hline Ленинградская область & 19795 & 23767 & 18565 \\
\hline Мурманская область & 26744 & 21579 & 26797 \\
\hline Новгородская область & 8679 & 6229 & 7394 \\
\hline Псковская область & 9716 & 9550 & 8667 \\
\hline г. Санкт-Петербург & 32789 & 37576 & 32336 \\
\hline Южный федеральный округ & 165681 & 178921 & 164252 \\
\hline Республика Адыгея & 3329 & 2750 & 3281 \\
\hline Республика Калмыкия & 2029 & 2218 & 2032 \\
\hline Республика Крым & 16303 & 16727 & 18463 \\
\hline Краснодарский край & 49042 & 53644 & 50431 \\
\hline Астраханская область & 11500 & 8424 & 9266 \\
\hline Волгоградская область & 32441 & 37808 & 31864 \\
\hline Ростовская область & 47846 & 53806 & 45544 \\
\hline г. Севастополь & 3191 & 3544 & 3371 \\
\hline Северо-Кавказский федеральный округ & 34742 & 41199 & 33919 \\
\hline Республика Дагестан & 1128 & 1074 & 889 \\
\hline Республика Ингушетия & 344 & 166 & 58 \\
\hline Кабардино-Балкарская Республика & 4047 & 3814 & 3966 \\
\hline Карачаево-Черкесская Республика & 2311 & 2225 & 1985 \\
\hline Республика Северная Осетия - Алания & 1389 & 1154 & 1542 \\
\hline Чеченская Республика & 1613 & 1827 & 2050 \\
\hline Ставропольский край & 23910 & 30939 & 23429 \\
\hline
\end{tabular}




\begin{tabular}{|c|c|c|c|}
\hline & Сентябрь & & \\
\hline & $2020 z$. & $\begin{array}{c}\text { сентябрь } \\
2019 \text { г. }\end{array}$ & $\begin{array}{l}\text { aвгусm } \\
2020 \text { 2. }\end{array}$ \\
\hline Приволжский федеральный округ & 339711 & 323638 & 320588 \\
\hline Республика Башкортостан & 46773 & 49474 & 43235 \\
\hline Республика Марий Эл & 6203 & 5793 & 6015 \\
\hline Республика Мордовия & 7521 & 6390 & 6967 \\
\hline Республика Татарстан & 47086 & 48899 & 45947 \\
\hline Удмуртская Республика & 17375 & 13824 & 16250 \\
\hline Чувашская Республика & 16695 & 20293 & 17671 \\
\hline Пермский край & 20646 & 25732 & 20839 \\
\hline Кировская область & 17871 & 14376 & 16980 \\
\hline Нижегородская область & 51128 & 43381 & 44980 \\
\hline Оренбургская область & 13255 & 11164 & 10987 \\
\hline Пензенская область & 16833 & 10196 & 16117 \\
\hline Самарская область & 36392 & 31354 & 34514 \\
\hline Саратовская область & 26912 & 30620 & 25751 \\
\hline Ульяновская область & 15021 & 12142 & 14335 \\
\hline Уральский федеральный округ & 155403 & 124604 & 149706 \\
\hline Курганская область & 9676 & 7876 & 8663 \\
\hline Свердловская область & 44873 & 41948 & 43659 \\
\hline Тюменская область & 67303 & 48751 & 65796 \\
\hline $\begin{array}{l}\text { в том числе: } \\
\text { Ханты-Мансийский авт. округ - Югра }\end{array}$ & 17460 & 16405 & 15565 \\
\hline Ямало-Ненецкий авт. округ & 12528 & 10421 & 12656 \\
\hline Тюменская область без авт. округов & 37315 & 21925 & 37575 \\
\hline Челябинская область & 33551 & 26029 & 31588 \\
\hline Сибирский федеральный округ & 291393 & 279295 & 285428 \\
\hline Республика Алтай & 2209 & 1633 & 1872 \\
\hline Республика Тыва & 1697 & 1092 & 1072 \\
\hline Республика Хакасия & 5826 & 4925 & 5252 \\
\hline Алтайский край & 19290 & 21967 & 17482 \\
\hline Красноярский край & 79582 & 70981 & 78959 \\
\hline Иркутская область & 58121 & 51732 & 60426 \\
\hline Кемеровская область & 32553 & 37687 & 30361 \\
\hline Новосибирская область & 45428 & 41984 & 44276 \\
\hline Омская область & 33374 & 34311 & 33555 \\
\hline Томская область & 13313 & 12983 & 12173 \\
\hline Дальневосточный федеральный округ & 221464 & 229404 & 210122 \\
\hline Республика Бурятия & 12869 & 13583 & 10816 \\
\hline Республика Саха (Якутия) & 10070 & 13644 & 9741 \\
\hline Забайкальский край & 20798 & 15622 & 17926 \\
\hline Камчатский край & 7474 & 6671 & 7739 \\
\hline Приморский край & 65067 & 66971 & 65771 \\
\hline Хабаровский край & 24376 & 14791 & 19851 \\
\hline Амурская область & 55811 & 69751 & 53793 \\
\hline Магаданская область & 3302 & 4488 & 3307 \\
\hline Сахалинская область & 10637 & 12939 & 10771 \\
\hline Еврейская авт. область & 9711 & 9669 & 9075 \\
\hline Чукотский авт. округ & 1349 & 1275 & 1332 \\
\hline
\end{tabular}




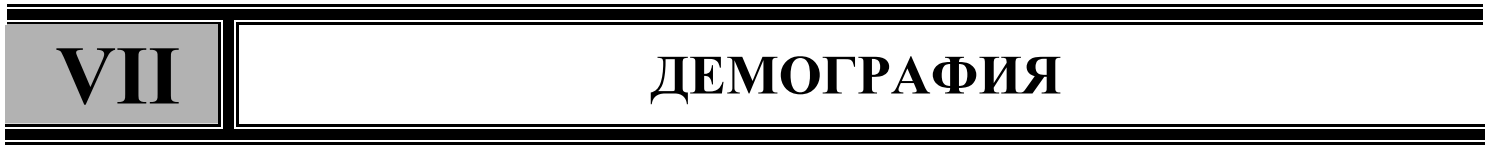

РОДИВШИЕСЯ, УМЕРШИЕ И ЕСТЕСТВЕННЫЙ ПРИРОСТ НАСЕЛЕНИЯ в январе-августе

человек

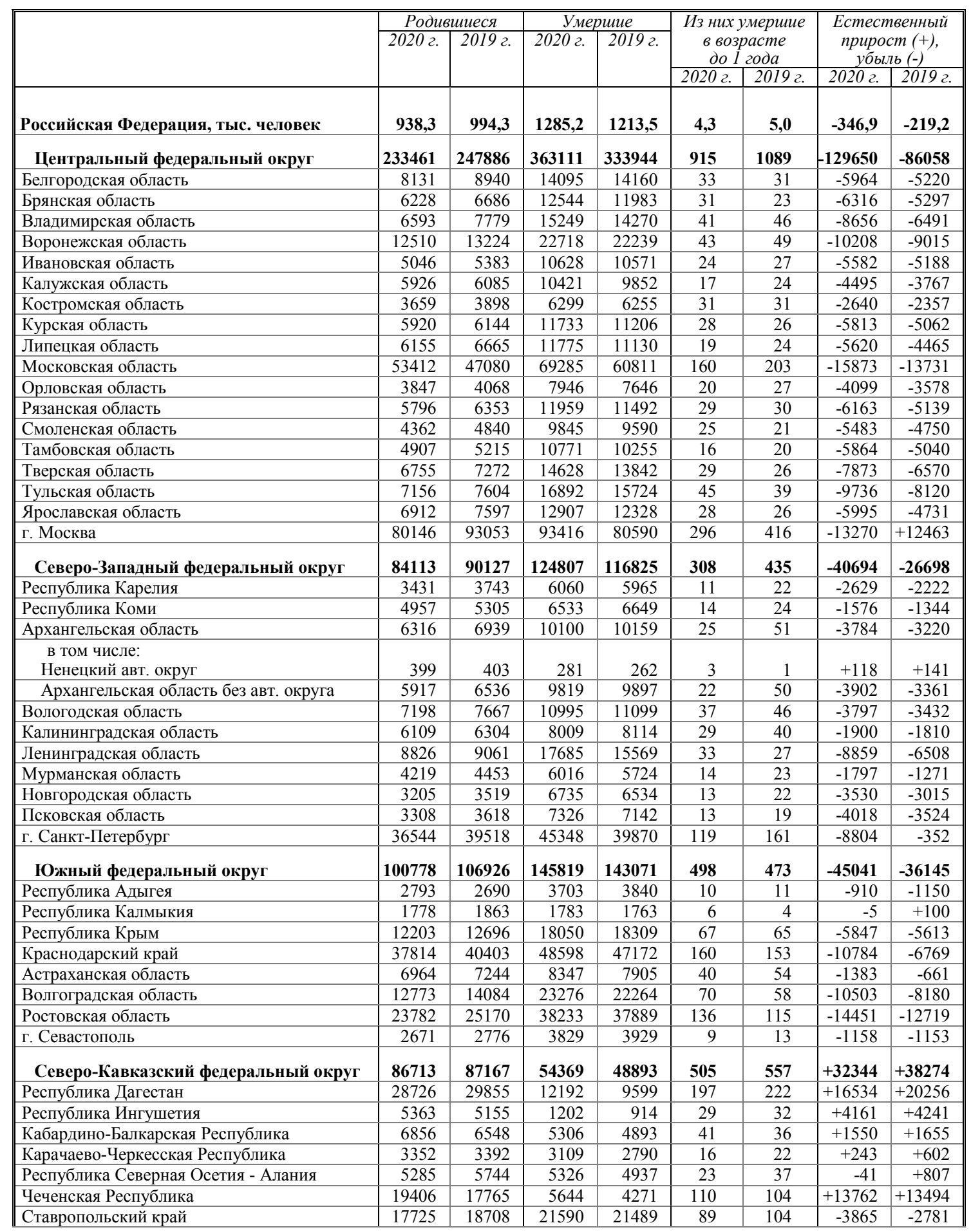




\begin{tabular}{|c|c|c|c|c|c|c|c|c|}
\hline & \multicolumn{2}{|c|}{ е Родившиеся } & \multicolumn{2}{|c|}{ "Умериие } & \multirow{2}{*}{\multicolumn{2}{|c|}{$\begin{array}{c}\text { Из них умершие } \\
\text { в возрасте } \\
\text { до 1 года }\end{array}$}} & \multirow{2}{*}{\multicolumn{2}{|c|}{$\begin{array}{c}\text { Естественный } \\
\text { прирост (+), } \\
\text { убыль (-) }\end{array}$}} \\
\hline & \multirow[t]{2}{*}{20202.} & \multirow[t]{2}{*}{20192.} & \multirow[t]{2}{*}{20202.} & \multirow[t]{2}{*}{20192.} & & & & \\
\hline & & & & & 20202. & 20192. & 20202. & $2019 z$. \\
\hline Приволжский федеральный округ & 177831 & 189205 & 275811 & 255417 & 795 & 908 & -97980 & -66212 \\
\hline Республика Башкортостан & 27084 & 28343 & 36076 & 33042 & 151 & 189 & -8992 & -4699 \\
\hline Республика Марий Эл & 4378 & 4503 & 5901 & 5471 & 23 & 19 & -1523 & -968 \\
\hline Республика Мордовия & 3651 & 4040 & 7772 & 7071 & 9 & 17 & -4121 & -3031 \\
\hline Республика Татарстан & 27287 & 28467 & 33096 & 28674 & 116 & 141 & -5809 & -207 \\
\hline Удмуртская Республика & 9579 & 9889 & 12358 & 12087 & 45 & 44 & -2779 & -2198 \\
\hline Чувашская Республика & 7392 & 7833 & 11622 & 10185 & 16 & 28 & -4230 & -2352 \\
\hline Пермский край & 16792 & 18095 & 23940 & 23029 & 84 & 81 & -7148 & -4934 \\
\hline Кировская область & 7019 & 7623 & 12322 & 12220 & 24 & 26 & -5303 & -4597 \\
\hline Нижегородская область & 18187 & 19421 & 33499 & 31370 & 94 & 103 & -15312 & -11949 \\
\hline Оренбургская область & 12472 & 13180 & 18238 & 17359 & 47 & 64 & -5766 & -4179 \\
\hline Пензенская область & 6401 & 7042 & 13990 & 12350 & 29 & 38 & -7589 & -5308 \\
\hline Самарская область & 18521 & 19939 & 30807 & 28325 & 75 & 83 & -12286 & -8386 \\
\hline Саратовская область & 12219 & 13523 & 23901 & 22734 & 54 & 46 & -11682 & -9211 \\
\hline Ульяновская область & 6849 & 7307 & 12289 & 11500 & 28 & 29 & -5440 & -4193 \\
\hline Уральский федеральный округ & 86189 & 91587 & 102573 & 97817 & 351 & 443 & -16384 & -6230 \\
\hline Курганская область & 4907 & 5186 & 8601 & 8754 & 32 & 23 & -3694 & -3568 \\
\hline Свердловская область & 29196 & 31548 & 41048 & 38838 & 127 & 156 & -11852 & -7290 \\
\hline Тюменская область & 30258 & 31604 & 20912 & 19353 & 116 & 141 & +9346 & +12251 \\
\hline $\begin{array}{l}\text { в том числе: } \\
\text { Ханты-Мансийский авт. округ - Югра }\end{array}$ & 13364 & 14112 & 7609 & 6752 & 49 & 61 & +5755 & +7360 \\
\hline Ямало-Ненецкий авт. округ & 4650 & 4568 & 2001 & 1691 & 14 & 26 & +2649 & +2877 \\
\hline Тюменская область без авт. округов & 12244 & 12924 & 11302 & 10910 & 53 & 54 & +942 & +2014 \\
\hline Челябинская область & 21828 & 23249 & 32012 & 30872 & 76 & 123 & -10184 & -7623 \\
\hline Сибирский федеральный округ & 111232 & 120637 & 151785 & 149932 & 640 & 710 & -40553 & -29295 \\
\hline Республика Алтай & 1940 & 2023 & 1531 & 1476 & 14 & 20 & +409 & +547 \\
\hline Республика Тыва & 4140 & 4100 & 1929 & 1879 & 20 & 28 & +2211 & +2221 \\
\hline Республика Хакасия & 3544 & 3788 & 4524 & 4487 & 14 & 13 & -980 & -699 \\
\hline Алтайский край & 13222 & 14502 & 21256 & 22261 & 71 & 77 & -8034 & -7759 \\
\hline Красноярский край & 19271 & 20671 & 24344 & 23807 & 110 & 133 & -5073 & -3136 \\
\hline Иркутская область & 18088 & 19141 & 21421 & 21141 & 122 & 116 & -3333 & -2000 \\
\hline Кемеровская область & 14869 & 16322 & 25169 & 25975 & 84 & 105 & -10300 & -9653 \\
\hline Новосибирская область & 18083 & 20214 & 25514 & 24112 & 96 & 93 & -7431 & -3898 \\
\hline Омская область & 11531 & 12840 & 17689 & 16689 & 76 & 93 & -6158 & -3849 \\
\hline Томская область & 6544 & 7036 & 8408 & 8105 & 33 & 32 & -1864 & -1069 \\
\hline Дальневосточный федеральный округ & 57978 & 60768 & 66924 & 67552 & 292 & 357 & -8946 & -6784 \\
\hline Республика Бурятия & 8314 & 8307 & 6949 & 7414 & 44 & 58 & +1365 & +893 \\
\hline Республика Саха (Якутия) & 8234 & 8435 & 5232 & 5128 & 36 & 42 & +3002 & +3307 \\
\hline Забайкальский край & 8129 & 8405 & 8895 & 8935 & 48 & 57 & -766 & -530 \\
\hline Камчатский край & 2092 & 2173 & 2477 & 2314 & 10 & 13 & -385 & -141 \\
\hline Приморский край & 11476 & 12247 & 17218 & 17430 & 62 & 75 & -5742 & -5183 \\
\hline Хабаровский край & 8774 & 9694 & 11862 & 11866 & 36 & 41 & -3088 & -2172 \\
\hline Амурская область & 5150 & 5272 & 7395 & 7461 & 24 & 31 & -2245 & -2189 \\
\hline Магаданская область & 856 & 899 & 1054 & 1099 & 4 & 4 & -198 & -200 \\
\hline Сахалинская область & 3589 & 3808 & 4036 & 4090 & 19 & 18 & -447 & -282 \\
\hline Еврейская авт. область & 1007 & 1175 & 1484 & 1505 & 6 & 12 & -477 & -330 \\
\hline Чукотский авт. округ & 357 & 353 & 322 & 310 & 3 & 6 & +35 & +43 \\
\hline
\end{tabular}


КОЭФФИЦИЕНТЫ РОЖДАЕМОСТИ, СМЕРТНОСТИ

И ЕСТЕСТВЕННОГО ПРИРОСТА НАСЕЛЕНИЯ

(в пересчете на год)

в январе-августе

\begin{tabular}{|c|c|c|c|c|c|c|c|c|}
\hline & \multicolumn{6}{|c|}{ На 1000 человек населения } & \multirow{4}{*}{\multicolumn{2}{|c|}{$\begin{array}{c}\text { Число детей, } \\
\text { умерших в } \\
\text { возрасте до } \\
1 \text { года, на } 1000 \\
\text { родившихся } \\
\text { живыми }\end{array}$}} \\
\hline & \multicolumn{2}{|c|}{ родивиихся } & \multicolumn{2}{|c|}{ умериих } & \multirow{2}{*}{\multicolumn{2}{|c|}{$\begin{array}{c}\text { естественный } \\
\text { прирост (+), } \\
\text { убыль (-) }\end{array}$}} & & \\
\hline & \multirow[t]{3}{*}{20202} & \multirow[t]{3}{*}{20192.} & \multirow[t]{3}{*}{20202} & \multirow[t]{3}{*}{20192.} & & & & \\
\hline & & & & & 20202 & 20192. & & \\
\hline & & & & & & & 20202. & $2019 z$. \\
\hline Российская Федерация & 9,6 & 10,2 & 13,2 & 12,4 & $-3,6$ & $-2,2$ & 4,4 & 4,8 \\
\hline Центральный федеральный округ & 8,9 & 9,5 & 13,8 & 12,8 & $-4,9$ & $-3,3$ & 3,8 & 4,3 \\
\hline Белгородская область & 7,9 & 8,7 & 13,7 & 13,8 & $-5,8$ & $-5,1$ & 3,9 & 3,3 \\
\hline Брянская область & 7,9 & 8,4 & 15,8 & 15,0 & $-7,9$ & $-6,6$ & 4,8 & 3,2 \\
\hline Владимирская область & 7,3 & 8,6 & 16,9 & 15,7 & $-9,6$ & $-7,1$ & 5,8 & 5,6 \\
\hline Воронежская область & 8,1 & 8,5 & 14,7 & 14,4 & $-6,6$ & $-5,9$ & 3,4 & 3,5 \\
\hline Ивановская область & 7,6 & 8,1 & 16,0 & 15,9 & $-8,4$ & $-7,8$ & 4,6 & 4,6 \\
\hline Калужская область & 8,9 & 9,1 & 15,6 & 14,7 & $-6,7$ & $-5,6$ & 2,9 & 3,6 \\
\hline Костромская область & 8,7 & 9,2 & 14,9 & 14,8 & $-6,2$ & $-5,6$ & 8,2 & 7,7 \\
\hline Курская область & 8,1 & 8,4 & 16,0 & 15,2 & $-7,9$ & $-6,8$ & 4,6 & 3,9 \\
\hline Липецкая область & 8,1 & 8,8 & 15,5 & 14,6 & $-7,4$ & $-5,8$ & 3,0 & 3,4 \\
\hline Московская область & 10,4 & 9,3 & 13,5 & 12,0 & $-3,1$ & $-2,7$ & 3,1 & 3,9 \\
\hline Орловская область & 7,9 & 8,3 & 16,3 & 15,6 & $-8,4$ & $-7,3$ & 5,1 & 6,3 \\
\hline Рязанская область & 7,9 & 8,6 & 16,2 & 15,5 & $-8,3$ & $-6,9$ & 4,8 & 4,5 \\
\hline Смоленская область & 7,0 & 7,7 & 15,8 & 15,3 & $-8,8$ & $-7,6$ & 5,5 & 4,2 \\
\hline Тамбовская область & 7,3 & 7,7 & 16,1 & 15,2 & $-8,8$ & $-7,5$ & 3,2 & 3,7 \\
\hline Тверская область & 8,1 & 8,6 & 17,5 & 16,4 & $-9,4$ & $-7,8$ & 4,1 & 3,4 \\
\hline Тульская область & 7,3 & 7,7 & 17,3 & 16,0 & $-10,0$ & $-8,3$ & 6,1 & 4,9 \\
\hline Ярославская область & 8,3 & 9,1 & 15,5 & 14,7 & $-7,2$ & $-5,6$ & 3,8 & 3,2 \\
\hline г. Москва & 9,5 & 11,1 & 11,1 & 9,6 & $-1,6$ & $+1,5$ & 3,4 & 4,6 \\
\hline Северо-Западный федеральный округ & 9,0 & 9,7 & 13,4 & 12,6 & $-4,4$ & $-2,9$ & 3,5 & 4,6 \\
\hline Республика Карелия & 8,4 & 9,1 & 14,8 & 14,5 & $-6,4$ & $-5,4$ & 3,1 & 5,6 \\
\hline Республика Коми & 9,1 & 9,6 & 12,0 & 12,0 & $-2,9$ & $-2,4$ & 2,7 & 4,3 \\
\hline Архангельская область & 8,3 & 9,1 & 13,4 & 13,4 & $-5,1$ & $-4,3$ & 3,7 & 7,0 \\
\hline $\begin{array}{l}\text { в том числе: } \\
\text { Ненецкий авт. округ }\end{array}$ & 13,5 & 13,8 & 9,5 & 9,0 & $+4,0$ & $+4,8$ & 7,6 & 2,5 \\
\hline Архангельская область без авт. округа & 8,1 & 8,9 & 13,5 & 13,5 & $-5,4$ & $-4,6$ & 3,5 & 7,3 \\
\hline Вологодская область & 9,3 & 9,9 & 14,2 & 14,3 & $-4,9$ & $-4,4$ & 5,0 & 5,7 \\
\hline Калининградская область & 9,1 & 9,5 & 11,9 & 12,2 & $-2,8$ & $-2,7$ & 4,7 & 6,0 \\
\hline Ленинградская область & 7,1 & 7,4 & 14,2 & 12,7 & $-7,1$ & $-5,3$ & 3,7 & 2,9 \\
\hline Мурманская область & 8,5 & 8,9 & 12,2 & 11,5 & $-3,7$ & $-2,6$ & 3,2 & 4,8 \\
\hline Новгородская область & 8,1 & 8,8 & 17,0 & 16,4 & $-8,9$ & $-7,6$ & 3,9 & 5,9 \\
\hline Псковская область & 8,0 & 8,7 & 17,6 & 17,1 & $-9,6$ & $-8,4$ & 3,8 & 5,0 \\
\hline г. Санкт-Петербург & 10,2 & 11,0 & 12,6 & 11,1 & $-2,4$ & $-0,1$ & 3,1 & 3,9 \\
\hline Южный федеральный округ & 9,2 & 9,8 & 13,3 & 13,1 & $-4,1$ & $-3,3$ & 4,7 & 4,2 \\
\hline Республика Адыгея & 9,1 & 8,9 & 12,0 & 12,7 & $-2,9$ & $-3,8$ & 3,5 & 3,8 \\
\hline Республика Калмыкия & 9,8 & 10,3 & 9,9 & 9,7 & $-0,1$ & $+0,6$ & 3,2 & 2,0 \\
\hline Республика Крым & 9,6 & 10,0 & 14,2 & 14,4 & $-4,6$ & $-4,4$ & 5,3 & 4,9 \\
\hline Краснодарский край & 10,0 & 10,8 & 12,9 & 12,6 & $-2,9$ & $-1,8$ & 4,0 & 3,6 \\
\hline Астраханская область & 10,4 & 10,7 & 12,5 & 11,7 & $-2,1$ & $-1,0$ & 5,5 & 7,1 \\
\hline Волгоградская область & 7,7 & 8,5 & 14,0 & 13,4 & $-6,3$ & $-4,9$ & 5,1 & 3,8 \\
\hline Ростовская область & 8,5 & 9,0 & 13,7 & 13,6 & $-5,2$ & $-4,6$ & 5,5 & 4,3 \\
\hline г. Севастополь & 8,9 & 9,4 & 12,8 & 13,3 & $-3,9$ & $-3,9$ & 3,2 & 4,5 \\
\hline Северо-Кавказский федеральный округ & 13,1 & 13,2 & 8,2 & 7,4 & $+4,9$ & $+5,8$ & 5,7 & 6,0 \\
\hline Республика Дагестан & 13,8 & 14,5 & 5,9 & 4,7 & $+7,9$ & $+9,8$ & 6,6 & 7,1 \\
\hline Республика Ингушетия & 15,8 & 15,5 & 3,5 & 2,7 & $+12,3$ & $+12,8$ & 5,4 & 6,1 \\
\hline Кабардино-Балкарская Республика & 11,8 & 11,3 & 9,2 & 8,5 & $+2,6$ & $+2,8$ & 6,1 & 5,1 \\
\hline Карачаево-Черкесская Республика & 10,8 & 10,9 & 10,0 & 9,0 & $+0,8$ & $+1,9$ & 4,7 & 6,5 \\
\hline Республика Северная Осетия-Алания & 11,4 & 12,3 & 11,5 & 10,6 & $-0,1$ & $+1,7$ & 4,1 & 6,2 \\
\hline Чеченская Республика & 19,6 & 18,2 & 5,7 & 4,4 & $+13,9$ & $+13,8$ & 5,7 & 5,4 \\
\hline Ставропольский край & 9,5 & 10,1 & 11,6 & 11,6 & $-2,1$ & $-1,5$ & 4,8 & 5,2 \\
\hline
\end{tabular}




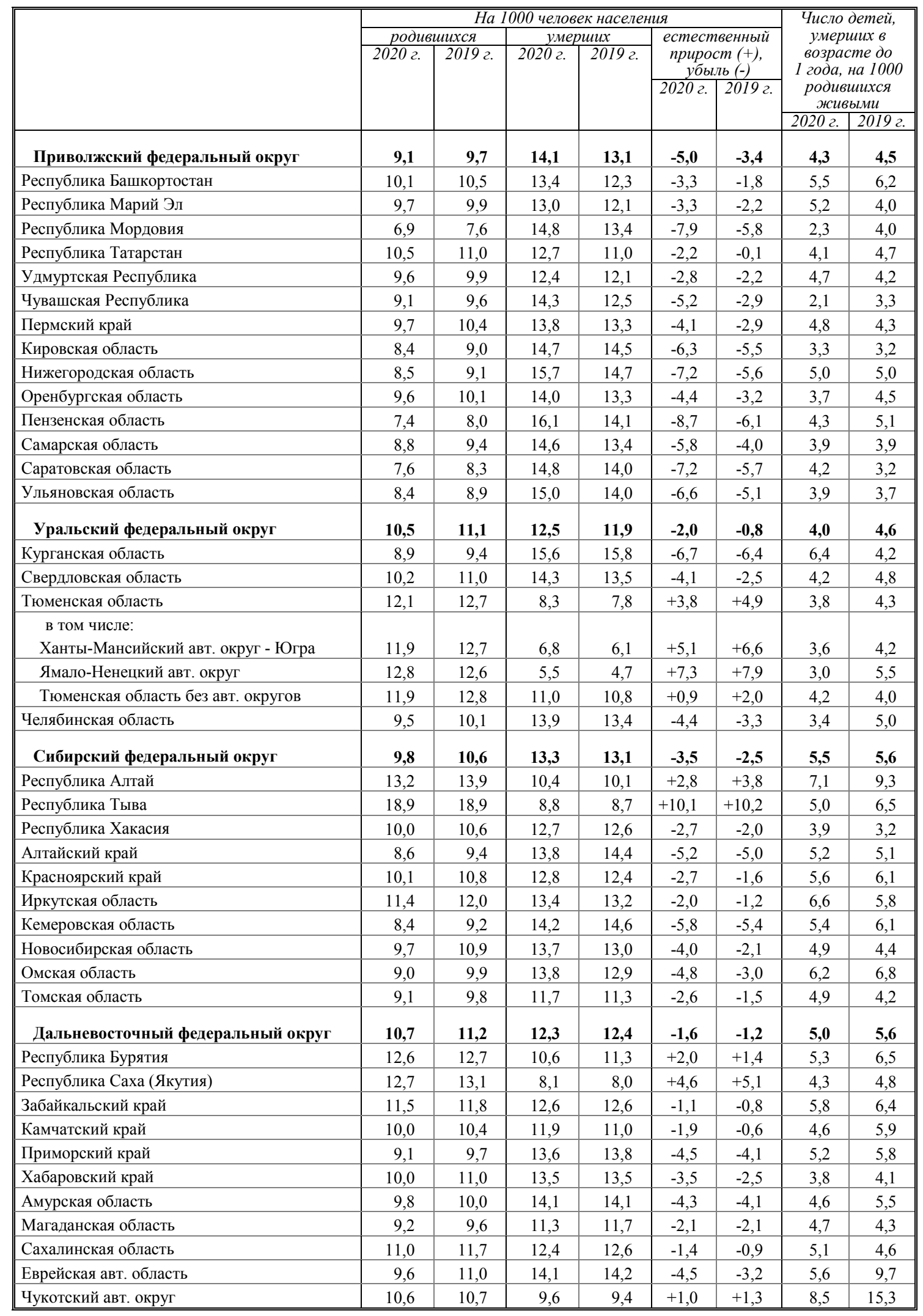


ЧИСЛО БРАКОВ И РАЗВОДОВ

в январе-августе

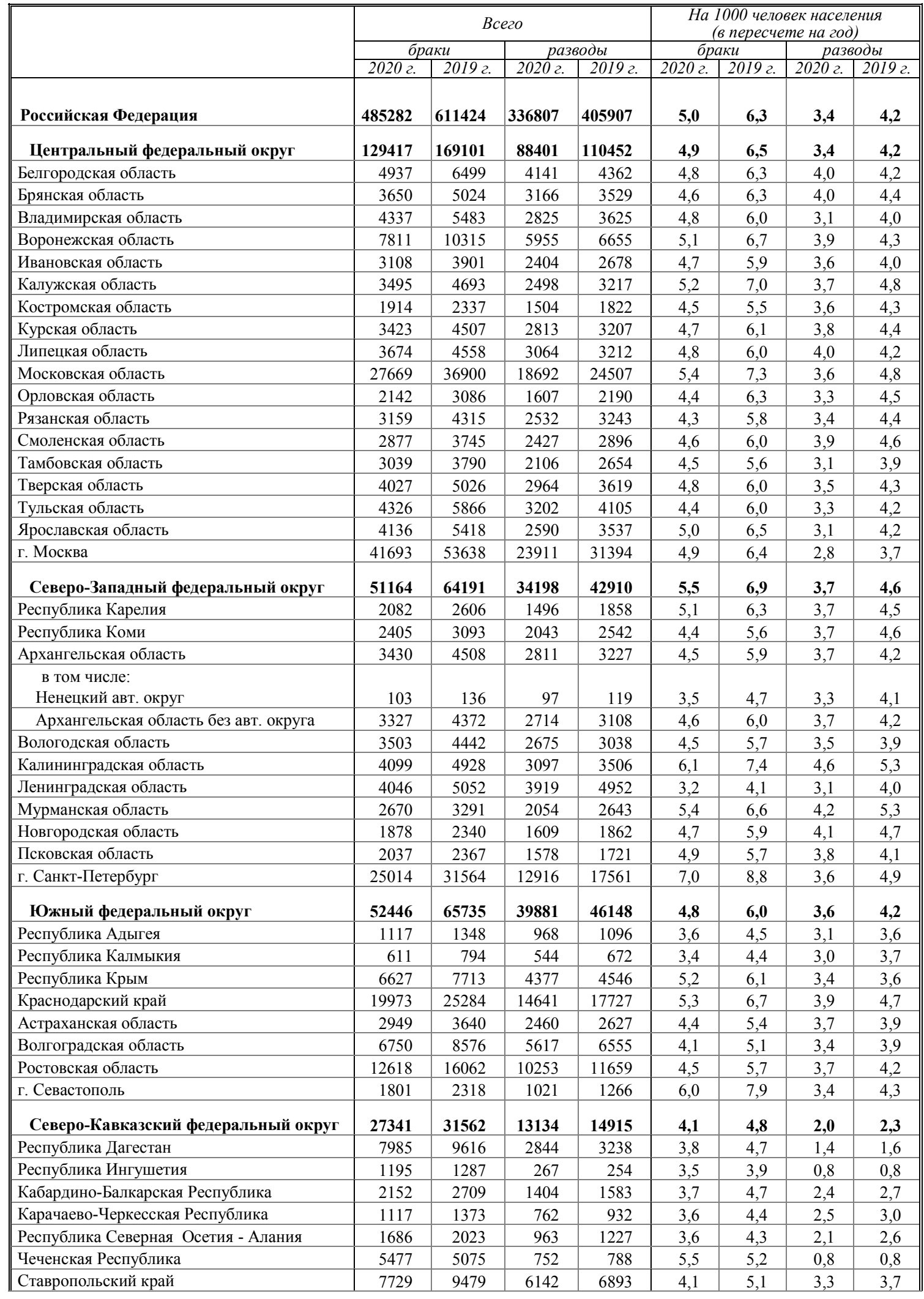




\begin{tabular}{|c|c|c|c|c|c|c|c|c|}
\hline & \multicolumn{4}{|c|}{ Всего } & \multicolumn{4}{|c|}{$\begin{array}{c}\text { На } 1000 \text { человек населения } \\
\text { (в пересчете на год) }\end{array}$} \\
\hline & \multicolumn{2}{|c|}{ браки } & \multicolumn{2}{|c|}{ paзводbl } & \multicolumn{2}{|c|}{ браки } & \multicolumn{2}{|c|}{ paзводbl } \\
\hline & 20202. & 20192. & 20202. & 20192. & 20202 & 20192. & 20202. & 20192. \\
\hline Приволжский федеральный округ & 90788 & 114679 & 64429 & 74953 & 4,7 & 5,9 & 3,3 & 3,8 \\
\hline Республика Башкортостан & 12817 & 16355 & 8787 & 10109 & 4,8 & 6,1 & 3,3 & 3,8 \\
\hline Республика Марий Эл & 1680 & 2234 & 1344 & 1542 & 3,7 & 4,9 & 3,0 & 3,4 \\
\hline Республика Мордовия & 1936 & 2647 & 1422 & 1750 & 3,7 & 5,0 & 2,7 & 3,3 \\
\hline Республика Татарстан & 12432 & 15630 & 6634 & 8886 & 4,8 & 6,0 & 2,6 & 3,4 \\
\hline Удмуртская Республика & 4136 & 5586 & 3149 & 3536 & 4,1 & 5,6 & 3,1 & 3,5 \\
\hline Чувашская Республика & 3028 & 4130 & 2219 & 2552 & 3,7 & 5,1 & 2,7 & 3,1 \\
\hline Пермский край & 8415 & 11006 & 6284 & 7113 & 4,9 & 6,3 & 3,6 & 4,1 \\
\hline Кировская область & 3674 & 4351 & 2926 & 3292 & 4,4 & 5,1 & 3,5 & 3,9 \\
\hline Нижегородская область & 10386 & 13244 & 7514 & 8919 & 4,9 & 6,2 & 3,5 & 4,2 \\
\hline Оренбургская область & 6671 & 7922 & 5055 & 5486 & 5,1 & 6,1 & 3,9 & 4,2 \\
\hline Пензенская область & 3900 & 4731 & 2953 & 3447 & 4,5 & 5,4 & 3,4 & 3,9 \\
\hline Самарская область & 10653 & 13061 & 7820 & 8772 & 5,0 & 6,2 & 3,7 & 4,1 \\
\hline Саратовская область & 7055 & 8897 & 5543 & 6486 & 4,4 & 5,5 & 3,4 & 4,0 \\
\hline Ульяновская область & 4005 & 4885 & 2779 & 3063 & 4,9 & 5,9 & 3,4 & 3,7 \\
\hline Уральский федеральный округ & 43874 & 55193 & 31722 & 38959 & 5,3 & 6,7 & 3,9 & 4,7 \\
\hline Курганская область & 2558 & 3071 & 2217 & 2564 & 4,6 & 5,5 & 4,0 & 4,6 \\
\hline Свердловская область & 15524 & 19479 & 10581 & 13483 & 5,4 & 6,8 & 3,7 & 4,7 \\
\hline Тюменская область & 13846 & 17740 & 9537 & 12325 & 5,5 & 7,1 & 3,8 & 5,0 \\
\hline $\begin{array}{l}\text { в том числе: } \\
\text { Ханты-Мансийский авт. округ - Югра }\end{array}$ & 6315 & 8361 & 4254 & 5861 & 5,6 & 7,5 & 3,8 & 5,3 \\
\hline Ямало-Ненецкий авт. округ & 1956 & 2376 & 1549 & 1848 & 5,4 & 6,6 & 4,3 & 5,1 \\
\hline Тюменская область без авт. округов & 5575 & 7003 & 3734 & 4616 & 5,4 & 6,9 & 3,6 & 4,6 \\
\hline Челябинская область & 11946 & 14903 & 9387 & 10587 & 5,2 & 6,4 & 4,1 & 4,6 \\
\hline Сибирский федеральный округ & 60443 & 74488 & 43556 & 51798 & 5,3 & 6,5 & 3,8 & 4,5 \\
\hline Республика Алтай & 829 & 986 & 682 & 659 & 5,6 & 6,8 & 4,6 & 4,5 \\
\hline Республика Тыва & 1055 & 1355 & 366 & 465 & 4,8 & 6,3 & 1,7 & 2,1 \\
\hline Республика Хакасия & 1983 & 2348 & 1626 & 1568 & 5,6 & 6,6 & 4,6 & 4,4 \\
\hline Алтайский край & 7524 & 9016 & 6194 & 6784 & 4,9 & 5,8 & 4,0 & 4,4 \\
\hline Красноярский край & 10515 & 13241 & 7773 & 9369 & 5,5 & 6,9 & 4,1 & 4,9 \\
\hline Иркутская область & 9314 & 11569 & 6768 & 7833 & 5,8 & 7,3 & 4,2 & 4,9 \\
\hline Кемеровская область & 8674 & 10660 & 6365 & 7526 & 4,9 & 6,0 & 3,6 & 4,2 \\
\hline Новосибирская область & 10129 & 12534 & 6966 & 8820 & 5,4 & 6,7 & 3,7 & 4,7 \\
\hline Омская область & 6526 & 8084 & 4416 & 5654 & 5,1 & 6,3 & 3,4 & 4,4 \\
\hline Томская область & 3894 & 4695 & 2400 & 3120 & 5,4 & 6,5 & 3,3 & 4,4 \\
\hline Дальневосточный федеральный округ & 29809 & 36475 & 21486 & 25772 & 5,5 & 6,7 & 3,9 & 4,7 \\
\hline Республика Бурятия & 2875 & 3767 & 2180 & 2421 & 4,4 & 5,8 & 3,3 & 3,7 \\
\hline Республика Саха (Якутия) & 2910 & 4078 & 1941 & 2801 & 4,5 & 6,3 & 3,0 & 4,3 \\
\hline Забайкальский край & 3616 & 4661 & 2999 & 3329 & 5,1 & 6,6 & 4,2 & 4,7 \\
\hline Камчатский край & 1297 & 1603 & 898 & 1255 & 6,2 & 7,7 & 4,3 & 6,0 \\
\hline Приморский край & 7312 & 8849 & 5048 & 6256 & 5,8 & 7,0 & 4,0 & 4,9 \\
\hline Хабаровский край & 5107 & 6266 & 3697 & 4551 & 5,8 & 7,1 & 4,2 & 5,2 \\
\hline Амурская область & 3342 & 3547 & 2378 & 2124 & 6,4 & 6,7 & 4,5 & 4,0 \\
\hline Магаданская область & 527 & 641 & 373 & 506 & 5,6 & 6,8 & 4,0 & 5,4 \\
\hline Сахалинская область & 2046 & 2213 & 1393 & 1848 & 6,3 & 6,8 & 4,3 & 5,7 \\
\hline Еврейская авт. область & 601 & 645 & 437 & 531 & 5,7 & 6,1 & 4,1 & 5,0 \\
\hline Чукотский авт. округ & 176 & 205 & 142 & 150 & 5,2 & 6,2 & 4,2 & 4,5 \\
\hline
\end{tabular}


ОЖИДАЕМАЯ ПРОДОЛЖИТЕЛЬНОСТЬ ЖИЗНИ ПРИ РОЖДЕНИИ

в 2019 году

число лет

\begin{tabular}{|c|c|c|c|c|c|c|c|c|c|}
\hline & & населе & & $\overline{\Gamma o p c}$ & кое нас & iue & Сел & oe нace & ine \\
\hline & $\begin{array}{c}\text { муж- } \\
\text { чнньл } \\
\text { и жен- } \\
\text { щчиньл }\end{array}$ & $\begin{array}{l}\text { муж- } \\
\text { чиньь }\end{array}$ & $\begin{array}{l}\text { жен- } \\
\text { щинны }\end{array}$ & $\begin{array}{c}\text { муж- } \\
\text { чиньь } \\
\text { и жен- } \\
\text { ичиньь }\end{array}$ & $\begin{array}{l}\text { муж- } \\
\text { чиньl }\end{array}$ & $\begin{array}{l}\text { жен- } \\
\text { щиинь }\end{array}$ & $\begin{array}{c}\text { муж- } \\
\text { чиньь } \\
\text { и жен- } \\
\text { щчиньь }\end{array}$ & $\begin{array}{l}\text { мужс- } \\
\text { чинье }\end{array}$ & $\begin{array}{l}\text { жен- } \\
\text { щиныь }\end{array}$ \\
\hline Российская Федерация & 73,34 & 68,24 & 78,17 & 73,72 & 68,56 & 78,41 & 72,21 & 67,36 & 77,39 \\
\hline $\begin{array}{l}\text { Центральный } \\
\text { федеральный округ }\end{array}$ & 74,54 & 69,70 & 79,06 & 74,92 & 70,12 & 79,27 & 72,89 & 68,02 & 78,03 \\
\hline Белгородская область & 74,21 & 69,30 & 78,85 & 74,41 & 69,37 & 78,95 & 73,63 & 69,00 & 78,40 \\
\hline Брянская область & 72,31 & 66,55 & 77,92 & 72,75 & 66,90 & 78,12 & 71,23 & 65,81 & 77,36 \\
\hline Владимирская область & 71,87 & 66,12 & 77,26 & 71,81 & 65,90 & 77,18 & 71,99 & 66,93 & 77,23 \\
\hline Воронежская область & 73,63 & 68,20 & 78,84 & 73,88 & 68,30 & 78,98 & 73,08 & 67,91 & 78,47 \\
\hline Ивановская область & 71,84 & 66,49 & 76,71 & 71,82 & 65,99 & 76,94 & 71,83 & 68,15 & 75,25 \\
\hline Калужская область & 72,35 & 66,75 & 77,90 & 72,11 & 66,25 & 77,75 & 73,08 & 68,26 & 78,18 \\
\hline Костромская область & 72,35 & 66,90 & 77,51 & 72,62 & 67,04 & 77,59 & 71,32 & 66,22 & 76,83 \\
\hline Курская область & 72,27 & 66,67 & 77,67 & 73,23 & 67,59 & 78,23 & 70,15 & 64,73 & 76,30 \\
\hline Липецкая область & 73,34 & 67,89 & 78,48 & 73,70 & 68,13 & 78,66 & 72,57 & 67,33 & 78,03 \\
\hline Московская область & 73,86 & 69,04 & 78,25 & 73,53 & 68,59 & 77,97 & 75,44 & 71,15 & 79,67 \\
\hline Орловская область & 72,56 & 67,10 & 77,67 & 73,16 & 67,43 & 78,22 & 71,23 & 66,38 & 76,31 \\
\hline Рязанская область & 73,20 & 67,66 & 78,51 & 73,25 & 67,43 & 78,57 & 72,76 & 68,02 & 77,80 \\
\hline Смоленская область & 71,89 & 66,53 & 77,10 & 72,34 & 66,55 & 77,62 & 70,64 & 66,18 & 75,55 \\
\hline Тамбовская область & 73,56 & 68,00 & 79,01 & 73,64 & 68,04 & 78,76 & 73,33 & 67,83 & 79,20 \\
\hline Тверская область & 71,24 & 65,79 & 76,51 & 71,57 & 66,02 & 76,54 & 70,07 & 65,04 & 76,22 \\
\hline Тульская область & 72,21 & 66,68 & 77,47 & 72,11 & 66,27 & 77,54 & 72,51 & 67,85 & 77,24 \\
\hline Ярославская область & 72,92 & 67,35 & 77,96 & 73,00 & 67,33 & 77,90 & 72,45 & 67,24 & 78,02 \\
\hline г. Москва & 78,36 & 74,83 & 81,71 & 78,39 & 74,88 & 81,72 & 75,79 & 70,80 & 80,33 \\
\hline $\begin{array}{l}\text { Северо-Западный } \\
\text { федеральный округ }\end{array}$ & 73,72 & 68,62 & 78,41 & 74,11 & 69,00 & 78,62 & 71,59 & 66,75 & 77,09 \\
\hline Республика Карелия & 71,46 & 65,73 & 76,88 & 72,62 & 66,88 & 77,68 & 66,41 & 61,07 & 72,53 \\
\hline Республика Коми & 71,30 & 65,78 & 76,68 & 72,28 & 66,68 & 77,37 & 67,28 & 62,37 & 73,59 \\
\hline Архангельская область & 72,34 & 66,81 & 77,72 & 73,40 & 67,72 & 78,49 & 67,95 & 63,50 & 73,66 \\
\hline $\begin{array}{l}\text { в том числе: } \\
\text { Ненецкий авт. округ }\end{array}$ & 73,19 & 67,68 & 78,40 & 75,70 & 70,50 & 79,81 & 67,41 & 61,87 & 72,69 \\
\hline $\begin{array}{l}\text { Архангельская область } \\
\text { без авт. округа }\end{array}$ & 72,30 & 66,77 & 77,68 & 73,33 & 67,64 & 78,44 & 67,94 & 63,43 & 73,60 \\
\hline Вологодская область & 71,82 & 65,90 & 77,63 & 72,31 & 66,20 & 77,84 & 70,13 & 64,73 & 76,55 \\
\hline Калининградская область & 73,56 & 68,70 & 77,99 & 73,79 & 68,86 & 78,15 & 72,93 & 68,41 & 77,38 \\
\hline Ленинградская область & 73,64 & 68,51 & 78,64 & 72,63 & 67,14 & 77,85 & 75,83 & 71,62 & 80,30 \\
\hline Мурманская область & 71,75 & 66,49 & 76,57 & 71,55 & 66,29 & 76,40 & 74,44 & 68,66 & 79,78 \\
\hline Новгородская область & 70,52 & 64,51 & 76,42 & 70,65 & 64,29 & 76,41 & 69,65 & 64,46 & 75,35 \\
\hline Псковская область & 70,65 & 65,36 & 75,78 & 70,28 & 64,61 & 75,45 & 71,13 & 66,77 & 75,91 \\
\hline г. Санкт-Петербург & 76,31 & 71,99 & 79,99 & 76,31 & 71,99 & 79,99 & 0,00 & 0,00 & 0,00 \\
\hline $\begin{array}{l}\text { Южный } \\
\text { федеральный округ }\end{array}$ & 73,73 & 68,88 & 78,36 & 73,72 & 68,68 & 78,36 & 73,74 & 69,19 & 78,35 \\
\hline Республика Адыгея & 73,85 & 69,06 & 78,42 & 74,35 & 69,19 & 79,03 & 73,44 & 68,92 & 77,85 \\
\hline Республика Калмыкия & 74,84 & 69,32 & 80,27 & 75,06 & 69,15 & 80,08 & 74,71 & 69,55 & 80,48 \\
\hline Республика Крым & 72,71 & 67,76 & 77,41 & 72,10 & 66,76 & 77,08 & 73,35 & 68,76 & 77,76 \\
\hline Краснодарский край & 73,91 & 68,98 & 78,66 & 73,43 & 68,21 & 78,25 & 74,53 & 69,93 & 79,18 \\
\hline Астраханская область & 73,86 & 68,95 & 78,58 & 74,01 & 68,96 & 78,70 & 73,36 & 68,76 & 78,14 \\
\hline Волгоградская область & 74,07 & 69,10 & 78,78 & 74,50 & 69,42 & 79,14 & 72,64 & 68,03 & 77,55 \\
\hline Ростовская область & 73,69 & 69,11 & 78,02 & 73,98 & 69,27 & 78,25 & 73,05 & 68,73 & 77,48 \\
\hline г. Севастополь & 73,53 & 68,65 & 78,05 & 73,31 & 68,43 & 77,83 & 76,98 & 71,91 & 81,22 \\
\hline $\begin{array}{c}\text { Северо-Кавказский } \\
\text { федеральный округ }\end{array}$ & 76,64 & 72,92 & 80,05 & 76,95 & 73,24 & 80,22 & 76,30 & 72,58 & 79,85 \\
\hline Республика Дагестан & 79,10 & 76,62 & 81,44 & 79,85 & 78,26 & 81,53 & 78,35 & 75,35 & 81,14 \\
\hline Республика Ингушетия & 83,40 & 80,00 & 86,27 & 83,40 & 79,65 & 86,59 & 83,39 & 80,37 & 85,45 \\
\hline $\begin{array}{l}\text { Кабардино-Балкарская } \\
\text { Республика }\end{array}$ & 76,46 & 72,62 & 79,94 & 76,71 & 73,18 & 79,68 & 76,19 & 71,98 & 80,29 \\
\hline $\begin{array}{l}\text { Карачаево-Черкесская } \\
\text { Республика }\end{array}$ & 76,21 & 71,68 & 80,40 & 76,53 & 71,90 & 80,42 & 75,90 & 71,42 & 80,27 \\
\hline $\begin{array}{l}\text { Республика Северная } \\
\text { Осетия - Алания }\end{array}$ & 75,75 & 70,52 & 80,57 & 75,87 & 70,65 & 80,32 & 75,56 & 70,02 & 81,08 \\
\hline Чеченская Республика & 75,88 & 73,61 & 77,97 & 73,73 & 71,60 & 75,71 & 77,07 & 74,66 & 79,23 \\
\hline Ставропольский край & 74,66 & 70,10 & 78,90 & 75,40 & 70,72 & 79,54 & 73,61 & 69,23 & 77,96 \\
\hline
\end{tabular}




\begin{tabular}{|c|c|c|c|c|c|c|c|c|c|}
\hline & \multicolumn{3}{|c|}{ Все население } & \multicolumn{3}{|c|}{ Г Городское население } & \multicolumn{3}{|c|}{ Сельское население } \\
\hline & $\begin{array}{c}\text { муж- } \\
\text { чиньл } \\
\text { и жен- } \\
\text { ичины }\end{array}$ & $\begin{array}{l}\text { мужс- } \\
\text { чины }\end{array}$ & $\begin{array}{l}\text { жен- } \\
\text { щиньь }\end{array}$ & $\begin{array}{c}\text { муж- } \\
\text { чиньл } \\
\text { и жен- } \\
\text { щинь }\end{array}$ & $\begin{array}{l}\text { муж- } \\
\text { чиньь }\end{array}$ & $\begin{array}{l}\text { жен- } \\
\text { щиньи }\end{array}$ & $\begin{array}{c}\text { муж- } \\
\text { чиньь } \\
\text { и жен- } \\
\text { ичинь- }\end{array}$ & $\begin{array}{l}\text { мужс- } \\
\text { чиньв }\end{array}$ & $\begin{array}{l}\text { жен- } \\
\text { щиньь }\end{array}$ \\
\hline $\begin{array}{l}\text { Приволжский } \\
\text { федеральный округ }\end{array}$ & 72,94 & 67,46 & 78,17 & 73,36 & 67,77 & 78,36 & $\mathbf{7 1 , 7 4}$ & 66,63 & 77,47 \\
\hline Республика Башкортостан & 72,64 & 67,26 & 77,96 & 73,49 & 68,05 & 78,38 & 71,10 & 65,93 & 77,02 \\
\hline Республика Марий Эл & 72,90 & 66,94 & 78,83 & 73,37 & 67,23 & 78,96 & 71,86 & 66,24 & 78,33 \\
\hline Республика Мордовия & 73,95 & 68,80 & 78,89 & 74,51 & 69,28 & 79,09 & 72,70 & 67,63 & 78,20 \\
\hline Республика Татарстан & 75,03 & 69,74 & 79,92 & 75,33 & 70,00 & 79,96 & 73,95 & 68,92 & 79,52 \\
\hline Удмуртская Республика & 72,80 & 67,01 & 78,27 & 73,44 & 67,46 & 78,63 & 71,39 & 66,19 & 77,33 \\
\hline Чувашская Республика & 73,44 & 67,64 & 79,25 & 74,43 & 68,46 & 79,60 & 71,76 & 66,50 & 78,12 \\
\hline Пермский край & 71,32 & 65,52 & 76,89 & 72,08 & 66,14 & 77,42 & 68,85 & 63,64 & 74,92 \\
\hline Кировская область & 72,96 & 67,35 & 78,43 & 73,63 & 67,88 & 78,88 & 70,04 & 65,24 & 76,14 \\
\hline Нижегородская область & 72,32 & 66,51 & 77,79 & 72,38 & 66,41 & 77,79 & 71,89 & 66,73 & 77,50 \\
\hline Оренбургская область & 72,04 & 66,62 & 77,31 & 72,21 & 66,65 & 77,30 & 71,57 & 66,40 & 77,11 \\
\hline Пензенская область & 73,61 & 68,09 & 78,87 & 74,09 & 68,39 & 79,24 & 72,51 & 67,39 & 77,93 \\
\hline Самарская область & 72,77 & 67,48 & 77,70 & 72,83 & 67,42 & 77,68 & 72,51 & 67,70 & 77,68 \\
\hline Саратовская область & 73,07 & 67,95 & 77,89 & 73,41 & 68,12 & 78,16 & 72,00 & 67,37 & 76,94 \\
\hline Ульяновская область & 72,96 & 67,70 & 77,96 & 73,02 & 67,82 & 77,72 & 72,38 & 66,97 & 78,24 \\
\hline $\begin{array}{l}\text { Уральский } \\
\text { федеральный округ }\end{array}$ & 72,52 & 67,08 & 77,69 & 72,99 & 67,51 & 78,01 & $\mathbf{7 0 , 3 7}$ & 65,20 & 76,10 \\
\hline Курганская область & 71,14 & 65,29 & 77,11 & 71,63 & 65,33 & 77,61 & 70,20 & 65,05 & 76,10 \\
\hline Свердловская область & 71,81 & 66,10 & 77,23 & 72,03 & 66,25 & 77,34 & 70,44 & 65,21 & 76,37 \\
\hline Тюменская область & 74,04 & 69,17 & 78,69 & 74,89 & 70,12 & 79,28 & 70,80 & 65,69 & 76,39 \\
\hline $\begin{array}{l}\text { в том числе: } \\
\text { Ханты-Мансийский } \\
\text { авт. округ - Югра }\end{array}$ & 75,04 & 70,60 & 79,28 & 75,24 & 70,83 & 79,39 & 72,59 & 67,98 & 77,55 \\
\hline Ямало-Ненецкий авт. округ & 74,18 & 69,39 & 78,61 & 74,98 & 70,48 & 79,00 & 69,97 & 64,60 & 76,00 \\
\hline $\begin{array}{l}\text { Тюменская область } \\
\text { без авт. округов }\end{array}$ & 72,75 & 67,52 & 77,83 & 73,93 & 68,68 & 78,67 & 70,54 & 65,36 & 76,18 \\
\hline Челябинская область & 72,08 & 66,53 & 77,31 & 72,60 & 66,99 & 77,71 & 69,63 & 64,48 & 75,22 \\
\hline $\begin{array}{l}\text { Сибирский } \\
\text { федеральный округ }\end{array}$ & 71,12 & 65,72 & 76,32 & 71,74 & 66,21 & 76,80 & 69,20 & 64,20 & $\mathbf{7 4 , 7 6}$ \\
\hline Республика Алтай & 70,29 & 64,52 & 76,05 & 71,11 & 63,98 & 76,62 & 69,59 & 64,23 & 75,50 \\
\hline Республика Тыва & 67,57 & 62,51 & 72,47 & 69,80 & 64,94 & 73,96 & 63,92 & 59,05 & 70,13 \\
\hline Республика Хакасия & 71,05 & 65,44 & 76,55 & 72,23 & 66,53 & 77,50 & 68,37 & 62,99 & 74,16 \\
\hline Алтайский край & 71,61 & 66,31 & 76,77 & 72,22 & 66,65 & 77,33 & 70,57 & 65,62 & 75,77 \\
\hline Красноярский край & 71,16 & 65,83 & 76,30 & 72,08 & 66,62 & 77,03 & 67,91 & 63,16 & 73,44 \\
\hline Иркутская область & 69,55 & 63,80 & 75,14 & 70,09 & 64,14 & 75,62 & 67,56 & 62,60 & 73,16 \\
\hline Кемеровская область & 69,78 & 64,32 & 75,11 & 69,97 & 64,41 & 75,23 & 68,48 & 63,73 & 74,15 \\
\hline Новосибирская область & 72,25 & 67,06 & 77,17 & 72,85 & 67,54 & 77,69 & 69,84 & 65,10 & 75,13 \\
\hline Омская область & 72,32 & 66,93 & 77,41 & 73,11 & 67,68 & 77,94 & 70,21 & 65,04 & 75,84 \\
\hline Томская область & 72,85 & 67,66 & 77,88 & 73,79 & 68,69 & 78,42 & 70,46 & 65,11 & 76,29 \\
\hline $\begin{array}{l}\text { Дальневосточный феде- } \\
\text { ральный округ }\end{array}$ & 70,22 & 64,99 & 75,57 & 70,82 & 65,43 & 76,09 & 68,52 & 63,80 & 73,96 \\
\hline Республика Бурятия & 70,77 & 65,36 & 76,12 & 72,20 & 66,52 & 77,27 & 68,70 & 63,72 & 74,31 \\
\hline Республика Саха (Якутия) & 73,00 & 68,14 & 77,87 & 73,19 & 68,25 & 77,89 & 72,41 & 67,63 & 77,67 \\
\hline Забайкальский край & 68,88 & 63,30 & 74,76 & 69,80 & 64,15 & 75,37 & 66,67 & 61,32 & 73,20 \\
\hline Камчатский край & 70,57 & 65,63 & 75,89 & 71,46 & 66,26 & 76,84 & 67,63 & 63,44 & 72,46 \\
\hline Приморский край & 70,54 & 65,57 & 75,62 & 71,20 & 66,13 & 76,19 & 68,30 & 63,81 & 73,52 \\
\hline Хабаровский край & 70,05 & 64,44 & 75,72 & 70,24 & 64,44 & 75,96 & 69,07 & 64,34 & 74,29 \\
\hline Амурская область & 68,66 & 63,52 & 73,91 & 69,19 & 63,73 & 74,48 & 67,43 & 63,05 & 72,40 \\
\hline Магаданская область & 69,66 & 64,21 & 75,33 & 69,81 & 64,20 & 75,59 & 64,24 & 59,36 & 67,71 \\
\hline Сахалинская область & 70,28 & 65,03 & 75,73 & 70,68 & 65,37 & 75,98 & 68,12 & 62,94 & 73,99 \\
\hline Еврейская авт. область & 68,08 & 63,23 & 72,82 & 68,19 & 62,85 & 73,28 & 67,73 & 63,95 & 71,40 \\
\hline Чукотский авт. округ & 68,09 & 64,37 & 72,77 & 73,28 & 69,85 & 77,22 & 57,36 & 52,11 & 64,62 \\
\hline
\end{tabular}


ОБЩИЕ ИТОГИ МИГРАЦИИ НАСЕЛЕНИЯ

в январе-августе

человек

\begin{tabular}{|c|c|c|c|c|c|c|}
\hline & \multicolumn{3}{|c|}{20202.} & \multicolumn{3}{|c|}{ Справочно 2019 г. } \\
\hline & $\begin{array}{c}\text { число } \\
\text { прибывших }\end{array}$ & $\begin{array}{c}\text { число } \\
\text { выбывиших }\end{array}$ & $\begin{array}{c}\text { мигра- } \\
\text { иионньй } \\
\text { прирост (+), } \\
\text { убыль (-) } \\
\end{array}$ & $\begin{array}{c}\text { число } \\
\text { прибывиих }\end{array}$ & $\begin{array}{c}\text { число } \\
\text { выбывиших }\end{array}$ & $\begin{array}{c}\text { мигра- } \\
\text { иионный } \\
\text { прирост (+), } \\
\text { убыль (-) } \\
\end{array}$ \\
\hline Российская Федерация & 2537365 & 2468260 & +69105 & 3037000 & 2870342 & +166658 \\
\hline Центральный федеральный округ & 652993 & 638997 & +13996 & 840221 & 740535 & +99686 \\
\hline Белгородская область & 32769 & 29151 & +3618 & 38814 & 34848 & +3966 \\
\hline Брянская область & 21175 & 18472 & +2703 & 24531 & 23162 & +1369 \\
\hline Владимирская область & 18968 & 18349 & +619 & 25196 & 22742 & +2454 \\
\hline Воронежская область & 42449 & 42572 & -123 & 53383 & 49714 & +3669 \\
\hline Ивановская область & 15077 & 15122 & -45 & 19104 & 18775 & +329 \\
\hline Калужская область & 21784 & 18903 & +2881 & 20708 & 23611 & -2903 \\
\hline Костромская область & 14033 & 12986 & +1047 & 15122 & 15005 & +117 \\
\hline Курская область & 21751 & 18509 & +3242 & 28699 & 26135 & +2564 \\
\hline Липецкая область & 20173 & 19401 & +772 & 27302 & 24726 & +2576 \\
\hline Московская область & 188880 & 161898 & +26982 & 236578 & 168647 & +67931 \\
\hline Орловская область & 9884 & 10123 & -239 & 13204 & 13333 & -129 \\
\hline Рязанская область & 21644 & 21840 & -196 & 26186 & 24379 & +1807 \\
\hline Смоленская область & 18144 & 19974 & -1830 & 23207 & 23770 & -563 \\
\hline Тамбовская область & 18484 & 18290 & +194 & 22951 & 23325 & -374 \\
\hline Тверская область & 22971 & 22324 & +647 & 28037 & 26658 & +1379 \\
\hline Тульская область & 26370 & 25255 & +1115 & 31966 & 31411 & +555 \\
\hline Ярославская область & 18951 & 20287 & -1336 & 23635 & 24084 & -449 \\
\hline г. Москва & 119486 & 145541 & -26055 & 181598 & 166210 & +15388 \\
\hline Северо-Западный федеральный округ & 313628 & 300636 & +12992 & 381102 & 362355 & +18747 \\
\hline Республика Карелия & 11097 & 10972 & +125 & 13810 & 14027 & -217 \\
\hline Республика Коми & 17533 & 18550 & -1017 & 18881 & 23241 & -4360 \\
\hline Архангельская область & 20484 & 20321 & +163 & 26787 & 27833 & -1046 \\
\hline $\begin{array}{l}\text { в том числе: } \\
\text { Ненецкий авт. округ }\end{array}$ & 1374 & 1173 & +201 & 1533 & 1462 & +71 \\
\hline Архангельская область без авт. округа & 19110 & 19148 & -38 & 25254 & 26371 & -1117 \\
\hline Вологодская область & 14767 & 14927 & -160 & 18464 & 18043 & +421 \\
\hline Калининградская область & 29936 & 22984 & +6952 & 34505 & 25728 & +8777 \\
\hline Ленинградская область & 64116 & 44226 & +19890 & 74834 & 49190 & +25644 \\
\hline Мурманская область & 18623 & 20668 & -2045 & 23528 & 25822 & -2294 \\
\hline Новгородская область & 15329 & 13485 & +1844 & 15139 & 14234 & +905 \\
\hline Псковская область & 17880 & 16953 & +927 & 21342 & 19828 & +1514 \\
\hline г. Санкт-Петербург & 103863 & 117550 & -13687 & 133812 & 144409 & -10597 \\
\hline Южный федеральный округ & 293281 & 247583 & +45698 & 311497 & 272787 & +38710 \\
\hline Республика Адыгея & 12011 & 11081 & +930 & 15811 & 9211 & +6600 \\
\hline Республика Калмыкия & 7000 & 7034 & -34 & 8346 & 9086 & -740 \\
\hline Республика Крым & 37279 & 27848 & +9431 & 30338 & 24353 & +5985 \\
\hline Краснодарский край & 104289 & 82551 & +21738 & 117497 & 91040 & +26457 \\
\hline Астраханская область & 11112 & 13896 & -2784 & 14515 & 18339 & -3824 \\
\hline Волгоградская область & 37793 & 33590 & +4203 & 39804 & 42278 & -2474 \\
\hline Ростовская область & 69965 & 61825 & +8140 & 72002 & 69309 & +2693 \\
\hline г. Севастополь & 13832 & 9758 & +4074 & 13184 & 9171 & +4013 \\
\hline Северо-Кавказский федеральный округ & 109361 & 107187 & +2174 & 135301 & 128597 & +6704 \\
\hline Республика Дагестан & 24563 & 25220 & -657 & 30625 & 32658 & -2033 \\
\hline Республика Ингушетия & 5184 & 3469 & +1715 & 6021 & 3853 & +2168 \\
\hline Кабардино-Балкарская Республика & 7309 & 6820 & +489 & 8247 & 8229 & +18 \\
\hline Карачаево-Черкесская Республика & 7263 & 6854 & +409 & 7336 & 7650 & -314 \\
\hline Республика Северная Осетия - Алания & 5238 & 6872 & -1634 & 7099 & 9019 & -1920 \\
\hline Чеченская Республика & 9258 & 9681 & -423 & 11433 & 12058 & -625 \\
\hline Ставропольский край & 50546 & 48271 & +2275 & 64540 & 55130 & +9410 \\
\hline
\end{tabular}




\begin{tabular}{|c|c|c|c|c|c|c|}
\hline & \multicolumn{3}{|c|}{20202.} & \multicolumn{3}{|c|}{ Справочно 2019 г. } \\
\hline & $\begin{array}{c}\text { число } \\
\text { прибывших }\end{array}$ & $\begin{array}{c}\text { число } \\
\text { выбьввиих }\end{array}$ & $\begin{array}{c}\text { мигра- } \\
\text { иионньй } \\
\text { прирост (+), } \\
\text { убыль (-) }\end{array}$ & $\begin{array}{c}\text { число } \\
\text { прибывших }\end{array}$ & $\begin{array}{c}\text { число } \\
\text { выбывших }\end{array}$ & \begin{tabular}{|c|} 
мигра- \\
иионный \\
прирост (+), \\
убьльь (-) \\
\end{tabular} \\
\hline Приволжский федеральный округ & 450389 & 449190 & +1199 & 532422 & 532310 & +112 \\
\hline Республика Башкортостан & 77694 & 77406 & +288 & 90165 & 91547 & -1382 \\
\hline Республика Марий Эл & 13205 & 13495 & -290 & 15190 & 15307 & -117 \\
\hline Республика Мордовия & 11294 & 13377 & -2083 & 14580 & 15225 & -645 \\
\hline Республика Татарстан & 54750 & 50921 & +3829 & 59272 & 56239 & +3033 \\
\hline Удмуртская Республика & 19665 & 19033 & +632 & 21589 & 22506 & -917 \\
\hline Чувашская Республика & 22666 & 23755 & -1089 & 27869 & 29253 & -1384 \\
\hline Пермский край & 41405 & 44014 & -2609 & 50129 & 52261 & -2132 \\
\hline Кировская область & 25749 & 26350 & -601 & 30843 & 32501 & -1658 \\
\hline Нижегородская область & 43165 & 42142 & +1023 & 52519 & 47777 & +4742 \\
\hline Оренбургская область & 31765 & 29665 & +2100 & 37784 & 36794 & +990 \\
\hline Пензенская область & 16661 & 16440 & +221 & 21151 & 23795 & -2644 \\
\hline Самарская область & 42435 & 41883 & +552 & 52814 & 46940 & +5874 \\
\hline Саратовская область & 34905 & 35900 & -995 & 40725 & 43555 & -2830 \\
\hline Ульяновская область & 15030 & 14809 & +221 & 17792 & 18610 & -818 \\
\hline Уральский федеральный округ & 234905 & 225424 & +9481 & 272362 & 259387 & +12975 \\
\hline Курганская область & 18794 & 18504 & +290 & 20014 & 20935 & -921 \\
\hline Свердловская область & 66760 & 64230 & +2530 & 77226 & 72838 & +4388 \\
\hline Тюменская область & 93784 & 87197 & +6587 & 109218 & 101857 & +7361 \\
\hline $\begin{array}{l}\text { в том числе: } \\
\text { Ханты-Мансийский авт. округ - Югра }\end{array}$ & 44487 & 39812 & +4675 & 46610 & 47494 & -884 \\
\hline Ямало-Ненецкий авт. округ & 17417 & 17954 & -537 & 21226 & 22600 & -1374 \\
\hline Тюменская область без авт. округов & 31880 & 29431 & +2449 & 41382 & 31763 & +9619 \\
\hline Челябинская область & 55567 & 55493 & +74 & 65904 & 63757 & +2147 \\
\hline Сибирский федеральный округ & 298855 & 310880 & -12025 & 351387 & 356514 & -5127 \\
\hline Республика Алтай & 7772 & 7048 & +724 & 8920 & 7885 & +1035 \\
\hline Республика Тыва & 7197 & 5855 & +1342 & 8154 & 6433 & +1721 \\
\hline Республика Хакасия & 12869 & 11981 & +888 & 13764 & 13338 & +426 \\
\hline Алтайский край & 41321 & 41088 & +233 & 51527 & 51346 & +181 \\
\hline Красноярский край & 69671 & 70884 & -1213 & 75804 & 79933 & -4129 \\
\hline Иркутская область & 32106 & 34594 & -2488 & 37005 & 38082 & -1077 \\
\hline Кемеровская область & 40026 & 39244 & +782 & 45978 & 46268 & -290 \\
\hline Новосибирская область & 44637 & 44989 & -352 & 53587 & 47987 & +5600 \\
\hline Омская область & 25682 & 31436 & -5754 & 32706 & 39927 & -7221 \\
\hline Томская область & 17574 & 23761 & -6187 & 23942 & 25315 & -1373 \\
\hline Дальневосточный федеральный округ & 183953 & 188363 & -4410 & 212708 & 217857 & -5149 \\
\hline Республика Бурятия & 24440 & 23630 & +810 & 29385 & 27669 & +1716 \\
\hline Республика Саха (Якутия) & 31658 & 24702 & +6956 & 25554 & 27337 & -1783 \\
\hline Забайкальский край & 15962 & 17364 & -1402 & 19100 & 21727 & -2627 \\
\hline Камчатский край & 8218 & 8083 & +135 & 8367 & 10332 & -1965 \\
\hline Приморский край & 41588 & 45122 & -3534 & 52451 & 51710 & +741 \\
\hline Хабаровский край & 23489 & 28470 & -4981 & 32310 & 35804 & -3494 \\
\hline Амурская область & 16232 & 17525 & -1293 & 20585 & 18587 & +1998 \\
\hline Магаданская область & 4421 & 4723 & -302 & 5212 & 5525 & -313 \\
\hline Сахалинская область & 12455 & 12792 & -337 & 12907 & 12745 & +162 \\
\hline Еврейская авт. область & 2570 & 2635 & -65 & 3007 & 3162 & -155 \\
\hline Чукотский авт. округ & 2920 & 3317 & -397 & 3830 & 3259 & +571 \\
\hline
\end{tabular}

Федеральная служба государственной статистики 